\title{
La estructura del territorio en la Edad Media: la Batllia de Cervera. Criterios de intervención
}

VICENTE DUALDE VIÑETA 


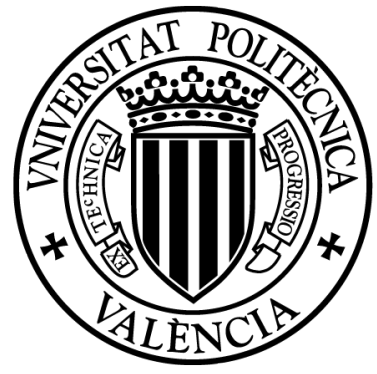

\title{
TESIS DOCTORAL
}

La estructura del territorio en la Edad Media:

La Batllia de Cervera. Criterios de intervención

\author{
AUTOR: VICENTE DUALDE VIÑETA \\ Arquitecto \\ DIRECTOR: FRANCISCO TABERNER PASTOR \\ Doctor Arquitecto \\ CO-DIRECTOR: ARTURO ZARAGOZA CATALÁN \\ Doctor Arquitecto \\ Programa de doctorado en arquitectura, \\ edificación, urbanística y paisaje
}

Departamento de Urbanismo

Valencia, febrero de 2015 


\section{Colección Tesis Doctorales}

(c) Vicente Dualde Viñeta

(C) 2015, de la presente edición: Editorial Universitat Politècnica de València Telf.: 963877012 / www.lalibreria.upv.es

ISBN: 978-84-9048-349-7 (versión impresa)

Queda prohibida la reproducción, distribución, comercialización, transformación, y en general, cualquier otra forma de explotación, por cualquier procedimiento, de todo o parte de los contenidos de esta obra sin autorización expresa y por escrito de sus autores. 


\section{a Silvia}





\section{LA ESTRUCTURA DEL TERRITORIO EN LA EDAD MEDIA: LA BATLLIA DE CERVERA. CRITERIOS DE INTERVENCIÓN}

A partir de un territorio determinado, que ha permanecido casi intacto desde la Edad Media, y de la documentación existente sobre el mismo en dicho periodo, se identifica la estructura de este territorio, los elementos que la componen y la forma en que estos se organizan y relacionan.

Esta estructura o tapiz esta conformado por un soporte natural o cañamazo y unos elementos antroposociales que sobre él se tejen. La conformación del territorio es un proceso, el habitar en el sentido de Heidegger, que se sustancia en cinco procesos, cuatro de ellos responden a la relación del hombre con su entorno y son: el modelado del soporte, el acceso al territorio para poder dominarle, el reparto del territorio y el uso del mismo; el quinto responde a la relación del hombre con los otros hombres, a la necesidad de vivir el hombre en comunidad.

De la superposición del cañamazo inicial con los elementos antroposociales y de las relaciones que entre ellos se producen identificamos cuales son los componentes de la estructura del territorio. Estos son:las arquitecturas, los lugares, las redes, los tejidos, las ciudades y las partes completas del Territorio.

Las partes completas nos permiten identificar seis tipologias antropogeográficas distintas de estructuras del territorio: Montaña, valle, ladera, llano, altiplano-ondulado y atalaya

Esta estructura embrionaria de un territorio en la Edad Media se comporta como un sistema termodinámico abierto que consume energía en su conformación y en el mantenimiento de la misma o rehabilitación tomándola de componente superior o esfera al que pertenece. Así las arquitecturas lo hacen del lugar, estos de los tejidos, las arquitecturas, lugares y tejidos de las ciudades y éstas de la parte del territorio a la que pertenecen.

Como en cualquier otro ecosistema el territorio en la Edad Media es conformado fundamentalmente por la aportación de la luz y de la gravedad. No obstante el hombre empieza a hacer uso de otras energías como el agua, el viento o el fuego y a aprovechar la organización social-el trabajo colectivo- .

Este consumo se ve “compensado” por la energía que recuperan en forma de información y que permite que el territorio tenga cada vez una estructura mas compleja y eficiente energéticamente. Esta información en la Edad Media se encuentra depositada en la propia forma de los componentes del territorio, en su disposición y trazado, en su proporción, en los tipos, en la huella que dejan y en su tacto.

Una vez analizado el Territorio en la Edad Media como un sistema físico complejo, integrado por un sistema disipativo que genera y transforma energía y por un sistema autoorganizativo que recupera la energía disipada como información, establecemos la tesis según la cual la morfoestasis del territorio se produce a partir de:

- La identidad de los distintos componentes del territorio -arquitecturas, lugares, tejidos, ciudades y partes completas- independientemente de sus características morfológicas y funcionales, dependen de la información y energía que administran para desarrollar sus actividades en función de si mismos.

- La relación entre los componentes, el intercambio de materia, energía e información entre ellos y el medio, permite su adaptación a las nuevas situaciones sobrevenidas.

- La evolución de los distintos componentes busca una mayor eficiencia en la administración de la información y la energía.

- La organización cada vez mas compleja de los distintos componentes y del territorio en su 
conjunto es consecuencia del grado evolutivo de los mismos. Es la manifestación material de los cambios morfológicos y funcionales de los componentes territoriales al incrementar información, energía y la eficiencia en su gestión, permitiendo que la evolución se haga efectiva. 


\section{L'ESTRUCTURA DEL TERRITORI EN L'EDAT MITJANA: LA BATLLIA DE CERVERA. CRITERIS D'INTERVENCIÓ}

A partir d'un territori determinat, que ha romàs quasi intacte des de l'Edat Mitjana, i de la documentació existent sobre el mateix en el dit període, s'identifica l'estructura d'este territori, els elements que la componen i la forma en què estos s'organitzen i relacionen.

Esta estructura o tapís esta conformat per un suport natural o canemàs i uns elements antroposociales que sobre ell es tixen. La conformació del territori és un procés, l'habitar en el sentit de Heidegger, que se substància en cinc processos, quatre d'ells responen a la relació de l'home amb el seu entorn i són: el modelatge del suport, l'accés al territori per a poder dominar-li, el repartiment del territori i l'ús del mateix; el quint respon a la relació de l'home amb els altres hòmens, a la necessitat de viure l'home en comunitat

De la superposició del canemàs inicial amb els elements antroposociales i de les relacions que entre ells es produïxen identifiquem quals són els components de l'estructura del territori. Estos son:las arquitectures, els llocs, les xarxes, els teixits, les ciutats i les parts completes del Territori.

Les parts completes ens permeten identificar sis tipologies antropogeogràfiques diferents d'estructures del territori: Muntanya, vall, vessant, pla, altiplà-ondulat i talaia"

Esta estructura embrionària d'un territori en l'Edat Mitjana es comporta com un sistema termodinàmic obert que consumix energia en la seua conformació i en el manteniment de la mateixa o rehabilitació prenent-la de component superior o esfera a què pertany. Així les arquitectures ho fan del lloc, estos dels teixits, les arquitectures, llocs i teixits de les ciutats i estes de la part del territori a què pertanyen

Com en qualsevol altre ecosistema el territori en l'Edat Mitjana és conformat fonamentalment per l'aportació de la llum i de la gravetat. No obstant l'home comença a fer ús d'altres energies com l'aigua, el vent o el foc i a aprofitar l'organització social-el treball col·lectiu-

Este consum es veu "compensat" per l'energia que recuperen en forma d'informació i que permet que el territori tinga cada vegada una estructura mes complexa i eficient energèticament. Esta informació en l'Edat Mitjana es troba depositada en la pròpia forma dels components del territori, en la seua disposició i traçat, en la seua proporció, en els tipus, en l'empremta que deixen i en el seu tacte.

Una vegada analitzat el Territori en l'Edat Mitjana com un sistema físic complex, integrat per un sistema disipativo que genera i transforma energia i per un sistema autoorganitzatiu que recupera l'energia dissipada com a informació, establim la tesi segons la qual la morfoestasis del territori es produïx a partir de:

- La identitat dels distints components del territori - arquitectures, llocs, teixits, ciutats i parts completes- independentment de les seues característiques 
morfològiques i funcionals, depenen de la informació i energia que administren per a desenrotllar les seues activitats en funció de si mateixos.

- La relació entre els components, l'intercanvi de matèria, energia i informació entre ells i el mig, permet la seua adaptació a les noves situacions sobrevingudes.

- L'evolució dels distints components busca una major eficiència en l'administració de la informació i l'energia.

- L'organització cada vegada mes complexa dels distints components i del territori en el seu conjunt és conseqüència del grau evolutiu dels mateixos. És la manifestació material dels canvis morfològics i funcionals dels components territorials a l'incrementar informació, energia i l'eficiència en la seua gestió, permetent que l'evolució es faça efectiva. 


\section{THE STRUCTURE OF THE LAND IN THE MIDDLE AGES: THE BATLLIA OF CERVERA. INTERVENTION CRITERIA}

Starting from a given territory, which has been almost intact since the Middle Ages, and from the existing documentation about it in that time, the structure of this land, the elements that compose it and how they are organized and relate are identified.

This structure, or tapestry, is shaped by a natural backing, or canvas, and some anthroposocial elements that are woven on it. The conformation of the land is a process, the inhabit in the way Heidegger meant, which is synthesized in five processes, four of them respond to the relation between the people and their environment and are: the modelling of the backing, the access to the territory in order to control it, the division of that territory and the use of it; the fifth responds to the relation between the man with other people, to the need of living in community.

The components of the structure of the land are identified from the overlap of the initial canvas with the anthroposocial elements and the relations that occur between them. These components are: the architectures, the places, the nets, the fabric, the cities and the complete parts of the territory.

The complete parts allow us to identify six different anthropogeographical typologies of territory structures: mountain, valley, hillside, plain, plateau-wavy and watchtower-like.

This embryonic structure of a territory in the Middle Ages behaves as an open thermodynamical system that consumes energy in its conformation and during the maintenance or rehabilitation of it, taking that energy from the upper component or sphere to which it belongs. So the architectures take from the place, the place from the fabrics, the architectures, places and fabrics from the cities and the cities from the part of the territory to which they belong.

As in any other ecosystem the land in the Middle Ages is basically conformed by the contribution of the light and the gravity. However, men start to make use of other types of energy like the water, the wind or the fire and to take advantage of the social organization -the collective work-.

This consumption is offset by the energy recovered as information and allows the territory to have an increasingly complex and efficient structure in an energetic way. In the Middle Ages this information is located in the shape itself of the components of the territory, in its arrangement and layout, in its proportion, in the types, in the footprint that it leaves and in its touch.

After analyzing the territory in the Middle Ages as a complex physical system, integrated by a dissipative system that generates and transform energy and by a self-organized system that recovers the dissipated energy as information, the thesis is established according to which the morphostasis of the territory occurs from:

- The identity of the different parts of the territory -architectures, places, fabric, cities and complete parts- regardless of their morphological and functional characteristics, they depend on the administrated information and energy to develop their activities as a function of themselves.

- The relation between the components, the matter, energy and information exchange between them and the environment, allows their adaptation to the new supervening situations.

- The evolution of the different components seeks greater efficiency in the information and energy administration.

- The increasingly complex organization of the components and the territory as a whole is the consequence of the evolutionary degree of themselves. It is the material demonstration of the morphological and functional changes of the territorial components to increase information, energy and efficiency in their management, allowing changes to take effect. 



\section{ÍNDICE}

CAPÍTULO 1. INTRODUCCIÓN. 9

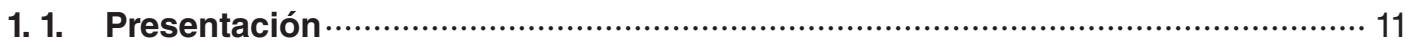

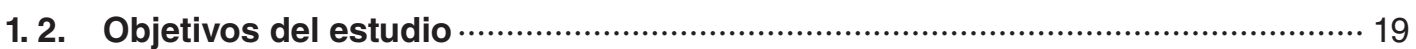

1. 3. Metodología: Análisis del Territorio en términos termodinámicos ……............... 21

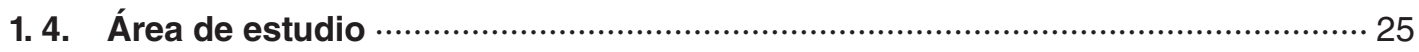

CAPÍTULO 2. LA FORMA DEL TERRITORIO ………………………………….... 27

2. 1. La forma y el análisis termodinámico del territorio ………………………...... 29

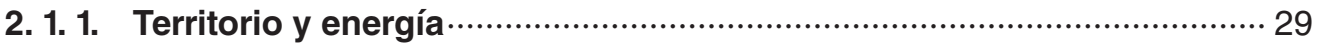

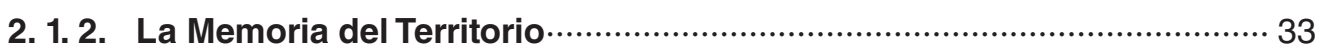

2. 1. 3. La forma y las fases del Territorio como sistema ……......................... 35

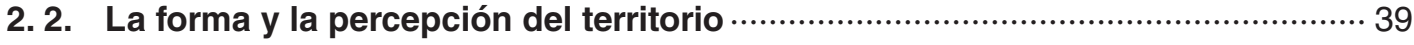

2. 2. 1. El observador como parte del sistema …............................................... 39

2. 3. La forma del territorio y su representación gráfica ….......................................... 44

CAPÍTULO 3. ORGANIZACIÓN DEL TERRITORIO COMO SOPORTE. 47

3. 1. Los elementos del Territorio como soporte, su análisis y su representación

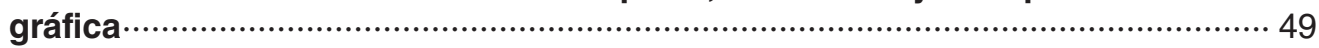

3. 2. La con-formación del soporte territorial …….................................................... 53

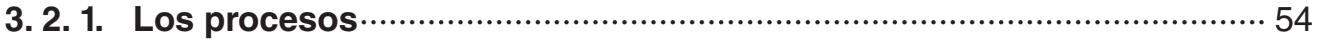

3. 2. 2. Los elementos de la con-formación ……............................................... 57

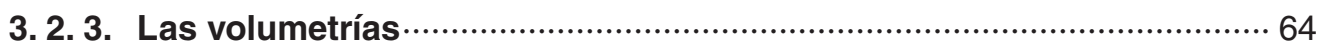

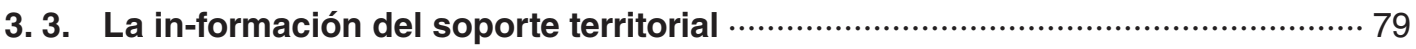

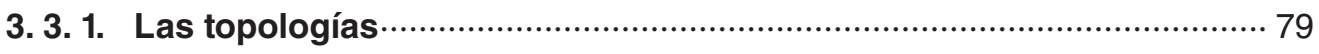

3. 3. 2. La aptitud del territorio …….................................................................... 109

3. 4. La percepción del soporte territorial ……................................................... 123

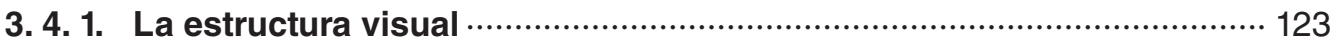

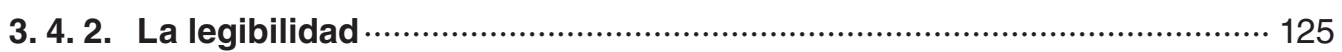

CAPÍTULO 4. ORGANIZACIÓN DEL TERRITORIO ANTROPOSOCIAL …..... 129

4. 1. El Hombre y el medio: la dimensión humana …….......................................... 131

4. 1. 1. Propiedad del territorio y su gestión. Los periodos anteriores al estudio

4. 1. 2. Propiedad del territorio y su gestión. Los periodos del estudio ……...... 132

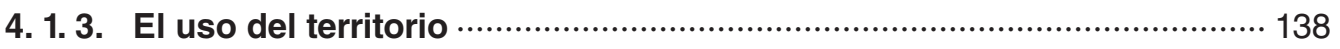

4. 1. 4. Representación gráfica de los usos y arquitecturas de la Batllia en la Edad Media …........................................................................ 140

4. 2. Los elementos del territorio antroposocial y su representación gráfica ……..... 147 
4. 3. La con-formación del territorio antroposocial..........................................231

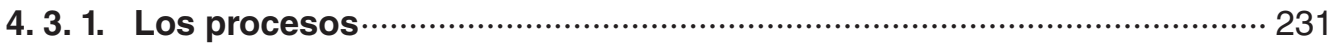

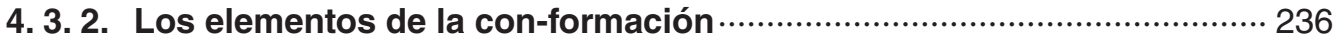

4. 3. 3. Sistemas de elementos …................................................... 317

4. 4. La in-formación del territorio antroposocial ........................................... 350

4. 4. 1. Los tipos

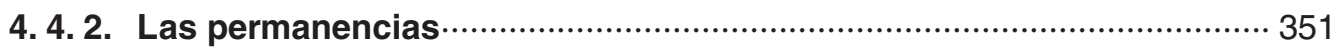

4. 5. La percepción de los elementos del territorio antroposocial ........................ 356

4. 5. 1. Los elementos que estructuran la percepción y caracterizan el Territorio

\section{CAPÍTULO 5. LA COMPOSICIÓN DE LA ESTRUCTURA DEL TERRITORIO DE LA BATLLIA EN LA EDAD MEDIA …………………........... 359}

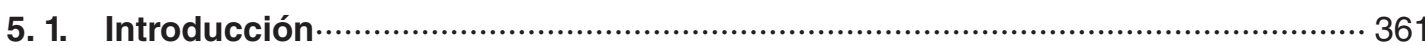

5. 2. Las relaciones sintagmáticas simples: El sitio ……...................................... 363

5. 3. Las relaciones sintagmáticas complejas: El lugar ……..................................... 390

5. 4. La estructura de la estructura: los tejidos ….................................................. 428

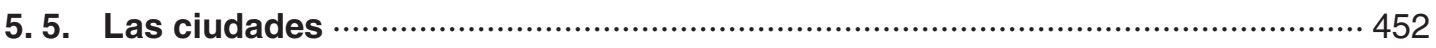

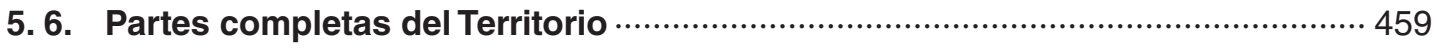

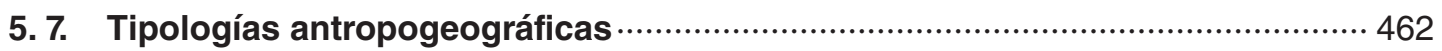

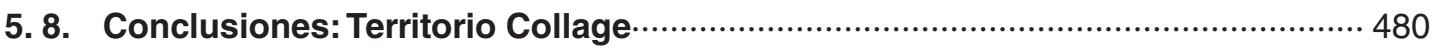

\section{CAPÍTULO 6. LA ENERGÍA QUE NUTRE EL TERRITORIO DE LA BATLLIA EN LA EDAD MEDIA ……........................................................... 485}

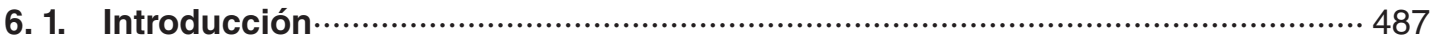

6. 2. La energía como con-formación en el territorio medieval................................. 488

6. 2. 1. El suelo estratificado por bancales. Gradientes de energía ….............. 488

6. 2. 2. El consumo de energía en el transporte horizontal: la trashumancia .. 490

6. 2. 3. El aprovechamiento del flujo de energía del agua ……........................ 493

6. 2. 4. El Territorio medieval y la gravedad …….............................................. 499

6. 2. 5. El fuego: el hogar y los hornos …….................................................... 501

6. 2. 6. El Territorio medieval y la búsqueda de la luz ……..............................5 505

6. 2. 7. El mantenimiento del Territorio ……....................................................... 511

6. 3. La energía como in-formación en el territorio medieval: la materia luz gastada

6. 3. 1. La disposición de la forma y su trazado ….................................... 512

6. 3. 2. La proporción de la forma …................................................. 517

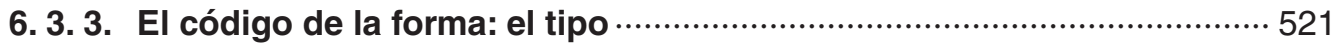

6. 3. 4. La forma como huella: el suelo estratificado por bancales, la parcelación

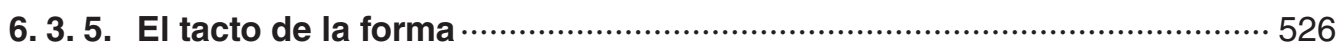

6. 4. Conclusiones: Territorio sistema termodinámico abierto …......................... 528 


\section{CAPÍTULO 7. EL DESARROLLO DE LA ESTRUCTURA DEL TERRITORIO}

DE LA BATLLIA EN LA EDAD MEDIA ……………….............. 539

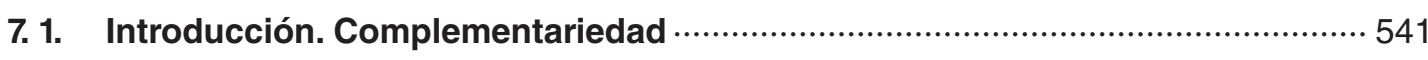

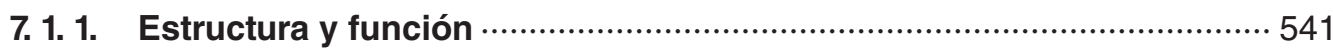

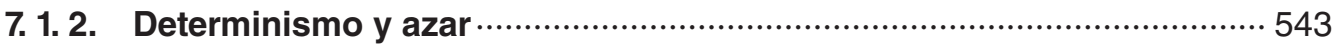

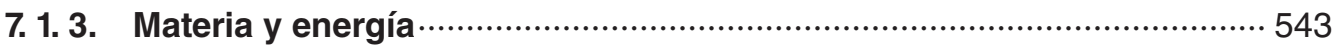

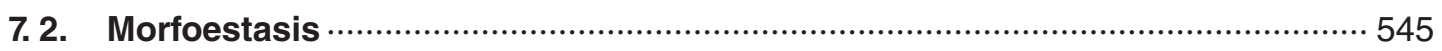

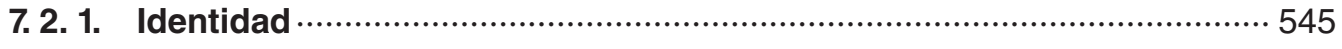

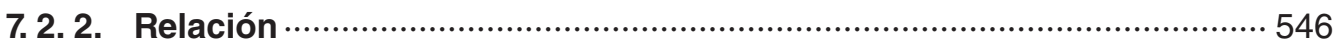

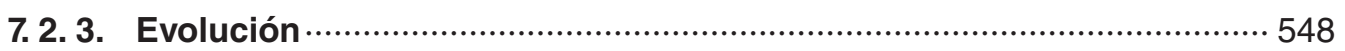

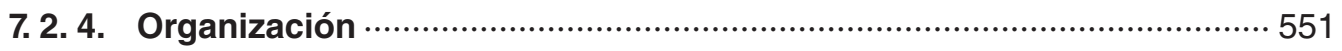

7. 3. La esclerosis y el envejecimiento del territorio ……......................................... 556

7. 3. 1. La pérdida de la identidad …............................................................. 556

7. 3. 2. La interrupción de las relaciones ………………………………..... 556

7. 3. 3. La ineficiencia en la administración de la energía …………………...... 557

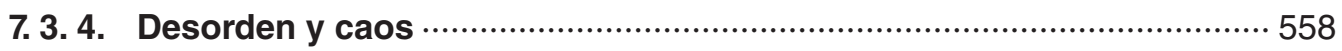

7. 4. Conclusiones: Territorio entre la termodinámica y el juego …….......................559

\section{APÉNDICE. LA RESTAURACIÓN DEL TERRITORIO} DE LA EDAD MEDIA EN LA BATLLIA ……………………....... 561

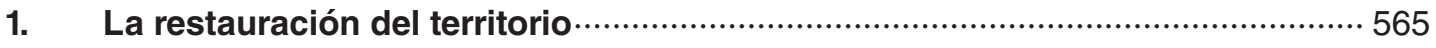

2. La vida sobria del Territorio frente a su imagen embalsamada: criterios de intervención.

ANEXO I. BIBLIOGRAFÍA UTILIZADA PARA LA LOCALIZACIÓN DE LOS COMPONENTES DEL TERRITORIO EN LA EDAD MEDIA

ANEXO II. COMPONENTES DEL TERRITORIO EXISTENTES EN LA ÉPOCA DE ESTUDIO

ANEXO III. APÉNDICE DOCUMENTAL ……………………………………... 599

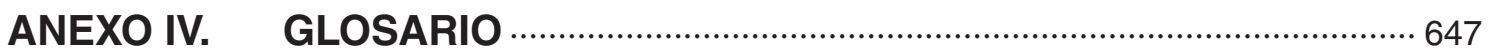





\section{ÍNDICE DOCUMENTACIÓN GRÁFICA}

\section{CAPÍTULO 3: PLANIMETRÍA DEL SOPORTE TERRITORIAL}

- Plano y esquema de volumétrico de la Batllia Cervera y entorno E. 1:200.000 65

- Planos y esquemas de volumetrías de las 12 zonas de estudio E. 1:75.000. 66-77

- Planos y esquemas en 3D de las simplificaciones volumétricas de las 12 zonas de estudio E. 1:80.000

- Esquema simplificado con las pendientes de la Batllia Cervera y entorno E. 1:200.000

- Esquemas simplificados con pendientes de las 12 zonas de estudio E. 1:75.000 …..96-98

- Plano de la superposición del topográfico y del esquema de volumetría de la Batllia Cervera y entorno E. 1:200.000

- Planos de la superposición del topográfico y de los esquemas de volumetría de las 12 zonas de estudio E. 1:75.000 ...... 100-102

- Esquemas geomorfológicos con la topografía superpuesta de las 12 zonas de estudio E. 1:75.000.

- Esquemas geomorfológicos sin la topografía superpuesta de las 12 zonas de estudio E. 1:75.000

- Planos de información: ortofoto, topografía, pendientes, soleamiento y aptitud del suelo para uso agrícola de las 12 zonas de estudio E. 1:80.000 111-122

\section{CAPÍTULO 4: PLANIMETRÍA ORGANIZACIÓN ANTROPOSOCIAL}

- Plano de los usos agrícolas del suelo en la Edad Media en la Batllia de Cervera y su entorno E. 1:150.000

- Plano arquitecturas en la Edad Media en la Batllia de Cervera y su entorno E. 1:150.000

- Plano volumétrico de referencia de las 12 zonas de estudio y ortofoto de la zona 1 indicando los elementos de estudio E. 1:200.000 y 1:60.000

- Planos de la zona de estudio 1 (Bel) a partir de los levantamientos del núcleo urbano de Bel, mas de les Cardones y mas d'Insa E. 1:500, 1:1.000, 1:2.000, 1:5.000, 1:7.500, $1: 15.000$ y $1: 50.000$

- Plano volumétrico de referencia de las 12 zonas de estudio y ortofoto de la zona 2 indicando los elementos de estudio E. 1:200.000 y 1:60.000

- Planos de la zona de estudio 2 (La Barcella) a partir de los levantamientos de la Ermita y Torre de Sant Marc de La Barcella, Mas de Ausencia y Mas Astellat E. 1:500, 1:1.000, $1: 2.000,1: 5.000,1: 7.500,1: 15.000$ y $1: 50.000$

- Plano volumétrico de referencia de las 12 zonas de estudio y ortofoto de la zona 3 indicando los elementos de estudio E. 1:200.000 y 1:60.000

- Planos de la zona de estudio 3 (Molinar) a partir de los levantamientos de la Iglesia de Xert, Mas del Regall, Molino-torre del Molinar, Molino-puente del Molinar y Torre de les Solsides E. 1:500, 1:1.000, 1:2.000, 1:5.000, 1:7.500, 1:15.000 y 1:50.000 .

- Plano volumétrico de referencia de las 12 zonas de estudio y ortofoto de la zona 5 indicando los elementos de estudio E. 1:200.000 y 1:60.000

- Planos de la zona de estudio 5 (Canet) a partir de los levantamientos de la Iglesia de San Miguel, ermita de Santa Isabel y la Font de la Roca E. 1:500, 1:1.000, 1:2.000, $1: 5.000,1: 7.500,1: 15.000$ y $1: 50.000$ 
- Plano volumétrico de referencia de las 12 zonas de estudio y ortofoto de la zona 10 indicando los elementos de estudio E: 1/200.000 y 1/60.000

- Planos de la zona de estudio 10 (Cervera) a partir de los levantamientos del castillo de Cervera, la Ermita del Carmen y el Molí d'oli a E. 1:500, 1:1.000, 1:2.000, 1:5.000, $1: 7.500,1: 15.000$ y $1: 50.000$

- Plano volumétrico de referencia de las 12 zonas de estudio y ortofoto de la zona 12 indicando los elementos de interés E: 1/200.000 y 1/60.000

- Planos de la zona de estudio 12 (Serra de Sant Pere) a E. 1:15.000 y 1:50.000 ... 228-230

- Plano red de muros de separación y contención en la Batllia Cervera y su entorno E. $1: 200.000$

- Planos red de muros de separación y contención de las zonas de estudio $1,2,3,5,6,9,10$ y 12 E. $1: 75.000$

- Plano red de infraestructuras de la Batllia de Cervera y su entorno E. 1:200.000 . 249

- Planos redes de infraestructuras de las 12 zonas de estudio E. 1:75.000 250-252

- Planos de las zonas de estudio 2, 3, 5 y 10 confeccionados a partir de los croquis de los polígonos catastrales de principios del siglo XX, E. 1: 10.000, 1:20.000 y 1:40.000.

- Plano red de parcelación de la Batllia de Cervera y su entorno E. 1:200.000 261

- Planos redes de parcelación de las 12 zonas de estudio E. 1:75.000 262-264

- Plano red de usos agrícolas de la Batllia de Cervera y su entorno E. 1:200.000 269

- Planos redes de usos agrícolas de las 12 zonas de estudio E. 1:75.000 270-272

- Plano levantamiento Mas de les Cardones E. 1:500 289

- Plano levantamiento Mas d'Insa E. 1:500 290

- Plano levantamiento Mas del Regall E. 1:500 291

- Plano levantamiento Mas de Maciá E. 1:500 292

- Plano levantamiento Molino-puente del Molinar E. 1:500 …................................... 293

- Plano levantamiento Molí d'oli de Cervera E. 1:500 ............................................... 294

- Plano levantamiento Molino del sol de la Costa en Ares E. 1:500 .............................. 295

- Plano levantamiento Iglesia de Sant Jaume en bel E. 1:500 …..................................296

- Plano levantamiento Iglesia de Sant Marc de la Barcella E. 1:500 …........................ 297

- Plano levantamiento Iglesia Nuestra Señora de la Asunción de Xert E. 1:500 ..............298

- Plano levantamiento ermita de Santa Isabel de Canet E. 1:200 ….............................299

- Plano levantamiento norias y regadío entorno Santa Isabel E. 1:500 ….....................300

- Plano levantamiento Santuario Virgen de la Salud en Traiguera E. 1:500 ….................301

- Plano levantamiento Iglesia Arciprestal Santa Maria de Sant Mateu E. 1:500 .............. 302

- Plano levantamiento Iglesia Sant Jaume en Coratxar E. 1:500 ….............................. 303

- Plano levantamiento Santuario de Sant Pau en Albocacer E. 1:500 …...................... 304

- Plano levantamiento Torre ermita de la Barcella E. 1: 200 ….................................... 305

- Plano levantamiento Torre de lers Solsides E. 1:200 ........................................... 306

- Plano levantamiento Torre molinar E. 1:500 …................................................. 307

- Plano levantamiento Torre de Calig E. 1:500 …............................................... 308

- Plano levantamiento Puente del Molinar E. 1:200 …............................................ 309 
- Plano levantamiento puente Pobleta de San Miguel E. 1:500 ………………………........310

- Plano levantamiento Horno de Sant Mateu E. 1:500 ……................................................

- Plano levantamiento Palau Mestral de Sant Mateu E. 1:500 …………………………........312

- Plano levantamiento castillo de Cervera E. 1:1.000 …..........................................................313

- Plano levantamiento Casa Comunal de Ares E. 1:500 ……...................................................314

- Plano levantamiento casa Comunal de Catí E. 1:500 ……………………………………...315

- Plano levantamiento Fuente/abrevadero de la Roca en Canet E. 1:500 …….....................316

- Plano de superposición redes de muros e infraestructuras en la Batllia de Cervera y su

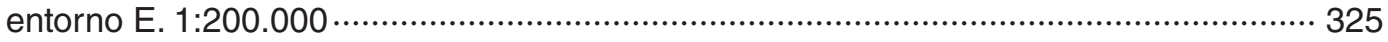

- Planos de superposición redes de muros e infraestructuras en las zonas de estudio $1,2,3,5,6,9,10$ y 12 E. 1:75.000

- Plano de superposición redes de muros y parcelario en la Batllia de Cervera y su entorno E. 1:200.000.

- Planos de superposición redes de muros y parcelario en las zonas de estudio $1,2,3,5,6,9,10$ y 12 E. 1:75.000.

- Plano de superposición redes de muros y usos agrícolas en la Batllia de Cervera y su entorno E. 1:200.000.

- Planos de superposición redes de muros y usos agrícolas en las zonas de estudio $1,2,3,5,6,9,10$ y 12 E. $1: 75.000$.

- Plano de superposición redes de infraestructuras y parcelario en la Batllia de Cervera y su entorno E. 1:200.000

- Plano de superposición redes de infraestructuras y parcelario en las 12 zonas de estudio E. 1:75.000.

- Plano de superposición redes de infraestructuras y usos agrícolas en la Batllia de Cervera y su entorno E. 1:200.000.

- Plano de superposición redes de infraestructuras y usos agrícolas en las 12 zonas de estudio E. 1:75.000.

- Plano de superposición redes de parcelario y usos agrícolas en la Batllia de Cervera

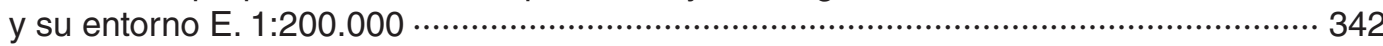

- Plano de superposición redes de parcelario y usos agrícolas en las 12 zonas de estudio E. 1:75.000.

\section{CAPÍTULO 5: PLANIMETRÍA ESTRUCTURA DEL TERRITORIO}

- Plano superposición topografía simplificada y red de muros en la Batllia de Cervera y su entorno E. 1:200.000

- Planos superposición topografía simplificada y red de muros en las zonas de estudio $1,2,3,5,6,9,10$ y 12 E. $1: 7.500$ y $1: 37.500$ 366-369

- Plano superposición topografía simplificada y redes de infraestructuras E. 1:200.000

- Planos superposición topografías simplificadas y red de infraestructuras en las 12 zonas de estudio E. 1:7.500 y 1:37.500

- Plano superposición topografía simplificada y red de parcelación E. 1:200.000

- Planos superposición topografías simplificadas y red de parcelación en las 12 zonas de estudio E. 1:7.500 y 1:37.500

- Plano superposición topografía simplificada y redes de usos agrícolas E. 1:200.000 ‥ 384 
- Planos superposición topografías simplificadas y red de usos agrícolas en las 12 zonas de estudio E. 1:7.500

- Plano levantamiento lugar/mas de les Cardones E. 1:1.000 …...........................................401

- Plano levantamiento lugar/mas d'Insa E. 1:1.000 …....................................................... 402

- Plano levantamiento lugar/mas del Regall E. 1:1.000 …................................................... 403

- Plano levantamiento lugar/mas de Maciá E. 1:1.000 …….................................................... 404

- Plano levantamiento lugar/molinos molinar E. 1:2.000 …………............................ 405-406

- Plano levantamiento lugar/molí d'oli en Cervera E. 1:1.000 ….......................................... 407

- Plano levantamiento lugar/molino del sol de la costa E. 1:1.000 …...................................408

- Plano levantamiento lugar/ermita de la Barcella E 1:1.000 ……................................. 409-410

- Plano levantamiento lugar/iglesia Xert E. 1:1.000 …….................................................... 411

- Plano levantamiento lugar/ermita Santa Isabel E. 1:1.000 ……....................................412-413

- Plano levantamiento lugar/Santuario Virgen de la Salud E. 1:1.000 ….............................414

- Plano levantamiento lugar/iglesia Sant Jaume Coratxar E. 1:1.000 …................................415

- Plano levantamiento lugar/calle en Bel E. 1:500 ….........................................................416

- Plano levantamiento lugar/plaza de Sant Mateu E. 1:500 …….......................................417

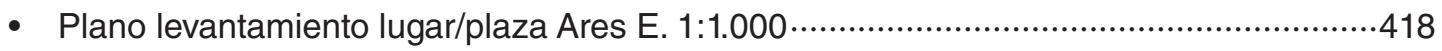

- Plano levantamiento lugar/castillo de Cervera E. 1:2.000 …..............................................419

- Plano levantamiento lugar/torre de les Solsides E. 1:1.000 ….......................................... 420

- Plano levantamiento lugar/puente Pobleta de San Miguel E. 1:1.000 ……..................421-422

- Plano levantamiento lugar/Palau Mestral de Sant Mateu E. 1:1.000 ….............................. 423

- Plano levantamiento lugar/fuente -abrevadero de la Roca E. 1:1.000 …............................ 424

- Plano levantamiento lugar/abrevadero Sant Mateu E. 1:4.000 …………………….......... 425

- Plano levantamiento lugar/abrevadero Belladona en Ares E. 1:4.000 …………............... 426

- Plano levantamiento tejido agrícola secano entorno Bel E. 1:5.000 ….............................. 437

- Plano levantamiento tejido agrícola secano de masías en la Barcella E. 1:7.500 …....... 438

- Plano levantamiento tejido agrícola regadío en masías del Molinar E. 1:7.500 …............ 439

- Plano levantamiento tejido agrícola y de secano en Canet E. 1:7.500 ………................... 440

- Plano levantamiento tejido agrícola de regadío en Canet E. 1:7.500 ……........................ 441

- Plano levantamiento tejido preindustrial (molinos) en el Molinar E. 1:5.000 …................ 442

- Plano levantamiento tejido preindustrial (molinos) en Ares E. 1:4.000 …………............... 443

- Plano levantamiento tejido defensivo Molinar/ Xert E. 1:10.000 …….................................. 444

- Plano levantamiento tejido urbano de Traiguera E. 1:2.000 …........................................... 445

- Plano levantamiento tejido urbano de Ares E. 1:2.000 …................................................... 446

- Plano levantamiento tejido urbano de Les Albaredes en Portell E. 1:1.000 …..................... 447

- Plano levantamiento ciudad compacta: Sarañana E. 1:1.000 …..................................... 453

- Plano levantamiento ciudad en cadena: Bel E. 1:1.000 …….............................................. 454

- Plano levantamiento ciudad radial: Morella E. 1:4.000 …….................................................... 455

- Plano levantamiento ciudad en malla: Sant Mateu E. 1:5.000 ………………………......... 456 



\section{1. Presentación}

El ecólogo Ramón Margalef en el prólogo de su libro "La Biosfera entre la termodinámica y el juego" dice: "La vida combina acontecimientos e información sobre el espacio y el tiempo. Acontecimientos aislados que se podrían comparar a echar una moneda al aire, resultan ser movimientos de una partida muy complicada que se está jugando sobre un tablero amplio y cambiante".

La comparación que hace Margalef del territorio con un tablero de juego, merece ser explicada con más detenimiento. El territorio no es más que un soporte natural, que se ha ido transformando a lo largo de los siglos por la acción del hombre, e integrándose en él, conformando un medio ambiente humanizado. Es un tapiz con relieve, formado por dos tejidos que se entrelazan y se superponen uno con otro, aunque en un primer momento no lo percibamos. Este "tablero de juego" responde a dos organizaciones distintas, un tejido de carácter biofísico y otro cultural; es el fruto de la simbiosis de la organización del territorio como ecosistema y la organización antroposocial que la civilización humana ha desarrollado sobre este soporte natural originalmente virgen.

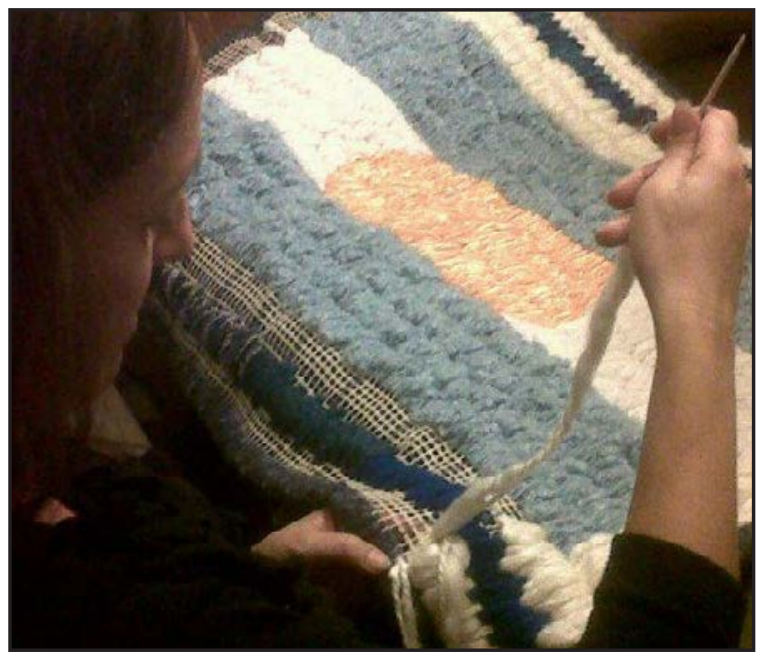

Fig. 1. 1. Mujer tejiendo un tapiz sobre un cañamazo.

En el tapiz considerado, el ecosistema es el "tejido conectivo" o cañamazo que sirve de armazón o sostén, mientras que la organización antroposocial es el "tejido funcional" o tapizado, en el que se sustancia la actividad cultural humana. Cada una de estas dos visiones o tejidos nos permite conocer fragmentos de nuestro tablero, pero a nosotros nos interesa conocerlo completo. Las dos realidades están impregnadas una de la otra, la naturaleza tiene un carácter cultural y la cultura uno natural.

Sobre el tablero, sin pausas, se desarrolla el "juego" de la vida que obedece a unas reglas físicas determinadas. La "partida" no tiene fin, el propio tablero va modificándose como parte del juego. Como en el ajedrez, el conocimiento de las reglas, la información de partidas anteriores depositada en el tablero y en la memoria del jugador, condicionan el desarrollo del mismo. No es el simple azar el que lo dirige.

¿Cuáles son las leyes físicas que condicionan tanto las reglas para el desarrollo de la partida como para la modificación del tapiz/tablero? Los dos tejidos, el del ecosistema y el antroposocial, están compuestos de materia y energía. La materia para ser transformada necesita de la energía, sin ésta la materia está muerta.

Algunos autores a esta energía le llaman "inmenso depósito de fatigas". Para el ilustrado italiano Carlo Cattaneo, en su libro editado en 1925 "Agricoltura e morale", el territorio como realidad física es manufactura del trabajo humano: "la fatiga construye las casas, los diques, los canales, las vías" (Texto citado por A. Rossi en "La Arquitectura de la ciudad".'

Otros autores como D'Arcy Thompson en la introducción de su libro "Sobre el crecimiento y la forma", editado por vez primera en 1917, lo comparan con una "fuerza": "la forma de cualquier porción de materia tanto viva como inerte, y los cambios de forma que se manifiestan en su crecimiento y sus movimientos, pueden en todos los casos describirse como debidos a la acción de

1 MARGALEF LÓPEZ, R. "La biosfera entre la termodinámica y el juego” pág. 8

2 Texto citado por ROSSI, A. "La Arquitectura de la ciudad” pág. 107 
una fuerza. En resumen, la forma de un objeto es un “diagrama de fuerzas” en el sentido, al menos, de que a partir de él podemos juzgar o deducir las fuerzas que están actuando o han actuado sobre él; es un diagrama -en el caso de un sólido- de las fuerzas que se han aplicado sobre él en el momento de su conformación, junto con aquellas que le capacitaron para retener dicha conformación". 3

La estructura, crecimiento y forma del tapiz se atribuye en un primer momento a la aplicación de las leyes físicas de la mecánica, de las trayectorias. El territorio es interpretado como una estructura jerárquica de fuerzas que actúan entre sí; esta interacción queda asegurada con un dispositivo básico de sincronización, un sentido de orden. La materia que conforman los tejidos del tapiz/tablero tiene un orden perceptible reflejo de una estructura subyacente física, social o cognoscitiva. En definitiva el territorio es un sistema compuesto de elementos y de las interacciones que ponen en relación a unos elementos con otros, que dan la apariencia de un orden natural.

Durante gran parte del siglo XX se sigue estudiando las formas. ¿Cómo surgen?, ¿Cómo se transforman? ¿Cómo crecen? De los numerosos estudios que se realizan destacaremos el llevado a cabo por el ingeniero francés Robert Le Ricolais sobre la visión topológica de la realidad. Su idea de forma no va ligada a nuestra percepción sensorial de la realidad, ya que rechaza la importancia de la imagen por el carácter engañoso que a menudo tiene nuestra percepción del mundo. ${ }^{4}$ No entiende la forma como algo estático, sino como algo dinámico y fluido en continua transformación unido a los parámetros del tiempo y del movimiento, como ocurre en los seres vivos. Lo importante es encontrar lo que permanece pese a los continuos cambios. Por ello su interés por la topología, esa rama de las matemáticas que estudia las propiedades de los cuerpos geométricos que permanecen inalteradas por las transformaciones continuas. ${ }^{5}$

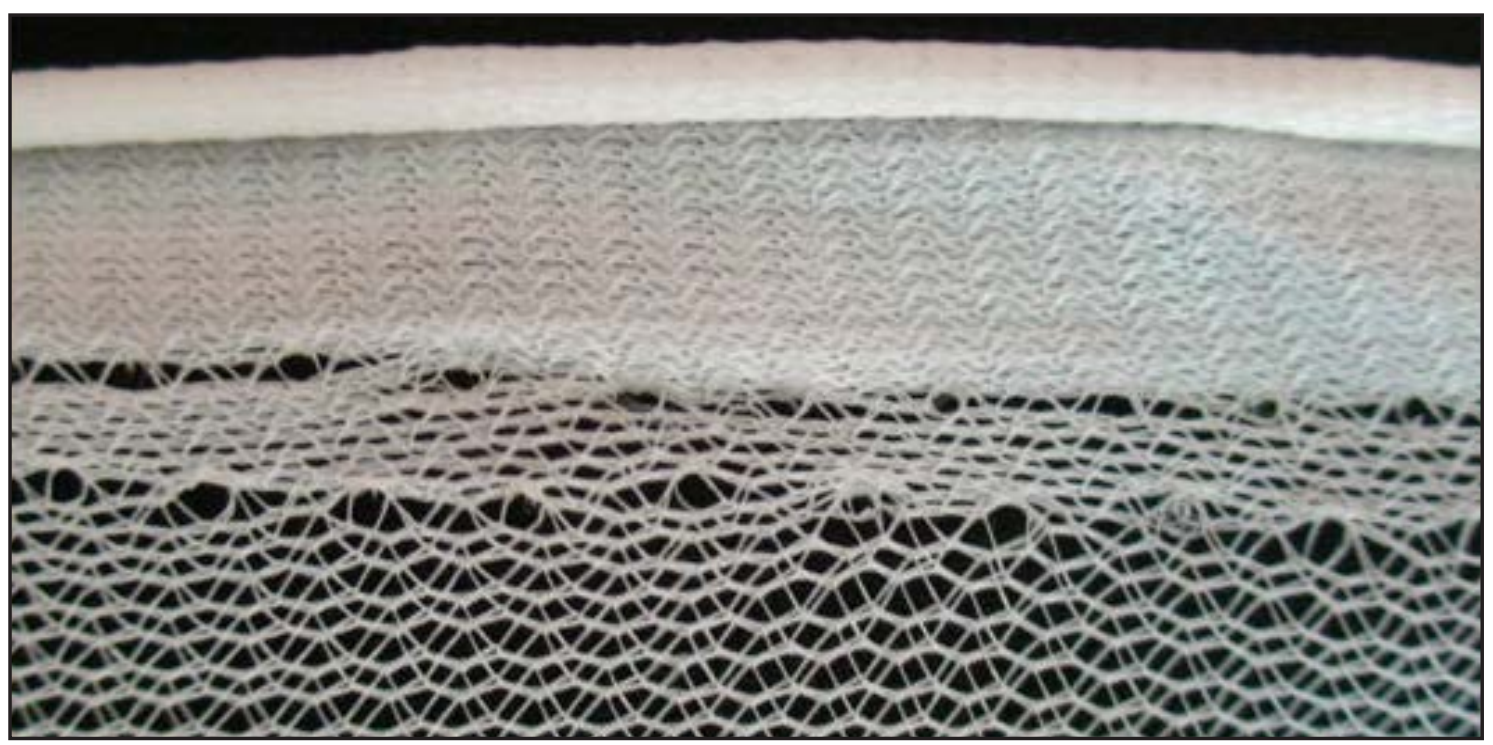

Fig. 1. 2. Tejido y cañamazo.

Este mundo estructurado, ordenado y transformable de estos textos del siglo XX no se contradecía con la concepción mecanicista del Universo. Sin embargo, ya a mediados del siglo XIX esta teoría

3 THOMPSON, D’Arcy “Sobre el crecimiento y la forma” pág. 10

4 JUÁREZ CHICOTE, A. “El universo imaginario de Louis Kahn” pág. 33

5 De una forma intuitiva se presenta la topología como la "geometría del chicle", ya que a diferencia de la geometría euclidiana, en topología dos objetos son equivalentes en un sentido mucho más amplio, ya que esta permitido doblar, estirar, encoger, retorcer, etc. los objetos pero siempre que se haga sin romper ni separar lo que estaba unido, ni pegar lo que estaba separado, por ejemplo un cubo topológicamente es igual que una esfera. 
se había derrumbado con la concepción termodinámica del mismo. El mundo heredado de Kepler, Galileo, Copérnico, Newton y Laplace de movimientos perpetuos, de orden implacable, de medida, de equilibrio, de trayectorias; se sustituye por el mundo de Carnot, Joule y Clausius de movimientos irreversibles, de desorden, de gasto, de desequilibrio, de procesos.

El segundo principio de la termodinámica dice que parte de la energía utilizada en un determinado proceso de transformación de la materia se pierde en forma de calor que provoca el desorden de las moléculas de las materias procesadas. Esta parte de energía que se pierde y no vuelve a poder utilizarse para generar trabajo en futuras acciones sobre la materia, se llama entropía. Por tanto este principio nos dice que: la cantidad de entropía del Universo tiende a incrementarse en el tiempo.

El mundo material pasa de estados ordenados a un desorden siempre creciente, y el estado final del universo será el del máximo desorden. Así, Max Planck, en sus conferencias sobre física teórica pronunciadas en la Universidad de Columbia en 1909, decía: "Por lo tanto, no es la distribución atómica, sino la hipótesis del desorden elemental, lo que forma el verdadero núcleo del principio del aumento de la entropía y, por consiguiente, la condición preliminar para la existencia de la entropía. Sin el desorden elemental no hay entropía ni procesos irreversibles". ${ }^{6}$

¿Cómo se pueden organizar en nuestro tapiz las estructuras del ecosistema y antroposocial, si en las sucesivas transformaciones de la materia se tiende hacia el desorden? ¿Cómo se articula el segundo principio de la termodinámica y las ideas de entropía con el aumento de la complejidad física? ¿De donde surge el Orden?, ¿Cómo se desarrolla con cada vez mayor complejidad el Orden? ¿Por qué percibimos el Orden?

Para dar respuesta a todas estas preguntas desde mediados del siglo pasado numerosos pensadores han construido un pensamiento filosófico que da cuerpo y sustenta una metodología que da respuesta a las cuestiones que plantean la filosofía, la economía, la ecología, la sociología y la arquitectura.

Tras la crisis energética de los años 70, se desarrollaron estudios de los aspectos energéticos de los sistemas ecológicos como métodos generales para la aplicación de las leyes básicas de la energía y la materia en los sistemas complejos de la naturaleza y el hombre. Los análisis energéticos ayudaron a responder a muchas de las cuestiones que planteaban estas ciencias.

Al considerar los sistemas en términos de energía, el mundo pierde un tanto de su desconcertante complejidad; situaciones de los más variados tipos y dimensiones resultan ser casos particulares de unos cuantos tipos básicos.

Desde una visión general del mundo basada en la teoría de sistemas, la aplicación de los flujos de energía tanto en los sistemas ecológicos, los procesos bioquímicos microscópicos o los grandes sistemas globales del hombre, ayudan a examinar los grandes problemas de la economía, la contaminación, el territorio, la población, etc. liberándolos de los corsés de las teorías al uso.

Entre los estudios realizados en esos años -finales del siglo pasado- citaremos siete por ser los que más nos pueden ayudar a entender el Territorio:

- El primero de ellos es el libro del ecólogo Howard T. Odum "Ambiente, energía y sociedad", publicado en 1971. Para él los fenómenos de la biosfera, incluidos la naturaleza y el hombre, se pueden medir y representar mediante trayectorias de potencia que forman sistemas susceptibles de representación mediante diagramas de flujo de energía. "Todos y cada uno de los fenómenos que tienen lugar sobre la Tierra entrañan un flujo de energía potencial que discurre desde las fuentes hasta disiparse como calor siguiendo trayectorias determinadas por fuerzas que se originan en depósitos de energía. (...). Los flujos de energía a través de complejas cadenas alimentarías y de sistemas económicos y culturales siguen las leyes básicas, y podemos usar esas relaciones cuantitativas si nos damos cuenta de que los flujos del mundo macroscópico son en esencia paralelos a los flujos de poblaciones de elementos grandes y pequeños, incluidas las poblaciones de moléculas, células, organismos, personas, grupos profesionales, y otras asociaciones de componentes activos". ${ }^{7}$

6 Texto citado por ARNHEIM, R. "Hacia una psicología del arte; Arte y Entropía” pág. 340

7 ODUM, H.T. “Ambiente, energía y sociedad” pág. 60 
- El segundo se publica en 1971 por Harvard University Press de Cambridge: “The Entropy Law and the Economic Process" del economista Nicolás Georgesc-Roegen; la traducción en español es de 1996: "La ley de la entropía y el proceso económico" y es editado por la Fundación Argentaria. Tiene una visión "pesimista", la entropía es necesidad que conduce irremediablemente hacia el desorden. "Puesto que el proceso económico consiste materialmente en una transformación de baja en alta entropía, es decir, en deshechos, y, dado que esa transformación es irrevocable, los recursos naturales han de constituir necesariamente parte de la noción de valor económico; y, supuesto que el proceso económico no es automático sino deseado, los servicios de todos los agentes, humanos o materiales, pertenecen también a la misma faceta de esa noción. Por otro lado habría que resaltar que sería totalmente absurdo pensar que el proceso económico existe solamente para producir deshechos. La conclusión irrefutable de todo ello es que el verdadero producto de ese proceso es un flujo inmaterial, el placer de vivir.(...) Y, por muy paradójico que pueda parecer, es la Ley de la Entropía, una ley de la materia elemental, la que no nos deja otra opción sino la de reconocer el papel de la tradición cultural en el proceso económico. Tal como lo proclama esta ley, el derroche de energía se produce de forma automática en todas partes, y esta es precisamente la razón por la que la inversión entrópica contemplada en cada línea productiva lleva el sello indeleble de la actividad deliberada; además, el modo en que esta actividad se planea y se lleva a cabo depende por supuesto de la matriz cultural de la sociedad de que se trata". ${ }^{8}$

- El tercero se publica en Francia en 1977, es "El Método I. La naturaleza de la Naturaleza" del filosofo Edgar Morin. En él se pretende articular la ciencia del hombre con la ciencia de la naturaleza; propone a partir del segundo principio de la termodinámica una concepción compleja de la relación orden/desorden/organización. Para él, el problema del conocimiento de la naturaleza no se puede disociar del de la naturaleza del conocimiento. Estudia desde dos puntos de vista complementarios: el conocimiento físico en su enraizamiento antroposocial y el conocimiento de la realidad social en su enraizamiento físico.

En definitiva se trata de un método que analiza la realidad desde el punto de vista termodinámico. El orden, el desorden y la organización son las bases sobre las que desarrolla su análisis. A partir de la idea de entropía y del dialogo entre orden y desorden construye un método de análisis de la realidad, siendo algunas de sus claves: la organización por partes, la existencia de emergencias y constreñimientos, el mantenimiento de lo que mantiene, la morfostasis y reorganización permanente, la negentropía, la memoria, la organización del conocimiento, la relatividad del observador.

- El cuarto es el libro del químico Ilya Prigogine y de Isabelle Stengers: "La nueva alianza. Metamorfosis de la ciencia", publicado en 1979. En el se da respuesta a dos interrogantes fundamentales de la naturaleza y como en el prólogo del libro destacan sus autores: "La primera cuestión es la relación entre lo ordenado y lo desordenado, entre el orden y el desorden. La famosa ley del crecimiento de la entropía, del segundo principio de la termodinámica, describe un mundo en evolución hacia el desorden, hacia la muerte térmica. Sin embargo, la evolución biológica y la evolución social nos aparecen con emergencia de organizaciones complejas a partir de formas más sencillas. ¿Cómo es ello posible? ¿Cómo ocurre que tales estructuras, ordenadas, surgen del desorden? (...).

La segunda cuestión es aún más básica. La física cuántica, la mecánica cuántica, describen una evolución irreversible y corresponden a una visión estática del tiempo. No hay auténtica evolución y no es posible con ellas una clara distinción entre ordenado y desordenado o caótico. La "información" tal y como cabe definirla con ellas no cambia con el tiempo. Hay, pues, una contradicción obvia entre visión estática de la dinámica y la evolución que nos señala la termodinámica. ¿Que es, en qué consiste la irreversibilidad? ¿Qué es la entropía? (...) Ya empezamos a esbozar respuestas, a entender de manera precisa la relación entre 
dinámica y termodinámica. Una tal visión unificada transforma profundamente las ideas que habitualmente nos guiaban en el estudio de la materia. Ya no es suficiente pensar que el mundo material se rige por leyes puramente deterministas y predictivas, cuyo conocimiento nos permitiría, en principio, prever toda evolución y, así, poder manipularla a placer. (...) Hemos de aceptar la materia dotada de actividad intrínseca limitadora de nuestras posibilidades de conocimiento y, a su vez, de nuestras posibilidades de manipulación y de predicción".

- El quinto es el libro de J.E. Lovelock "Gaia, a new look at life on Earth" Ed. Oxford University Press en 1979 y editado en español en 1985 por Ediciones Orbis S.A. Lovelock plantea la hipótesis según la cual "la materia viviente de la Tierra y su aire, océanos y superficie forman un sistema complejo al que puede considerarse como un organismo individual capaz de mantener las condiciones que hacen posible la vida en nuestro planeta". ${ }^{10}$ A este "organismo" le denomina Gaia y según él las interacciones existentes entre las partes orgánicas -incluida la especie humana- y las inertes del planeta -incluidas las actuaciones del hombre-, se rigen por las leyes de la termodinámica y le permiten mantener las condiciones gracias a las cuales la Tierra es hábitat adecuado para la vida al "comportares como un sistema cibernético por retroalimentación que se encarga de mantener en el planeta un entorno física y químicamente óptimo para la vida". ${ }^{11}$

- El sexto es el libro ya citado del ecólogo Ramón Margalef, publicado en 1980, al que debemos la elaboración del vínculo entre las estructuras materiales de la naturaleza y la información: "la información o la forma aparecen siempre asociadas al desarrollo histórico. En un mundo que ya posea cierta estructura, cualquier interacción entre materia y energía- que significa un aumento de la entropía- modifica la estructura y hace que los cambios futuros sean más predecibles y no menos predecibles que en un momento anterior". ${ }^{12}$ En definitiva la construcción del espacio resulta del reconocimiento progresivo de la información.

- Por último en 1991 el arquitecto Luis Antonio Fernández-Galiano publica "El fuego y la memoria", para él "la arquitectura o, si se prefiere, la construcción del entorno artificial, se presta admirablemente al estudio en términos termodinámicos". ${ }^{13}$ Así mismo en el primer capítulo de su libro nos dice: "Cuando no es ignorada, la irrupción de la energía en el universo de la arquitectura desbarata sus imágenes cristalinas, agita su perfil mudo y la instala definitivamente en el ámbito de los procesos y de la vida. La arquitectura se contempla entonces como transformación del ambiente material por seres vivos y cambiantes, continuamente modificada para adecuarse a las variaciones de uso y del entorno, en permanente degradación y reparación ante las agresiones del tiempo, interminablemente gestándose y pereciendo". ${ }^{14}$

$\mathrm{Al}$ mismo tiempo, en este periodo de tiempo hemos asistido a la seducción de la sociedad occidental y su cultura por el término paisaje; desde todos los ámbitos culturales -del arte, de la filosofía, de la geografía, del urbanismo...- se habla de él como uno de los acervos más importantes de nuestro planeta. Surgen por doquier estudios de todas estas disciplinas que estudian este concepto desde distintos puntos de vista aportando nuevas ideas y arrojando nueva luz sobre él, que por primera está en peligro la Tierra y por ello desde todos los ámbitos se intenta estudiar, preservar y valorar como un bien que debemos de transmitir a las civilizaciones futuras.

9 PRIGOGINE, I y STENGERS, I. “La nueva alianza. Metamorfosis de la ciencia” pág. 3

10 LOVELOCK, J.E. “Gaia, una nueva visión de la vida sobre la Tierra” pág. 4

11 LOVELOCK, J.E. “Gaia, una nueva visión de la vida sobre la Tierra” pág. 16

12 MARGALEF LÓPEZ, R. “La biosfera entre la termodinámica y el juego” pág. 19

13 FERNÁNDEZ-GALIANO, L.A. "El fuego y la memoria. Sobre arquitectura y energía” pág. 75

14 FERNÁNDEZ-GALIANO, L.A. "El fuego y la memoria. Sobre arquitectura y energía” pág. 23 
El paisaje en la sociedad mediática en la que vivimos, en la que la naturaleza se ha convertido en un producto publicitario, se ha trocado en un objeto de "culto". Como dice Javier Maderuelo en su libro "El Paisaje, génesis de un concepto", "Nuestra cultura consumista nos ha conducido a una "cosificación" del paisaje". ${ }^{15}$

La palabra paisaje significa en la cultura occidental tanto el territorio real, como una representación -pictórica, literaria...- de ese territorio; mientras que en las culturas orientales existen palabras de raíces distintas para denominar estos conceptos, uno nombra al territorio real y otro a su representación.

Ello es así por que en la cultura occidental estos conceptos han surgido y se han desarrollado juntos. Es evidente que ante esta doble interpretación del concepto de paisaje, autores como Javier Maderuelo dan su importancia al segundo concepto. Para ellos "el paisaje no es un ente objetual ni un conjunto de elementos físicos cuantificables, tal como lo interpretan las ciencias positivas, sino que se trata de una relación subjetiva entre el hombre y el medio en el que vive, relación que se establece a través de la mirada."16

Para él:

"El paisaje, en cuanto idea que representa al medio físico, es lo otro, algo que se encuentra fuera de nosotros y nos rodea, pero en cuanto constructo cultural es algo que concierne muy directamente al individuo, ya que no existe paisaje sin interpretación.

Existen unos elementos físicos, como montañas, valles, bosques, ríos, praderas, asentamientos humanos, costas o rebaños de animales, que son mensurables y cuantificables y, como tales, pueden ser objeto de narraciones literarias y catalogaciones científicas o pueden ser descritos y registrados en documentos notariales y mercantiles, también pueden ser representados en dibujos o planos y recogidos en fotografías. Estos elementos, entre otros, constituyen el "sustrato físico" de lo que entendemos por paisaje.

Para nombrar el conjunto de esos elementos utilizamos el término"paraje" que designa un sitio o lugar dispuesto de una manera determinada. Pero para que estos elementos antes nombrados adquieran la categoría de "paisaje", para poder aplicar con precisión ese nombre, es necesario que exista un ojo que contemple el conjunto y que se genere un sentimiento, que lo interprete emocionalmente.

El paisaje no es, por lo tanto, lo que está ahí ante nosotros, es un concepto inventado o, mejor dicho, una construcción cultural. El paisaje no es un mero lugar físico, sino el conjunto de una serie de ideas, sensaciones y sentimientos que elaboramos a partir del lugar y sus elementos constituyentes. La palabra paisaje, con una letra más que paraje, reclama también algo más; reclama una interpretación, la búsqueda de un carácter y la presencia de una emotividad". ${ }^{17}$

¿Pero es posible disociar estos dos conceptos - paisaje y paraje- de una forma tan clara como plantea Maderuelo? ¿No se utilizará el mismo vocablo porque es difícil disociarlos?

Busquemos la ayuda de otras palabras y conceptos para intentar aclarar esta situación. Cuando hablamos del hombre nos estamos refiriendo tanto a su propia constitución física a los elementos materiales que lo conforman y a la forma en la que estos se agrupan, estructuran y relacionan; como al concepto inventado, la construcción cultural formada por el conjunto de ideas, sensaciones y sentimientos que representa la construcción cultural que es el hombre para nuestra sociedad. Es también una construcción cultural que concierne al individuo y como este lo filtre a través de los valores culturales de la sociedad en la que vive. Estas dos facetas son ciertas y no puede existir una sin la otra. Para conocer al hombre es condición necesaria estudiar y conocer las dos, no es suficiente conocer solo una de ellas, ambas son complementarias. Sin la cultura el hombre no seria lo que es, pero sin una saludable estructura física de poco sirve la cultura.

15 MADERUELO, J. "El paisaje, génesis de un concepto” pág. 17

16 MADERUELO, J. “El paisaje, génesis de un concepto” pág. 12

17 MADERUELO, J. “El paisaje, génesis de un concepto” pág. 36-37 
Por ello la medicina desde hace ya siglos entendió que era prioritario comprender como estaba constituido y como funcionaba el cuerpo humano, como es la estructura física que da soporte al hombre. Para ello diseccionó el cuerpo del hombre, desmenuzó sus elementos, tejidos, órganos y sistemas, para conocerlo y a partir de ahí entender como funcionaba y saber como crece, envejece y sobre todo como poder tratarlo ante la enfermedad. Y así descubrir que su funcionamiento depende de como se relacionan los distintos elementos entre sí y como intercambian la materia y la energía con el mundo que les rodea.

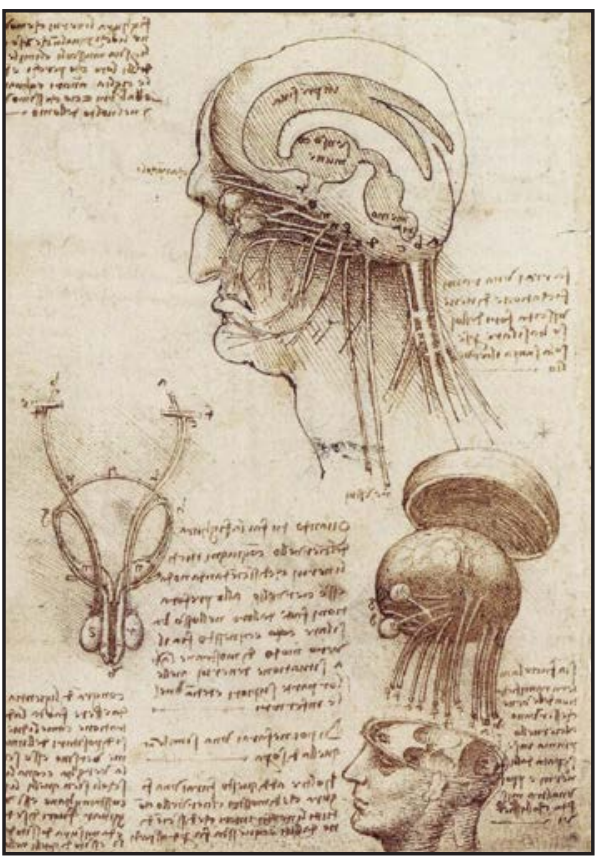

Fig. 1. 3. Dibujo del cerebro humano realizado por Leonardo da Vinci en colaboración con el médico Marcantonio de la Torre en 1510-11.

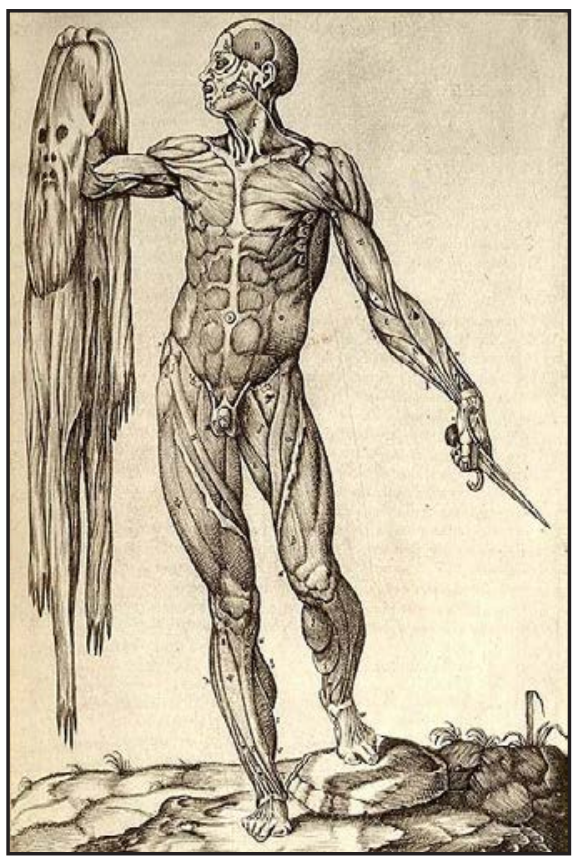

Fig. 1. 4. Dibujo de Vesalio de la anatomía del cuerpo humano, del libro "De Humani Corporis Fabrica" publicado en Basilea en 1543.

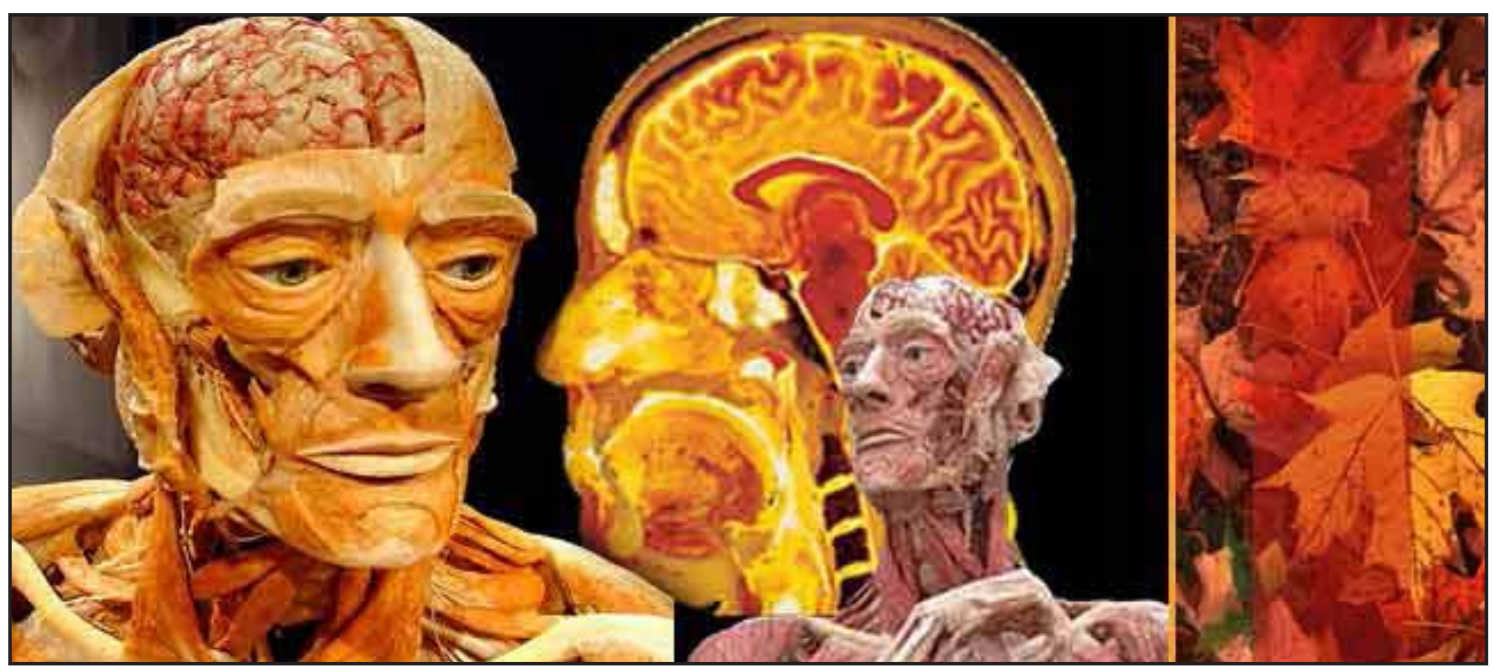

Fig. 1. 5. Imagen de la exposición "Más allá de la piel" (Human bodies).

Desde los bellos dibujos de Leonardo (1452-1519) o de Vesalio (1514-1564) o la exposición "más allá de la piel" (Human Bodies) que se inicio en 2005 y que se ha expuesto en diversas ciudades del mundo; nos muestran como debajo de la piel de un bello cuerpo existe una estructura conformada por elementos, tejidos, órganos y sistemas que es la que da vida a esa imagen externa del hombre que aparece ante nuestros ojos. Para que podamos disfrutar de la vida -y con ella de la cultura- existe una compleja maquinaria que funciona debajo de nuestra piel. 
¿Que pasaría si le quitáramos la "piel” al territorio y observáramos lo que "oculta”? ¿encontraríamos una estructura formada por elementos, tejidos, órganos y sistemas como en el cuerpo humano? ¿debajo de un bello paisaje, como debajo de la piel de un bello cuerpo, no habrá una maquinaria que permite que viva? ¿si no mantenemos con vida el territorio, como podremos mantener los valores culturales que atesora?

Para dar respuesta a estas preguntas vamos a estudiar un determinado territorio en un momento determinado-la Edad Media- y vamos a diseccionarlo, a desollarlo y estudiar su estructura interna, sus elementos, tejidos, órganos, sistemas y a analizar como funciona como se relaciona esos elementos dentro de la estructura y con las estructuras vecinas.

Hemos elegido este territorio por encontrarse él y sus vecinos, prácticamente "congelado" desde la Edad Media en la que se configuró tal y como hoy en día podemos percibir. No pensemos en él como un territorio primitivo sino como uno con una vigorosa juventud en comparación a lo que en la actualidad representan nuestros "ancianos" territorios urbanizados de la franja costera. Del mismo modo que en biología los estudios de embriología nos ayudan a conocer la estructura de los cuerpos adultos y desarrollados, pretendemos que el estudio de la estructura de un territorio "joven" nos permita entender la estructura de nuestros actuales territorios. 


\section{2. Objetivos del estudio}

El objetivo es “desollar" el paisaje para desvelar la estructura del territorio, buscar las leyes geométricas para la lectura de las formas naturales y artificiales que permitan estudiar la relación entre la naturaleza y la intervención humana, y así establecer las leyes que regulan el territorio como realización que se conforma, crece y envejece. El análisis se preocupa, pues, de conocer las relaciones espaciales tanto sintagmáticas como sincrónicas, la forma y la evolución de las dos subestructuras -la ecológica y la antroposocial- que entretejidas conformar el tapiz del territorio. El análisis ha de permitir una definición del territorio y ha de evitar, al mismo tiempo, el peligro de caer en un conocimiento meramente abstracto, vacío.

Podemos distinguir dos fines en nuestros objetivos: uno cognoscitivo y otro propositivo.

Empezaremos el primero realizando una descripción, lo cual significa definir, es decir, clasificar. La clasificación es una reducción esquemática, una abstracción, un apartarse de la realidad estudiada. Para evitarlo nos apoyaremos en aportaciones extradisciplinares a la arquitectura y realizaremos la clasificación en dos fases:

- Una primera contemplará clasificaciones realizadas por criterios extradisciplinares (geográficos, históricos, económicos...) que contemplen el territorio desde distintas perspectivas y aseguren una visión completa, alejando el peligro de ilusiones ópticas a que este sometido el que ve la imagen desde un solo punto de vista.

- Una segunda fase, íntimamente ligada a la primera, será más ambiciosa; se tratará de buscar los criterios clasificatorios en el interior del propio territorio -del tapiz-. La visión del territorio como sistema nos permite una clasificación estructural de la realidad basada en las relaciones que se establecen en su interior entre unos elementos y otros. En esta tarea, las relaciones externas- geográficas, sociológicas, económicas- mantienen un papel inexcusable, pero solo en la medida en que iluminan las relaciones interiores.

Podríamos decir que se trata de una clasificación estructural, que se apoya en el mismo territorio, en las relaciones que se establecen entre los distintos elementos y las relaciones de cada una de las subestructuras -ecosistema y antroposocial- así como las relaciones entre ellas y el conjunto total.

A partir de la clasificación previa de los elementos del ecosistema obtendremos una serie de elementos que analizaremos sincrónica y diacrónicamente. De las relaciones que se establecen entre ellos obtendremos las topologías de los distintos ecosistemas que aparecen formando un conjunto que da sentido y continuidad a la forma territorial, a la forma del "tapiz de juego".

Partiendo de la clasificación previa de los elementos antroposociales, estableceremos en primer lugar las relaciones sincrónicas con las que construimos los tipos como abstracción racional. La tipología es entendida como el sistema constituido por las invariantes que pueden ser deducidas de la morfología. De las relaciones diacrónicas encontraremos las permanencias, como aquellos elementos que perduran a lo largo del tiempo.

La tipología permite una comprensión estructural de los tejidos del ecosistema y antroposocial. "Los tipos aparecen allí doblemente determinados por una cultura y una localización; pero esta determinación no significa en absoluto un determinismo. En un punto determinado y en una época concreta son posibles varias soluciones, si bien las huellas de las ocupaciones anteriores siguen marcando la forma urbana". 18

De la interacción en el soporte natural a través de la forma construida de la cultura humana, siguiendo las directrices que nos marca la topología del soporte, obtendremos modelos formales de disposición, de organización que irá desde los más simples o lugares, a los tejidos, a las ciudades y a los más complejos o partes completas del Territorio que denominaremos como tipologías territoriales de las

18 PANERAI, P. “Elementos de análisis urbano” pág. 158 
estructuras antropogeográficas. Este será desde el punto de vista cognoscitivo nuestro objetivo. "Como ha sido observado por muchos, más importante que la naturaleza misma de las cosas, bien sean moléculas, átomos o electrones, lo que importa es el modo de disposición que estas partículas elementales y sus agrupaciones adoptan". ${ }^{19}$

Desde el punto de vista propositivo o proyectual, pretendemos tener instrumentos útiles que nos permitan "Restaurar el Territorio",y para ello no solo debemos de conocer la estructura del Territorio sino también su funcionamiento.

Analizaremos el Territorio desde el punto de vista termodinámico ya que partiremos de la hipótesis de que se trata de una estructura disipativa autoorganizativa. El Territorio es algo más que la piel que llamamos paisaje y llegar a entender como es y como funciona nos permitirá actuar en él para conservarlo y restaurarlo. Tenemos que mantenerlo vivo, no podemos limitarnos a simples operaciones de cirugía estética; el Territorio no se puede convertir en un mero museo de paisajes, ya que esto no es sostenible. 


\section{3. Metodología: Análisis del Territorio en términos termodinámicos}

A partir de la base teórica de la Tendenza y de los escritos de Aldo Rossi, la urbanística a finales de los años 60 desarrolla una metodología que analiza los procesos territoriales, sus estructuras y formas, así como las lógicas de formación y cambio. En 1966 Aldo Rossi publica "La Arquitectura de la ciudad" que supuso el abandono de "aquellos ideales ingenuos de construir una ciudad que proporcionase al hombre un hábitat mejor y más digno, la renuncia a cualquier valor universal, la afirmación absoluta de lo subjetivo, el rechazo de la virtualidad estética de la razón. En definitiva, la sustitución de una razón absoluta y universal por un voluntarismo radical y subjetivo" (J. Luque "La ciudad de la arquitectura". ${ }^{20}$ Se cambió la inocencia de un mundo ordenado por la de un mundo sometido a un desorden generalizado con "islas" de orden.

A partir de este cuerpo teórico se construye una ciencia urbana autónoma, una ciencia que estudia y considera la ciudad como arquitectura, cuyas principales claves conceptuales son: la idea de ciudad estructurada por partes, la noción de permanencia, el valor de los monumentos y de los elementos primarios, la importancia que para el proyecto urbano adquieren lo conceptos de lugar, tipo y memoria. ¿Y no son estas claves las que postula en su método de análisis Edgar Morin? ¿No podríamos analizar el territorio en términos termodinámicos utilizando la metodología de Rossi para el análisis de la ciudad?

Esta metodología se estructura en dos fases: la primera plenamente analítica, es seguida por otra fase de síntesis y conclusión.

En la fase analítica se relacionan tres operaciones complementarias: observación, clasificación y comparación. Se trata de un método de análisis del territorio a partir de su forma. Método que descansa en la lectura codificada de las relaciones sintéticas entre los elementos formales y los factores naturales de la construcción territorial. Pretende analizar empíricamente producciones constructivas del espacio a partir de sus componentes morfológicos, entiende el territorio como un artificio elaborado y lo considera desde su orden arquitectónico, esto es, desde las abstracciones geométricas que lo guían. Este análisis se complementa con otros de criterios extradisciplinares a la arquitectura (geográficos, históricos, económicos...).

Sobre la base de esta metodología, el Laboratorio de Urbanismo de la Universidad Politécnica de Barcelona bajo la dirección de Manuel de Solá-Morales, en los años 80, analizó la estructura agraria del territorio en Cataluña. Entre estos estudios destacamos las siguientes tesis doctorales: "L'abstracció del territori" de Rosa Barba en el año 1987; "Los componentes formales del territorio rural" de X. Eizaguirre en 1990 y "La construcció de l'espai rural al Baix Empordá” de A. Aguilar en 1993.

Como en estos ejemplos, en nuestro caso, optamos por una metodología que centra su análisis en las relaciones entre elementos y factores. Tal proceder supone una toma de posición al situar el Análisis del Territorio en la confluencia entre la geografía y la urbanística, o dicho de otro modo en la intersección entre la descripción y la proposición. Nos acercamos así a un principio básico del análisis territorial que sostiene que, analizar el territorio no es únicamente representarlo, sino describir el estatuto que el hombre le da a una situación geográfica determinada.

Identificábamos una fase propiamente analítica seguida de otras de síntesis. Pues bien, ya en la fase analítica deberán estar presentes criterios, de modo que las clasificaciones obtenidas tengan una dimensión estructural; por otra parte, su aplicación es esencial en la fase de síntesis, cuando los distintos análisis formales y extradisciplinares son sintetizados en un análisis global.

Los elementos que se analizan, se ven siempre desde el prisma del proceso que les da la forma. Este será el nexo de unión con el análisis termodinámico del territorio; los procesos son los que en definitiva conforman el territorio.

20 LUQUE VALDIVIA, J. “La ciudad de la arquitectura. Una relectura de Aldo Rossi” pág. 15 


\section{Los criterios analíticos derivan de tres proposiciones básicas:}

1. Continuidad temporal: La primera de estas proposiciones sostiene que el desarrollo territorial es correlativo en sentido temporal; es decir, que en el territorio hay un antes y un después; esto significa reconocer y demostrar que a lo largo de la coordenada temporal estamos situando fenómenos que son estrictamente comparables y que por naturaleza son homogéneos. Entendido el territorio como arquitectura, su continuidad cronológica aparece como una conclusión necesaria. La construcción del territorio como obra colectiva se prolonga en el tiempo de modo que cada cambio-sustitución, destrucción o crecimientopuede y debe medirse o compararse con lo que existía antes.

La persistencia se manifiesta no solo en determinados elementos materiales-muros, acequias, ríos, colinas, valles- sino también en la posición de las construcciones, en el trazado de los caminos y de las parcelas. El territorio permanece sobre ejes de desarrollo, mantiene la posición de su trazado, crece según la dirección y con el significado de hechos más antiguos que los actuales, remotos a menudo. Pierre Lavedan desarrolla esta misma teoría, para él, la persistencia se convierte en la generatriz del plano; sus investigaciones se dirigen primordialmente a identificar esta generatriz, a comprender su virtualidad.

El territorio es una gran obra de origen colectivo interrumpida, cada generación asume el territorio como propio, lo vive, lo modifica y lo cede a las siguientes generaciones. No queda nunca concluido, pero no por ello hay que conocerlo, asumirlo y continuarlo. Tenemos que entender el territorio a partir de su continuidad temporal.

2. Continuidad espacial: La segunda proposición se refiere a la continuidad espacial del territorio; aceptar esta continuidad equivale a considerar como hechos de naturaleza homogénea todos aquellos elementos que encontramos en determinado territorio, sin suponer exista ruptura entre un hecho y otro.

En el territorio se observan hechos acotables espacialmente, adscribibles a lugares concretos; pueden identificarse zonas con características propias, sin embargo sus límites-por otra parte problemáticos en su determinación, como tendremos ocasión de comprobar- no pueden considerarse como líneas de rotura, sino quizás más bien como charnelas.

La continuidad y la diversidad, suponen entender cada uno de los elementos como parte de una unidad, de una totalidad. Ni el territorio en su conjunto puede entenderse sin atender a sus partes, ni las partes son comprensibles aisladamente.

Rossi en el análisis de la continuidad espacial, diferencia tres fases en la evolución urbana: La primera se inicia al final de la Edad Media, cuando desaparece la identidad entre lugar de trabajo y vivienda; la segunda viene determinada por la progresiva industrialización, que destruye la relación de vecindad al separa definitivamente residencia y trabajo; por último el desarrollo publico de los medios de transporte, que permite una localización de la residencia independiente del trabajo.

De forma análoga, con matices podemos extrapolar a la evolución del territorio rural tres fases sincrónicas con las anteriores y que son: La primera en la que la ciudad es un elemento más del territorio; la segunda cuando la ciudad adquiere protagonismo, se convierte en un elemento de referencia dentro del territorio y se diferencia de él y la tercera cuando la ciudad se disemina, invade el territorio y éste pierde su carácter.

3. Administración de energía. La tercera proposición sostiene que siendo el territorio un sistema termodinámico abierto sus elementos y la estructura que ellos conforman administran la energía y la información para desarrollar sus actividades.

"La relación entre forma, materia y energía; la capacidad de la materia de acumular energía como información y la necesidad de la materia de recibir energía para mantener su conformación" ${ }^{21}$ son las bases sobre las que en el territorio como tablero de juego, el hombre va

21 FERNÁNDEZ-GALIANO, L.A. "El fuego y la memoria. Sobre arquitectura y energía” pág. 76 
jugando partidas unas tras otras. El hombre en el proceso del “juego” precisa energía para mantener la forma del territorio, a la vez que hace uso de la energía almacenada en el mismo como información.

La conformación morfológica de los elementos del territorio y la relación entre ellos depende de como estos administren la energía y la información.

Explicitados los criterios analíticos, para proceder a la lectura del Territorio el análisis lo ordenaremos en dos niveles:

- Los del suelo o soporte (ecosistema).

- Los elementos de intervención que lo modifican (antroposocial).

Pretendemos descubrir la relación entre la estructura de la naturaleza y la estructura de la forma construida por el hombre. Es decir tal como dice Robert Le Ricolais "la estructura de la estructura". El propone una estructura de la forma muy cercana a la topología, una "interpretación de la forma como entidad no polarizada hacia una configuración precisa, sino tendiendo solamente hacia una configuración posible". ${ }^{22}$ La forma del territorio como una estructura abierta, fluida, susceptible de ser determinada en varias direcciones.

Para ello de cada uno de los dos niveles haremos en primer lugar un inventario de elementos que configuran la forma del sitio y de los sistemas de elementos en que se organizan. Estos sistemas serán resultado tanto de las relaciones sincrónicas entre ellos, que nos permitirá detectar los tipos; como de las diacrónicas, que nos permitirá detectar las permanencias, tanto las de carácter patológico como las que se conviertan en catalizadores del desarrollo del territorio. En definitiva, observaremos y clasificaremos los elementos y los sistemas de elementos. Posteriormente valoraremos su percepción por el hombre y el significado cultural añadido que ello supone. Dedicaremos un capítulo del estudio a cada uno de los dos tejidos analizados.

Para realizar la síntesis analizaremos la mutua relación que establecen estos dos niveles y que constituye la estructura del territorio, entendiendo como tal el orden global que hace a un lugar diferente y característico. Lo específico del lugar está en un orden global, traducible además en una condición geométrica y por tanto medible que viene de una condición de partida, el ecosistema, a la que las aportaciones construidas por el hombre, la cultura, van imprimiendo órdenes de intervención y por tanto, de lectura y de disfrute estético como complemento de la lectura funcional.

Para ello analizaremos las relaciones entre los elementos y los sistemas de elementos del soporte y de la organización antroposocial. Primero veremos las relaciones sintagmáticas simples, es decir, los "sitios" con los que se construye el territorio y posteriormente pasaremos a analizar las complejas, los lugares, para de entre ellos descubrir los "genuis loci" y por tanto la memoria del territorio. Los criterios sintéticos que usaremos derivan de tres proposiciones básicas:

\section{Intercambio de energía e información con el medio.}

Analizados los dos niveles del territorio, el del soporte y el antroposocial, al proceder al estudio de las relaciones entre ambos y de la forma en la que esta se lleva a cabo, en primer lugar hay que considerar que todo elemento territorial se relaciona con su medio y con él intercambia energía e información. El analizar los elementos del territorio desde esta perspectiva nos obligará a analizarlos siempre en relación con el entorno en el que se encuentran y no de forma individual ya que no pueden vivir aislados de él.

2. Consumo de energía e información.

En el análisis termodinámico del territorio que vamos a realizar, será un factor importante a tener en cuenta no solo el hecho del intercambio de energía e información, sino también el

22 LE RICOLAIS, R. “Louis Kahn” Architecture d'aujourd’hui nº 128 pág. 1 
consumo de las mismas. Intentaremos establecer las posibles relaciones que puedan existir entre los elementos territoriales y su desarrollo con la cantidad de energía e información que necesiten consumir para el desarrollo del territorio ¿La conformación morfológica será función de la eficiencia en el consumo de la energía y la información? ¿el emplazamiento de los elementos antroposociales en el soporte territorial estará relacionado con esa eficiencia?

\section{Constitución del hecho territorial.}

"Como tercera y última proposición hemos de admitir que dentro de la estructura urbana hay algunos elementos de naturaleza particular que tienen el poder de retrasar o acelerar el proceso urbano y que por su naturaleza son bastante destacados". ${ }^{23}$

Esta proposición de Rossi puede aplicarse no solo al análisis urbano sino también al territorial. Rossi entiende esta proposición como una conclusión de las dos anteriores; al examinarlas se evidencia que la homogeneidad -temporal y espacial- no es ni absoluta ni uniforme.

Permite identificar, sobre esa homogeneidad básica, determinados elementos emergentes que no están caracterizados ni por su peculiaridad temporal -pueden tener una naturaleza histórica o no-, ni por caracterización espacial -no necesariamente se tratara de construcciones- sino precisamente por su influencia en la construcción del territorio.

Esta proposición sostiene por tanto la existencia en el territorio, entendido como manufactura, de hechos que pueden ser identificados precisamente en su relación con el conjunto de la construcción. La circunstancia de que aparezcan como emergentes subraya la propia estructura territorial.

Pretendemos utilizar una metodología fundamentalmente gráfica que incorpore planos y dibujosesquemas que nos expliquen como es el soporte y cual es el orden formal de sus características físicas. El análisis del plano como primer paso para la actuación, permite descubrir estructuras autónomas que superpuestas constituyen la compleja imagen del paisaje urbano y rural. Estas serán, al menos, la del soporte territorial por un lado y por otro la de los elementos de intervención; las redes de muros, de infraestructuras (caminos, vías pecuarias, acequias, acueductos...); el vacío y el lleno de lo edificado, las manchas de la vegetación y el código de la parcelación rural.

Siguiendo con un proceso de cada vez más complejidad del análisis, pasaremos a analizar las relaciones sintagmáticas entre los lugares que construyen el territorio, lo que nos permitirá definir primero los tejidos territoriales de la Edad Media en este Territorio y posteriormente las ciudades y las partes completas del mismo, que nos permitirá identificar las tipologías antropogeográficas.

En definitiva pretendemos realizar un análisis estrictamente disciplinar desde un punto de vista termodinámico. Este análisis en un territorio concreto en la Edad Media, en un momento en el que empieza a crecer y desarrollarse como lo entendemos hoy en día, nos permite hacer un estudio "embriológico" sobre cuales son las pautas de desarrollo y crecimiento del Territorio desde entonces y hasta nuestros días.

23 16. ROSSI, A. "Para una arquitectura de tendencia. Escritos 1956-1972” pág. 173 


\section{4. Área de estudio}

Todo análisis ha de realizarse sobre una muestra previamente elegida y que sea significativa respecto al objeto que se esta investigando; en el análisis territorial la elección se centra en la delimitación del área que va a ser objeto del estudio.

La metodología estructural reviste aun de mayor importancia la elección del área de estudio; la clasificación tipológica requiere el análisis de las relaciones de los distintos elementos con el conjunto; los límites del área estudiada deben por tanto garantizar, al menos, la presencia de las relaciones fundamentales.

El área estudio puede considerarse una abstracción respecto al espacio del territorio; según Rossi: "Estas áreas originales pueden ser individualizadas como unidades del conjunto urbano que ha emergido mediante una operación de diferentes momentos de crecimiento y diferenciación". ${ }^{24}$

Puede ser delimitada por sus características históricas, por sus peculiaridades morfológicas o sociológicas; o bien acudir a la legibilidad territorial como ha puesto de relieve K. Lynch en sus investigaciones.

Ante los objetivos cognoscitivos y propositivos del análisis, optamos por delimitar un área de estudio no solo en el espacio, sino también en el tiempo. Los motivos para la delimitación, de forma análoga a la empleada por Carlo Aymonino para la delimitación de las áreas de estudio en la ciudad de Padua son:

- Tener una dimensión histórica y geográfica amplia que garantice los fenómenos territoriales cualitativamente complejos.

- La existencia en el área de fenómenos del pasado que habitualmente en las proximidades de las grandes ciudades han desaparecido.

- La continuidad en su propia historia que garantiza la ausencia de saltos o vacíos en su transformación y en su configuración actual.

El área estudio que analizaremos es el primitivo territorio de la Batllia de Cervera al norte de la provincia de Castellón, conformado por los actuales municipios de: Cervera del Maestre, Calig, Sant Jordi, Traiguera, San Rafael del río, Canet lo Roig, Rosell, Xert y Sant Mateu y en un periodo de tiempo concreto, el del 1169-1482 que comprende tres fases claramente diferenciadas. La primera corresponde al periodo desde la Reconquista de Cantavieja (1169) Tortosa (1148) y Alcañiz (1157) hasta el comienzo de la Reconquista del Reino de Valencia (1169-1234). El segundo corresponde al periodo desde dicho inicio hasta la creación de la Orden de Montesa (1234-1317). El tercer periodo dura hasta la muerte del Maestre Lluis Despuig (1482) que supone la pérdida de la mayor influencia de dicha Orden Militar.

La complejidad que encontramos en el área-estudio como consecuencia del doble orden de relaciones a la que ella está sometida: relaciones centrífugas con el resto del continuo territorial y relaciones centrípetas con el interior de la propia área-estudio; nos aconseja no limitar el análisis al contorno determinado por el área-estudio, así como al periodo de estudio, pues ello impediría conocer las relaciones que el área mantiene con el resto del territorio, relaciones que intervienen decisivamente en su configuración.

Por ello en ocasiones analizaremos elementos de territorios vecinos de condiciones análogas o trasladaremos el análisis a épocas anteriores o posteriores a las del estudio.

24 ROSSI, A. "La Arquitectura de la ciudad” pág. 116 




\section{1. La forma y el análisis termodinámico del territorio}

\section{1. 1. Territorio y energía}

El territorio es un sistema físico complejo, integrado por un sistema disipativo y uno autoorganizativo. El territorio se ajusta a las mismas leyes de la física, que rigen la mecánica de todos los sistemas físicos. Al tratarse de un sistema complejo esta a su vez integrado por sistemas menores, una suerte de "sistemas subsumidos en sistemas". Entendemos por sistema físico al conjunto de elementos, que conforman una estructura con por lo menos alguna función común. Y la condición de "complejos" se debe a que las partes que lo constituyen, son diferentes entre sí.

Pero dicho así, un coche se ajusta a la definición, y satisface incluso, el requerimiento de ser un sistema físico complejo. ¿Cómo explicar entonces, que el territorio no es como una máquina, o como cualquier otro sistema físico inerte? Sistemas físicos complejos, hay muchos en la naturaleza. Pero no todos son capaces de recuperar la energía que disipan como información. Recuperar la energía disipada como información, es la gran diferencia. Ello nos permite generar estructura, o provocar cambios irreversibles en la misma.

La diferencia radica en la capacidad de "autoorganizarse". No todos los sistemas físicos, complejos o no, son autoorganizativos. Sólo unos pocos, cumplen con tal condición. El territorio es un sistema físico complejo que es autoorganizativo.

El sistema disipativo, genera (obviamente "transforma") energía; y el sistema autoorganizativo, recupera la energía disipada, como información. Esta recuperación de la energía como información, se aprecia en la generación de estructura, o en los cambios irreversibles de la misma, ligando indisolublemente el territorio al concepto de "historia" (producir hechos irreversibles).

A modo de simplificación, la auto-organización puede definirse como la capacidad del sistema para generar y/o modificar su propia estructura, a partir de la información que recupera de la propia energía disipada.

Finalmente, antes de considerar las leyes de la termodinámica y su impacto en este sistema físico que es el territorio, revisaremos el concepto de historia, tan ligado al territorio.

En física, historia es producir hechos irreversibles, y ello se vincula directamente con la única evidencia física que tenemos sobre la presencia de información: la estructura material (su aparición, o sus cambios irreversibles) del territorio. La información se aprecia por los cambios irreversibles de la estructura, de modo que el territorio se halla ligado de manera indisoluble a la creación de su propia historia, y el concepto de historia encuentra sus bases en la noción de información.

Se debe tener entonces, una clara idea de lo que es la información, y su significado en el marco de la creación de historia. De algún modo, el conjunto de valores de las variables de estado de un sistema físico, constituyen la información sobre el mismo. Pero esa información, puede o no estar disponible para el observador, sólo cuando esos valores se encuentran disponibles para él, dichos valores dejan de ser datos sobre el sistema para pasar a ser información sobre el mismo. O como dice Margalef, para tener información, es necesario contar con un observador que "levante acta" de lo ocurrido. Estamos ligados estrechamente al concepto de información, y a través del mismo, a la creación de historia.

Y en este marco teórico, ¿qué significado tienen las leyes de la termodinámica en el territorio?

La termodinámica es la rama de la física que estudia los valores de las variables de un sistema durante la transición entre dos estados estacionarios y describe al sistema en dicha fase. Permite conocer la energía total del sistema, así como los flujos de la misma, el grado de orden del sistema, y la información disponible sobre el mismo. Tales conocimientos permiten luego, clasificar los sistemas físicos (desde el punto de vista termodinámico) como aislados, cerrados y abiertos (el territorio). 
La idea de conocer la energía total del sistema y los flujos de la misma, nos lleva a enfrentar directamente los postulados de la primera y la segunda ley: La primera reza que la energía no se crea ni se destruye, sino que se transforma, mudando de una forma en otra. La energía es una, pero tiene diversas formas, según los efectos que provoque en el mundo físico. Así tenemos diferentes tipos, como la energía calórica, eléctrica, mecánica, química, etc.

Y sea cual sea la forma de energía con la que estemos tratando, admite a su vez que se la clasifique en cinética y potencial: nacida en la descripción del comportamiento de la energía mecánica, es aplicable a cualquiera de las formas de energía mencionadas.

Se considera energía potencial a aquella que no está provocando sus efectos en el presente, pero puede hacerlo en el futuro. En tanto que se considera cinética a la energía cuya acción o efecto, se encuentra en pleno desarrollo en el presente.

A juicio de la primera ley, todas las formas de energía son intercambiables entre sí. Es decir que, cualquier forma de energía puede transformarse en otra. Lo único que no ocurrirá, será la creación de nueva energía, o la destrucción de la misma.

Sin embargo, un hecho incontrovertible modificó la escena del pensamiento: una forma de energía, el calor, no es completamente transformable en otra forma de energía. Esto generó la aparición de nuevos conceptos, como el de "eficiencia" en la transformación de la energía. La transformación del calor en otra forma de energía, no es completa, y un porcentaje del calor quedará como tal. Así, resulta claro que una forma de energía, el calor, va en constante aumento, en detrimento de otras formas de la energía. Esto es cuantificable a través de la temperatura.

La segunda ley resume el concepto en que, el calor no es transformable completamente en otra forma de energía, y dado que la energía total es la misma, habida cuenta que la misma no se crea ni se destruye, sino que se transforma de una forma en otra, el calor va en aumento, al paso que las otras formas de energía disminuyen. Esto otorga direccionalidad a los procesos físicos que conllevan transformación de la energía: el agua del curso de los ríos erosiona el territorio, y no al revés. Toda transformación de la energía, implica entonces algún grado de irreversibilidad.

Existe pues, una flecha termodinámica que indica "en qué dirección” ocurren las cosas de manera espontánea. Todos los sucesos del mundo "clásico" macroscópico, responden a esta direccionalidad e irreversibilidad. Pero el microscópico "mundo cuántico", no reconoce esta barrera de irreversibilidad y direccionalidad. No habría problema si estos mundos no coexistieran, pero lo hacen. ¿Cómo coexisten el determinismo y el azar?, ¿cómo conviven la causalidad y la casualidad? No se pone en duda que coexistan, pero ¿cómo lo hacen?, y aún más: ¿por qué?

Los sistemas físicos como el territorio encierran parte de la respuesta. “¿Cómo funciona la $2^{\circ}$ ley de la termodinámica?" Para comprender mejor la situación, es preciso avanzar algo sobre los conceptos de orden, e información. De lo contrario, es fácil caer en falsas interpretaciones, como aquellas que "profetizan" el final de la vida en el universo, y del universo mismo, cuando el calor sea la única forma de energía presente. Así, se calcula cuándo la tierra dejará de albergar vida, cuándo el Sol dejará de brillar, y cuándo se acabará con todo el orden que se conoce, se haya conocido o se llegue a conocer. Ello es fruto de no comprender que la $2^{\circ}$ ley de la termodinámica es la misma para todos los sistemas físicos, pero su impacto sobre tales sistemas no es el mismo si se trata de sistemas físicos inertes, o de sistemas físicos autoorganizativos. En el caso de los sistemas inertes, la disipación de energía acaba con el orden en los mismos, ya que ellos no recuperan como información la energía disipada. Pero en el caso de los sistemas físicos autoorganizativos, la disipación de energía, garantiza su orden y su creciente organización, ya que los mismos son capaces de recuperar como información la energía disipada.

Ramón Margalef lo resume al sentenciar, "el truco de los seres vivos, consiste en hacerse el centro de la generación de procesos irreversibles, generando orden a partir de la energía disipada". ${ }^{25}$

La cuestión del orden se expresa con claridad en las llamadas funciones de estado termodinámico, como la entropía y la entalpía, que contribuyen a comprender el tema y a darle incluso, un mayor

25 MARGALEF LÓPEZ, R. “La biosfera entre la termodinámica y el juego” pág. 24 
alcance. La entropía es una medida del desorden de un sistema físico, y la entalpía es una medida del orden de dicho sistema.

El concepto de orden para los ecólogos supone la compartimentalización del sistema, su diferenciación y su potencial diversificación. El desorden, en cambio, supone la uniformización del sistema, así como su incapacidad de diferenciación y diversificación.

En cuanto a la cuestión de la información disponible sobre el sistema, la misma se halla estrechamente vinculada a las funciones de estado termodinámico y el grado de orden del sistema en estudio. Un aumento de la entropía, implica un incremento en la uniformización del sistema, o lo que es lo mismo decir, un mayor grado de desorden, una pérdida de la compartimentalización y la capacidad de diferenciación y diversificación. El calor es la forma de energía creciente en el sistema, mientras que otras formas reducen su presencia.

Por el contrario, cuanto más ordenado se encuentre un sistema físico, es decir, cuanto más compartimentalizado se halle, de tanta más información dispondremos sobre el mismo. La mayor entalpía, se acompañará también de una creciente capacidad de diferenciación y diversificación.

Y como el tema de la información es una parte muy importante de los sistemas físicos complejos como el territorio, ya que los mismos consisten en la asociación de un sistema disipativo que genera y administra la energía, y otro autoorganizativo que administra la información, el punto merece mayor atención.

Imaginemos un sistema físico constituido por un muro de mampostería de piedra en seco que contiene las tierras de un bancal. En un primer momento, el sistema se encuentra ordenado y perfectamente compartimentalizado, por lo que disponemos de suficiente información sobre el mismo. Sabemos con precisión el sitio exacto en donde se encuentran los distintos mampuestos-y como estos se disponen-, la grava del trasdós, la tierra de cultivo y la humedad que la misma contiene. Cuando el muro se arruina por el empuje excesivo de las tierras o por la escorrentía de las aguas, el sistema se uniformiza, se mezclan los mampuestos con la grava y con la tierra de cultivo, pierde su compartimentalización y el sistema llega al máximo grado de desorden. Entonces no disponemos de información sobre el mismo: ¿Dónde van los mampuestos y donde la grava? ¿Qué espesores han de tener? ¿Cómo se disponen los mampuestos? ¿Qué forma ha de tener el muro? Ya no lo sabemos, ni podremos volver a saberlo, ya que se trata de un proceso irreversible, a no ser que busquemos la información en otro muro vecino que no se haya colapsado.

La cuestión de contar con información y saber qué hacer con ella, es fundamental. El territorio cuenta con información, y con ella genera su propia estructura, o en otras palabras, se auto-organizan. Esta tendencia a auto organizarse, es opuesta al caos y el desorden. Sin embargo, no supone que el territorio deje de cumplir con la segunda ley de la termodinámica. El territorio se ordena, al paso que desordena el ambiente en el que se encuentra. La creciente entalpía de parte del territorio (las ciudades), se acompaña de la creciente entropía de su entorno. La tendencia general es hacia una creciente entropía, y las ciudades representan una tendencia local hacia el orden.

El territorio cumple con la segunda ley de la termodinámica, como cualquier otro sistema físico. Pero esto tampoco debe mal interpretarse. A primera vista el hecho se presta a suponer que el territorio, finalmente muere "en cumplimiento" de la segunda ley, porque la creciente entropía acaba con él.

Nada más lejos de la realidad. Autores como Ilya Prigogine y el mismo Ramón Margalef han dado fundadas pruebas, que demuestran el yerro de tal aseveración.

La creciente entropía procede de la disipación de energía, lo que explica el final de cualquier sistema físico no autoorganizativo. Pero ese no es el caso del territorio, que es un sistema físico autoorganizativo. Y la auto organización deviene, en parte, de recuperar como información la energía disipada. Esta particularidad, hace del territorio, sistema físico especial y análogo a los seres vivos.

Así, la disipación de energía, que incrementa la entropía de los sistemas físicos inertes hasta acabar con los mismos, es la fuente de la información que sostiene la creciente organización del territorio. El territorio cumple con la segunda ley, pero ello, lejos de ser su "certificado de defunción", es la garantía de su creciente orden y diferenciación. No envejece y muere por causa de la segunda ley de la termodinámica, sino por razones que están más allá de ella.

Sin embargo el territorio que veremos tiene la capacidad de recuperar la energía como información, en determinados momentos esta capacidad decrece y el territorio "envejece” ¿cuál es la causa? 
Las leyes de la termodinámica, aunque expresadas en términos de las transformaciones de la energía, comprenden las profundas relaciones entre la materia, la energía y la información. Luego, ¿cómo se verían estas leyes desde el punto de vista de la dinámica de la información?

Siguiendo a Margalef, deberíamos decir que si no está disponible, el observador no puede hacer uso de ella, y por lo tanto no tendríamos información. Quizá sea preferible decir que, si el observador no puede hacer uso de la información, no tenemos información... "disponible".

Cuando obtenemos energía a partir de la materia, no creamos energía, sino que la transformamos. La combustión de los derivados del petróleo no crea energía, sino que torna disponible la energía de los mismos. Materia y energía son dos caras de la misma moneda.

De manera análoga, cuando los sistemas físicos recuperan la energía como información, no "crean" la información, sino tan sólo la tornan disponible para el sistema. La información puede estar disponible o no, pero es una condición inherente al sistema en cuestión, habida cuenta que las variables de estado del sistema tienen un valor, más allá que el mismo se encuentre disponible o no para el observador. Existe pues, una "flecha de la información", contraria y complementaria a la comentada flecha de la termodinámica. La irreversibilidad de la $2^{\circ}$ ley de la termodinámica no se debe a que el calor no pueda ser transformado completamente en otra forma de energía, sino que esto es una consecuencia de que la información se ha tornado disponible. Cada vez que en el territorio se disipa energía, la recupera como información, disponible para el sistema bajo la forma de cambios irreversibles de su estructura. En todo esto, lo que menos importa es el calor en sí. Desde el punto de vista de la información, así funcionaría la $2^{\circ}$ ley. (Contra más fuego más información y por tanto más desarrollo del territorio, de ahí la importancia del fuego que veremos más adelante).

Esta es la razón por la que Margalef sentencia: "la $2^{\circ}$ ley, lejos de ser el certificado de defunción de los seres vivos, es la garantía de su creciente orden y diferenciación". ${ }^{26}$ Decir que el territorio se ordenan desordenando su entorno sigue siendo correcto, pero el gradiente de disipación de energía en el territorio, lleva a la degradación del mismo, pero esa misma disipación "siembra" por doquier sistemas (las ciudades) que se auto organizan, hacen que el territorio "viva" en ellos, e incluso, tenga consciencia de sí mismo.

Si las amplificaciones son irreversibles, es porque tornan la información disponible: la incertidumbre cede ante la certidumbre, la casualidad ante la causalidad, y el mundo comienza a hacerse algo más familiar. La materia no puede transmitir la información, pero puede sustentarla en su estructura, mientras que la energía puede transmitir la información, pero no puede sustentarla.

Así, la generación de estructura o los cambios de la misma, se erigen como la "manifestación" de la información. Cambios que son entonces irreversibles, ligan el territorio a la creación de historia. Sin embargo, esto de la creación de historia, no debe servir para confundir la historia con el devenir del tiempo: La historia no tiene que ver con el tiempo transcurrido, sino con la generación de hechos irreversibles. Esto es, con el flujo de la información..$^{\frac{27}{3}}$

Sea cual fuere el diseño experimental que se proponga, una vez que la información está disponible (entendiendo por disponible, que el observador accede a la misma), el proceso es irreversible.

El caso del muro de mampostería, invita a pensar que la información puede fluir también en sentido inverso al que se propone, de disponible a no disponible. Parece que la información, puede pasar del estado disponible al no disponible. Pero en realidad, lo que ocurre es que es el sistema en sí mismo el que ya no está disponible. La información no se ha tornado "no disponible", sino que se ha perdido junto con todo el sistema.

La $2^{\circ}$ ley no puede dar cuenta por sí misma, de los cambios que se operan en el flujo de la energía a la información. Y con la información como parte de este curioso círculo de transformación en

26 MARGALEF LÓPEZ, R. "La biosfera entre la termodinámica y el juego” pág. 32

27 No es el tiempo transcurrido el que termina con la incertidumbre, sino la disponibilidad de la información: Un arquitecto puede hacer hoy un proyecto y no saber si se llegará a construir, pero no basta con esperar hasta que transcurra la crisis económica actual, puede que lleguen épocas de bonanza económica y aún no saberlo. Lo único que acaba con la situación es construirlo -aunque si ya has cobrado el proyecto lo mejor es que nunca se llegue a construir-. Entonces, bromas aparte, cesa la incertidumbre. Y no lo hace por el tiempo transcurrido, sino porque la información se ha tornado disponible. Esta aparente trivialidad, encierra una de las llaves más poderosas para comprender nuestro mundo. 
el que participan también la energía y la materia, la analogía de las caras de una moneda (materia y energía) deja de ser efectiva. Esto se parece a una piedra roseta, que en una cara tiene escrita leyes de la física según la energía, en otra según la materia, y en otra según la información. Materia, energía e información, se hallan íntimamente relacionadas entre sí.

En otras palabras, la $2^{\circ}$ ley no puede explicar por qué la recuperación de energía como información crece (cuando el sistema se auto organiza), o decae (cuando el sistema declina o envejece). Luego, ¿por qué envejece el territorio?, ¿por qué se origina y auto organiza?

\section{1. 2. La Memoria del Territorio}

Los lugares en los que la información se almacena y puede recuperarse con facilidad, los llamamos memoria.

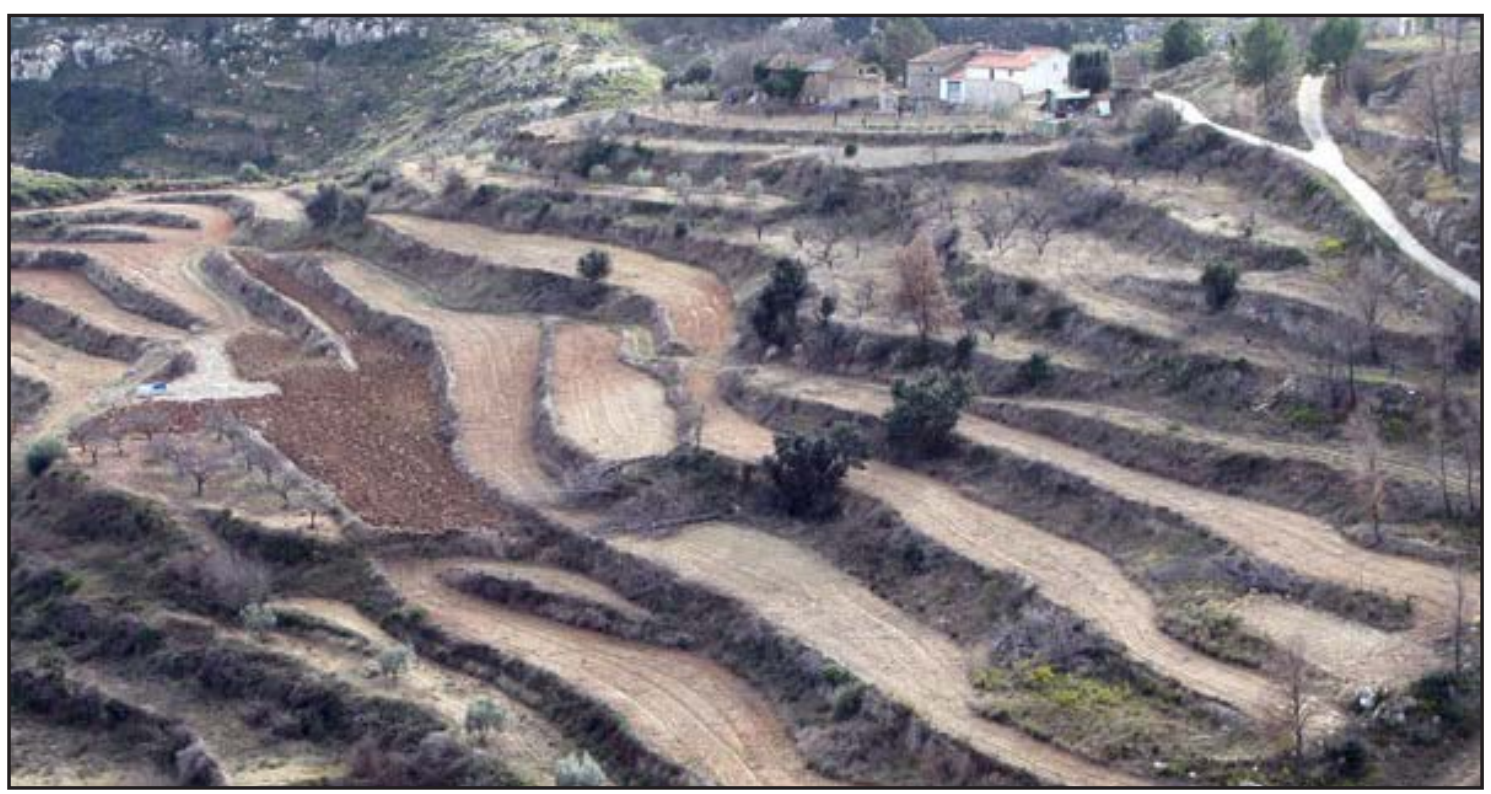

Fig. 2. 1. Terreno abancalado en la comarca de "Els Ports" en Castellón.

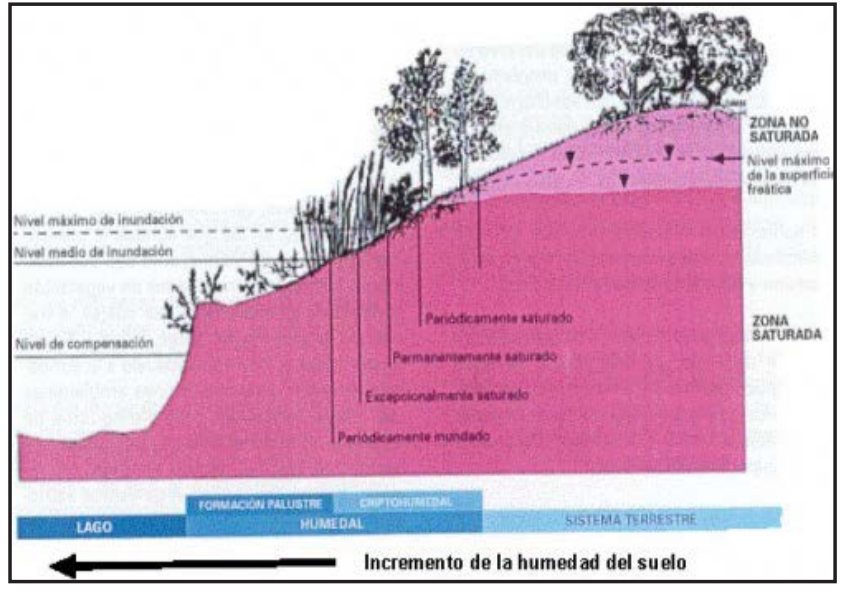

Fig. 2. 2. Dibujo esquemático del incremento de la humedad del suelo y los cambios de vegetación que comporta.
En los ecosistemas los lugares más apropiados y preferidos para acumular y almacenar información, son los límites entre sistemas. En estas fronteras, la densidad de acontecimientos es mayor y la memoria, según Margalef, "ordinariamente toma la forma de ondas estacionarias o progresivas, o bien consiste en estructuras que se pueden analizar a modo de ondas y que permiten reconstruir escenarios en el espacio y en el tiempo, como si se tratara de una holografía". 28 
Tres ejemplos de este tipo de memorias son:

- Las ondas provocadas por el mar en el lecho de arena de la playa. Las olas del mar al encontrarse con la arena de la playa, "dibujan" sobre ella una forma ondulada, no solo de granos de arena, sino también de conchas, algas, residuos...

- Las curvas termoclinas en el agua del mar o de un lago. Es la capa de transición entre la capa llamada de mezcla y la capa de agua profunda. La definición de estas capas está basada en su temperatura. La capa de mezcla se localiza cerca de la superficie, donde la temperatura se aproxima a la temperatura superficial. En la termoclina, la temperatura de la capa de mezcla baja bruscamente y alcanza la temperatura mucho más fría de la capa profunda. En otras palabras, tanto la capa de mezcla como la capa profunda son relativamente uniformes en temperatura; la termoclina representa la zona de transición entre ambas capas.

- Los ecotonos o zonas de frontera que "dibujan" ondas de diferentes tipos de vegetación alrededor de una zona pantanosa, en función del grado de humedad del suelo.

En estos casos, la forma se materializa como una holografía en el límite entre dos sistemas con distintas propiedades termodinámicas y con gradientes muy marcados.

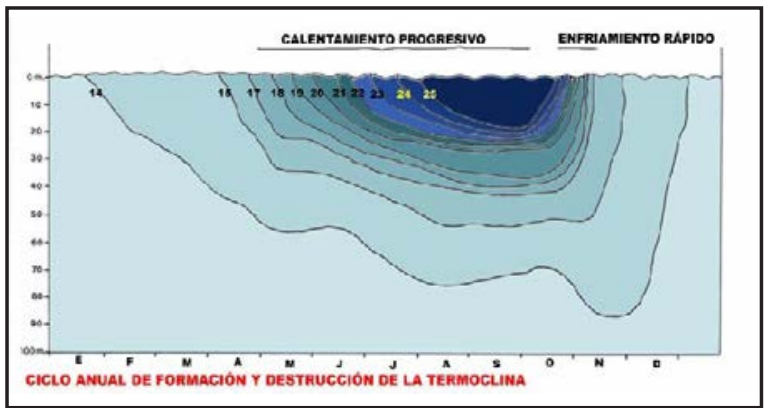

Fig. 2. 3. Dibujo de las termoclinas marcando los distintos gradientes de temperatura.
De forma análoga el hombre ha transformado el relieve, ha creado bancales para el cultivo. Este relieve humanizado, consigue un suelo de más calidad para el cultivo, por un mayor espesor y por una mayor humedad al conseguir retener el agua de escorrentía de las lluvias. Las "ondas" que dibujan los muros de contención de los bancales en el territorio, se producen en el límite, en el cambio de gradiente entre dos sistemas: el relieve del ecosistema y el de la cultura.

El Territorio se puede considerar como una membrana en la que se grava la información, como si se tratara de una holografía, o mejor una serigrafía en tres dimensiones. Retomando el símil del tapiz, el ecosistema es la malla base, mientras que la cultura es la tinta, que aplicada sobre la malla, imprime la serigrafía que es la Memoria del Territorio.

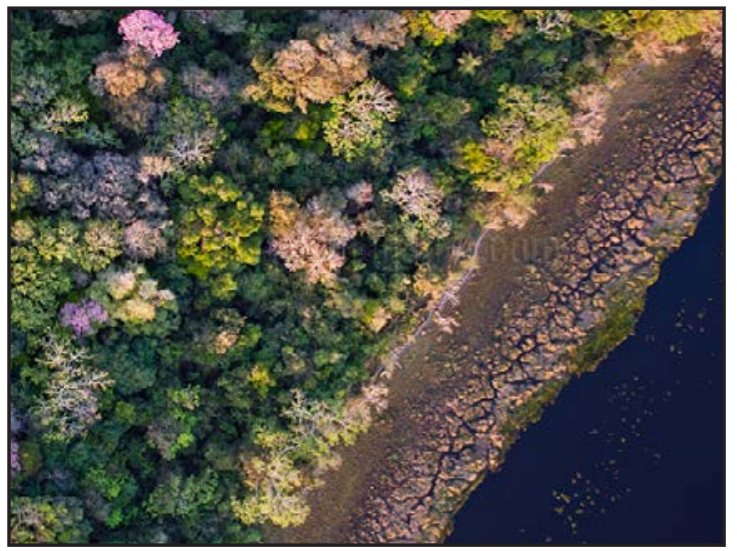

Fig. 2. 4. Foto aérea de las franjas de vegetación de un ecotono.
De forma análoga Robert Le Ricolais considera que las estructuras de la naturaleza nos presentan mensajes en clave que nos permiten ver y desvelar lentamente la propia estructura de la materia: "la cara de las estructuras un mensaje en clave que se nos envía en el modo en que las cosas se nos aparecen, descifrando lentamente, demasiado lentamente a pesar de nuestra impaciencia de saber...un despliegue de lo barroco, de lo inesperado, de las fuerzas que gobiernan nuestro universo, (...) de sus impulsos en la superficie de las cosas... Es siempre en las fronteras donde los serios incidentes afloran a la superficie.". ${ }^{29}$

29 LE RICOLAIS, R. "Matiers” pág. 114 


\section{1. 3. La forma y las fases del Territorio como sistema}

La biosfera esta compuesta de materia y de energía. Estos dos componentes se organizan en sistemas y la manera como se combinan y extienden en el espacio lo denominamos forma.

Como fruto del orden en el que se dispone la materia por la acción de la energía, surgen formas regulares por ser las configuraciones más equilibradas posibles. Esto es verdad tanto para los sistemas inorgánicos tanto como para los orgánicos, para la simetría de los cristales como para las de las flores o los cuerpos de los animales.

¿Por qué son lo más equilibradas posibles? Como consecuencia del segundo principio de la termodinámica, las estructuras surgidas de los sistemas en que actúa la materia y la energía se encuentran en un ajuste continuo de orden, motivado por los continuos desordenes a los que se ve sometido. Las estructuras "evolucionan" hacia sistemas equilibrados cada vez más ordenados y menos susceptibles de desordenarse.

El estado de equilibrio es el único en el que el sistema permanece en reposo y el equilibrio engendra el orden porque representa la configuración más simple de los componentes del sistema. De esta manera se con-forman las estructuras. Pero el sistema demanda un ajuste continuo de orden y no podemos mantener organizadas las estructuras-su forma- sino las restauramos continuamente. Igual que reparamos un coche, hemos de reparar continuamente todo tipo de estructuras.

Como cualquier otro sistema complejo podemos considerar en el desarrollo y evolución del Territorio las siguientes cinco fases: autogénesis, morfogénesis, morfoestasis, esclerosis y disolución. La primera o nacimiento de un nuevo sistema y la última o muerte del sistema sobrepasan el alcance de este estudio por lo que describiremos las tres centrales porque sí que forman parte del análisis del territorio que estamos haciendo.

La morfogénesis es el crecimiento y desarrollo del sistema por la diferenciación interna y la asimilación de elementos externos. El periodo en que estudiamos este territorio pertenece en gran parte a este fase, el territorio esta empezando a crecer y a desarrollarse. Las fases no las podemos considerar absolutamente estancas sino que se puede producir a la vez que el territorio se este creciendo a la vez que se encuentra en parte en un proceso de maduración correspondiente a la siguiente fase.

El territorio al principio se organiza en base a la disposición de la forma y no por la forma en sí misma; el territorio crece desde la multiplicidad de unidades, desde la reunión de estas de tal modo que la reunión constituya un organismo con unas leyes de crecimiento interno fruto del modo en que las partes se conectan y relacionan entre sí. En definitiva como una estructura flexible sin una forma cerrada, sino con una predisposición a una determinada evolución y crecimiento. Esta capacidad del sistema-territorio se denomina homeorhesis.

Esta capacidad va ligada a la teoría matemática, a la topología. La idea platónica de forma como estructura estática, la topología la abre a la consideración de problemas contemporáneos entendiendo la noción de forma como un "concepto más fluido" que esta "a menudo unido con el parámetro de tiempo, que implica movimiento". ${ }^{30}$

En contra de la noción de forma como algo estático y cristalizado contrapone la noción de forma "como la vemos en los organismos vivos, conectando lo estático y lo dinámico, que se hace comprensible por la relativamente reciente mecánica ondulatoria y por la comprensión del movimiento vibratorio.". ${ }^{1}$ Lo importante es la disposición, que es la que establece el marco general sobre el que se va a producir el desarrollo y evolución del territorio.

La morfoestasis, es la fase de maduración de estabilización estructural del sistema. Una vez desarrollado el sistema se mantiene por su capacidad de autoorganización. Por una parte consume

30 LE RICOLAIS, R. "Introduction to the notion of form” pág. 55

31 LE RICOLAIS, R. "Introduction to the notion of form” pág. 55 
energía para mantener su estructura, pero por otra recupera la energía que disipa como información. La capacidad del sistema para mantener la forma con el aporte de energía se denomina homeostasis y es el conjunto de fenómenos de autorregulación que intentan mantener equilibradas las composiciones y las propiedades del territorio.

"La constancia de la forma viene asegurada por la interacción dinámica de procesos catabólicos y anabólicos que se relacionan a través de un bucle retroactivo de carácter genésico, ordenador"32, que por decirlo en palabras de Morin "opera el paso de la termodinámica del desorden a la dinámica de la organización", 33

"La presencia de este bucle retroactivo permite garantizar la permanencia morfológica en situaciones de desequilibrio, como es, sin duda la del territorio considerado como un sistema termodinámico abierto, atravesado por flujos de energía y materiales". ${ }^{34}$

Un terreno abancalado dedicado al cultivo agrícola, una vez con-formado, necesita del continuo aporte de energía (cuidados y reparación) para mantener su forma, sino se arruina.

La capacidad del sistema para recuperar la energía como información se denomina histéresis y es el fenómeno por el cual el territorio presenta un estado de evolución que no depende solo de la causa que lo provoca, sino también de sus estados anteriores.

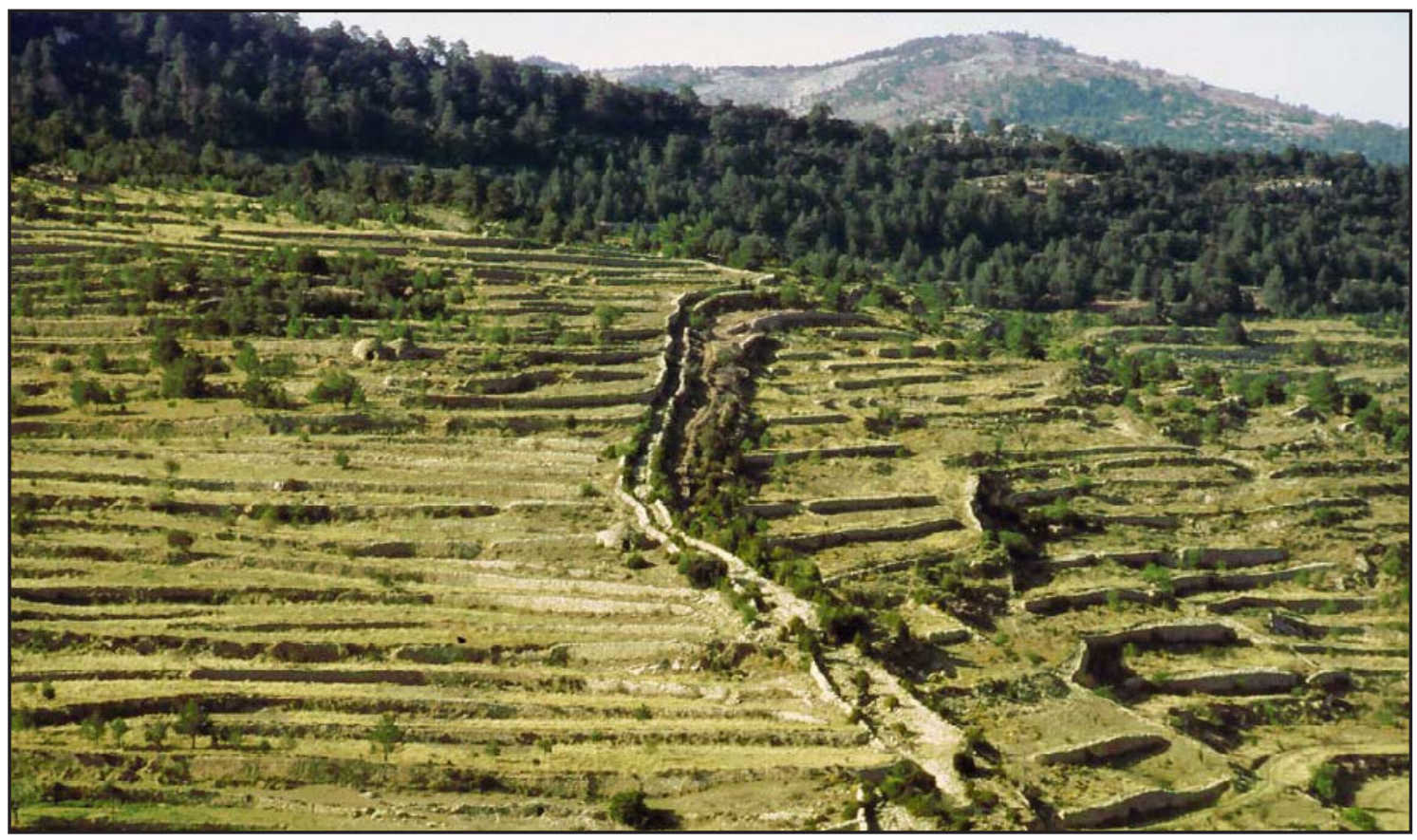

Fig. 2. 5. Foto de bancales y azagador en la comarca del Maestrazgo de Castellón.

El ecólogo Ramón Margalef, al que se debe la elaboración del vínculo entre las estructuras materiales de la naturaleza y la información, ha subrayado que "la información o la forma aparecen siempre asociadas al desarrollo histórico. En un mundo que ya posea cierta estructura, cualquier interacción entre materia y energía -que significa un aumento de la entropía- modifica la estructura y hace que los cambios futuros sean más predecibles y no menos predecibles que en un momento anterior". ${ }^{35}$ En la conformación del territorio cada modificación del relieve por la construcción de bancales escalonados sustentados por muros de piedra, condiciona y hace más predecible construcciones posteriores como

32 FERNANDEZ-GALIANO, L.A. “El fuego y la memoria. Sobre arquitectura y energía” pág. 100

33 MORIN, E. "El Método 1: la naturaleza de la naturaleza” pág. 215

34 FERNANDEZ-GALIANO, L.A. “El fuego y la memoria. Sobre arquitectura y energía” pág. 101

35 MARGALEF LÓPEZ, R. “La biosfera entre la termodinámica y el juego” pág. 19 
la construcción de un camino o el crecimiento de un núcleo de población. La energía necesaria para la construcción de los muros y el movimiento de tierras para obtener las terrazas facilitan la construcción futura del camino o de la ampliación de la población; y por otra parte puede utilizarse para la lectura de los acontecimientos constructivos pretéritos.

"La energía almacenada en la construcción -tanto en los propios materiales como en el orden significativo en que se encuentran, resultado del transporte y puesta en obra de los mismos- se proyecta pues hacia el futuro, en cuya conformación interviene, y hacia el pasado, que permite interpretar". ${ }^{36}$ La estructura urbana de una ciudad medieval como Morella es fruto del relieve de bancales de uso agrícola previo, que determina una topografía que luego es "asumida" por la ciudad; al mismo tiempo que los propios muros de contención de los bancales, pasan a ser muros de la edificación directamente. Por ello, como señala Margalef, "la información que esta presente en las estructuras actuales y que se puede utilizar en reconstruir el pasado, se puede considerar que refleja realmente la energía usada y degradada del pasado. Esta energía no se ha perdido completamente, puesto que las estructuras que ha formado o informado, siguen siendo importantes al canalizar los cambios futuros, haciendo determinados estados futuros más probables que otros. Es posible descubrir o interpretar la "utilidad" de dicha información, si estamos dispuestos a aceptar que las estructuras acumuladas hacen "más eficiente" la degradación futura de más energía" ${ }^{37}$ Los bancales agrícolas no solo se "usan" directamente para la construcción de la ciudad, sino que los propios sistemas constructivos de los bancales forman parte de la fenoteca que se usará como in-formación para futuras construcciones. "En la mayor parte de los organismos, la organización del espacio se puede relacionar con cierto consumo de energía que se recupera en parte como información, en forma de comportamiento, tradiciones, senderos, túneles, etc. En calidad de información significativa, ahorran energía en la proyección hacia el futuro (...) El espacio archiva mucha información, no solo a través de la localización y de los movimientos activos o pasivos de los organismos, más también por sus motivos de crecimiento y en la forma en que organiza el transporte, así como a través de toda clase de construcciones externas a la propia biomasa, resultado de la actividad de los organismos. Los ejemplos más espectaculares se encuentran en el hombre, pero no se limitan en particular a esta especie". ${ }^{38}$

"Como se ve, la energía se almacena indistintamente como forma (organización material del espacio) y como información (organización mental del mismo espacio); y esta acumulación facilita una mayor eficiencia, tanto en el uso del espacio como en su reproducción". ${ }^{39}$

La morfoestasis del territorio se consigue gracias tanto a la homeostasis como a la histéresis.

La esclerosis es el decaimiento y la progresiva reducción de la capacidad de fluctuación y regulación del sistema, es el envejecimiento del mismo.

El envejecimiento es la gradual perdida de la homeostasis y de la capacidad de autoorganización. Los sistemas físicos describen ciclos en un ambiente que sufre cambios lentos, ciclo tras ciclos algunos de sus variables no recobran sus valores originales, es decir, sufren un cambio de fase geométrica y la predisposición inicial topológica se ve trastocada. Ello se produce por que en el ambiente se producen cambios en su geometría lo que provoca que las variables de estado no recobren cíclicamente sus valores originales.

La tendencia al orden y a la homeostasis depende de la ausencia de cambios en la geometría ambiental que impiden la predisposición topológica inicial.

36 FERNANDEZ-GALIANO, L.A. "El fuego y la memoria. Sobre arquitectura y energía” pág. 36

37 MARGALEF LÓPEZ, R. “La biosfera entre la termodinámica y el juego” pág. 20

38 MARGALEF LÓPEZ, R. “La biosfera entre la termodinámica y el juego” pág. 132

39 FERNANDEZ-GALIANO, L.A. "El fuego y la memoria. Sobre arquitectura y energía” pág. 78 


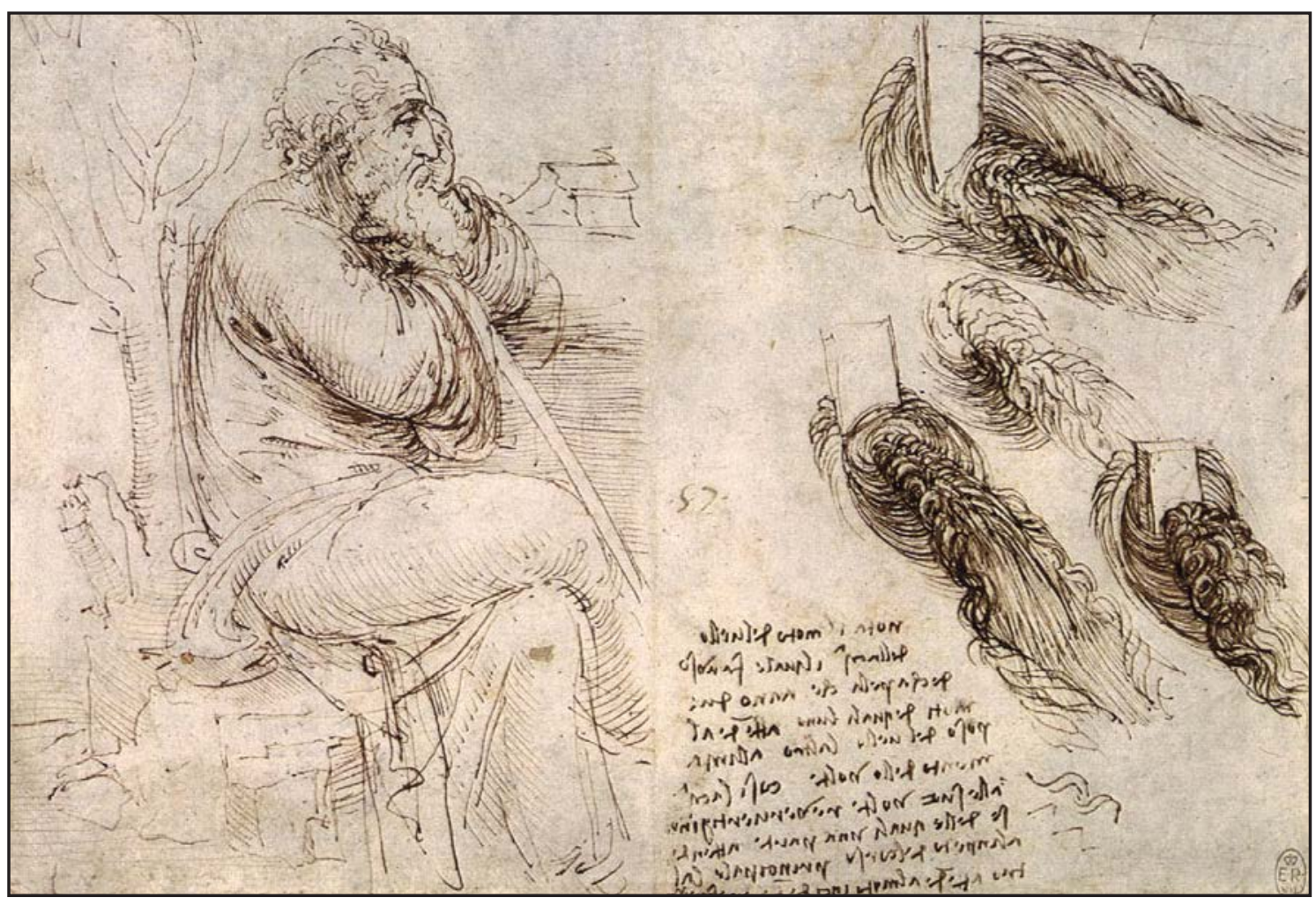

Fig. 2. 6. "Anciano pensativo" Último autorretrato de Leonardo da Vinci. Biblioteca Real, Windsor.

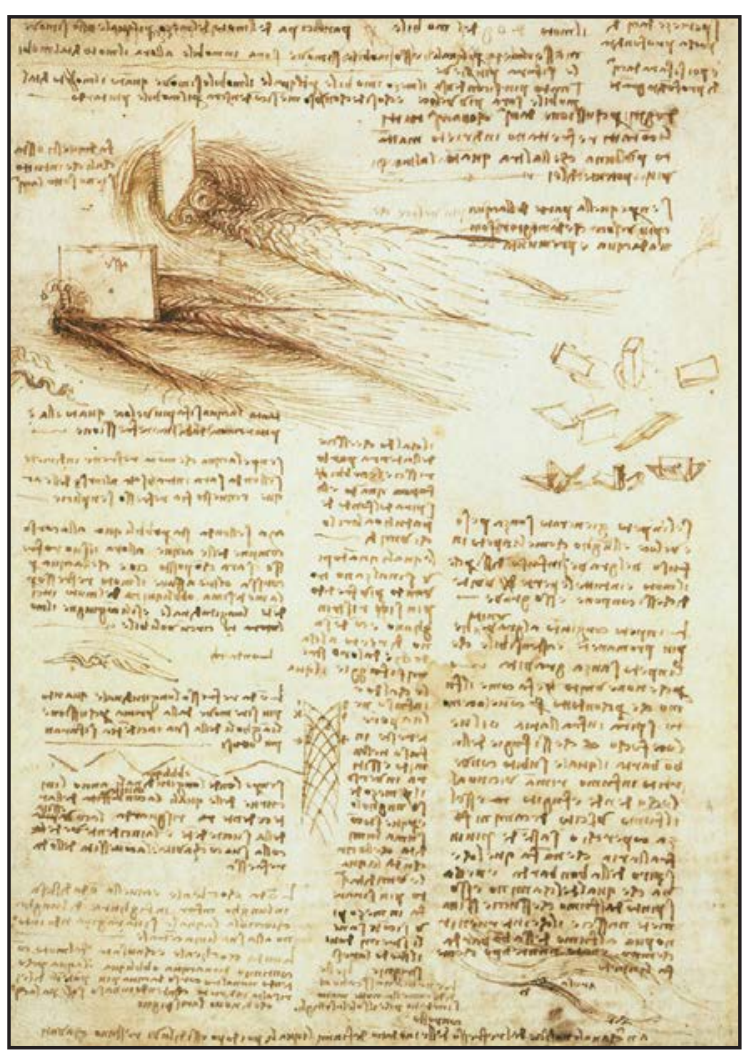

Fig. 2. 7. Dibujo del "Estudio sobre las turbulencias" de Leonardo da Vinci.

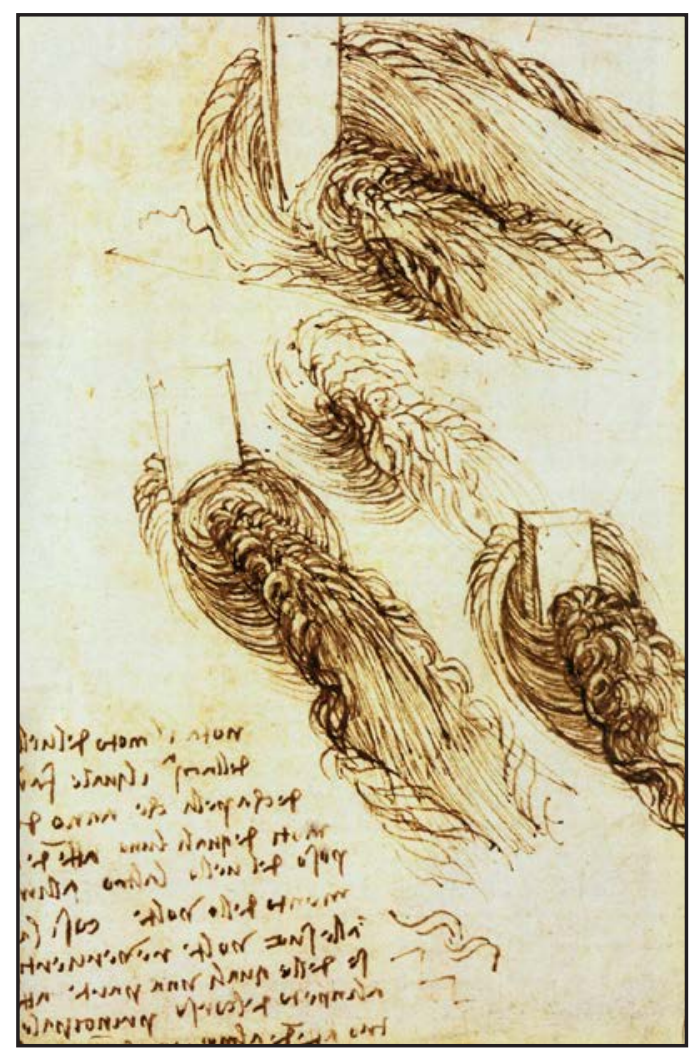

Fig. 2. 8. Dibujo del "Estudio sobre las turbulencias" de Leonardo da Vinci.

Un ejemplo paradigmático del mantenimiento de la forma por la presencia de un bucle retroactivo, es el de los remolinos de agua o aire, que ya llamaron la atención de Leonardo, y que utiliza Edgar Morin como ejemplo. Su persistencia morfológica, es debida a la existencia de un flujo de energía que lo mantiene. Si se interrumpe la corriente de energía -agua o viento-, la forma se arruina. 


\section{2. La forma y la percepción del territorio}

\section{2. 1. El observador como parte del sistema}

Desde el comienzo, desde el origen el hombre ha existido y ha permanecido presente. La comunicación es inseparable de una praxis dialéctica entre el observador y la observación de un conocimiento en bucle, donde el conocimiento físico necesite tanto del conocimiento antroposocial como este del conocimiento físico. "Del mismo modo que todo objeto debe estar integrado en su realidad física, todo sujeto debe estar integrado en su realidad antroposocial; la integración del observador en una comunidad científica, lejos de neutralizar el sujeto y de anular la subjetividad, le sitúa por el contrario en una cultura y una sociedad. Y por supuesto la realidad antroposocial necesita ser integrada ella misma en la evolución biológica, la cual necesita ser integrada en la evolución organizacional de la physis, la cual remite al observador-sujeto y así sucesivamente.

Y de este modo la relación recursiva primera que une la física del conocimiento al conocimiento de la física, nos lleva de nuevo al imposible y fabuloso viaje espiral, en el que creemos todos los riesgos de girar y dispersarnos, pero donde vemos la única posibilidad de producir método". 40

Ningún concepto físico puede ser radicalmente abstraído de su conceptuador, al igual que ningún fenómeno físico puede ser abstraído de su observador. La posición del observador, su ángulo de mira, su encuadre, determinan la naturaleza de la observación y modifican el fenómeno observado. El observador es un sujeto humano dotado de un espíritu conocedor sumergido en su praxis científica intelectual, cultural y social.

Nuestros conceptos físicos no están unidos solamente a una visión del mundo, sino que se inscriben en una praxis antroposocial unida a esta visión del mundo. Y esto, lejos de anular al observador/ conceptuador, le obliga a considerarse como sujeto, es decir a preguntarse que papel juega, donde se sitúa dentro y en relación con su sociedad, de que medios dispone para concebirla y concebirse.

El hombre percibe sucesivamente el territorio con tres tipos de percepción: formal, existencial y mental, que "enriquecen" la misma a la vez que le dan una mayor complejidad

\section{La percepción de la forma}

La cultura occidental siempre ha considerado la vista como el sentido más importante, que nos permite percibir los objetos y nuestro entorno de la manera más "objetiva".

$\mathrm{Su}$ origen podemos encontrarlo en el Renacimiento con la invención de la representación en perspectiva que hizo al ojo el punto central del mundo perceptivo. El descubrimiento de la imprenta, consiguió arrinconar la palabra hablada por la escrita y con ello la primacía de la vista en la transmisión de los conocimientos.

En el último siglo con el descubrimiento de los múltiples instrumentos que potencian aun más si cabe este sentido como el cine, la televisión, la publicidad, Internet, vivimos en una dictadura del ojo. Nuestro entorno se ha convertido en una gran escenografía en la que nosotros habitamos.

Esta situación en la que nos encontramos fue propiciada entre otras cosas por la teoría de la Gestalt que surgió a principios del siglo XX. Esta afirma que, de entre las posibles maneras de agrupar un material estimular dado, se tiende a escoger la que depara la mejor estructura y aquella en la que sus rasgos visibles resultan ser los más llamativos y los primeros en ser percibidos. Nos dice, por lo tanto, que tiene lugar una selección sobre la base de su función estructural.

Postula que las categorías perceptivas no son destilaciones intelectuales obtenidas mediante la experiencia a partir de un gran número de casos, sino más bien formas puras de la percepción visual,

40 MORIN, E. "El Método 1: la naturaleza de la naturaleza” pág. 405 
espontánea y explicable posiblemente por la tendencia a la simplicidad estructural propia de los procesos que tienen lugar en la corteza visual como respuesta a los distintos estímulos, motivada por una tendencia en nuestra percepción hacia las configuraciones simples, las líneas rectas, los círculos y otros órdenes simples, y a ver tales regularidades más que las formas al azar en nuestro encuentro con el caótico mundo exterior...

En definitiva la percepción es una respuesta a unos estímulos visuales, y por tanto las formas se adjetivan en función de cómo son percibidos por el ojo con una visión enfocada que nos convierte en meros espectadores.

Esta forma de percepción la consideramos insuficiente, más aun si analizamos el territorio de la Edad Media -antes del comienzo de la dictadura del ojo- y necesitamos saber como el observador percibía el territorio, dado que esa percepción influye en la evolución y desarrollo del mismo y por tanto en su conformación.

"La concepción de la vista como nuestro sentido más importante esta basado en hechos fisiológicos, perceptivos y psicológicos. Los problemas surgen a partir del momento en que se aísla el ojo de su interacción natural con el resto de modalidades sensoriales y de que se eliminan e inhiben los otros sentidos, con lo que se reduce y restringe cada vez más la experiencia del mundo a la esfera de la visión. Esta separación y reducción fragmenta la complejidad, la globalidad y la plasticidad innatas del sistema perceptivo reforzando la sensación de distanciamiento y alienación". ${ }^{41}$

El hombre de la Edad Media enfrenta el territorio con su cuerpo -no solo con la vista-, sus piernas miden la superficie de los campos, sus manos construyen los muros, su olfato percibe la frescura de los bosques, su mirada proyecta inconscientemente su cuerpo sobre las arquitecturas del territorio, el peso de su cuerpo se encuentra con la masa de los muros y sus manos acarician los frutos que la naturaleza le proporciona. El territorio y su cuerpo se complementan y se definen uno al otro. Habita en el territorio y el territorio habita en él.

El hombre capta lo que le rodea, lo que observa, y da forma a esas percepciones, en realidad "toca el mundo". El hombre medieval "toca la piel de su mundo con el mismo sentido de la maravilla con la que un niño raya la superficie de una ventana con escarcha”. ${ }^{4}$

\section{La percepción existencial}

Para comprender como el observador medieval interactúa con su territorio, acudimos a la concepción del espacio existencial que esta en el pensamiento de Heidegger, que nos permite entender el territorio y su estructura.

Heidegger parte de la concepción del hombre como un ser-en-el-mundo. Esto implica por una parte que no puede entenderse aislado de lo circundante y, por otra, que nuestra comprensión del territorio se relaciona siempre con el hombre.

En su obra Ser y Tiempo (1927), Heidegger analiza las estructuras básicas del Ser. Dividiendo en dos el término Ser-en-el-mundo, investiga la estructura de ser-en (Insein) así como la de mundo. Analiza las estructuras existenciales básicas. Ser-en comprende tres estructuras:

- Comprensión (Verstehen), que significa algo más complejo que entendimiento o conocimiento, Lo que es, se entiende como algo en relación con una estructura existencial. $\mathrm{Al}$ aspecto espacial de la comprensión, le llama orientación; mediante ella aceptamos el orden del territorio. El hombre para no hallarse perdido en el territorio tiene que conocerlo y saber orientarse en él.

- Estado de ánimo (Befindlichkeit), denota el carácter que constituye la relación primordial entre el hombre y lo circundante, o por decirlo en palabras de Heidegger "...los estados de

41 PALLASMAA,J. "Los ojos de la piel” pág. 41

42 PALLASMAA, J. "La mano que piensa. Sabiduría existencial y corporal en la arquitectura” pág. 143 
ánimo descubren al hombre en su estar arrojado en el mundo". ${ }^{43}$ A su aspecto espacial, le llama identificación, es decir, nuestro estado de ánimo se determina entre otros elementos por el carácter del territorio.

- Ser-con (Mitsein), designa las estructuras de relación social y asociación, tomando como punto de partida el hecho de que "el mundo es siempre lo que yo comparto con otros". La concreción espacial consiste en reuniones de gente establecidas, que determinan nuestras instituciones.

Para completar su análisis Heidegger discute el concepto de mundo. En Ser y Tiempo describe el mundo como una multitud de entes que se entienden a la luz de una mundaneidad esencial. Entre estos entes presentan especial interés lo que denomina útiles, que componen nuestro entorno pragmático cotidiano. El mundo se entiende así en términos de uso y como una especialidad. En otros escritos describe la relación existente entre el mundo y las cosas cotidianas dadas, llegando a la definición del mundo como un cuadrángulo de tierra, cielo, mortales y divinidades. "La tierra es el soporte que sirve, florece y fructifica, se extiende en roca y agua y se yergue en animal y planta. El cielo es el camino abovedado del sol, el curso de la luna y las estrellas, las estaciones y sus cambios, la luz y el ocaso del día, la oscuridad de la noche, el clima..."

La forma en la que los mortales están en el cuadrángulo, le llama habitar. Para él habitar supone algo más que estar en un lugar, significa una autentica relación entre el hombre y las estructuras existenciales. Habitar se convierte en el carácter básico del Ser.

Heidegger en Edificar, habitar, pensar subraya que los hombres tienen que aprender primero a habitar. Ser hombre significa habitar. Con habitar se designa siempre un modo de encontrarse en el espacio. Habitar caracteriza la relación del hombre con respecto al espacio, su modo de encontrase en él. La especialidad del hombre en conjunto se comprende como habitar. Habitar es construir en sentido amplio que incluye el cultivar y el compartir. ${ }^{45}$

A diferencia del espacio euclidiano que es un objeto desligado del sujeto, completamente uniforme y que se extiende en todas direcciones hacia el infinito, el espacio vivencial no está desligado del sujeto. "El espacio no esta simplemente ahí, independiente del hombre. Solo hay espacio en la medida en que el hombre es un ser espacial, es decir, que crea espacio, que lo "despliega" a su alrededor". ${ }^{46}$

\footnotetext{
43 HEIDEGGER, M. “Ser y tiempo” pág. 54

44 HEIDEGGER, M. “Ser y tiempo” pág. 93
}

45 Obsérvese la relación existente entre la concepción existencial de Heidegger y la del hombre medieval que podemos extraer de estos fragmentos de la Carta Puebla que otorga la Orden del Hospital en el Carrascal en 1237 y que figura en el apéndice documental como no 5 pág. 607.

Para ello vamos a extraer dos párrafos con su correspondiente traducción:

\footnotetext{
"faciunt totam dictam hereditatem a celo usque in abisum vobis et vestris et omni posteritati vestre damus in perpetum melius et sanius intelligi potest at vestrum vestrorum que bonum intellectum et comodum.”

"Os doy dicha heredad desde el cielo hasta el abismo para vosotros, los vuestros y toda vuestra descendencia a perpetuidad, como mejor podáis entender para el bien y comodidad de vosotros y de los vuestros."

"Et nos prenominati populatores promettimus vobis fratri Hugonis de Fullalqueiro et aliorum fractrum Hospitali quod ibi laborabimus et cultivabimus et casis faciemus et ibi habitatimus cum omnibus rebus nostris."

"Y nosotros los antedichos, prometemos a vosotros, hermano Hugo de Fullalquer y demás hermanos del Hospital, que allí trabajaremos, sembraremos, cultivaremos, edificaremos casas y habitaremos con todas nuestras cosas."
} 
El arquitecto Norberg-Schulz, en su libro "Existencia, presencia y arquitectura", concretiza las estructuras existenciales básicas de Heidegger, en tres componentes básicos:

- La topología que afecta al orden espacial y que se concreta como organización espacial. Se corresponde con el concepto espacial de orientación de Heidegger. En el análisis que realizaremos en nuestro estudio más adelante se corresponde con la parte del soporte o cañamazo.

- La morfología que afecta al como de las formas arquitectónicas y que se concreta como articulación formal en el territorio. Una organización espacial puede encarnarse en un número infinito de formas y cambia de carácter dentro de los diversos tipos de organización. Las formas en el Territorio como veremos más adelante vienen motivadas por los siguientes procesos: modelado del relieve, transporte de flujos, reparto del suelo y aprovechamiento del suelo. Estos procesos se encarnan en determinadas estructuras construidas que son las que hacen presente el estado de ánimo de Heidegger.

- La tipología que se refieren a las estructuras básicas del Ser-con de Heidegger, esto es el encuentro con los seres humanos y que se concreta con la forma concreta de un tipo particular de arquitectura. Ejemplo de ellos serían: el poblado, la calle, la plaza, la casa, la escuela, etc.

En el análisis de nuestro estudio, tal como veremos más adelante, la morfología y la tipología de Norberg-Schulz se corresponden con la organización antroposocial del territorio.

\section{La percepción mental: atmosférica}

El análisis existencial de Heidegger es básicamente un análisis del tiempo más que del espacio. Heidegger pasa muy deprisa por delante del "dónde" y se centra en el "quién", perdiendo la oportunidad de explorar la inmensa diversidad de los universos de la espacialidad humana. Este, sin embargo es el propósito principal de Peter Sloterdijk en su trilogía "Esferas", en la que rescata la poética del espacio de Gastón Bachelard: las esferas son estructuras inmunes, generadoras de espacio interior.

"Sloterdijk convoca los sentidos, las sensaciones y el entendimiento para conseguir claridad sobre lo cercano...., aquello que la filosofía pasa a menudo por alto: el espacio vivido y vivenciado. Vivimos siempre en espacios, esferas, atmósferas; la experiencia del espacio es la experiencia primaria del existir... Los fenomenólogos, sobre todo Martin Heidegger, habían comenzado en el siglo XX la búsqueda de un lenguaje para el espacio vivido y para el hombre como ser compartidor de espacio, coexistente. No es exagerado decir, sin embargo, que Sloterdijk ha elevado a un nivel completamente nuevo la filosofía de la coexistencia en el espacio común... Esferas significa, en cualquier caso, no un espacio neutro, sino uno animado y vivido; un receptáculo en el que estamos inmersos. No hay vida sin esferas. Necesitamos esferas como el aire para respirar". ${ }^{47}$

Sloterdijk retoma la gran pregunta de Heidegger: ¿dónde estamos cuando decimos que estamos en el mundo? Para responder que en burbujas, esferas, incubadoras, invernaderos, donde el hombre se construye, se protege y cambia. La vida humana se auto organiza siempre creando espacios protegidos e inmunes, del protoplasma a la vida intrauterina, del afianzamiento del hombre en su identidad a la conformación de sus espacios íntimos, sus casas, sus ciudades y sus espacios metafísicos e imaginarios.

La existencia humana tiene lugar en los mundos de las posibilidades, moldeadas por nuestras capacidades de fantasía e imaginación. El hombre vive en universos de la mente donde lo material y lo mental, así como lo experimentado, lo recordado y lo imaginado se fusionan completamente entre sí. El espacio existencial se estructura sobre la base de significados y valores que sobre él reflejan un

47 SLOTERDIJK, P. "Esferas I" pág. 14 
individuo o un grupo, ya sea consciente o inconscientemente; el espacio existencial es una experiencia única interpretada, a través de la memoria y de la experiencia del individuo.

La teoría de las esferas es un instrumento morfológico y mental que constituye un proceso bilateral entre observador y observado que permite fortalecer la imagen del espacio que habitamos mediante artificios simbólicos y dotarlo de una atmósfera en la que el hombre se encuentra protegido.

Los hombres vivimos en espacios, en esferas, en atmósferas. El hombre intenta recrear su original caverna confortable y protectora, pero las esferas están sujetas siempre al riesgo de estallar y dejarnos a la intemperie; pero el hombre es capaz de crear nuevas atmósferas en esferas más amplias que absorben a las que tenían las ya explosionadas. El ser humano descascarado busca así responder al enfriamiento exterior con el desarrollo de curiosas políticas de climatización.

Y así la evolución del hombre le ha llevado desde las microesferas íntimas como la casa, a las macroesferas como la ciudad para terminar en la espuma del actual mundo virtual. Generación, destrucción y traslado de las esferas son los ejes de la transformación del espacio que habita el hombre. 


\section{3. La forma del territorio y su representación gráfica}

Percibir el Territorio no es todavía conocerlo. Para sentirse cobijado, para desplazarse por él y en definitiva para "poseerlo" el hombre necesita conocerlo. Al percibir y dar significado a sus elementos damos un primer paso. El siguiente es realizar una construcción mental, simplificada o abstracta, que trate de describir las relaciones entre los elementos del territorio.; ello supone cierta compatibilidad entre el funcionamiento de la naturaleza y el cableado de nuestro cerebro, es decir, su lógica.

El paso que se da a partir de la Edad Media con la representación gráfica de la percepción del territorio le añade aun más si cabe una mayor complejidad. Poco a poco conforme se desarrolla ésta sobre un soporte "ajeno" al territorio percibido, se va configurando una realidad "virtual" paralela a la propia del Territorio.

La influencia entre la técnica de la representación y el objeto representado es mucha, las cosas en ocasiones son según como se perciben o representan, llegándose hoy en día, gracias a, los medios informáticos, a la representación de una realidad virtual autónoma y capaz de existir sin el soporte de una materialidad.

En la elaboración de la idea y en la construcción de la misma es imprescindible un documento que explique y lo haga reproducible a través de leyes geométricas elementales y que a la vez permita, en el proceso de construcción de la idea, verificarla en cada momento. El plano es el documento que, hasta ahora, ha resultado más idóneo para fijar los datos que un proyecto ha de tener de su soporte y del entorno que lo contiene.

La ciencia que se ocupa de esta descripción es la cartografía, entendida como evaluación del estado de hecho de la superficie de la tierra, y esta herramienta es tan importante por sí misma, que en todos los documentos monográficos dedicados al estudio del territorio siempre hay un espacio dedicado a la representación, como herramienta fundamental de conocimiento.

La cartografía no es una técnica de representación plana de un ámbito a partir de la indicación de los contornos físicos de los distintos elementos del territorio, a la manera de testimonio objetivo de este, sino que es una forma de lectura analítica que describe este ámbito a partir de la idea que tenemos del territorio. Creer posible una visión aséptica del territorio como se ha pretendido a partir de la fotogrametría, es no entender la naturaleza histórica del espacio que se esta representando y por tanto el valor de cada uno de los elementos que se incluyen en la representación. ${ }^{48}$

La representación gráfica de un territorio nos puede ser útil para: conocer su estructura, orientarnos en él y como exponente de una determinada cultura.

Para poder llegar a conocer la estructura es necesario considerar dos puntos de partida opuestos: por un lado la abstracción artística es la representación de algunas de las características estructurales de una forma organizada. Por otro lado, el sentido y la expresión de un dibujo se manifiestan solo en la medida en que la representación consta de formas bien definidas en cuanto a forma, proporción, dirección, color, etc. Percibir una cosa, lo mismo que representarla, significa encontrar una forma abstracta en su estructura.

Comprender el mundo con arreglo a la estructura más sencilla posible es algo de la mayor importancia biológica, porque la forma visual se aproxima bastante a la estructura física de la mayor parte de las cosas con las que tenemos de vérnoslas. La virtud de hacer fielmente justicia al objeto es esencial no solo para la orientación sensorial elemental, sino también para los objetivos del filósofo, del científico y del artista.

Para orientarnos en un primer momento se utiliza el propio territorio como soporte. Del mismo modo que Hansel y Gretel, en el cuento infantil de los hermanos Grimm, marcan el camino de vuelta a casa con migas de pan, el hombre "marca" su territorio para reconocerlo.

Para conseguir este objetivo, inicialmente las culturas primitivas recurren a la concepción simbólica del espacio. Mediante la utilización de símbolos "señalan" y caracterizan determinados puntos del

48 SOLÁ-MORALES, M. “La identitat del territori” pág. 51 
espacio que les permite imaginarlo y dominarlo. Los primeros mapas se realizan "in situ", el territorio es su soporte.

Cuando la cultura se desarrolla, el hombre dispone de otras herramientas para conseguir este objetivo. La invención del código de la escritura y del dibujo, permite obtener representaciones escritas o grafiadas del espacio en el que el hombre vive pudiendo así abstraer el espacio en el que vive, obtener una reproducción del mismo en el que se indican sus características: limites, virtudes, peligros... El territorio deja de ser el soporte y la representación se desliga del territorio; por ello la cartografía más primitiva se realiza de las rutas marítimas, ante la imposibilidad de "marcar" un espacio uniforme y homogéneo como es el mar.

$\mathrm{Al}$ mismo tiempo, sin embargo, hasta las reacciones sensoriales elementales ante el mundo están sujetas a las condiciones de los mecanismos receptores y a medida que vamos ascendiendo por la escala de lo orgánico, cada vez resulta más difícil pasar por alto la forma del receptáculo que efectúa la recepción. Las experiencias previas, las normas y preferencias convencionales, las creencias y esperanzas, los deseos y los temores, todo cuenta a la hora de configurar la imagen del mundo concebida por la mente creadora.

Cada cultura y cada época han representado el territorio de una forma. El problema de expresar un conocimiento por medio de la confección de mapas, significa hacer del dibujo un instrumento de representación, afrontando, junto a las cuestiones de lenguaje, los problemas de criterio que eso comporta. ${ }^{49}$ Así pues la representación consiste en crear, valiéndose de un medio en concreto, un equivalente de un concepto perceptual. Hay que encontrar una manera de traducir el precepto en forma tangible. Es obvio que tal labor no la efectúa el lápiz sobre el papel, sino la mente que lo guía y juzga los resultados.

El valor del plano dibujado está no solo en enseñar el territorio, sino en presentar una forma de verlo. No es solo un testimonio objetivo de este, sino que es una forma de lectura analítica que describe este ámbito a partir de la idea que tenemos de él. Creer posible una visión aséptica del territorio como se ha pretendido a partir de la fotogrametría, es no entender la naturaleza histórica del espacio que se esta representando y por tanto el valor de cada uno de los elementos que se incluyen en la representación. ${ }^{50}$ Por tanto la propia representación gráfica se convierte en un nuevo elemento cultural que entra a formar parte de la concepción que el observador tiene del territorio.

49 SOLÁ-MORALES, M. “La identitat del territori” pág. 12

50 SOLÁ-MORALES, M. “La identitat del territori” pág. 51 

CAPÍTULO 3. ORGANIZACIÓN DELTERRITORIO COMO SOPORTE EL ECOSISTEMA Y SU RELIEVE 



\section{1. Los elementos del Territorio como soporte, su análisis y su representación gráfica}

El relieve lo consideramos como el tejido base o cañamazo sobre el que se desarrolla la actividad humana. El hombre ha construido sobre el relieve adaptándose a sus condiciones topográficas. La identificación de las huellas del hombre sobre el Territorio y los elementos topográficos considerados representativos, son importante porque permiten encarnar la vocación del territorio que durante tanto tiempo ha presidido la lectura geográfica; como dice Vidal La Blanche, existe una correlación de carácter determinista de los hechos sobre un tipo geológico de origen.

Analizaremos en primer lugar los elementos que con-forman el soporte, las formas del relieve. Posteriormente estableceremos las relaciones sincrónicas entre ellas, las volumetrías que son el punto de partida, el recipiente para ser llenado.

Más adelante analizaremos las relaciones diacrónicas que se establecen entre ellos, es decir, como el paso del tiempo afecta a los mismos. Esta evolución esta condicionada por una parte por la disposición topológica de los volúmenes y por otra por los aspectos climatológicos: la temperatura, la insolación, las precipitaciones, el viento, así como por las pendientes del relieve; en definitiva como en todos los ecosistemas por la fuerza de la gravedad, el agua y la luz solar. Estas relaciones nos interesan en cuanto el soporte es apto para que se desarrolle en él la agricultura, ya que este es el uso primordial que le dará el hombre en la Edad Media.

El análisis lo hacemos con el apoyo instrumental fundamental de la representación gráfica, por ello es básico traducir el territorio a una realidad abstracta que sea representable gráficamente.

Las aproximaciones a la abstracción de la forma del territorio la podemos encontrar en Viollet le Duc cuando estudia el paisaje de las montañas de los Alpes. En 1876 publica "Le massif du Mont Blanc: Etude sur sa Constitution Geodésique et Géologique sur ses Transformations et sur l'Etat Ancien et Modern de ses Glaciers". En dicho trabajo tiene 112 ilustraciones que son un interesante ejercicio de abstracción geométrica de las montañas que estudia.

Se trata de ejercicio de descomposición y abstracción de la superficie de las montañas hasta encontrar una representación ideal con el mínimo de planos y aristas que definan de forma abstracta la complejidad de la forma natural.

Este ejercicio es de una belleza gráfica indudable a la vez que evidencia el interés de Viollet por llegar a la "esencia" de la forma de la montaña como elemento fundamental para el conocimiento y estudio de su formación, su posterior evolución y, como él dice, conocer las causas de su ruina, de forma análoga a la de un edificio. "De hecho, nuestro mundo es un gran edificio en el que todas las partes tienen una razón de ser; su superficie constituida por formas controladas por leyes irresistibles y seguidas de un orden lógico. Curiosamente analizar un conjunto de montañas, su formación y las causas de su ruina; reconocer el orden que dio lugar a su formación, las condiciones de su resistencia y duración a los agentes atmosféricos, estudiar su historia, es a mayor escala como realizar un trabajo análoga al trabajo analítico de un arquitecto y un arqueólogo que establecen sus deducciones del estudio de los monumentos". ${ }^{51}$

51 VIOLLET LE DUC, E. "Le massif du Mont Blanc; étude sur sa constitution géodésique et géologique, sur ses transformations, et sur l'état ancien et moderne de ses glaciers" pág. XV-XVI 


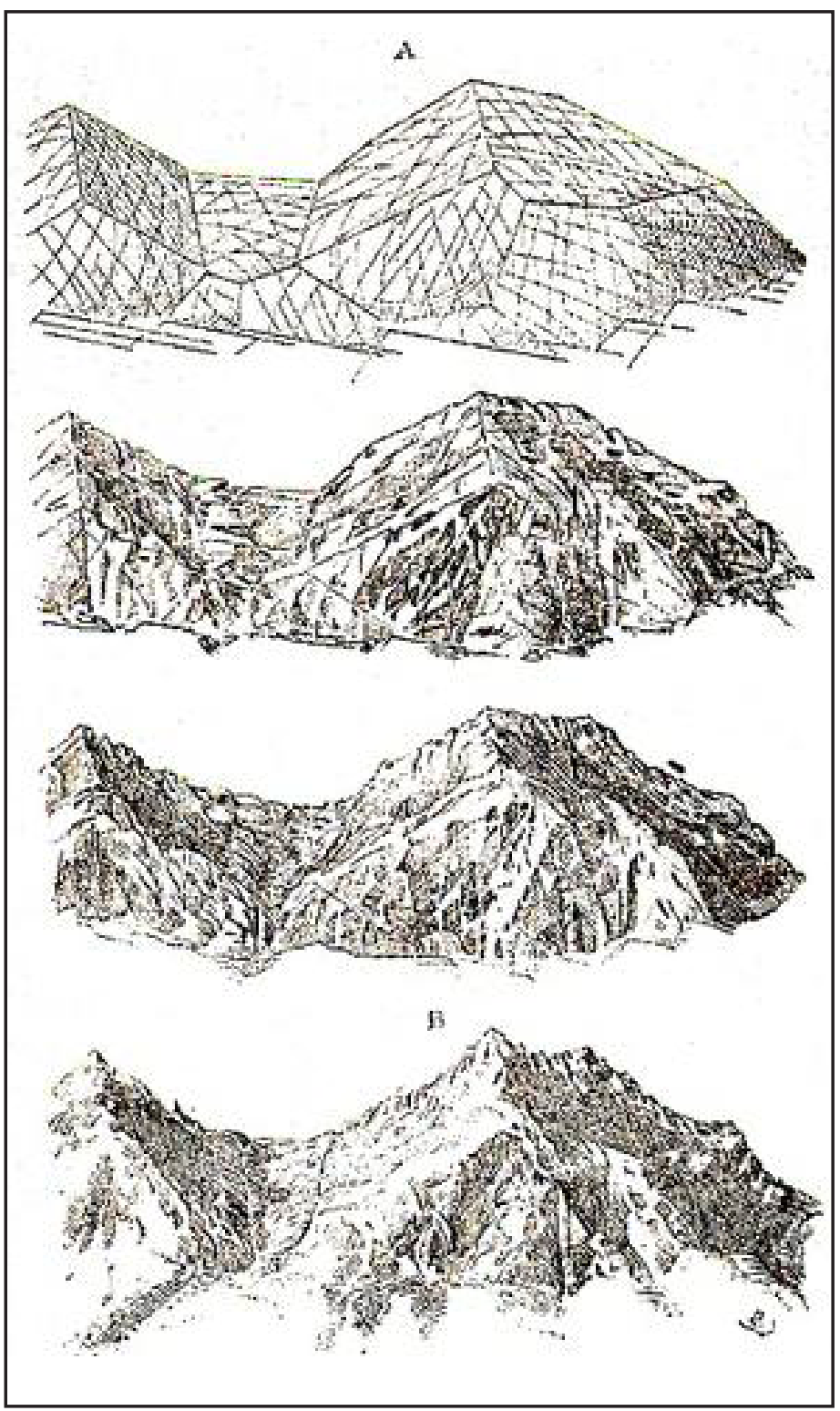

Fig. 3. 1. Croquis del estudio del macizo del Mont Blanc, triangulando la topografía de la montaña de 1.876 .

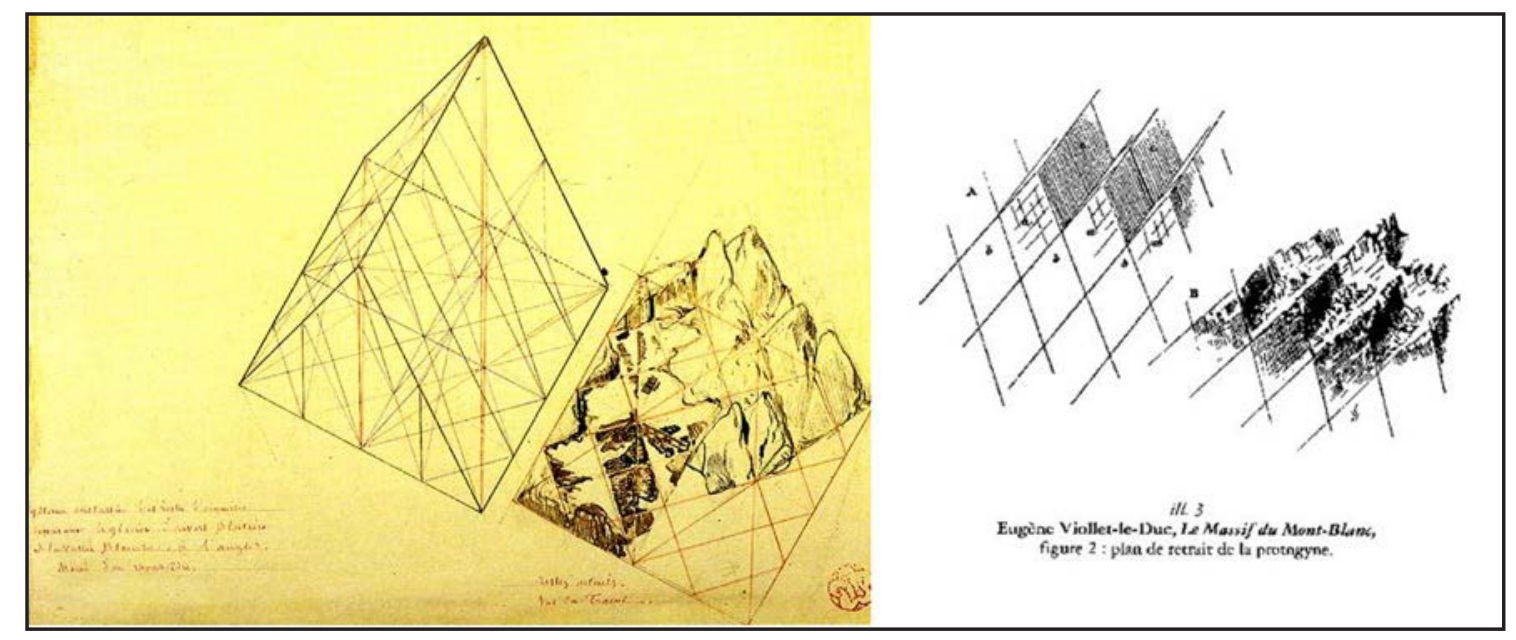

Fig. 3. 2. Dibujo con la triangulación del macizo del Mont Blanc de Viollet le Duc de 1.876. 
En 1993 Eduardo Martínez de Pisón en el artículo Arquitecturas Cordilleras publicado en la revista ERIA ${ }^{52}$, realiza otro análisis análoga creando una disposición en red de rombos, "la red que hemos estudiado responde también a una geometría en piezas sistemáticas, en un sistema repetitivo y encajado en parámetros de fracturación que es posible modelizar por ordenador, lo que permite su inserción en la teoría de fractales. De este modo a partir de una figura geométrica simple, un triángulo, se ha construido por agregación sistemática la figura de una montaña (ver Fig. 3. 1 en la página 50). A la inversa, las estructuras fractaliformes tienden, por disminución (por erosión) a reproducir la forma, acoplada a esa estructura basada en la auto similitud. Por sistema inverso pues, se obtiene el mismo sistema de fractos. Ello explica varias cuestiones morfológicas, pero además permite modelizar y ello abre una puerta mayor al entendimiento de las formas terrestres"

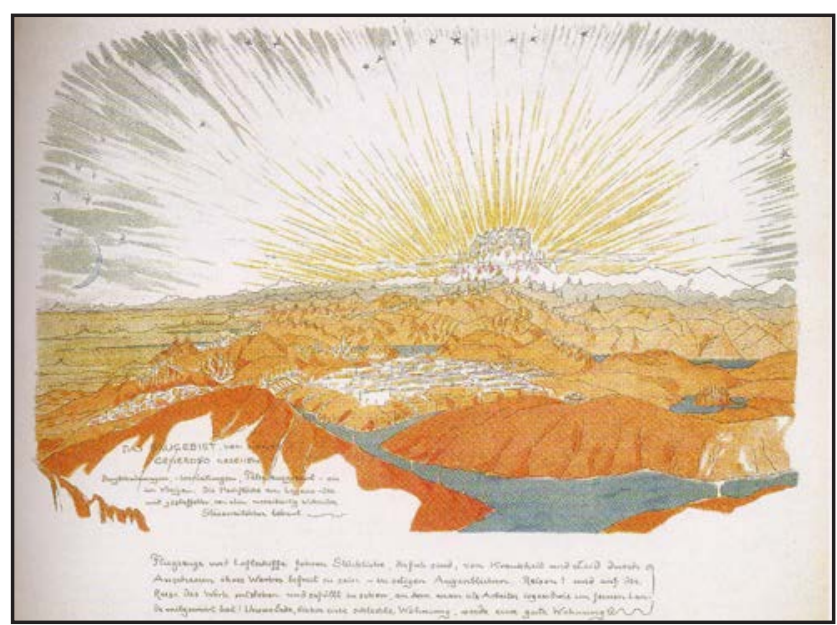

Fig. 3. 3. Dibujo de la abstracción de las montañas de Bruno Taut de su libro "Arquitectura Alpina" de 1919.

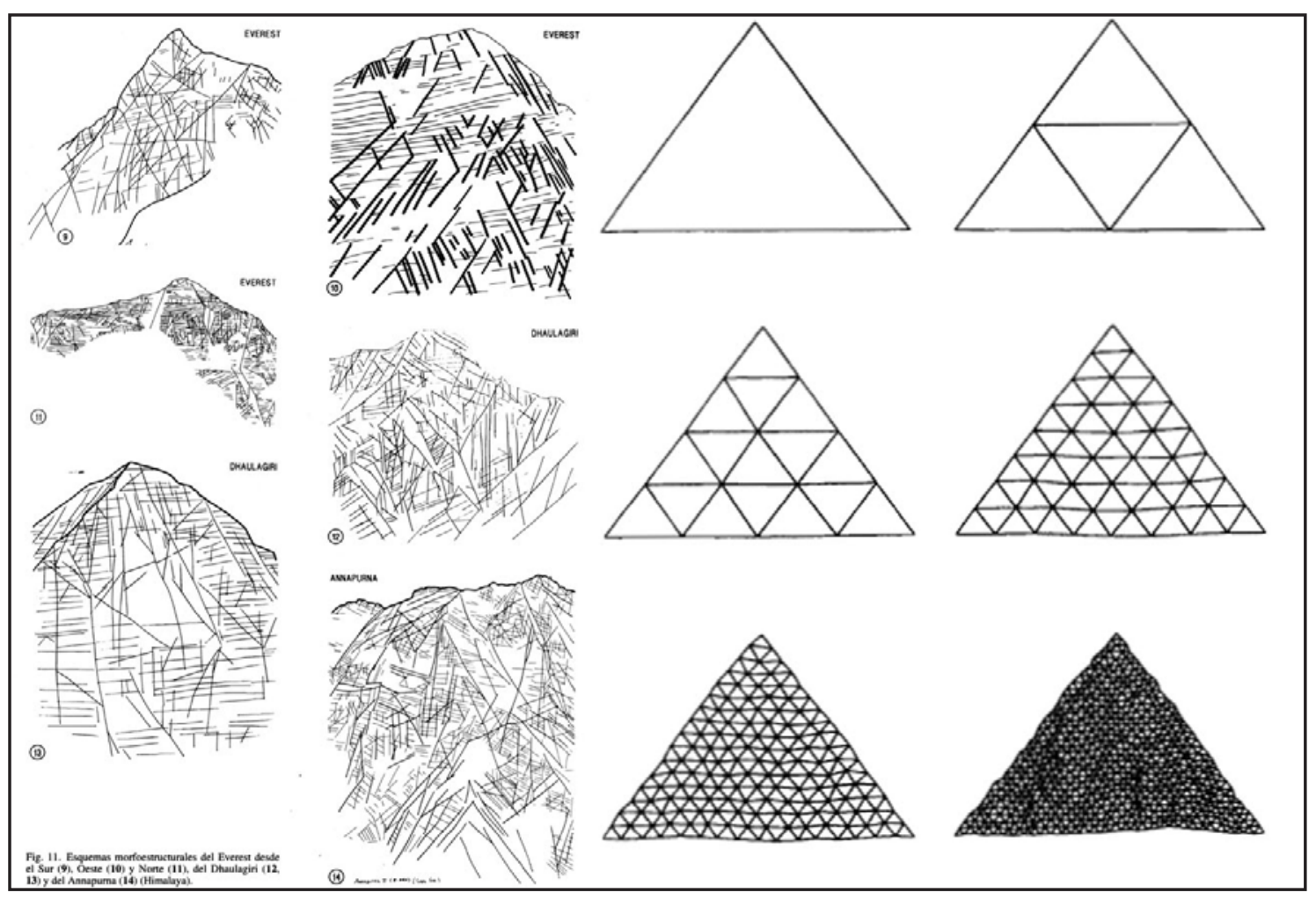

Fig. 3. 4. Dibujo de fractales de Eduardo Martínez de Pisón de su artículo "arquitecturas, cordilleras" publicado en la revista Eria en 1.993. 
Pues bien nosotros vamos a intentar llegar a abstraer la forma de este territorio y así detectar aquellos elementos comunes que nos permitan obtener distintos tipos de topologías de territorio, para ello utilizado las herramientas técnicas que tenemos hoy en día en nuestras manos desde el software de dibujo, el SIG, la fotogrametría, etc. representaremos gráficamente el cañamazo del territorio como un volumen abstracto formado por una serie de planos triangulares ${ }^{53}$. Las aristas que delimitan estos planos forman la malla mientras que los planos definen los "vacíos" del tejido.

Esta malla tiene un carácter topológico que se va modificando con el tiempo según la disposición de sus elementos. Como veremos los vacíos se "rellenan" con las actuaciones antroposociales y sobre las fibras se disponen los elementos de conexión entre las actuaciones.

El análisis grafico volumétrico lo haremos a dos escalas; es muy importante la selección de la escala a la que se representa el soporte. En primer lugar por que debe ser la adecuada para poder "leer" adecuadamente los elementos del territorio que queremos representar y en segundo lugar por que cuando en esta fase de análisis (y posteriormente en las fases sucesivas del trabajo en la síntesis) queremos comparar distintos elementos o estructuras, deben estar a la misma para que las podamos "superponer" y analizar cuales son las relaciones que se establecen entre ellas.

Las dos escalas seleccionadas, son una que engloba el conjunto del área de estudio y otra posterior que con más detalle permite analizar las 12 zonas que consideramos más significativas. En estas doce zonas analizaremos gráficamente su aptitud en función de los condicionantes climatológicos y topológicos, a partir de la abstracción del territorio. Como resultado del análisis obtendremos 6 topologías distintas dentro del área de estudio. Este análisis nos servirá de base para elaborar los planos geomorfológicos de cada una de las 6 topologías distintas del área de estudio.

Por último analizaremos la percepción que tenemos de dichas formas como lectura secuencial que deriva de la visión, que nos permite leer las distintas topologías como recintos y a algunos elementos topográficos como ejes, barreras o hitos.

53 En gráficos 3D por computadora, se usan redes de polígonos para modelar objetos tridimensionales juntando los polígonos para imitar la superficie del objeto. En general se usan redes de triángulos que cumplen la condición de Delaunay por ser los polígonos más simples y con muchas propiedades favorables para representar una superficie coplanaria. 


\section{2. La con-formación del soporte territorial}

Para entender como se conforma el territorio vamos a acercarnos al pensamiento del ingeniero francés Robert le Ricolais y despojarnos de nuestras ideas de la forma del territorio tan ligadas a lo estético y a la percepción. El auxilio de la teoría matemática para la aproximación numérica y topológica de la forma de Le Ricolais desarrolla un proceso de pensamiento que trasciende las normas de percepción usuales. Su idea de forma no va ligada a nuestra percepción sensorial de la realidad, ya que rechaza la importancia de la imagen por el carácter engañoso que a menudo tiene nuestra percepción del mundo. Ricolais rechaza la idea platónica de forma como estructura estática porque la entiende como un "concepto más fluido" que esta a menudo unido al parámetro de tiempo, que implica movimiento. De un modo sorprendentemente contemporáneo escribía:

Nunca más será la plaza de la antigua Roma nuestro foro, sino cierto tipo de sistema nervioso que permita a la gente entrar en contacto con otros y realizar las actividades del modo más corto y rápido. Ahora que nuestros movimientos se aceleran más que el crecimiento de la población, nuestros objetivos futuros puede que no sean como estructurar los edificios sino como estructurar las circulaciones. ${ }^{54}$

Al reflexionar sobre la estructura de la materia y de la naturaleza, la intención de Le Ricolais consiste en encontrar aquello que subyace a lo que para él es la constante de nuestro universo: el cambio. En sus estudios asimila de un modo analógico enseñanzas de diversas disciplinas incluida la arquitectura. Su aproximación a la forma no es solo desde el punto de vista estético sino más bien matemático, tratando de eliminar las visiones individuales y cualquier idea prefabricada de belleza, escribía:

"Una tendencia nueva, probablemente de origen abstracto o matemático, quiere hacernos considerar la forma como una pura geometría de ocupación del espacio, sustituyendo así las impresiones sensoriales imprecisas por una noción más útil de la organización o disposición y, en ciertos casos particulares, de medida". ${ }^{5}$

Según Le Ricolais en la naturaleza no encontramos modelos formales, sino modelos de organización, de disposición. "Más importante que la naturaleza misma de las cosas, bien sea moléculas, átomos o electrones, lo que importa es el modo de disposición que esas partículas elementales y sus agrupaciones adoptan". 56

La materia se puede entender como algo dinámico, vivo, lleno de energía salvaje que le hace configurarse de acuerdo con leyes de transformación, de erosión, de cambio que producen continúas metamorfosis.

"Al contemplar la materia desnuda observamos como se va modificando buscando equilibrios internos y atravesando sorprendentes fases a lo largo de su entrópica desintegración, con sus luces, sombras y texturas, nos hace cuestionarnos sobre las muchas fases de su forma, sobre el denso entrelazado de sus componentes, que se anudan y se retuercen". ${ }^{57}$

La naturaleza y sus leyes han sido las únicas herramientas que han trabajado el soporte del territorio, y estas herramientas invisibles nos sugieren también modos distintos de transformación, diferentes modos espaciales de organización con sus profundas leyes de agregación, crecimiento, acumulación, rotura y descomposición.

54 LE RICOLAIS, R. “Visiones y Paradojas” pág. 34

55 LE RICOLAIS, R. “1935-1969. Études et recherches” pág. 18

56 LE RICOLAIS, R. “1935-1969. Études et recherches” pág. 19

57 JUÁREZ CHICOTE, A. “El universo imaginario de Louis Kahn” pág. 36 
Usaremos la topología en la búsqueda de los mecanismos de la configuración de la forma. Esta es una estructura abierta, fluida, susceptible de ser determinada en varias direcciones. No tiene predeterminada una ordenación precisa sino que tiende únicamente a una ordenación posible.

\section{2. 1. Los procesos}

Ya centrándonos en el análisis establecido en la metodología en primer lugar observaremos los elementos que componen el soporte territorial para después clasificarlos. Estos responden a una serie de procesos que son los que consiguen darles forma y que los analizaremos previamente, evidenciando la constante que subyace en nuestro universo: el cambio.

\section{La orogénesis}

La orogénesis es el proceso a lo largo del tiempo de la formación o rejuvenecimiento de montañas y cordilleras causada por la deformación compresiva de regiones más o menos extensas de litosfera continental.

La teoría de placas es la que explica este proceso que provoca diversas deformaciones tectónicas de carácter compresivo, incluido plegamiento, fallamiento e incluso el corrimiento de mantos.

La orogénesis se produce siempre en bordes convergentes de placa, es decir en las regiones contiguas al límite entre dos placas litosféricas cuyos desplazamientos convergen.

Existen los siguientes tipos:

\section{- Orogénesis térmica u ortotectónica}

Se produce cuando una placa subduce por debajo de otra. Se llama orogénesis térmica por la importancia de los fenómenos magmáticos, incluidos los volcánicos, que se ponen en marcha como consecuencia de la fricción entre placas.

\section{- Orogénesis mecánica o paratectónica}

Ocurre cuando el movimiento convergente de dos placas tectónicas arrastra un fragmento continental contra otro. Las fuerzas y movimientos predominantes son horizontales (paratectónicos) y de origen propiamente tectónico (mecánico), con muy pequeña participación de procesos específicamente volcánicos o, más generalmente, magmáticos.. La orogénesis de tipo mecánico ha producido el relieve más importante del planeta, el formado por los Himalayas y la Meseta del Tibet, que se han levantado por el choque de la placa que ahora forma la India, después de que se separara de África Oriental, con el continente eurasiático. En el proceso desapareció el mar de Tetis actual mar Mediterráneo, el mar Negro y los lagos mar y mar de Aral son sus restos.

\section{La erosión}

La erosión es la degradación y el transporte de suelo o roca que producen distintos procesos en la superficie de la Tierra. Entre estos agentes está la circulación de agua o hielo, el viento, o los cambios térmicos. La erosión implica movimiento, transporte del material, en contraste con la disgregación de las rocas, fenómeno conocido como meteorización. La erosión es uno de los principales factores del ciclo geográfico. La erosión puede ser incrementada por actividades humanas o antropogénicas. La erosión produce el relieve de los valles, gargantas, cañones, cavernas y mesetas

Podemos distinguir dos tipos fundamentales de erosión:

La erosión hídrica es el proceso de sustracción de masa sólida al suelo o a la roca de la superficie llevado a cabo por un flujo de agua que circula por la misma. La segregación, transporte y sedimentación de las partículas del suelo por las gotas de lluvia y el escurrimiento superficial definen el proceso de erosión hídrica. Este se ve afectado por varios factores, como son, el clima, el suelo, la vegetación y la topografía. 
Nuestra zona de estudio participa de las características climáticas del Mediterráneo occidental en la que se inscribe: unas precipitaciones nunca abundantes, con un mínimo acusado en verano y unas temperaturas moderadas debido a la proximidad al mar. ${ }^{58}$

La erosión eólica es el desgaste de las rocas o la remoción del suelo debido a la acción del viento. El viento es un agente de modelado del relieve que puede acarrear grandes cantidades de polvo a través del mundo, pero los granos de arena solo pueden ser transportados a distancias relativamente cortas. El viento desplaza las partículas sueltas, básicamente, según los mismos mecanismos que las escorrentías hídricas, en función del tamaño del grano y de la velocidad del fluido. Saltación y suspensión son los mecanismos más importantes del transporte eólico. Las partículas realizan saltos a favor del viento; tras el impacto con granos en la superficie, pueden rebotar de nuevo y elevarse. De este modo, el viento transfiere energía cinética al grano, el cual, al chocar con la superficie de arena, disloca otras partículas y puede proyectarlas al aire. Las partículas de limo y arcilla pueden permanecer en suspensión con viento turbulento, e incluso casi indefinidamente para los granos muy pequeños.

\section{La sedimentación en las áreas de drenaje}

La sedimentación es el proceso por el cual el sedimento en movimiento se deposita. Un tipo común de sedimentación ocurre cuando el material sólido, transportado por una corriente de agua, se deposita en el fondo de un río, embalse, canal artificial, o dispositivo construido especialmente para tal fin. Toda corriente de agua, caracterizada por su caudal, velocidad y forma de la sección tiene una capacidad de transportar material sólido en suspensión y otras moléculas en disolución. El cambio de alguna de estas características de la corriente puede hacer que el material transportado se deposite o precipite; o que el material existente en el fondo o márgenes del cauce sea erosionado.

Puesto que la mayor parte de los procesos de sedimentación se producen bajo la acción de la gravedad, las áreas elevadas de la litosfera terrestre tienden a ser sujetas prevalentemente a fenómenos erosivos, mientras que las zonas deprimidas están sujetas prevalentemente a la sedimentación. Las depresiones de la litosfera en la que se acumulan sedimentos, son llamadas cuencas sedimentarias.

\section{La vida sobre el soporte.}

El desarrollo de la vida de las distintas especies animales y vegetales influye también en la conformación del soporte del Territorio. Los procesos que desarrollan los seres vivos influyen fundamentalmente retrasando o adelantando los procesos de erosión y de sedimentación. Su influencia y en especial la del hombre son determinantes en la transformación de nuestro relieve.

Las plantas constituyen un factor imprescindible para el mantenimiento de la biosfera. Su importancia radica en que en ellas se desarrollan unos procesos bioquímicos conocidos como fotosíntesis. ¿Qué proceso ha conducido a la localización y distribución de determinadas especies vegetales en una zona concreta? Fundamentalmente su evolución, producto de la adaptación de aquellas a variables ambientales de las que hay que influyen sobremanera: el clima y el suelo; a ellas se aúna la acción

58 Las características más significativas del clima en estas tierras de forma resumida son:

Las precipitaciones oscilan entre 600 y $800 \mathrm{~mm}$ en los observatorios de una franja central paralela a la costa que se va abriendo desde los Puertos de Beceite hacia el suroeste y alcanza una máxima amplitud en el eje Gudar-Penyagolosa. Esta franja abarca municipios como San Mateo o Benasal, e interiores como Morella y Villafranca. Sin embargo el análisis de las precipitaciones no debe hacerse atendiendo únicamente a las medias anuales, estacionales o mensuales. Existen otros aspectos, como la irregularidad o la torrencialidad, cuyo análisis reviste tanto interés como el realizado hasta aquí. La provincia de Castellón presenta una mayor torrencialidad de las precipitaciones, es decir, puede registrar lluvias más cuantiosas en un mismo periodo de tiempo. Un ejemplo concreto: en las franjas costeras y llanos prelitorales las lluvias registradas en un día, con un periodo de retorno de 10 años, alcanza los 150 litros por metro cuadrado.

Con respecto a las temperaturas siempre se ha afirmado que la península ibérica las temperaturas están gobernadas básicamente por el factor altitud y en menor medida por el alejamiento respecto al mar: Aquí se cumplen estas premisas, de manera que la relación más estrecha es la que se establece entre la temperatura media anual y la altitud del observatorio. En la zona de la Batllia representa la transición del clima costero al húmedo de las tierras altas. Los elementos de esta transición son un aumento paulatino del total de lluvias, un descenso de las temperaturas, un incremento de las lluvias de primavera frente a las de otoño y como consecuencia una atenuación de la aridez. 
humana, considerable sobre todo desde el establecimiento de las sociedades modernas.

El ambiente climático que se presenta en una determinada área depende de unos factores establecidos más o menos permanentemente -latitud, distribución de los continentes, relieve y corrientes marinas-. Los elementos del clima son los que inciden directamente sobre las plantas y entre ellas se encuentran las temperaturas, las precipitaciones, la intensidad luminosa y la disponibilidad de agua. Este último elemento, es quizás el más importante en nuestra área, por cuanto limita grandemente su tipo de flora. La razón de este límite viene dado por un principio general que rige la biología de cualquier sistema del planeta: la estructura y funcionamiento biológicos de un área concreta están condicionados por el elemento ambiental que se encuentre en menor cantidad. Ello hace que la escasez de a recursos hídricos, como es nuestro caso, solo permita la supervivencia de plantas adaptadas a la sequedad, aunque las temperaturas, los vientos y la intensidad luminosa sean favorables a otras muchas especies. ${ }^{59}$

59 Historia geológica del Maestrat:

Todos estos procesos son los que han conformado el relieve de nuestra zona de estudio a lo largo de los siglos. De una forma resumida la evolución del relieve del territorio del Maestrazgo sería:

A finales de la Era Primaria o Paleozoica, hace 350 millones de años (m.a) y durante el primer periodo de la Era Secundaria (Triásico 225-195 m.a.) se depositan los materiales del zócalo o basamento de nuestra región. Estos materiales solo afloran en la zona de Benicasim-Castelló, Desierto de las Palmas; Villafames y la Puebla Tornesa. Se trata de algunas calizas del Paleozoico, pero fundamentalmente areniscas rojas vaporizas (Llucena y Argelita) y otros materiales detríticos triásicos que representan la existencia en dicho momento de un clima árido o desértico, que fue común en toda Europa y Norteamérica. En el Maestrazgo se encuentran entre 2000 y 3000 metros de profundidad.

Los citados materiales al comportarse de una manera plástica, permitieron el deslizamiento sobre ellos del paquete de materiales depositados posteriormente durante el Jurásico, Cretácico y Terciario, que constituyen la llamada cobertura superficial de la región.

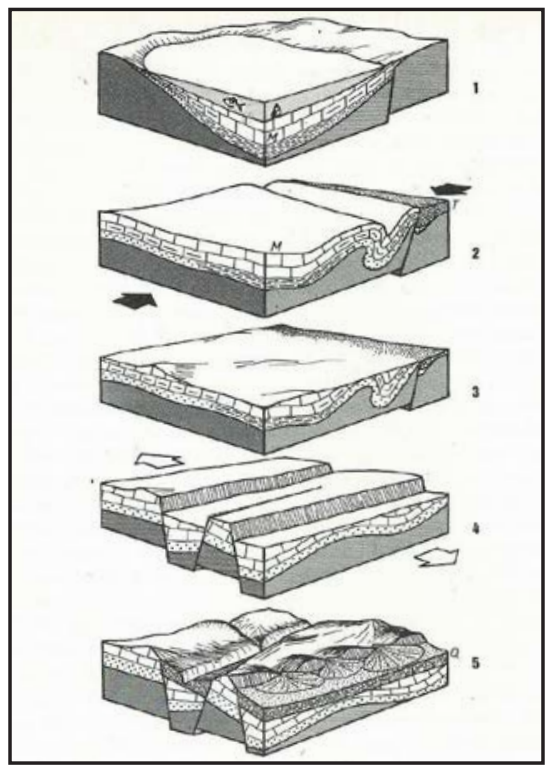

Fig. 3a Plano evolución geológica Maestrazgo Pérez y Simón (1982).

Jurásico (195.-136 m.a.). En este periodo es cuando podemos considerar empieza la historia geológica del Maestrat de una forma más clara y sobre todo durante en Jurásico Superior (157-136 m.a,). La región del Maestrazgo se ha hundido y queda ocupada por una amplia cubeta sedimentaria mariona, la cual recibe un importante aporte de sedimentos procedentes de las áreas colindantes. En ella se depositaran las calizas y dolomitas que aparecen en las sierras (Irta, Valdangel, Turmell, Tossa, Vallivana,...) Esta cubeta corresponde a un golfo de la zona más occidental del antiguo Mar Tethys, que separaba los continentes del Norte (Laurasia) de los del sur (Gondwana). Reliquias del cual son los mares Mediterráneo, Negro y Caspio.

Dos amplios periodos sedimentarios acontecen durante el Jurásico, separados por una ligera fase regresiva (retirada del mar) en el Jurásico medio. El ambiente generalizado durante todo el periodo es de plataforma continental o nerítico ( 0 a $250 \mathrm{~m}$. de profundidad) y litoral. En la comarca no es muy fosilífero, pero en otras regiones abundan los amonites.

Triásico Jurásico-Cretácico (136 m.a.). Se retira el mar, gracias a la emersión y levantamiento de la corteza correspondiente a la epirogenia Neocimérica (Facies Weald). En el Baix Maestrat apenas es perceptible, más al interior el ambiente es claramente continental y detrítico. Es probable que gran parte de los materiales jurásicos sufran una intensa erosión. En la mayor parte de la cordillera ibérica los materiales depositados son areniscas, arcillas, conglomerados, etc. En nuestro territorio esta mal representada dicha facies y podemos observar suelos ferruginizados o lateríticos, y algunos débiles niveles bauxitíferos.

Cretácico inferior (136-100 m.a.). Empieza y un nuevo ciclo sedimentario. La cuenca del Maestrat sigue en la misma situación de cubeta de golfo como en el Jurásico. Podemos hablar de dos pulsaciones marinas y lo subdividimos en cuatro fases: La primera es un régimen sedimentario alternante, en el que conviven sucesivamente ambientes litorales, intralitorales y lagunares. En el segundo el mar se retira del Maestrat interior y els Ports (regresión). En el tercero el mar vuelve a invadir la región (transgresión) llegando hasta la zona actual de Teruel. Y la cuarta el mar vuelve a retirarse, con lo cual la línea de costa en el Maestrazgo va oscilando de oeste a este. En este momento las principales redes fluviales de la península se dirigían hacia el este, es decir hacia el Mediterráneo antiguo o Tethys.

Cretácico superior (100 m.a.). El mar vuelve a invadir la cuenca. Es la máxima transgresión marina conocida de la historia de la Tierra. En la península ibérica llega hasta la zona de Madrid-Toledo. Se depositan calizas y margas de plataforma continental con niveles de ostreidos y prealveolinas. Este periodo esta mal representado en la zona y únicamente queda algunos retazos en localidades como Sarratella, Serra Engarceran, Vilanova, Rosell. Suponemos que debido a la erosión sufrida durante el terciario. 


\section{2. 2. Los elementos de la con-formación}

Analizados los procesos, veamos cuales son los elementos que con-forman el territorio

\section{Montañas}

El relieve actual es el fruto de un árbol cuyas raíces se adentran millones de años en la historia geológica: ha sido configurado por la integración de todos los hechos referidos hasta ahora, es decir,

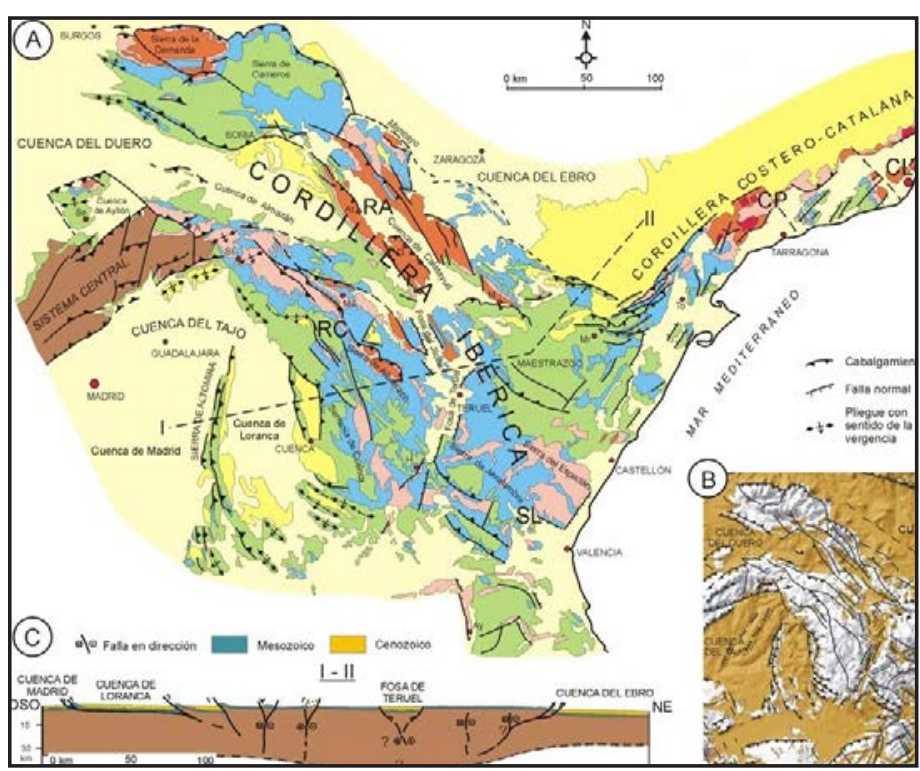

Fig. 3b Dibujo esquemático de la composición geológica de la cordillera ibérica del artículo de la "Historia geológica del Maestrazgo" de J. Cardona Gavaldá (1993).
Al final del Cretácico y comienzos del terciario (65 m.a.) coincidiendo con la desaparición de los dinosaurios y de los amonites, termina el gran ciclo sedimentario mesozoico y comienza la retirada del mar al elevarse la cuenca (Orogenia alpina) que poco a poco se irá haciendo definitiva. Durante el Terciario Inferior se implantará un nuevo ciclo sedimentario de carácter continental con una gran variedad de ambientes. Al principio quedarán ambientes litorales, que poco a poco desaparecerán. En ciertas áreas se presentaran ambientes lagunares (Alcalá, Rosell..) Ya en el Oligoceno (37-22 m.a.) la compresión, elevación y plegamiento de la cuenca del Maestrat serán definitivos, con lo que desaparecerán aquellos ambientes. No debemos olvidar que paralelamente a la elevación sobre el nivel del mar y cuanto más intensa sea esta, la erosión de las zonas emergidas se ira agudizando y por tanto el transporte y depósito de sedimentos hacia zonas bajas.

En el Mioceno (22-7 m.a.) ya comenzado el Terciario Superior, habrá terminado el levantamiento y seguirá una fase distensiva causante de la aparición de fallas y fracturas paralelas a la dirección del anterior plegamiento (SO-NE). Sigue la erosión y deposición de conglomerados, arenas y arcillas en las zonas deprimidas. Al final del Mioceno, los relieves montañosos habrán sido muy arrasados por la erosión, con lo que quedará constituida la llamada penillanura fundamental o superficie de arrasamiento, con relieves suaves y alomados.

El Plioceno (7-2 m.a.), último periodo de la era Terciaria, comenzará con un abombamiento generalizado, pero mucho más intenso en la zona del macizo Gudar-Peñagolosa, que elevará la antigua penillanura fundamental sobre los 2.000 metros. La mayor parte del Maestrat quedara en la periferia del abombamiento y se vera afectada enseguida por una nueva distensión y fisuración que dará lugar definitivamente a la disposición del sistema de sierras y fosas hundidas, entre las sierras (Irta, Atalaies, Valdangel, Engarceran, Motsia etc) y fosas (Alcala, Ulldecona, Tortosa-San Mateu-Les Coves_Albocasser_ Adzaneta) y al alineamiento de la línea de la costa en su disposición actual paralela a las sierras y las fosas.

El rejuvenecimiento del relieve contribuirá otra vez a que comience la erosión en las sierras y por tanto el consiguiente relleno de las fosas y zonas costeras. Se generaran también piedemonte y glacis al pie de las sierras.

Era Cuaternaria (2 m.a.).Durante el Pleistoceno tiene lugar una reactivación de la fracturación, que contribuirá al realineamiento y encajamiento definitivo de la red hidrográfica actual. Se formaran abanicos, conos aluviales, nuevos glacis y colusiones que aumentaran el relleno de las fosas, lo que motivara el aislamiento de su drenaje en su salida hacia el mar y la generación de lagunas interiores.

Los ríos principales como el Servol, Senia, de les Coves, etc. Formaran algunas terrazas fluviales, gracias a las etapas erosióndepósito contemporánea de los periodos glaciales e interglaciares de la Era Cuaternaria. Las glaciaciones provocarán un descenso del nivel del mar y los periodos interglaciares, al fundirse gran parte de los hielos, determinaran su ascenso. Estos movimientos marinos obligaran al reajuste cíclico y alternativo de la red hidrográfica.

La Historia Geológica Actual es la relativa a la acción antrópicas. La aparición de la civilización humana y sus actividades motivaran continuamente cambios morfológicos en el Maestrazgo. Al principio no serán notables, pero con la aparición de la sociedad agrícola-ganadera del Neolítico, todo empieza a cambiar. Cada momento histórico, con su cultura, economía y posibilidades técnicas, ha dejado su impronta huella morfogenéticas en las tierras del Maestrazgo. Hoy en día resulta difícil encontrar espacios donde el ser humano no haya alterado la morfología originaria.

Comenzara la deforestación para establecer campos de cultivo, para el pastoreo, para utilizar la madera o la leña en muy diversos usos. Con el paso de la historia el proceso aumenta a ritmo exponencial y sobre todo de comienzos de la Edad Media. Desaparecen la mayoría de los bosques de la Península Ibérica. Así las montañas del Maestrat aparecen ahora como desnudas o cubiertas en parte por el típico matorral xerofítico mediterráneo. Quedan el bosque autóctono o el repoblado con especies foráneas como reliquias en pocas y reducidas zonas agrestes de alta montaña.

CARDIONA GAVALDÁ, J.V. "Historia Geológica del Maestrazgo" Centro Estudios del Maestrazgo no 43-44 1993 
la sedimentación preorogénica, la orogenia alpina y la erosión y sedimentación cuaternarias, aunque sean estos dos últimos los que han tenido un mayor peso en el resultado final.

Los rasgos del relieve que observamos hoy en día resultan de la distribución de montes, valles y llanos. En nuestra región, la proporción de estos elementos topográficos resalta una de sus características básicas: se trata de un paisaje montañoso, en ocasiones escarpado. El área periférica de Gúdar o la zona de los Puertos de Beceite ilustran perfectamente esta idea, pero no hemos de olvidar toda la cuenca del río Montlleó, en torno a Vistabella del Maestrat, o los hondos tajos del río Guadalope, aguas arriba del pantano de Santolea. Una extensa relación de lugares podría seguir a los citados y hace innegable la desproporción existente entre áreas montañosas y llanas, a favor de la primera. ¿Cuál es la razón?

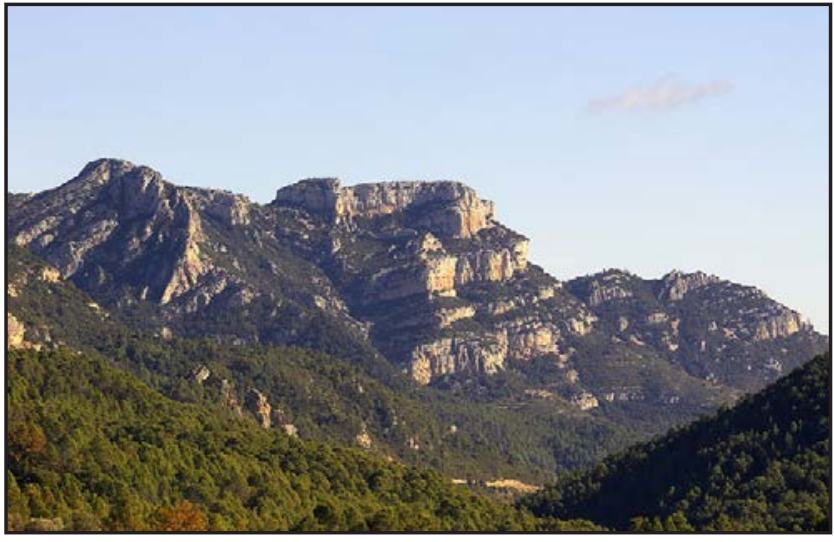

Fig. 3. 5. Foto Peña de Bel.

Por una parte, tras la segunda etapa de distensión, estas tierras quedaron ubicadas a la altura en que las vemos hoy y expuestas al ataque de los agentes erosivos. La mayor parte se situaron entre 800 y 1200 metros sobre el nivel del mar actual. Mientras tanto, el abombamiento de Gúdar elevo esta zona hasta los 1600-20000 metros y la franja litoral se hundió, por el efecto de las fallas, quedando por debajo de los 800 metros de altitud.

Por otra parte es comprensible que tras esta acentuación de los relieves la red

fluvial respondiese de alguna manera, y lo hizo encajándose progresivamente a partir de los puntos de desnivel brusco. Ya que el proceso de erosión todavía no había acabado, tenemos hoy un relieve joven y montañoso prácticamente en toda el área. Únicamente escapan a este carácter montañoso las áreas de acumulación de sedimentos, como el pla de Vinaros o algunas fosas prelitorales. También son llanas las áreas que han sido endorreicas o que lo son actualmente, como el llano entre San Mateo y Salsadella o las proximidades de la Jana.

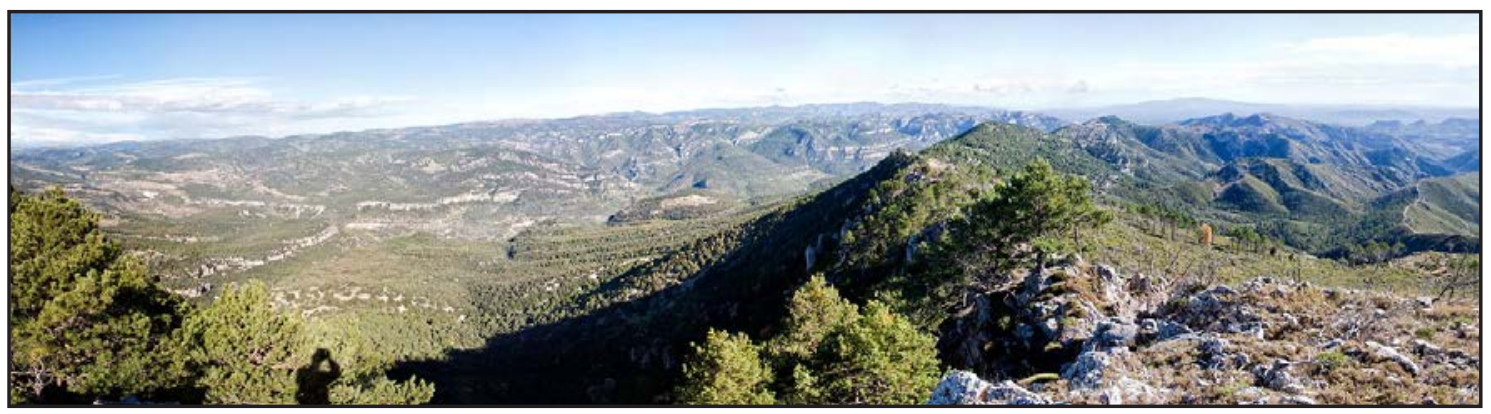

Fig. 3. 6. Vista desde el Turmell.

\section{Hidrografía-rios}

El hecho de que acentuase la pendiente hacia el Valle del Ebro y, sobre todo, hacia el Mediterráneo ha posibilitado que se mantengan estas dos direcciones básicas de drenaje de la red fluvial. Decimos que se han mantenido porque previamente ya existía un avenamiento que seguía estas dos direcciones, pues tanto la cuenca mediterránea como la Depresión del Ebro estaban esbozadas antes de la distensión pliocuaternaria. Así pues, lo que hace ésta al acentuar los desniveles es afirmar la red fluvial en sus líneas de relieve y rejuvenecer el relieve.

Un mapa de las cuencas de drenaje de los distintos cursos fluviales nos permite esbozar rápidamente 
las características de la hidrografía. Existe un eje montañoso de dirección ibérica, la línea divisoria Gudar-Penyagolosa, que separa claramente el drenaje mencionado del que vierte hacia el sudoeste, mientras que en la mitad sudoriental discurren los cortos ríos mediterráneos, con una dirección predominante noroeste-sudeste. La cuenca más importante es la de la rambla de la Viuda, a la cual el río Montlleó contribuye en mayor medida que otros afluentes. Este río es una muestra evidente del rejuvenecimiento del relieve al que antes aludíamos. Tiene una cabecera muy llana en los alrededores de Puertomingalvo, donde se vislumbran todavía retazos no erosionados de la penillanura fundamental. Aguas abajo se va encajando progresivamente hasta los congostos que, entre Culla y Benafigos, alcanzan desniveles de 500 metros. Finalmente se abre cuando llega a la fosa de Atzeneta y únicamente se estrecha al atravesar las sierras que separan estas fosas. La Rambla Carbonera y el río de Llucena son los otros dos grandes afluentes de la Rambla de la Viuda, que únicamente toma el nombre cuando confluye la primera con el río Montlleo cerca de Els Ibarsos.

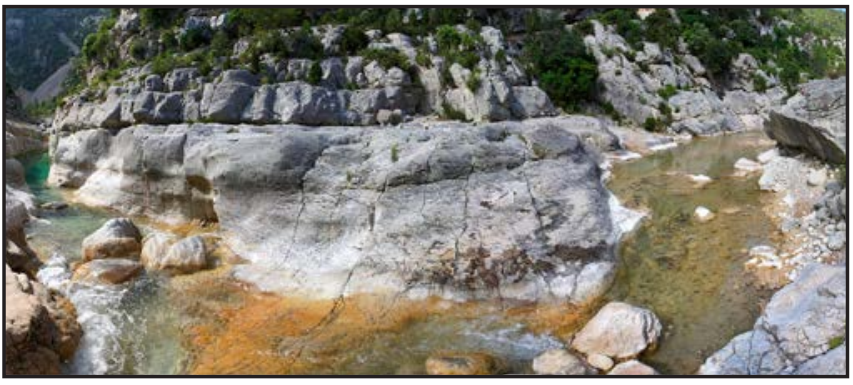

Fig. 3. 7. Foto del río Cervol.

Los otros ríos que afluyen directamente al Mediterráneo son de muy escasa consideración. El río de les Coves drena un amplio corredor interior desde la Torre d 'En Domenech hasta la Salsadella y mediante el barranco de la Valltorta, llega incluso a recoger las aguas de parte de la fosa de Catí. Todas estas aguas, reunidas en Les Coves, atraviesan las Talaias d'Alcala y llegan a edificar un pequeño llano costero al sur de Alcossebre. Finalmente, el río Cervol, como la Rambla de Cervera y el río de la Senia presentan un mismo diseño de la red. Tienen una pequeña y abrupta cabecera que muerde el borde montañoso en áreas inmediatas a las fosas. Cuando entran en estas tienden a depositar sus acarreos, configurando de este modo los vastos llanos litorales y prelitorales.

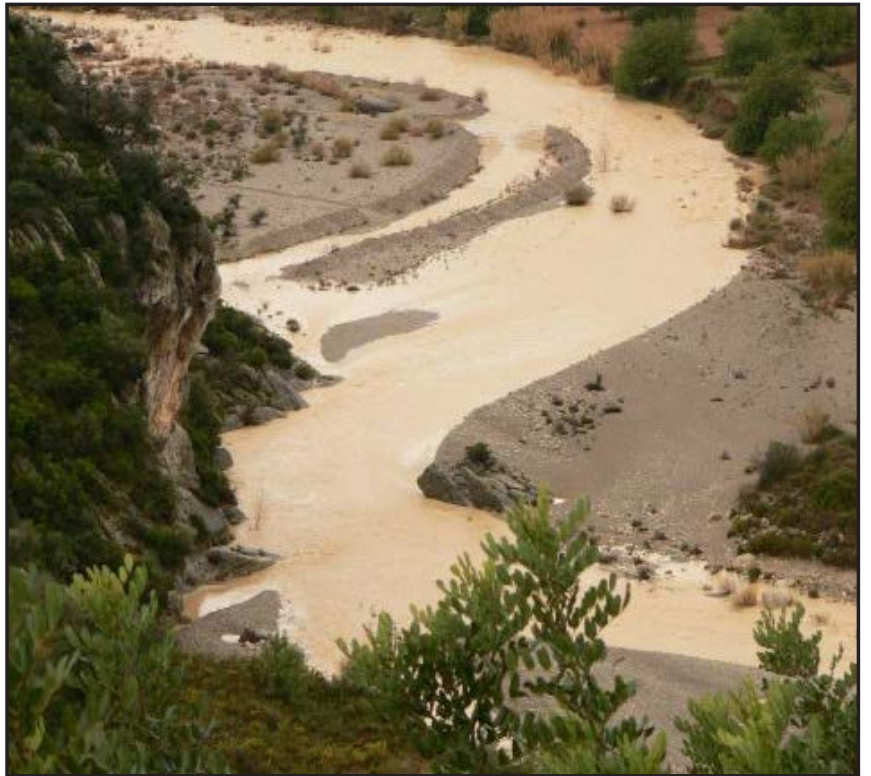

Fig. 3. 8. Foto de la rambla Cervera tras una fuerte tormenta en otoño.
Hemos insistido en la existencia de dos direcciones preferentes: una NE-SW para los ríos afluentes del Ebro y otra NW-SE para los ríos mediterráneos; sin embargo, se dan numerosas muestras de drenaje perpendicular al dominante en cada área: La rambla de la Viuda es un magnifico ejemplo de cómo las fosas prelitorales, perpendiculares al drenaje previo a su formación, llegan a afectarla hasta tal punto que tiene que alcanzar el mar confluyendo mucho más al sur con el Mijares. Al norte de Gúdar, ya en la cuenca del Ebro, se observa como los pliegues ibéricos llegan a determinar la ubicación perpendicular al Guadalope de algunos cursos fluviales como el río de Miravete y el Pitarque. ${ }^{60}$

60 Los caudales de estos ríos son muy bajos: inferiores a $1 \mathrm{~m}^{3} / \mathrm{s}$. Los ríos pequeños son muy irregulares en su caudal estando a merced de las lluvias. Tan normal es que estén secos como que registren alguna avenida fuerte en el que el caudal medio pude llegar a multiplicarse por 100.

El hecho de que los habitantes diferencien entre río y rambla es un índice de la importancia del fenómeno de la estacionalidad de las lluvias en la conciencia popular. A ello hay que añadir que el lecho de las ramblas en ocasiones al ser de gravas favorece que en determinados tramos discurra sin que se perciba en la superficie del mismo. 


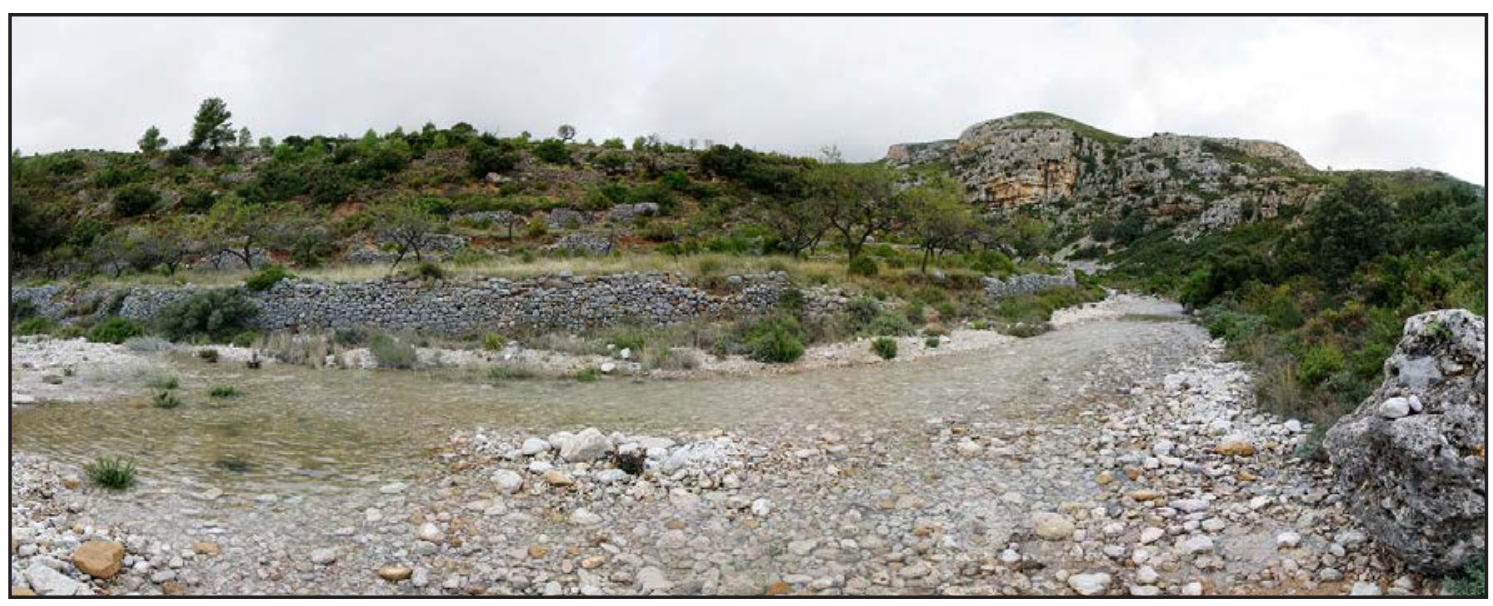

Fig. 3. 9. Foto rambla Cervera.

\section{Hidrografía-lagunas}

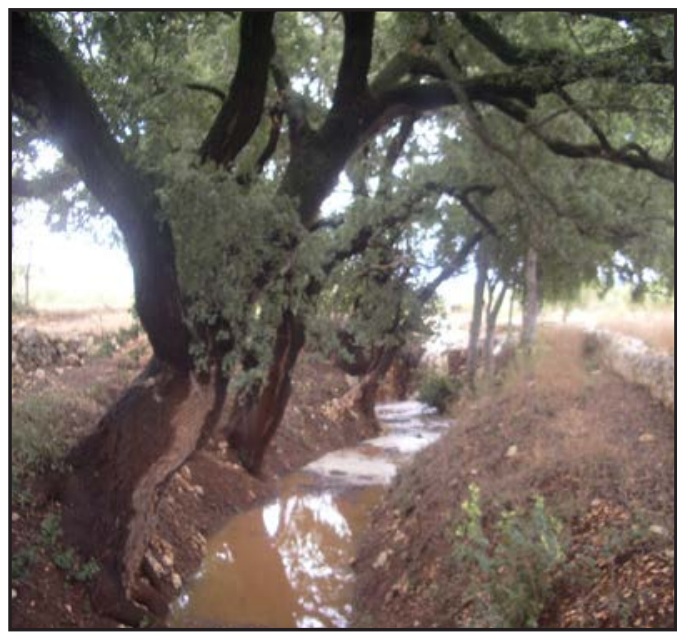

Fig. 3. 10. Foto del poljé de La Jana.

Las áreas de drenaje deficiente, se localizan dentro del sector fracturado oriental, preferentemente en las proximidades de la intersección de lechos fluviales de componente catalana y "mediterránea"; por lo general estos espacios coinciden con divisorias de agua dentro de un pasillo. Estas áreas son las que contienen lagunas como las de Sant Mateu-Salsadella

Por otra parte las características geomorfológicas, con un amplio desarrollo de grandes formas cársticas de absorción, propicia una importante circulación de agua subterránea. Al igual que en otras zonas cársticas, la circulación del agua se caracteriza por su desaparición-parcial o total- desde la superficie con auge de la escorrentía a través de conductos subterráneos.

Dentro de este ámbito destacamos por sus dimensiones y por la importancia de cara a los asentamientos humanos, el polje de la Jana, cerca del antiguo poblado del Carrascal, que desagua por un "avenc" posteriormente antropizados.

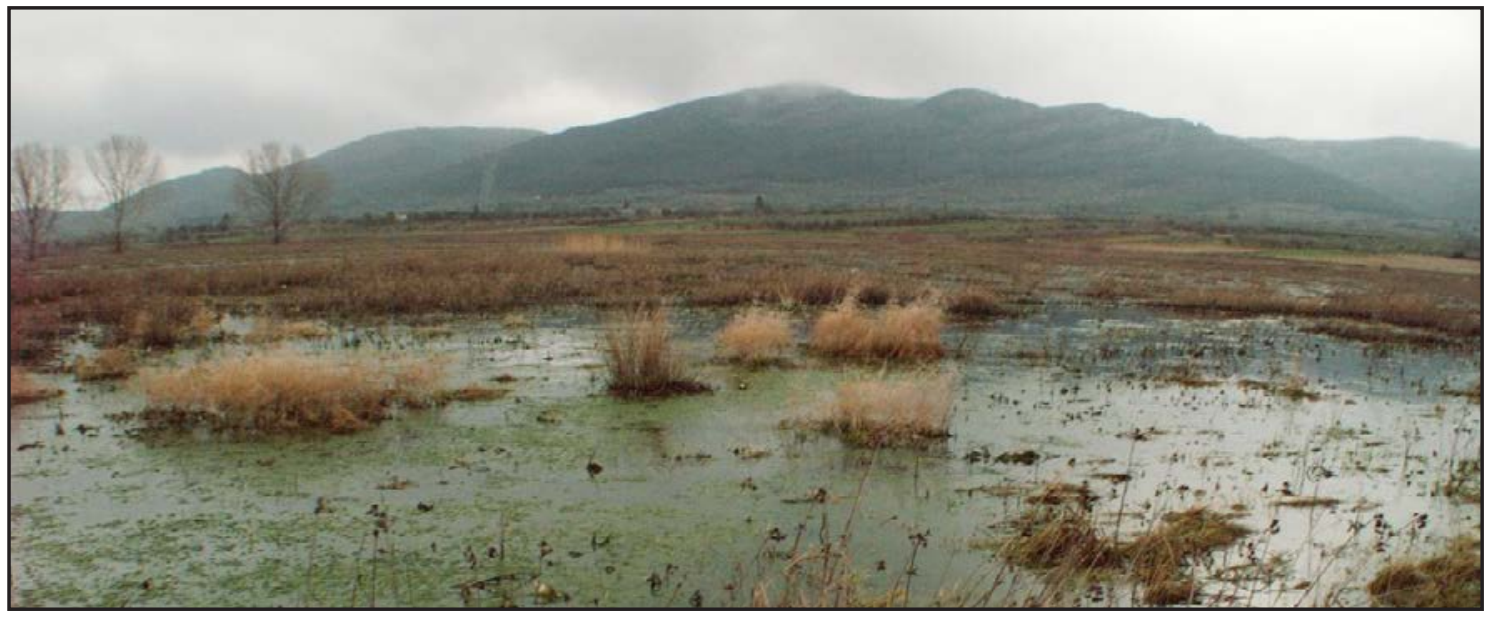

Fig. 3. 11. Foto de las lagunas de Sant Mateu. 


\section{Sedimentación en las áreas de drenaje}

Los abanicos aluviales son acumulaciones sedimentarias, en forma de semicono o abanico, edificadas por ríos y torrentes en la base de los retablos montañosos. Un relieve estructural profundamente marcado por la fracturación y el dislocamiento de los bloques, es marco idóneo para la presencia de abanicos aluviales. De acuerdo con la tipología adoptada por Juan F. Mateu Bellés en nuestro caso se encuentran los siguientes:

- Conos torrenciales encajados con acumulación predominante basal, que aparecen en los pasillos y corredores deficientemente articulados por la red fluvial. Ejemplo de ellos tenemos en Alcalá de Xivert, Pla de Catí y en el llano entre Sant Mateu y Salsadella.

- Paleoconos fluviales, son aquellos formados por un curso variable que en su cabeza discurre encajado y cuya base se ve erosionada. Ejemplo de este tipo es el abanico del río de la Senia, que se abre desde la población que da nombre al río y que desde ese punto su curso discurre totalmente encajado, "ajeno" al cono de deyección que en su día formó. El abombamiento central del cono junto con el "descenso" del cauce del río, hace que los primitivos lechos que anteriormente desembocaban en el río tanto en la margen derecha e izquierda, "le dan la espalda" de forma que en los dos laterales del río surgen dos barrancos, el de Barbiguera y el Les Mangranes que junto con el propio río Senia van erosionando la base del cono inicial.

- Paleoconos torrenciales, son aquellos formados por un curso intermitente que en su cabeza discurre encajado y cuya base se ve erosionada. Ejemplo de este tipo se encuentran donde los segmentos fluviales de orden superior discurren perpendiculares a la base de los conos, provocando la erosión de los mismos, como ocurre en el abanico de los barrancos del Molinar y contiguos que vierten directamente a la rambla Cervera que discurre perpendicular. Otro caso es el de la ladera en la que se encuentra Rosell, con los barrancos que vierten al Cervol.

Mientras que las planas de sedimentación se producen en los cursos bajos de los canales de escorrentía en los que se depositan los suelos arrastrados, conformando un terreno con poca pendiente y sin prácticamente elementos singulares que modifiquen la topografía. Ejemplo de ello serían Canet y la parte norte de San Mateo.

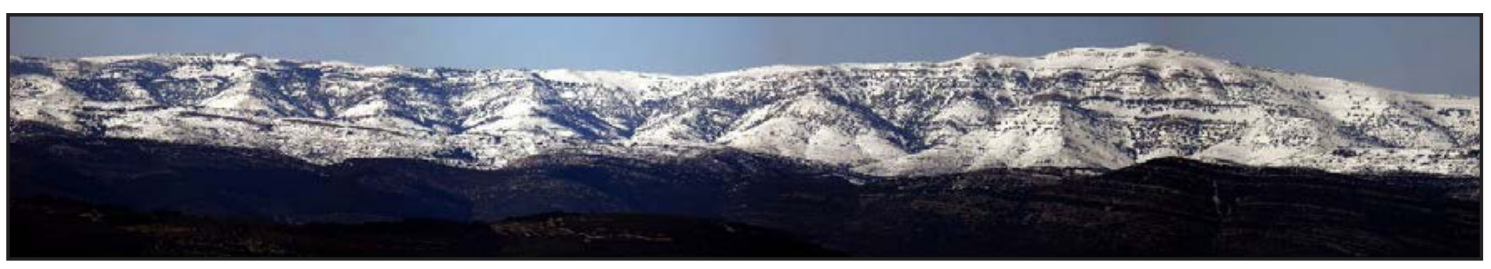

Fig. 3. 12. Foto de sedimentación por paleoconos.

\section{Vegetación}

Los sistemas de vegetación se especializan en función del sistema edafo-climático, determinando una vegetación típica de esta zona:

- Vegetación influenciada por el clima.

- Los carrascales. Representan la vegetación arbolada más extendida, en ocasiones deja de ser arbolado y se convierte en un chaparral, lo que sucede en los enclaves montañosos sometidos a fuertes vientos. Las relaciones cresta-ladera-valle ejercen un importante papel, en el que la alternancia de la carrasca con el coscojar-lentiscar se combina con otras especies.

Los carrascales (Quercus rotundifolia) están adaptados a condiciones xéricas, mientras que las encinas (Quercus ilex) de apetencias ombroclimáticas subhúmedas, es un árbol que consigue su hábitat óptimo en el mediterráneo central. 


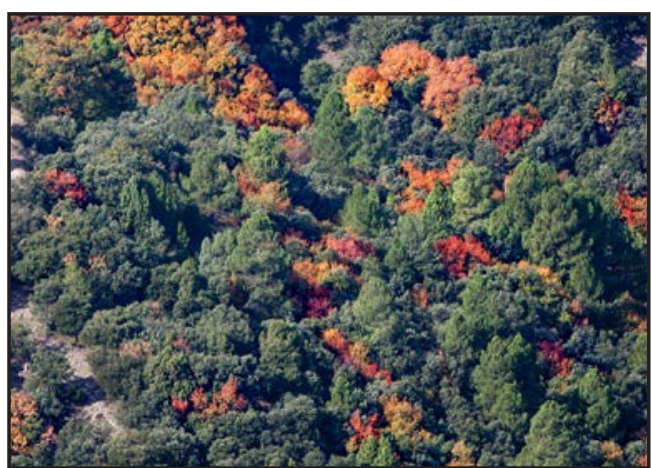

Fig. 3. 13. Bosques mediterráneo de carrascas y arces

El sotobosque arbustivo que acompaña estos bosques es rico y variado, plantas como el madroño o arbocer (Arbutus uneda), el durillo (Virbunum tinus), el laurel (Laurus nobilis), junto con lianas como las rubias (Rubia peregrina), la madreselva (Loricera implexa), la zarzaparrilla (Smilax áspera) se encuentran fácilmente en umbrías y valles.

Debe destacarse las grandes extensiones de carrascales y los bosques con ombrotipos subhúmedo. Son carrascales densos formados por un estrato arbóreo de "Quercus", al que acompañan otros árboles y arbustos como el enebro (Juniperus oxicedrus), la sabina (Juniperos phoenicia) o la hiedra ((hedera helix). Como arbustos se representan el aladierno (Rhamnus alaternus), la ginesta (Cytisus heterochrous) así como la roseta (Rubia peregrina) entre otros. En el estrato herbáceo destacan las violetas, el heleboro y las orquídeas, así como distintas colonias de líquenes y epifitos.

La degradación de estos carrascales da lugar a un estrato arbustivo compuesto de tomillares, brezos y aliagas, entre otras especies.

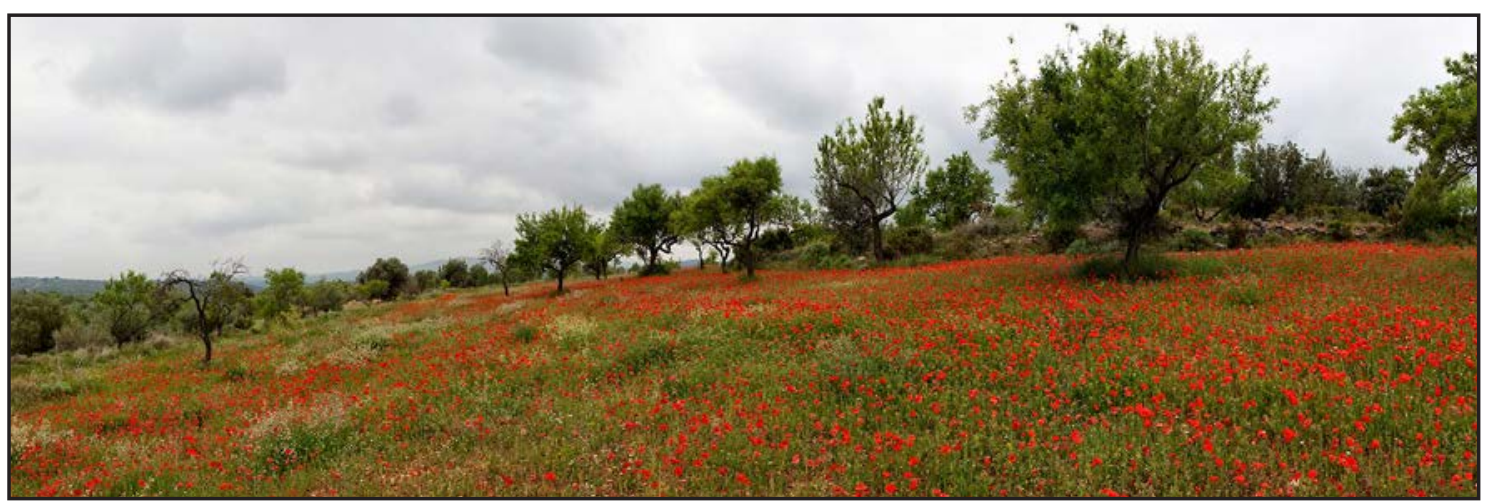

Fig. 3. 14. Campo de almendros y amapolas en primavera.

- Los robledales. El robledal de mayor extensión es el Quejigo (Quercus faginea). Es un bosque dominado por el quejigo acompañado por el pino negral (Pinus nigra-pinaster) o con sabinares a medida que el ambiente se continentaliza. Pobre en arbustos destaca el majuelo o espinera (Crataegus monogyna jacq) y diversas plantas trepadoras. Además el estrato herbáceo es rico en cuanto a variedad de especies, como corresponde al típico bosque subhúmedo del mediterráneo.

- Los sabinares. Es un bosque abierto donde domina este árbol y en el que aparecen árboles acompañantes como los enebros (Juniperuis communis). El estrato de matorral y herbáceo es bastante pobre y poco desarrollado. Dentro del sabinar podemos encontrar especies labiadas como la salvia (Salvia lavandulifolia) y la aliaga (genista scorpius).

- Los pinares. El pino carrasco es un elemento dominante de sustitución de los encinares o carrascales en el paisaje mediterráneo.

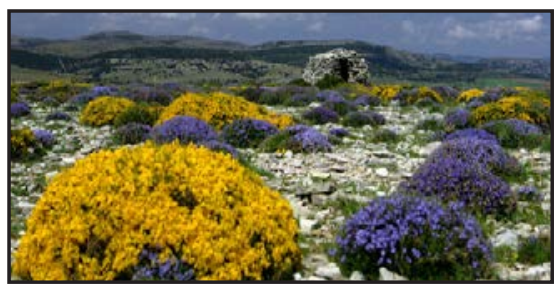

Fig. 3. 15. Foto de monte con matorrales.
- Series de matorral. La degradación de los bosques conduce a una serie de etapas de sustitución que se corresponden con diversos tipos de vegetación, entre la que destaca la formación de coscojares, lentiscares y espinales de sotobosque. Las praderas mediterráneas están dominadas por espartarales, albadinares y lastonares, formados por gramíneas que ocupan zonas de extraordinaria. 
- Vegetación influenciada por el suelo.

- Los bosques de ribera: ríos Cenia y Cervol y rambla Cervera. Los ecosistemas de ribera están considerados como uno de los más productivos, formando líneas de vegetación que sirvan de unión entre el agua y los ecosistemas terrestres. La vegetación de ribera esta formada por saucedas, choperas y olmedas y aparecen en los cursos permanente de agua situadas en bandas. En el caso de las ramblas que poseen aguas temporales los tipos de vegetación dominante son los tarayares y adelfares. La presencia de adelfares imprime un especial carácter a las ramblas por la espectacularidad y colorido.

- Lagunas de San Mateo y de La Jana. En sus bordes no domina la vegetación de arbolado, sino que lo hacen los cañaverales y las praderas de juncales. Las formaciones vegetales que aparecen son las de carrizos y eneas, que se distribuyen por los bordes formando comunidades terrestres cuando cesa la influencia del agua.

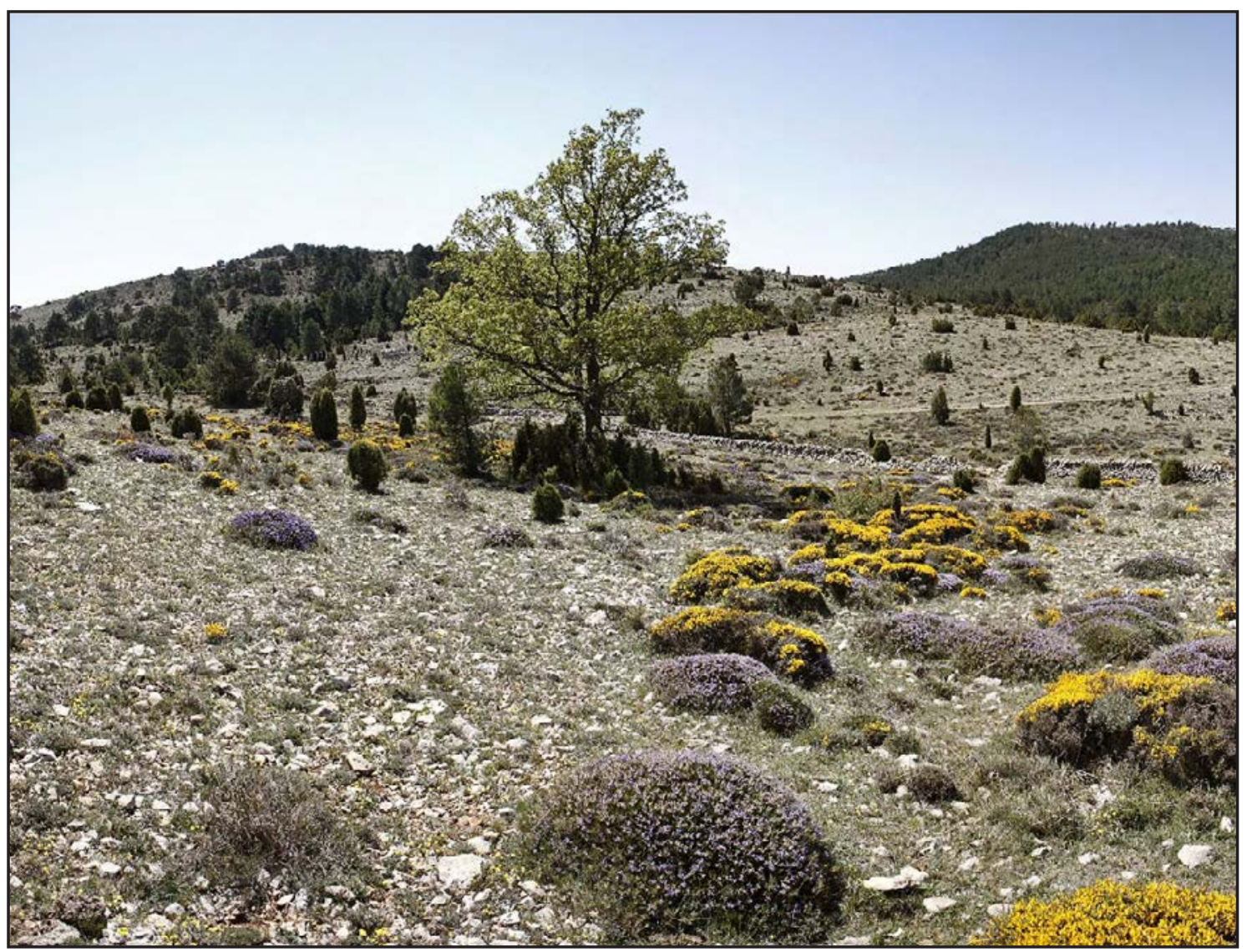

Fig. 3. 16. Vista del Pla de Santa Agueda. 


\section{2. 3. Las volumetrías}

Las relaciones que se establecen entre los elementos que con-forman el territorio: montañas, ríos, lagunas, abanicos aluviales, llanos sedimentados y la vegetación que sobre ellos vive, conforman un volumen sobre la superficie terrestre que es la base de nuestros ecosistemas.

Estos volúmenes como soportes o cañamazo del territorio que queremos analizar, lo hemos representado a partir de la obtención del MDT (Modelo Digital del Terreno). Para ello se ha usado el archivo topográfico de AutoCAD del área de estudio con las curvas de nivel cada $10 \mathrm{~m}$. obtenido del Instituto Cartográfico Valenciano al cual se le ha aplicado una simplificación angular de $5^{\circ}$ (es decir, se han eliminado los vértices que forman un ángulo menor de $5^{\circ}$ con respecto a los 2 vértices adyacentes) para poder manejar más cómodamente un archivo tan grande sin perder la definición de las curvas (el área total de la zona de estudio es de unos 455,6 millones de $\mathrm{m}^{2}$, siendo cada subzona de unos 16,6 millones de $\mathrm{m}^{2}$ ). Esta simplificación se ha llevado a cabo mediante la herramienta "elimina vértices inútiles en curvas de nivel" del plugin para AutoCAD ARKITool 2012.

Seguidamente se ha importado el resultado en .DWG al programa de modelado 3D SketchUp Pro 8 y se ha obtenido la malla triangular generada en base a las curvas de nivel mediante la herramienta "generar terreno desde contornos". Estos procesos se han repetido tanto para la zona completa o área de estudio como para las 12 subzonas estudiadas en que desarrollamos el análisis con más detalle ${ }^{61}$. Las zonas seleccionadas son:

1. La zona de montaña en el límite norte de la Batllia con los dominios del Monasterio de Bennifasar.

2. La zona de montaña del Turmell y del valle de la Barcella.

3. La ladera de la montaña donde se encuentra Xert.

4. La ladera de la montaña donde se encuentra Rosell.

5. El llano de Canet.

6. El llano de La Jana-Carrascal.

7. El llano de San Mateo.

8. El llano de Traiguera.

9. La zona de media montaña entre Cervera y Calig.

10. La zona de media montaña entre el Ermitorio de la Virgen de la Salud y el mas dels Stellers.

11. El llano entre los ríos Cenia y Cervol.

12. La atalaya de San Pere entre Traiguera y Canet.

De cada una de ellas representamos el volumen y posteriormente una serie de secciones tanto longitudinales y transversales que nos dan una idea inicial de cual es el ámbito de los posibles recintos naturales que tendremos en el área de estudio.

Esta información gráfica inicial volumétrica será la base que usaremos posteriormente en el desarrollo de las simplificaciones que nos permitirán abstraer la imagen del territorio para su posterior análisis.

61 Se eligen las 12 zonas con una disposición este-oeste, ya que la comarca está en gran parte condicionada por las redes fluviales que se dirigen hacia el este. Se ha procurado que cada zona sea representativa de una topografía concreta. La zona 12 es un caso singular que ejemplifica una elevación contraria a la de las redes fluviales. 
Mapa general (situación de las zonas de estudio) - $[\mathrm{e}=1 / 200.000]$

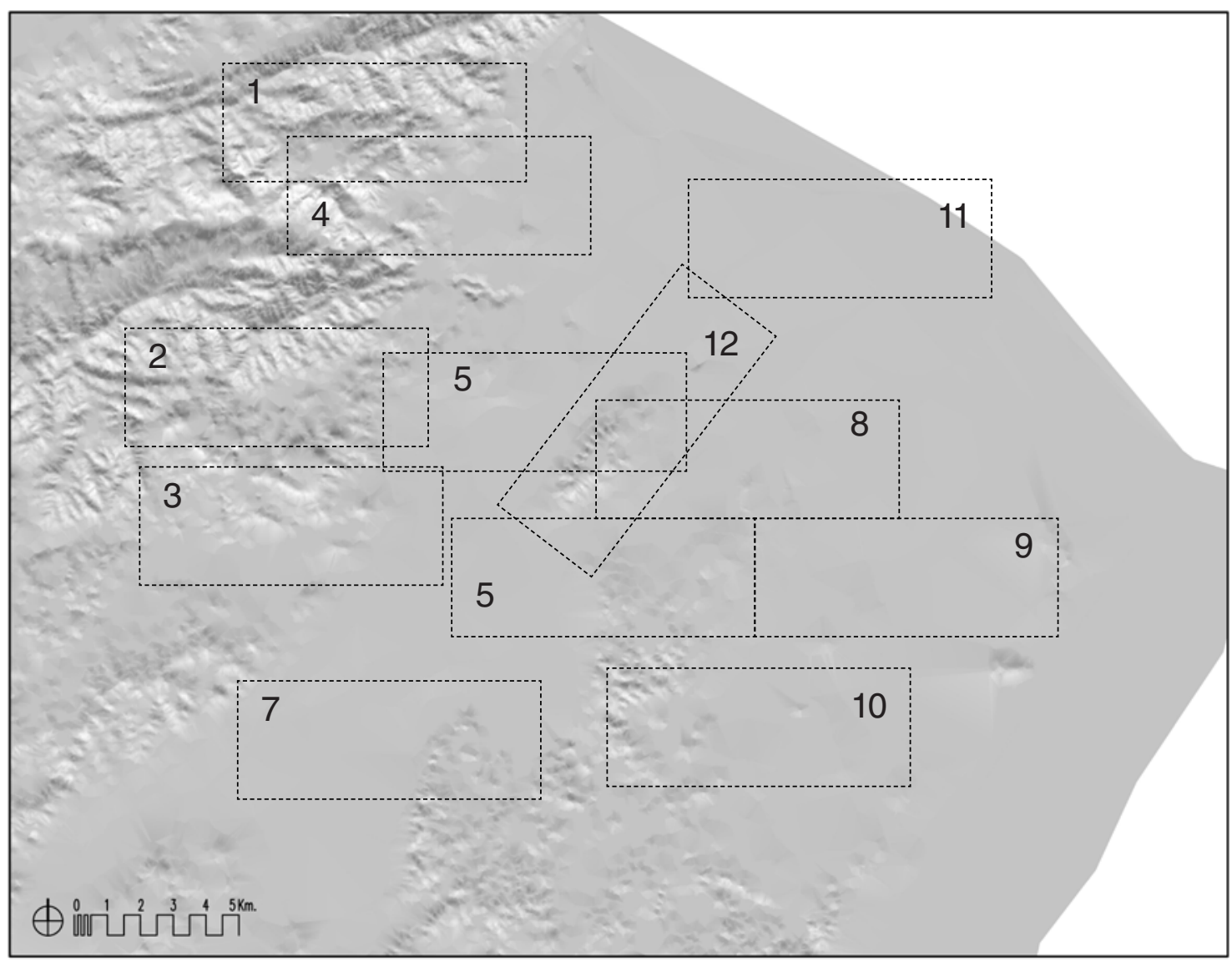

Fig. 3. 17. Plano a escala 1/200.000 de la topografía de la Batllia de Cervera y alrededores y la situación de las 12 zonas de estudio.

La conformación del Maestrat se caracteriza por la disposición de sierras y fosas hundidas paralelas a la costa y por tanto perpendiculares a los cursos fluviales principales. Esta es la característica fundamental de este soporte. Esta forma del soporte-tras diversas opciones que hemos barajado- nos ha hecho decantar por elegir las 12 zonas de estudio con mayor detalle con la dirección E-O que nos permite analizar las zonas de "cambio" del soporte y por tanto sus elementos más característicos. La zona 12 es una excepción, ya que su objeto es el estudio de la Sierra de Sant Pere en su totalidad. 
Información volumétrica - Zona $1(\mathrm{Bel})$ - [e=1/75.000]
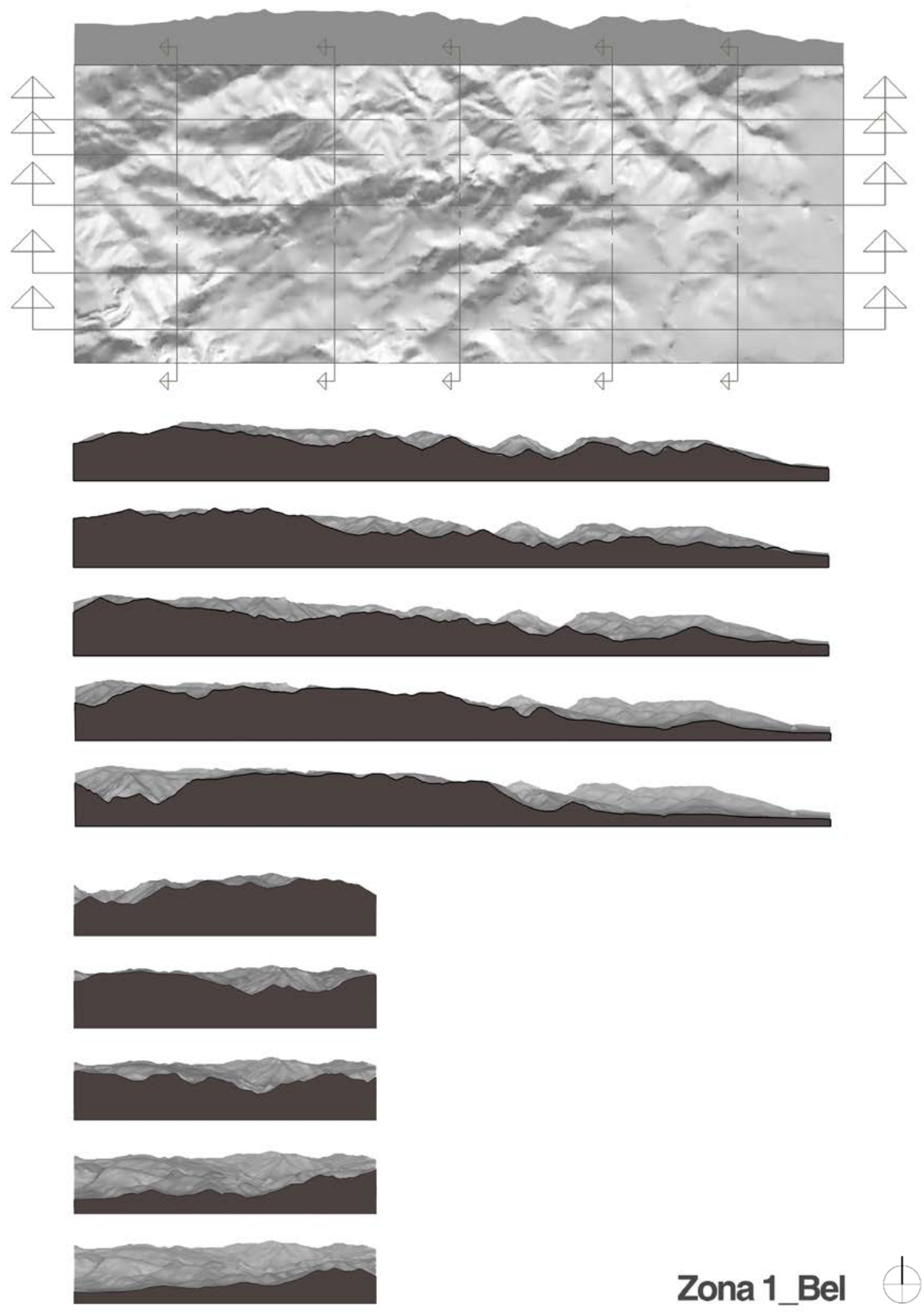
Información volumétrica - Zona 2 (Barcella) - [e=1/75.000]
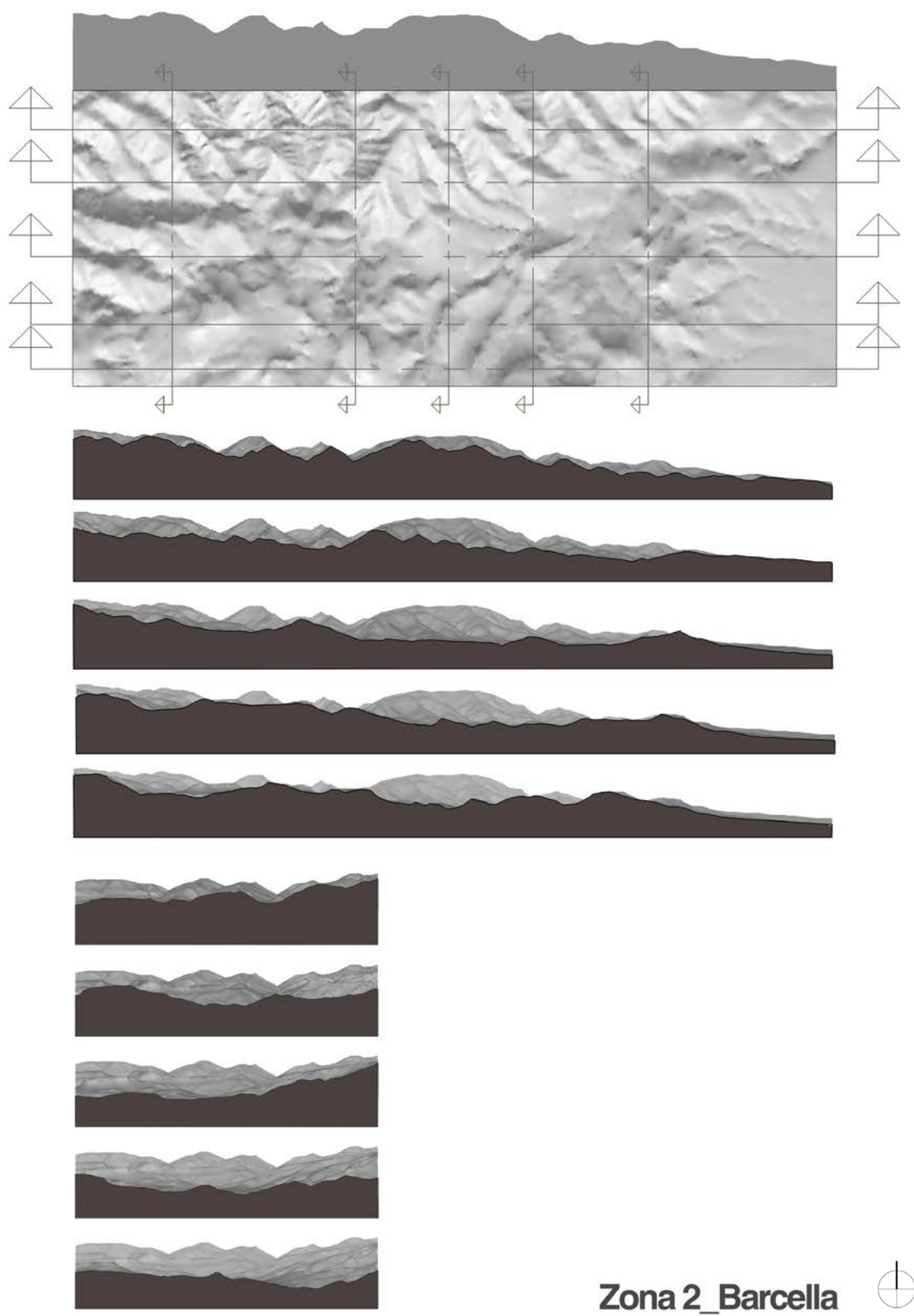
Información volumétrica - Zona 3 (Molinar / Xert) - [e=1/75.000]
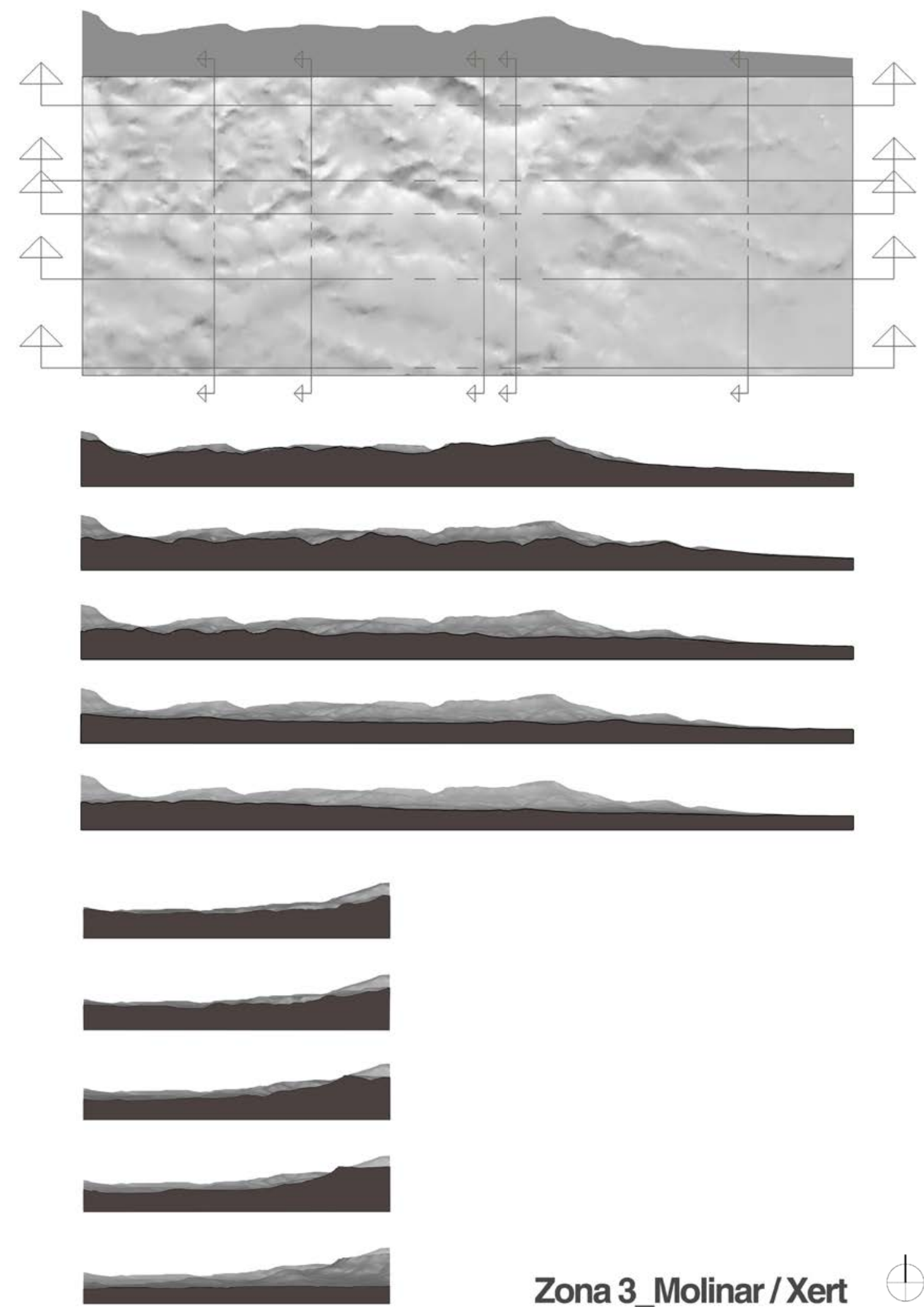

\section{Zona 3 Molinar / Xert}


Información volumétrica - Zona 4 (Más del Coll / Rosell) - [e=1/75.000]
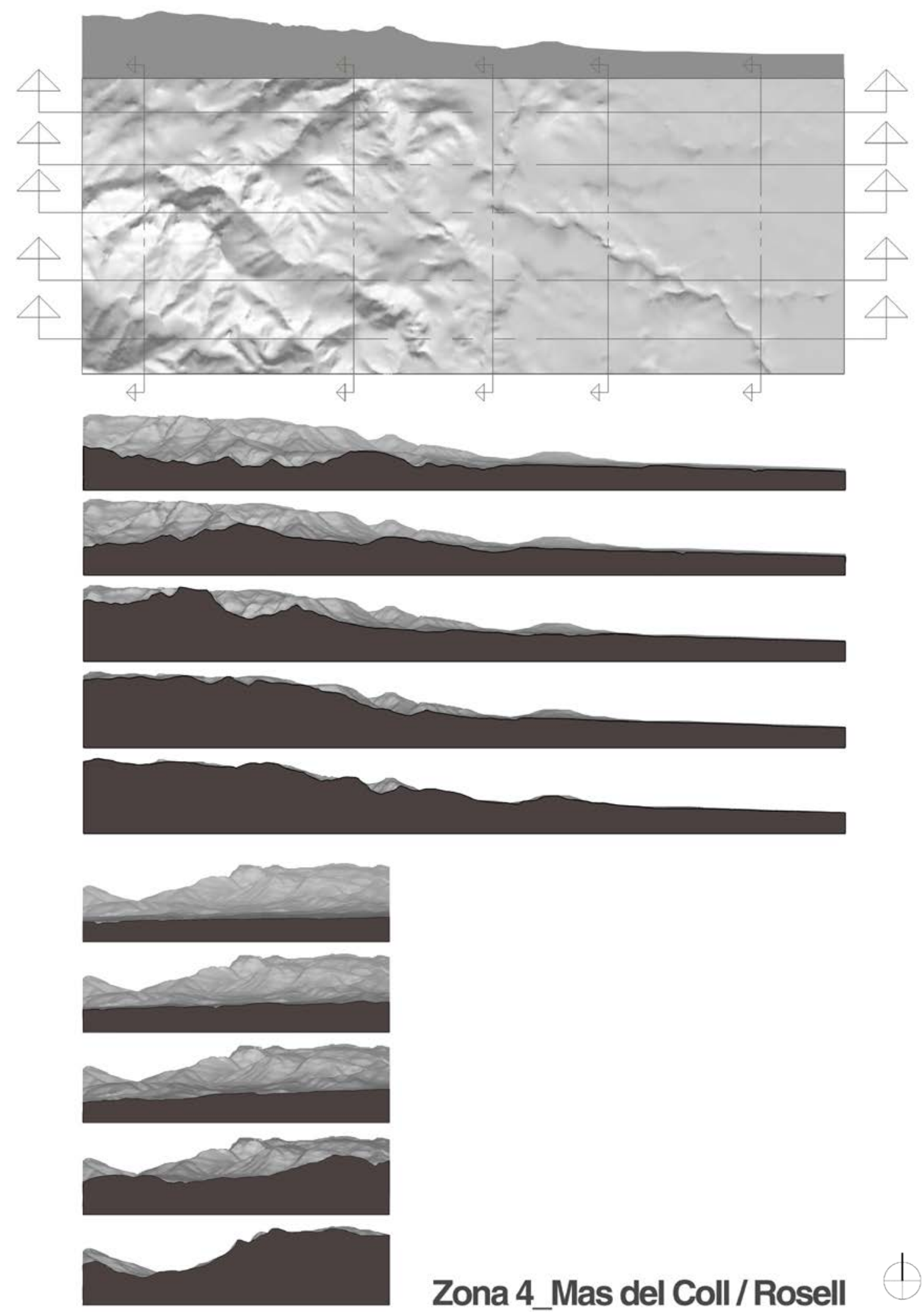

Zona 4_Mas del Coll / Rosell 
Información volumétrica - Zona 5 (Canet) - [e=1/75.000]
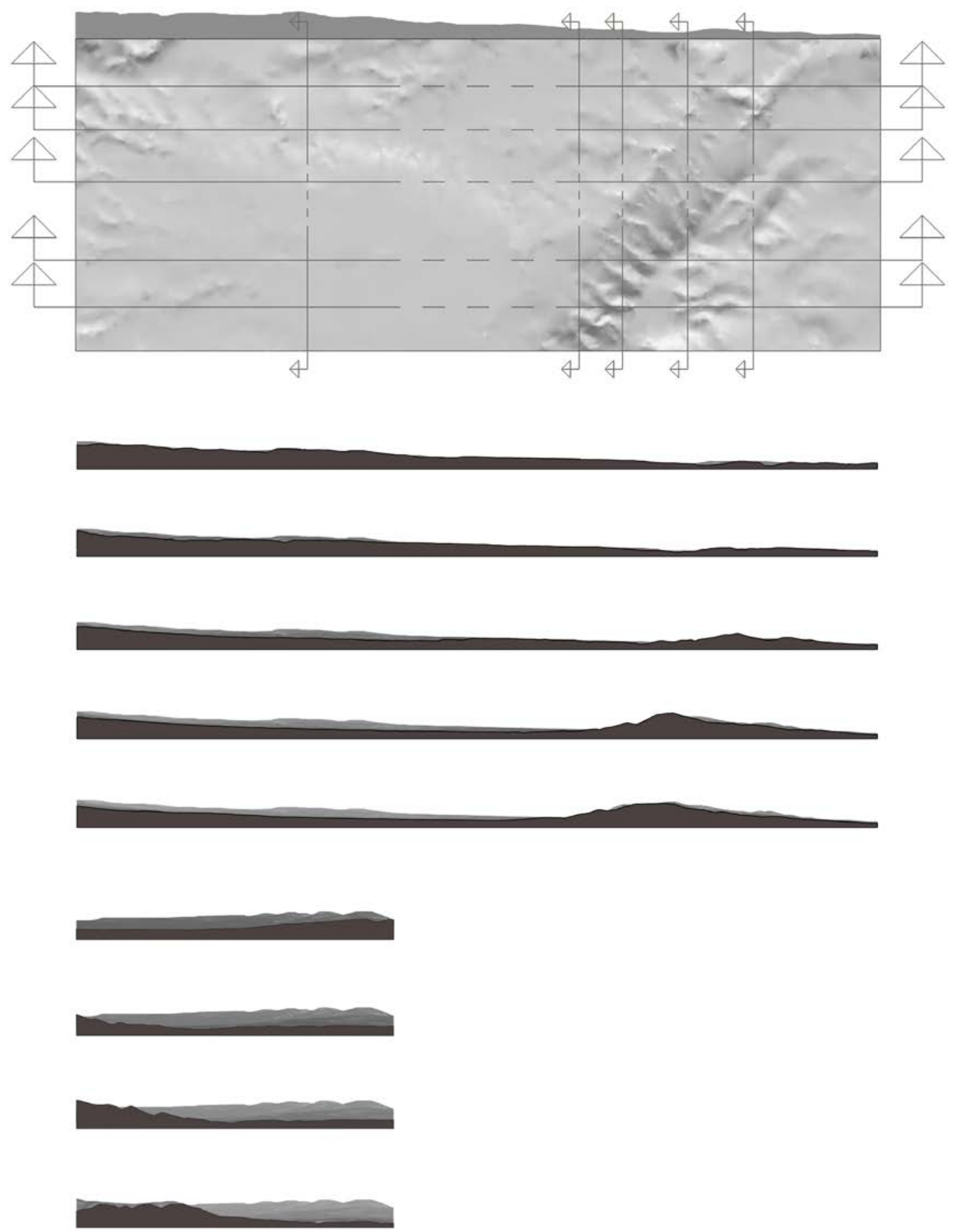

\section{Zona 5_Canet}


Información volumétrica - Zona 6 (La Jana / Carrascal) - [e=1/75.000]
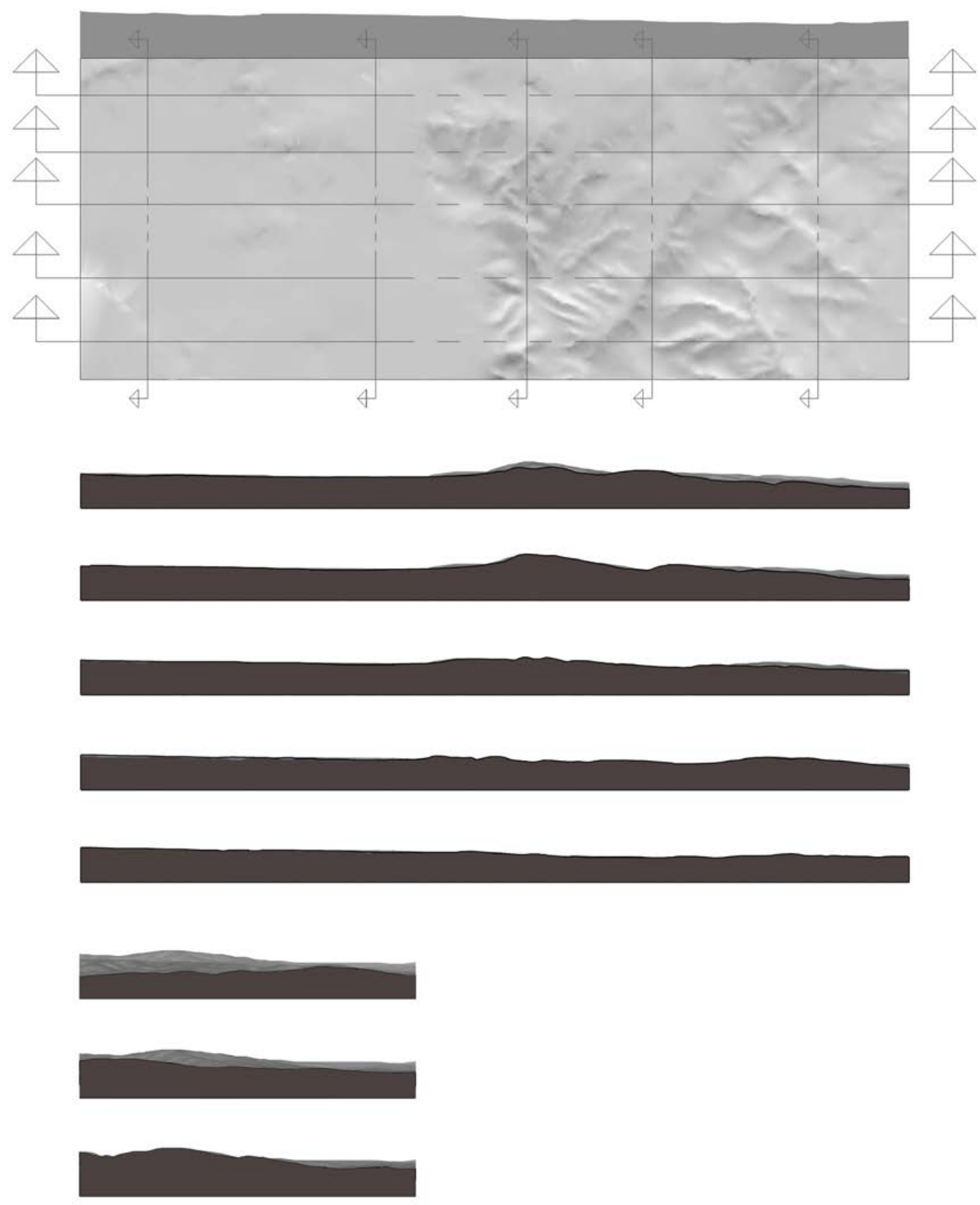
Información volumétrica - Zona 7 (San Mateo) - [e=1/75.000]
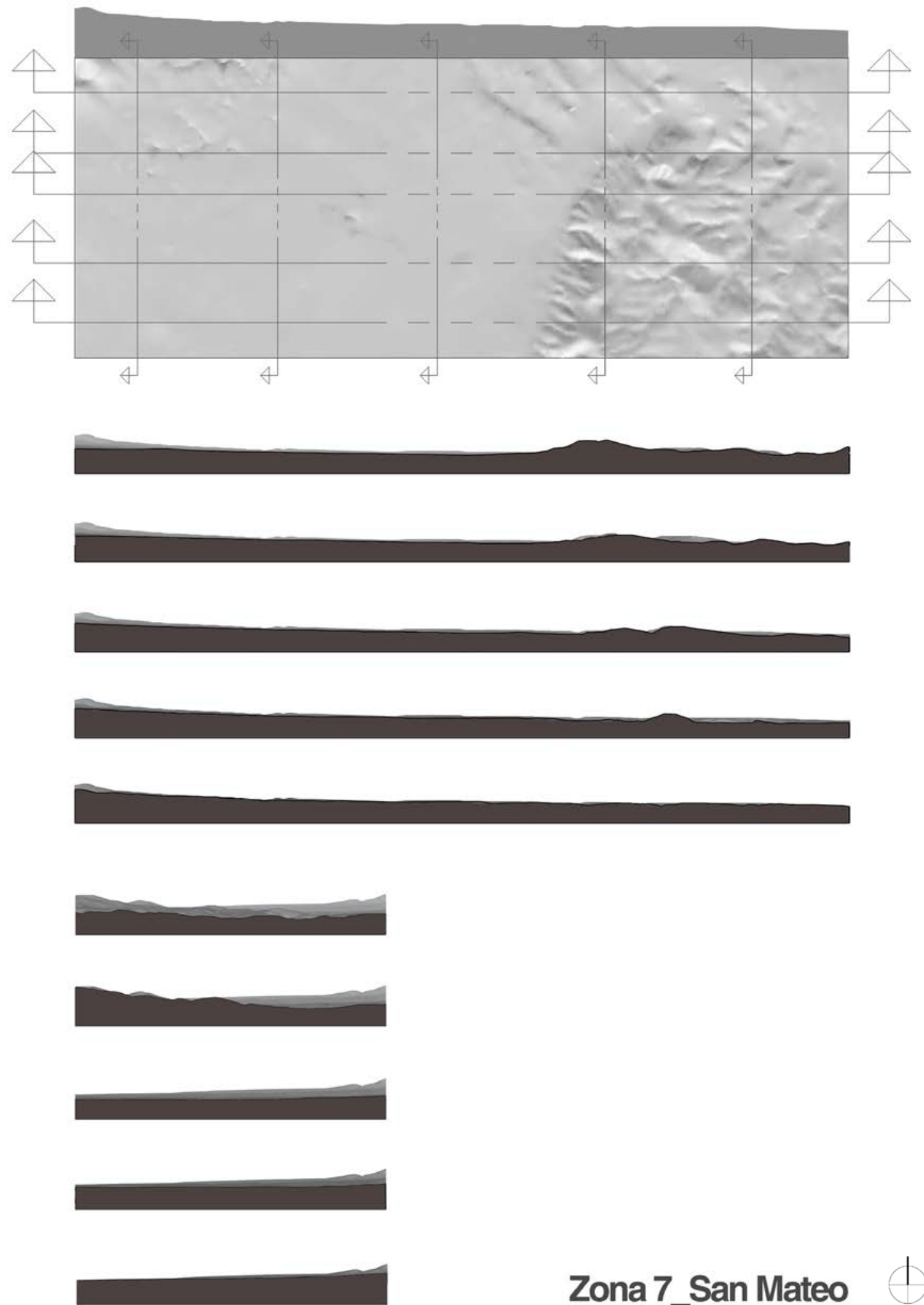
Información volumétrica - Zona 8 (Traiguera) - $[\mathrm{e}=1 / 75.000]$
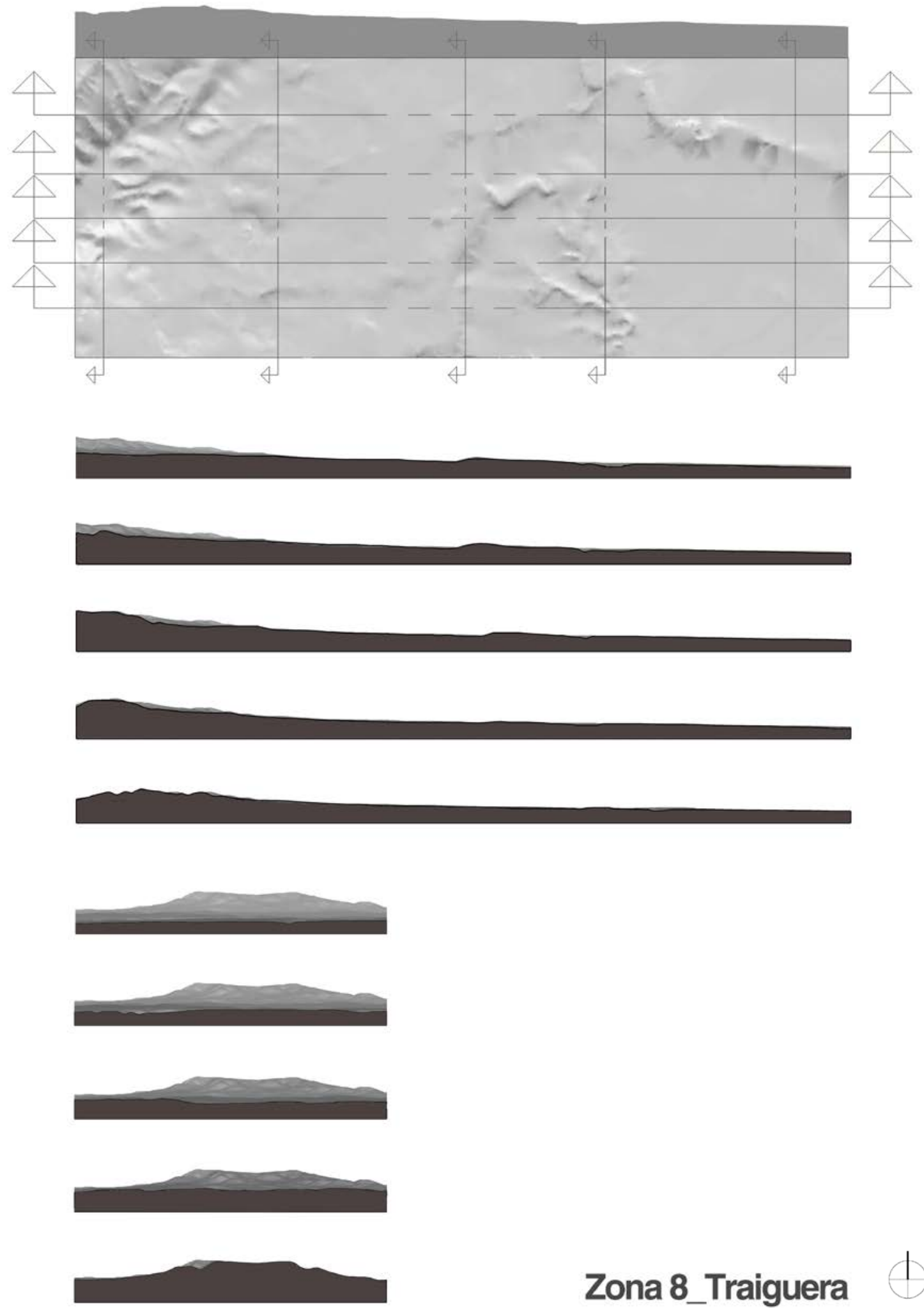

Zona 8_Traiguera 
Información volumétrica - Zona 9 (Mas Stellers) - [e=1/75.000]
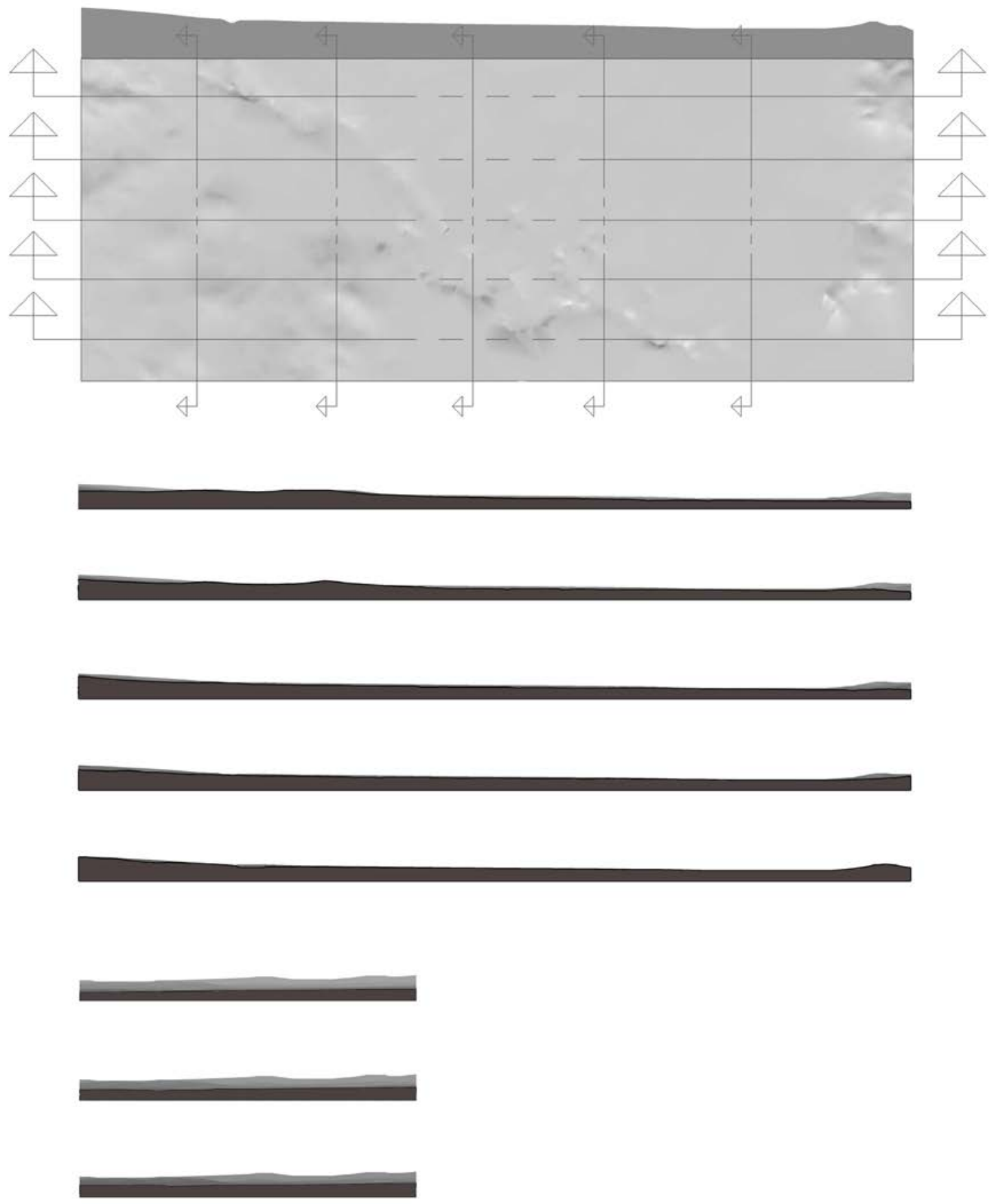

Zona 9_Mas Stellers 
Información volumétrica - Zona 10 (Cervera / Calig) - [e=1/75.000]
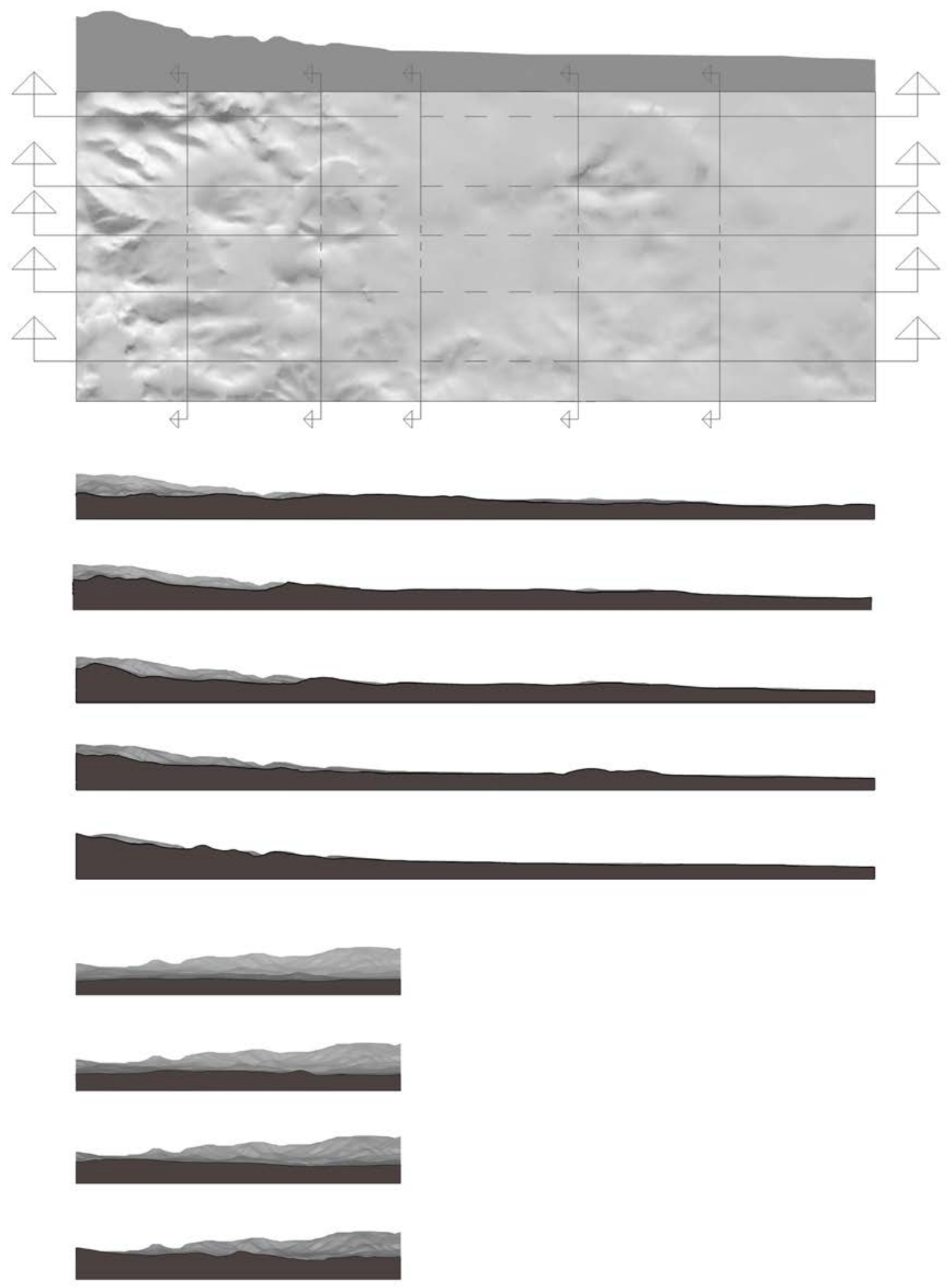

Zona 10_Cervera/Calig 
Información volumétrica - Zona 11 (San Joan del Pas) - [e=1/75.000]
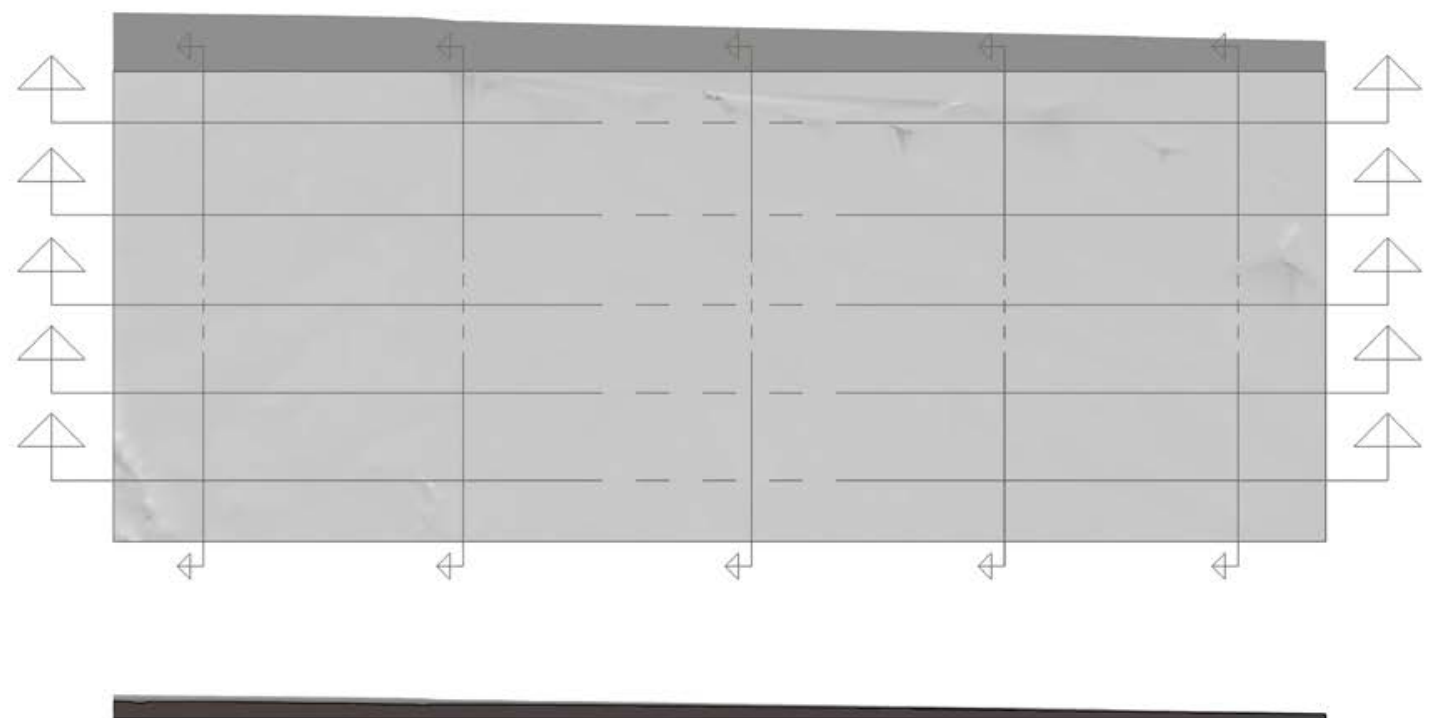

$$
\text { (1) }
$$


Información volumétrica - Zona 12 (Atalaya San Pere) - [e=1/75.000]
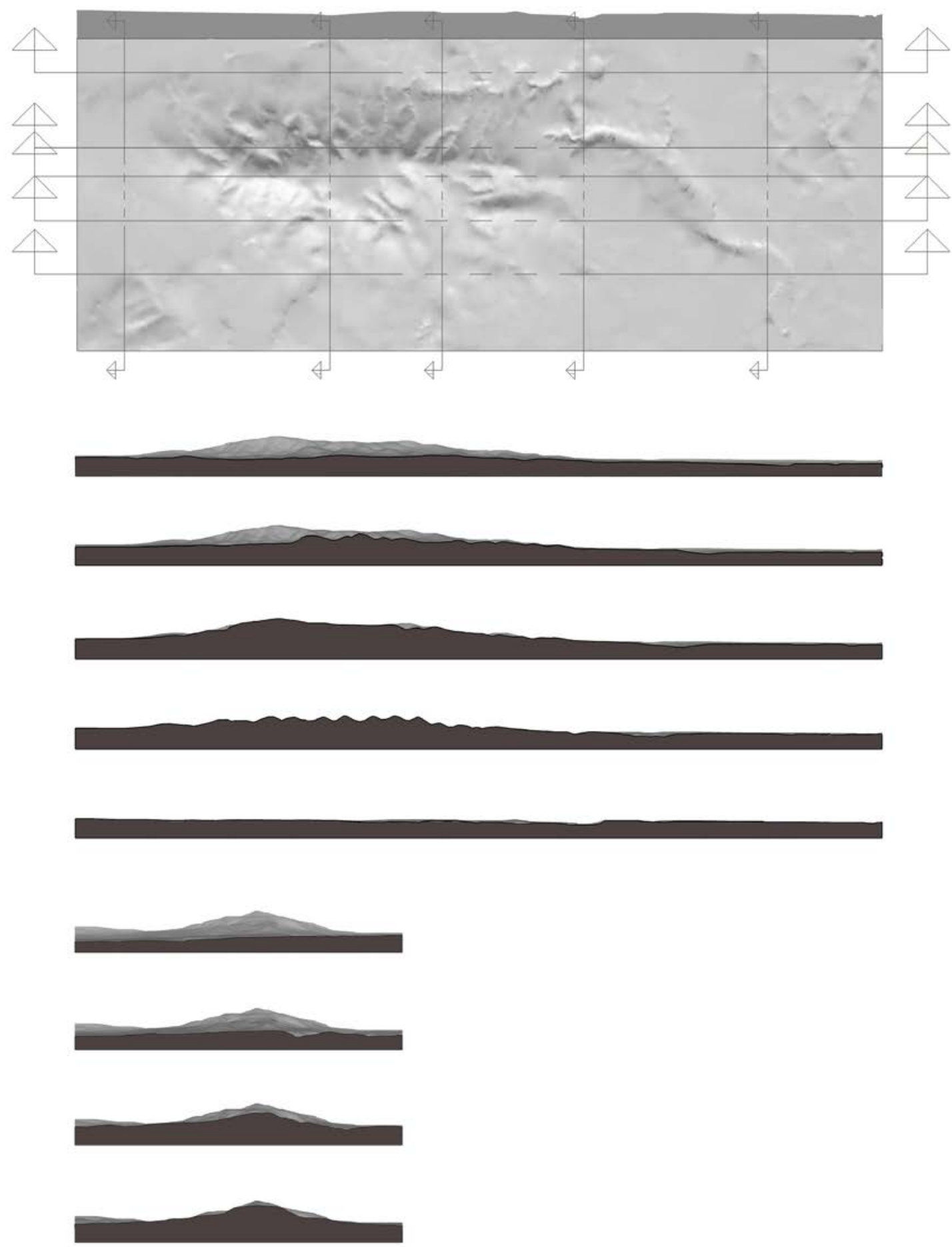

Zona 12_Atalaya San Pere 



\section{3. La in-formación del soporte territorial}

\section{3. 1. Las topologías}

El relieve se representa gráficamente en volumen a partir de una triangulación de planos que definen las cotas y pendientes del objeto representado. Esta triangulación es una abstracción del relieve, a la que nosotros "sometemos" a posteriores abstracciones reduciendo el número de planos que conforman el relieve inicial y que a cada paso que damos conseguimos un mayor grado de abstracción. Para obtener las simplificaciones de las mallas tridimensionales de terreno se ha usado el software libre de tratamiento de mallas MeshLab. Para ello se ha exportado cada archivo de .SKP obtenido de SketchUp al formato .DAE (COLLADA) por su gran compatibilidad a la hora de trabajar con modelos tridimensionales.

Una vez importado a MeshLab se procede a la simplificación de la malla original aplicando el filtro "Remeshing - Quadric Edge Collapse Decimation" (que se podría traducir como "rehacer malla mediante la destrucción por colapso de las aristas de la cuádrica) manteniendo activada la opción de conservar topología. Este filtro nos da la opción de reducir el número de caras (triángulos) de la malla en sucesivas subdivisiones, que para el caso de estudios han sido de 1/4, 1/16, 1/64 y 1/256 del número inicial de polígonos de cada malla. Posteriormente estos estados de simplificación de cada zona se han vuelto a importar a SketchUp para poder trabajar con ellos y obtener las imágenes necesarias para analizar los resultados.

Posteriormente seleccionamos en seis grupos los planos así obtenidos por sus pendientes, en intervalos comprendidos entre $0^{\circ}$ a $35^{\circ}$, creando una representación abstracta del volumen del territorio en función de los planos que lo conforman y de sus pendientes.

A continuación se detalla el proceso de simplificación para cada zona de estudio, siendo en el caso concreto de la zona 3 (ver *) se hizo a $1 / 128$.

\begin{tabular}{|c|c|c|c|c|c|}
\hline ZONA & \multicolumn{3}{|c|}{ FACTOR DE SIMPLIFICACIÓN } & \multicolumn{2}{|c|}{ NÚMERO DE CARAS } \\
\hline \multirow{5}{*}{ Zona completa } & \multicolumn{3}{|c|}{$1 / 1$ (original) } & \multicolumn{2}{|c|}{294.385} \\
\hline & \multicolumn{3}{|c|}{$1 / 4$} & \multicolumn{2}{|c|}{73.556} \\
\hline & \multicolumn{3}{|c|}{$1 / 16$} & \multicolumn{2}{|c|}{18.389} \\
\hline & \multicolumn{3}{|c|}{$1 / 64$} & \multicolumn{2}{|c|}{4.596} \\
\hline & \multicolumn{3}{|c|}{$1 / 256$} & \multicolumn{2}{|c|}{1.148} \\
\hline ZONA & FACTOR & $\mathbf{N}^{\circ}$ CARAS & ZONA & FACTOR & $\mathrm{N}^{\circ}$ CARAS \\
\hline \multirow{5}{*}{$\begin{array}{c}\text { Zona } 1 \\
\text { (Bel) }\end{array}$} & $1 / 1$ (original) & 67.325 & \multirow{5}{*}{$\begin{array}{c}\text { Zona } 7 \\
\text { (San Mateo) }\end{array}$} & $1 / 1$ (original) & 31.450 \\
\hline & $1 / 4$ & 16.830 & & $1 / 4$ & 7.861 \\
\hline & $1 / 16$ & 4.206 & & $1 / 16$ & 1.964 \\
\hline & $1 / 64$ & 1.050 & & $1 / 64$ & 489 \\
\hline & $1 / 256$ & 262 & & $1 / 256$ & 121 \\
\hline \multirow{5}{*}{$\begin{array}{c}\text { Zona } 2 \\
\text { (Barcella) }\end{array}$} & $1 / 1$ (original) & 54.224 & \multirow{5}{*}{$\begin{array}{c}\text { Zona } 8 \\
\text { (Traiguera) }\end{array}$} & $1 / 1$ (original) & 29.995 \\
\hline & $1 / 4$ & 13.556 & & $1 / 4$ & 7.498 \\
\hline & $1 / 16$ & 3.389 & & $1 / 16$ & 1.874 \\
\hline & $1 / 64$ & 847 & & $1 / 64$ & 467 \\
\hline & $1 / 256$ & 211 & & $1 / 256$ & 115 \\
\hline \multirow{5}{*}{$\begin{array}{c}\text { Zona } 3 \\
\text { (Molinar / Xert) }\end{array}$} & $1 / 1$ (original) & 25.937 & \multirow{5}{*}{$\begin{array}{c}\text { Zona } 9 \\
\text { (Virgen de la Salut / } \\
\text { Más Stellers) }\end{array}$} & $1 / 1$ (original) & 12.847 \\
\hline & $1 / 4$ & 6.483 & & $1 / 4$ & 3.210 \\
\hline & $1 / 16$ & 1.619 & & $1 / 16$ & 802 \\
\hline & $1 / 64$ & 403 & & $1 / 64$ & 199 \\
\hline & $1 / 128^{*}$ & 201 & & $1 / 256$ & 49 \\
\hline \multirow{5}{*}{$\begin{array}{c}\text { Zona } 4 \\
\text { (Más del Coll / } \\
\text { Rosell) }\end{array}$} & $1 / 1$ (original) & 81.711 & \multirow{5}{*}{$\begin{array}{c}\text { Zona } 10 \\
\text { (Cervera / Calig) }\end{array}$} & $1 / 1$ (original) & 36.477 \\
\hline & $1 / 4$ & 20.426 & & $1 / 4$ & 9.118 \\
\hline & $1 / 16$ & 5.106 & & $1 / 16$ & 2.279 \\
\hline & $1 / 64$ & 1.276 & & $1 / 64$ & 569 \\
\hline & $1 / 256$ & 318 & & $1 / 256$ & 140 \\
\hline \multirow{5}{*}{$\begin{array}{l}\text { Zona } 5 \\
\text { (Canet) }\end{array}$} & $1 / 1$ (original) & 22.435 & \multirow{5}{*}{$\begin{array}{c}\text { Zona } 11 \\
\text { (San Joan del Pas) }\end{array}$} & $1 / 1$ (original) & 10.303 \\
\hline & $1 / 4$ & 5.607 & & $1 / 4$ & 2.560 \\
\hline & $1 / 16$ & 1.401 & & $1 / 16$ & 639 \\
\hline & $1 / 64$ & 349 & & $1 / 64$ & 159 \\
\hline & $1 / 256$ & 86 & & $1 / 256$ & 39 \\
\hline \multirow{5}{*}{$\begin{array}{c}\text { Zona } 6 \\
\text { (La Jana / Carrascal) }\end{array}$} & $1 / 1$ (original) & 27.883 & \multirow{5}{*}{$\begin{array}{c}\text { Zona } 12 \\
\text { (Atalaya San Pere) }\end{array}$} & $1 / 1$ (original) & 38.058 \\
\hline & $1 / 4$ & 6.969 & & $1 / 4$ & 9.514 \\
\hline & $1 / 16$ & 1.740 & & $1 / 16$ & 2.378 \\
\hline & $1 / 64$ & 435 & & $1 / 64$ & 594 \\
\hline & $1 / 256$ & 107 & & $1 / 256$ & 147 \\
\hline
\end{tabular}



Simplificaciones - Zona 1 (Bel) - $[e=1 / 80.000]$
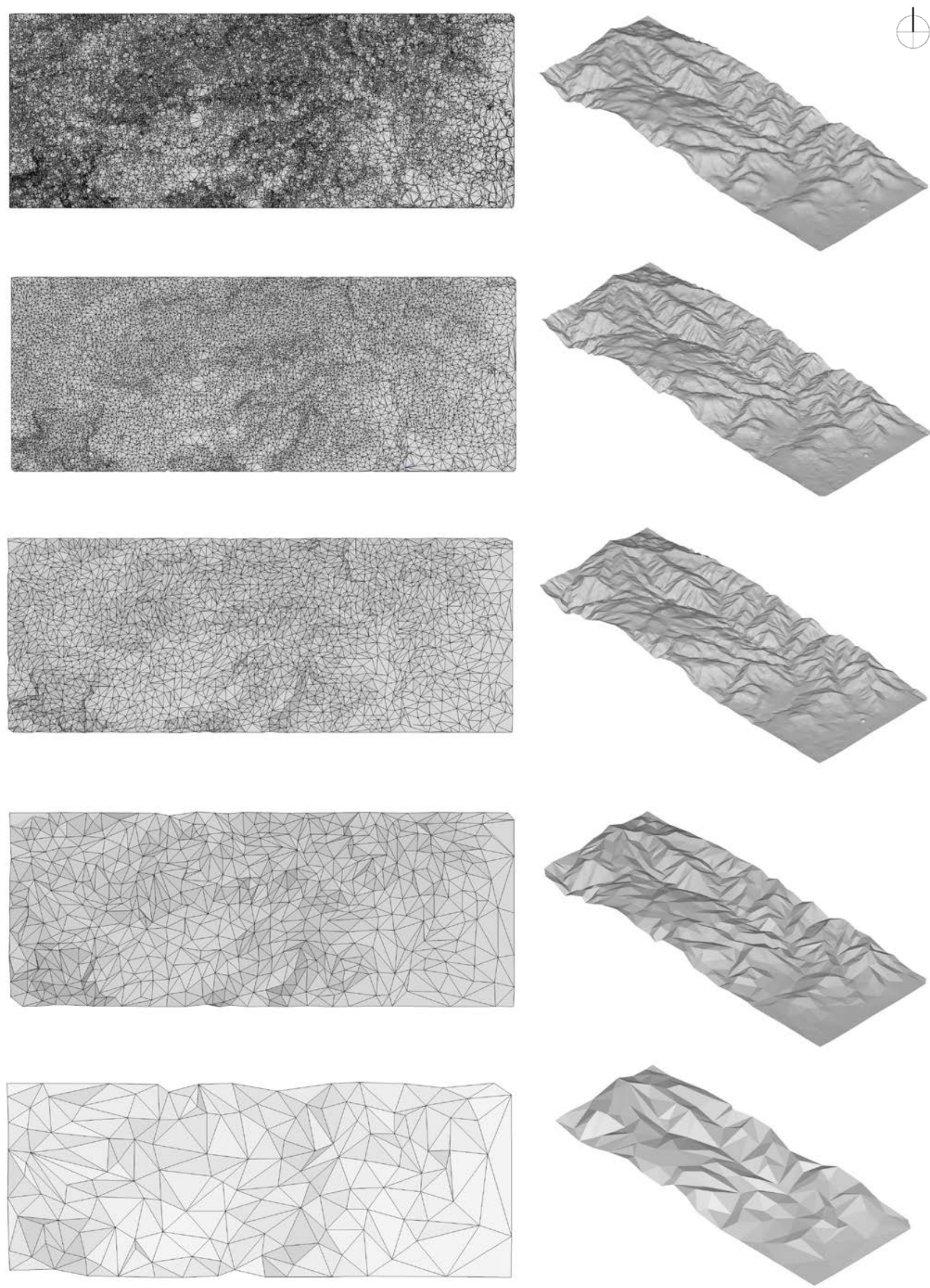
Simplificaciones - Zona 2 (Barcella) - $[e=1 / 80.000]$
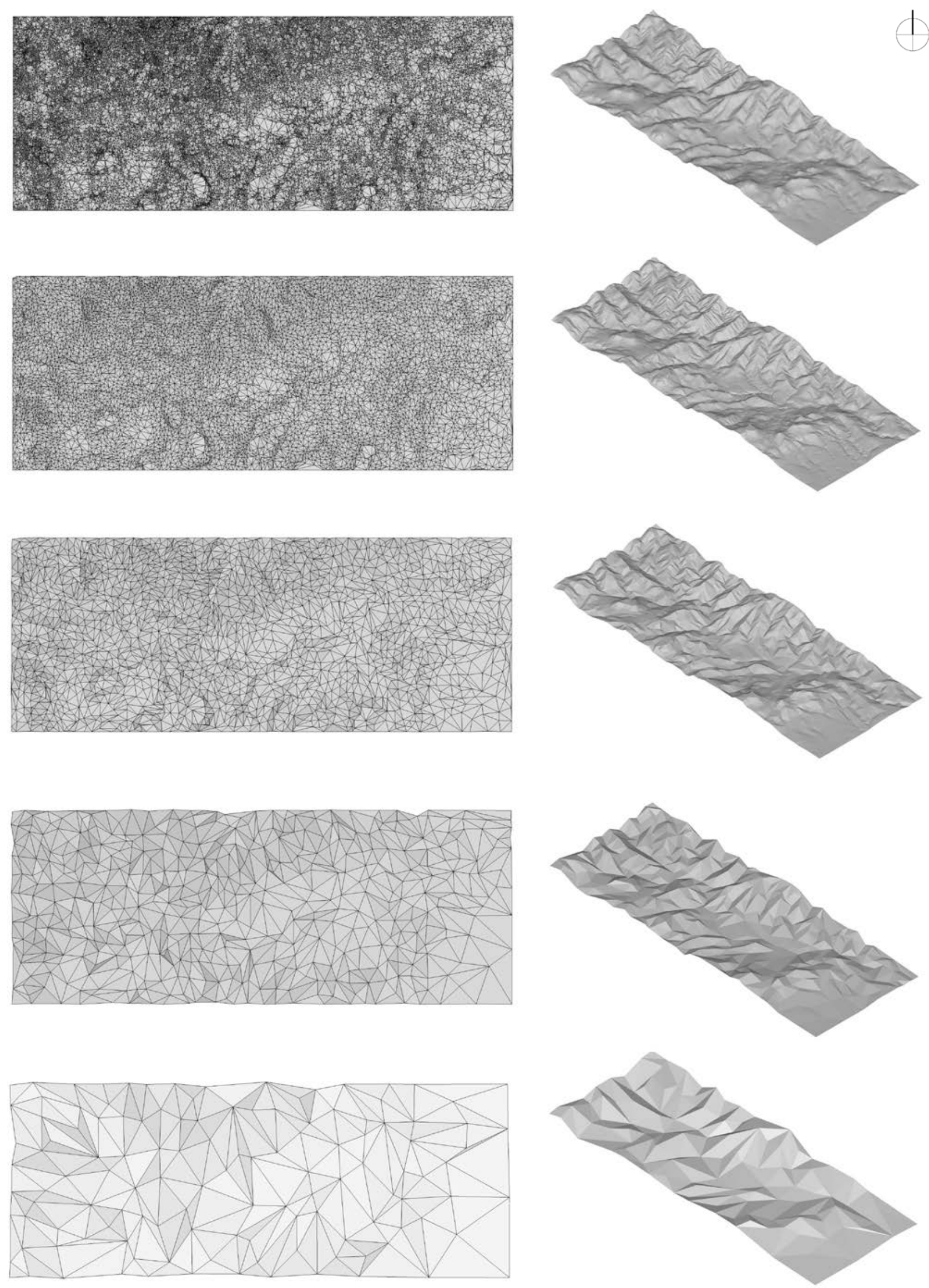
Simplificaciones - Zona 3 (Molinar / Xert) - $[e=1 / 80.000]$
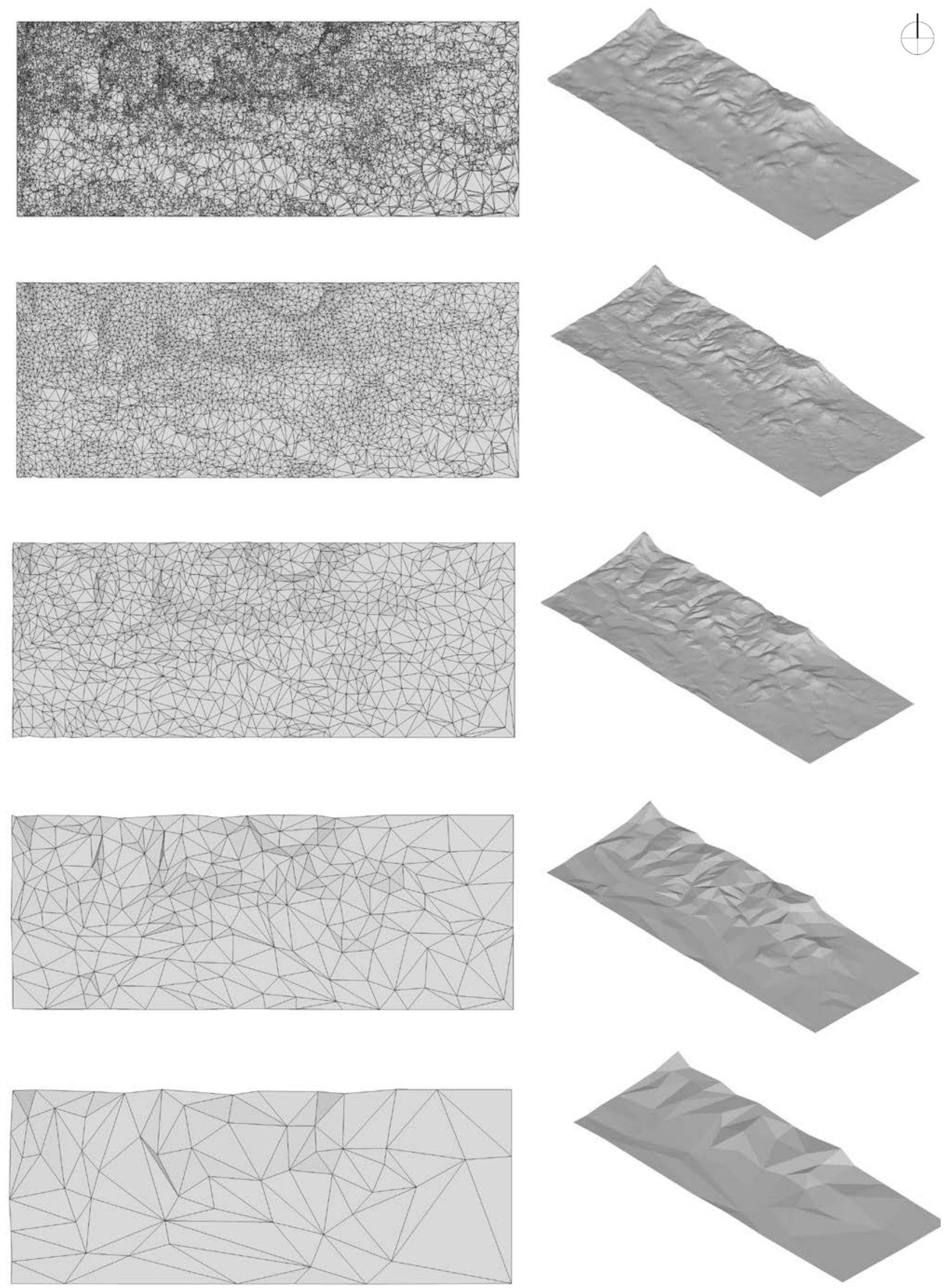
Simplificaciones - Zona 4 (Mas del Coll / Rosell) - $[\mathrm{e}=1 / 80.000]$
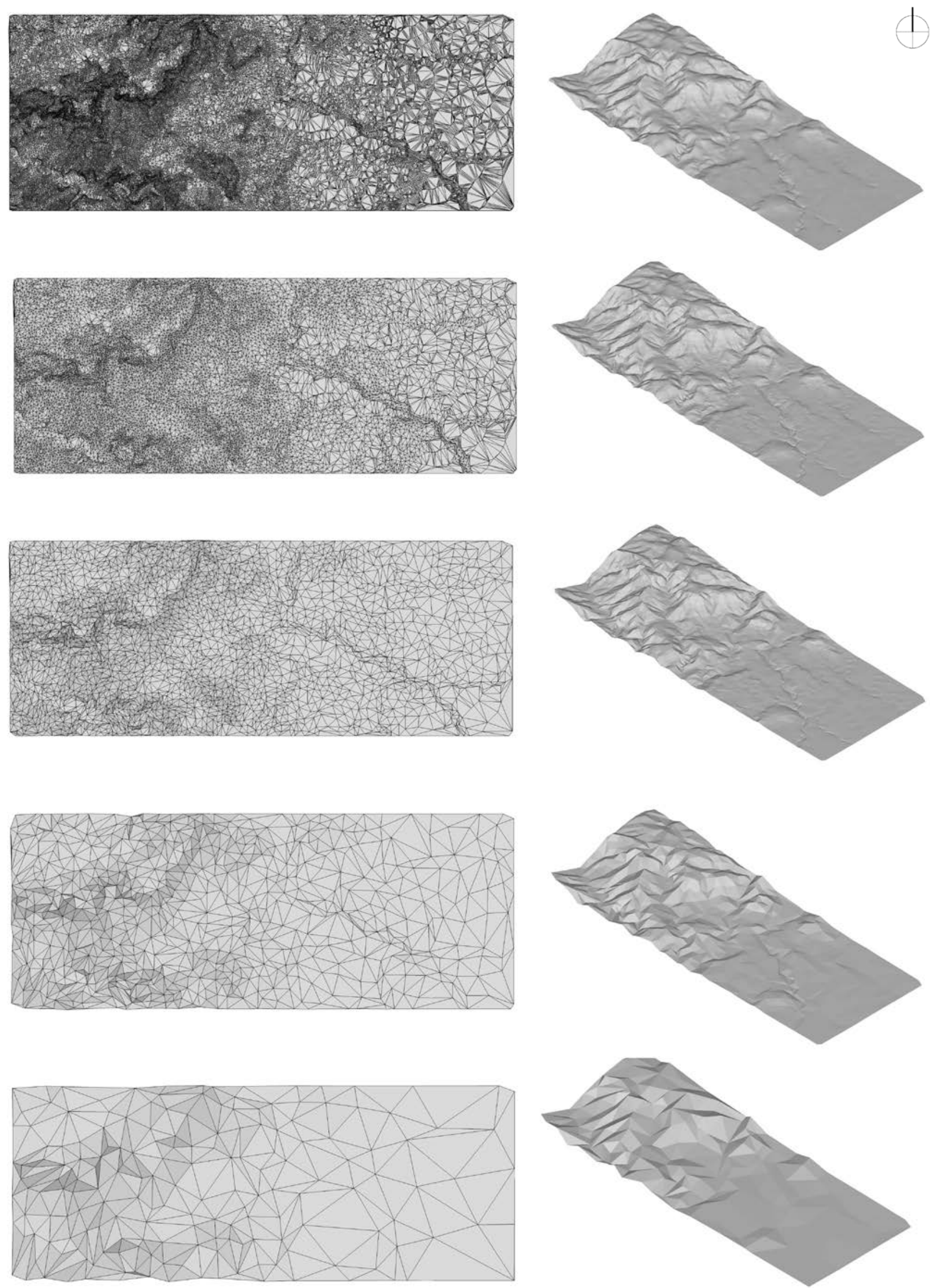
Simplificaciones - Zona 5 (Canet) - $[\mathrm{e}=1 / 80.000]$
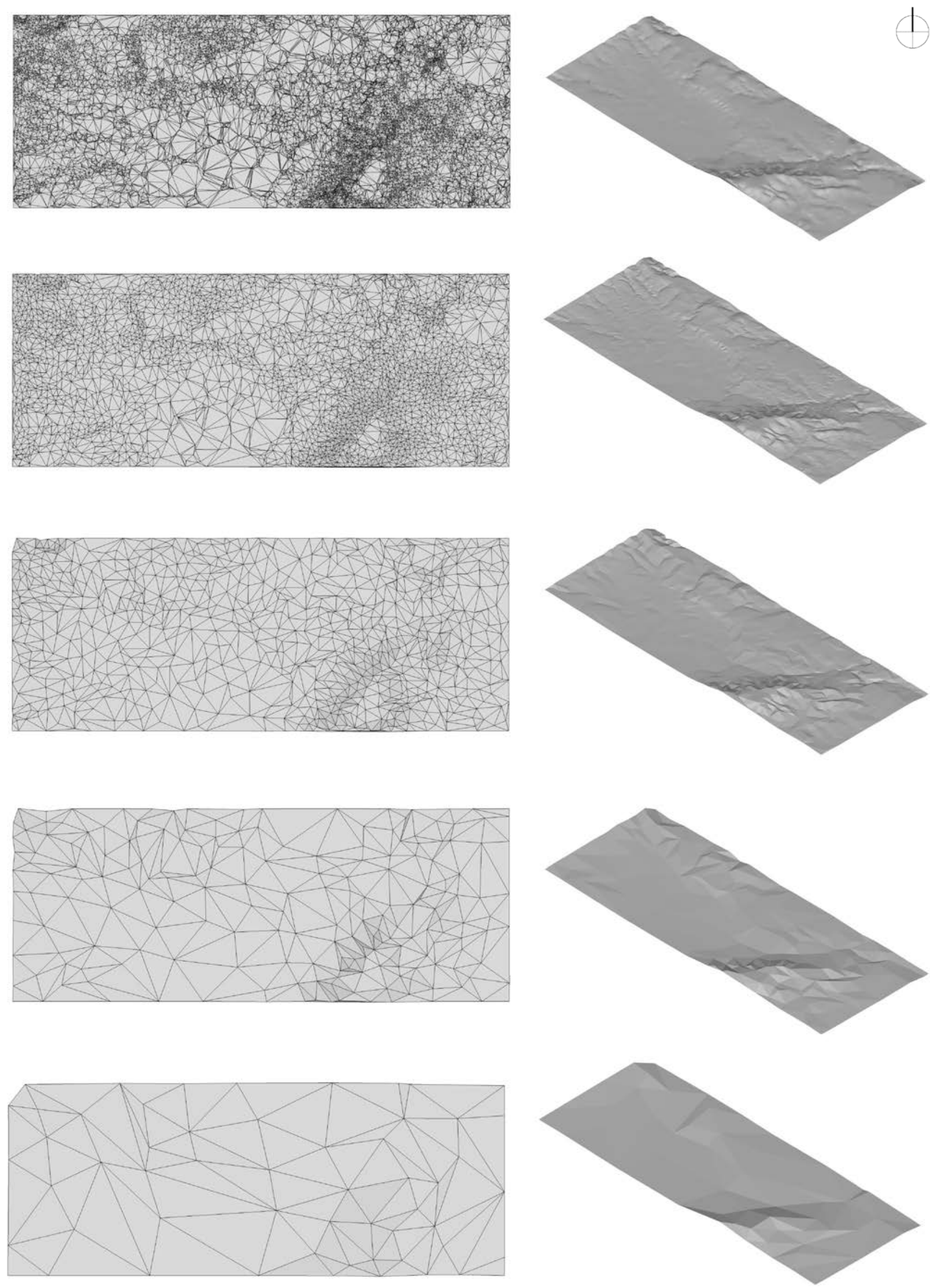
Simplificaciones - Zona 6 (La Jana / Carrascal) - $[e=1 / 80.000]$
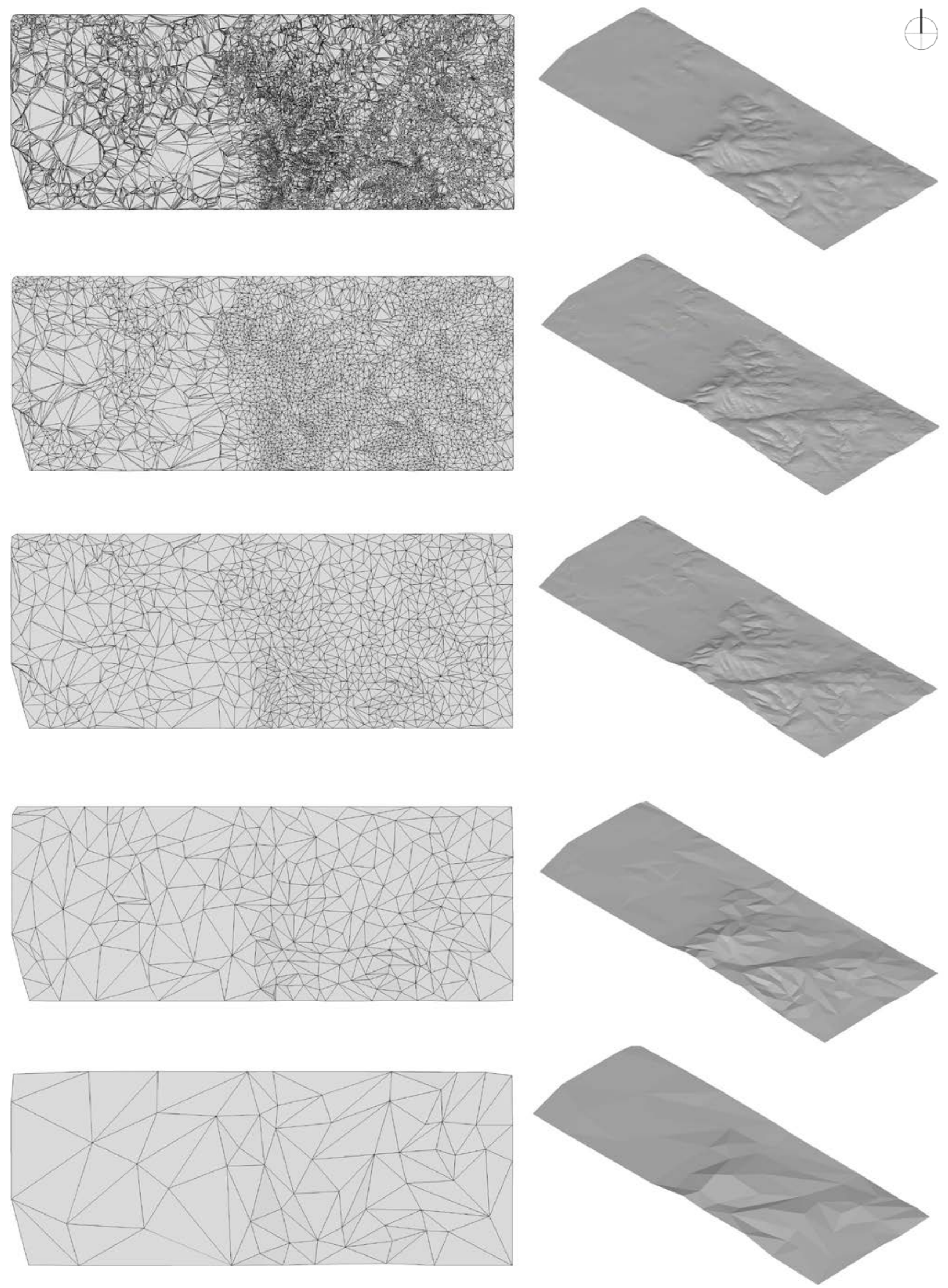
Simplificaciones - Zona 7 (San Mateo) - $[e=1 / 80.000]$
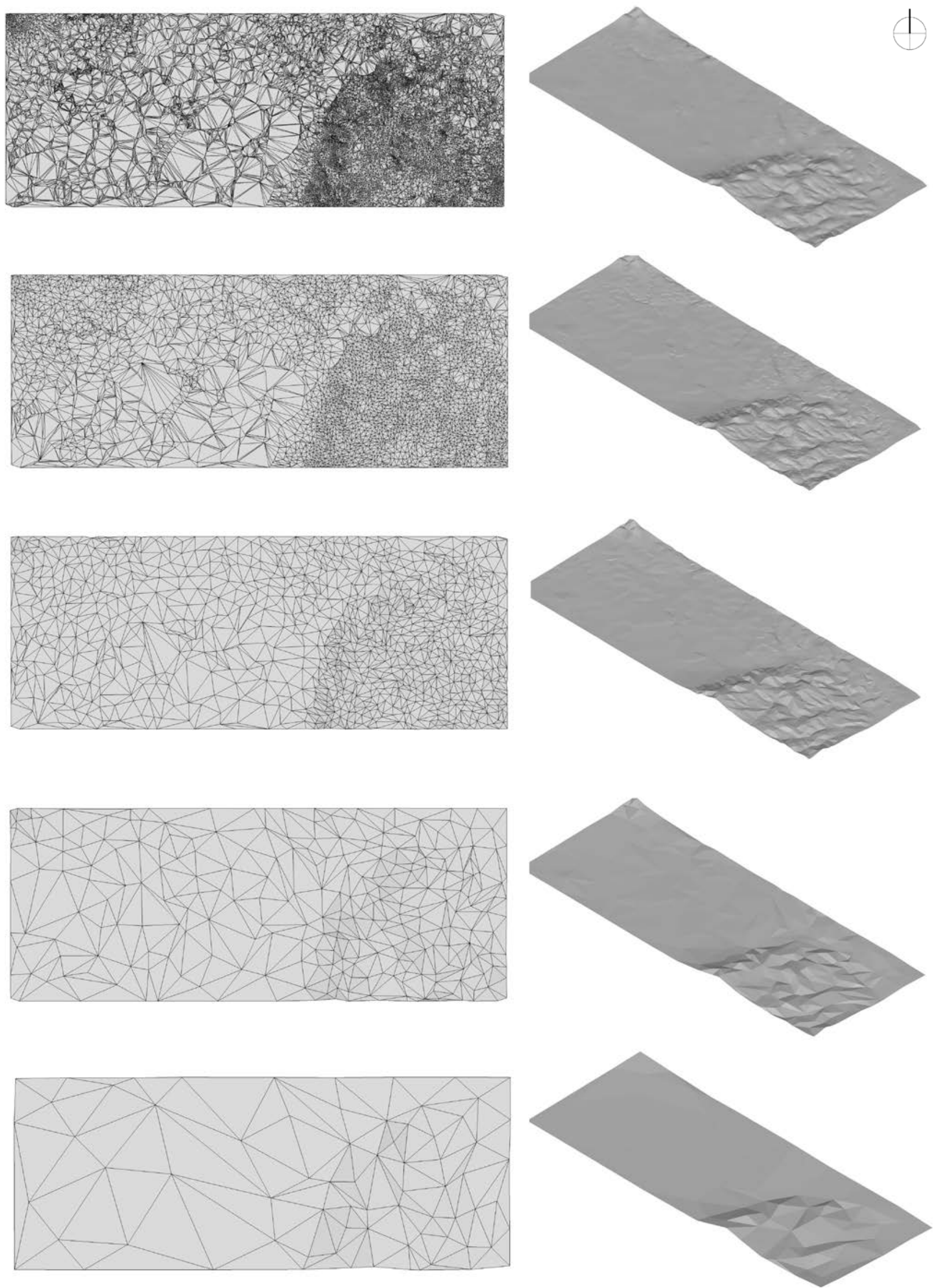
Simplificaciones - Zona 8 (Traiguera) - $[e=1 / 80.000]$
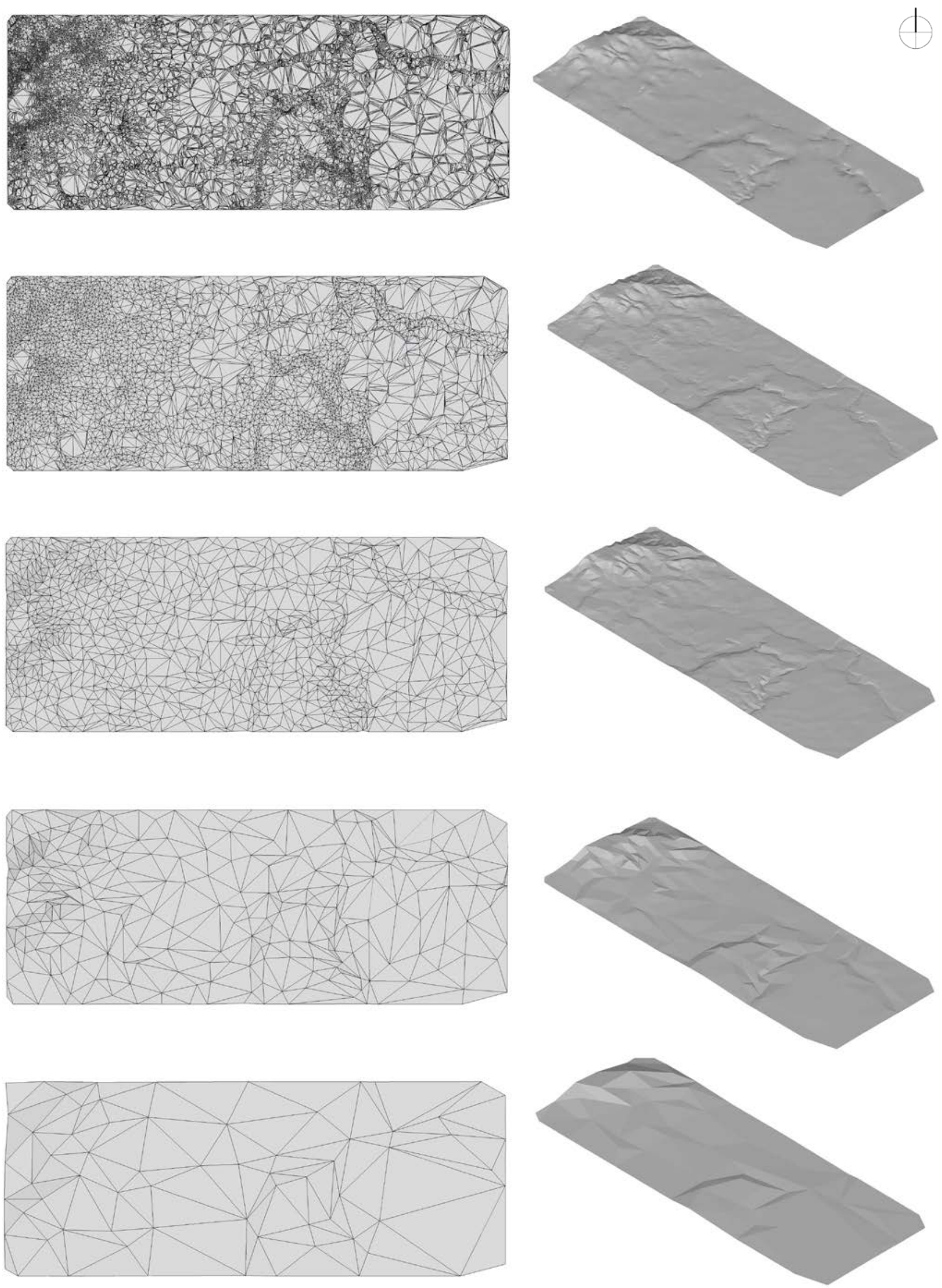
Simplificaciones - Zona 9 (Mas Stellers) - $[e=1 / 80.000]$
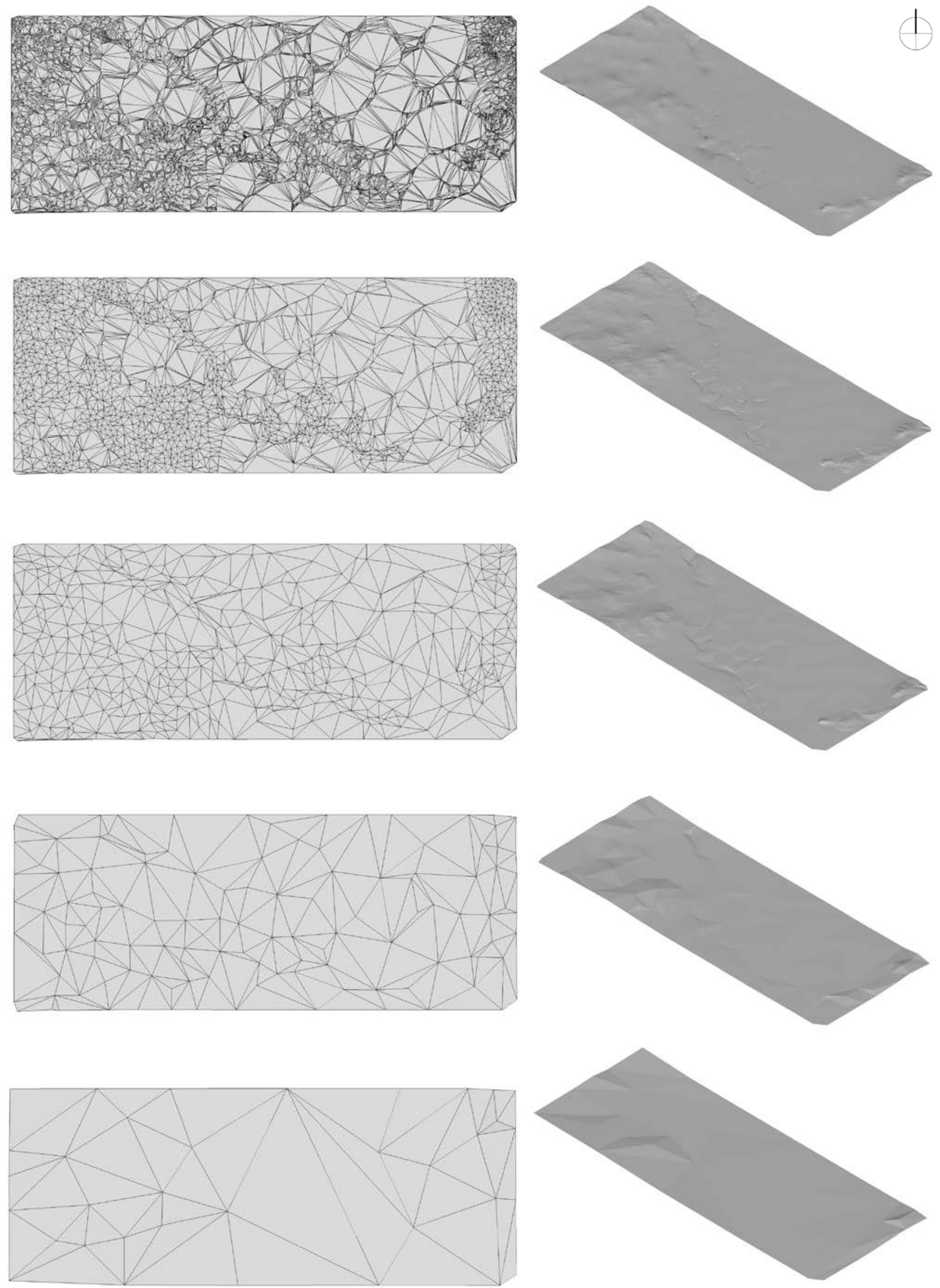
Simplificaciones - Zona 10 (Cervera / Calig) - $[\mathrm{e}=1 / 80.000]$
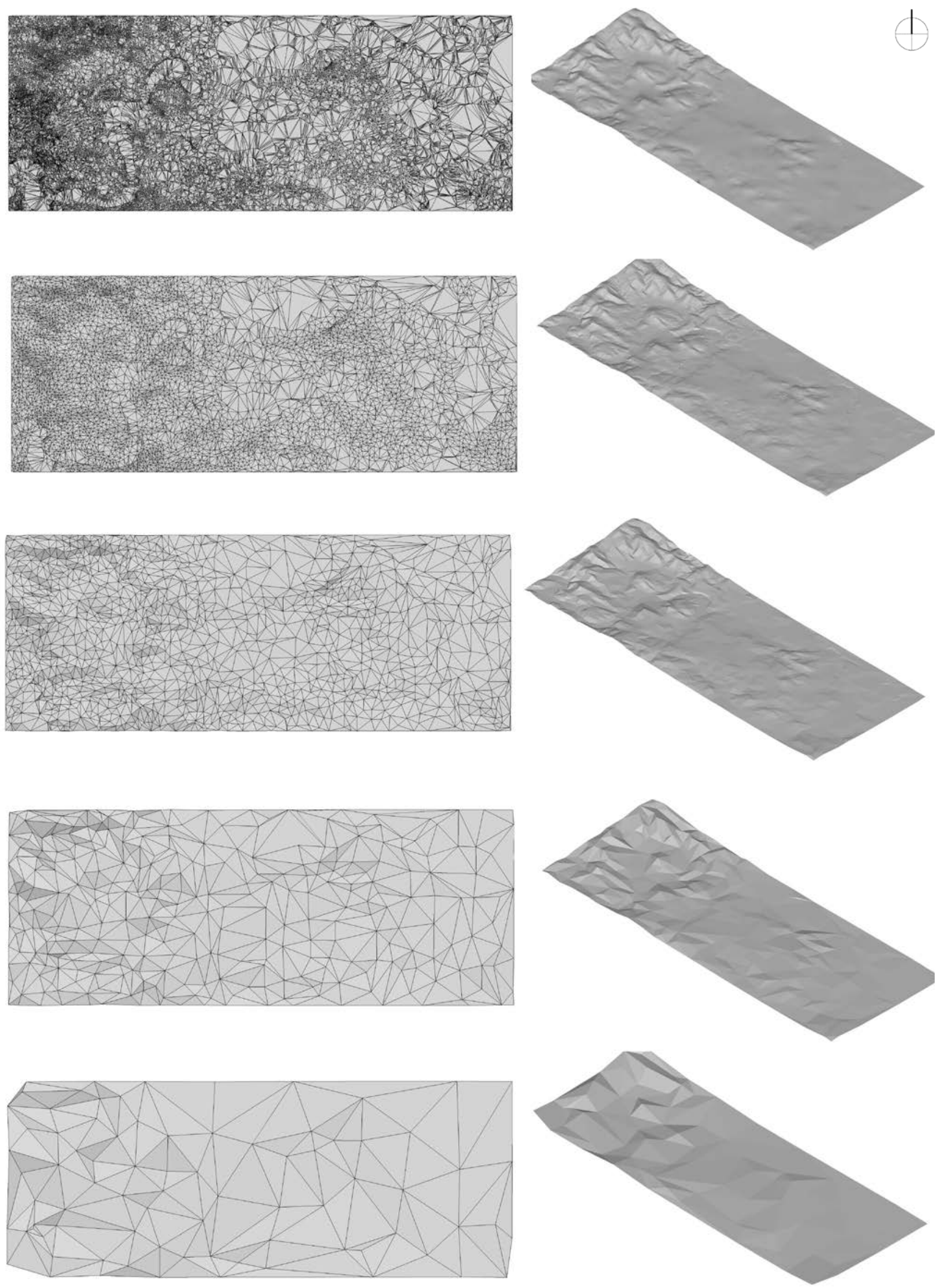
Simplificaciones - Zona 11 (San Joan del Pas) - $[e=1 / 80.000]$
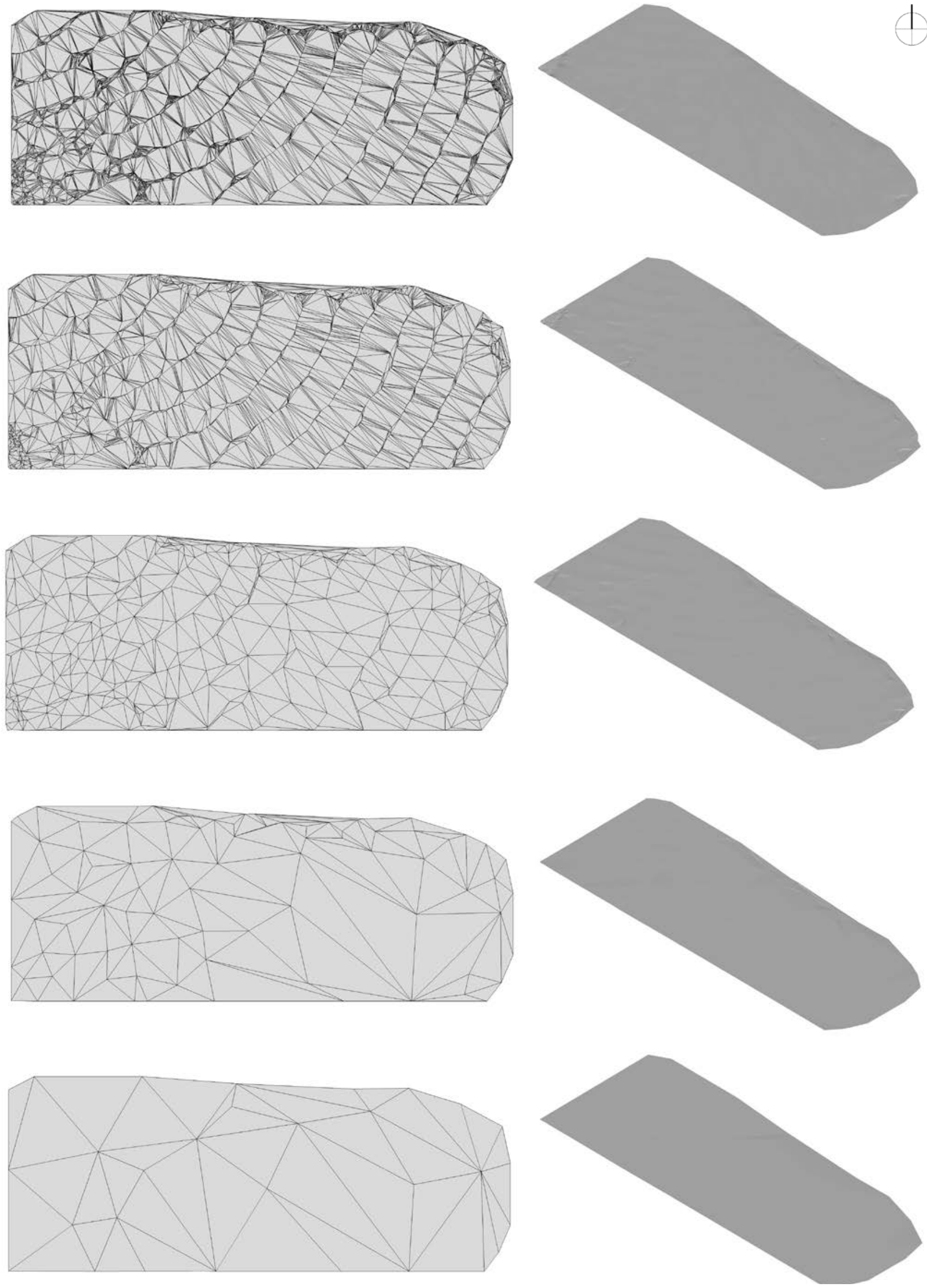
Simplificaciones - Zona 12 (Atalaya San Pere) - $[e=1 / 80.000]$
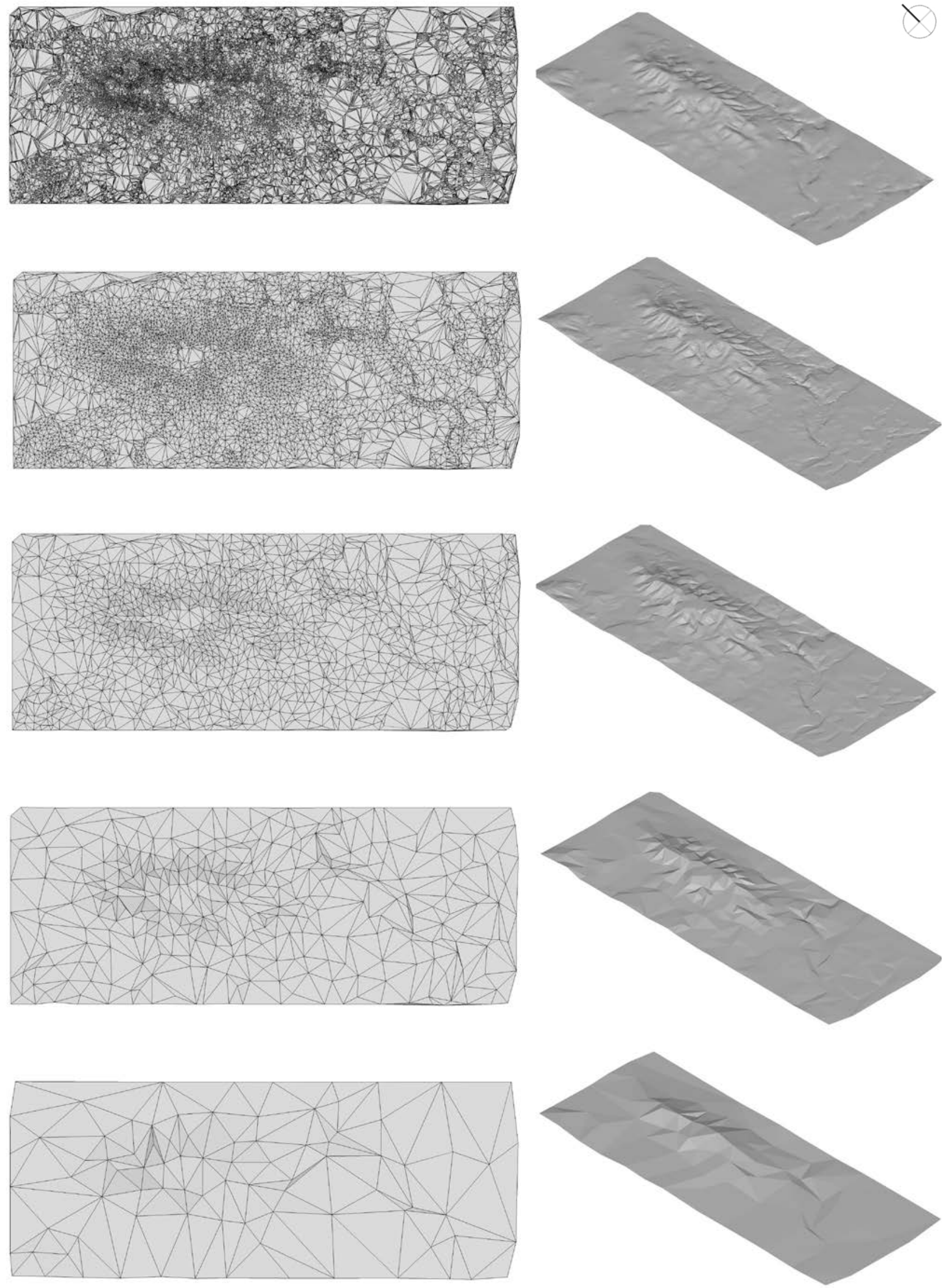
Realizada la abstracción obtenemos, tanto en planta como en volumen, una malla o estructura gráfica de la topología de cada una de las zonas de estudio. Del análisis individual de cada una de ellas podemos, en primer lugar comparando los pasos sucesivos de simplificación, percibir cuales son los elementos fundamentales de su estructura por permanecer invariables en los sucesivos pasos, en segundo lugar que las zonas llanas están mucho menos fragmentadas y con fragmentos más regulares y homogéneos que las montañosas y en tercer lugar que cuanto mayor es la simplificación aumenta la relevancia de las aristas y se pierde la de los planos que las definen.

Del análisis comparativo entre las zonas podemos comprobar que del mismo modo que ocurre dentro de cada una de las zonas, aquellas que son más llanas están mucho menos fragmentadas y con fragmentos más regulares y homogéneos que las montañosas; que cuanto más llana es una zona las sucesivas simplificaciones van "desdibujando" el volumen, mientras que si es montañoso lo van "clarificando" y que en todos los casos existen unas aristas que tienen una mayor continuidad y que estructuran las zonas.

Tanto la abstracción obtenida en planta como en volumen nos ofrece información útil para conocer la estructura del soporte, por ello para unir ambas informaciones en una única abstracción procedemos a grafiar los planos triangulares de colores distintos según la pendiente de los mismos, ello nos permite tener en una representación en planta una visión abstracta también del volumen. Esto lo hacemos de la mayor simplificación obtenida de las doce zonas.

Consideramos seis pendientes distintas: menores de 3,50\%; entre 3,50\% y $8,00 \%$; entre $8,00 \%$ y $15,00 \%$; entre $15,00 \%$ y $25,00 \%$; entre $25,00 \%$ y $35,00 \%$ y aquellas que tengan una pendiente superior al $35,00 \%$. Mediante el uso del "plugin" color por pendiente se asigna una graduación de colores a las diferentes pendientes de cada plano

Este artificio nos permite "clarificar" el territorio y visualizar con mayor nitidez las aristas de la malla y con ello las limatesas y limahoyas, así como la homogeneidad de cada una de ellas y las zonas susceptibles de aprovechamiento por su pendiente. 

Mapa general simplificado (situación de las zonas de estudio) y código de colores según la pendiente $-[e=1 / 200.000]$

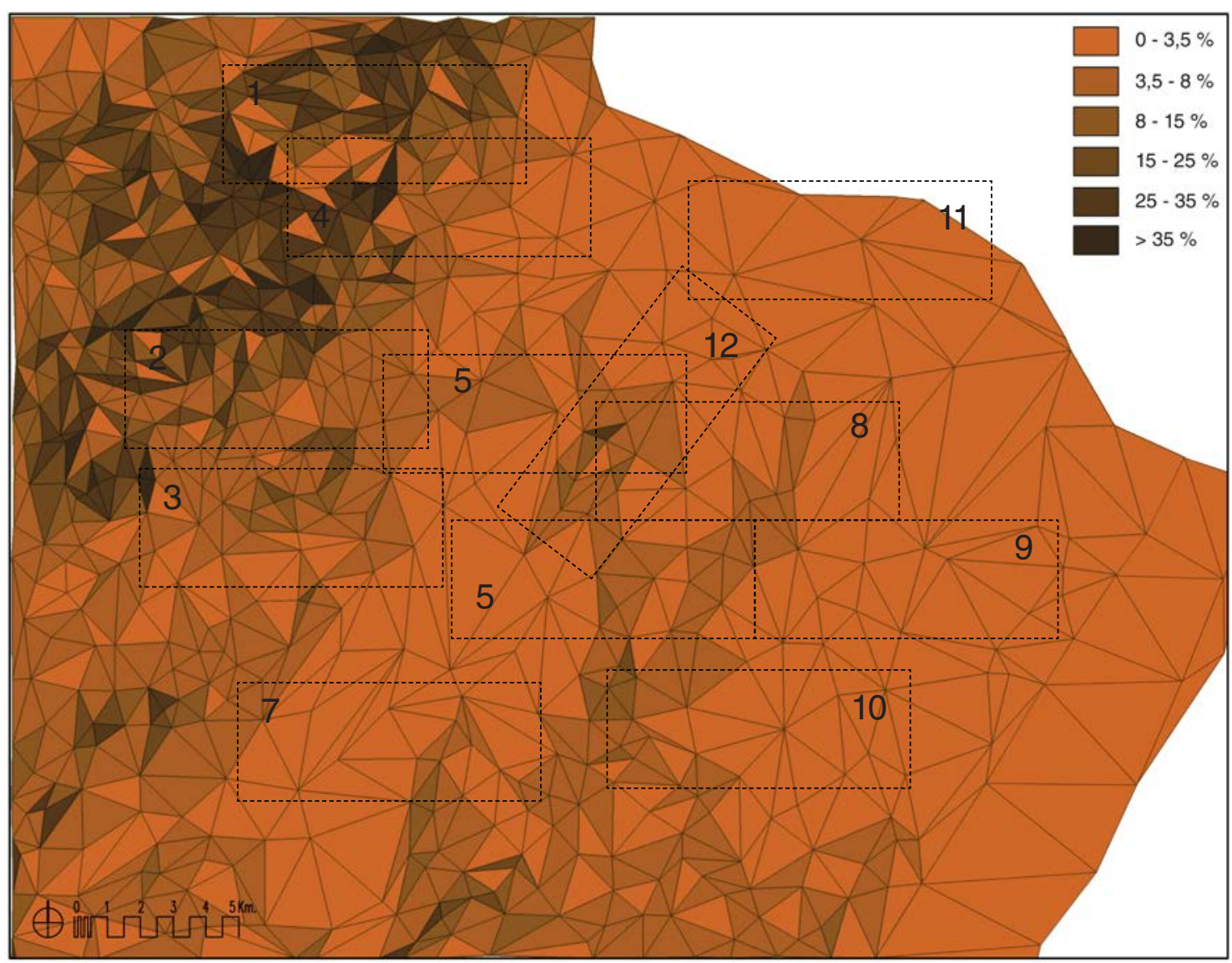

Fig. 3. 18. Plano a escala 1/200.000 de la topografía simplificada y códigos de colores por pendientes de la Batllia de Cervera y alrededores y la situación de las 12 zonas de estudio. 
Simplificaciones (color por pendiente) - Zonas 1-4 - $[e=1 / 75.000]$

\section{Zona 1_Bel}

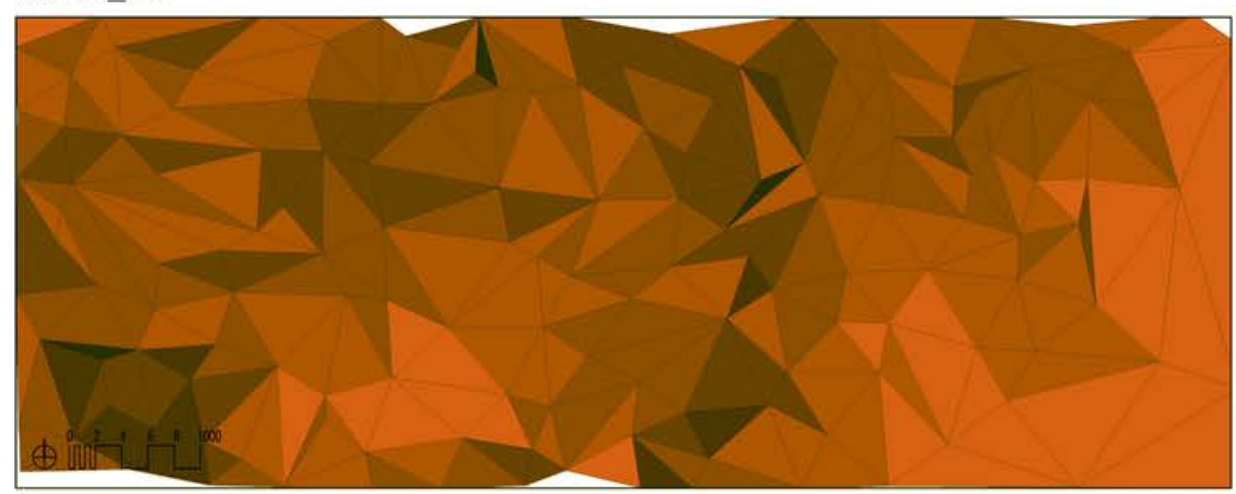

\section{Zona 2_Barcella}

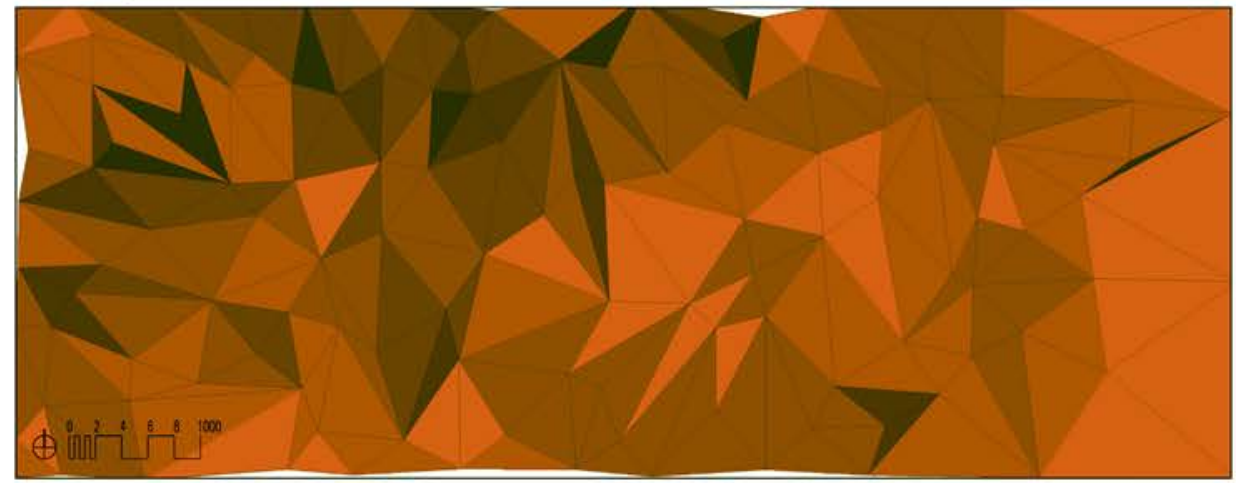

\section{Zona 3_Molinar/Xert}

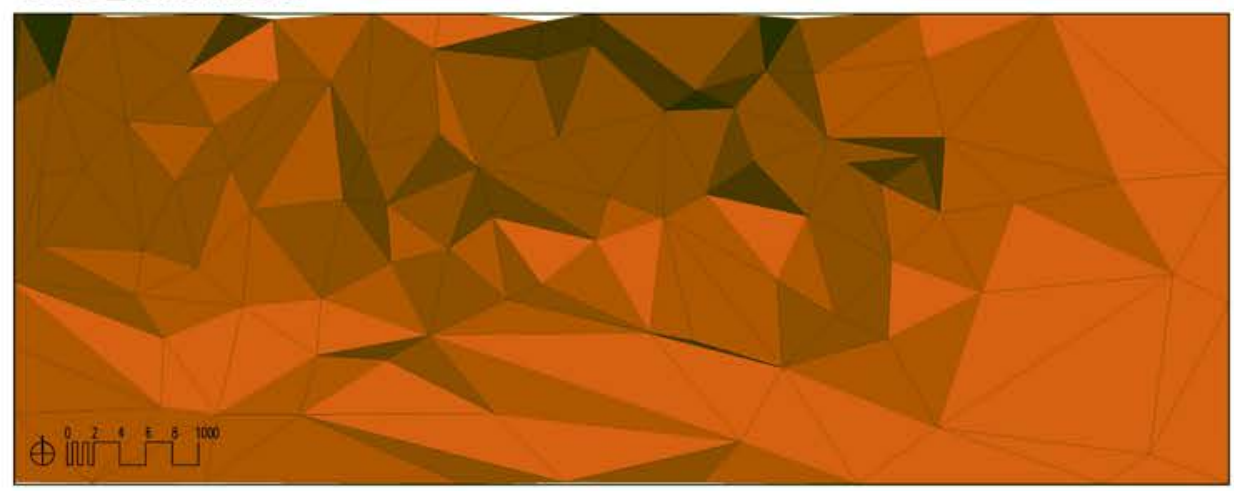

\section{Zona 4 Mas del Coll / Rosell}

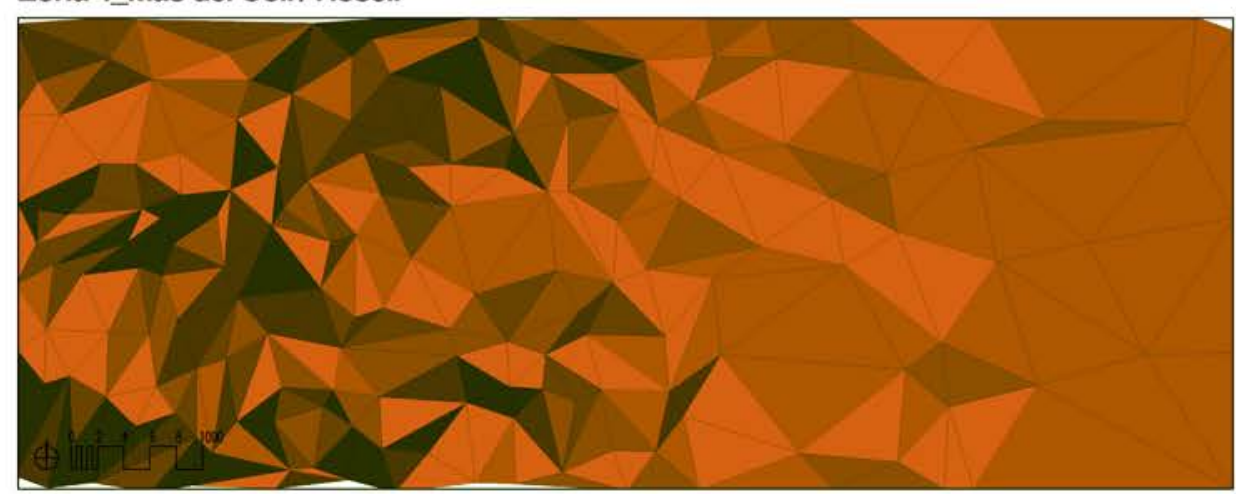


Simplificaciones (color por pendiente) - Zonas 5-8 - $[e=1 / 75.000]$

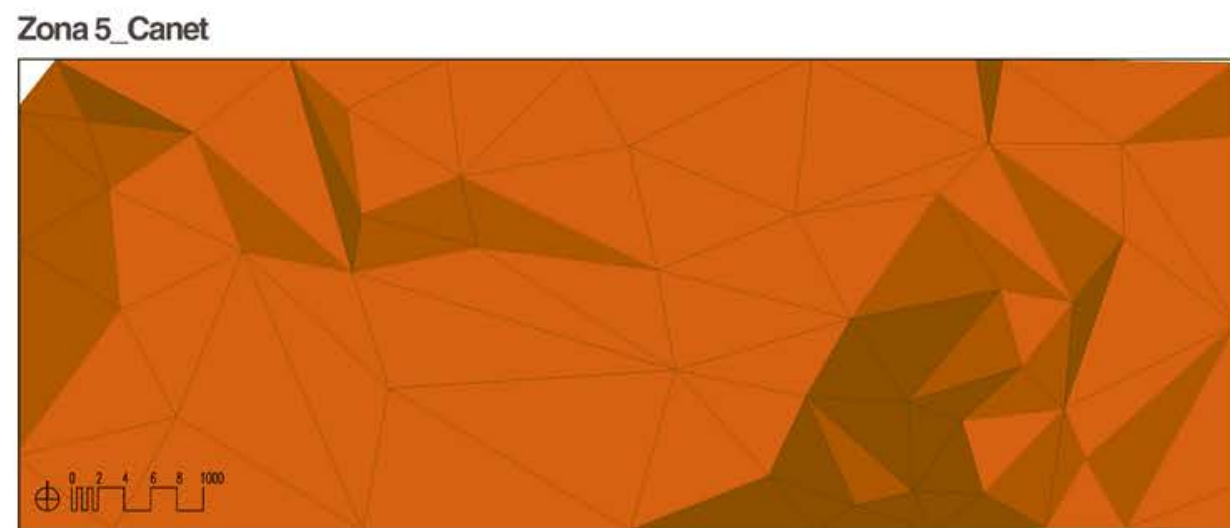

\section{Zona 6_La Jana/Carrascal}

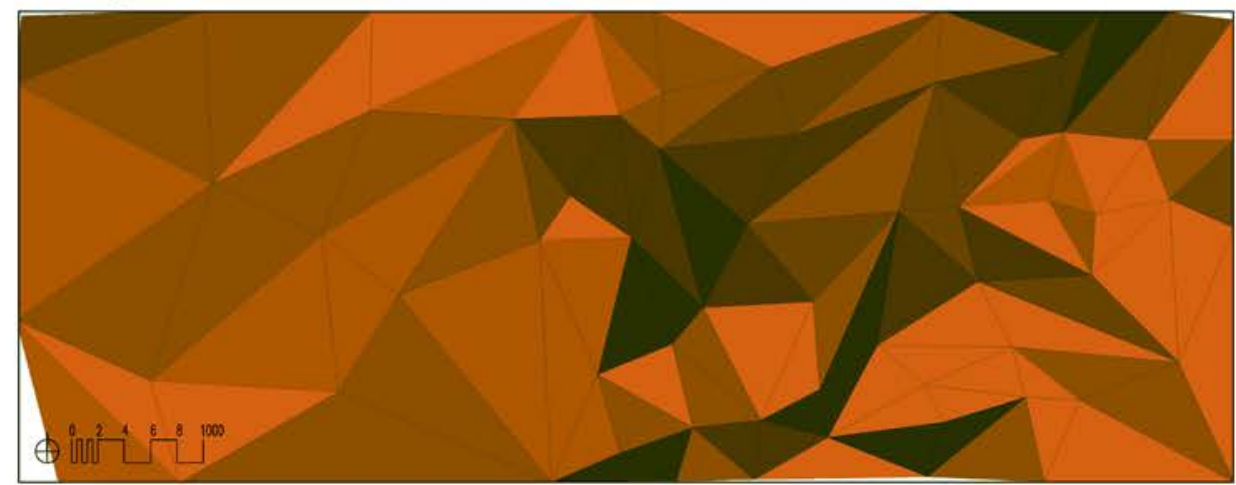

\section{Zona 7_San Mateo}

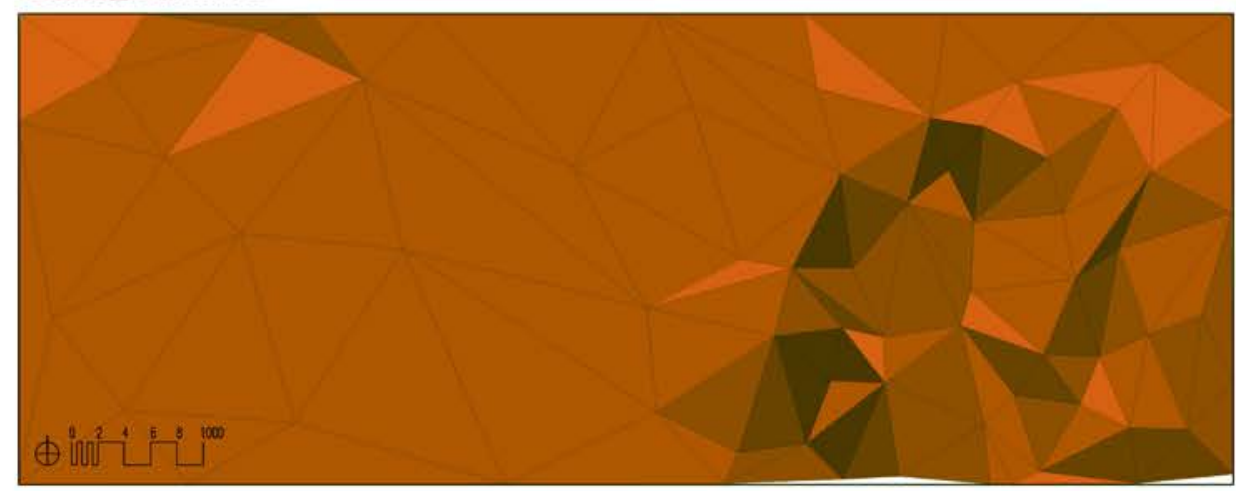

\section{Zona 8_Traiguera}

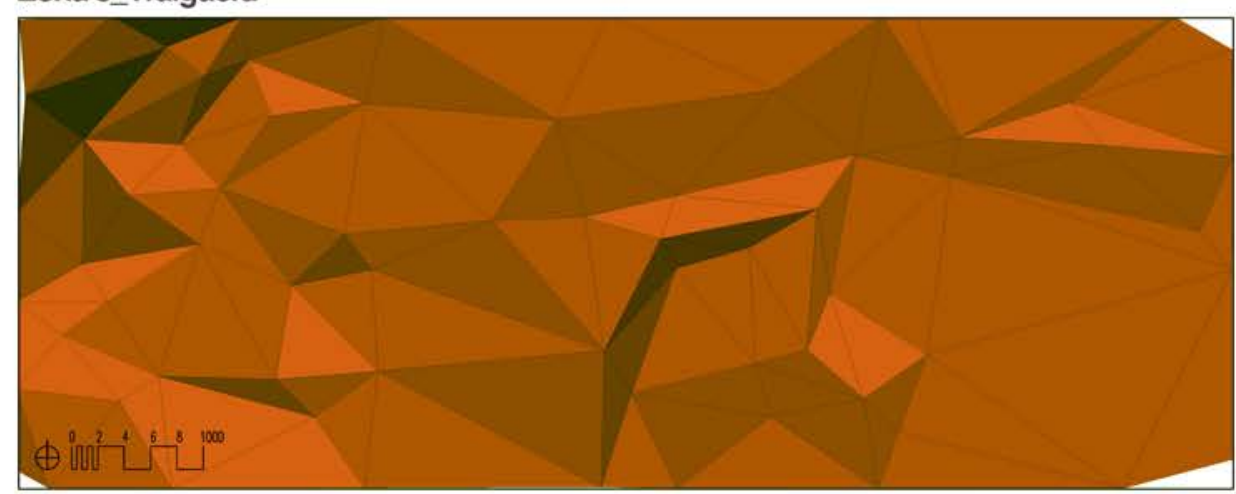


Simplificaciones (color por pendiente) - Zonas 9-12 - $[e=1 / 75.000]$

Zona 9_Mas Stellers

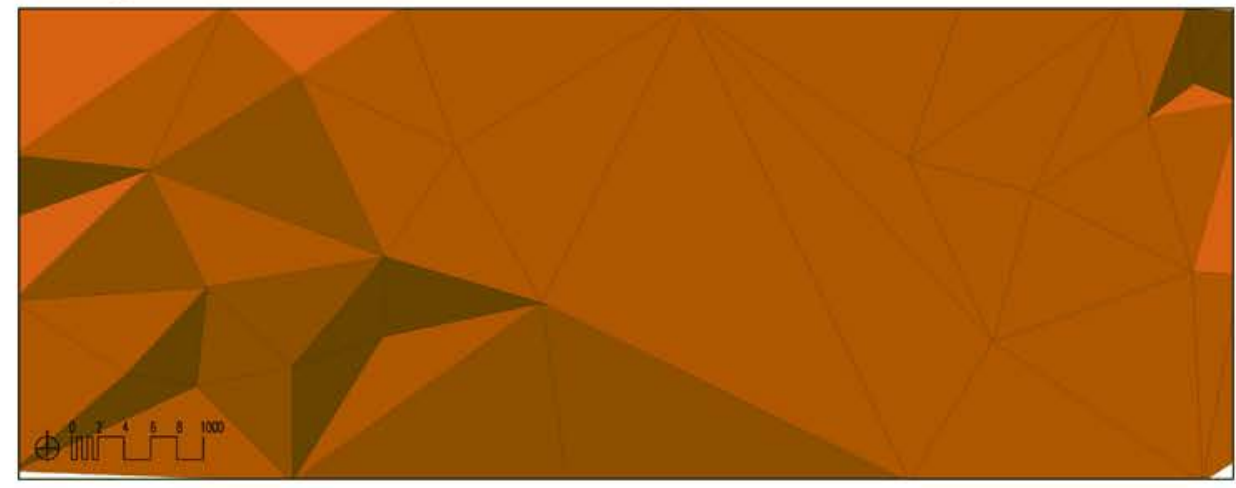

\section{Zona 10_Cervera/Calig}

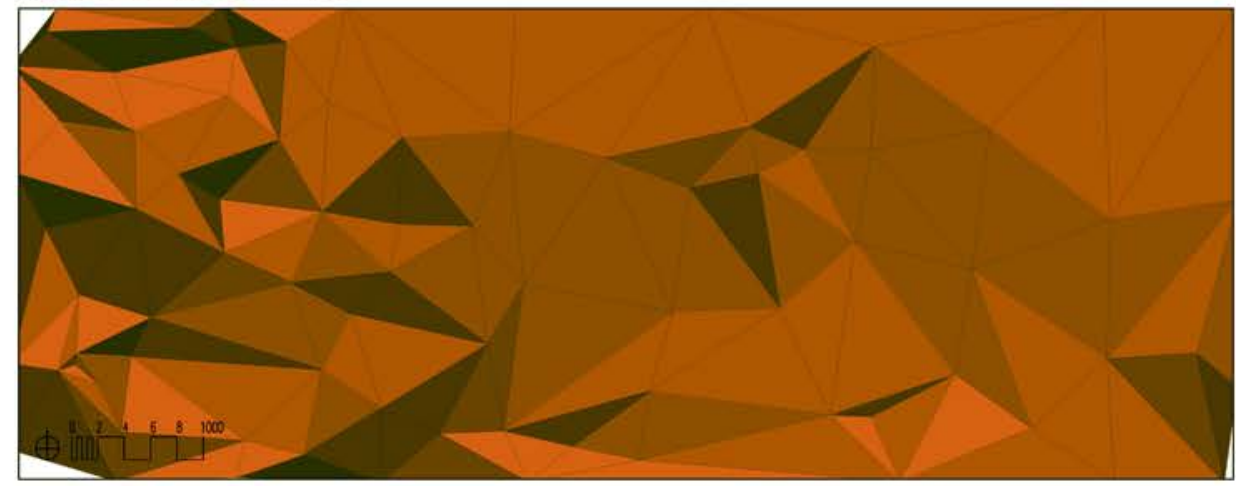

\section{Zona 11_San Joan del Pas}

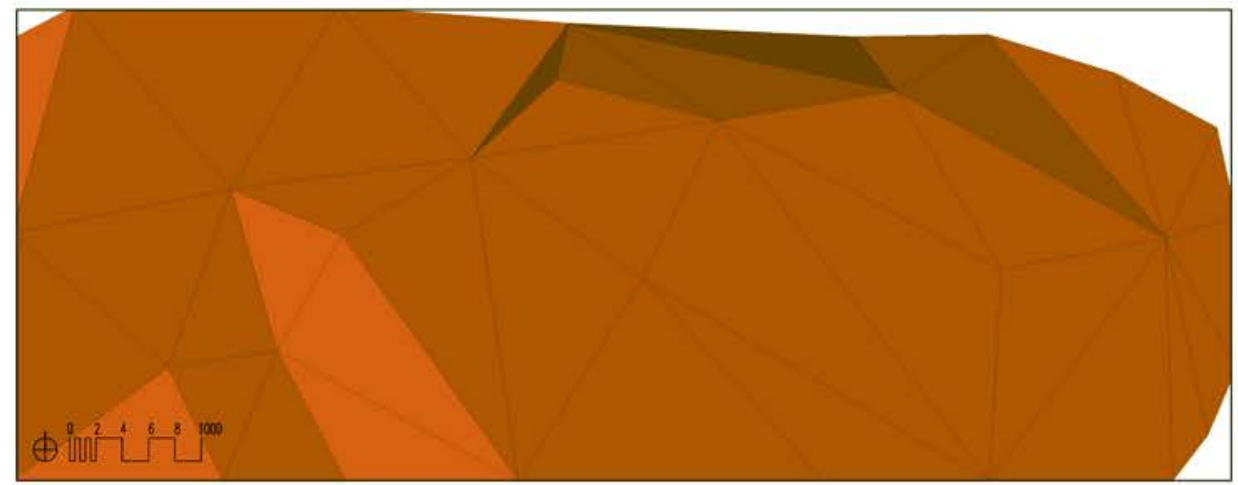

\section{Zona 12_Atalaya San Pere}

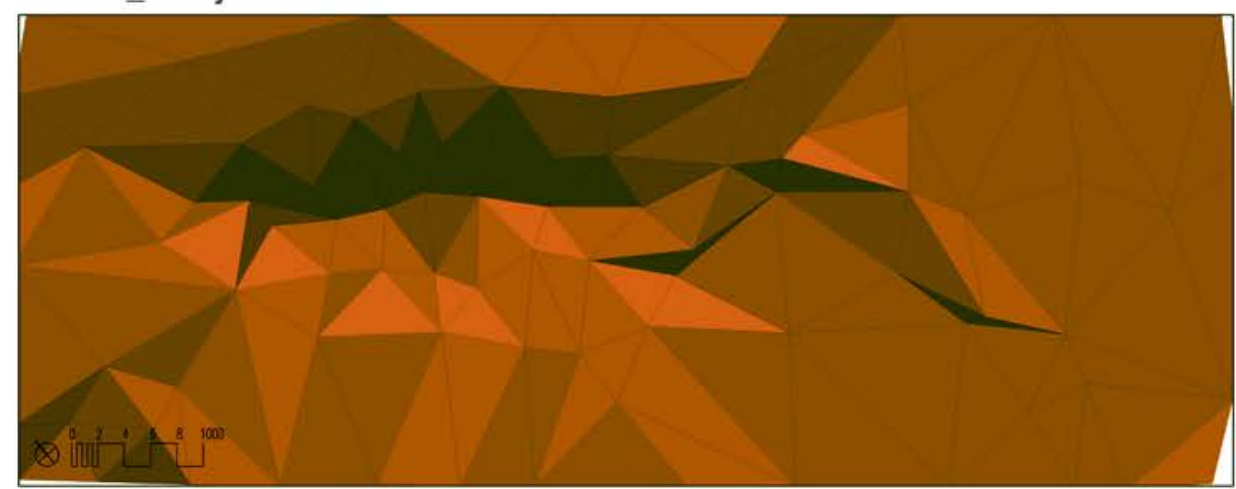


Superposición del mapa general simplificado + curvas de nivel + ríos $-[e=1 / 200.000]$

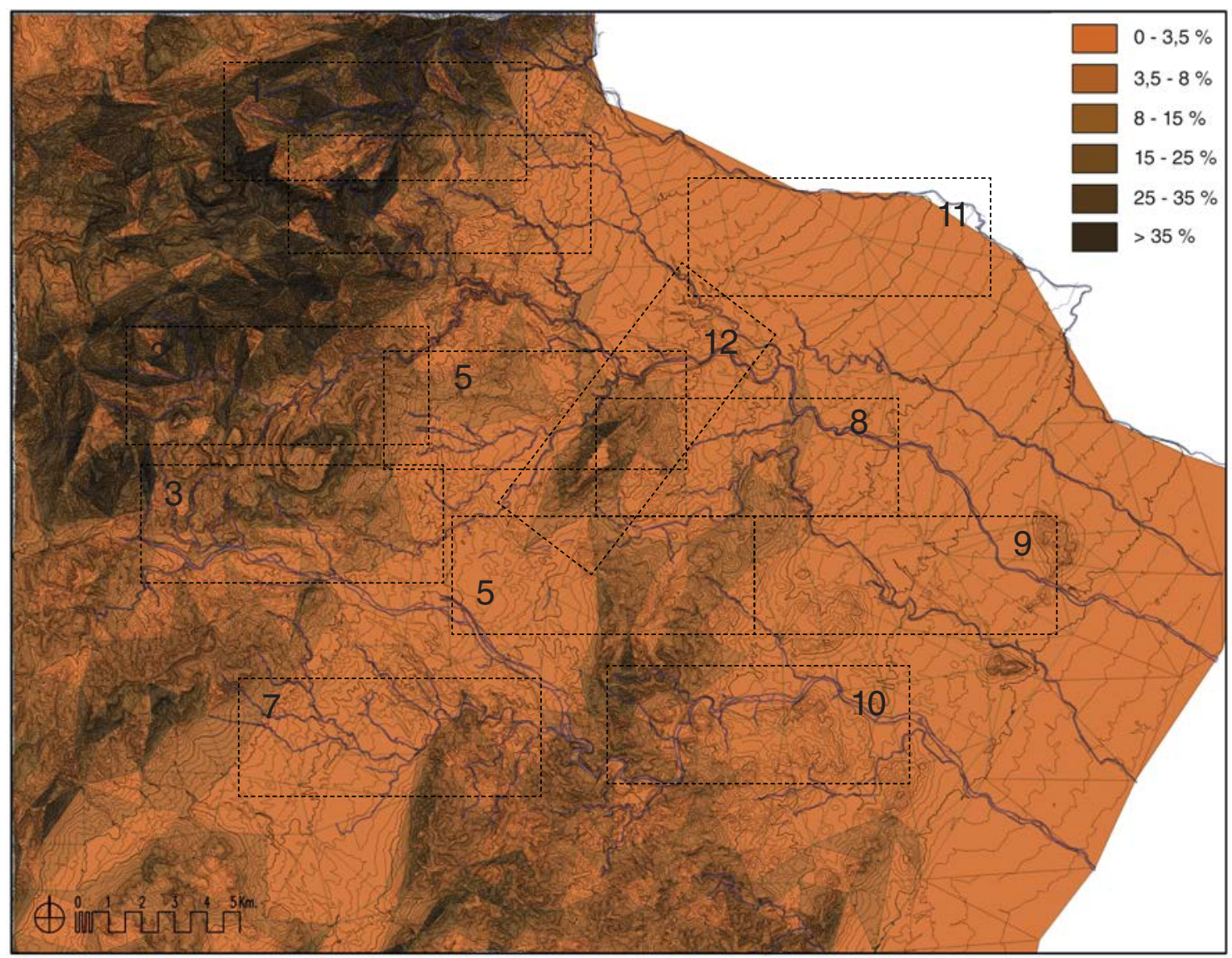

Fig. 3. 19. Plano a escala $1 / 200.000$ de la topografía simplificada y códigos de colores por pendientes, con la superposición de las curvas de nivel, de la Batllia de Cervera y alrededores y la situación de las 12 zonas de estudio.

Este análisis lo complementamos superponiendo a cada una de las abstracciones gráficas las curvas de nivel y los cursos de agua en cada una de las zonas. Este recurso nos permite contextualizar las abstracciones gráficas y así poder comprender mejor como es la estructura del soporte territorial.

Superpuesta la abstracción sobre las curvas de nivel obtenemos los planos geomorfológicos de las doce zonas, que grafiamos fácilmente a partir de la máxima simplificación obtenida. En el señalaremos las carenas o limatesas y los vértices de las emergencias visuales, los ríos y barrancos que marcan las limahoyas y la curva de nivel que define el cambio de nivel característico, que nos marca la "separación" entre el suelo llano y el suelo con pendiente. El análisis de estas formas abstractas nos pone de manifiesto la importancia del agua de escorrentía en la formación del relieve.

Posteriormente si "eliminamos" la topografía y los cursos de agua obtenemos los planos geomorfológicos en sentido estricto de cada una de las zonas. 
Simplificaciones (curvas de nivel + ríos) - Zonas 1-4 - $[\mathrm{e}=1 / 75.000]$

\section{Zona 1_Bel}

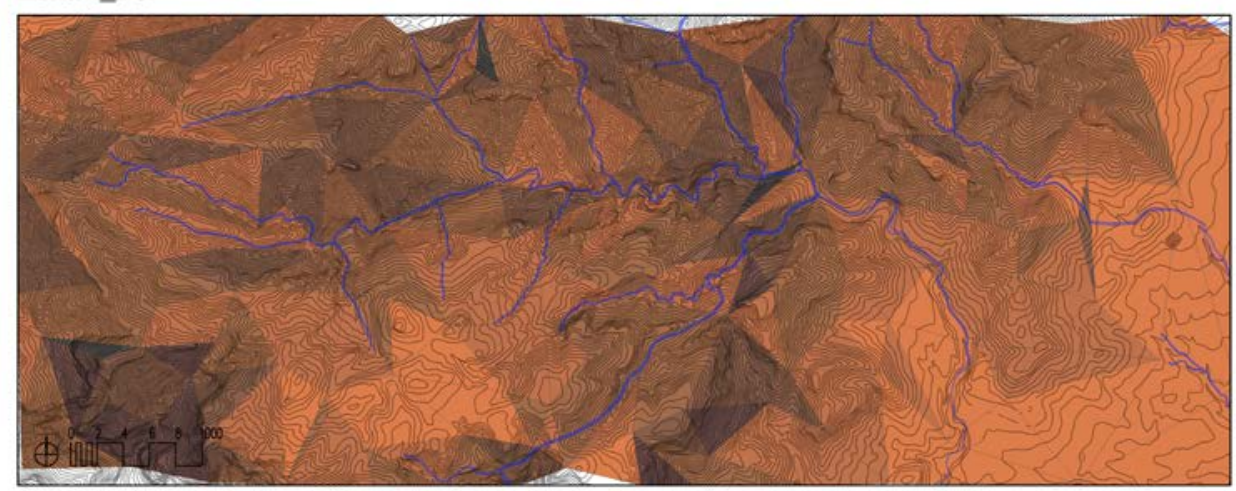

\section{Zona 2 Barcella}

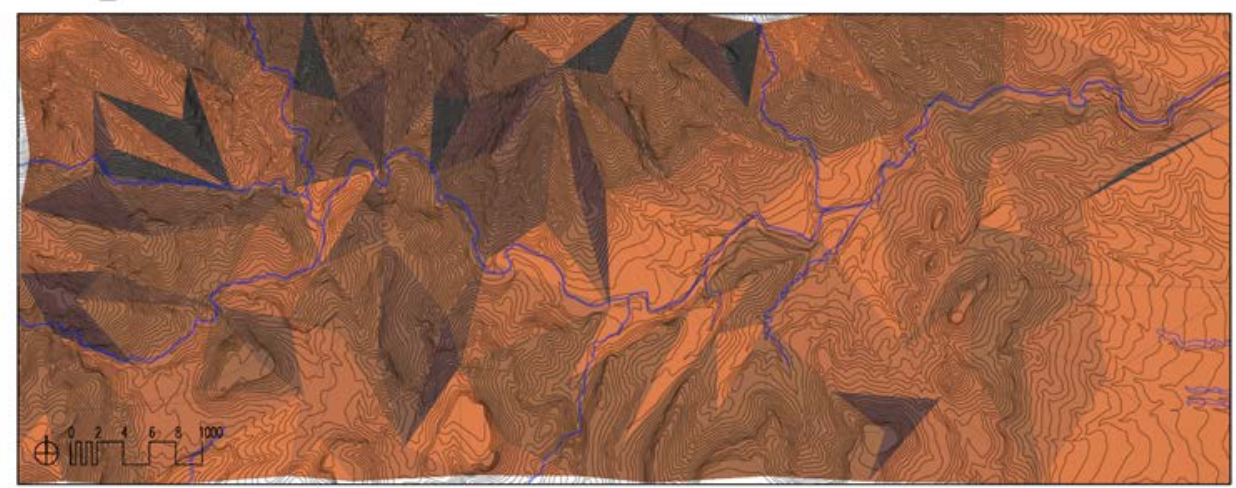

\section{Zona 3_Molinar/Xert}

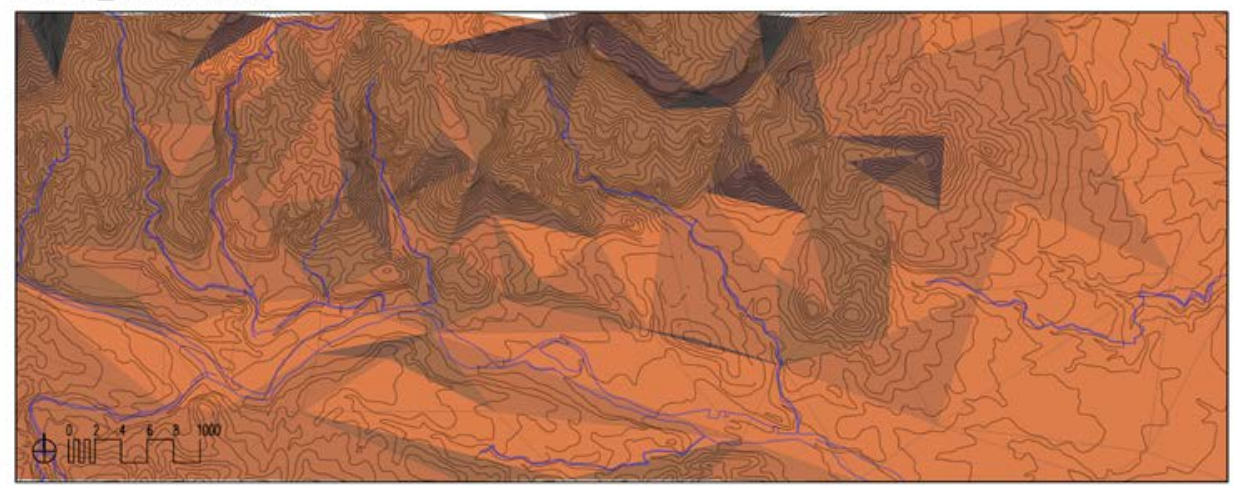

\section{Zona 4 Mas del Coll / Rosell}

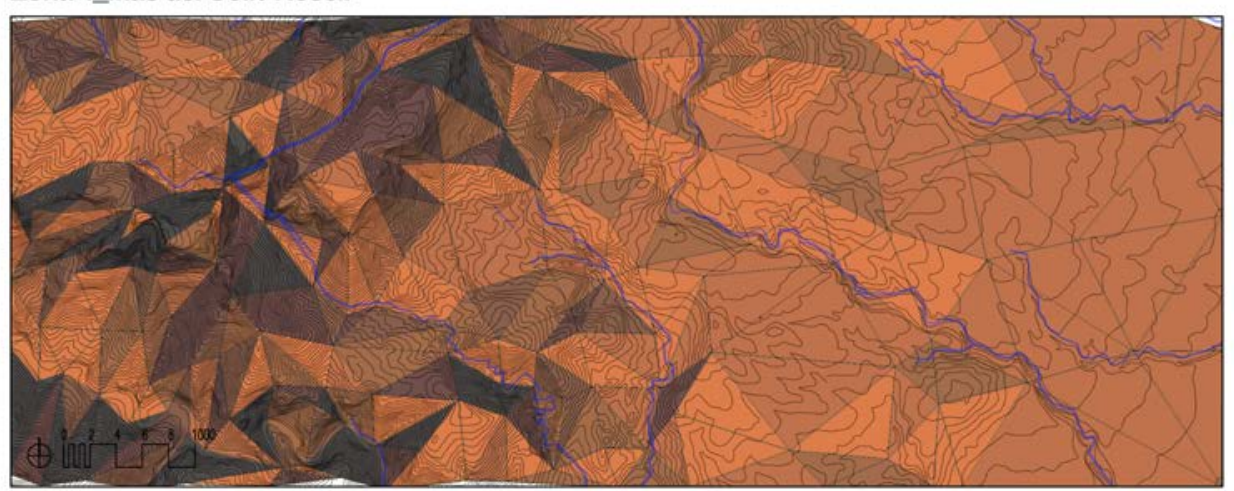


Simplificaciones (curvas de nivel + ríos) - Zonas 5-8 - $[\mathrm{e}=1 / 75.000]$
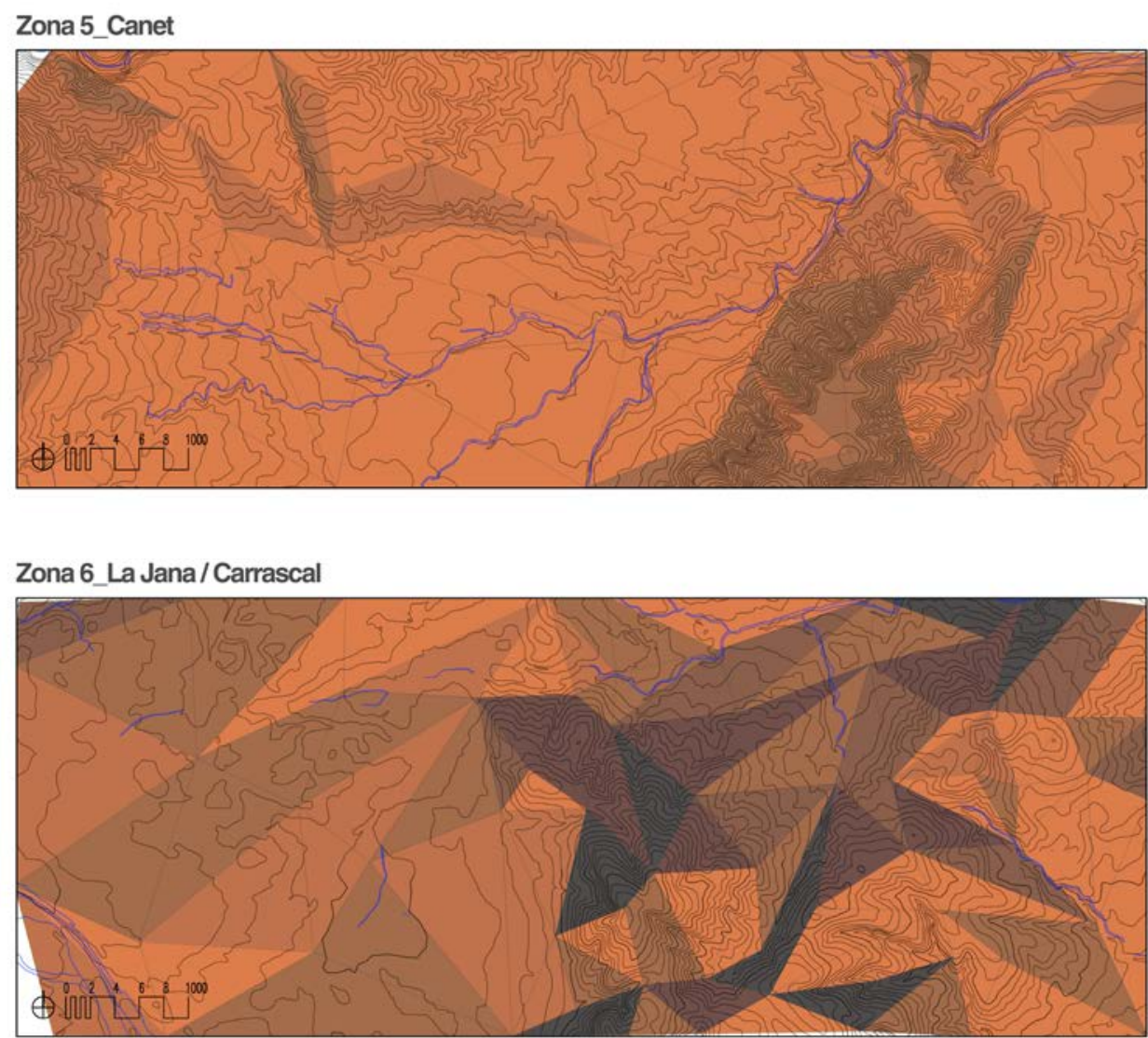

\section{Zona 7 San Mateo}

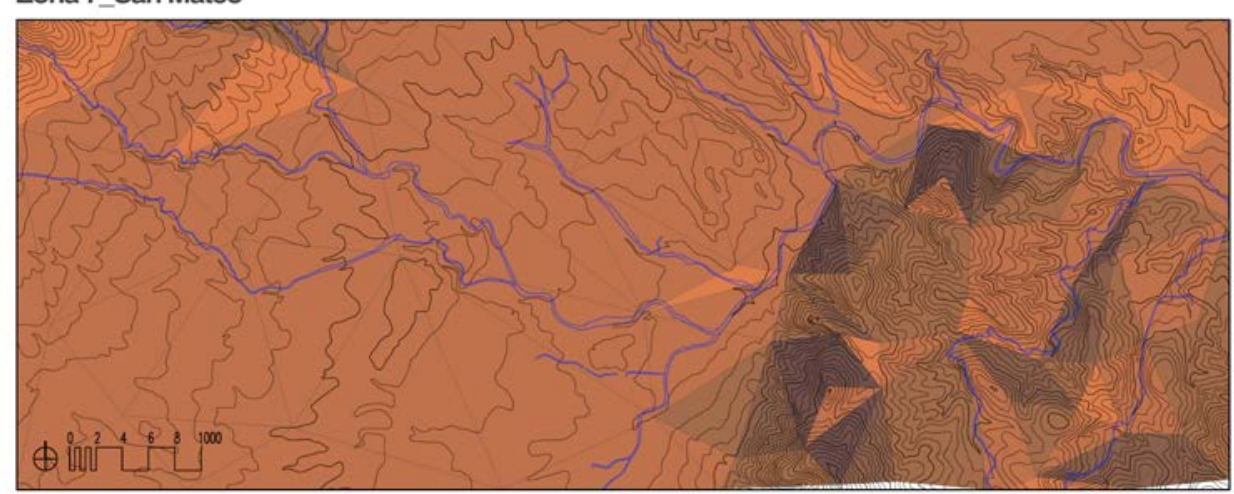

\section{Zona 8 Traiguera}

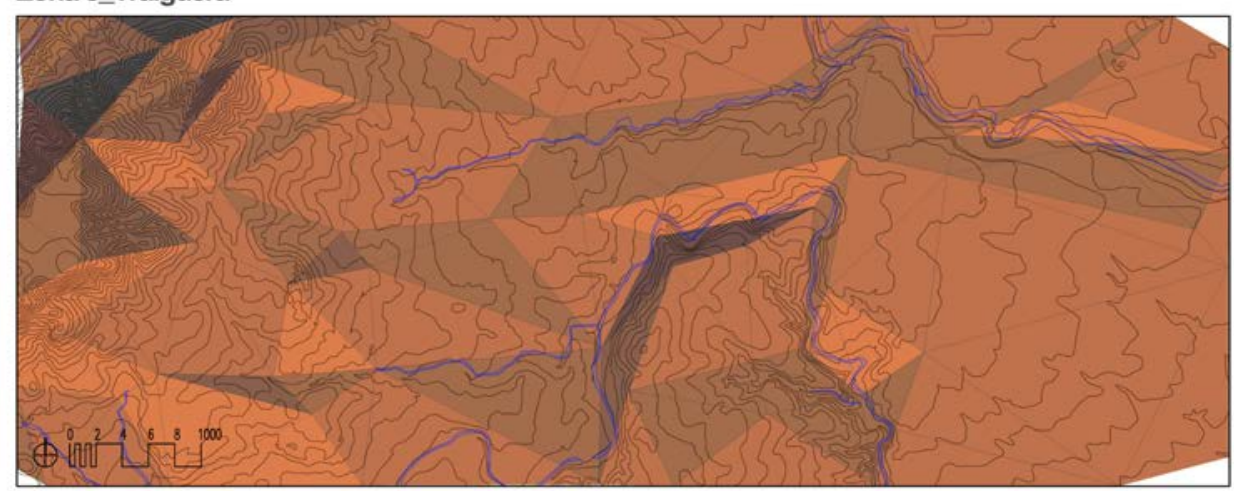


Simplificaciones (curvas de nivel + ríos) - Zonas 9-12 - [e=1/75.000]

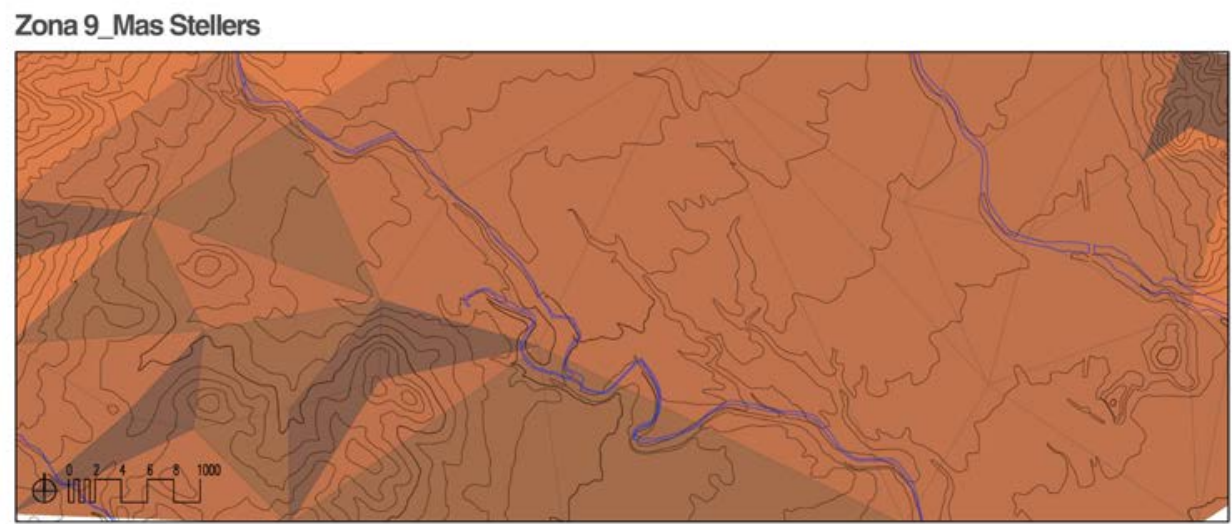

\section{Zona 10_Cervera/Calig}

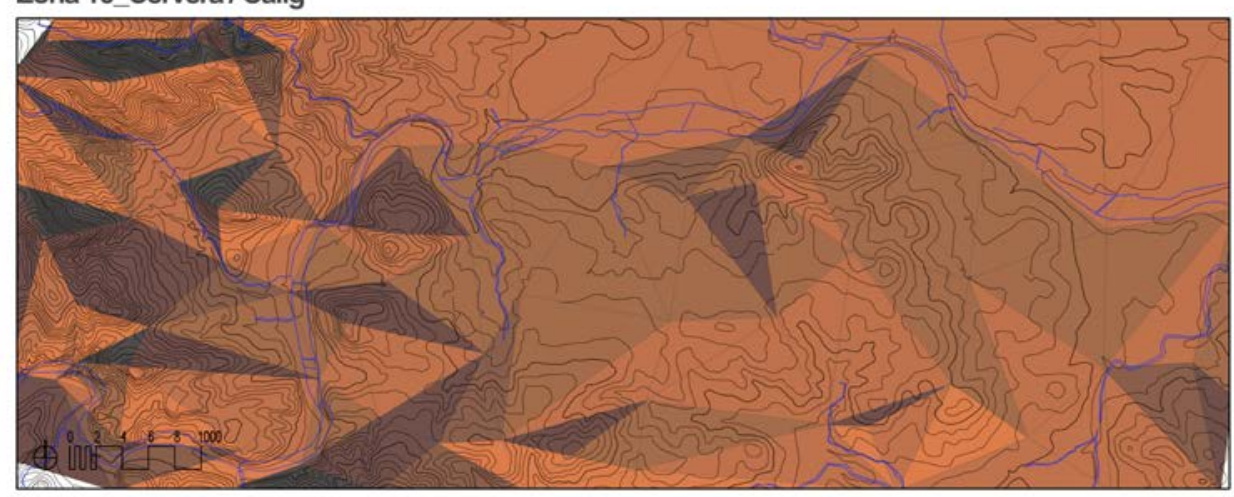

\section{Zona 11 San Joan del Pas}

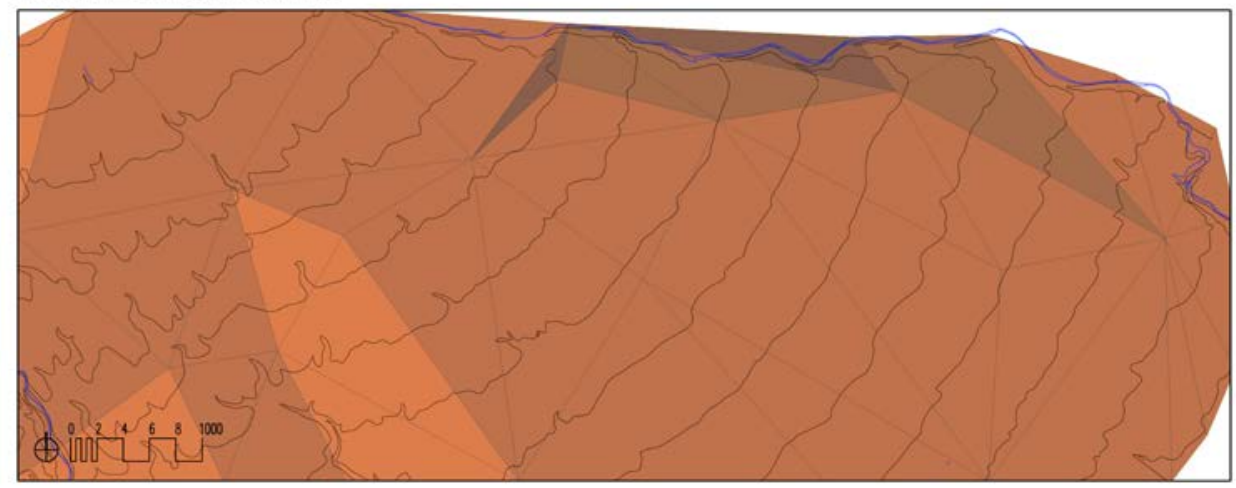

Zona 12_Atalaya San Pere

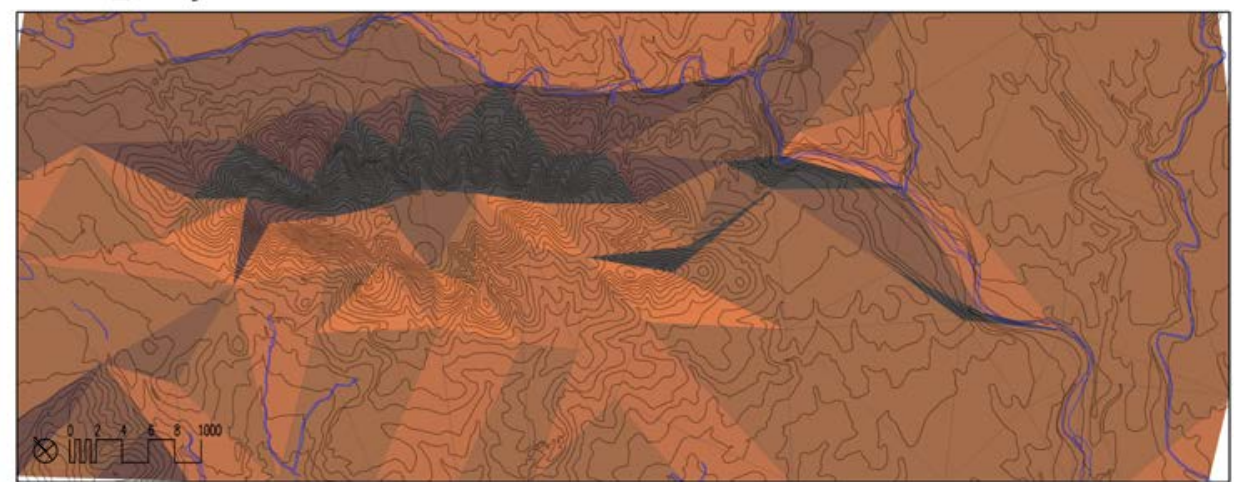


Planos geomorfológicos (curvas de nivel + ríos) - Zonas 1-4 - $[\mathrm{e}=1 / 75.000]$

\section{Zona 1_Bel}

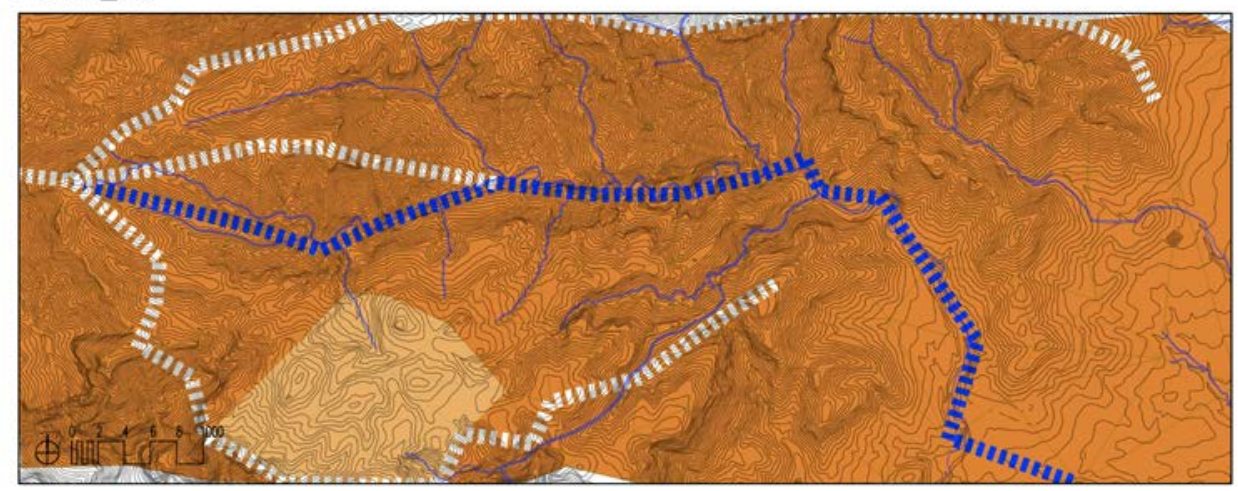

\section{Zona 2 Barcella}

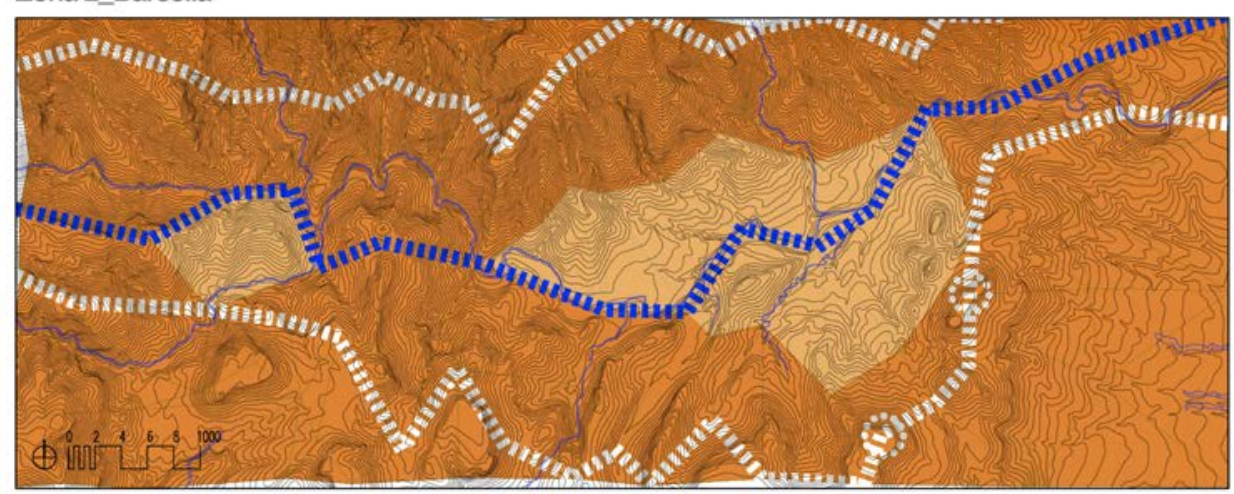

\section{Zona 3 Molinar/Xert}

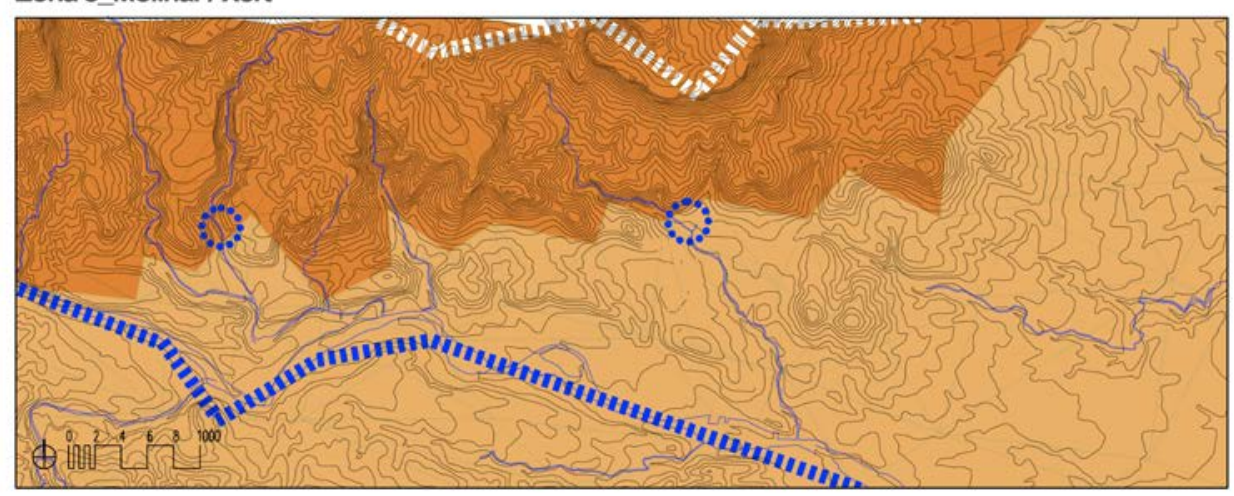

Zona 4_Mas del Coll / Rosell

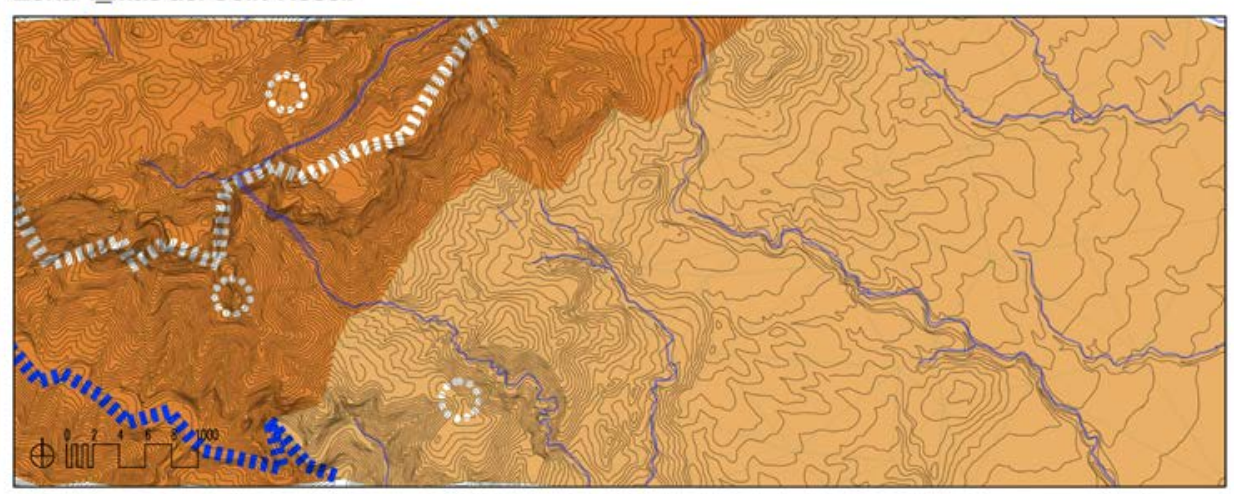


Planos geomorfológicos (curvas de nivel + ríos) - Zonas 5-8 - [e=1/75.000]

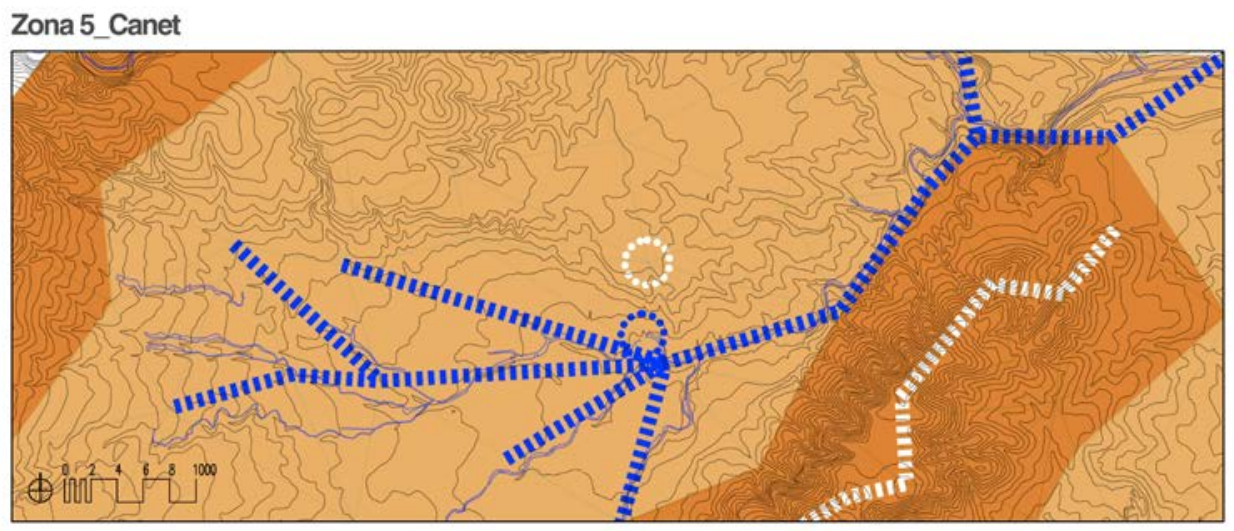

\section{Zona 6 La Jana/Carrascal}

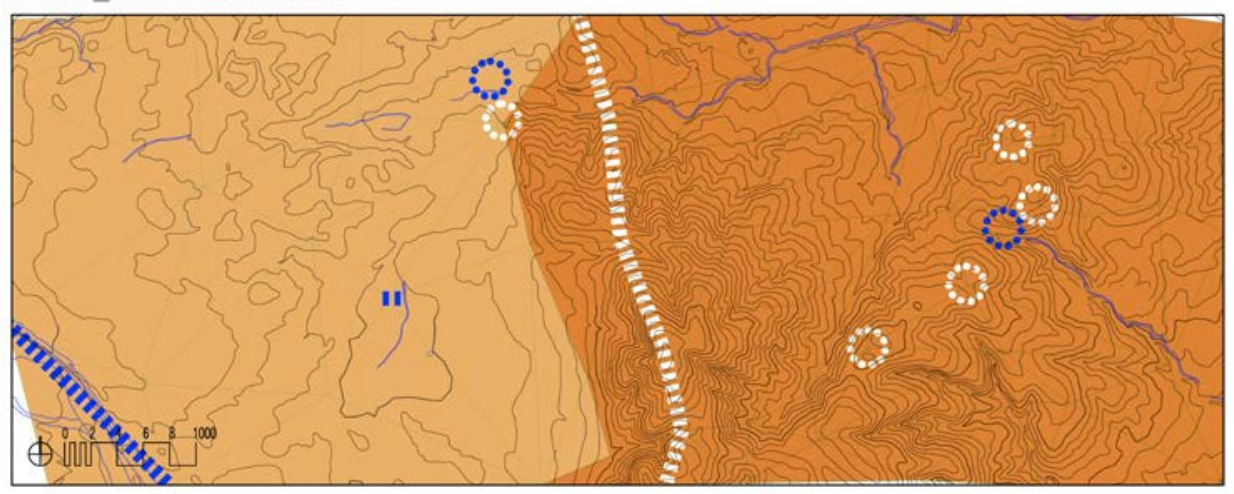

\section{Zona 7_San Mateo}

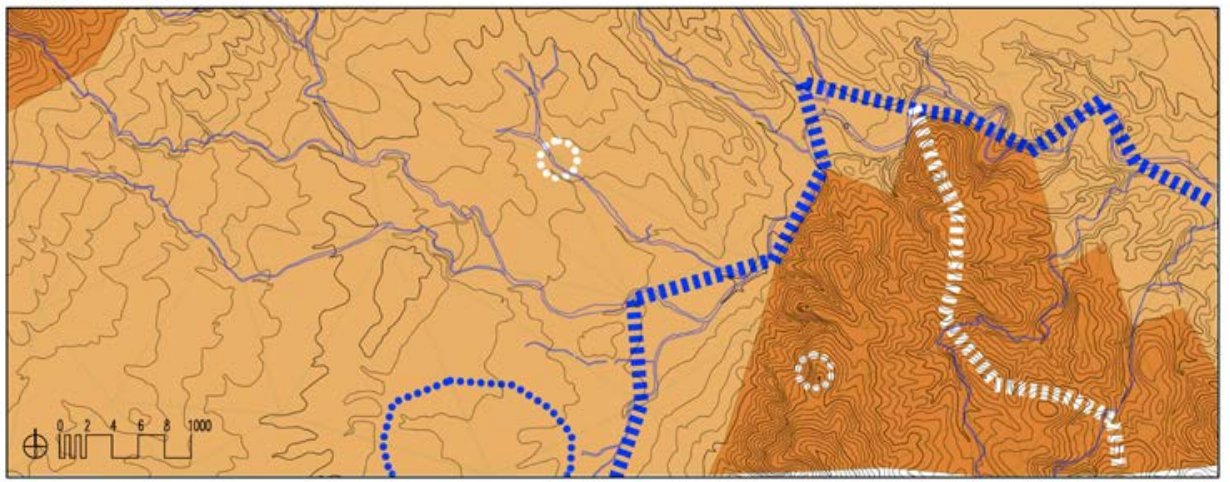

\section{Zona 8_Traiguera}

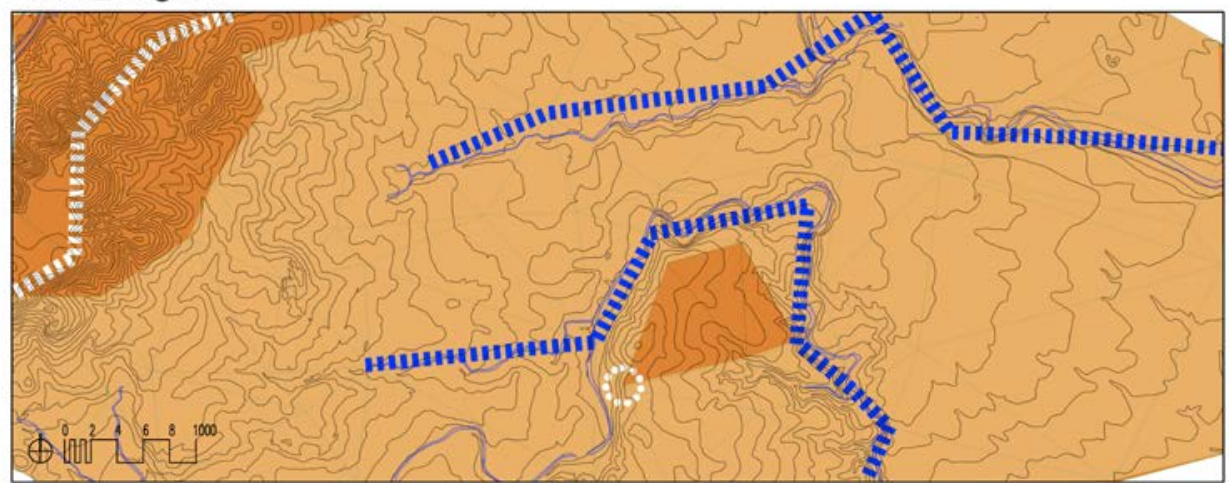


Planos geomorfológicos (curvas de nivel + ríos) - Zonas 9-12 - $[\mathrm{e}=1 / 75.000]$

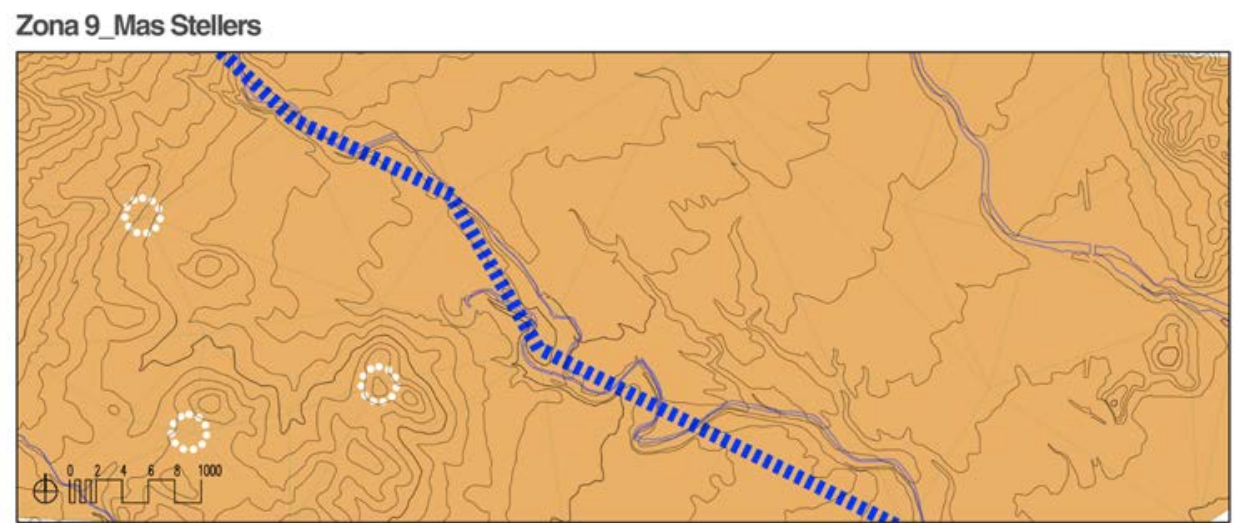

\section{Zona 10_Cervera/Calig}

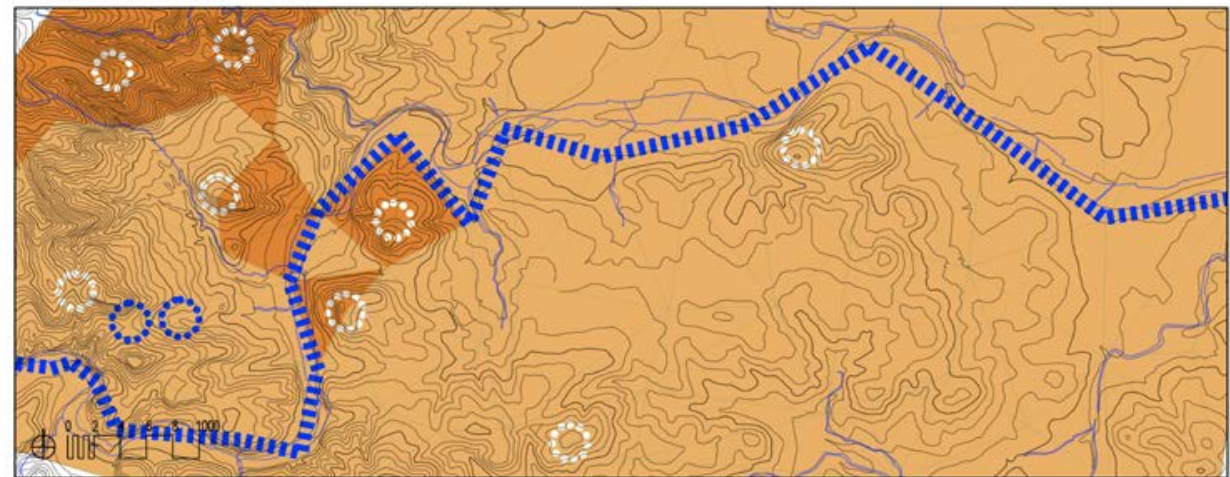

\section{Zona 11_San Joan del Pas}

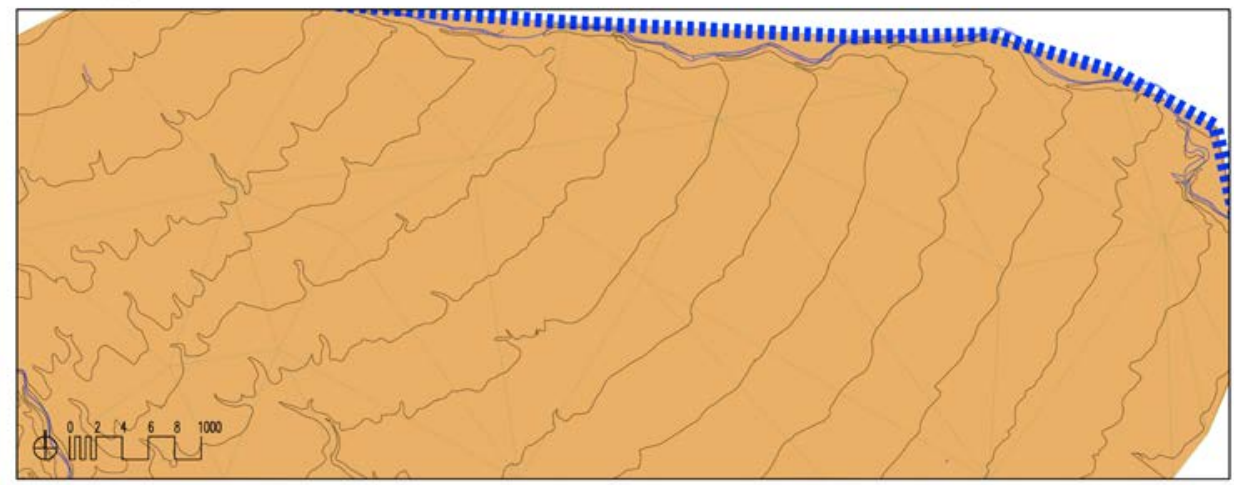

Zona 12_Atalaya San Pere

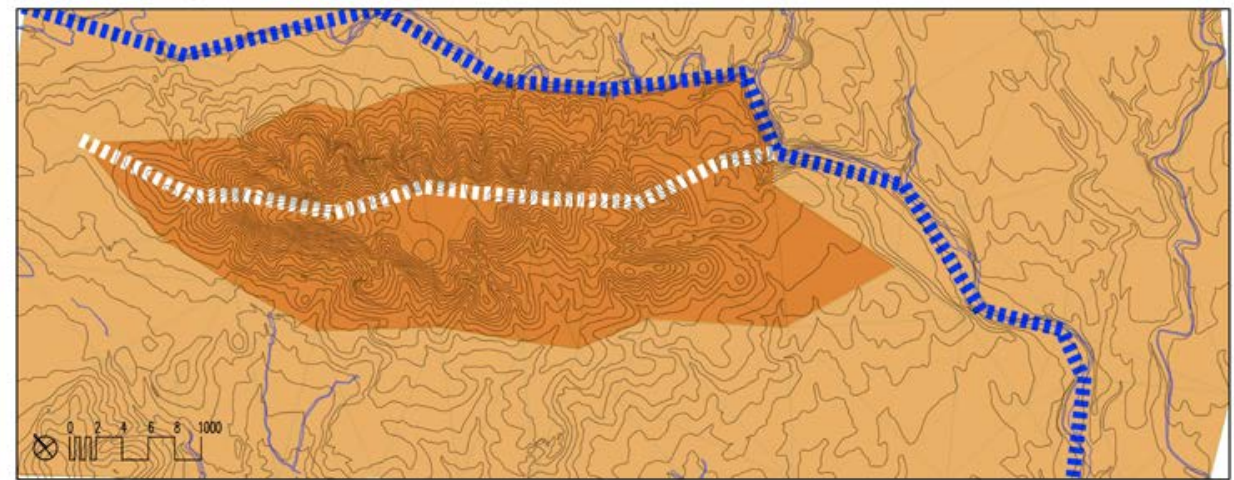


Planos geomorfológicos puros - Zonas 1-4 - [e=1/75.000]

\section{Zona 1_Bel}

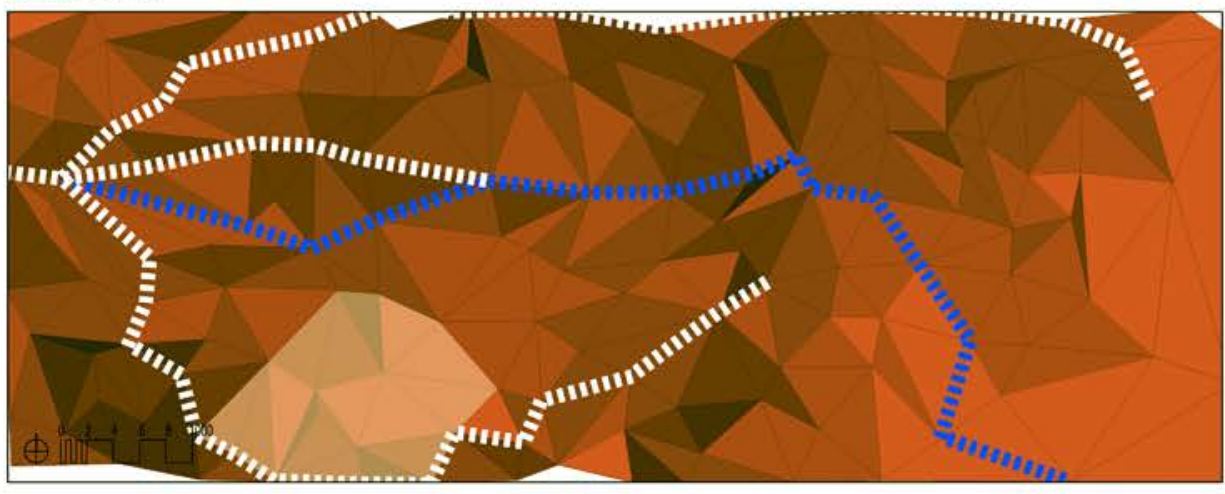

\section{Zona 2 Barcella}

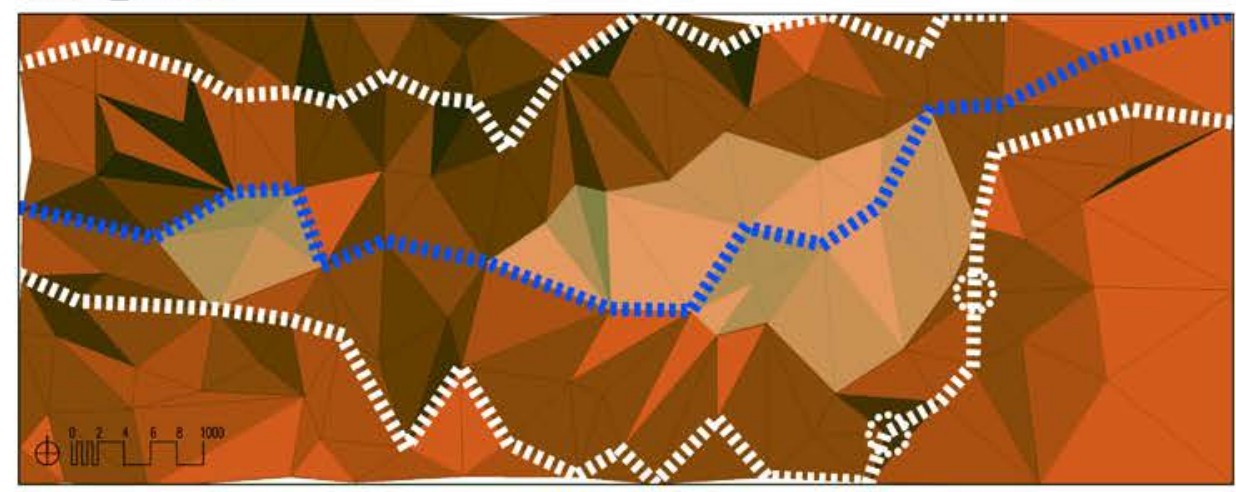

\section{Zona 3_Molinar/Xert}

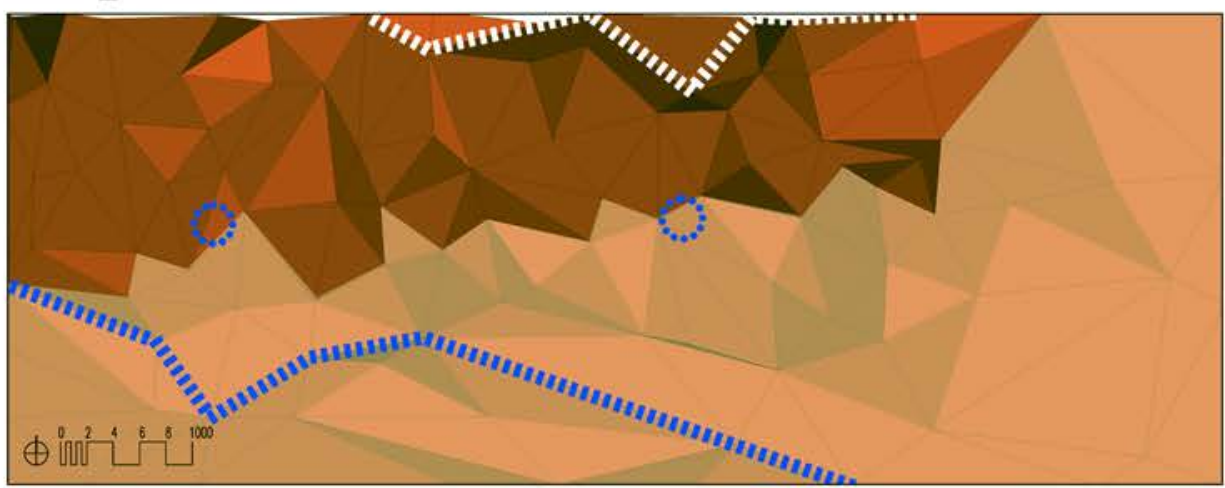

\section{Zona 4_Mas del Coll / Rosell}

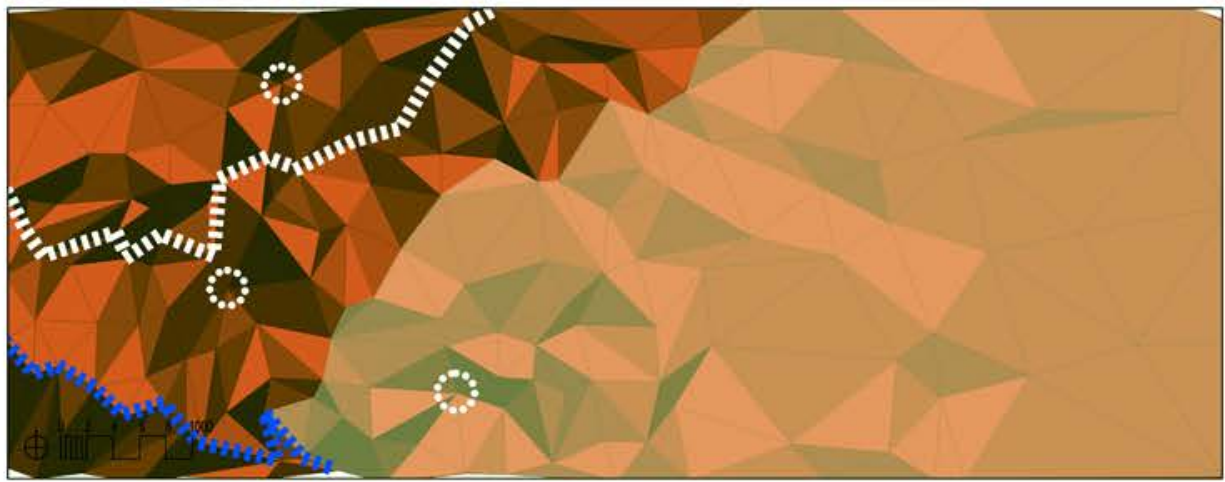


Planos geomorfológicos puros - Zonas 5-8 - [e=1/75.000]

\section{Zona 5 Canet}

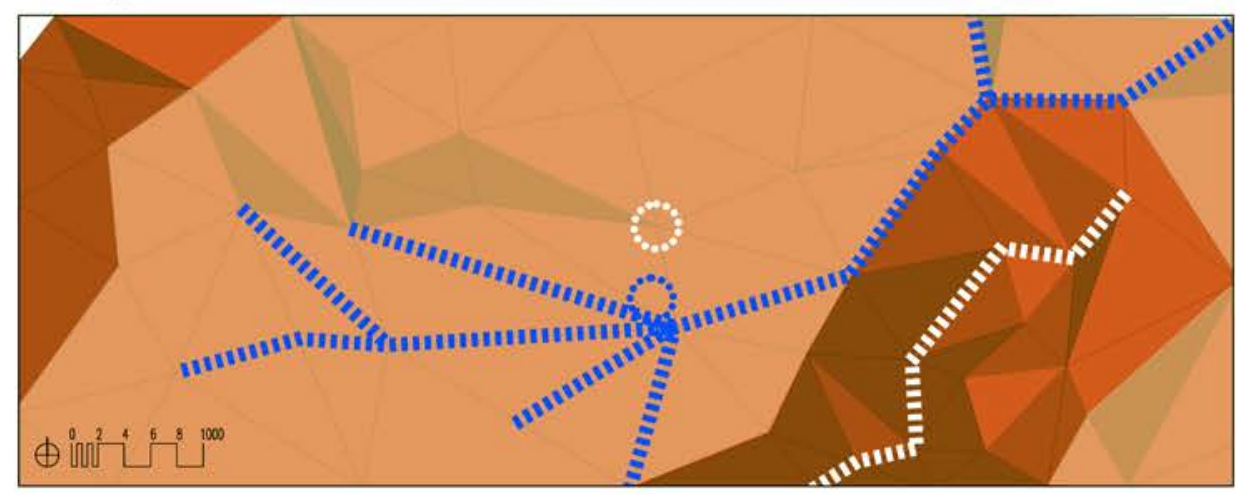

\section{Zona 6_La Jana / Carrascal}

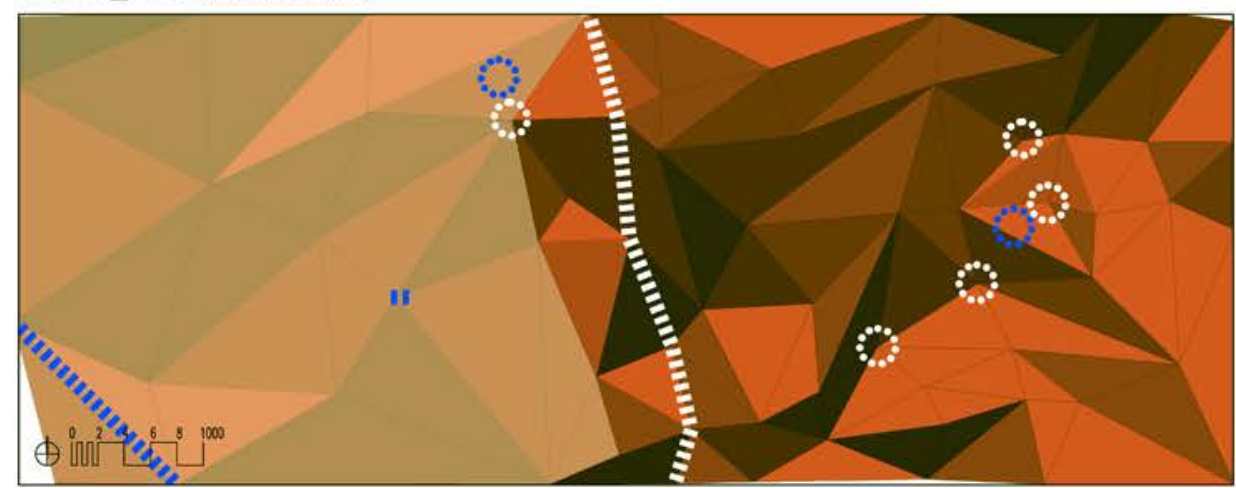

\section{Zona 7_San Mateo}

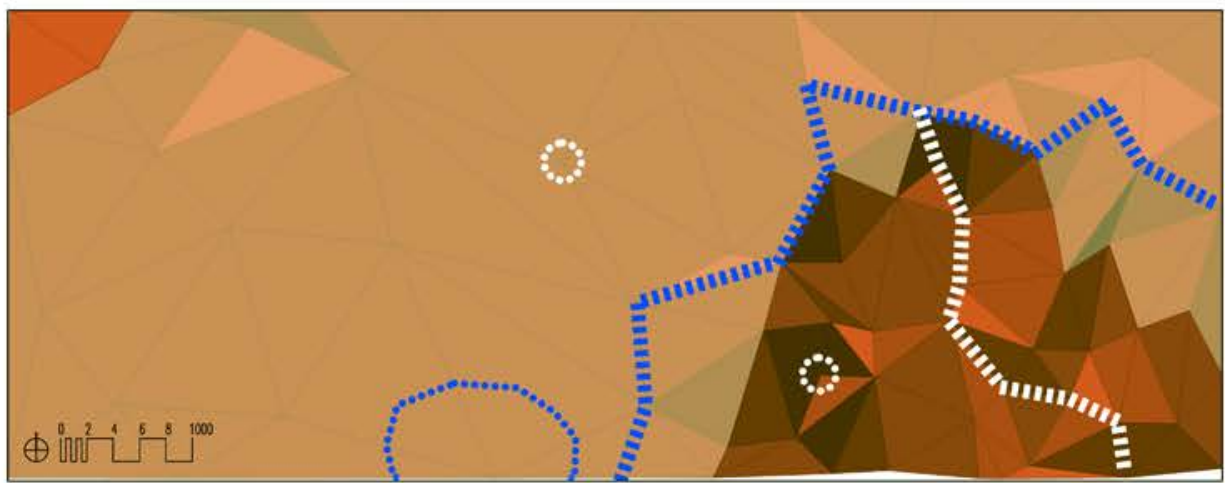

\section{Zona 8_Traiguera}

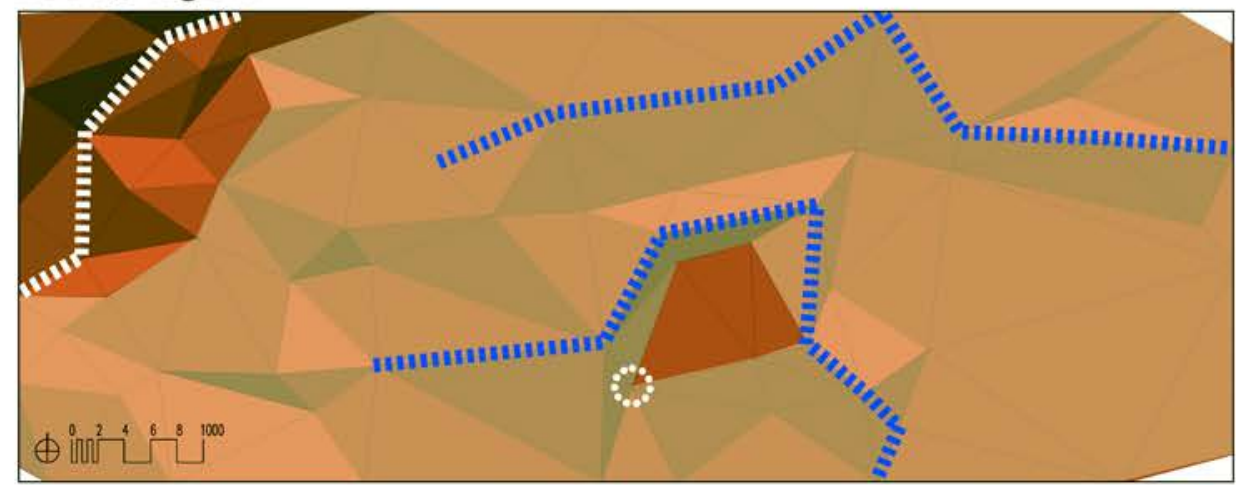


Planos geomorfológicos puros - Zonas 9-12 - $[\mathrm{e}=1 / 75.000]$

Zona 9_Mas Stellers

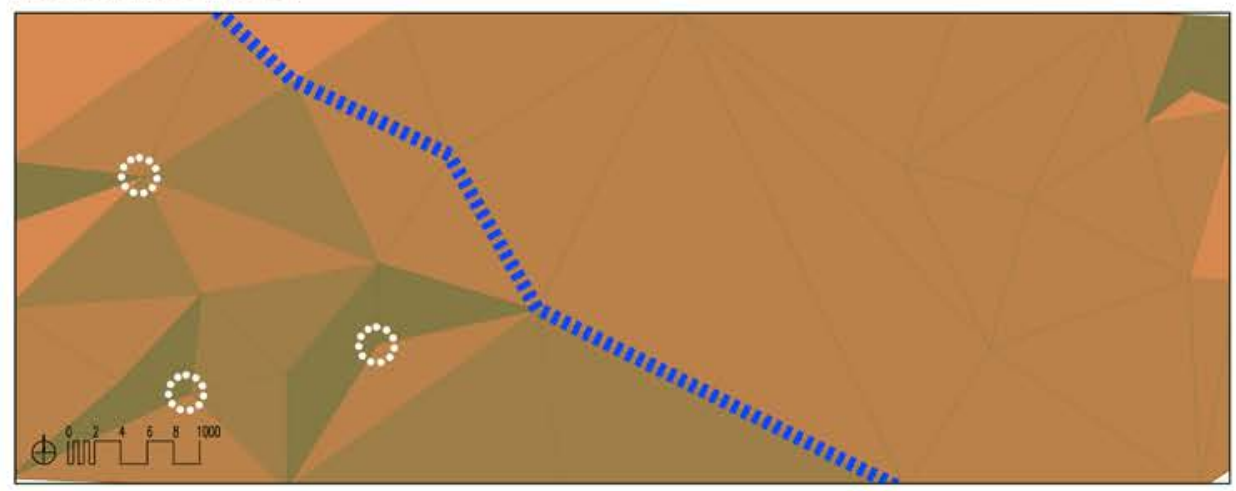

\section{Zona 10 Cervera/Calig}

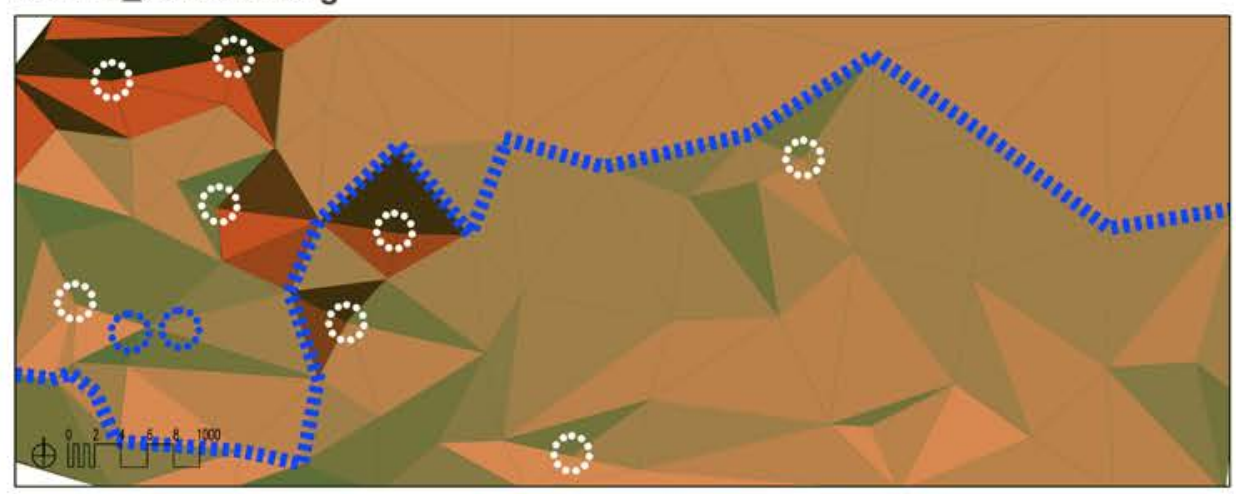

\section{Zona 11_San Joan del Pas}

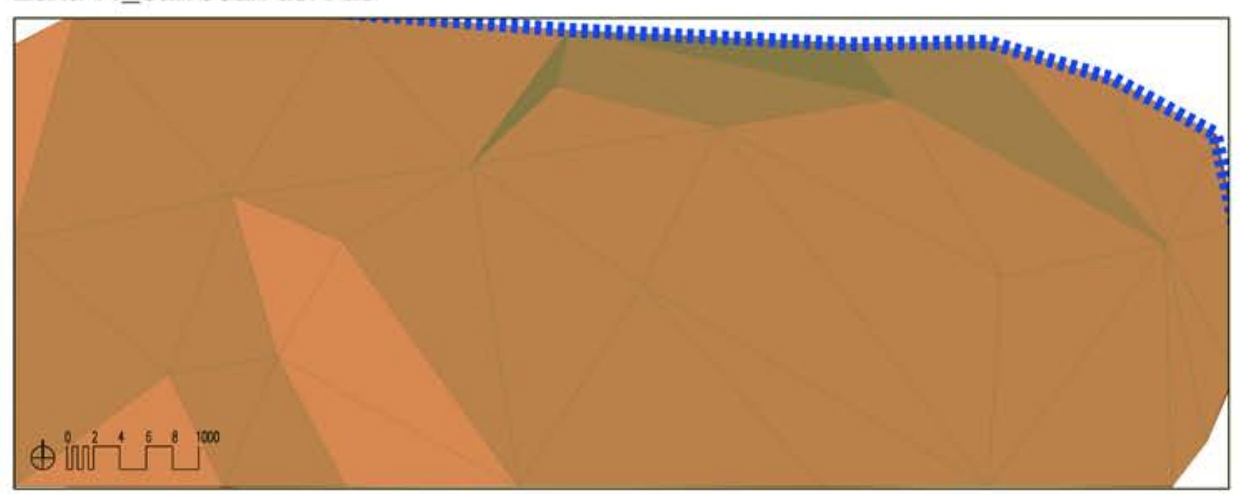

Zona 12_Atalaya San Pere

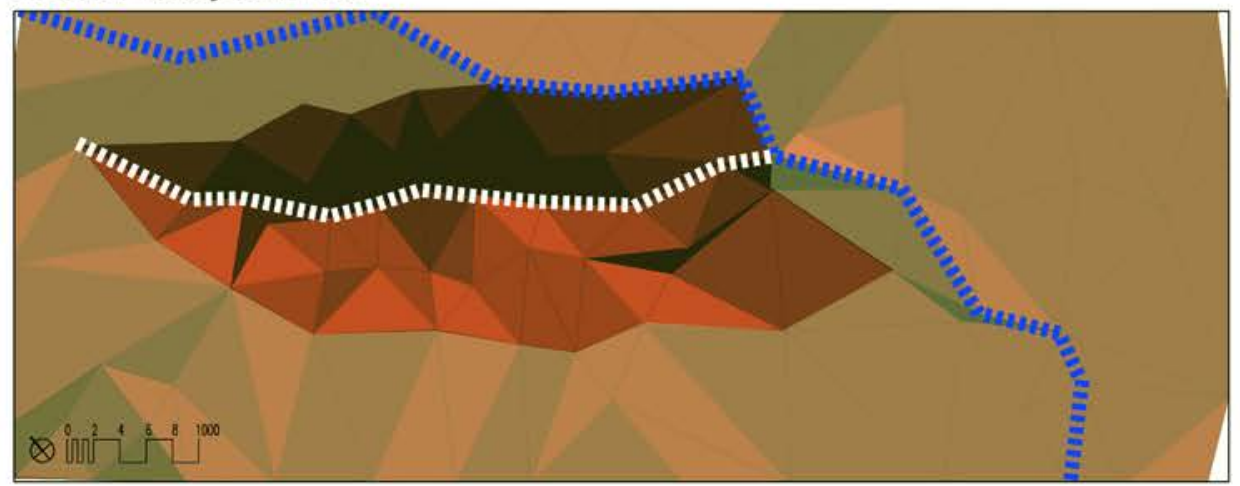




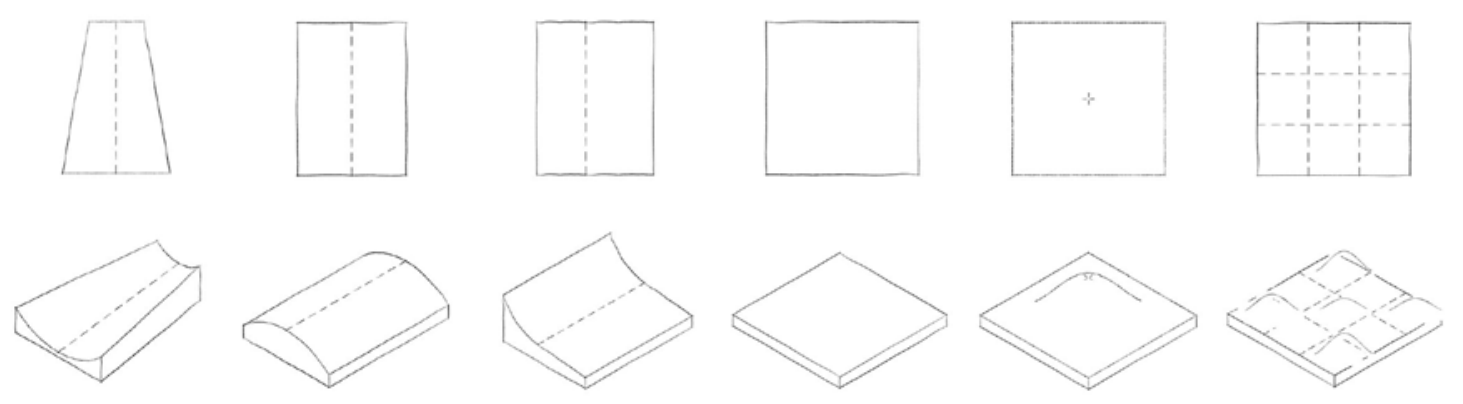

Fig. 3. 20. Dibujos esquemáticos en planta y perspectiva de los seis tipos de topologías del área de estudio.

Analizada esta información gráfica, observamos que detectamos una serie de elementos comunes que nos permiten establecer 6 tipos de topologías en el territorio:

- Recinto de montaña, es cóncavo y simétrico respecto a un eje que marca una dirección y homogéneo a lo largo de él. Corresponde a parte de la zona 1 (Bel) y parte de la 2 (Mas Torre del Rey).

- Recinto de valle, es convexo y simétrico respecto a un eje que marca una dirección y heterogéneo a lo largo de él. Corresponde con parte de la zona 2 (Sant Marc de la Barcella).

- Recinto de ladera, es asimétrico con eje en una dirección y homogéneo a lo largo de él. Corresponde a la zona 3 (Molinar-Xert) y zona 4 (Rosell-Coll).

- Recinto de llano, es plano y sin ejes de simetría y con vocación de tener centro. Corresponde a parte de las zonas 5 (Canet), 6 (La Jana-Carrascal), 7 (San Mateo) y 11 (entre rios).

- Recinto ondulado-altiplano, es convexo y cóncavo con varios ejes que conforman una malla. Corresponde a las zonas 8 (Traiguera), 9 (Cervera-Calig) y 10 (Mas Stellers).

- Atalayas, son cóncavos con un centro y sin ejes de simetría. Corresponde a la zona 12 (Sant Pere).

El análisis desde el punto de vista topológico, nos permite ver el territorio desde un punto de vista más abstracto, matemático, sustituyendo así las impresiones sensoriales imprecisas por la noción de disposición. Lo importante de las estructuras no es su forma en un momento dado sino su disposición, que es la que permitirá su crecimiento y evolución.

A partir de las topologías estudiaremos las aptitudes como formas obtenidas por la "decantación" de las mismas con el paso del tiempo y que atesoran una predisposición a una determinada evolución.

\section{3. 2. La aptitud del territorio}

Debemos de destacar que la energía que se acumula como in-formación depende del uso al que vaya destinado ese suelo. En nuestro caso se trata de un uso agrícola, por lo que la aptitud la hemos definido en virtud de ese uso.

Analizado gráficamente el territorio como disposición topológica y como depósito de energía, superpondremos en las doce zonas de estudio ambas para obtener gráficamente los planos de aptitud del suelo en cada una de las topologías.

El análisis realizado a partir de la comparación de las relaciones diacrónicas nos permite ver que el territorio acumula energía como in-formación, aquellas formas que son más aptas para el uso humano 
(obtención de recursos y hábitat) requieren invertir en ellas menos energía para transformarlas y usarlas por el hombre, es decir, esas formas son en sí mismas un "depósito” de energía susceptible de ser utilizado por el hombre. Estos relieves más “aptos” son también los más estables, los que menos se erosionan y por tanto que menos se transforman por la acción de los elementos atmosféricos. ${ }^{62}$ La aptitud del relieve como "depósito" de energía la estudiaremos, con el apoyo del Sistema de Información Geográfica (SIG) en función de cinco parámetros:

- La altura del suelo como factor directo del que depende la temperatura ambiente. Consideraremos alturas cada 120 metros.

- El soleamiento al que está expuesto el territorio, como factor del que depende tanto la temperatura como las posibilidades de cultivo agrícola. Consideraremos las siguientes posibilidades, de menos a mayor grado de exposición al sol: suelos con orientación norte; noreste y noroeste; este; oeste; sureste y suroeste y sur.

- La pendiente del suelo como factor que permite el uso agrícola del territorio. Consideraremos las siguientes grados de pendiente de menos a más: $0-3,5 \% ; 3,5-8 \% ; 8-15 \% \% ; 15-25 \%$; 25 $35 \%$ y $>35 \%$.

- La exposición al viento del suelo. Consideráremos de mayor a menor incidencia en el uso del suelo las siguientes posibilidades: suelo expuesto viento del norte; vientos del noreste; vientos del noroeste; vientos del este y el resto. Los vientos del este son importantes en esta zona por ser los que propician las precipitaciones y por tanto son zonas más húmedas.

- El grado de humedad del suelo motivado bien por su exposición a los vientos húmedos del este, por la existencia de cursos de agua superficial o por la existencia de un nivel freático alto por la existencia de agua subterránea.

En función de la combinación de estos cinco factores obtendremos tres aptitudes de suelo distintas: suelo apto, suelo apto con limitaciones y suelo no apto.

El suelo apto es aquel con una altura inferior a 960 metros; no orientado ni norte, noreste o noroeste; con una pendiente inferior al 8\%; protegido de los vientos del norte y con un nivel medio de humedad del suelo.

El suelo no apto es aquel que tiene al menos alguna de estas condiciones: una altura superior a 1200 metros; orientado al norte; con una pendiente superior al 25\%; expuesto a los vientos del norte y sin recursos de agua.

Suelo apto con limitaciones es el resto de suelo.

Los planos de in-formación se realizan de la Batllia de Cervera (1:200.000) y de las doce zonas seleccionadas (1:80.000). Se grafía planos de alturas, pendientes, soleamiento, vientos, agua y aptitud para el asentamiento humano.

El proceso se realizó a través del software GIS Arcmap de la empresa ESRI. A partir de ortofotos, archivos .shp y .ers se usaron las herramientas "aspect" y "slope", así como una reclasificación por colores de la topografía. Posteriormente, se combinaron las capas resultantes a través de solapes de capas, intersecciones y extracciones para crear los planos de aptitudes.

$62 \mathrm{La}$ aptitud del suelo en el caso de estudio es para el uso agrícola que era el fundamental en la Edad Media. 
Planos de in-formación - Zona 1 (Bel) - [e=1/80.000]

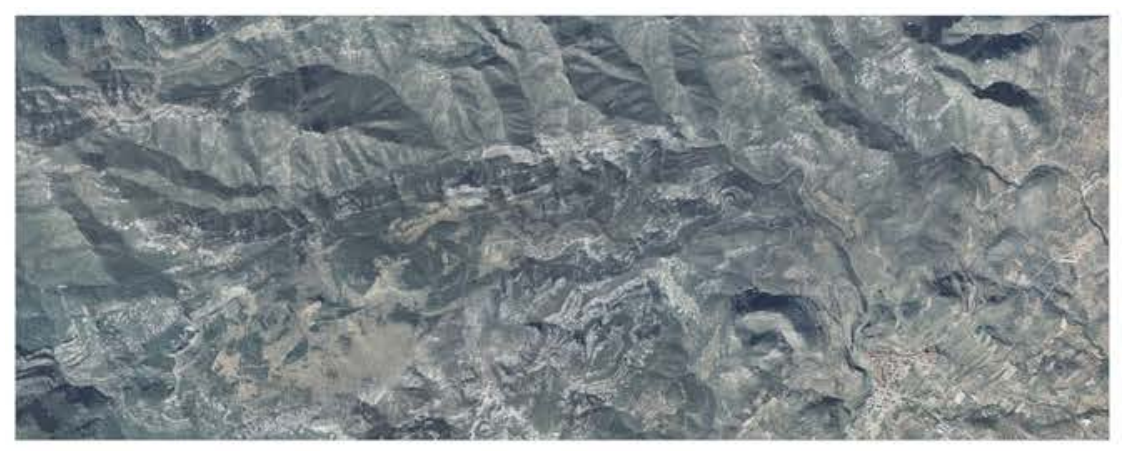

\section{Zona 1}

Bel

Ortofoto
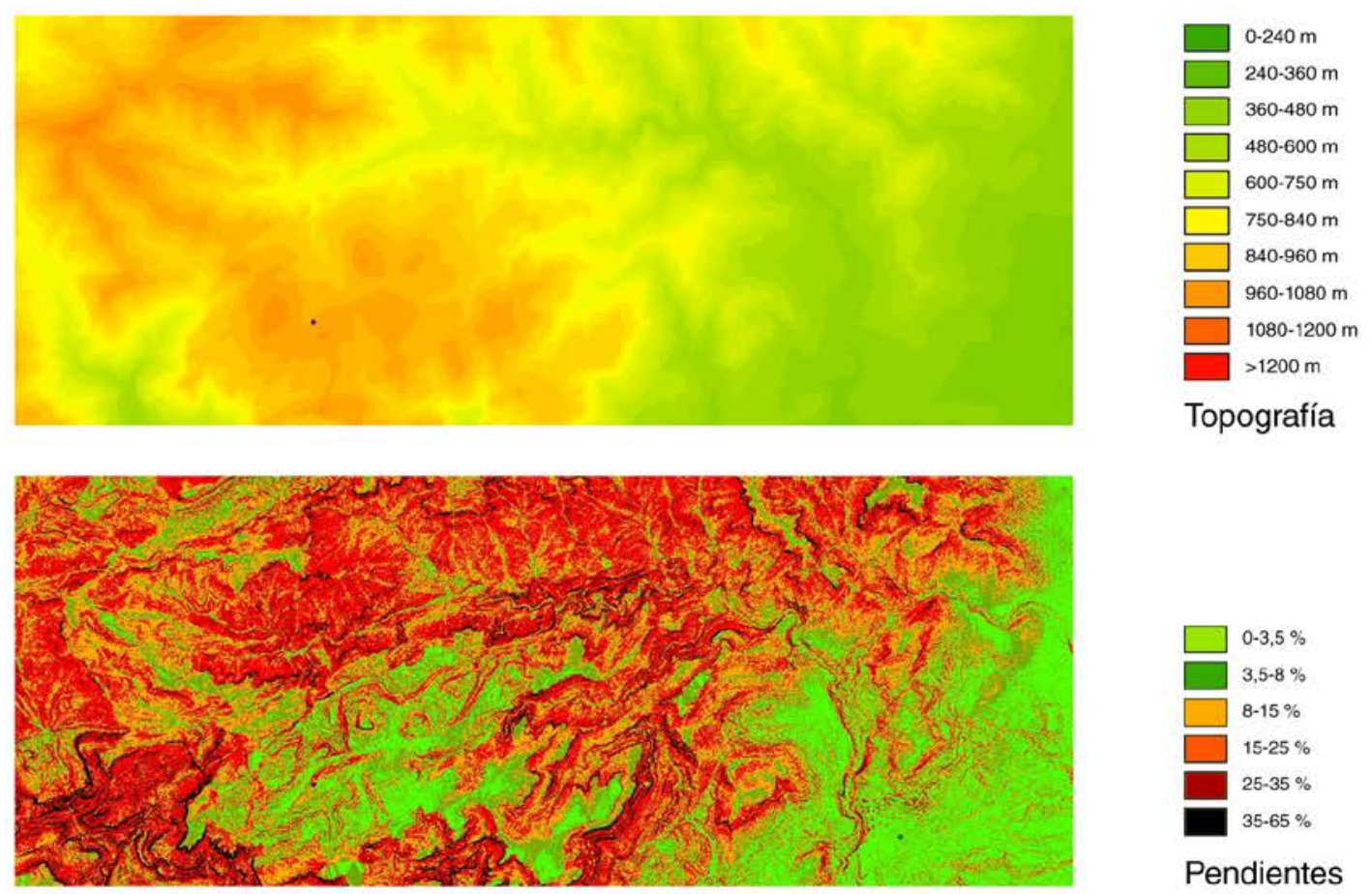

Topografía
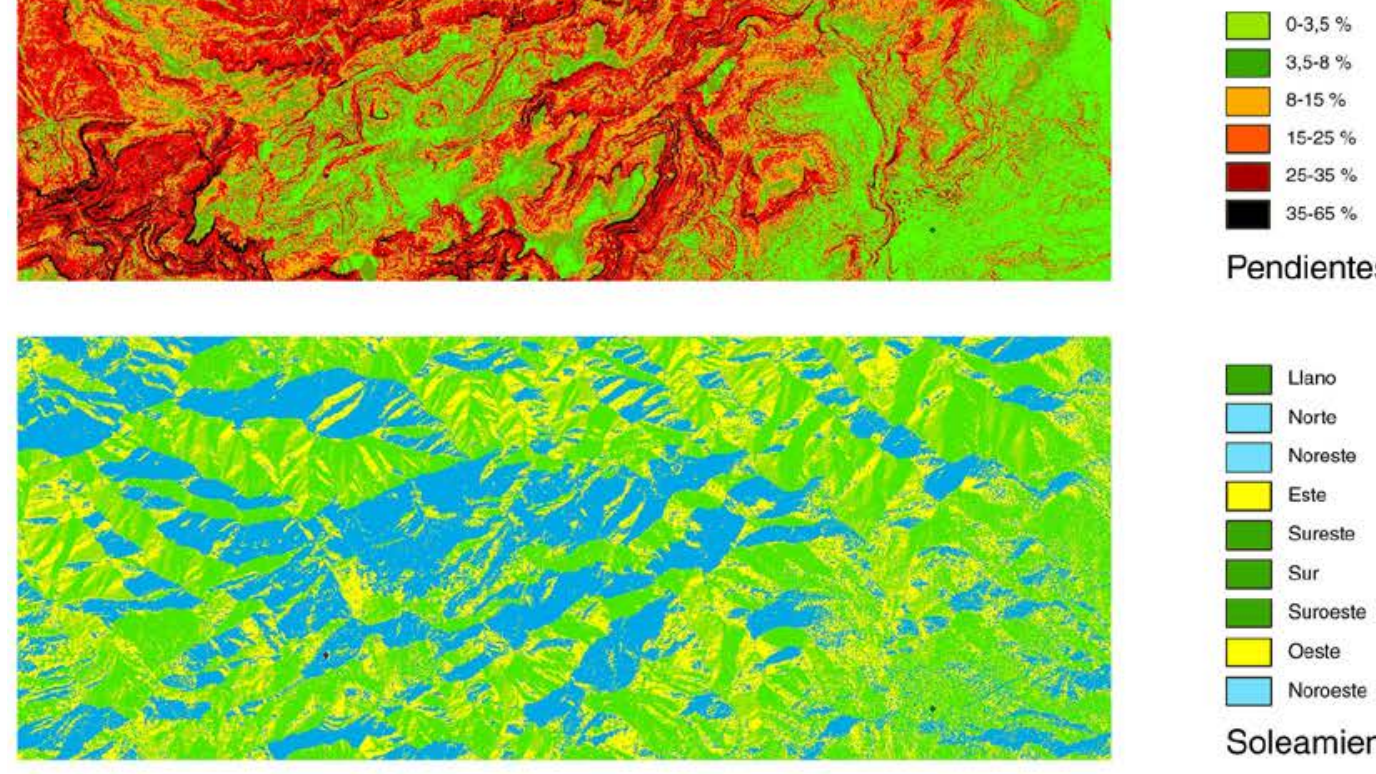

Pendientes

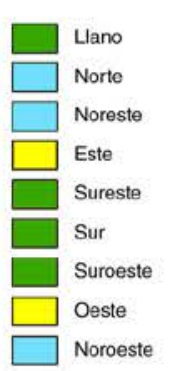

Soleamiento

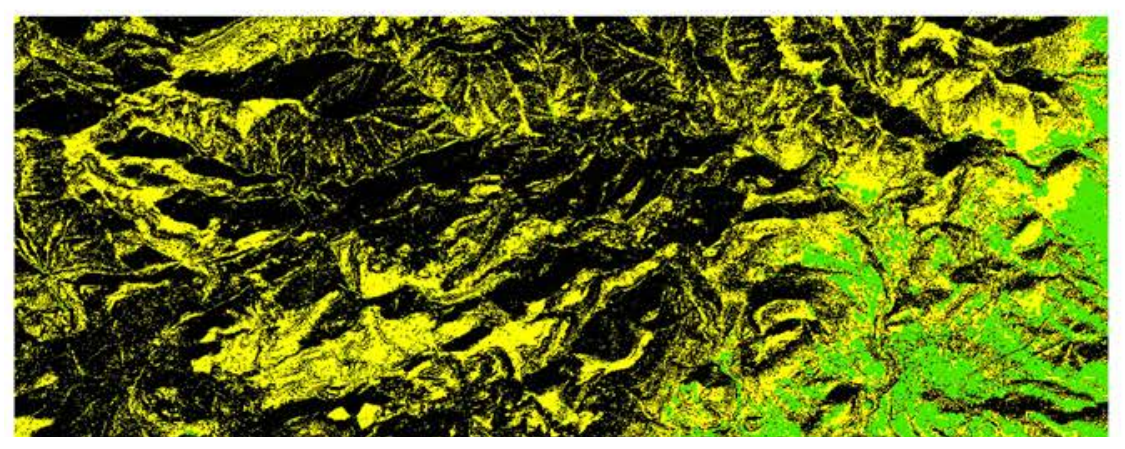

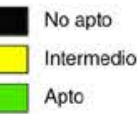

Aptitud uso del suelo 
Planos de in-formación - Zona 2 (Barcella) - [e=1/80.000]

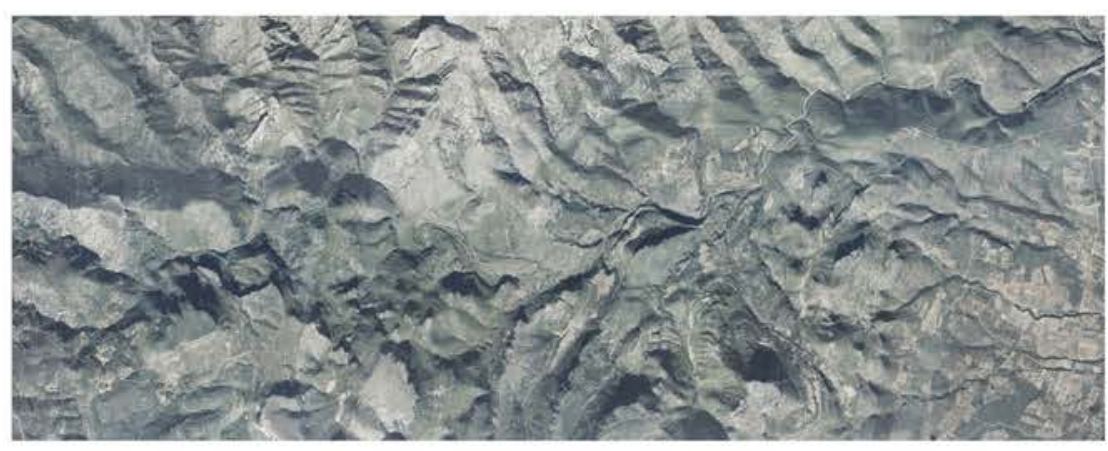

Zona 2

Barcella

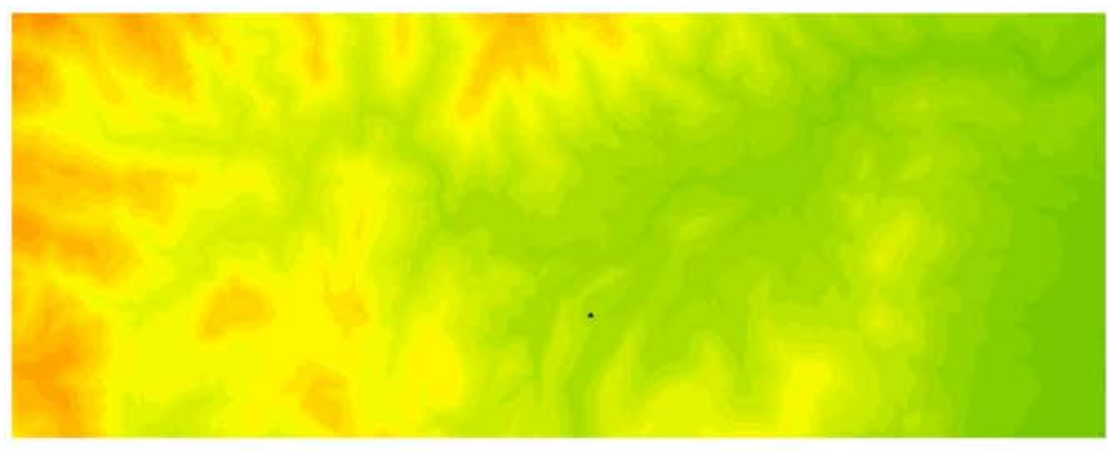

Ortofoto
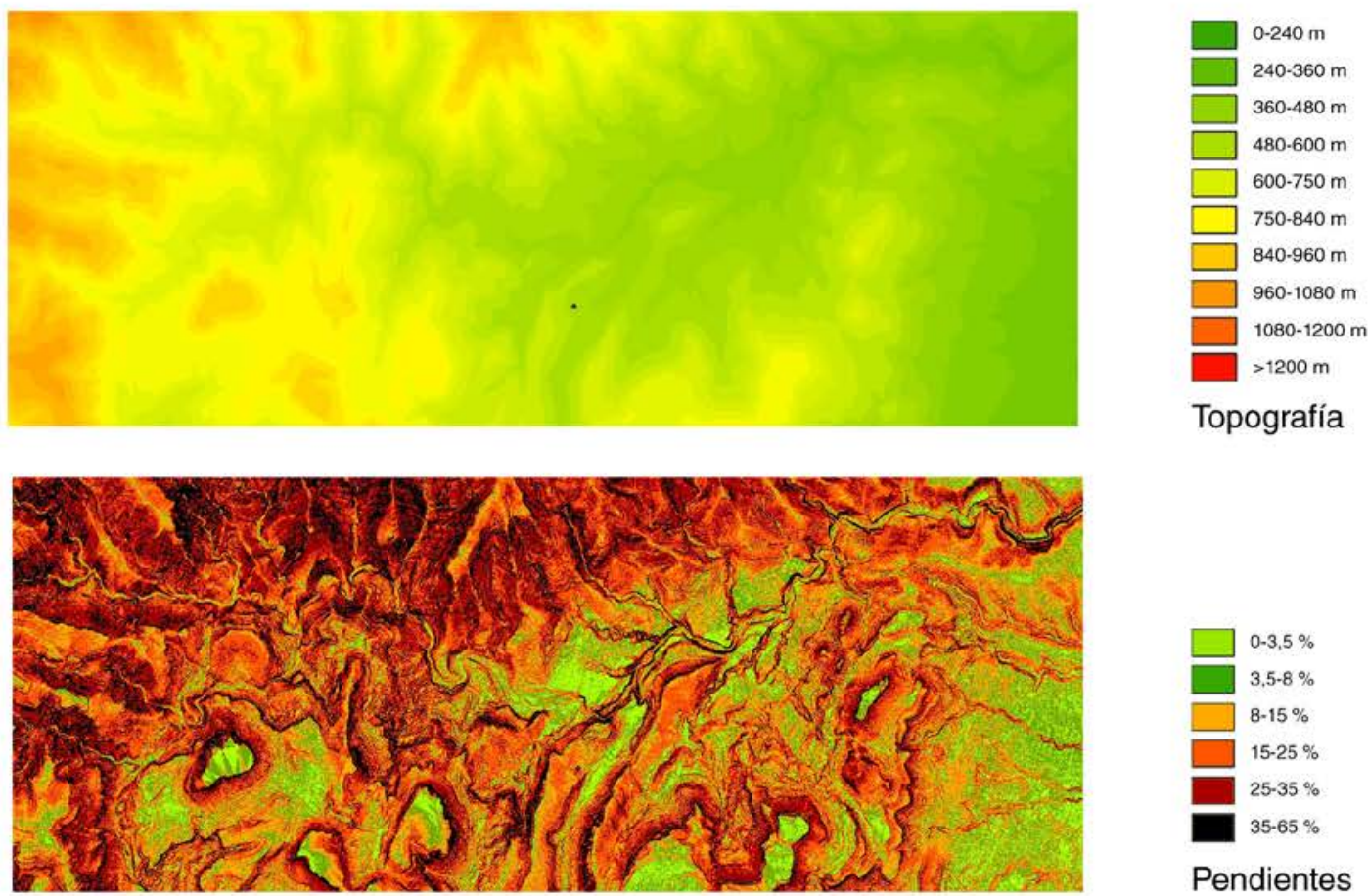

Topografía
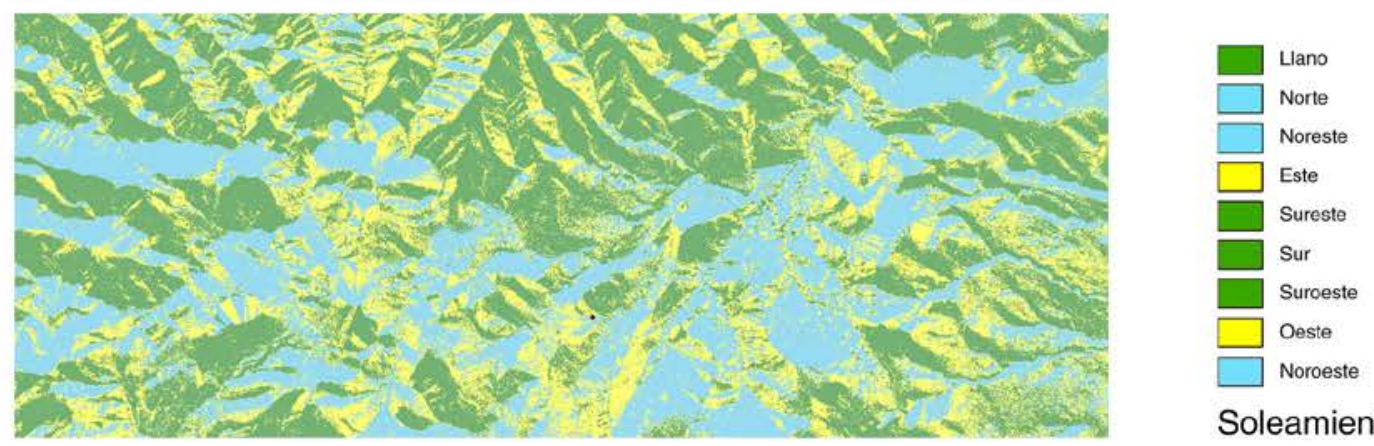

Soleamiento

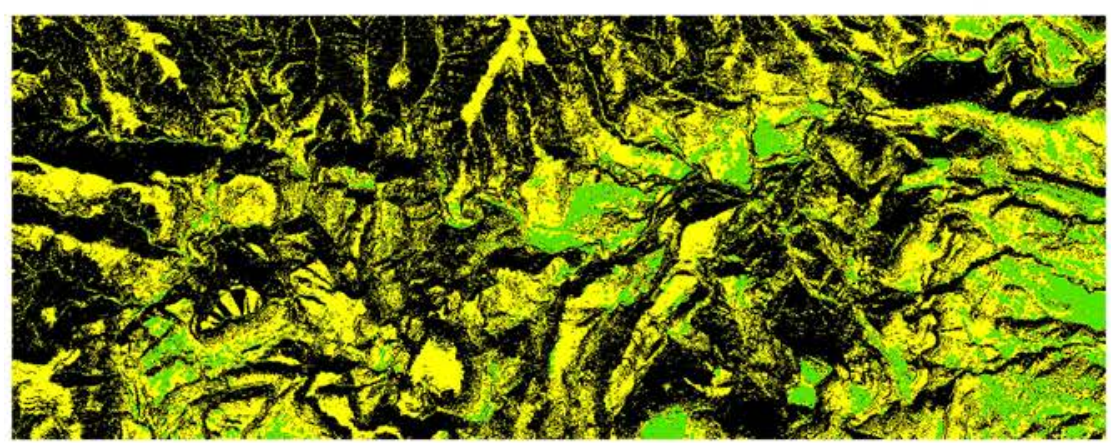


Planos de in-formación - Zona 3 (Molinar / Xert) - [e=1/80.000]

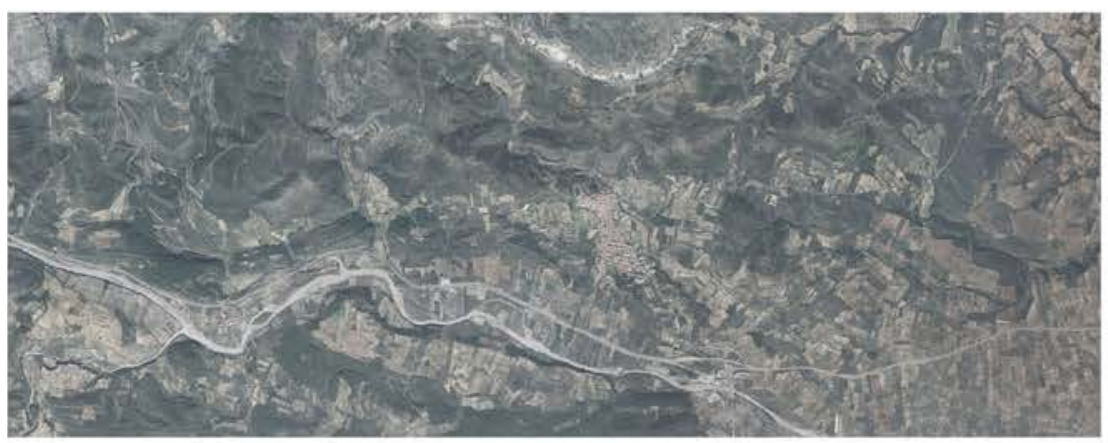

Zona 3

Molinar/Xert

Ortofoto
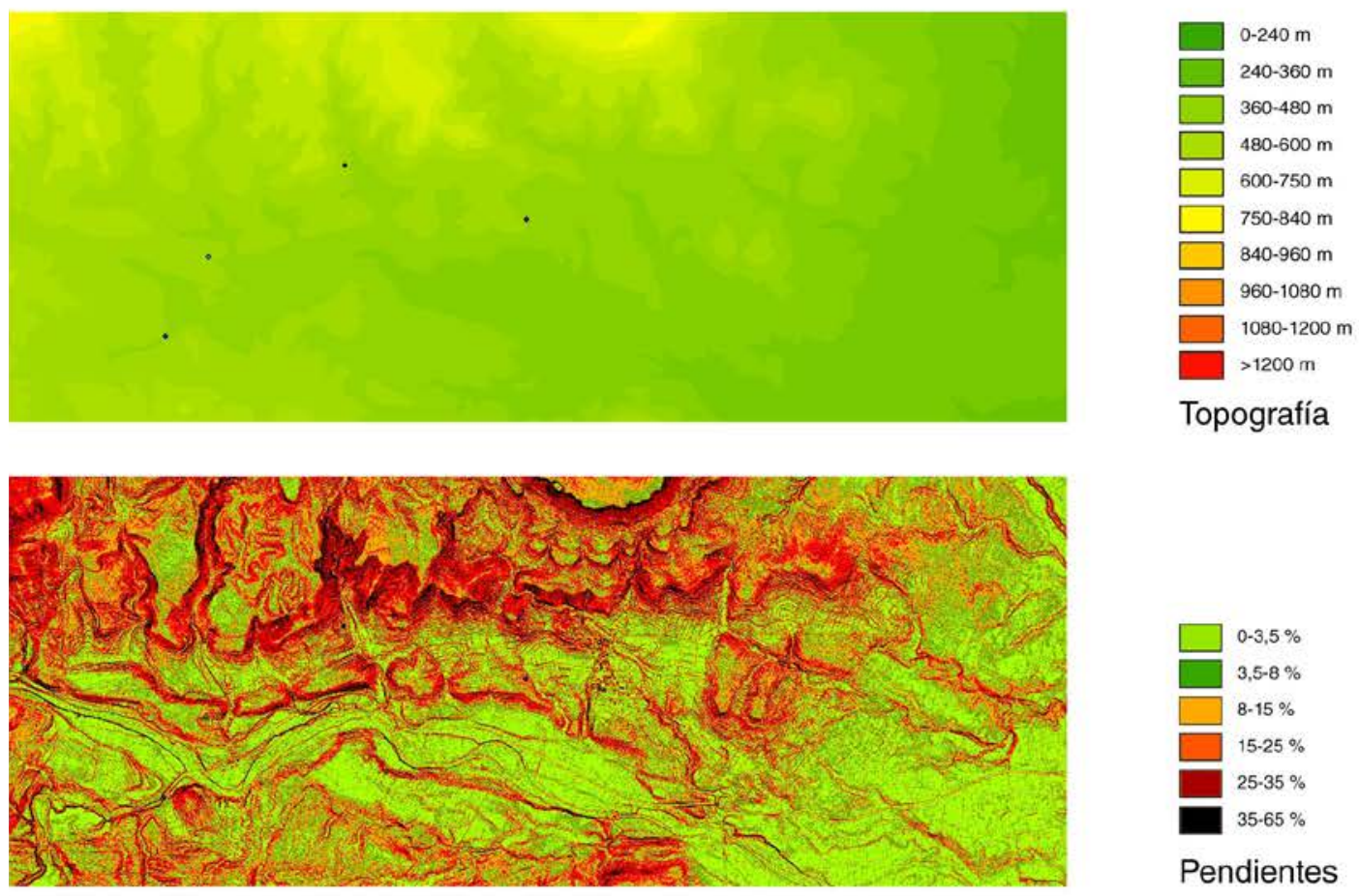

Topografía
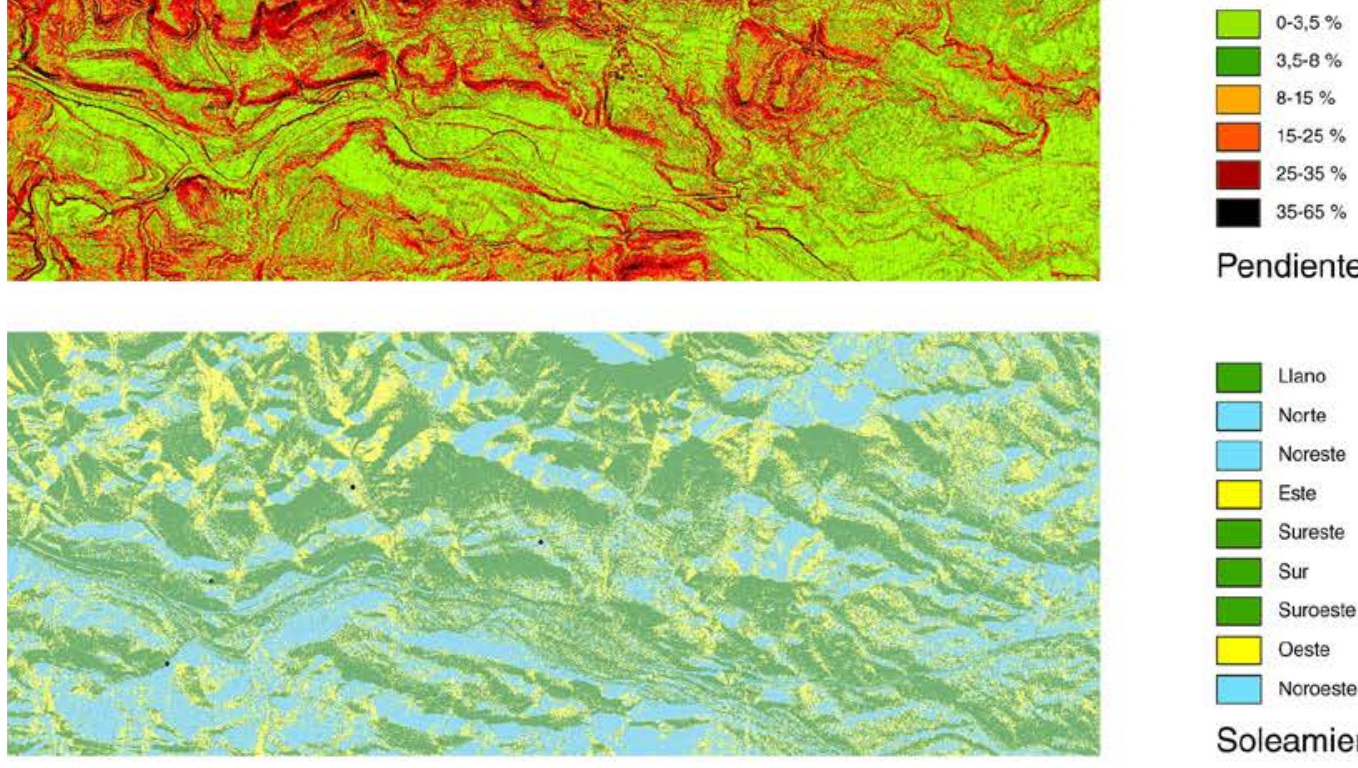

Pendientes

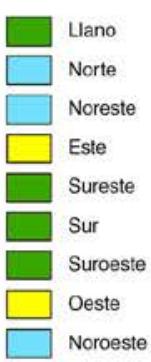

Soleamiento
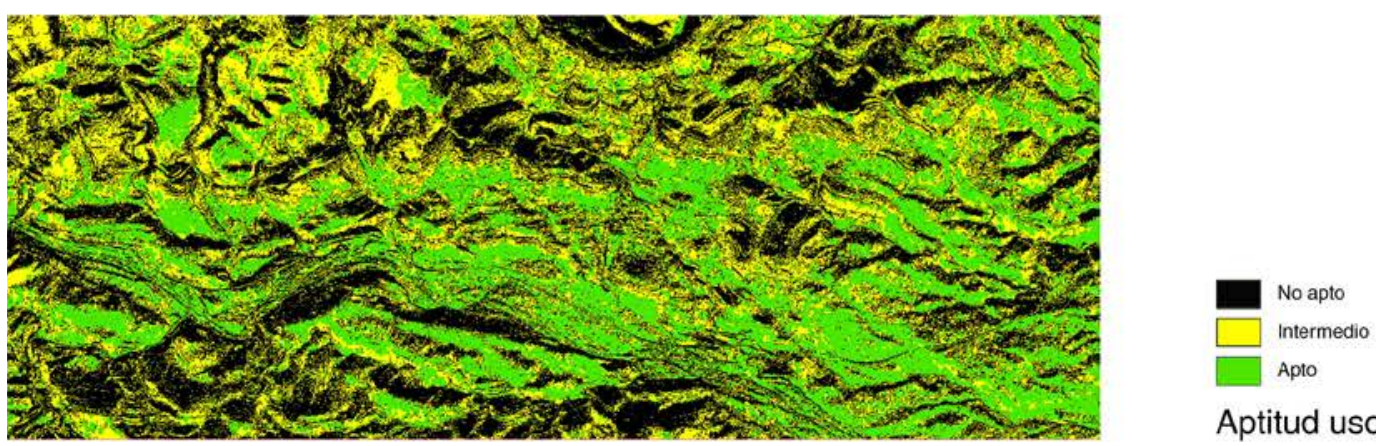

Aptitud uso del suelo 
Planos de in-formación - Zona 4 (Mas del Coll / Rosell) - $[e=1 / 80.000]$

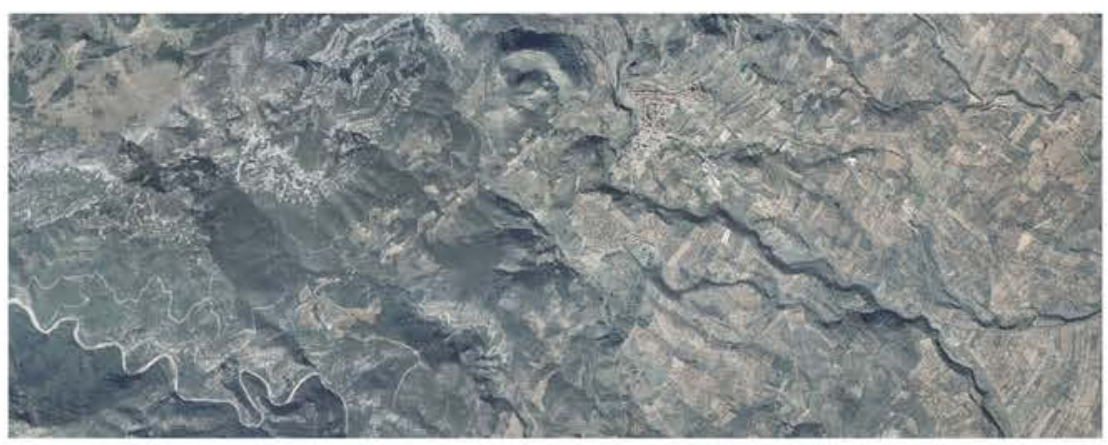

Zona 4

Mas del Coll /

Rosell

Ortofoto
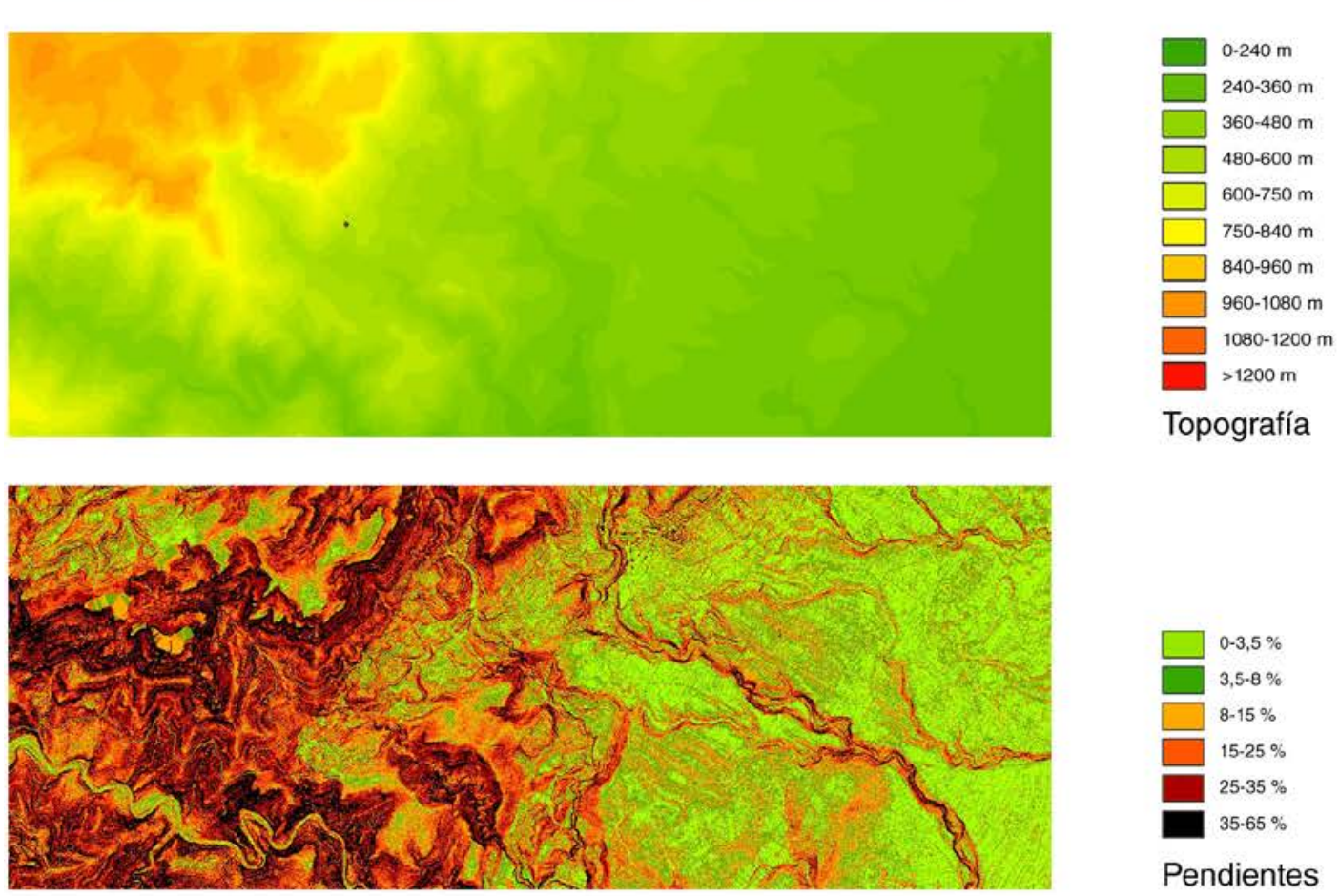

Topografía
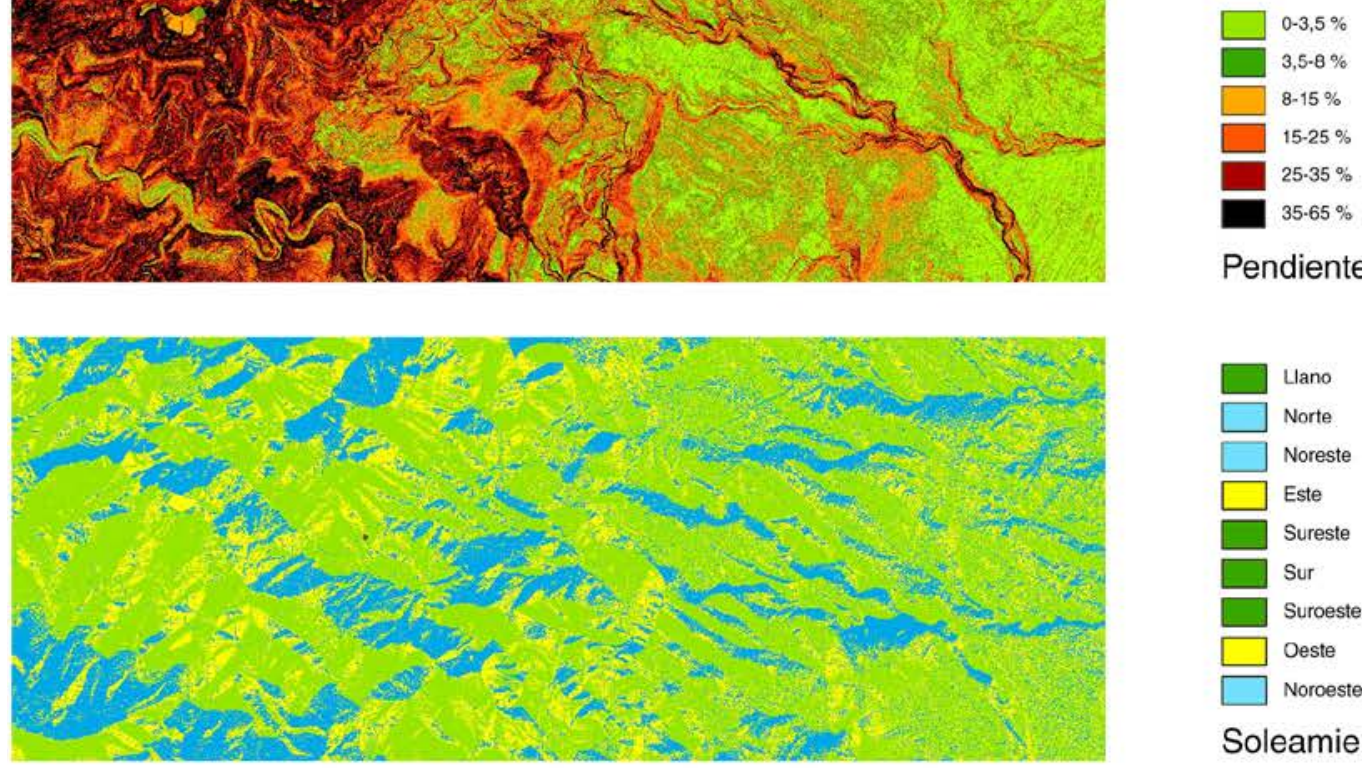

Pendientes

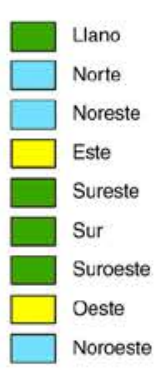

Soleamiento

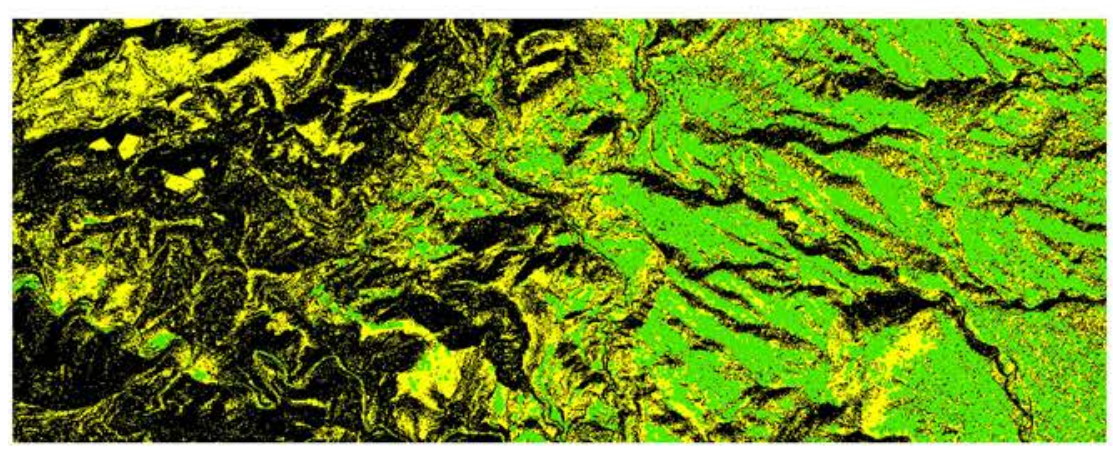


Planos de in-formación - Zona 5 (Canet) - [e=1/80.000]

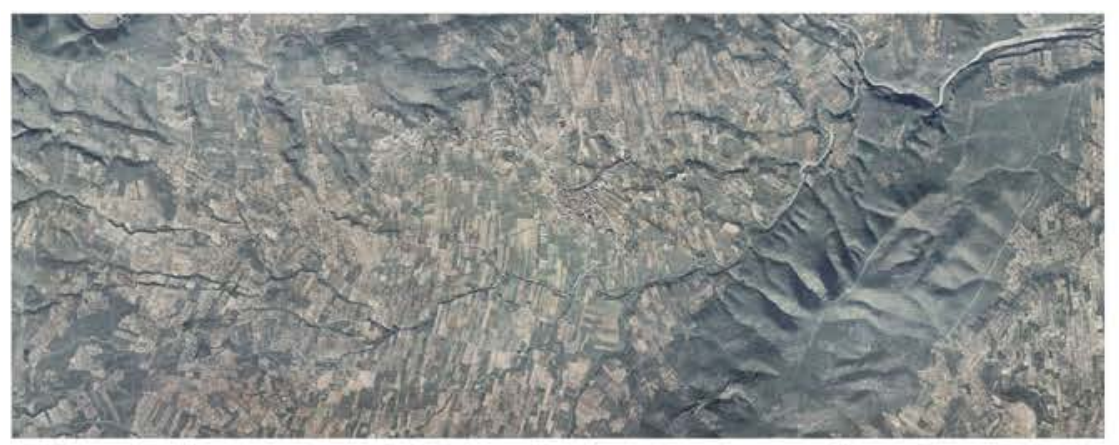

\section{Zona 5 \\ Canet}

\section{Ortofoto}
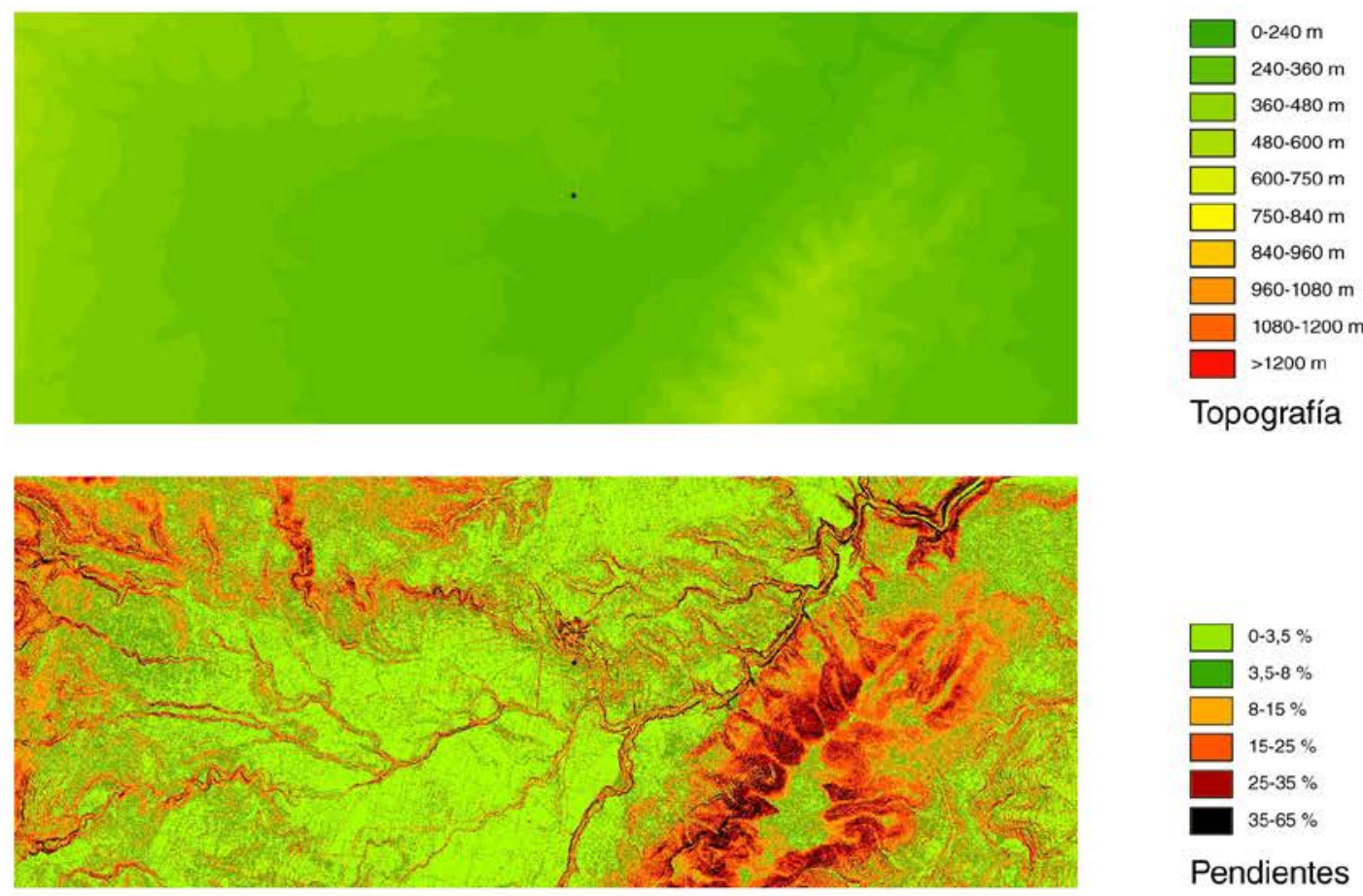

Topografía
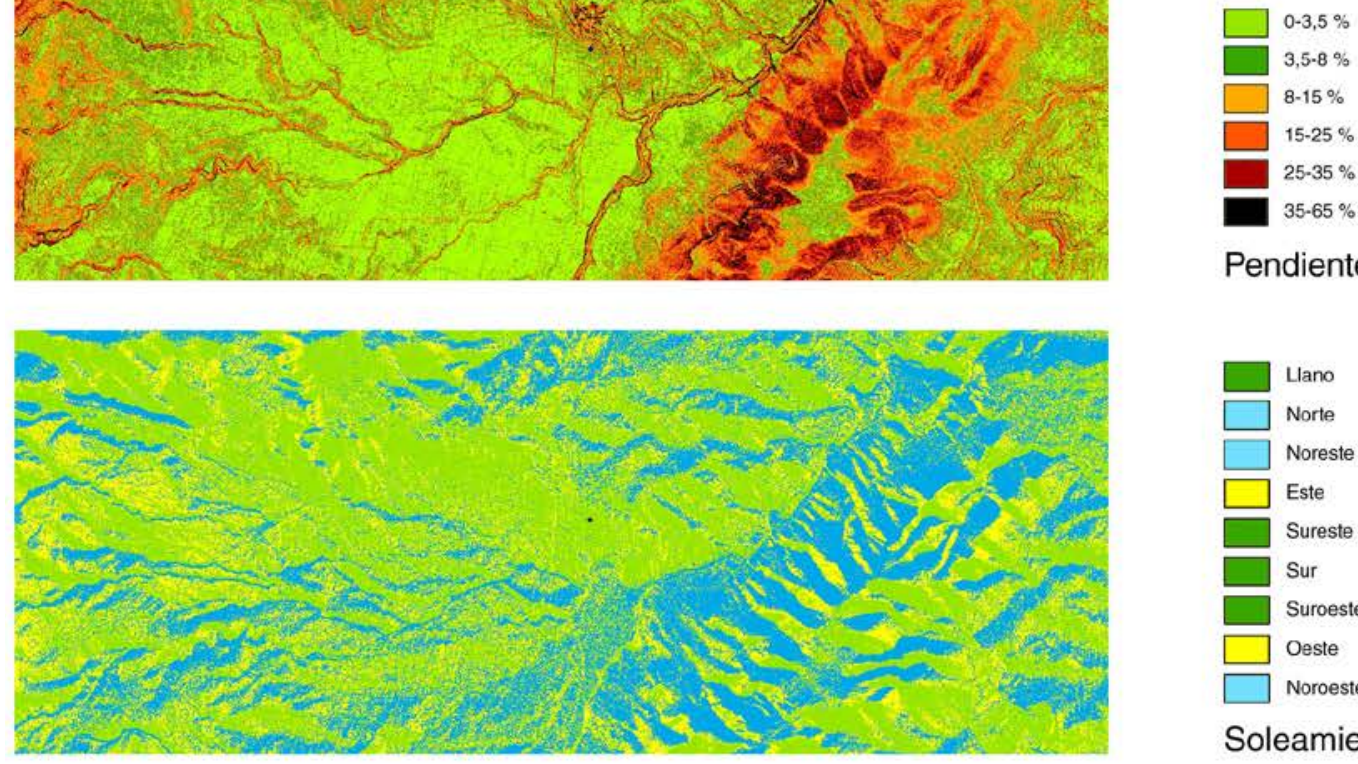

Pendientes

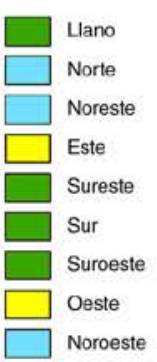

Soleamiento

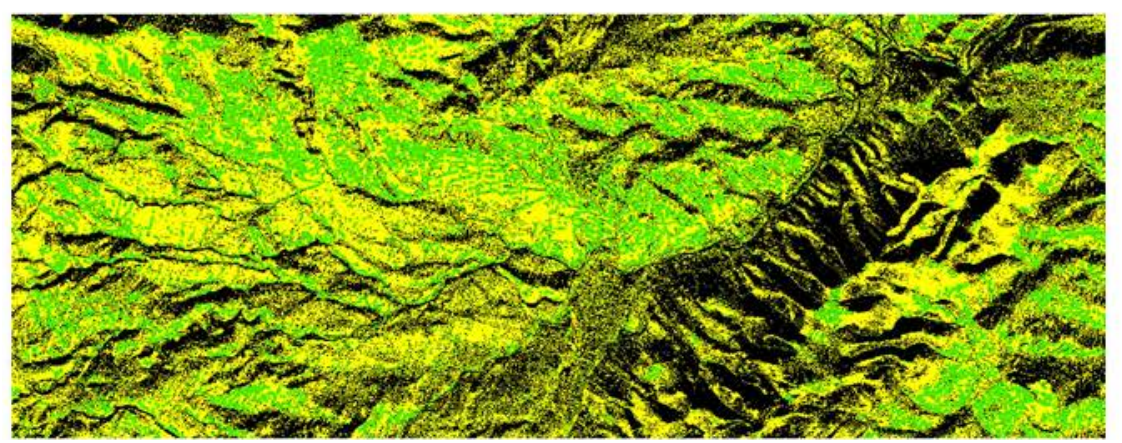

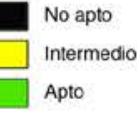

Aptitud uso del suelo 
Planos de in-formación - Zona 6 (La Jana / Carrascal) - [e=1/80.000]

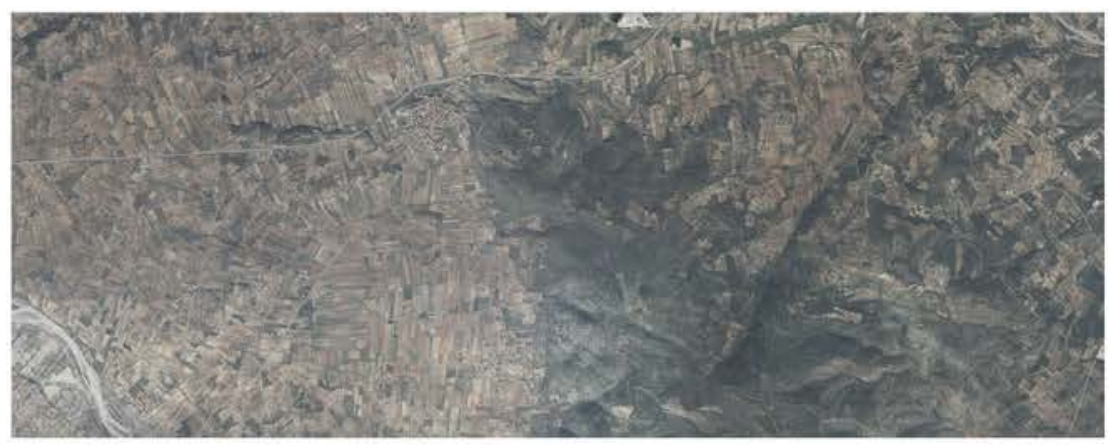

\section{Zona 6 \\ La Jana / \\ Carrascal}

Ortofoto
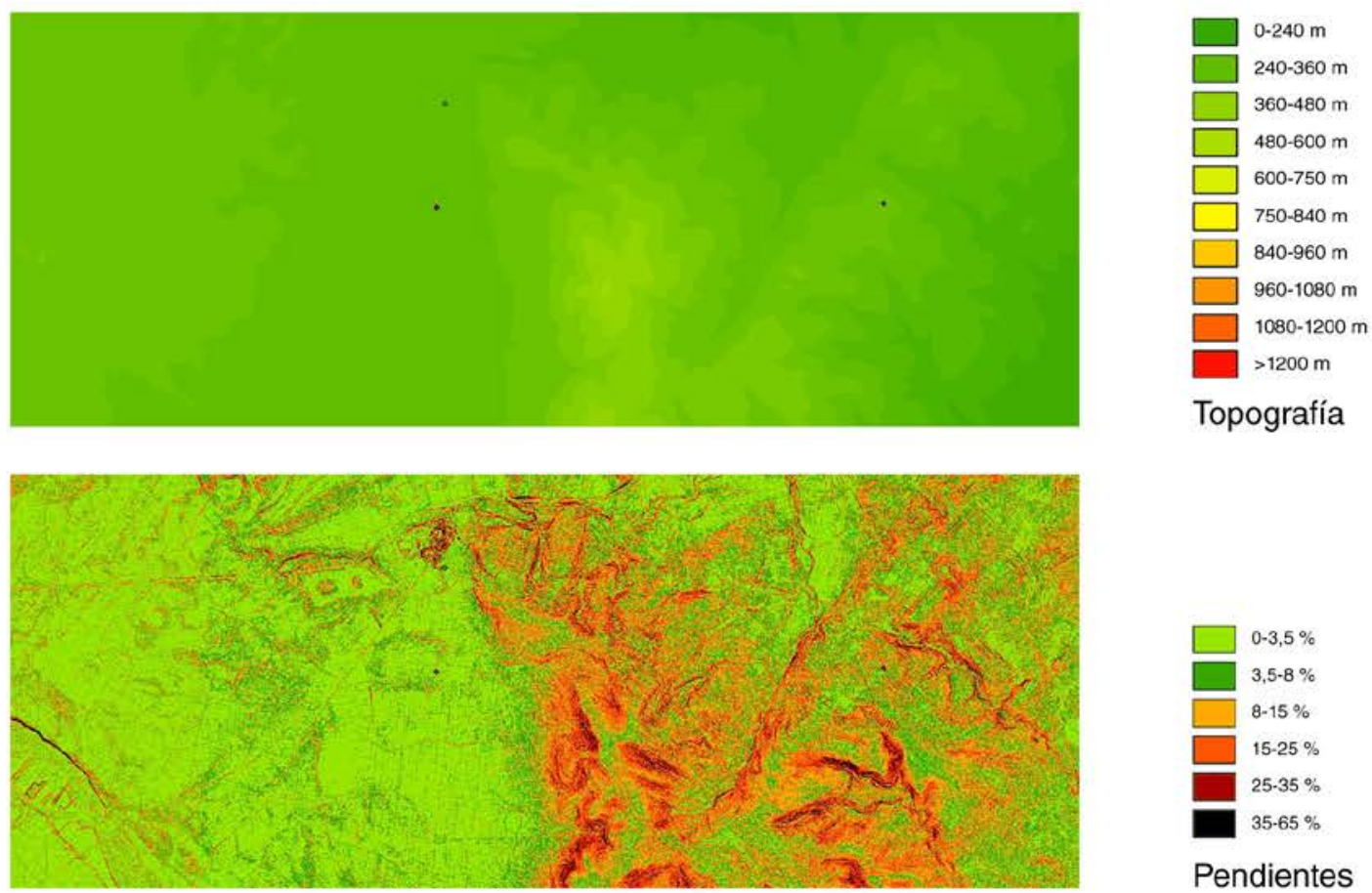

Topografía
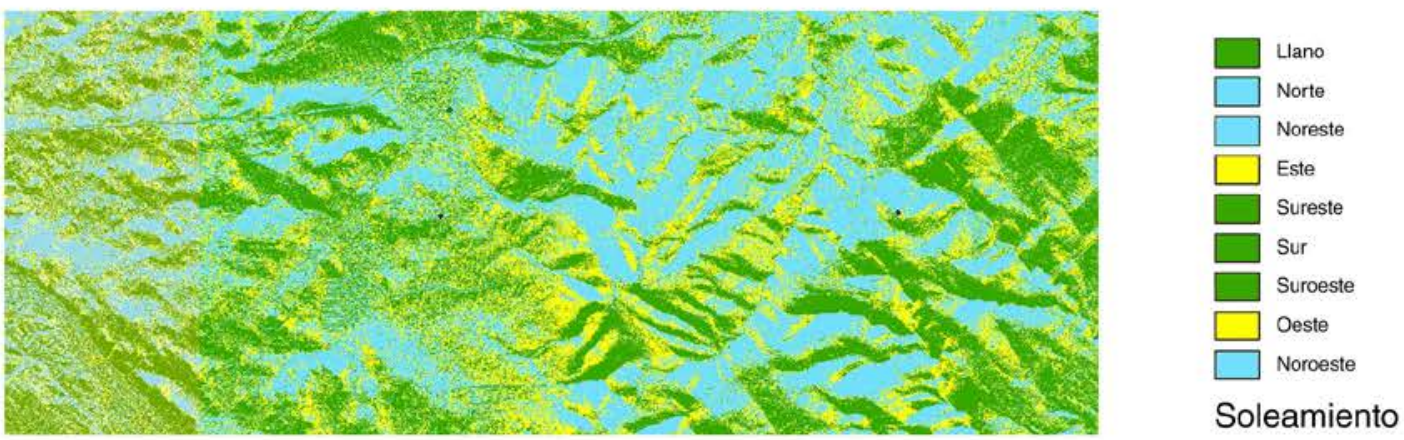

Soleamiento
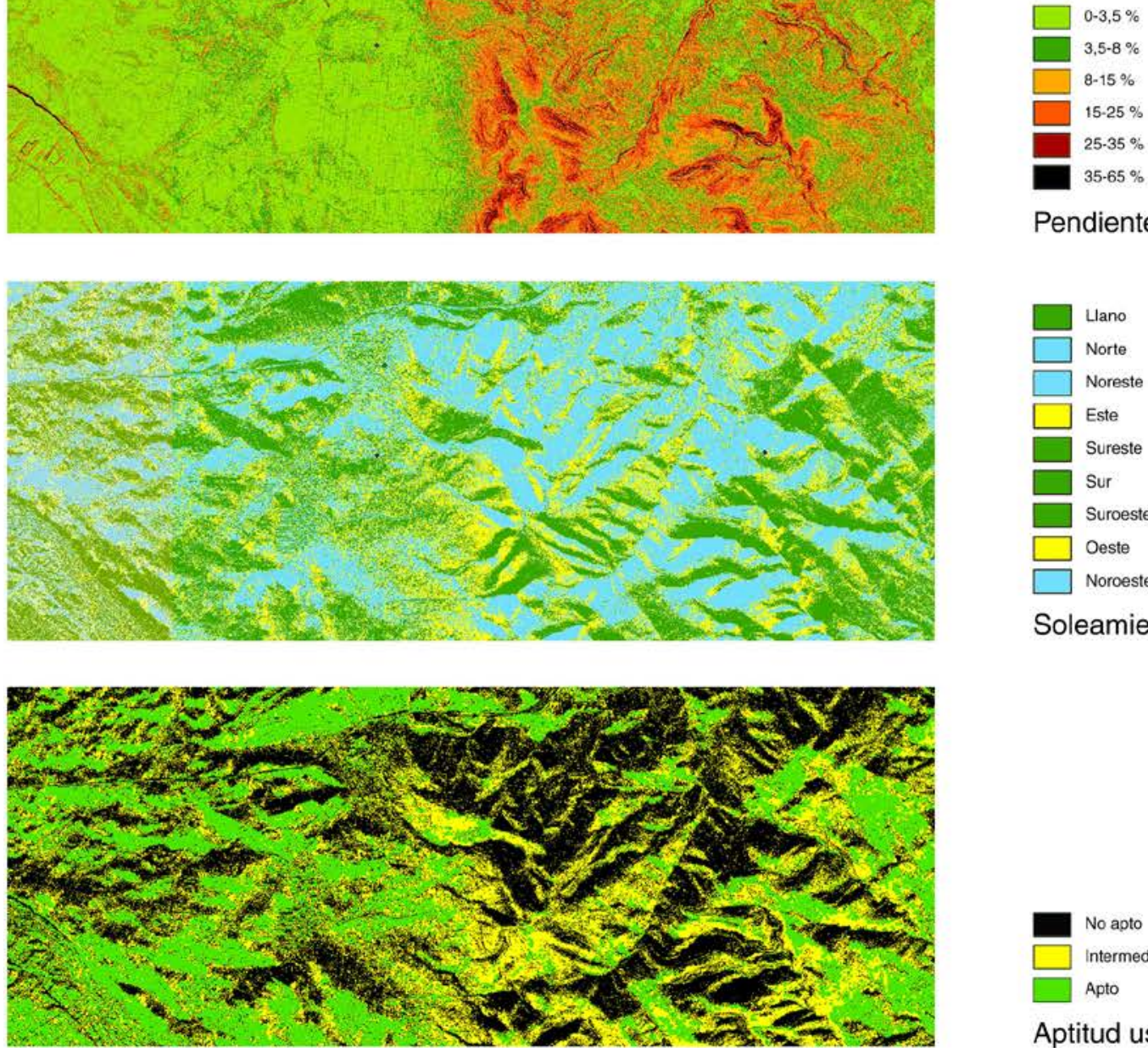

Pendientes 
Planos de in-formación - Zona 7 (San Mateo) - [e=1/80.000]

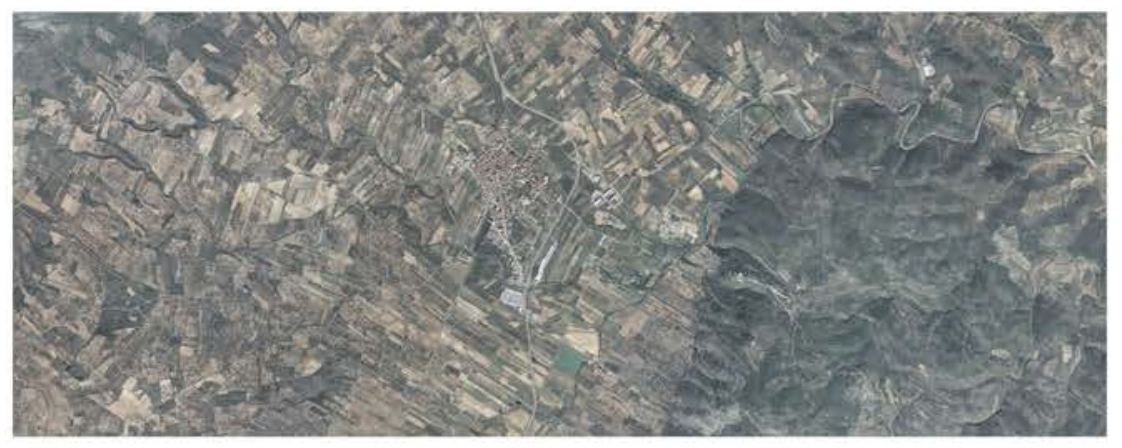

\section{Zona 7 \\ San Mateo}

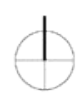

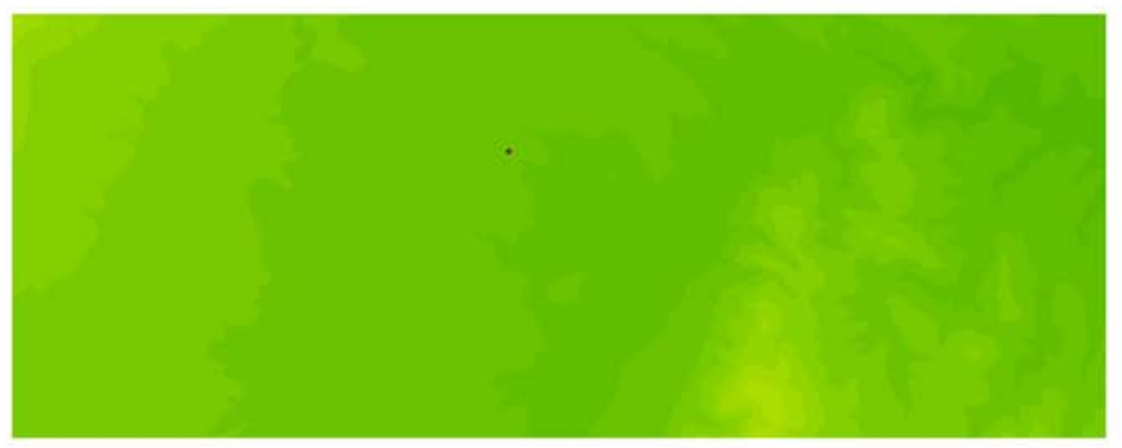

\section{Ortofoto}
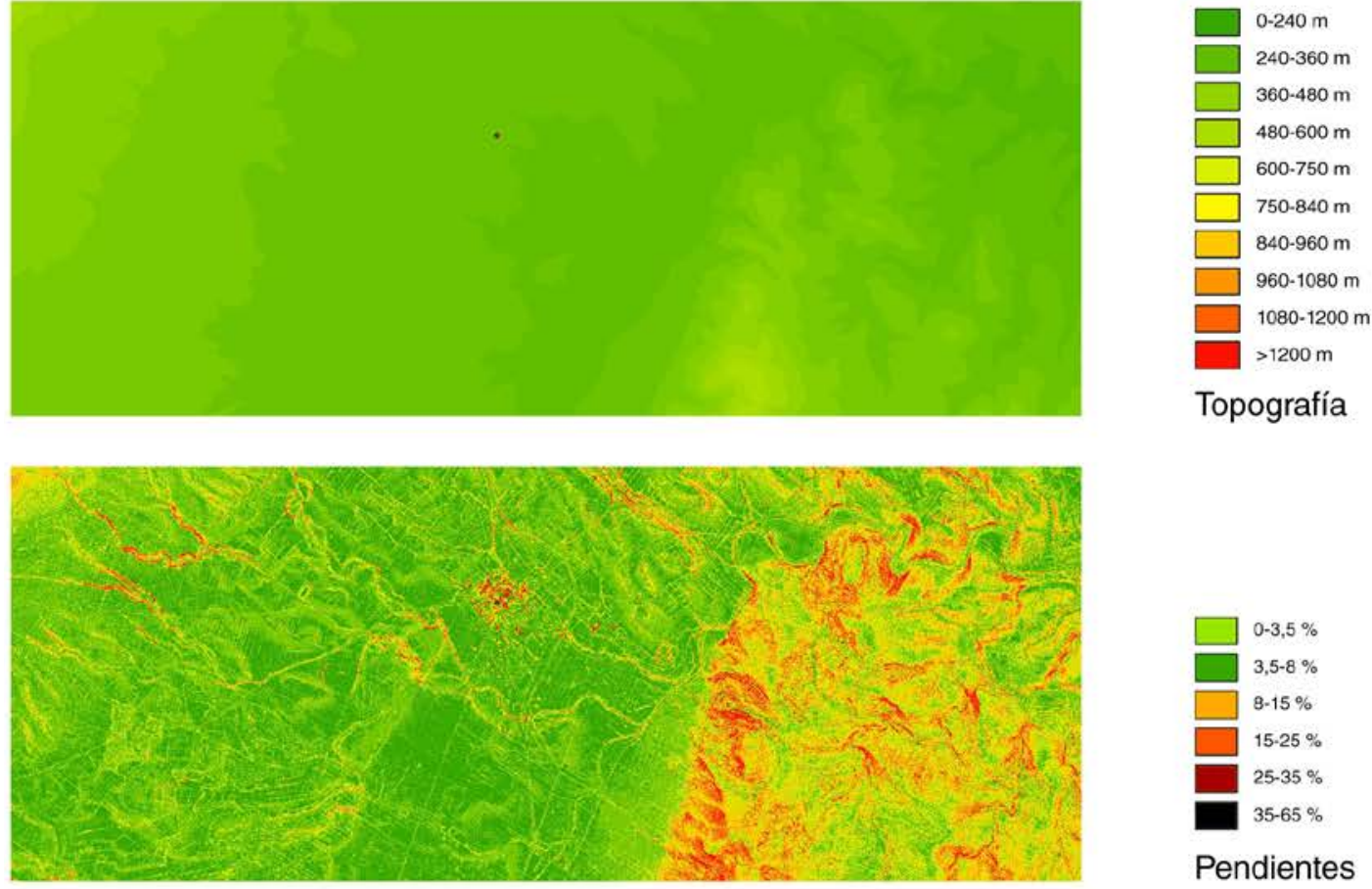

Topografía
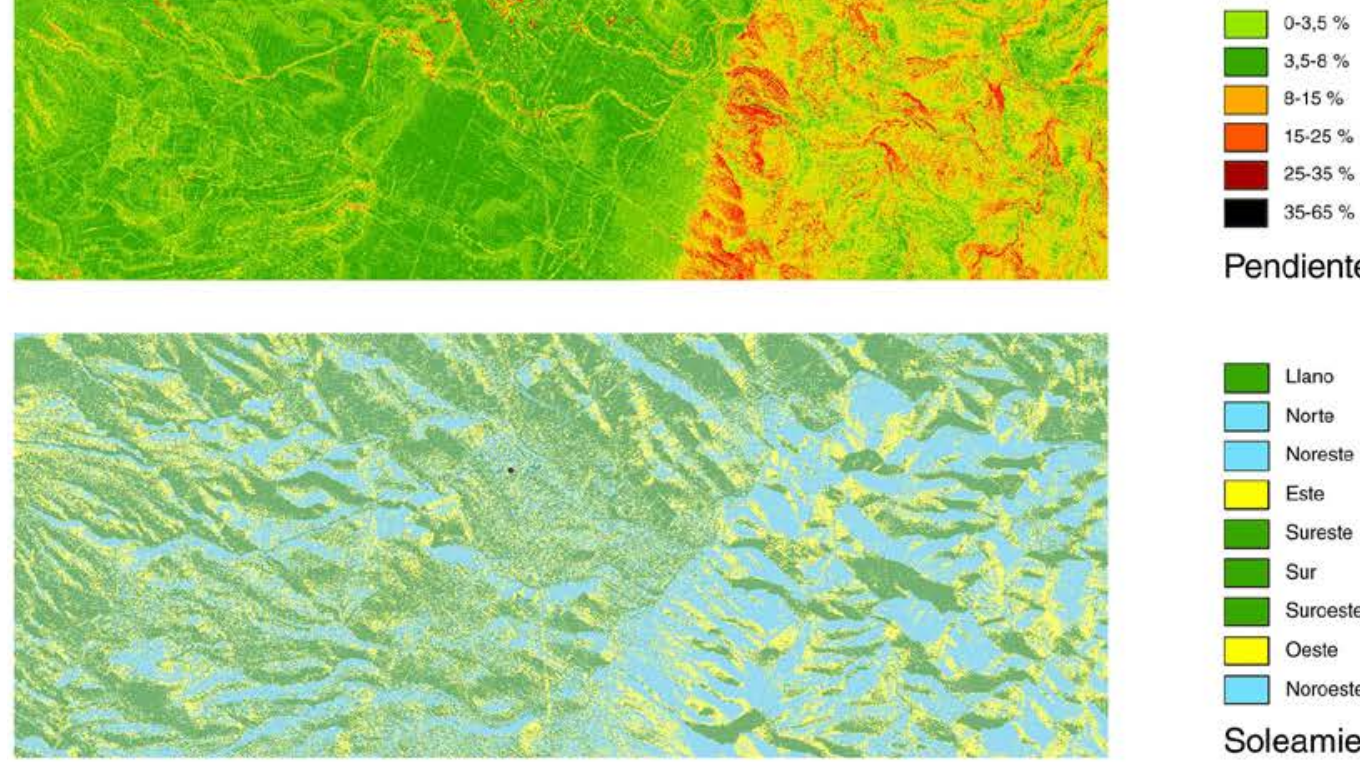

Pendientes

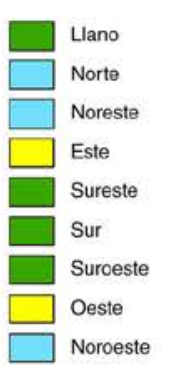

Soleamiento

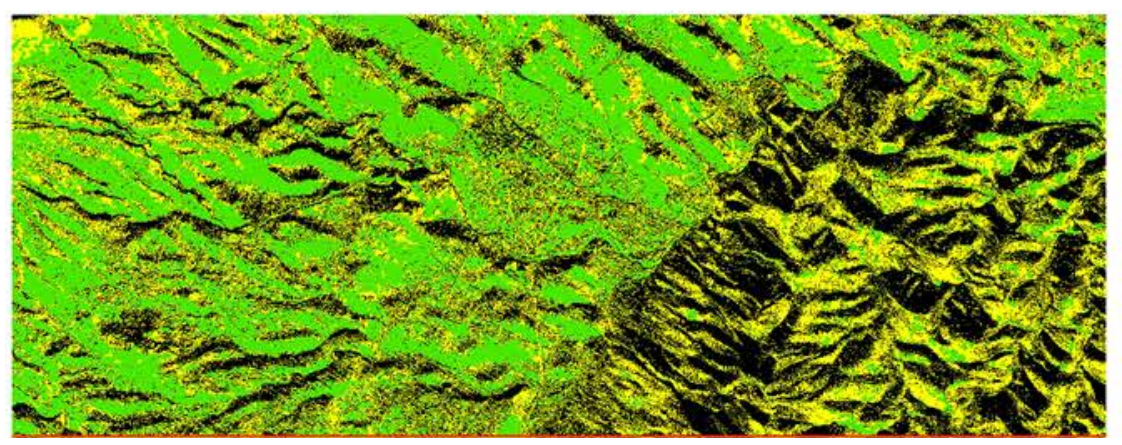

No apto Intermedio Apto

Aptitud uso del suelo 
Planos de in-formación - Zona 8 (Traiguera) - [e=1/80.000]

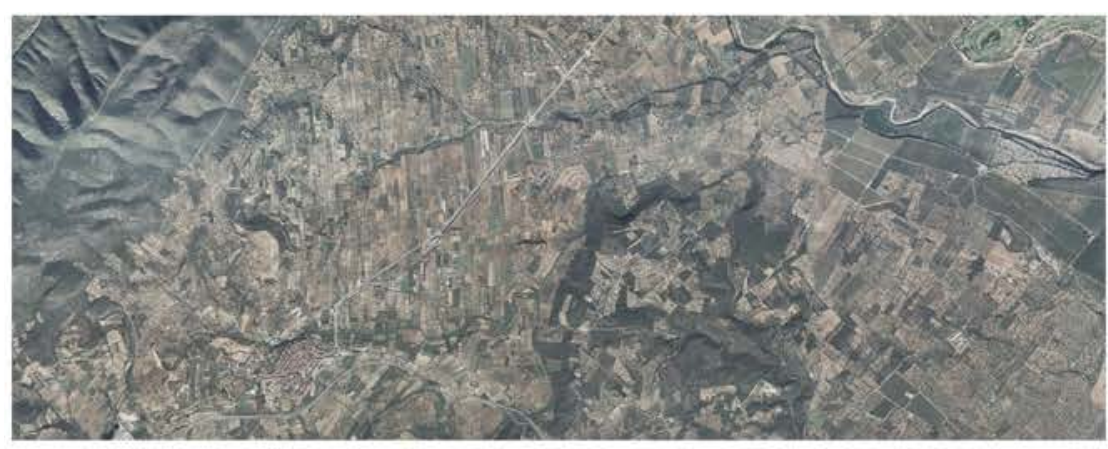

\section{Zona 8 \\ Traiguera}

\section{Ortofoto}
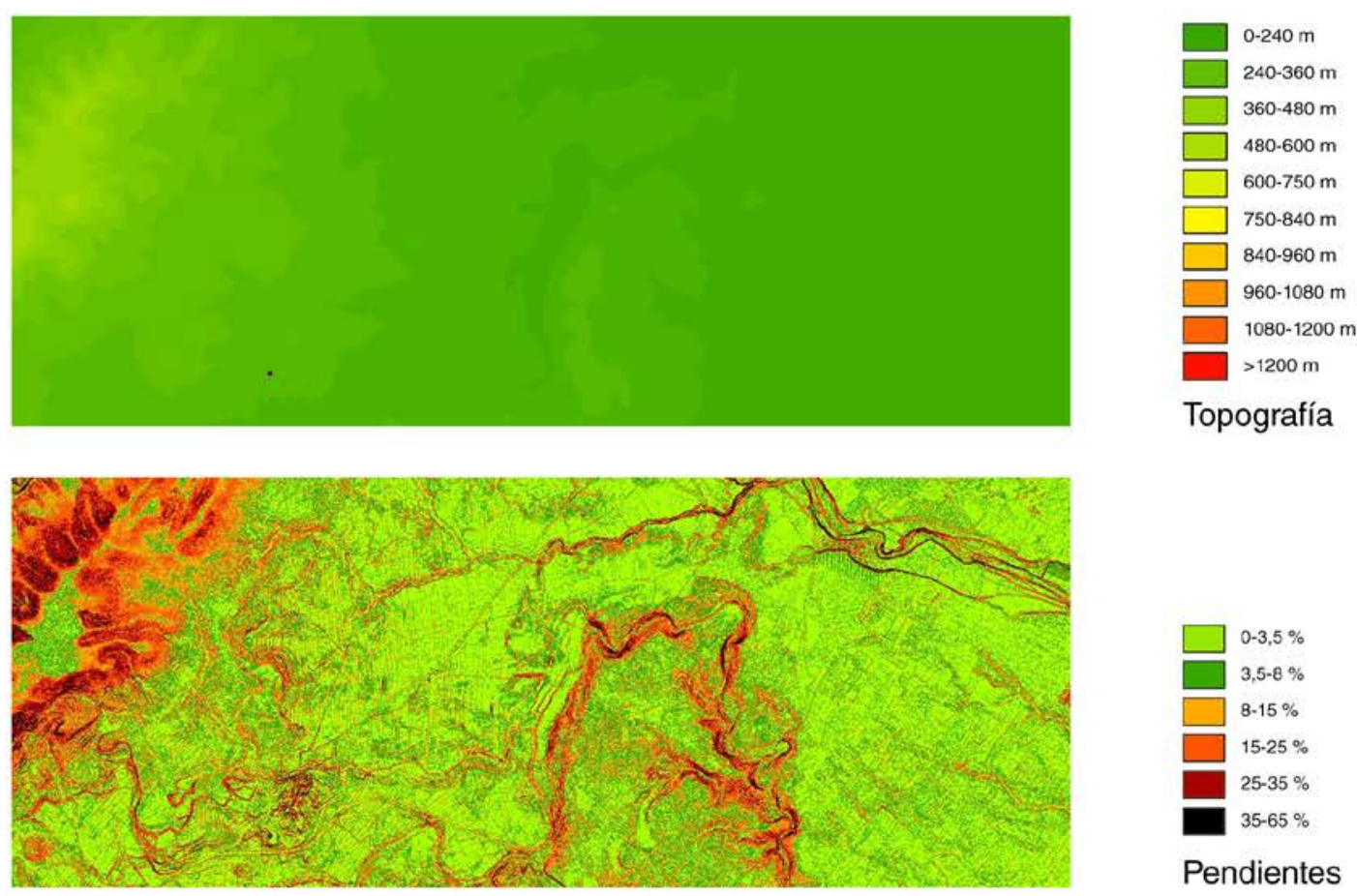

Topografía
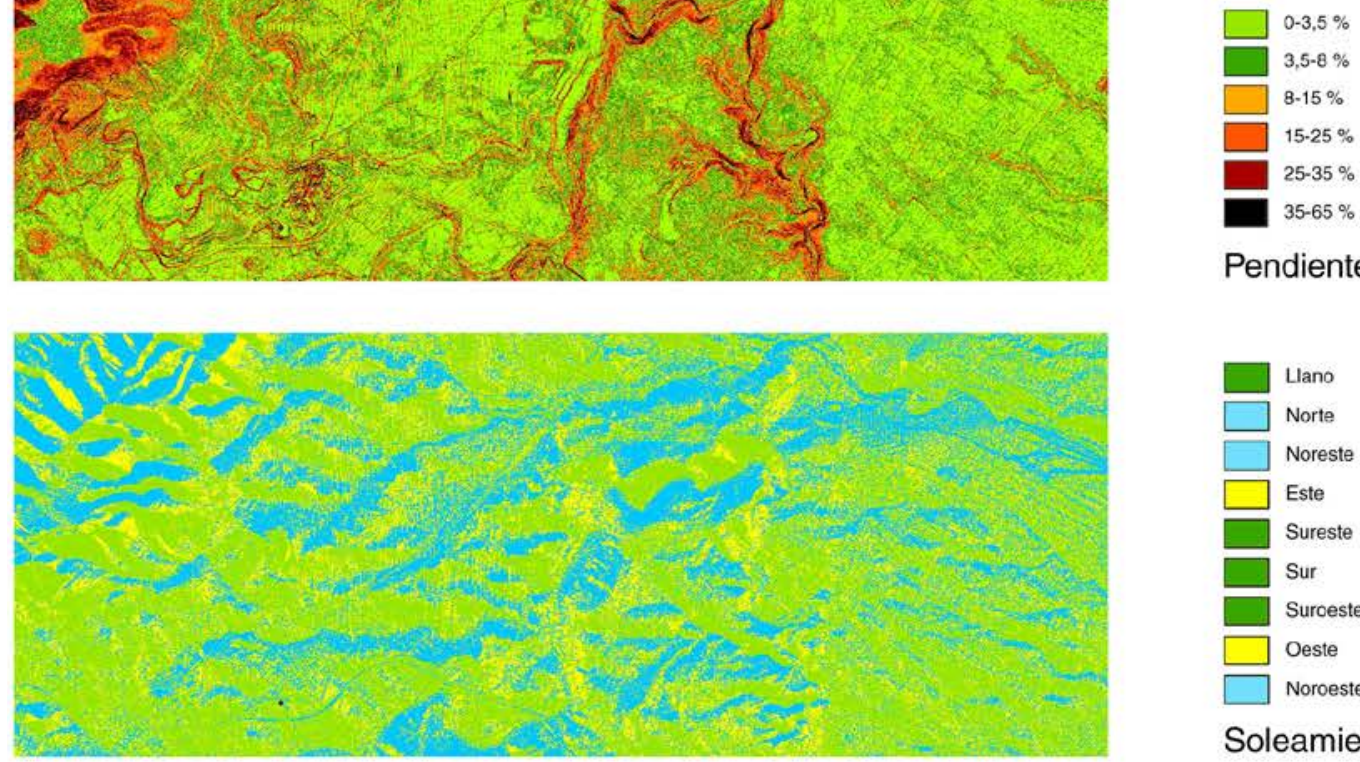

Pendientes

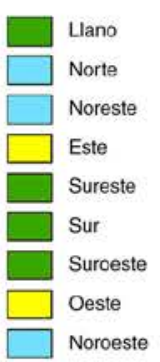

Soleamiento

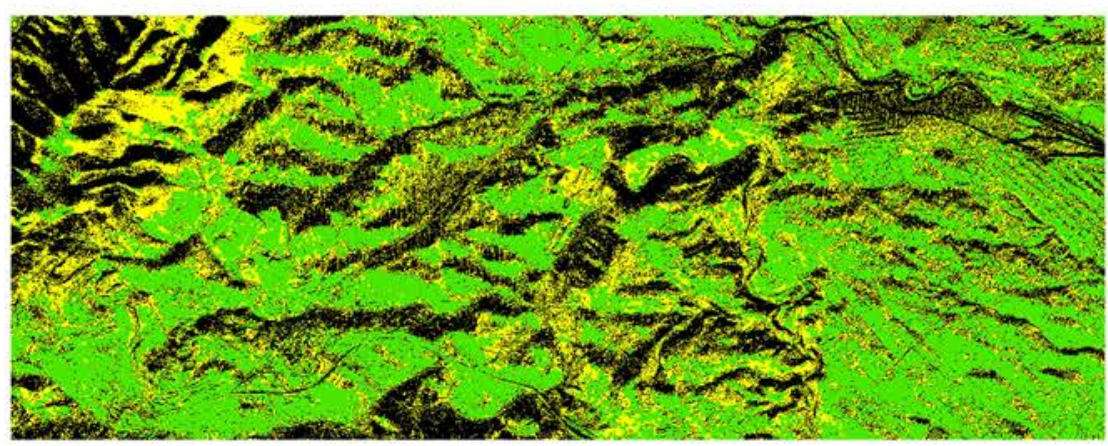

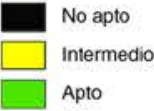

Aptitud uso del suelo 
Planos de in-formación - Zona 9 (Mas Stellers) - [e=1/80.000]

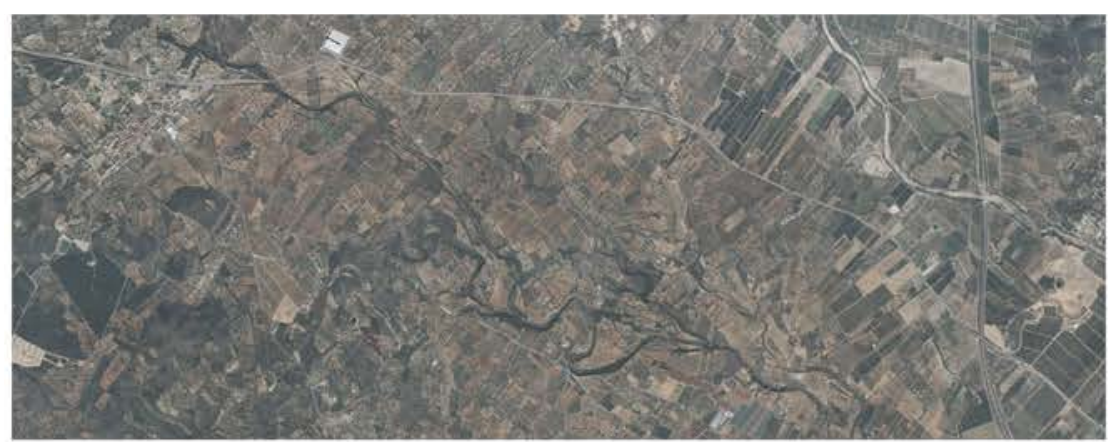

\section{Zona 9 \\ Mas Stellers}

Ortofoto
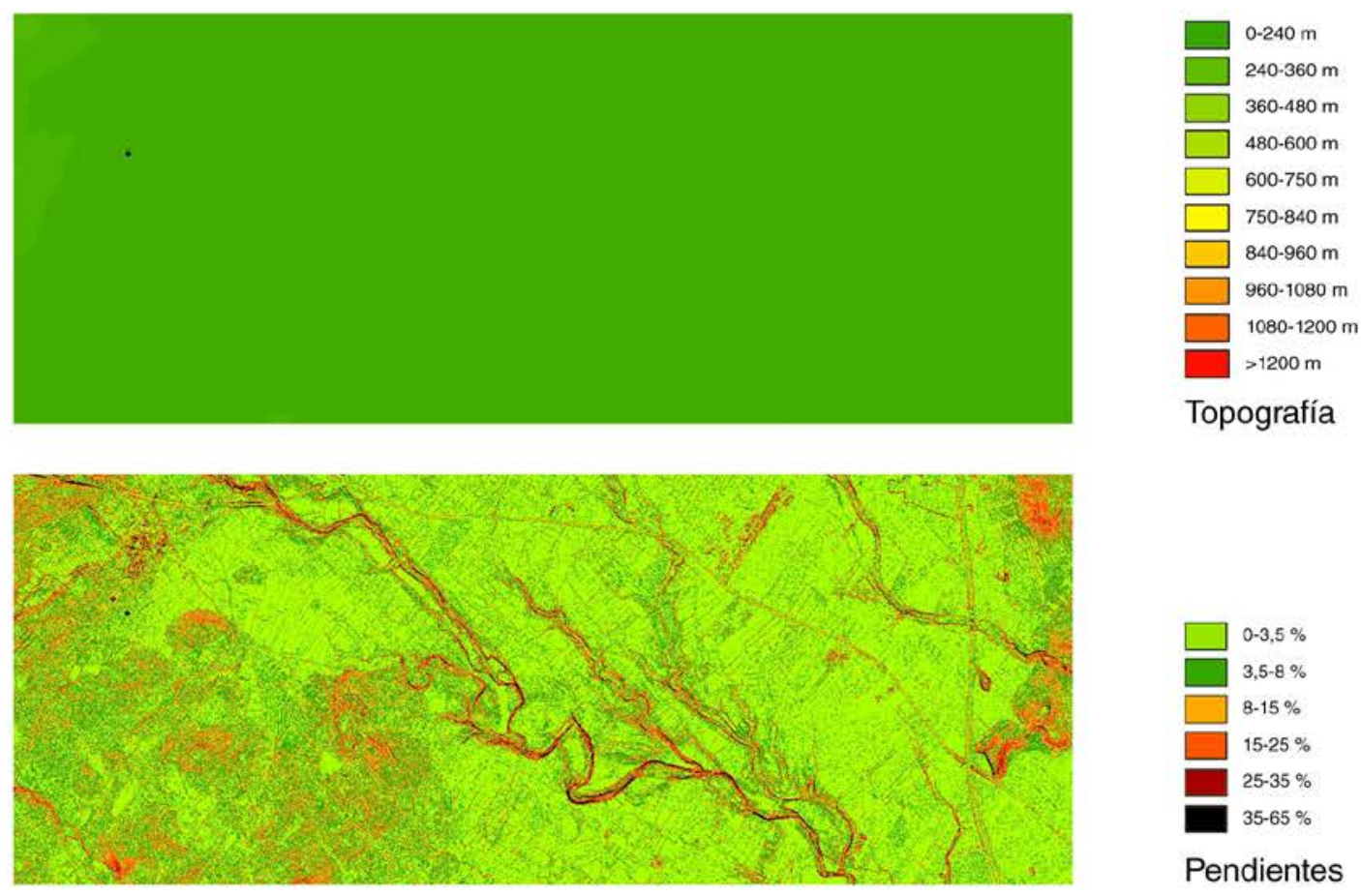

Topografía
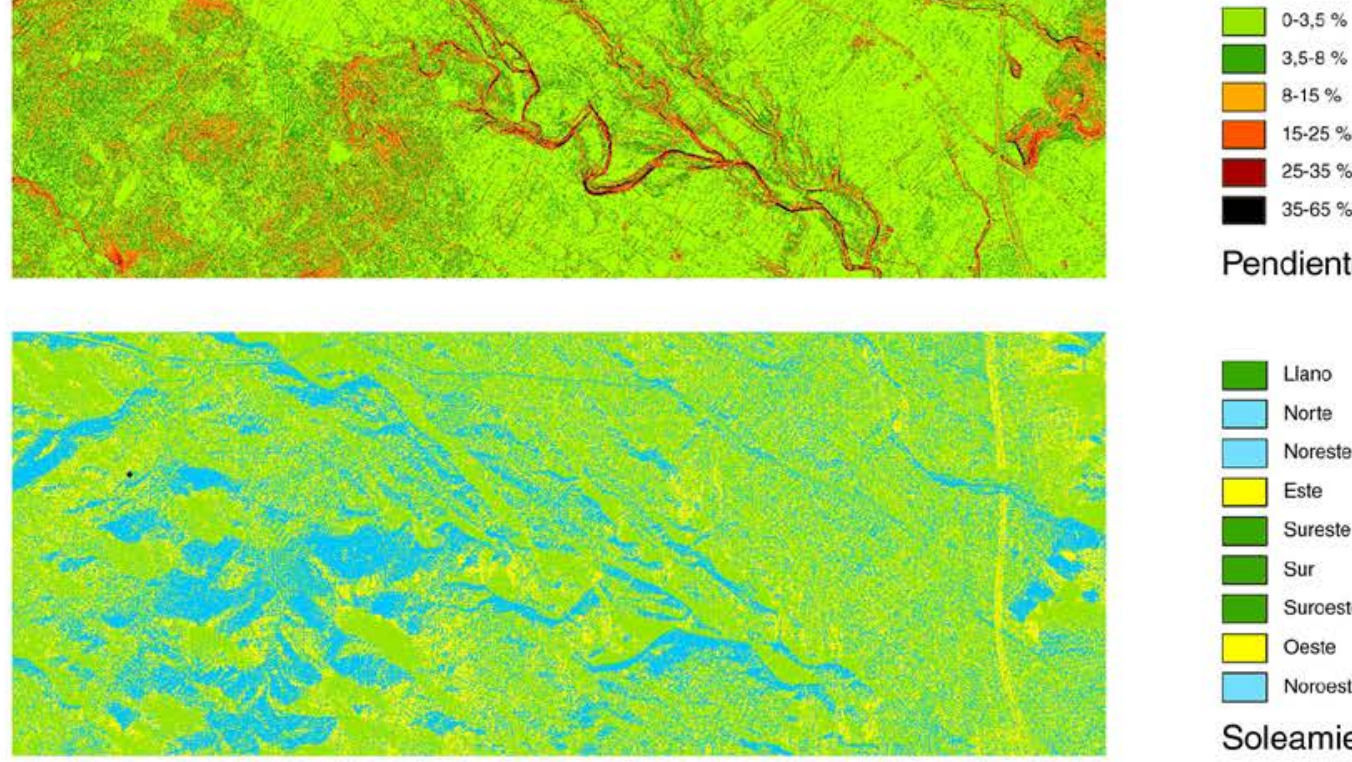

Pendientes

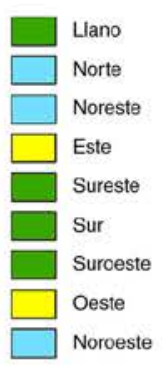

Soleamiento

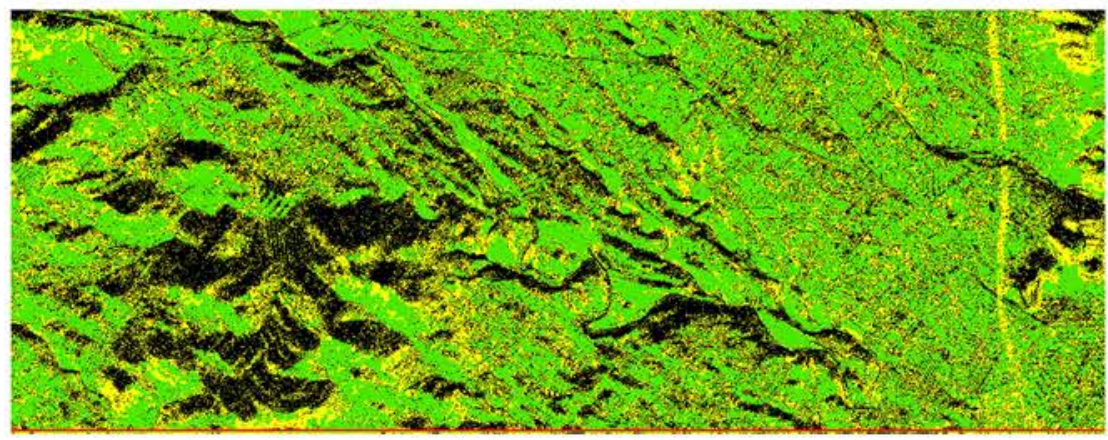

$\square$ No apto
$\square$ Intermedio
$\square$ Apto

Aptitud uso del suelo 
Planos de in-formación - Zona 10 (Cervera / Calig) - [e=1/80.000]

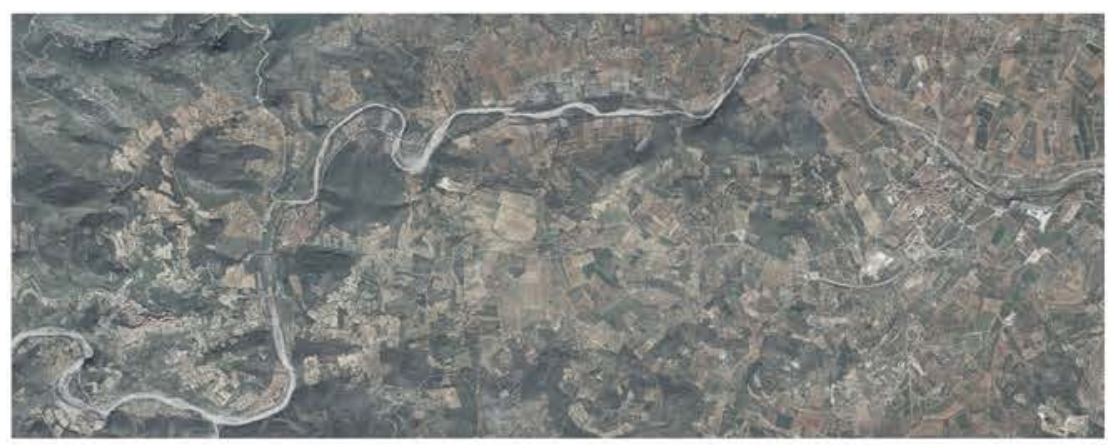

Zona 10

Cervera/Calig

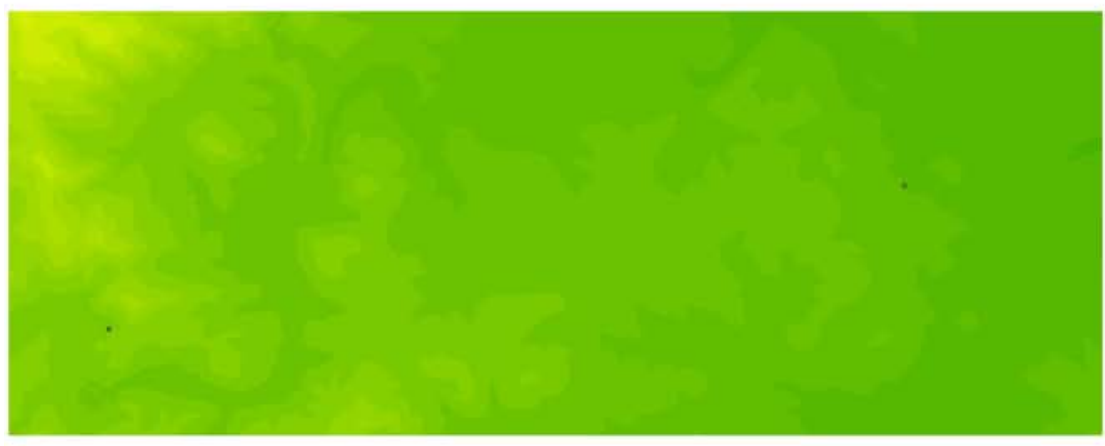

Ortofoto
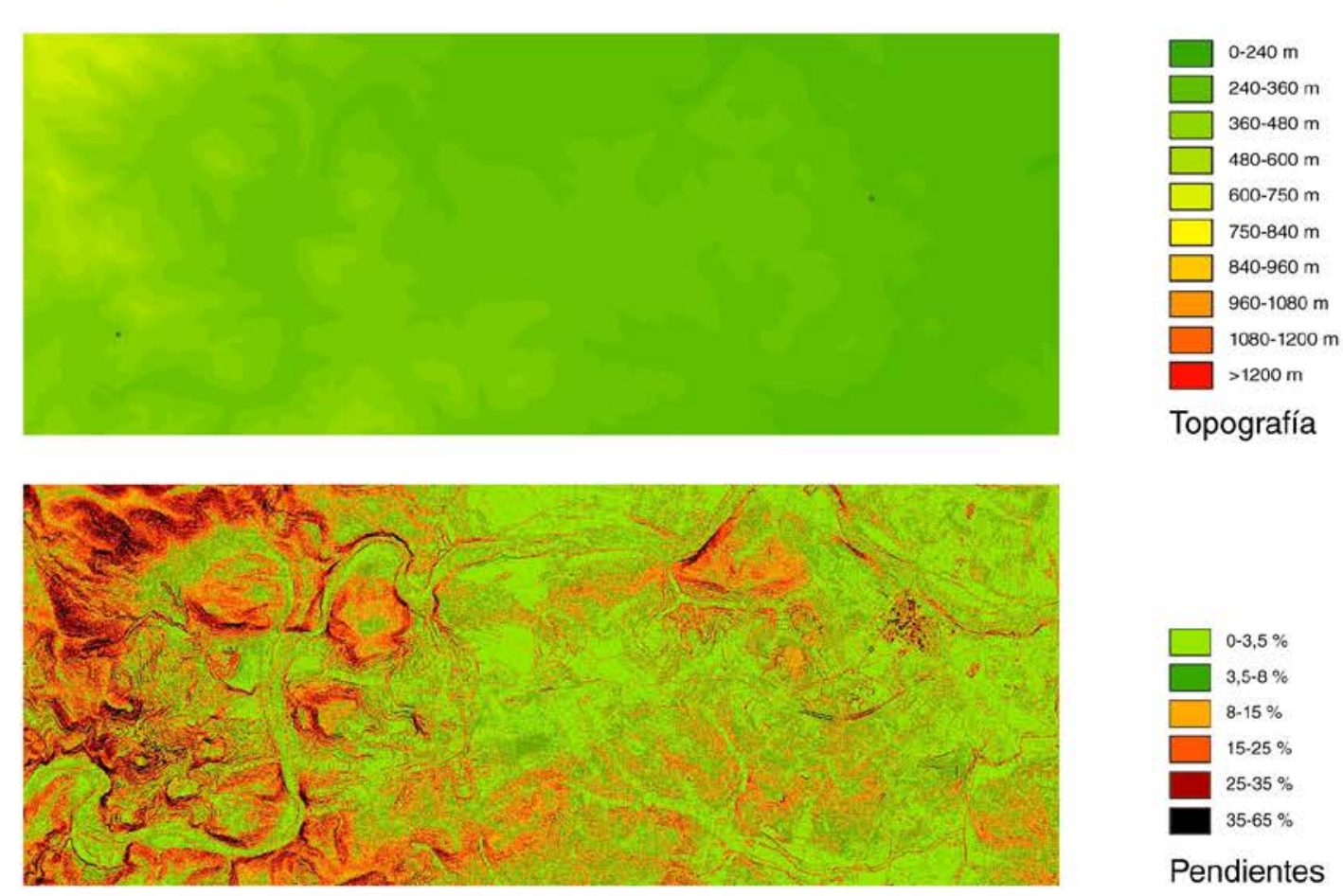

Topografía
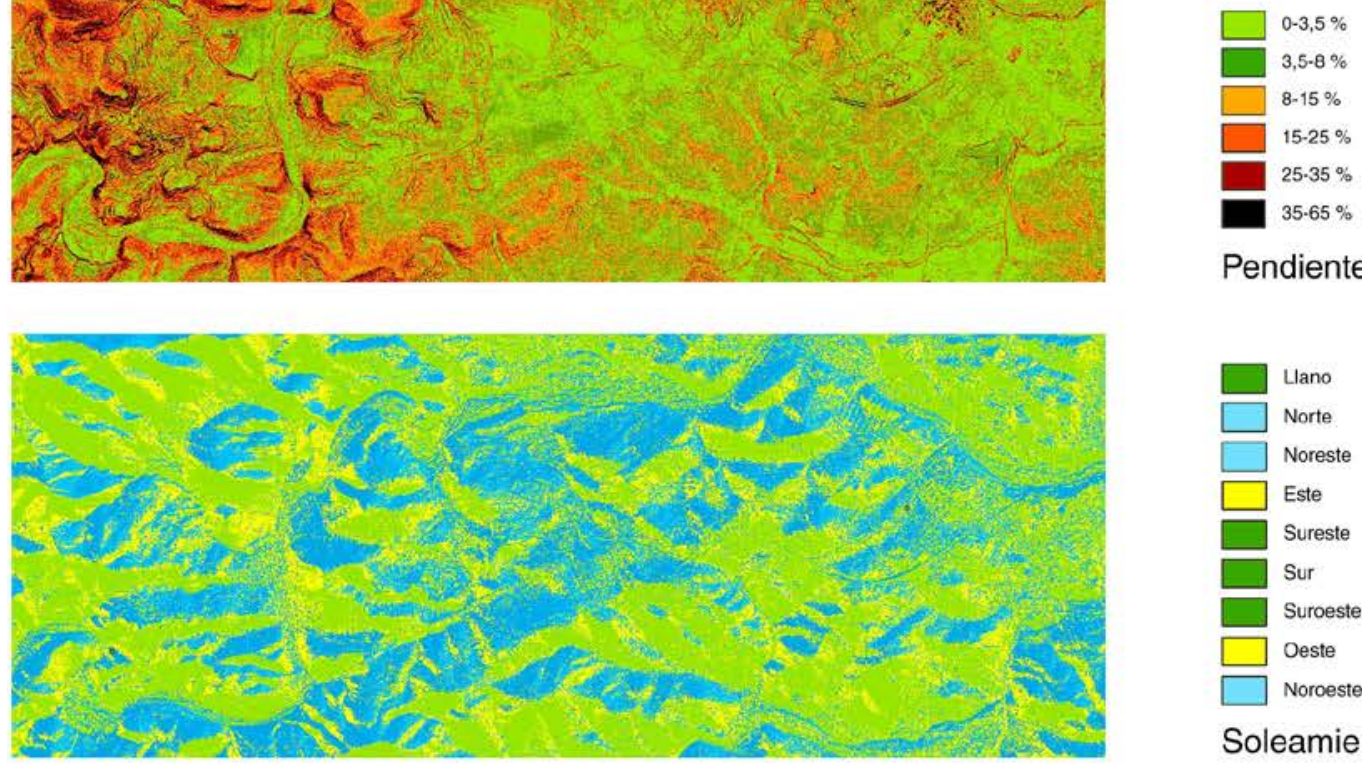

Pendientes

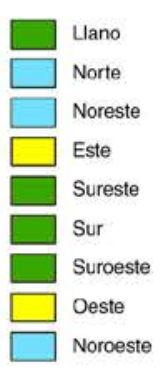

Soleamiento

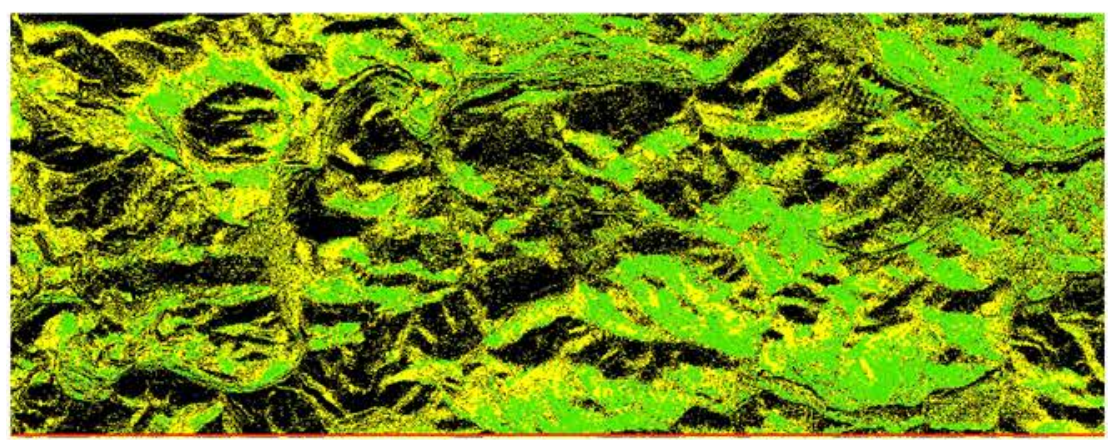

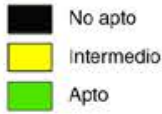

Aptitud uso del suelo 
Planos de in-formación - Zona 11 (San Joan del Pas) - [e=1/80.000]

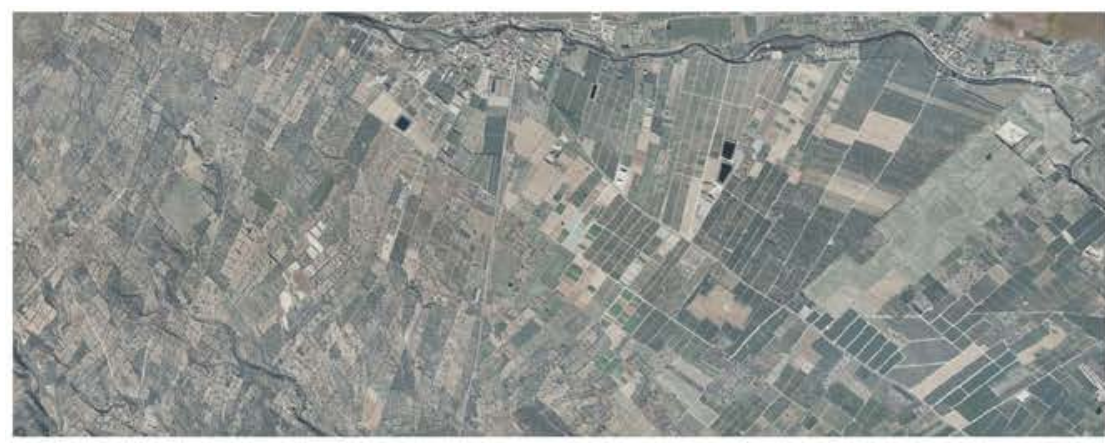

\section{Zona 11_ San Joan del Pas}

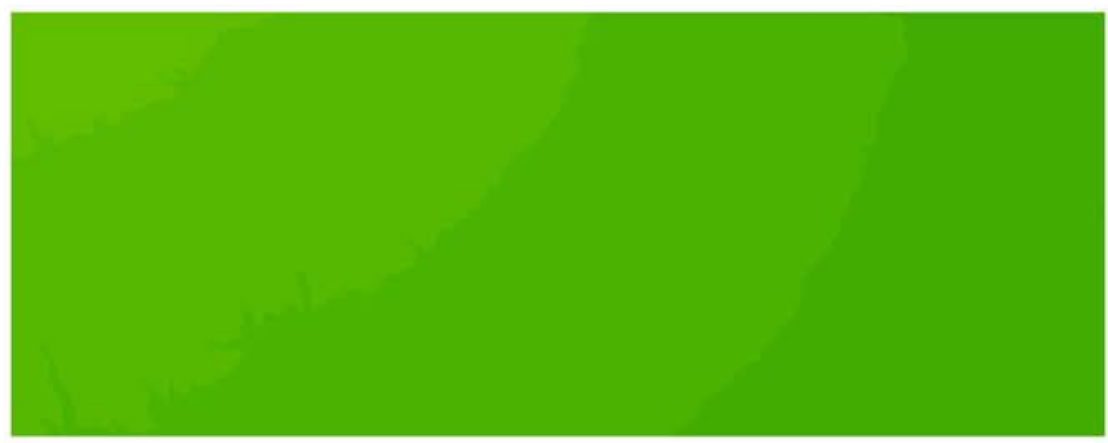

\section{Ortofoto}
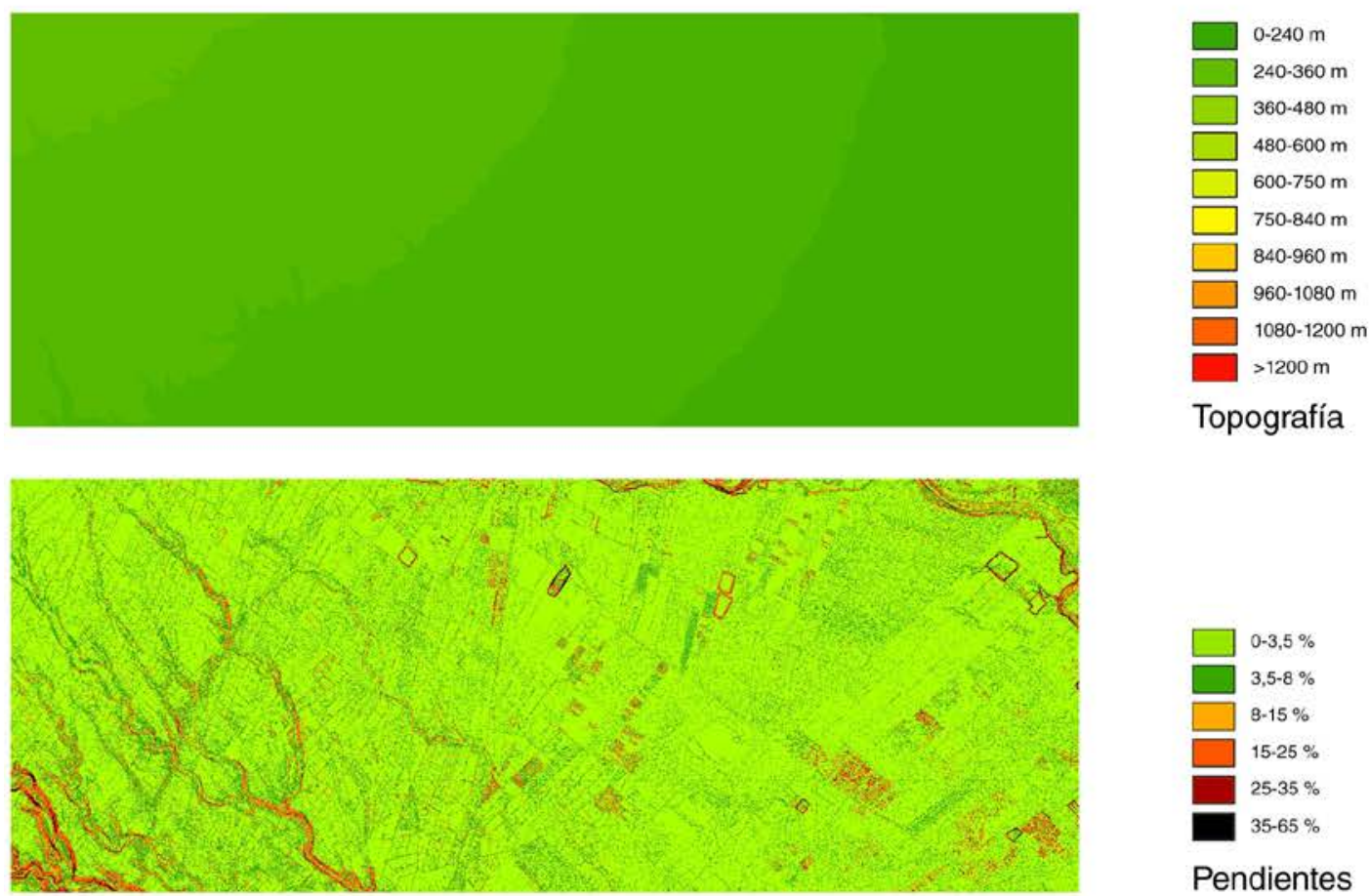

Topografía
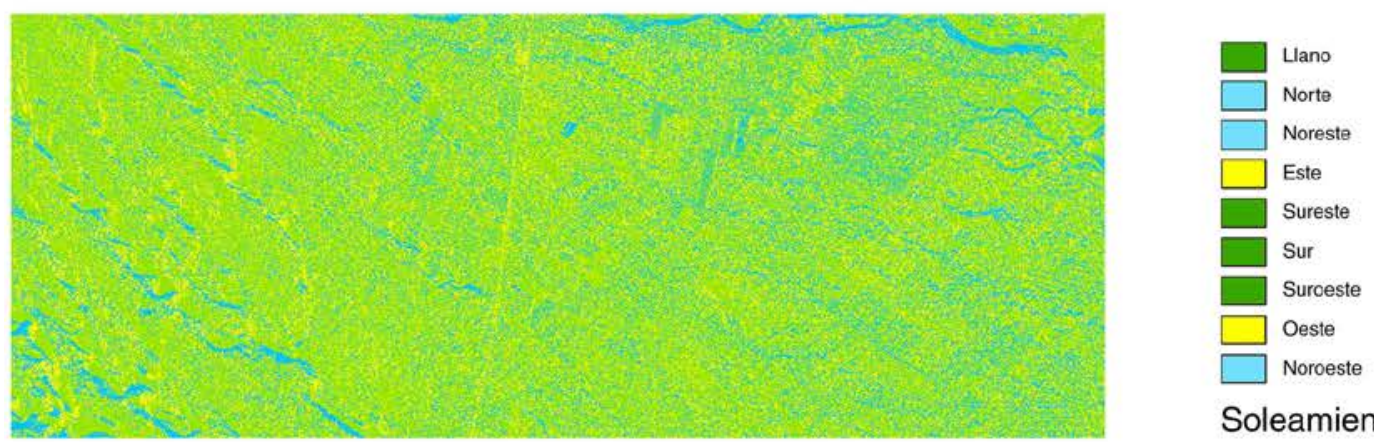

Soleamiento

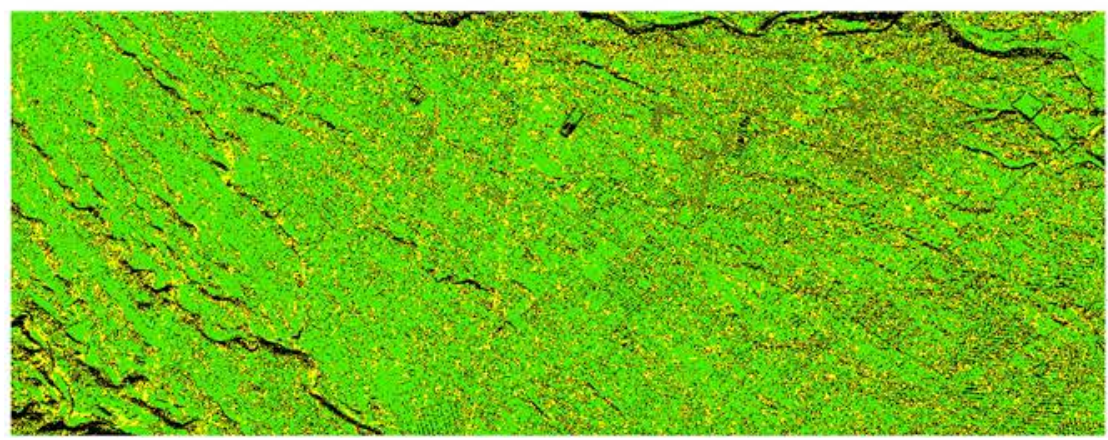


Planos de in-formación - Zona 12 (Atalaya San Pere) - [e=1/80.000]

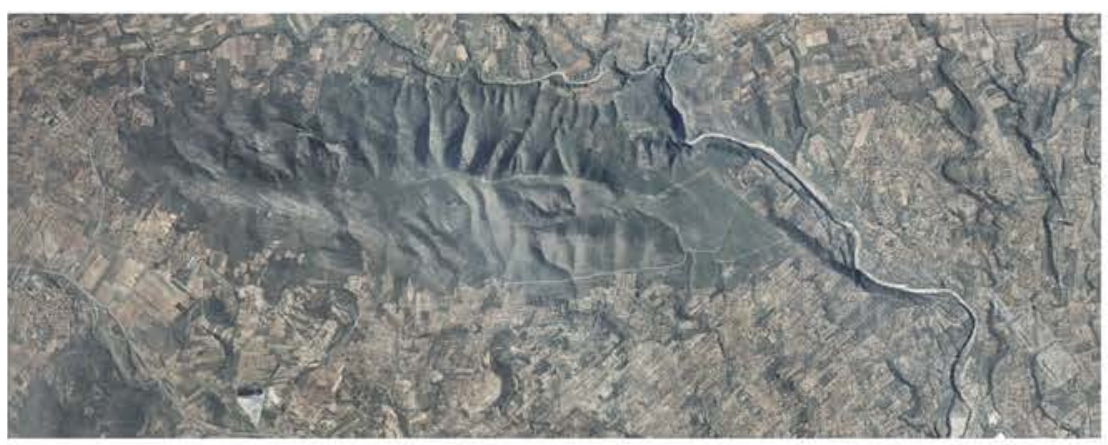

Zona 12 Atalaya San Pere

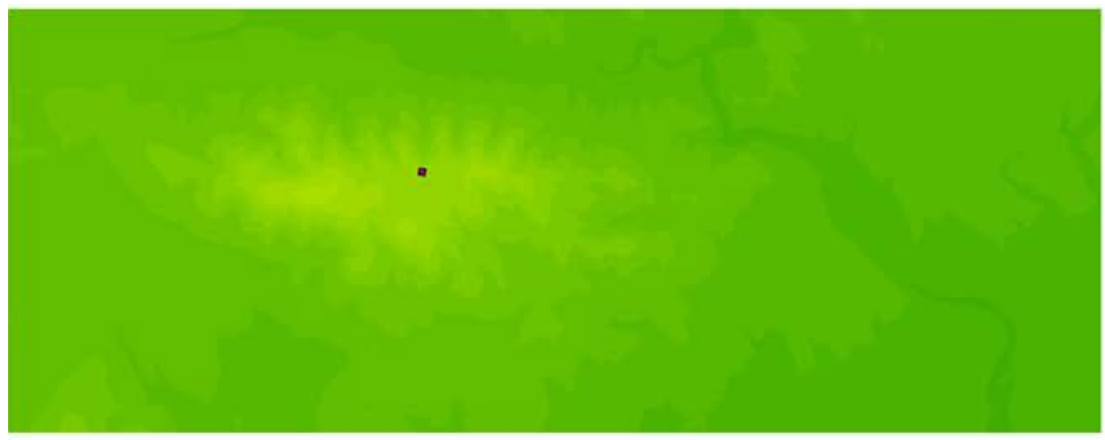

Ortofoto
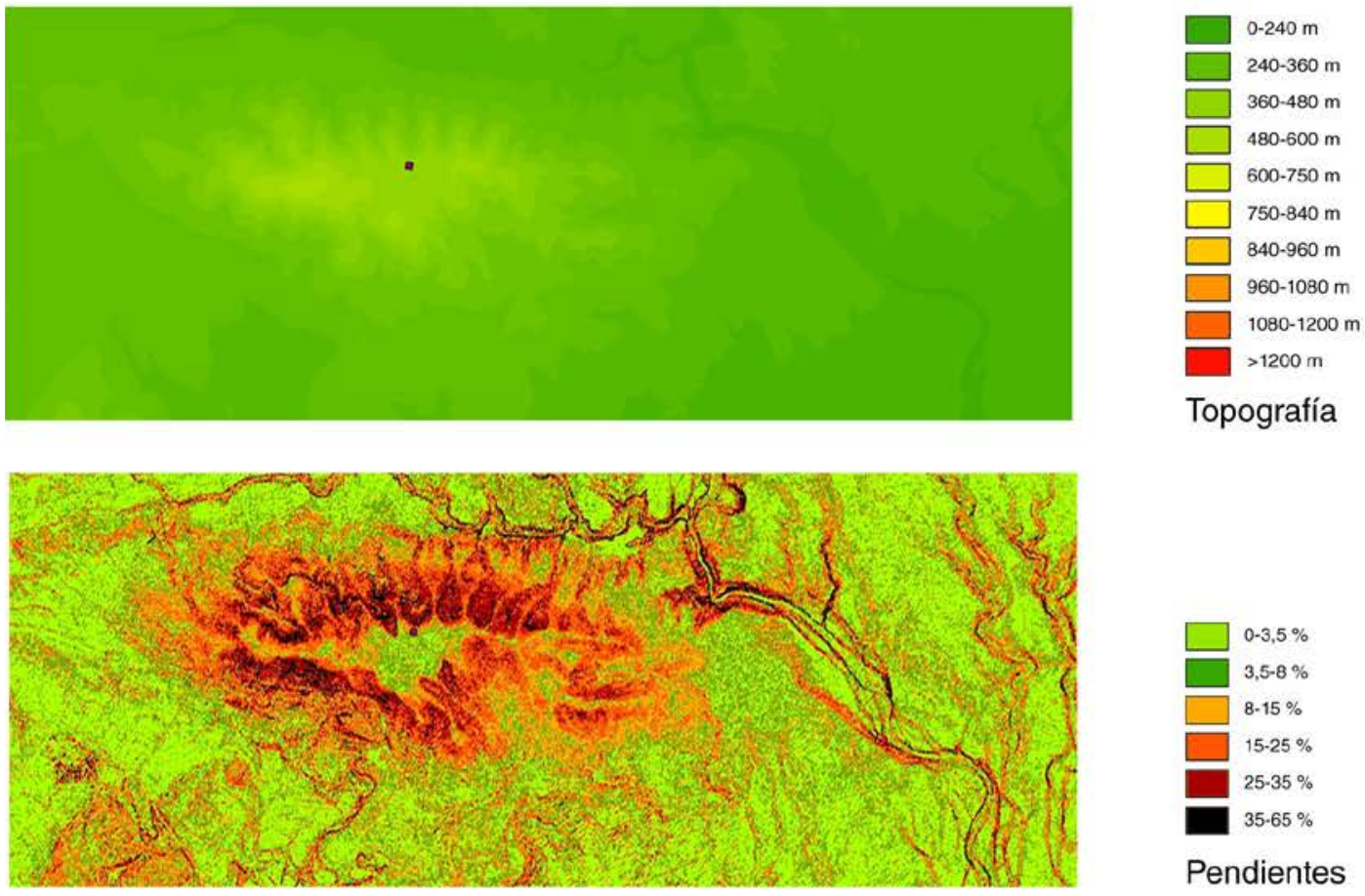

Topografía
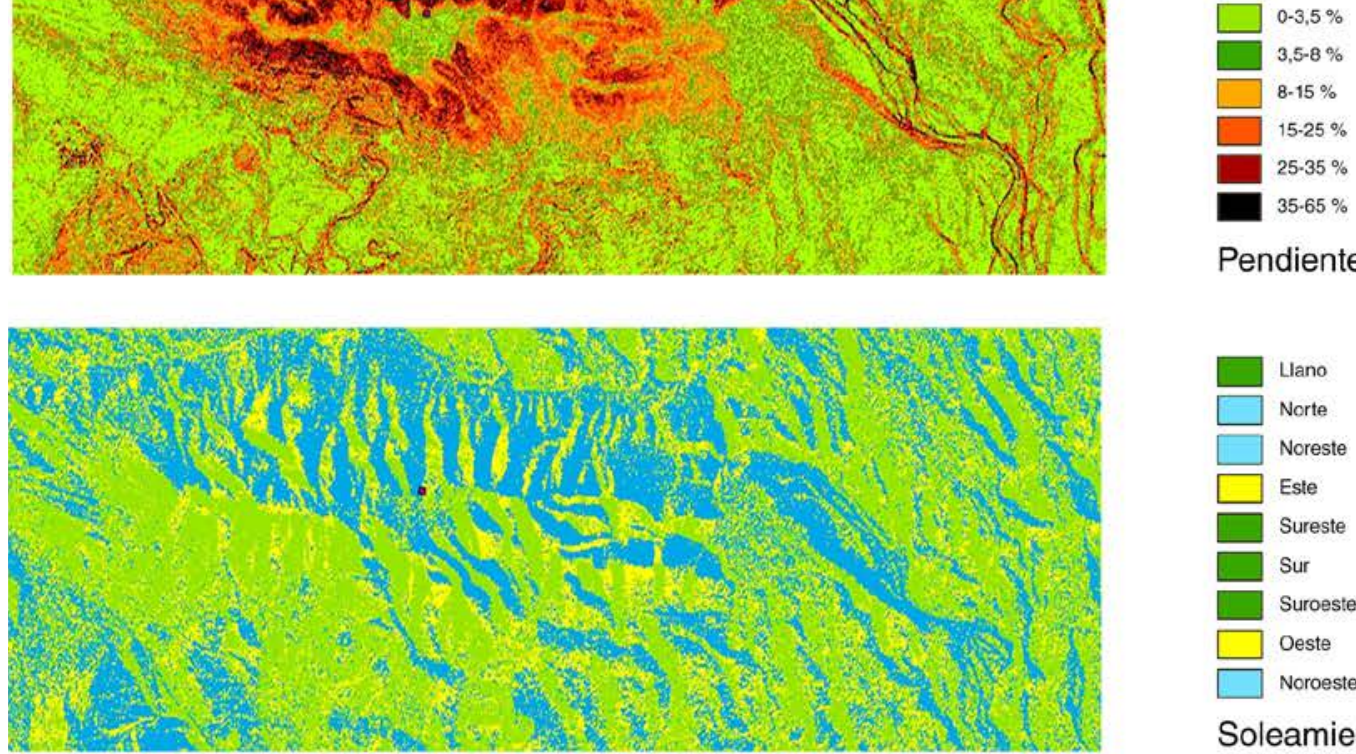

Pendientes

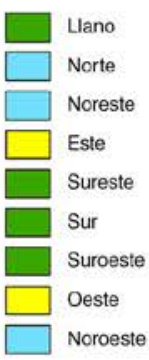

Soleamiento

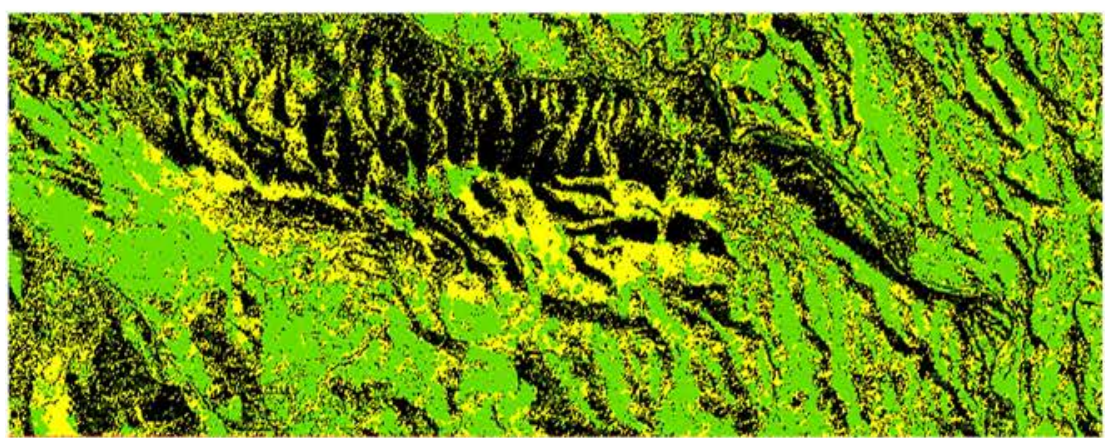

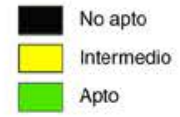

Aptitud uso del suelo 


\section{4. La percepción del soporte territorial}

\section{4. 1. La estructura visual}

Analizada cual es la forma del soporte, ahora debemos analizar como se percibe esa forma, es decir, cual es la forma visual del soporte. Tadahiko Higuchi en su libro "The visual and Spatial Structure of Landscape" establece para el análisis de la estructura visual una serie de índices, que le permiten clasificar distintos tipos de recintos en función de su forma visual. Los índices que considera son:

1. El efecto distancia. Al margen de las condiciones atmosféricas, Higuchi establece tres campos visuales en función de la distancia desde el punto del observador. Distancia corta hasta 180360 metros, que corresponde a la visión claro horizontal de la copa de un árbol de 6 metros de diámetro. Distancia media hasta 3,30-6,60 Km, que corresponde a la visión de las texturas de un grupo de árboles. Distancia lejana desde esta distancia hasta el horizonte.

2. Profundidad o invisibilidad. Medida que hace referencia a la altura que han de tener los obstáculos para que queden por debajo de la línea de visión los elementos situados detrás de ellos.

3. Profundidad de campo. Es una variable que depende de la textura y de la posición de la superficie que se visualiza, de su ángulo de incidencia. Las texturas lisas y continuas dificultan la lectura y superficies con una pendiente superior al 30\% se lee como vertical.

4. Ángulos de visión:

- Ángulo de incidencia. Es el que forma el rayo visual inferior del cono de $60^{\circ}$ que se produce en vertical desde el punto de vista y el plano que está visualizando. Los planos pueden ser longitudinales y verticales. Cuento más vertical es una superficie, más cerca está de $60^{\circ}$ su ángulo de incidencia y mejor es la observación que se tiene de ese plano. Para las superficies longitudinales, en cambio, contra más cerca este de $30^{\circ}$ este ángulo, mejor es la visión, ya que no varía la inclinación del plano, sino la posición próxima o lejana del plano que se visualiza.

- Ángulo de depresión. Es el que define el concepto de aquí y allí. Es el ángulo que se forma entre la horizontal y el rayo que entre en el ojo a partir del objeto que se mira. $\mathrm{Si}$ se supone que el centro de visión esta $10^{\circ}$ por debajo de la horizontal que sale del ojo y que el cono de abertura visual vertical es de $60^{\circ}$, el ángulo que marca la diferencia entre aquí y allí es de $40^{\circ}$. Eso quiere decir que la línea que separa lo contiguo de lo próximo es de aproximadamente 2 metros del espectador, y la que separa lo próximo de lo lejano se encuentra aproximadamente a 8,60 metros, si se tiene una altura visual de 1,50 metros. Si estamos a 150 metros (en una montaña o un mirador), el centro de la visión esta a la distancia de 860 metros y la línea de aquí y allí a 200 metros. Lo que esta más cerca en este caso no se ve.

- Ángulo de elevación. Es el que define los planos de visión que nos rodean, los elementos sobresalientes que están por debajo de un ángulo de elevación de $5^{\circ}$ se ven bajos; los que están por debajo de un ángulo de $9^{\circ}$ y por encima de $5^{\circ}$, como unos elementos que pueden caracterizar un paisaje; los que están por encima de $9^{\circ}$ y por debajo de $14^{\circ}$, son elementos mayores que destacan; y los que están por encima de los $14^{\circ}$, alrededor de los $20^{\circ}$, forman parte de visiones excepcionales o emergencias singulares. 

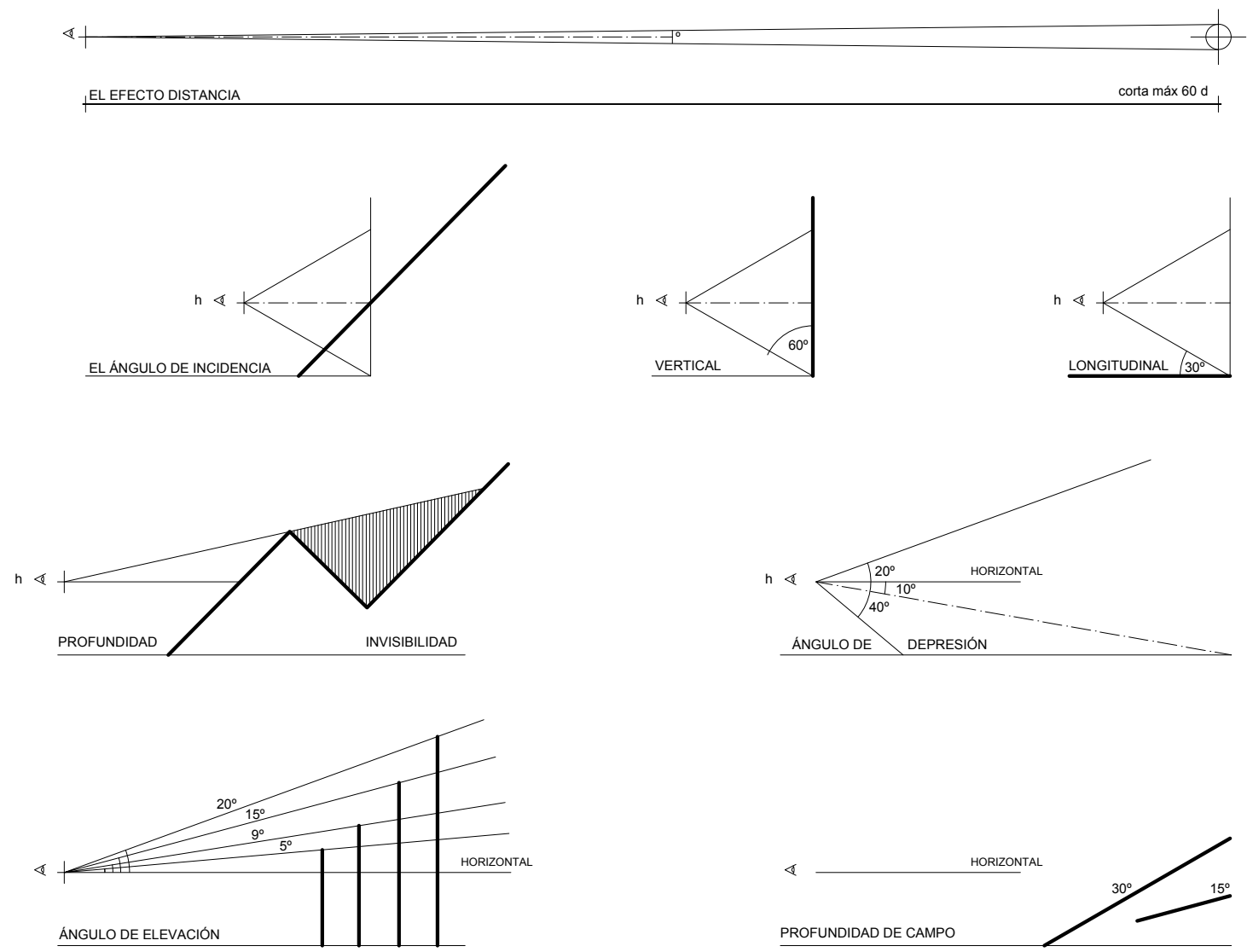

Fig. 3. 21. Dibujos esquemáticos de los índices de visibilidad del libro de Tadahiko Higuchi de 1.983.

En nuestro caso, dadas las características topográficas de nuestro soporte, los índices que consideraremos para caracterizar nuestros distintos recintos visuales son:

1. Distancias. La distancia corta la establecemos en 350 metros que es la que permite la visión de la copa de un árbol de 6 metros, siendo el ángulo de visión a esta distancia de $1^{\circ}$. La distancia media será desde los 350 metros hasta 4,20 Km, correspondiente a la visión de la textura de la vegetación con un ángulo de visión a esta distancia máxima de 5' y la distancia lejana a partir de los 4,20 Km y hasta el horizonte. Estas distancias son las que condicionan dadas las características topográficas de nuestro soporte el posterior emplazamiento de las edificaciones y poblaciones. Las masías se sitúan a unos 700 metros y los núcleos urbanos en la época de estudio se sitúan aproximadamente a una distancia de $8 \mathrm{Km}$, es decir, cada uno tiene un ámbito de influencia de unos 4,20 Km.

2. Delimitación de recintos. Para clasificar los distintos tipos de recintos establecemos la distancia a la que nos encontramos los planos que delimitan nuestra visión y nos convierten un espacio abierto en un recinto con referencias perimetrales que lo delimitan. Basándonos en los ángulos de visión y la profundidad de campo de Higuchi, y el limite de $9^{\circ}$ del ángulo de elevación, consideraremos como límites los siguientes:

- A una distancia de 350 metros una altura de 60 metros $\left(\operatorname{tag} 9^{\circ}=60 / 350\right)$.

- A una distancia de 1050 metros una altura de 180 metros.

- A una distancia de 2100 metros una altura de 360 metros. 
Estos índices de lectura permiten leer los recintos con los accidentes que los caracterizan, los que están cerca y los que están lejos. Se puede conocer el ámbito visual desde un punto, caracterizarlo y sobretodo reducir a medidas geométricas el componente visual de la estructura topográfica que tiene un recinto geográfico, visto desde su interior.

Ello significa que el relieve del territorio que nos rodea forma un recinto visual que podemos reconocer cuando nos lo encontramos y que, estos ámbitos visuales, están diferenciados por la forma en que aparecen dos temas básicos a la hora de definir un recinto desde la visualidad interior: el límite y la direccionalidad.

\section{4. 2. La legibilidad}

Otros autores como Kevin Lynch para establecer la imagen de los recintos postulan definir lo que se entiende como visibilidad, con el intento de encontrar métodos que permitan proyectar actuando con el control sobre el sistema de relaciones visuales y no solo sobre la forma abstracta del relieve. Kevin Lynch plantea fundamentalmente un aspecto: el tema de la secuencia y de la visibilidad desde un punto, para estudiar las relaciones visuales de una intervención en su recinto. Uno de los temas de la visibilidad, el de la percepción desde un punto de vista móvil, es ampliamente desarrollado.

Para analizar la secuencia de telones que se ven desde un recorrido, pasa lista a los métodos que se toman: el conocido de la serie de perspectivas, la cámara cinematográfica o el video que filma la realidad o una maqueta. Finalmente propone un sistema de notación del "sentido del espacio" que hay en un recorrido, que el mismo aplico al estudio de la North Express Way de Boston. De esta experiencia y del estudio de las formas visualizadas de los tejidos de la ciudad que presenta en sus libros: "The view from de road" y "La imagen de la ciudad", postula una forma ingeniosa de representar gráficamente la percepción del espacio que se tiene desde una ruta, cuando se circula por ella, o de un barrio cuando se recorre.

Esto es muy útil para conocer el interés de las formas y el valor simbólico de los elementos del recorrido, pero no nos permite llegar a conocer la relación que, como estructura, tiene un cierto recorrido con el territorio que atraviesa. El recorrido se nos muestra como una sucesión de relaciones de encuadres que nos pueden "decorar", pero que no muestran el espacio de las panorámica más que esporádicamente, como hitos en un sistema de recorridos recordables.

De todas formas, en el libro "Mannaging the sense of the region", Kevin Lynch resume la "visibilidad" no solo como la lectura desde un recorrido, sino como el conjunto de las variables que describen la visual como lectura variable de una forma abstracta. Para él, por tanto, el tema de la visibilidad es el tema de la panorámica, de la visión que se tiene desde un cierto lugar sobre los otros. La forma abstracta, la lee como una suma de elementos significativos, no como geometría que describe un orden de relaciones, ni como permanente condición para el desarrollo visual.

A partir de los tipos de topologías que nos encontramos en este Territorio y analizando la visibilidad de forma similar a la descrita por Lynch podemos deducir que en este territorio se dan tres casos distintos. En el primero no hay límite y la vista se extiende hasta el horizonte; en el segundo como limite hay una secuencia de planos a la distancia media que forma el entorno inmediato; y finalmente en el último caso podemos encontrar una serie de planos entre la distancia lejana y el horizonte que delimitan el ámbito del recito, del ámbito donde nos movemos.

Así según cual sea la disposición de planos del relieve, se puede percibir desde un doble cierre del espacio que nos rodea, un encadenamiento de recintos próximos y lejanos que dan una visión doblemente cerrada, y en el otro extremo, se puede dominar el conjunto del ámbito si se está en un paisaje abierto y llano, y no hay interferencias visuales hasta el horizonte, o se esta situado sobre una atalaya de visión. Por tanto los ámbitos los podemos diferenciar por la existencia de límites o no y por la distancia y forma en la que estos se encuentran. 
Según la distancia de estos límites podemos establecer una primera clasificación en tres grandes grupos, por la profundidad en que se encuentra el límite del recinto respeto a los ojos. Como ya hemos comentado dadas las características topográficas de la zona establecemos el límite de los 4,20 $\mathrm{Km}$ para situar el primero de los planos lejanos que vemos. Un espectador situado en el centro de un radio de 4,2 Km, identifica los llanos que se producen más allá como lejanos, comienza a formar parte del horizonte, y los que se encuentran más cerca los reconoce como espacios que cierran y que se integran como dominio de la vista.

Así pues, en un ámbito genéricamente cóncavo con un radio máximo de esas dimensiones, porque esta delimitado por un ángulo de elevación, tenemos un entorno del que conocemos el limite y sin interferencias se domina entero desde el interior.

Este es el ámbito máximo que en nuestra casa se identifica como cercanía, espacio que puede ser más pequeño por limitaciones del relieve o incluso, por la disminución de la visibilidad que provocan las condiciones atmosféricas desfavorables.

Este espacio de 8,40 por $8,40 \mathrm{Km}$ es el que podemos encontrar reflejado por la separación entre los núcleos de población de la Batllia, e incluso de las comarcas próximas surgidos a partir de la Reconquista. La posibilidad de controlar visualmente el entorno forma parte de las características que permiten tipificar los sistemas de poblamiento.

Si consideramos la forma geométrica interior del lugar, y nos referimos a los recintos en que el asentamiento se dispone, veremos que sus particularidades nacen de considerar las características de los límites y su direccionalidad.

Del análisis de las doce zonas se deduce que existen también seis tipos por su percepción visual:

- Montaña: Existencia en todo el entorno de un limite en un primer plano no muy definido y en un segundo plano el horizonte. Direccionalidad formando parte de un recorrido de paso.

- Valle: existencia en todo el entorno de un primer plano muy definido y sin percibir el horizonte. Direccionalidad muy marcada en cul de sac.

- Ladera: Existencia en uno de los lados de un limite muy definido y en los otros limites en planos medios u horizonte. Direccionalidad muy marcada como recorrido de paso.

- Ondulado: Existencia de un límite en un segundo plano no muy definido, obstaculizado por interferencias en primeros planos que impiden la visión global del conjunto. Espacio isótropo o casi en función del valor de las interferencias que pueden darle cierta direccionalidad al espacio.

- Llano: Existencia de un limite definido en las distancias medias y un segundo plano de horizonte. Espacio isótropo sin ninguna direccionalidad marcada.

- Atalaya: En estos emplazamientos la idea de lugar es la helénica, el pequeño pedazo de territorio que tiene el dominio de las distancias media o, puntualmente, de la distancia larga si es un lugar de defensa, pero donde no se puede considerar que haya un ámbito que cuente con cierta estructura visual interior compleja, que se modifica parcialmente con la evolución histórica. 


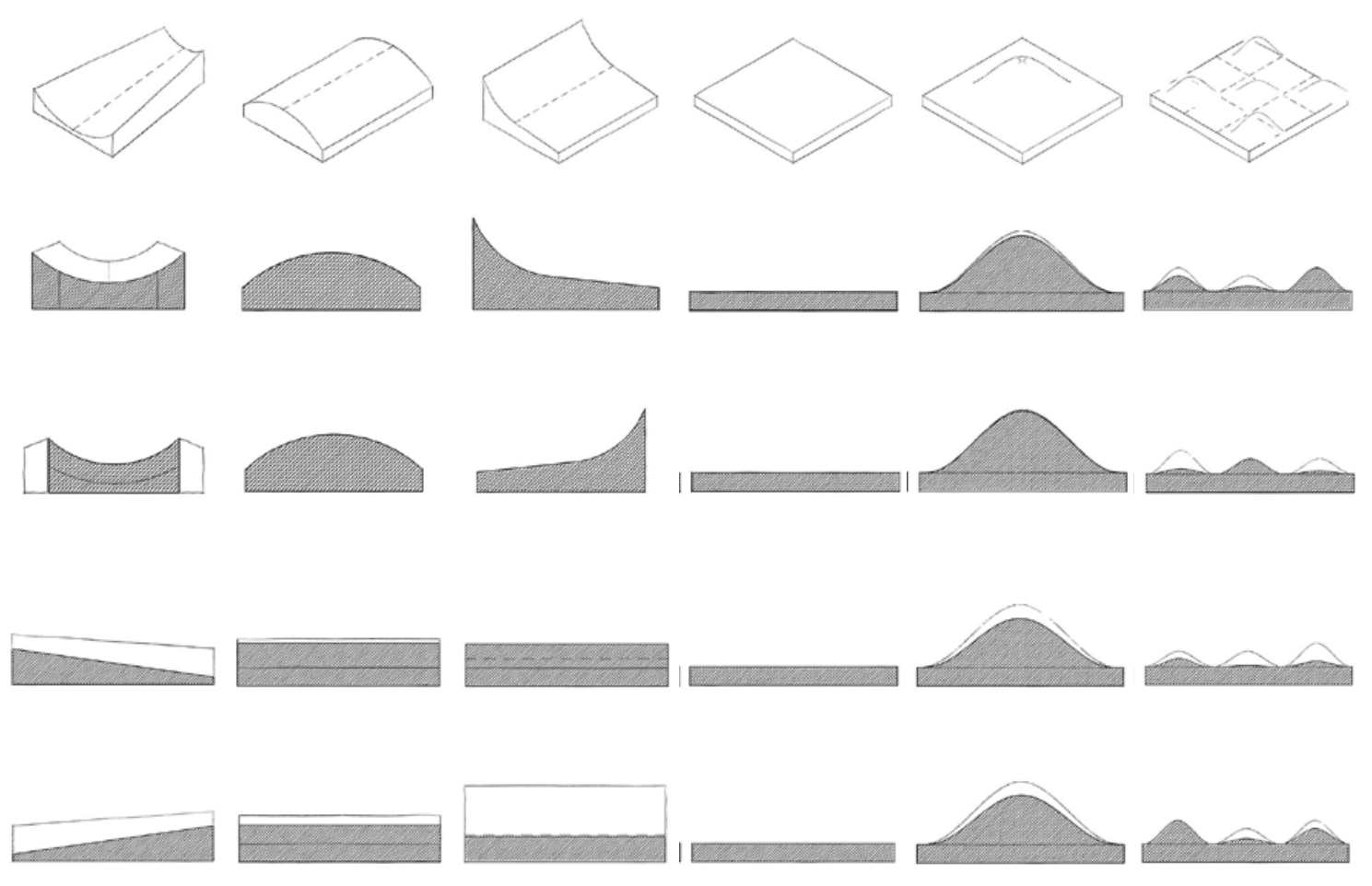

Fig. 3. 22. Esquemas de secciones de las distintas topologías de territorio.

Tenemos, pues, seis tipos a partir de la estructura que, caracterizados por su geometría pueden condicionar el dominio visual el entorno, evidentemente, el dominio funcional de la tierra. Ejemplos de cada uno de estos tipos son:

- Montaña: Bel y Boixar, Coratxar, Castell de Cabres, Herbeset, Ares...

- Valle: La Barcella y Vallibona, Xiva Morella, Les Albaredes de Portell, Herbes, Pobla de Benifassar, Tirig.

- Ladera: Molinar -Xert y Rosell- Mas del Coll, Catí-La Belluga, Vega río Bergantes.

- Llano: Canet, La Jana, San Mateu, Traiguera, La Llecua, Villafranca del Cid...

- Ondulado: Mas del Stellers, Calig, Cervera...

- Atalaya La Mola Garumba en Morella, la Mola de Ares o las Molas de Xert. 


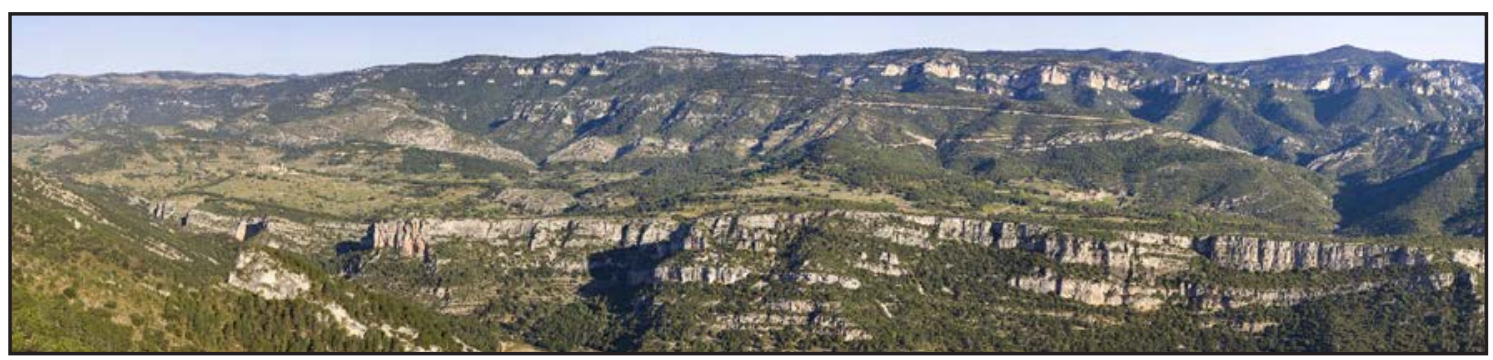

Fig. 3. 23. Vista de la sierra de Bel. Topología de montaña.

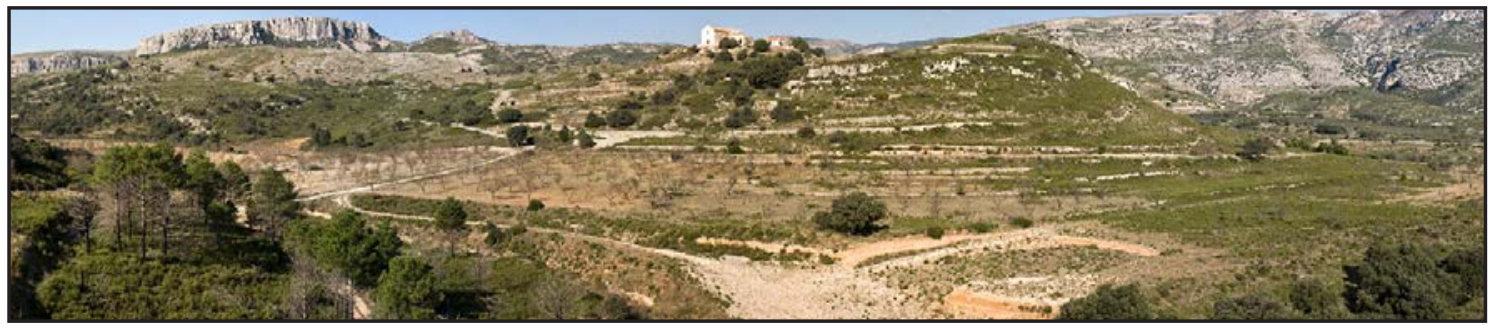

Fig. 3. 24. Vista de La Barcella. Topología de valle.

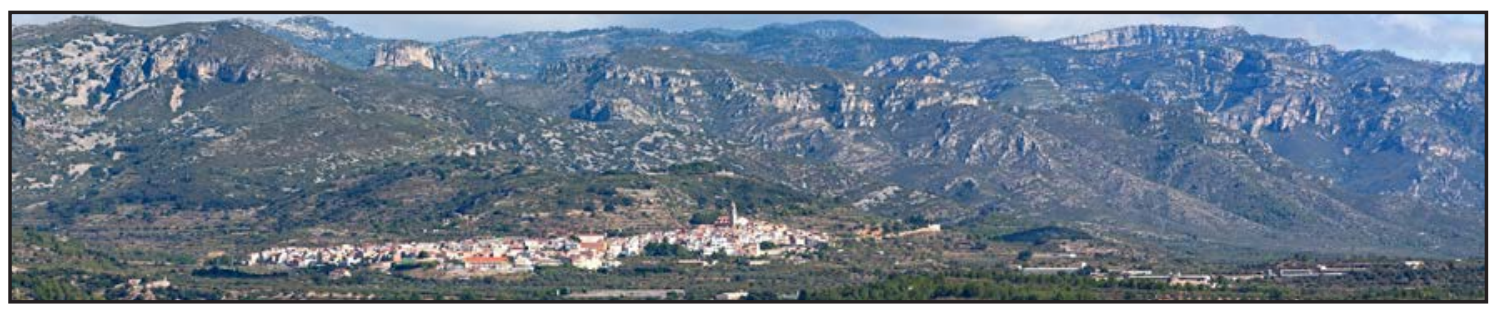

Fig. 3. 25. Vista de Rosell. Topología de ladera.

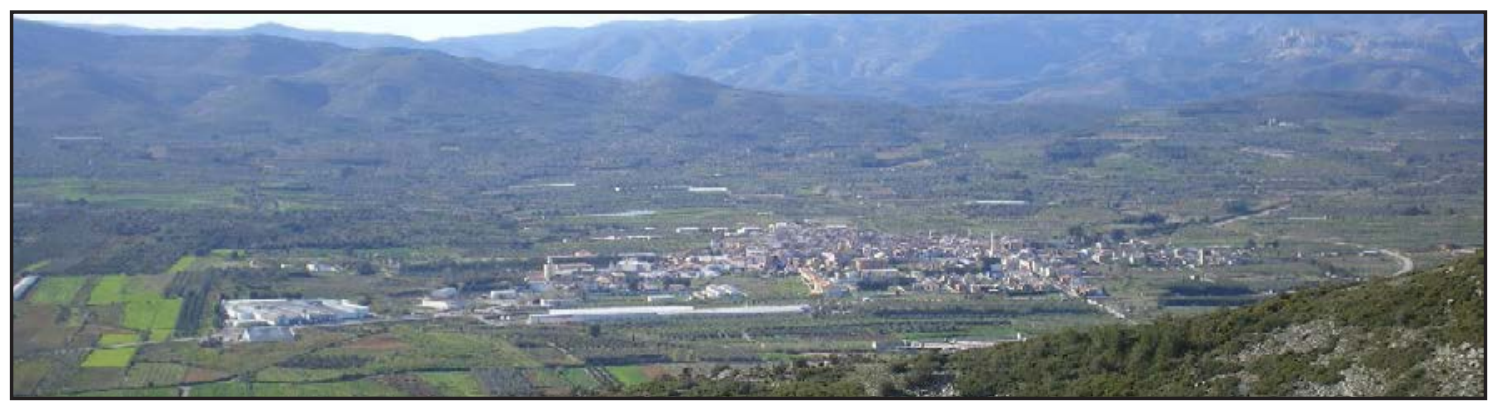

Fig. 3. 26. Vista de Sant Mateu. Topología de llano.

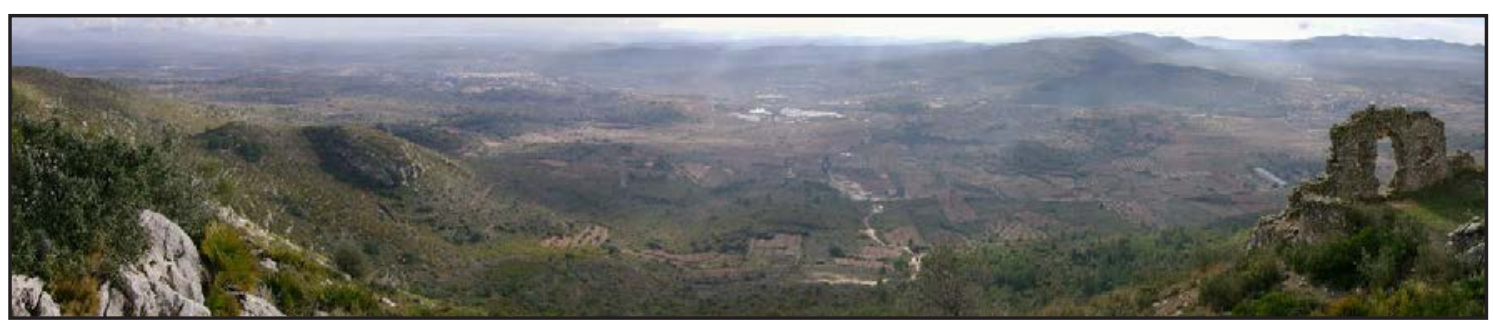

Fig. 3. 27. Vista de Traiguera desde Sant Pere. Topología de suelo ondulado.

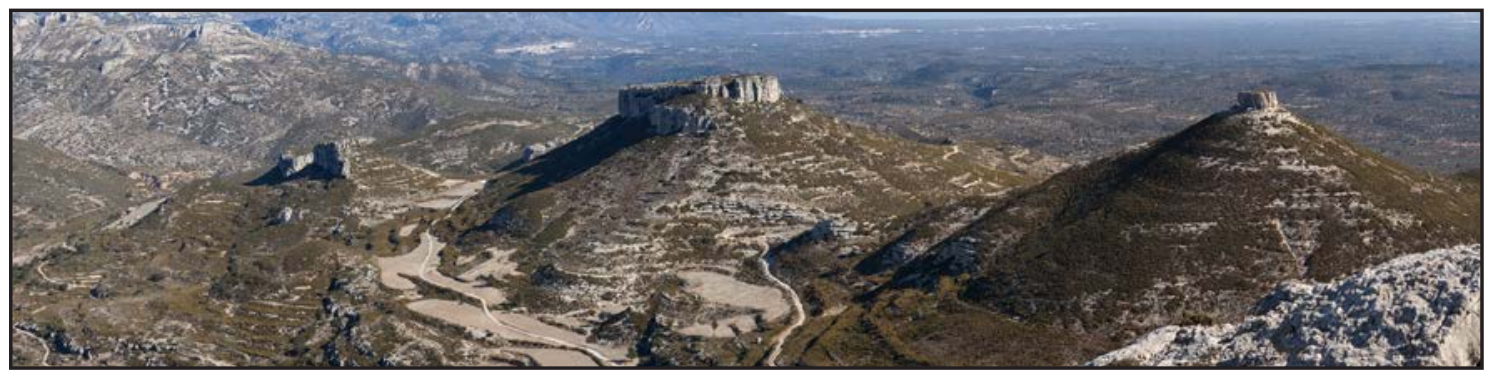

Fig. 3. 28. Vista de las molas de Xert. Topología de atalaya. 
CAPÍTULO 4. ORGANIZACIÓN DELTERRITORIO ANTROPOSOCIAL 



\section{1. El Hombre y el medio: la dimensión humana}

\section{1. 1. Propiedad del territorio y su gestión. Los periodos anteriores al estudio}

Los pueblos de diferentes culturas y órdenes sociales organizan el espacio y fijan unas pautas de asentamiento diferentes sobre el territorio. En la Batllia de Cervera los primeros pobladores que ocupan este territorio serían los íberos, que ocupan en principio enclaves en lugares elevados, protegidos y fáciles de defender, ya que prima para ellos la seguridad sobre la explotación agrícola o la relación a través de los flujos de comunicación.

En la época de esplendor del Imperio romano se ocupan los llanos y las zonas próximas a la costa. El comercio es floreciente y por tanto los flujos de intercambio, existe una seguridad física que permite que los primitivos enclaves y asentamientos humanos en las montañas, los antiguos oppida ibéricos sean abandonados por nuevos asentamientos en el llano. Es ese momento en nuestra zona de estudio, se construye la vía Augusta que cruce el territorio por su parte media y se produce el auge de ciudades como Sagunto, Tortosa, etc.

La ciudad es el centro de toda la actividad. Siglos más tarde, tras la crisis económica del siglo III el espacio rural volvió a ser importante, la población se fue desplazando paulatinamente hacia él abandonando las ciudades, de forma que el siglo IV fue el de apogeo de las villas romanas y de los grandes dominios rurales y en parte se vuelven incluso a ocupar los asentamientos íberos.

A continuación llegan los visigodos, sus asentamientos son continuación de los tardorromanos, sin diferencias significativas; los enclaves romanos se fueron integrando gradualmente en la estructura política y económica visigoda. La lex visigothorum menciona cuatro tipos de asentamiento: civitas, castellum, vicum y villa. El caserío campesino y la vieja villa se hicieron indistinguibles. Desde el siglo VI las iglesias convirtieron las antiguas villae en puntos de atracción. Un castrum o un castellum de los que defendían puntos estratégicos de la red de vías romanas también podían reunir un núcleo de población, bien en forma de aldea fortificada bien como poblado asociado a un edificio militar.

Los paisajes urbanos tardorromanos, con sus distintos edificios públicos, se vieron reemplazados definitivamente por ciudades de aspecto medieval, dominadas por iglesias y monasterios. Los únicos edificios nuevos fueron las iglesias y las sedes episcopales. Estas supusieron una estructuración del territorio, en el caso de la diócesis de Tortosa la división que se produjo aún persiste hoy en día en gran parte cogiendo parte de las provincias de Tarragona y Castellón.

La sociedad visigoda fue desmantelada con facilidad por los árabes porque previamente habían sufrido una severa crisis agraria que provoco una contracción demográfica en 640-680 que supuso baja de la recaudación fiscal y todo ello agravado por las plagas que durante 70 años azotaron este territorio a finales del siglo VI.

La llegada de los árabes supuso un cambio importante en la estructura del territorio rural. En el caso de Al-Andalus, el mundo rural se estructuro en sistemas formados por fortificaciones y un grupo de alquerías a su alrededor dependientes, vinculadas normalmente al cultivo de campos irrigados.

La huida ya mencionada en la época tardorromana hacia los primitivos emplazamientos íberos en las montañas, fueron también significativos durante los dos primeros siglos de la presencia islámica en la península (por ello esos primeros castillos tienen nombre latinos). De este modo la función social ejercida por el castillo y su territorio cristalizo en la más alta Edad Media antes de que la arabización lingüística tuviese lugar. Los castillos con topónimos árabes, como el de Alcala, son más recientes.

El caso del de Cervera sería de los primitivos y corresponde a los citados como poblaciones íberas, abandonadas, ocupadas posteriormente en la época tardorromana, así como al principio de la invasión árabe, convirtiéndose desde el inicio de la ocupación árabe en un centro territorial.

Posteriormente la "fitna" o conflicto civil de finales del siglo IX produjo un nuevo movimiento de "incastillamiento". Estos castillos (husûn) fueron más tardíos, formaban un sistema político y estratégico; eran también más complejos, capaces de sostener funciones permanentes y eventualmente una pequeña población campesina. 
Desde el siglo X los poblados fortificados desempeñan un papel que sobrepasa la simple función militar: constituyen las estructuras que contienen el hábitat y organizan el espacio agrario, tanto en el mundo cristiano como en el árabe.

Toubert define el "incastillamiento" como la estructura formada por sistemas castrales en las que se establecen relaciones entre los hábitats fortificados y los establecimientos campesinos que gravitan a su alrededor y que se articulan con estructuras defensivas secundarias (atalayas, torres,..) y fenómenos asociados como la irrigación.

La unidad básica del asentamiento rural era el complejo castillo-alquería (hisn- qarya); cierta cantidad de alquerías dependían de un castillo a efectos de usar el albacar como refugio. El alcaide era el representante del Estado y recaudaba los impuestos; los campesinos eran libres no pagaban rentas sino impuestos, manteniendo la misma concepción desde la época romana.

Junto a las alquerías, que eran posesiones colectivas de un segmento tribal, habían también propiedades privadas llamadas rahal que tenían también un carácter agrícola. La alquería constituía la unidad básica de los ingresos fiscales del estado, tenían una superficie de unas $90 \mathrm{Ha}$ y los rahal de $40 \mathrm{Ha}$ y se situaban de forma marginal.

El sistema estaba formado por un castillo o refugio que controlaba unos $100 \mathrm{Km}^{2}$-el de Cervera controlaba $360 \mathrm{Km}^{2}$ más ${ }^{63}$ los $120 \mathrm{Km}^{2}$ de la franja entre los ríos- y entre 7 a 10 alquerías con espacios irrigados. El complejo cubría las necesidades del campesino: defensa y protección del castillo, religión (1 o varias mezquitas), agricultura y los espacios intersticiales dedicados a usos ganaderos, cultivos de cereales, explotación forestal y de otros recursos. En algunas ocasiones el hisn o poblado asociado a él era la sede de un distrito administrativo. Los asentamientos de las alquerías no dependían de cuestiones defensivas sino de la presencia de acuíferos que permitían los espacios irrigados.

De forma paralela en la zona cristiana y en concreto en Cataluña se produce el sistema de "incastillamiento", pero en este caso las aldeas son de propietarios alodiales que poco a poco van a ser "expulsados" por los grandes terratenientes (iglesia y monasterios) quedando las tierras en poder de ellos. Esto favorecerá que se produzca la reconquista hacia el sur, ya que se les promete que se les otorgarán nuevas tierras en propiedad.

\section{1. 2. Propiedad del territorio y su gestión. Los periodos del estudio}

\section{Periodo anterior a la conquista (1150-1234)}

La conquista cristiana de las tierras valencianas responde a la dinámica interna del desarrollo y expansión del modo de producción feudal, la tierra es la fuente básica de la riqueza y su ampliación se realiza primordialmente de una forma cuantitativa con la ocupación de nuevos territorios.

En el momento de la conquista no existe un Reino musulmán de Valencia, no es un país unificado y consciente de su existencia. El territorio esta dividido en "trozos" alrededor de un castillo, en este caso el de Cervera, que les da protección. Sobre el territorio existen diseminadas una serie de unidades agrícolas o alquerías con un cierto carácter de autogestión, ajeno a la corriente feudal del momento según algunos autores. Esa falta de cohesión, que ha provocado incluso la guerra entre los distintos castillos musulmanes, facilito la ocupación uno a uno de las poblaciones y castillos existentes.

En un primer momento el reparto de las tierras ocupadas en el norte de Castellón se hace siguiendo las pautas de la organización del territorio en época musulmana, así los territorios del primitivo castillo de Cervera de época musulmana pasan a manos de la Orden del Hospital con toda su zona de influencia, dado que se trata de una ocupación militar, realizada por la fuerza y por una minoría que necesita concentrarse en los nudos de la red de ocupación, los cuales lógicamente eran los

63 Esta diferencia en la superficie de afección del castillo de Cervera obedece a ser durante muchos años territorio de frontera y por tanto con un menor desarrollo económico por la inseguridad física que suponía la proximidad a la frontera y por tanto a las incursiones militares de uno y otro bando. 
castillos. Es lógico por tanto mantener inicialmente la organización musulmana del territorio, tanto por las facilidades defensivas y militares de control, como por las facilidades de organización de la renta y apropiación del excedente campesino, y de ahí también el reparto producido de una forma jerarquizada y organizada entre los repobladores.

\section{Periodo Orden del Hospital (1234-1317)}

\section{Primera parte. (1234-1276)}

La Orden del Hospital recibe antes del reinado de Jaime I $(1208)^{64}$ la promesa del territorio y castillo de Cervera, siendo en el año 1234 cuando recibe de facto dichos territorios, ya que en junio de 1234 el Maestre de la Orden ya da la carta puebla de Cálig, siendo el 23 de diciembre de 1235 cuando la Orden recibe la confirmación "oficial" de dichas propiedades.

En un primer momento, aunque solo se dispone de documentación respecto a Xivert en el caso del castillo de Cervera debió de ser similar, se procede al establecimiento de unos "pactos de ocupación" que establecen las condiciones con las que la población musulmana convivirá con la Orden del Hospital como nuevo propietario, es decir en un primer momento la población musulmana y sus "propiedades" se mantienen casi de manera integra, pero con duras condiciones económicas.

Posteriormente en el periodo 1234-1248 se dan una primera serie de cartas pueblas como las de Calig y Ali (1234), término del castillo de Cervera (1235) ${ }^{65}$, Rossell (1237), Sant Mateu (1237) ${ }^{66}$, Carrascal (1239) ${ }^{67}$; no se han conservado pero debieron existir cartas semejantes en estos años para Canet, Traiguera y La Jana. En dichas cartas la Orden del Hospital como señor concreta unas relaciones de producciones muy duras y decantadas a su favor. Se concede para uso comunal los yermos, montañas, aguas y ríos, pastos y bosques, leña y piedras, en fin, todo aquello que en una economía de subsistencia representa un complemento esencial para la vida diaria.

A continuación las cartas entran ya en la concreción y relación de los elementos de la renta feudal. En primer lugar se menciona la reserva; la Orden como señor del término retiene una parte de él que no puede ser utilizado por los campesinos, aunque no concreta que extensión tiene, ni su localización.

La Orden del Hospital realiza una ordenación del territorio, al marcar la extensión de las propiedades campesinas, cada una de ellas tendrá 24 "cafissadas" 68 según la medición de Lleida (12 hectáreas), dándolas sin ninguna retención: no se paga censo ni en especie ni en dinero ni hay partición de frutos; son por tanto tierras francas aunque no se diga explícitamente.

Esta libre disponibilidad de los bienes poseídos en régimen enfitéutico esta limitada a la prohibición de su venta a clérigos o caballeros, esto es, a personas exentas de las contribuciones señoriales por su estatuto personal. Pero lo que si es específico de estos pueblos Hospitalarios es la franqueza de la fadiga, es decir, la posibilidad de dirigir y controlar la evolución de la propiedad, de su traspaso.

La renta fundamental que obtiene la Orden es por el diezmo y la primicia, en este primer momento se la van a apropiar de una forma integra lo que provocara conflictos con la autoridad eclesiástica del obispado de Tortosa. Por tanto podemos concluir que en este periodo la Orden se apropia de un poco más de un décimo de la producción campesina.

Además la Orden retendrá los monopolios de molinos, hornos y herrería, con unas condiciones no excesivamente gravosas frente a las de las zonas próximas, a la vez que denota una clara preocupación en establecer las condiciones de trabajo para mejorar las condiciones de producción en su provecho. Llama la atención que no se establezcan como hacen otras Órdenes derechos señoriales sobre el ganado dada la importancia que luego tendrá esta actividad.

64 Ver apéndice documental nº 2 pág. 603

65 Ver apéndice documental no 4 pág. 605

66 Ver apéndice documental nº 6 pág. 607

67 Ver apéndice documental no 5 pág. 607

68 Ver apéndice documental no 4 y 6 pág. 605 y pág. 607 
Tras la primera rebelión musulmana en 1248 y la consecuente orden de expulsión de los musulmanes, se genera un segundo grupo de cartas pueblas en el periodo 1248-1251, al objeto por parte de la monarquía de apuntalar la repoblación, asegurando el control de los núcleos urbanos, expulsando a los musulmanes que los habitaban y asentando cristianos en su lugar.

Así se redacta la carta puebla de Cervera $(1250)^{69}$ junto con otras cuatro más de territorios o antiguos castillos musulmanes en los que solo había hasta ese momento población musulmana. La carta establece que la Orden reparte las tierras a los nuevos pobladores poco a poco, conformen estos se van asentando. La carta es similar a la anterior de 1235 reservándose fundamentalmente como renta el diezmo y la primicia, pero concretando que para evitar fraudes exige a los labradores que deben esperar a un delegado de la Orden para recoger la parte que les corresponde de las propias eras o del campo y detallara minuciosamente el pago correspondiente al ganado.

Deja libertad de vender las tierras, renunciando la orden a la fadiga, pero con la limitación de venta a clérigos y caballeros. Introduce la reserva del derecho de recuperar la orden aquellas tierras que quede inculta y sin producir.

Posteriormente existe un nuevo grupo de cartas pueblas en el periodo 1260-1275 entre las dos rebeliones musulmanas, en este momento ya no es urgente poblar antiguos castillos musulmanes de los que se ha expulsado a la antigua población y que hay que dotar por su importancia defensiva y militar; en este periodo de nueva calma la clase feudal fija de nuevo su objetivo en la colonización de los términos de los castillos, en la disgregación de una parte del territorio para crear una nueva población a partir casi siempre de una alquería ya existente.

Dentro de este grupo en la Batllia de Cervera encontramos la confirmación de la carta puebla de Sant Mateu (1274) ${ }^{70}$, en la que hace una serie de modificaciones y aclaraciones de la inicial dada 37 años antes. La diferencia sustancial consiste en que el documento tiene un origen distinto, no surge de arriba abajo, sino que los "prohoms" de Sant Mateu son los que propician la redacción de la nueva carta puebla para fundamentalmente aclarar los problemas que surgen de la coexistencia de dos derechos, por una parte la "Costum" de Lleida con la que se redactan las cartas pueblas iniciales y el "Fuero" de Valencia que se aplica en otros casos lo que había creado numerosos conflictos. La Orden pasará a ratificar el uso exclusivo de la "Costum" de Lleida.

\section{Segunda parte (1276-1317)}

El último grupo de cartas pueblas se redacta a partir de 1276 tras la segunda revuelta musulmana, y en el caso de la Batllia de Cervera no tiene consecuencias reseñables ya que la mayor repercusión se produjo en la zona meridional en la que había mayor influencia de población musulmana.

Poco a poco fue creciendo una forma de vida, de organización socio-económica que iba a extenderse lentamente. Sus bases eran las cartas puebla y privilegios posteriores; sus vías el modelo de feudalismo; sus resultados la confluencia de estos aspectos con los medios de producción existentes, con la tierra y los hombres que van a trabajarla, con la clase dominante que va a explotarla. Como dice Pierre Guichard:

"El Reino de Valencia conoció entonces una notable expansión económica, claramente perceptible en la documentación y en fuerte contraste con el ambiente del periodo anterior en el que no se encuentra datos semejantes. Se podría bosquejar la hipótesis de que durante medio siglo después de la conquista la actividad y los esfuerzos de los valencianos habían sido invertidos en la reconstrucción económica del país luego de las destrucciones y perturbaciones provocadas por la conquista, o empleadas en la lucha por establecer y mantener el dominio cristiano. Solo después de la gran crisis de 1276-1278, el reino conoció la estabilidad suficiente para permitir un desarrollo económico favorecido por el ambiente general que prevalecía en la Europa mediterránea de la época." 71

69 Ver apéndice documental nº 17 pág. 616

70 Ver apéndice documental no 30 pág. 624

71 GUICHARD, P. “Al-Andaluis frente a la conquista cristiana. Los musulmanes de Valencia (siglos XI-XIII)” pág. 85 
En poco más de una década la frontera se ha alejado mucho hacia el sur, por tanto es lógico que en la zona norte de Castellón, en el Maestrat, se plantee por parte de los señores, la clase feudal dominante, la construcción de un modelo socioeconómico que le permita la apropiación del excedente campesino. Las cartas pueblas Hospitalarias dejan claro que en su mente tienen un modelo marcadamente agrario, la ganadería todavía no se desarrolla y se esta de espaldas al mar, a la comunicación con otras comunidades.

\section{En definitiva se detectan los siguientes síntomas de crecimiento en el Maestrat:}

- La ocupación del territorio. La enumeración de las cartas puebla deja claro la tendencia a extenderse por todo el territorio, creando nuevas poblaciones. Pero no solo hay un crecimiento urbano cuantitativo, sino también cualitativo, como en San Mateo que "desplazan” el centro urbano a la nueva plaza en 1257. Se trata de un proceso elástico y heterogéneo pero que apunta hacia arriba, solo en épocas posteriores se producirán una serie de despoblados.

- Las nuevas parcelaciones. Las cartas puebla citan inicialmente a un número de pobladores e indicaban que aceptarían hasta un tope máximo de gente que viniese después. Pero el crecimiento posterior supuso seguramente el establecimiento de nuevas parcelas, ya que las tierras aparecen posteriormente en cultivo, pero la carencia de documentación local y la pérdida absoluta de protocolos notariales medievales del Maestrat resulta imposible comprobarlo y ratificarlo. En el caso de los señoríos, interviene en el establecimiento de nuevas tierras el Maestre junto con el Capítulo y el Comendador del lugar, gracias a ello sabemos el establecimiento de un "camp de terra" en Sant Mateu en 1281, con su censo y demás derechos enfitéuticos, y este seria el sistema generalizado de los nuevos establecimientos.

- La organización y expansión ganadera. En un principio no es el plato fuerte del desarrollo. Frente a las minuciosas descripciones de la actividad agrícola en las cartas puebla, no ocurre lo mismo con la ganadería. Por ello el pago de diezmos de ovejas y cabras en Hospital, e incluso de los derechos de caza se incluyen con posterioridad a las primeras cartas puebla. No aparecen la creación de bovalares y dehesas. La ganadería fue creciendo poco a poco, fue empezando a ser rentable y fue empezando a crear problemas por lo que con posterioridad se tuvo que reglamentar. A ello contribuyo el tipo de terreno del Maestrat y su clima aptos plenamente para la ganadería y la trashumancia desde las tierras altas de la ibérica. La ganadería trashumante asienta su actividad plenamente en la década 1310-1320, cuando aparecen las noticias de establecimientos de dehesas, acotamientos de zonas y defensas de los derechos de cada pueblo motivados por la escalada de conflictos/normativas. ${ }^{72}$

- La evolución en la situación de los monopolios. Los más significativos están relacionados con la actividad agrícola y su desarrollo va ligado al de aquella. El crecimiento de la producción de cereales hace que se establezcan nuevos molinos y el de la producción de olivos de nuevas almazaras (entre 1281 y 1283 en la mayor parte de los pueblos de la Batllia) ${ }^{73}$. El aumento de la población hace que crezcan el número de hornos (1308 Sant Mateu) y otras actividades urbanas.

72 La escalada de prohibiciones quejas y cobro de exacciones es continuo en esta década. En esta década y solo para los ganados de Sant Mateu hay quejas de sus síndicos contra los pueblos de Tronchón (1310), contra Iglesuela (1312), Cantavieja (1317), Fortanete y Aliaga (1317) y Morella (1318).

En un proceso que durará unos pocos años más, los Hospitalarios regularan la existencia de varias dehesas en la Batllia de Cervera, caso de la de Cominyer (1313) a Sant Mateu o la de la Barcella (1316) dada conjunta a todos los pueblos de la Batllia.

Un síntoma de la importancia que empezó a tener para la comunidad es la normativa minuciosa de funcionamiento y la legislación disuasoria que se estableció para los infractores que causó graves problemas y litigios entre las comunidades vecinas que veían mermados sus derechos de siempre.

73 Ver apéndice documental nº 33 pág. 626 
- El crecimiento comercial. Un síntoma claro del crecimiento es la creación de mercados y ferias. Sant Mateu mercado semanal en $1243^{74}$ y feria de 15 días en la Ascensión en unos años después ${ }^{75}$; lo que provoca que se convierta en la cabeza de la Batllia en detrimento de Cervera.

- Conflictividad entre los pueblos. Existen diversos documentos de esta época que denotan que la ocupación del territorio se "concretaba" no era difusa como en la época de división por castillos. La explotación del territorio, de sus posibilidades económicas hace que sea importante delimitar hasta donde alcanza cada término. Se trata de una ordenación del territorio "compacta" sin "huecos". El territorio se reparte en su totalidad. ${ }^{76}$

\section{Periodo Orden de Montesa (1317-1482)}

La fundación de la Orden de Montesa en 1317 fue un proceso político, desencadenado a partir de la evolución de la situación internacional y que se resolvió en función de la situación e intereses de la monarquía catalana-aragonesa, tanto en su contexto internacional como en el interno. Su desencadenante fue la disolución de la Orden del Temple y la incorporación de sus bienes a la Orden del Hospital, lo que llevó a negociar a Jaime II una salida que no implicase la creación de un patrimonio excesivo para dicha Orden en sus reinos.

La solución costó de aceptar cinco años y la existencia de un nuevo Papa, siendo fruto de la negociación la aplicación de una salida intermedia. El 17 de julio de 1317 se creaba la Orden de Montesa con todos los bienes del Hospital y del Temple en el Reino de Valencia, pasando en el resto de la Corona todos a manos del Hospital.

Las características de la renta feudal de la que iba a disfrutar Montesa en un periodo inicial estaban marcadas por como se había constituido su señorío procedente de reunir pueblos de origen diverso, unos de realengo, otros de señorío laico, otros del eclesiástico, por lo que resultaban diferentes las formas concretas que había adoptado la renta feudal en cada uno. ${ }^{77}$

Dado el carácter tan diverso del origen de las distintas rentas feudales que conformaron la renta de la nueva Orden, se redactó un documento o "auditoría" inicial de fecha 25 de marzo de 1320 que contemplaba la situación de cada uno de los pueblos de la nueva Orden. Este documento es fundamental para conocer la situación de estos territorios y en particular el de la Batllia de Cervera que nos ocupa en esas fechas y gracias a él conocemos cual era la situación del territorio en esas fechas Las tierras en explotación directa de la Orden eran mínimas. La mayor parte estaban explotadas en enfiteusis (donación a perpetuidad o por un largo periodo a cambio de un pago periódico). Los monopolios bien estaban arrendados, bien eran explotados también en régimen de enfiteusis.

\footnotetext{
74 Ver apéndice documental nº 10 pág. 610

75 Ver apéndice documental nº 20 pág. 618

76 Ver apéndice documental nº 11 pág. 611
}

77 La Orden de Montesa quedó constituida por las siguientes localidades:

Batllia de Cervera: Cervera, Sant Mateu, Traiguera, La Jana, Carrascal, Canet, Calig, Xert, Rosell y la Barcella.

Batllia de Peñíscola: Peñíscola, Benicarló y Vinaros.

Batllia de Xivert: Alcalá de Xivert, Xivert, Castellnou, Polpis y Alcossebre.

Batllia de Ares: Ares.

Tenencia de Culla: Culla, Atzeneta, Benafigos, Benassal, Vistabella, Molinell, Boi, Torre d'en Besora, Vilar de Canes y Corbó. Tenencia de les Coves: Les Covers, Albocasser, Salzadella, Tirig, Vilanova d'Alcolea, Torre en Domènec y Serratella. Castillo de Vilafamés: Vilafamés y Vall d'Alba.

Castillo de Onda: Onda, Tales y Artesa.

Batllia de Montcada: Montcada, Carpeas, Borbotó y Massarrotjos.

Batllia de Sueca: Sueca, Silla y Montroy

Convento de Montesa: Montesa y Vallada.

Castillo de Perputxent: Vall de Perputxent.

Rentas aisladas en: Ciudad de Valencia, Lliria, Denia, Ademús y Castellfabib, Borriana y Morella 
En la evolución global del sistema hasta el periodo de crisis de reproducción de él, que podemos fijar a partir de 1370-1380 podemos definir tres áreas explicativas:

La evolución demográfica. Se produjo un crecimiento continuo del número de habitantes del señorío, se adjunta cuadro con el número de fuegos de cada uno de los pueblos en este periodo.

\begin{tabular}{|l|l|l|l|}
\hline Población & Siglo XIII & $\mathbf{1 3 2 0}$ & $\mathbf{1 3 7 3}$ \\
\hline Cervera & & 250 & 303 \\
\hline Sant Mateu & & 900 & 951 \\
\hline Xert & 44 & 134 & 151 \\
\hline La Barcella & & 25 & \\
\hline Rosell & 20 & 50 & 69 \\
\hline Canet & 40 & 140 & 173 \\
\hline La Jana & & 86 & 128 \\
\hline Carrascal & & & \\
\hline Traiguera & 40 & 300 & 343 \\
\hline Calig & & 120 & 198 \\
\hline Total Batllia Cervera & 144 & 2005 & 2316 \\
\hline
\end{tabular}

Fig. 4. 1. Tabla con el número de habitantes de las poblaciones de la Batllia de Cervera, extraído del libro "Feudalismo en expansión en el norte valenciano y desarrollo de la Orden de Montesa. S. XIII y XIV" de E. Guinot Rodríguez 1986.

Dadas las condiciones en las que se produjo la conquista de la zona norte de Castellón el nivel inicial de población fue cero, al no mantenerse prácticamente población musulmana. A partir de ahí se creció aprisa sumándose al crecimiento vegetativo el aporte inmigratorio ya como zona cada vez más “desarrollada”. El periodo entre 1350 y 1380 se puede calificar de transición por la acumulación de problemas: las pestes, la guerra de la Unión, la guerra con Castilla, las multas y castigos a los pueblos rebeldes, los gastos de amurallamiento y defensa y las nuevas demandas fiscales tanto del Rey como de Montesa.

E1 desarrollo de las fuerzas productivas. El crecimiento de la actividad agrícola a lo largo del Siglo XIV se mantuvo con respecto al siglo anterior, manteniendo un papel secundario. Se podría hablar de una disminución del cultivo de cereales, llegando a carestías, un mantenimiento del viñedo acompañado de medidas proteccionistas y un aumento de la producción olivarera y del azafrán. Esta dinámica en parte recesiva esta provocada por que los recursos naturales eran cada vez menos abundantes para una mayor población; prueba de ello son los conflictos que se generan por el uso del agua del río Cenia en 1332 entre Ulldecona por una lado y la Orden de Montesa por otro, por la proliferación de acequias y molinos en sus orillas. ${ }^{78}$

Paralelamente se produce un gran auge de la actividad ganadera y de exportación de lanas a lo largo de todo el siglo XIV, no limitándose a niveles cuantitativos sino introduciendo transformaciones sociales en el contexto del señorío, contribuyendo a consolidar y estructurar las comunidades rurales, a impulsar su proceso de diferenciación social y a dotarlas de mecanismos de poder local frente al señor.

En este proceso fueron frecuentes los conflictos entre pueblos por el control de los pastos e incluso dentro de ellos entre los grupos ganaderos más ricos y el resto de los vecinos dedicados a la agricultura, saliendo vencedores normalmente los primeros al ser quienes controlaban la comunidad rural, muchas veces con el apoyo indirecto de Montesa. Pero esta, aunque el crecimiento global del sistema le favorecía a nivel cuantitativo, tuvo su contradicción en las características de su renta feudal, basada abrumadoramente en la producción agrícola, con lo que no pudo acompañar el aumento de sus rentas al nivel que estaban alcanzando al menos un sector de sus vasallos, produciéndose un desfase

78 Ver apéndice documental nº 41 pág. 633 
importante entre el nivel de excedente que se iba produciendo cada vez y la parte proporcional que lograba apropiarse la Orden como señora de la zona.

Estos conflictos propiciaron la creación de la institución del "ligallo", creada para la resolución de los problemas entre los ganaderos de pueblos vecinos, creando incluso la figura de la justicia del "ligallo". El primer en crearse es el de Morella en $1271^{79}$ y ratificado en 1316; y en las tierras de la Batllia de Cervera debieron existir estos "ligallos", aunque solo se conserva el documento de fundación del "ligallo" que reúne a los pueblos de Calig, Canet, Rosell, La Jana y la Barcella creado el 22 de marzo de $1358^{80}$

La actividad comercial creció de forma considerable, ligada al auge ganadero por la exportación de lanas y que contó con el apoyo señorial a través de su política de consolidación de puertos y embarcaderos, creación de nuevos mercados y ferias, reducción de la legislación prohibitiva a la libre circulación de mercancías e incluso cesión de algunas de las rentas que gravaban el comercio. Las consecuencias no fueron tampoco un aumento directo de las rentas señoriales pues eran muy escasos los mecanismos por los que incidía sobre dicha actividad. ${ }^{81}$

La evolución de las relaciones de producción. A partir de la creación de Montesa y mientras el sistema siguió creciendo, el interés señorial se centró en la alteración de este marco de privilegios y franquicias que poseían los pueblos desde la etapa inicial de la repoblación, pugnando la Orden por el control de los mecanismos jurisdiccionales, y no por sus rentas, que eran muy reducidas, sino porque estos eran la expresión e instrumento del poder feudal y eran los medios con los que lograría imponerse en los momentos de crisis y al mismo tiempo aumentar de manera efectiva la presión sobre el señorío, la presión necesaria para conseguir subsidios y donativos extra.

A nivel interno del señorío y de las relaciones Orden / vasallos se constata una política en cierto modo contradictoria. Por una parte se dan una serie de concesiones, al objeto de mejorar la actividad productiva, que favorecen la consolidación de la comunidad campesina, su capacidad de organización y también de mayor resistencia a futuras presiones señoriales. Prueba de ello es el proceso desarrollado en la década 1320-1330 de consolidación del poder municipal con la regulación de poderes y formas de elección, similar al realengo, de los cargos municipales: Justicia, Jurats y Mustassá, sin ninguna intervención señorial en el proceso de elección.

Por otra parte, la Orden de Montesa consiguió controlar toda la jurisdicción y la cesión de las apelaciones reales, con lo que consiguió poco a poco quitar determinados privilegios con los que contaban determinados pueblos desde la época de la conquista y con posterioridad a la guerra de la Unión, como castigo a la participación de los pueblos con el bando perdedor (no así la Orden), consiguió que los pueblos pagaran fuertes multas a lo largo de varios años, renunciaron a parte de la primicia las arcas municipales y sobre todo los pueblos que quedaban renunciaron al fuero de Aragón y tuvieron que aceptar el de Valencia.

\section{1. 3. El uso del territorio}

En un primer momento tanto el periodo anterior a la repoblación como el inicial de esta, este enclave era un territorio de frontera, en el que por tanto primaban los intereses militares sobre todos los demás. El uso militar del territorio era prioritario. Los elementos defensivos, como castillos, torres, masías fortificadas, etc. junto con la red de caminos militares organizaban y estructuraban el territorio, era la prioridad para subsistir. Los demás usos quedaban supeditados a la defensa del territorio.

Posteriormente poco a poco conforme la frontera se fue alejando y las necesidades militares dejaron de ser vitales y podemos considerar tres usos fundamentales a partir de ese momento: el agrícola, el ganadero y el comercial.

79 Ver apéndice documental nº 25 pág. 621

80 Ver apéndice documental no 44 pág. 640

81 Ver apéndice documental nº 48 pág. 643 


\section{Uso agrícola}

En el primer periodo de ocupación sarraceno la agricultura era la forma principal de subsistencia de los habitantes de este territorio, se cultivaban tanto cultivos de secano como cereales, olivos, vid, algarrobos como de regadío en pequeñas huertas situadas junto a los ríos, barrancos o fuentes o bien regadas por la extracción de agua mediante norias en las que se producían hortalizas y frutales.

La repoblación supuso un gran impulso a la agricultura, no obstante uno de los motivos fundamentales de la misma fue la explotación de nuevas tierras conquistadas o bien la usurpación directa de las que ya estaban en explotación por parte de los sarracenos. Durante el resto del periodo fue aumentando el territorio dedicado a la agricultura, como así nos lo atestiguan documentos como el "Llibre de Censos de la Jana" en el que se aprecia el aumento de las parcelas cultivables a lo largo de los años. Así mismo durante el paso de los años, el tamaño de las parcelas fue disminuyendo por particiones sucesivas de las primitivas originales.

La parte de la Batllia fue una zona relativamente estable aunque también se produjeran conflictos bélicos, dada su lejanía de las fronteras con Castilla y con los reinos árabes del sur, por lo que los periodos de recesión que se produjeron, Rossell se despobló en el periodo 1463-1469 tal como podemos comprobar en los libros de los morabatins, fueron producto de la suma de los factores militares junto con problemas de sequía o epidemias que diezmaban a la población y por tanto a la mano de obra para cultivar los campos.

Todos los términos de las Vilas de la Batllia tenían parte de su territorio dedicado a la agricultura, algunos como los de La Jana y Carrascal prácticamente en su totalidad y otros como el de La Barcella con una reducida parte de su término.

Los cultivos fundamentales de secano eran los cereales, viña y olivos. A lo largo del periodo estudiado el cultivo que más aumenta, en parte porque inicialmente era menor a los otros dos, es el del olivo. En líneas generales por tanto se podría hablar de una importancia relativa de la producción agrícola, con un desequilibrio que se iba ampliando entre los más importante productos: una disminución de los cereales panificables, probablemente por una reducción de la extensión cultivada; un mantenimiento a niveles altos de la producción vitícola, tal como se constata con la existencia de medidas proteccionistas locales que obligaban a la producción para el autoconsumo; y al mismo tiempo un aumento de la producción olivarera de forma generalizada en toda la Batllia y por último la aparición de un nuevo cultivo, el azafrán, que en un principio intenta eludir la exacción señorial y aprovechar su fácil y rentable comercialización. ${ }^{82}$

Las tierras destinadas a regadío no son significativas en la Batllia; se limitan prácticamente a las existentes antes de la repoblación, aprovechando el agua de los ríos, barrancos y fuentes. Solo existe un aumento del suelo cultivado de regadío en las zonas en las que se instalan nuevas norias en las partes bajas de los términos de Canet, La Jana y San Mateo fundamentalmente. El cultivo de regadío sigue siendo el de hortalizas y frutales fundamentalmente.

\section{Uso ganadero}

El territorio de la Batllia de Cervera, si como el de las comarcas vecinas, tiene una homogeneidad física y vegetal y aunque existen diversos llanos fácilmente roturables es muchos mayor la superficie abrupta, recubierta parcialmente de pinos y encinas, idónea para la explotación ganadera extensiva, especialmente con cabras y ovejas, tal como sigue siendo en la actualidad.

Toda el área era punto de confluencia desde antiguo no solo de los ganados locales sino de otros de muy diversa procedencia, los cuales tomaban las sierras de San Mateo, Cervera y circundantes como polo invernal de las rutas trashumantes viniendo especialmente de las zonas más altas de la serranía ibérica: Mosqueruela, Cantavieja, Morella,etc. Y también venían de más lejos incluso como la zona pirenaica. Ese mismo recorrido era "devuelto" por las cabañas ganaderas de la Batllia que en verano se desplazaban hacia las tierras altas del sistema ibérico.

A lo largo del siglo XIV dicha actividad no dejó de crecer, aumentando el número de dehesas y zonas

82 Una idea general de los tipos de cultivo en la Edad Media la podemos ver en el apéndice documental no 16 pág. 615 
de pastos así como la organización autónoma de los grupos ganaderos locales quienes fueron dentro de su población y con respecto de la Orden de Montesa fueron creando un área de poder propia que se fue enfrentando cada vez más al resto de grupos sociales.

Esta actividad se encuentra en gran parte descrita por la gran cantidad de documentos que existen al respecto y que demuestran que la actividad ganadera fue potenciada en este periodo en la Batllia, siendo cuatro factores los que favorecieron su desarrollo:

- Un extenso territorio, abrupto, casi virgen y muy adecuado para pastar el ganado. Un territorio con gran cantidad de dehesas, boberales y bosques.

- Una legislación favorable, tal como se puede constatar en la documentación de la época, que protege y favorece la actividad ganadera dentro de los distintos términos de este territorio.

- La estrategia económica de los señores feudales, primero del Hospital y luego de Montesa, de aprovechar las posibilidades económicas de otorgar dehesas a particulares a cambio de cuantiosas rentas.

- Una gran actividad comercial de los productos ganaderos, especialmente la lana, con la apertura de mercados fuera de sus fronteras.

\section{Uso comercial}

Dentro de la actividad comercial distinguiremos tres aspectos: los monopolios, la actividad artesanal y las relaciones comerciales.

Los monopolios. El sistema feudal vigente primero con la Orden del Hospital y luego con la de Montesa obtenía cuantiosos beneficios de las rentas de la explotación de dos tipos de monopolio básicos. Los que se desarrollaban dentro de la Vila y que en gran parte eran explotados por el municipio como la carnicería, herrería, horno, etc. y los que se ubicaban fuera de la Vila y que eran explotados por particulares como los molinos harineros y los de aceite.

La actividad artesanal. Se trata de actividades esenciales en cualquier comunidad rural tales como las de carpinteros, tejedores maestros de obra, etc. Se desarrollaron dentro de las Vilas y fundamentalmente en las dos más grandes: Sant Mateu y Traiguera, por que había más demanda y más posibilidades de comercialización.

Las relaciones comerciales. Durante todo el periodo fueron aumentando paulatinamente, inicialmente por el comercio interno favorecido por la existencia de mercados y ferias en los municipios más importantes y posteriormente por el comercio exterior, fundamentalmente de la lana, tejidos y de algunos productos agrícolas como el azafrán; este comercio incremento de forma notable la actividad portuaria de los puertos próximos y el transporte de las mercancías hasta los mismos.

\section{1. 4. Representación gráfica de los usos y arquitecturas de la Batllia en la Edad Media}

Hemos realizado un vaciado bibliográfico para poder relacionar, localizar y posteriormente grafiar todos los elementos del territorio que aparecen documentados como existentes en la época de estudio. Las fuentes de la documentación son:

- Cartas pueblas de las distintas poblaciones.

- El llibre del Repartiment.

- Las crónicas de Jaime I.

- Crónicas de historiadores o viajeros árabes o cristianos anteriores a la conquista.

- Documento sobre el "Estado de cuentas" de la Batllia de Cervera en el momento de la creación de la Orden de Montesa.

- Documentos de las cuentas de la Orden de Montesa durante el periodo en el que controló este territorio. 
- Documentos notariales, judiciales o del obispado de Tortosa de la época.

- Excavaciones arqueológicas llevadas a cabo.

- Análisis arquitectónico-constructivo de los elementos.

La bibliografía consultada que recoge dichas fuentes de documentación y en la que hemos "localizado" dichos elementos se relaciona en el Anexo $\mathbf{I}^{83}$.

La relación que adjuntamos en el Anexo II $^{84}$, viene ordenada por los términos de las distintas poblaciones de la época. En cada uno de ellos se indica la fuente o fuentes documentales en las que aparece citada, la bibliografía que la cita, la persistencia o no de tal elemento, la ubicación del mismo y la persistencia del nombre o el cambio del mismo. Así mismo relacionamos los elementos genéricos que sin tener una localización geográfica concreta nos definen el carácter del territorio de la época de estudio.

La relación adjunta consta de 342 elementos de los cuales 203 podemos localizar hoy en día en una ubicación concreta.

Con la relación de elementos que hemos podido ubicar en la actualidad, hemos confeccionado los planos en los que se grafían los elementos y usos de la Batllia de Cervera en la Edad Media, lo cual nos da una idea global del territorio en esa época. ${ }^{85}$

Los usos de la época los podemos reducir a las siguientes zonas:

- Zona de bosques dedicada a la caza y al aprovechamiento de la leña y de la madera.

- Zona de pastos de vegetación mediterránea.

- Zona de terrenos yermos de nulo aprovechamiento agrícola o ganadero.

- Zona de cultivo de cereales.

- Zona de cultivo de vid.

- Zona de cultivo de olivo.

- Zona de huerta (frutales y hortalizas).

- Zona de forraje de animales.

Las arquitecturas de la época las podemos reducir a las siguientes:

- Núcleos urbanos.

- Castillos.

- Recintos amurallados.

- Palacios.

- Torres.

- Parroquias.

- Ermitas.

- Conventos.

- Hornos.

- Molinos de aceite.

- Molinos de harina.

- Masías.

- Varios.

83 Anexo I. Bibliografía utilizada para la localización de los componentes del territorio en la edad media en la página 583

84 Anexo II. Componentes del territorio existentes en la época de estudio en la página 585

85 Nota importante: En la documentación medieval no aparecen todos los elementos existentes, solo aquellas que controlaba el poder feudal, las propiedades francas no se encuentran en dicha documentación. Esta solo aparece en los protocolos notariales, de los que quedan muy pocos. 


\section{RELACIÓN ELEMENTOS CONSTRUIDOS DOCUMENTADOS:}

Núcleos urbanos:
Xert
Barcella
Rosell
Canet
Sant Mateu
La Jana
Carrascal
Traiguera
Cervera
Calig
Bel

Castillos: 1 Cervera

2 Garrotxa

Recintos amurallados: Sant Mateu

Xert

Traiguera

Rosell

Canet

Cervera

Palacios:

Montesa (palacio urbano)

Torres:

1 Solsides (Xert)

2 Molinar (Xert)

3 Barcella (Xert)

4 Anroig (Xert)

5 Calig (Calig)

6 Molí d'oli (Cervera)

7 Torredona (Sant Mateu)

Parroquias:

1 Asunción de Xert

2 Sant Marc de La Barcella

3 Asunción de Rosell

4 San Miguel Arcángel de Canet

5 Santa María de Sant Mateu

6 Sant Pere de Sant Mateu

7 La Jana

8 Carrascal (es posterior)

9 Asunción de Traiguera

10 Asunción de Cervera

11 San Lorenzo de Calig

$12 \mathrm{Bel}$

Ermitas: 1 Santa Isabel de Canet

2 Sant Cristofol de Sant Mateu

3 Santa Ubaldesa de Sant Mateu

4 Nuestra Señora de Los Ángeles de Sant Mateu

5 Font De La Salut de Traiguera

6 Sant Pere de Traiguera

7 Virgen del Carmen (Cervera) 
Conventos:

Hornos:

Molino de aceite:

\section{Molino de harina:}

Varios:

Xert:

Carrascal:

Traiguera:

Cervera:

Masías:

Bel:

Xert:
San Francisco en Sant Mateu

1 Xert

2 La Barcella

3 Sant Mateu (3 hornos)

4 Carrascal

5 Traiguera (2, uno en el Más dels Stellers)

6 Cervera

7 Bel

1 Xert (junto Font de la Vila)

2 Canet

3 Molí Pla dels Homs en Sant Mateu

4 Molí del Portal d'Espital o de la Vedilla en Sant Mateu

5 La Jana

6 Carrascal

7 Traiguera

8 Mas dels Stellers en Traiguera

9 Cervera

10 Calig

1 Molí Xert (junto Font de la Vila)

2 Molinar (3 molinos)

3 Barcella

4 Molí en Río Servol en Rosell (desaparecido)

5 Molí de Malany en Río Senia de Rosell

6 Molins de Vinatea en Río Senia de Rosell

7 Molí Marc de Pontons en Río Senia de Rosell

8 Molí de l'Hospital en Río Senia de Rosell

9 Molí Font de la Roca en Canet

10 Molí Gatellar (Canet Río Servol)

11 Molí d'en Guerau (Canet Río Servol, actual Moli Roca)

12 Molí de Canet en el Río Senia

13 Molí de la Roca en Canet Río Senia

14 Molí de la Peguera en Sant Mateu

15 Molins (varios) en la Coma dels Molins

16 Molí del Castell en el Río Senia en Traiguera (San Rafael)

17 Molí de la Tosca o de Noguera en Río Senia de Traiguera

18 Molí de les Canals en Río Senia Traiguera

19 Molí del Pas en Traiguera (junto Puente Río Servol)

1 Poblado Ibérico Curolla

2 Otros Poblados o Restos Ibéricos

3 Poblado Ibérico Vilaroig, junto Lagunas

4 Villa Romana les Carrasques

5 Puente del Pas al Servol

6 Hospital actual Ermita de San Sebastián

Mas d'Insa

Mas Cardones

Mas d'en Ferreres

Mas d'en Roig

Mas del Rei 


\begin{tabular}{|c|c|}
\hline & Mas del Regall \\
\hline & Mas del Molinar \\
\hline \multirow[t]{6}{*}{ Barcella: } & Mas d'en Segura \\
\hline & Mas d'en Capafons \\
\hline & Mas d'en Tiboba \\
\hline & Mas d'en Dauder \\
\hline & Mas d'en Costa \\
\hline & Mas d'en Sabater \\
\hline \multirow[t]{5}{*}{ Rosell: } & Mas d'en Capafons \\
\hline & Mas d'en Coll \\
\hline & Mas d'en Roca \\
\hline & Mas d'en Salom \\
\hline & Mas d'en Savit \\
\hline \multirow[t]{3}{*}{ Canet: } & Mas d'en Dauder (actual Encruella) \\
\hline & Mas Plajove (junto Serra Major, actual d'en Jus) \\
\hline & Mas Vell (camino Vallibona) \\
\hline \multirow[t]{4}{*}{ Sant Mateu: } & Mas d'Anglada \\
\hline & Mas de Simó \\
\hline & Mas de Vaquer \\
\hline & Torre Palomar \\
\hline La Jana: & Mas del Batlle \\
\hline \multirow[t]{4}{*}{ Traiguera: } & Mas dels Stellers \\
\hline & Mas de Na Bota (junto Más dels Stellers) \\
\hline & Mas de Na Cabanes (junto Más dels Stellers) \\
\hline & Mas d'en Serra o Más Roig (junto Actual San Rafael) \\
\hline \multirow[t]{9}{*}{ Cervera: } & Mas Blau (junto Rambla Cerca Población) \\
\hline & Mas l'Aller (junto Molí d'Oli) \\
\hline & Mas d'en Costa (camino Salsadella) \\
\hline & Mas d'en Losco (camino a La Jana) \\
\hline & Mas dels Paüls (camino Benicarló) \\
\hline & Mas de la Roca (camino La Jana) \\
\hline & Mas d'en Pere Xerta (cerca pueblo, persiste denominación) \\
\hline & Mas de Vegue (camino Alcala, existe denominación) \\
\hline & Mas Xirosa (hacia San Mateo, existe denominación) \\
\hline \multirow[t]{4}{*}{ Calig: } & Ali (junto población en Els Murrons) \\
\hline & Benigutfur (junto Ali) \\
\hline & Beniterey \\
\hline & Oleya \\
\hline
\end{tabular}




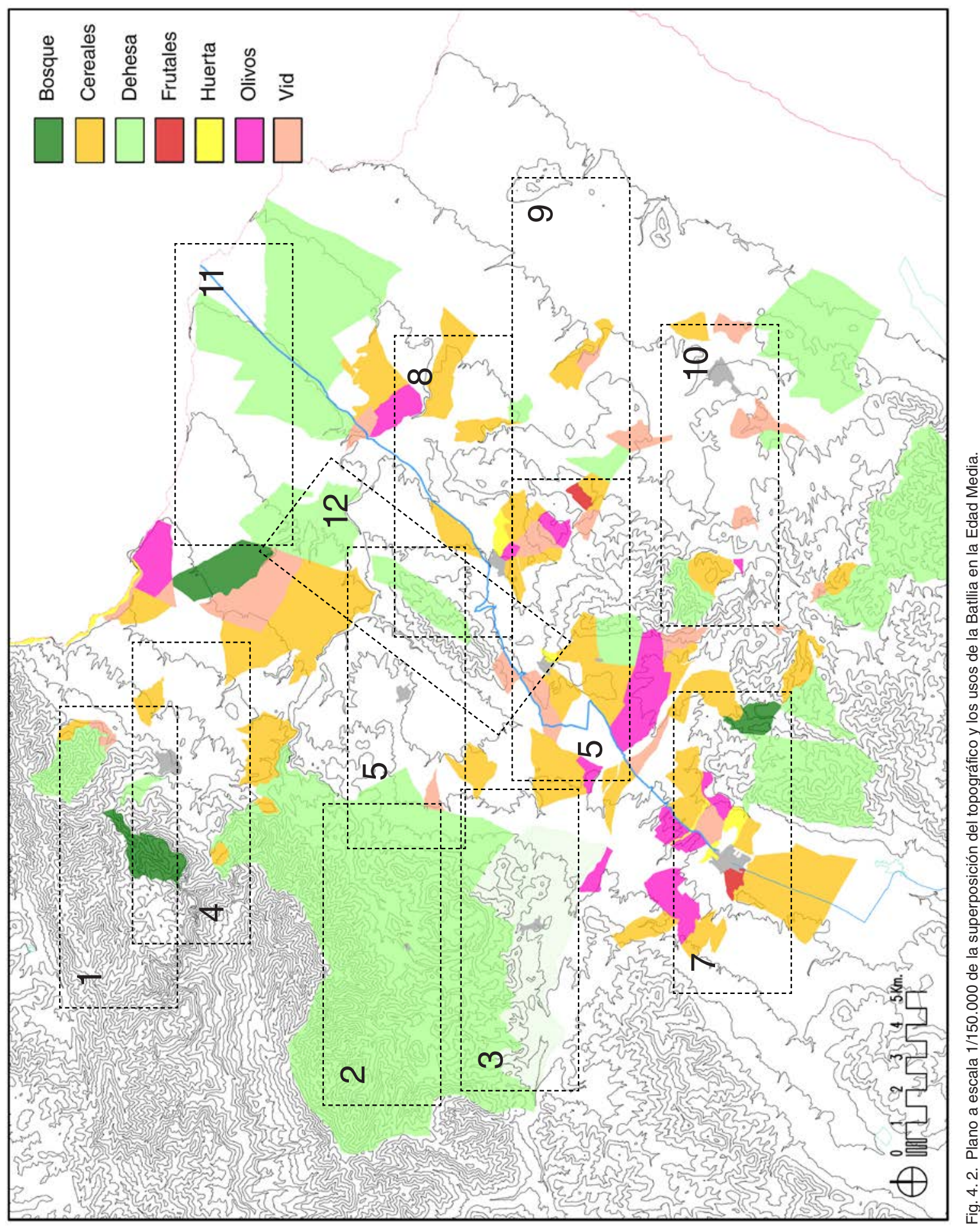




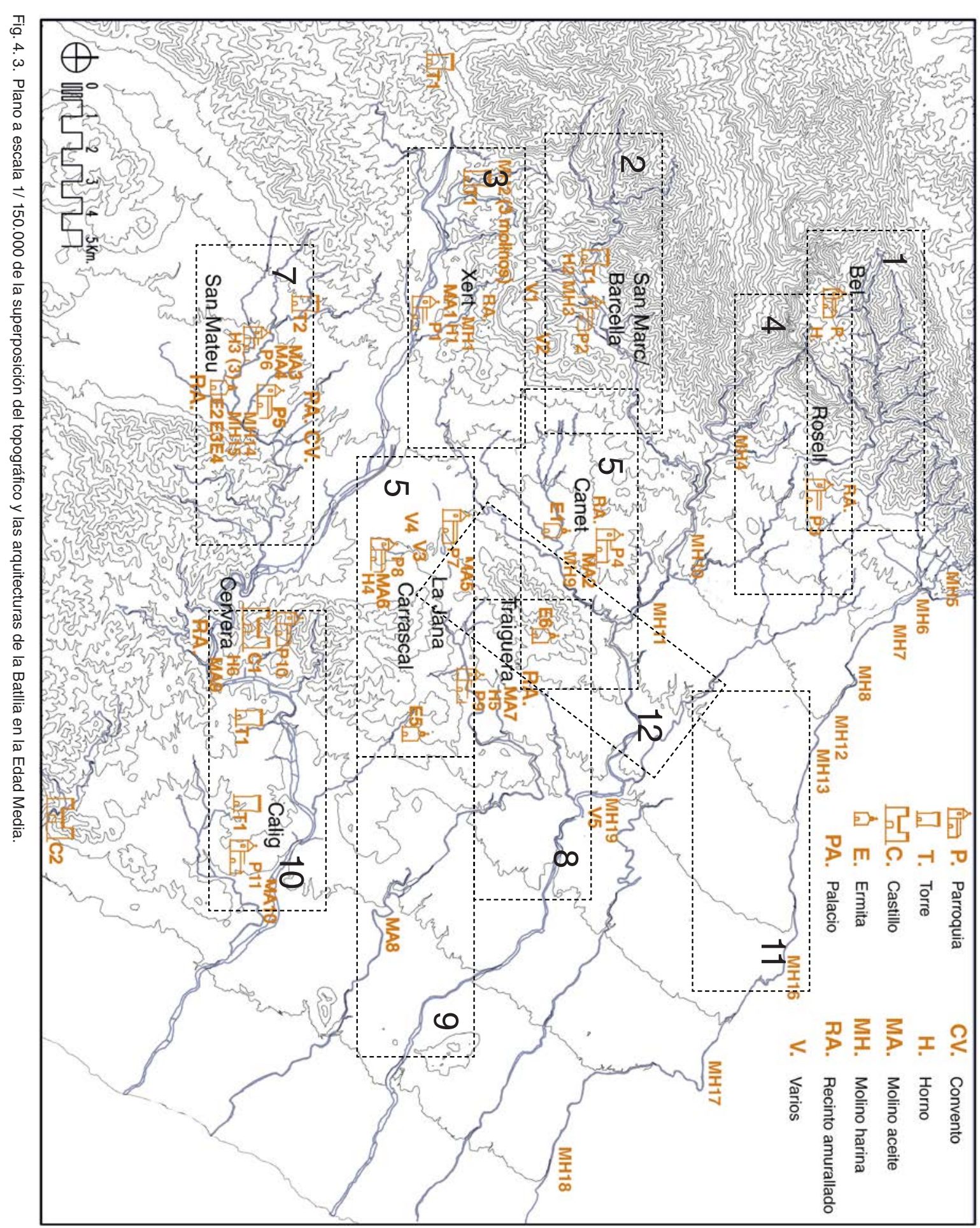




\section{2. Los elementos del territorio antroposocial y su representación gráfica}

El soporte territorial tiene la invisible realidad de una malla abstracta geométrica y etérea que ordena el espacio topológico, sobre la que la intervención humana teje elementos con textura que le dan una dimensión táctil al territorio y que permite transformar en tangible el orden abstracto y etéreo de la malla.

El hombre teje sus actuaciones sobre el cañamazo a la vez que las teje entre sí, obteniendo un "collage" con diferentes texturas y colores. Pero no se trata de meras agregaciones con valor en sí mismas, sino que se integran en el todo armónico de la malla.

Se superponen dos órdenes, uno abstracto y geométrico del soporte y otro táctil, físico, material que refleja como el hombre habita el territorio. Los órdenes están unidos por una secreta energía que los mantiene inseparablemente unidos ya que no son absolutamente independientes. La superposición de estos dos órdenes nos revela así un singular "collage" una superposición de estratos cada uno de ellos con diferentes cualidades espaciales, de acuerdo con un entendimiento estratificado del espacio. En un nivel se presta atención a la estructura en el segundo a lo físico del territorio, a su carácter táctil, matérico.

Son dos ordenes que como dos tramas se superponen creando una realidad única, positivo y negativo, anverso y reverso del territorio, como una figura y el molde que lo produce.

Si contemplamos el territorio desde la distancia para alejarnos de los problemas inmediatos y captar lo más esencial, observamos que el cañamazo es el más resistente al paso del tiempo, menos susceptible de ser alterado, podríamos decir que es un entramado de constantes que es un marco de referencia estable. Sin embargo superpuesto sobre él- tejido- vemos una expresión de lo variable, de lo móvil, de lo cambiante de la vida. Mientras que el cañamazo es un entramado conceptual que nos habla de un espacio abstracto las superposiciones son un mosaico de texturas vivas que nos dice que el territorio no esta constituido por unos volúmenes sueltos que se posan sobre el soporte, sino que la geometría que genera estos volúmenes se funde sutilmente con la naturaleza transformándola.

El análisis del soporte y de los recintos lo hemos hecho a una gran escala y con un zoom de aproximación para analizar las 12 zonas seleccionadas. El análisis de la actuación del hombre sobre el soporte lo haremos a la inversa, partiremos de las actuaciones concretas a una escala próxima y nos iremos alejando paulatinamente.

Para ello partiremos del plano de usos y arquitecturas de la Batllia en la Edad Media y seleccionaremos dentro de las 12 zonas seleccionadas, seis ámbitos que corresponda cada una de ellas a uno de los seis tipos de recinto diferentes que hemos descrito.

Estos ámbitos los seleccionaremos con los siguientes criterios:

- Elementos significativos de cada tipo en ese ámbito.

- Elementos no contaminados por el tiempo.

- Elementos que permitan la lectura como permanencias.

- Densidad de elementos para buscar relaciones.

Una vez seleccionados constatamos que las atalayas son recintos inhabitables que aparecen como hitos o bordes, pero en los que la actividad humana no se desarrolla. Esta nace al abrigo en el fondo de los valles; en la plana surcada por caminos a mitad vertiente y en ocasiones junto a los caminos de carena; dominando los accesos, punteando el altiplano y aprovechando las tierras para el cultivo. La actividad humana transforma el relieve, actúa extensamente sobre los lugares tipo de paisaje y, desde allí, lanza las rutas que dominan los confines y las relaciones con sus vecinos, a partir de un ámbito visual que domina y que le sirve de cobijo. Por ello de los seis ámbitos nos quedamos solo con cinco para hacer el análisis antroposocial y que son: 
- Montaña. Elegimos Bel, que aunque no pertenezca a la Batllia está en el límite y es un caso paradigmático de este tipo por lo que consideramos importante su estudio.

- Valle. Elegimos San Marc de la Barcella.

- Ladera. Elegimos el conjunto Molinar-Xert.

- Llano. Elegimos el entorno de Canet.

- Ondulado. Elegimos el conjunto Cervera-Calig.

$\mathrm{Al}$ igual que en la representación del soporte vamos a grafiar a buscar las leyes geométricas que guían la intervención humana en el territorio de forma que posteriormente las podamos relacionar con los del soporte y nos permita estudiar la relación entre ambas. De la misma forma que hemos encontrado ordenaciones con geometrías sencillas en el soporte, queremos encontrar explicaciones que resuelvan la complejidad de la actuación humana, en una serie de geometrías sencillas que nos permitan entender y proyectarla aunque sea parcialmente o por trozos. Las dos lecturas posibles del territorio se reducen a una cuestión geométrica.

Vamos a representar las huellas del hombre sobre el territorio y al cotejarlos con los elementos topográficos considerados representativos, nos permitirán representar la vocación del territorio, el carácter determinista de la correlación de hechos sobre un tipo geológico de origen que postulaba Vidal La Blanche, en definitiva esa "vocación" no deja de ser el desarrollo natural de la topología.

Conviene construir la imagen del territorio y entender su composición territorial de cada conjunto de asentamientos, que no puede limitarse a una mancha homogénea en un puzzle de colores. Toda la historia social esta descrita en la disposición de los caminos, en los lugares de intercambio, en la ruptura de los cultivos, en la construcción de los canales o en el cultivo de las huertas, en las formas de la propiedad o el crecimiento de las ciudades.

Realizaremos un juego de planos de cada uno de las cinco zonas de estudio partiendo del ámbito de las arquitecturas y ampliándolo al del espacio de actuación y posteriormente llegar al envolvente. Nos interesa representar el territorio como lugar de la vida humana y como resultado cultural de su huella. Posteriormente realizaremos a una escala más grande una serie de planos sintéticos y analíticos que nos permitirán analizar globalmente en cada uno de las zonas de estudio las redes "marcadas" sobre el territorio por la acción humana y compararlas entre ellas para destacar el carácter de cada una de ellas.

Los planos los dibujamos a partir de la propia realidad, del levantamiento de los elementos de forma directa con su medición, levantamiento topográfico y un completo levantamiento fotográfico.

De las cinco zonas que hemos seleccionado de la Batllia para el análisis -montaña, valle, ladera, llano y ondulado- seleccionamos de cada una de ellas algunos trozos -diecisiete en total- para estudiarlos con mayor detalle a escala 1:500 y realizar un análisis morfológico de las mismas. Detallaremos y representaremos gráficamente los caminos, azagadores, acequias, cauces de río o barrancos, superficies de cultivo, muros, arquitecturas, etc.; con sus correspondientes texturas y volúmenes que emergen visualmente en el territorio. La representación gráfica se realizara tanto en AutoCAD 2012 como en SketchUp Pro 8, de forma que obtendremos tanto plantas, alzados, secciones y volúmenes de los elementos del territorio.

La escala inicial de estudio la ampliaremos sucesivamente a 1:1.000, 1:2.000, 1:5.000, 1:7.500, 1:15.000 y finalmente a 1:40.000, en cada una de estas escalas continuaremos con el análisis morfológico de los distintos elementos y sistemas del territorio.

Esta información gráfica es la que usaremos de base para el posterior desarrollo de la tesis. Los elementos de con-formación que desarrollaremos a continuación en este capítulo los representaremos ampliando la escala hasta 1: 75.000 para realizar las comparaciones entre los distintos tipos de recintos entre los distintos elementos y redes antroposociales, así como su relación con el propio soporte o cañamazo del soporte natural. 
Mapa general (situación de las zonas de estudio) - $[e=1 / 200.000]$

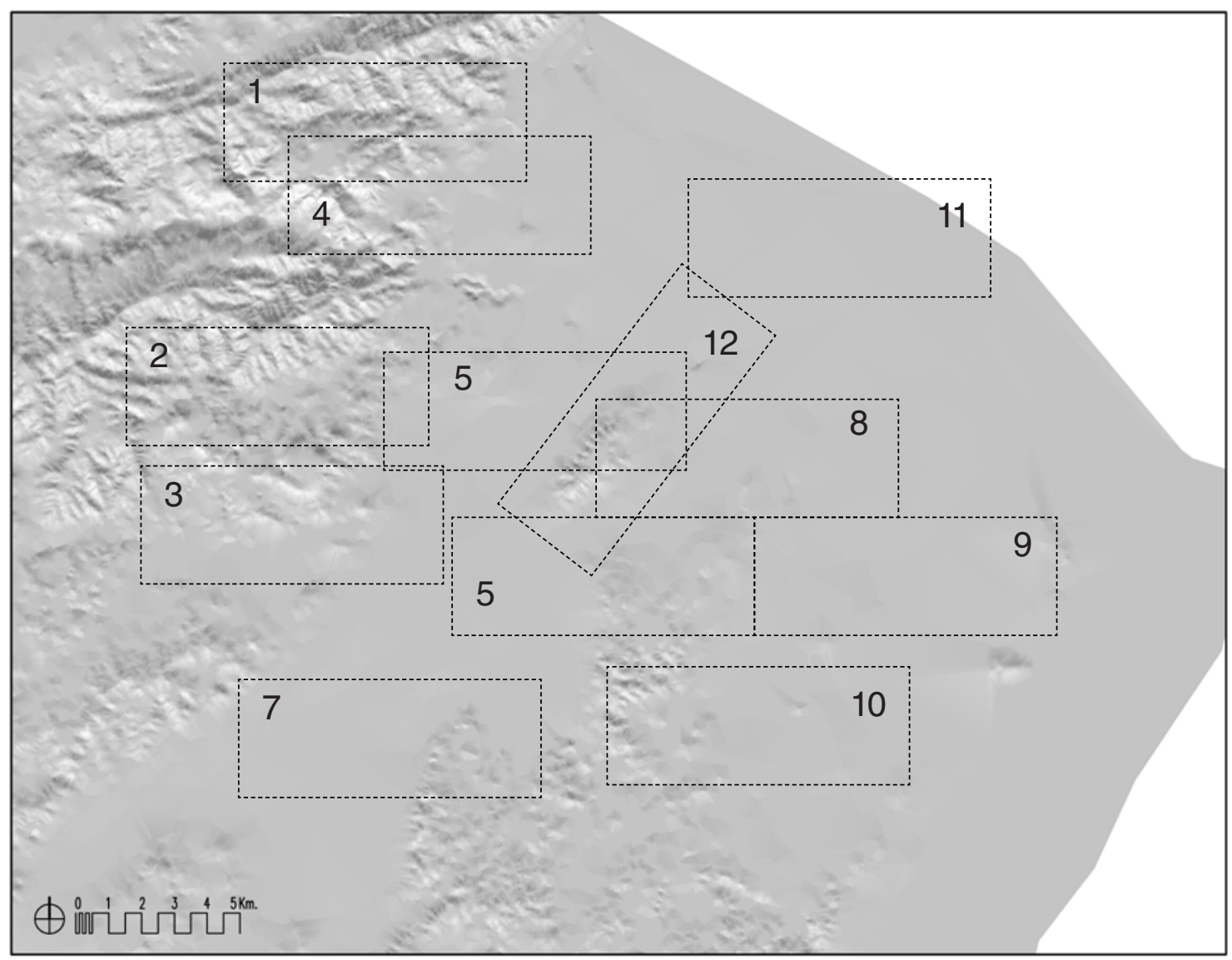

Fig. 4. 4. Plano 1/200.000 de la topografía de la Batllia y de las 12 zonas de estudio.

Detalle zona 1 (situación de los elementos de interés) - [e=1/60.000]

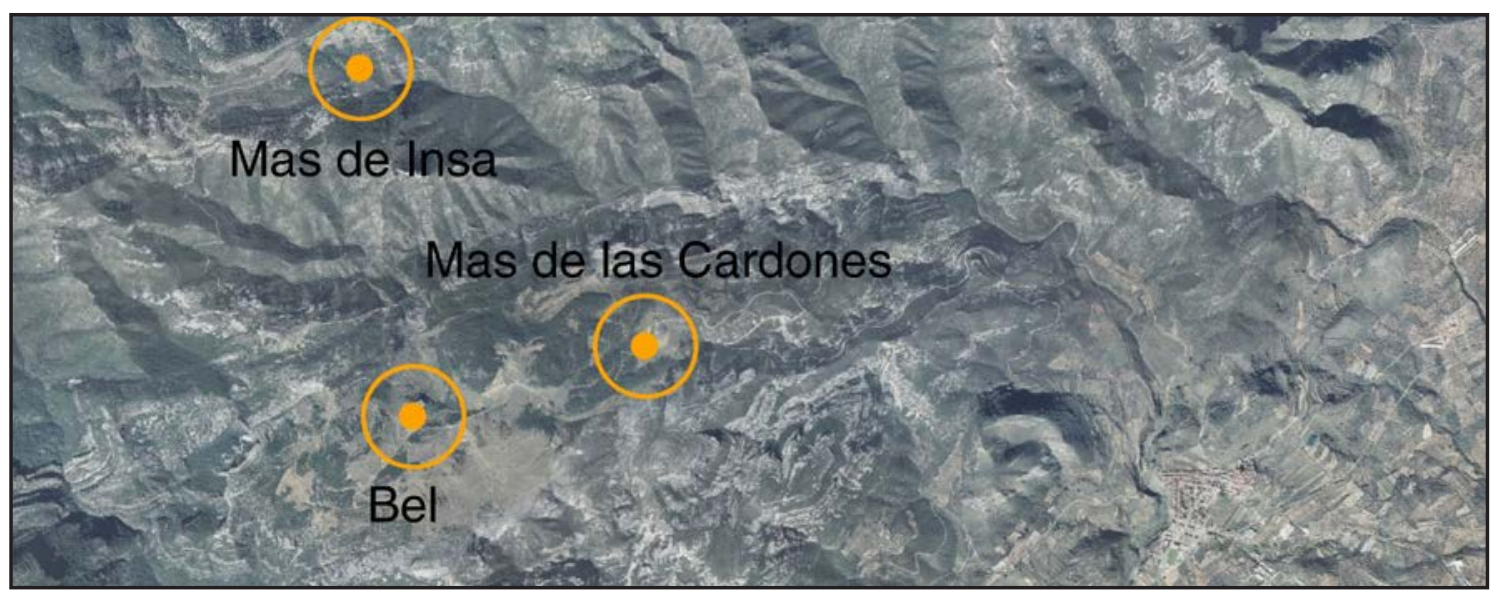

Fig. 4. 5. Ortofoto $1 / 60.000$ de la zona 1 con la ubicación de las arquitecturas que se estudian. 


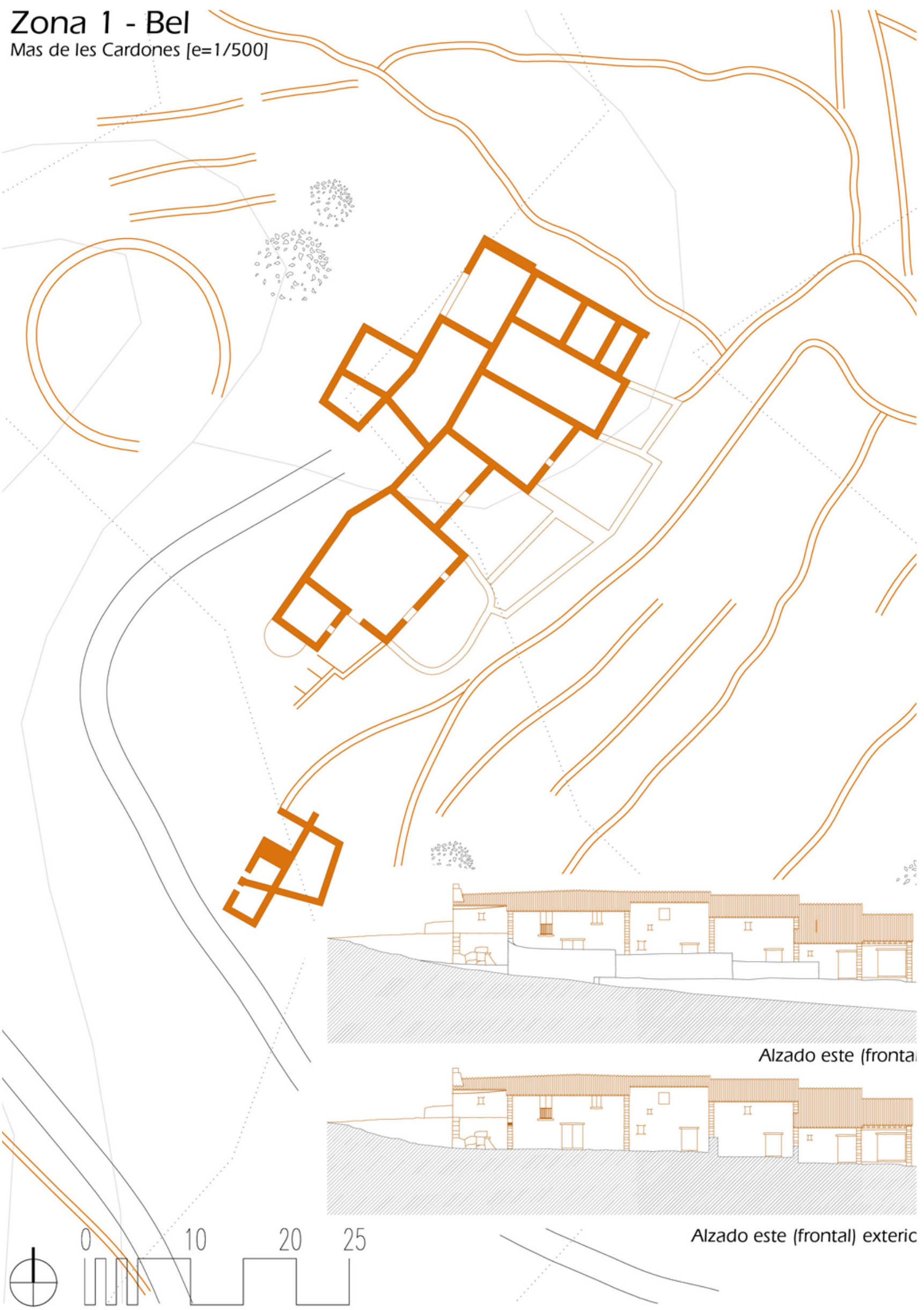



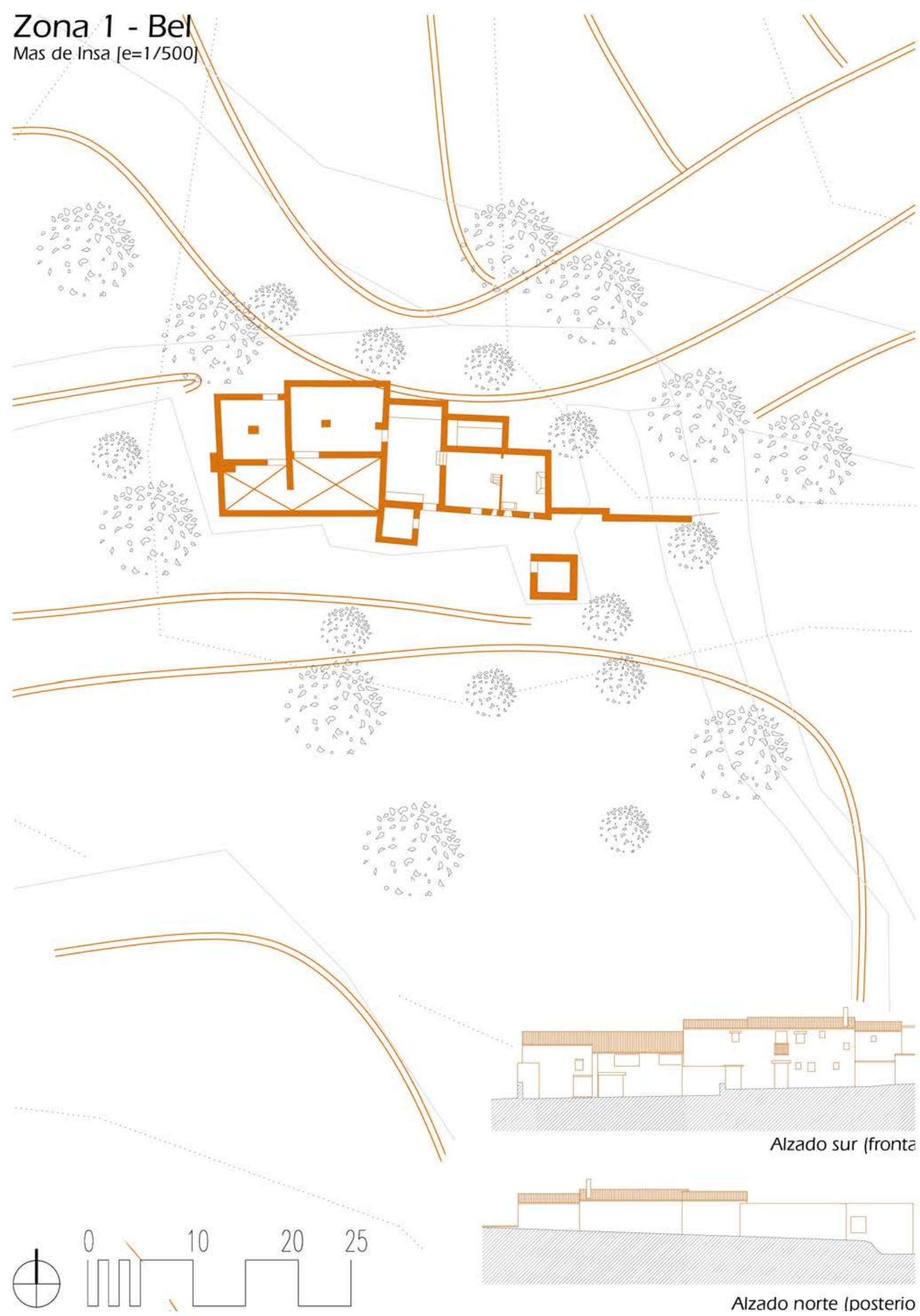


\section{Zona 1 - Bel} tglesia de Bel $[\mathrm{e}=1 / 500]$
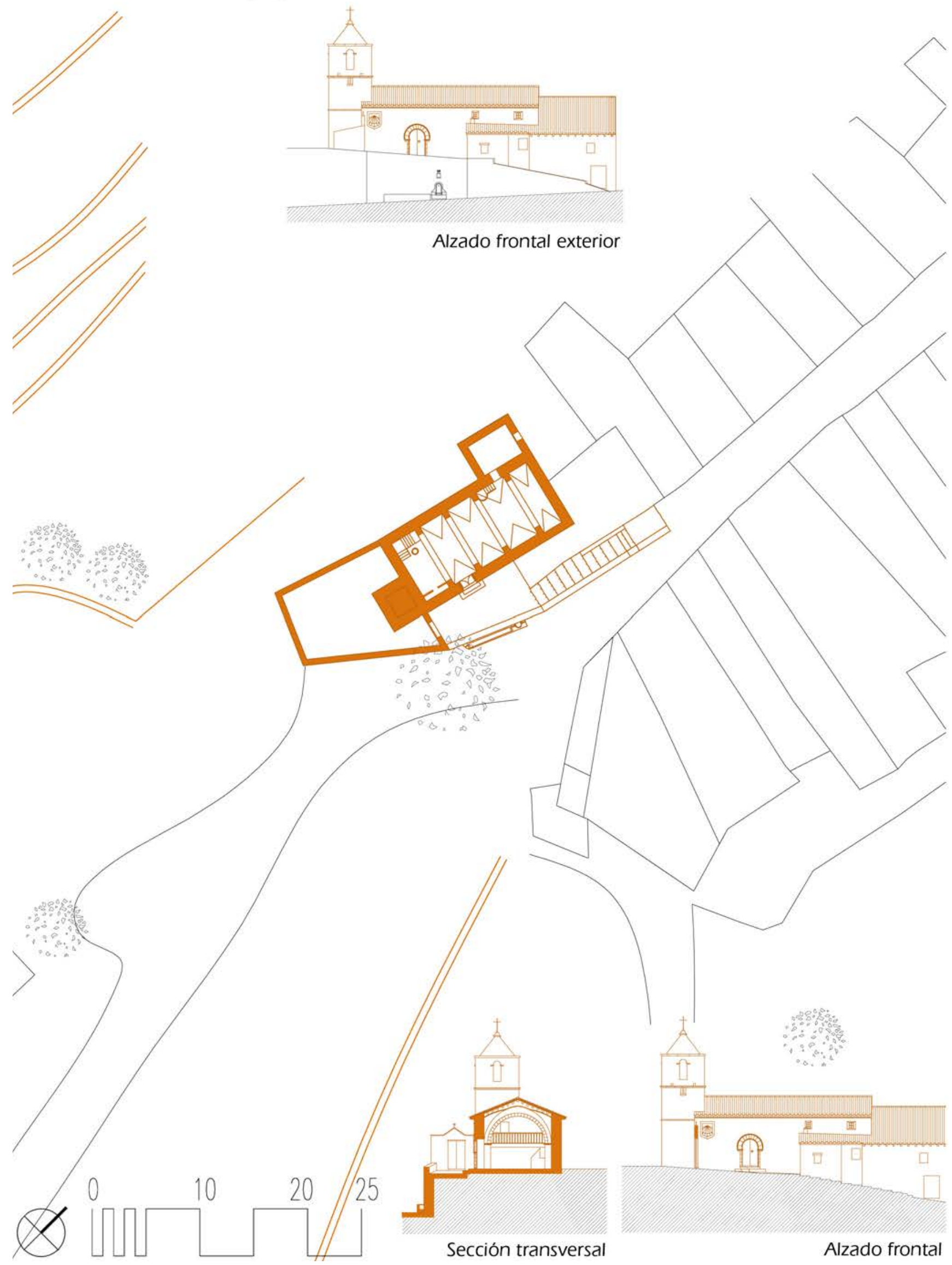


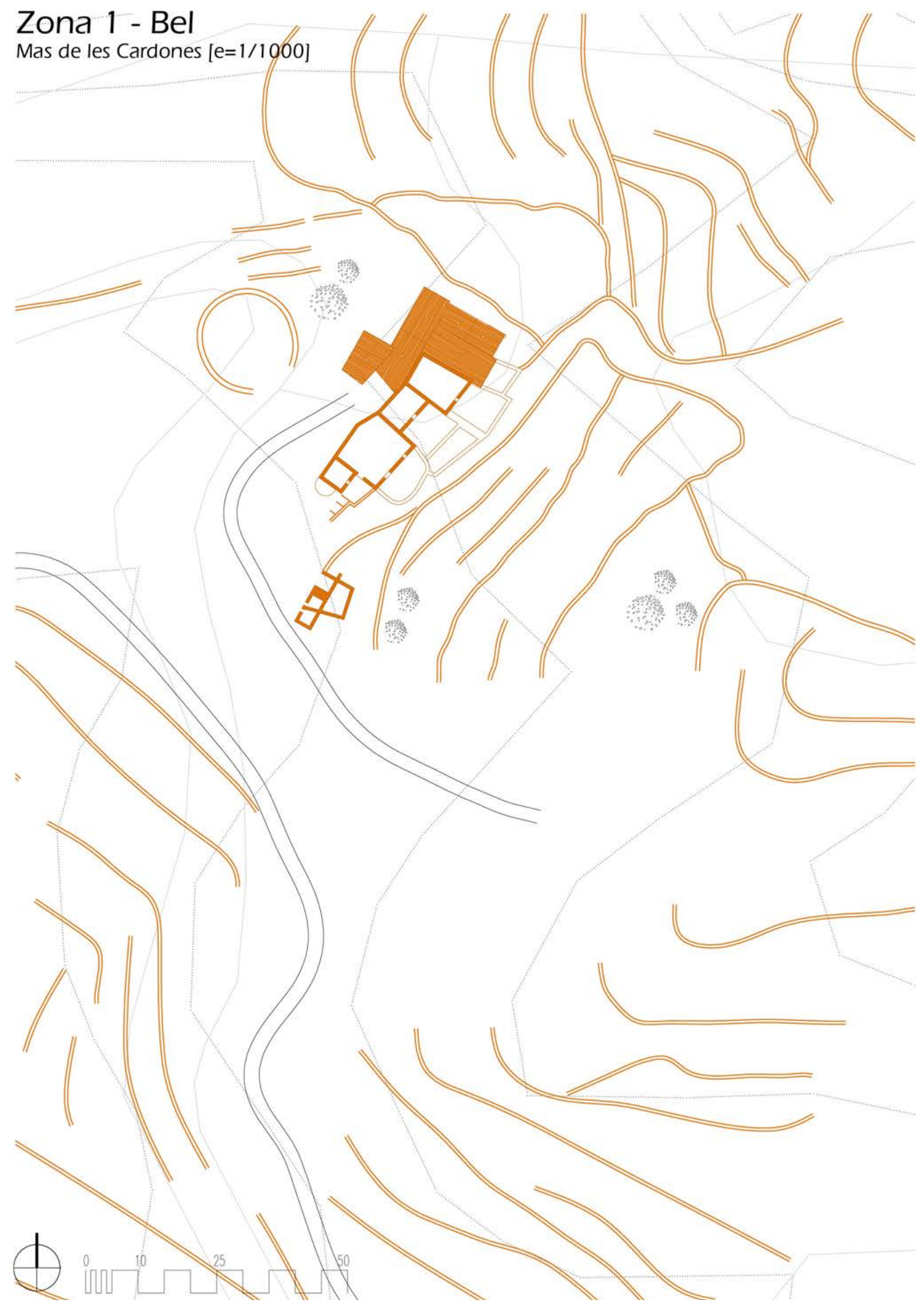




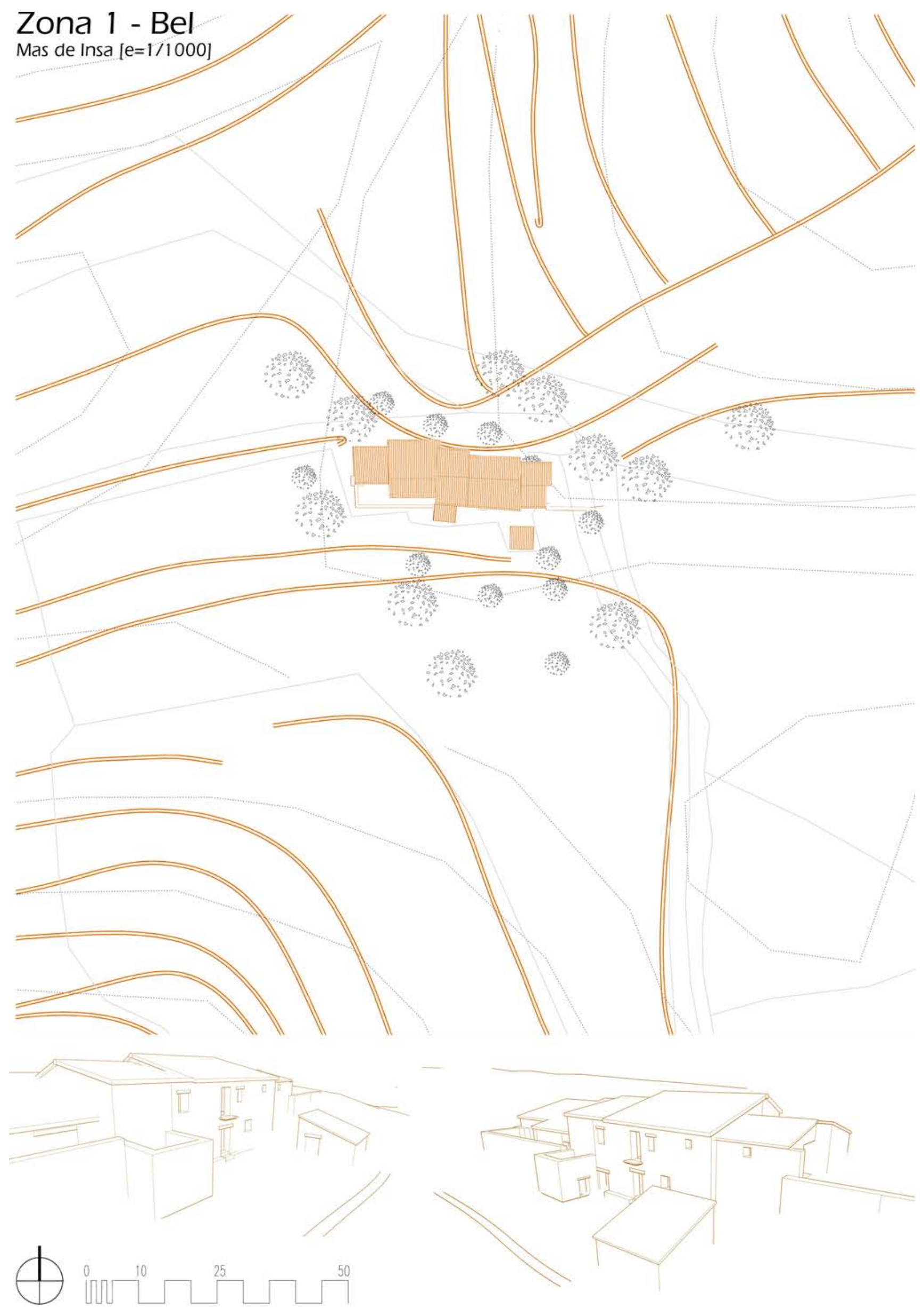




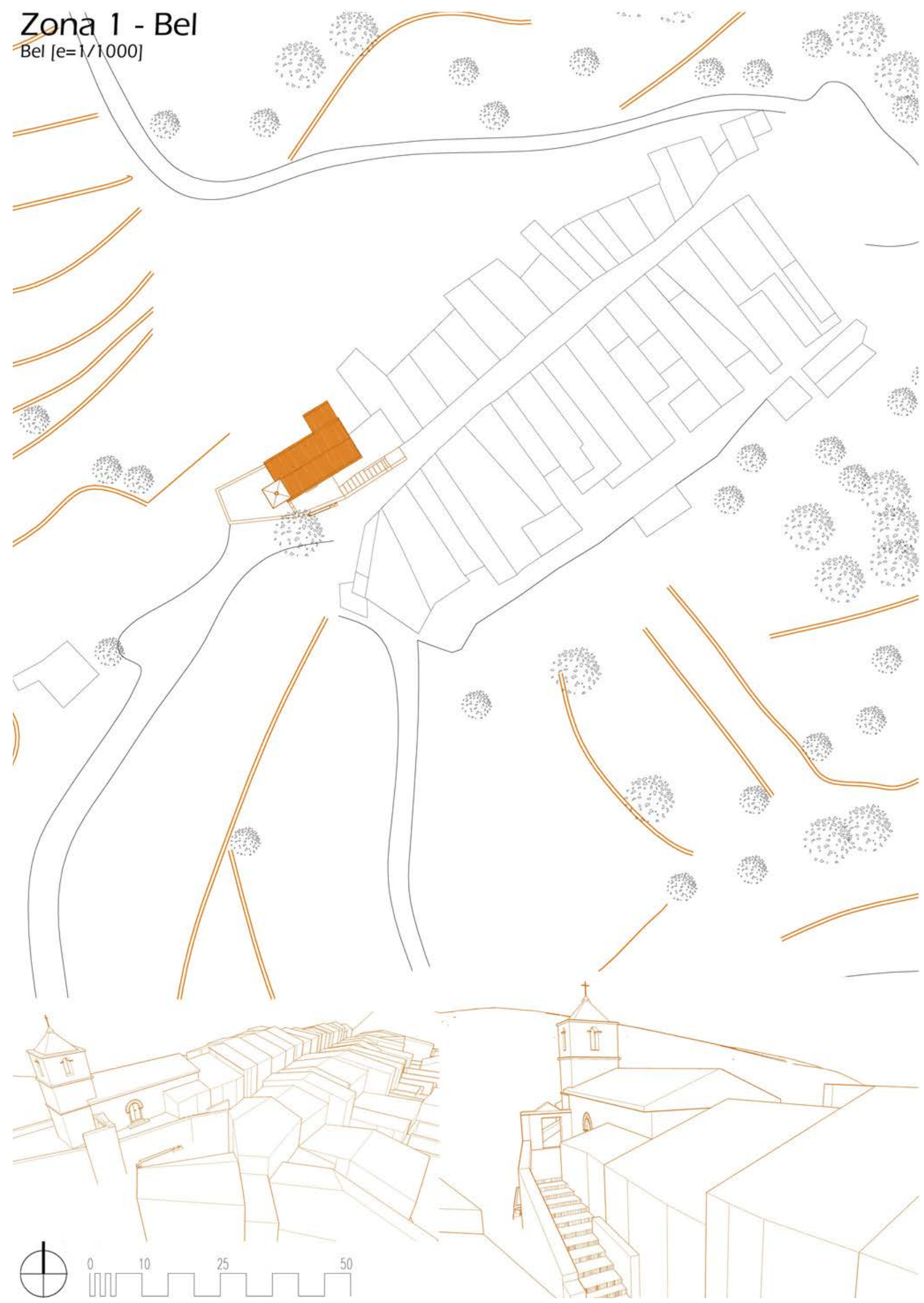




\section{Zona 1 - Bel}

Entorno Mas de les Cardones [e $=1 / 2000]$

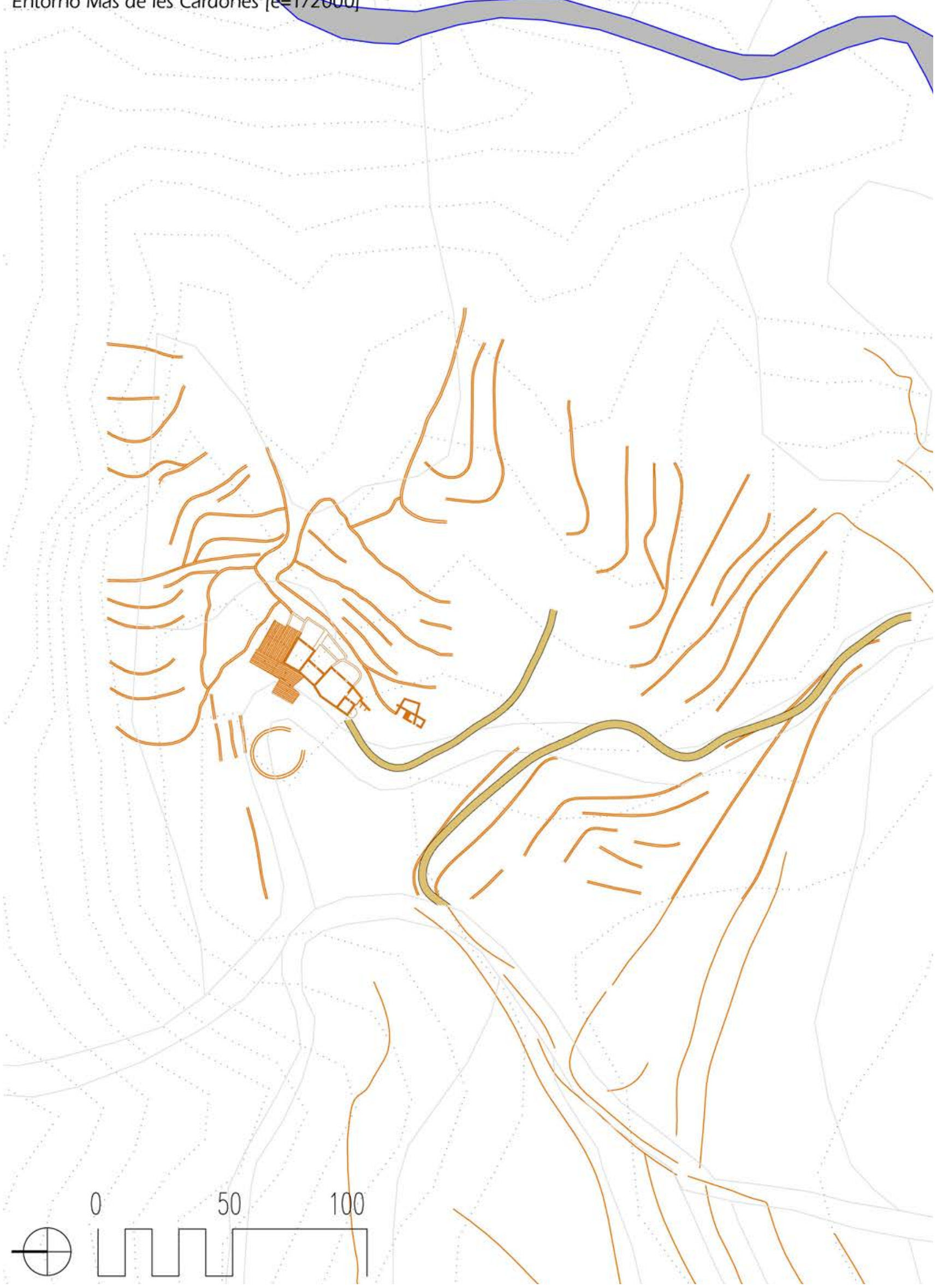




\section{Zona 1 - Bel}

Entorno Mas de Insa $[\mathrm{e}=1 / 2000]$

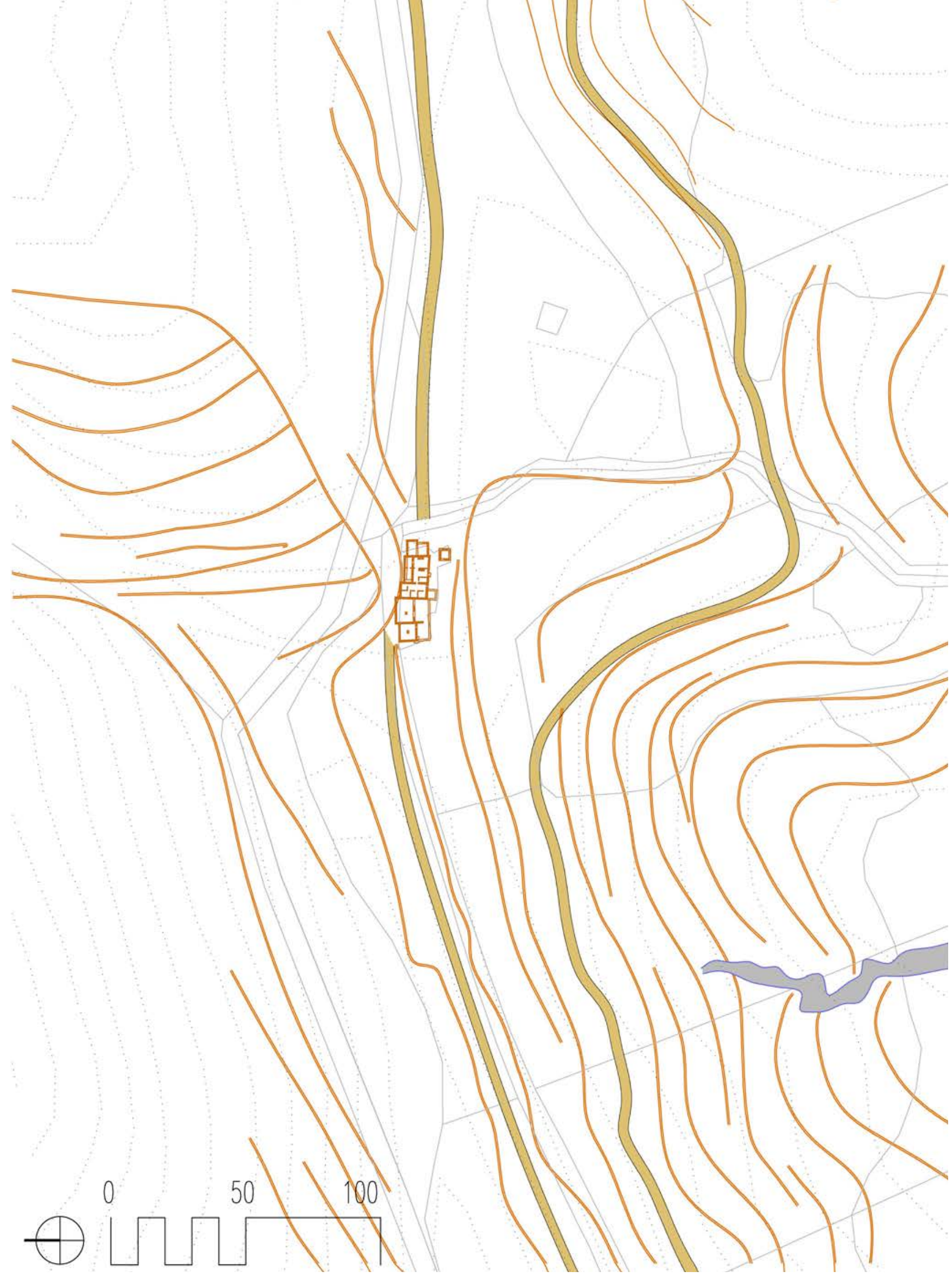




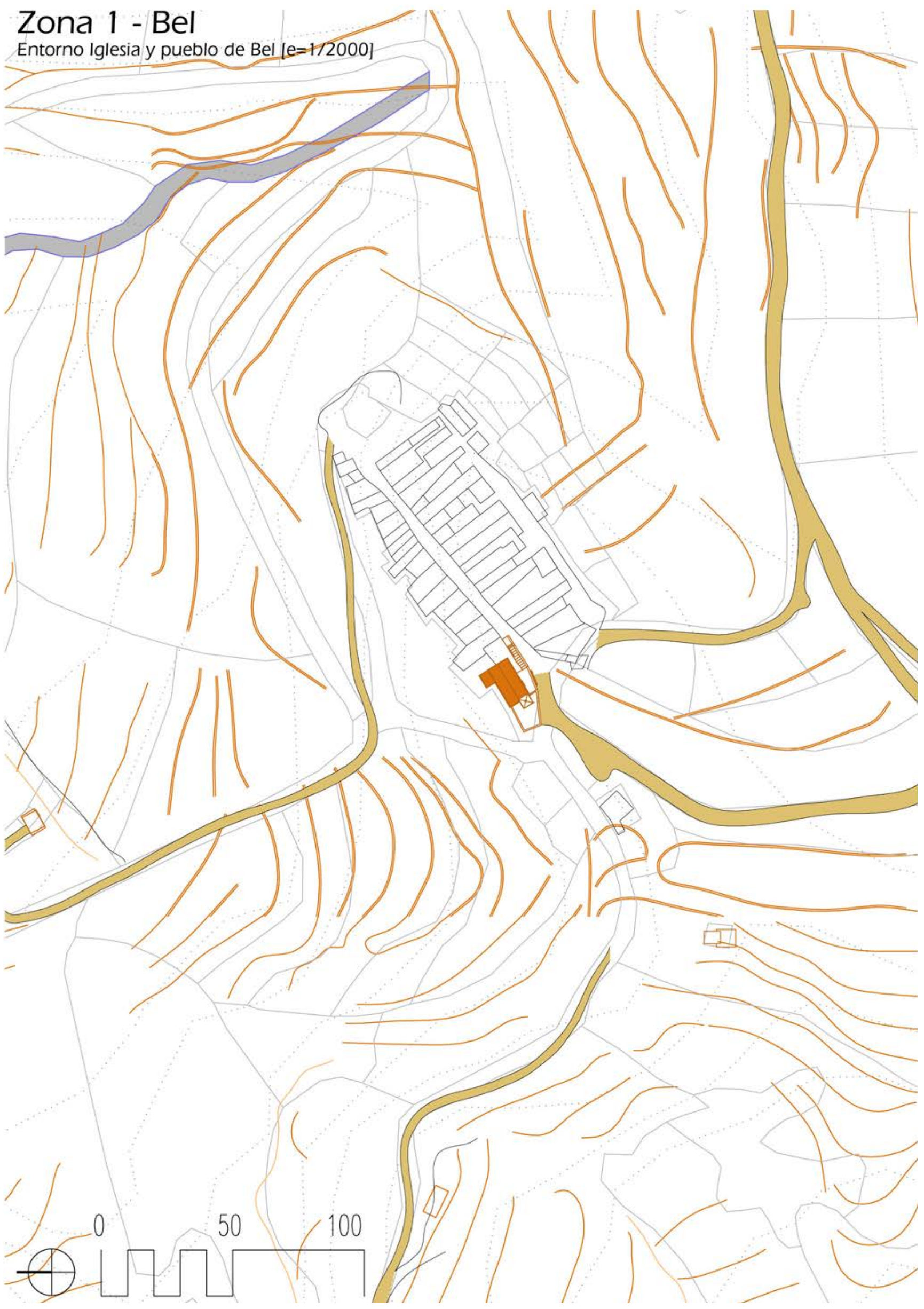




\section{Zona - Bél} Morfologia entorno Bel $[\mathrm{e}=1 / 5000]$

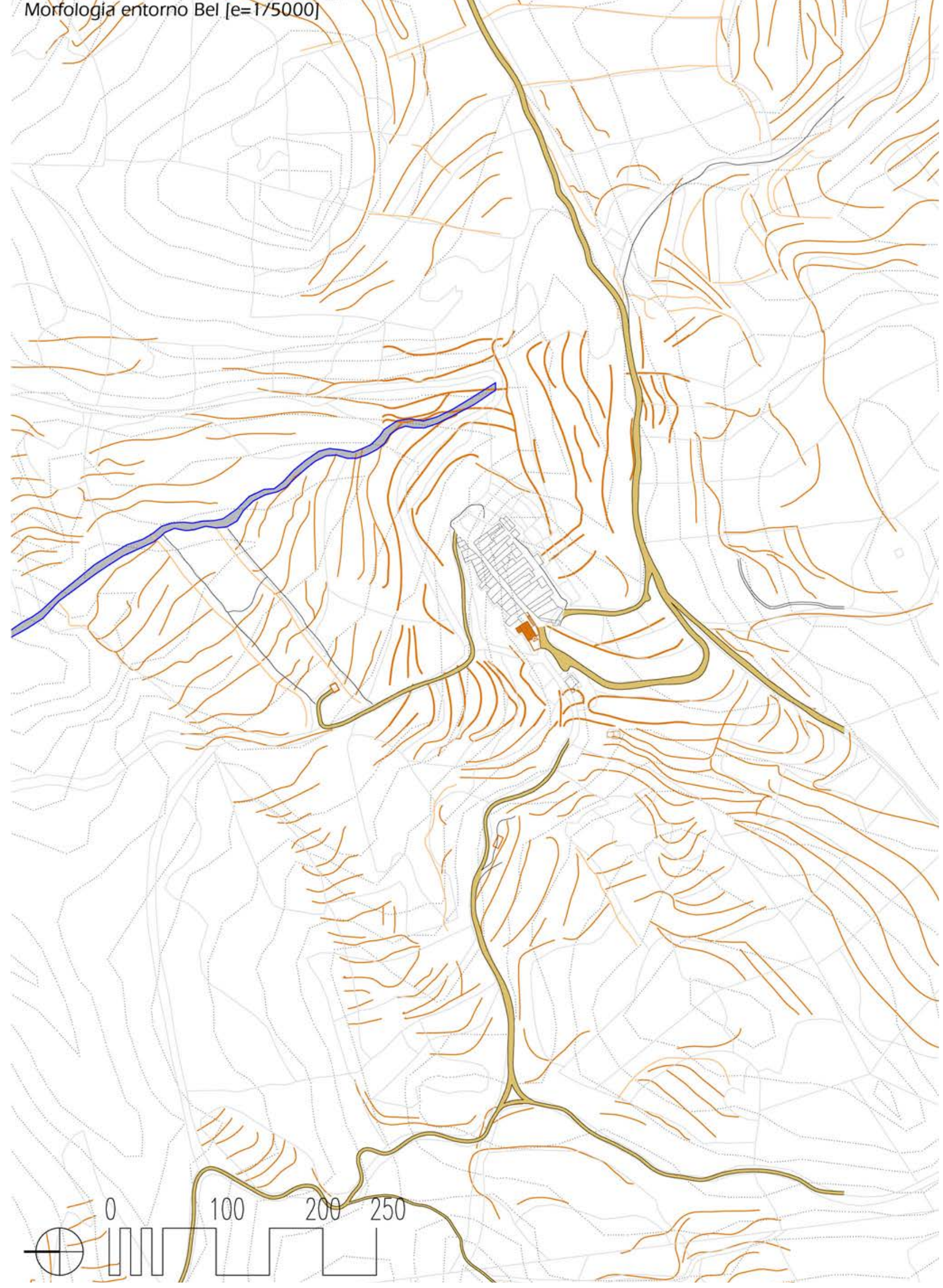




\section{Zona 1 - Bel}

Morfologia entorno Bel y Mas de les Cardones yè $=1 / 775001$

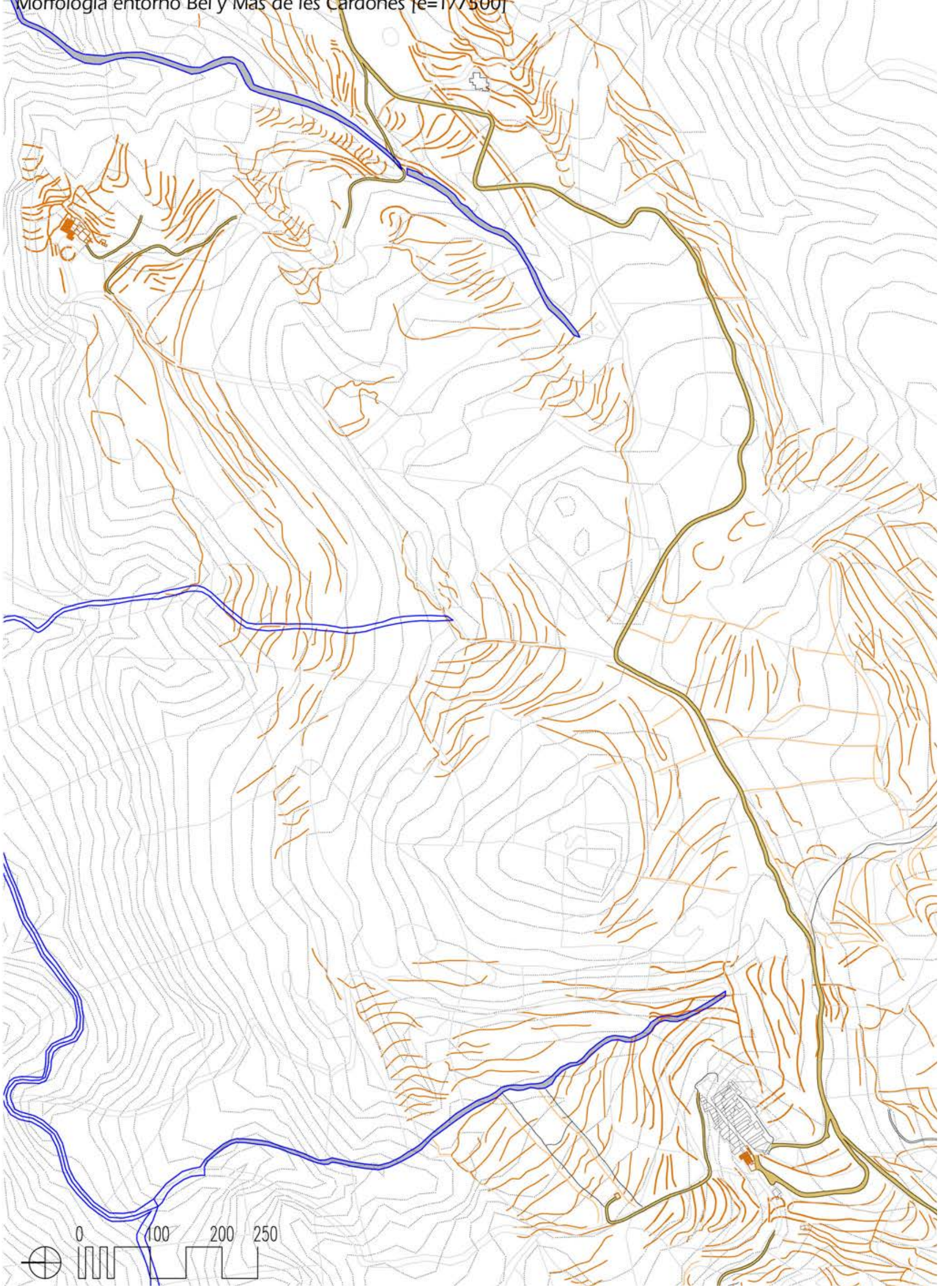




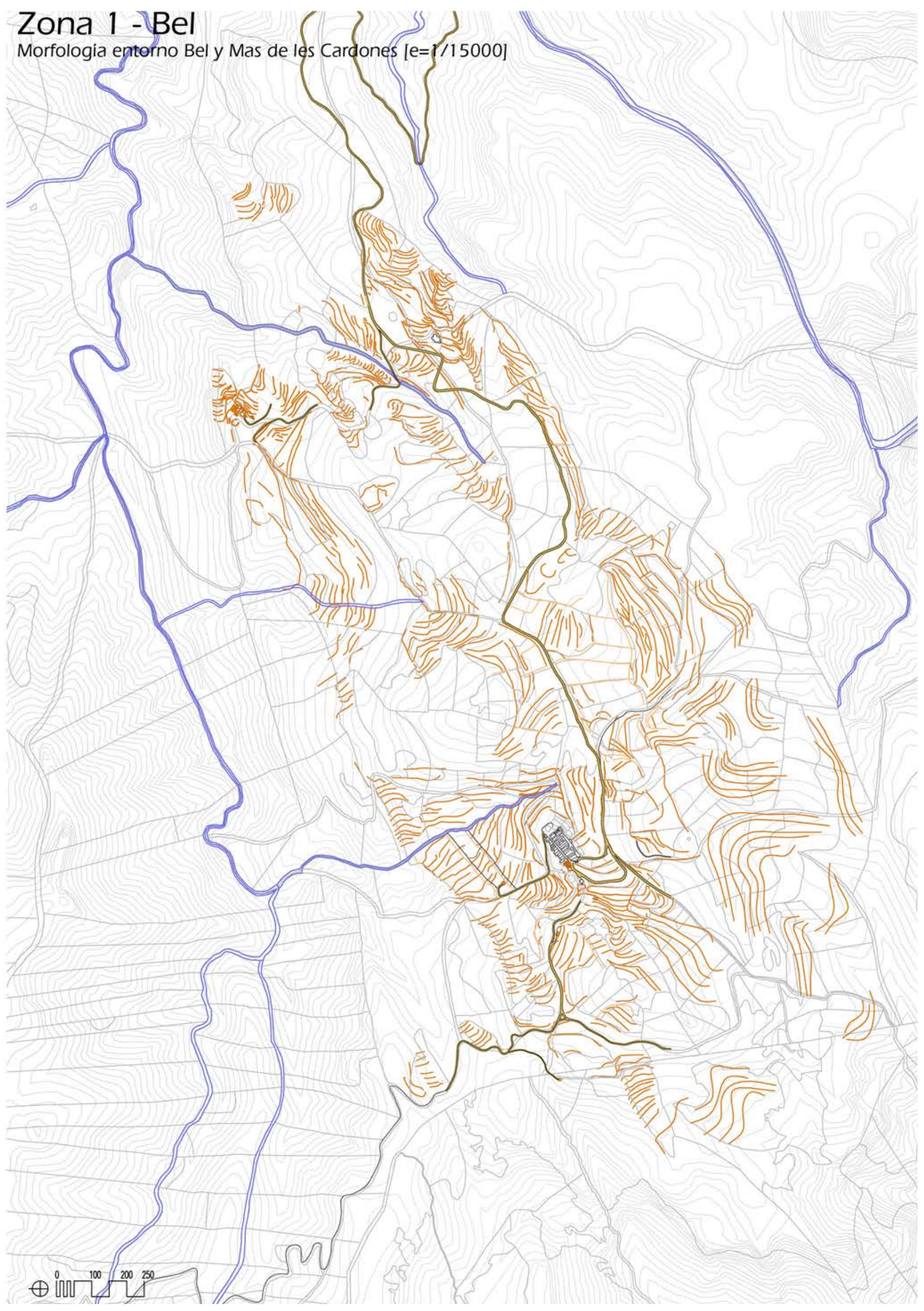


Plano parcelario + muros + bancales zona $1-[e=1 / 40.000]$

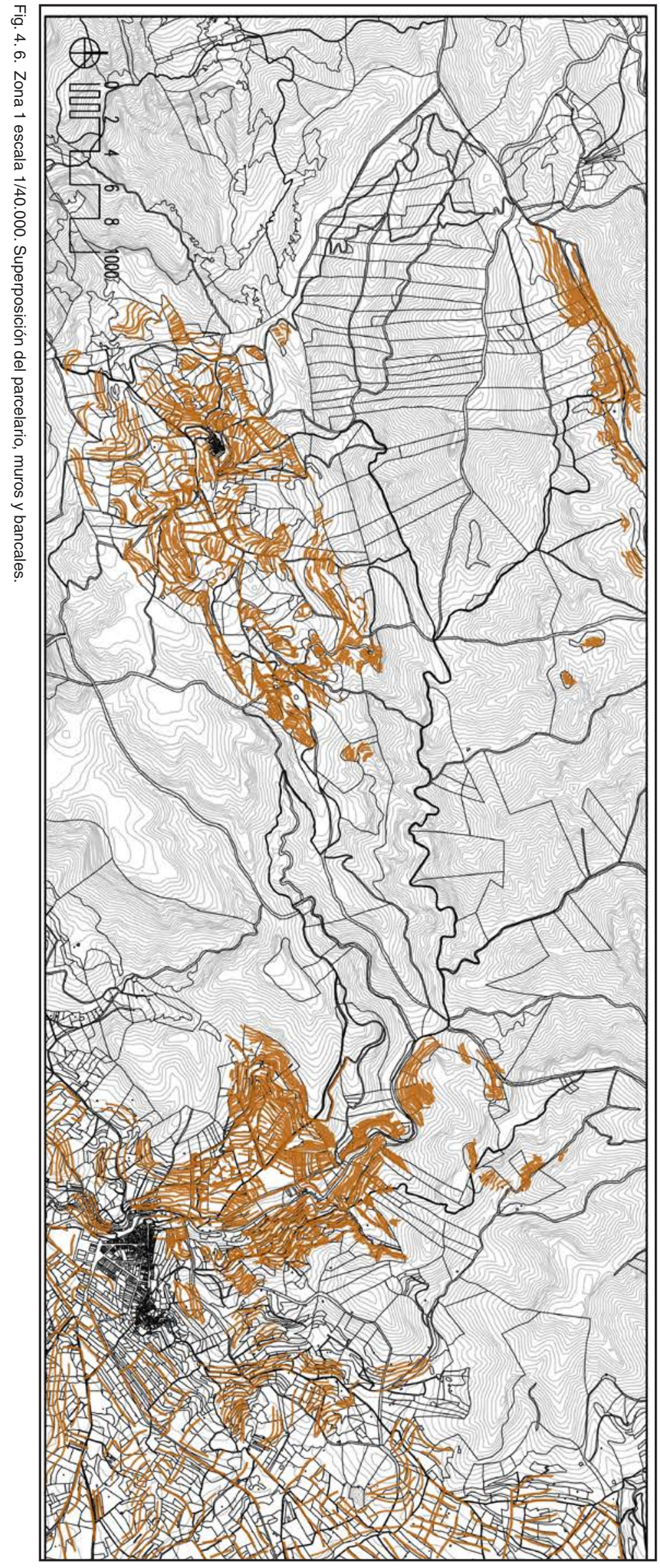


Ortofoto zona 1 - [e=1/40.000]

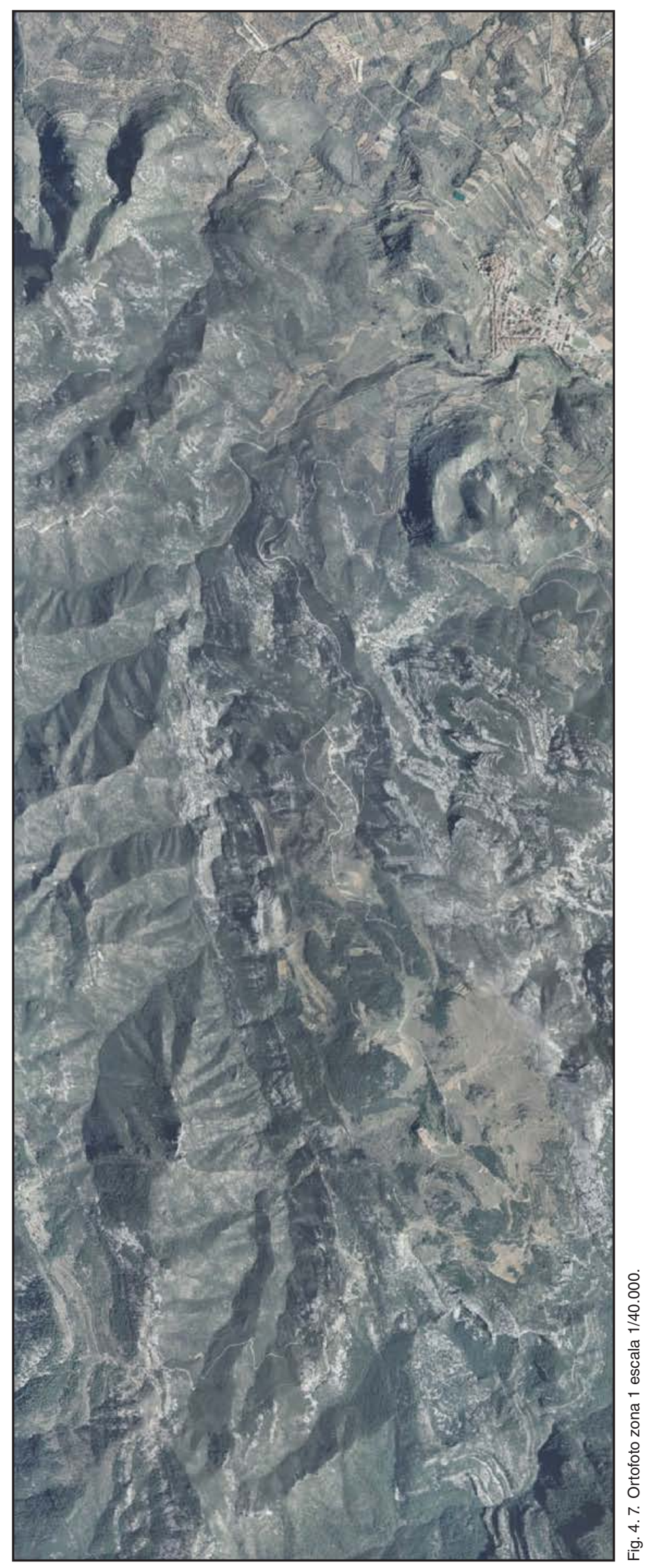


Mapa general (situación de las zonas de estudio) - $[e=1 / 200.000]$

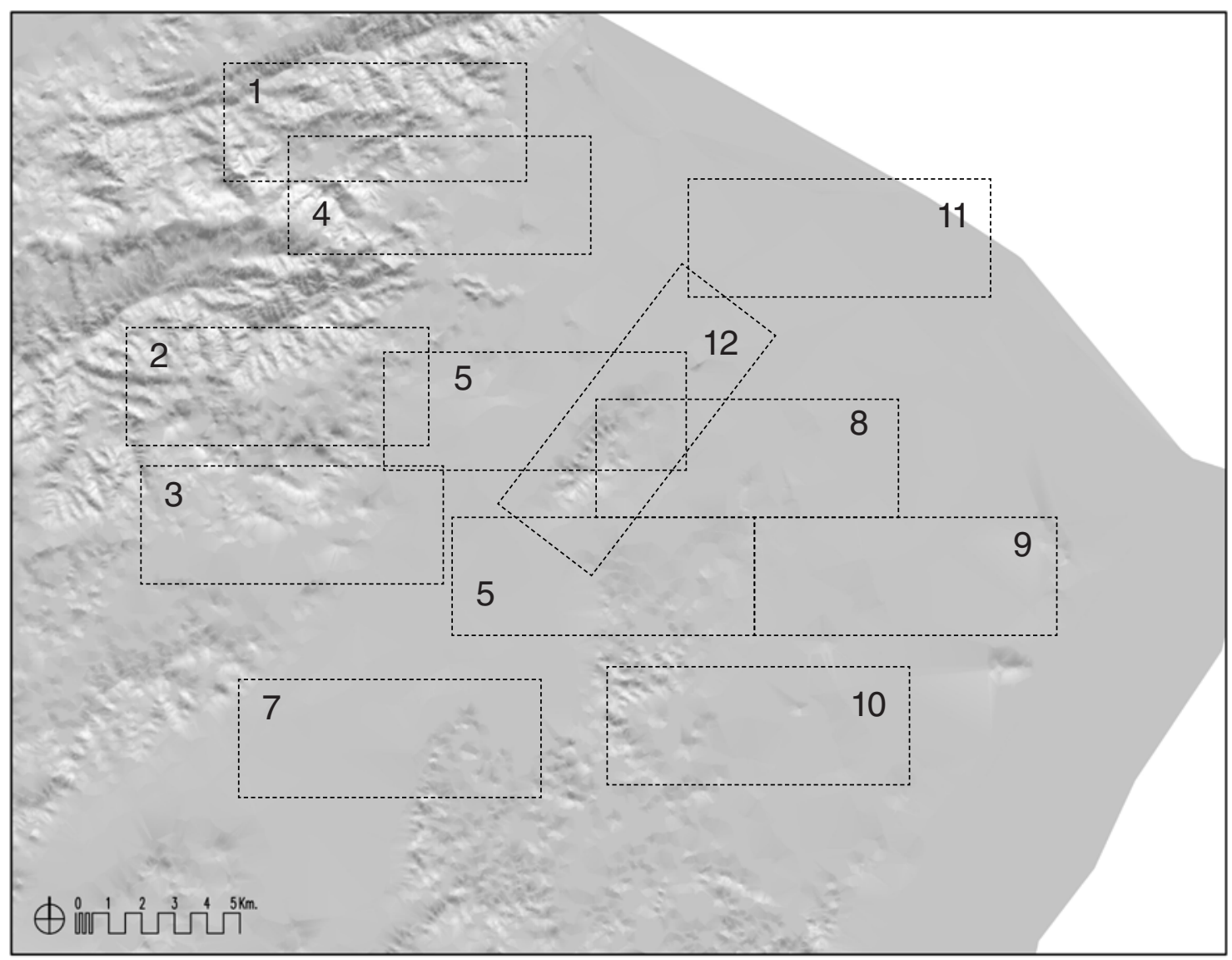

Fig. 4. 8. Plano 1/200.000 de la topografía de la Batllia y de las 12 zonas de estudio.

Detalle zona 2 (situación de los elementos de interés) - [e=1/60.000]

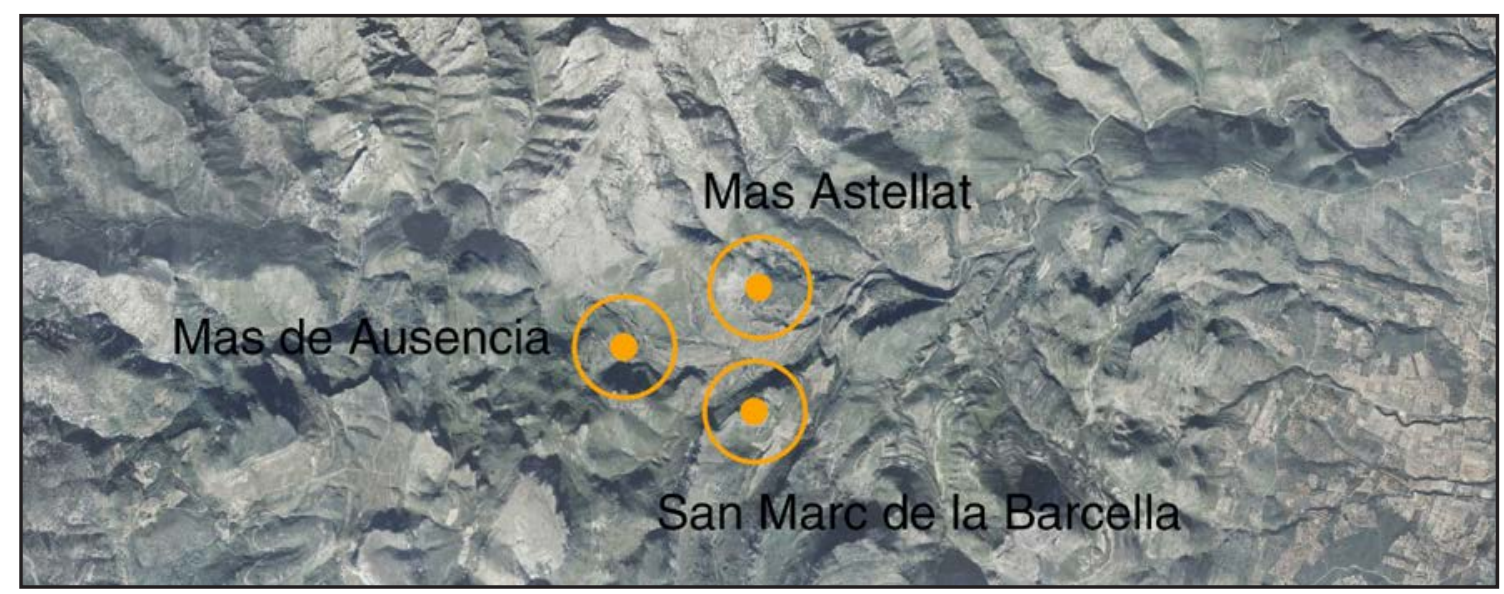

Fig. 4. 9. Ortofoto $1 / 60.000$ de la zona 2 con la ubicación de las arquitecturas que se estudian. 


\section{Zona 2 - Barcella}

Ermita de San Marc de la Barcella $[e=1 / 500$ ]

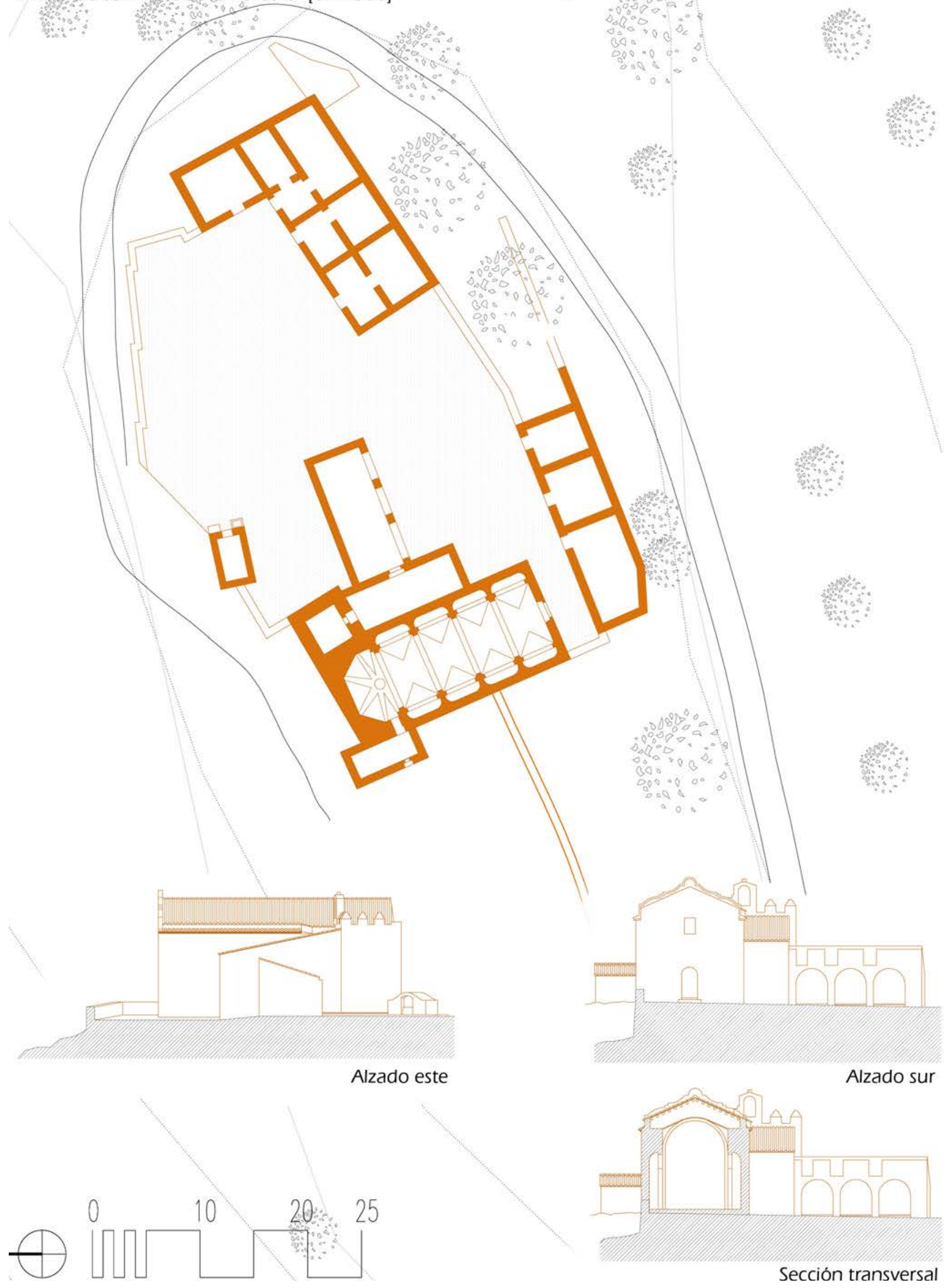




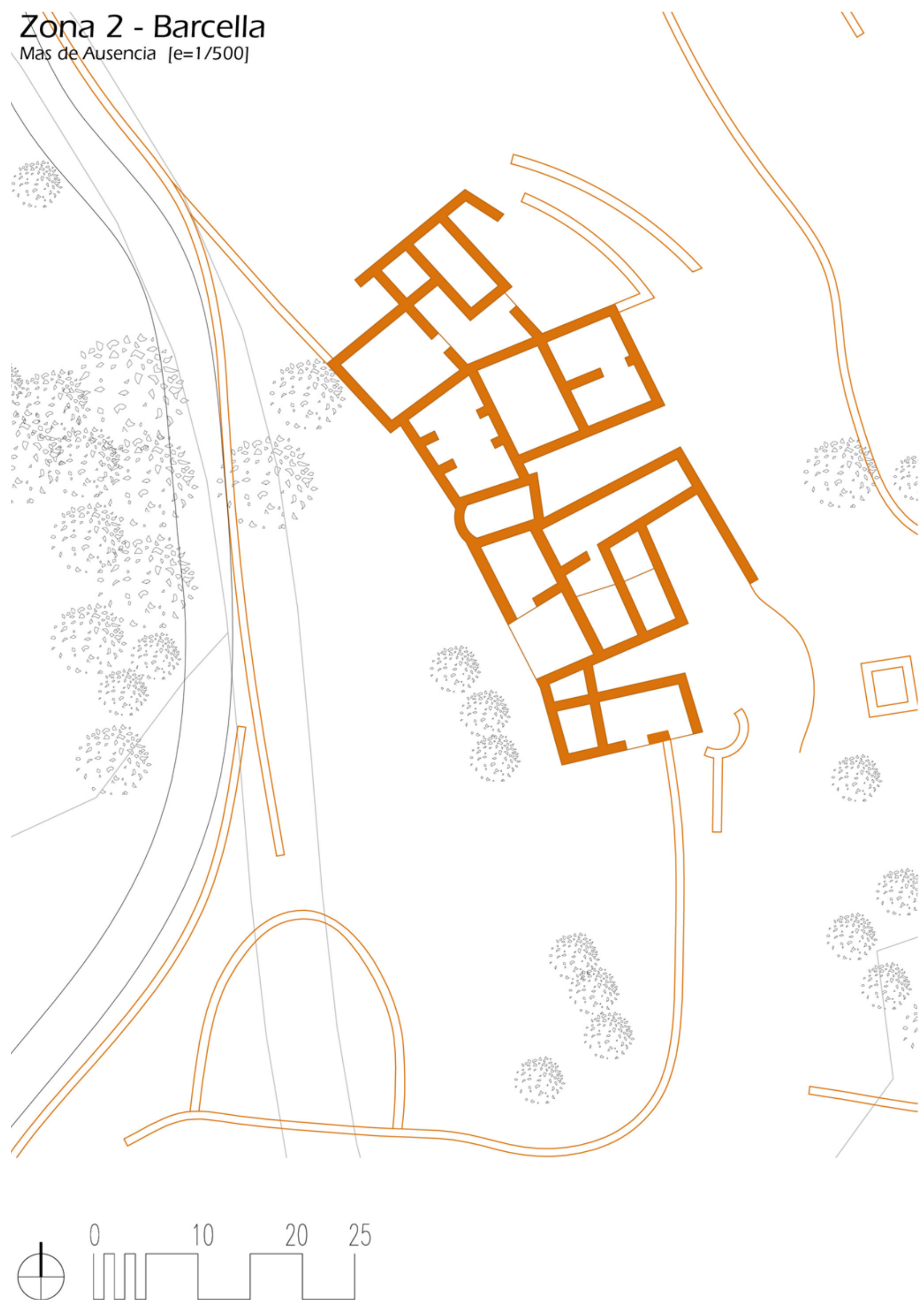




\section{Zona 2 - Barcella Mas Astellat $[e=1 / 500]$}

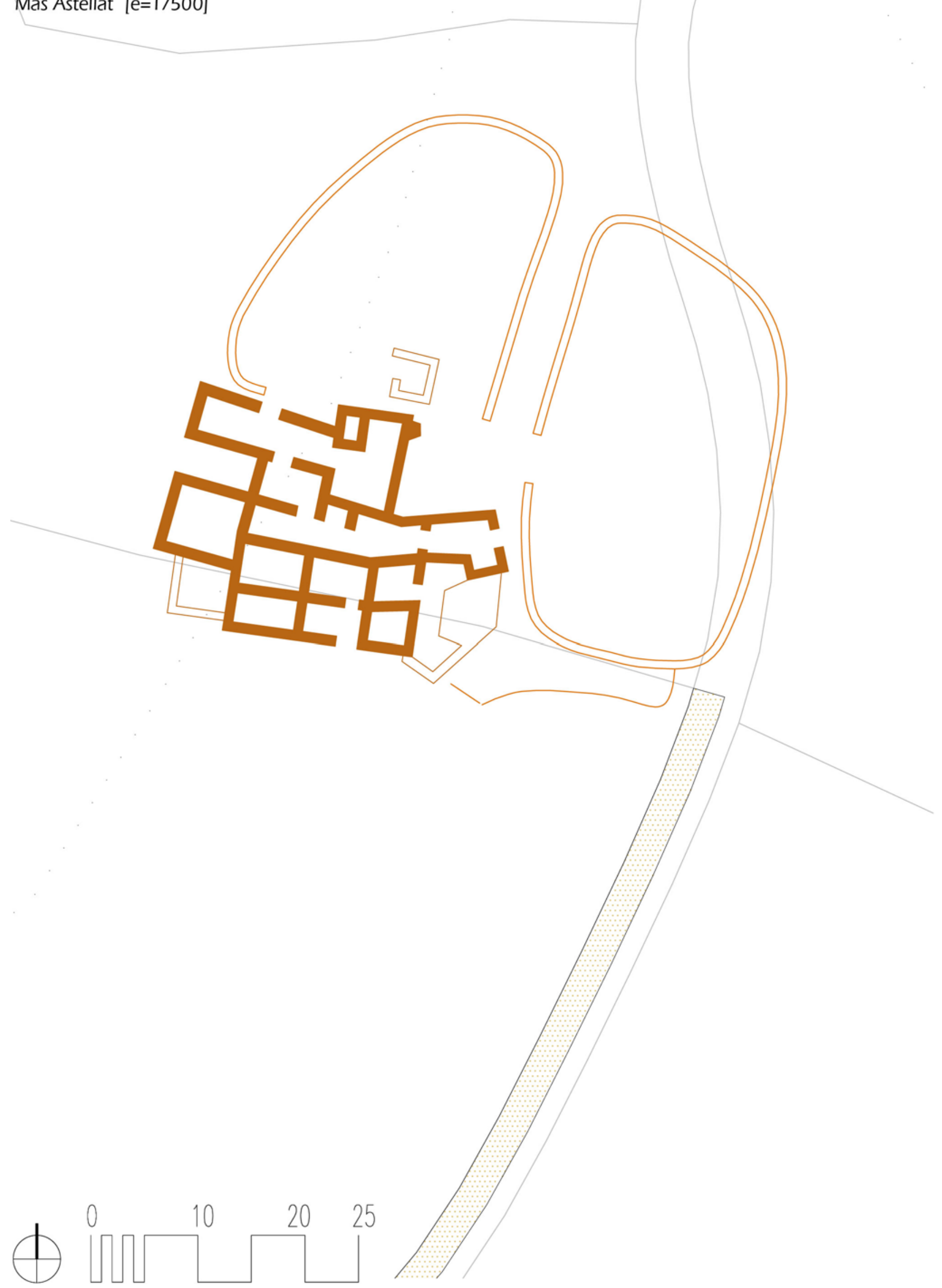




\section{Zona 2 - Barcélla}

Ermita San Marc de la Barcella [e=1/1000]

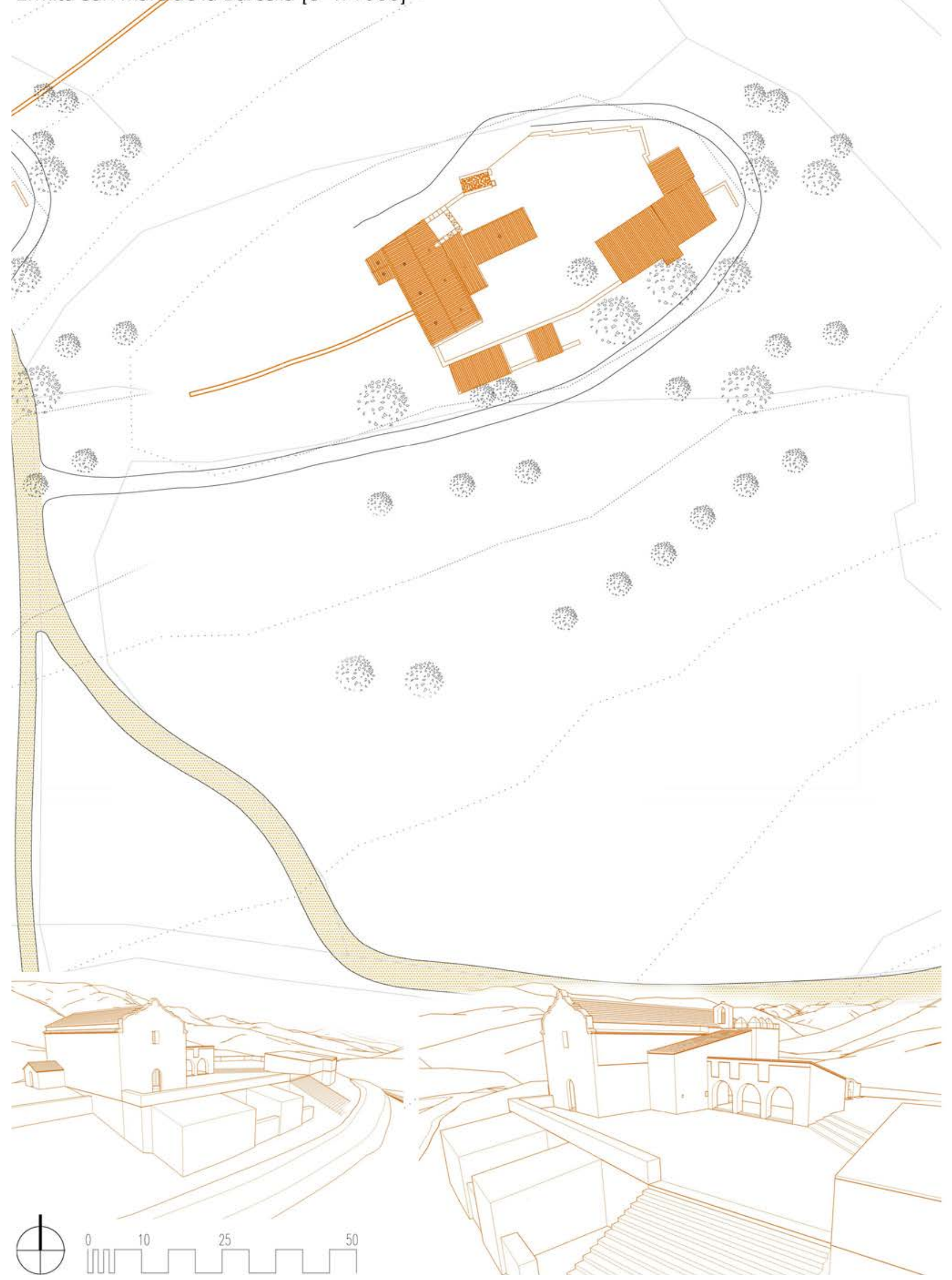




\section{Zona 2 - Barcella} Mas de Ausencia $[\mathrm{e}=1 / 1000]$

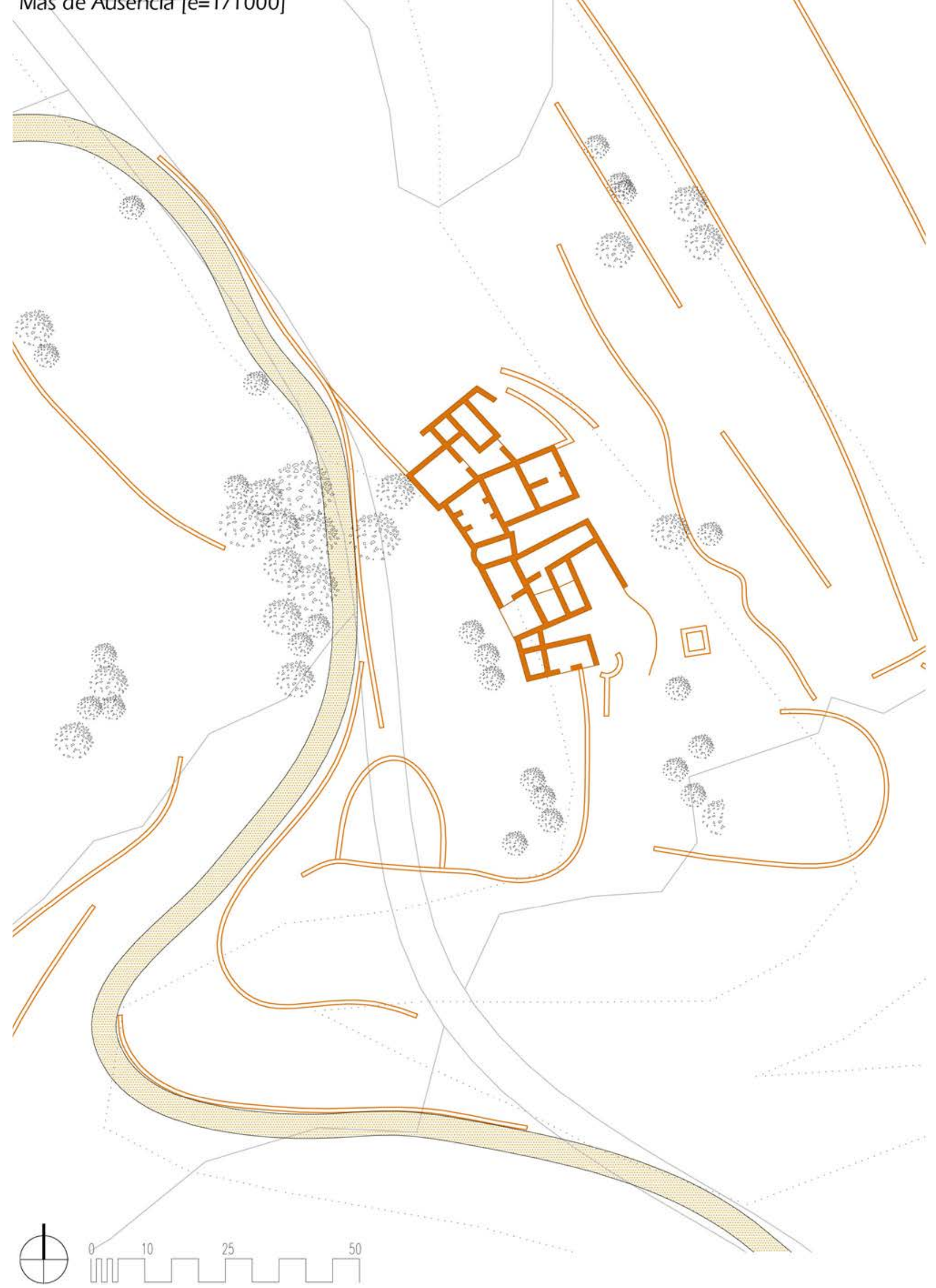




\section{Zona $2 \Vdash$ Barcella}

Mas Astellat $[e=1 / 1000]$

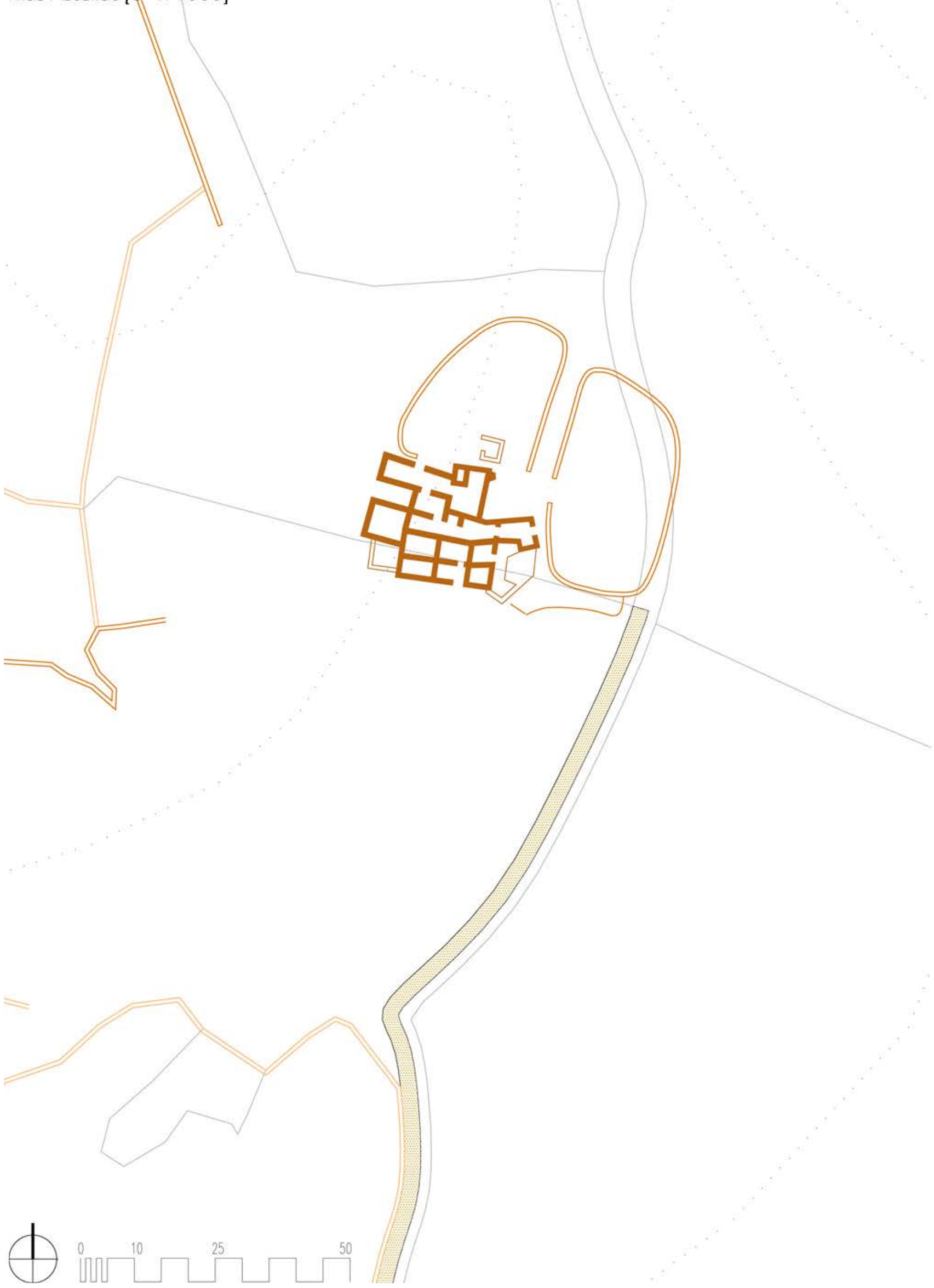




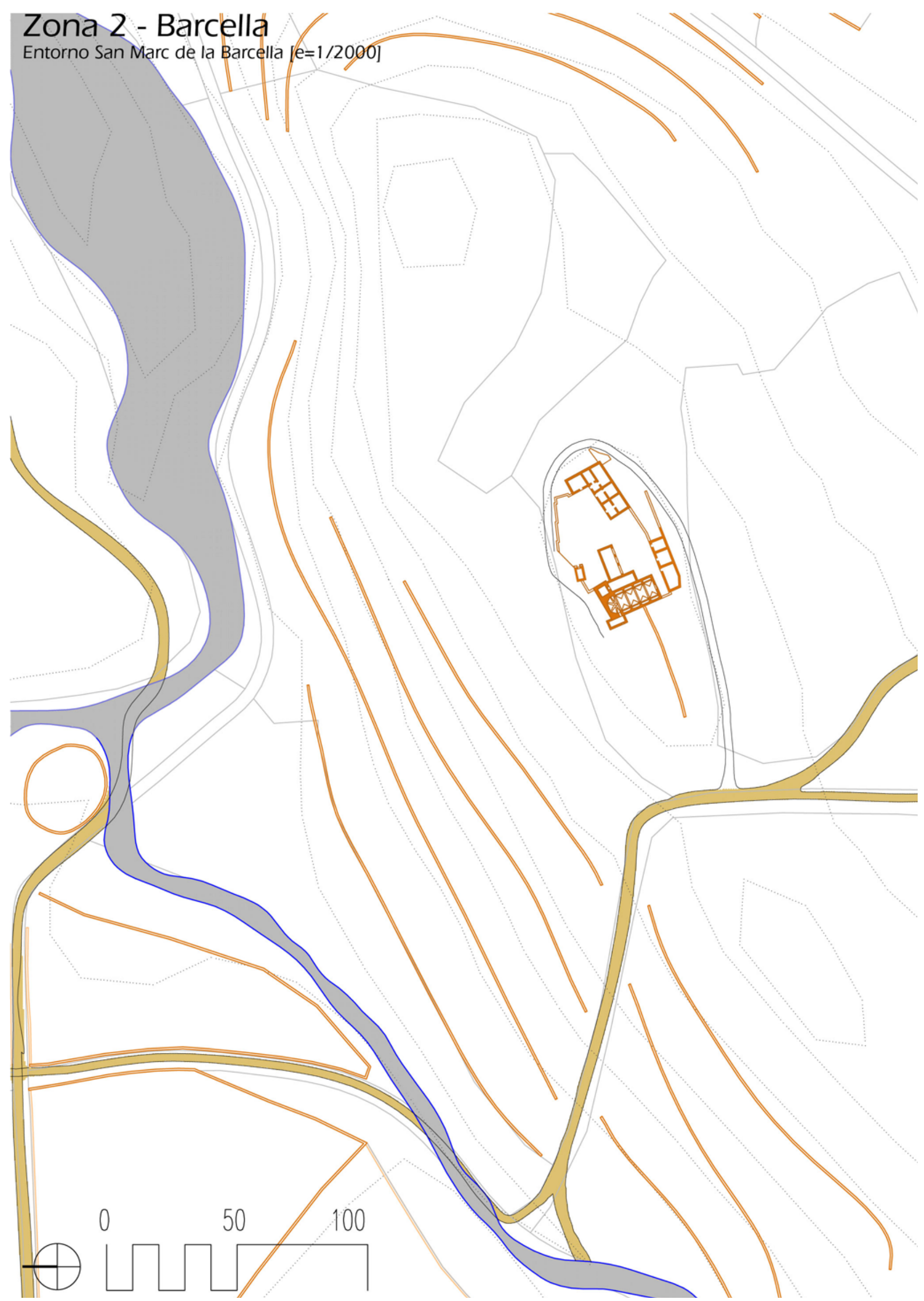




\section{Zona 2 - Barcella}

Entorno Mas de Ausencia $[e=1 / 2000]$

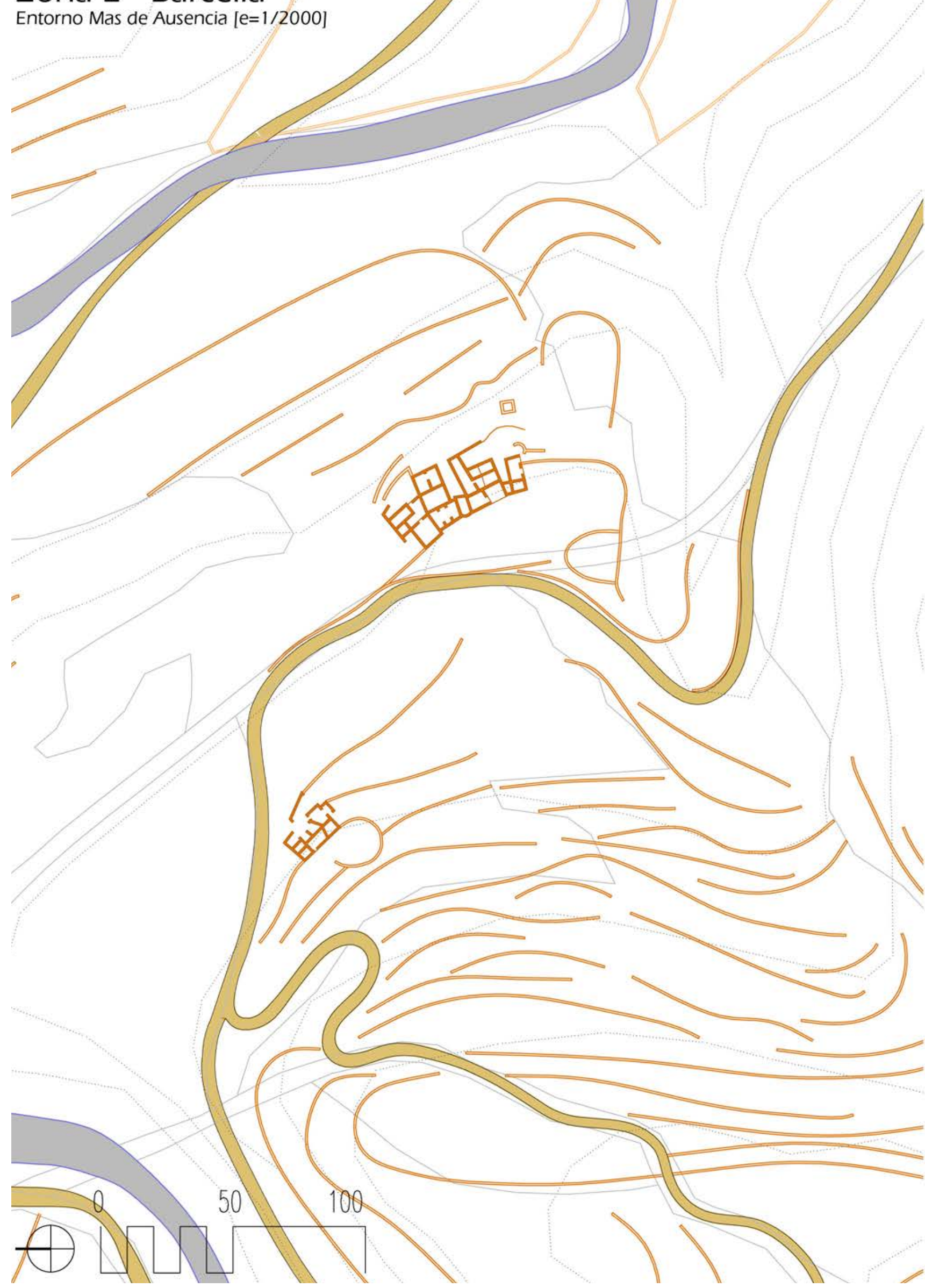




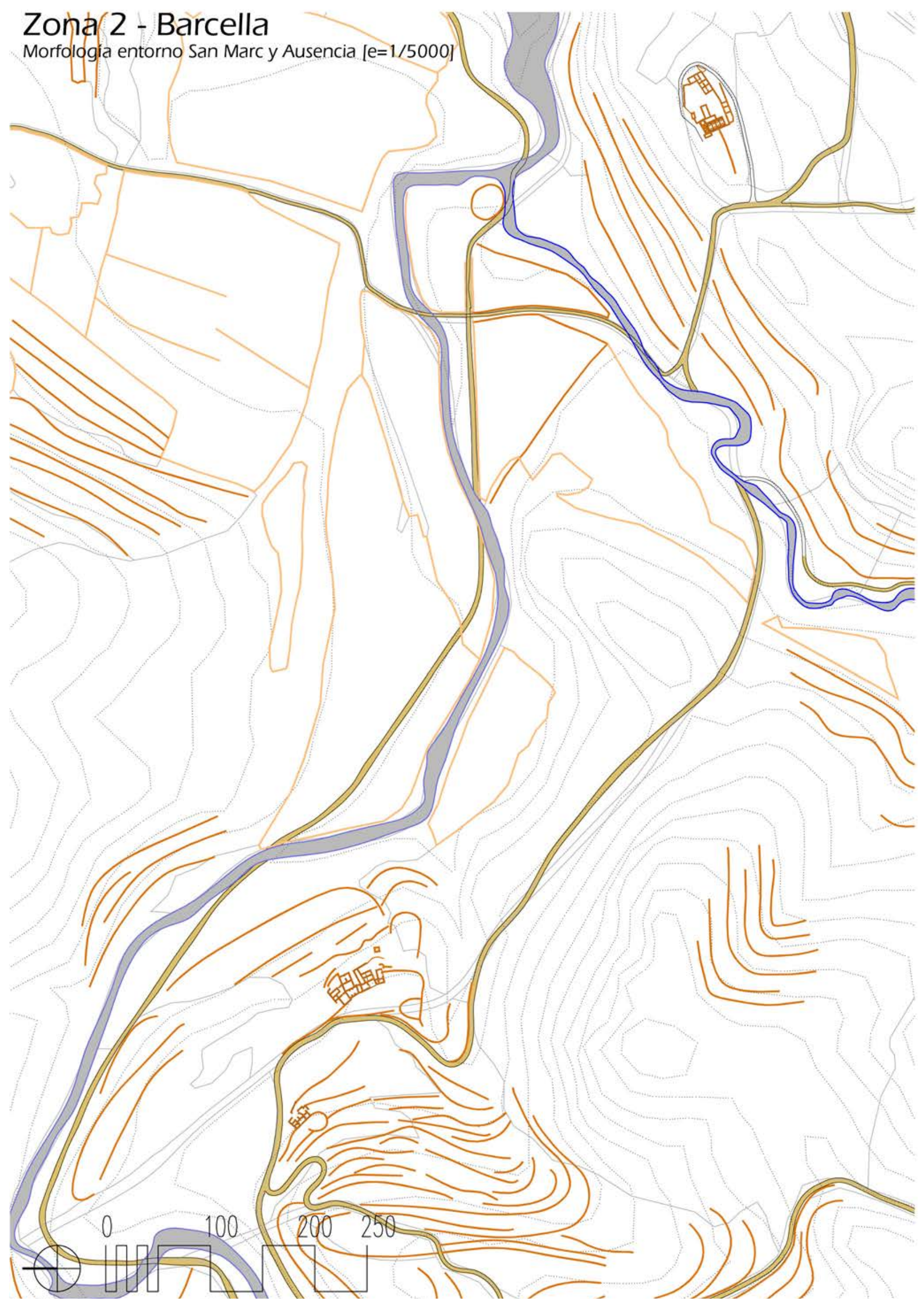




\section{Zoña 2 - Barcella}

\section{Morfologia entorno San Marc y Ausencia $[e=1 / 7500]$}

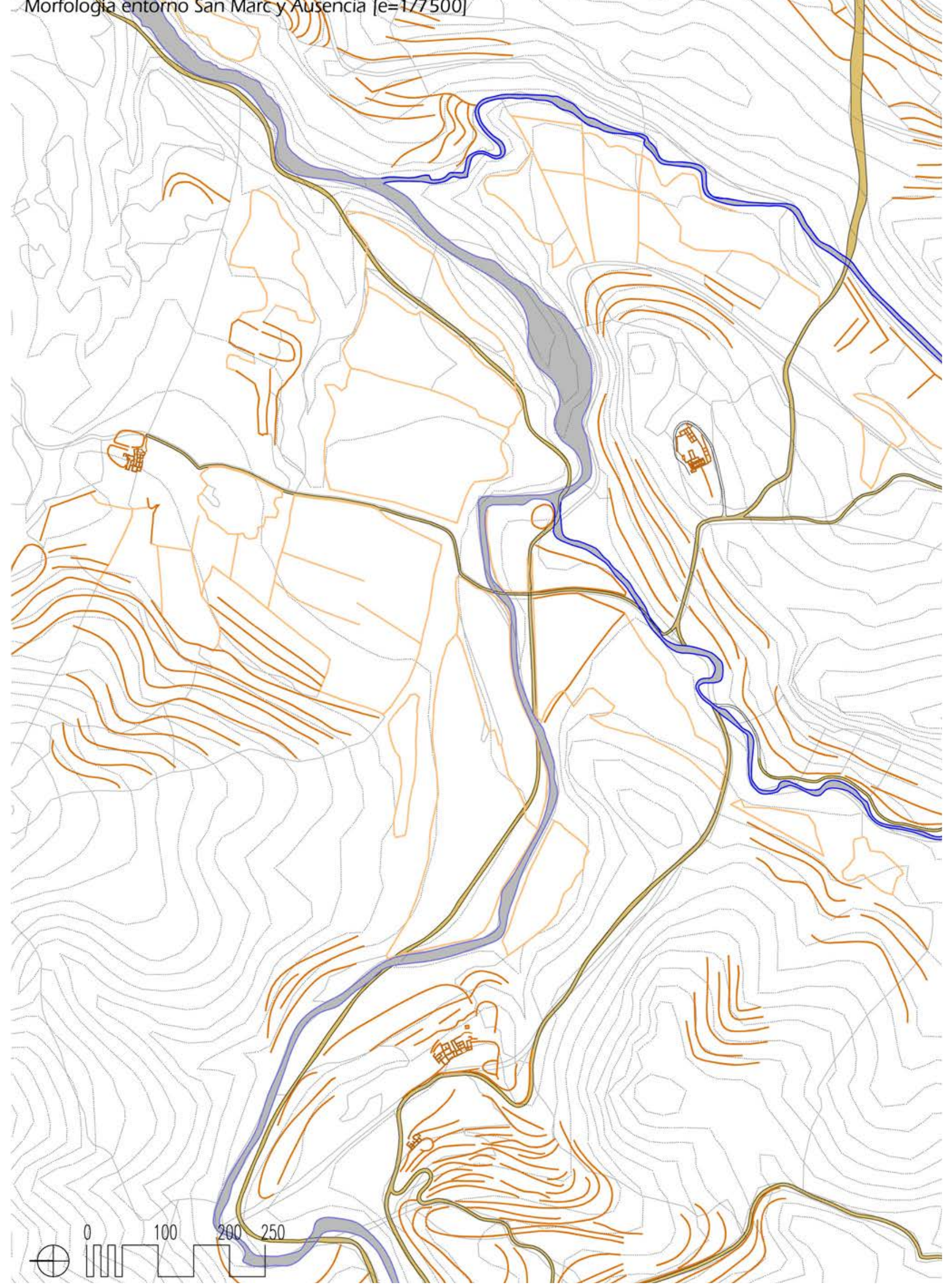




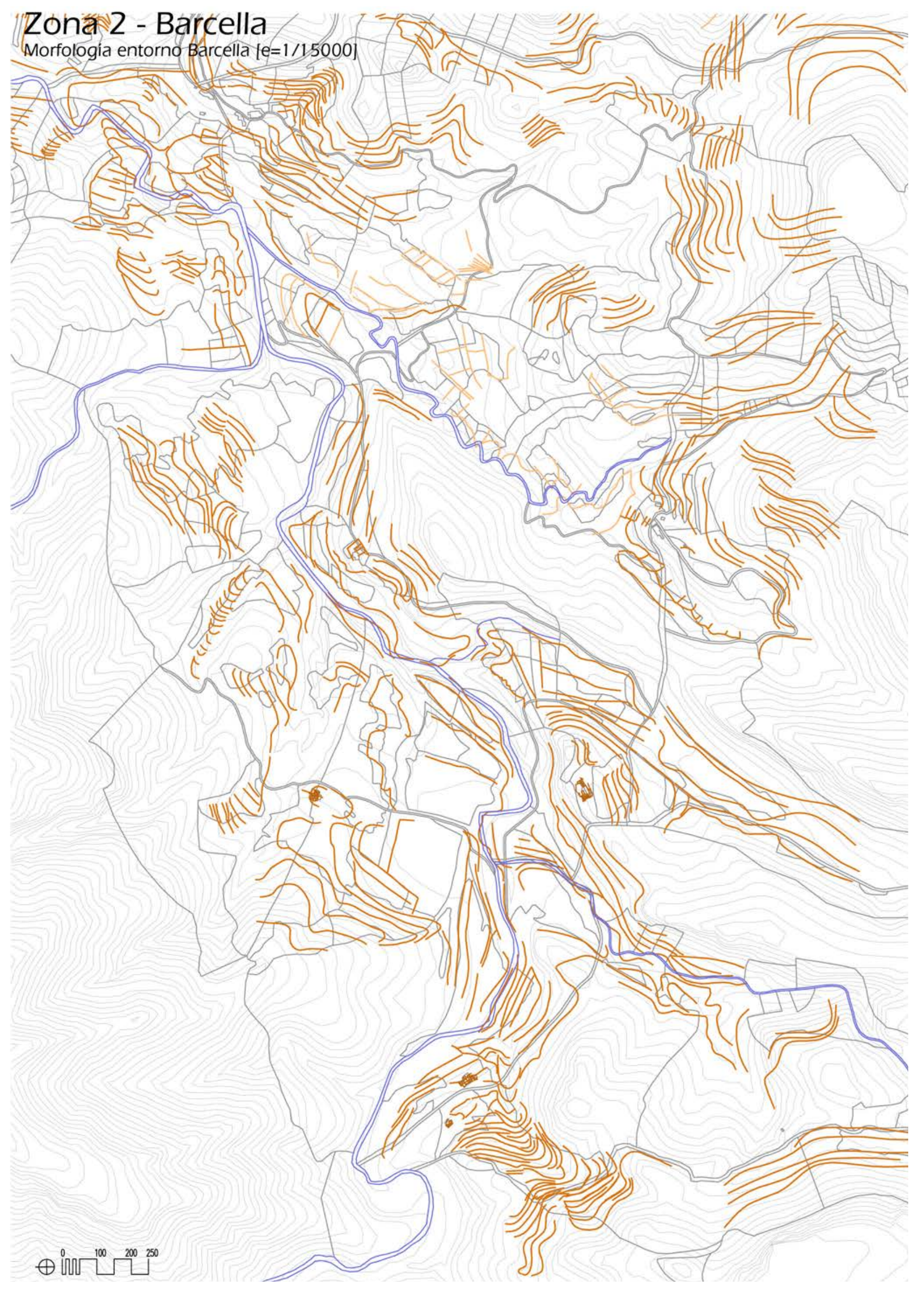


Plano parcelario + muros + bancales zona $2-[e=1 / 40.000]$

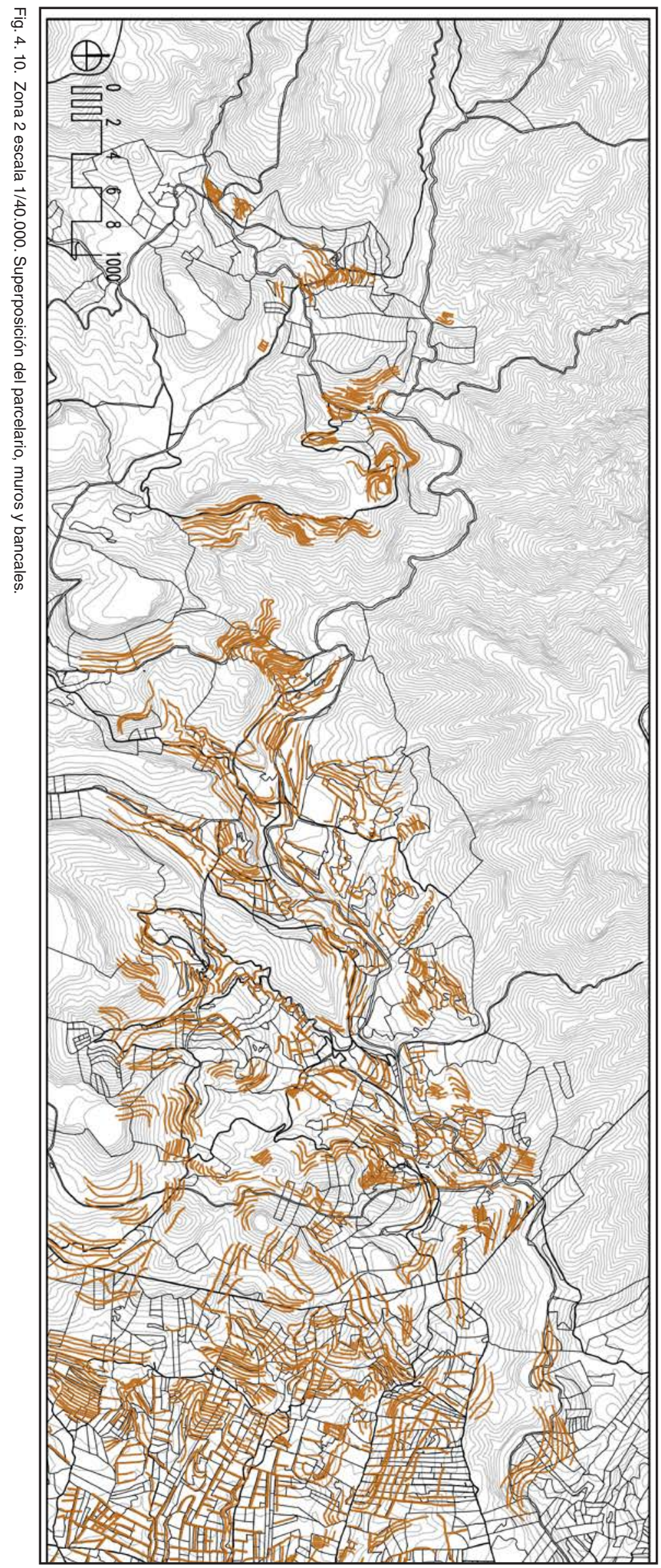


Ortofoto zona 2 - [e=1/40.000]

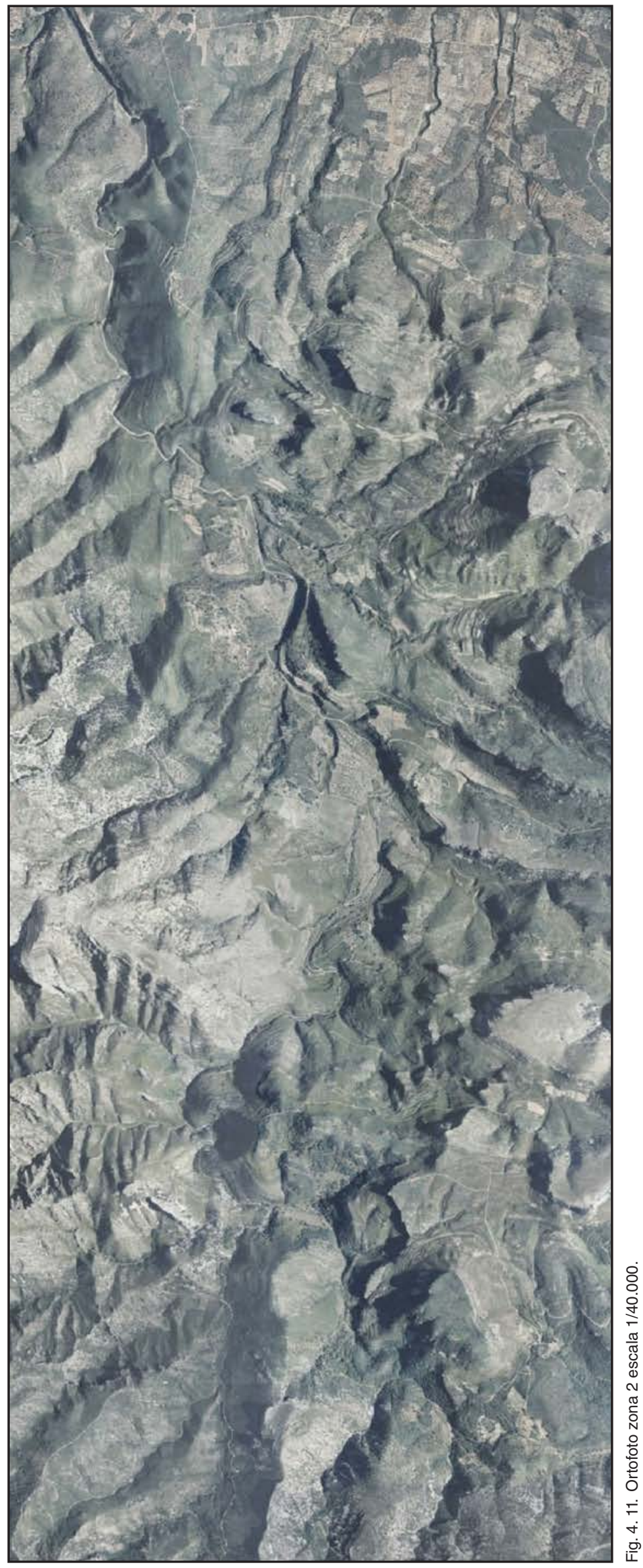


Mapa general (situación de las zonas de estudio) - $[e=1 / 200.000]$

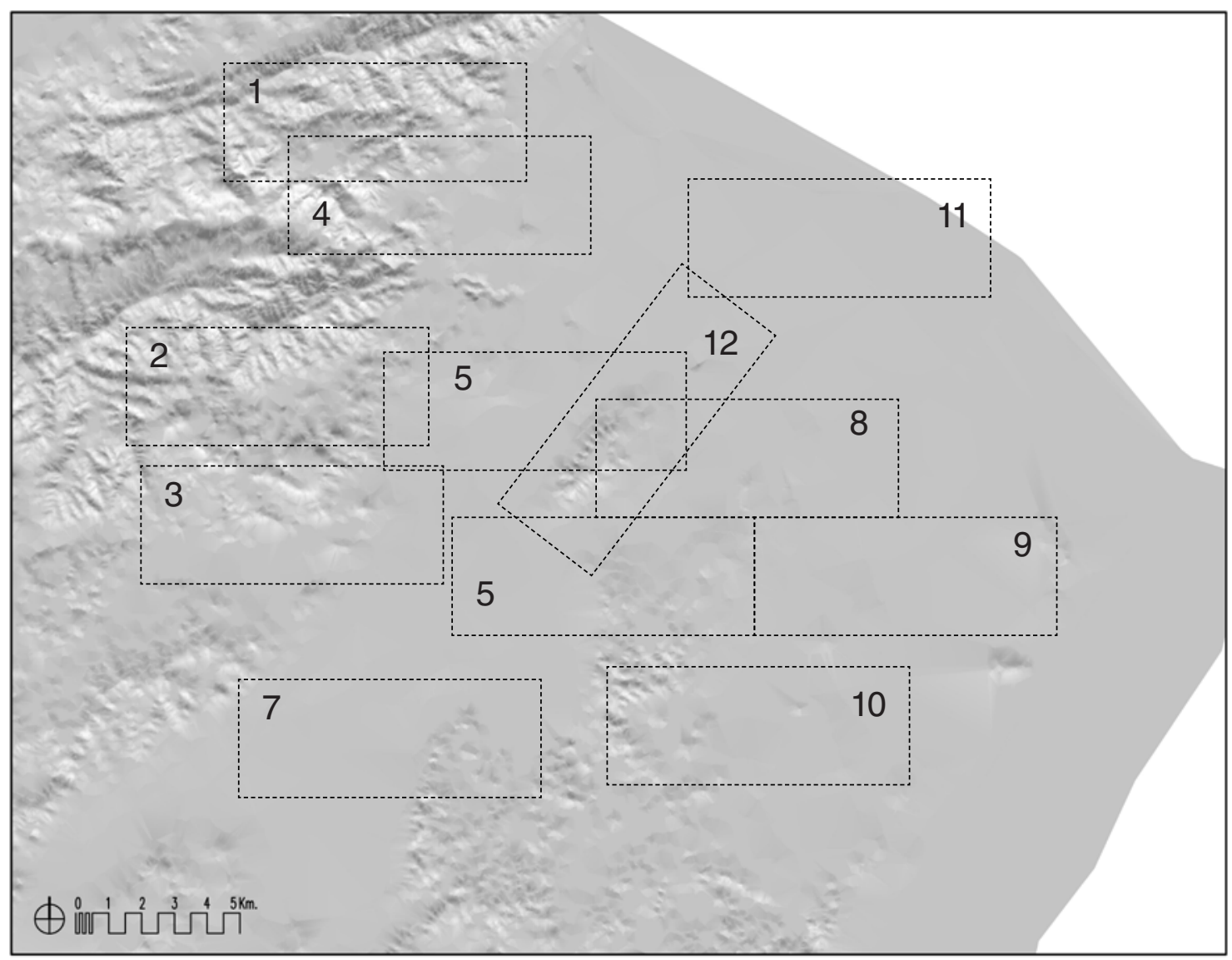

Fig. 4. 12. Plano $1 / 200.000$ de la topografía de la Batllia y de las 12 zonas de estudio.

Detalle zona 3 (situación de los elementos de interés) - [e=1/60.000]

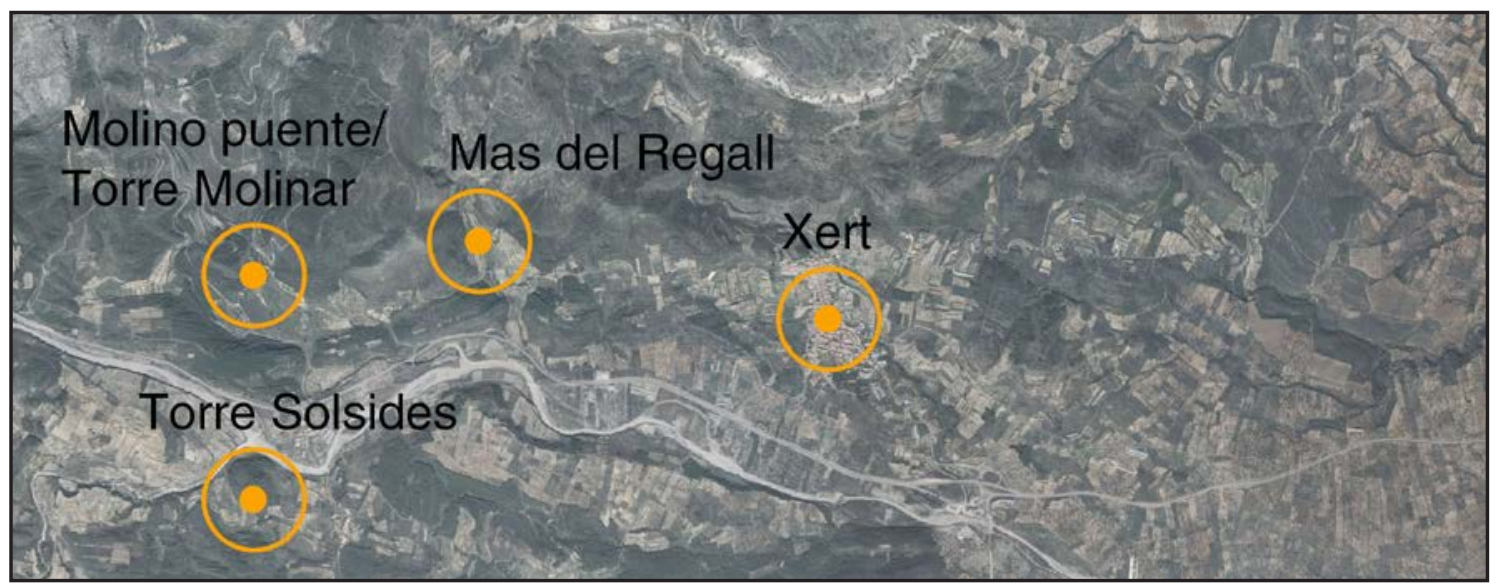

Fig. 4. 13. Ortofoto $1 / 60.000$ de la zona 3 con la ubicación de las arquitecturas que se estudian. 


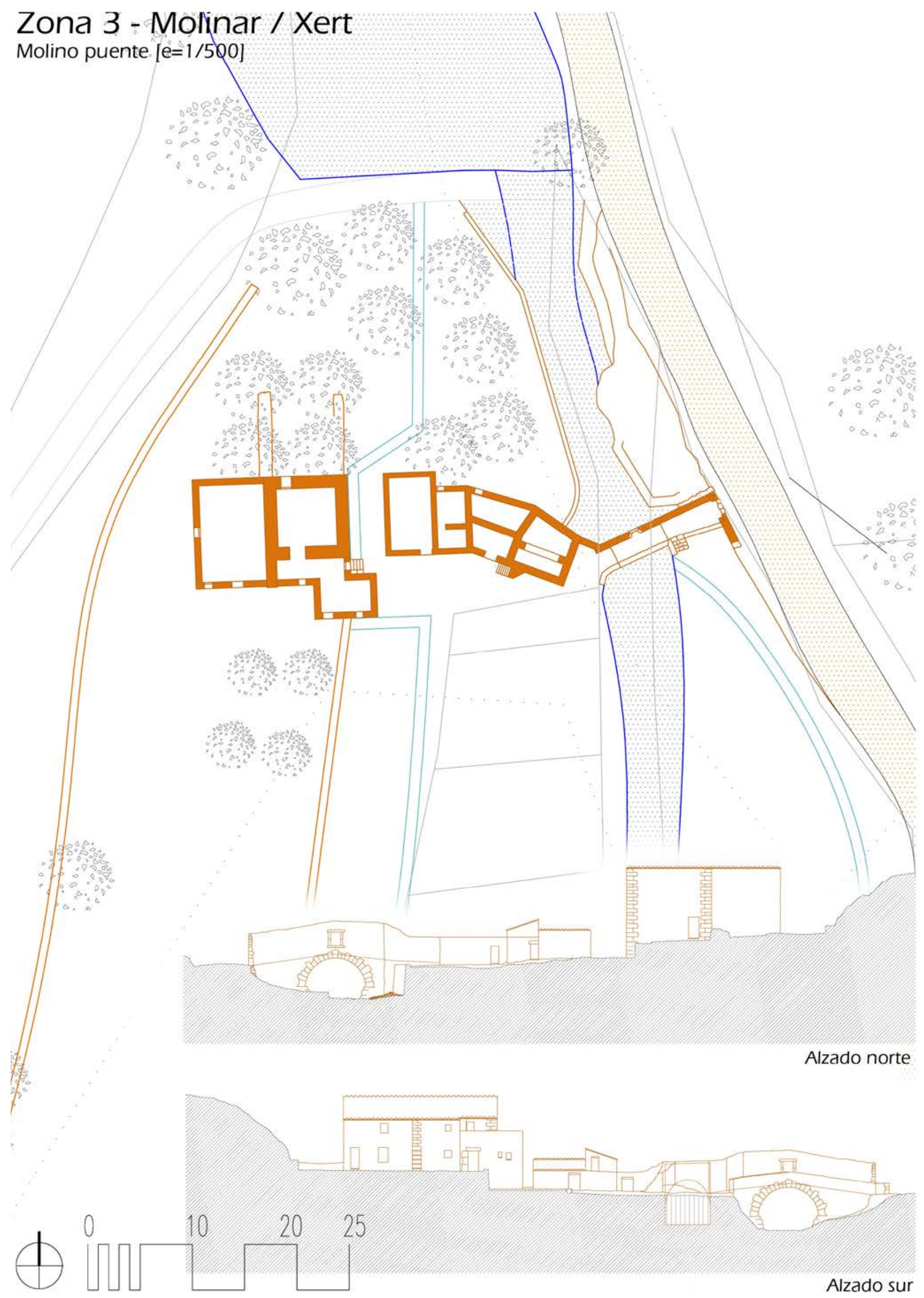




\section{Zona 3 - Molinar 7 Xert} Torre Molinar $[e=1 / 500]$

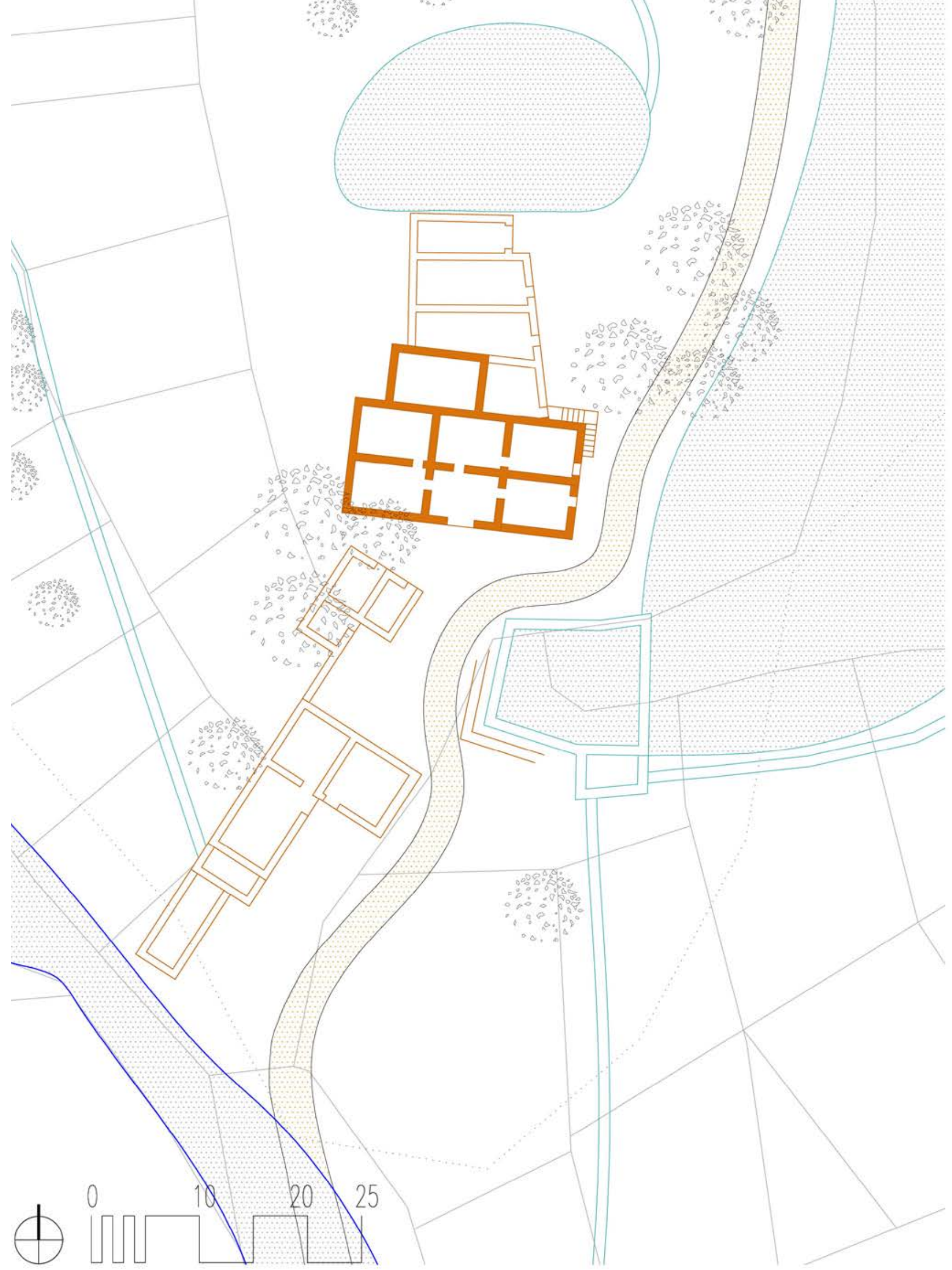




\section{Zona 3 - Molinar / Xert \\ Mas del Regall $[e=1 / 500]$}
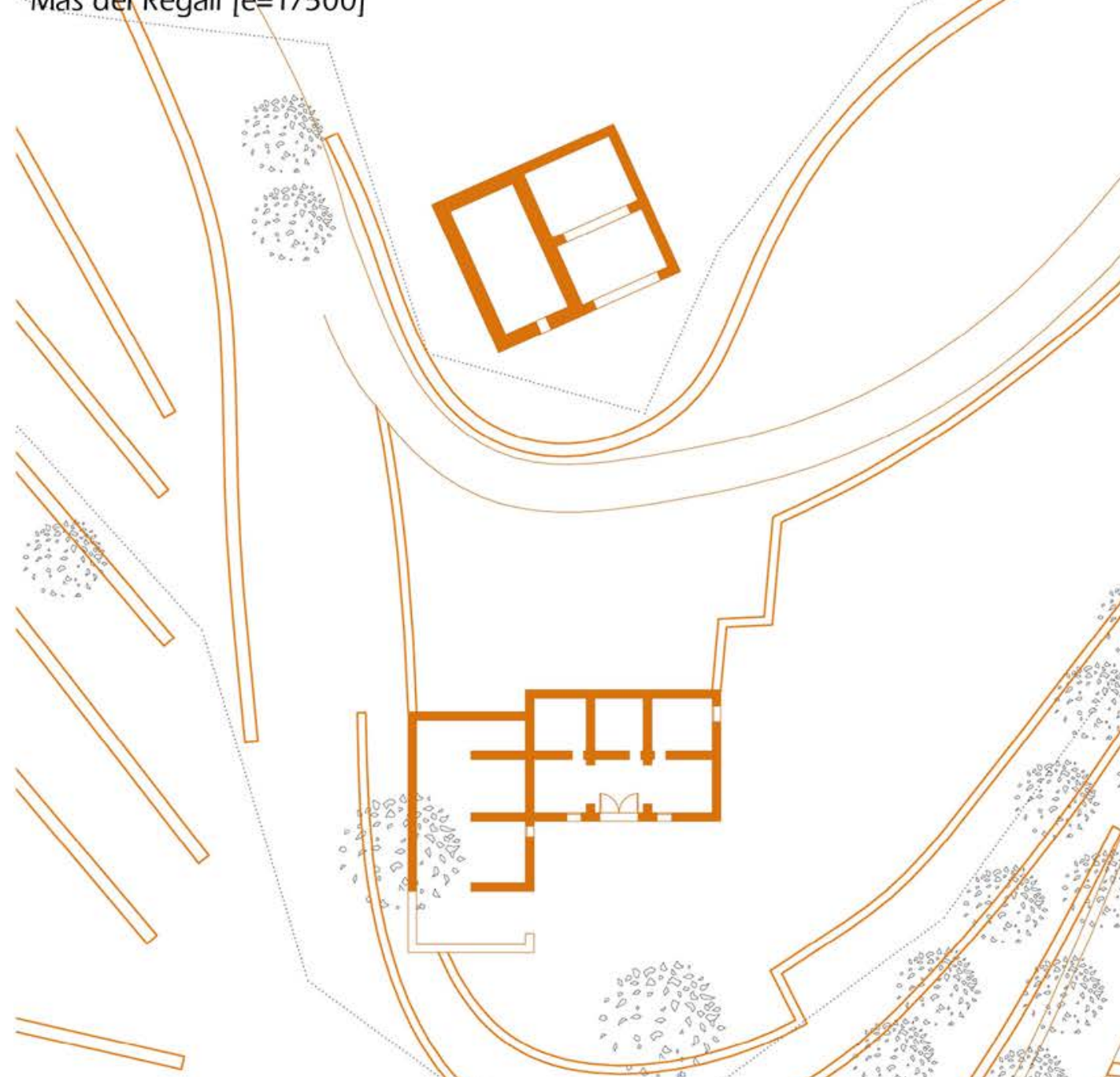
Zóna 3 - Molinar / Xert Iglesia de Xert $[\mathrm{e}=1 / 500]$
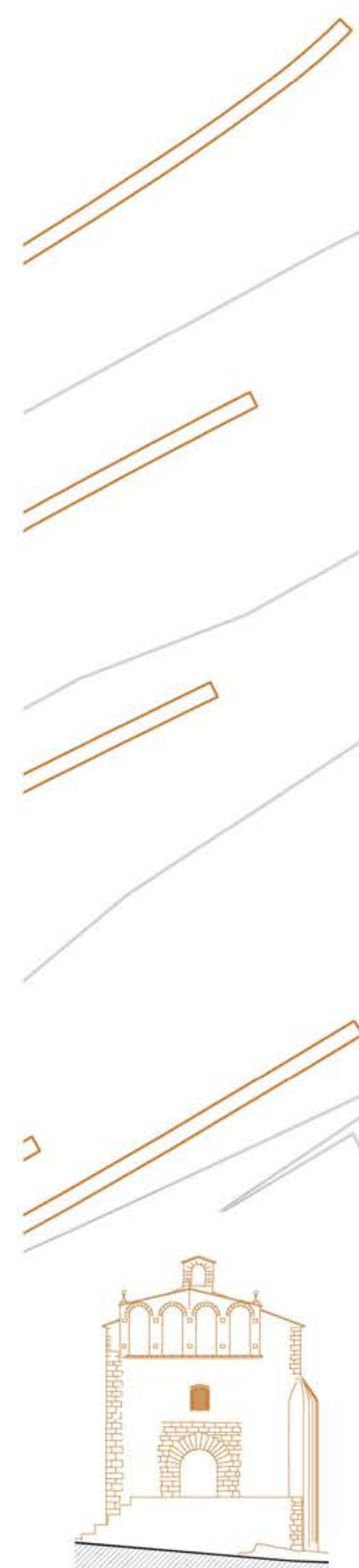

Alzado este

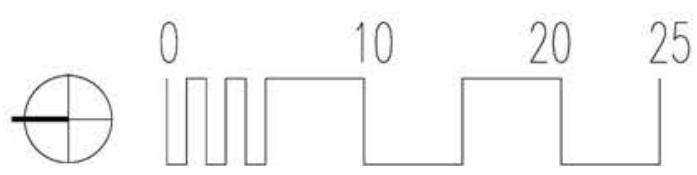

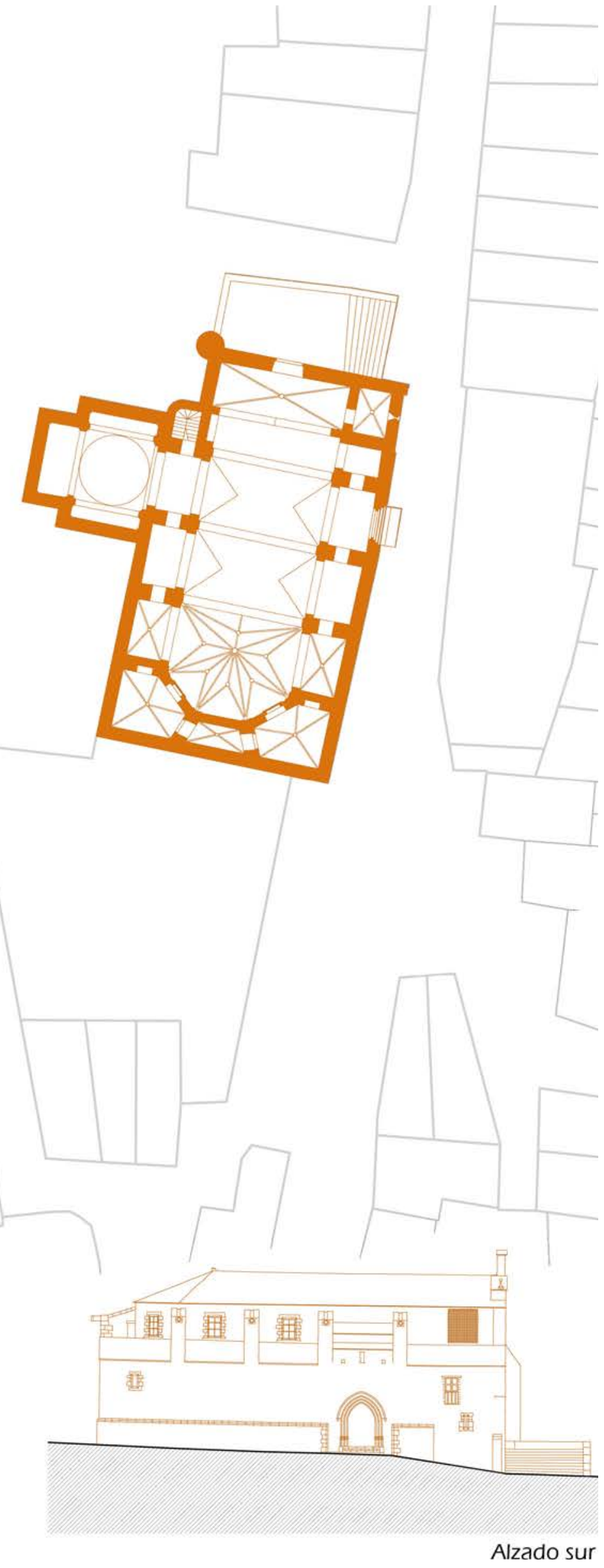




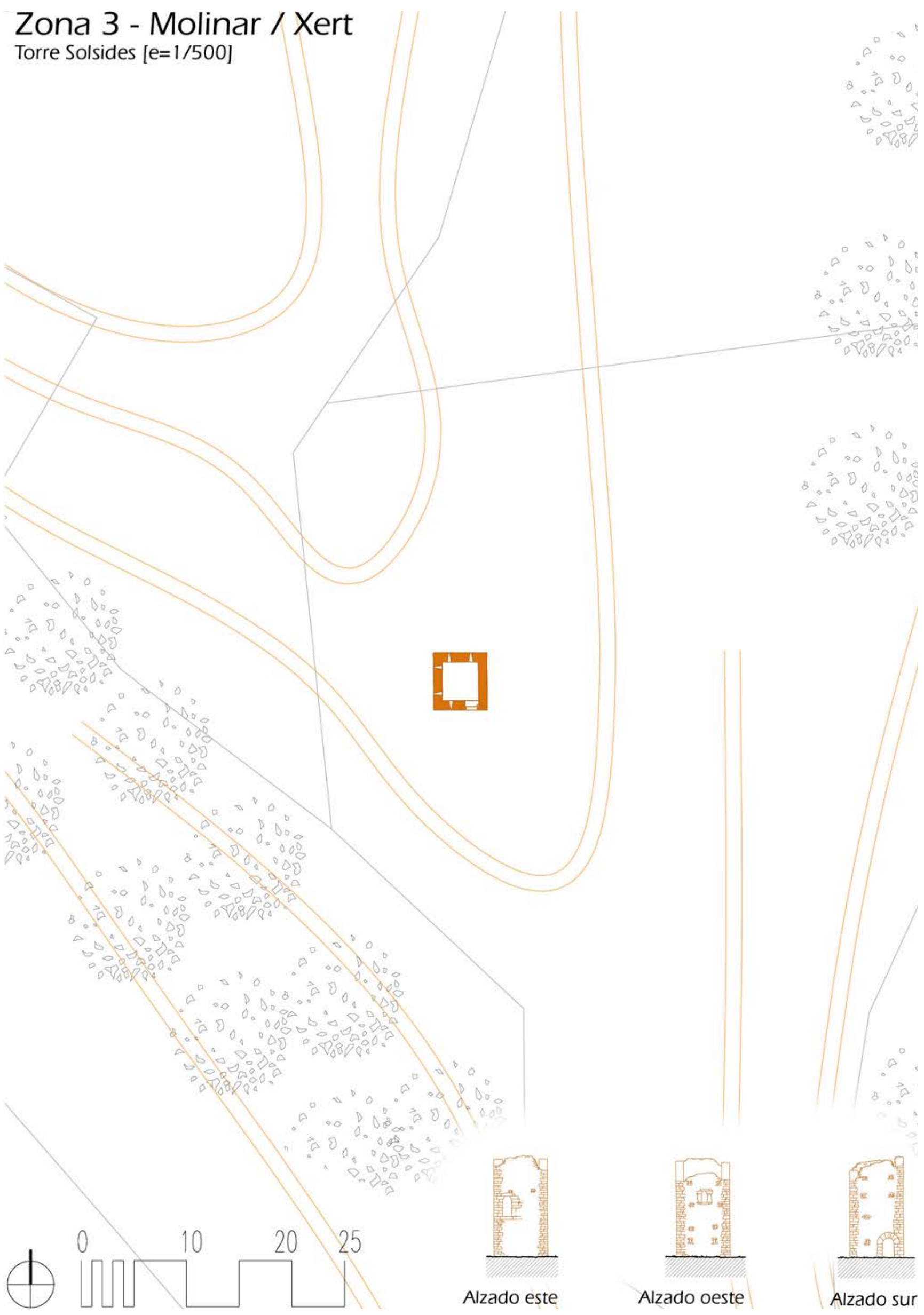




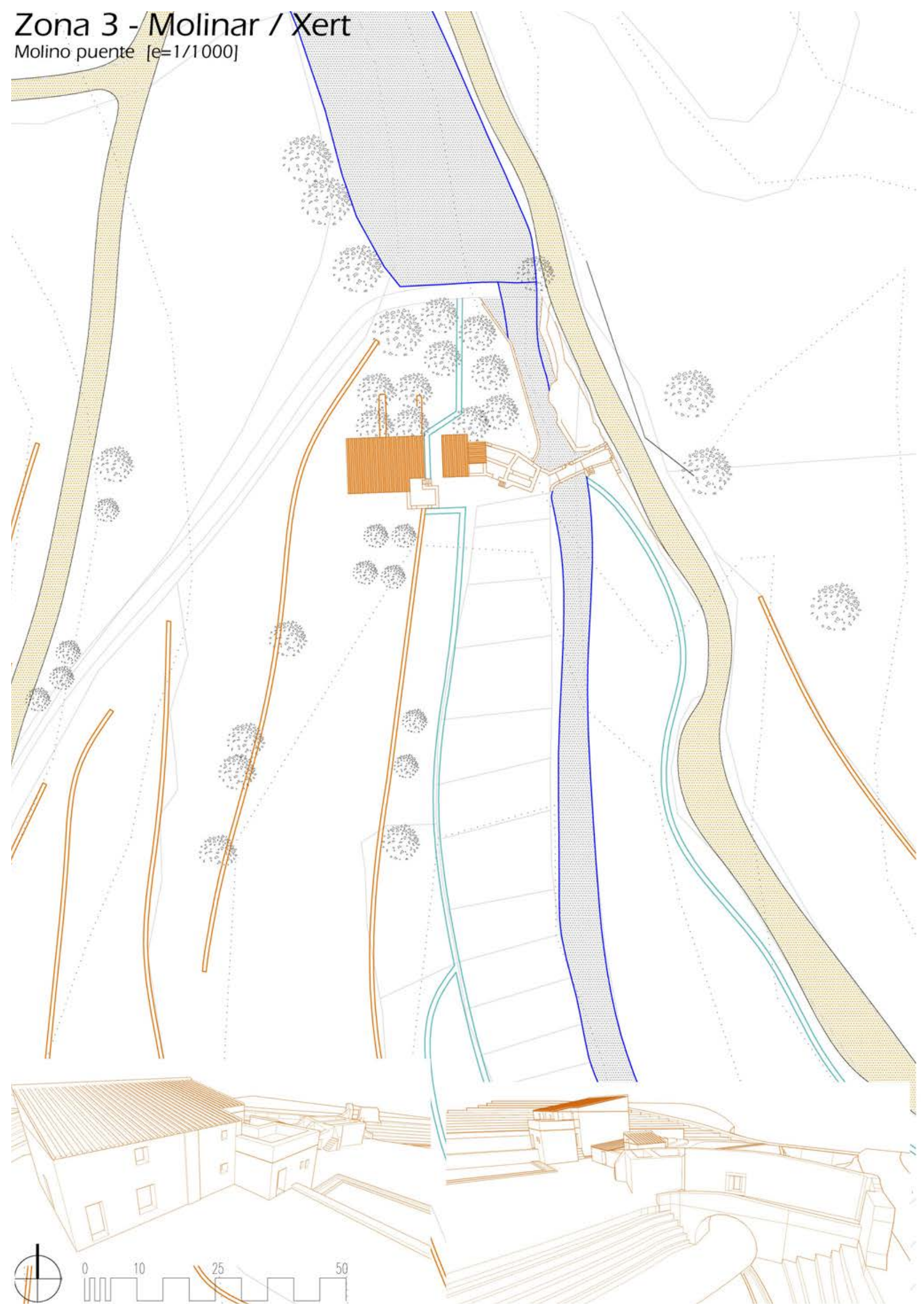




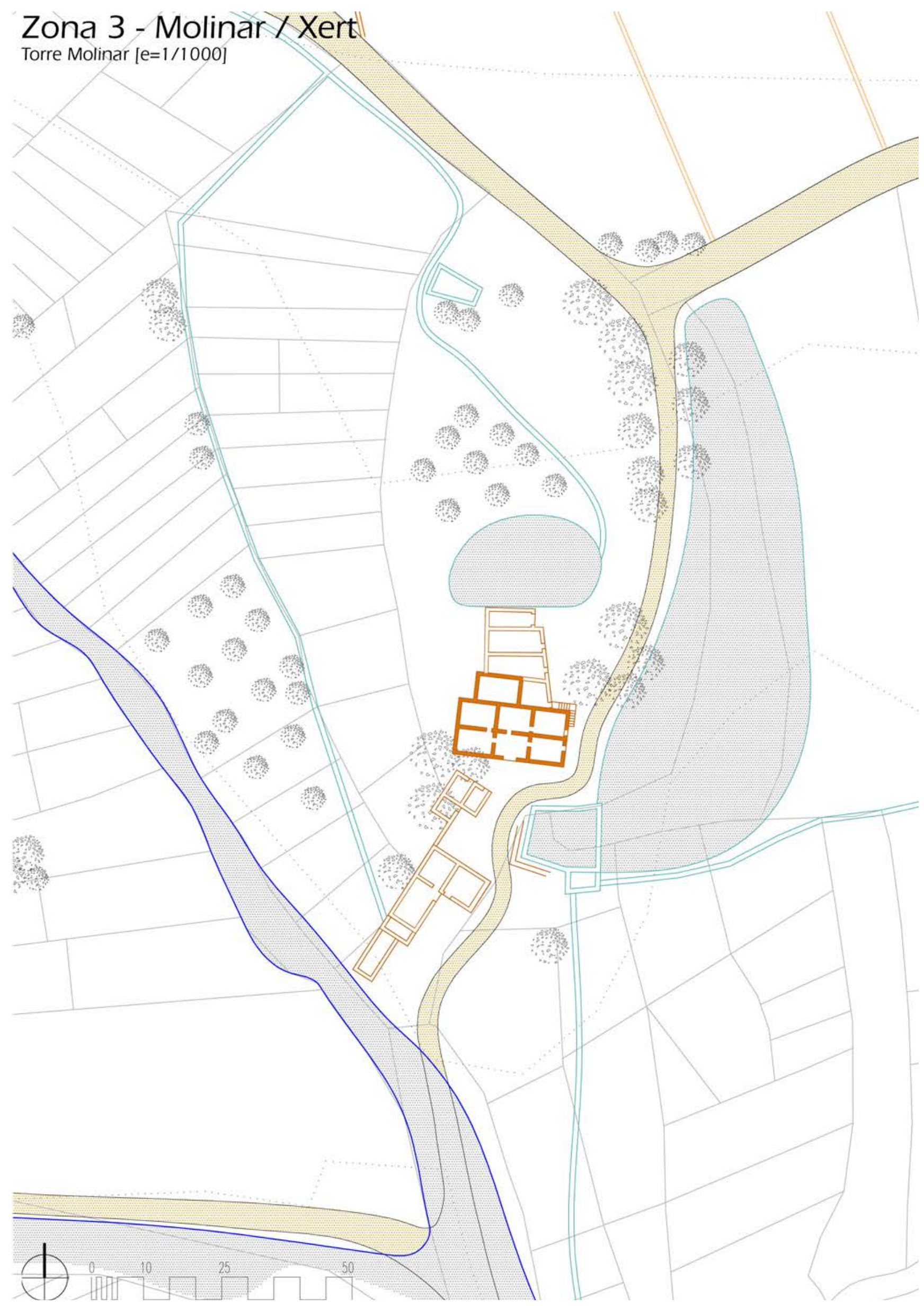




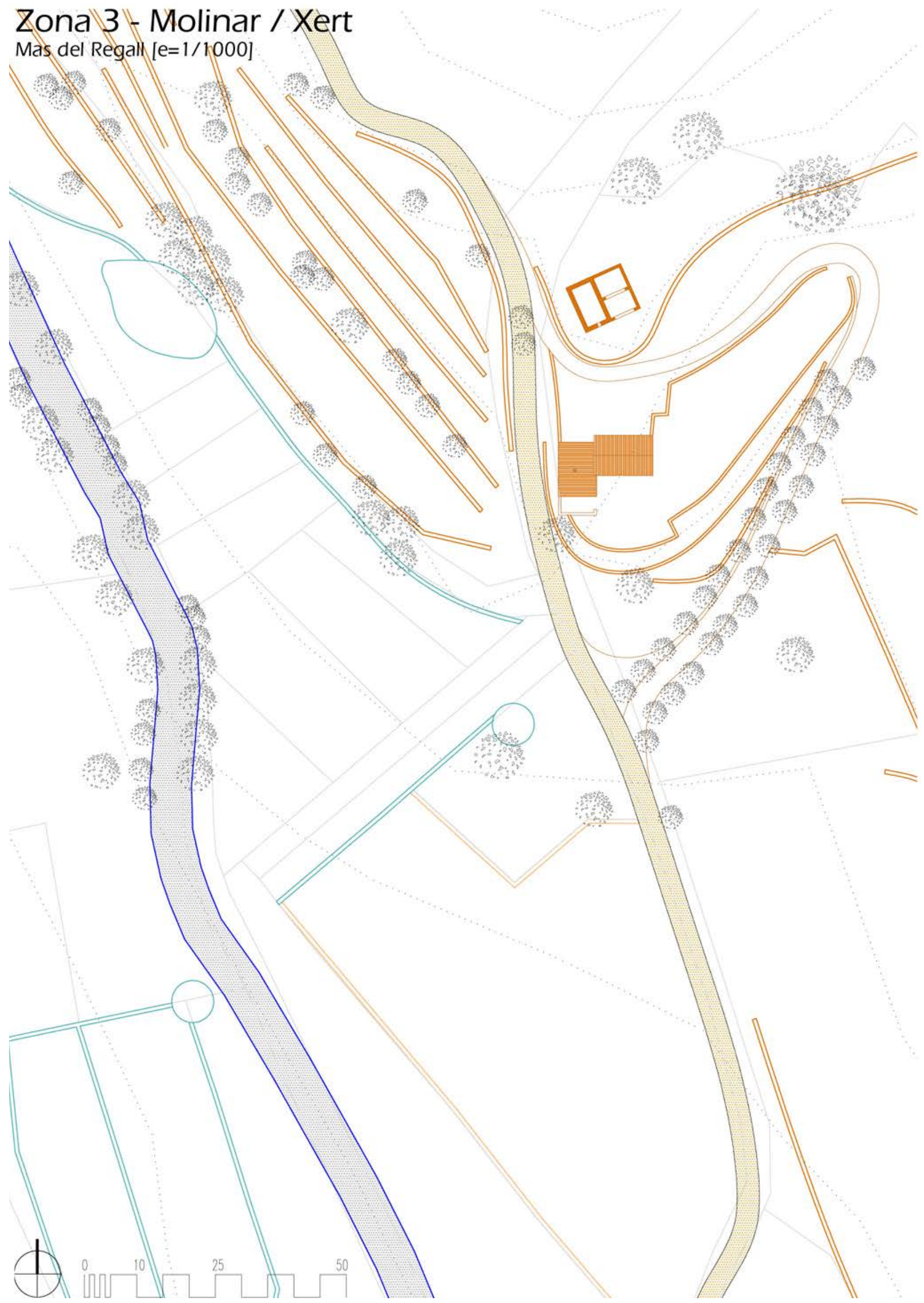




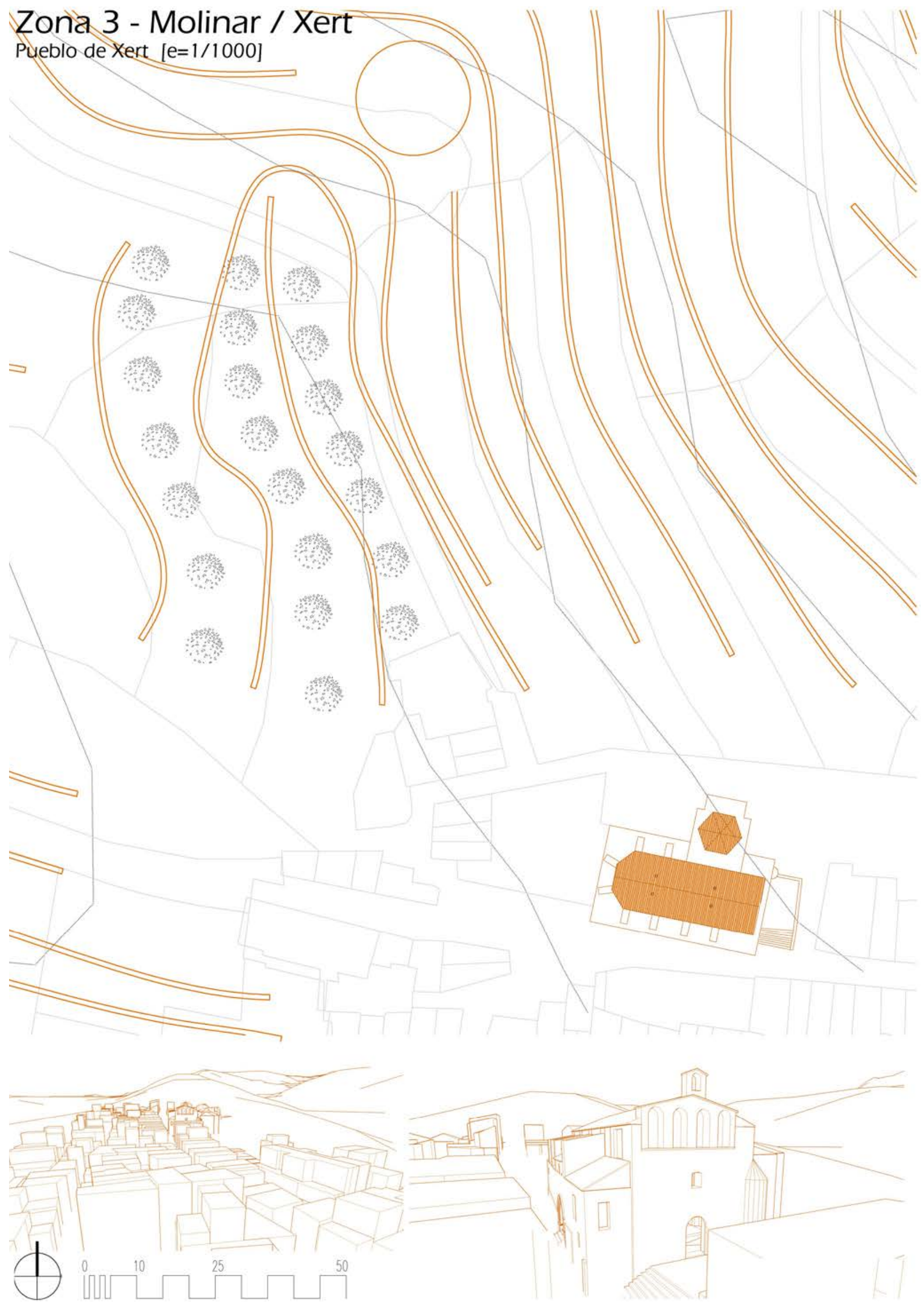




\section{Zona 3 - Molinar / Xert Torre Solsides $[\mathrm{e}=1 / 1000]$}

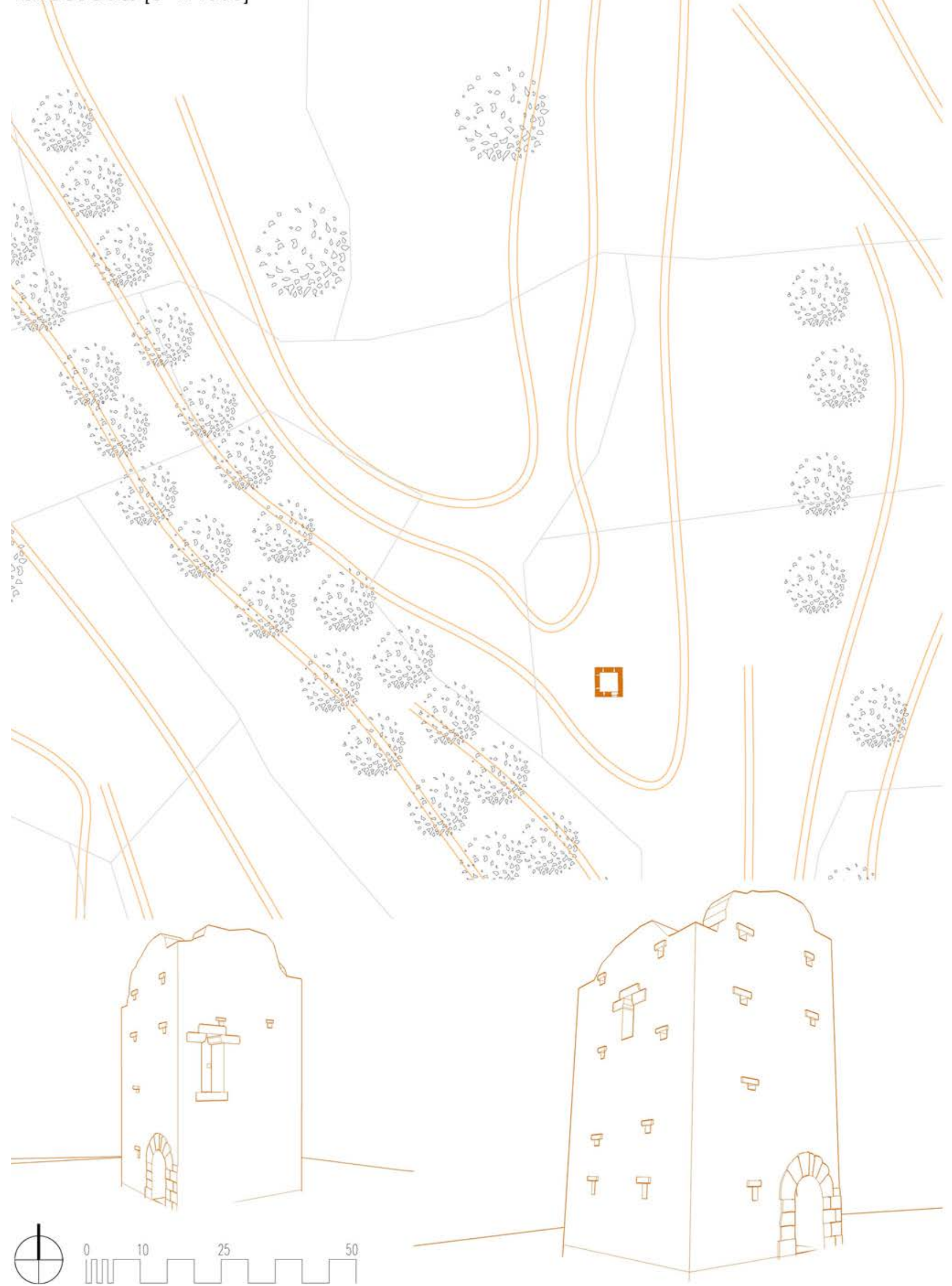




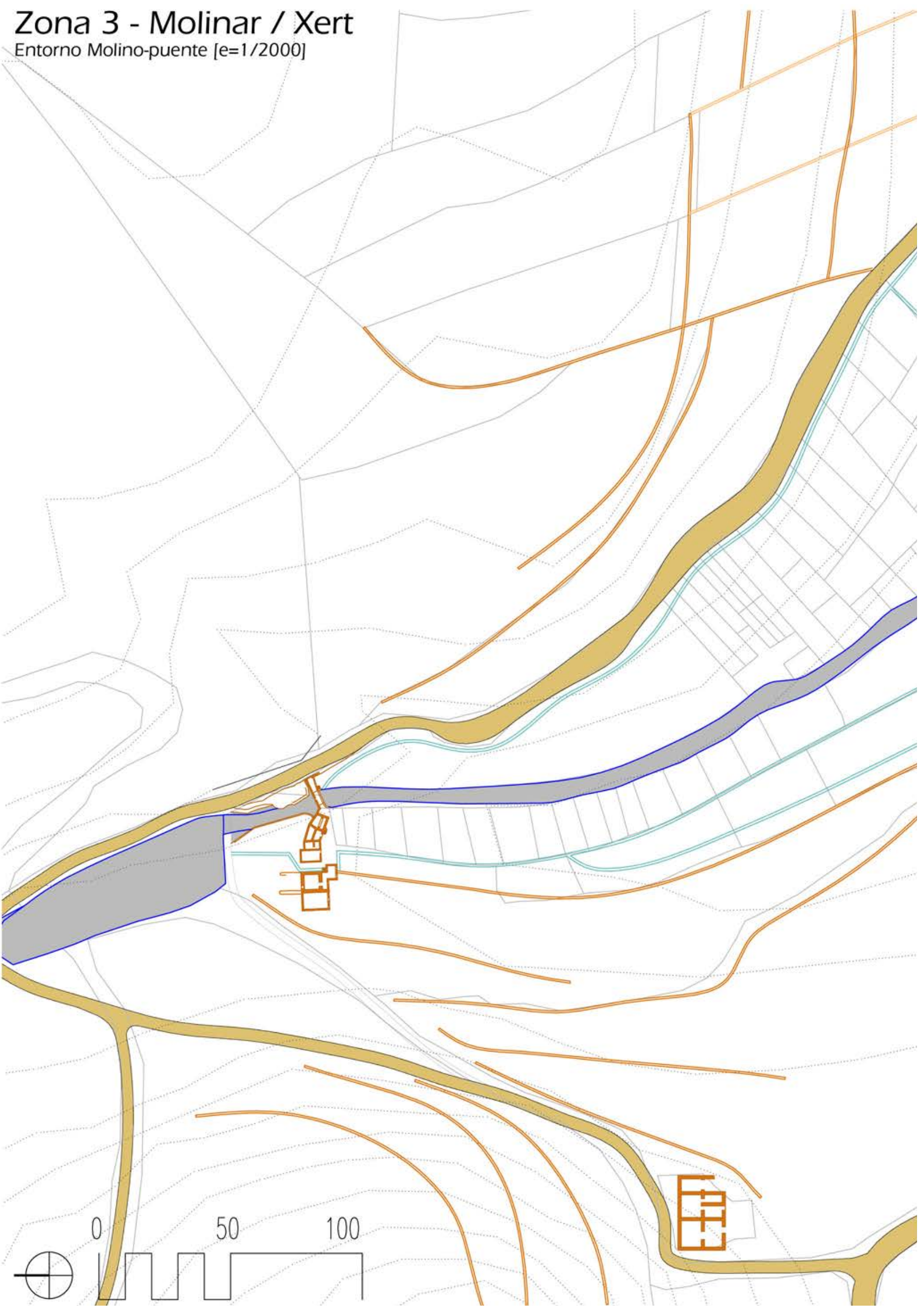




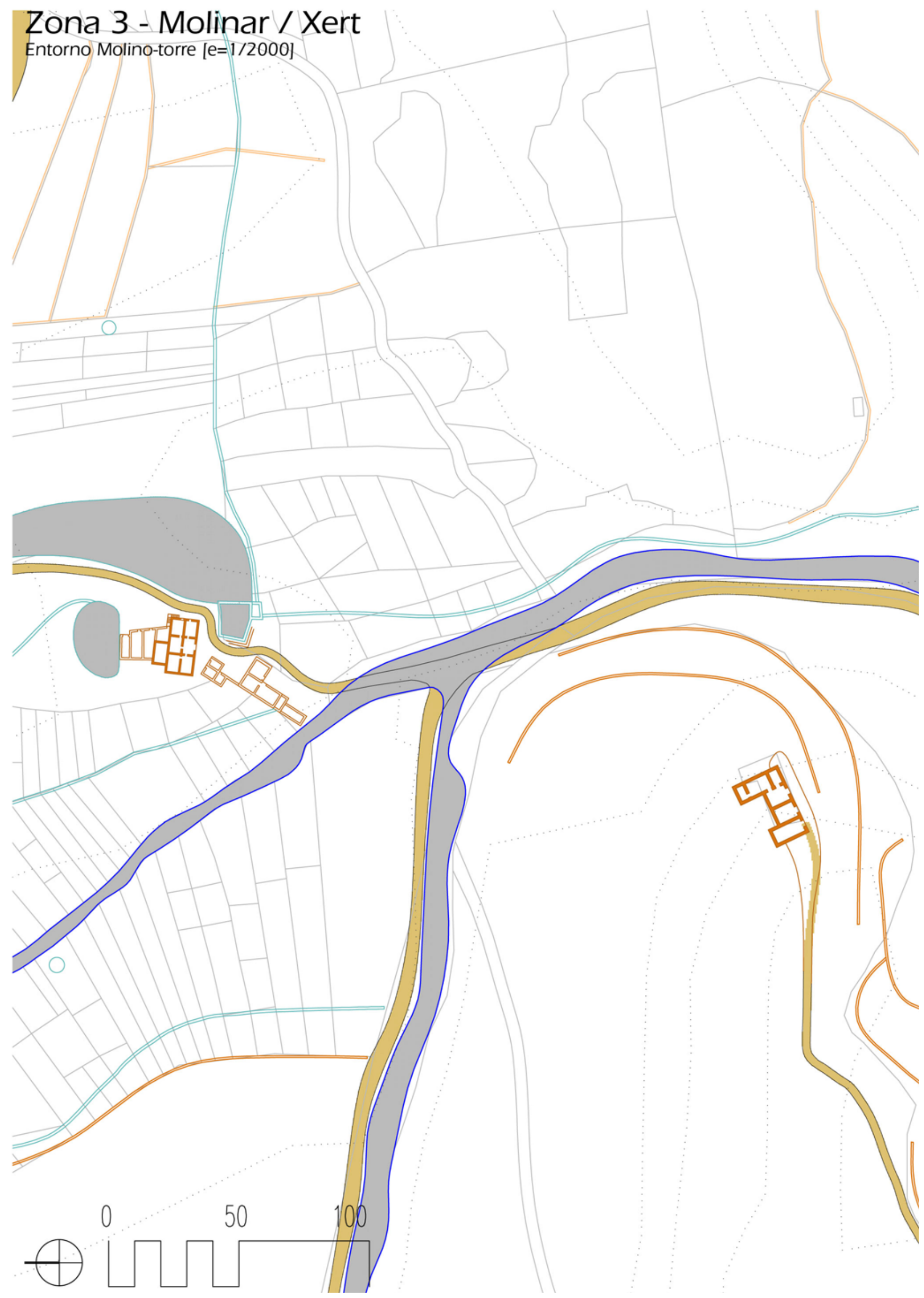




\section{Zona 3 - Molinar / Xert}

Entorno Mas del Regall $[\mathrm{e}=1 / 2000]$

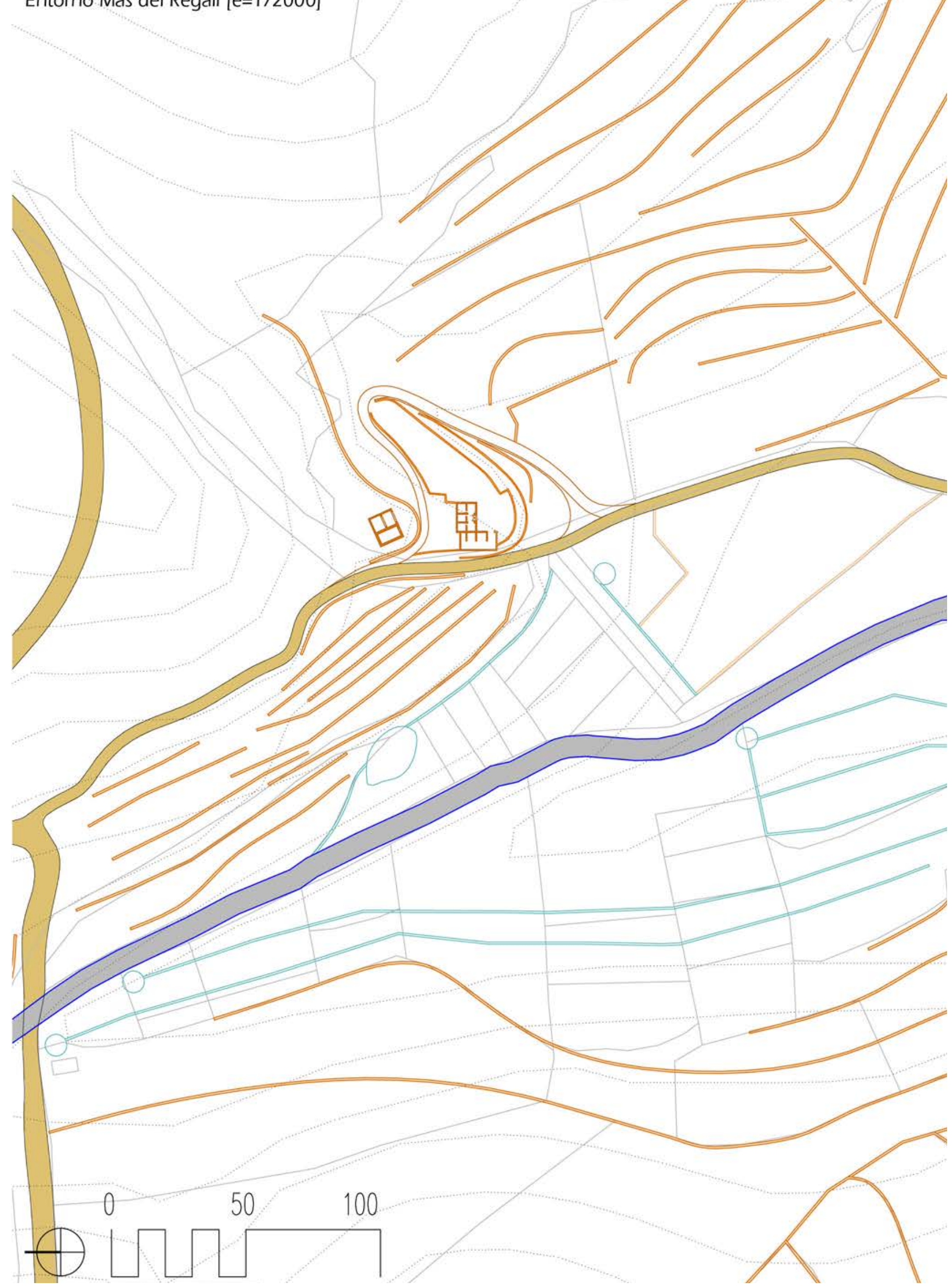




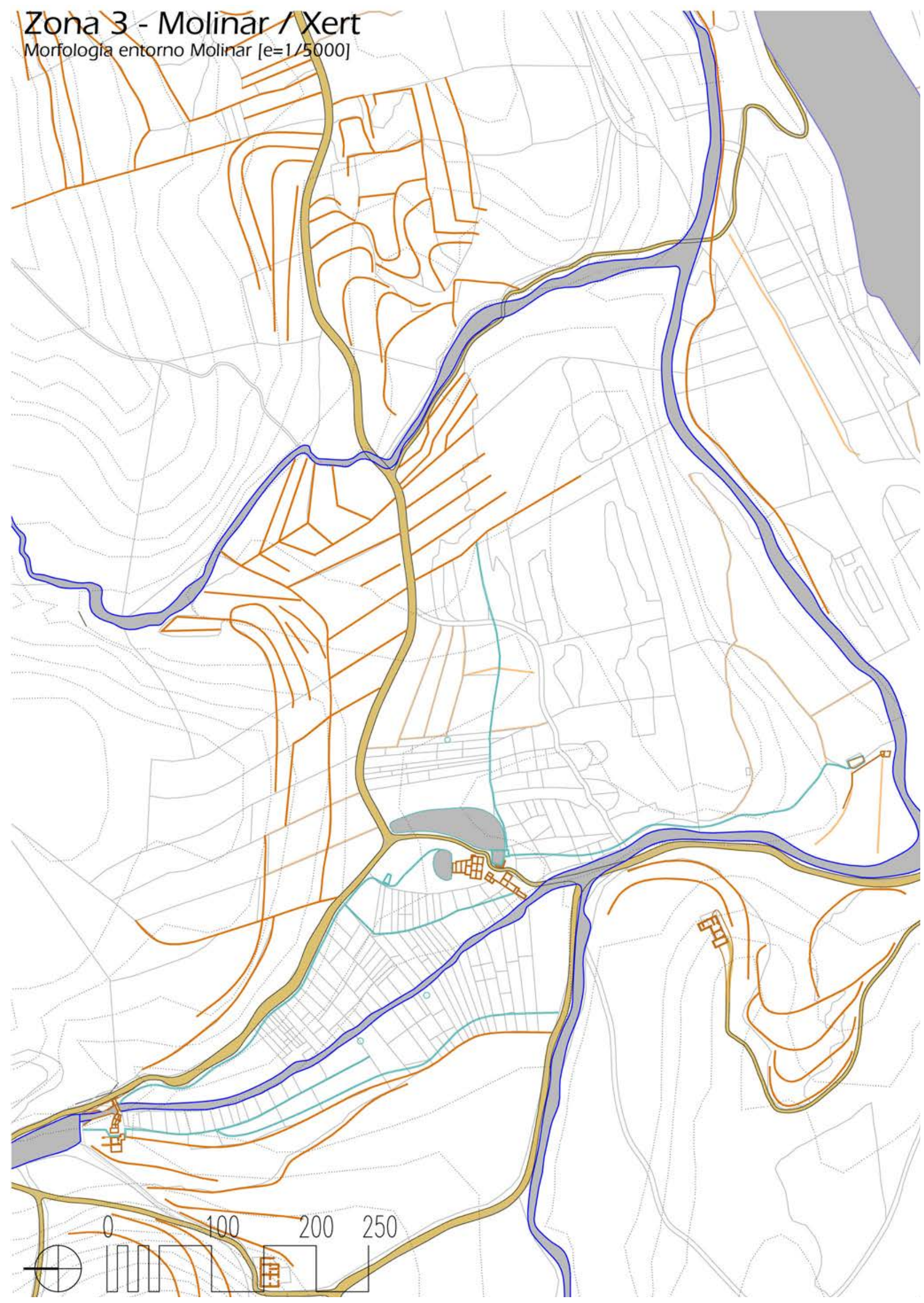




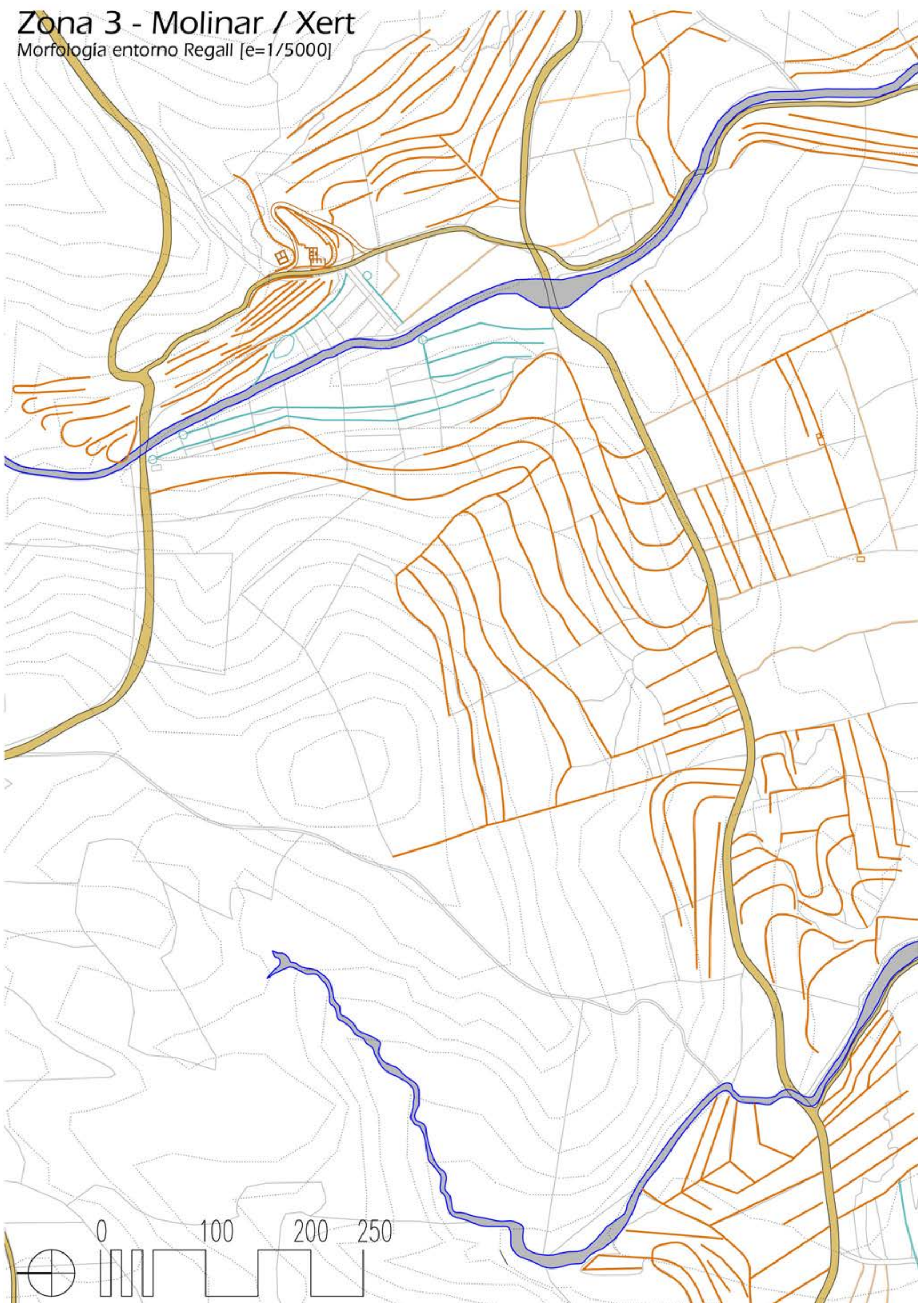




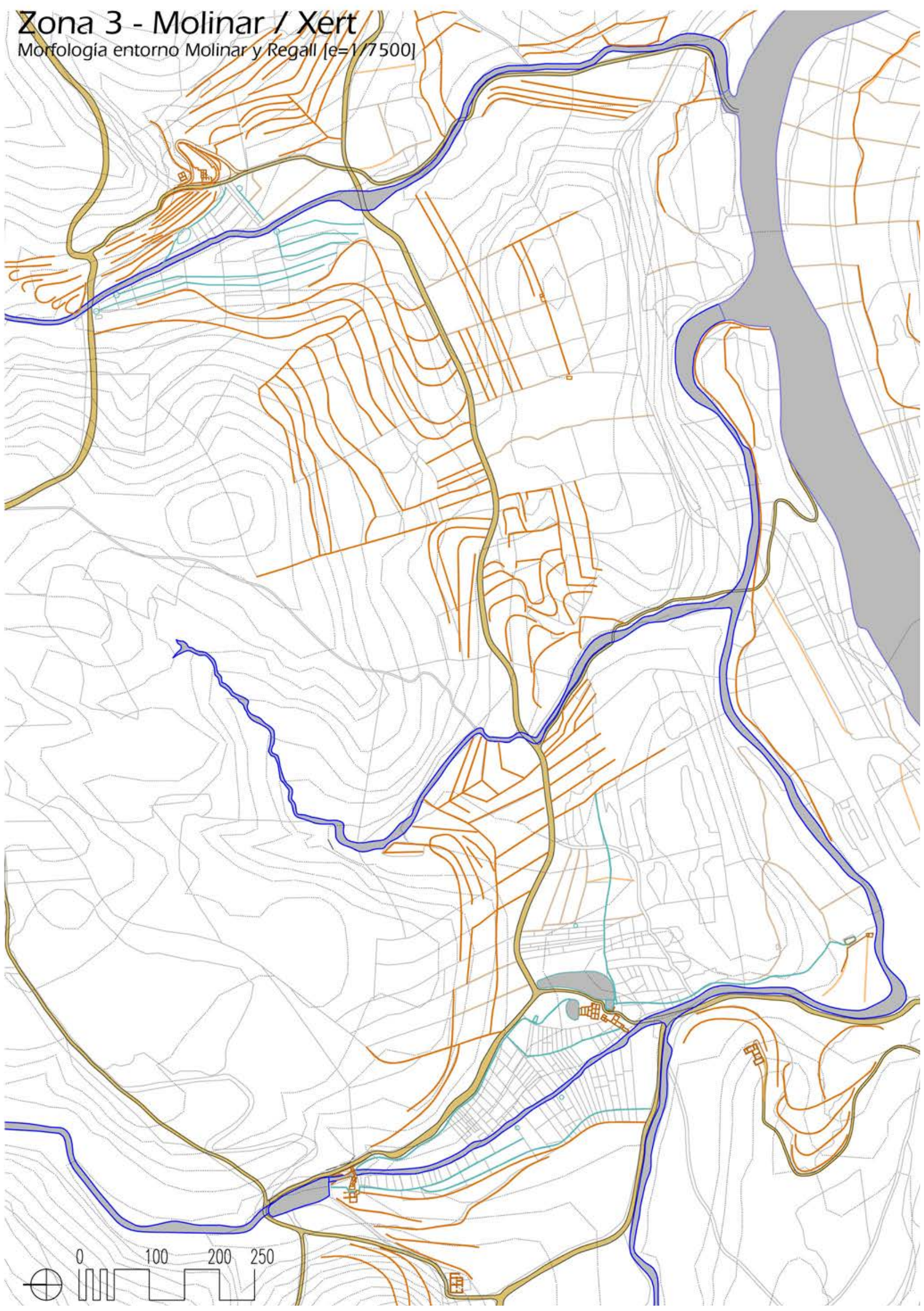




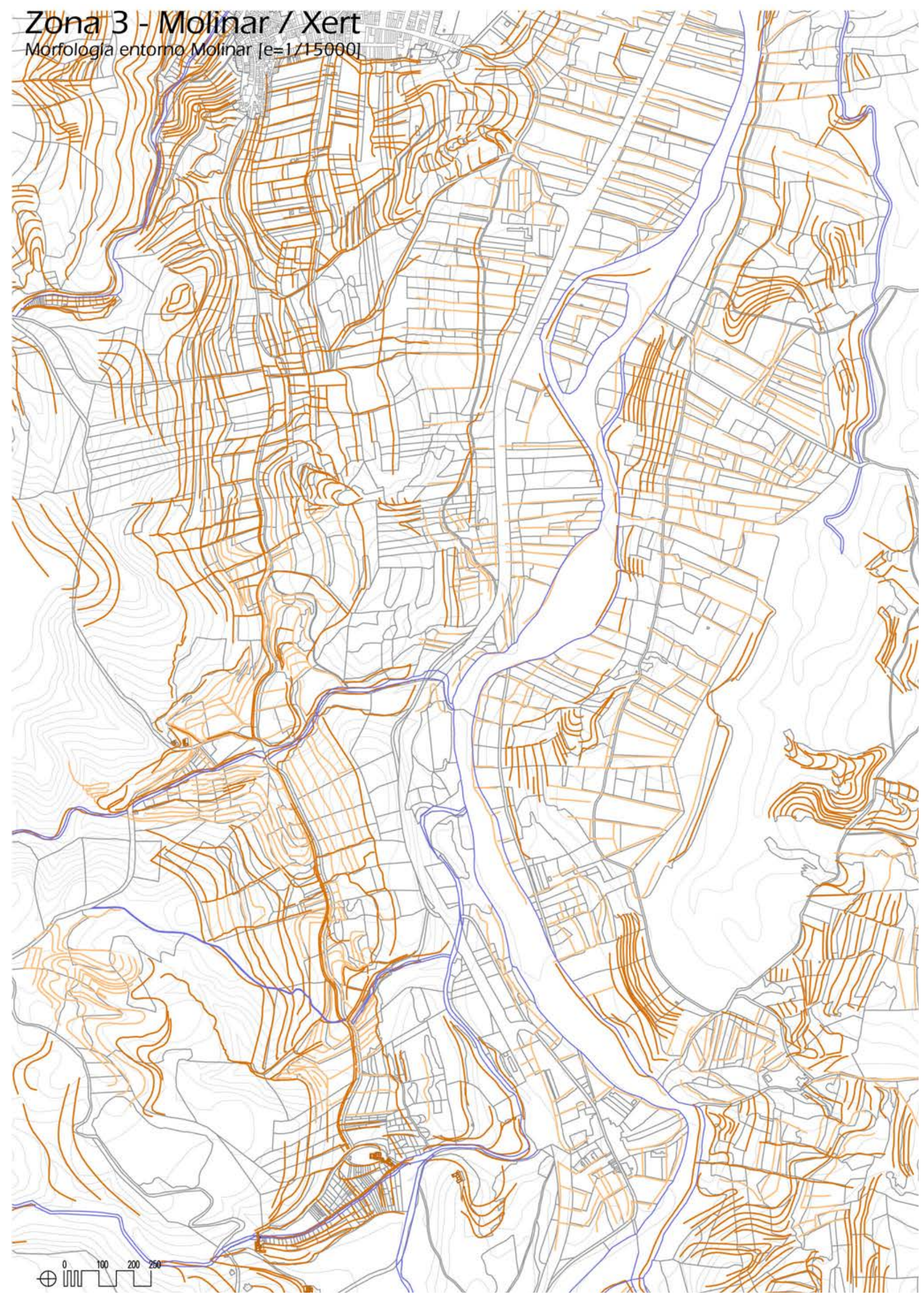


Plano parcelario + muros + bancales zona $3-[e=1 / 40.000]$

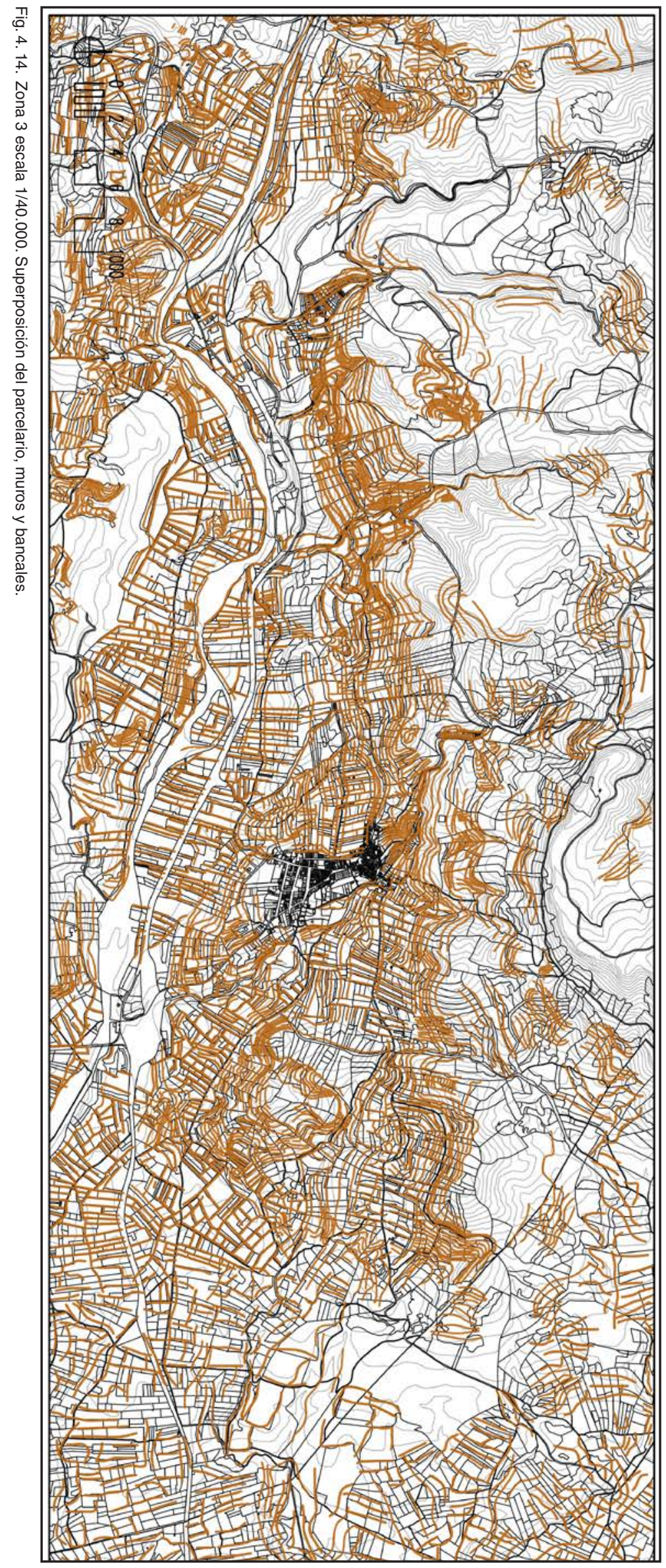


Ortofoto zona 3 - [e=1/40.000]

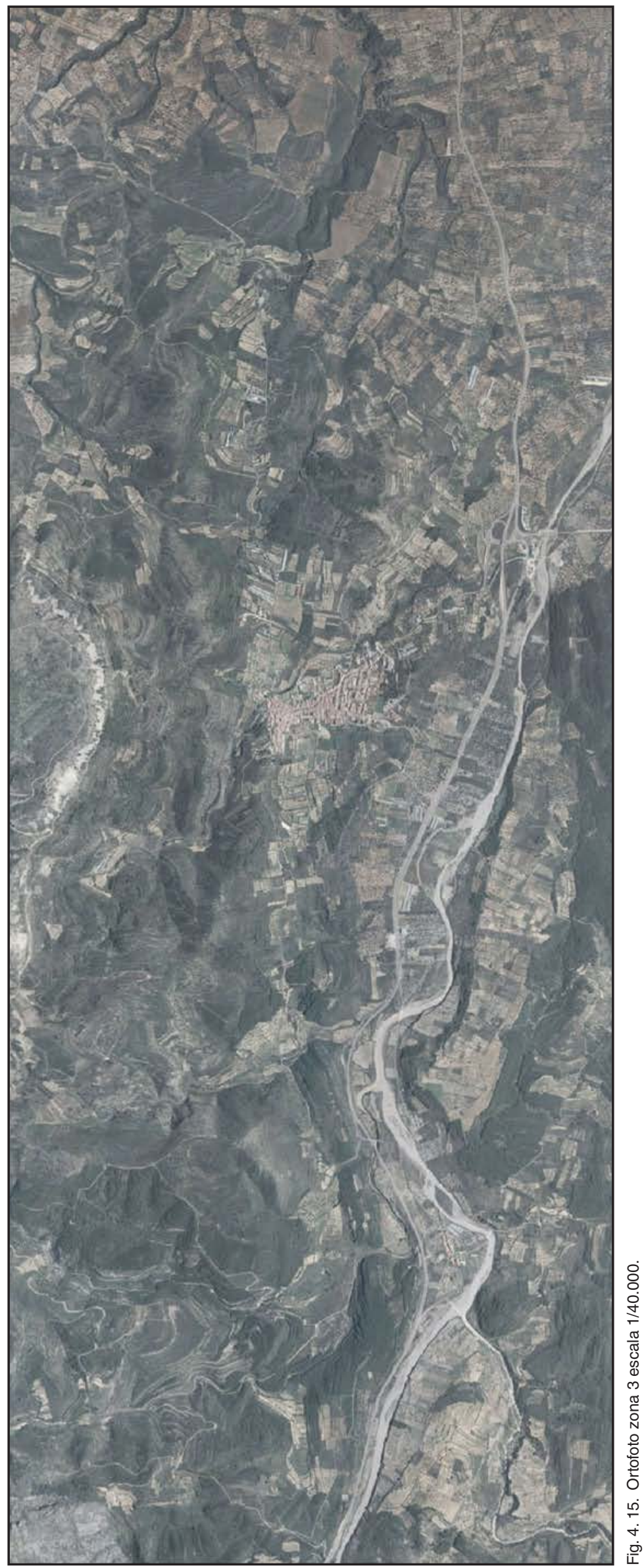


Mapa general (situación de las zonas de estudio) - $[e=1 / 200.000]$

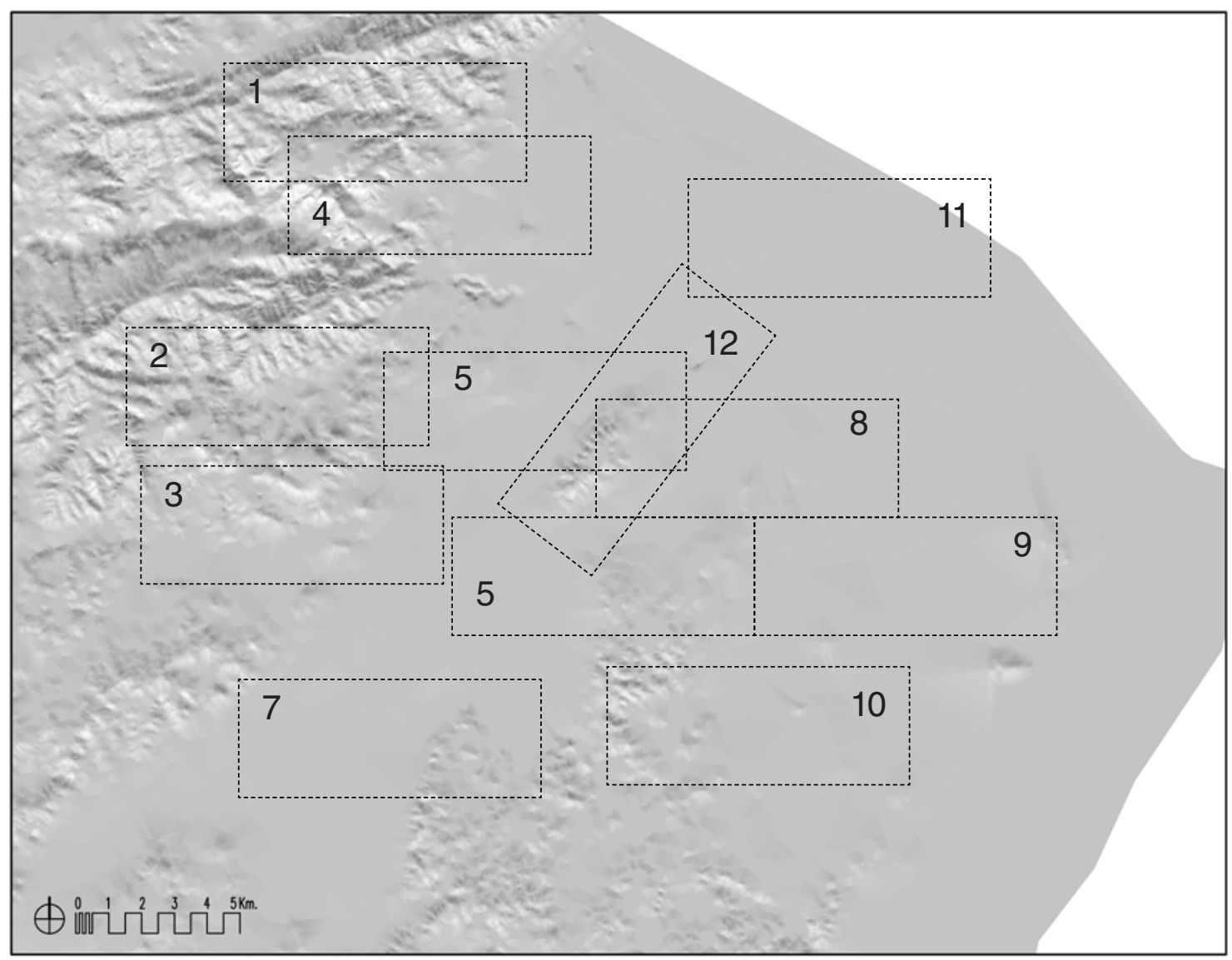

Fig. 4. 16. Plano $1 / 200.000$ de la topografía de la Batllia y de las 12 zonas de estudio.

Detalle zona 5 (situación de los elementos de interés) - [e=1/60.000]

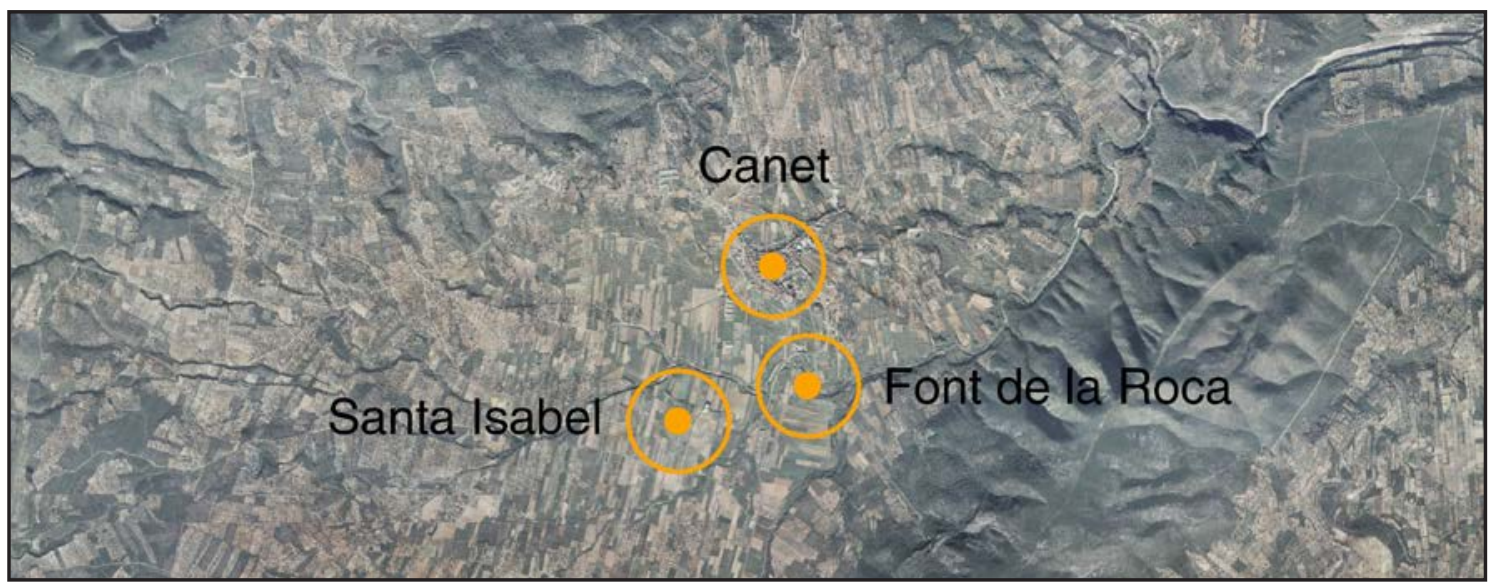

Fig. 4. 17. Ortofoto $1 / 60.000$ de la zona 15 con la ubicación de las arquitecturas que se estudian. 


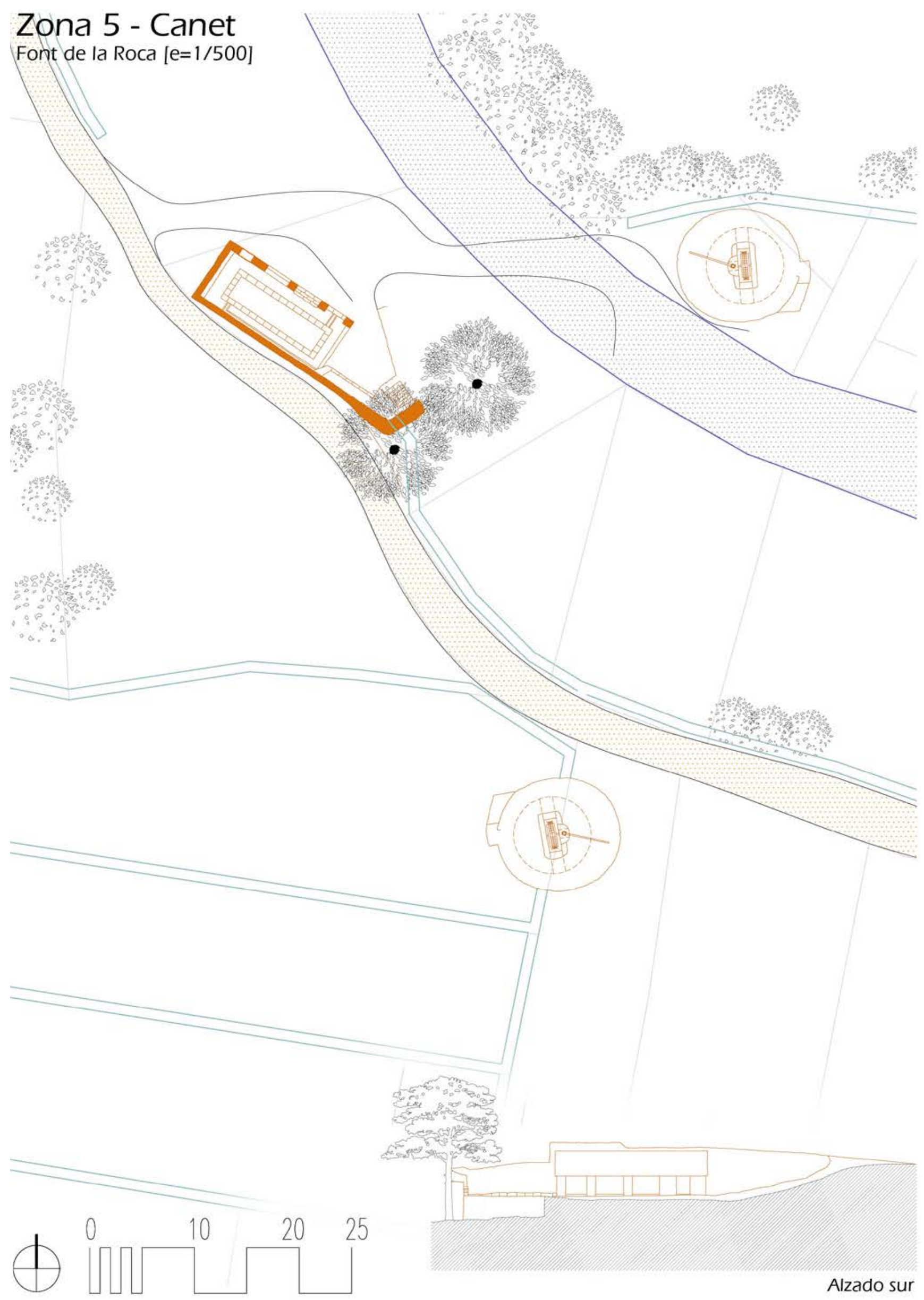




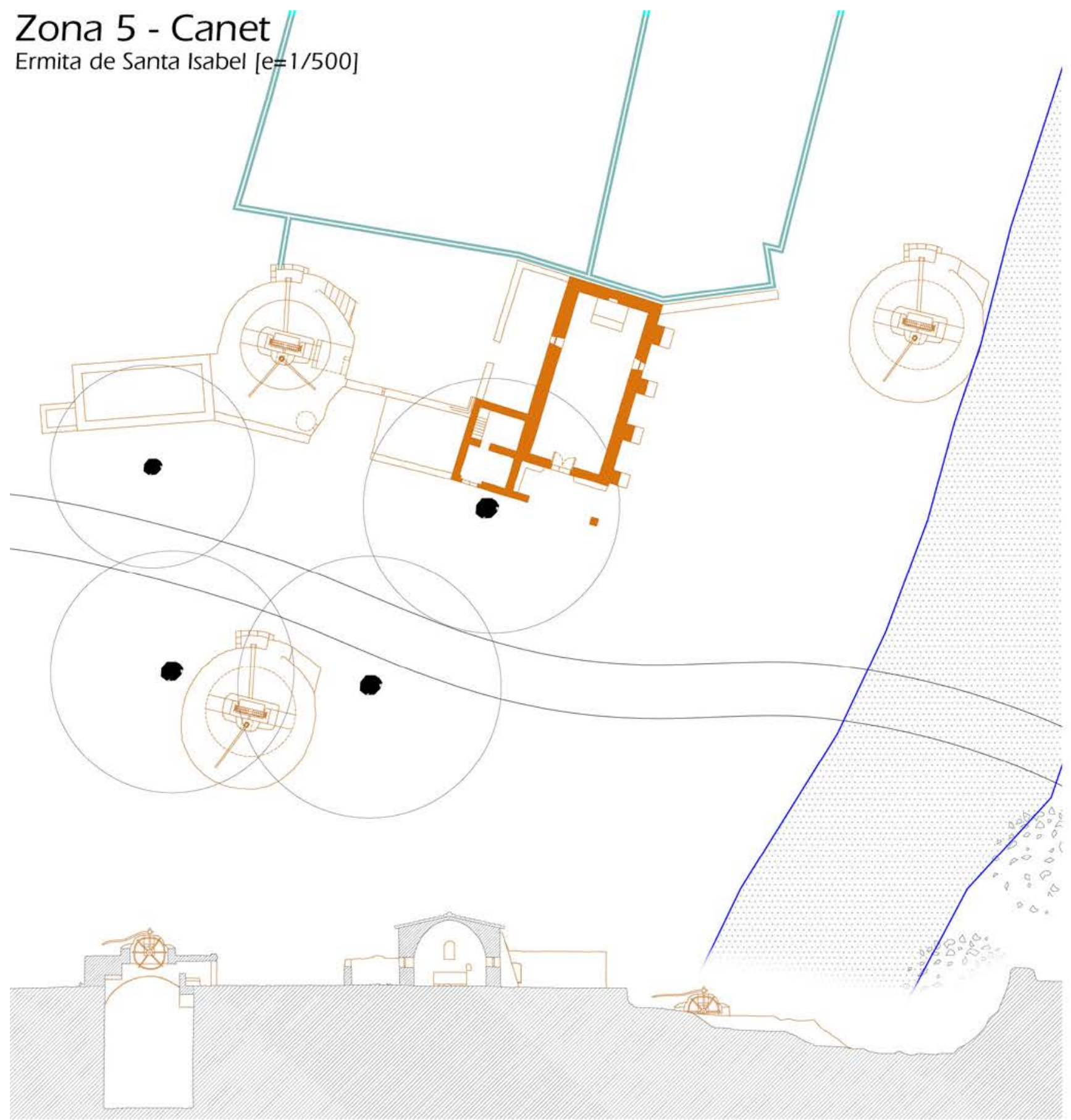

Sección transversal

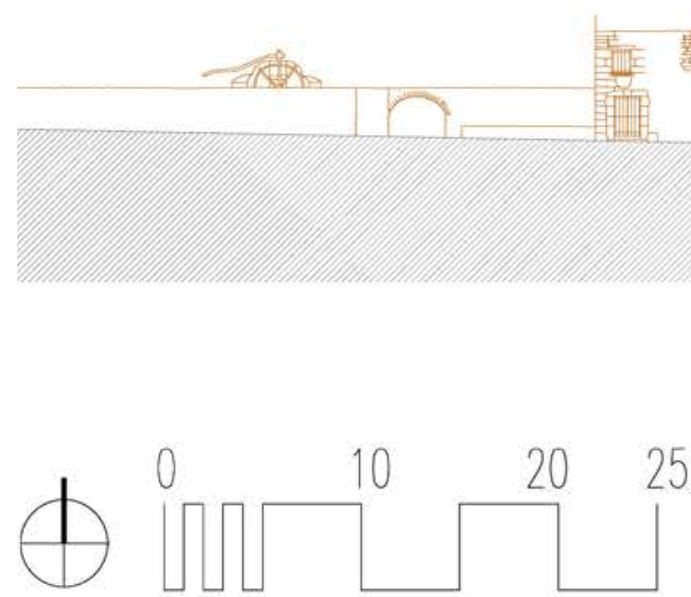

Alzado sur

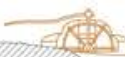




\section{Zona 5 - Canet} Iglesia de San Miguel [e=1/500]

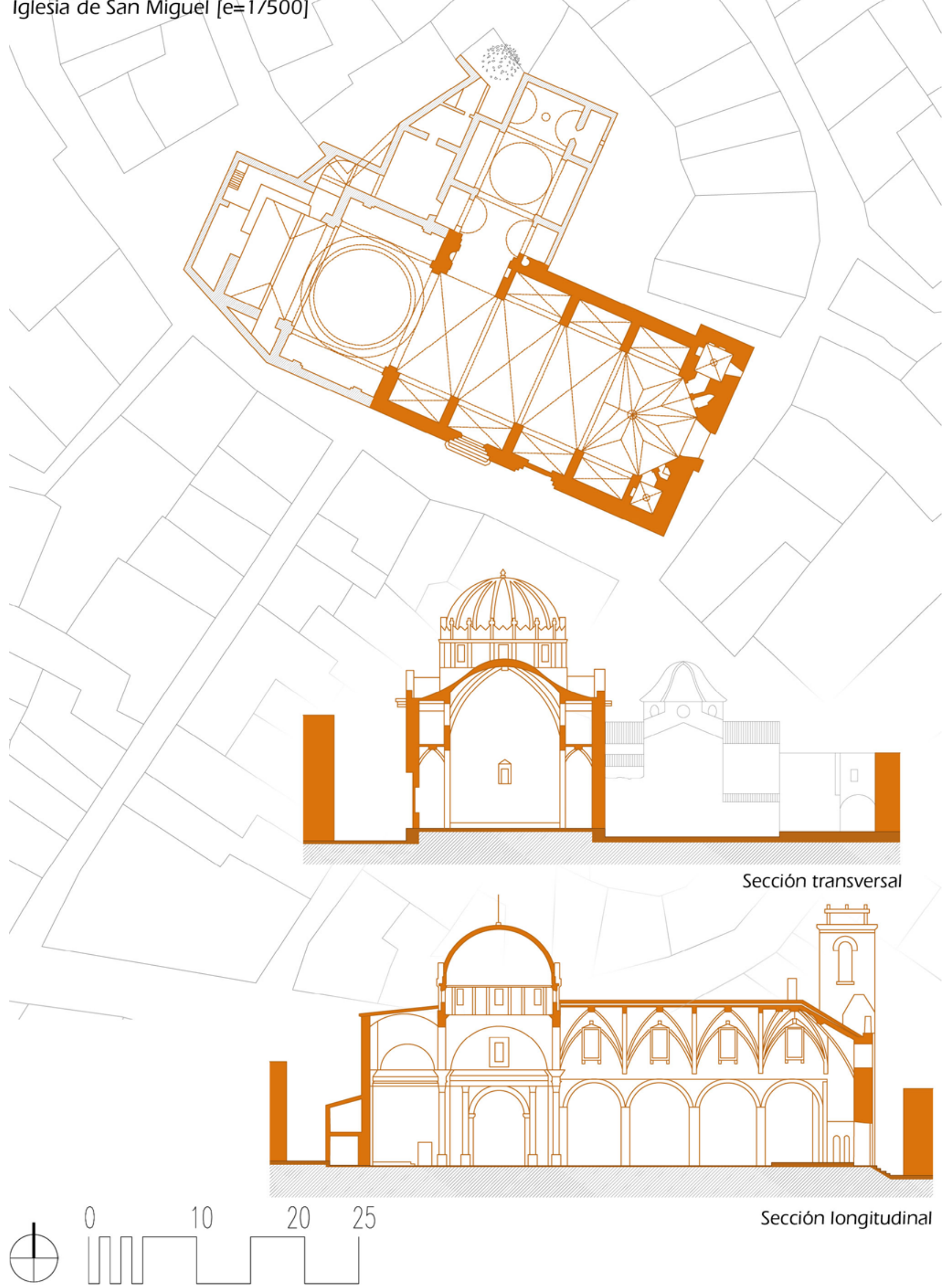




\section{Zona 5 - Canet}

\section{Font de la Roca $[\mathrm{e}=1 / 1000]$}

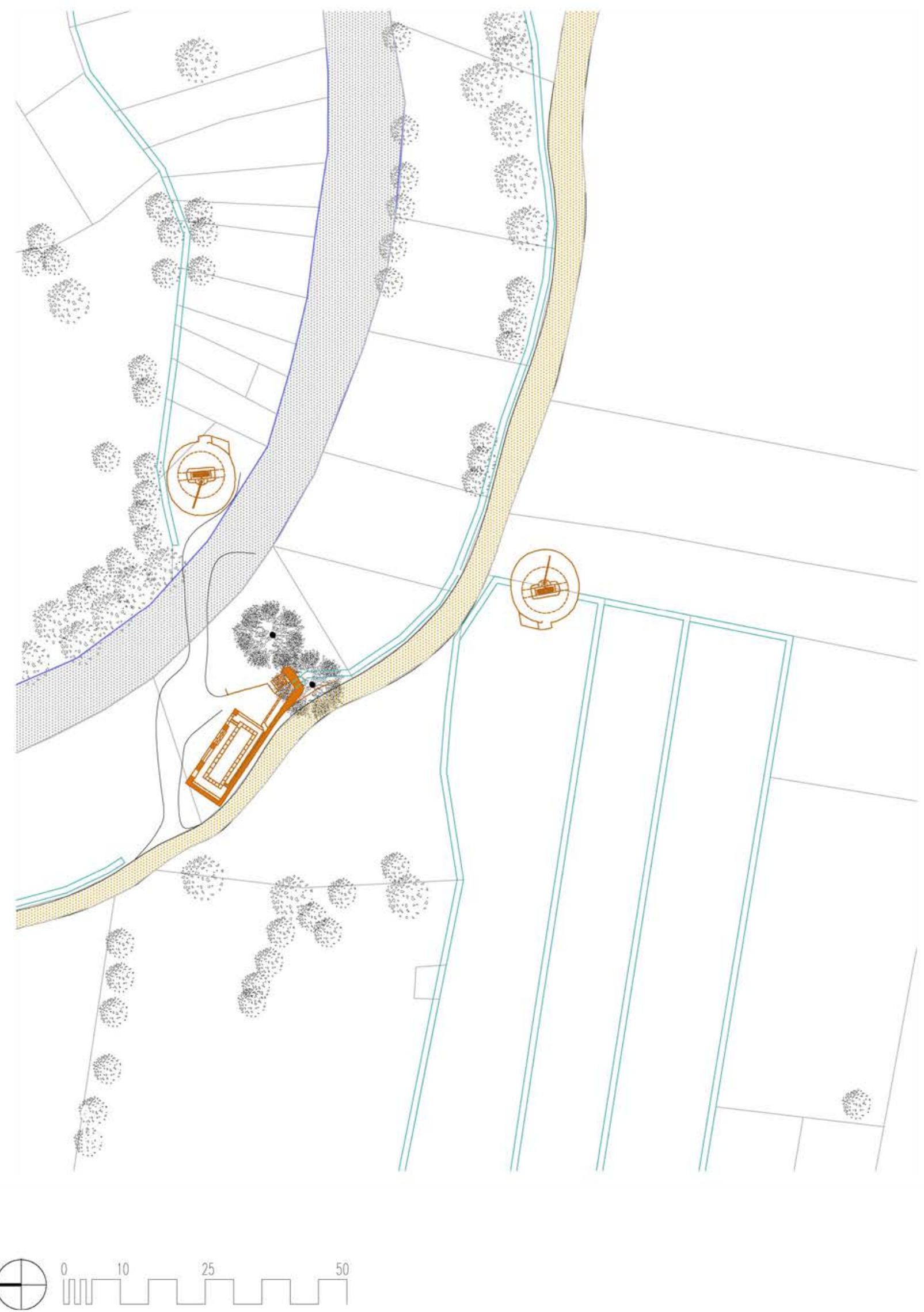




\section{Zona 5 - Canet}

Conjunto de Santa Isabel $[e=1 / 1000]$

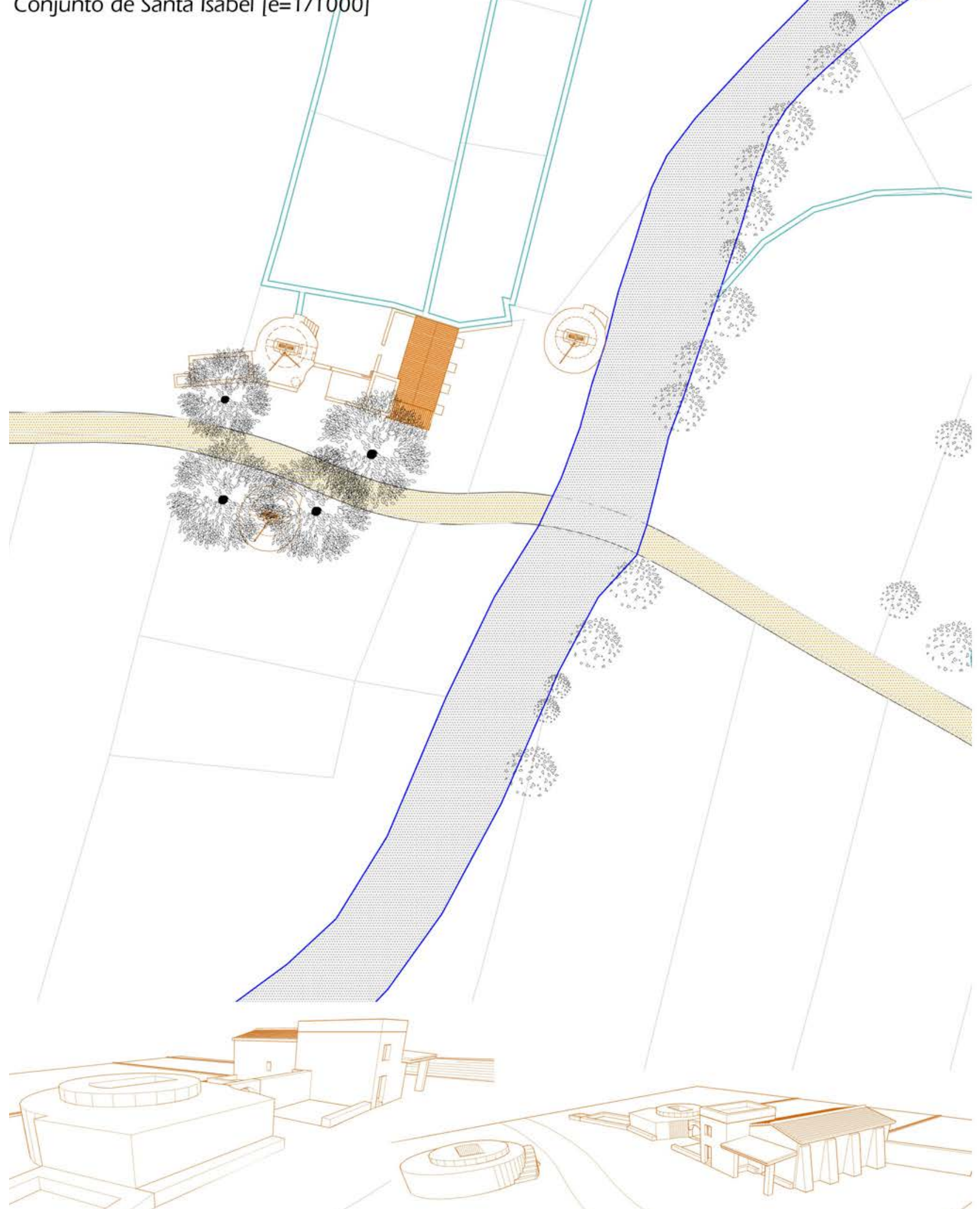

(1) 


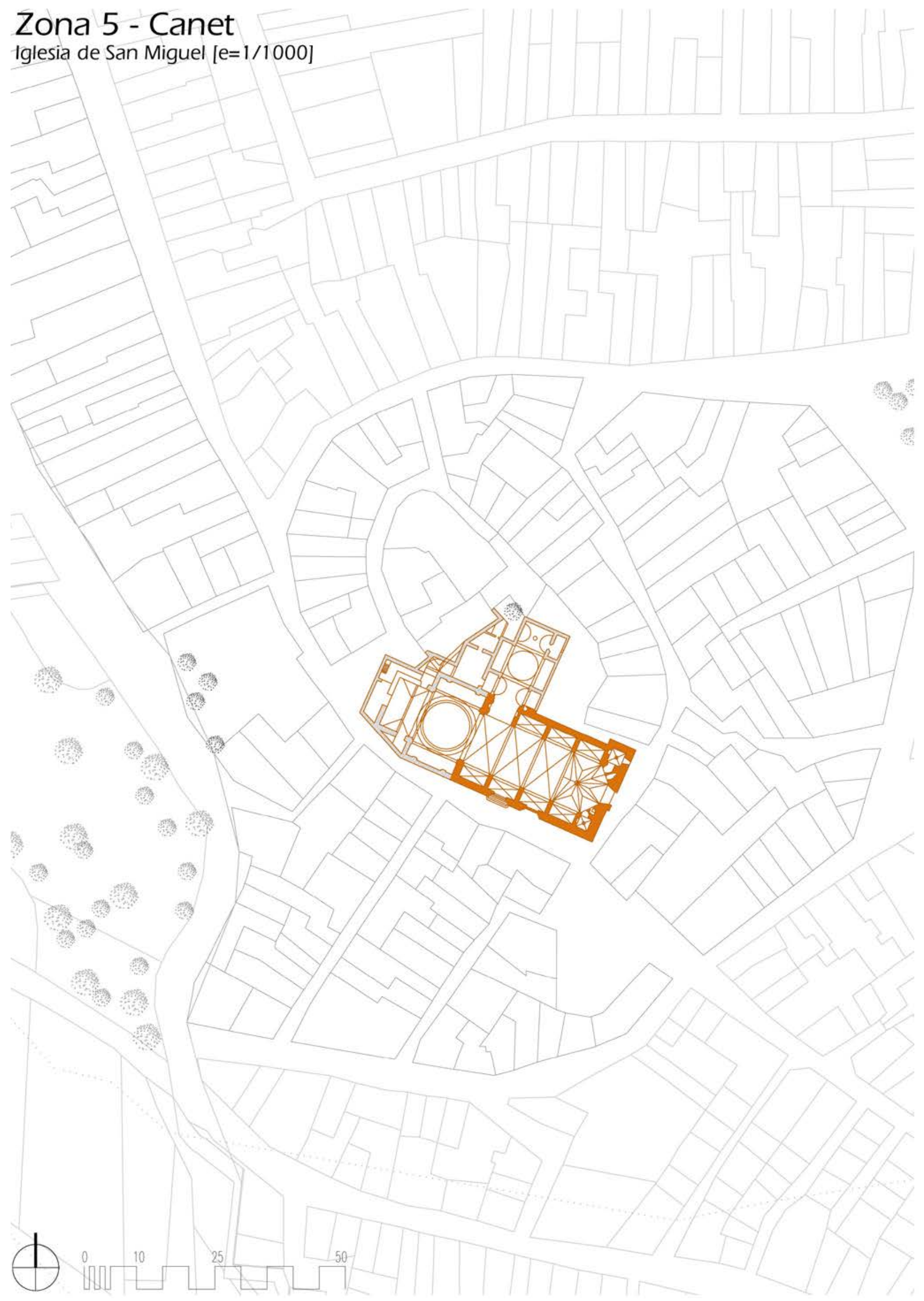




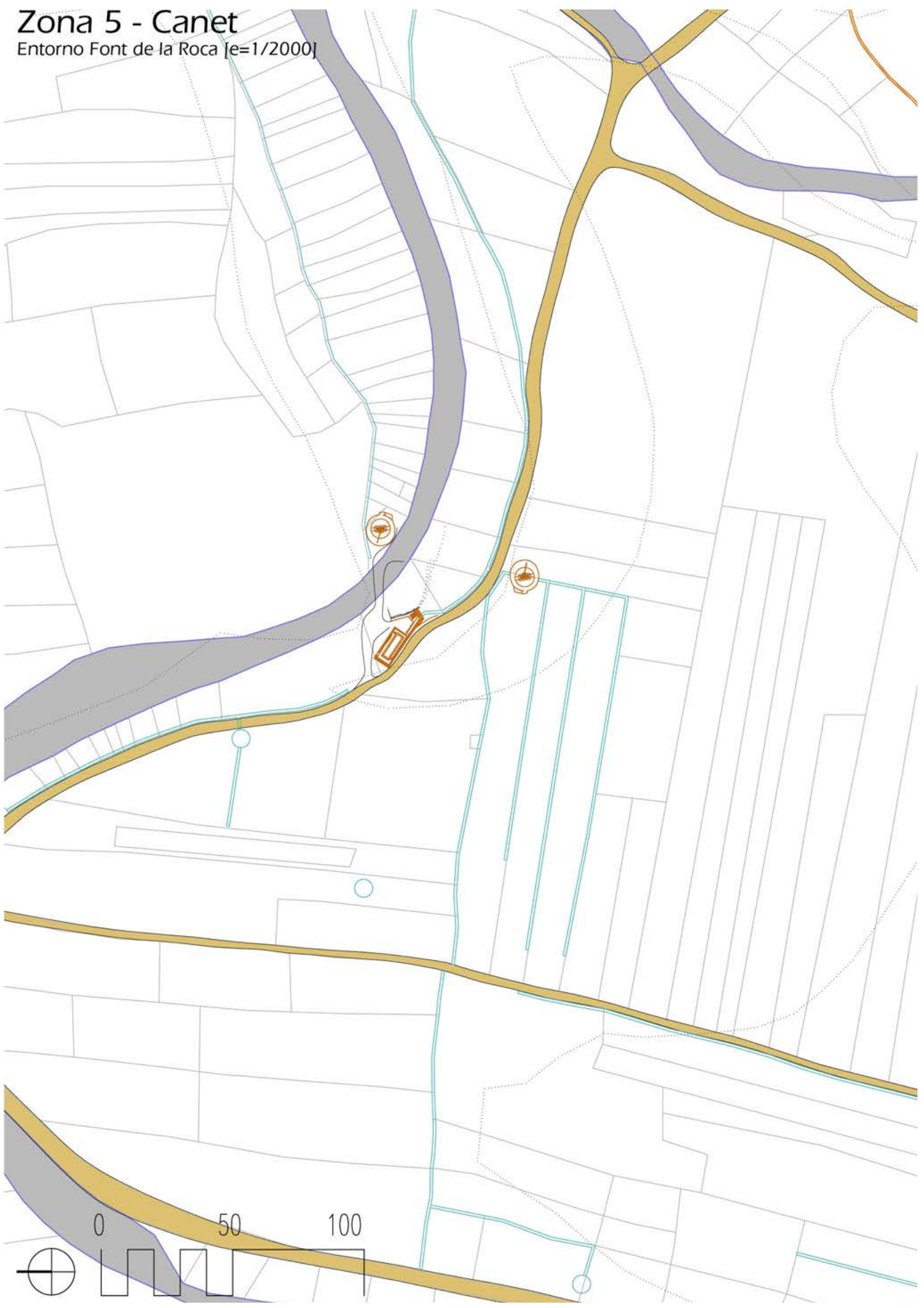




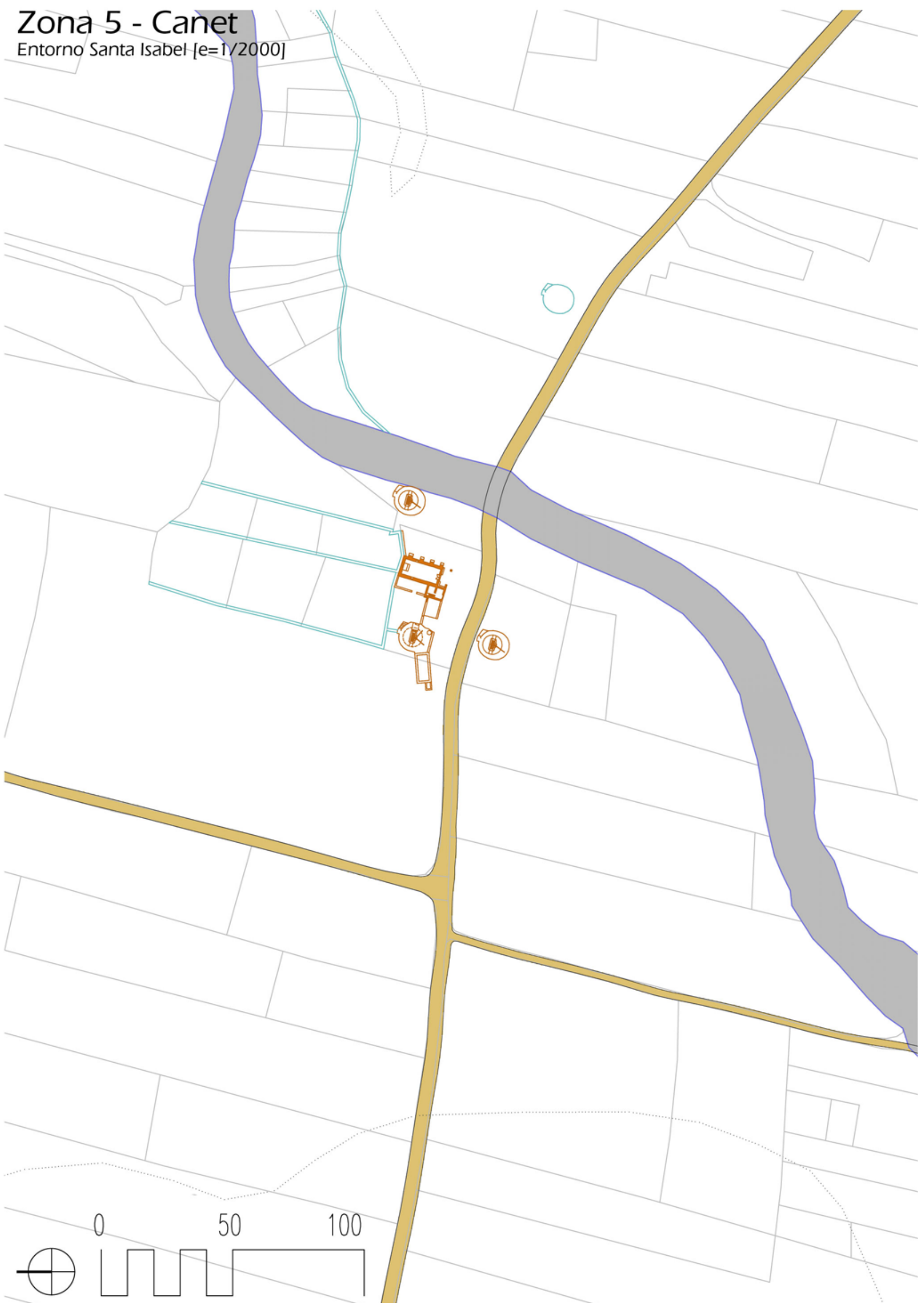




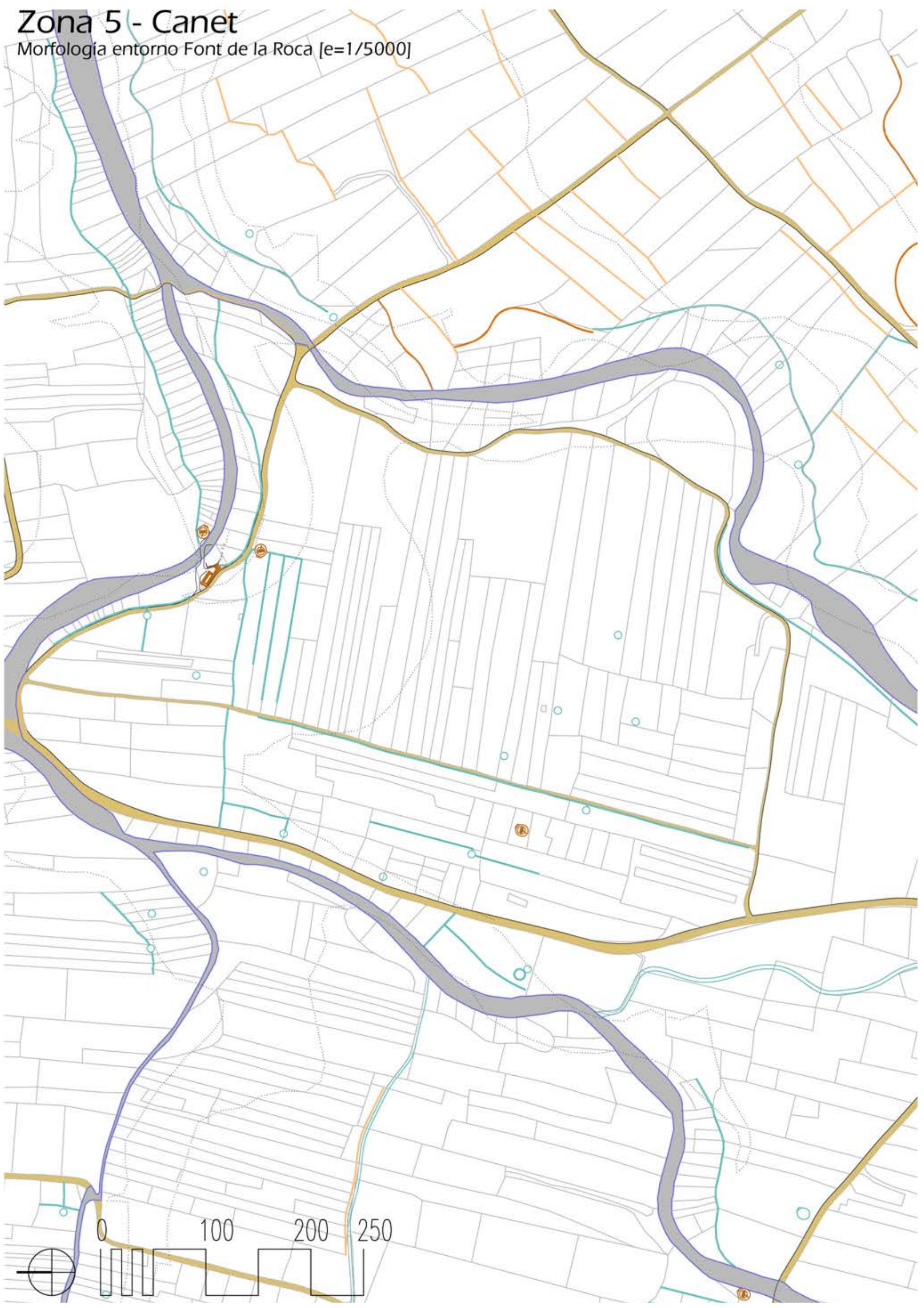




\section{Zona 5 - Canet}

Morfología entorno Santa Isabel $[e=1 / 5000]$

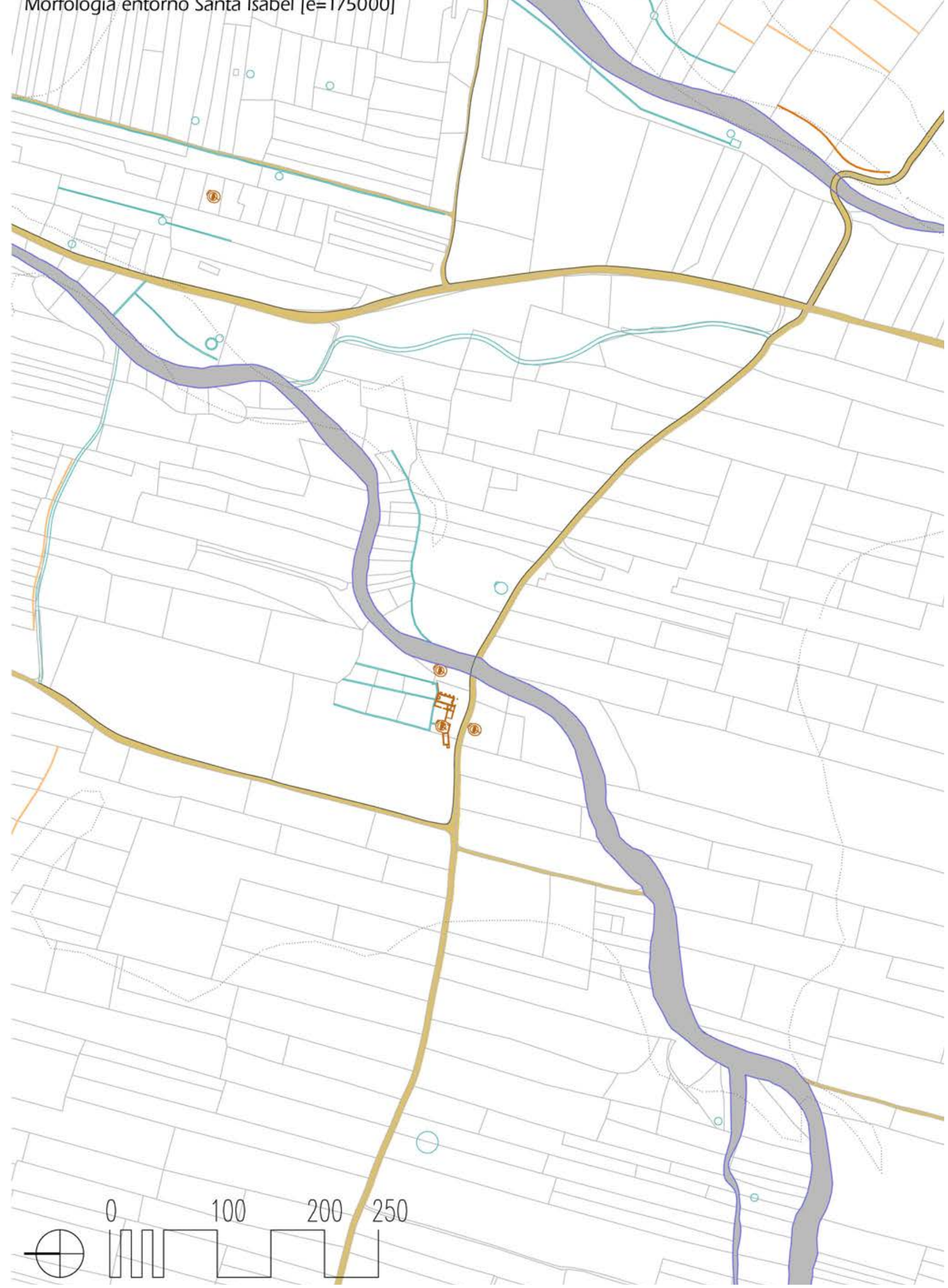




\section{Zona 5 - Canet}

Morfologia entorno Font de la Roca y Santa ssabel $[e=1 / 7500]$

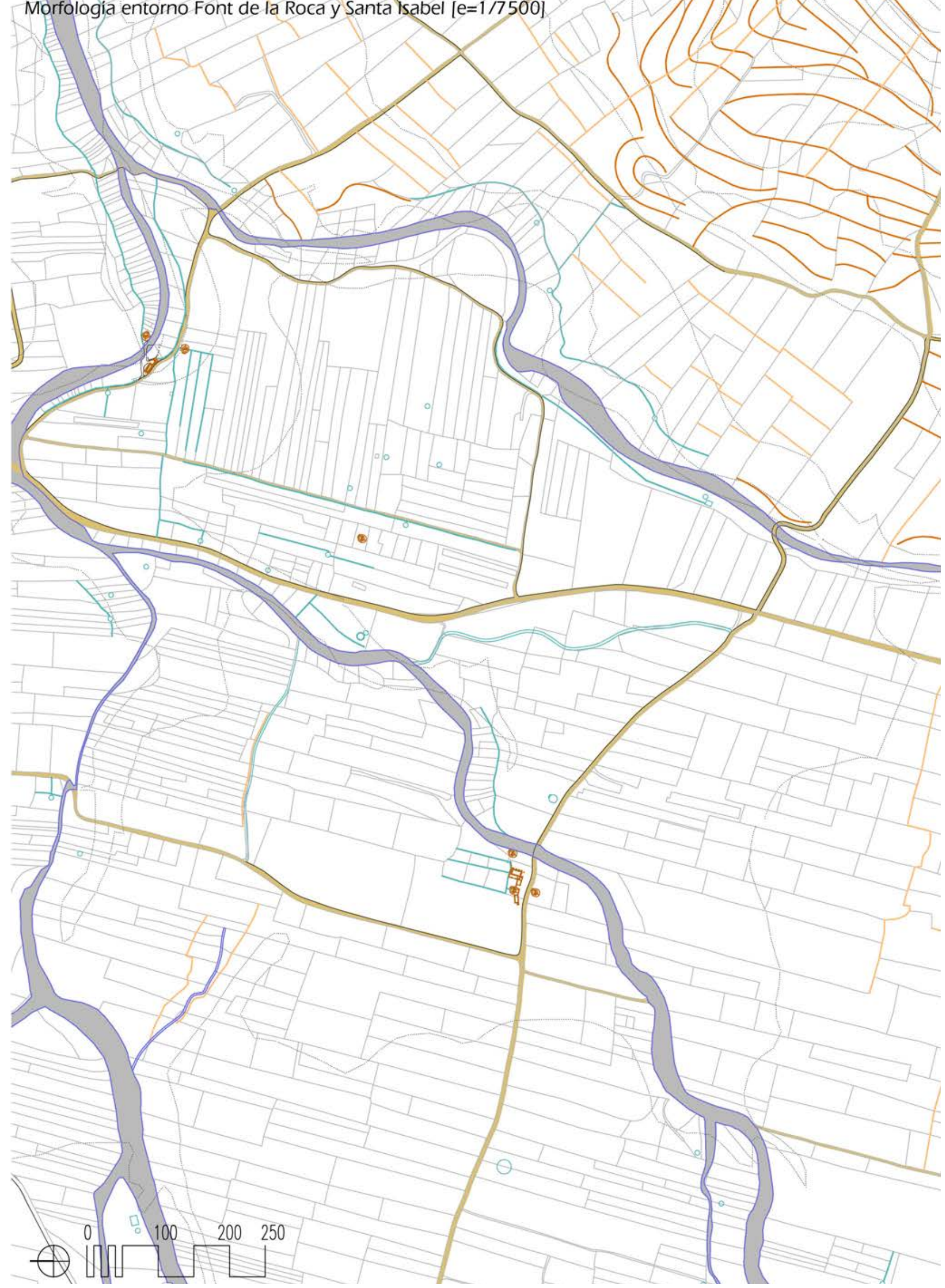




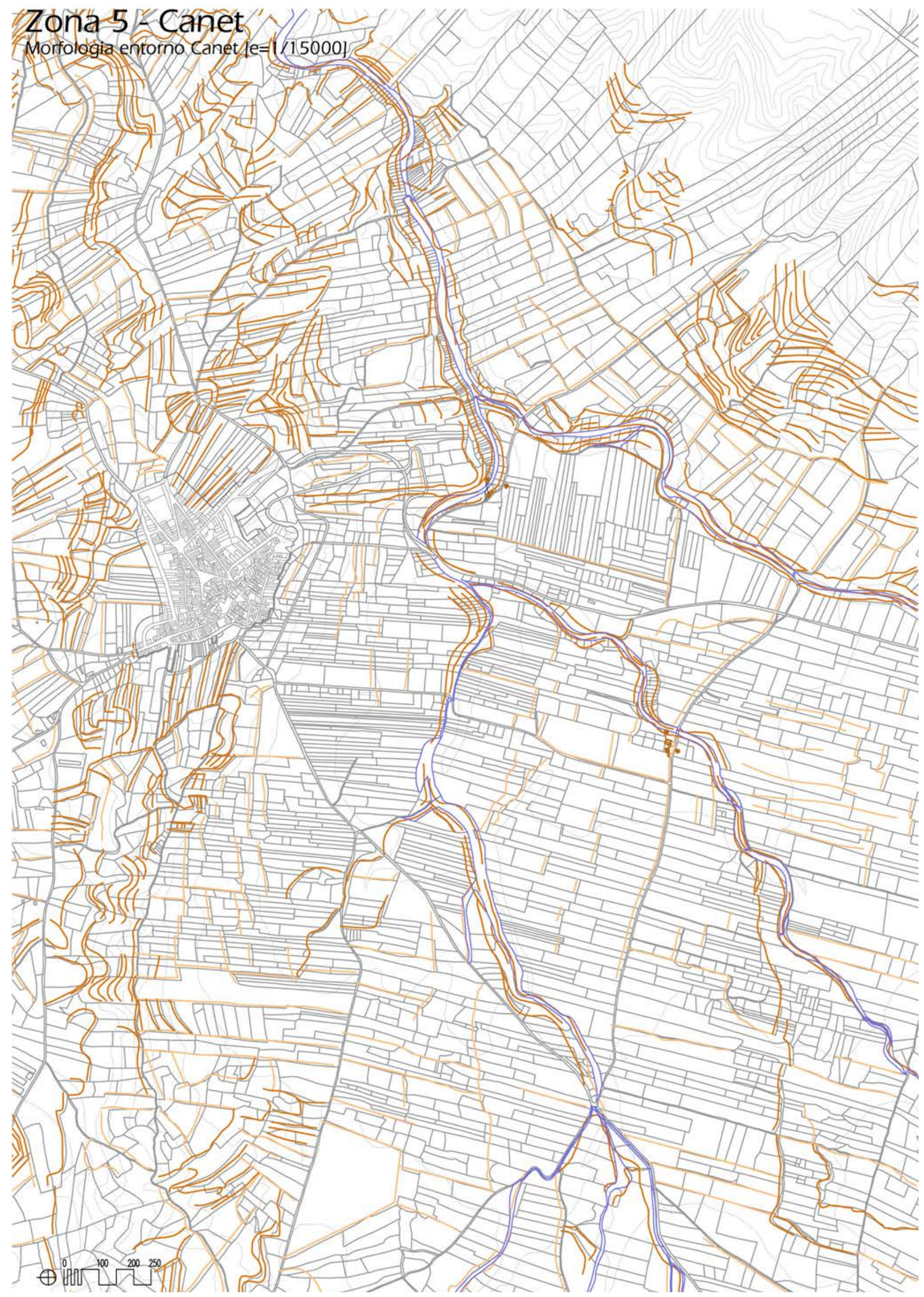


Plano parcelario + muros + bancales zona $5-[e=1 / 40.000]$

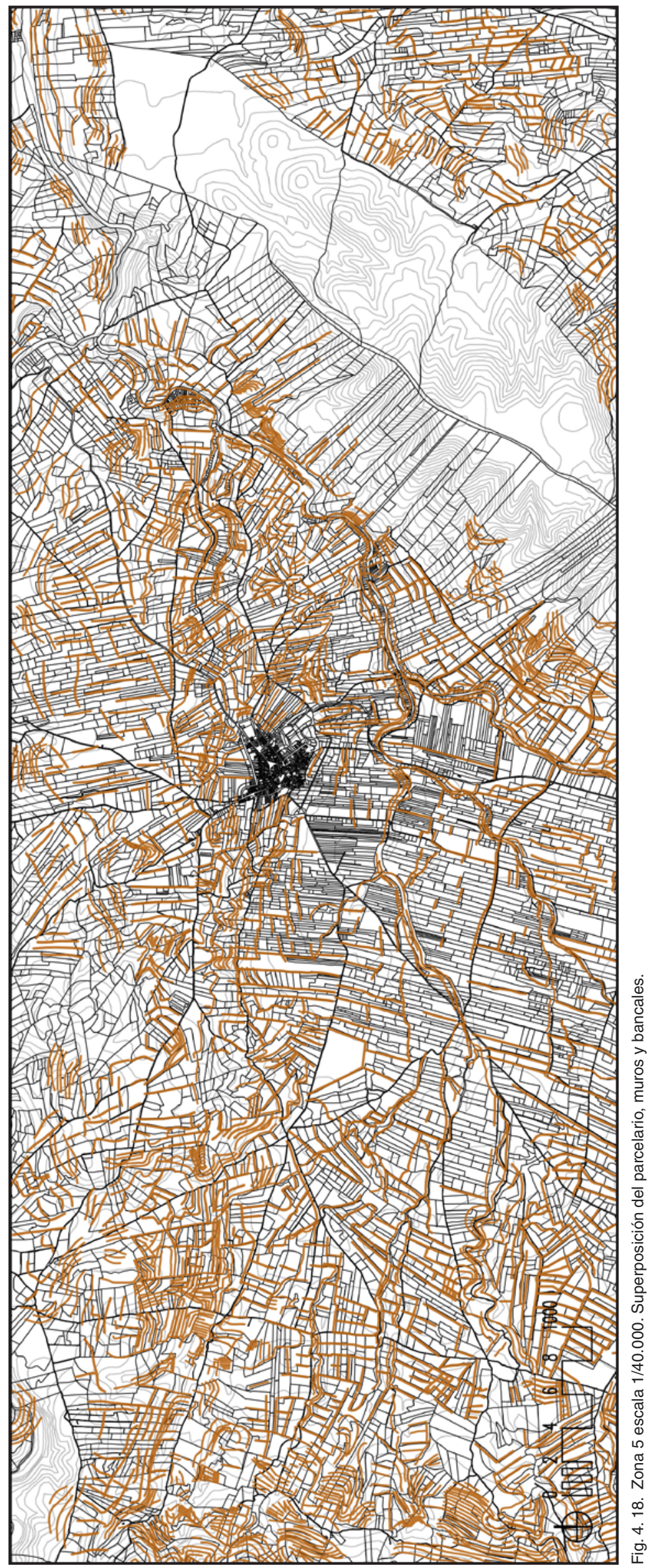




\section{Ortofoto zona 5 - $[e=1 / 40.000]$}

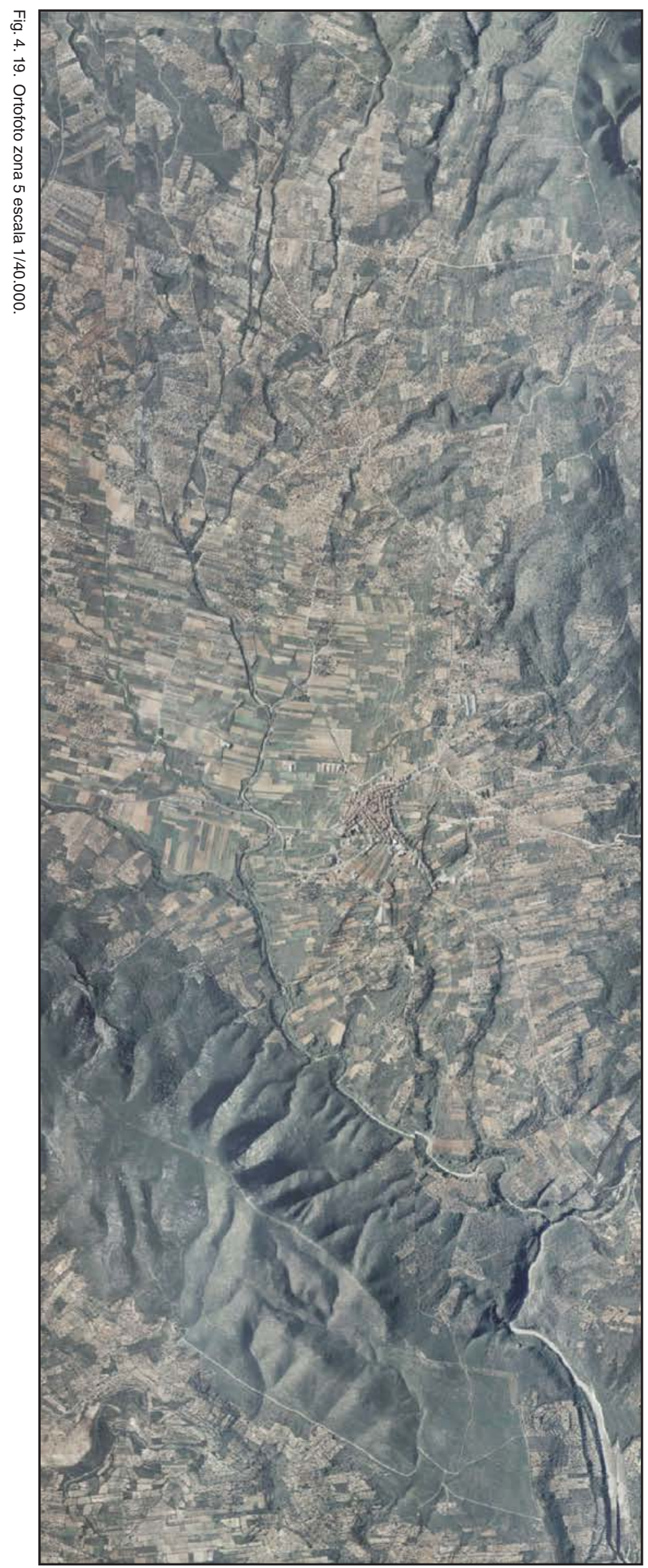


Mapa general (situación de las zonas de estudio) $[\mathrm{e}=1 / 200.000]$

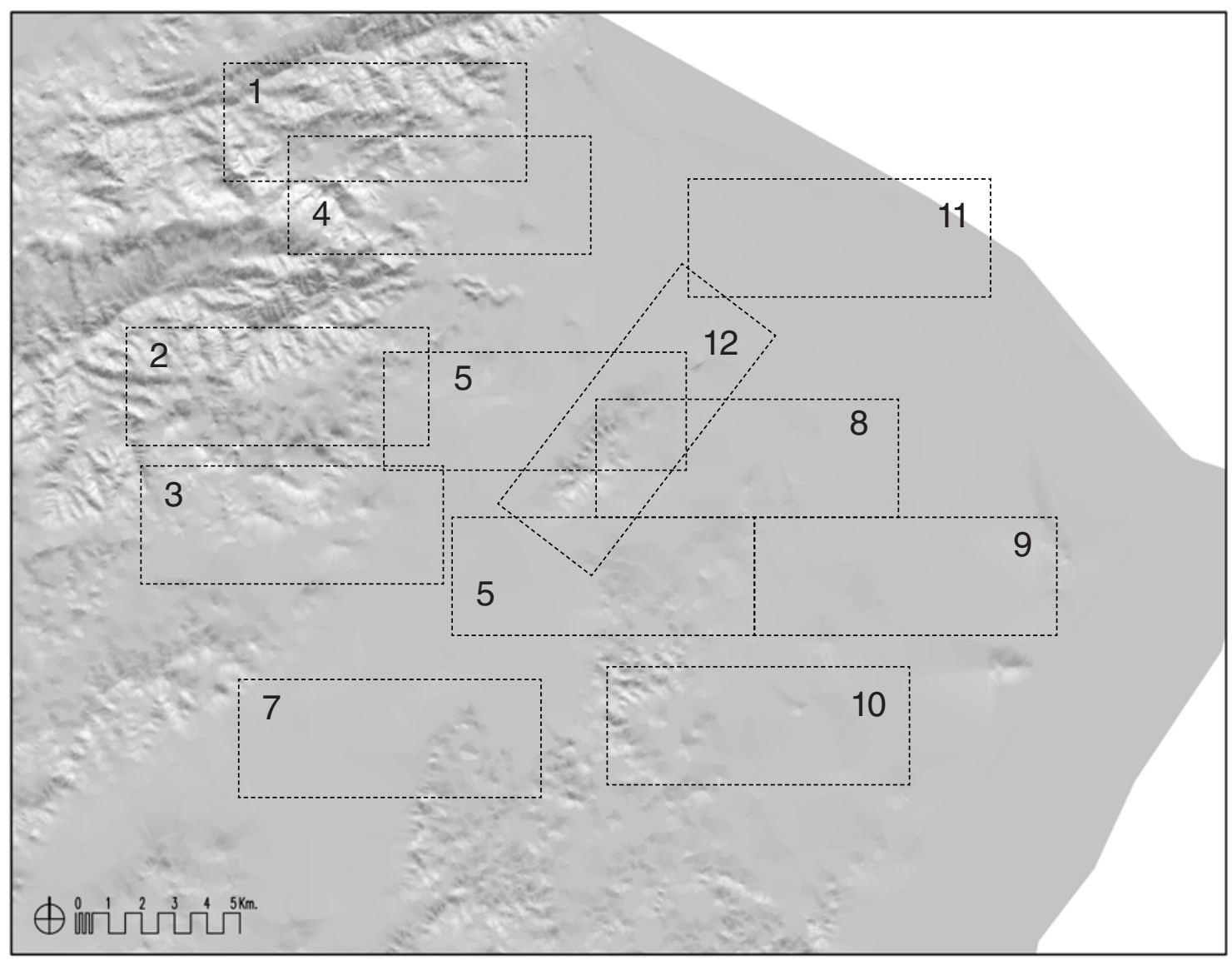

Fig. 4. 20. Plano 1/200.000 de la topografía de la Batllia y de las 12 zonas de estudio.

Detalle zona 10 (situación de los elementos de interés) - [e=1/60.000]

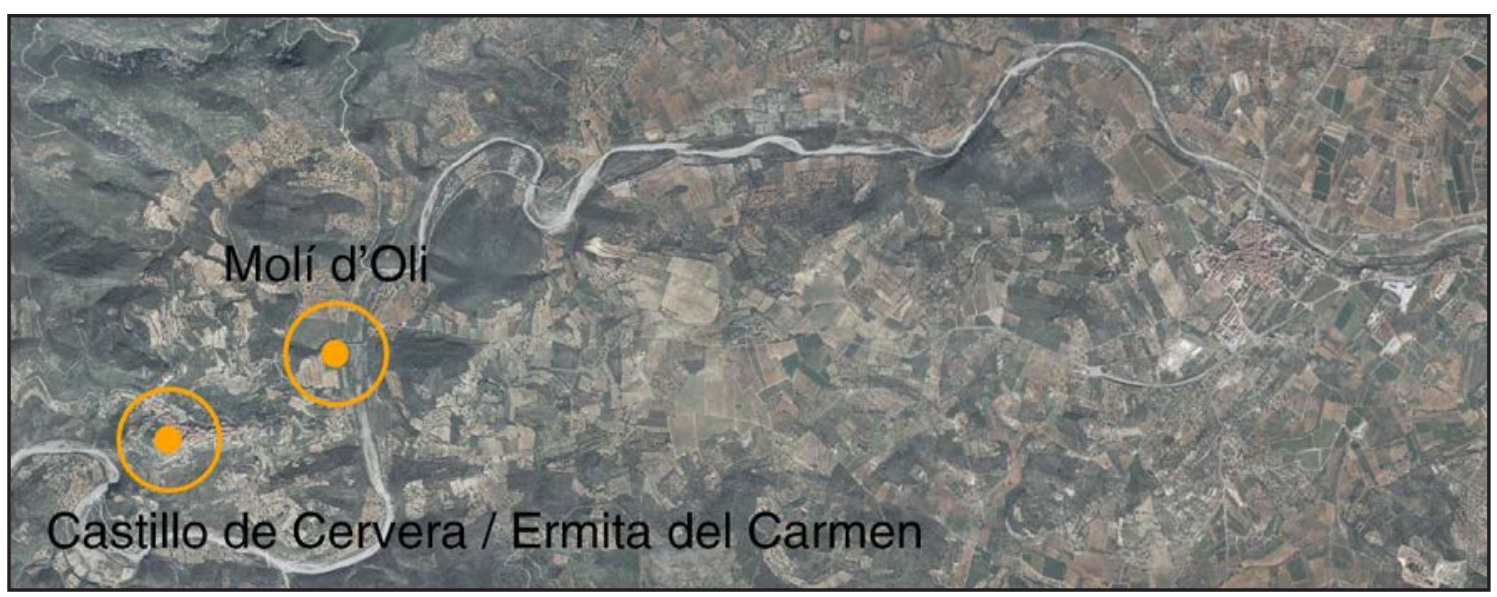

Fig. 4. 21. Ortofoto $1 / 60.000$ de la zona 10 con la ubicación de las arquitecturas que se estudian. 


\section{Zona 10 - Cervera / Calig}

Moli d'oli $[e=1 / 500]$

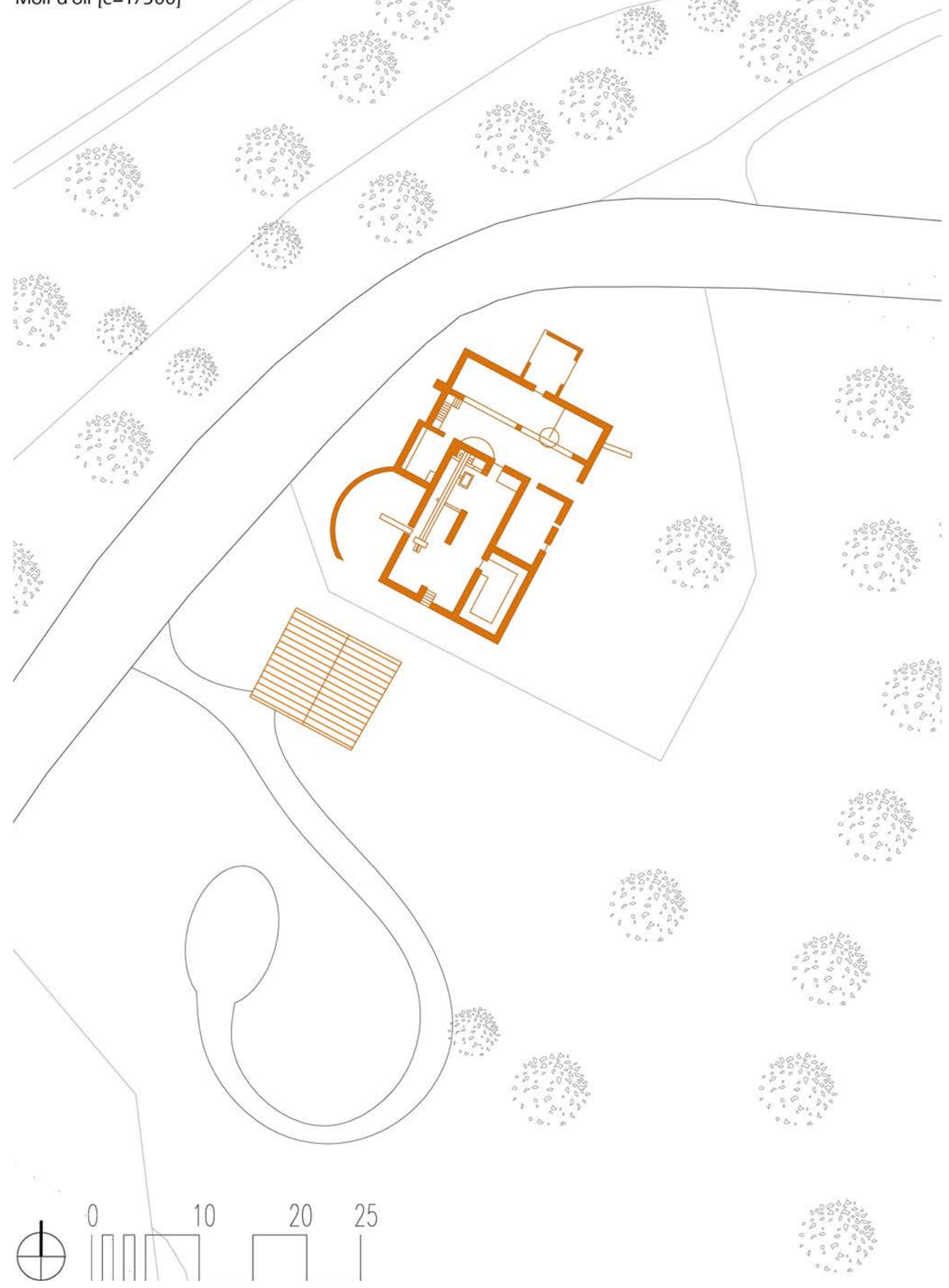




\section{Zona 10 - Cervera / Calig} Castillo de Cervera $[e=1 / 500]$
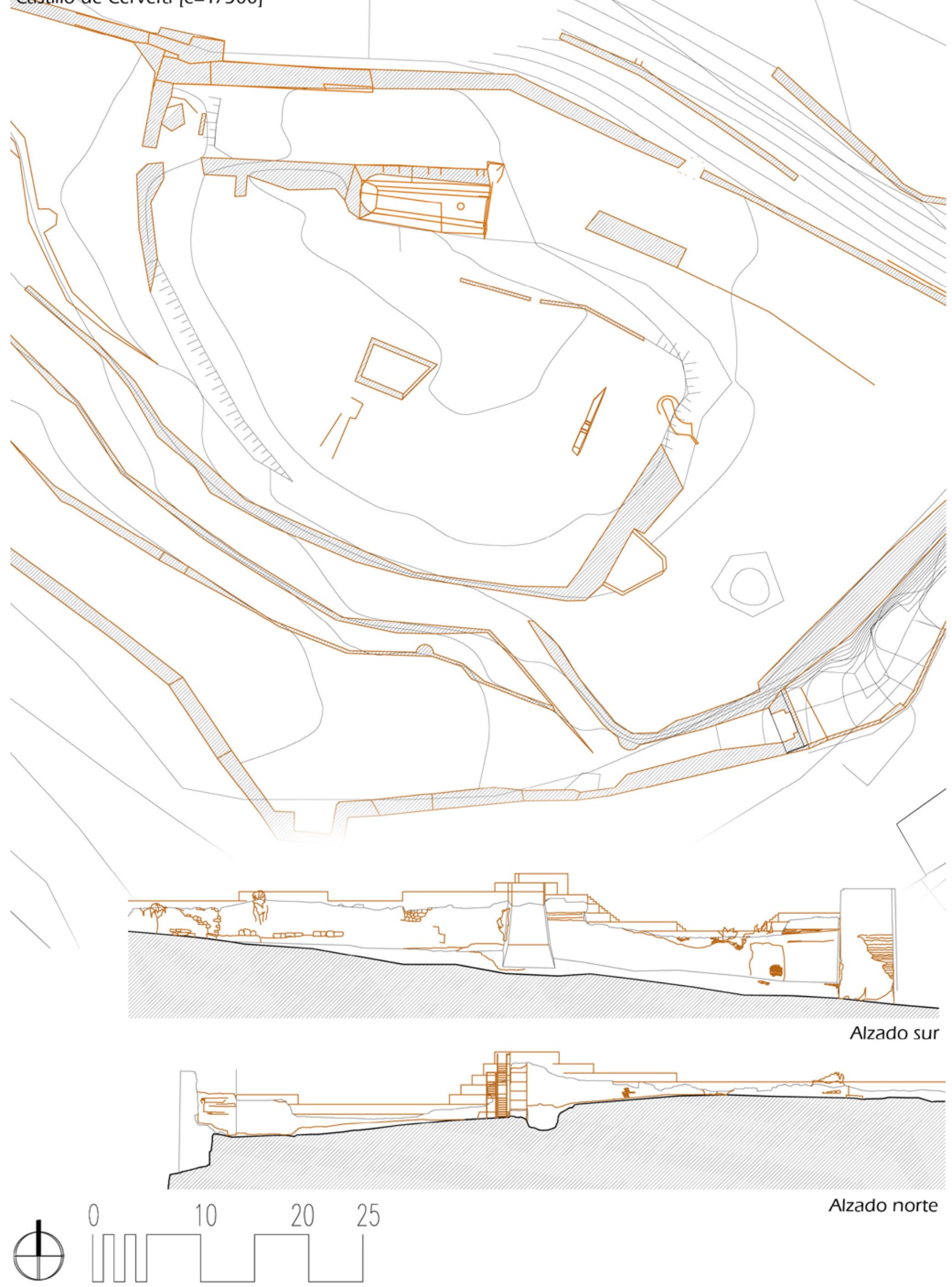

Alzado norte 


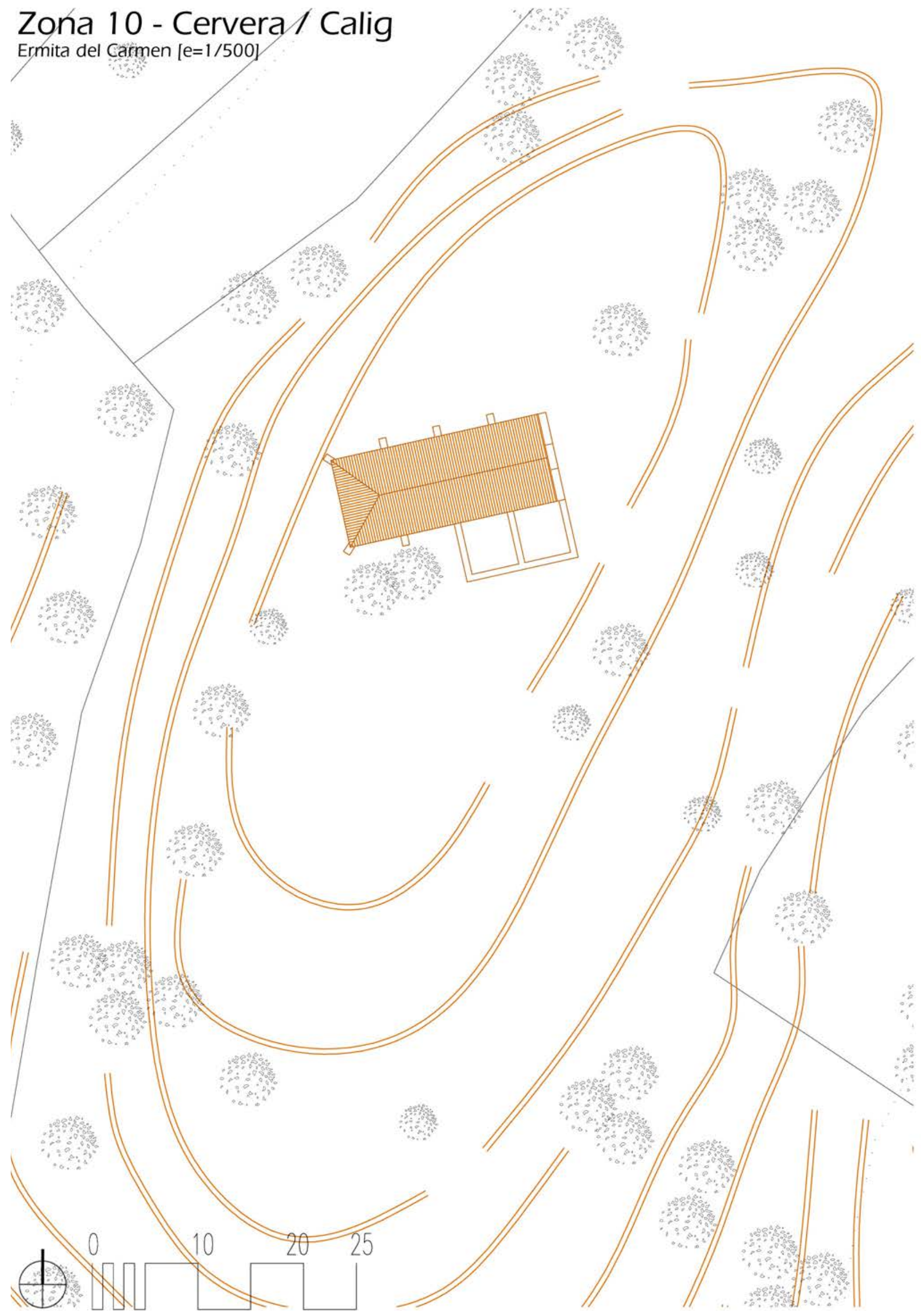




\section{Zona 10 - Cervera / Calig \\ Moli d'oli $[\mathrm{e}=1 / 1000]$}

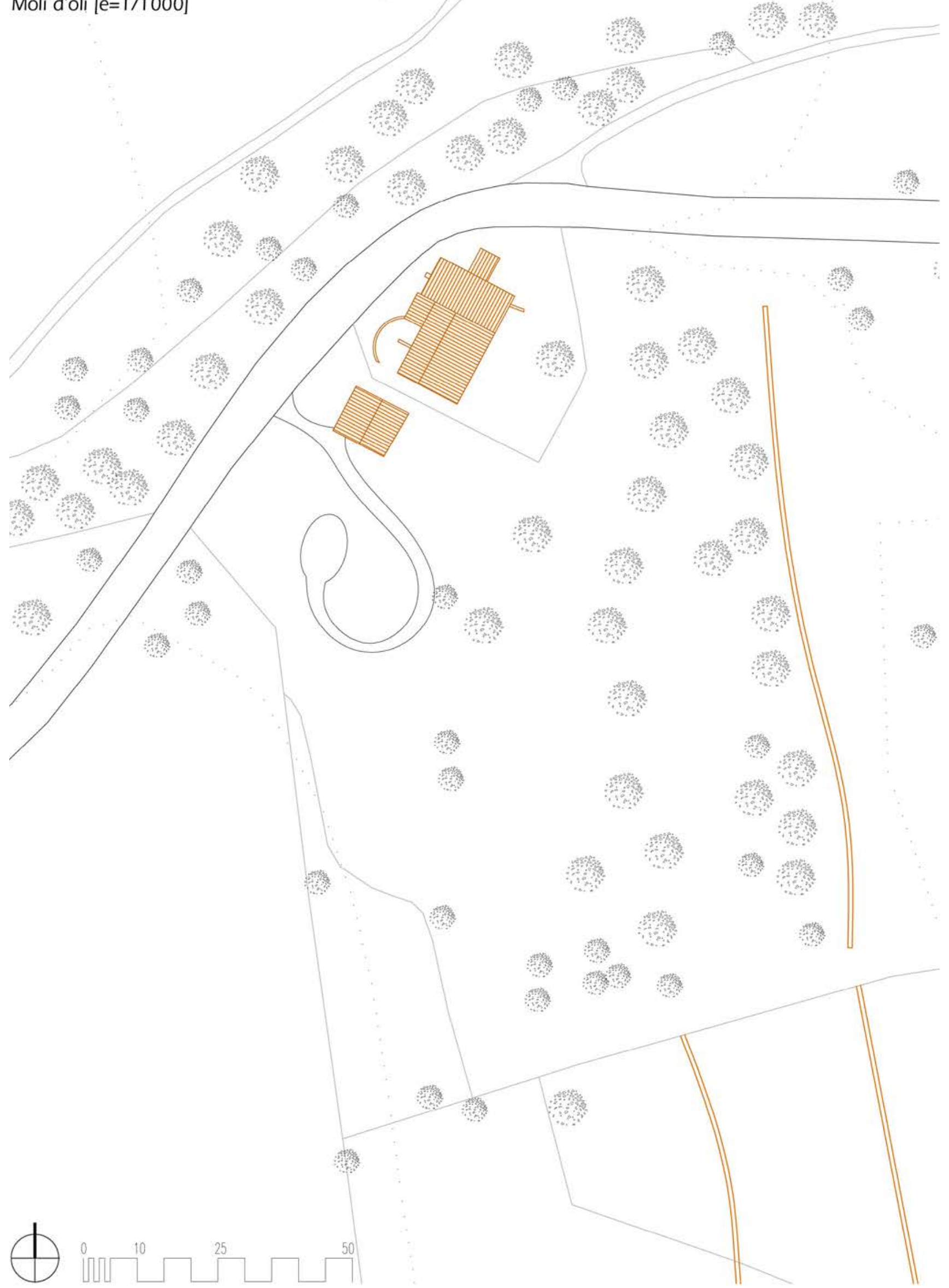




\section{Zona 10 - Cervera / Calig} Castillo de Cervera [e=1/1000]

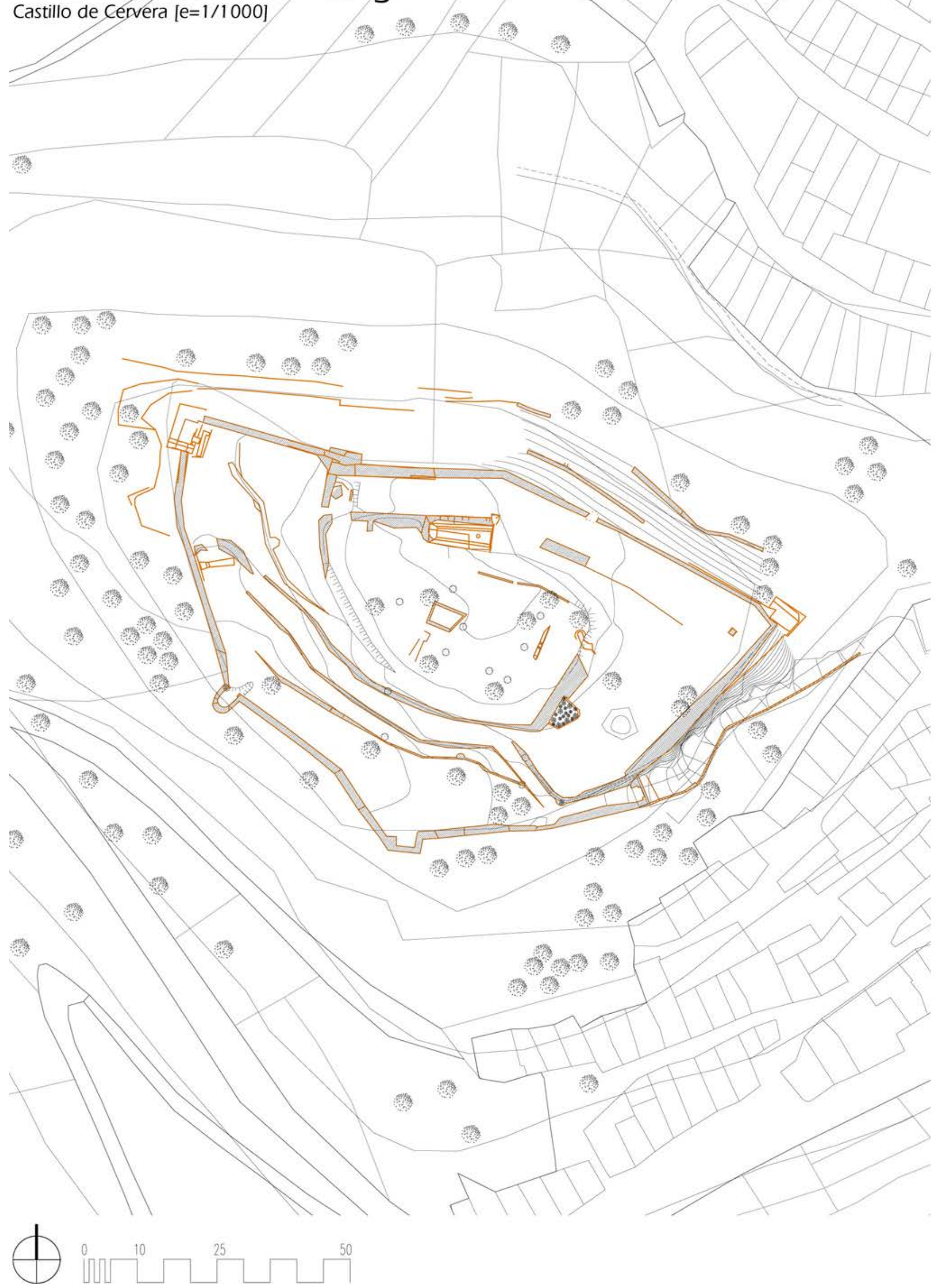




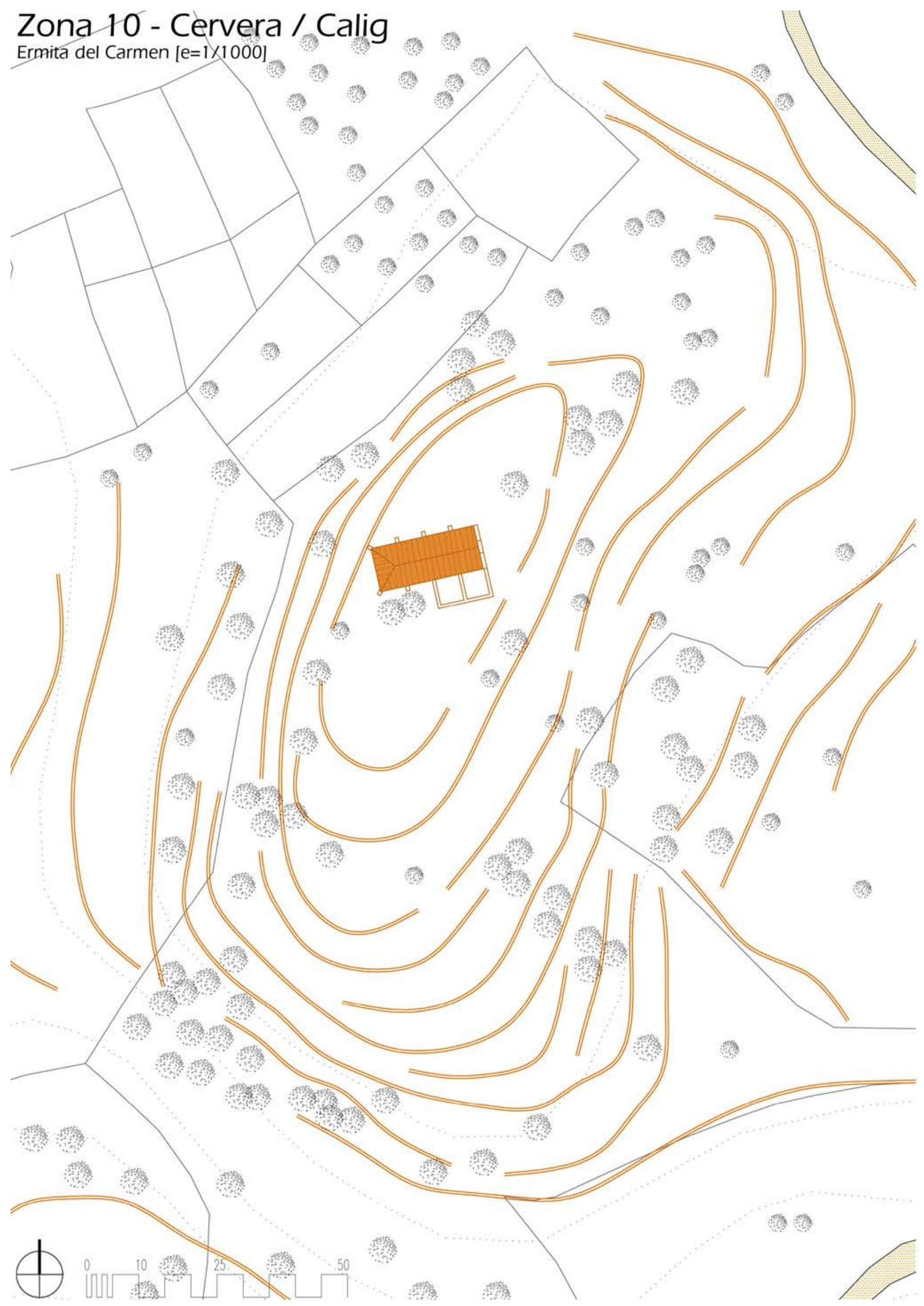




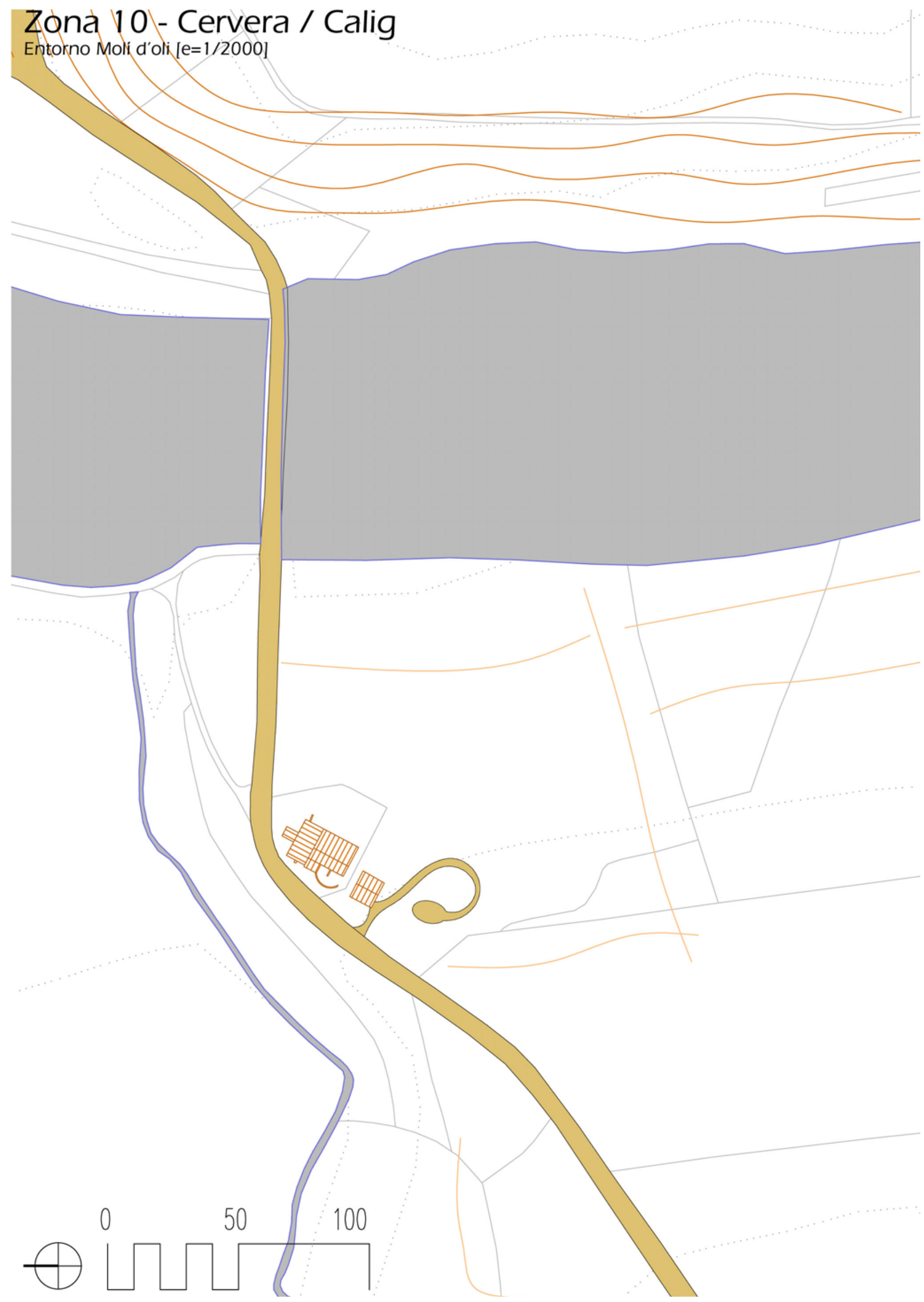




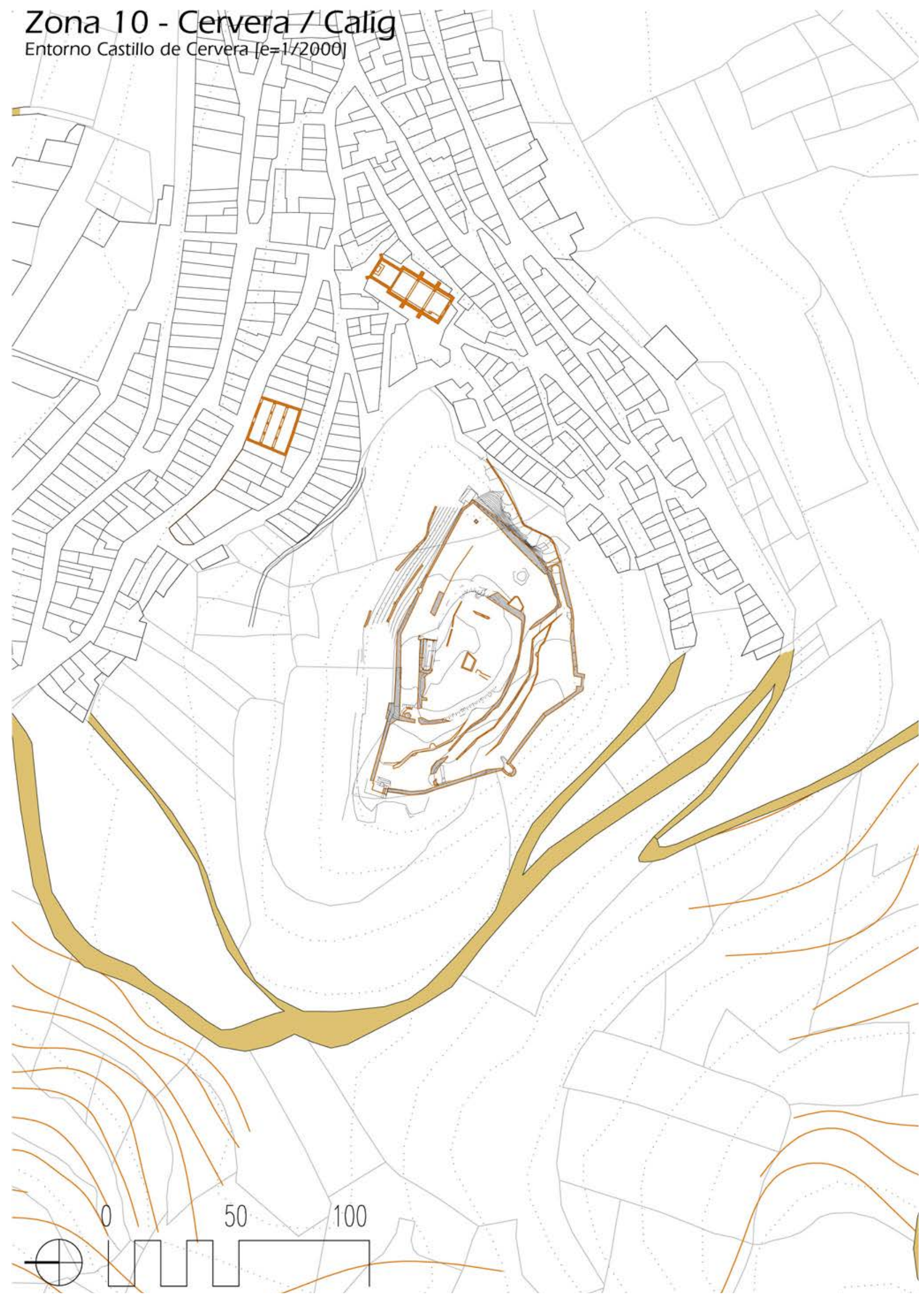




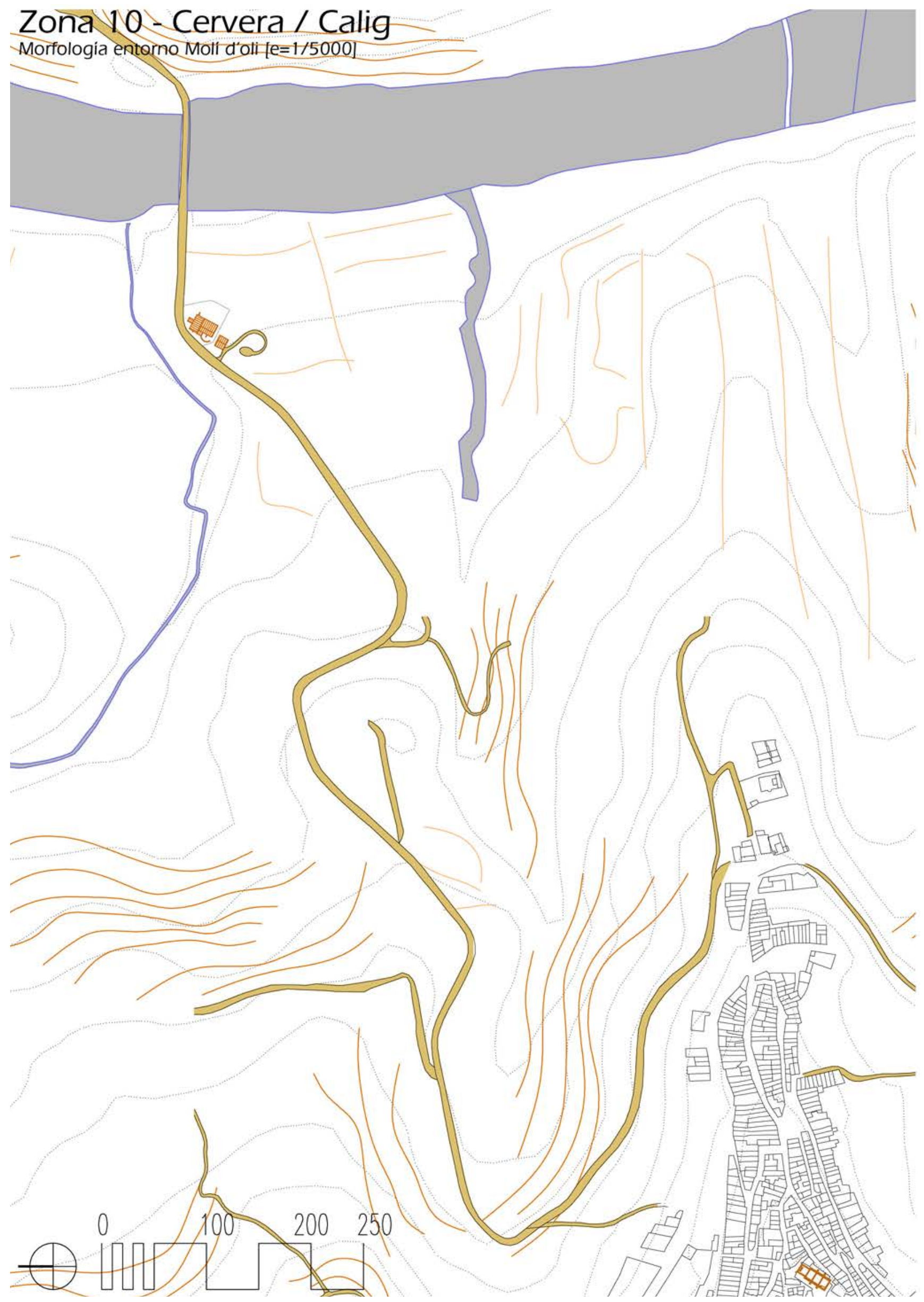




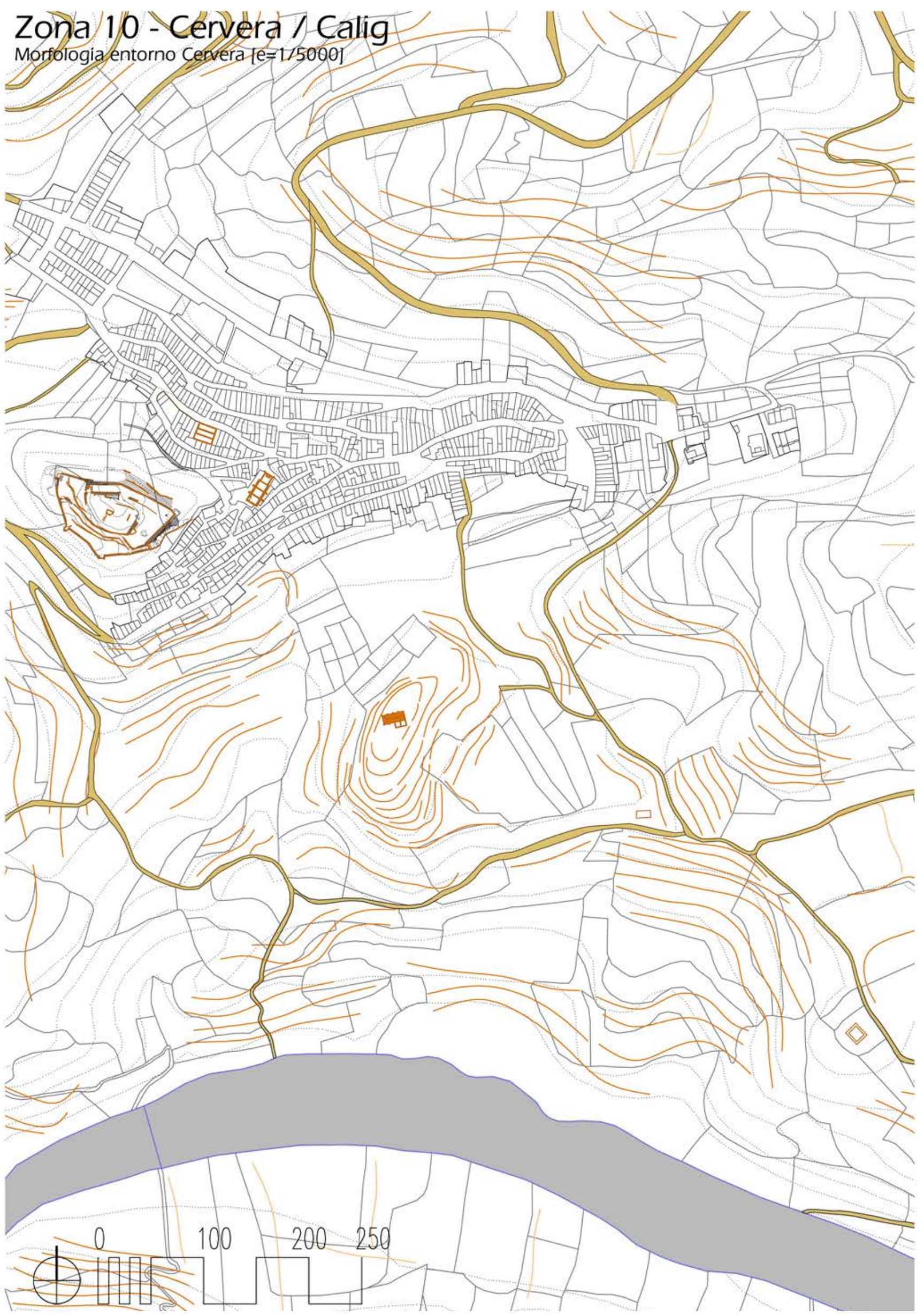




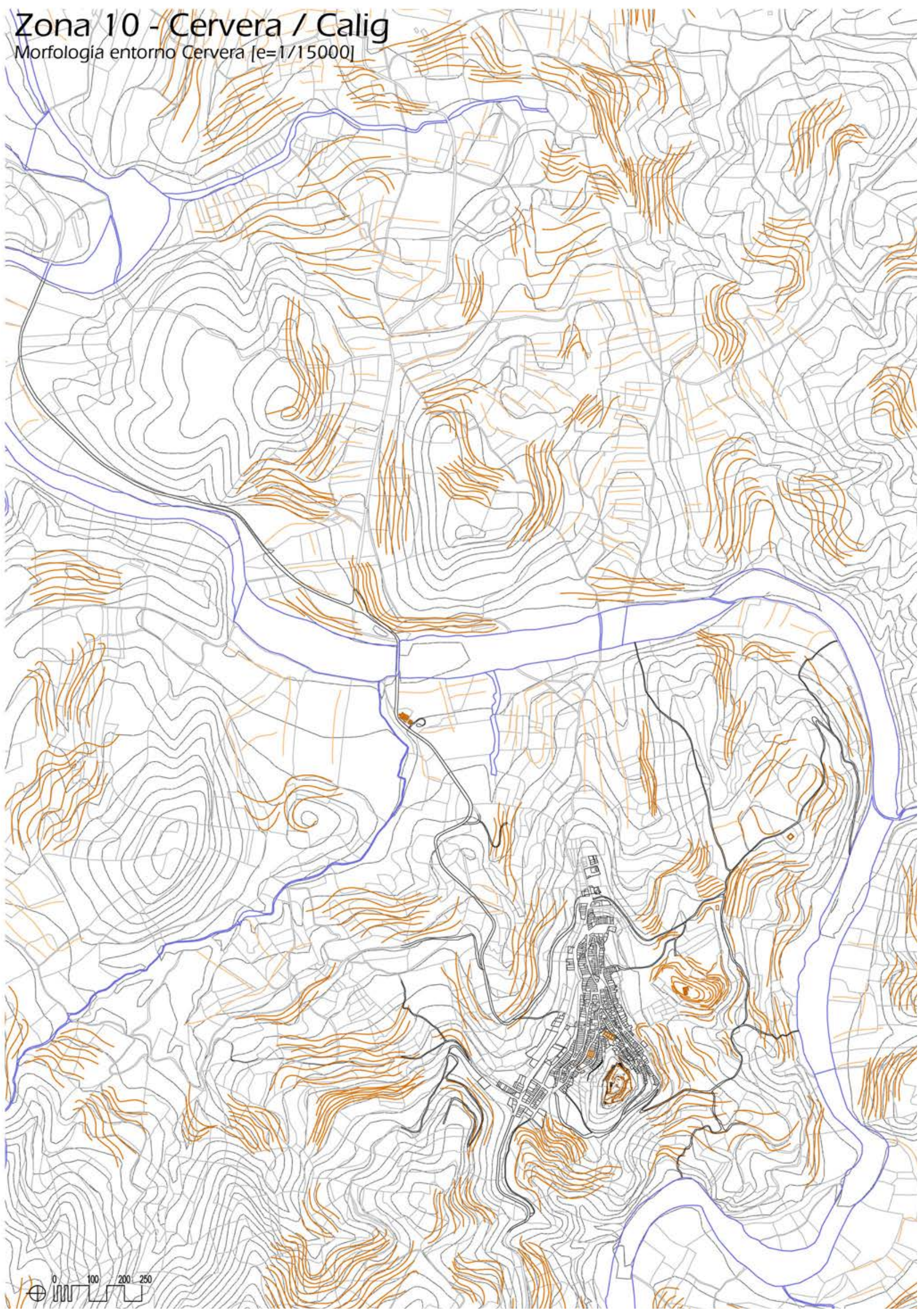


Plano parcelario + muros + bancales zona $10-[e=1 / 40.000]$

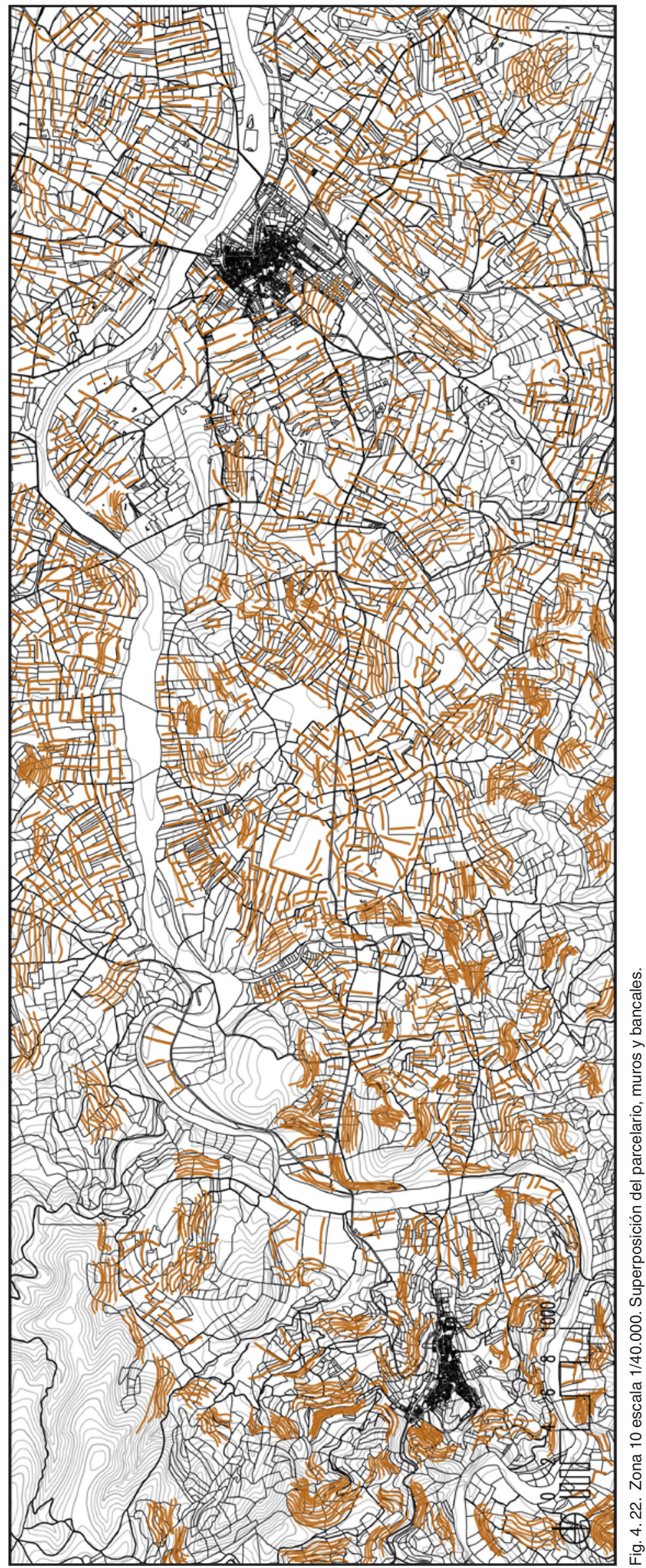


Ortofoto zona 10 - $[\mathrm{e}=1 / 40.000]$

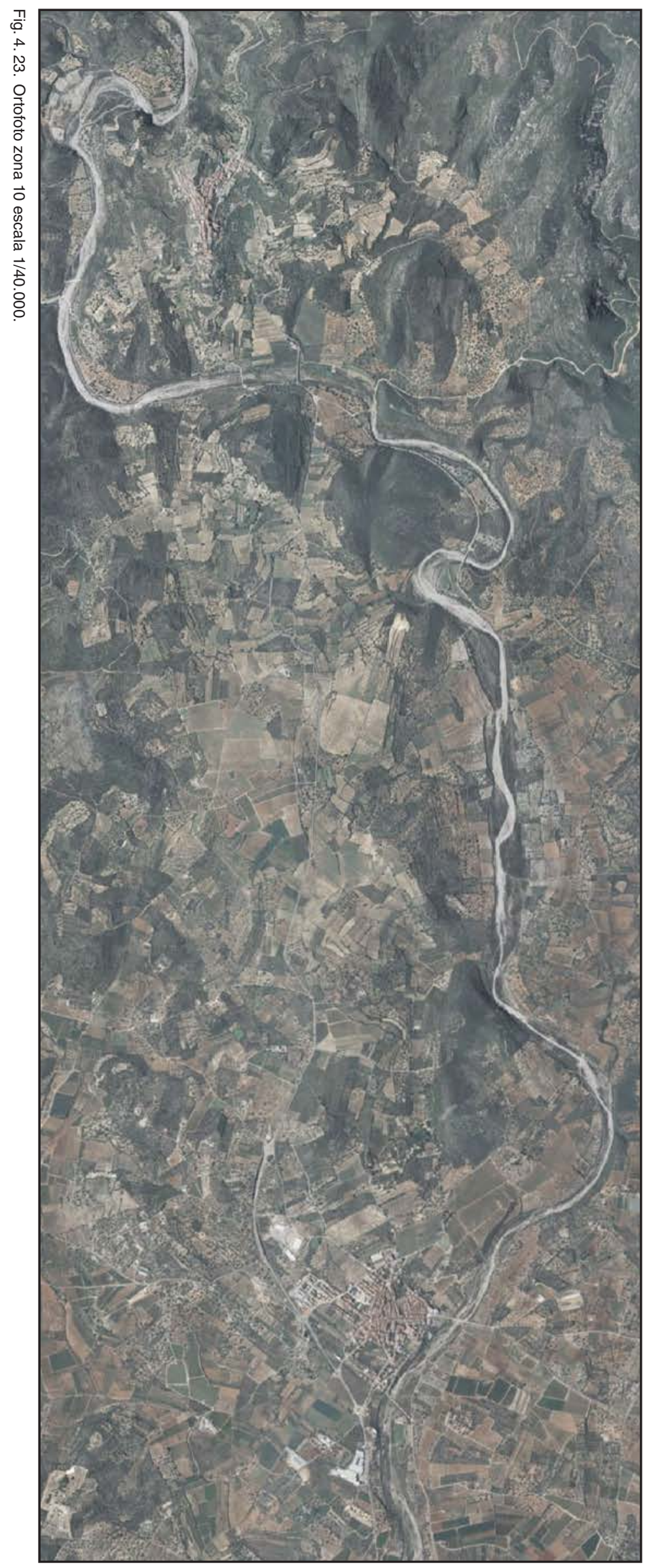


Mapa general (situación de las zonas de estudio) - $[e=1 / 200.000]$

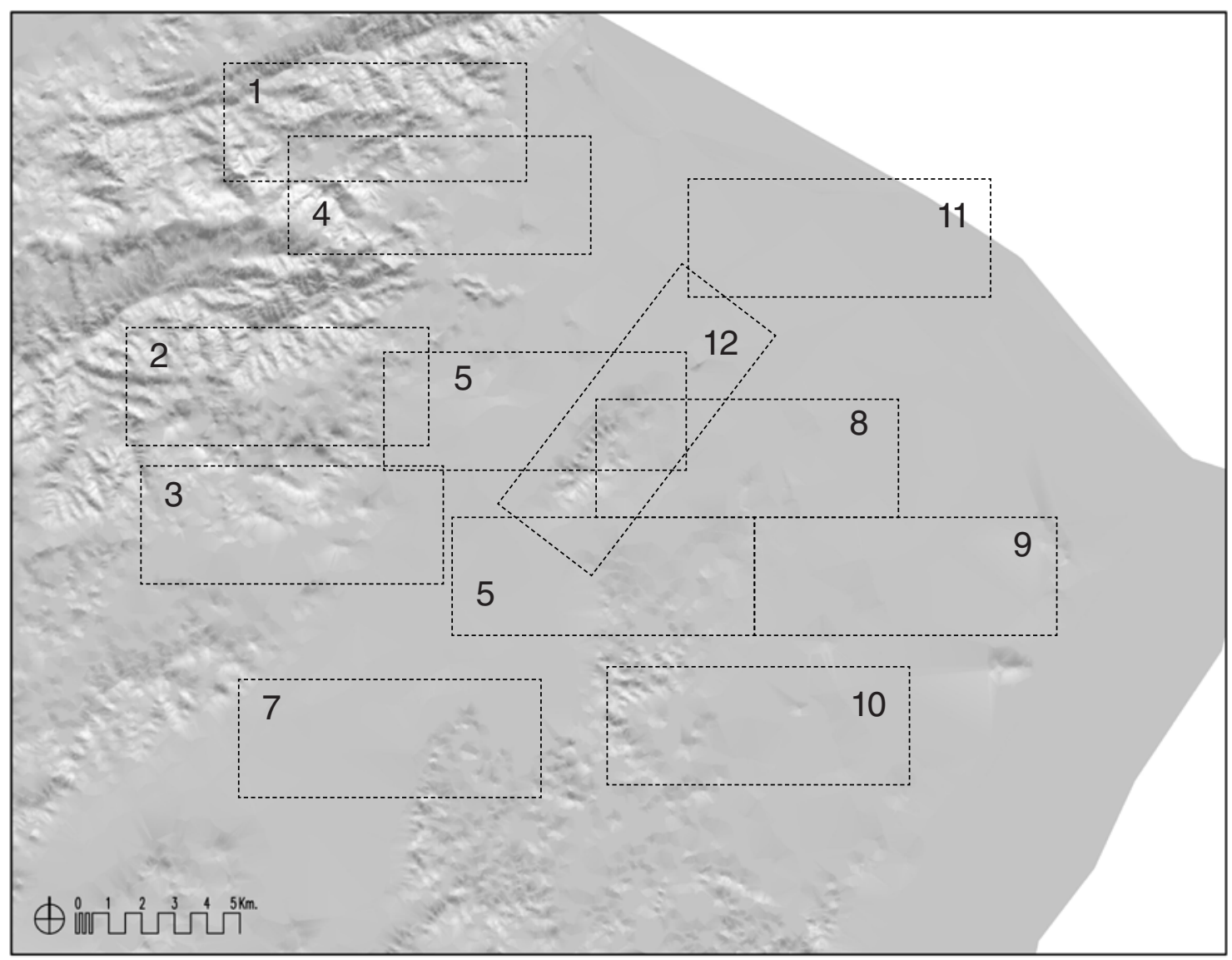

Fig. 4. 24. Plano 1/200.000 de la topografía de la Batllia y de las 12 zonas de estudio.

Detalle zona 12 (situación de los elementos de interés) - [e=1/60.000]

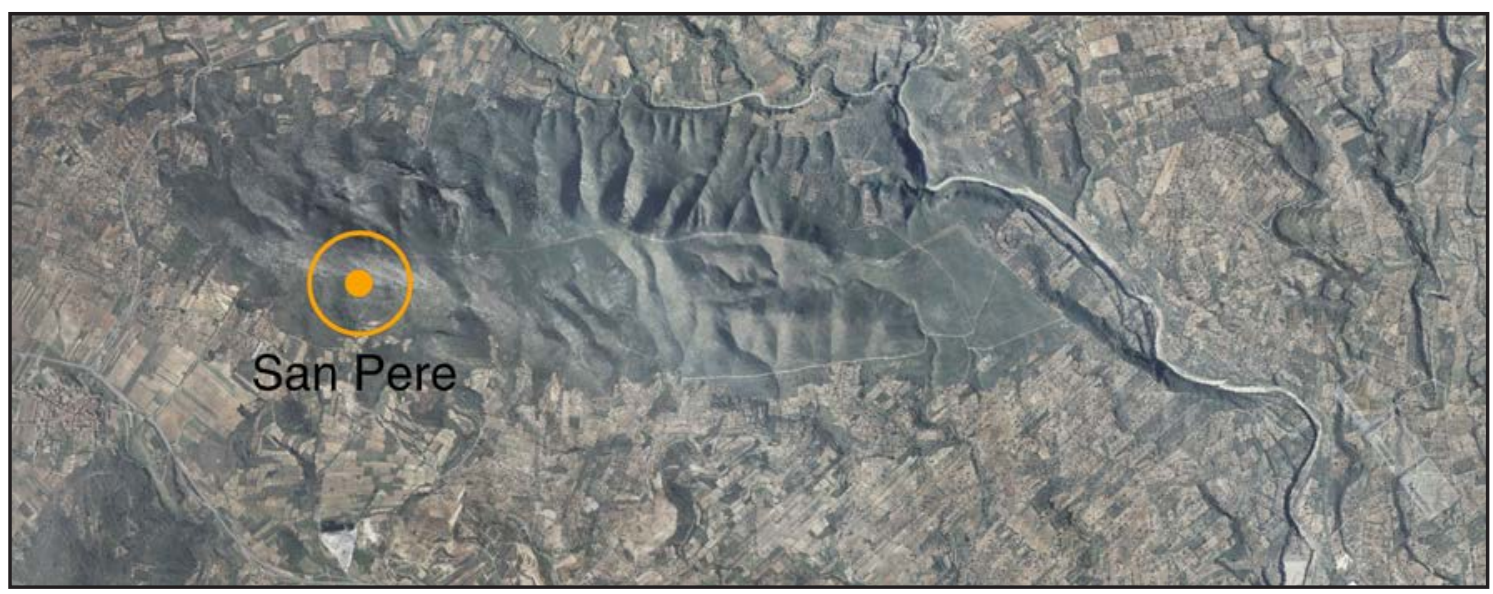

Fig. 4. 25. Ortofoto $1 / 60.000$ de la zona 12 con la ubicación de las arquitecturas que se estudian. 


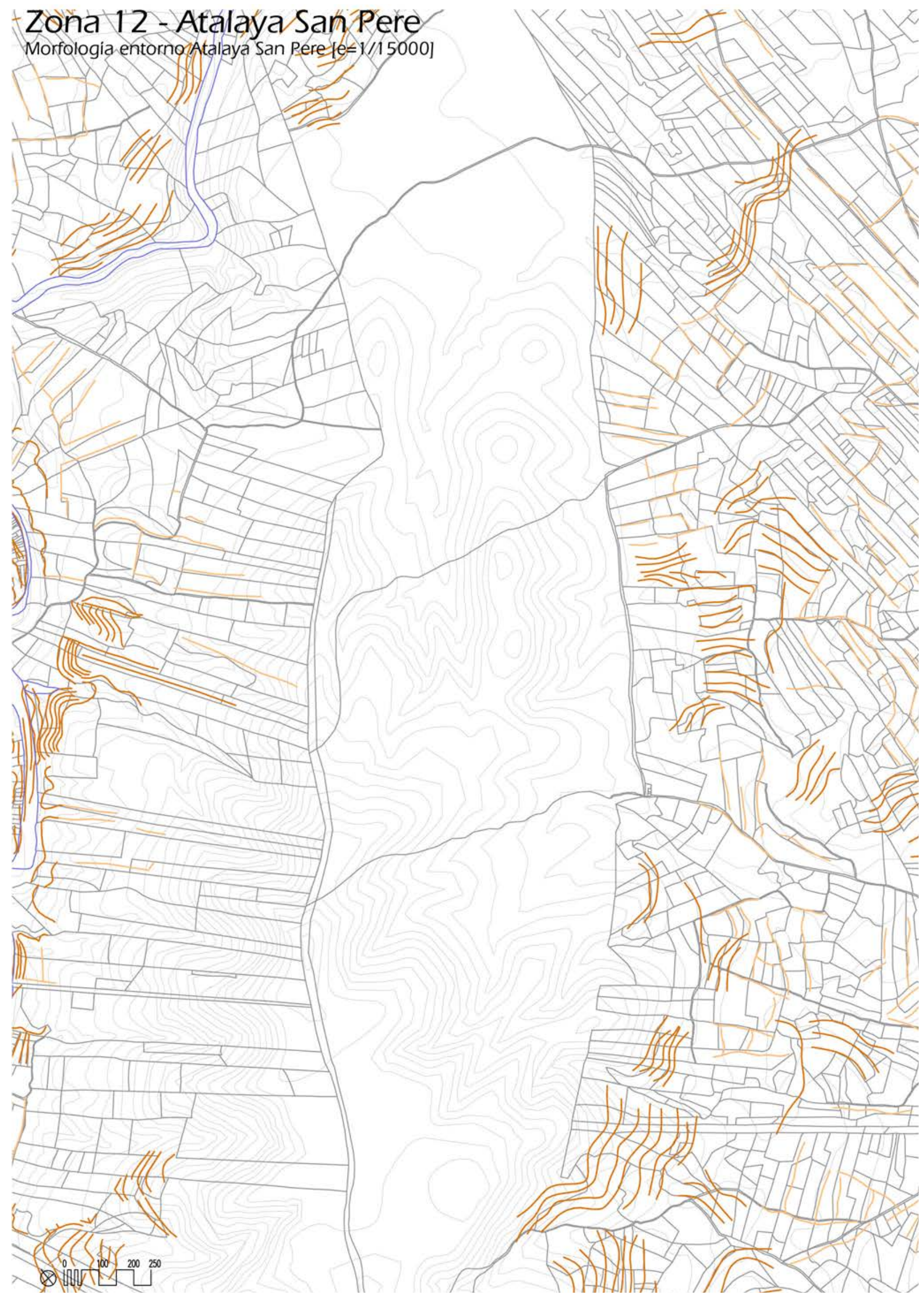


Plano parcelario + muros + bancales zona 12 - $[\mathrm{e}=1 / 40.000]$

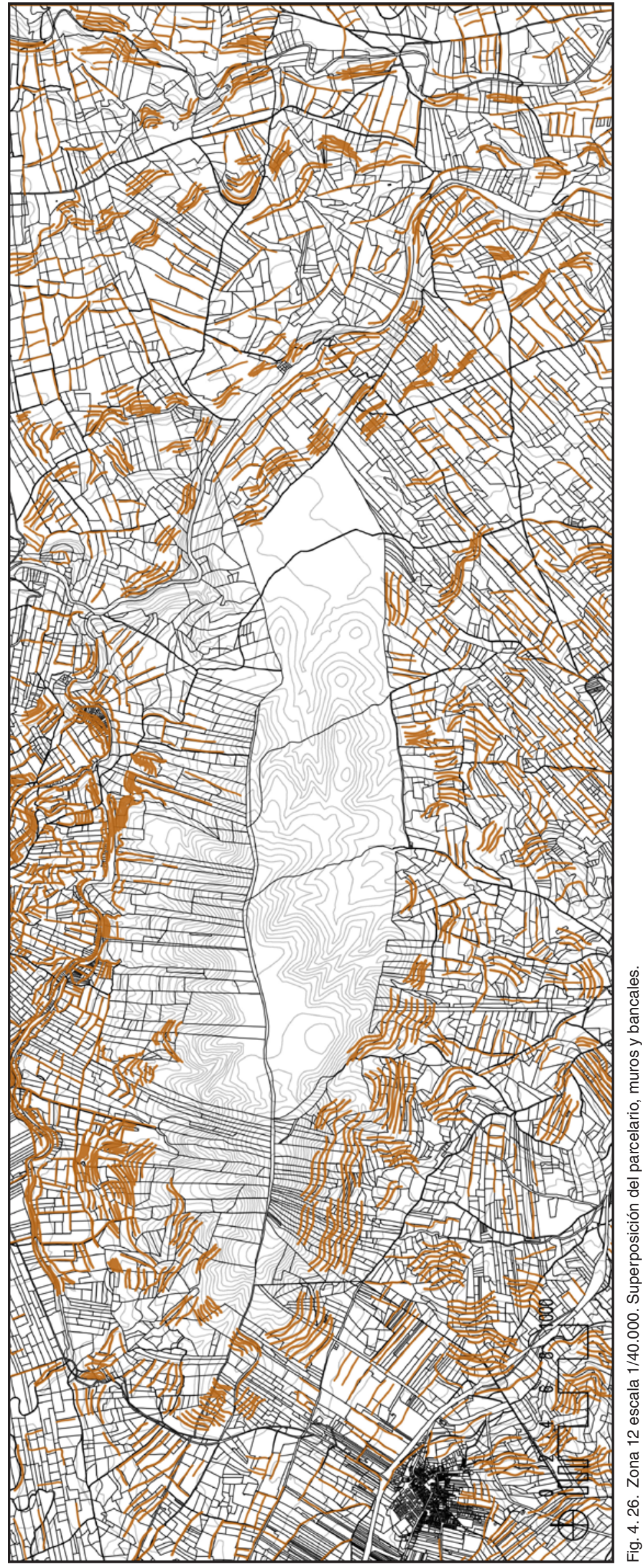




\section{Ortofoto zona 12 - $[\mathrm{e}=1 / 40.000]$}

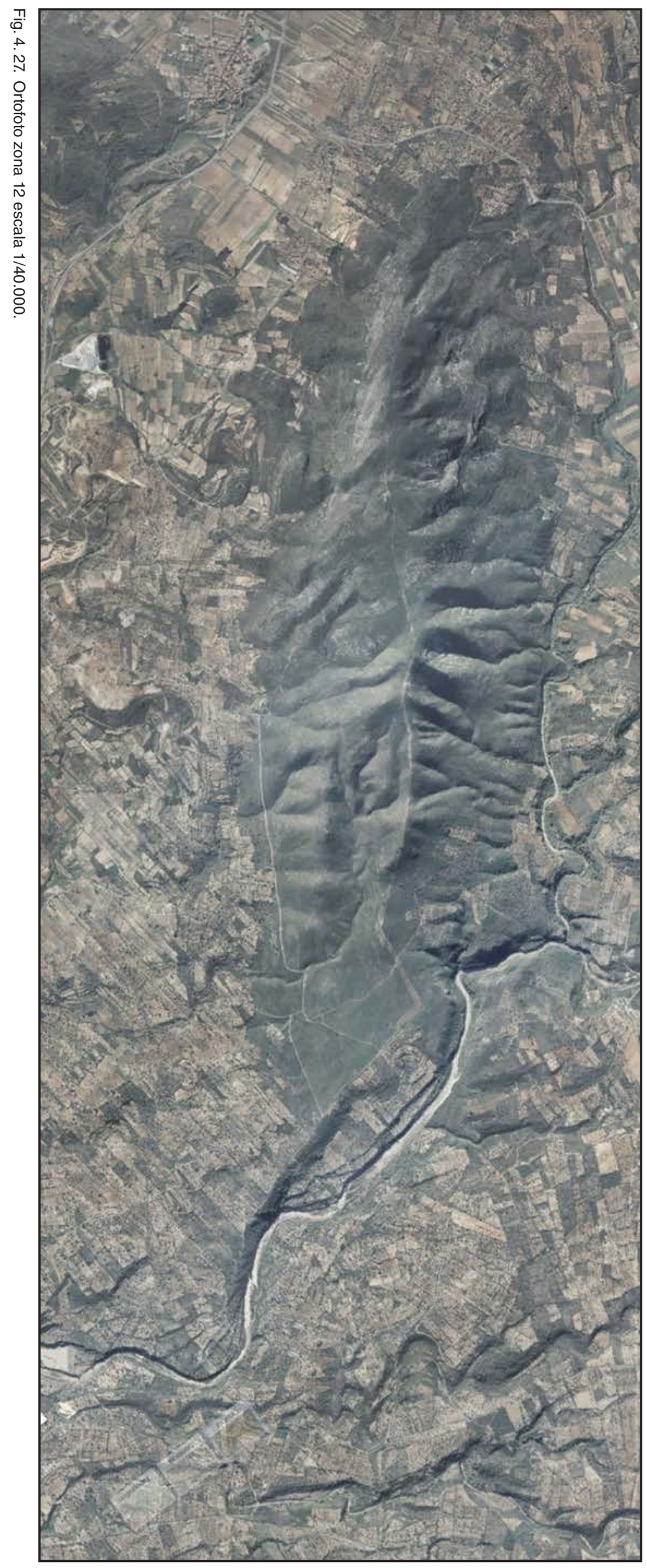




\section{3. La con-formación del territorio antroposocial}

\section{3. 1. Los procesos}

La con-formación del territorio es un proceso de procesos. El proceso que guía la conformación del territorio es el de habitar en el sentido de Heidegger, como cultivar y construir. El hombre como forma de estar en este mundo (en un territorio) lo habita, lo hace suyo, lo adapta a sus necesidades vitales, estas en la Edad Media eran la agricultura, la ganadería y conseguir una morada que lo protegiera de la intemperie; y todo ello de forma que el territorio estuviera referenciado para orientarse y no encontrarse perdido.

Este proceso "genérico" de habitar, se "sustancia" mediante cinco procesos. Cuatro de ellos responden a la relación del hombre con su entorno, y son: modelar el soporte para adaptarlo a sus necesidades, acceder para poder dominar el territorio, usarlo para obtener el máximo de frutos que el territorio pueda proporcionar y repartirlo para el uso de cada colectividad o miembro de la misma. El quinto responde a la relación del hombre con los otros hombres, a la necesidad del ser humano de reunirse con sus congéneres, de vivir en comunidad, primero con su familia y después con el grupo al que pertenece.

Cada uno de estos procesos se llevan a cabo con una serie de elementos que son los que con-forman el territorio antroposocial. Estos son: los muros de contención para modelar, las infraestructuras para acceder, la parcelación para repartir, los cultivos para usarlo y las arquitecturas para reunirse.

En la Edad Media el territorio se construye siguiendo dos pautas fundamentales a la vez que complementarias: la topología del relieve y la estereotomía. Los elementos que conforman el territorio parten de la topología natural del relieve y siguen las directrices que dicha topología marca para su evolución y crecimiento, el hombre sigue la predisposición topológica del territorio que habita.

Por otra parte conforma el territorio guiándose por los principios de la gravedad, el agua y la luz -como en cualquier otro ecosistema-, los elementos que construye trabajan en continuidad con la tierra, quieren pertenecer a ella. Los materiales son la tierra, la piedra, el adobe, el tapial... Los materiales se apilan y la fuerza de la gravedad se transmite de una manera continua, en un sistema estructural continuo que trabaja a compresión y donde la continuidad constructiva es completa, es una arquitectura masiva, pétrea, pesante que se asiente sobre la tierra como si de ella naciera.

Estas pautas hacen que el territorio se conforme construyendo volúmenes apilando material a los que luego se les sustrae parte de él. Se crean espacios interiores-cuevas- que buscan la luz. A los volúmenes y muros macizos se les sustrae material para obtener luz, para iluminar los vacíos interiores. Es la arquitectura de los castillos de arena en la playa, se amontona arena -sustrayéndola del entorno próximo- y luego se recorta, se vacía, se definen los planos, los macizos, los vacíos...y por último se le ponen las banderas.

El territorio se desarrolla desde los propios sistemas constructivos con los que el hombre dispone los materiales. El modo de trabar, ensamblar, unir y ordenar los materiales y espacios ordenan el territorio. No es primero forma y después adquiere sentido constructivo, sino que desde un sistema constructivo, desde las propias leyes que este impone, el territorio toma forma La forma pasa a través del filtro que el sistema constructivo impone, el modo de construir determina el resultado. 


\section{El modelado del relieve}

El soporte que el hombre hereda de la naturaleza, en un principio es suficiente para darle alimento para subsistir, en el momento en el que deja de ser nómada y se hace agricultor necesita modelar ese soporte para obtener más beneficios de él, mejores cosechas.

Su primer objetivo es aumentar la superficie a cultivar y aprovechar al máximo el agua como nutriente imprescindible para los cultivos. Para ello modifica el soporte, en las zonas con pendientes lo abancala consiguiendo aumentar la superficie susceptible de ser cultivada y retener las aguas de escorrentía que se van depositando y manteniendo en las terrazas aumentando el grado de humedad del suelo y por tanto sus posibilidades de cultivo; y en las zonas de llano de drenaje deficiente, lo drena y rellena, permitiendo utilizar tierras de una gran fertilidad.

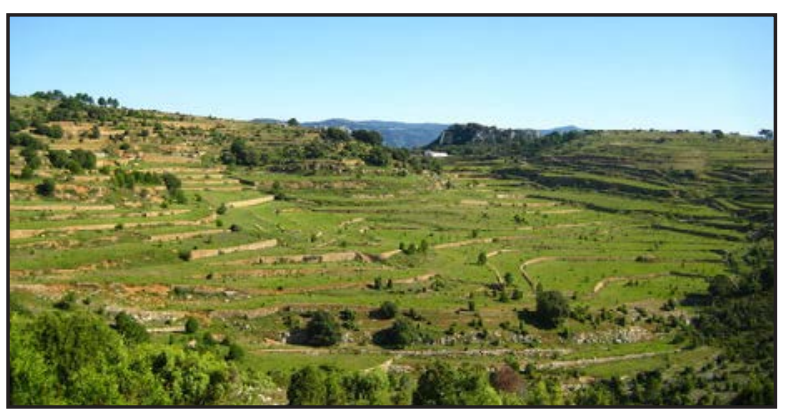

Fig. 4. 28. Terreno abancalado en Bel.

Los bancales se modelan por tanto con dos objetivos: aumentar la superficie de suelo con pendientes aptas para el cultivo y reconducir el agua por gravedad de forma que recorra todas las terrazas mantenga la humedad en una mayor superficie de suelo. En este proceso podemos encontrar paralelismo con la mayoría de los ecosistemas que tienden a desarrollar su ciclo interno siguiendo el eje vertical definido por la luz y la gravedad, en los que el transporte horizontal, dependiente de energía externa, se puede considerar como una perturbación, o por lo menos, como una modificación impuesta sobre aquel esquema fundamental de trayectorias verticales.

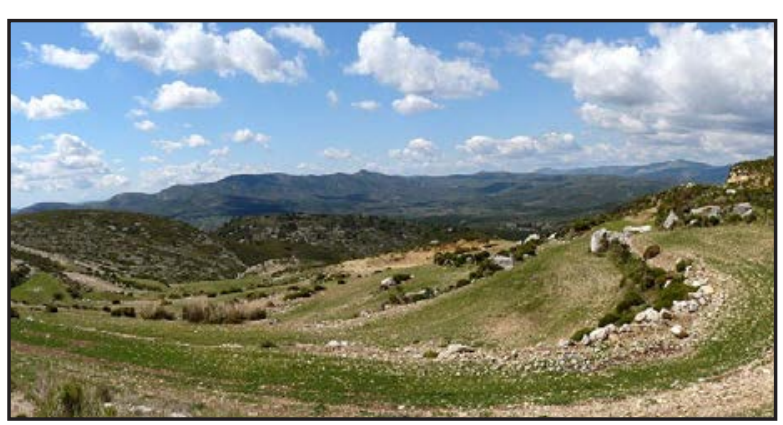

Fig. 4. 29. Terreno abancalado en Els Ports.

Rellenar el marjal o las lagunas es el caso contrario, se trata de eliminar el exceso de humedad para conseguir que este tenga el grado adecuado para ser cultivado. En ambos casos el hombre imita los procesos naturales, construye muros como una "orogénesis natural", deposita suelos como sedimentación y elimina agua mediante cursos artificiales que drenan determinados lugares. ${ }^{86}$

Con la aportación inicial de energía por parte del hombre para construir los muros, depositar suelos y drenar otros, se consigue que sobre el relieve una vez modelado, las acciones de la energía solar y potencial del agua al desplazarse por gravedad se obtengan unos rendimientos agrícolas muchos mayores. 


\section{El transporte de flujos. El dominio del territorio}

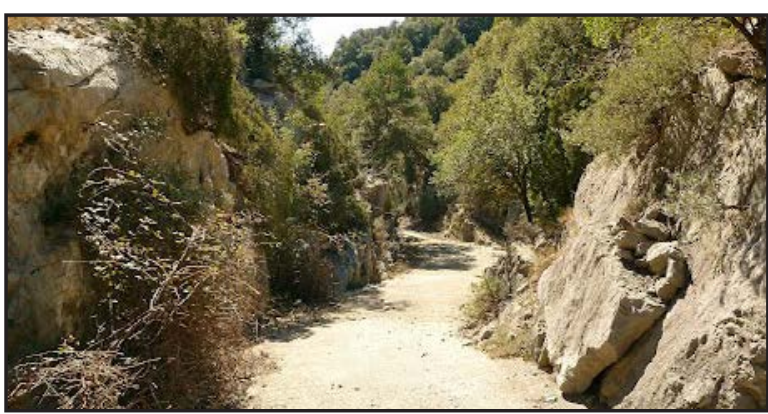

Fig. 4. 30. Camino por el interior de un barranco.

En todos los ecosistemas, el transporte horizontal es de una gran importancia por ser uno de los procesos de mayor consumo de energía. El hombre necesita sistemas complejos de flujo, movimiento e intercambio, que discurren por el territorio para así dominarlo. Los conquistadores establecían rutas sobre el territorio, definían enclaves y hacían fortificaciones. Los leñadores tenían rutas en el interior del bosque, sabían las fuentes, las cuevas y los claros que los senderos enlazaban. La llave, la posibilidad o la hipótesis del dominio es el acceso, se domina la montaña cuándo se sube. Atravesar el territorio permite mirarlo, mostrando sus particularidades formales como volumen y como recinto, haciendo posible el dominio

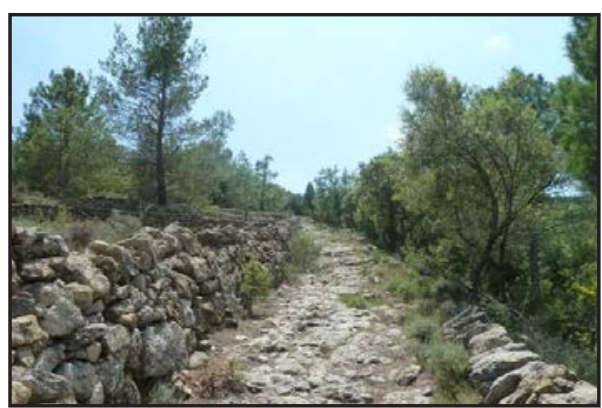

Fig. 4. 31. Camino en la Batllia.

El hombre necesita encauzar el agua para domesticar el territorio, tanto para conseguir construir caminos duraderos y útiles como para obtener el máximo rendimiento del territorio que tiene a su alcance posibilitando el suministro de agua para las personas, animales o cultivos y aprovecharse de la energía potencial y cinética que posee.

Para gastar el mínimo de energía el establecimiento de la traza que atraviesa el territorio, no significa más que una ligerísima modificación del soporte, es como una arruga o una cicatriz en la piel del relieve. En las redes de agua permite que esta se desplace por gravedad y en los caminos se buscan las mínimas pendientes, buscando las limatesas, limahoyas y las líneas de charnela entre las pendientes pronunciadas de las laderas y el llano. ${ }^{87}$

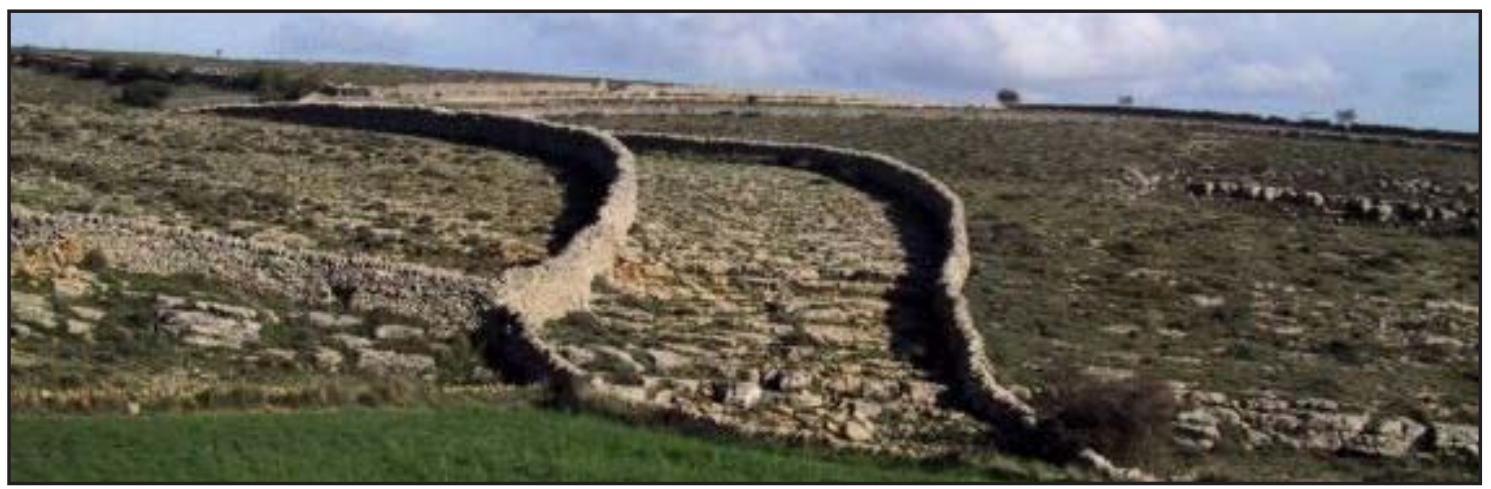

Fig. 4. 32. Azagador en Els Ports.

\section{El reparto y fragmentación del suelo}

El hombre no se conforma con modelar el relieve sino que también reparte el territorio en el que vive. En un primer momento se trata de un proceso similar al de otras especies animales, que para su subsistencia a los distintos grupos se les asignan trozos de territorio suficientes para poder subsistir, que ellos mismos delimitan y controlan.

87 Ver apéndice documental nº 15, 27 y 28 pág. 614 y pág. 622 
Sin embargo este reparto del territorio para la subsistencia del grupo a partir del aprovechamiento natural de un determinado lote de terreno, el hombre lo sustituye de una forma cualitativa sustancial al pasar a la propiedad del suelo.

En la época precristiana, el territorio no se encuentra totalmente ocupado. Cada castillo tiene asignado un territorio alrededor de él, con una serie de pequeñas alquerías o núcleos de población diseminados dependientes, pero existen "vacíos" entre las zonas de influencia de cada alquería y de cada castillo. En el puzzle del territorio existen huecos que hacen que no se "complete" el territorio en su conjunto, existe suelo de nadie.

En el momento de la conquista cristiana, el territorio se divide totalmente de forma que no existen "vacíos" entre el territorio asignado a cada núcleo de población en sus cartas pueblas, de ahí los conflictos que surgen por los lindes entre diversos núcleos y que dan lugar a conflictos que en ocasiones perduran durante varios años. El suelo es "repartido" entre los nuevos colonos y en un primer momento los antiguos habitantes árabes se mantienen con sus propiedades y actividades. No solo se reparten nuevas tierras junto a los nuevos núcleos sino que se reparten territorios más amplios (masías) a algunos pobladores "especiales", siendo en muchos casos antiguas alquerías árabes abandonadas por sus propietarios en la conquista.

Por último en el último periodo, conforme va aumentando la población y el desarrollo agrícola y ganadero, se parcela más suelo por parte de la propiedad feudal, se "reparten" las propiedades de los habitantes árabes que después de la conquista acaban marchando o son expulsados y a la vez se puede observar la subdivisión de las parcelaciones iniciales por herencias o ventas de los beneficiarios iniciales.

Por tanto al final de este periodo tenemos un territorio totalmente ocupado y repartido, con una gran cantidad de parcelaciones alrededor de los núcleos urbanos, un gran número de masías en las partes más alejadas y una completa organización del territorio en lo referente a pastos y aprovechamientos forestales. El territorio es "explotado" en su totalidad.

El "Repartiment" supuso un cambio sustancial con respecto al estatus del suelo existente hasta ese momento. Por una parte se repartió el suelo en su totalidad, no quedaron porciones de suelo "amorfas" en el Territorio, se definieron claramente los límites entre las aldeas y dentro de estas entre los propietarios. Y por otra el suelo pasó a ser propiedad de personas o instituciones, no solo su uso. La colonización significo otorgar el suelo a un propietario, el establecimiento de la propiedad dominial y del catastro. Desde el momento de la fundación esta es la pauta que condicionara la forma del territorio. $^{88}$

\section{Uso y aprovechamiento del suelo}

El uso que le da el hombre al territorio determina cual sera su estructura; en la Edad Media su uso era agícola y ganadero. En un principio el hombre utilizó el suelo para cultivarlo para subsistir, posteriormente con la evolución social ese mínimo de subsistencia no es suficiente; la explotación de unos hombres sobre otros hace que a esos mínimos se añadan los "tributos" que las élites exigen a los hombres que tiene bajo su control.

El "Repartiment" supuso un cambio sustancial con respecto a la fiscalidad existente hasta el momento. Los aprovechamientos que se obtenían del suelo y del resto de bienes productivos dejaron de tributar en base a impuestos y pasaron a tributar en base a las rentas que producían. Este hecho junto con el de la propiedad es fundamental para entender los cambios sociales de la época, así como la transformación y evolución del Territorio en esta época.

La obtención de la máxima renta y del modo que esta se pagaba con cereales guió todas las actuaciones en el territorio. Los cultivos se sustituyeron en parte para obtener mejores cosechas de cereales y los molinos y los hornos fueron fundamentales como elementos por una parte de aportar rentas y por otro del control de la producción y por ende de las rentas de los vecinos.

Los nuevos sistemas de regadío y de cultivo, la introducción de máquinas como los molinos o las norias, consiguieron una mayor rentabilidad del suelo a costa de un mayor consumo de energías exógenas.

88 Ver apéndice documental no 4 y 6 pág. 605 y pág. 607 
La ganadería se convierte en uno de los mayores aprovechamientos del suelo, primero por obtener rentabilidad del suelo inculto y segundo por ser el precursor del comercio a gran escala a partir del mercado de la lana.

El uso del territorio subyace en el resto de los procesos. El modelado, las conexiones de flujos y la parcelación dependen del uso que el hombre quiera dar al territorio y de la forma en la que este uso se lleve a cabo. Como dice Heidegger, habitar no solo es edificar sino también cultivar. El hombre habita un territorio y lo "construye" al cultivarlo y compartirlo. ${ }^{89}$

\section{Usos y arquitecturas}

Las instituciones humanas, como dice Kahn, tiene sus raíces en los orígenes, cuando el hombre tomó conciencia de sus deseos o inspiraciones. Las inspiraciones más importantes son las de aprender, vivir, trabajar, reunirse, cuestionar y expresarse. Kahn solía mencionar la escuela como ejemplo de instituciones que surgen de las inspiraciones: "Las escuelas empezaron con un hombre que, sin saber que era profesor, discutía sus ideas con un grupo de personas que no sabían que eran alumnos. Los estudiantes pensaron sobre las cosas que había tratado y consideraron que era algo muy positivo. Aspiraron a que sus hijos escucharan también a aquel hombre. Pronto se erigieron espacios especiales y surgieron las primeras escuelas". ${ }^{90}$

Kahn está hablando de la forma de ser-con de Heidegger en ser-en-el-mundo. La vida no es arbitraria sino que tiene una estructura que comprende al hombre y a la naturaleza. Ser-con designa las estructuras de relación social y de asociación, tomando como punto de partida el hecho de que "el mundo es siempre lo que yo comparto con otro". " Habitar no es un fenómeno individual, siempre constituye una forma de reunión, de participación y un modo de compartir. El hombre habita siempre en comunidad. ${ }^{92}$

Un territorio lo es porque, además de la eventual aportación de un relieve único e irrepetible, estos cinco procesos han llegado a configurar la forma del lugar. El territorio es la suma de diversos órdenes, el natural del origen, del soporte y los artificiales superpuestos por las diferentes culturas; el resultado es complejo y no se degrada con la transformación porque puede contrastar este nuevo orden.

Si nos ponemos en la tesitura del "ojo inocente" que dice Ruskin, y miramos de nuevo al territorio o mejor un fotoplano, la representación más fidedigna de la realidad, veremos que los cinco elementos que hemos enunciado en principio se resuelven en un continuo de texturas y colores. El primer trabajo es el de incorporar a esta descripción el bagaje que nos permite leerlos como la consecuencia de una historia, para entender, el proceso de construcción.

El siguiente será, sin embargo, intentar descubrir su valor formal, su geometría, no como un puzzle, sino como piezas de una estructura que tiene un valor. Pero eso, tanto los elementos que realmente configuran la escala grande del paisaje como los materiales que muestran su transformación los hemos de ordenar para entender la manera en que se disponen como herramientas de la modificación. Conocida la doble relación de escala que nos habla de la relación de los elementos con el recinto, formando parte de sistemas territoriales o de sistemas de construcción-transformación del lugar, es imprescindible estudiar por separado las cinco categorías de elementos que configuran este collage.

89 Ver apéndice documental no 9, 16 y 50 pág. 610, pág. 615 y pág. 645

90 NORBERG-SHULZ, C. "Kahn, Heidegger. El lenguaje de la arquitectura” pág. 52

91 NORBERG-SHULZ, C. "Kahn, Heidegger. El lenguaje de la arquitectura” pág. 54

92 Ver apéndice documental no 8, 14, 31, 33 y 35 pág. 609, pág. 613, pág. 626 y pág. 627 


\section{3. 2. Los elementos de la con-formación}

Los procesos se materializan definiendo la forma del territorio. Podemos considerar el territorio como una arquitectura a gran escala construida sobre el soporte del relieve natural, con los volúmenes nuevos que crean los muros y que lo modelan, con las superficies definidas por la parcelación, con las líneas de infraestructuras que "cosen" los volúmenes y superficies, por los usos que proporcionan el color, olor, sabor, luz y sonido al territorio, y las arquitecturas que lo acentúan.

Sobre la matriz abstracta que ordena el espacio se adaptan las "distorsiones" que el hombre construye con la ayuda de los materiales, los elementos no son abstracciones están constituidos por materiales. La geometría actúa como catalizador y como tránsito entre lo ideal y lo material. Y en esta transformación las texturas juegan un papel determinante, la dimensión táctil de la acción del hombre obedece a la intención de transformar en tangible el orden abstracto y etéreo de la malla.

El hombre logra un difícil compromiso entre no hacer daño a la naturaleza, conservando sus leyes, su trama, y el deseo de construir un marco ordenado, una estancia ante el infinito del cosmos, una operación que conduce a transformar el soporte natural, a dar cortes, a intervenir en los límites. Cada material toca sus límites y revela su naturaleza y adquiere esplendor a través de sus decisiones con la masa, la línea, la forma y el color.

El material adquiere presencia gracias a la luz, la luz hace presente a la materia. Materia y luz son dos fuentes en constante intercambio de energía, reclamándose mutuamente necesitándose mutuamente. La luz necesita de un obstáculo físico para materializarse; el material requiere de la luz para hacerse visible. La luz da vida al espacio. Esta actitud es muy próxima a la de un gran arquitecto como L. Khan que podemos ver reflejada en estas dos citas:

"Un puente de piedra es una construcción como un elefante. Conocemos su belleza, su armonía por que se ha utilizado el material al máximo de sus posibilidades. Cuando simplemente se cubre una pared con piedra, debemos ser conscientes de que estamos haciendo una obra menor". ${ }^{93}$

"El deseo de ser y de expresar llega a la montaña y le habla de sus aspiraciones de construir un templo: Mira, no te quiero hacer daño, te voy a coger y te voy a tratar muy bien. Te voy a cortar los bordes, voy a poner una piedra sobre otra y voy a construir una envoltura, un lugar donde puedo expresar la grandeza de la eternidad de la que formo parte". ${ }^{94}$

El territorio es un gran tapiz de patch Word tejido sobre el cañamazo del relieve natural. Los materiales se tejen, se enhebran sobre el cañamazo, formando collages que destacan con la luz.

93 Texto citado en JUÁREZ CHICOTE, A. "El universo imaginario de Louis Kahn” pág. 68

94 Texto citado en JUÁREZ CHICOTE, A. "El universo imaginario de Louis Kahn” pág. 68 


\section{Los muros}

La materialización de la construcción se refiere al "como" de la forma arquitectónica. Una organización espacial puede realizarse de varias maneras y por tanto su carácter cambia dentro de los límites puestos por los varios tipos de organización. El modelado del relieve se materializa con los muros y bancales. Los muros se acomodan a la contingencia local manteniendo simultáneamente una continuidad general, son por encima de todo pragmáticos.

En general el carácter de una forma arquitectónica esta determinado por su modo de ser entre tierra y cielo. Esto lo intuyó Le Corbusier, que encabezó con la siguiente declaración cada uno de los tres capítulos teóricos de su "Hacia una Arquitectura":

"Mi casa es practica os doy las gracias como podía dárselas a los ingenieros del ferrocarril o al servicio de teléfonos. No me habéis tocado el corazón. Pero supongamos que sus muros se alcen al cielo hasta el punto de conmovernos. Me doy cuenta de vuestras intenciones. Os habéis comportado amablemente con determinación, de modo encantador o noble. Así me dicen las piedras que habéis erigido. Me fijáis en el sitio y mis ojos lo consideran. Vislumbran algo que expresa un pensamiento. Un pensamiento que se revela sin palabras ni sonido, sino solo por medio de formas que mantienen una relación recíproca. Estas formas son de tal manera que son claramente reveladas por la luz. Su relación recíproca no se refiere necesariamente a lo que es práctico o descriptivo. Son una creación matemática de vuestra mente. Son el lenguaje de la Arquitectura. Con el uso de materias primas y partiendo de condiciones más o menos utilitaristas habéis alcanzado una determinada relación que ha hecho resurgir mis emociones. Esta es Arquitectura. Ha surgido el Arte". ${ }^{95}$

Las formas concretas a que esta afirmación se refiere son los bien conocidos elementos de construcción: pavimento, muro y cubierta. Estos elementos componen lo que podemos llamar los confines espaciales. Heidegger dice: "Un confín no es el límite donde una cosa termina sino, como ya lo comprendieron los griegos, ese límite a partir del cual una cosa comienza a venir en presencia". ${ }^{6}$ Para él cultivar es también construir. Modelar el relieve es construir una arquitectura con bancales y muros cuya cubierta es el cielo.

Los muros se ocupan de la articulación de los confines espaciales como medios de definición de un carácter ambiental. El muro esculpe los volúmenes del territorio. Tierra y cielo se encuentran en el muro, y este encuentro incorpora el modo de estar del hombre sobre la tierra.

Algunos muros se adaptan al relieve, otras se elevan libremente, mientras que otras expresan un equilibrio significativo. El estar entre tierra y cielo no es expresado solamente con ritmos horizontales y tensiones verticales. "Tierra" y "cielo" implican propiedades concretas como la textura del material, el color y la luz. El muro dialoga con el relieve natural y construye el territorio, lo modela con una sucesión de planos horizontales con distintas texturas y colores, creados a partir de una serie de planos verticales de mampostería.

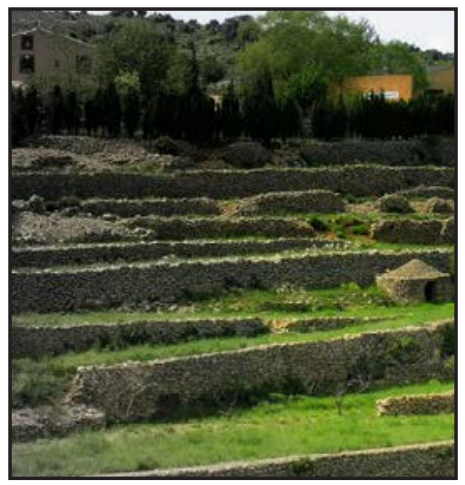

Fig. 4. 33. Bancales de piedra en seco.
El análisis del modelado lo haremos acudiendo a la topografía actual obtenida tanto de los planos como de las fotos aéreas, comparándola y contratándola con la parcelación histórica que nos da en ocasiones importantes pautas para entenderla como era.

A partir de los datos tomados "in situ" y posteriormente con la ayuda de la cartografía temática SIG, fotos aéreas, planos parcelarios históricos y referencias bibliográficas grafiamos planos con los muros de contención de las 5 ámbitos seleccionados, diferenciado los muros que suponen un cambio de nivel en el terreno (muros de contención) de los que simplemente son separaciones de propiedad o de uso.

95 LE CORBUSIER “Hacia una Arquitectura” pág. 47

96 HEIDEGGER, M. “Ser y tiempo” pág. 154 


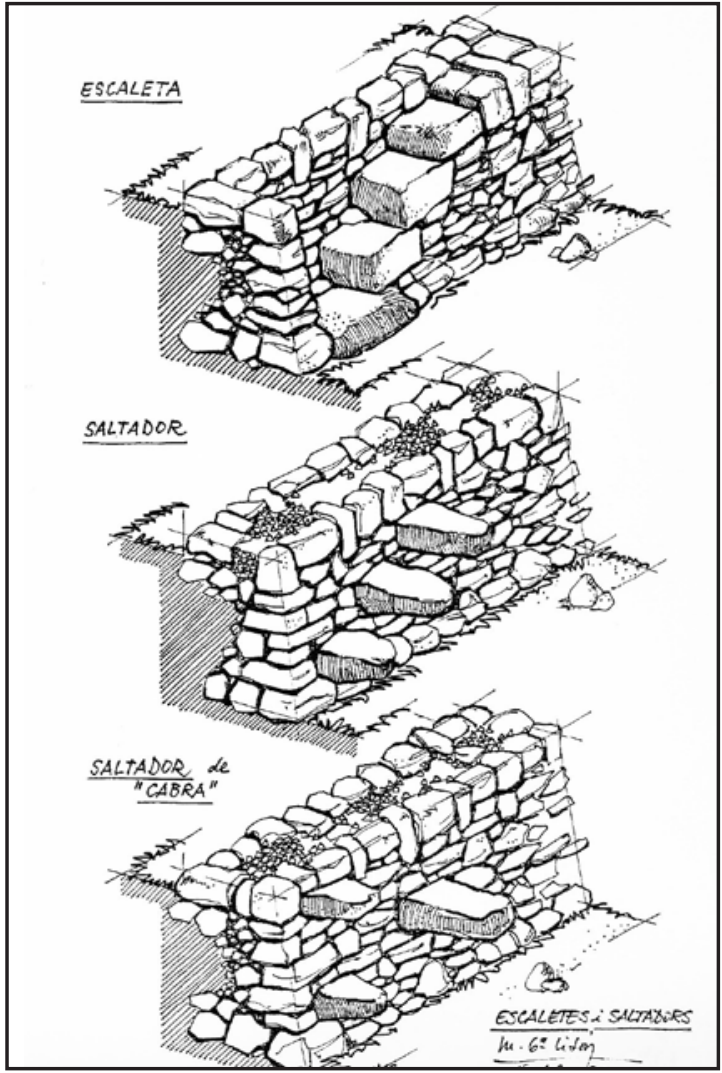

Fig. 4. 34. Dibujos paredes de piedra en seco del libro "Arquitectura rural primitiva en secà" de A. Zaragoza y M. García Lisón.

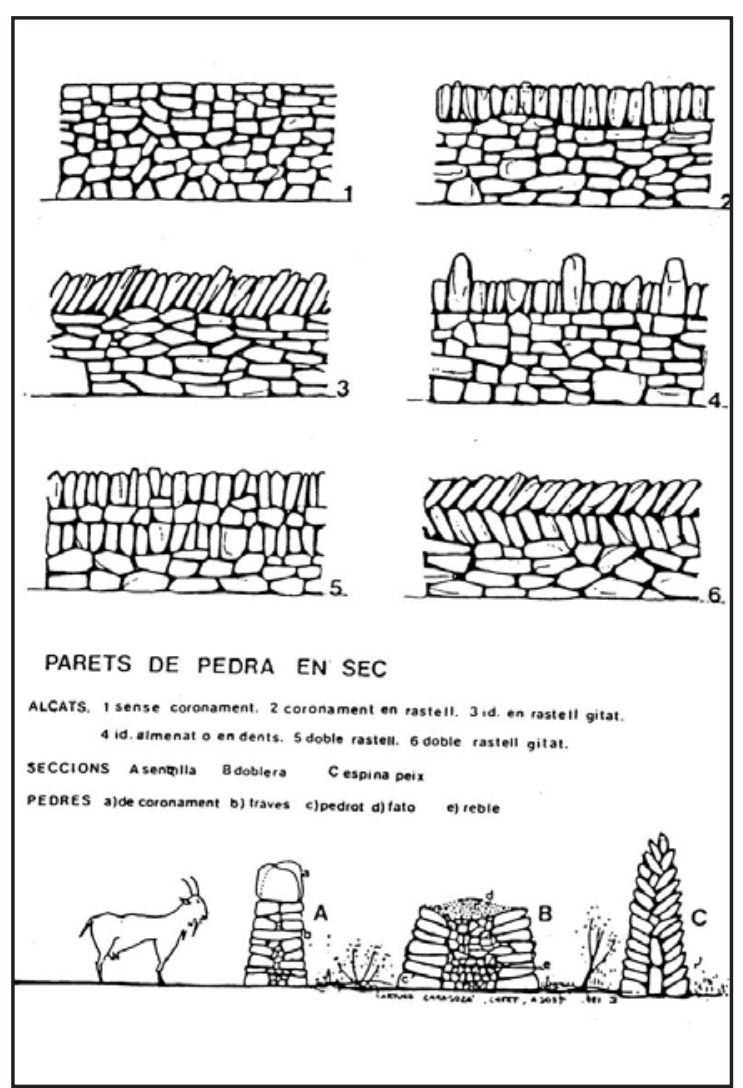

Fig. 4. 35. Dibujos paredes de piedra en seco del libro "Arquitectura rural primitiva en secà" de A. Zaragoza y M. García Lisón.

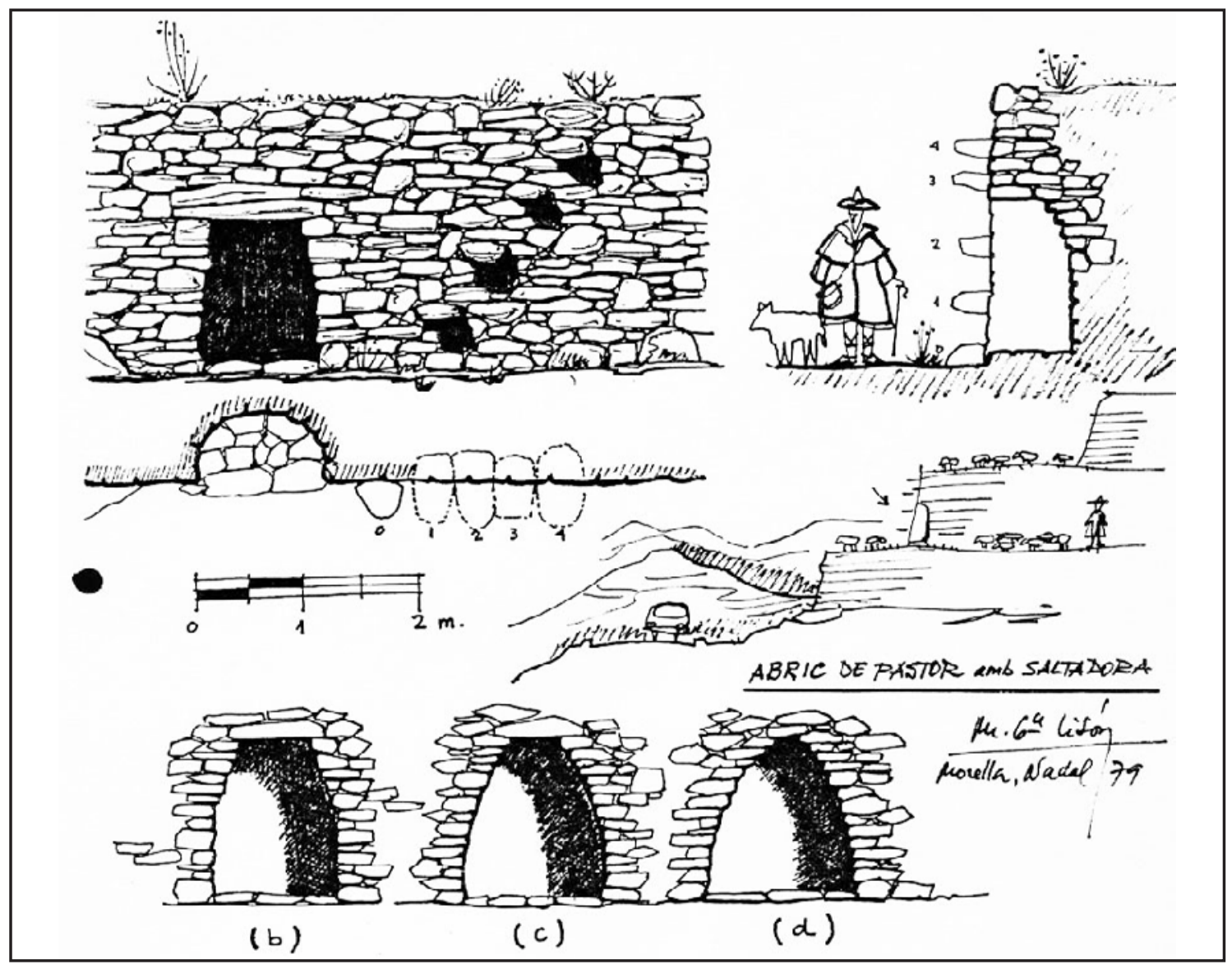

Fig. 4. 36. Dibujos paredes de piedra en seco del libro "Arquitectura rural primitiva en secà" de A. Zaragoza y M. García Lisón. 
En los muros no solo los materiales son los protagonistas, las juntas lo son tanto como ellos, son el contrapunto como lo es el vacío del lleno. La junta es lo importante en la disposición del muro, su resistencia es directamente proporcional a como están resueltas las trabas, más que cuan resistente es el material que lo conforma. Como dice Le Ricolais, en las estructuras lo importante es la disposición de los huecos. Estas juntas inicialmente constructivas, dispuestas por meros motivos estructurales de resistencia del propio muro, se transformaran en ornamento en las posteriores construcciones más elaboradas y cultas. La junta es el comienzo del ornamento.

Según cual sea la topografía del relieve, podemos distinguir de forma genérica cuatro clases de muros distintas, que se distinguen tanto por sus materiales como por los tipos de juntas:

1. Muros de contención a una cara de trazado con mucha curvatura, altura variable y sección ataluzada realizados con mampostería de dimensiones importantes y careada. Se construyen en los relieves con pendientes superiores al 15\% y en las zonas de las limahoyas. Crean bancales de formas orgánicas y dimensiones variables.

2. Muros de contención a una cara de

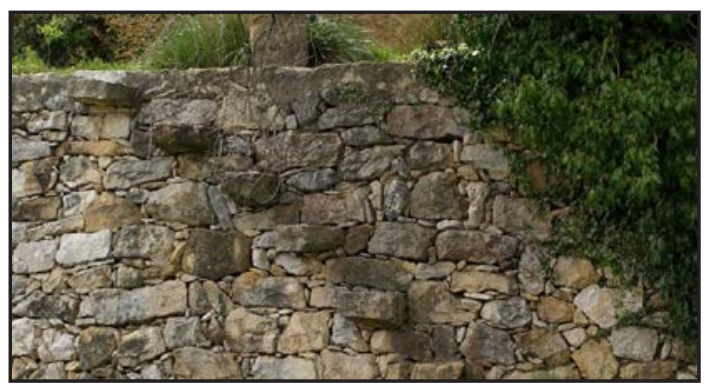

Fig. 4. 37. Escalera en muro de piedra en el "Molinar" de Xert. trazado con poca curvatura, altura variable y sección ataluzada realizados con mampostería careada. Se construyen en los relieves con pendiente entre el 8\% y el 15\%, al ser las pendientes inferiores se pierden las limahoyas y se extienden por toda la ladera. Crean bancales de formas trapezoidales y dimensiones variables.

3. Muros de contención a una cara de trazado recto, altura uniforme y sección recta realizados con mampostería de reducidas dimensiones y sin carear. Se construyen en los relieves con pendiente entre el 3,5\% y el 8\%. Se extienden de forma homogénea, creando bancales de formas rectangulares y dimensiones similares.

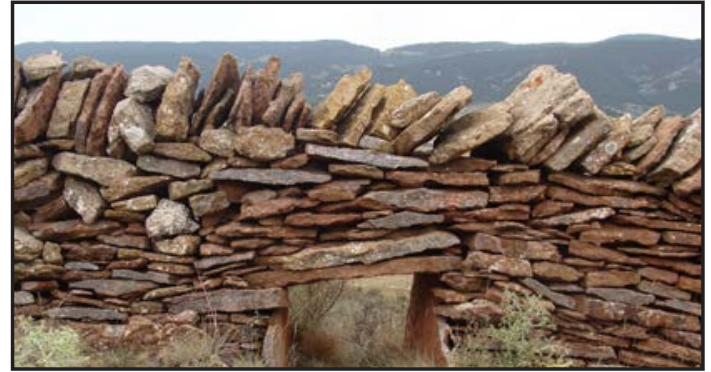

Fig. 4. 38. Remate de muro de piedra en seco en Villafranca.

4. Muros de separación a dos caras de trazado recto, altura uniforme y sección recta realizados con mampostería de poca calidad y sin carear. Se construyen en los relieves con pendientes menores al 3,5\%. Se extienden de forma homogénea creando parcelas de formas rectangulares y regulares. 

Mapa general (situación de las zonas de estudio) - $[e=1 / 200.000]$

Topográfico base + muros de separación + muros de contención

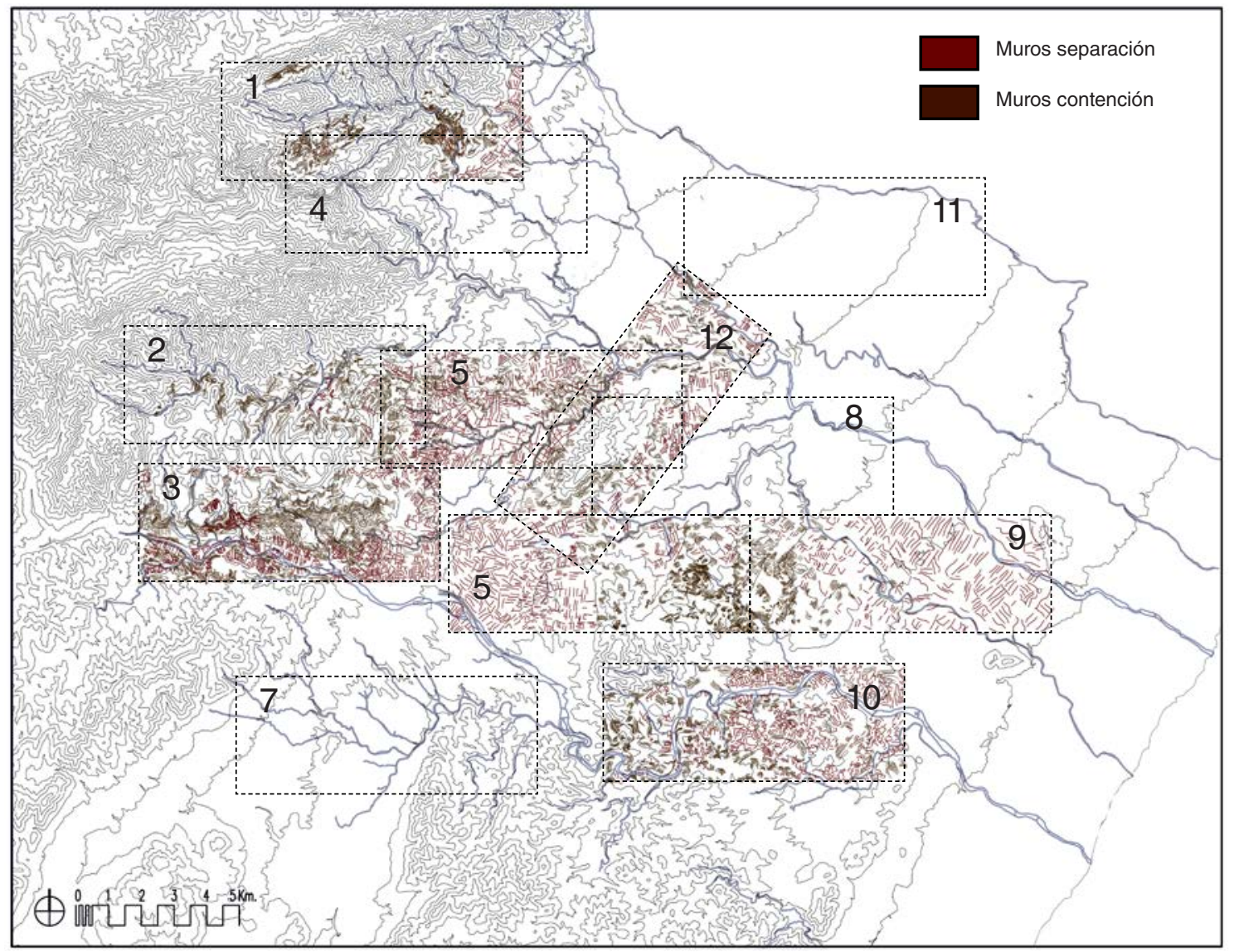

Fig. 4. 39. Plano de la Batllia a escala 1/200.000 del topográfico con los dos tipos de muros de los bancales. Señalización 12 zonas de estudio.

Hemos dibujado los muros en el territorio en 8 de las zonas seleccionadas. En las 6 que hemos seleccionado arquitecturas $(1,2,3,5,10$ y 12) y en las zonas 6 y 9 , por ser más heterogéneas y por tanto nos pueden ser útiles para el análisis posterior. 
Topográfico + muros separación + muros contención - Zonas 1, 2, 3, 5 - [e=1/75.000]

Zona1_Bel

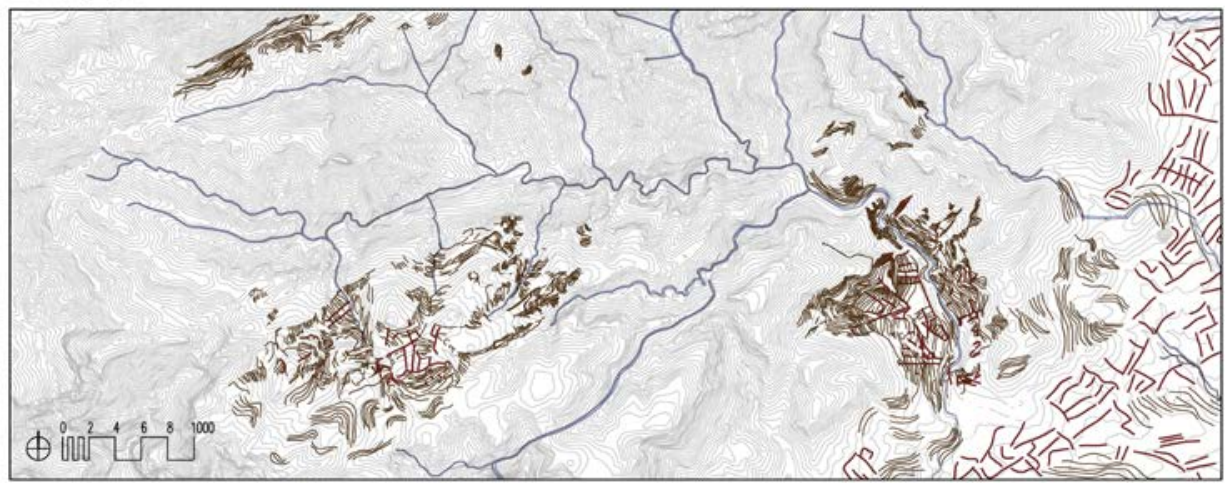

Zona 2_Barcella

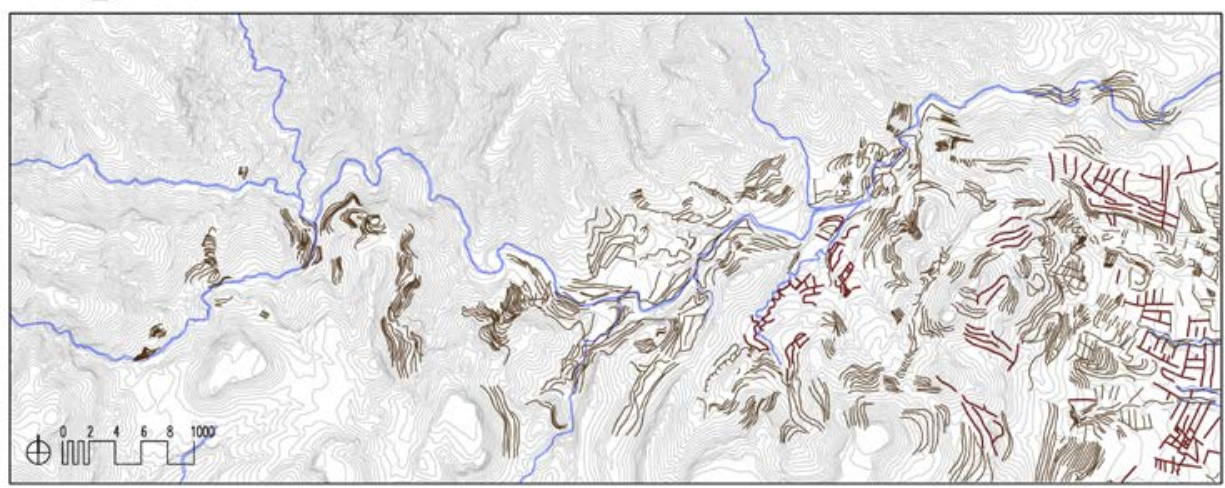

Zona 3_Molinar/Xert

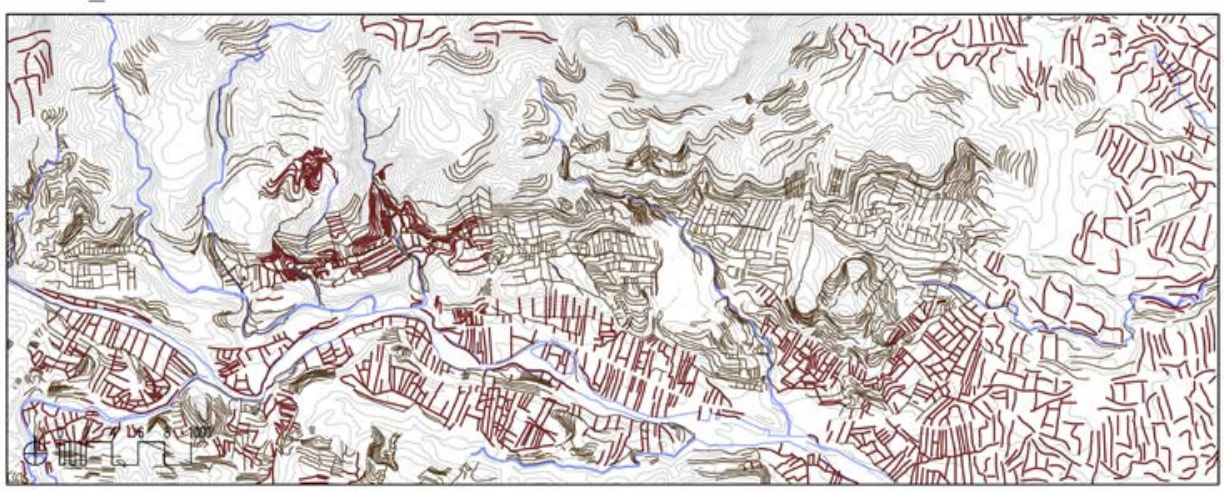

Zona 5_Canet

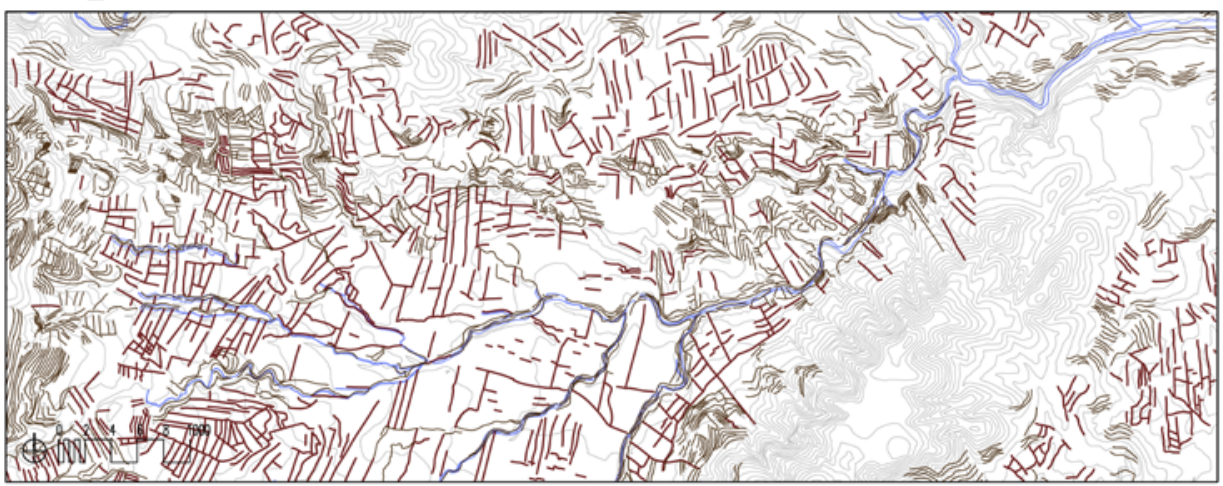


Topográfico + muros separación + muros contención - Zonas 6, 9, 10, 12 - [e=1/75.000]

Zona 6_La Jana/Carrascal

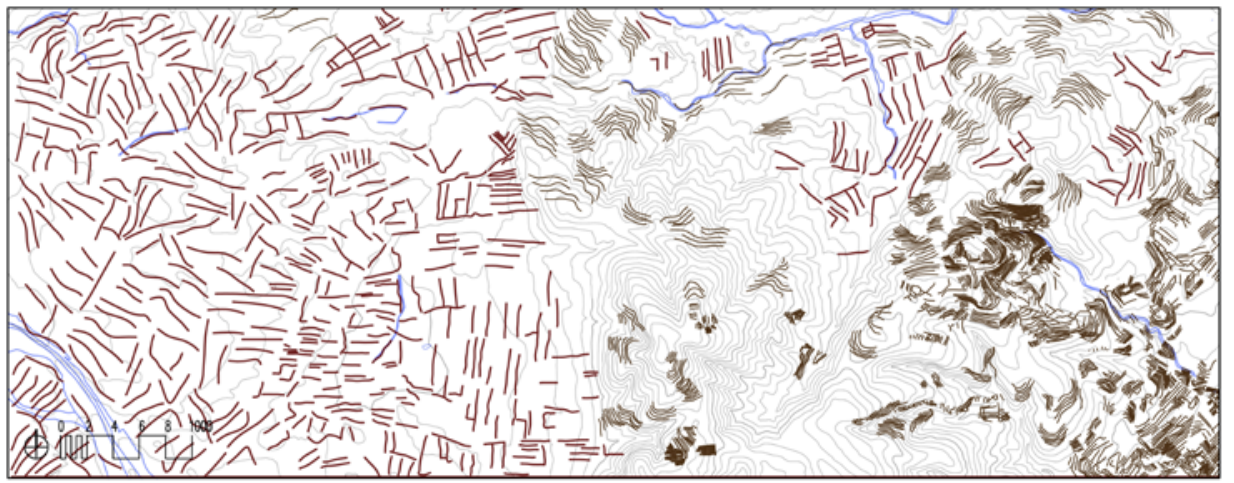

Zona 9_Mas Stellers

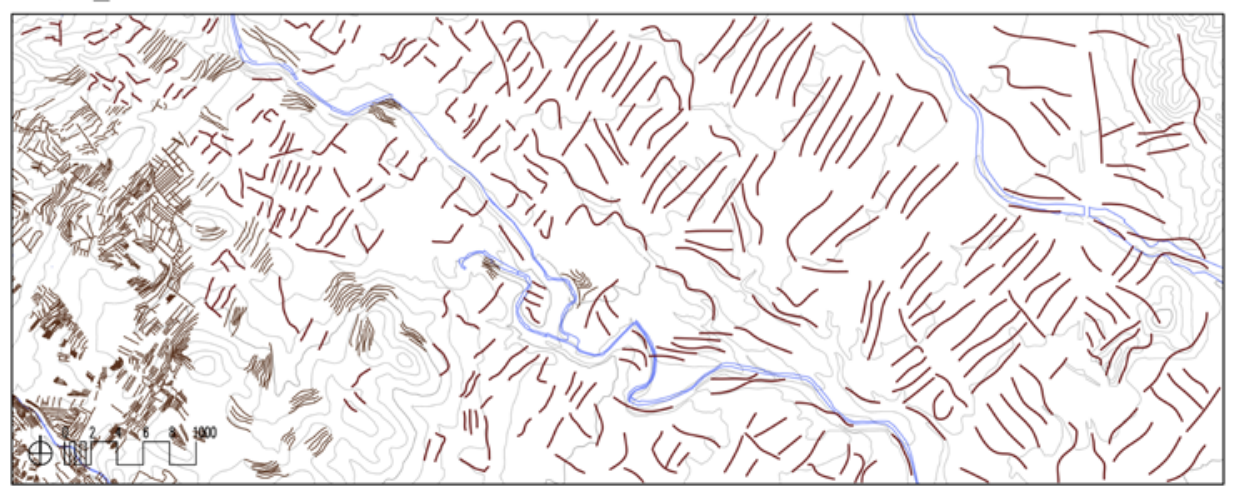

\section{Zona 10_Cervera / Calig}

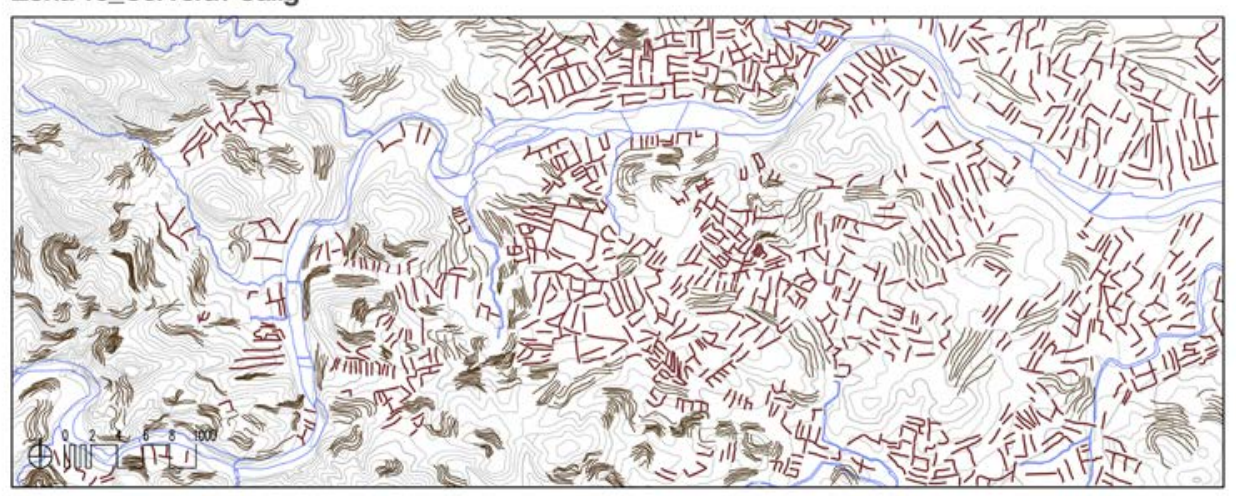

\section{Zona 12_Atalaya San Pere}

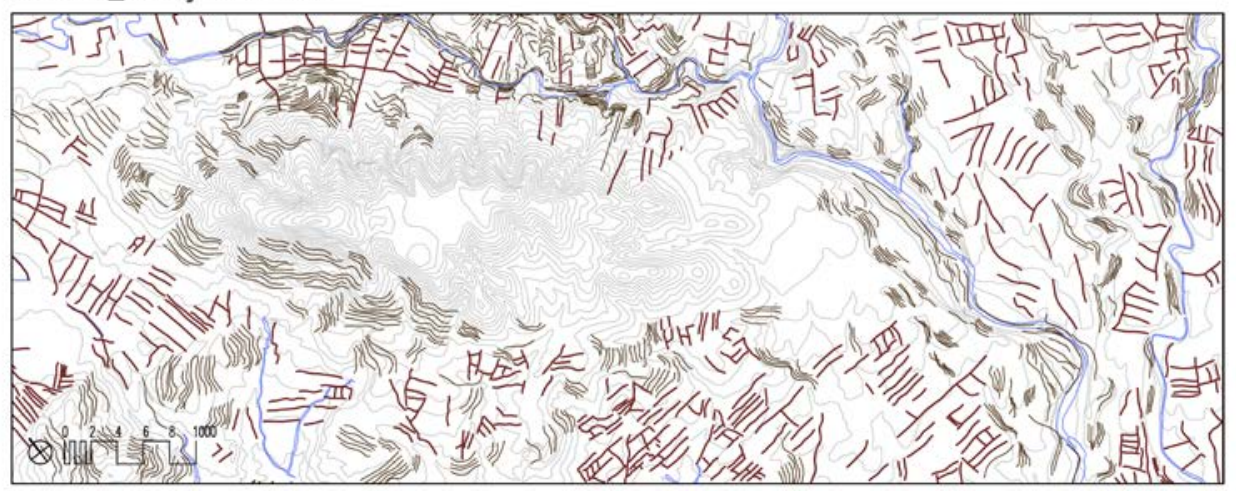



A partir de los planos obtenidos en la toma de datos de cada una de las zonas analizadas hacemos un análisis comparando de la clase de muro, de su ubicación, forma y densidad entre los ocho ámbitos de estudio del que posteriormente extraeremos las siguientes conclusiones previas:

- En los recintos de montaña y de valle, nos encontramos con la clase de muros 1; en las laderas con las tres clases según como vamos descendiendo por ellas; en el suelo ondulado nos encontramos con la clase 1 y 2 mientras que en el llano nos encontramos con la clase 2 y 3 .

- Se produce un dialogo muro-relieve. El territorio es una sucesión de planos más o menos horizontales con distintas texturas y colores, creados por el hombre a partir de una serie de planos verticales de mampostería.

- En la montaña, no todos los sitios son aprovechables por lo que los bancales construidos se combinan con suelo con el relieve natural, sin modelar que se dedican a pastos o bosques, configurando un territorio muy heterogéneo.

- En la ladera, es donde se produce la mayor acción del hombre. Los movimientos de tierra son más importantes el tejido sigue siendo heterogéneo en la parte más alta y conforme va descendiendo por la ladera se hace más homogéneo. Los muros son de dimensiones considerables, en la parte alta se adaptan a la topografía en su trazado y conforme van descendiendo se hacen más rectilíneos. Las pendientes de los parcelas en la parte alta son elevadas y conforme van descendiendo las parcelas se hacen cada vez más horizontales. Las dimensiones son también muy heterogéneas.

- Los muros permiten un diseño detallado de elementos típicos o estructuras repetitivas, facilitando una aproximación arquitectónica. Como veremos más adelante son elementos que no solo modelan el relieve, sino que construyen o definen las infraestructuras, las parcelaciones y las propias arquitecturas. Es un elemento que es utilizado en todos los procesos de con-formación. 


\section{Las infraestructuras}

Los flujos se canalizan a través de las infraestructuras que se disponen como redes por el territorio y posibilitan el transporte horizontal por él. Si no se elevan sobre el relieve, son cicatrices que se marcan sobre él. Las que se elevan totalmente o en un tramo, adquieren presencia y se convierten en hitos en el mismo, es el caso de los puentes y los acueductos en sus tramos elevados.

Estos elementos lineales distribuidos por todo el territorio relacionan los elementos creados por los otros procesos. Son los "hilvanes" que cosen todos los elementos del gran collage que es el territorio y los conductos por donde se transmite la energía que con-forma e in-forma el territorio.

Los flujos no solo definen una red de accesos, sino también un sistema de esclusa, puerta y válvula; una serie de mecanismos que regulan y controlan los flujos. Por ello tienden a ser jerárquicas, produciéndose efectos de escala (efecto capilar cuando los elementos se hacen numerosos y pequeños) y efectos de sinergia (cuándo los sistemas se superponen e intercambian).

La infraestructura funciona para construir el propio emplazamiento. Prepara el terreno para la edificación futura y crea las condiciones de futuro acontecimientos.

En el análisis diferenciamos dos infraestructuras: los caminos y los cursos de agua. Las dos permiten el transporte horizontal por el territorio, la segunda utilizando la fuerza de la gravedad y la primera siguiendo siempre la máxima de la mínima pendiente para consumir el mínimo de energía.

El trazado y forma de las infraestructuras la hemos obtenido a partir de los datos tomados "in situ" y posteriormente con la ayuda de la cartografía temática SIG, fotos aéreas, planos parcelarios actuales e históricos ${ }^{97}$, referencias bibliográficas y la documentación histórica muy abundante en cuanto a los azagadores y los aprovechamientos del agua: regadíos y molinos. Confeccionamos en cada una de las 12 zonas un plano con las redes de caminos y cursos de agua.

La lectura de los planos con el trazado de las infraestructuras en las doce zonas de estudio nos permite realizar una clasificación morfológica de los mismos. Los caminos los podemos clasificar en las siguientes clases:

1. Los caminos de dominio o carena, discurren por las divisorias de vertientes por las limatesas. Son caminos de carácter militar -de conquista- inicialmente elementales en cuanto a su construcción e indefinición de trazado y en muchos casos posteriormente se transformaran en azagadores, en caminos pecuarios. Son caminos que comunican regiones distintas a la vez que estructuran el territorio por el que discurren.

2. Los caminos de penetración en el fondo del valle, muchas veces en "cul de sac", que transcurre paralelo al torrente, más cercano a él cuanto más estrecho sea el valle y en la vertiente de mayor exposición solar. Son caminos con ciertos niveles de construcción y obra pública proporcional al territorio que sirven (puentes, muros de contención, canalizaciones de agua de lluvia o protecciones). Son caminos estructurantes que establecen los factores de localización de los asentamientos, jerarquizan las relaciones de producción, de intercambio y de accesibilidad.

3. Los caminos de "en medio" se sitúan a mitad ladera en la charnela en la que se produce la máxima inflexión de las pendientes, que coincide con el punto en el que los barrancos se abren al llano. Esta disposición facilita la comunicación entre los valles de los distintos barrancos, constituyéndose en un elemento integrador que servirá para el posterior establecimiento de los distintos usos. Son caminos que unen también regiones distintas además de estructuran el propio territorio que atraviesan. Son caminos con un nivel de construcción elevada para adaptarse al terreno y para salvar los distintos barrancos que cruza.

97 A partir de los croquis de los polígonos catastrales de principios del siglo XX, hemos confeccionado planos de conjunto de las zonas de estudio que nos han permitido identificar las distorsiones en las infraestructuras del territorio actual respecto al de la Edad Media. Ver planos pág. 257, pág. 258, pág. 259 y pág. 260 
4. Los caminos del "llano". Muchos son los caminos que discurren por este territorio que no opone grandes dificultades de relieve, pero para aprehender su identidad necesitamos centrarnos en el más importante de ellos que es el camino de loma o divisorio de vertientes, camino que organiza la colonización y las instalaciones territoriales. El camino de cresta jerarquiza y transita por los puntos altos del llano dando servicio a la organización de las unidades de cultivo. Posee un mayor grado de construcción, de pavimentación y es el camino de mayor transito. Que sea camino de cresta no implica el transcurso literal por ella, en ocasiones abandona la misma a fin de sortear diferentes accidentes del relieve. A través de su sección se puede comprobar que lleva adosados a ambos lados sistemas de desagüe a cielo abierto. Son caminos despejados de gran dominio territorial y son los caminos públicos por antonomasia.

Estos caminos conforme se van acercando a la ladera de la montaña, van dejando la divisoria y se van aproximando al curso de los torrentes como ocurre en la montaña. Por el otro extremo conforme el territorio se hace prácticamente llano el camino abandona la divisoria estricta de aguas y se convierte en una estructura regular de caminos sensiblemente paralelos. Hay caminos complementarios que tejen la malla como el contiguo a la ribera. Su configuración es semejante a los caminos divisorios ya que en ocasiones estructuran una colonización más tenue y cumple una función similar en la conquista del territorio.

Otros caminos complementarios que cierran la malla son los caminos de acceso a los campos o de intercomunicación entre los anteriores. Son caminos traveseros que ayudan a entender la estructura viaria como una malla si el relieve es suave.

5. Los azagadores, los caminos pecuarios, son las grandes "autopistas" desde el siglo XIII hasta el XIX, atraviesan el territorio dejando una importante huella en él por sus dimensiones tanto de longitud como de anchura -para poder absorber el flujo de ganados por ellos-, así como la serie de espacios de servicio que precisan.-zonas de reposo, abrevaderos, zonas de control para saber el número de cabezas de ganado, etc.-

Además tiene una característica formal singular, tiene límites, bordes para impedir que los animales se salgan del camino (una semejanza más con las actuales autopistas) y ello los convierte en algo más que en caminos, tienen "volumen" y se leen como construcciones en el territorio dividiéndolo, fragmentándolo. Son cicatrices que se dibujan claramente sobre el territorio, por lo que su permanencia se prolongara durante siglos, su huella difícilmente se borra y desaparece. Hasta hoy en día que prácticamente no existe la trashumancia de ganado, las vías pecuarias perduran y son reconocibles a simple vista en el territorio.

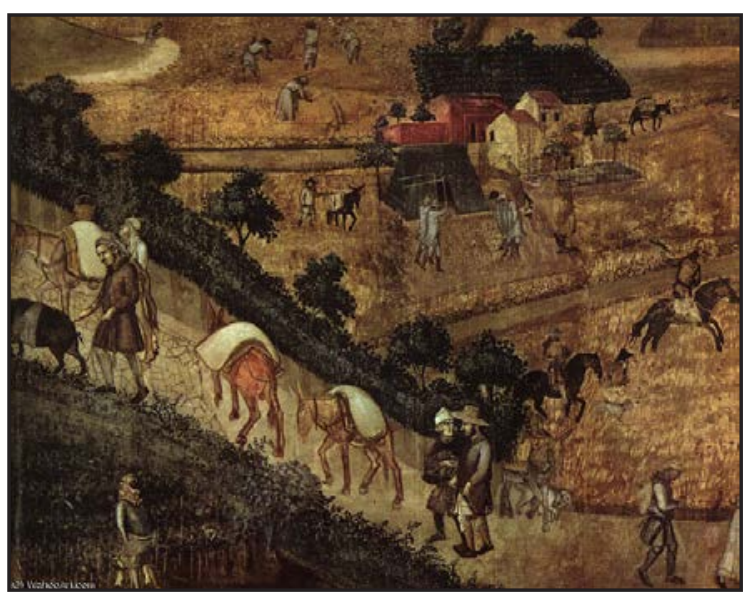

Fig. 4. 40. Detalle del cuadro de A. Lorenzetti "Los efectos del buen gobierno" Siena, entre 1338 y 1340.

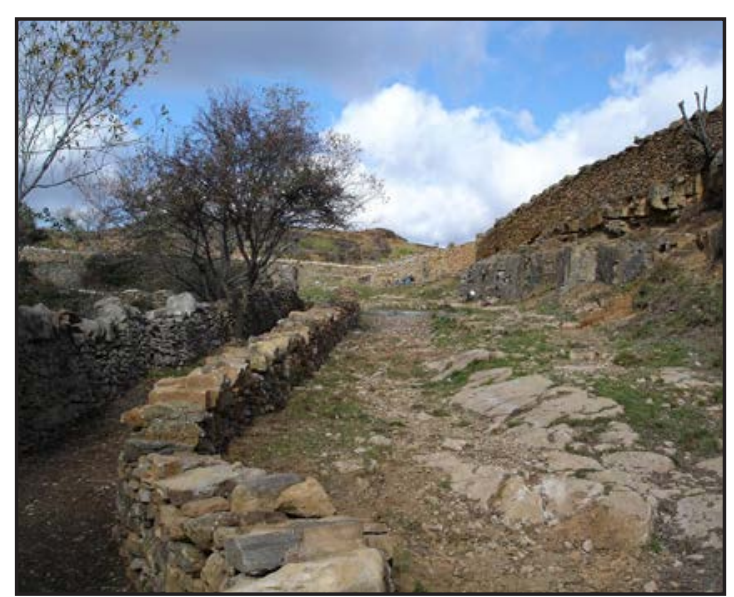

Fig. 4. 41. Camino de piedra del interior de Castellón similar al del cuadro de A. Lorenzetti. 
Las infraestructuras de agua las podemos clasificar en las siguientes clases:

1. Las acequias de riego que toman el agua de una fuente o manantial, de una balsa o estanque o del propio río. Hay de dos tipos las que discurren paralelas a la escorrentía o las que lo hacen perpendicularmente, cada una de ellas crea un sistema distinto de riego. ${ }^{98}$

2. Las acequias de los molinos. Hay dos la primera desde la toma de agua hasta una balsa y la segunda desde esta hasta el propio molino. Estas siempre discurren paralelas a los cauces de los ríos.

3. Los desagües que devuelven el agua una vez utilizada en los campos o en los molinos a los cursos de los ríos. Els Furs no contemplan la propiedad del agua, sino solo su uso, por lo que todas las redes de infraestructura de agua estarán siempre condicionadas por este hecho y por ello tan importante como las conducciones para aportar agua son las de desagüe para el posterior aprovechamiento.

4. Los acueductos que conducen el agua desde los manantiales hasta los núcleos de población. Las distancias en estos casos son importantes y su trazado discurre adaptándose al relieve pero en ocasiones debe salvar importantes desniveles por lo que su construcción se eleva del terreno y se convierte en un hito en el territorio. Podemos considerarlo el tipo de infraestructura más emblemática, conduce el flujo que da vida a la ciudad medieval, es el cordón umbilical que la alimenta de la madre territorio. ${ }^{99}$

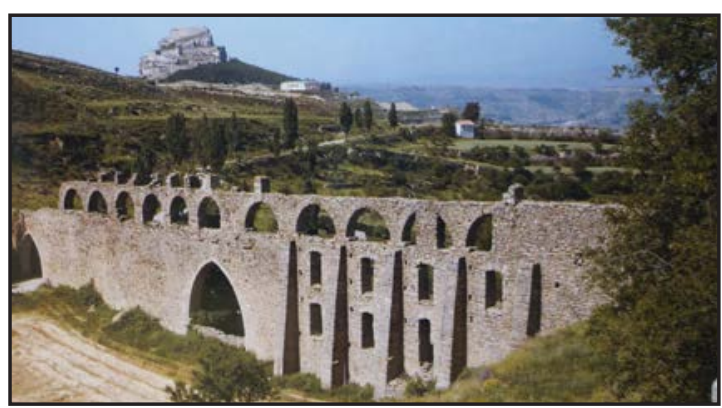

Fig. 4. 42. Acueducto de Morella (1338-1359).

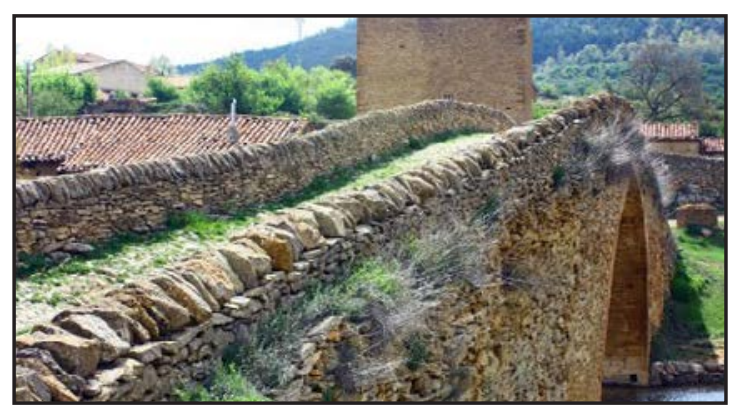

Fig. 4. 43. Puente sobre el río de las Truchas de la Pobleta de San Miguel de Villafranca (s. XIII).

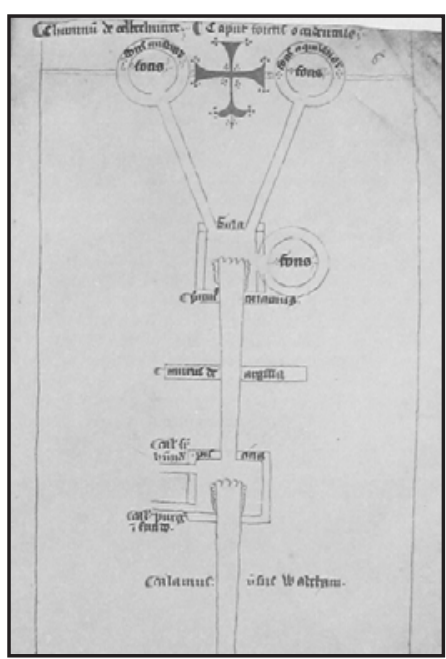

Fig. 4. 44. Dibujo del abastecimiento de agua de 1220 que se encuentra en la Abadía de Hertfordshire.

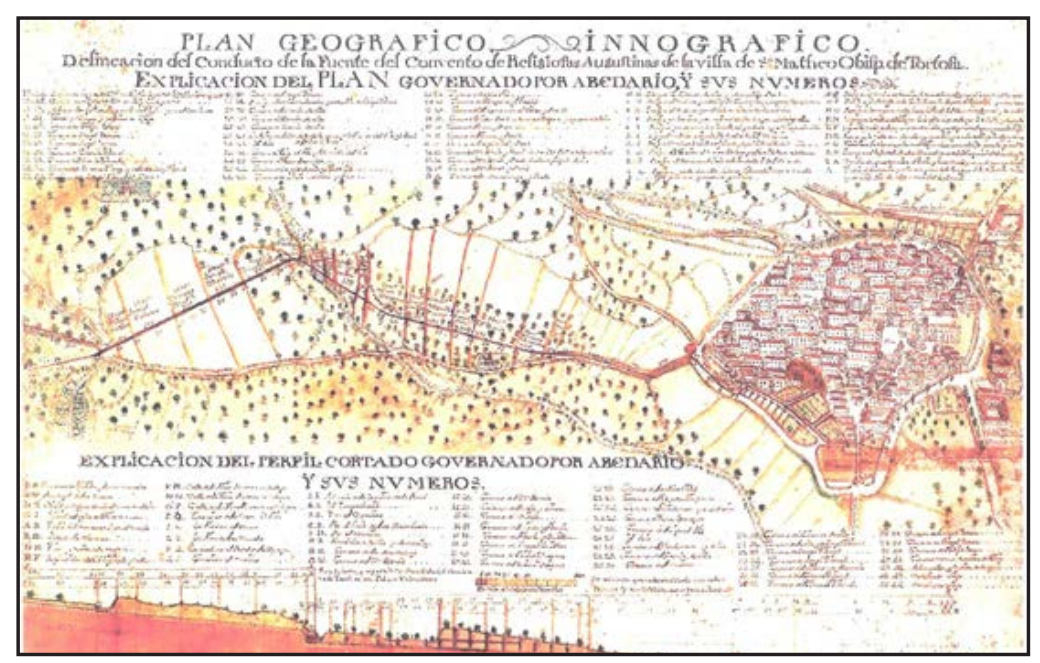

Fig. 4. 45. Plano del trazado del acueducto de Sant Mateu (Fuente convento Agustinas 1774).

98 Ver apéndice documental nº 28 pág. 622

99 Ver apéndice documental no 27 pág. 622 
Mapa general (situación de las zonas de estudio) - $[e=1 / 200.000]$

\section{Topográfico base + infraestructuras}

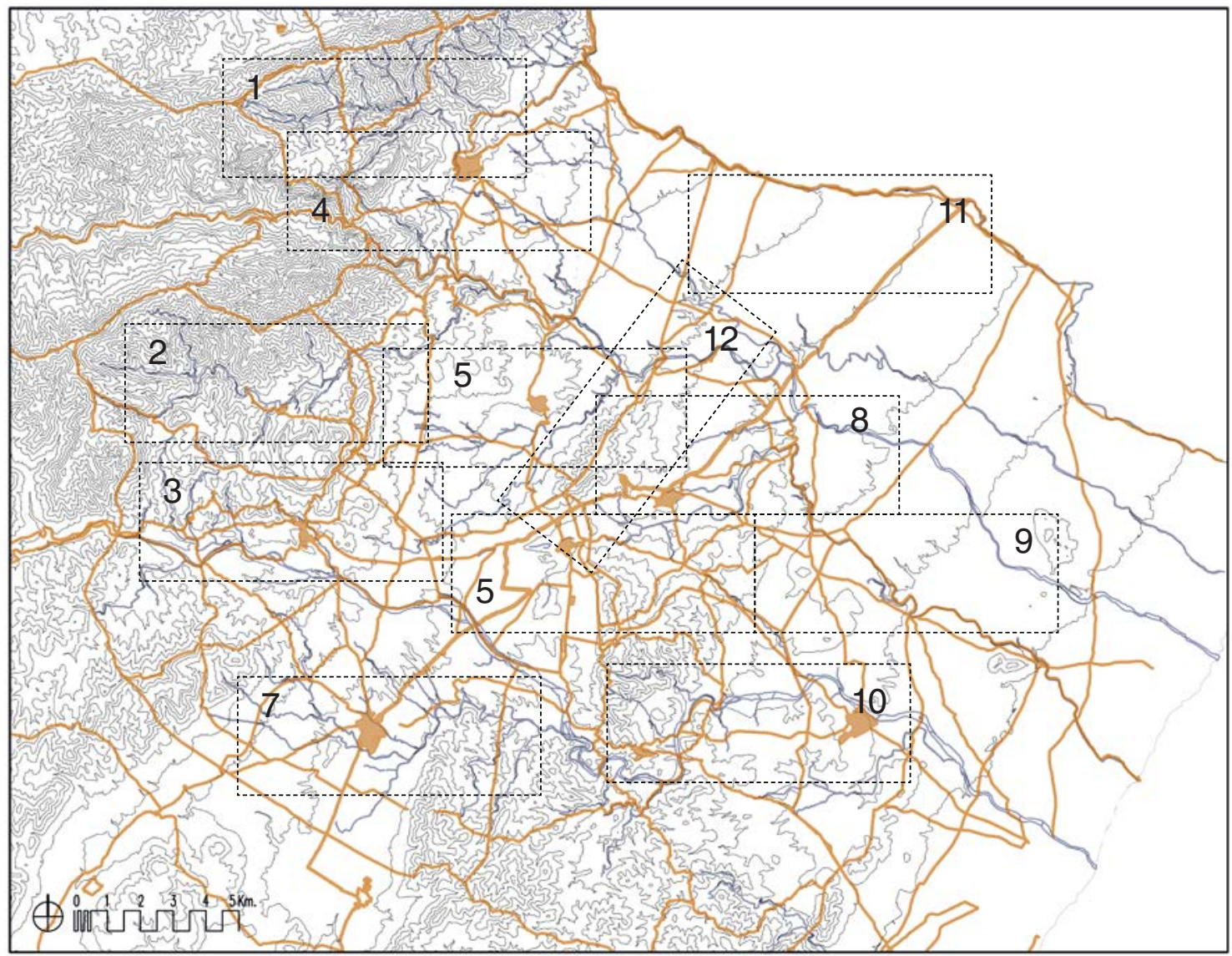

Fig. 4. 46. Plano de la Batllia a escala 1/200.000 del topográfico con las infraestructuras. Señalización 12 zonas de estudio. 
Topográfico base + infraestructuras - Zonas 1-4 - $[e=1 / 75.000]$

\section{Zona 1 Bel}

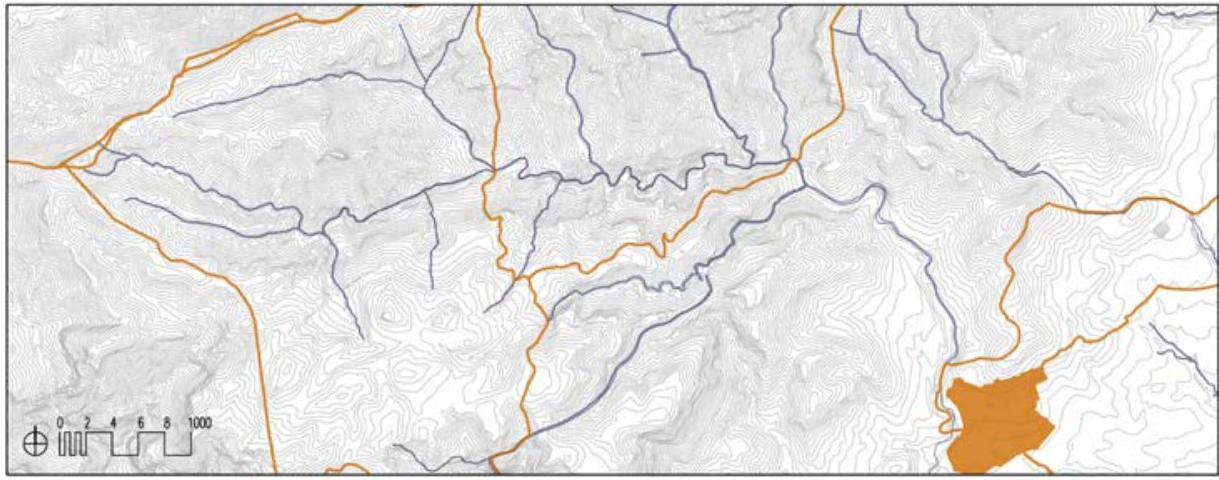

Zona 2_Barcella

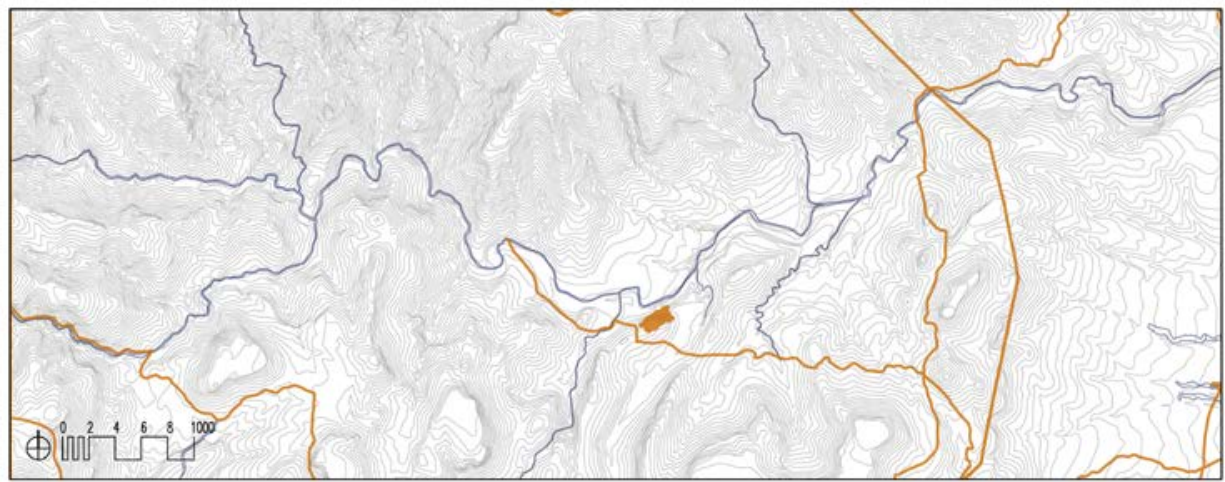

Zona 3_Molinar/Xert

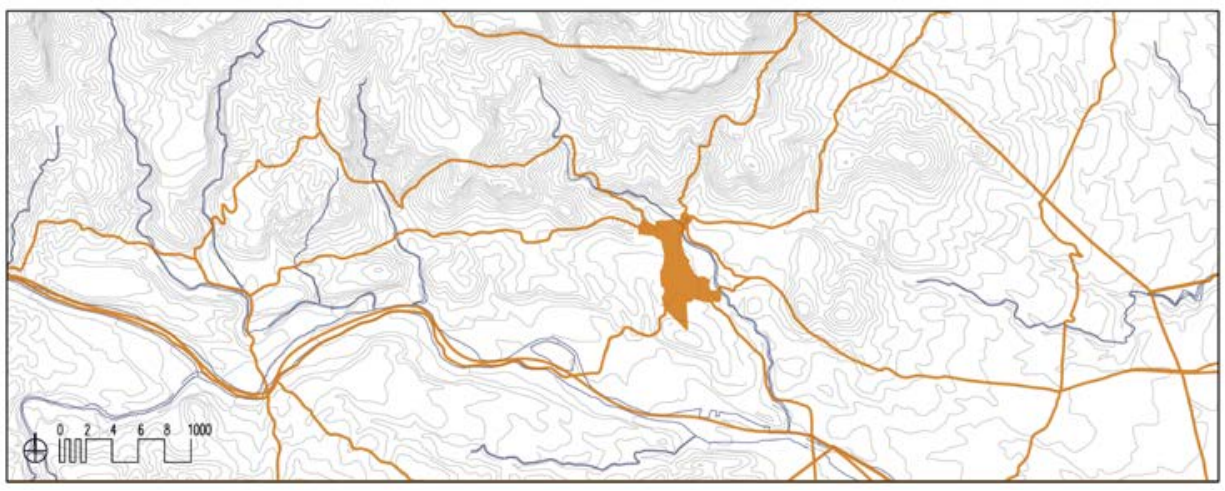

Zona 4_Mas del Coll/Rosell

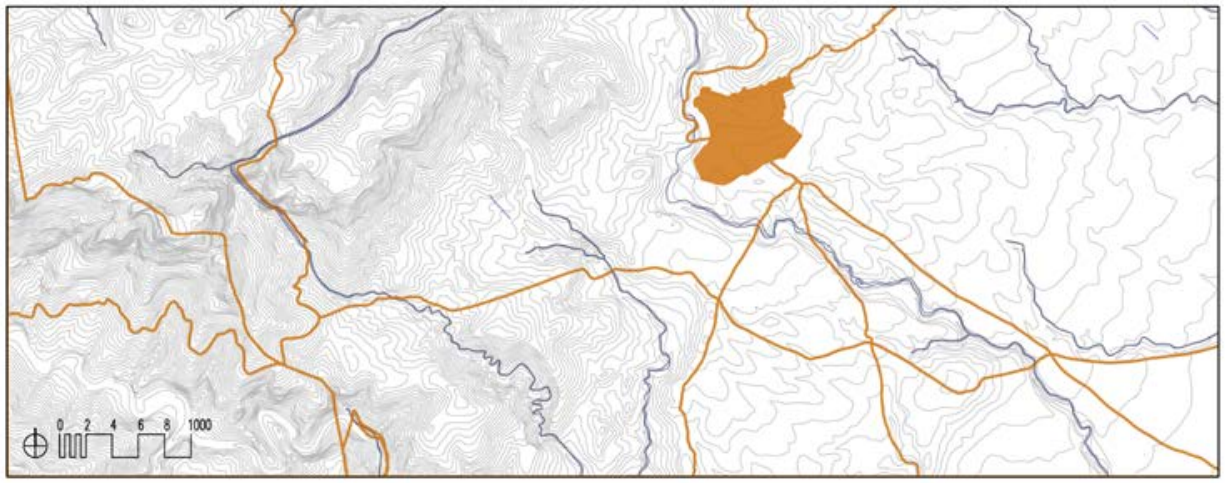


Topográfico base + infraestructuras - Zonas 5-8 - $[\mathrm{e}=1 / 75.000]$

Zona 5_Canet

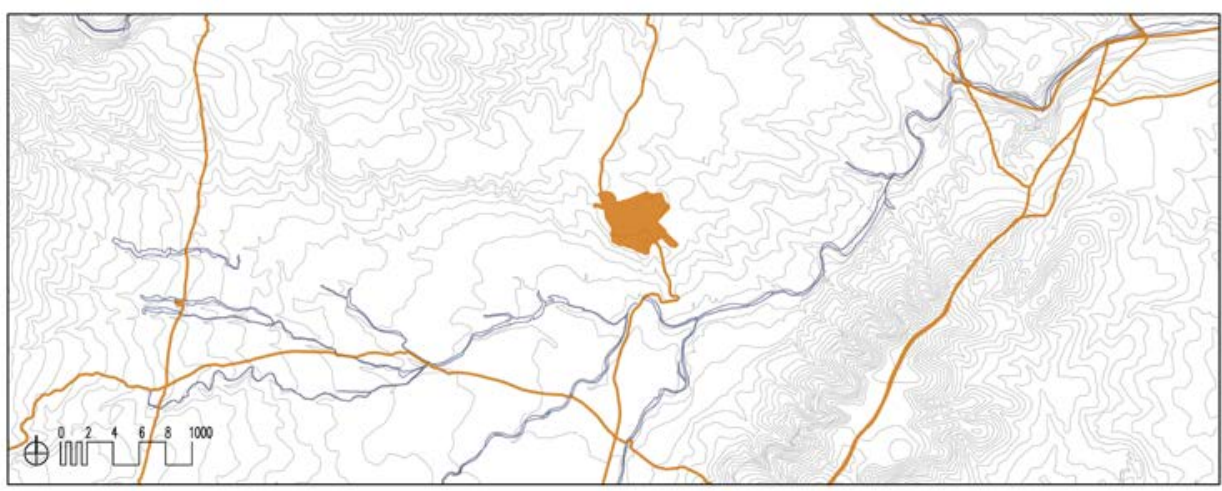

Zona 6 La Jana/Carrascal

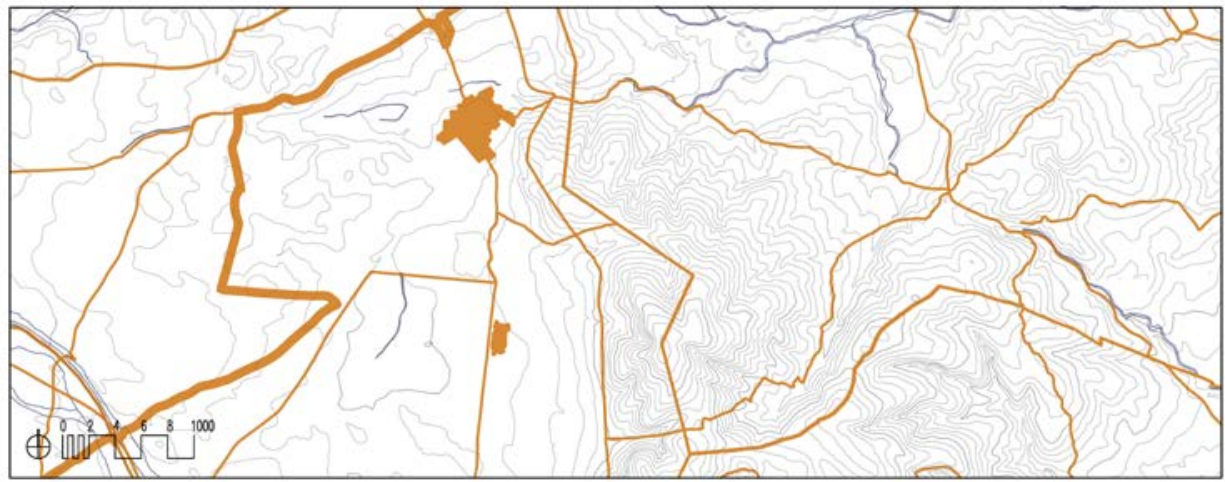

Zona 7_San Mateo

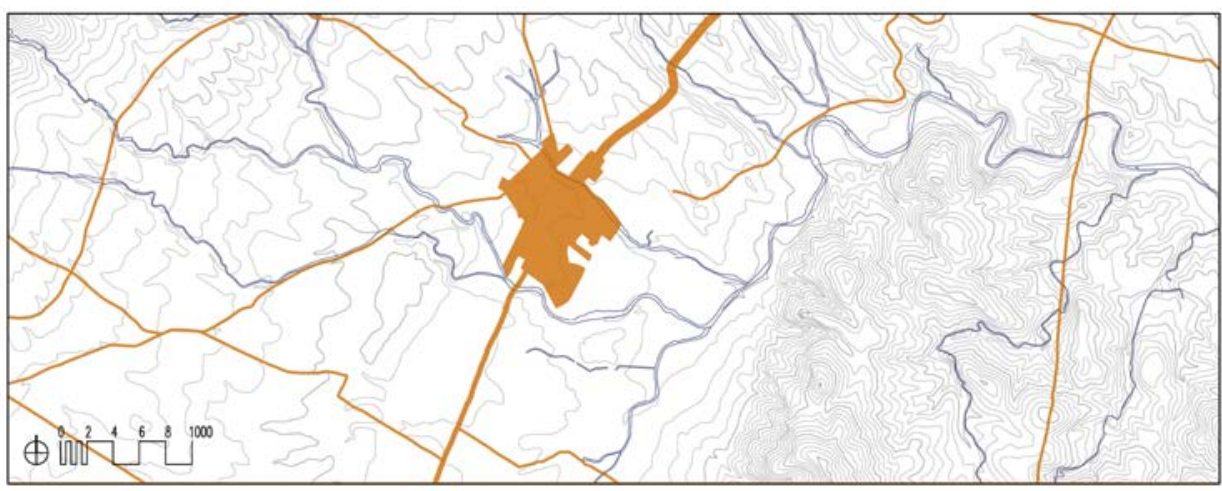

Zona 8_Traiguera

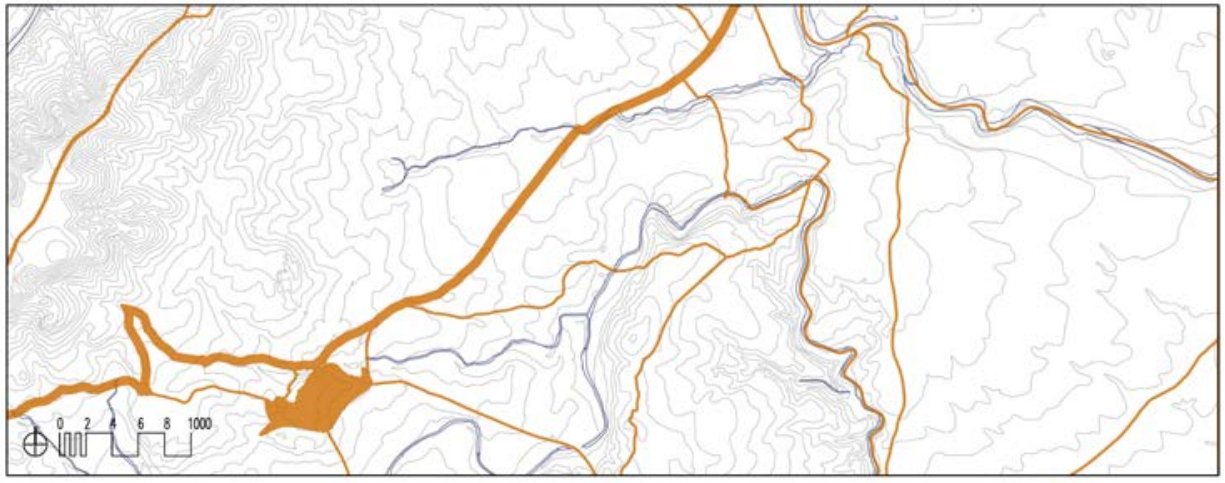


Topográfico base + infraestructuras - Zonas 9-12 - [e=1/75.000]

Zona 9_Mas Stellers

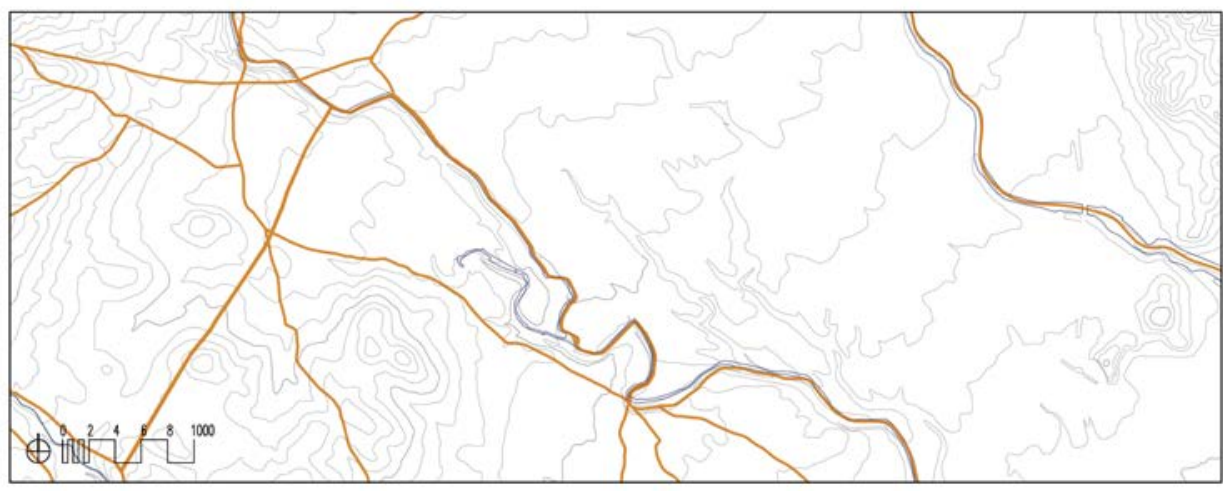

Zona 10_Cervera/Calig

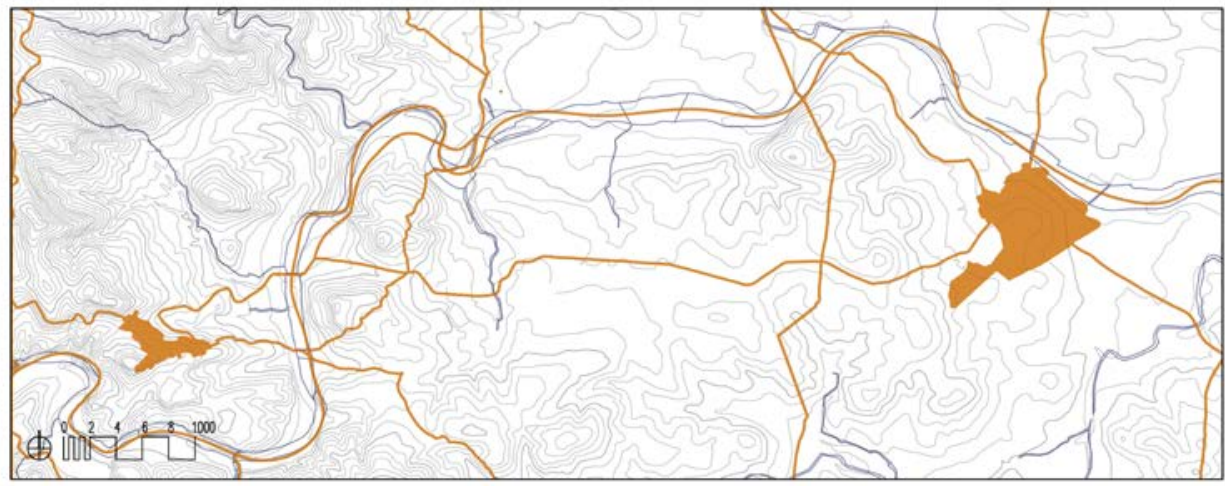

Zona 11_San Joan del Pas

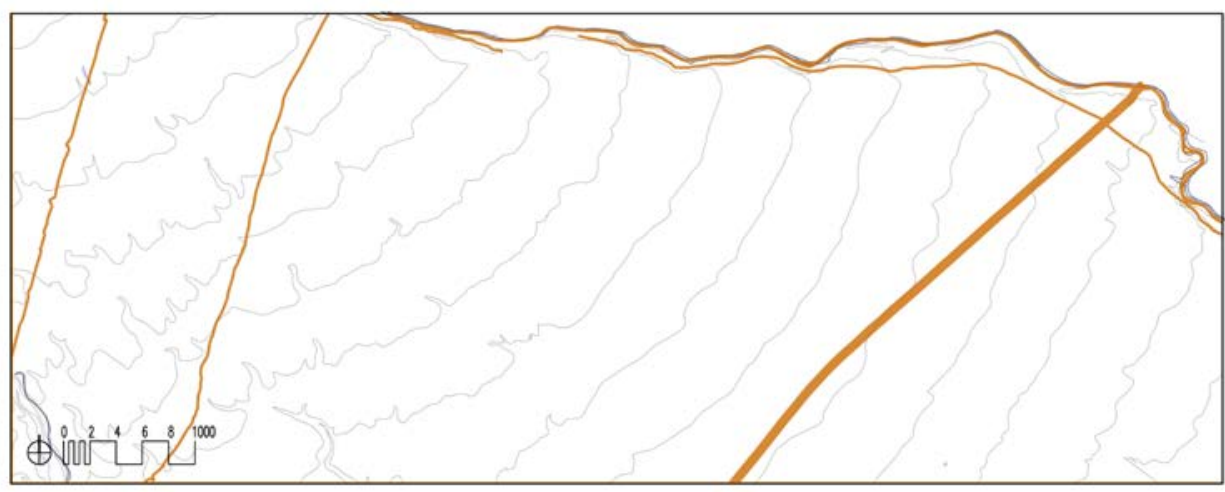

Zona 12_Atalaya San Pere

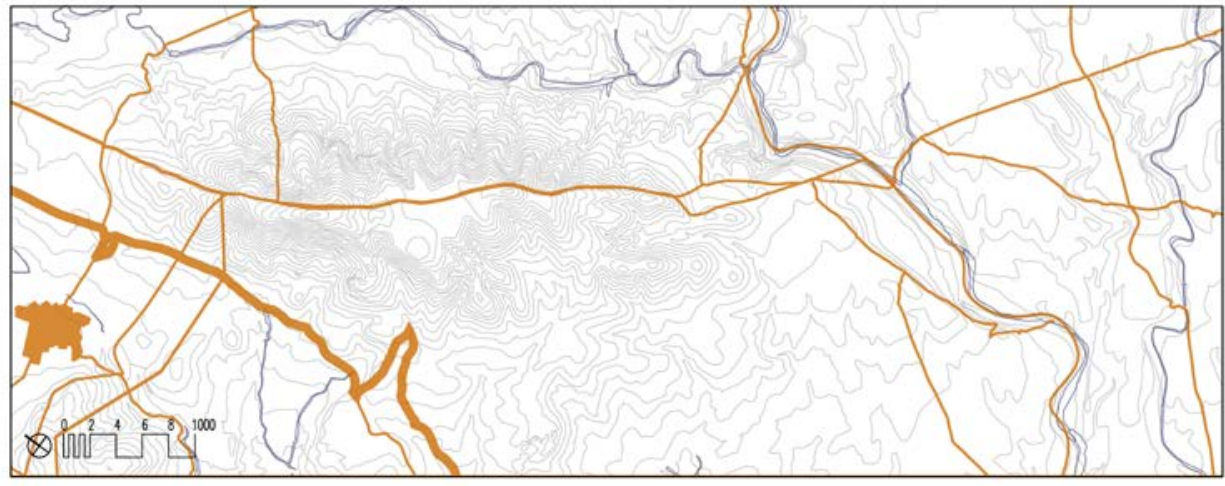


A partir de los planos obtenidos en cada una de las 12 zonas analizadas, hacemos un análisis comparado de la forma de las infraestructuras y de la densidad de las mismas. Una vez grafiados y comparados podemos extraer las siguientes conclusiones:

- Los caminos de carena se dan en la montaña, los de penetración en el valle, los de en medio en las laderas y los del llano en el llano y la malla en el ondulado.

- Los azagadores se dan en la montaña y en menor medida en la ladera, mientras que en las otras zonas tiene mucha menor importancia ya que solo llegan a ellas azagadores secundarios.

- Las conducciones de riego se dan de forma extensa en el llano y de forma puntual en el valle, ladera y ondulado. No existen en la montaña.

- Las conducciones asociadas a los molinos se dan en el valle y ladera, de forma puntual en el llano y en el ondulado. No se dan en la montaña.

- Los acueductos se construyen junto a las ciudades. 


\section{La parcelación}

El resultado del reparto y fragmentación del suelo es la parcelación. Si no hay parcelario que rompa el territorio, el paisaje es siempre la forma que resulta cuando se construye el uso, como un grafismo que actúe controlando la transformación de una forma unívoca. Eso convierte el paisaje en una forma muy frágil, ya que tiene muy poca inercia. En cambio con el parcelario roto, parcelas y usos compiten para dar forma al tejido que cubre el territorio.

Las parcelas son los planos que componen el territorio. Su forma y tamaño son fundamentales en su arquitectura. El territorio parcelado es muy estable, ciertos elementos del mismo se quedan tan integrados en el paisaje que han acabado siendo bases casi inseparables del mismo.

Usos y arquitecturas se apoyan siempre sobre el parcelario, que es el que, rompiendo el suelo, aunque no tenga una materialización directa sobre el mismo, es la llave de su transformación; rasgo, que es fundamental por cuanto estamos estudiando el territorio como algo cambiante, no como una figuración estética de un momento y un tiempo. Las relaciones de forma existen, incluso, en las líneas reales o abstractas del parcelario sobre el suelo, construidas o no. La forma del suelo, llano o inclinado, los valles y las carenas, se reconocen en el trazado de los límites de la propiedad, en el establecimiento de la forma del dominio.

El análisis de la fragmentación del suelo lo realizaremos acudiendo por una parte a las fuentes documentales escritas de la Edad Media y por otra a la información catastral de principios del siglo $\mathrm{XX}^{100}$ y a la actualmente existente.

Las fuentes documentales escritas nos permiten conocer o mejor dicho tener una idea general de cual eran los usos y por tanto las "texturas" y posiblemente grano de la parcelación en función de los usos. El plano que hemos confeccionado del conjunto de la zona de actuación, nos permite por tanto tener una imagen global de la Batllia, más que un detalle pormenorizado del grado de parcelación y texturas.

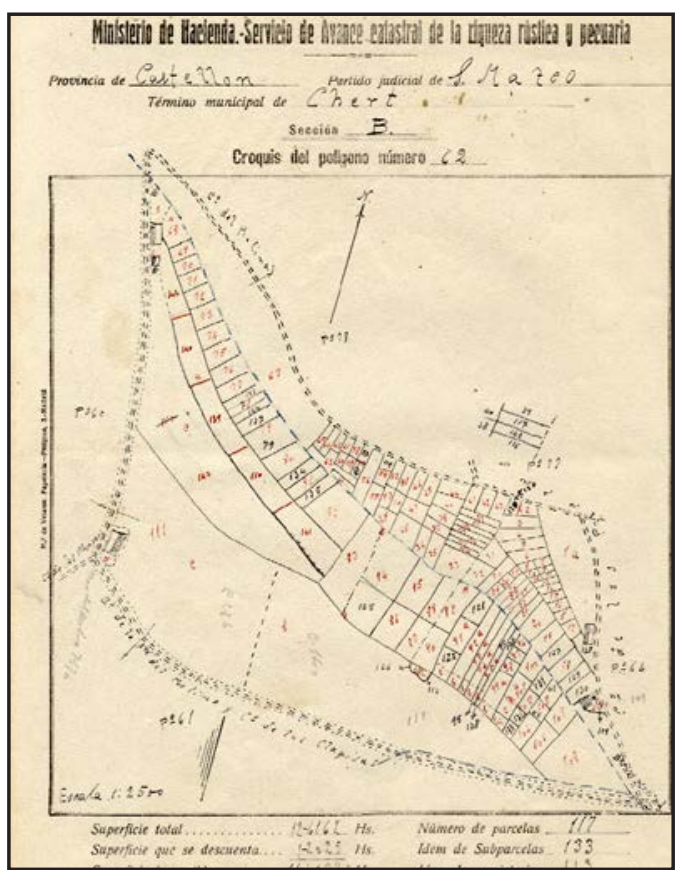

Fig. 4. 47. Croquis del catastro de principios del siglo $X X$ del polígono 62 de Xert, correspondiente a la zona del Molinar.
El levantamiento catastral dibujado a mano a escalas 1:5.000 y 1:12.500 según los polígonos, nos permite conocer no solo la parcelación de principios del siglo XX sino también aquellos elementos que definen el territorio y que hoy en día se han "difuminado", tales como acequias de riego, balsas, vías pecuarias, etc. ${ }^{101}$

Por último el levantamiento actual nos permite obtener una imagen global del grado de parcelación que "tamizada" con las dos fuentes de información anteriores nos permite aventurar una imagen del territorio en el periodo de análisis.

100 A partir de los croquis de los polígonos catastrales de principios del siglo XX, hemos confeccionado planos de conjunto de las zonas de estudio que nos han permitido identificar las distorsiones en las infraestructuras del territorio actual respecto al de la Edad Media. Ver planos pág. 257, pág. 258, pág. 259 y pág. 260

101 Ver planos confeccionados a partir de los catastros históricos pág. 257, pág. 258, pág. 259 y pág. 260 
Existen fuentes documentales gráficas de la parcelación y su importancia durante la Edad Media.
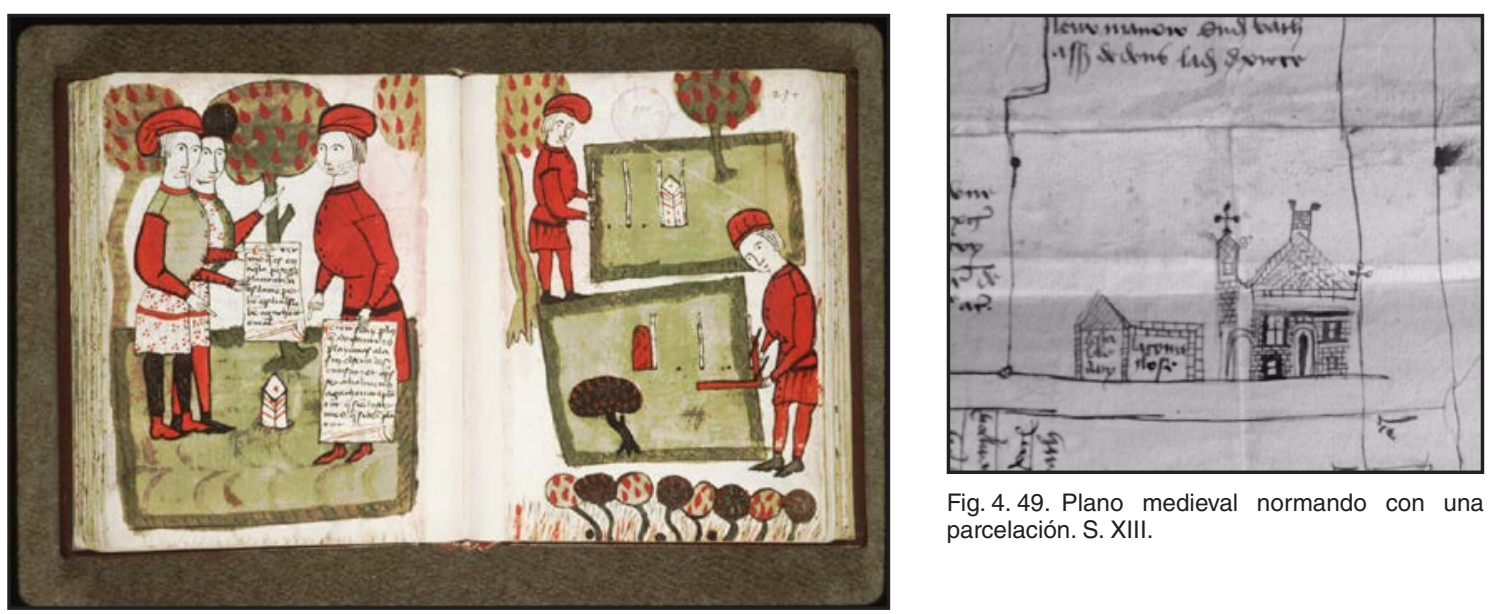

Fig. 4. 49. Plano medieval normando con una parcelación. S. XIII.

Fig. 4. 48. Láminas g243 y v244 del "Traité d'arpentage" de Bertrand Boysset de finales s. XIV, que trata de las parcelaciones.
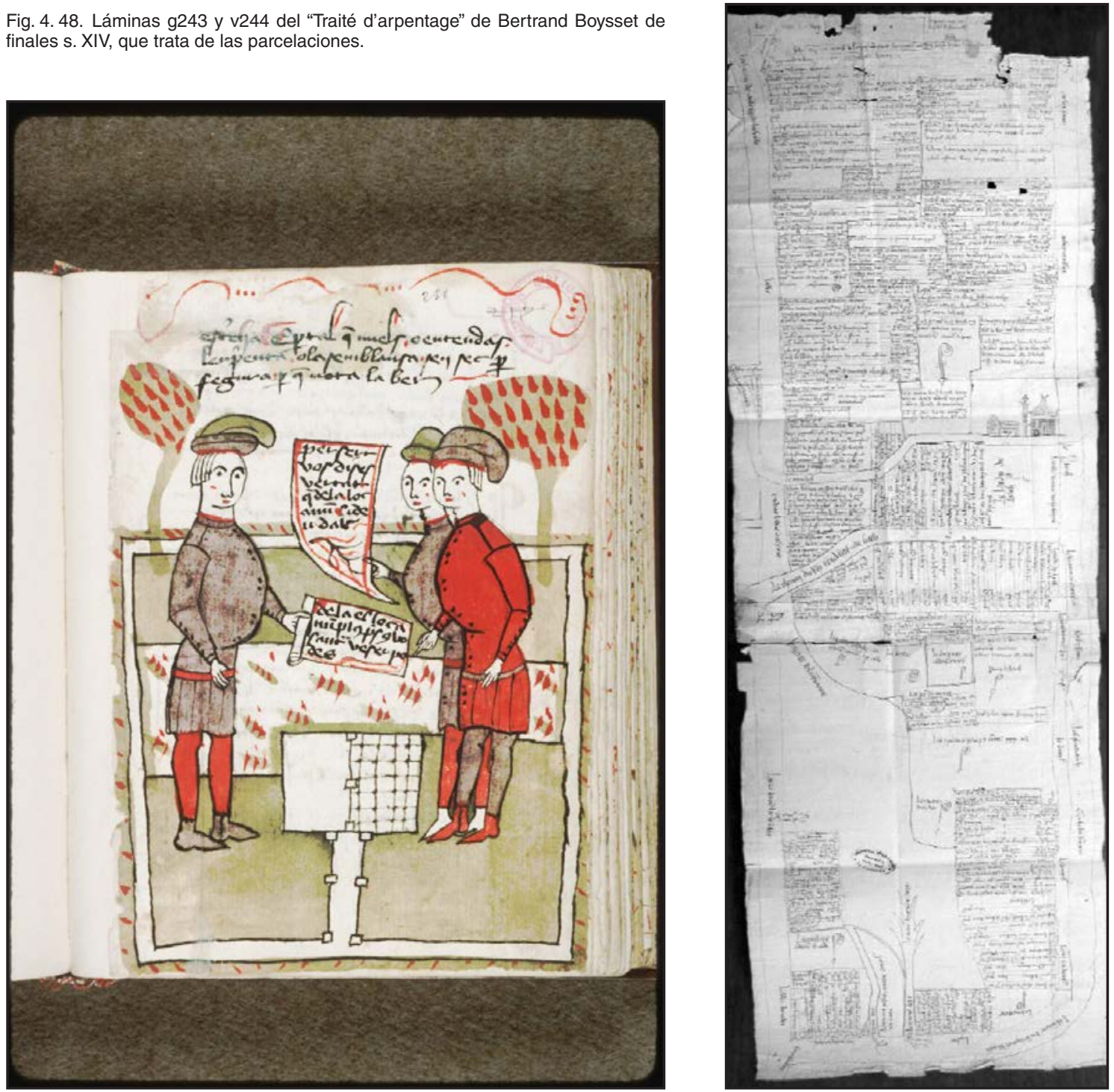

Fig. 4. 50. Lámina g231 del "Traité d'arpentage" de Bertrand Boysset de finales s. $X I V$, que trata del acceso a las fincas que no tienen camino.

Fig. 4. 51. Plano parcelario normando del s. XIII, nótese como se usa tanto el dibujo de las parcelas como los textos para poder identificar cada una de las parcelas y sus circunstancias singulares. 



\section{Zona 2 - Barcella}

Plano histórico Barcella $[\mathrm{e}=1 / 40.000]$

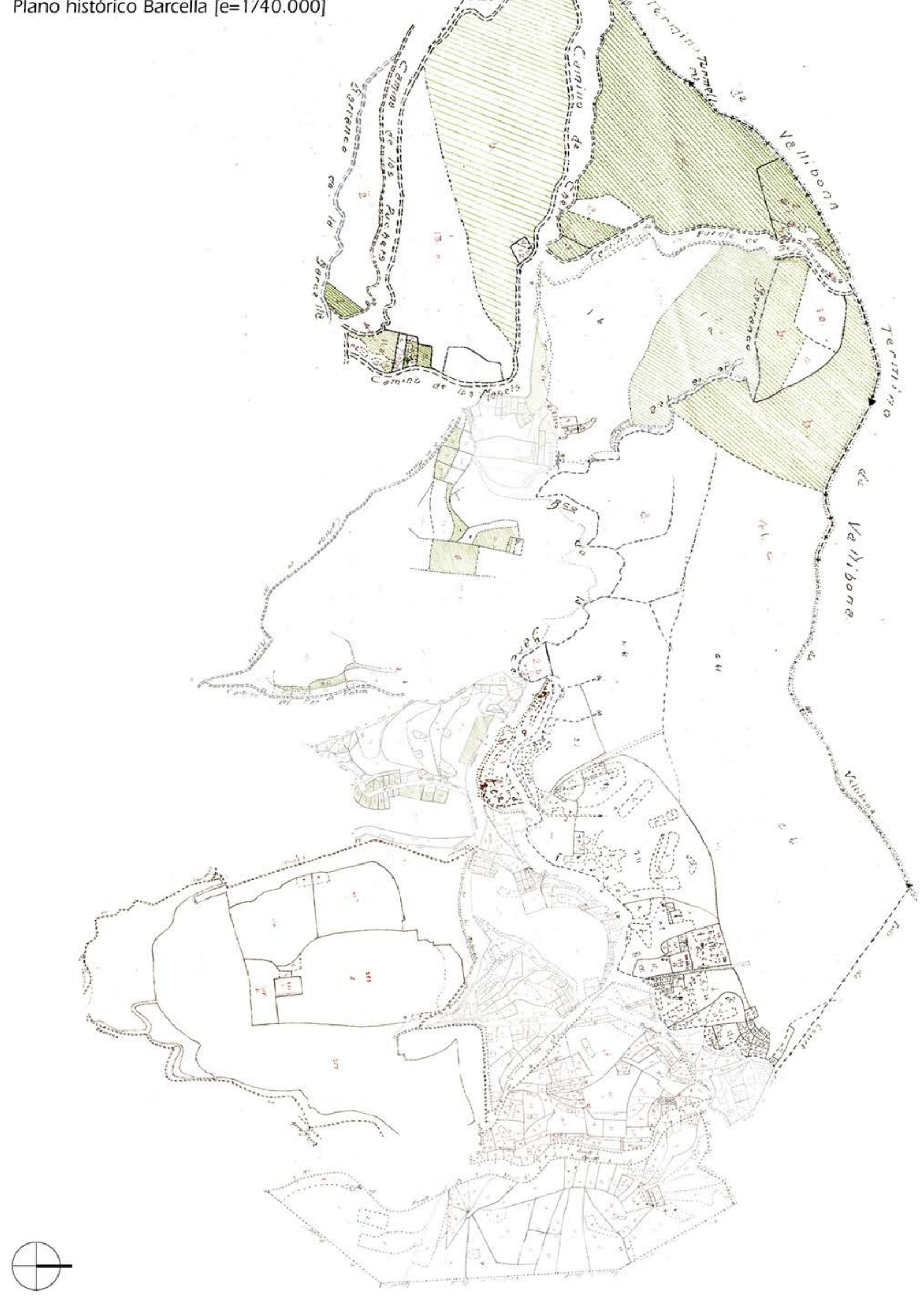




\section{Zona 3 - Molinar / Xert} Plano histórico Molinar $[\mathrm{e}=1 / 20.000]$

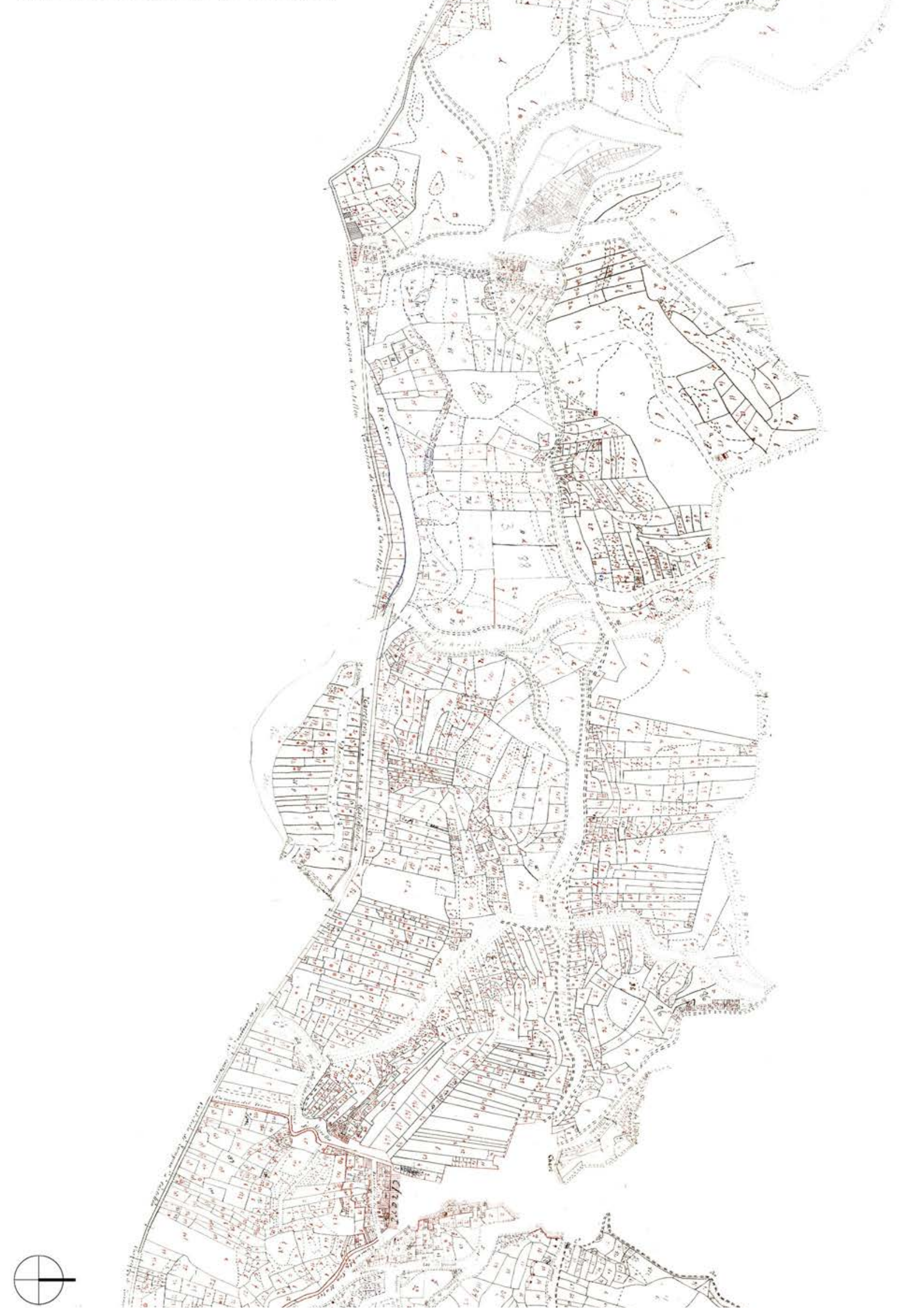




\section{Zona 5 - Canet}

Plano histórico Canet $[\mathrm{e}=1 / 20.000]$
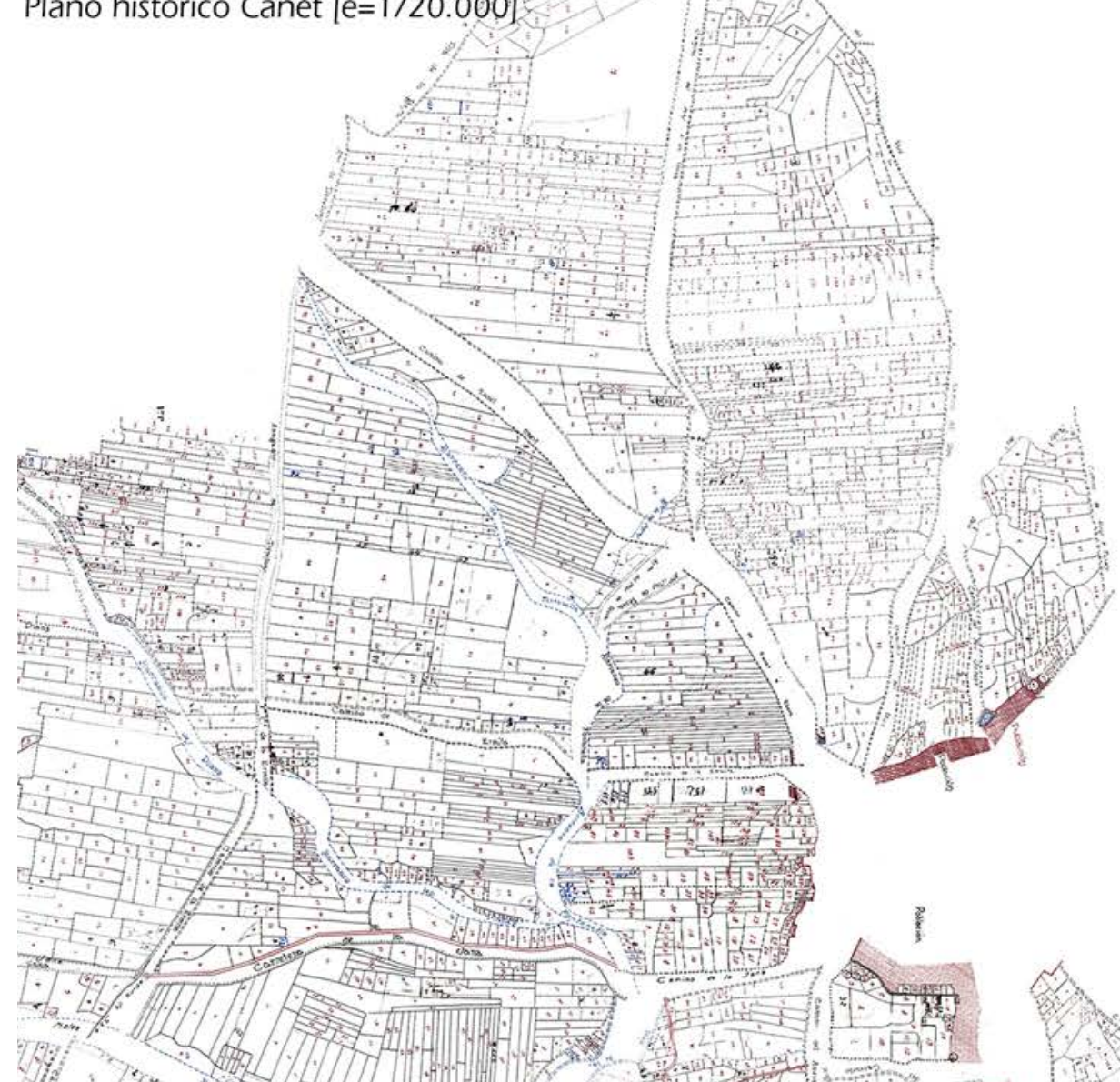

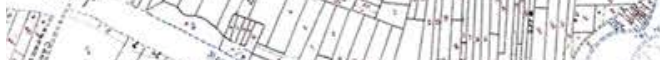
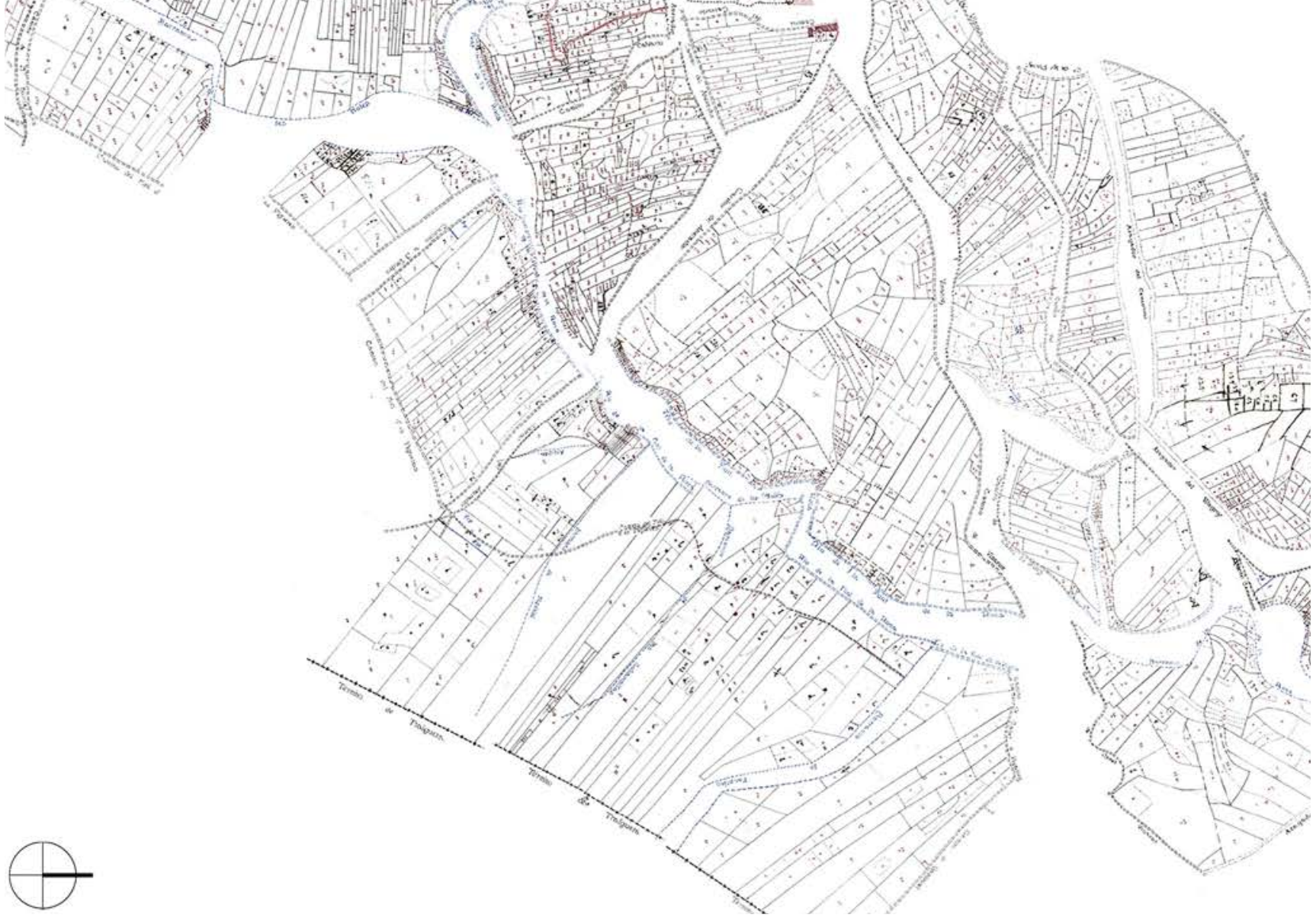


\section{Zona 7 - Cervera / Calig}

Plano histórico Cervera $[\mathrm{e}=1 / 10.000]$

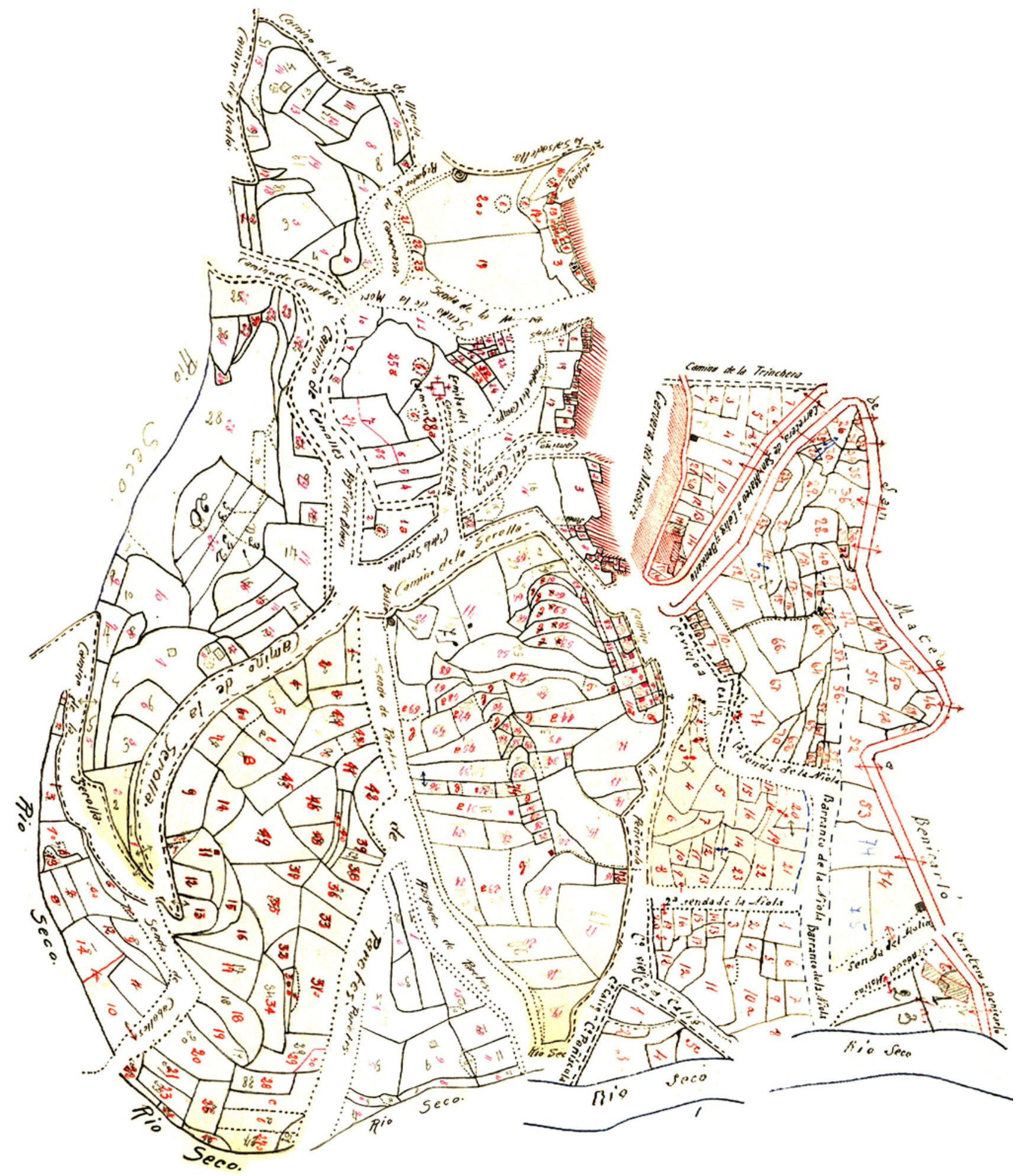


Mapa general (situación de las zonas de estudio) - $[e=1 / 200.000]$

\section{Parcelario}

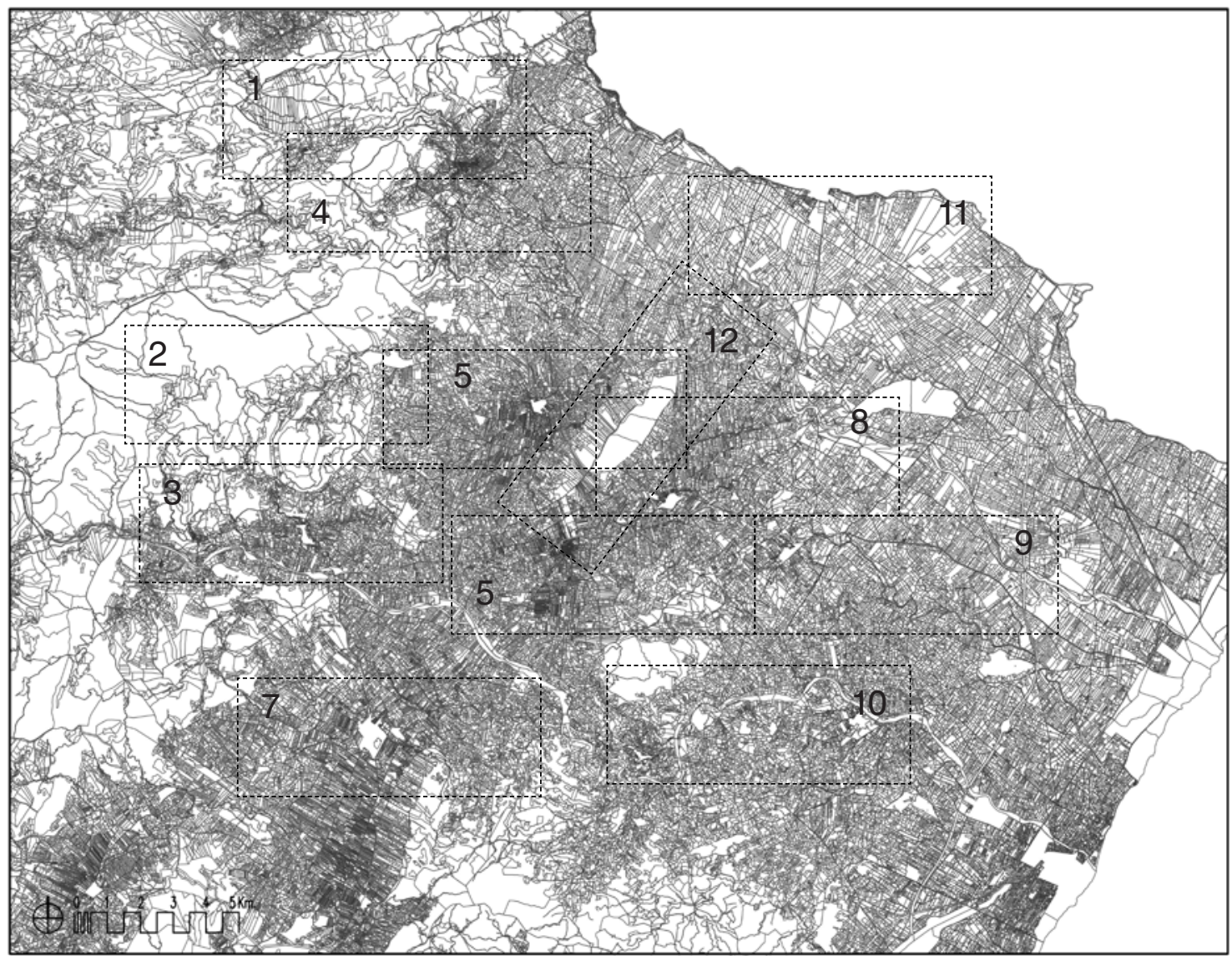

Fig. 4. 52. Plano de la Batllia a escala 1/200.000 del topográfico con el parcelario. Señalización 12 zonas de estudio. 
Parcelario - Zonas 1-4 - $[\mathrm{e}=1 / 75.000]$

Zona 1_Bel

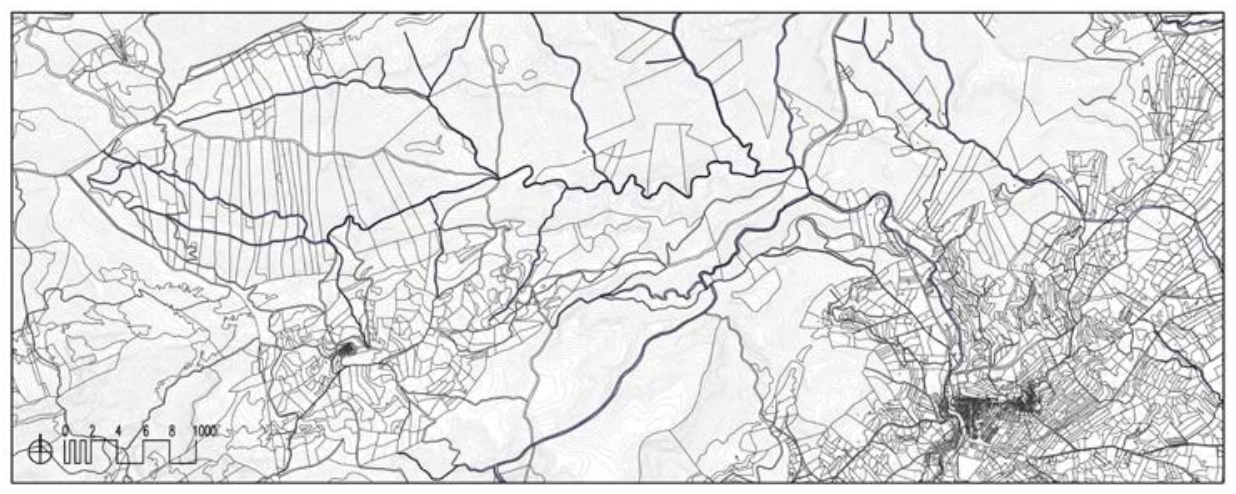

Zona 2_Barcella

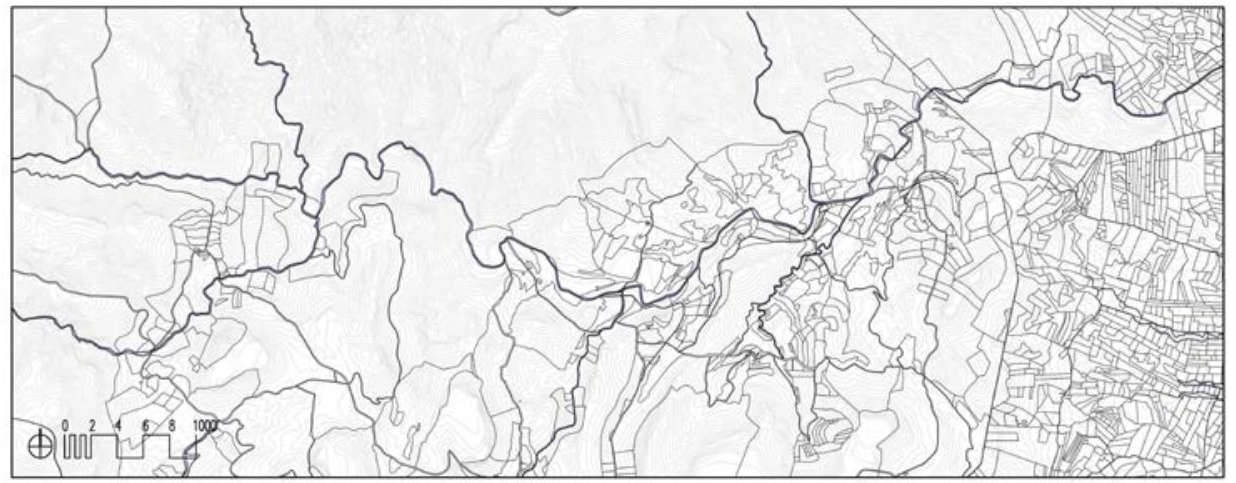

Zona 3_Molinar / Xert

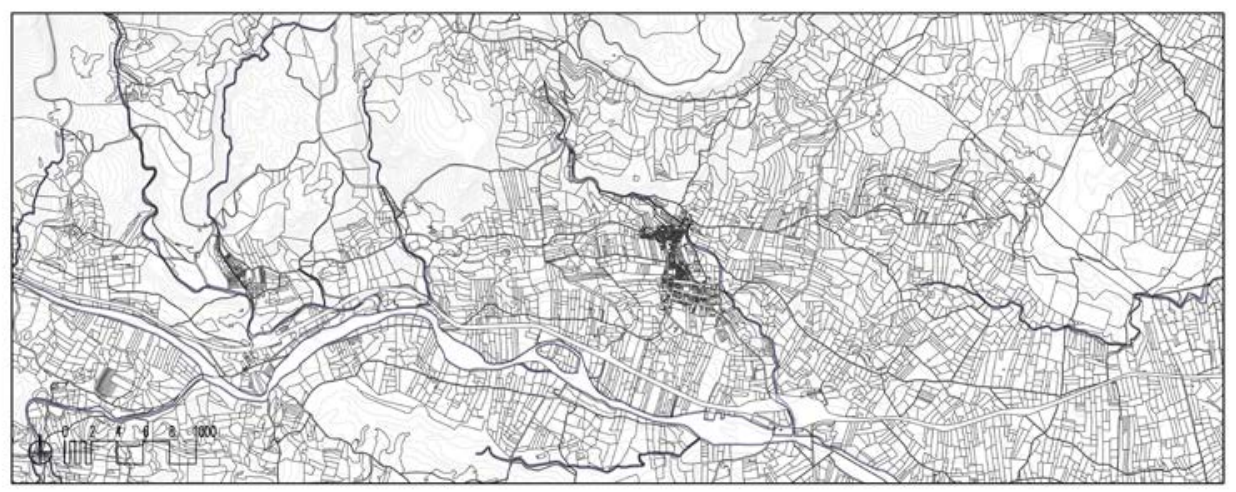

Zona 4_Mas del Coll / Rosell

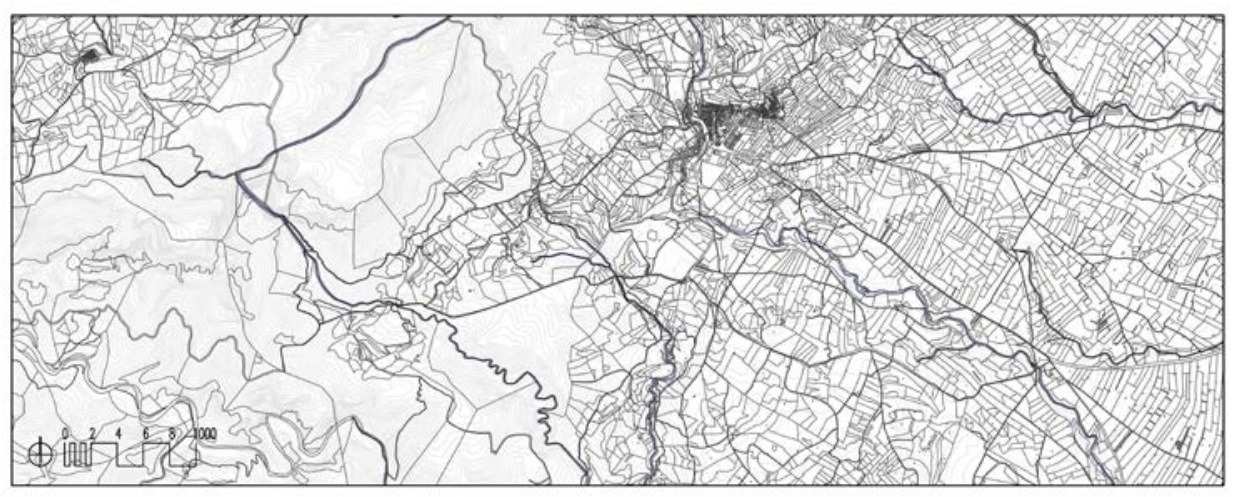




\section{Parcelario - Zonas 5-8 - $[\mathrm{e}=1 / 75.000]$}

\section{Zona 5_Canet}

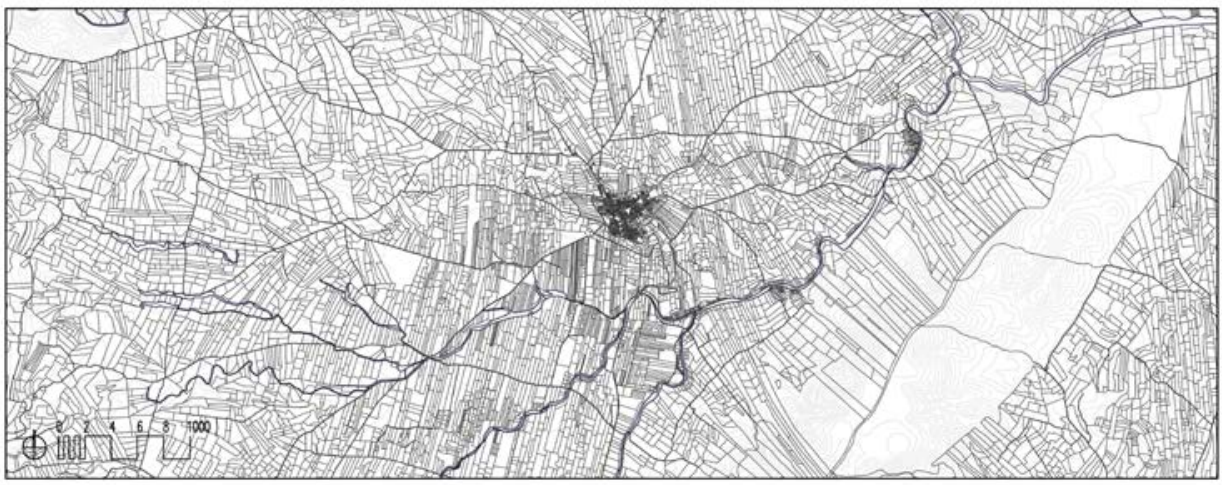

Zona 6_La Jana/Carrascal

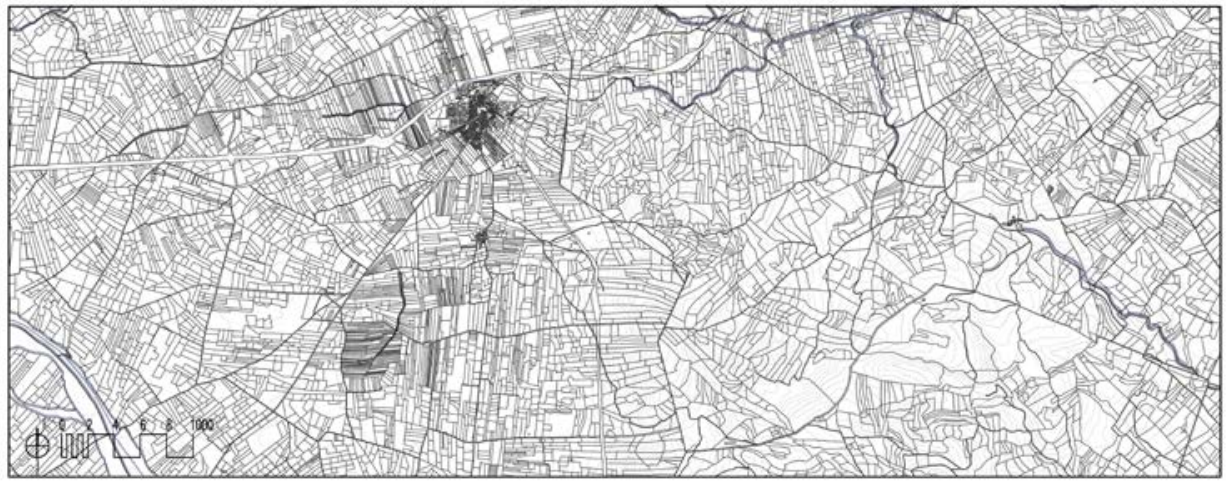

Zona 7_San Mateo

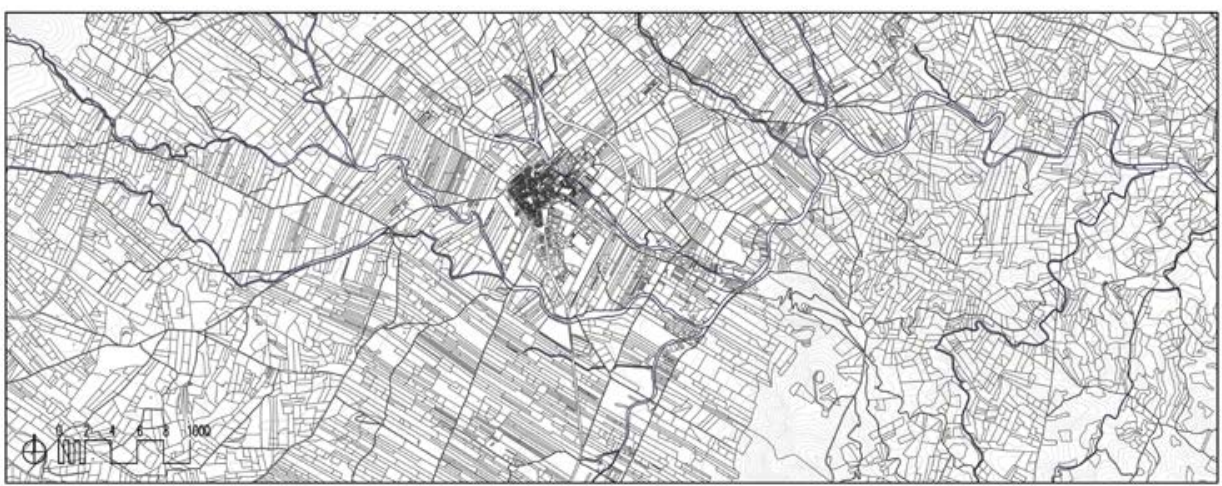

\section{Zona 8 Traiguera}

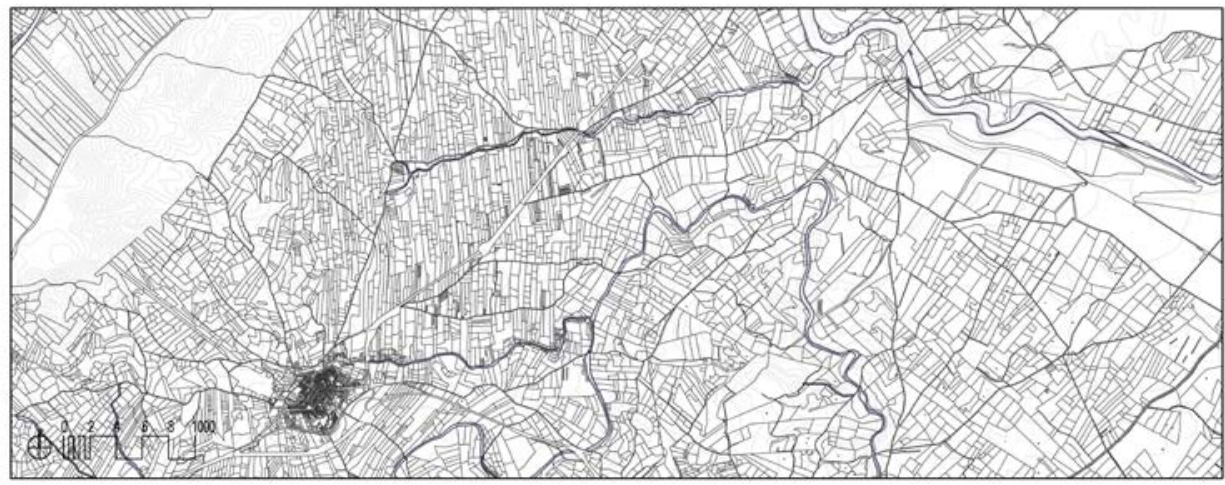


Parcelario - Zonas 9-12 - $[\mathrm{e}=1 / 75.000]$

Zona 9_Mas Stellers

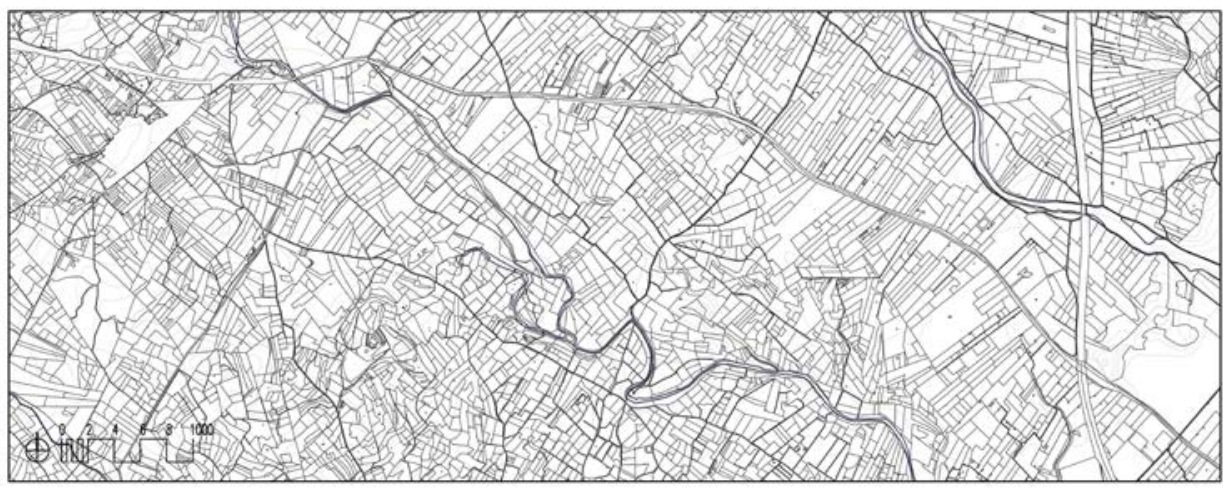

\section{Zona 10_Cervera / Calig}

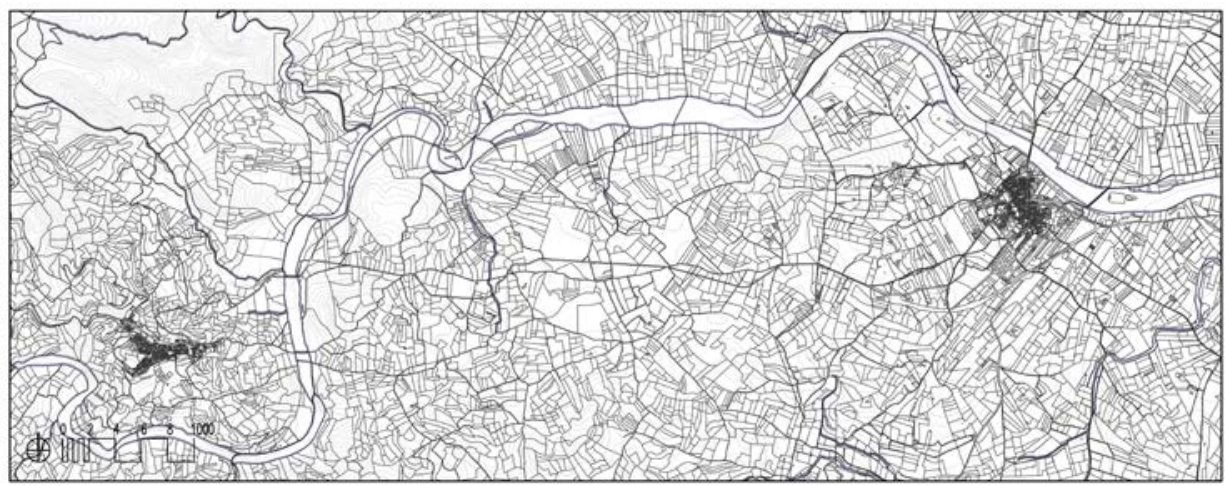

Zona 11_San Joan del Pas

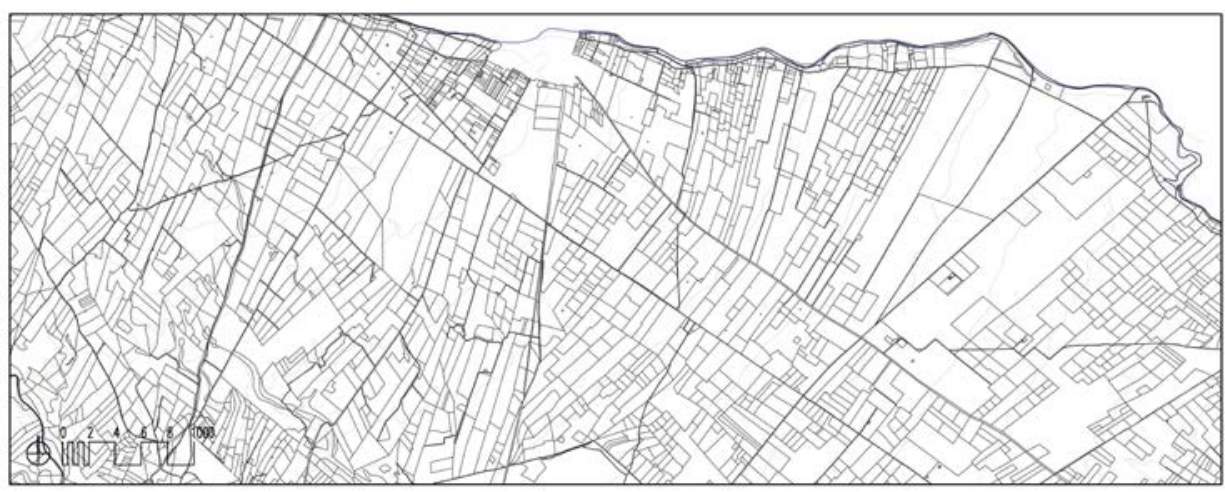

Zona 12_Atalaya San Pere

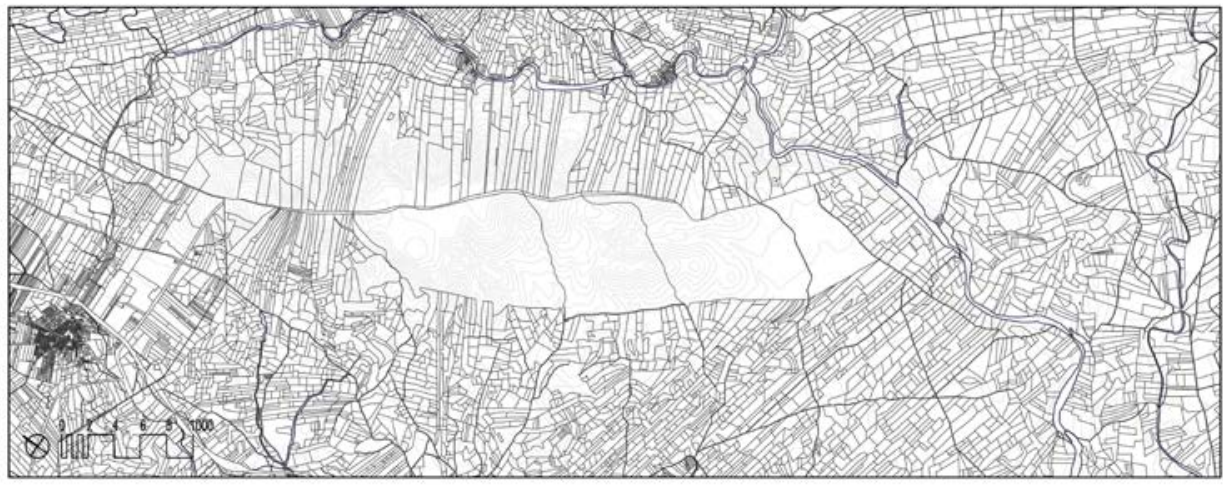


La lectura de los planos con el trazado de las parcelaciones en las doce zonas de estudio nos permite realizar una clasificación morfológica de las mismas, atendiendo a dos parámetros distintos: el cultivo y la forma de propiedad.

Las clases de las parcelas de cultivo son:

1. Parcelas de formas orgánicas y dimensiones variables situadas en los relieves de pendientes superiores al $15 \%$.

2. Parcelas de formas trapezoidales y dimensiones variables en las zonas de pendiente entre el $8 \%$ y el $15 \%$.

3. Parcelas rectangulares de dimensiones similares en los relieves de entre 3,5\% y $8 \%$.

4. Parcelas rectangulares, regulares y homogéneas en relieves de pendiente inferior al 3,5\%.

Las clases de parcelación de propiedad son:

1. Parcelas del reparto realizado a los vecinos de cada uno de los pueblos de la Batllia. Es suelo situado en el llano de una dimensión de 24 cafissadas $^{102}$ (12 ha, ver cartas puebla). Formas rectangulares y regulares.

2. Masías situadas en la montaña o en la ladera de la montaña y cedidas también en las cartas puebla. En muchos casos procedentes de anteriores propietarios árabes. Formas orgánicas y dimensiones muy variables.

3. Tierras comunales propiedad de las comunidades (Universidad), destinadas en su mayor parte a pastos ${ }^{103}$ o bosques. Muchos de ellos también proceden de anteriores propietarios musulmanes. Formas orgánicas y dimensiones muy variables.

4. Suelo que se reserva la Orden en un principio del Hospital y posteriormente de Montesa como de su propiedad ${ }^{104}$. Estas propiedades pueden ser de bosques, pastos o de cultivo que trabajan aparceros a su servicio.

Posteriormente haremos un análisis comparado de las clases de parcelación, de su ubicación, forma y densidad entre los doce ámbitos de estudio del que posteriormente extraeremos conclusiones.

En los recintos de montaña y de valle, nos encontramos con la clase de parcelación 1; en las laderas con las tres clases según como vamos descendiendo por ellas; en el suelo ondulado nos encontramos con la clase 1 y 2 mientras que en el llano nos encontramos con la clase 2 y 3 .

En definitiva se produce un dialogo parcela-relieve. El territorio es una sucesión de planos más o menos horizontales con distintas texturas y colores, creados por el hombre a partir de una serie de planos verticales de mampostería.

En la montaña el tejido es muy heterogéneo, existen diversas unidades de producción, gran parte del suelo es "natural" y las parcelas que se crean son muy orgánicos se adaptan al terreno tanto en sus pendientes como en el trazado de los muros que los configuran.

En la ladera se puede diferenciar dos zonas que divide el camino de en medio. De este hacia la parte llana es una parcelación continua y cada vez conforme nos vamos alejando más regular; mientras que del camino hacia arriba, la parcelación solo se produce junto a los barrancos, es orgánica e irregular, con la salvedad de pequeñas zonas de huerta junto a los manantiales o cenias.

102 Ver apéndice documental no 4 y 6 pág. 605 y pág. 607

103 Ver apéndice documental nº 9 pág. 610

104 Ver apéndice documental no 4, 5, 6 y 7 pág. 605, pág. 607, pág. 607 y pág. 609 
En el llano el tejido se hace más homogéneo. Las parcelas se hacen rectangulares y de dimensiones similares y cada vez más pequeñas, los cultivos son homogéneos. Las parcelas se ordenan a partir de la trama de caminos y cursos de agua formando cuadrículas más o menos regulares, a diferencia de las laderas en las que no se percibe un orden geométrico claro en la disposición de las parcelas y cultivos. En el valle se encuentra parcelada la parte baja, junto al río, mientras que las zonas altas tienen una parcelación de gran escala y amplitud.

En el territorio ondulado la parcelación se desarrolla con formas orgánicas "marcando" por las elevaciones de las montañas que lo configuran. En las zonas bajas la parcelación es de escala menor y regular mientras que en las zonas altas es más grande e irregular.

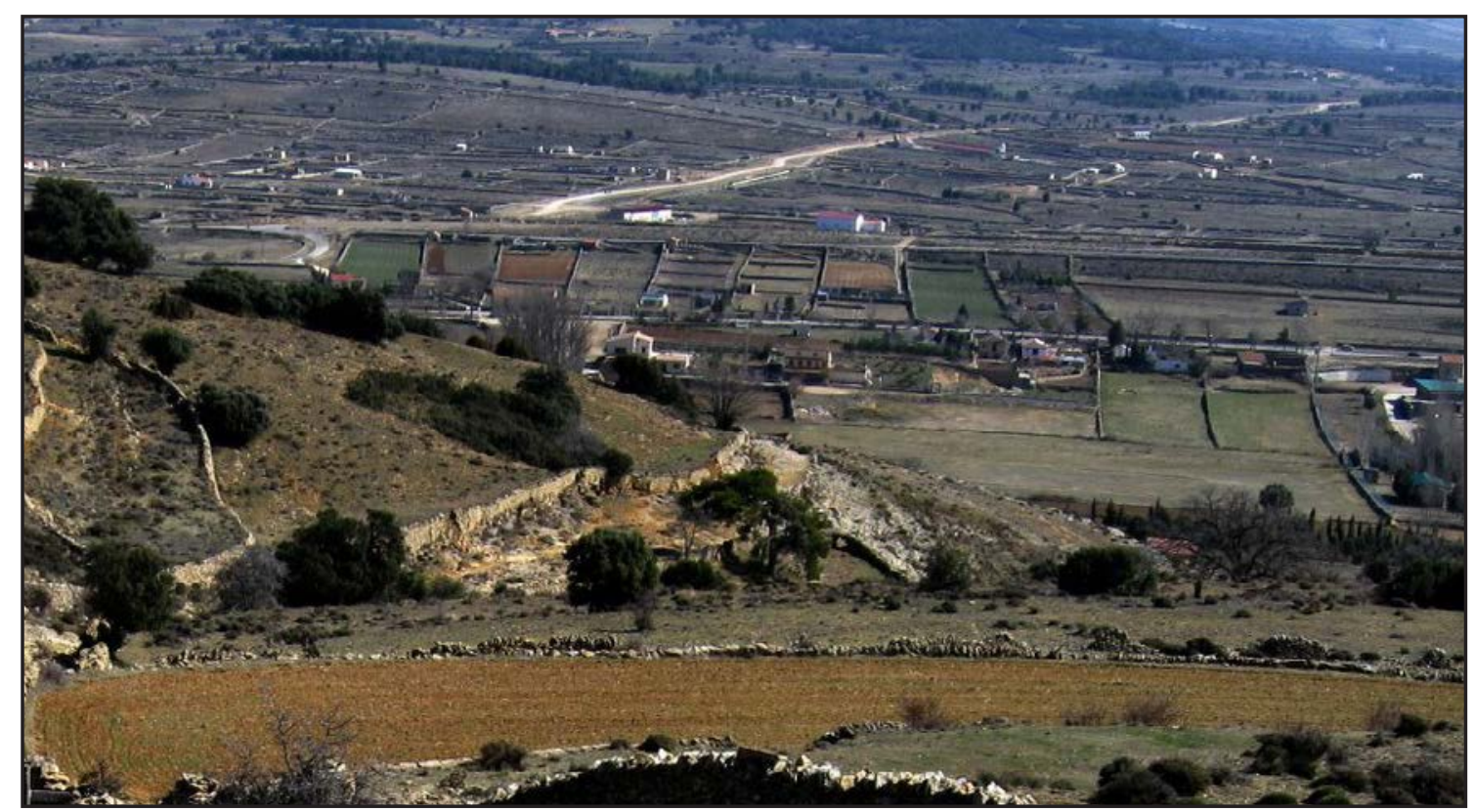

Fig. 4. 53. Vista de la parcelación con muros de piedra en seco en Villafranca. 


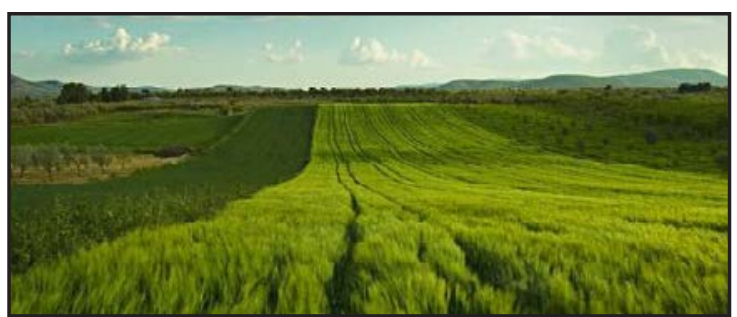

Fig. 4. 54. Vista de las tierras de cultivo en el llano de Sant Mateu junto a la laguna.
Los usos a través de los cultivos y la ganadería son los que adjetivan el territorio, distribuyéndose de forma heterogénea. Dan color, olor, sabor, luz y sonido al territorio, sin ellos seria monótono, uniforme, sin carácter, sin vida, parecería un paisaje lunar. Los usos complementan los volúmenes del relieve modelado y los planos de la parcelación.

El aprovechamiento del suelo es la consecuencia última del establecimiento. Usos, vegetales, tierras y aguas y arquitecturas construidas definirán finalmente el dominio, la forma del territorio que se juzga y disfruta. Los patrones que los usos y arquitecturas dibujan sobre el suelo de manera elemental resuelven el conflicto de apropiarse el perfil de la tierra aplicando una geometría que sigue la el relieve y manipula la forma del suelo, modificándolo o dando importancia al orden de construcción del nuevo uso, llegando a sustituir lo que el relieve propone, apoyándose entonces en la jerarquía que la red impone y creando espacios con una forma y una jerarquía interior independiente.

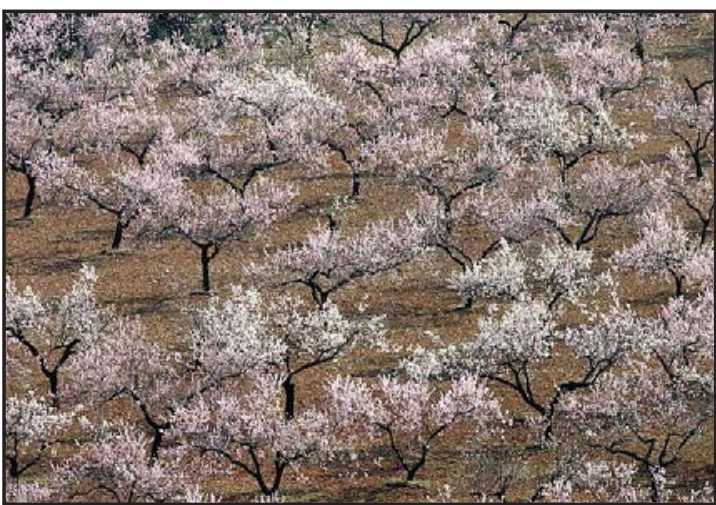

Fig. 4. 55. Vista campos de almendros en la Batllia.

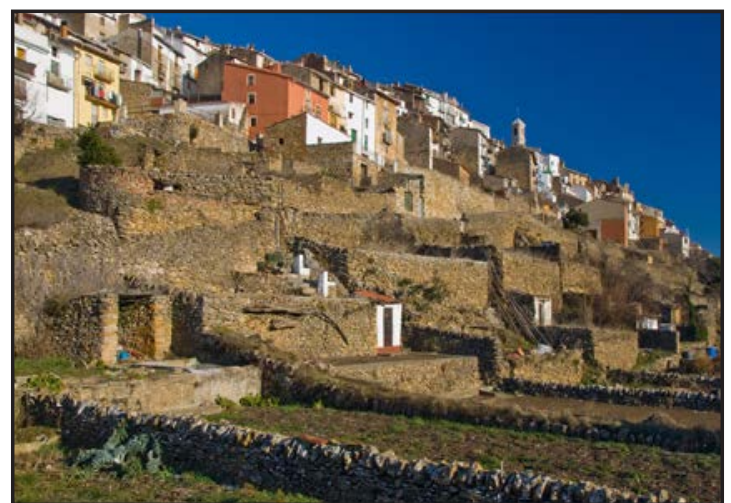

Fig. 4. 56. Vista de huertos o "freginales", junto a un núcleo urbano en Els Ports.

Los distintos tipos de usos son los que permiten adjetivar el territorio, creando un puzzle de colores, olores, luces y sonidos que varían con el día y con la época del año. Esta variación en el tiempo les hace imprescindibles en una época sin relojes para medir el tiempo. Las labores agrícolas marcan el calendario de estos hombres. Ello hace que todos estos usos son los que permiten al hombre habitar el territorio. Se trata de una habitabilidad táctil. ${ }^{105}$

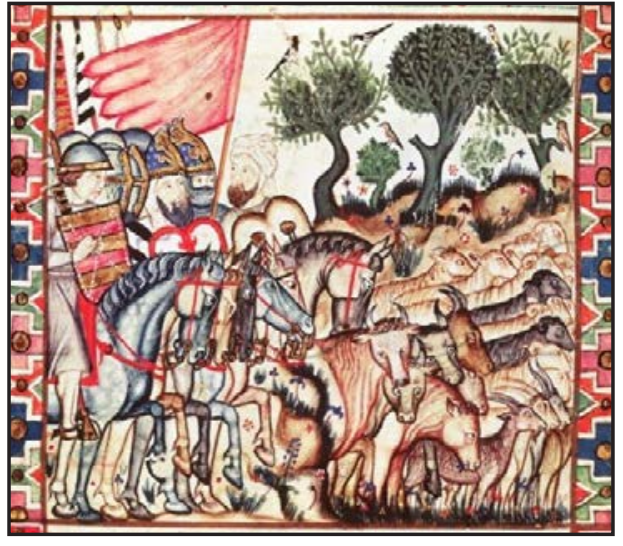

Fig. 4. 57. Miniatura Cantiga 46 (panel 2) s. XII.

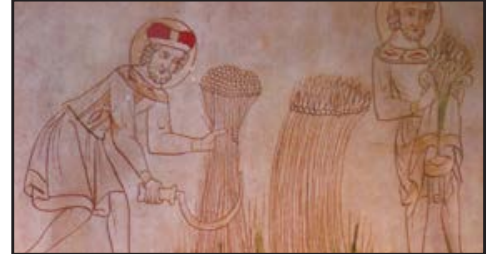

Fig. 4. 58. Miniatura que representa la siega.

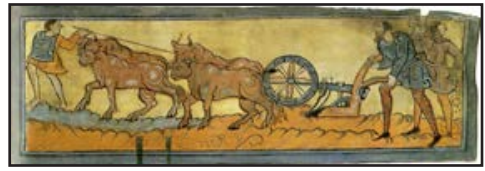

Fig. 4.59. Miniatura del calendario (l'aratura), 1000 circa. Tiberius B.V., Londra, British Library.

105 Ver apéndice documental no 16 pág. 615 
Hemos realizado un vaciado bibliográfico para poder relacionar, localizar y posteriormente grafiar todos los elementos del territorio que aparecen documentados como existentes en la época de estudio. Las fuentes de la documentación son:

- Cartas pueblas de las distintas poblaciones.

- El llibre del Repartiment.

- Las crónicas de Jaime I.

- Crónicas de historiadores o viajeros árabes o cristianos anteriores a la conquista.

- Documento sobre el "Estado de cuentas" de la Batllia de Cervera en el momento de la creación de la Orden de Montesa.

- Documentos de las cuentas de la Orden de Montesa durante el periodo en el que controló este territorio.

- Documentos notariales, judiciales o del obispado de Tortosa de la época.

- Excavaciones arqueológicas llevadas a cabo.

- Análisis arquitectónico-constructivo de los elementos.

La bibliografía consultada que recoge dichas fuentes de documentación y en la que hemos "localizado" dichos elementos se relaciona en el Anexo I.

La relación que adjuntamos en el Anexo II viene ordenada por los términos de las distintas poblaciones de la época. En cada uno de ellos se indica la fuente o fuentes documentales en las que aparece citada, la bibliografía que la cita, la persistencia o no de tal elemento, la ubicación del mismo y la persistencia del nombre o el cambio del mismo. Así mismo relacionamos los elementos genéricos que sin tener una localización geográfica concreta nos definen el carácter del territorio de la época de estudio.

La relación adjunta consta de 342 elementos de los cuales 203 podemos localizar hoy en día en una ubicación concreta. Con ella hemos confeccionado los planos en los que se grafía los cultivos y usos de la Batllia de Cervera en la Edad Media, lo cual nos da una idea global del territorio en esa época. ${ }^{106}$

La lectura de los planos con los cultivos y usos en las doce zonas en la época del estudio nos permite realizar la siguiente clasificación:

- Zona de bosques dedicada a la caza y al aprovechamiento de la leña y de la madera.

- Zona de pastos de vegetación mediterránea.

- Zona de terrenos yermos de nulo aprovechamiento agrícola o ganadero.

- Zona de cultivo de cereales.

- Zona de cultivo de vid.

- Zona de cultivo de olivo.

- Zona de huerta (frutales y hortalizas).

- Zona de forraje de animales.

106 Nota importante: En la documentación medieval no aparecen todos los elementos existentes, solo aquellas que controlaba el poder feudal, las propiedades francas no se encuentran en dicha documentación. Esta solo aparece en los protocolos notariales, de los que quedan muy pocos. 
Mapa general (situación de las zonas de estudio) - $[e=1 / 200.000]$

\section{Topográfico base + usos}

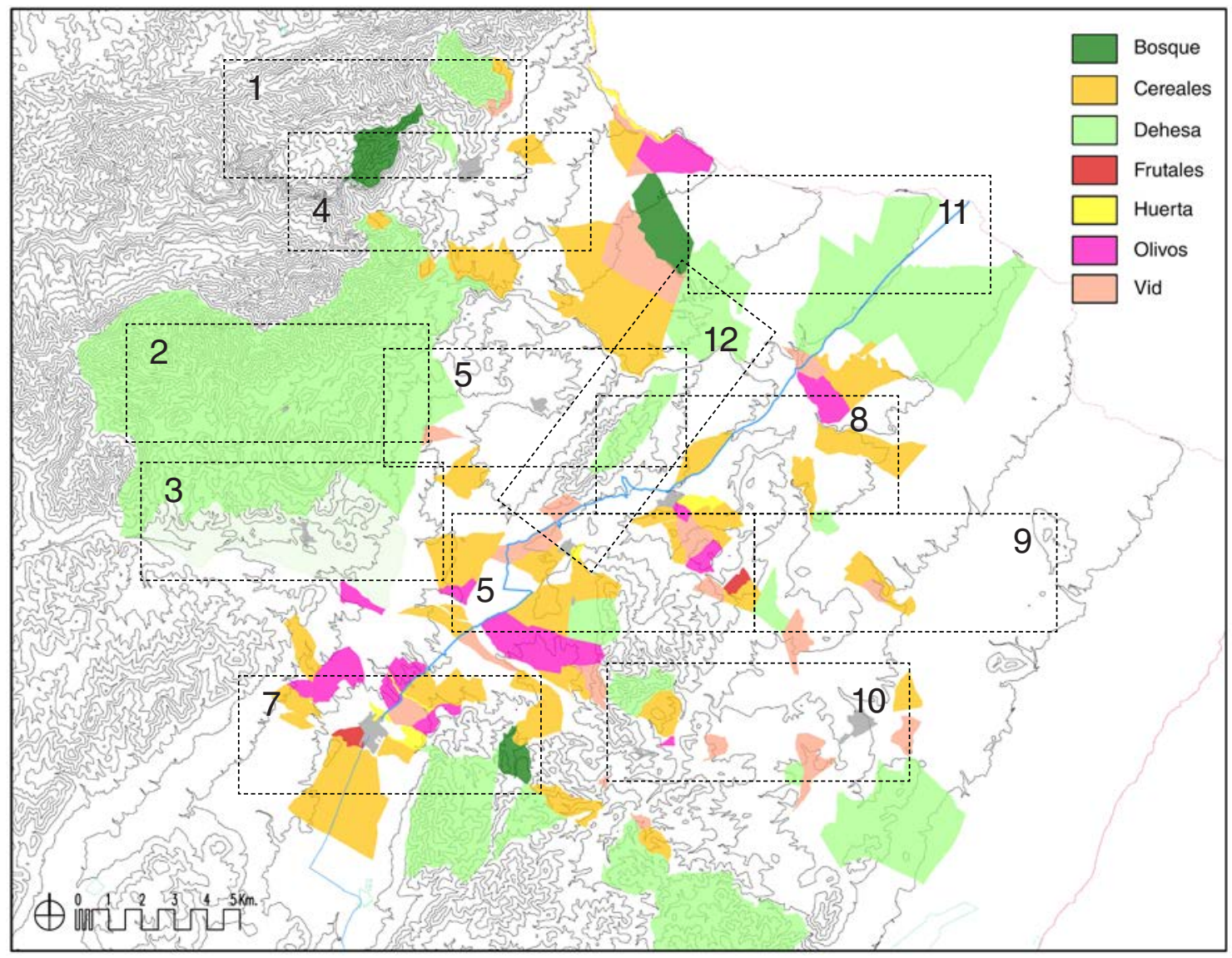

Fig. 4. 60. Plano de la Batllia a escala 1/200.000 del topográfico con los con los usos (cultivos). Señalización 12 zonas de estudio. 
Topográfico base + usos - Zonas 1-4 - $[\mathrm{e}=1 / 75.000]$

Zona 1_Bel

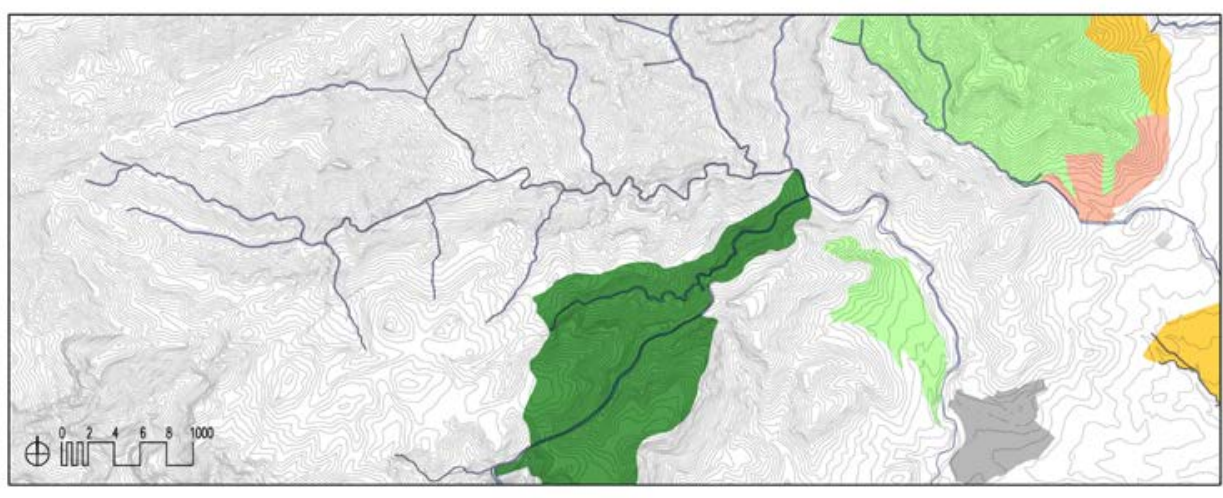

Zona 2 Barcella

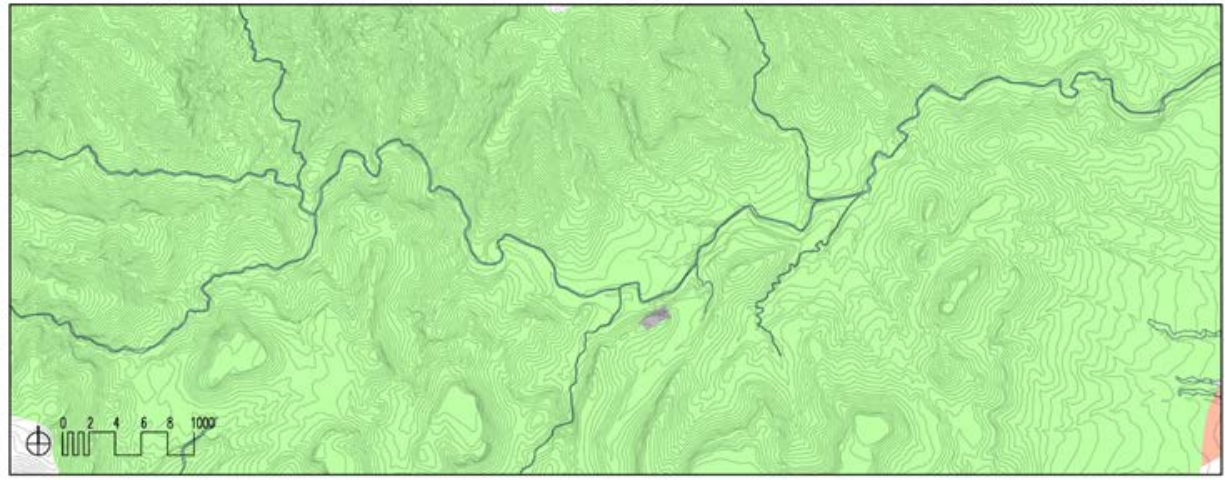

\section{Zona 3_Molinar/Xert}

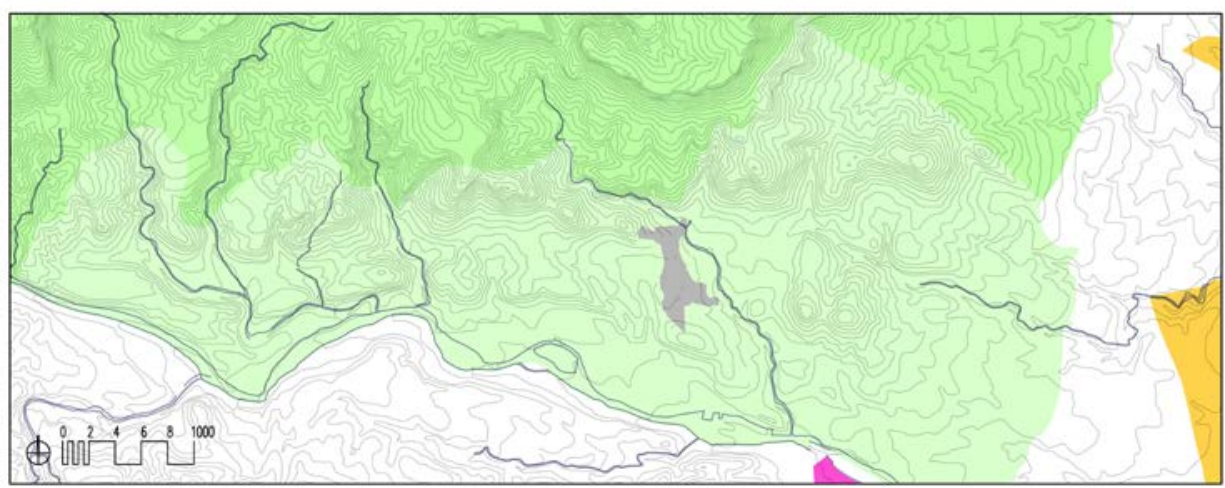

\section{Zona 4 Mas del Coll / Rosell}

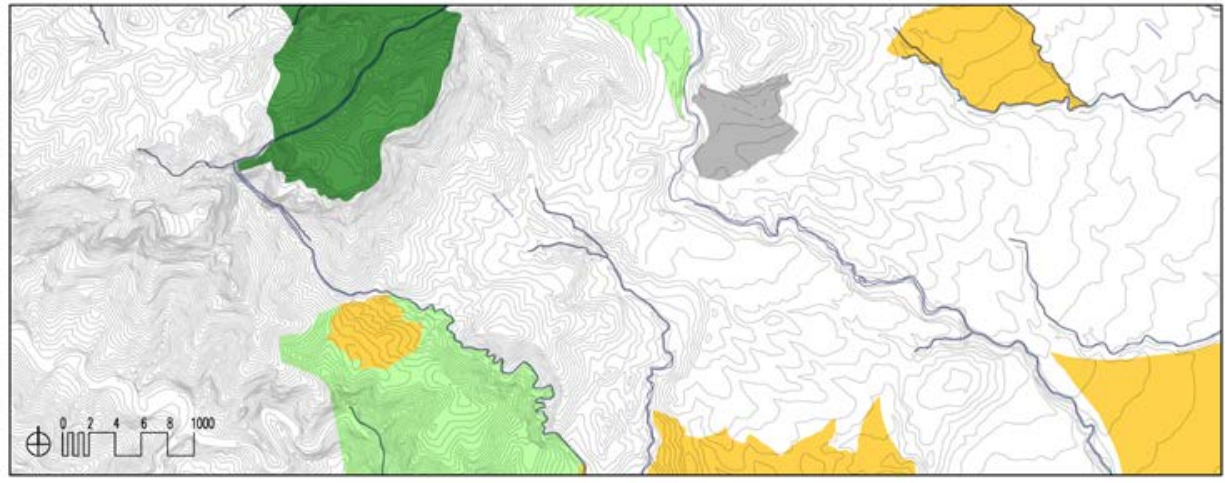


Topográfico base + usos - Zonas 5-8 - [e=1/75.000]

\section{Zona 5_Canet}

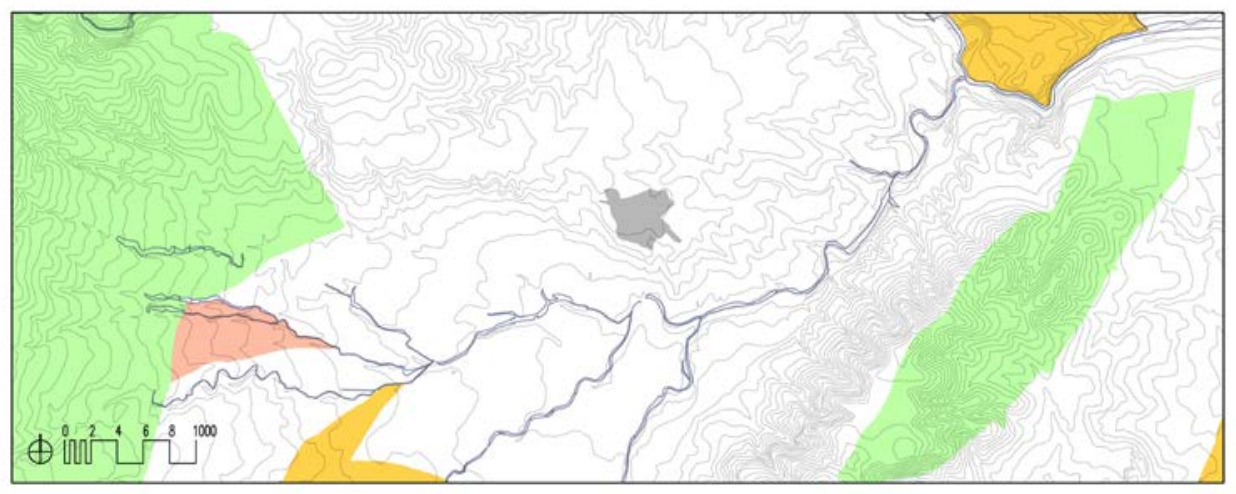

\section{Zona 6 La Jana/Carrascal}

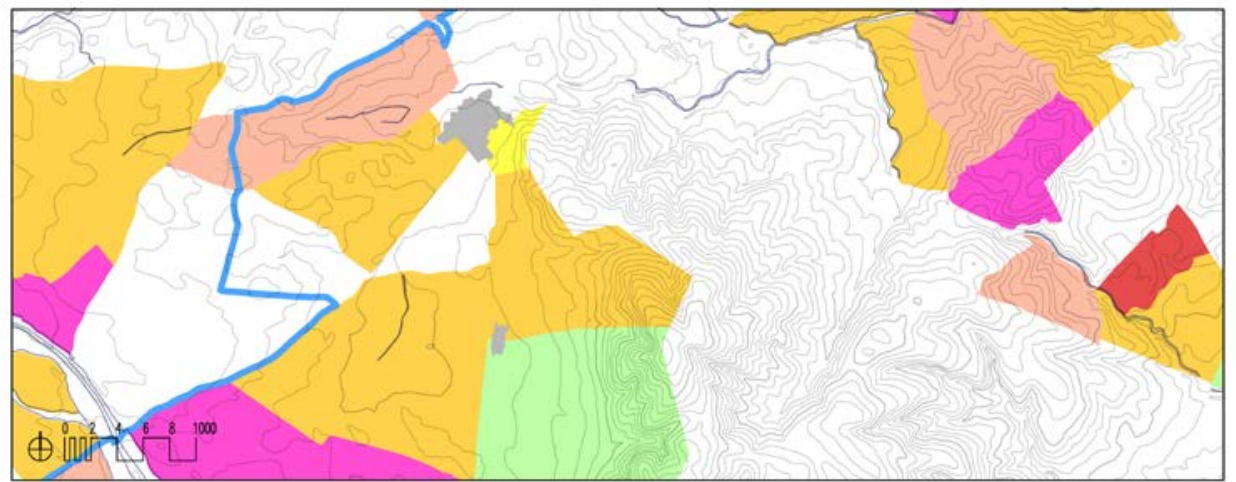

\section{Zona 7_San Mateo}

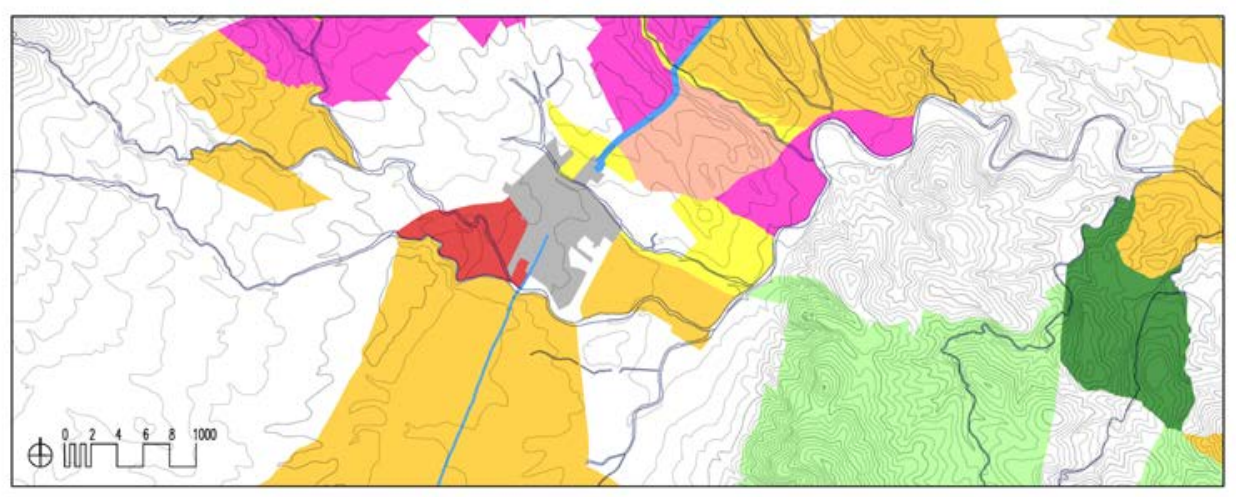

\section{Zona 8_Traiguera}

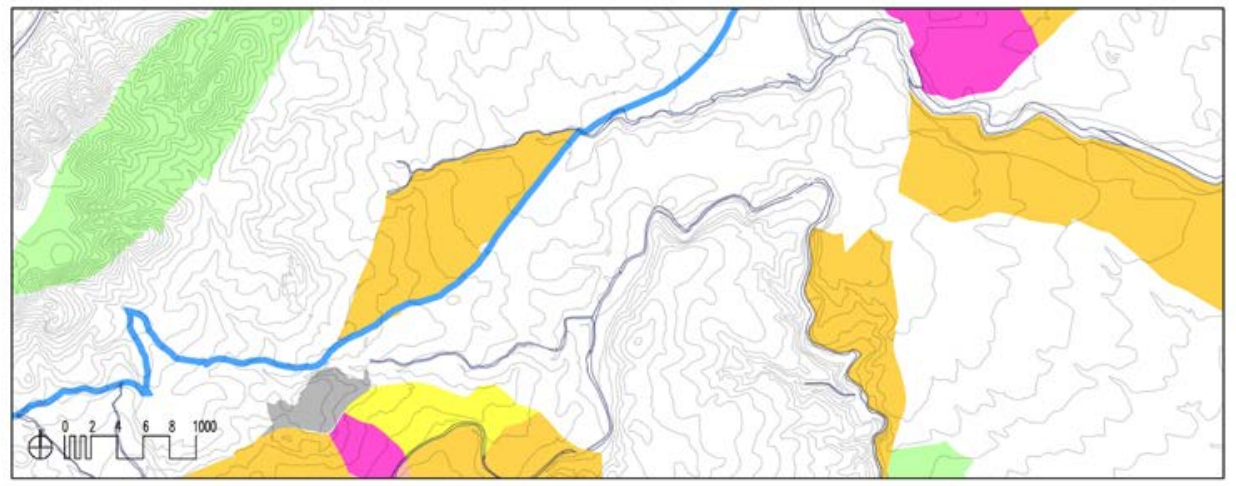


Topográfico base + usos - Zonas 9-12 - $[\mathrm{e}=1 / 75.000]$

Zona 9_Mas Stellers

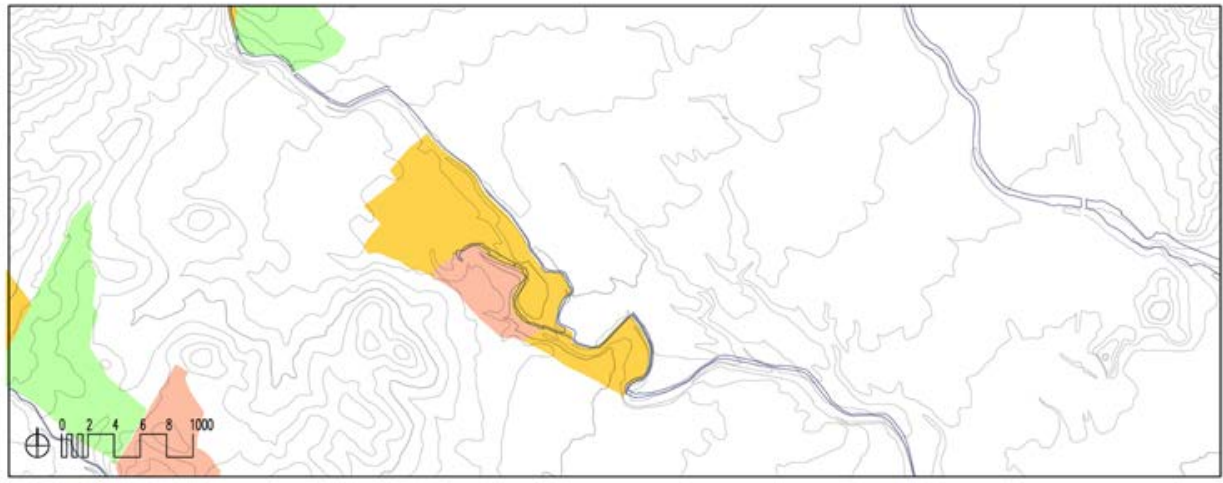

Zona 10_Cervera / Calig

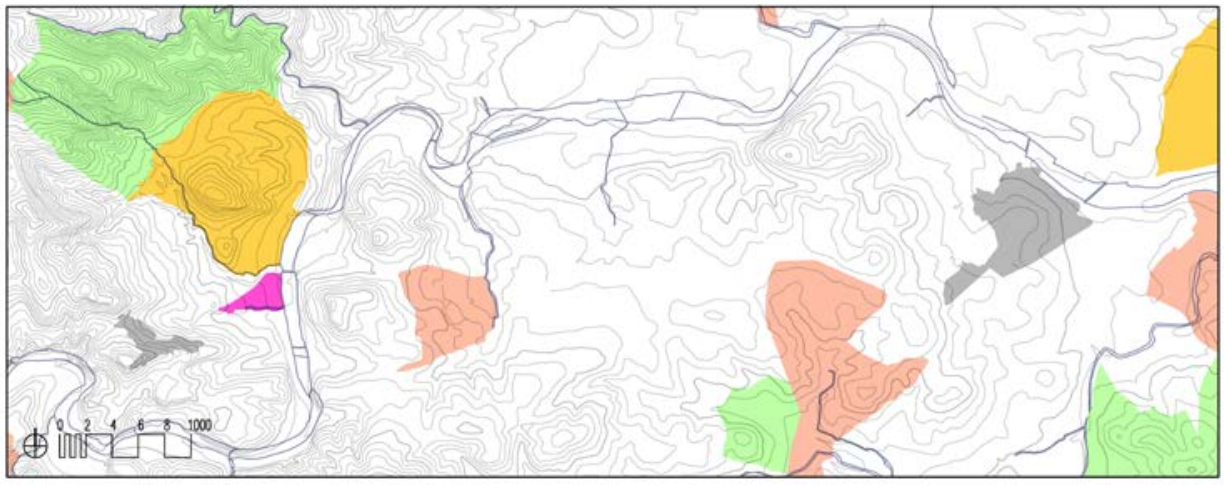

Zona 11_San Joan del Pas

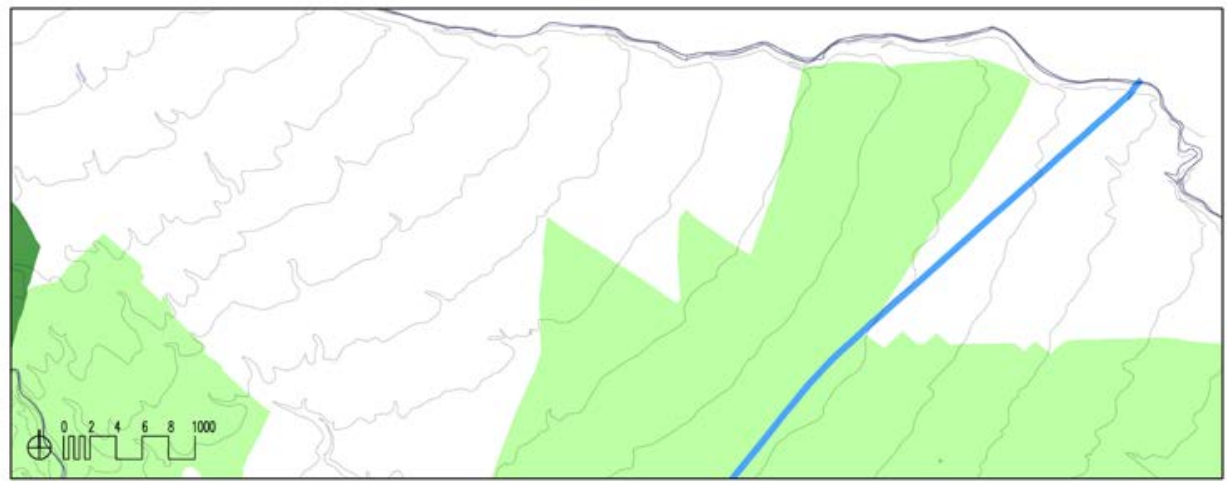

Zona 12_Atalaya San Pere

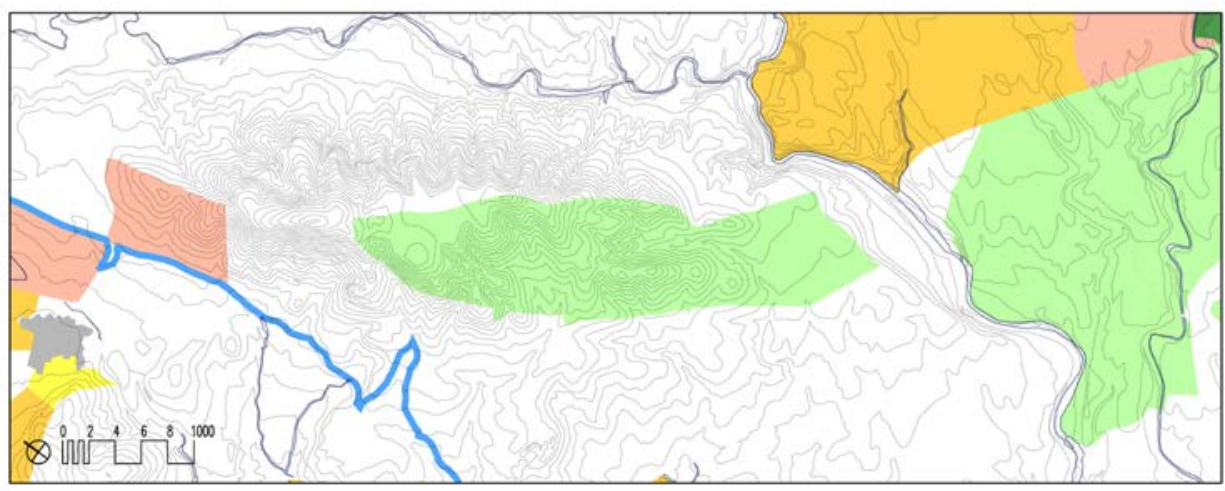


Posteriormente hacemos un análisis comparado de las clases de cultivos, de su ubicación, forma y densidad entre los doce ámbitos de estudio del que posteriormente extraeremos conclusiones:

- En la montaña existen zonas de bosques, pastos y yermos; solo hay una limitada zona de cultivos de cereal en los alrededores de las masías y de los núcleos urbanos.

- En los valles existen bosques, y pastos en las zonas altas. Zonas limitadas de cultivo de cereales, vid, olivo y huertas junto a las masías y núcleos urbanos.

- En las laderas existen zonas de bosques y pastos en la zona alta y zonas de cultivo en la parte baja, las zonas de huerta se limitan al entorno de las masías y núcleos urbanos.

- En el llano esta prácticamente ocupado por los cultivos, fundamentalmente de cereales, y solo junto a los núcleos urbanos hay huertas y otro tipo de cultivos. Existe una excepción singular que es el territorio entre el río Cervol y el río Cenia que esta destinado exclusivamente a pastos.

- En el ondulado es similar al llano, pero con un menor porcentaje de cereales y en las zonas altas parte de los terrenos están destinados a pastos.

- Se puede observar que existe una mayor fragmentación del suelo en las proximidades de los núcleos urbanos. Conforme nos alejamos de los núcleos la parcelación se hace de mayores dimensiones y menos regular. 


\section{Las arquitecturas}

La especie humana se caracteriza por vivir en común, el ser-con de Heidegger y sus correspondientes instituciones humanas. Desde las viejas culturas de cazadores de la Edad de Piedra los grupos humanos se unen, comparten y viven en común.

Los miembros de la sociedad primaria y primitiva no necesitan valla alguna, que los cerque y reúna, para constituir su relación fuerte recíproca. Cualquier grupo-nosotros, incluso sin sólidos refuerzos arquitectónicos, sabe cobijarse en una figura insinuada y por una especie de tensión centrípeta, instalarse en una forma de totalidad integradora.

El proyecto inmediato de cualquier sociedad es la continuidad del auto cobijo del grupo, de su envoltura morfológica: todas las sociedades son proyectos esferopoiéticos. Las gentes que viven en común, sus relaciones internas poseen una preeminencia absoluta sobre las relaciones externas con el entorno.

Se trata siempre de creaciones físicas y mentales de espacio interior, de cavernas. Por ello toda sociedad es un proyecto uterotécnico, es una zona cercada, autoprotegida, autocobijante, autoclimatizada y autoarrendondada.

La imagen de la caverna en todas las culturas ha estado relacionada con la del útero materno, y por tanto como receptáculo y fuente de energía vital. De lugar en el que protegerse de las inclemencias del tiempo y de los peligros, almacenar los alimentos necesarios para subsistir y convivir con el grupo. Esa clara relación entre la imagen de la caverna y la del útero materno la podemos observar a través de la imagen de "kongdong"-la caverna del vacío primordial a partir del cual surge la manifestación de todos los seres-. En la china existen diversos ideogramas para designar la caverna, uno de ellos es el "Xue". Se trata de un término muy utilizado tanto en los "feng shui" 107 como en la medicina china, y hace mención a los puntos, a los lugares tanto del cuerpo humano como del territorio en donde la energía está concentrada en grandes proporciones. Es el centro neurálgico donde se desarrolla la vida.

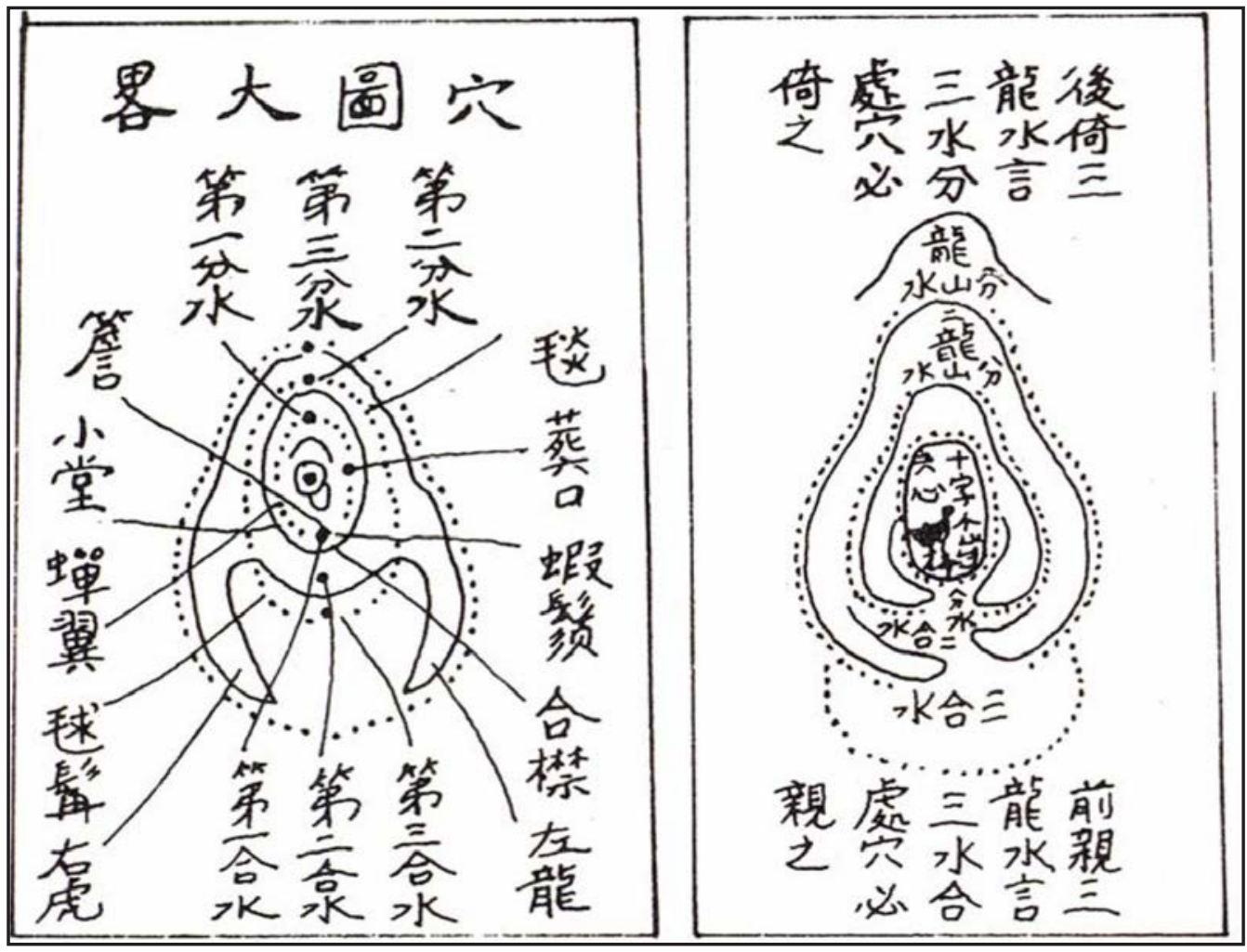

Fig. 4. 61. Mapas de Feng shui que señalan el punto Xue.

107 El feng shui es una forma de geomancia desarrollada en china, estudia los cambios que ocurren en la naturaleza, el clima y los astros, utilizando la doctrina taoísta. 
El ser humano es el animal que, junto con su otro esencial, crea endosferas en casi o cualquier situación, porque sigue marcado por el recuerdo de otro haber-sido-o-estado-dentro y por la anticipación de una última envoltura. Él es el ser vivo que nace y muere, que tiene un interior porque cambia de interior. En cualquier lugar del ser humano actúan tensiones de mudanza: por este motivo, su historia es siempre y en todas partes historia de paredes y de la metamorfosis de estas.

El ser humano necesita para cobijarse una envoltura viva protectora -una esfera- similar a la del amnios o membrana extraembrionaria que cobija al feto en el receptáculo de la bolsa amniótica.

Esta esfera se amplia y modifica posteriormente con la creación de una cubierta protectora que adquiere una forma redonda que por su propia nitidez reafirma la condición compacta de lo que está dentro.

Cuando más riesgo hay más necesidad hay de cobijarse, de construir espacios protegidos, almacenes tanto de recuerdos como de alimentos para tiempos de prueba. Para soportar malas cosechas, sequías, ataques de otros grupos humanos y situaciones erróneas en la vida hay que almacenar grano, agua y recuerdos de integridad. Para ello son necesarios edificaciones-receptáculo, que protejan al grupo y le permitan subsistir a esas situaciones; las paredes hechas con materiales inertes, crean espacios con vida.

En la península ibérica y unos 2000 años antes de Cristo encontramos arquitecturas con la imagen de la caverna y del útero materno. Las "motillas"108 son fortificaciones de la edad del bronce de un diámetro de unos 40 metros que esta integrado por una torre, varias líneas concéntricas de murallas, un gran patio y un gran pozo que llega al nivel freático. A su interior se accede mediante rampas embutidas en estrechos pasillos que van dando accesos a distintos espacios de almacenaje de alimentos en grandes vasijas, de hornos para la cocción de los alimentos y a zonas para la estabulación de los animales.

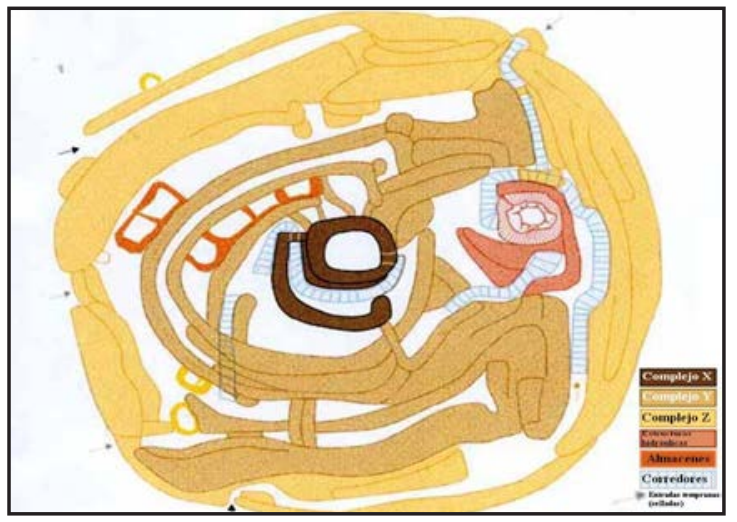

Fig. 4. 62. Croquis Motilla del Azuer en Daimiel, por T. Nájera y F. Molina.

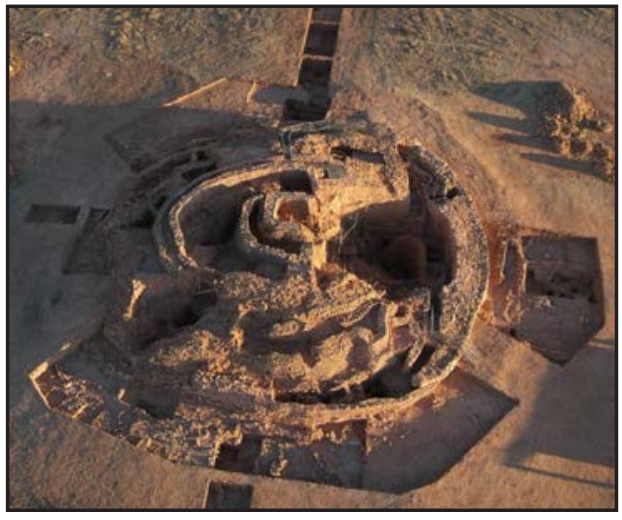

Fig. 4. 63. Vista aérea de las excavaciones arqueológicas en la Motilla del Azuer.

108 La Motilla del Azuer es un yacimiento prehistórico de la Edad del Bronce, situado en España, en el municipio manchego de Daimiel, en la provincia de Ciudad Real. Fue declarado bien de interés cultural en la categoría de zona arqueológica el 20 de junio de 2013. La publicación del acuerdo de aprobación se produjo el 03 de julio de 2013 en el Diario Oficial de Castilla-La Mancha.

Los yacimientos arqueológicos que se conocen con el topónimo de motillas representan uno de los tipos más singular de asentamiento prehistórico de la península Ibérica. Ocupan la región de La Mancha durante la Edad del Bronce entre el 2200 y el 1500 a. C. Se trata de montículos artificiales, de entre 4 a $10 \mathrm{~m}$ de altura, resultado de la destrucción de una fortificación de planta central con varias líneas amuralladas concéntricas. Su distribución en la llanura manchega, con equidistancias de 4 a 5 kilómetros, afecta a las vegas de los ríos y las zonas deprimidas dónde hasta momentos recientes era frecuente la existencia de lagunas y áreas palustres. Las especiales características de este yacimiento, así como la monumentalidad de las estructuras de su fortificación, con muros de mampostería que conservan más de 8 metros de alzado, confieren al asentamiento del Azuer un carácter relevante dentro de la Edad del Bronce de la península Ibérica.

Durante la Edad del Bronce estos asentamientos fortificados ejercieron una importante función de gestión y control de recursos económicos. En el interior de sus recintos fortificados se protegían recursos básicos como el agua, captada del nivel freático mediante un pozo, y se realizaba el almacenamiento y procesado de cereales a gran escala, la estabulación ocasional de ganado y la producción de cerámica y otros productos artesanales. 


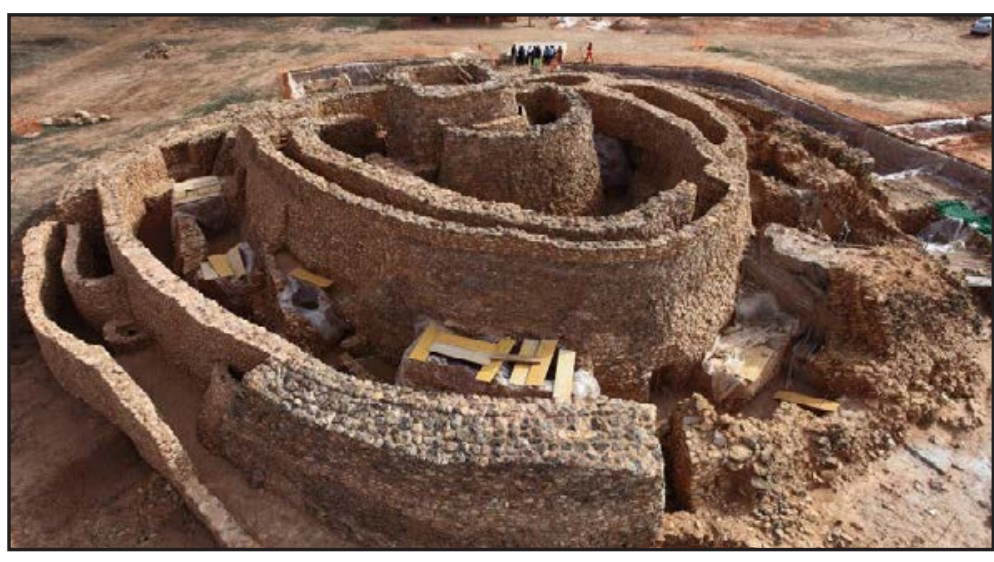

Fig. 4. 64. Vista exterior de la Motilla del Azuer.

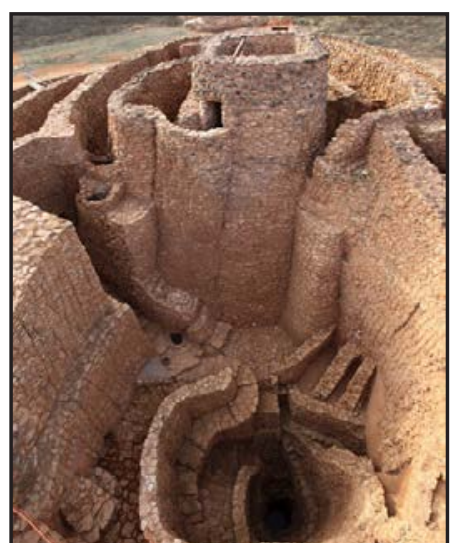

Fig. 4. 65. Vista del interior de la Motilla del Azuer.

No podemos menos que comparar las imágenes de estas "cavernas" con las de un pequeño ser vivo: los protozoos ${ }^{109}$. Son animales unicelulares pero funcionalmente son organismos complejos que desarrollan todas las funciones esenciales de los animales superiores. Se desplazan, se alimentan de elementos de su entorno, los almacenan, los digieren y posteriormente aprovechan parte de la energía para vivir y el resto lo excretan. Por último crecen y se reproducen.

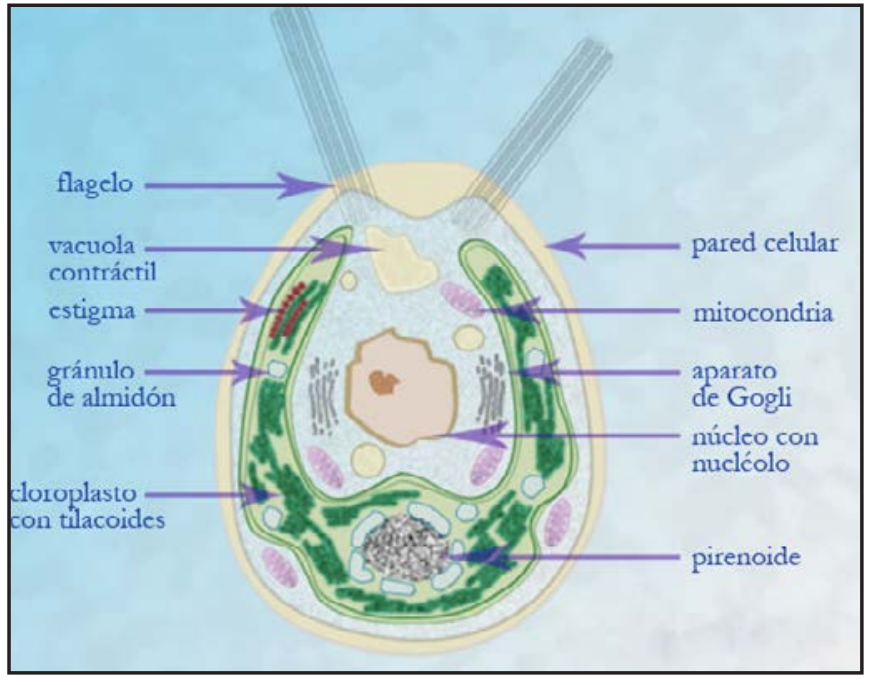

Fig. 4. 66. Dibujo de las partes de un protozoo.

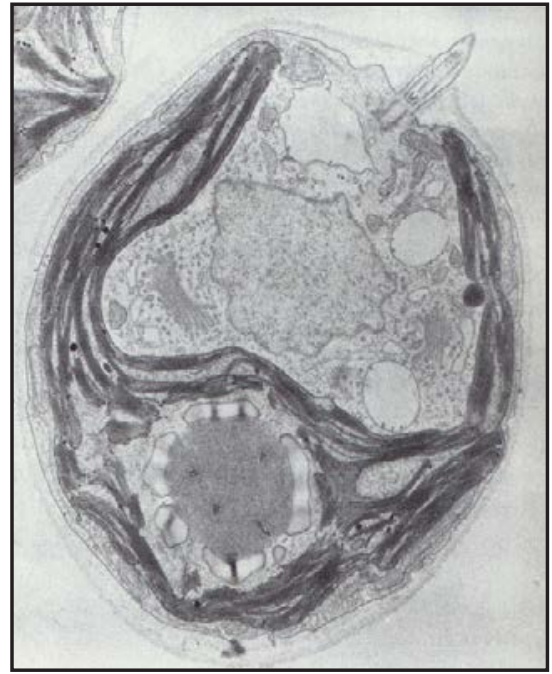

Fig. 4. 67. Foto al microscopio de un protozoo. Obsérvense las coincidencias formales con la Motilla de Azuer.

109 Del griego protos, primero y zoon, animal; son en su mayor parte animales unicelulares de tamaño microscópico. Constituyen el más inferior de todos los grades grupos o tipos del Reino animal que se diferencian de todos los demás, que son pluricelulares y que están formados por tejidos y se les llama Metazoos (del griego meta, después).

Por su estructura los protozoos se parecen a una célula de los Metazoos, pero funcionalmente son organismos completos, equilibrados fisiológicamente y realizan todas las funciones esenciales de un animal.

Algunos son de estructura muy simple y otros complejos, con orgánulos (celulares) que sirven para determinados procesos vitales y funcionalmente son análogos a los sistemas de órganos de los animales pluricelulares.

Se conocen 30000 protozoos diferentes, y el numero de individuos es superior al de todos los demás animales. Cada especie vive en un ambiente húmedo particular: en el agua de mar o en el fondo del océano, en tierra, en las aguas dulces, salobres o corrompidas; en el suelo o en la sustancia orgánica en descomposición. 


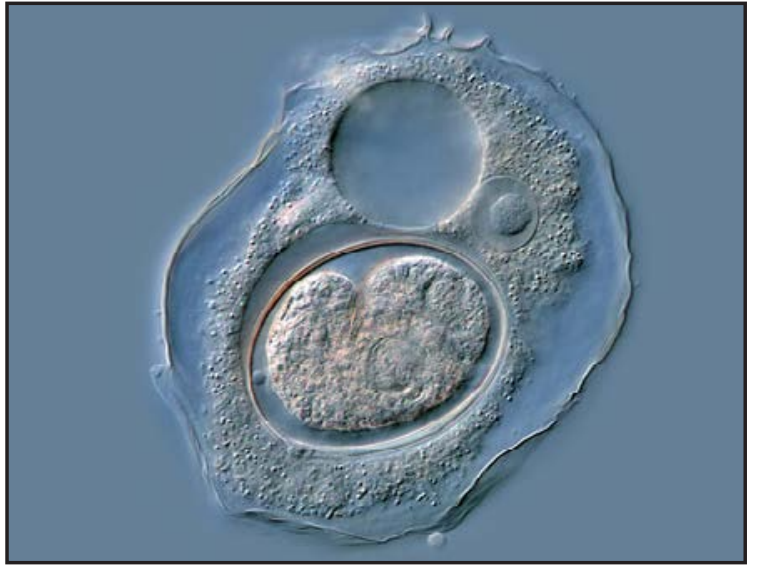

Fig. 4. 68. Foto al microscopio de una ameba.

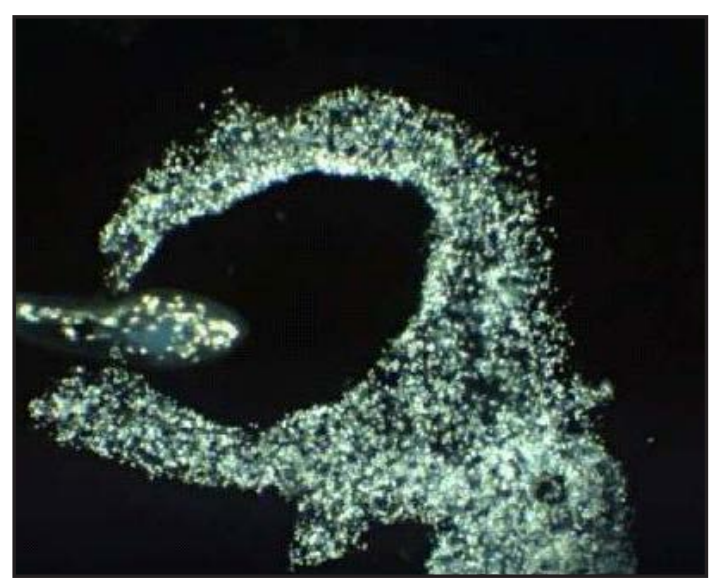

Fig. 4. 69. Foto al microscopio de una ameba comiendo.

La casa fue durante milenios la idea de espacio más importante de la humanidad, representa la figura más eficiente después del modo de convivir los seres humanos en autocobijos sin paredes.

Las reflexiones de Vitruvio al comienzo de su De Archietctura que dedica al origen de la construcción son elocuentes. Los primeros constructores de casas manifestaban una conciencia de la dificultad de concebir el tránsito de las formas de cobijo y sin paredes a aquellas caseras y entre paredes. Vitruvio afirma que el fuego salvaje estaría en el comienzo de las reuniones humanas y que la protección y conservación del fuego habría dado el impulso definitivo a la praxis arquitectónica de los seres humanos.

Para él la construcción sigue una fuerza centrípeta -el fuego- que produce primero la reunión de los seres humanos, para despertar después en los ya reunidos la necesidad de cobijo que se materializa en la casa. El calor se irradia de forma circular y alrededor de él el grupo se comunica y se alimenta. Esta atmósfera interior, implica cualidades miméticas del útero y de su sensación protectora.

Estas arquitecturas -a las que Peter Sloterdijk denomina esferas- veremos que se convierten en centros respecto al que se organiza la vida de la sociedad humana. Son las "células" que permiten el crecimiento del territorio; son los organismos que permiten el desarrollo del territorio utilizando la energía de su entorno.

Hemos realizado un vaciado bibliográfico para poder relacionar, localizar y posteriormente grafiar todas las arquitecturas que aparecen documentadas como existentes en la época de estudio.

Las fuentes de la documentación son:

- Cartas pueblas de las distintas poblaciones.

- El llibre del Repartiment.

- Las crónicas de Jaime I.

- Crónicas de historiadores o viajeros árabes o cristianos anteriores a la conquista.

- Documento sobre el "Estado de cuentas" de la Batllia de Cervera en el momento de la creación de la Orden de Montesa.

- Documentos de las cuentas de la Orden de Montesa durante el periodo en el que controlo este territorio.

- Documentos notariales, judiciales o del obispado de Tortosa de la época.

- Excavaciones arqueológicas llevadas a cabo.

- Análisis arquitectónico-constructivo de los elementos. 
La bibliografía consultada que recoge dichas fuentes de documentación y en la que hemos "localizado" dichos elementos se relaciona en el Anexo I.

La relación que adjuntamos en el Anexo II viene ordenada por los términos de las distintas poblaciones de la época. En cada uno de ellos se indica la fuente o fuentes documentales en las que aparece citada, la bibliografía que la cita, la persistencia o no de tal elemento, la ubicación del mismo y la persistencia del nombre o el cambio del mismo. Así mismo relacionamos los elementos genéricos que sin tener una localización geográfica concreta nos definen el carácter del territorio de la época de estudio.

La relación adjunta consta de 342 elementos de los cuales 203 podemos localizar hoy en día en una ubicación concreta.

Con la relación de elementos que hemos podido ubicar en la actualidad, hemos confeccionado los planos en los que se grafía los elementos y usos de la Batllia de Cervera en la Edad Media, lo cual nos da una idea global del territorio en esa época. ${ }^{110}$

\section{Mapa general (situación de las zonas de estudio) - $[e=1 / 200.000]$}

\section{Arquitecturas de la Batllia}

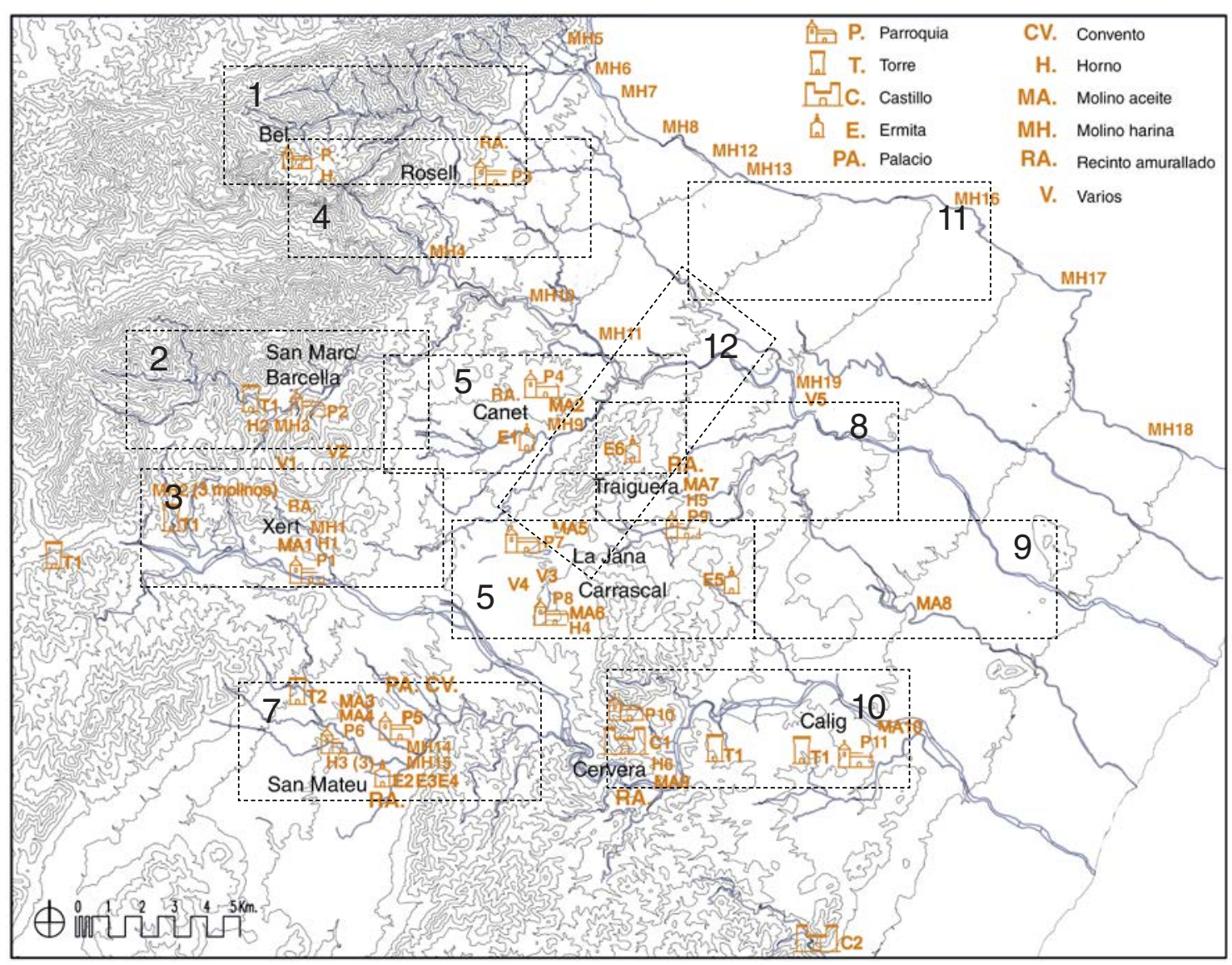

Fig. 4. 70. Plano de la Batllia a escala 1/200.000 del topográfico con las arquitecturas. Señalización 12 zonas de estudio.

110 Nota importante: En la documentación medieval no aparecen todos los elementos existentes, solo aquellas que controlaba el poder feudal, las propiedades francas no se encuentran en dicha documentación. Esta solo aparece en los protocolos notariales, de los que quedan muy pocos. 
Las arquitecturas son las esferas respecto a las que se organiza la vida de la sociedad humana. Son las "células" que permiten el crecimiento del territorio y permiten el desarrollo del mismo utilizando la energía de su entorno.

Las arquitecturas materializan las instituciones humanas, el ser-con de Heidegger, y por tanto suponen la forma de concretar el espacio en el que el hombre habita. Como hemos visto antes, las arquitecturas "embrionarias" que surgen de la caverna y en las que el hombre se reúne con su grupo tienen un centro y un límite.

En el territorio medieval se construyen una serie de esferas que conforman en palabras de Peter Sloterdijk una antroposfera. ${ }^{111}$

"En estado de desarrollo mínimamente completo la antroposfera es determinable como un espacio de nueve dimensiones. A ella pertenecen, como aportaciones configuradoras de mundo, imprescindibles cada una de ellas en su caso, las siguientes dimensiones o topoi:

1. El quirotipo: que incluye el ámbito de actuación de las manos humanas, la zona de lo que está ante ellas y a su disposición, el entorno de acción en el que se producen las manipulaciones objetivas primarias, los primeros lanzamientos, golpes y cortes, los primeros efectos característicos.

2. El fonotopo (o logotopo), que genera la campana vocal bajo la que los convivientes se oyen unos a otros, hablan unos con otros, se reparten ordenes unos a otros e inspiran unos a otros.

3. El uterotopo (o histerotopo), que sirve para la generalización del ámbito maternal y para la metaforización política de la gravidez, y produce una fuerza centrípeta, que, incluso en unidades más grandes, será experimentada por los incluidas en ellas como sentimiento de pertenencia y fluido existencial común.

4. El termotopo, que integra al grupo como receptor originario de los beneficios de la repartición de los efectos del hogar, que representan la matriz de todas las experiencias de confort y a causa de los cuales es dulce la patria.

5. El erotopo, que organiza el grupo como el lugar de las energías eróticas primarias de transferencia, y le pone bajo estrés como dominio de celos.

6. El ergotopo (o falotopo), en el que una fuerza paternal o sacerdotal de definición, con efectos en todo el grupo, genera un sensus communis, un decorum (una conveniencia) y un espíritu de cooperación, desde el que se formulan obras comunes, fundadas en la necesidad y se distinguen funciones laborales, hasta el enrolamiento de los miembros en el máximo estrés, la guerra, que se entenderá como la obra fundamental de una comunidad elegida para la victoria.

7. El alethotopo (o mnemotopo), por el que un grupo en aprendizaje se constituye como custodio de su continum de experiencia y se mantiene en forma como depósito central de la verdad con su propia pretensión de validez y su propio riesgo de falsificación.

8. El thanatotopo o theotopo (o bien, iconotopo) que ofrece a los antepasados, a los muertos, a los espíritus y dioses del grupo un espacio de revelación o un teclado semiótico para manifestaciones significantes del más allá.

9. El nomotopo, que vincula recíprocamente a las conexiones por "costumbres" comunes, por reparto del trabajo y expectativas recíprocas, con lo que, por el intercambio y el mantenimiento de la cooperación, aparece una tensegridad imaginaria, una arquitectura social compuesta de expectativas, apremios y resistencias mutuas, en una palabra: una primera constitución.”

Pues bien, haremos la clasificación tipológica en función de como se concreticen cada una de estas dimensiones en las arquitecturas. En ellas en muchas ocasiones se presentan varias de estas

111 SLOTERDIJK, P. “Esferas II” pág. 279 
dimensiones -y en ocasiones todas- pero hay siempre una que la hace característica y es la que nos ayudará en la clasificación que proponemos.

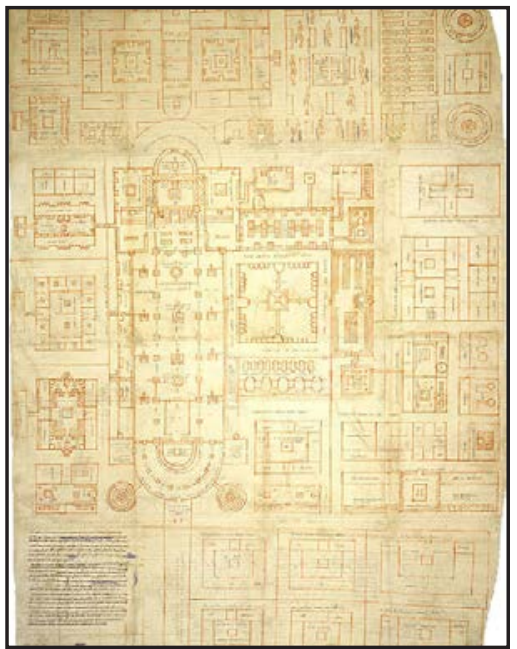

Fig. 4. 71. Plano monasterio de Sant Gull.

La concretización del termotopo es la casa. El confort lo proporciona desde los orígenes el fuego, alrededor de él el grupo humano se reúne. $\mathrm{Al}$ principio el hombre se dispone en círculo alrededor de una hoguera al aire libre, sin la protección de una cubierta. El primer paso es la construcción de una burbuja que contenga el fuego y cree la atmósfera de confort; esta es el fumeral aún existente en masías y hospederías de la comarca. Es la esfera más simple en la que el hombre se reúne. La disposición del fumeral es de planta cuadrada con banco corrido en todo su perímetro y en su "interior" se cocinan los alimentos, se come, se duerme y se habla; todo ello se hace por el grupo de forma colectiva. Esta crece y a su alrededor se crea la casa o masía, la esfera que da forma al termotopo.

Este tipo se relaciona con el primitivo megaron griego; consta de tres partes: el pórtico abierto al exterior con columnas, el vestíbulo también llamado pronaos y la sala principal a la que se accede a través del vestíbulo también llamada cella o naos y en la que se encuentra el fuego en el que se reúnen alrededor de él. Su forma es rectangular. Esta es la disposición de las antiguas masías en las que todavía hoy en día se puede reconocer esa disposición.

Pero no solo es el fuego el que proporciona el confort al hombre, también lo es el agua. Por ello alrededor de una fuente, noria o manantial surgen unas arquitecturas especiales. Por su importancia destacaremos dos, por una parte los abrevaderos que se encuentran a lo largo de las vías pecuarias. Son lugares cuyo centro es el abrevadero o balsa en la que bebe el ganado. El límite -en este caso único- son las construcciones complementarias tales como cercados para configurar corrales al aire libre, casetas de pastor y otras construcciones destinadas al control del paso del ganado, y por otra los regadíos que se disponen alrededor de una noria con sus correspondientes acequias y elementos de regulación del riego.

La concretización del uterotopo es el castillo (y torres). La protección, la seguridad que necesita el grupo humano ante el posible ataque de grupos rivales lo proporcionan las arquitecturas cuyos límites -membranas- están concebidas para controlar su permeabilidad y ofrecer refugio en su interior. Podemos hablar de los siguientes tipos:

- Si hablamos de una única edificación tendremos la torre como la mínima expresión del límite de protección en el que el hombre puede reunirse para defenderse.

- Si hablamos de una edificación a una escala mayor y que permite reunir un número importante de personas para defenderse, hablaremos de castillos.

- Por último, si lo que se reúne para defenderse es un núcleo urbano completo hablaremos de ciudad amurallada. 


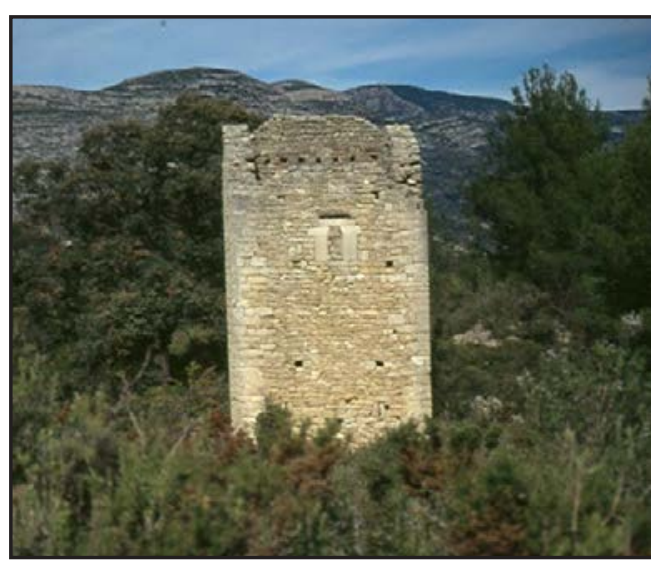

Fig. 4. 72. Foto Torre de les Solsides en Xert.

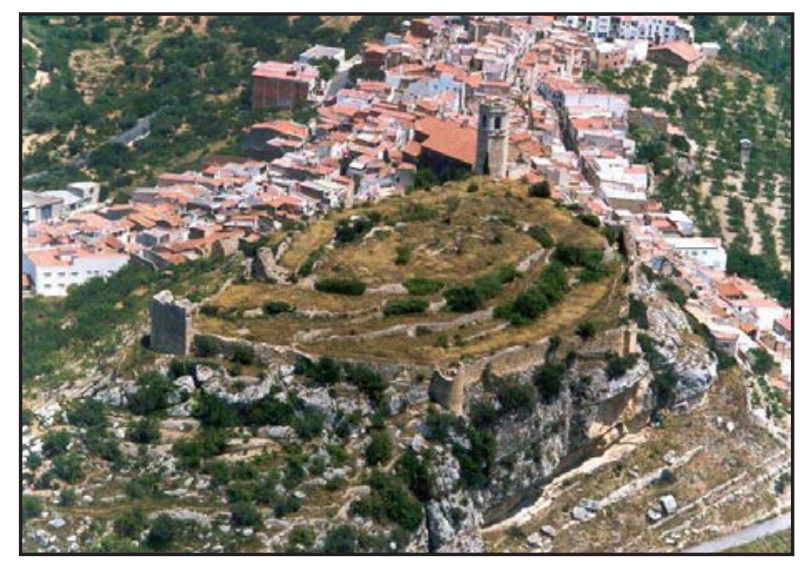

Fig. 4. 73. Vista aérea del castillo de Cervera.

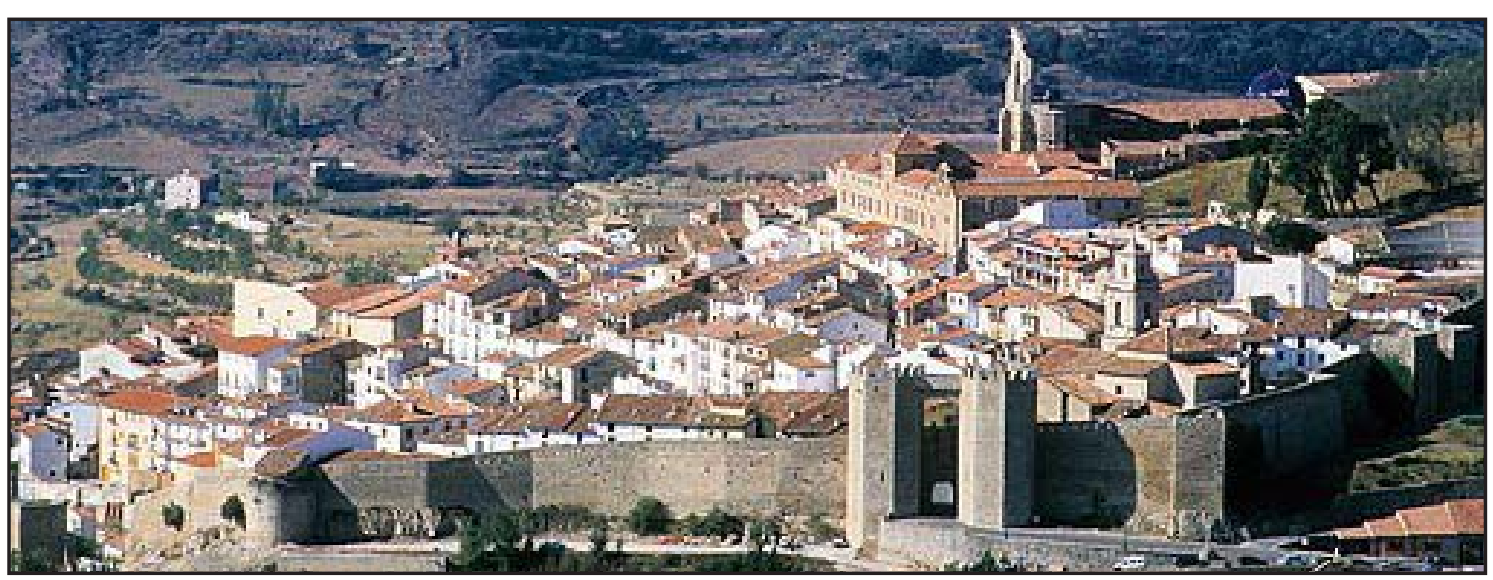

Fig. 4. 74. Vista aérea del recinto amurallado de Morella.

El grupo humano no necesita solamente protegerse él, sino también los excedentes de alimentos que le van a permitir subsistir en momentos de escasez o simplemente a lo largo de un año completo. A estas arquitecturas para el almacenaje de alimentos les llamaban en la Edad Media almudines y en muchas ocasiones se encontraban dentro o junto las arquitecturas defensivas.

Las "motillas" de la Edad del Bronce son un claro ejemplo de uterotopo en el que las membranas de cierra configuran el espacio para proteger no solo a las personas sino también a los alimentos y al pozo de agua que va a permitir subsistir al grupo humano. Obsérvese las semejanzas en las plantas de estas primitivas construcciones y las de los castillos de Cervera o Morella. 


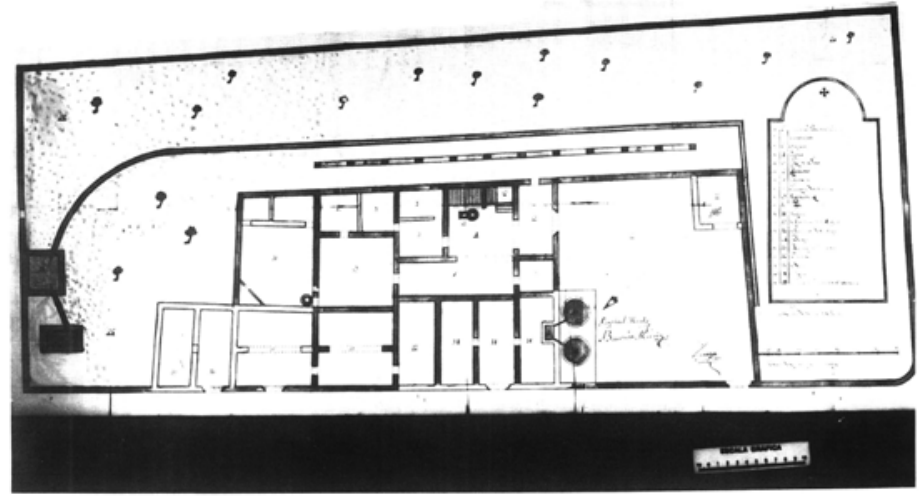

Fig. 4. 75. Plano planta baja del palacio de Montesa en Sant Mateu. Autor: R. Morata y B. Muñoz (1762).

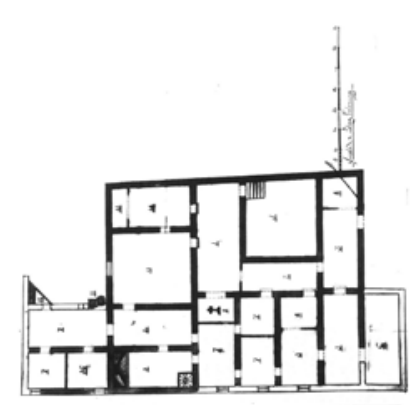

Fig. 4. 76. Plano planta superior Palacio de Montesa en Sant Mateu. Idem anterior.

Los palacios urbanos suponen una tipología intermedia entre el termotopo/casa y el uterotopo/ castillo. En el Palau del Mestre de Montesa en Sant Mateu, podemos a partir de los planos que se disponen del último tercio del siglo XVIII ${ }^{112}$ comprobarlo.

El elemento central es una torre rectangular y alrededor de ella varios cuerpos de edificación y de muros la protegen y rodean. La torre la preside el fuego, siendo el foco el punto central de todo el Palacio, la gran chimenea de la primera planta. Alrededor de ella distintas estancias sirven para almacenar los alimentos y estabular el ganado -véase que también se almacena usando recipientes cerámicos- y por último continuando con las semejanzas una noria de planta circular suministra el agua al alcanzar el nivel freático (como ocurre en las "motillas”).

La concreción del theotopo son las ermitas. El fuego no solo proporciona confort sino que desde antiguo es considerado una divinidad y se le da culto. A partir de la disposición ya citada del megaron griego y como apunta Ramón Rodríguez Culebras en "Para el estudio de la arquitectura religiosa medieval castellonense", el edificio se adopta para dar culto a los dioses y la sala pasa a ser la morada de los dioses.

\footnotetext{
"Todavía se encuentran algunas que nos trasladan -con naturales variantes-, al megaron griego: una sala rectangular con el hogar en uno de los extremos y no en el centro, banco corrido adosado y entrada con un pórtico en sentido longitudinal como imprescindible complemento de la gran salavivienda. La entrada y la situación del hogar son las diferencias más notables respecto al precedente griego. San Pablo de Albocácer nos brinda aún una de estas soluciones de origen medieval, integrado en el conjunto de la posterior edificación del santuario. El sencillo templo rural sitúa el santuario estrictamente dicho en la zona reservada al fuego de la sala-vivienda y muestra una notoria preferencia por la puerta y el gran pórtico corrido e una de los lados, en sentido longitudinal". ${ }^{113}$
}

Es evidente la permanencia en la disposición de las masías y posteriormente en las hospederías del precedente del megaron griego, así como este se mantiene en las primitivas iglesias llamadas de Reconquista en las que la sala con el fuego es sustituida por el altar. La reunión pasa de producirse alrededor del fuego para serlo alrededor del altar. En los primitivos templos como Sant Jaume de Coratxar, Santa Lucia en Castellfort o Santa Lucia en Morella, el acceso es lateral y a través del porche con la existencia del banco corrido. Posteriormente se abren puertas en el testero para remarcar el sentido longitudinal del espacio como ocurre en Sant Pere de Castellfort, la iglesia de Xert, los Santos Juanes de Albocacer, la Puritat de Morella, etc. Para finalmente producirse el acceso por el testero y eliminar el porche de acceso en muchos casos.

112 ZARAgOZÁ CATALÁN, A. “El Palacio Maestral de la Orden de Montesa en Sant Mateu

113 RODRÍGUEZ CULEBRAS, R. "Para el estudio de la arquitectura religiosa medieval castellonense” pág. 191-192 


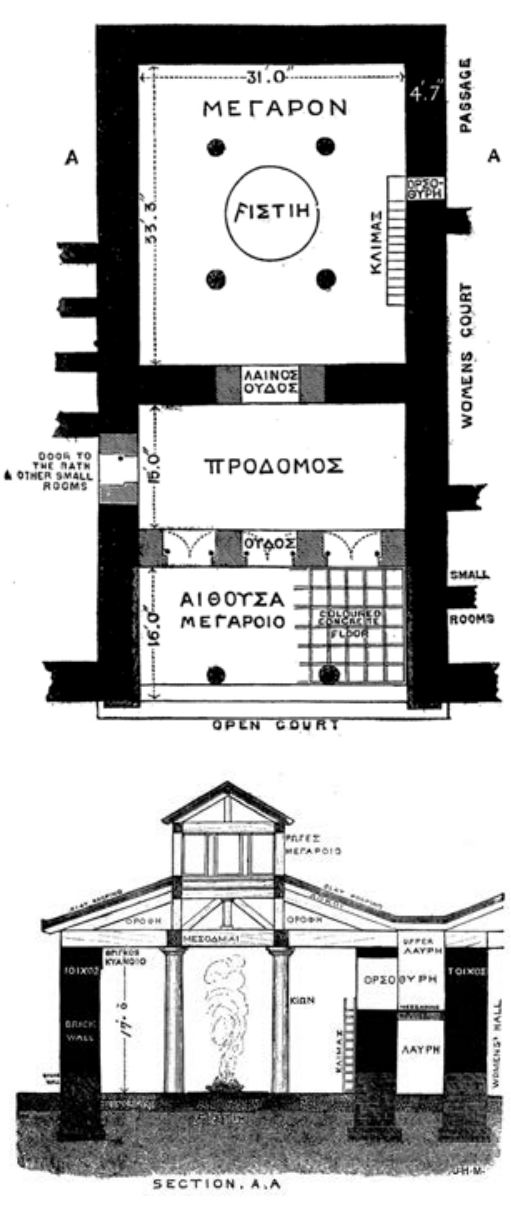

Fig. 4. 77. Planta y sección megaron en Tirinto.
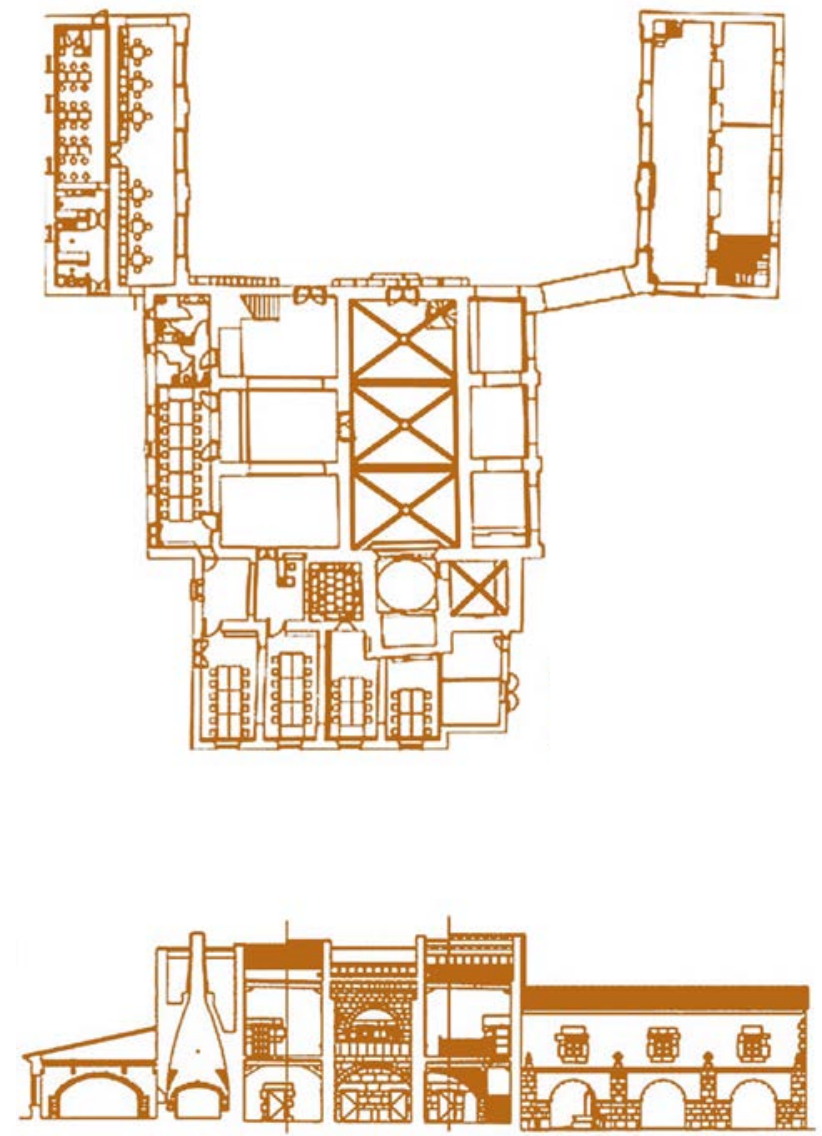

Fig. 4. 78. Planta y sección ermitorio de Sant Pau en Albocasser (dibujos de Carlos Campos).

En la antigua Grecia el megaron evoluciona también hacia el pritaneo. Un edificio de carácter público que se erigía en el centro de la ciudad en el que se custodiaba el fuego sagrado de Hestia. En él se daban comidas públicas y era también el granero público. En definitiva era el edificio público en el que el fuego era el "alma" que permitía la alimentación de los habitantes de la ciudad.

El elemento central donde se mantiene el fuego continuamente en los antiguos núcleos urbanos medievales es la olla, ante ella en la "fleca" o sala se reúne la gente para preparar el pan u otro tipo de comida, y que en ocasiones aun hoy en día sirve para hacer determinadas celebraciones en las fiestas patronales. Como en el caso de las masías u hospederías el alcabar tiene una gran importancia y en este caso además su función es la del almacenamiento y secado de la leña. Podemos ver en los casos del horno de Lliria y en el de San Mateo dos ejemplos que aun perduran de esta disposición que hunde sus raíces en los antiguos pritaneos. Los hornos son la concreción del theotopo del fuego como divinidad pagana.

La concreción del thanatotopo son las parroquias y los cementerios asociadas a los mismos. En el caso de las parroquias se trasciende el hecho de la reunión al concebirse el centro como espacio simbólico y sagrado. El centro como espacio simbólico en el que se unen el cielo, el hombre y la tierra, siendo el hombre el punto de mediación entre uno y otro. La arquitectura se convierte en espacio simbólico de manifestación de lo sagrado.

Estos espacios simbólicos van unidos a las imágenes del agua y de la montaña.. La imagen del agua atiende a una concepción en la que el centro, al relacionarse con el espacio del agua, se transmuta en principio femenino, adquiere dimensiones de matriz, de gran fuente primordial de la que todo mana y que nunca se agota, relacionándose con la imagen de la caverna/paraíso.

Por otro lado, la montaña es el espacio en donde moran las divinidades y el símbolo del centro o "axis mundi", a partir del cual se despliegan las cuatro direcciones del universo que conforman el 
espacio cosmológico. Su centro -el altar- adquiere una significación especial al convertirse en el centro desde el cual el hombre se sitúa en el territorio en el que vive y con respecto también a los territorios imaginarios del cielo y el infierno.

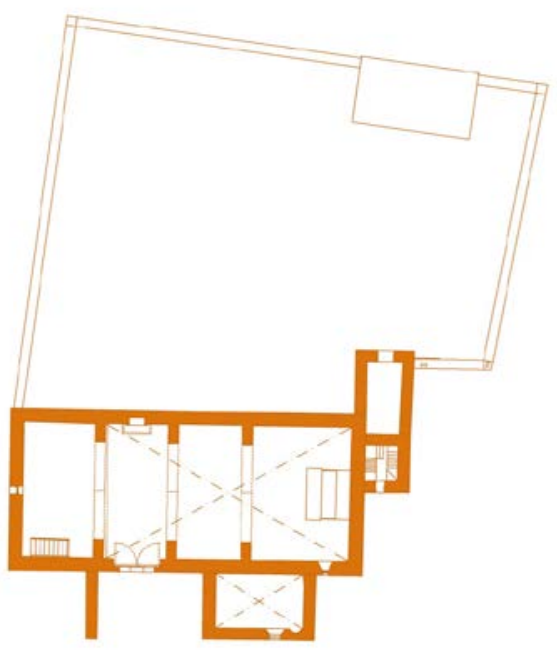

Fig. 4. 79. Planta iglesia de Sant Jaume de Coratxar.

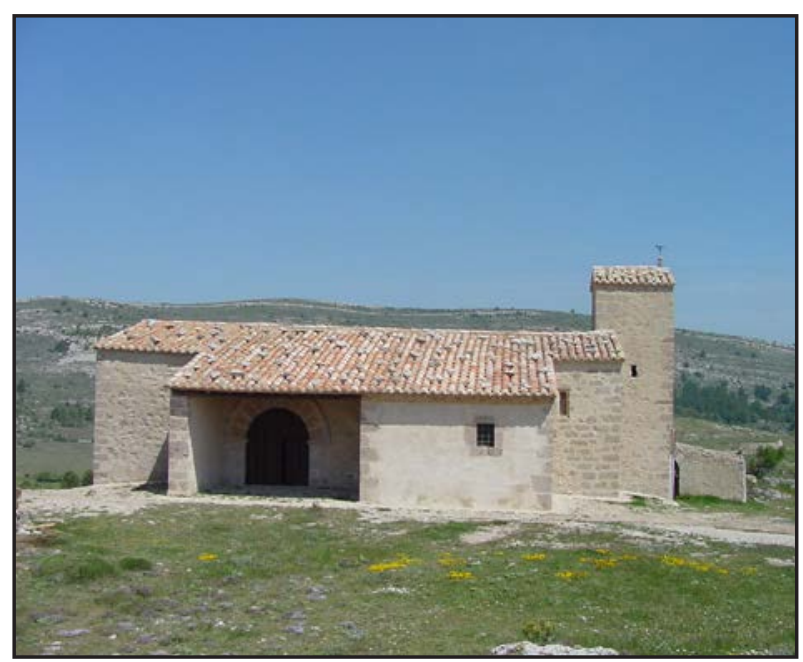

Fig. 4. 80. Vista fachada principal ermita Sant Jaume de Coratxar.

Desde el centro el hombre referencia las cuatro direcciones cardinales -norte, sur, este y oeste- así como el arriba y el abajo. Ejemplo paradigmático de ello es la Iglesia de Sant Jaume de Coratxar, como en todas esta orientada según los cuatro puntos cardinales pero además junto al altar tiene un pequeño campanario con una escalera que sube hacia arriba y a los pies del mismo en uno de los sillares tiene grabado la dirección hacia abajo hacia una cueva situada bajo la iglesia y que tiene acceso desde un lugar próximo.

En la Edad Media junto a las parroquias se encuentran los cementerios -o bien junto a los primitivos emplazamientos de los enterramientos se construyeron las parroquias-, ya que existe una ligazón permanente entre el mundo de los vivos y de los muertos y las tumbas constituyen los portales para el tráfico de cercanías entre el más acá y el más allá.

La concreción del nomotopo es la casa comunal. En las ciudades medievales también para dar respuesta a la necesidad del incipiente gobierno municipal y por tanto a la de reunirse los ciudadanos para poder tomar las decisiones necesarias para el gobierno de la misma e incluso para hacer justicia unos edificios cuyas raíces las podemos encontrar -como ya apuntaba Nicolas Pevsner- en el bouleuterion griego.

Este era el edificio en el que se reunía la boulé, el consejo, en las ciudades de la antigua Grecia. Su forma era rectangular y se disponía de asientos alrededor de una mesa o "altar" de piedra en la que se encontraba el orador y se cubría con una cubierta ligera de madera sobre pilares de sillería. Era el lugar en el que se resolvían las cuestiones referentes al correcto funcionamiento de la ciudad.

Este tipo evoluciona en la Edad Media y la reunión se produce alrededor de una mesa -tal como describe Viollet le Duc en su Dictionnaire Raisonné de l'Architecture Francaise- encontrándonos con la casa comunal que son el exponente de los nuevos poderes municipales de la Edad Media.

Las costumbres, reglas y leyes que rigen las dirige el gobierno municipal desde la casa comunal se complementa en ocasiones con la sala del Justicia que se ubica en el mismo edificio. 


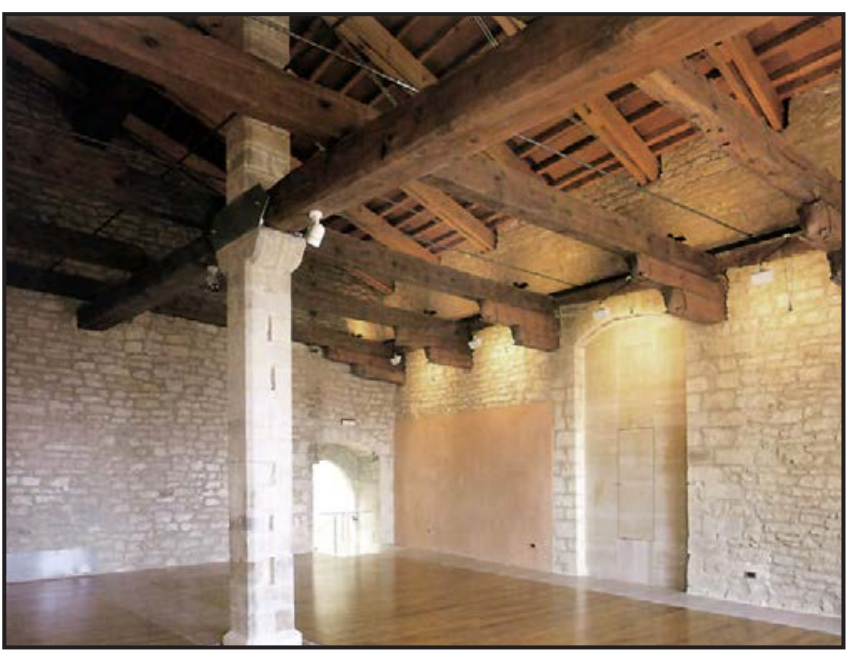

Fig. 4. 81. Vista interior sala del consell de la casa comunal de Morella.

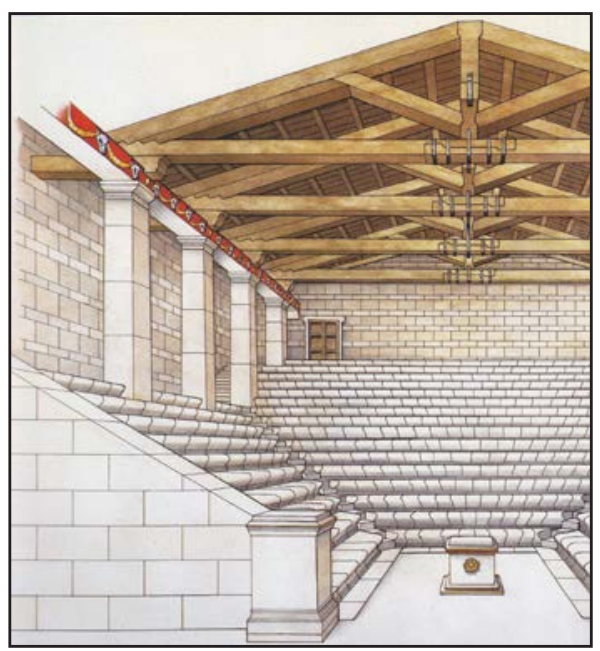

Fig. 4. 82. Reconstrucción virtual del boleuterion de Priene. Obsérvense las semejanzas de la cubierta con la sala de Morella.

La concreción del erotopo es la lonja o mercado. Las diferencias entre los miembros del grupo humano crean tensiones entre ellos. A partir de las relaciones iniciales más frugales, con el tiempo los habitantes del grupo se van diferenciando unos de otros, por lo que la sabiduría de la vida en grupo pertenece a la gestión de los celos. La primera consecuencia de ello es la aparición de la envidia.

El comercio y con él el aumento del uso del dinero y el enriquecimiento de determinados miembros de la comunidad produce el germen de la envidia y los celos en el grupo humano. La arquitectura que materializa ese comercio que a partir de la Edad Media sustituirá al uso del trueque, son las lonjas y mercados.

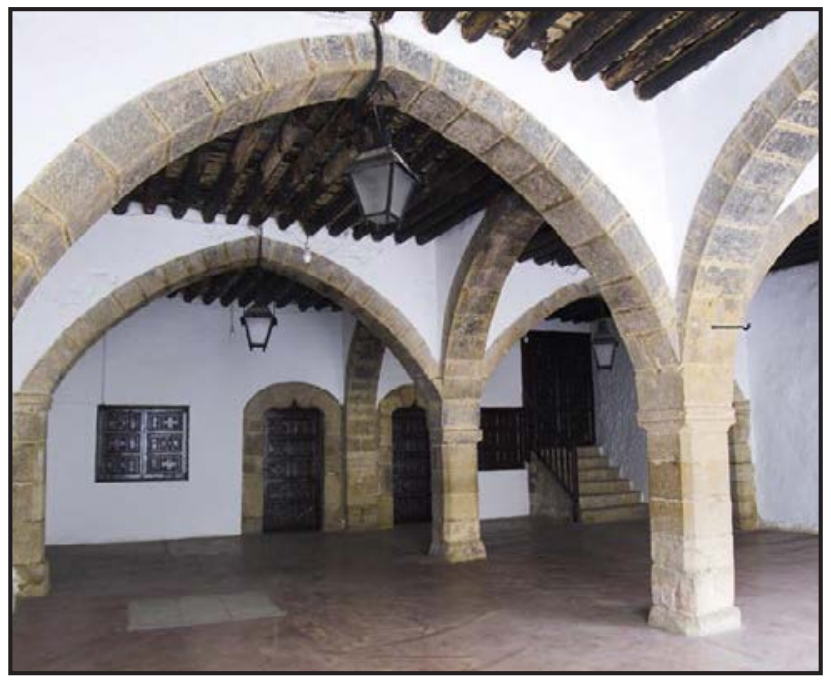

Fig. 4. 83. Lonja de la casa comunal de Catí.

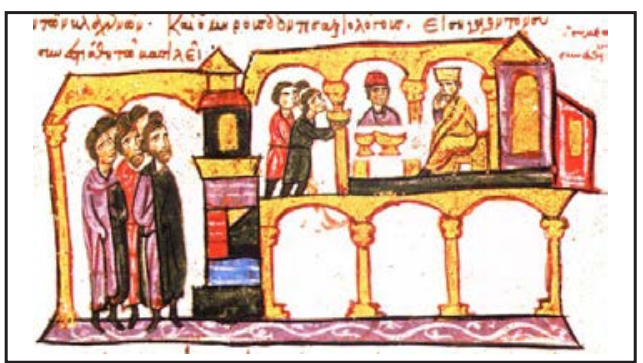

Fig. 4. 84. Miniatura medieval con edificio con la lonja en la parte inferior y la sala en la superior.

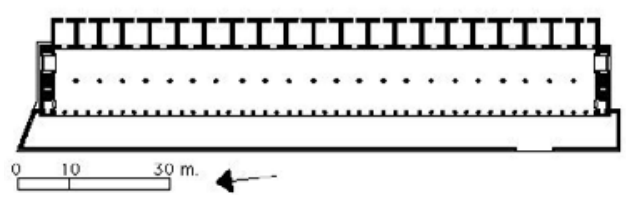

Fig. 4. 85. Planta de la stoa atalos de Atenas.

Por ello las lonjas pueden llegar a ser edificios ostentosos como es el caso de la Lonja de la ciudad de Valencia o a una escala más reducida el edificio de la lonja de la lana en Olocau del rey en els Ports de Morella. En la comarca en muchas ocasiones se encuentran en las plantas bajas de los edificios de la casa comunal.

La concreción del ergotopo son las cofradías. El espíritu de cooperación dentro del grupo en el que se formulan obras comunes fundadas en la necesidad y se procede a la distinción de diferentes funciones laborales.

Dentro de la comunidad se organizan grupos unidos por intereses comunes que se reparten cooperativamente el peso de las tareas, y se ven envueltas en obligaciones y tributos. 
Existen cofradías en muchos municipios en la Edad Media y los edificios en los que se reúnen y desarrollan su actividad se denominan cofradías. Muchas de ellas aun hoy en día todavía persisten y se reúnen de forma periódica.

Junto con las cofradías podemos hablar de los Hospitales, ya que en muchas ocasiones van asociados a algún tipo de cofradía.

La concreción del alethopo es la casa de Estudios o Universidad. Es el lugar en el que las cosas se vuelven manifiestas, en el que la experiencia de los antecesores del grupo humano se almacena y los conocimientos que de ella imanan se ofrecen para el aprendizaje de las nuevas generaciones del grupo. Desde el surgimiento de las culturas, esta organización se ha plasmado en instituciones que siempre han tenido un gran peso específico dentro de la comunidad. Como veremos más adelante una de las características más importantes y necesarias para evolucionar de las esferas de las arquitecturas individuales hacia otras más complejas será la inclusión del alethopo en dichas esferas superiores.

La concreción del fonotopo sería el teatro. El hombre necesita comunicarse y para ello inventa historias que cuenta con la actuación de unos personajes. En sus orígenes son un acto litúrgico y religiosos en el que participa el publico o pueblo. En su origen griego es la síntesis del género de la épica-del que toma los argumentos- y del de la lírica-del que toma la música y la danza-.

Es la materialización de la campana vocal de la que habla Peter Sloterdijk y a través de la cual se inspiran unos a otros los miembros de una misma sociedad. En la Edad Media la tradición teatral no se mantuvo, por lo que en esta comarca y en este periodo no podemos encontrar tipos de estas arquitecturas. Su trazado, disposición y dimensiones están supeditados a una perfecta acústica.

El centro sería la escena y el límite lo conforman las gradas donde el público se sienta.

Por último la concreción del quirotopo son todas las arquitecturas que usa el hombre para fabricar con sus manos todo tipo de objetos. En ella podríamos encuadrar a los molinos, tejerías, herrerías, etc. En estas arquitecturas el centro esta reservado al elemento generador de la actividad, en el caso de los molinos a la muela, en el de los alfareros al torno,en el de las herrerías a la fragua, etc

Estas actividades que inicialmente dependían en su origen del uso de las manos, poco a poco con la tecnificación dejaron de tener esa importancia y de ser el centro de la propia actividad.

Ingenios mecánicos de molinos encontramos ya en Vitruvio pero seguramente en la zona en la que nos encontramos independientemente de su origen se trata de instalaciones que continúan la tradición árabe existente en este territorio.

Hecha esta clasificación tipológica de las distintas esferas/arquitecturas que se pueden encontrar en la Edad Media, destacaremos la existencia de dos arquitecturas que lo que hacen no es concretar ninguna esfera, sino el cordón umbilical que unen a algunas de las esferas existentes con el territorio y permiten que se nutra de él, que se transfiera energía y posibilite su crecimiento y desarrollo. Destacaremos por su importancia dos:

- Los puentes permiten salvar las barreras infranqueables de los ríos. En la antigüedad las divisiones regionales no venían dadas por las limatesas de las cadenas montañosas sino por las limahoyas de los caces de los ríos. La unión que permite entre las dos orillas el puente permite que se reúna el hombre con los otros hombres, son elementos fundamentales en el desarrollo de territorio.

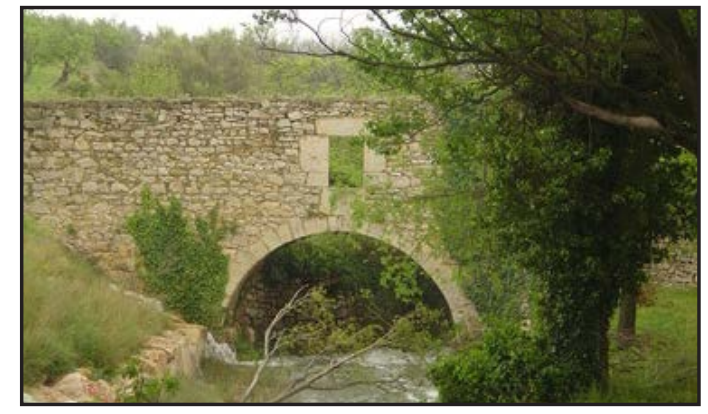

Fig. 4. 86. Vista exterior puente en el Molinar de Xert. 
- Los acueductos al permitir el flujo de agua de un punto a otro del territorio permite que los hombres se reúnan en un punto concreto, que crezcan determinados núcleos urbanos. La necesidad de agua de un núcleo urbano de una cierta entidad seria imposible sin que los acueductos permitieron el transporte del agua hasta las ciudades. Sin los acueductos los hombres no se podrían reunir en las ciudades. En este caso el acueducto simboliza la unión del núcleo urbano con el territorio que lo rodea, es el cordón umbilical que nutre la ciudad del alimento que necesita para

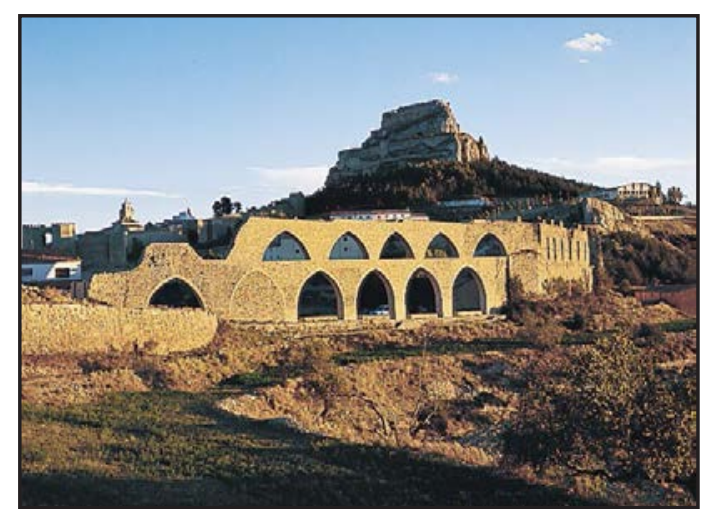

Fig. 4. 87. Foto del acueducto de Morella con la ciudad y castillo al fondo. sobrevivir.

Resumiendo las arquitecturas que encontramos en la época de estudio en este territorio son: Masías, Torres, Castillos, Recintos amurallados, Molinos de aceite, Molinos de harina, Hornos, LonjasAyuntamientos, Cofradías, Hospitales, Almudín, Palacio, Ermitas, Iglesias, Convento, Monasterio y Cementerio.

Posteriormente al hacer un análisis comparado de las clases de arquitecturas, de su ubicación, forma y densidad entre los doce ámbitos de estudio extraemos las siguientes conclusiones:

- Muchas arquitecturas se concentran en los núcleos urbanos. Estas son: hornos, lonja-casa comunal, cofradías, hospitales, almudín, palacios, iglesias, conventos y cementerios.

- Los molinos se sitúan junto a los ríos.

- Los castillos y torres se sitúan en sitios estratégicos (alturas, cruces caminos, vados de ríos...).

- Las masías se hallan diseminadas y lejos de los núcleos urbanos.

- Las ermitas se sitúan en lugares "míticos" como promontorios, cuevas, manantiales...

- En la montaña las arquitecturas se sitúan junto al camino de carena en las intersecciones con los barrancos de descenso de las aguas.

- En los valles las arquitecturas se sitúan junto al camino de penetración -paralelo al río- y en las intersecciones con los barrancos que afluyen al río.

- En la ladera las arquitecturas se sitúan en el camino de en medio y en la intersección con el cruce de los barrancos.

- En el llano se sitúa el núcleo urbano en una posición prominente de control visual, concentrándose todas las arquitecturas en su proximidad. Solo hay algunas arquitecturas dispuestas concéntricamente en el límite del territorio de ese núcleo urbano.

- En el ondulado las arquitecturas se disponen siguiendo la malla topológica, priorizando la parte de la red que tiene agua sobre la que no la tiene. 


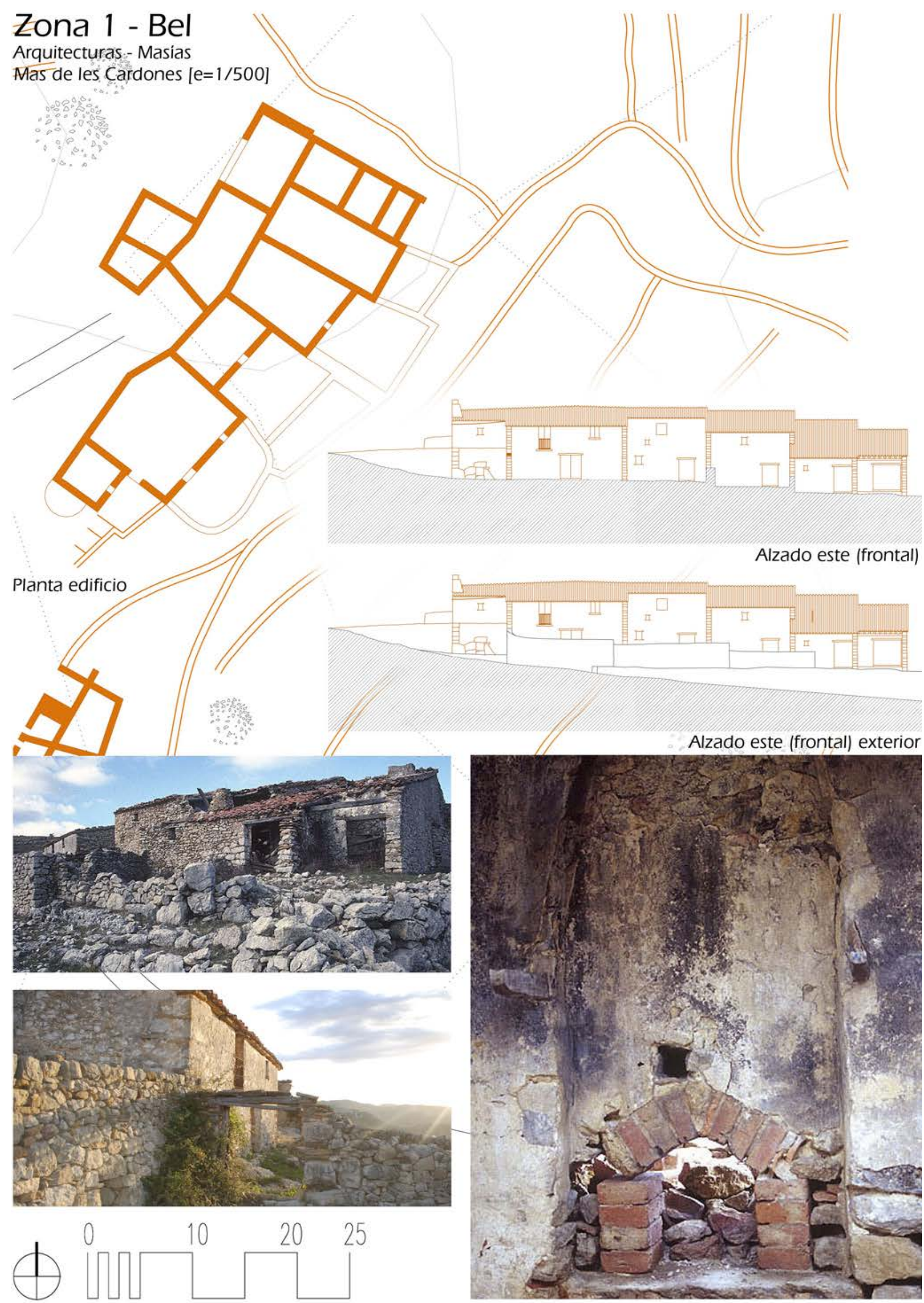

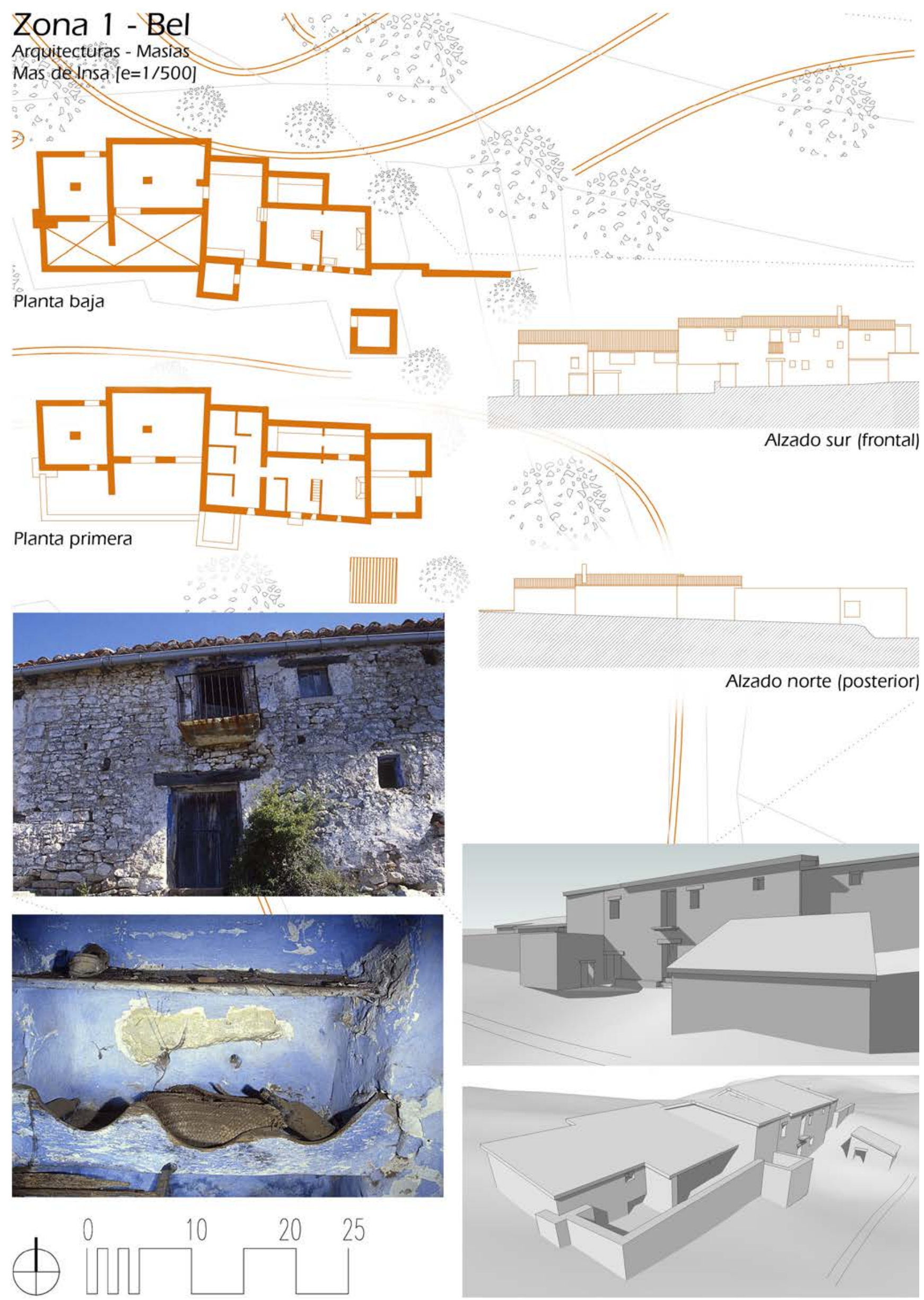

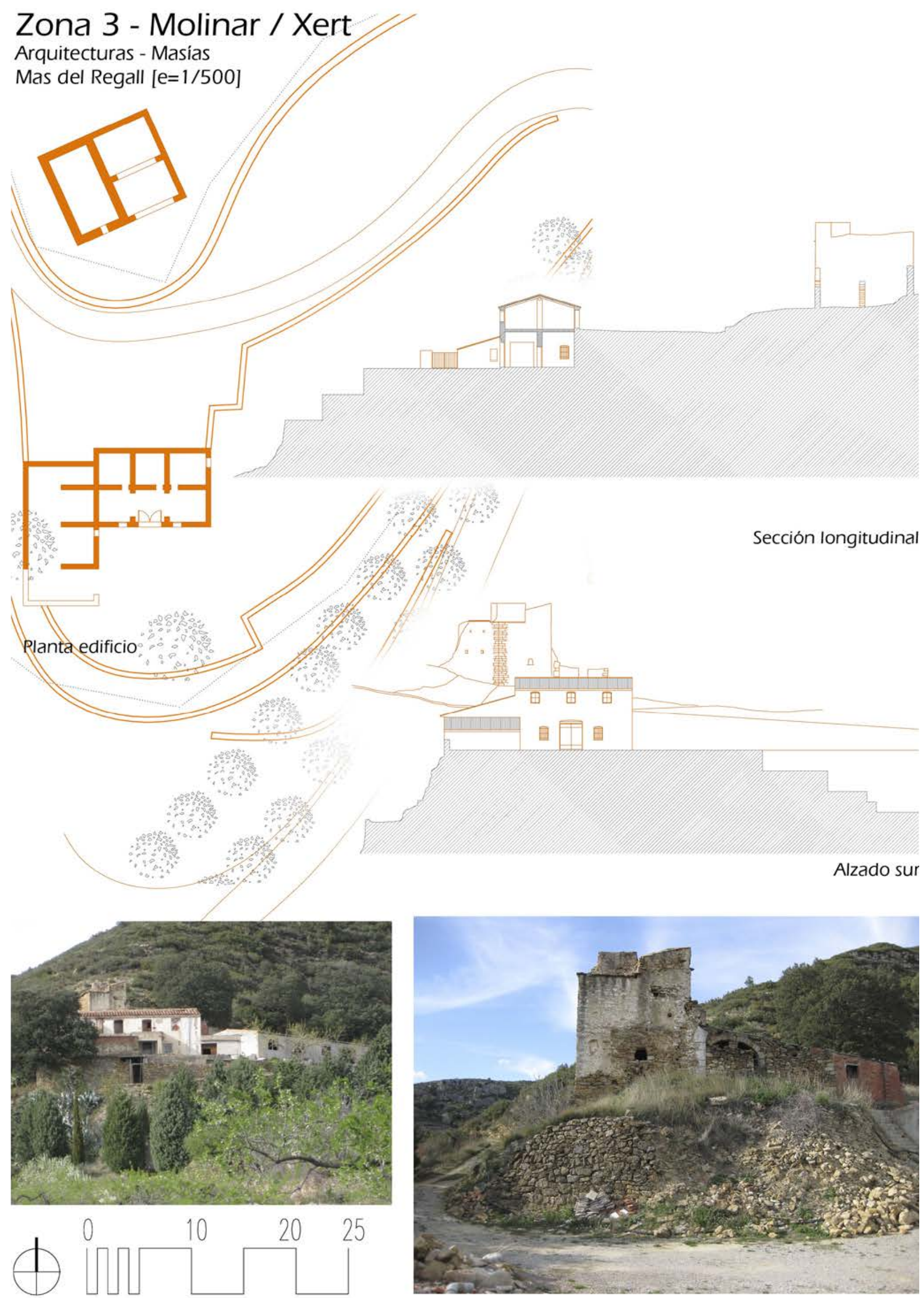

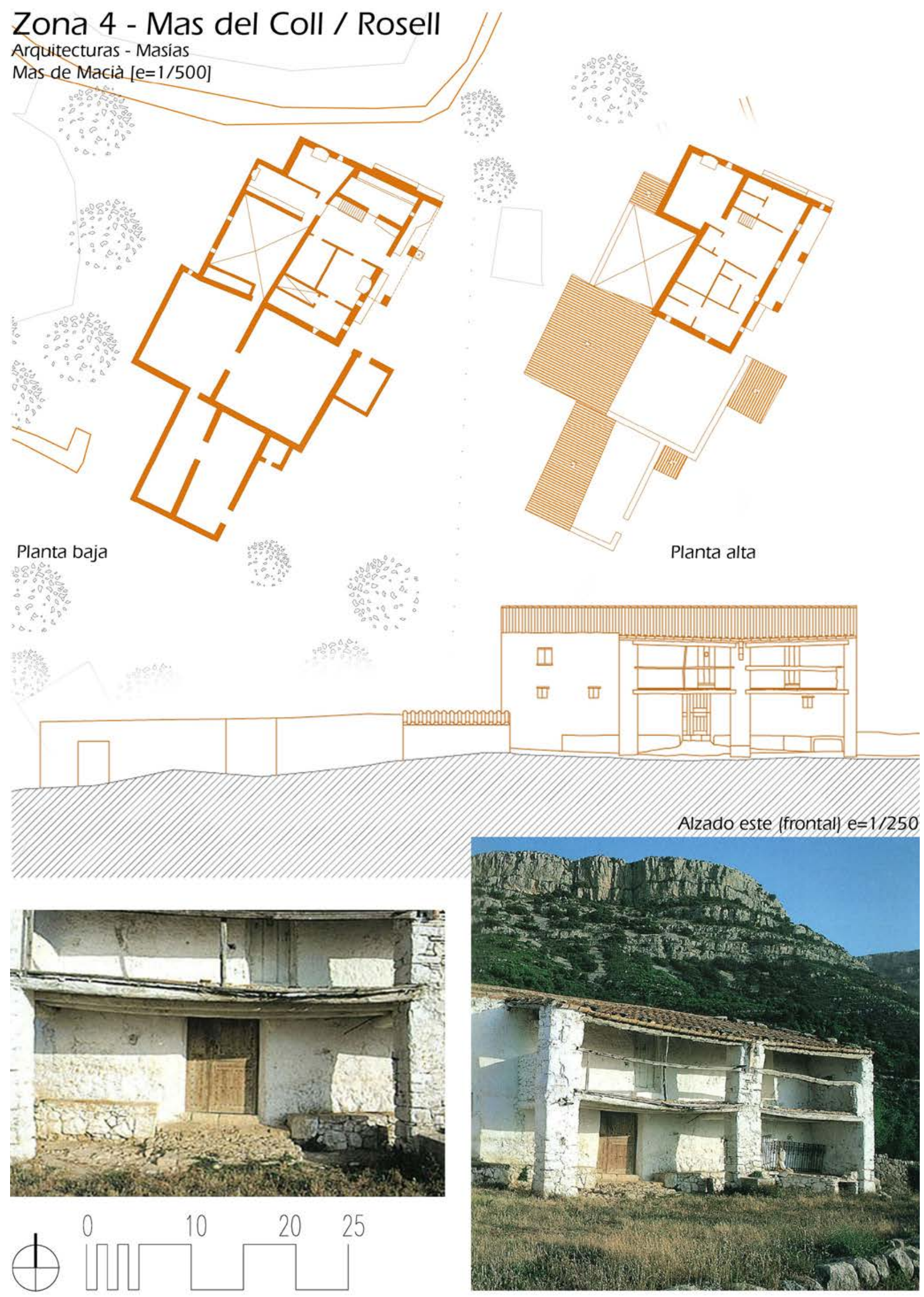


\section{Zona 3 - Molinar / Xert}

Arquitecturas - Molinos

Molino puente $[\mathrm{e}=1 / 500]$

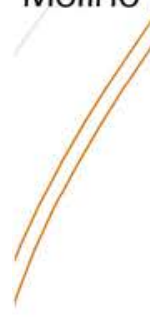

nersanso
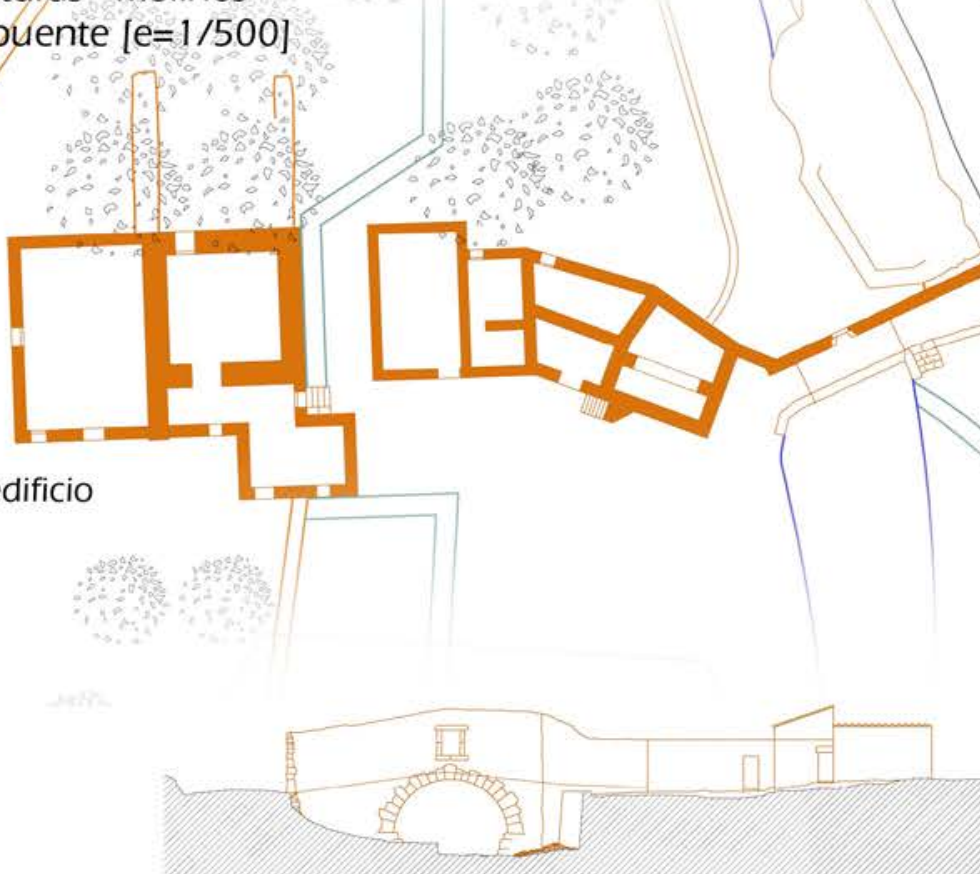

Alzado norte

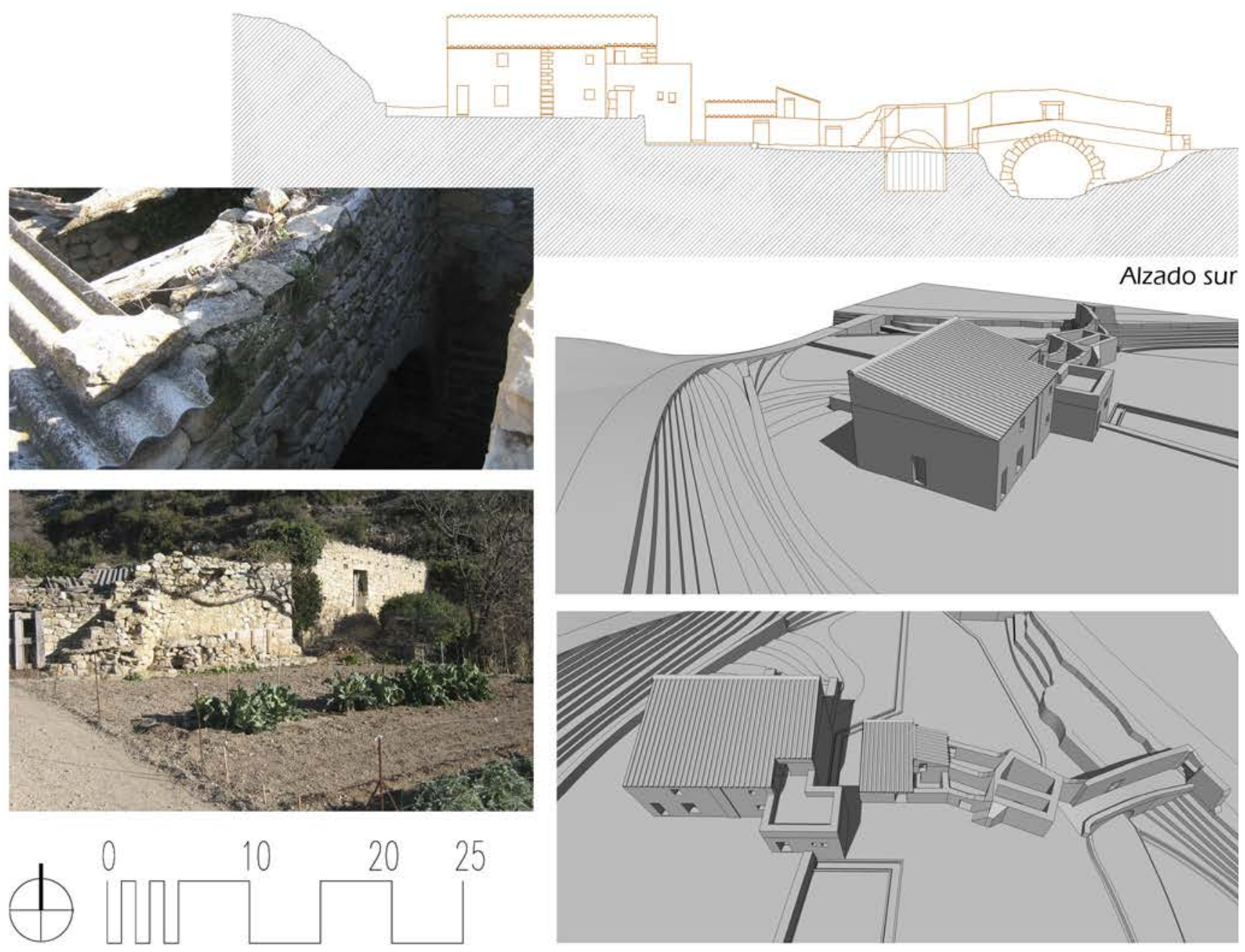




\section{Zona 10 - Cervera / Calig}

Arquitecturas - Molinos

Moli d'oli $[e=1 / 500]$

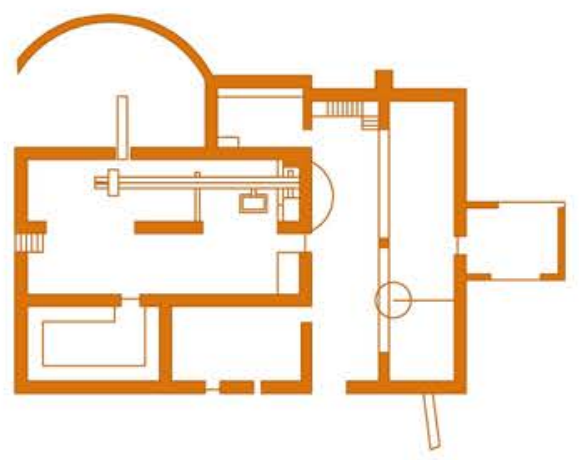

Fuente: Cuadernos TC $n^{\circ} 27$

Arquitecto: Jaime Prior -

Fernando Zaragoza

Planta baja
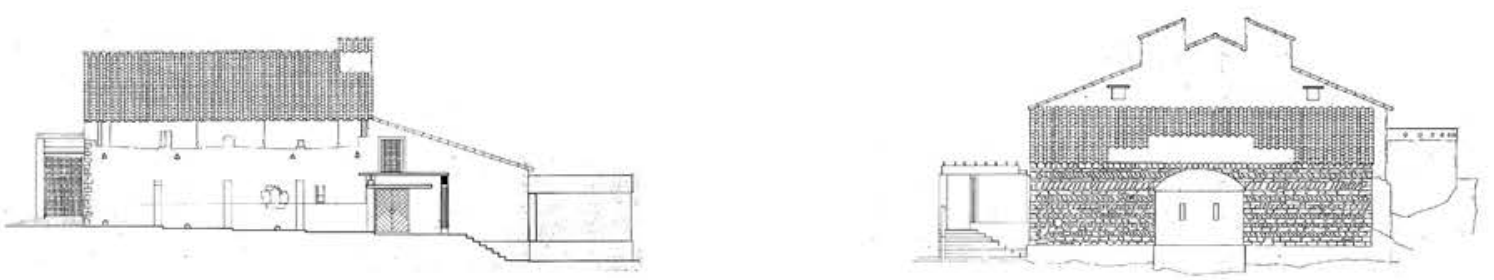

Alzado este

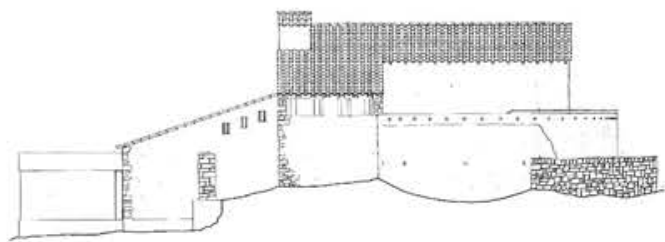

Alzado norte

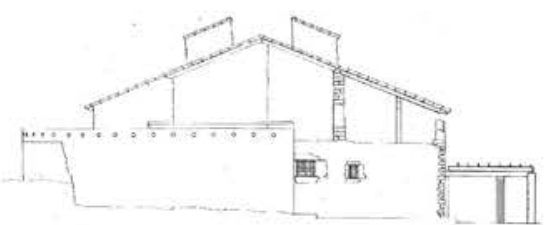

Alzado oeste

Alzado sur
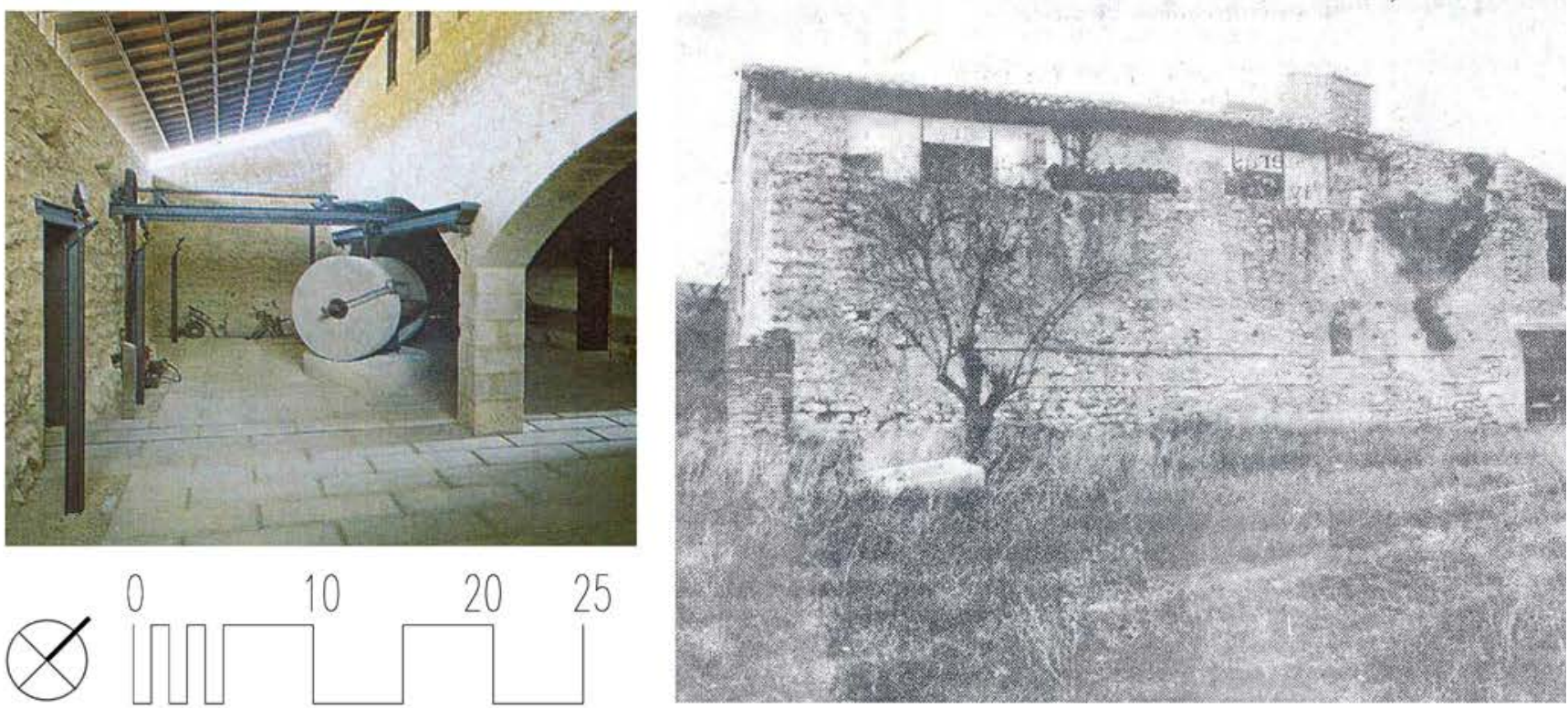


\section{Otras zonas de interés} Arquitecturas - Molinos Molinos de Ares $[e=1 / 500]$
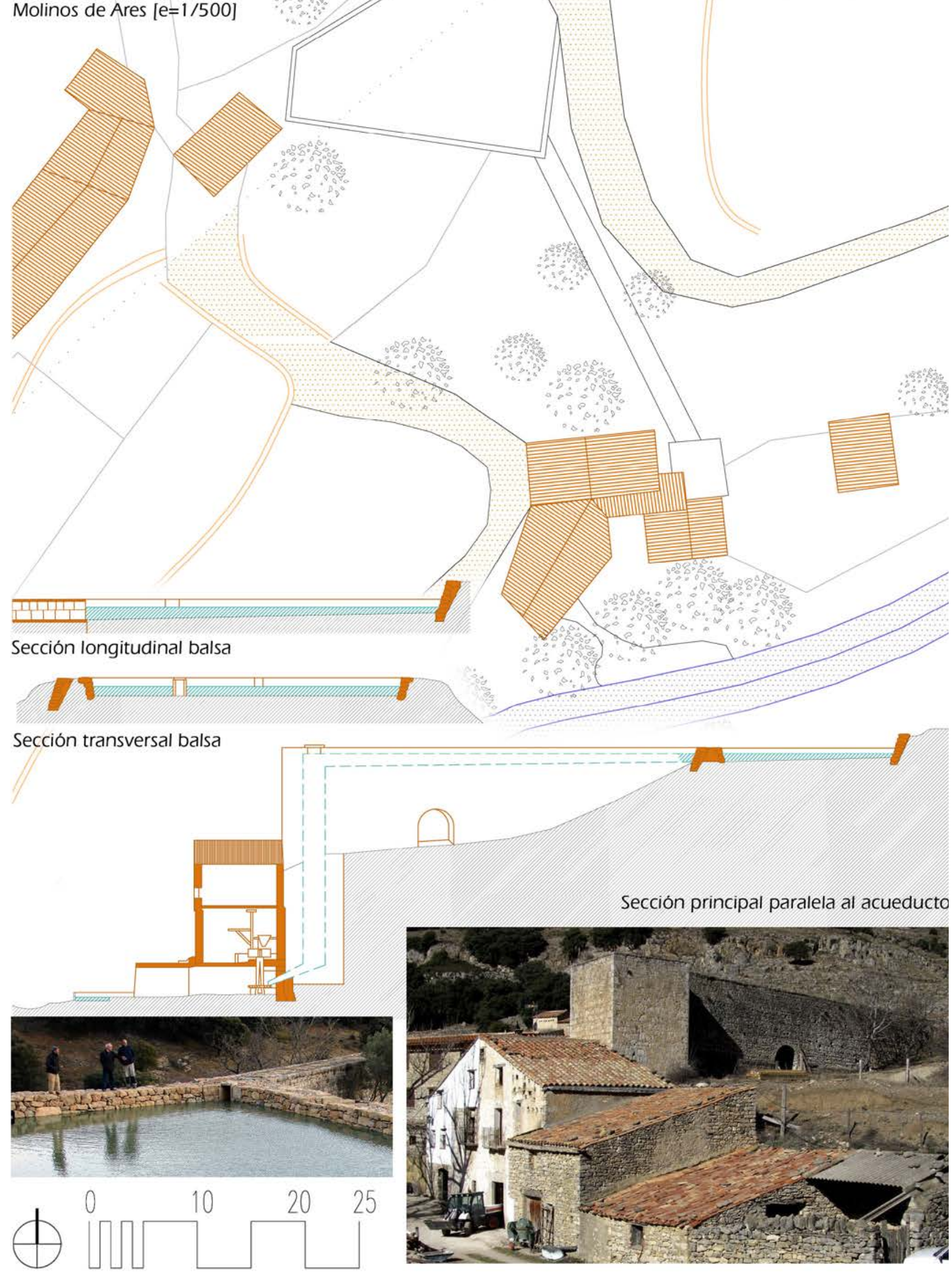


\section{Zona 1 - Bel}

Arquitetcuras - Iglesias / ermitas

Iglesia de Bel $[\mathrm{e}=1 / 500]$

Planta baja
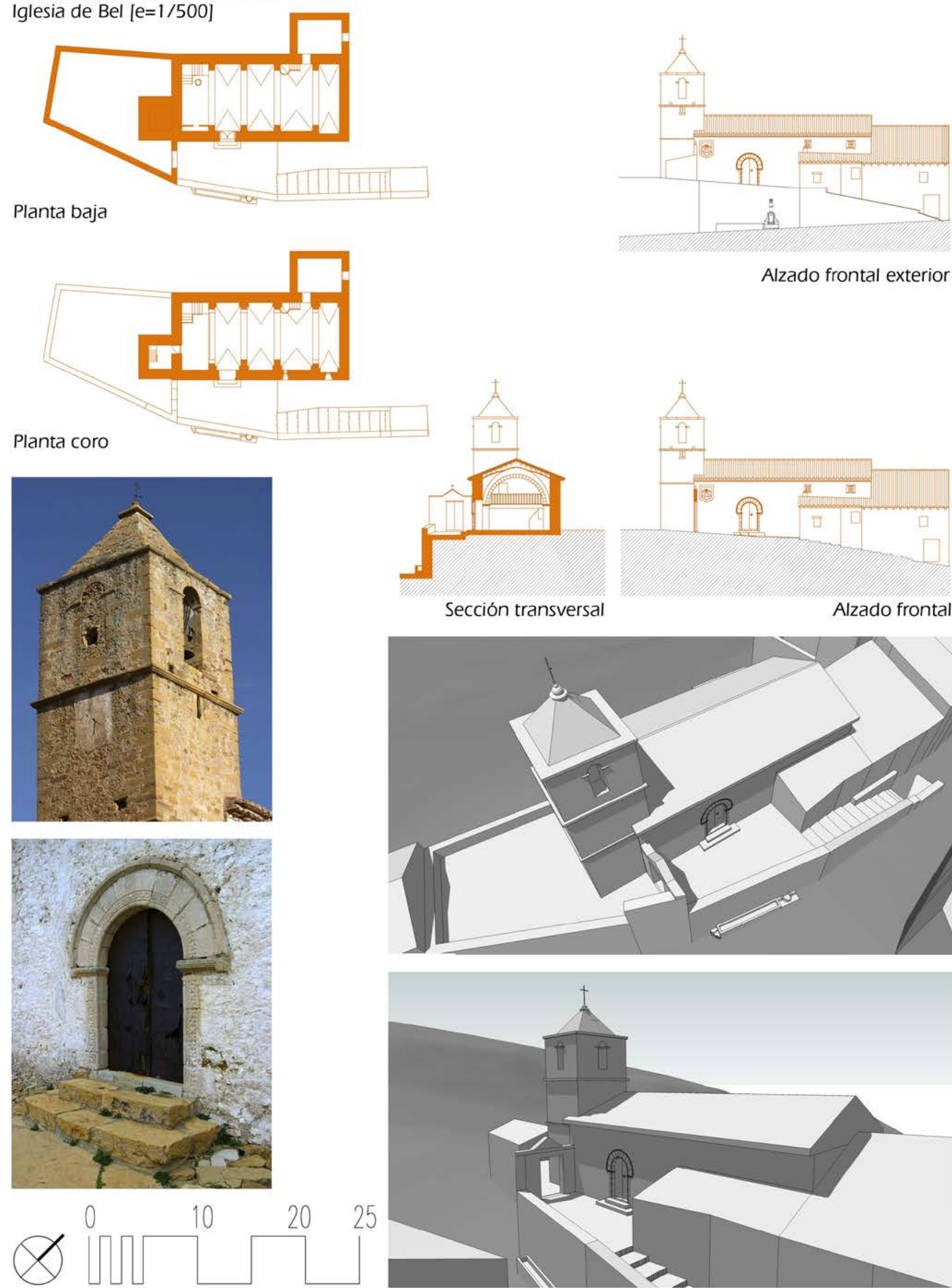

Sección transversal
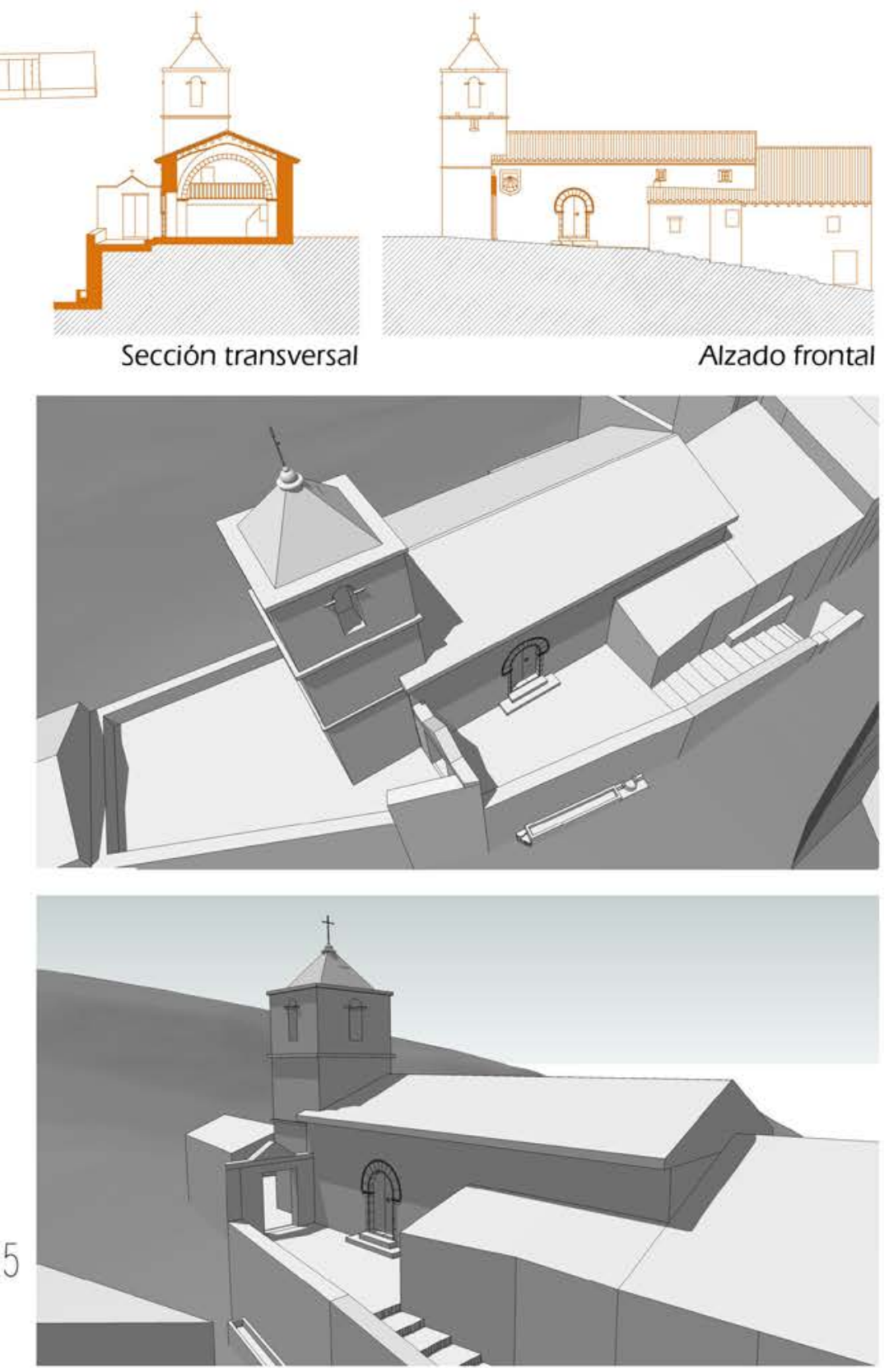


\section{Zona 2 - Barcella}

Arquitecturas - Iglesias / ermitas

Ermita de San Marc de la Barcella [e=1/500]

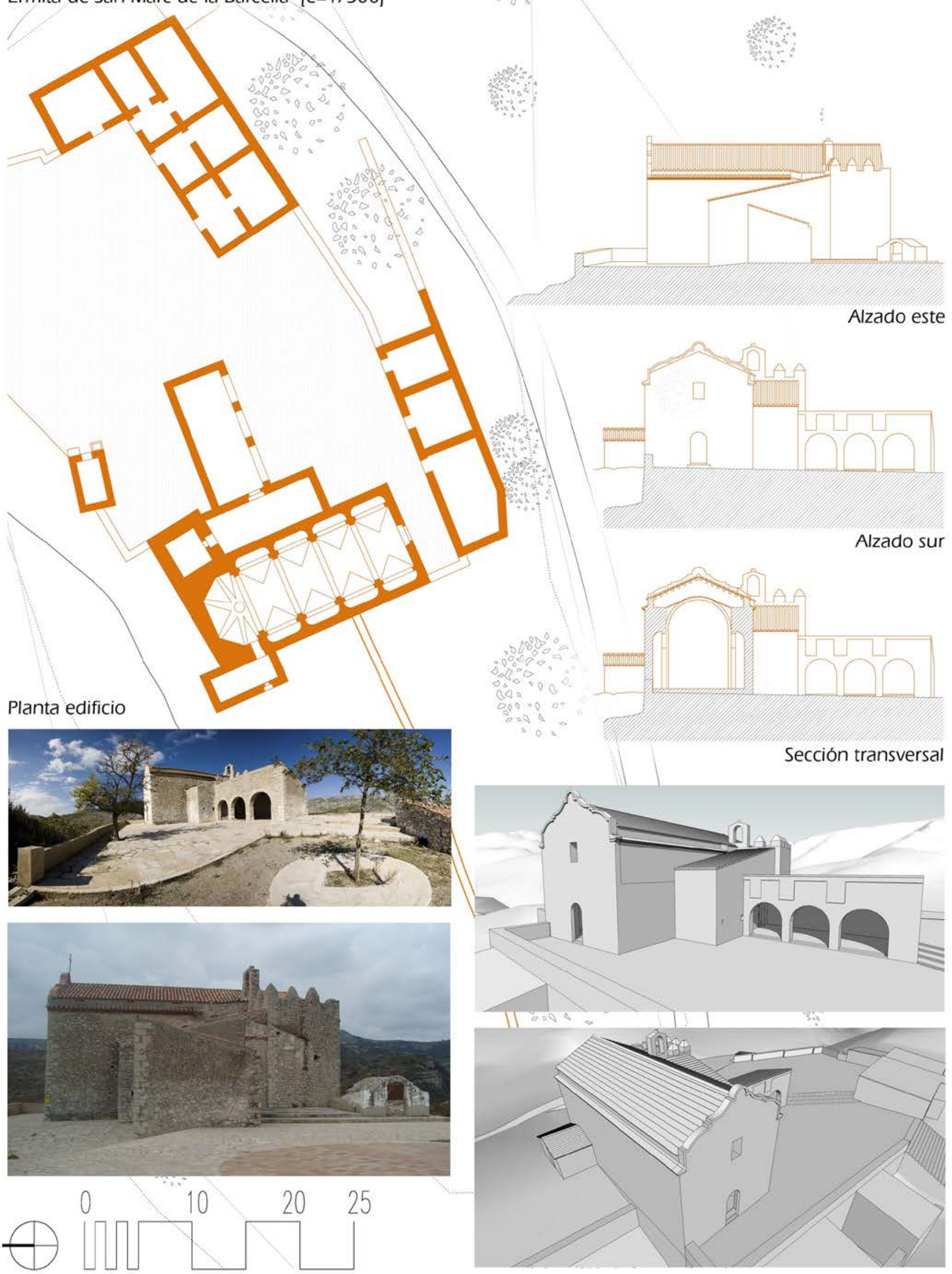




\section{Zona 3 - Molinar / Xert}

Arquitecturas - Iglesias / ermitas

Iglesia de Xert [e=1/500]
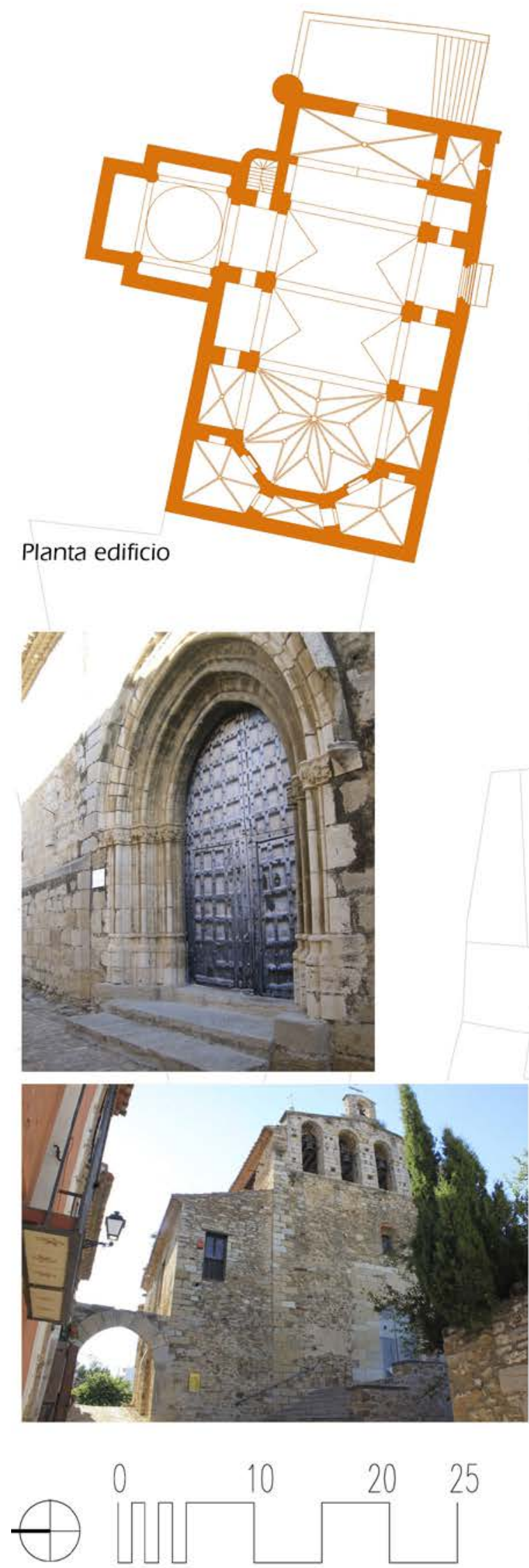

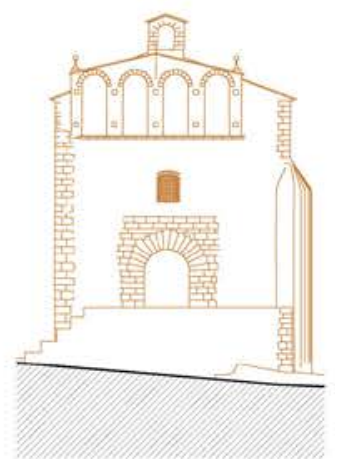

Alzado este

Alzado sur
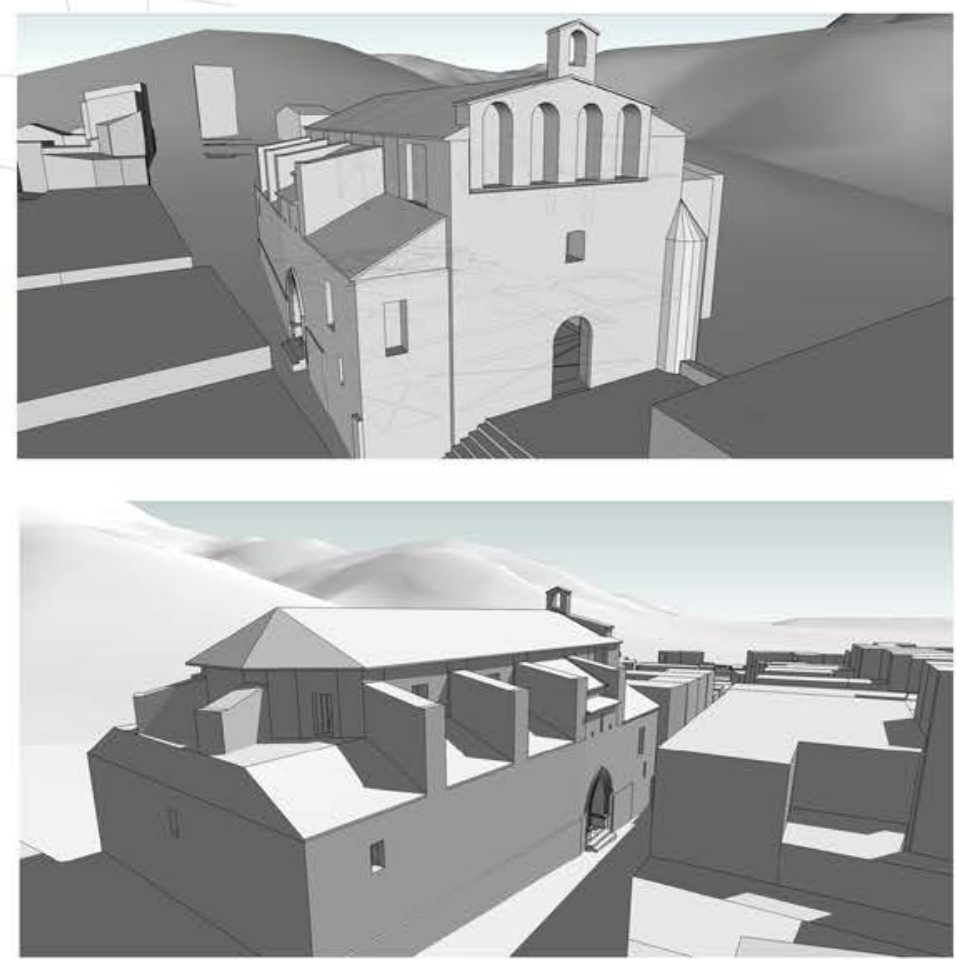


\section{Zona 5 - Canet}

Arquitecturas - Iglesias / ermitas

Ermita de Santa Isabel $[e=1 / 200]$
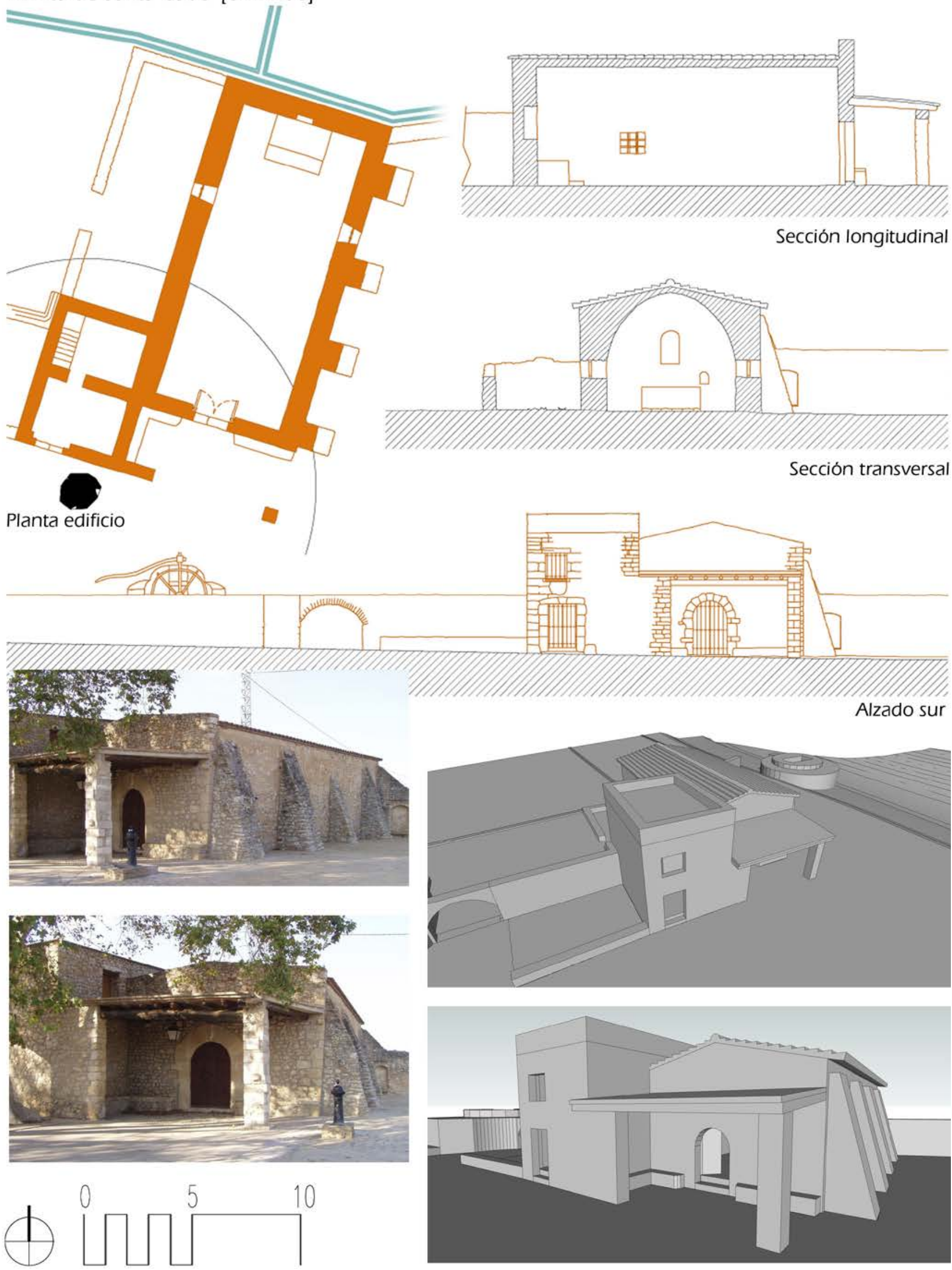

Alzado sur
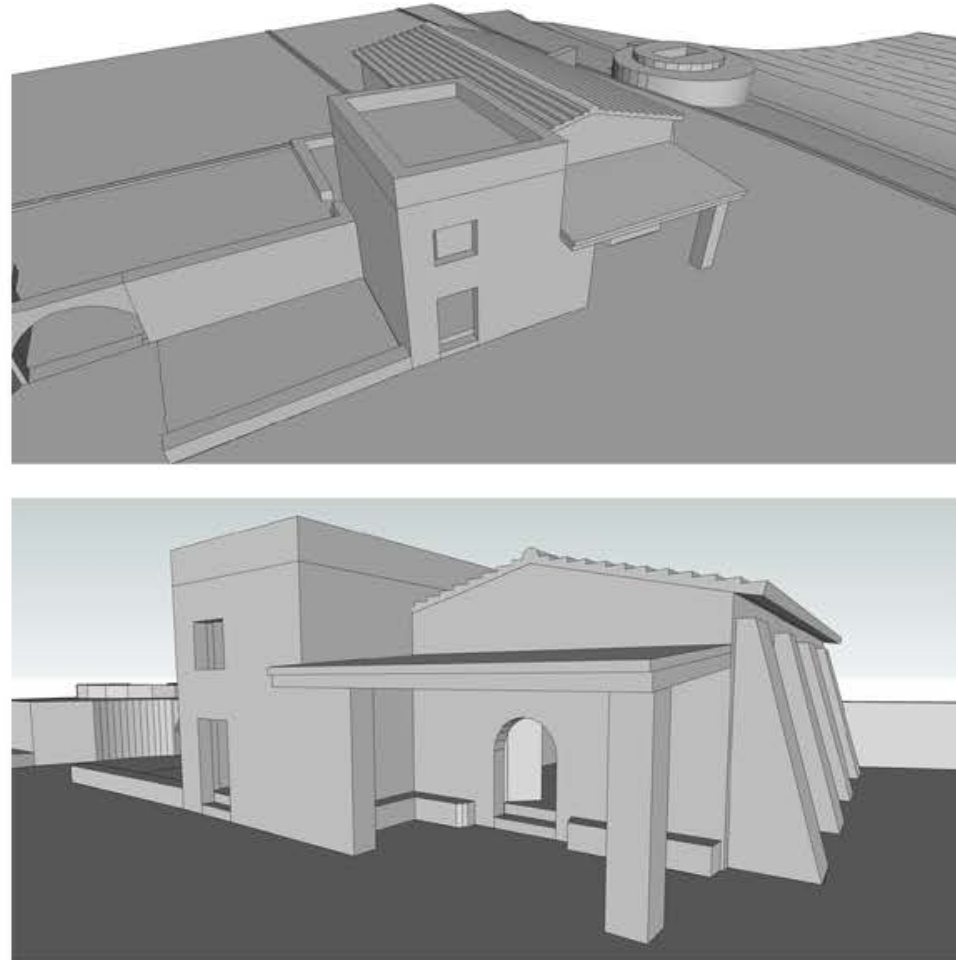


\section{Zona 5 - Canet}

Arquitecturas - Iglesias / ermitas

Ermita y norias de Santa Isabel $[e=1 / 500]$

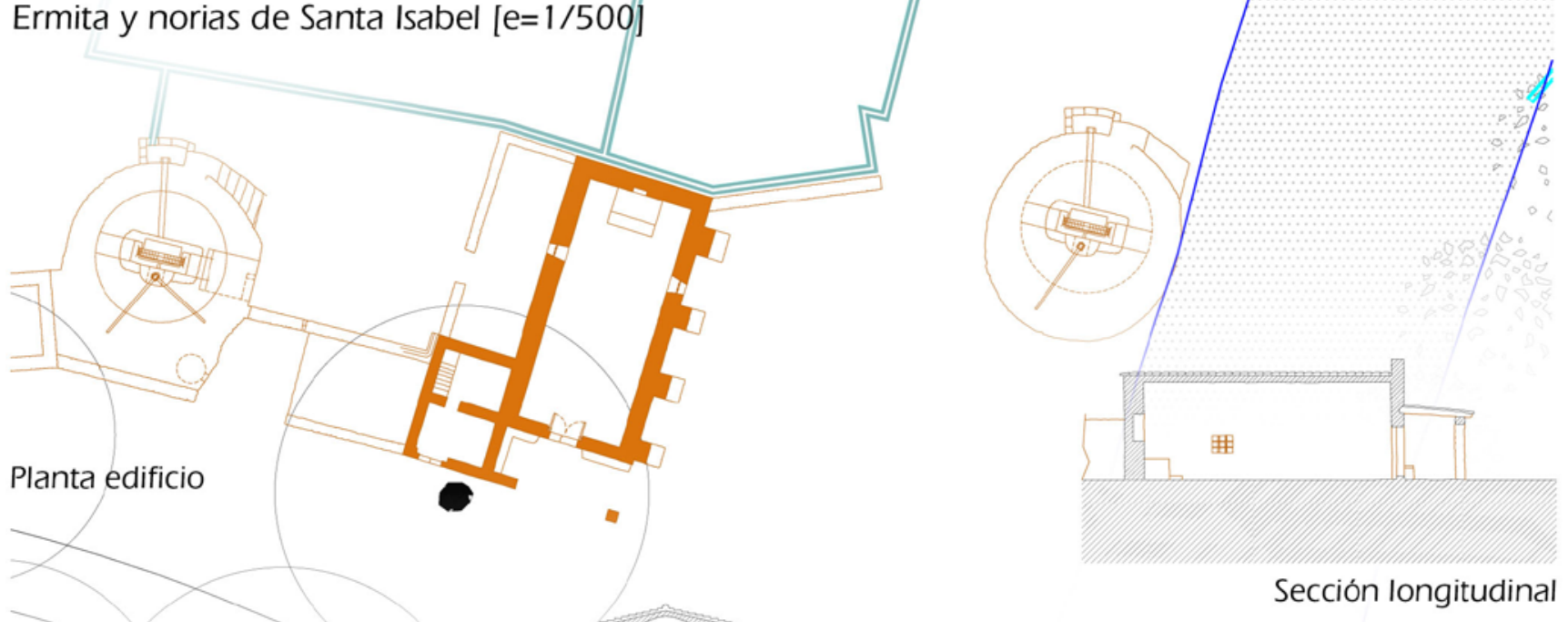

Sección transversal

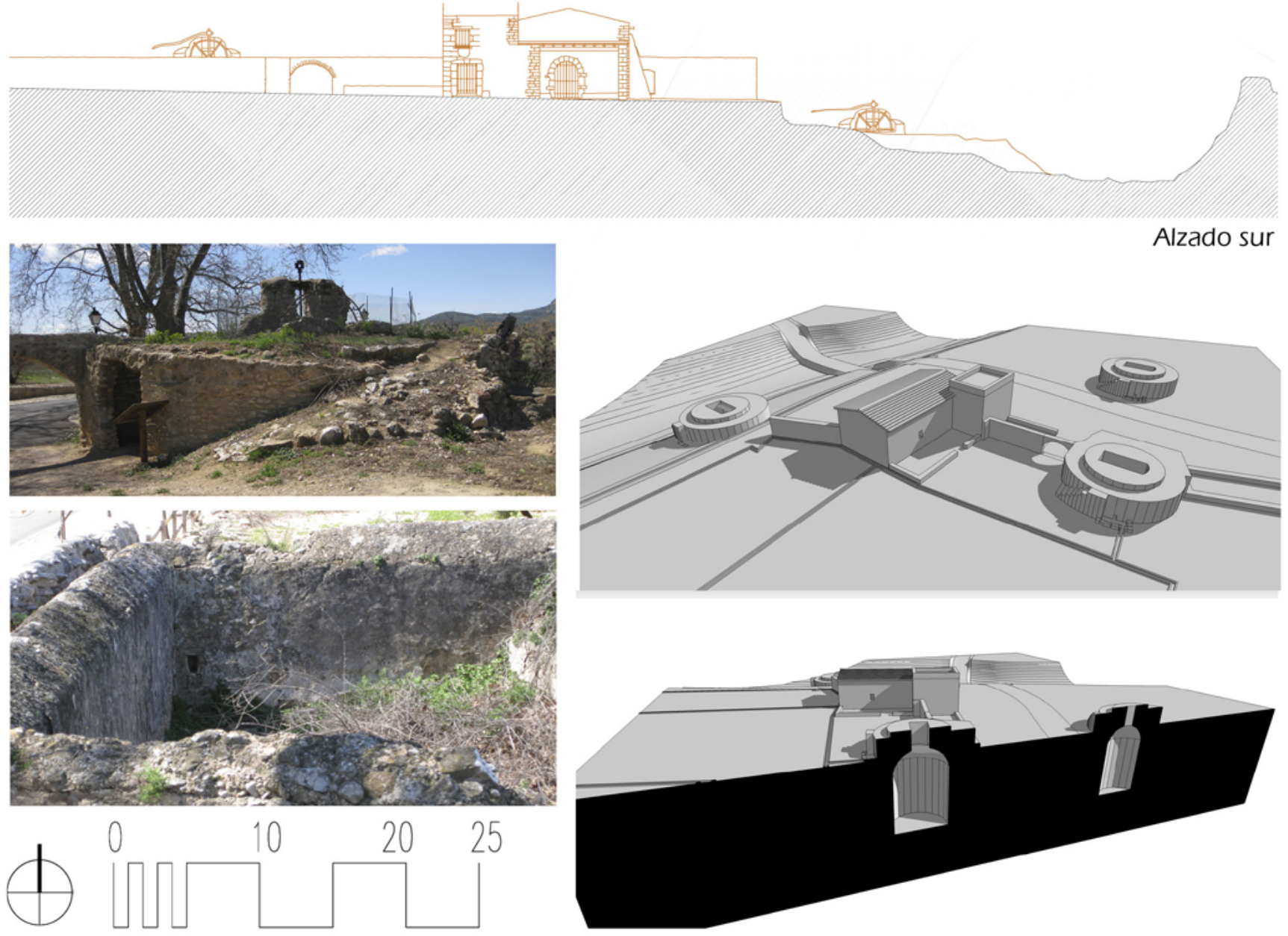




\section{Zona 6 - La Jana / Carrascal}

Arquitecturas - Iglesias / ermitas

Santuario Virgen de la Salut $[e=1 / 500]$

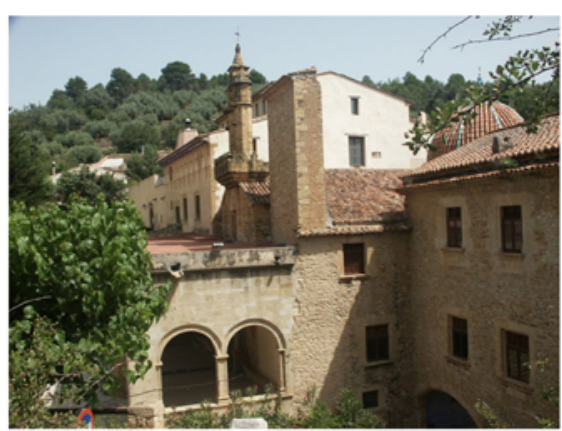

Fuente: Estudio previo Arquitecto: Francisco Grande Ignacio Gil Mascarell
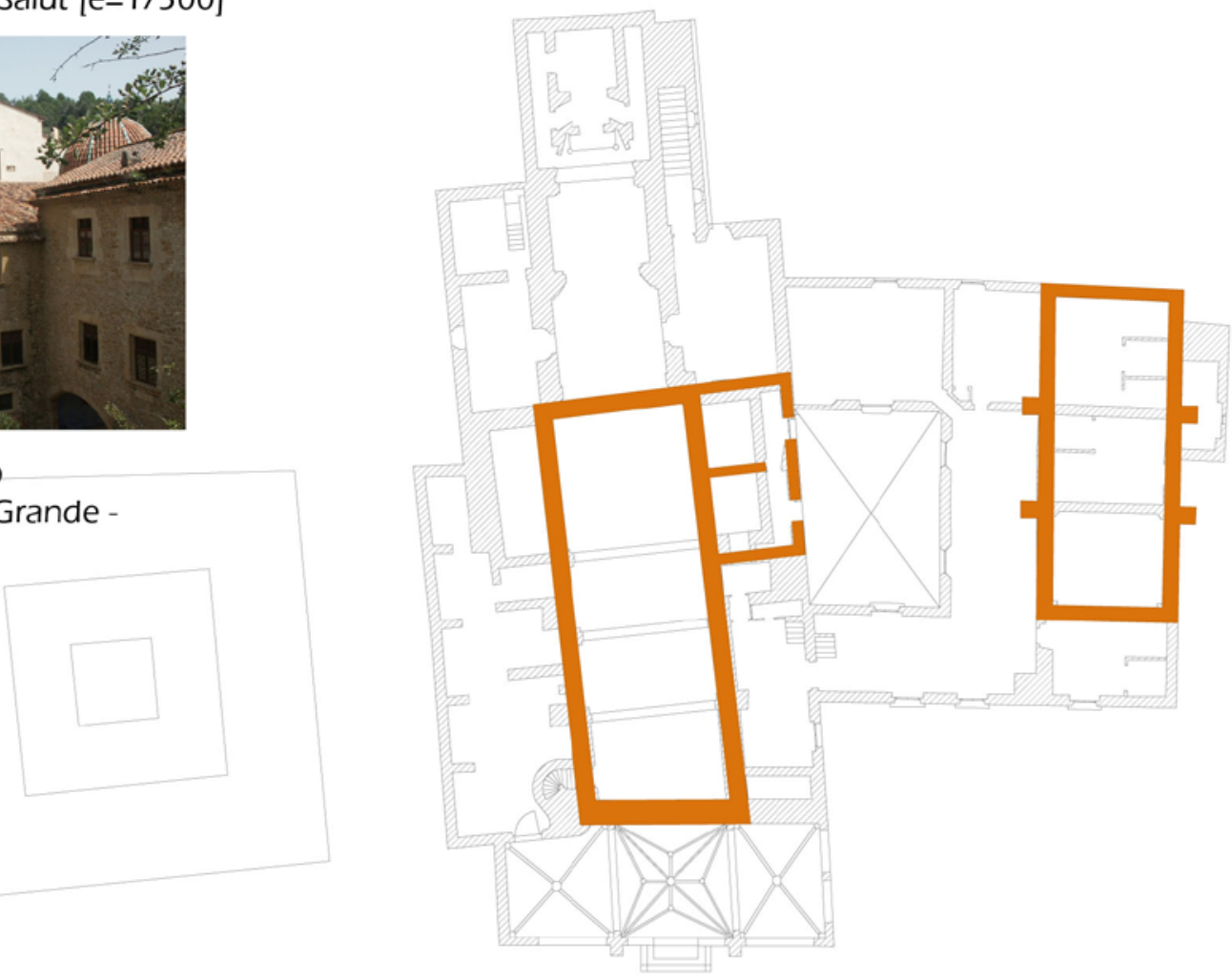

Planta baja (resaltado: hospedería e iglesia s. XIV - XV)
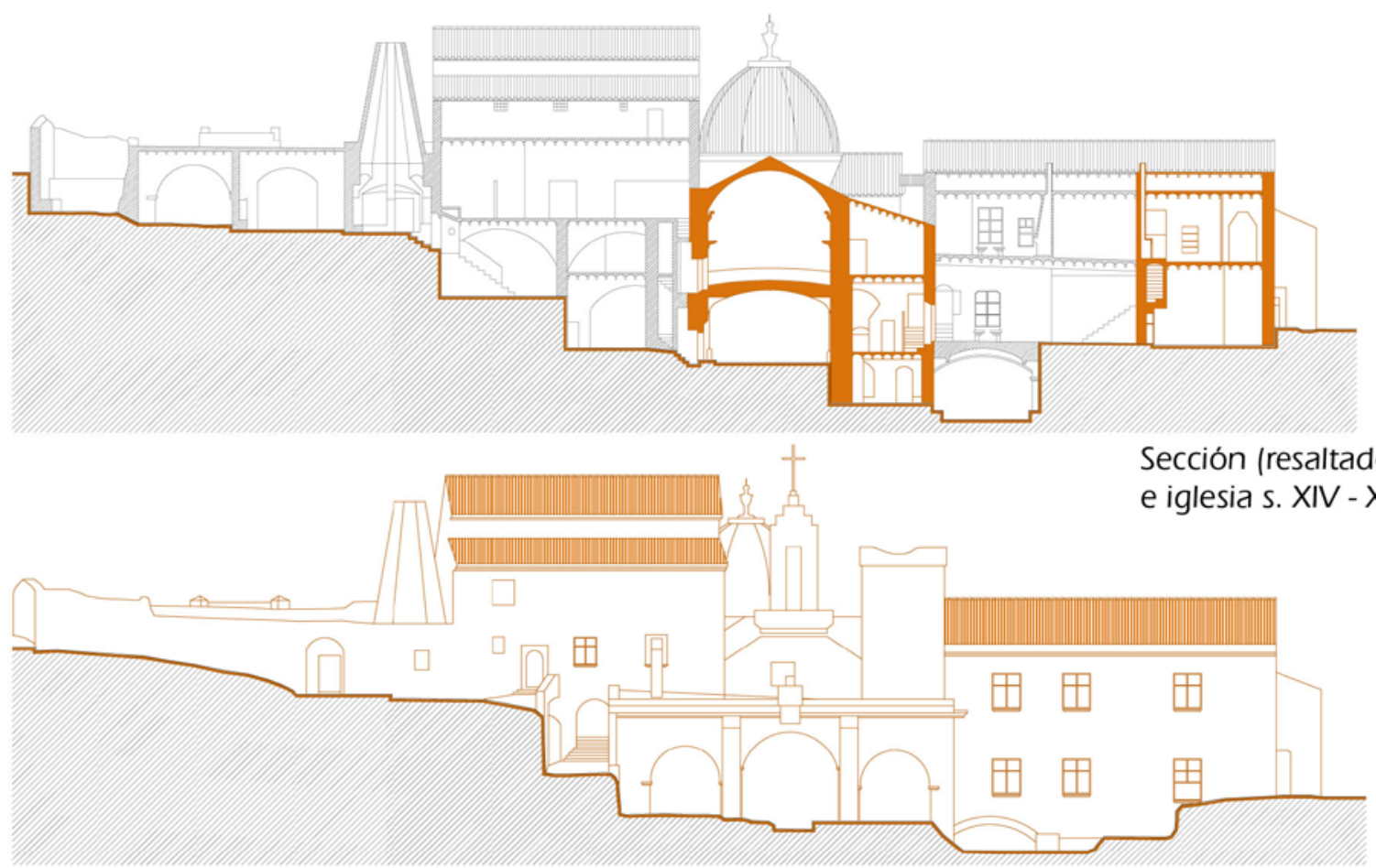

Sección (resaltado: hospedería e iglesia s. XIV - XV)

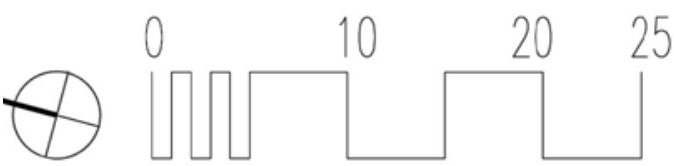

Alzado frontal 


\section{Zona 7 - Sán Mateo}

Arquitecturas - Iglesias / ermitas

Campanario Iglesia de San Mateo $[\mathrm{e}=1 / 500]$

Planta baja Iglesia y campanario

Fuente: Servici d'Arquitectura - Conselleria de Cultura Arquitecto: Teodoro Peñarroja Torrejón -

Juan Fco. Pérez Mengual (1985)

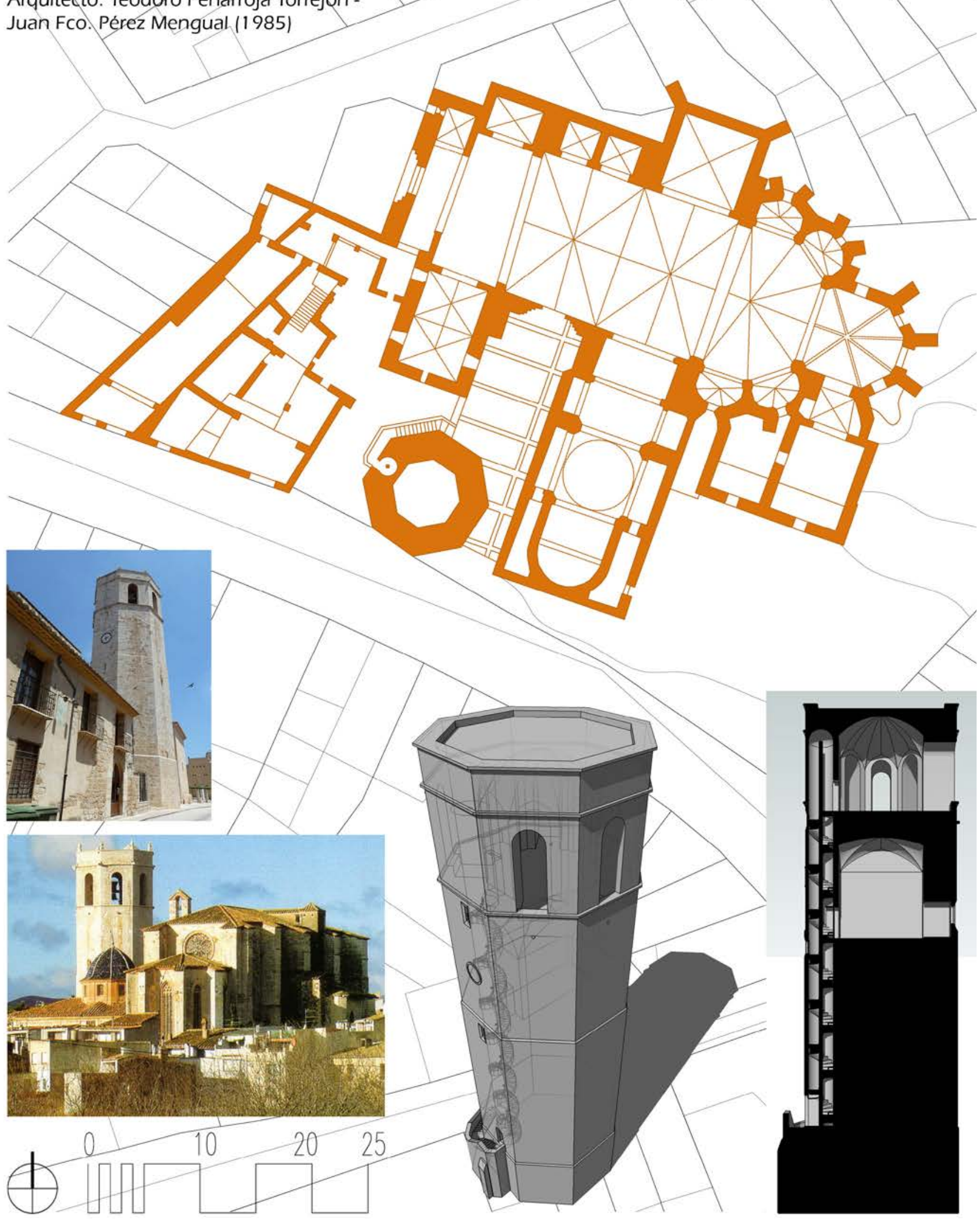




\section{Otras zonas de interés}

Arquitecturas - Iglesias / ermitas

Iglesia de Coratxar $[e=1 / 500]$
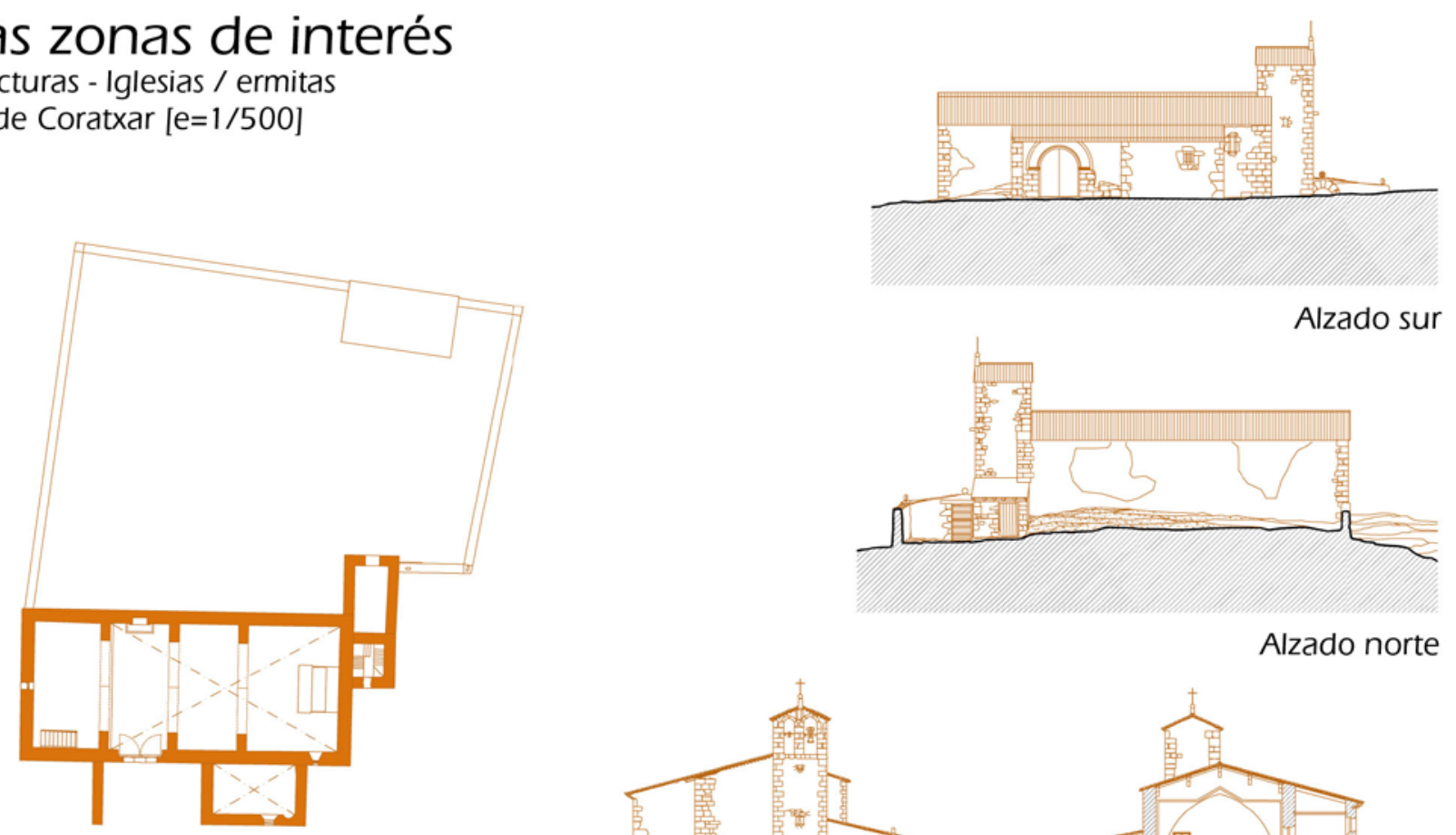

Planta baja
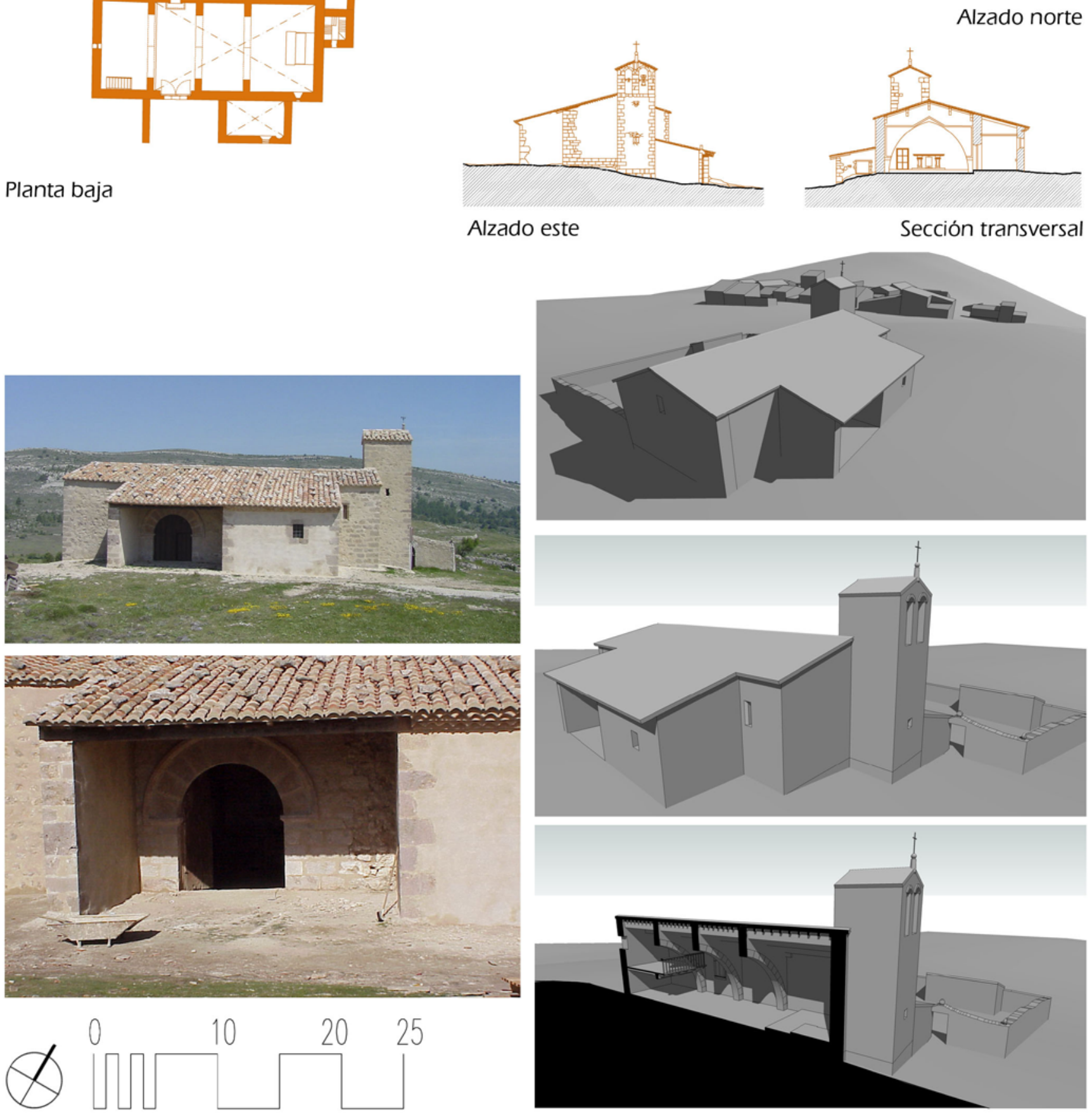


\section{Otras zonas de interés}

Arquitecturas - Iglesias / ermitas

Ermitorio de Sant Pau, Albocácer [e=1/500]
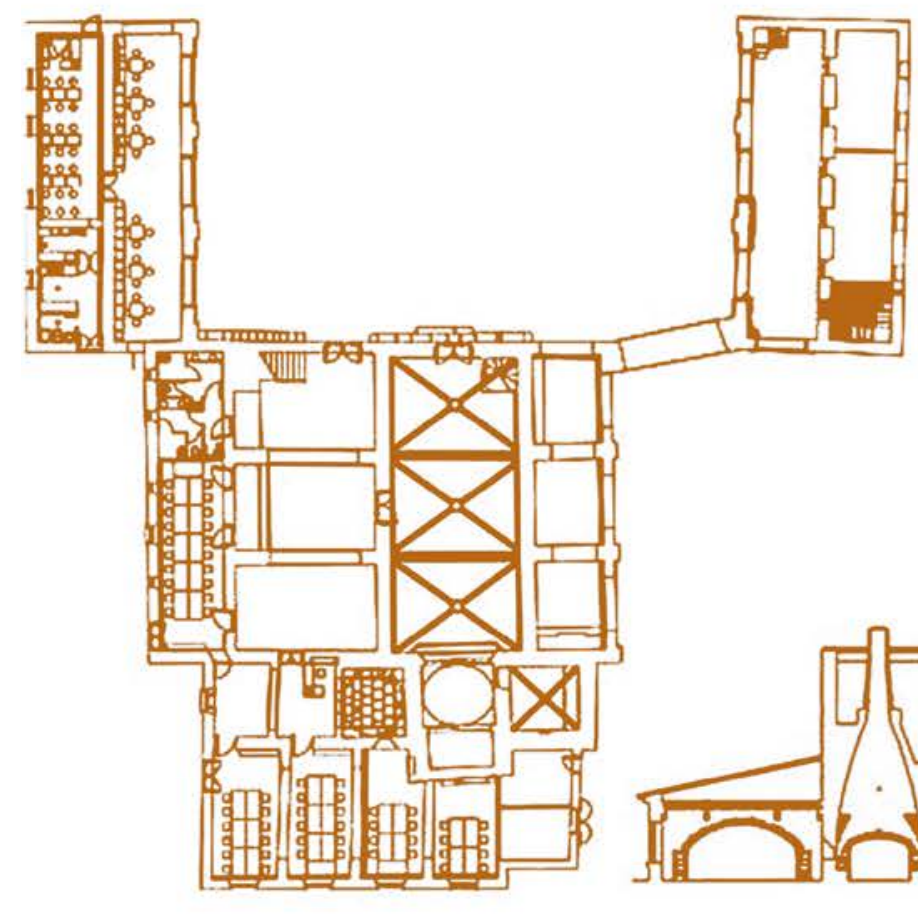

Planta baja y sección ermitorio Fuente: web oficial Carlos Campos

Arquitecto: Carlos Campos (2005)
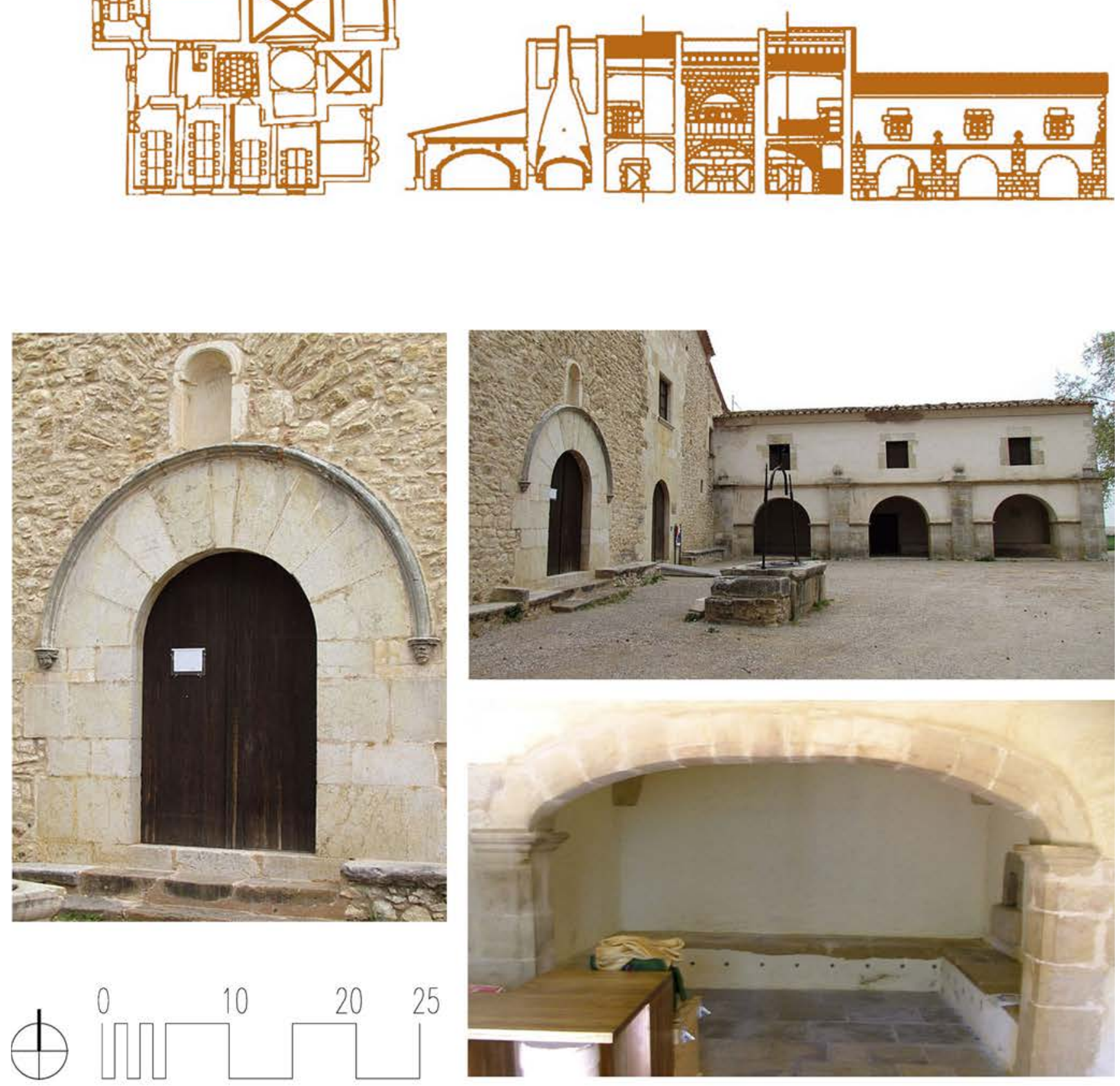


\section{Zona 2 - Barcella}

Arquitecturas - Torres

Ermita de San Marc de la Barcella $[e=1 / 200]$
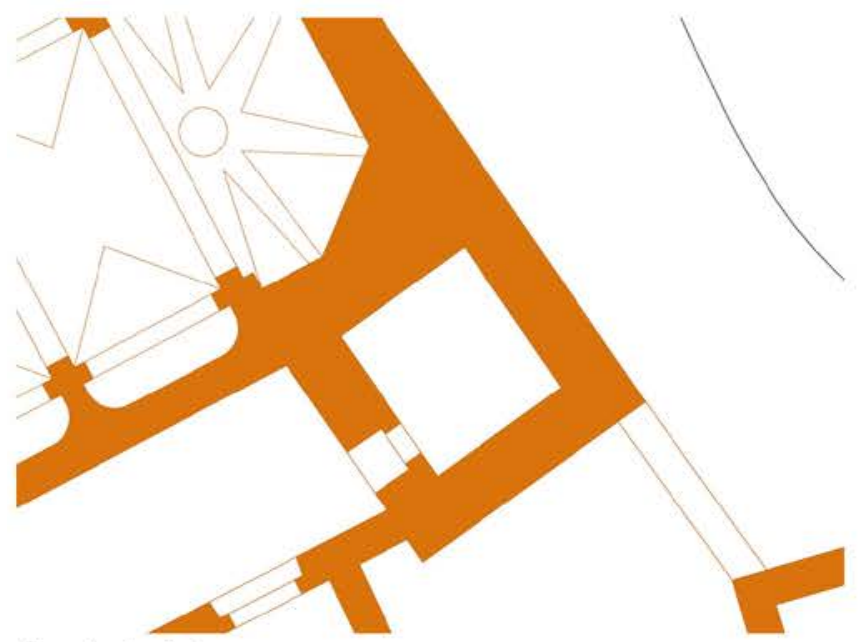

Planta baja torre
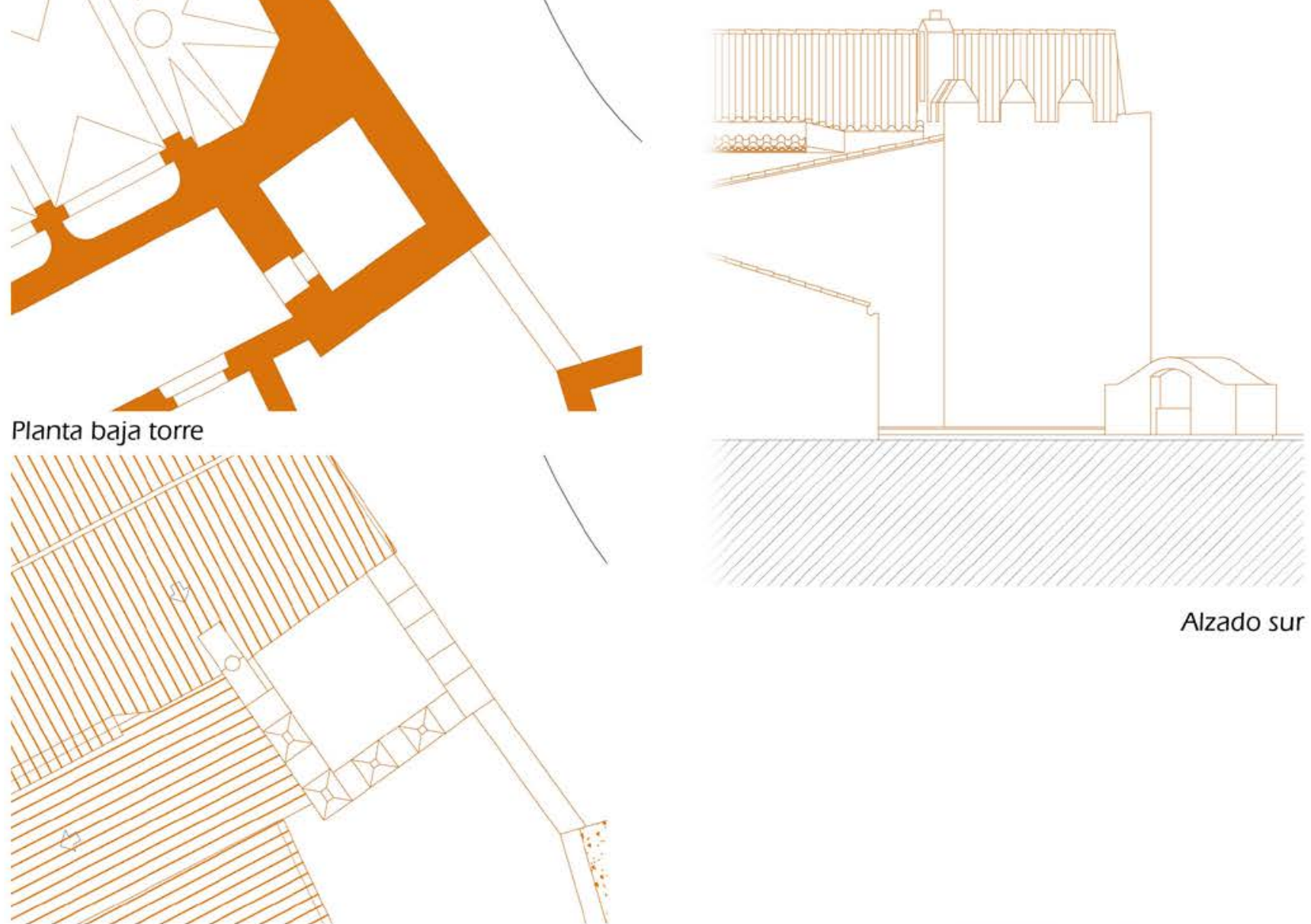

Planta cubiertas
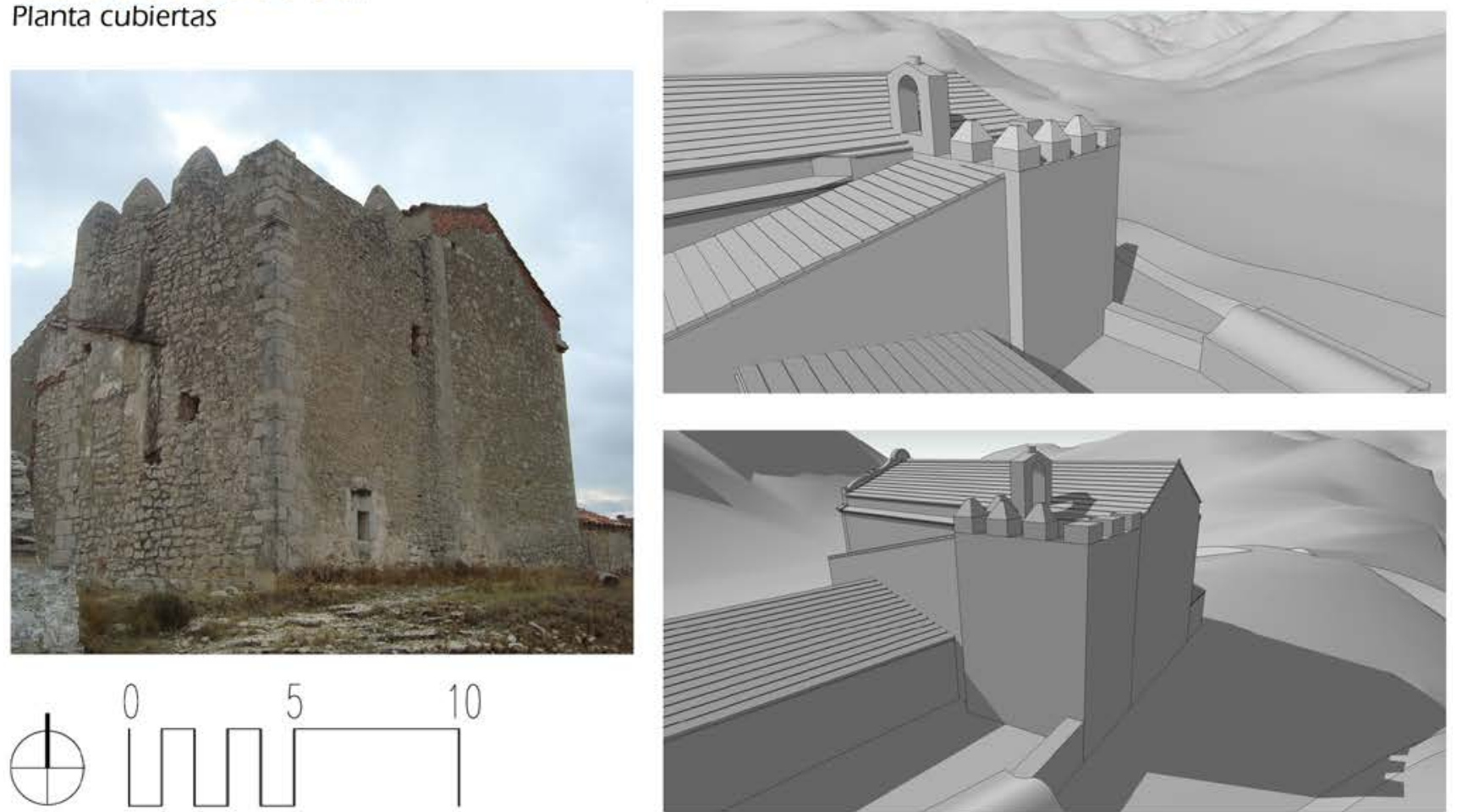


\section{Zona 3 - Molinar / Xert}

Arquitecturas - Torres

Torre Solsides $[\mathrm{e}=1 / 200]$

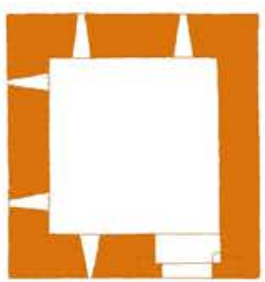

Planta edificio

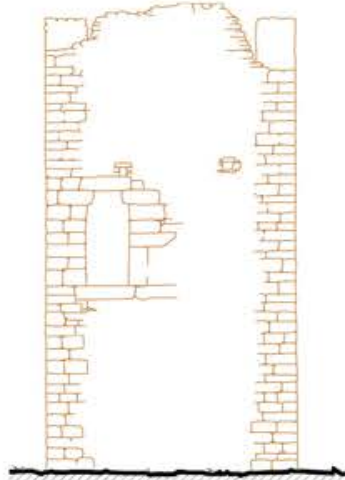

Alzado este
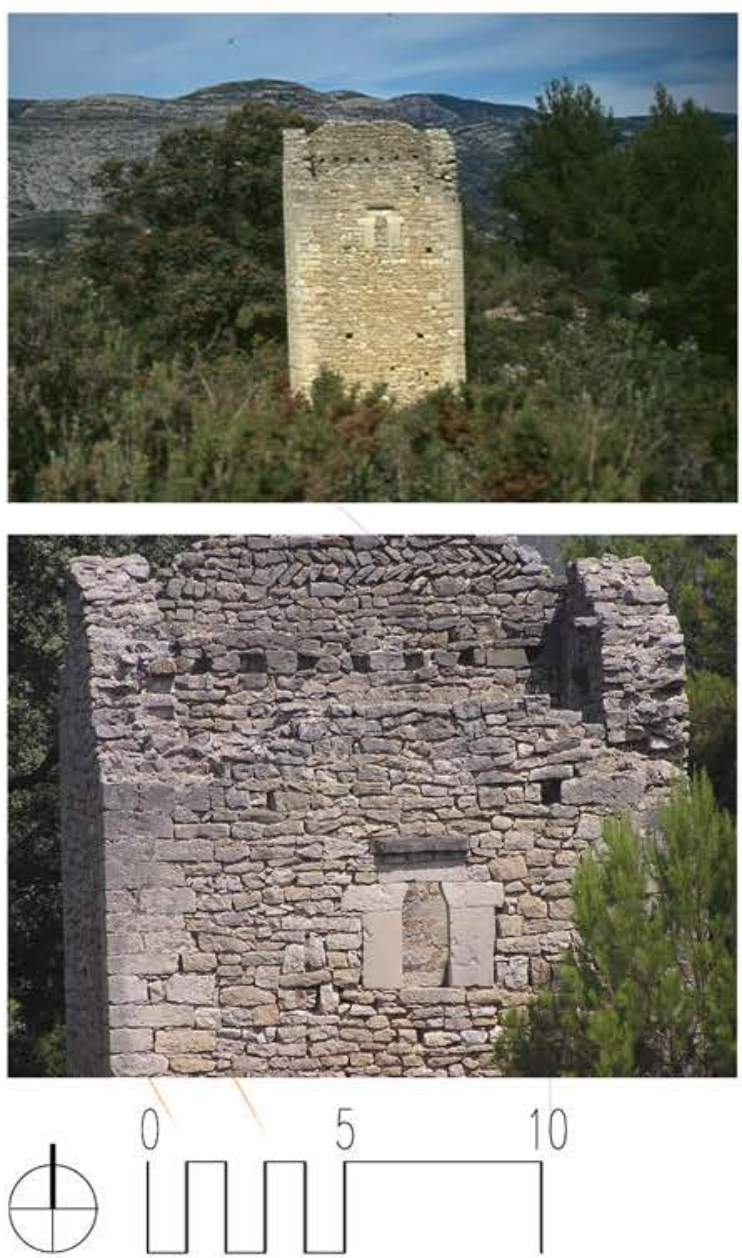

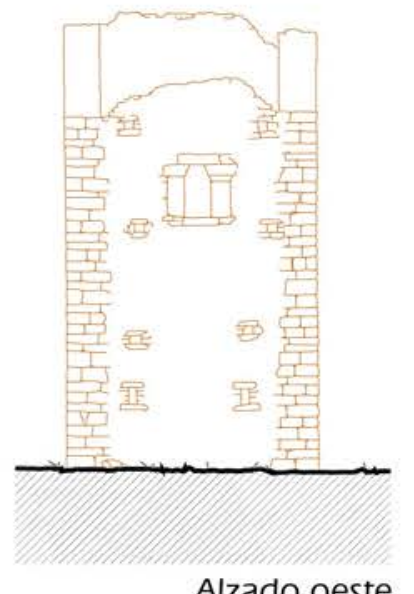

Alzado oeste

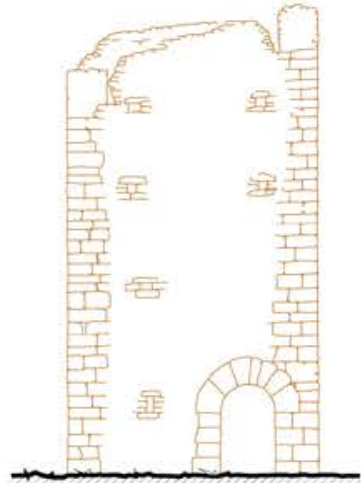

Alzado sur
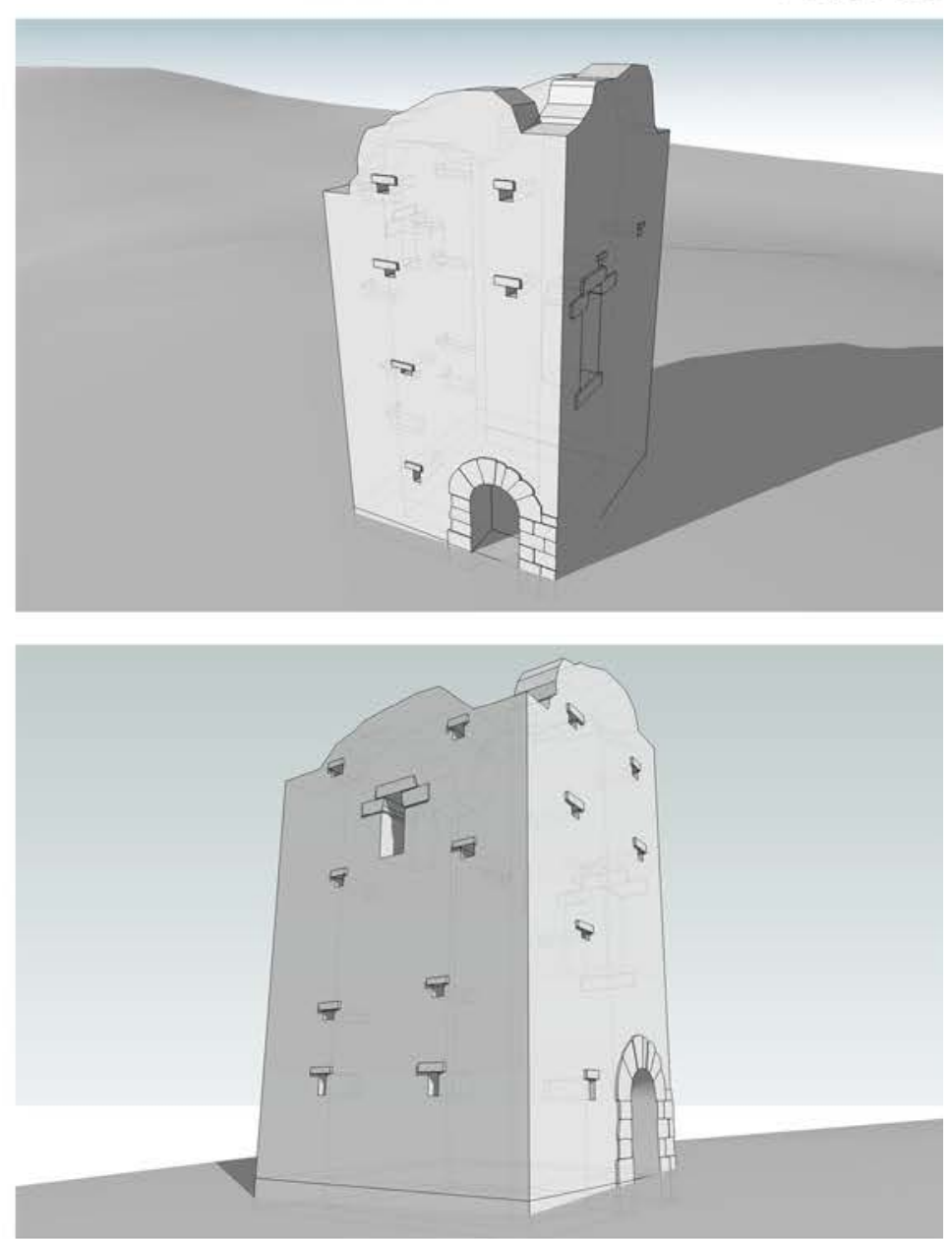


\section{Zona 3 - Molinar $/$ Xert}

Arquitecturas - Torres

Torre Molinar $[\mathrm{e}=1 / 500]$

Planta de entorno cercano
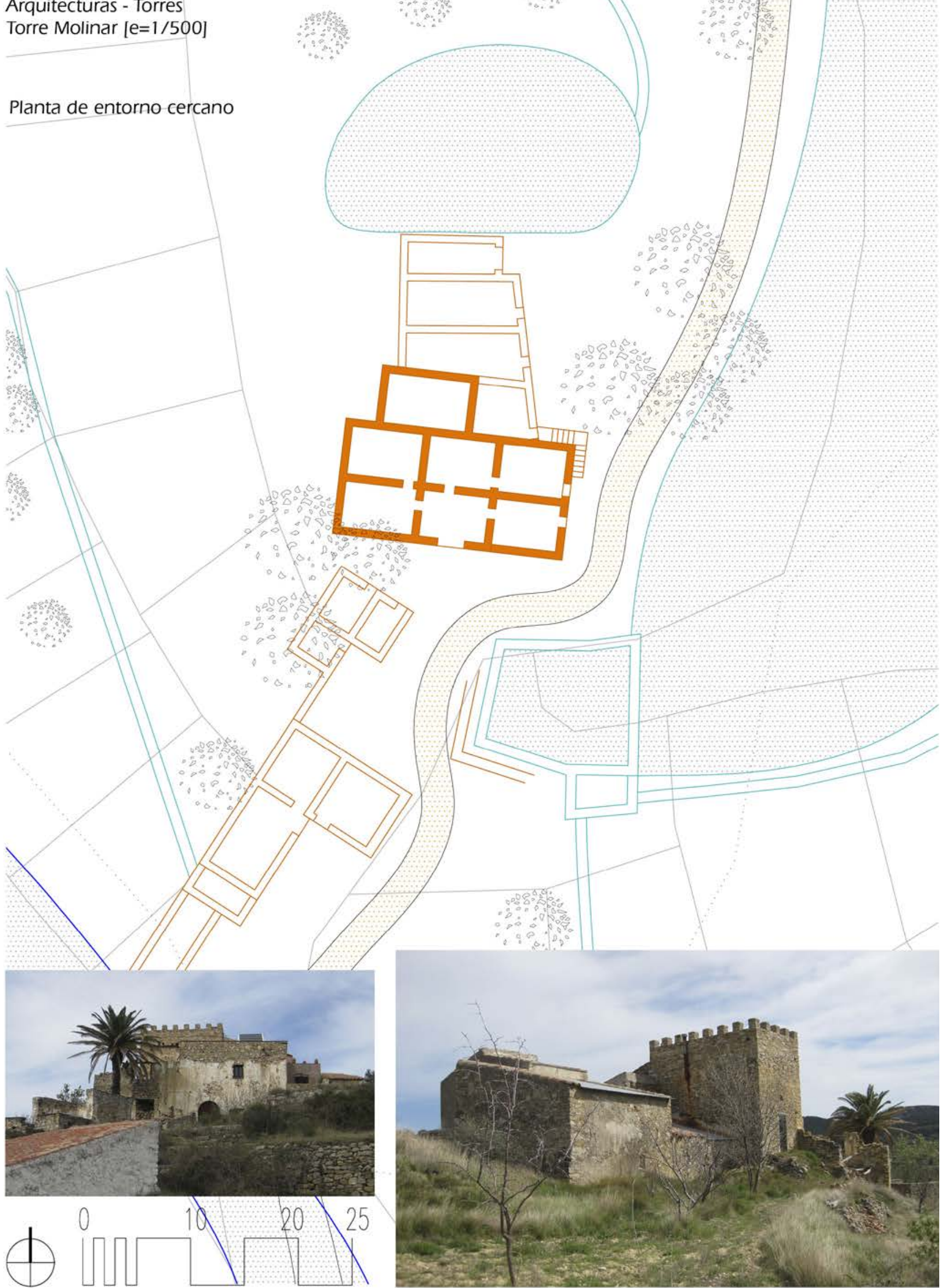


\section{Zona 10 - Cervera / Calig}

Arquitecturas - Torres

Torre de Calig $[\mathrm{e}=1 / 500]$

Fuente: Proyecto de restauración

Arquitecto: Fernando Vegas -

Camila Mileto

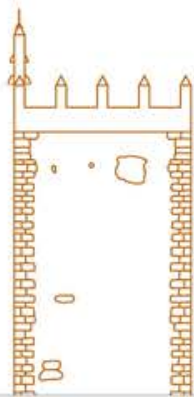

Alzado este
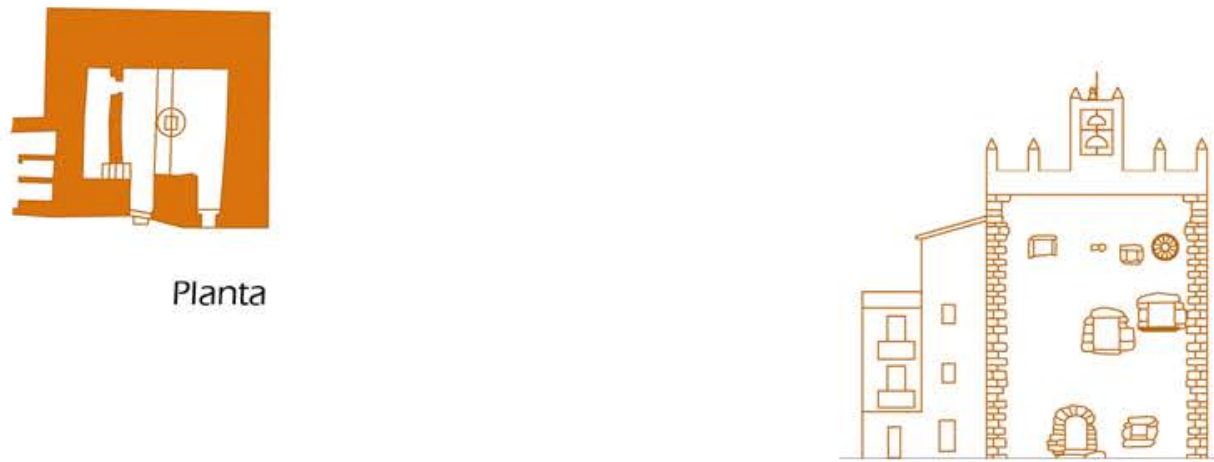

Alzado oeste
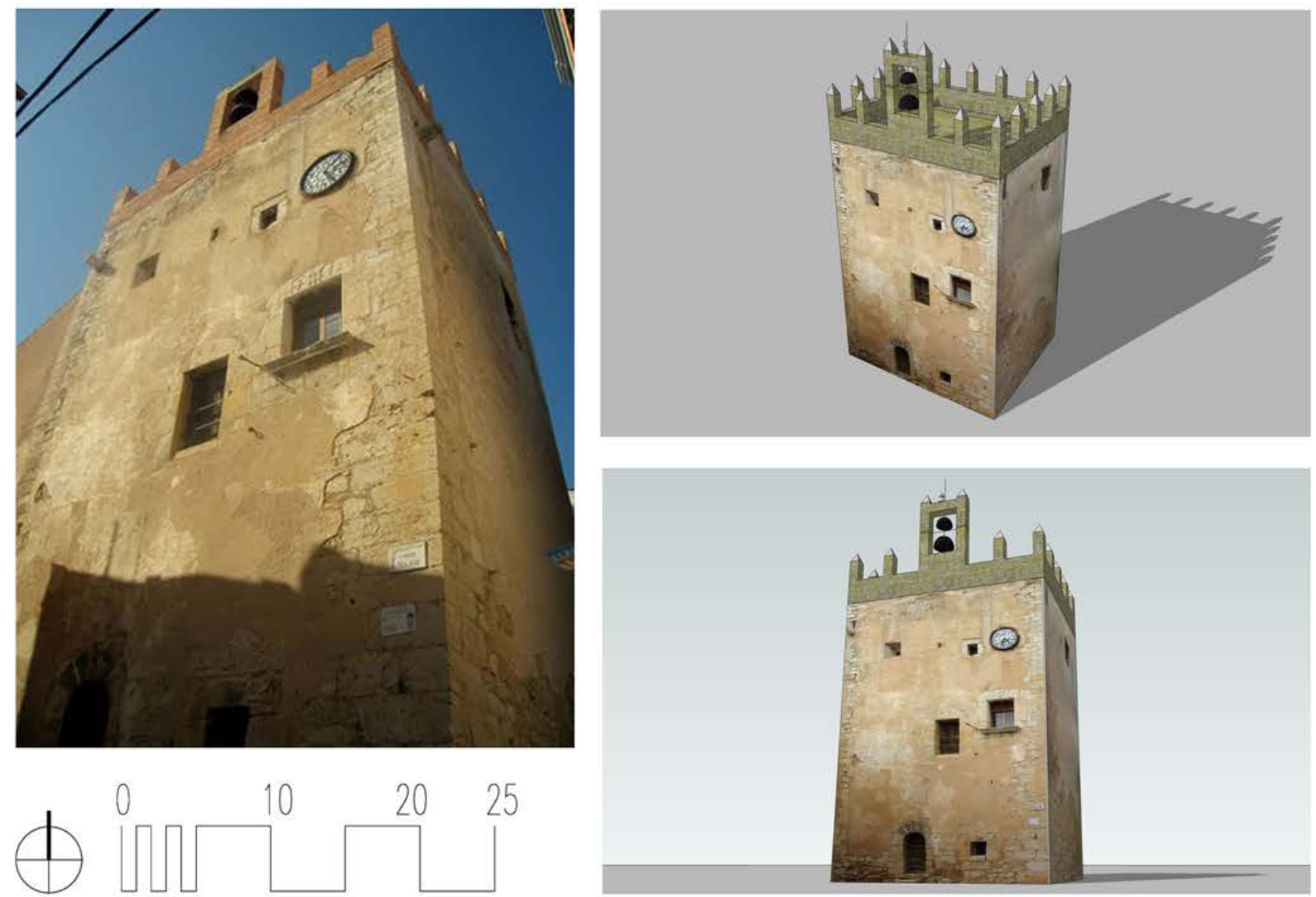


\section{Zona 3 - Molinar / Xert \\ Arquitecturas - Puentes \\ Molino puente $[e=1 / 200]$}
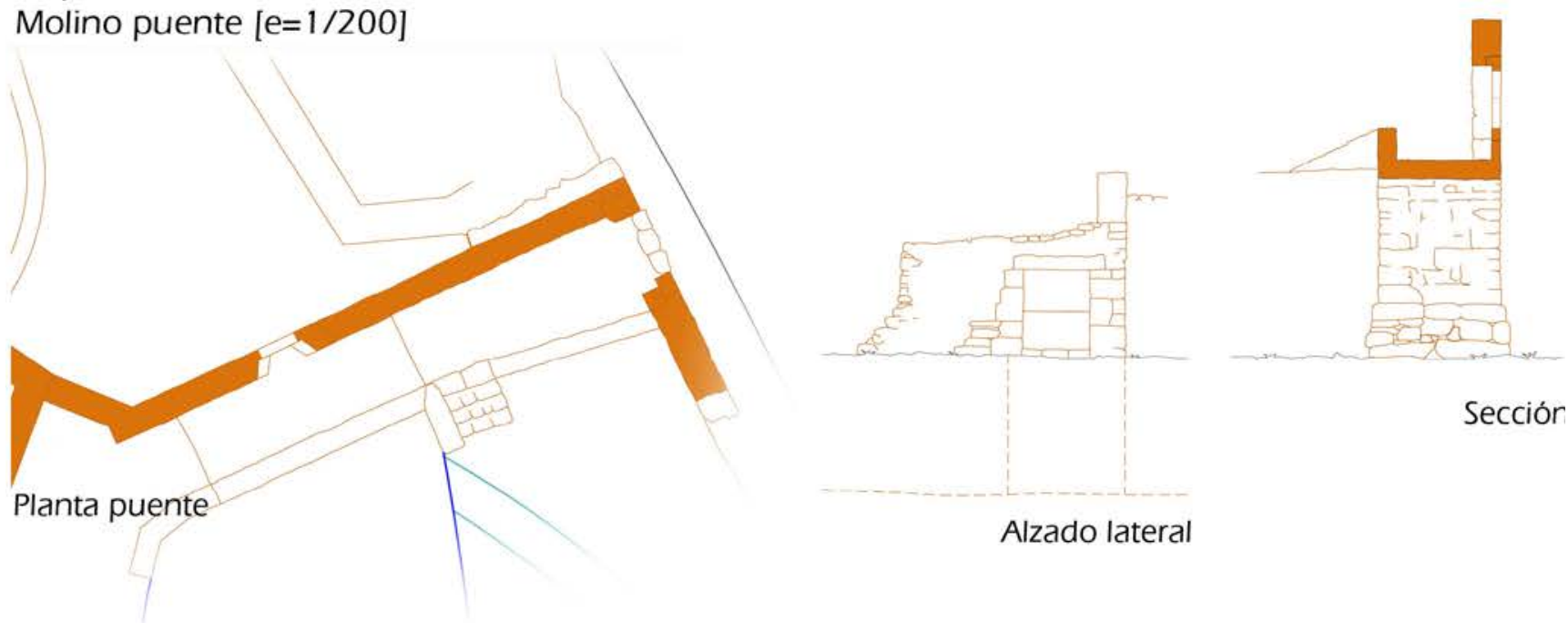

Secciór
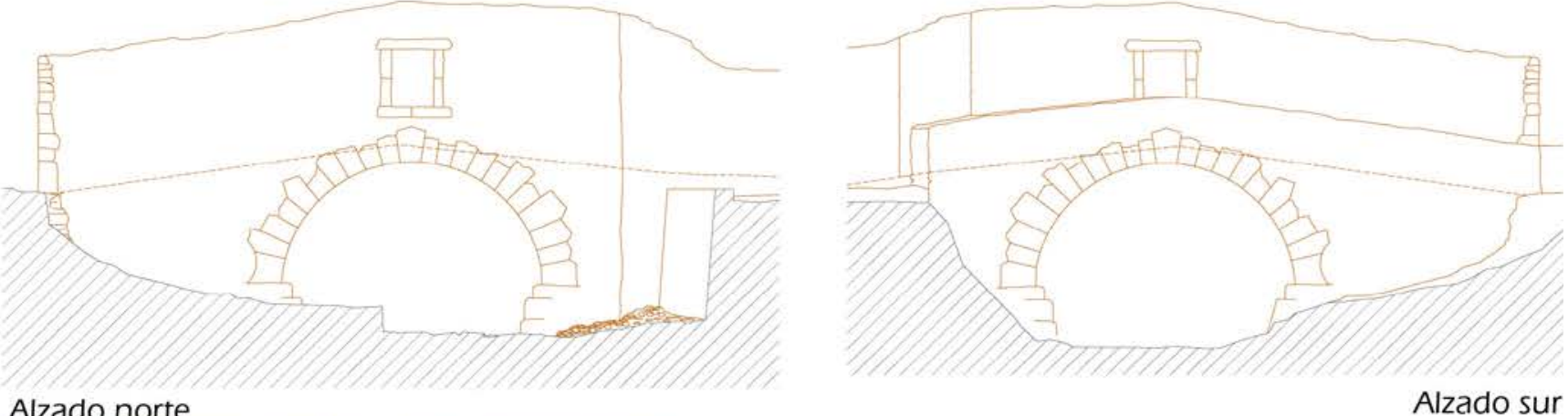

\section{Alzado norte}

Alzado lateral
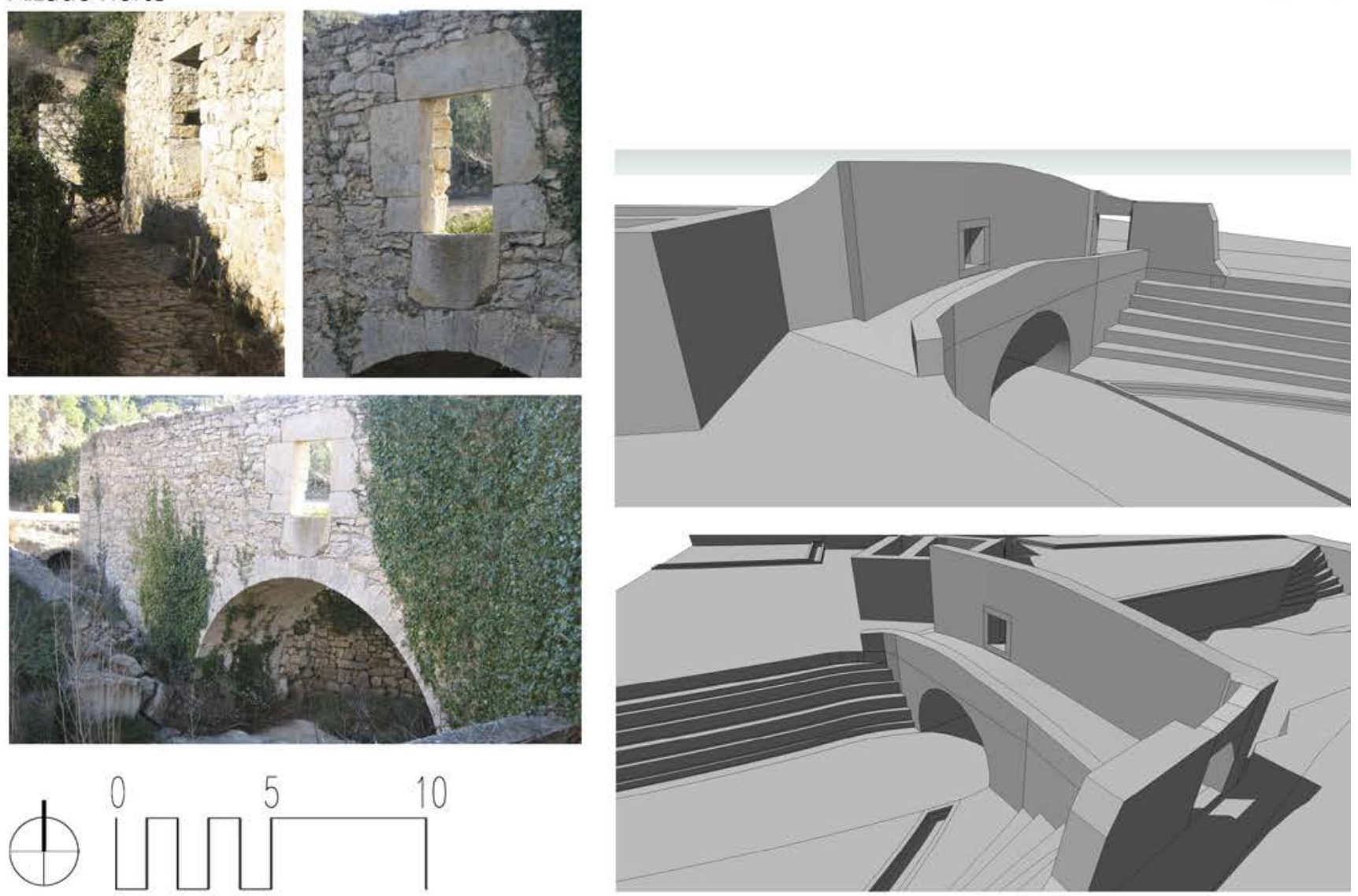


\section{Otras zonas de interés} Arquitecturas - Puentes

Puente medieval Pobla de Ballestar $[e=1 / 500]$
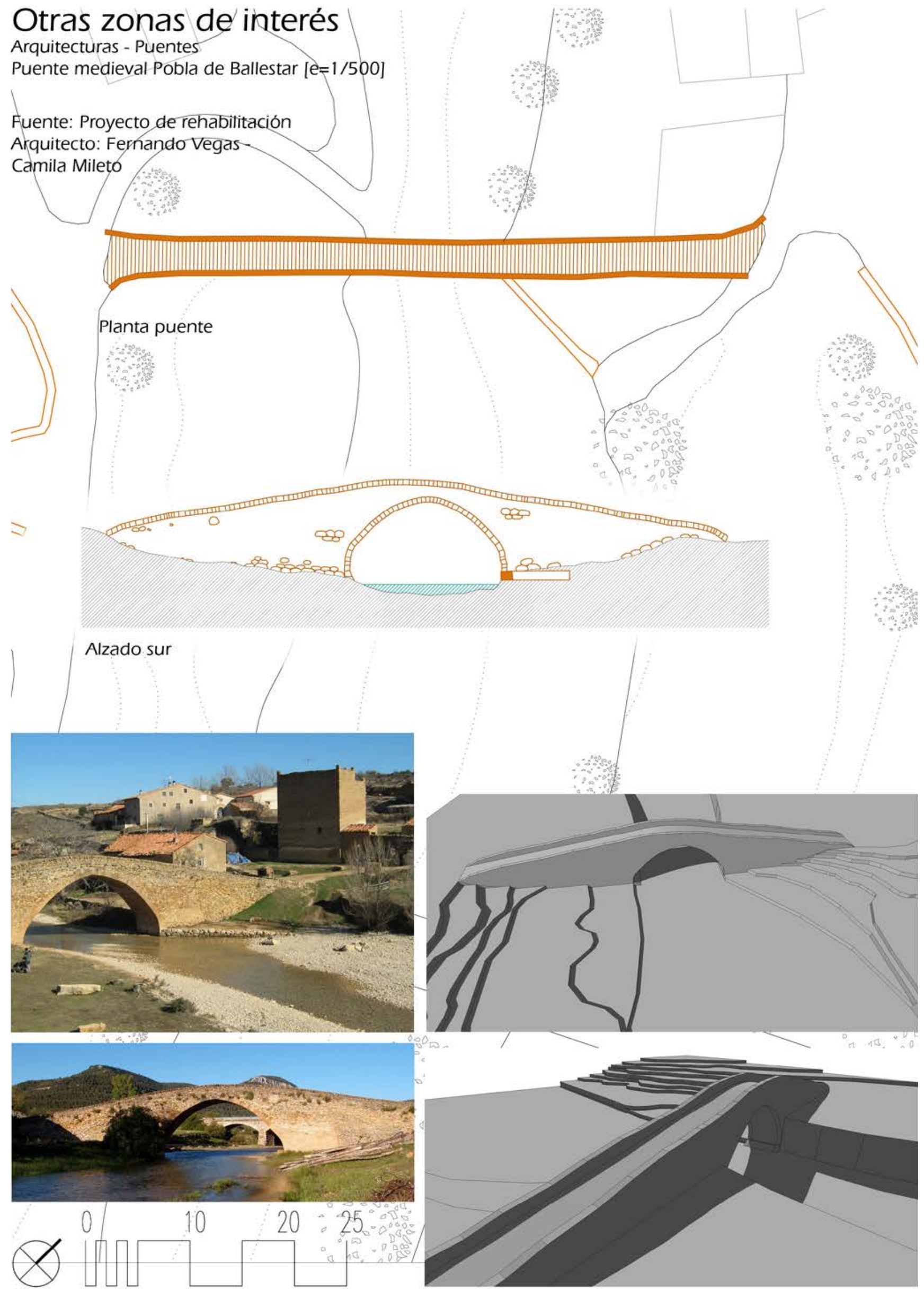


\section{Zona 7 - San Mateo}

Arquitecturas - Hornos

Horno de san Mateo $[e=1 / 500]$
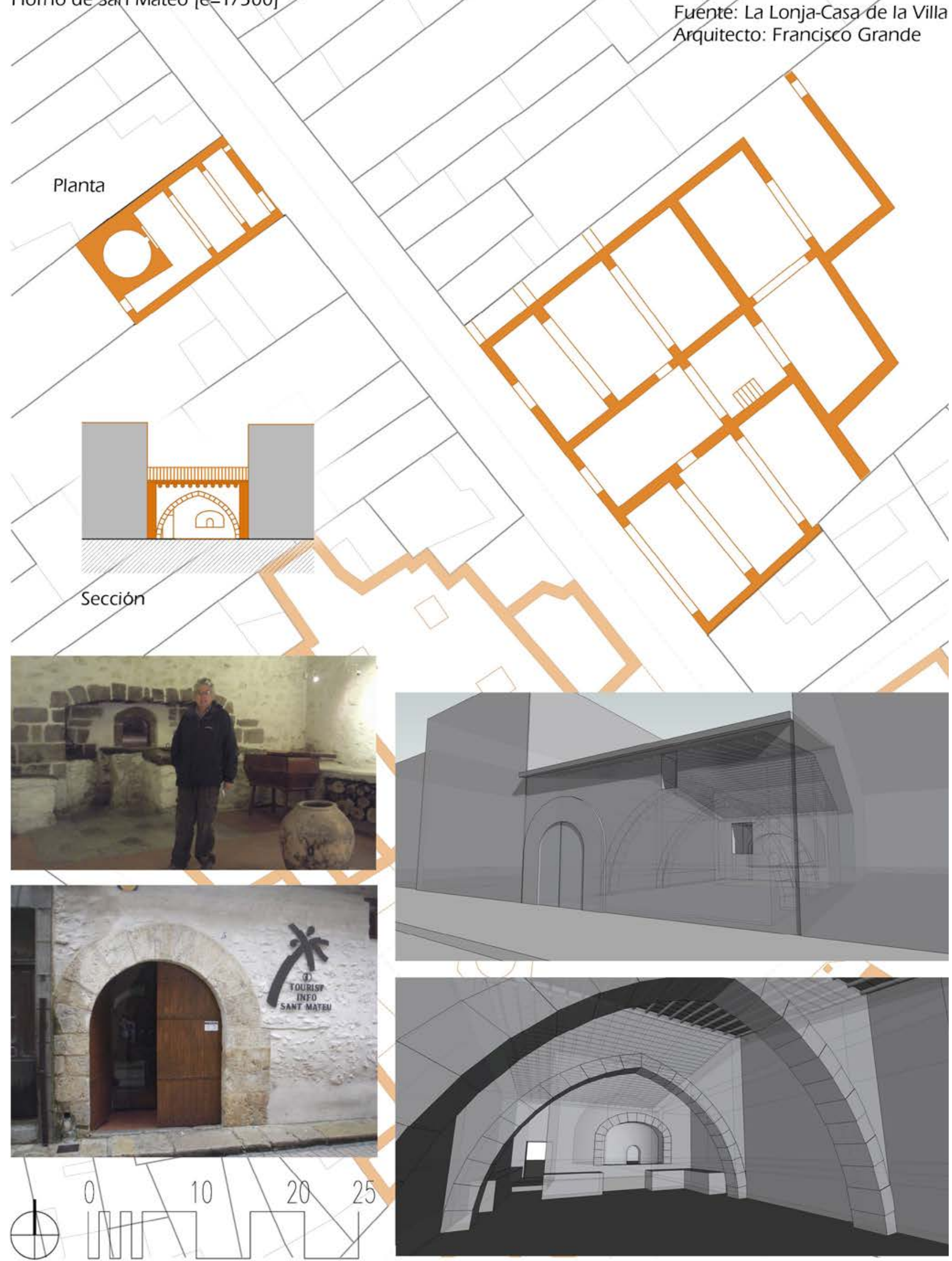


\section{Zona 7 - San Mateo}

\section{Arquitecturas - Palacios}

Palacio de San Mateo $[\mathrm{e}=1 / 500]$

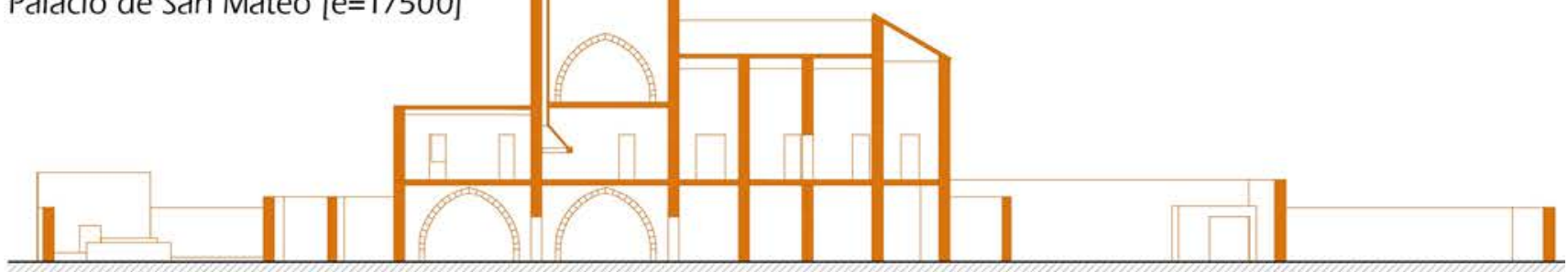

Sección longitudinal

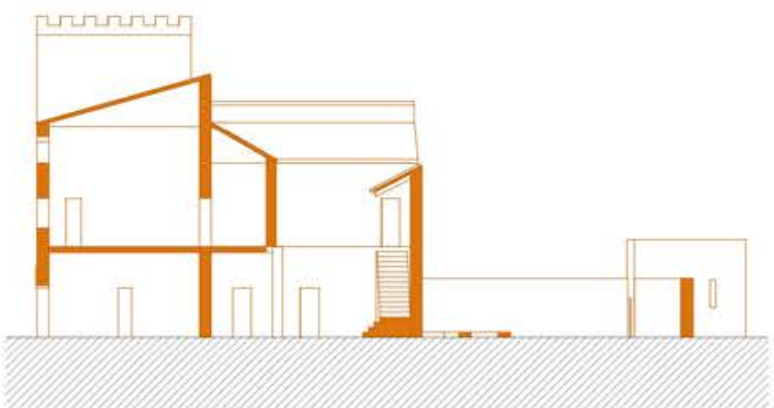

Sección transversal

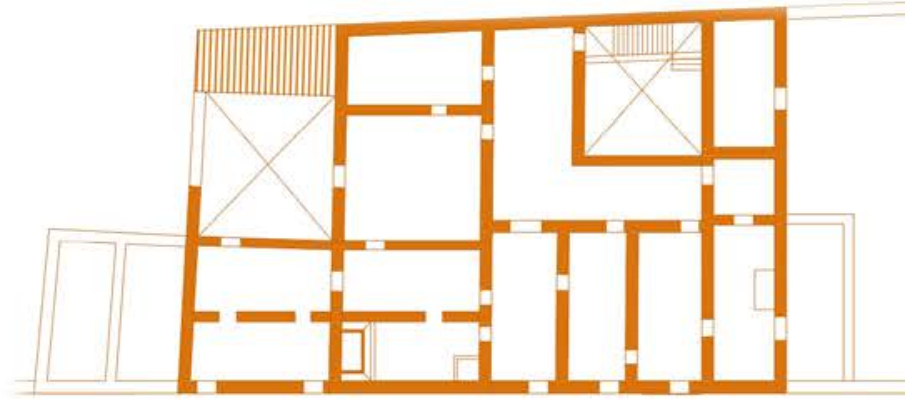

Planta primera

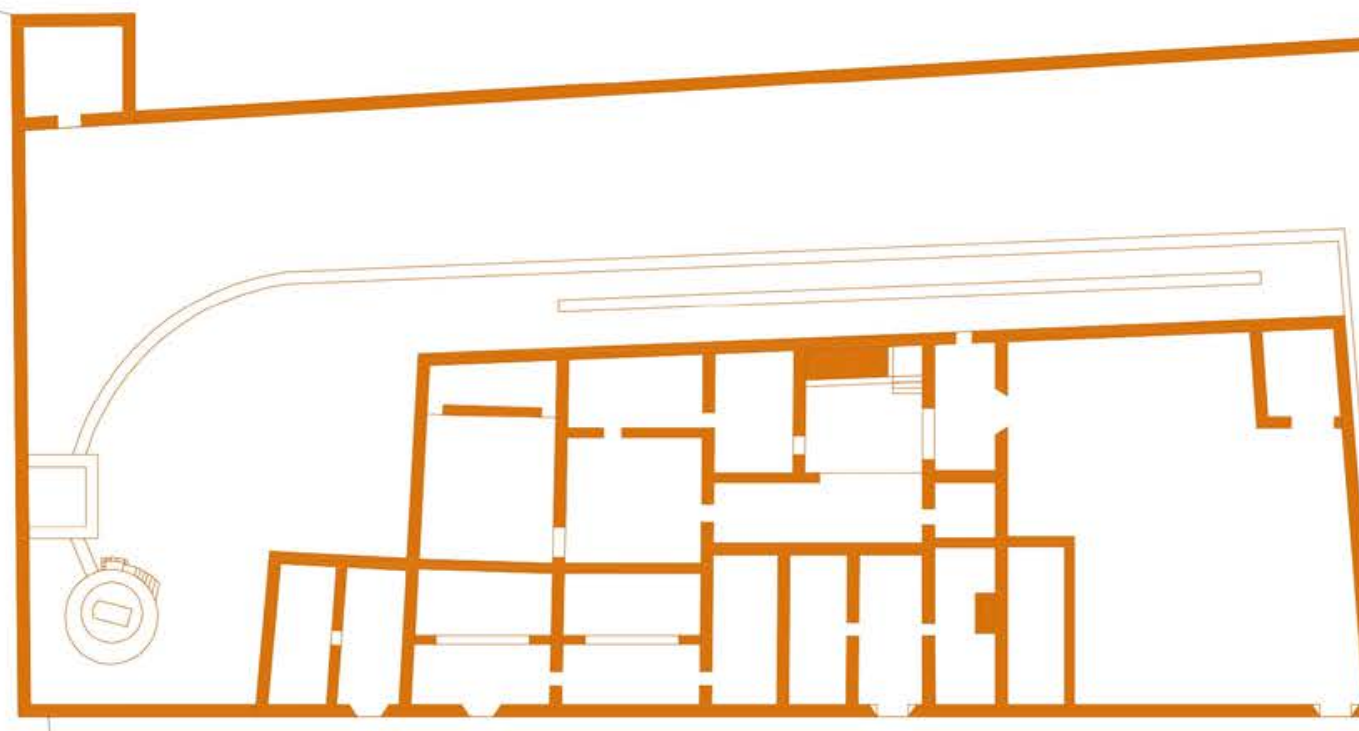

Planta baja

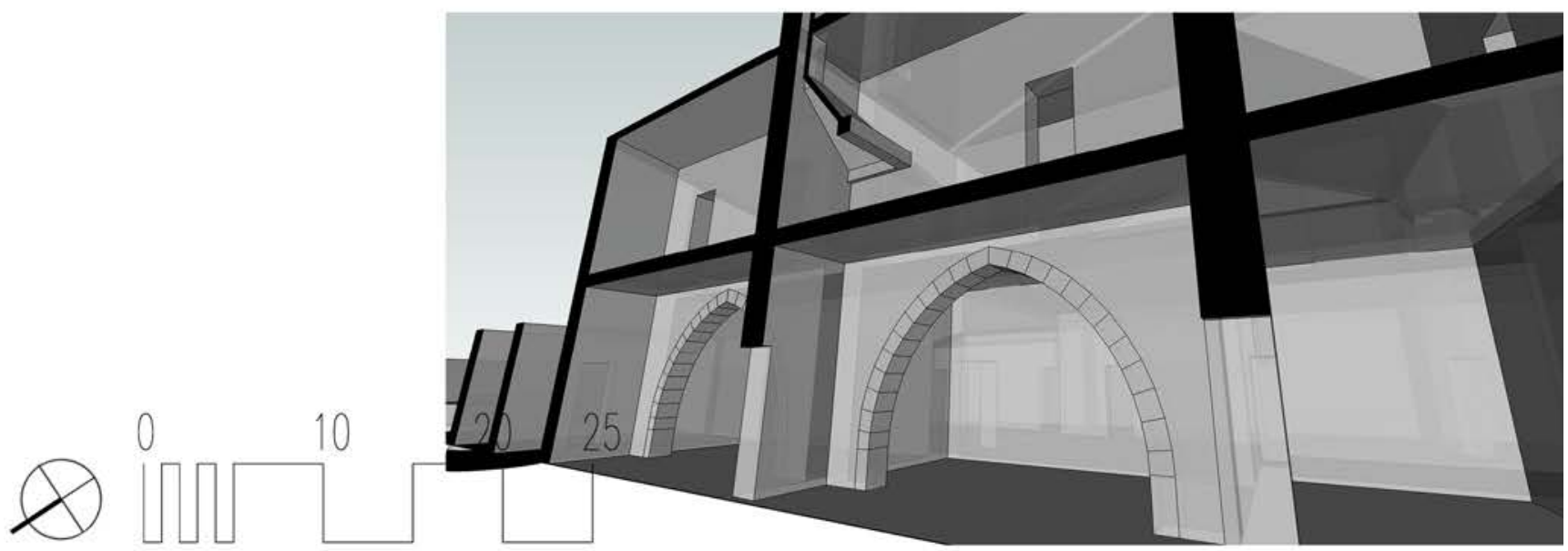




\section{Zona 10 - Cervera / Calig}

\section{Arquitecturas - Castillos}

Castillo de Cervera $[\mathrm{e}=1 / 1000]$

\section{Arquitecto: Ignacio Gil Mascarell}

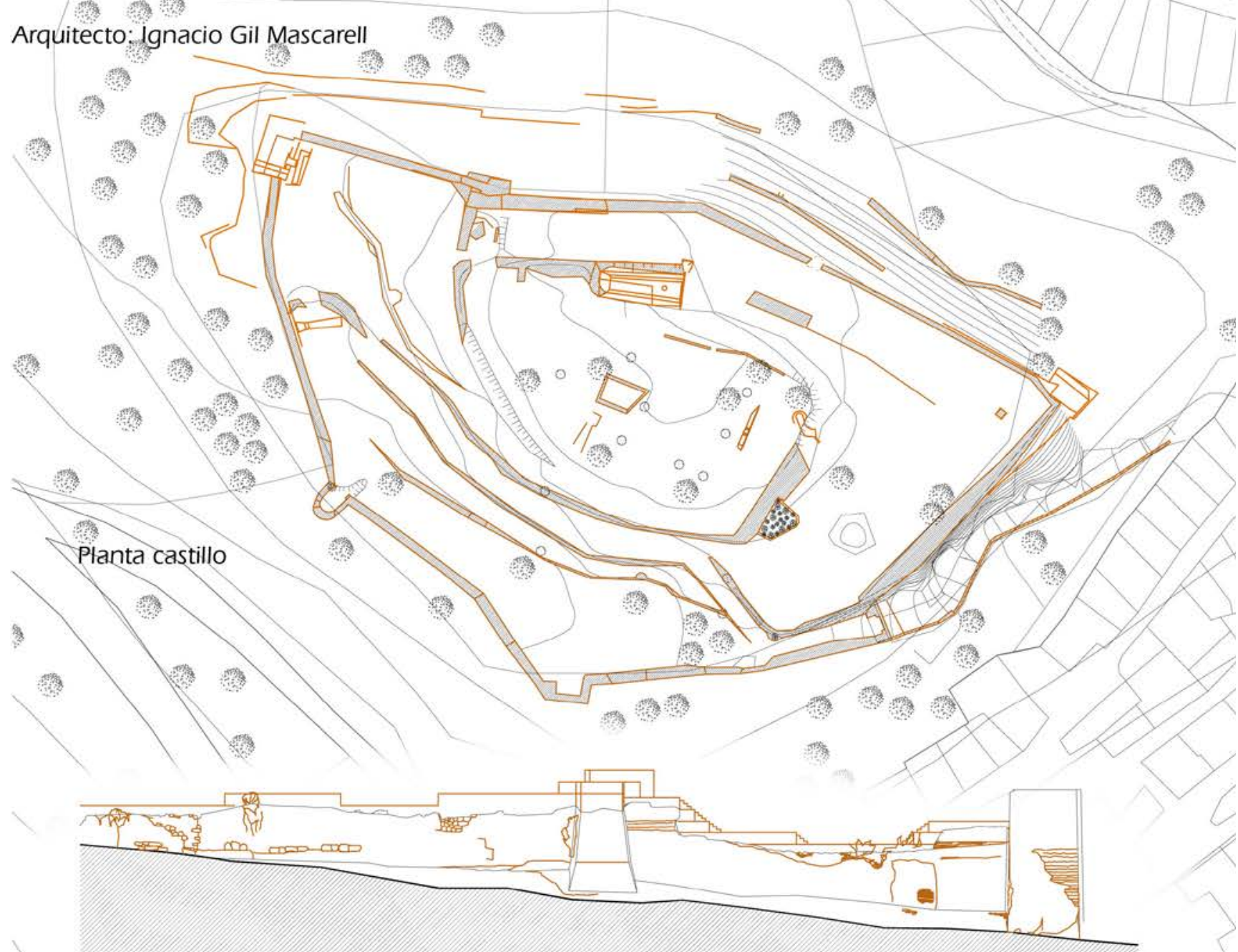

Alzado sur $(e=1 / 500)$

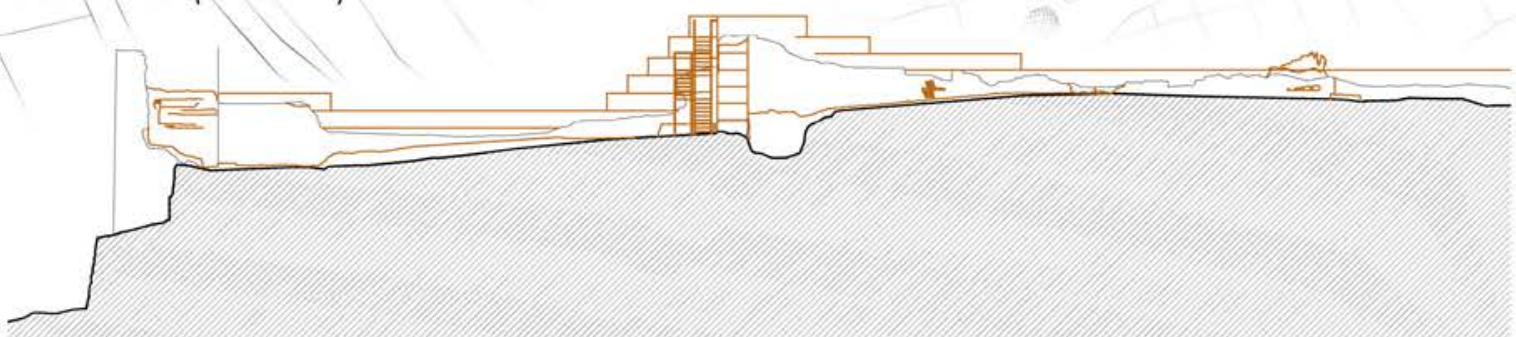

Alzado norte $(e=1 / 500)$

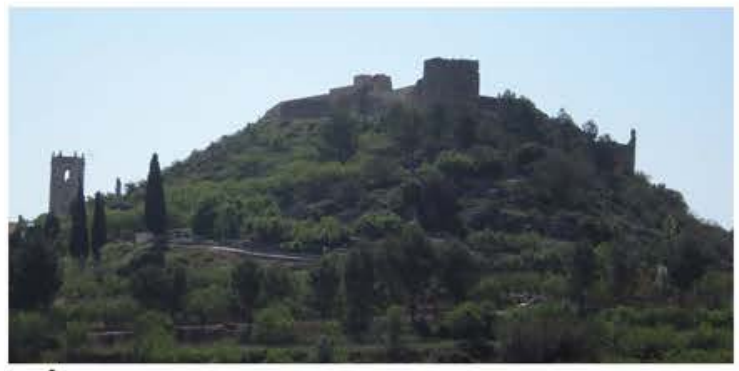

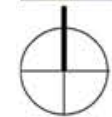

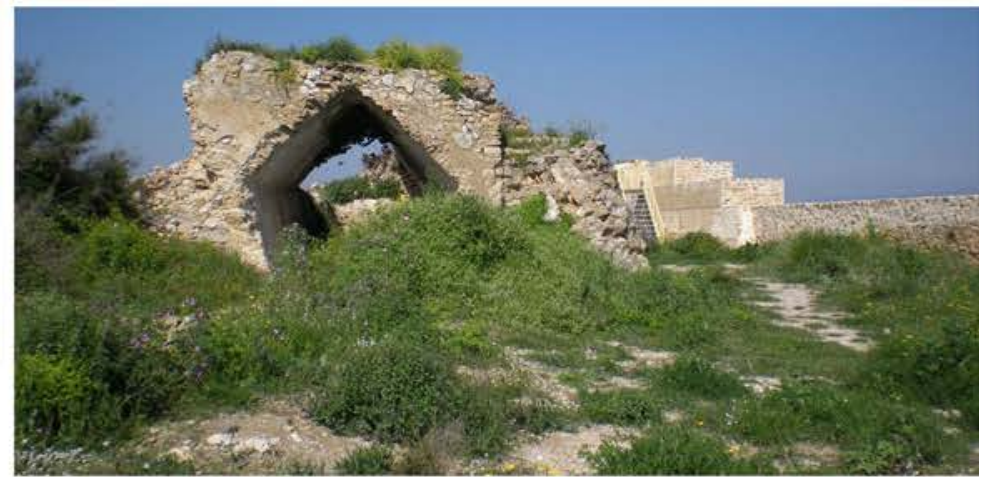




\section{Otras zonas de interés} Arquitecturas - Ayuntamientos

Ayuntamiento de Ares [e=1/500]

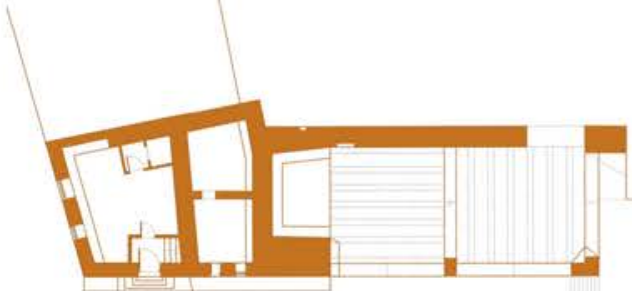

Planta baja

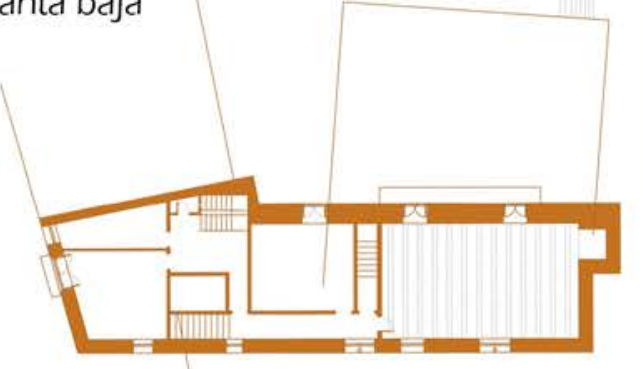

Planta primera

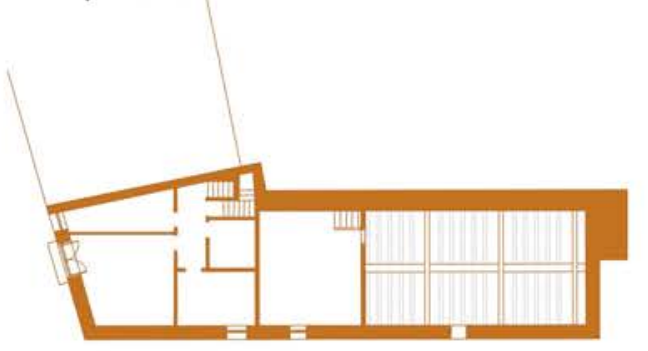

Planta segunda
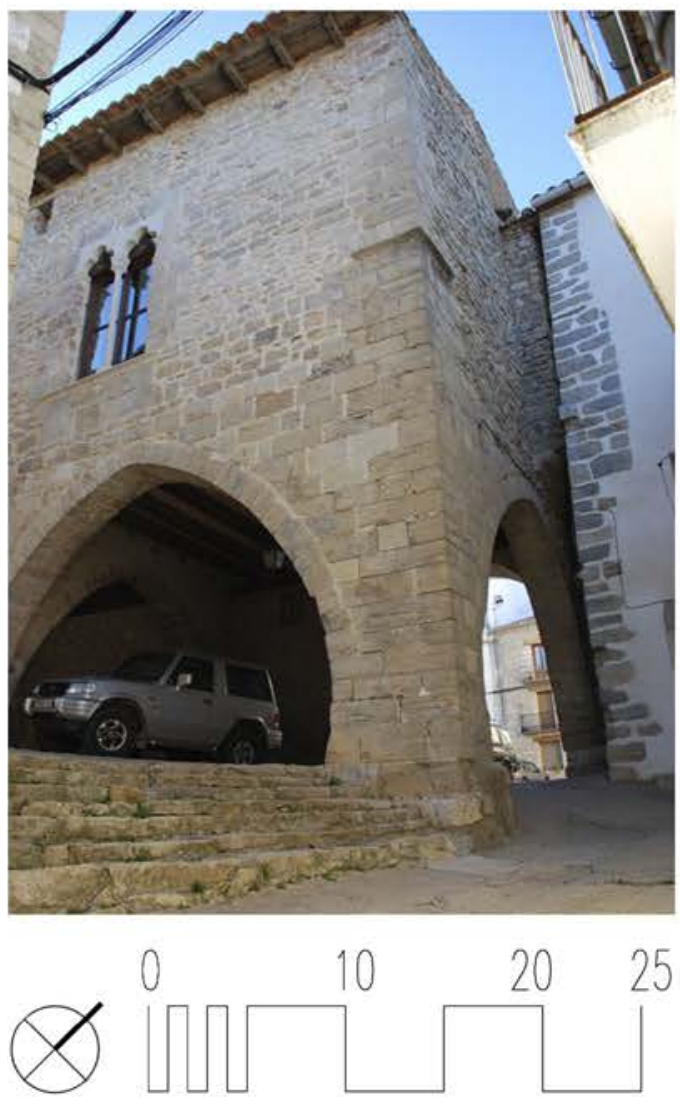

Levantamiento: Francisco Grande e Ignacio Gil Mascarell

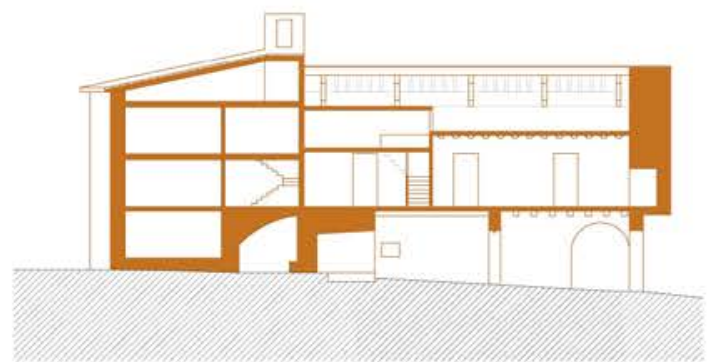

Sección longitudinal

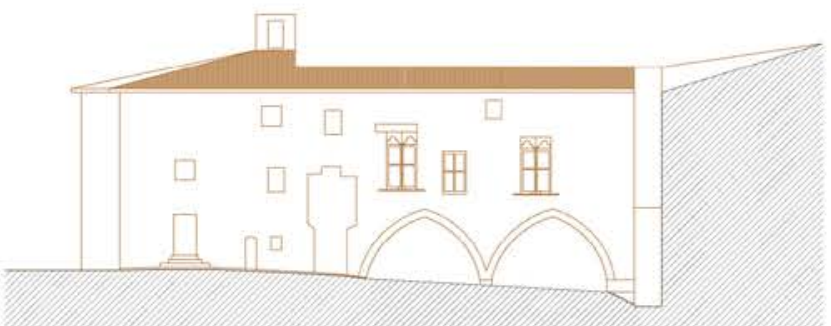

Alzado sur
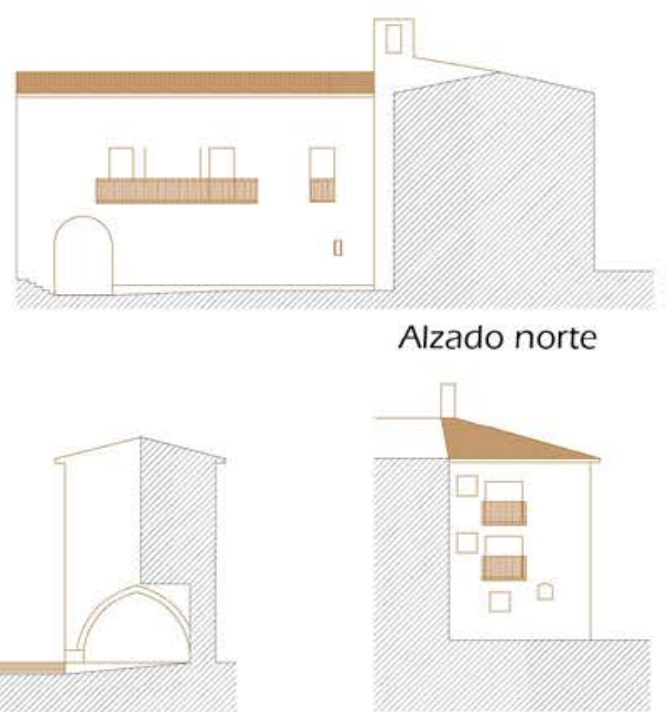

Alzado este

Alzado oeste

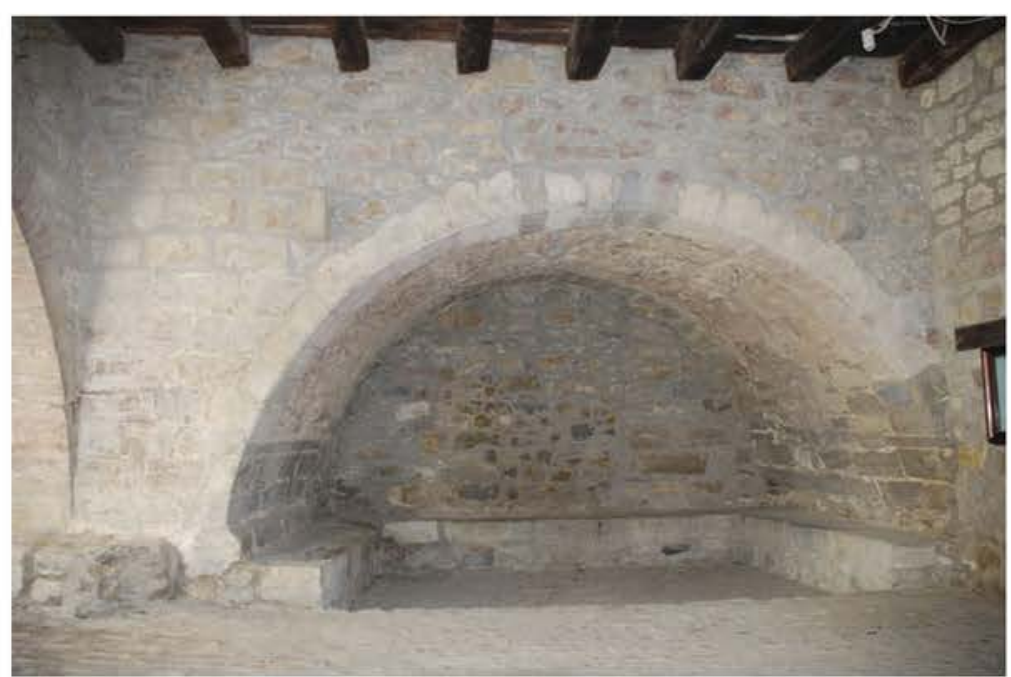




\section{Otras zonas de interés}

Arquitecturas - Ayuntamientos

Ayuntamiento de Catí $[\mathrm{e}=1 / 500]$

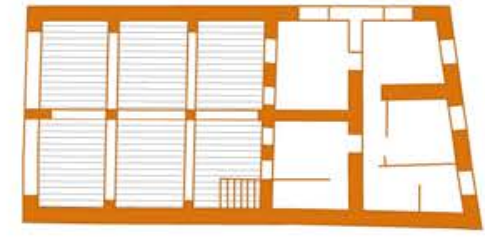

Planta baja

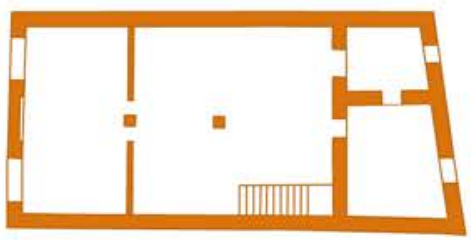

Planta primera
Levantamiento: Francisco Grande e Ignacio Gil Mascarell

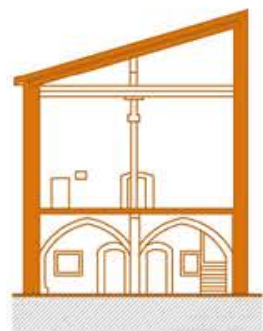

Sección transversal

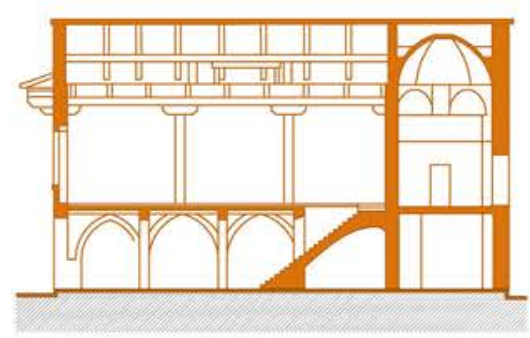

Sección longitudinal
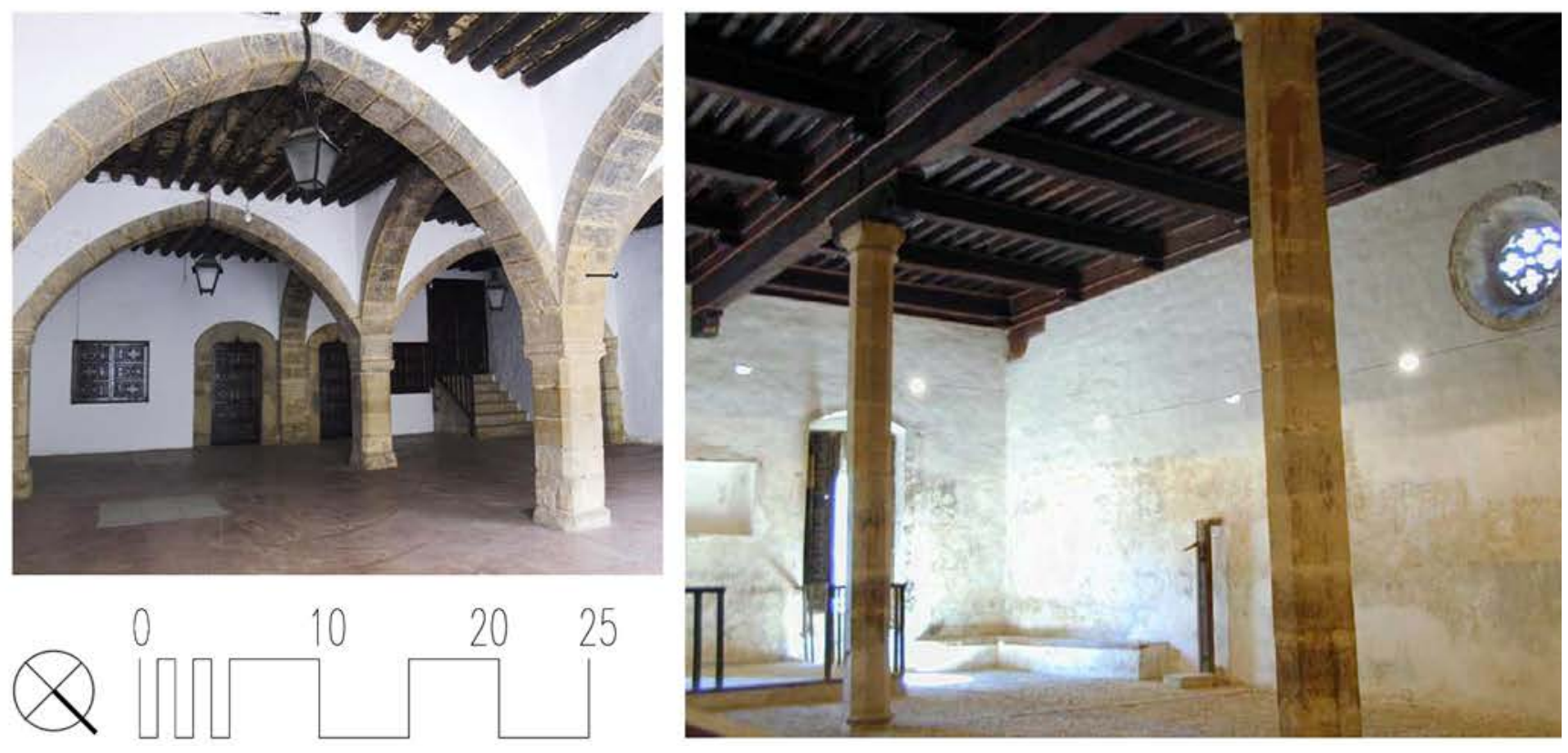


\section{Zona 5 - Canet Arquitecturas - Abrevaderos Font de la Roca $[e=1 / 500]$}
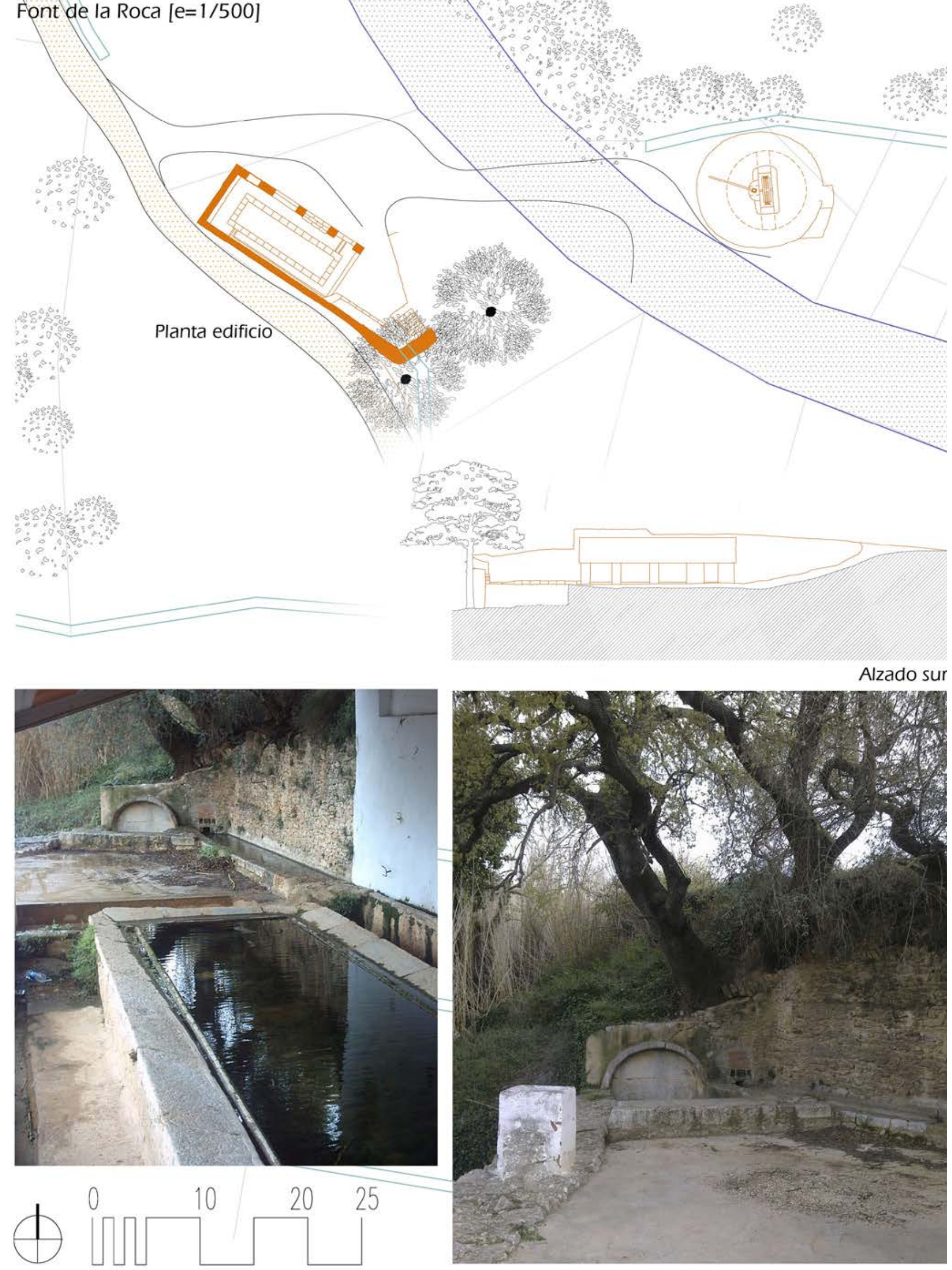

Alzado sur

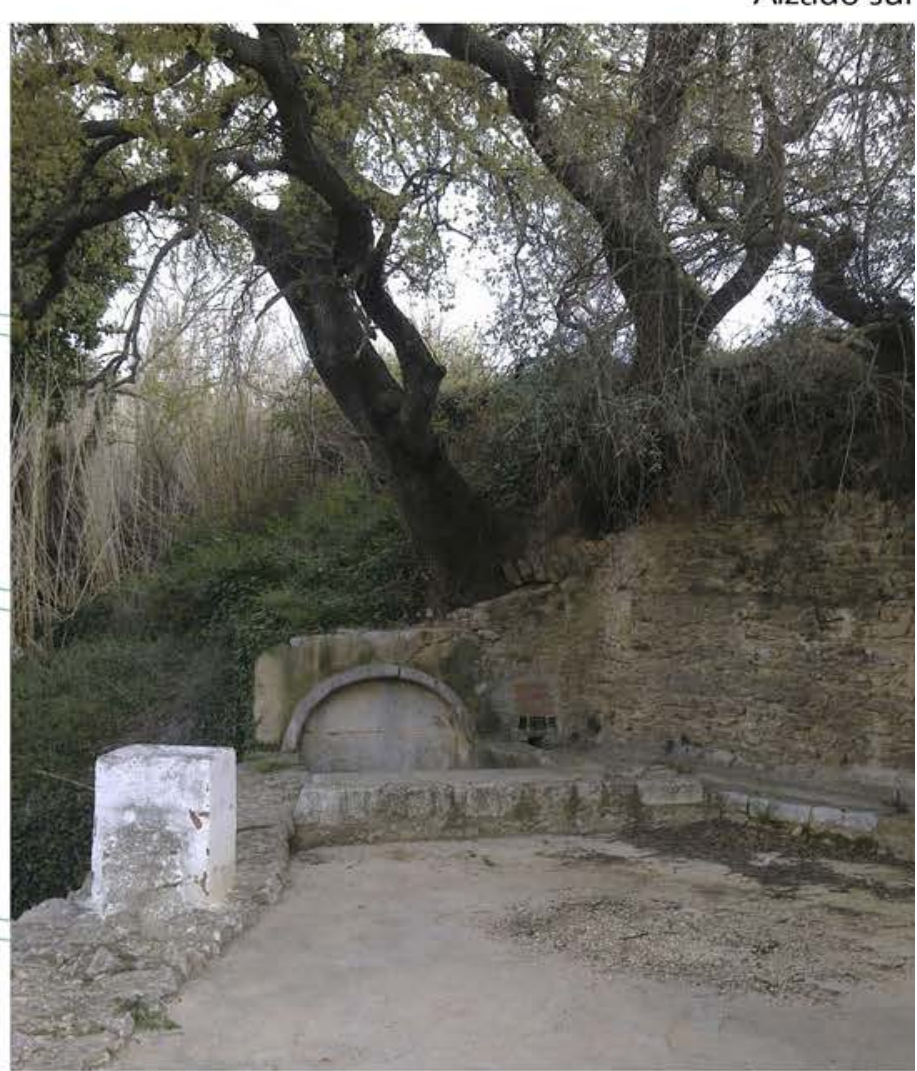




\section{3. 3. Sistemas de elementos}

Dada la escala a la que nos interesa analizar el territorio para detectar su estructura interna nos interesa analizar tanto los elementos de los cinco procesos como los sistemas que ellos forman. Estos son: sistemas de muros, sistemas de infraestructuras, sistemas de parcelación, sistemas de usos y sistemas de arquitecturas.

\section{Relaciones entre elementos}

Los elementos se relacionan entre sí de tres formas distintas, según cual sea la conectividad entre ellos:

- Conexión, si la conectividad se realiza mediante un espacio construido.

- Yuxtaposición, si la conectividad se realiza sin espacio intermedio.

- Interconexión cuando se busca la autonomía de cada tipo, a la vez que interactúan funcionalmente

Para sintetizar de una forma gráfica estas tres formas de conexión hemos elaborado un cuadro en el que ponemos algún ejemplo significativo de ellas, junto a ejemplos de arquitecturas de Louis Khan y de protozoos. Ello se debe a que ambos casos ejemplifican muy bien la clasificación que pretendemos hacer y que nos va a permitir comprender la estructura del Territorio.

En el cuadro ademas tenemos por una parte elementos de sistemas que no son arquitecturas-en este caso parcelas- tanto de la zona de estudio como de representaciones gráficas de la Edad Media y de arquitecturas tanto de la zona de estudio como representaciones gráficas de la Edad Media.

Las imágenes del cuadro Fig. 4.116 corresponden a:

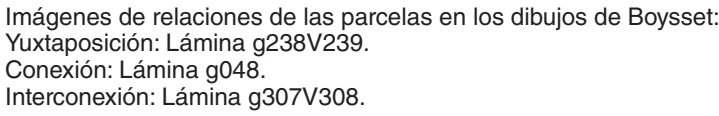

Relaciones de las parcelas en la Batllia. Croquis parcelaciones catastro histórico: Yuxtaposición: Parcelación entre el casco urbano de Cervera y la rambla.

Conexión: Parcelación del Molinar en Xert.

Interconexión: Parcelación en la Barcella.

Relaciones entre las arquitecturas de la Batllia:

Yuxtaposición: Sant Marc de la Barcella y torre defensiva.

Conexión: Molino y arquitectura del agua en Ares.

Interconexión: Edificios que conforman el Palau de la Orden de Montesa en Sant Mateu.

Relaciones entre arquitecturas medievales que conservan documentación gráfica:

Yuxtaposición: San Lorenzo del Códice Rustici.

Conexión: Pintura de Guidoriccio da Fogliano (1328) de Simone Martini.

Interconexión: Leyenda de Sant Margaret (s. XIV).

Relaciones en las arquitecturas de Luis Kahn:

Yuxtaposición: Casa Adler.

Conexión: Laboratorios Richards.

Interconexión: Residencia Eleanor Donnelly.

Relaciones en los protozoos:

Yuxtaposición.

Conexión.

Interconexión. 


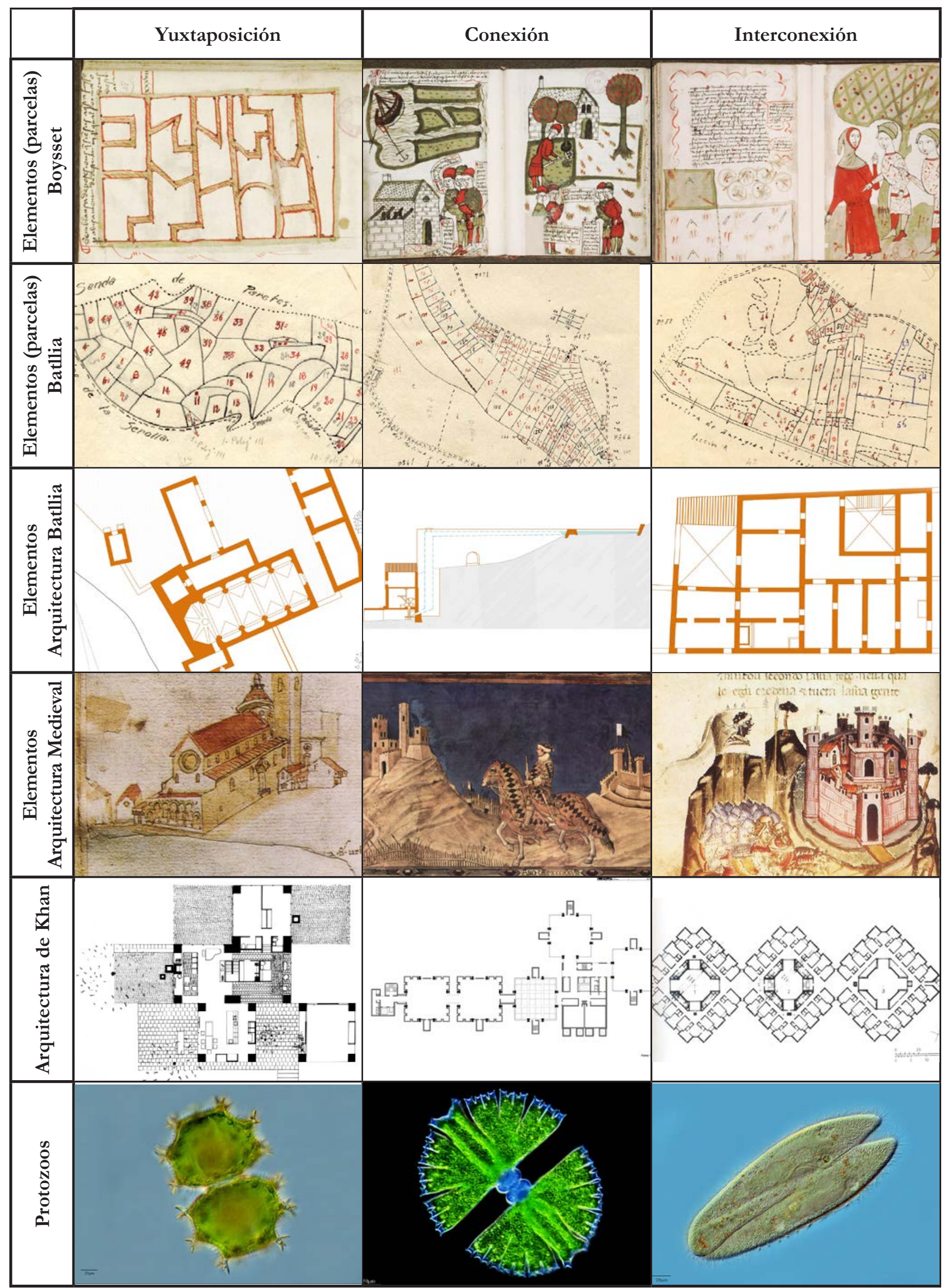

Fig. 4. 88. Cuadro tipos de redes según su relación: yuxtaposición, conexión e interconexión. 


\section{Agrupaciones de elementos: redes}

Los elementos se pueden agrupar formando sistemas de acuerdo con cuatro modelos básicos de agrupación, cuatro tipos de disposición, de organización topológica de la forma: modelos de crecimiento y de generación espacial. Los sistemas de elementos tienen una configuración formal sobre la base de parámetros geométricos y topológicos, dispuestos según proximidades y conexiones, continuidades y discontinuidades. Las formas de agrupación de los sistemas son:

- Agrupación compacta, en la que no se dejan espacios intersticiales y esta relacionada con las llamadas close-packed geométricas. Es la característica de la parcelación y de las redes de muros rectos.

- Agrupación en cadena, son secuencias de elementos conectados linealmente. Es el caso de algunas redes de infraestructuras que están conectadas a una principal o de determinadas arquitecturas (molinos en río, viviendas en núcleo urbano, masías en caminos...).

- Agrupación concéntrica o cerrada, es aquella en la que los elementos se concentran en torno a un centro o espacio común. Seria el caso de la red de muros en las montañas o de algunos núcleos urbanos o redes radiales de infraestructuras.

- Agrupación en malla, este caso en el que los elementos se conectan a partir de una malla de dos direcciones. Sería el caso de determinadas redes de infraestructuras.

En el territorio antroposocial hay una serie de elementos que conforman entre ellos sistemas. Estos que son: redes de muros, redes de infraestructuras, redes de parcelación, redes de usos y redes de arquitecturas, permiten habitar el territorio al configurar los procesos de: modelado del relieve, conexión de flujos, reparto de la tierra, aprovechamiento y uso del territorio y relación en comunidad.

Estas cuatro formas de agruparse hacen que nos encontremos con 17 modelos de agrupación o redes:

- Agrupación de muros lineales (perpendiculares a la máxima pendiente y paralelos).

- Agrupación de muros concéntricas (perpendiculares a la máxima pendiente y concéntricos).

- Agrupación de infraestructura lineales.

- Agrupación de infraestructura concéntrica (pueden ser circulares o radiales).

- Agrupación de infraestructura en malla (triangular, rectangular o circular).

- Agrupación de parcelas compactas.

- Agrupación de parcelas lineales.

- Agrupación de parcelas concéntricas.

- Agrupación de parcelas en malla.

- Agrupación de cultivos compactas.

- Agrupación de cultivos lineales.

- Agrupación de cultivos concéntricas.

- Agrupación de cultivos en malla.

- Agrupación de arquitecturas compactas.

- Agrupación de arquitecturas lineales.

- Agrupación de arquitecturas concéntricas.

- Agrupación de arquitecturas en malla. 


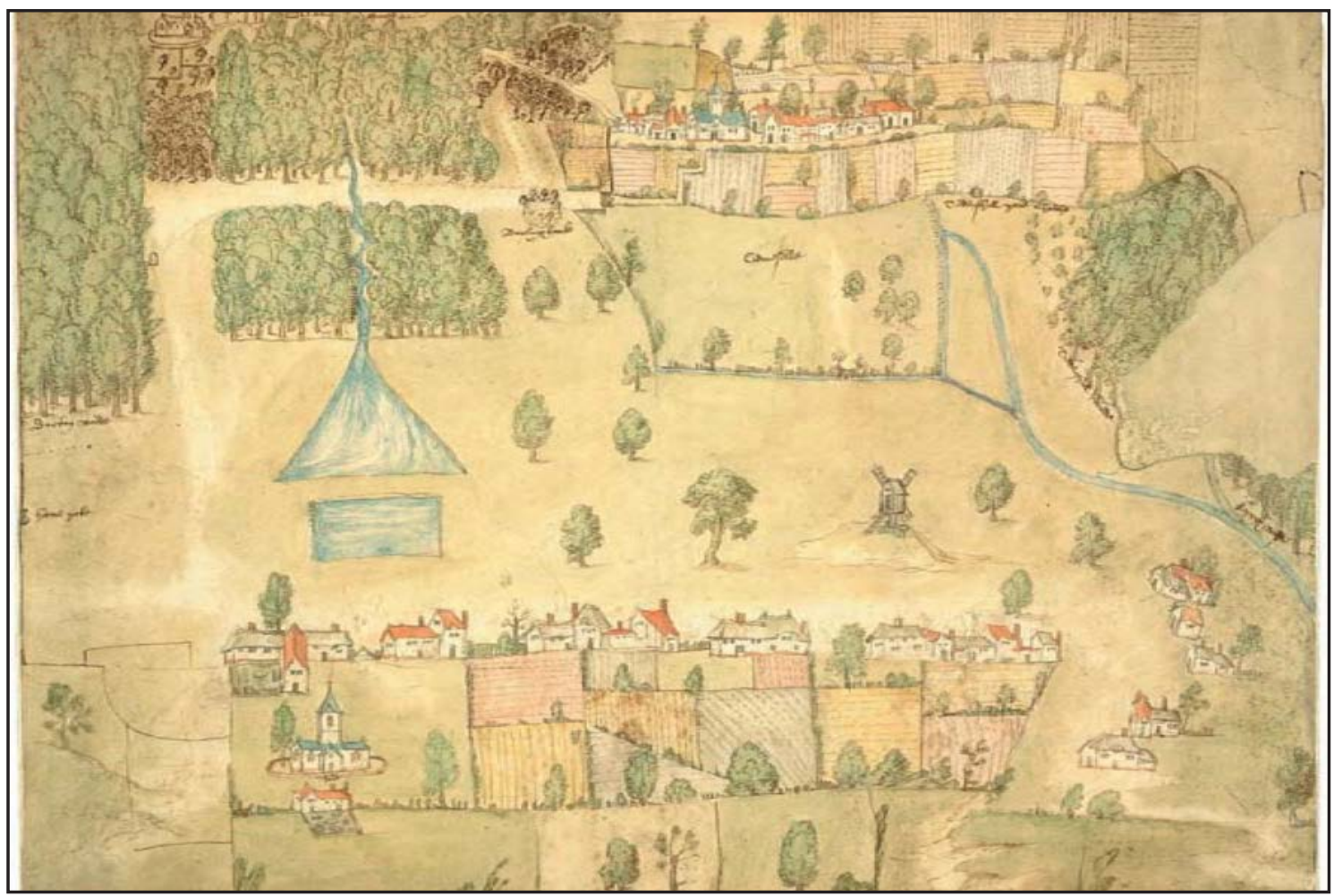

Fig. 4. 89. Agrupación de parcelas en cadena. Wotton Underwood, Buckingham shire, hacia 1564. Biblioteca de San Marino (Manuscrito ST 59).

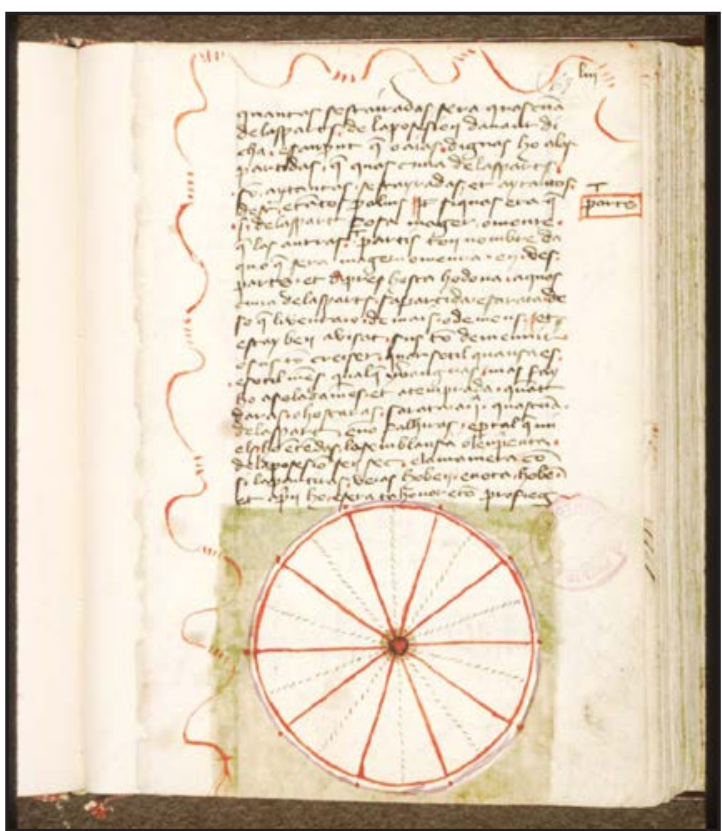

Fig. 4. 90. Agrupación de parcelas compactas. Lámina g048V del "Traité d'arpentage" de Bertrand Boysset de finales s. XIV, que representa una parcelación compacta.

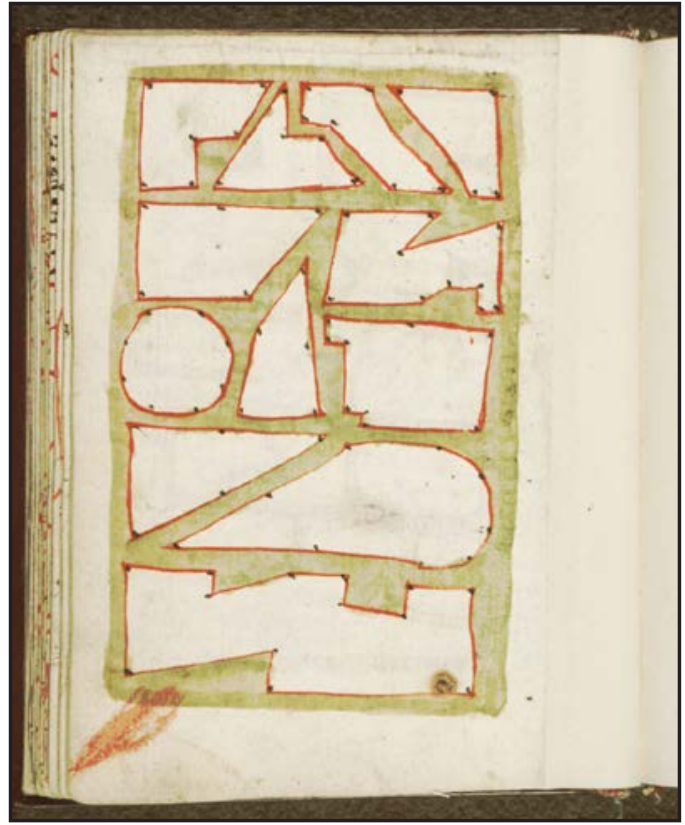

Fig. 4. 91. Agrupación de parcelas concéntricas. Lámina g063 del "Traité d'arpentage" de Bertrand Boysset de finales s. XIV, que representa una parcelación radial.

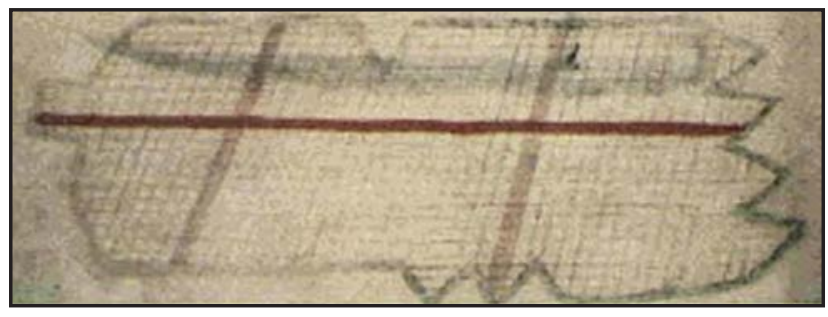

Fig. 4. 92. Agrupación de parcelas en malla. Dibujo 8 del libro "Frontin l'oeuvre gromatique" que recoge Corpus Agrimensorum romanorum IV de lulius Frontinus, que representa una parcelación en malla.
Distintos ejemplos gráficos de distintas agrupaciones de elementos formando sistemas. 
Estas agrupaciones o redes pueden ser continuas o discontinuas, es decir se puede establecer una agrupación de elementos "dispersa" en el territorio. Por ejemplo una agrupación en malla defensiva constituida por una serie de torres de defensa, se halla discontinua ya que su agrupación puede responder solamente a criterios visuales.

Para sintetizar de una forma gráfica estas cuatro formas de agrupación hemos elaborado un cuadro en el que ponemos algún ejemplo significativo de ellas, junto a ejemplos de arquitecturas de Louis Khan y de protozoos. Ello se debe a que ambos casos ejemplifican muy bien la clasificación que pretendemos hacer y que nos va a permitir comprender la estructura del Territorio.

En el cuadro además tenemos por una parte elementos de sistemas que no son arquitecturas-en este caso parcelas- tanto de la zona de estudio como de representaciones gráficas de la Edad Media y de arquitecturas tanto de la zona de estudio como representaciones gráficas de la Edad Media.

Las imágenes del cuadro Fig. 4.97 corresponden a:

Imágenes de redes medievales de parcelas que han llegado hasta nuestros días (libro de Boysset):

Compacta: Lámina g048.

Cadena: Lámina g055.

Malla: Lámina g253.

Radial: Lámina g063.

Redes de la Batllia de Cervera:

Compacta: Red de muros en el entorno de Bel.

Cadena: Red de parcelas en el molinar siguiendo eje río.

Malla: Red de parcelas en el entorno de Santa Isabel en Canet.

Radial: Red de muros en el entorno de Sant Marc de la Barcella.

Redes de arquitecturas de la Batllia:

Compacta: Iglesia de Sant Mateu.

Cadena: Puente y molino en el Molinar de Xert.

Malla: Ermitorio de la Virgen de la salud en Traiguera.

Radial: castillo de Cervera.

Redes de arquitecturas medievales de lugares distintos a la Batllia, cuyas imágenes han llegado hasta nuestros días: Compacta: Convento de Sant Gall.

Cadena: Catedral de Pavia.

Malla: Convento de Santa María de los Ángeles.

Radial: Dibujo Jerusalén del Beato de Liebana.

Redes de arquitecturas de Luis Kahn:

Compacta: Museo Kimbell de Bellas Artes.

Cadena: Laboratorios Richrds.

Malla: Centro comunitario judío en Trenton.

Radial: Centro gubernamental en Dacca.

Redes de protozoos:

Compacta: Pediastrum tetras.

Cadena: Setiformis.

Malla: Hydrotictyon.

Radial: Pediastrum boryanum. 


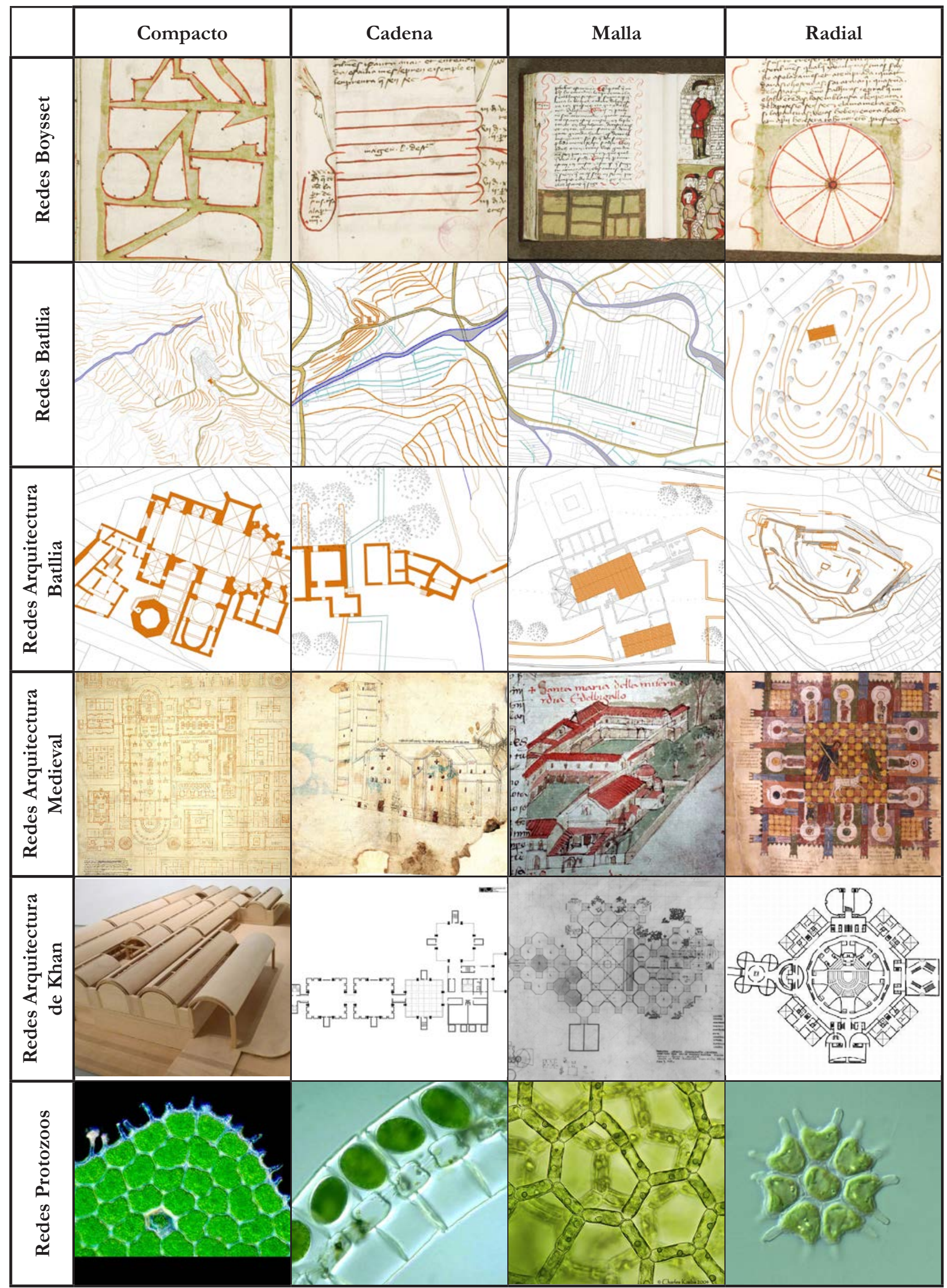

Fig. 4. 93. Cuadro sistemas de agrupación: compactos, cadena, malla y radial. Nota explicativa de las imágenes en página siguiente. 


\begin{tabular}{|c|c|c|c|}
\hline PROCESO & ELEMENTO & TIPOS & $\begin{array}{l}\text { SISTEMAS } \\
\text { REDES } \\
\end{array}$ \\
\hline MODELADO & MUROS & $\begin{array}{l}\text { Contención } 1 \text { muro: } \\
\text { - Mucha curvatura } \\
\text { - Poca curvatura } \\
\text { - Caras rectas } \\
\text { Separación a } 2 \text { muros } \\
\text { - Caras rectas }\end{array}$ & $\begin{array}{l}\text { Concéntricos } \\
\text { En malla }\end{array}$ \\
\hline ACCESO & INFRAESTRUCTURAS & $\begin{array}{l}\text { Caminos: } \\
\text { - Dominio o carena } \\
\text { - Penetración en el valle } \\
\text { - "En medio" } \\
\text { - Llano } \\
\text { - Azagadores } \\
\text { Agua: } \\
\text { - Acequias paralelas escorrentías } \\
\text { - Acequias perpendiculares } \\
\text { escorrentías } \\
\text { - Acequias molinos } \\
\text { - Desagües } \\
\text { - Acueductos }\end{array}$ & $\begin{array}{l}\text { Lineales } \\
\text { Concéntricas } \\
\text { En malla }\end{array}$ \\
\hline REPARTIR & PARCELACIONES & $\begin{array}{l}\text { Cultivos (forma): } \\
\text { - Orgánica } \\
\text { - Trapezoidal } \\
\text { - Rectangular variable } \\
\text { - Rectangular homogénea } \\
\text { Cultivos (propiedad parcela) } \\
\text { - Repartida } 24 \text { cafissadas } \\
\text { - Masías } \\
\text { - Comunales } \\
\text { - Orden } \\
\end{array}$ & $\begin{array}{l}\text { Compactas } \\
\text { Lineales } \\
\text { Concéntricas } \\
\text { En malla }\end{array}$ \\
\hline USAR & CULTIVOS & $\begin{array}{l}\text { - Bosques } \\
\text { - Pastos } \\
\text { - Sin uso } \\
\text { - Cereales } \\
\text { - Vid } \\
\text { - Olivo } \\
\text { - Huerta } \\
\text { - Forraje } \\
\end{array}$ & $\begin{array}{l}\text { Compactas } \\
\text { Lineales } \\
\text { Concéntricas } \\
\text { En malla }\end{array}$ \\
\hline $\begin{array}{l}\text { VIVIR EN } \\
\text { COMÚN }\end{array}$ & ARQUITECTURAS & $\begin{array}{l}\text { - Termotopo / Casa o masía } \\
\text { - Uterotopo / Torre o castillo } \\
\text { - Theotopo / Ermita } \\
\text { - Thanatopo / Parroquia y } \\
\text { cementerio } \\
\text { - Nomotopo / Casa comunal } \\
\text { - Erotopo / Lonja o mercado } \\
\text { - Ergotopo / Cofradías u hospital } \\
\text { - Alethopo / Casa estudios o } \\
\text { universidad } \\
\text { - Fonotopo / Teatro }\end{array}$ & $\begin{array}{l}\text { Compactas } \\
\text { Lineales } \\
\text { Concéntricas } \\
\text { En malla }\end{array}$ \\
\hline
\end{tabular}




\section{Simbiosis entre redes de elementos}

Una vez clasificados los distintos sistemas de elementos, pasaremos a compararlos y a analizar las relaciones tanto sincrónicas como diacrónicas que se establecen entre ellos.

Las redes las grafiamos en las doce zonas de estudio y las comparamos entre ellas. Vemos que los modelos a su vez forman entre ellos estructuras. Estas dependen de la forman que se relacionan topológicamente los modelos y que básicamente son tres: yuxtaposición, conexión e interconexión. Se trata nuevamente pero a otra escala de un problema de disposición de los sistemas de elementos. Las redes de muros, infraestructuras, parcelación, cultivos y arquitecturas las superpondremos gráficamente en cada una de las zonas de análisis, previamente dos a dos y posteriormente tres a tres o incluso cuatro o cinco de ellas.

En realidad estas relaciones responden al modo en que se realiza la conectividad entre los distintos redes en el territorio.

Partimos de la base de redes teóricamente autónomos (redes de muros, infraestructuras, parcelación, cultivos y arquitecturas). Si la conectividad se realiza mediante un espacio construido hablaremos de conexión (estos espacios son las propias infraestructuras), por lo tanto la relación entre infraestructuras con parcelación, cultivos o arquitecturas es siempre de conexión.

La relación de yuxtaposición se produce cuando se relacionan sin el espacio intermedio de conexión, por ejemplo seria la red de muros y arquitecturas o la de parcelación y cultivos.

La de interconexión busca la autonomía de cada tipo y a la vez que interactúen funcionalmente, seria el caso de los muros y la parcelación o la red de muros y las infraestructuras.

Por tanto podríamos resumir que las distintas relaciones entre tipos se producen de una de estas formas:

- Red de muros-infraestructuras: Interconexión

- Red de muros-parcelación: Interconexión

- Red de muros-arquitecturas: Yuxtaposición

- Red de muros-cultivos: Interconexión

- Infraestructuras-parcelación: Conexión

- Infraestructuras-cultivos: Conexión

- Infraestructuras-arquitecturas: Conexión

- Parcelación-arquitecturas: Interconexión

- Cultivos-arquitecturas: Interconexión

- Infraestructuras caminos-infraestructuras riego: Yuxtaposición

De este cuadro de relaciones se podría deducir que las infraestructuras producen conexiones, la red de muros yuxtaposiciones; las parcelaciones y las arquitecturas están interconectadas gracias a las conexiones mutuas con las infraestructuras. Las redes del mismo proceso se yuxtaponen.

El territorio se organiza alrededor de las tensiones inducidas por las relaciones que mantienen entre sí y de forma ordenada estos tipos de agrupaciones. 
Mapa general (situación de las zonas de estudio) - $[e=1 / 200.000]$

\section{Combinaciones: Muros + Infraestructuras}

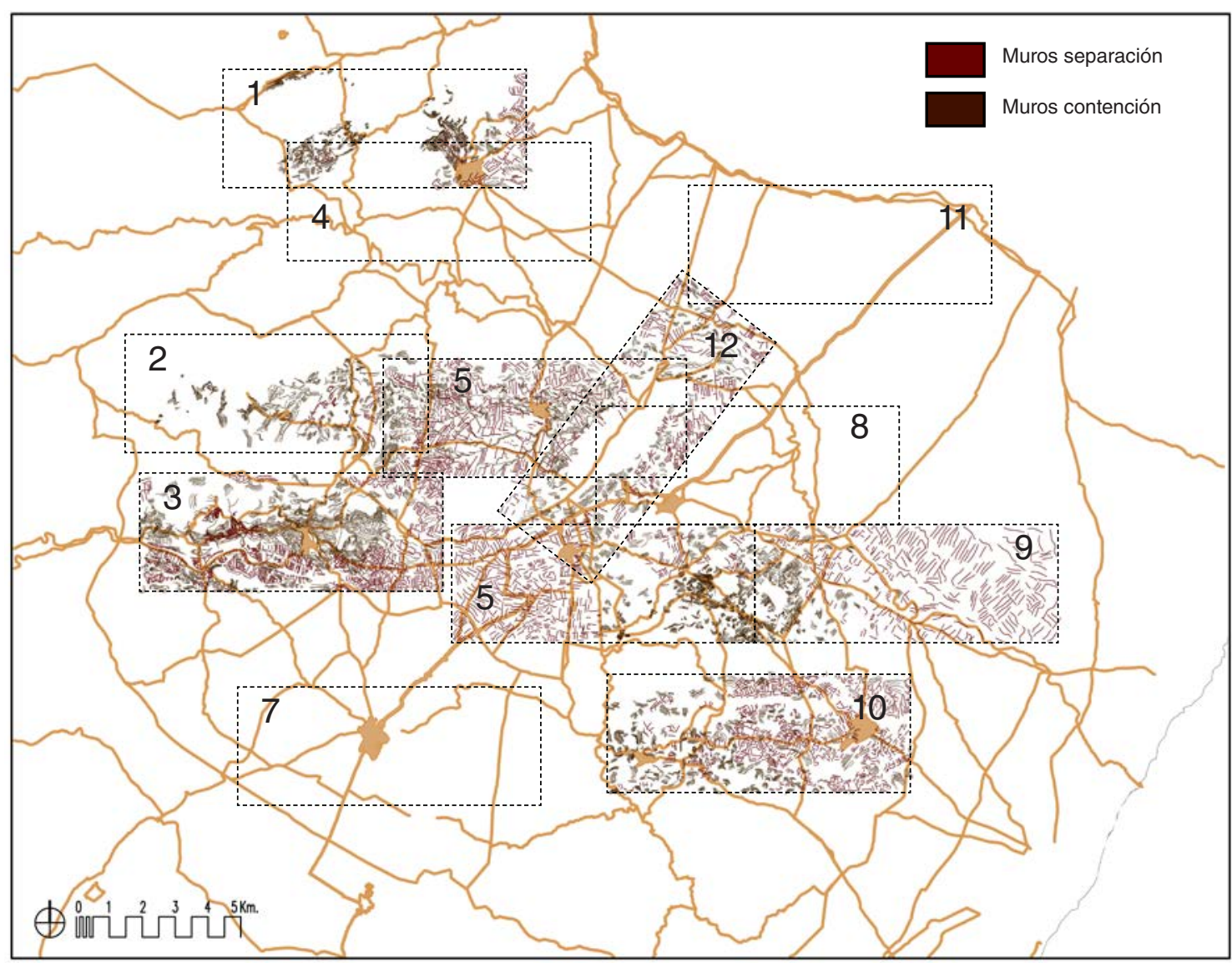

Fig. 4. 94. Plano de la Batllia a escala 1/200.000 del plano de infraestructuras y muros existentes en la Edad Media. Señalización 12 zonas de estudio. 
Muros + Infraestructuras - Zonas 1, 2, 3, 5 - [e=1/75.000]

Zona 1_Bel

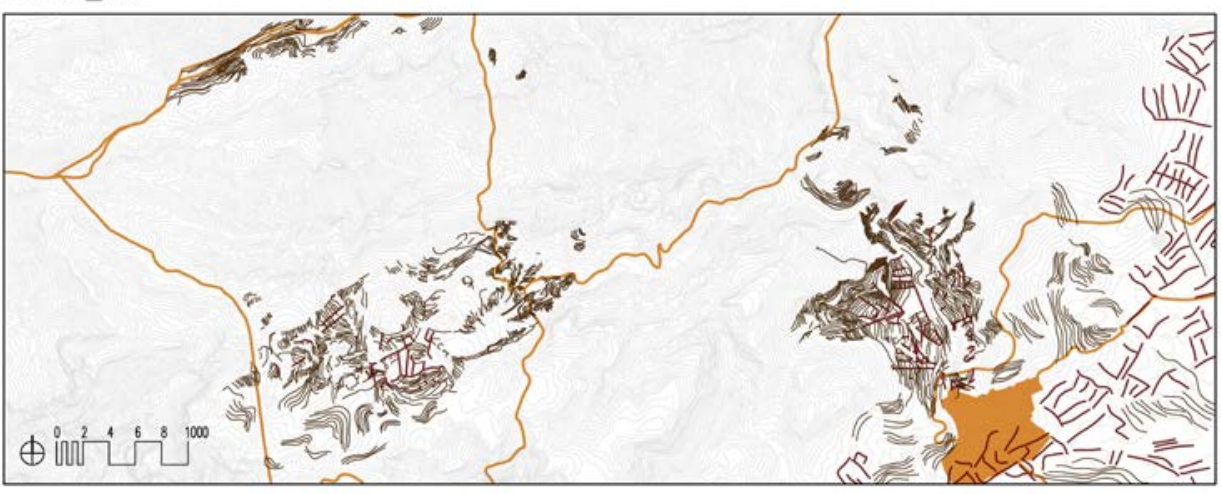

Zona 2_Barcella

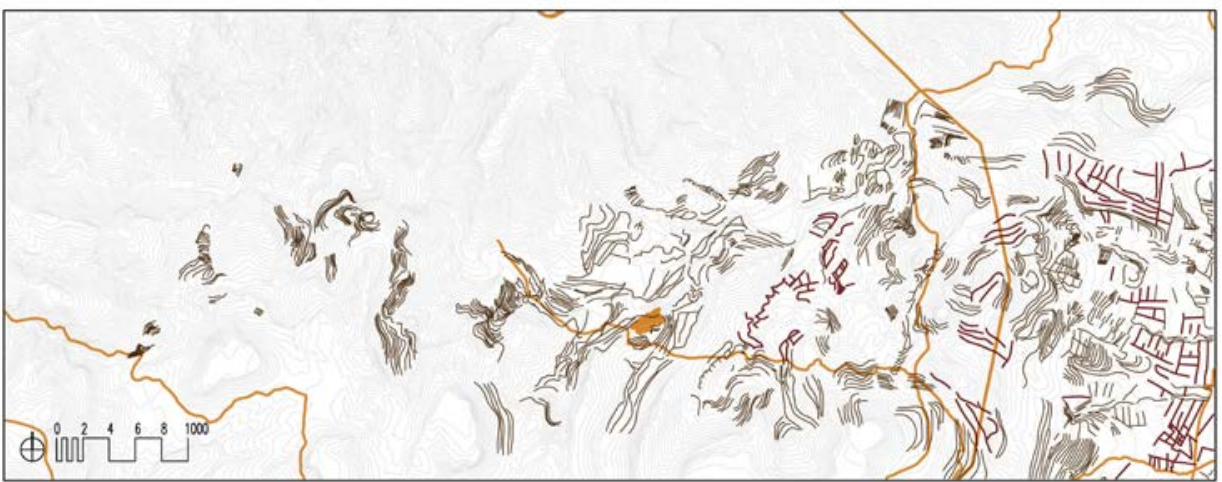

Zona 3_Molinar/Xert

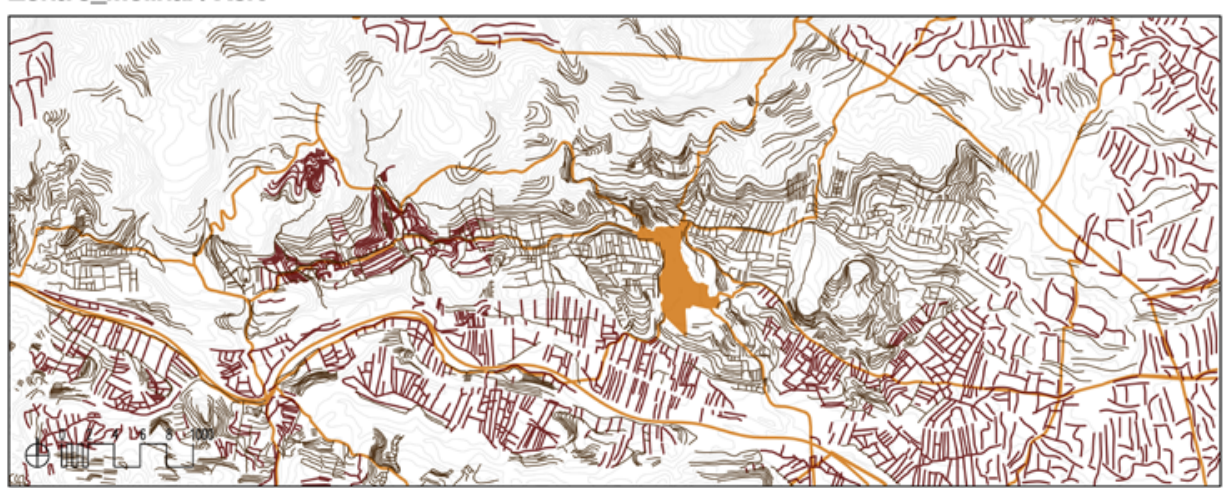

Zona 5_Canet

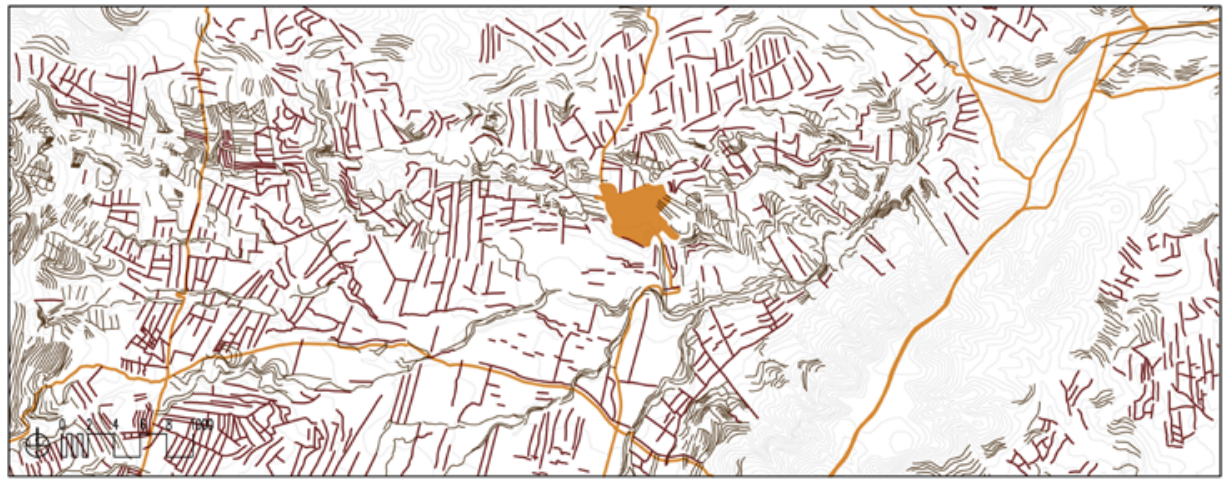


Muros + Infraestructuras - Zonas 6, 9, 10, 12 - $[\mathrm{e}=1 / 75.000]$

Zona 6_La Jana / Carrascal

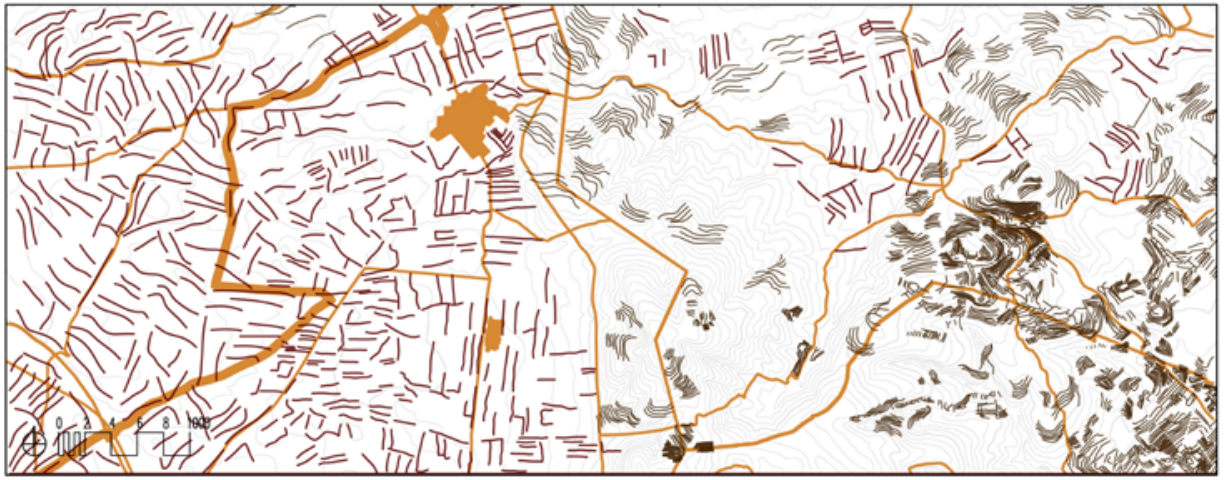

Zona 9_Mas Stellers

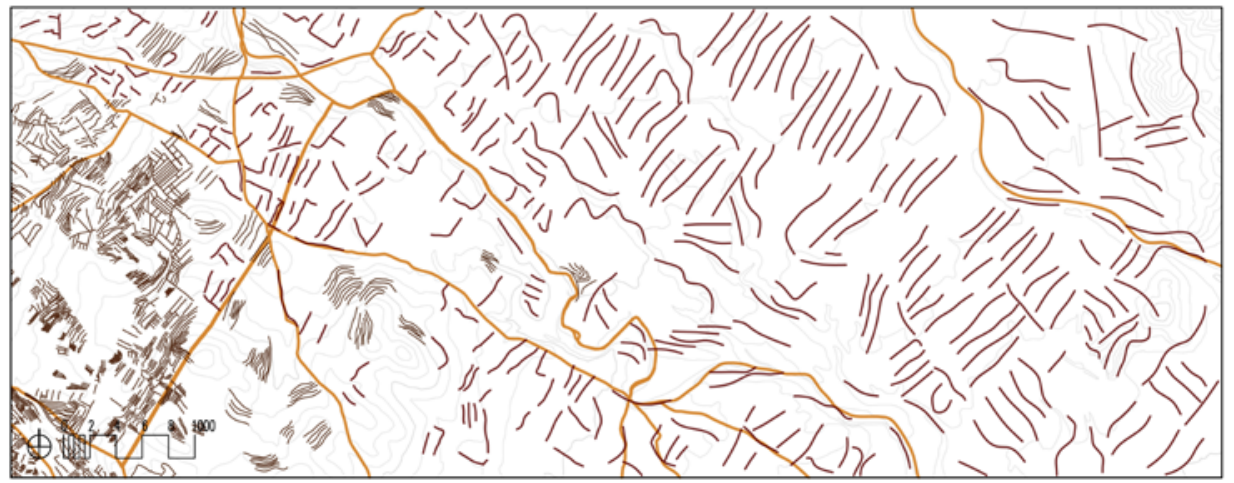

\section{Zona 10_Cervera/Calig}

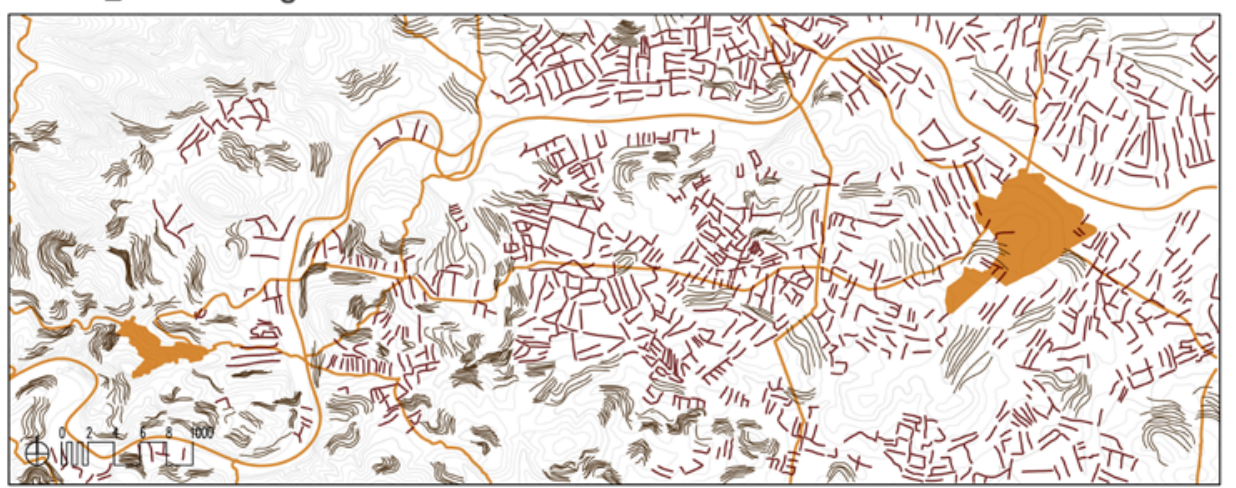

\section{Zona 12_Atalaya San Pere}

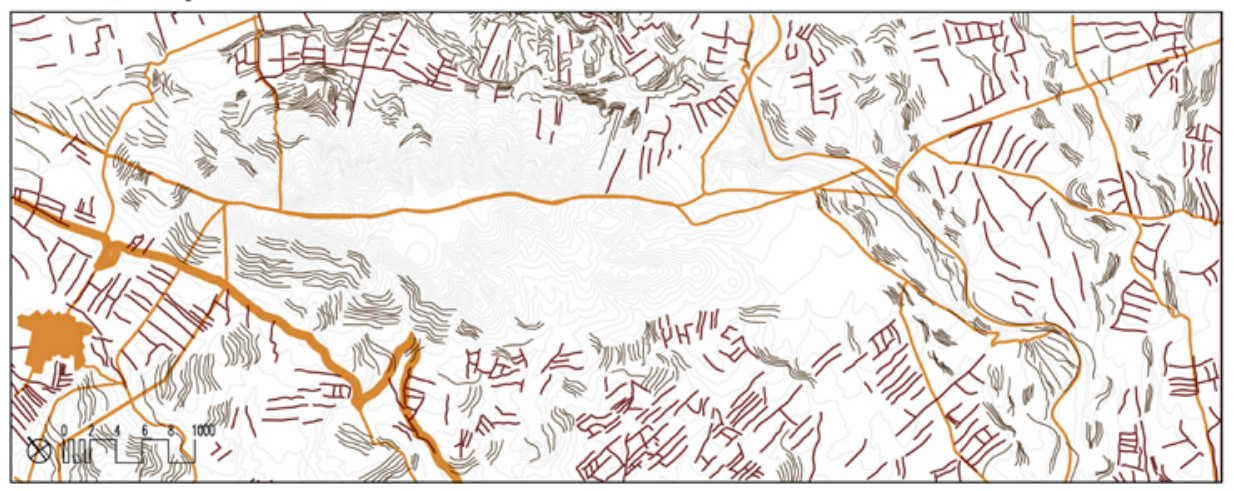


Mapa general (situación de las zonas de estudio) - $[e=1 / 200.000]$

\section{Combinaciones: Muros + Parcelario}

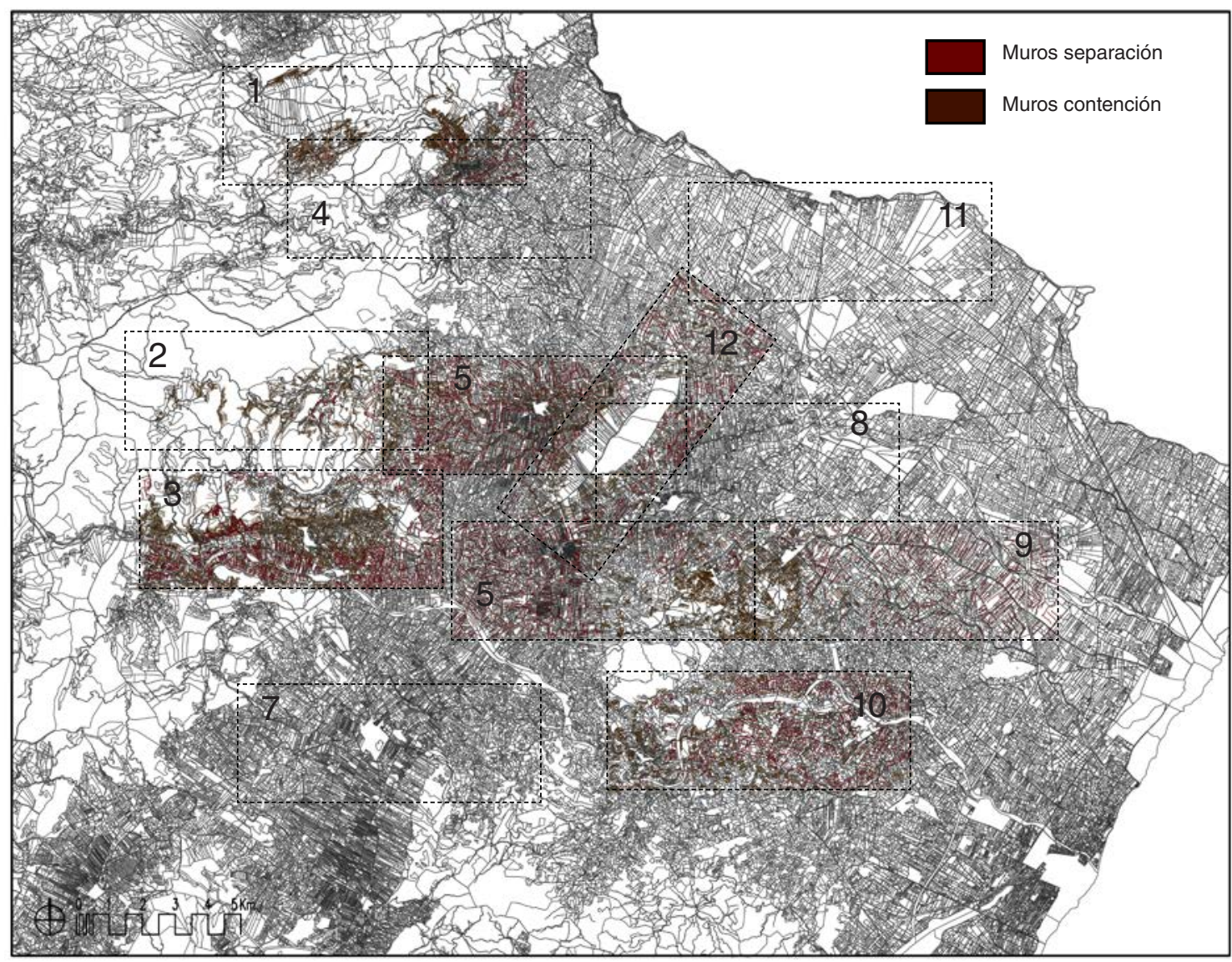

Fig. 4. 95. Plano de la Batllia a escala 1/200.000 del plano de parcelario y muros existentes en la Edad Media. Señalización 12 zonas de estudio. 
Muros + Parcelario - Zonas 1, 2, 3, 5 - $[\mathrm{e}=1 / 75.000]$

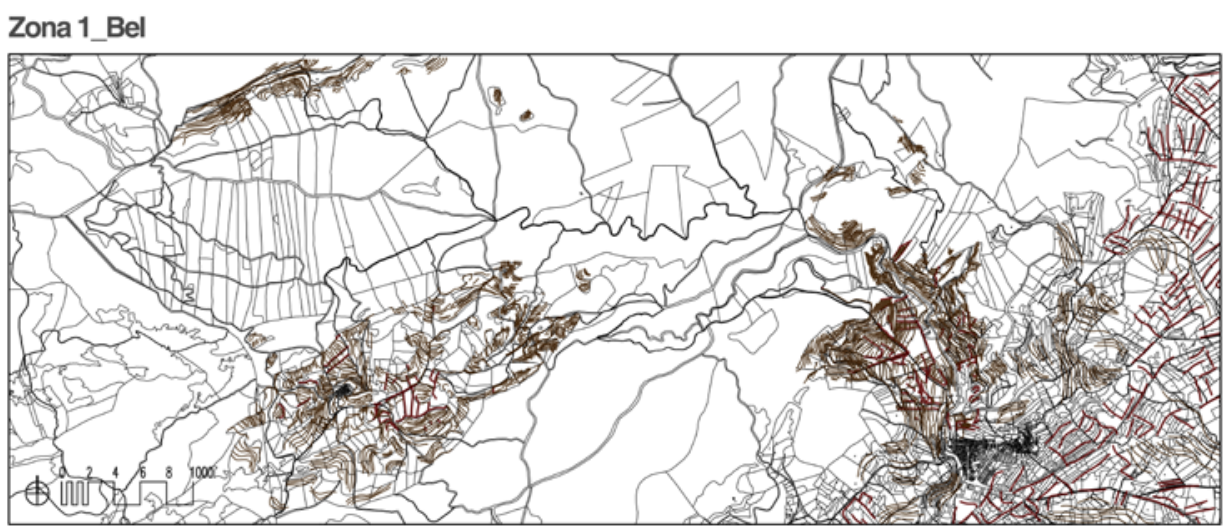

Zona 2_Barcella

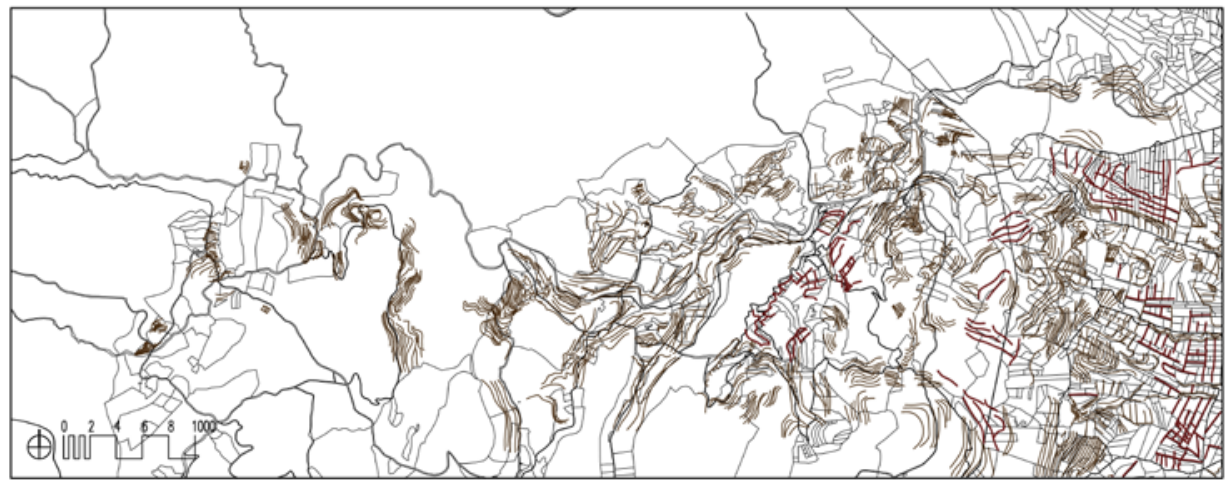

\section{Zona 3 Molinar / Xert}

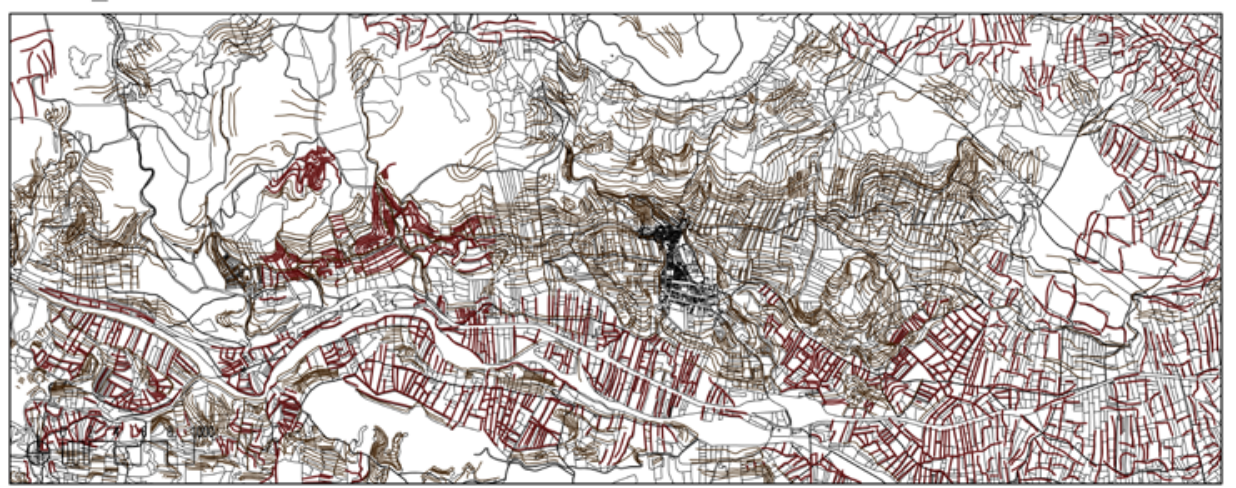

Zona 5_Canet

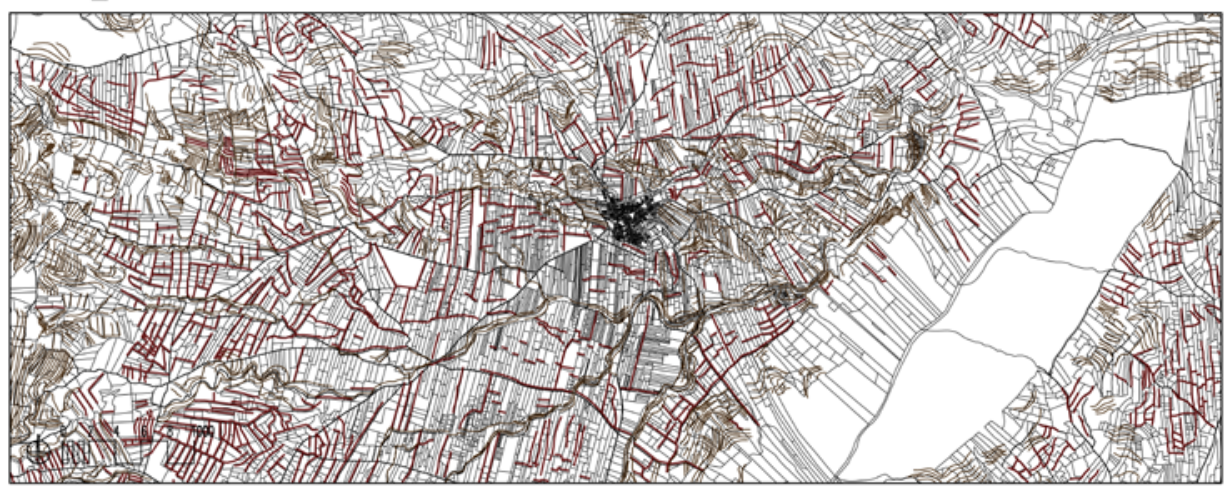


Muros + Parcelario - Zonas 6, 9, 10, $12-[\mathrm{e}=1 / 75.000]$

Zona 6_La Jana/Carrascal

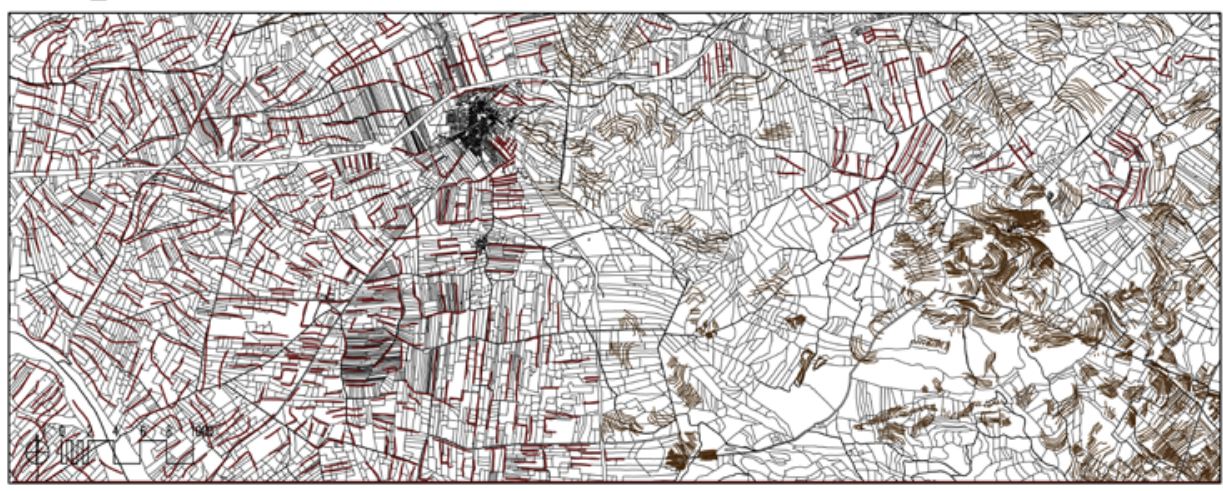

Zona 9_Mas Stellers

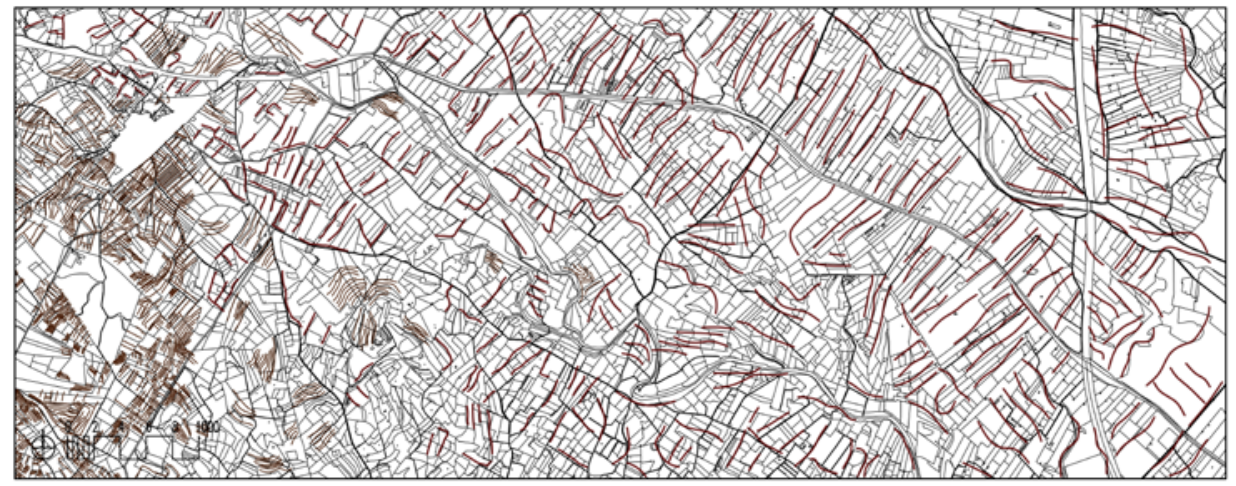

\section{Zona 10 Cervera / Calig}

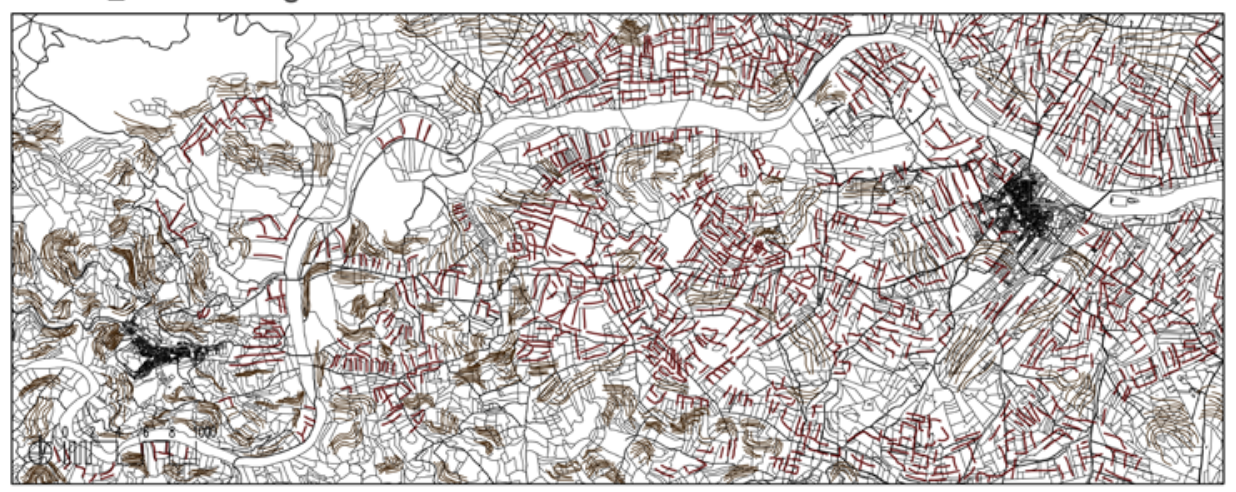

Zona 12_Atalaya San Pere

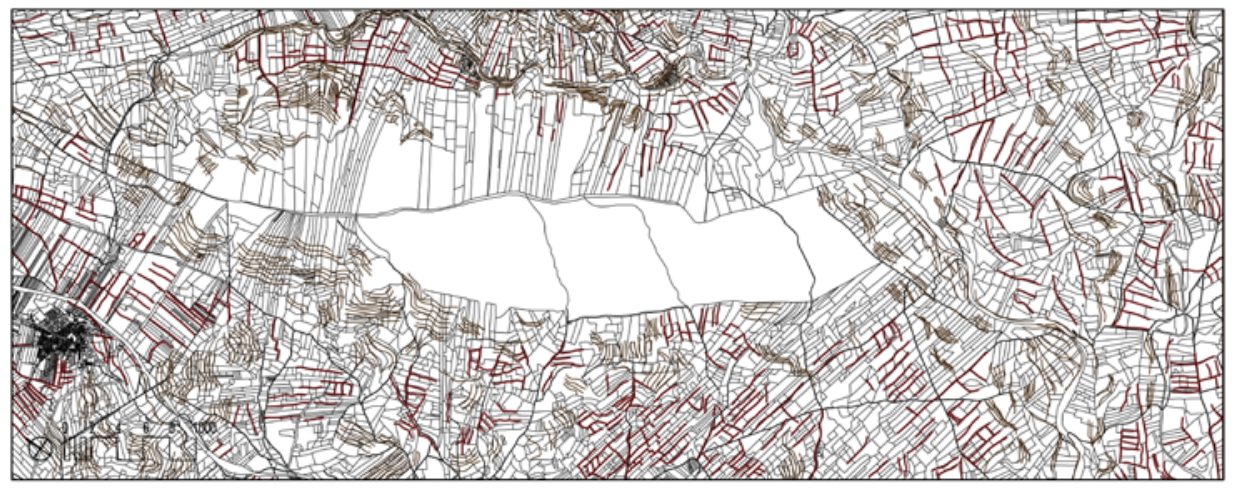


Mapa general (situación de las zonas de estudio) - $[e=1 / 200.000]$

\section{Combinaciones: Muros + Usos}

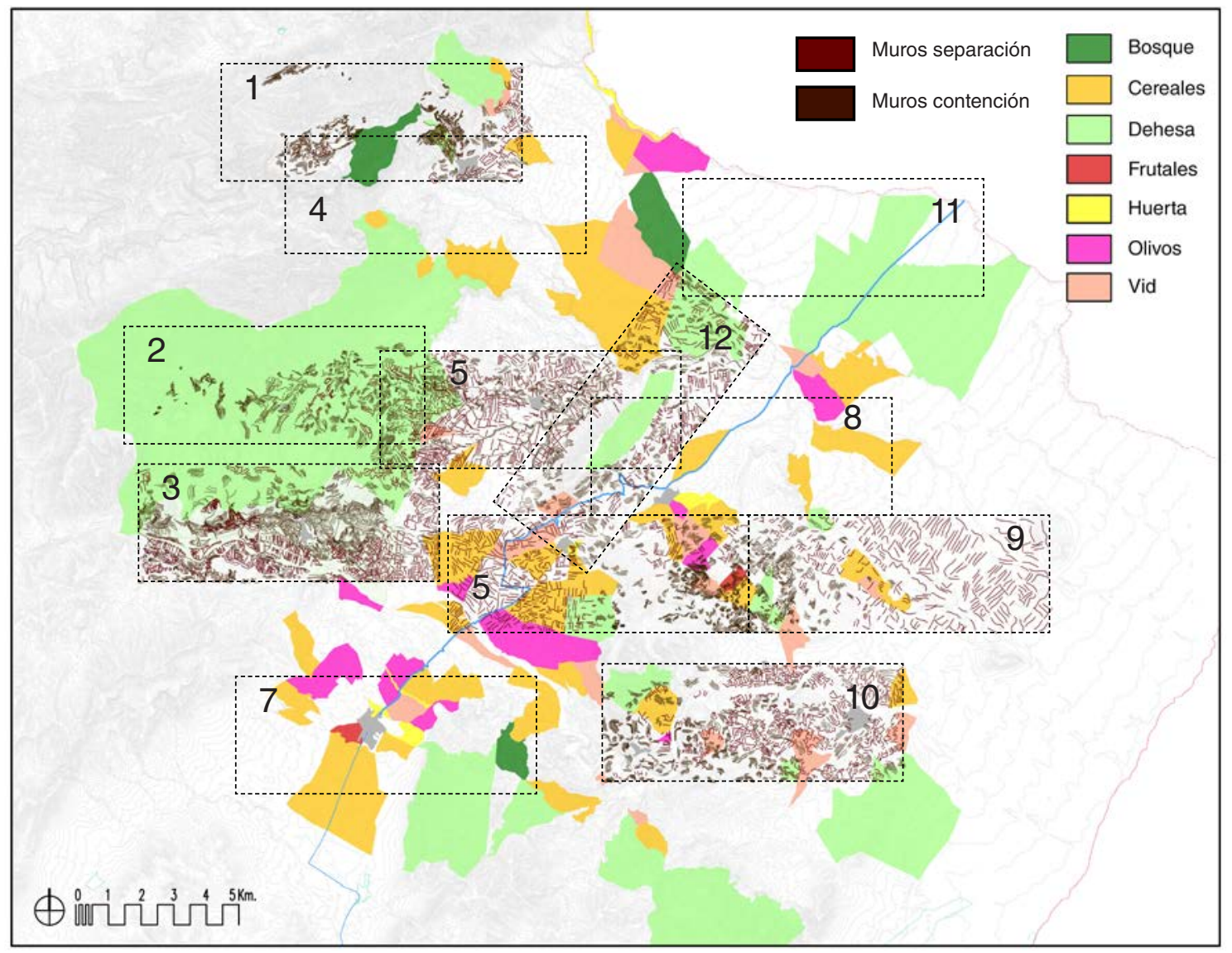

Fig. 4. 96. Plano de la Batllia a escala 1/200.000 del plano de usos y muros existentes en la Edad Media. Señalización 12 zonas de estudio. 
Muros + Usos - Zonas 1, 2, 3, 5 - [e=1/75.000]

Zona 1_Bel

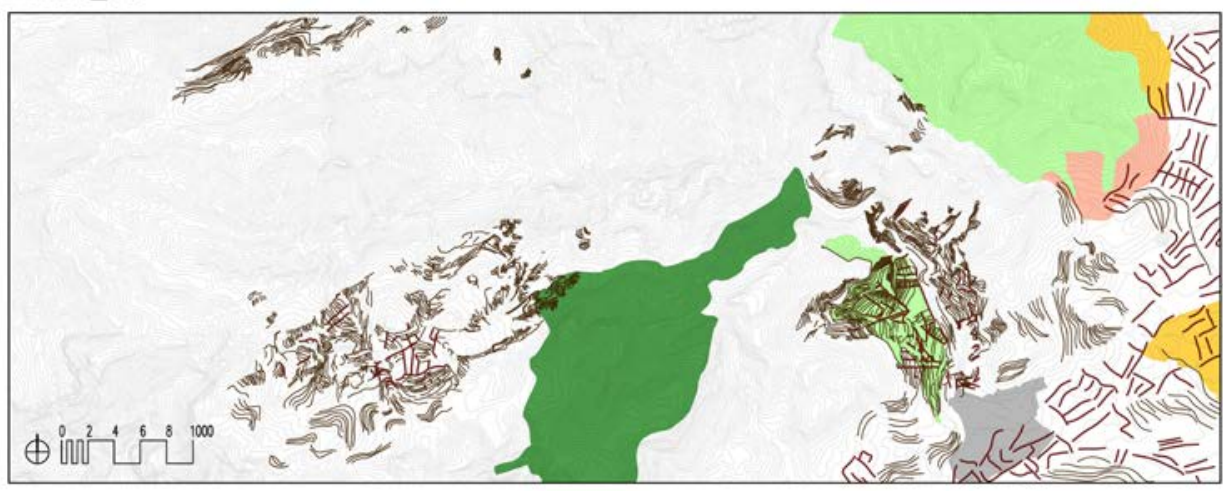

Zona 2_Barcella

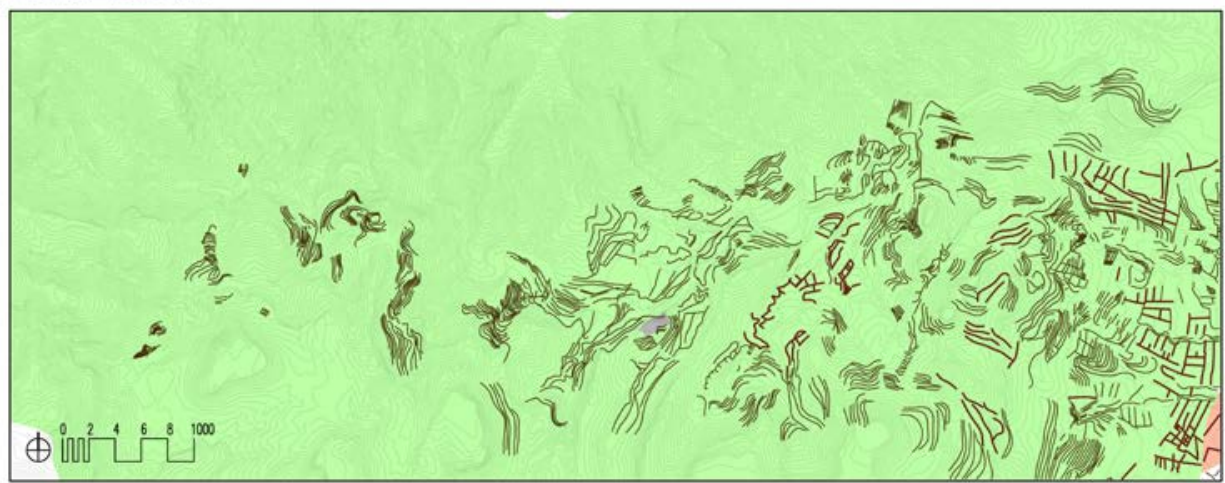

Zona 3_Molinar / Xert

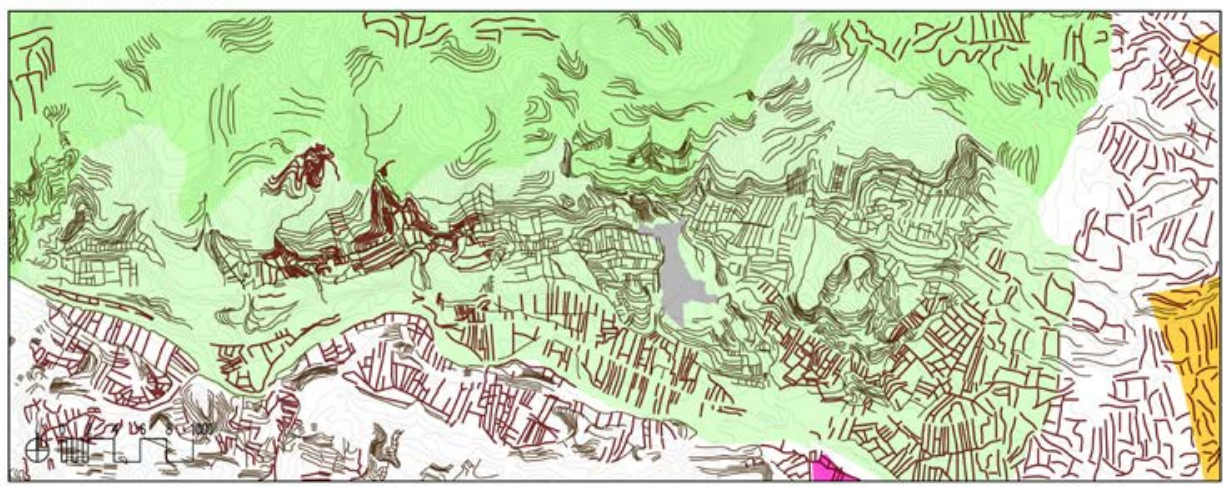

\section{Zona 5_Canet}

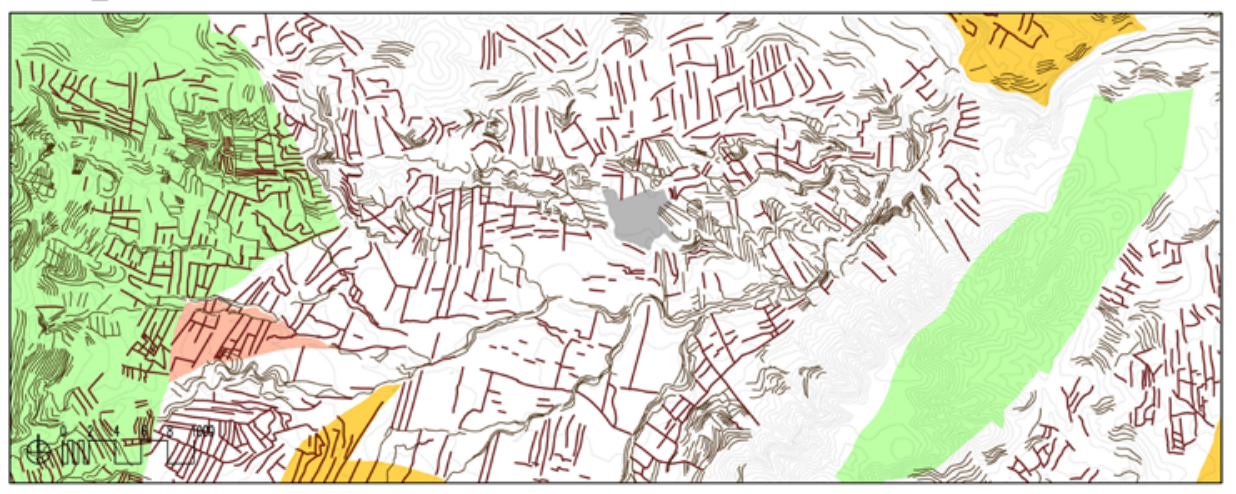


Muros + Usos - Zonas 6, 9, 10, 12 - $[\mathrm{e}=1 / 75.000]$

Zona 6_La Jana/Carrascal

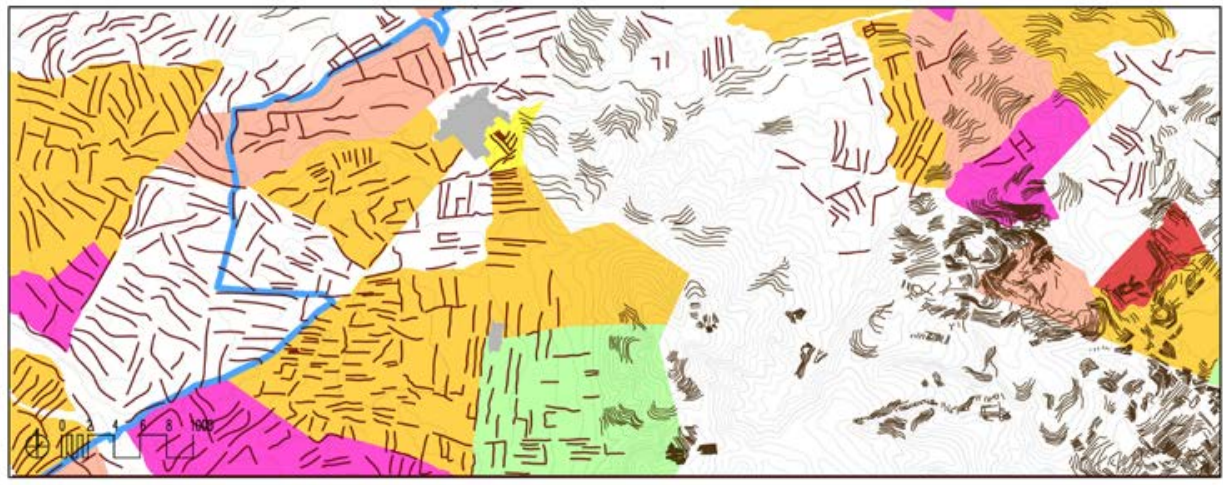

Zona 9_Mas Stellers

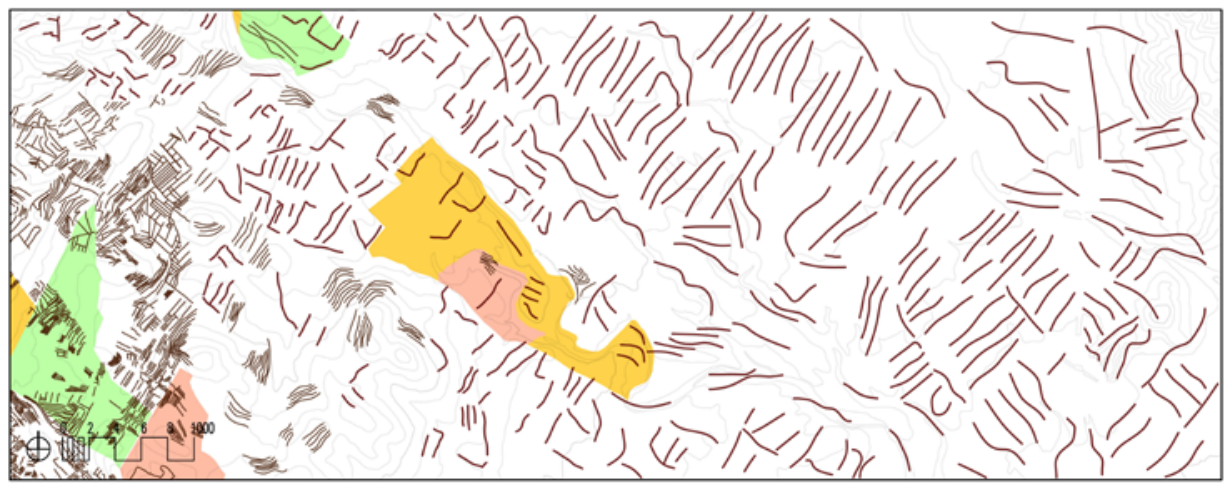

Zona 10_Cervera/Calig

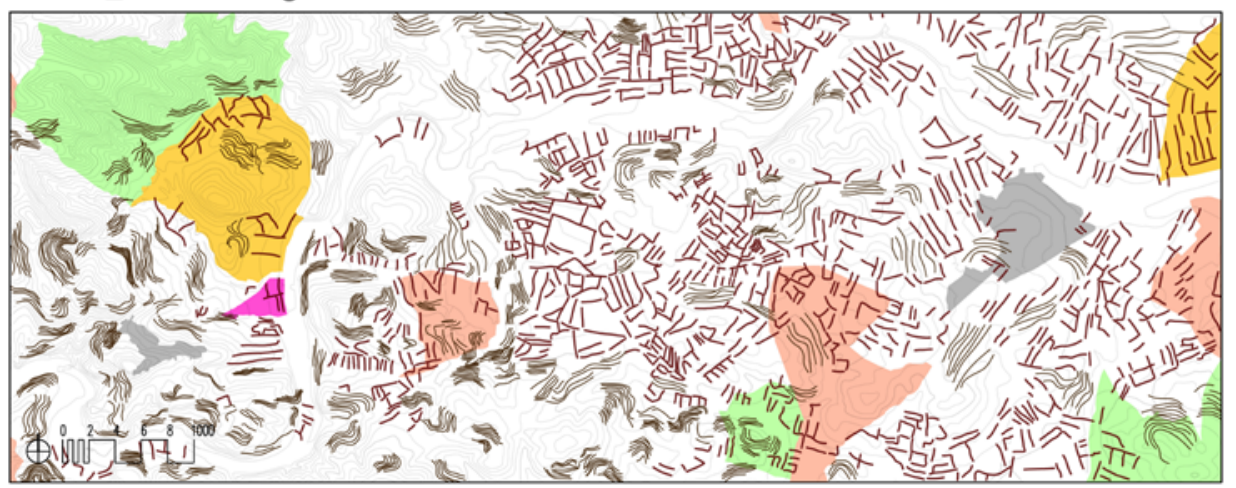

Zona 12_Atalaya San Pere

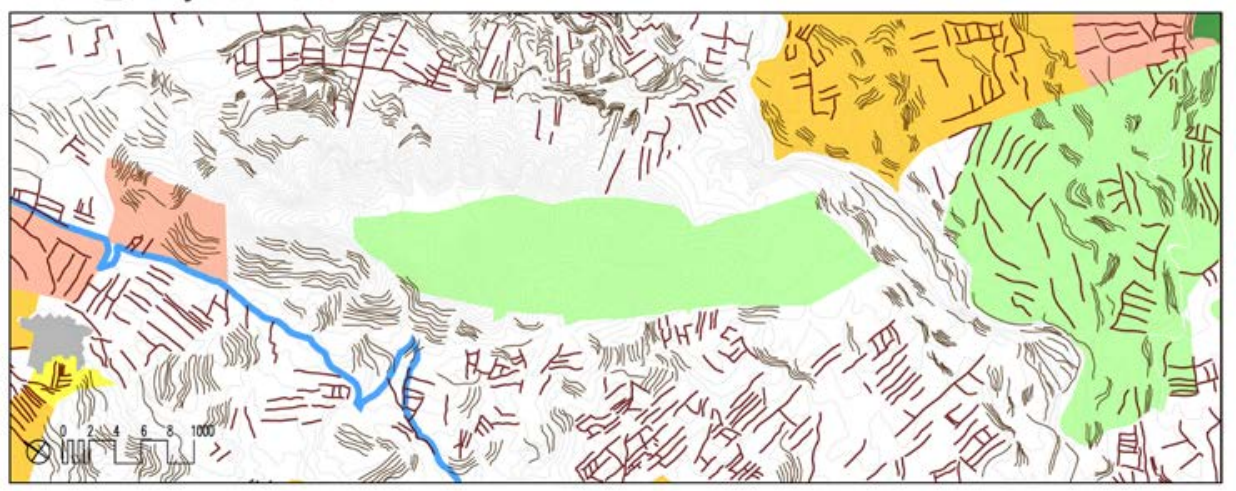


Mapa general (situación de las zonas de estudio) - $[e=1 / 200.000]$

\section{Combinaciones: Infraestructuras + Parcelario}

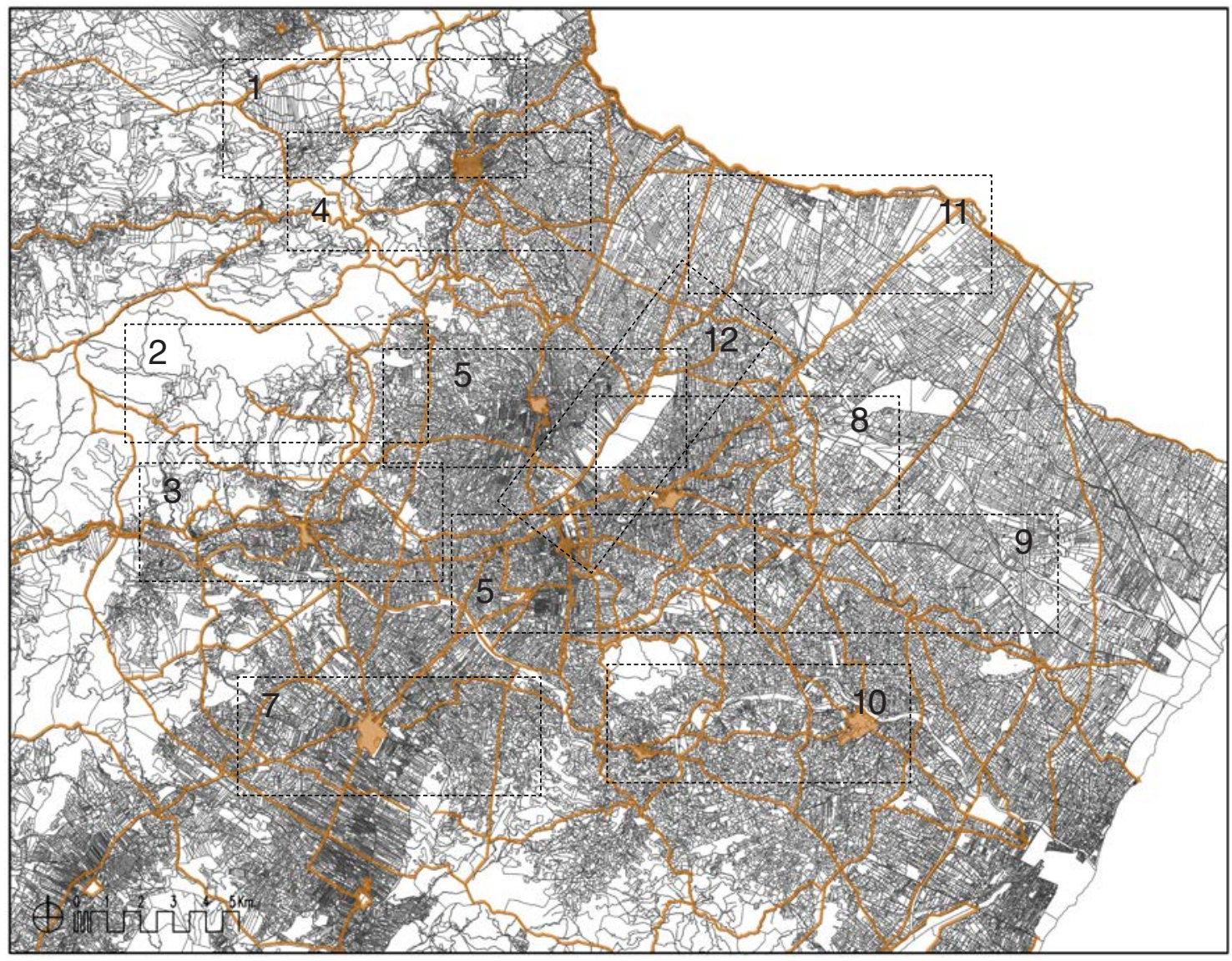

Fig. 4. 97. Plano de la Batllia a escala 1/200.000 del plano de infraestructuras y parcelario existentes en la Edad Media. Señalización 12 zonas de estudio. 
Infraestructuras + Parcelario - Zonas 1-4 - $[e=1 / 75.000]$

Zona1_Bel

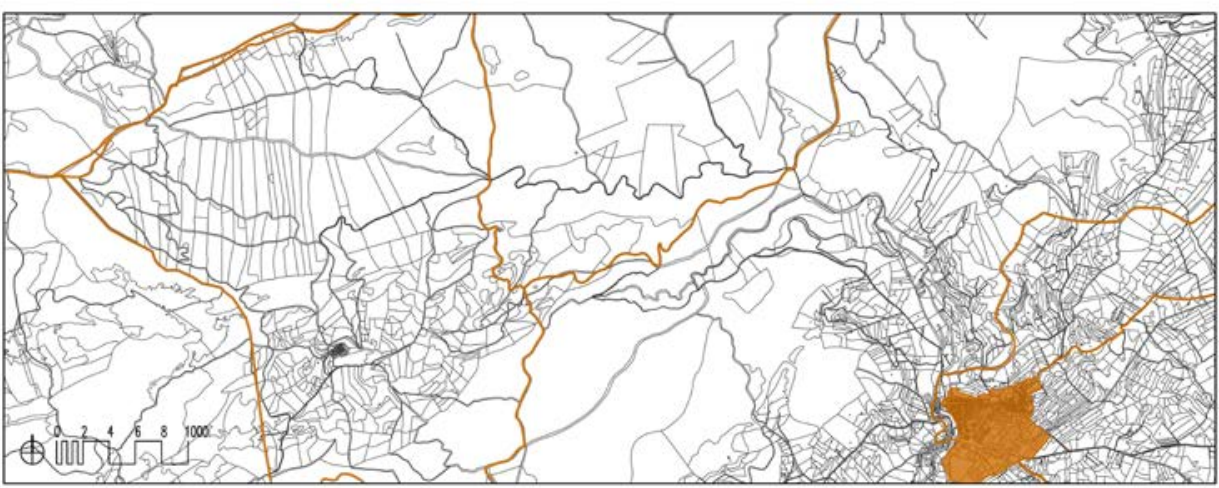

Zona 2 Barcella

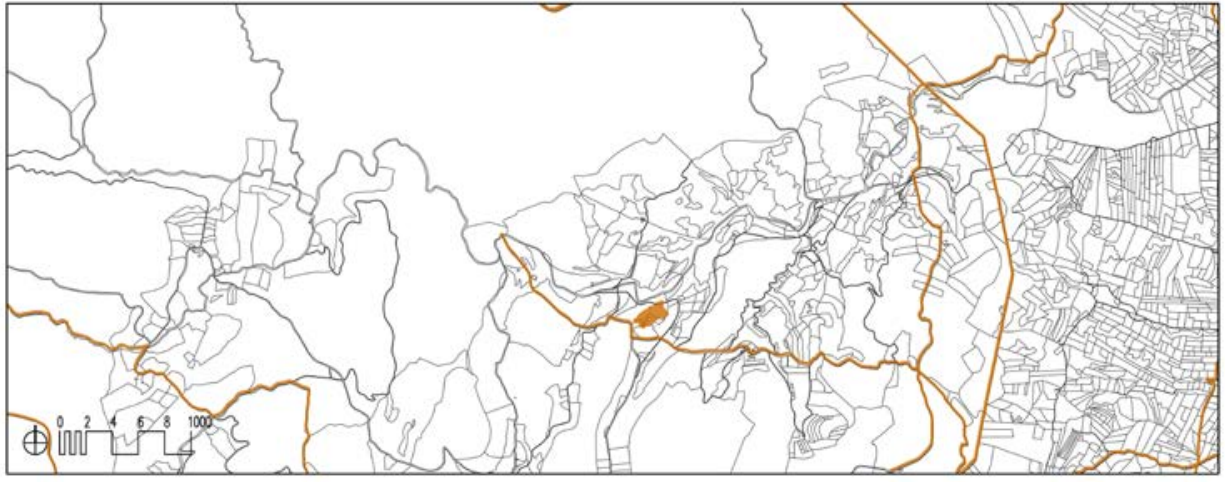

Zona 3 Molinar / Xert

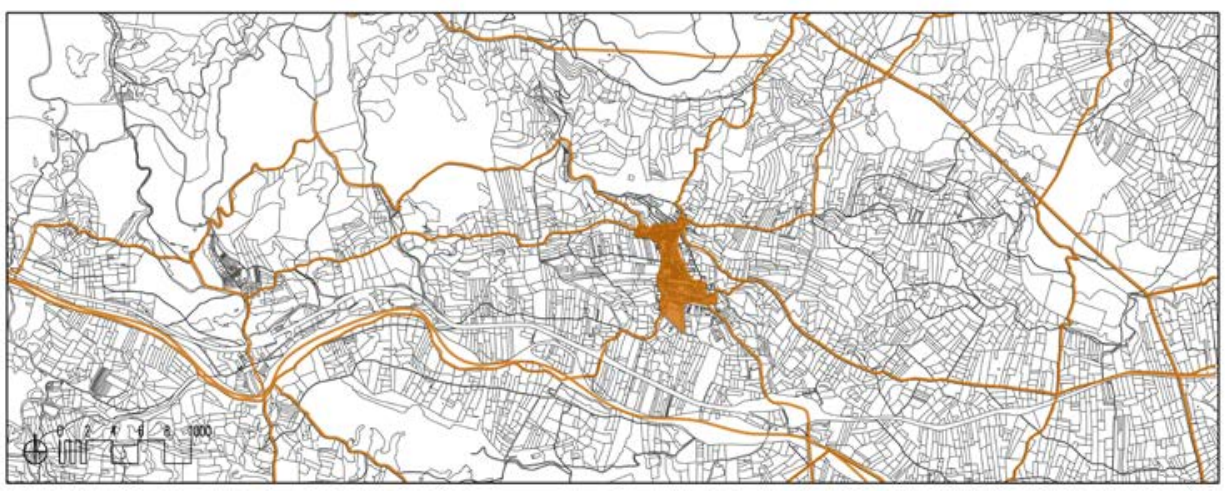

Zona 4_Mas del Coll / Rosell

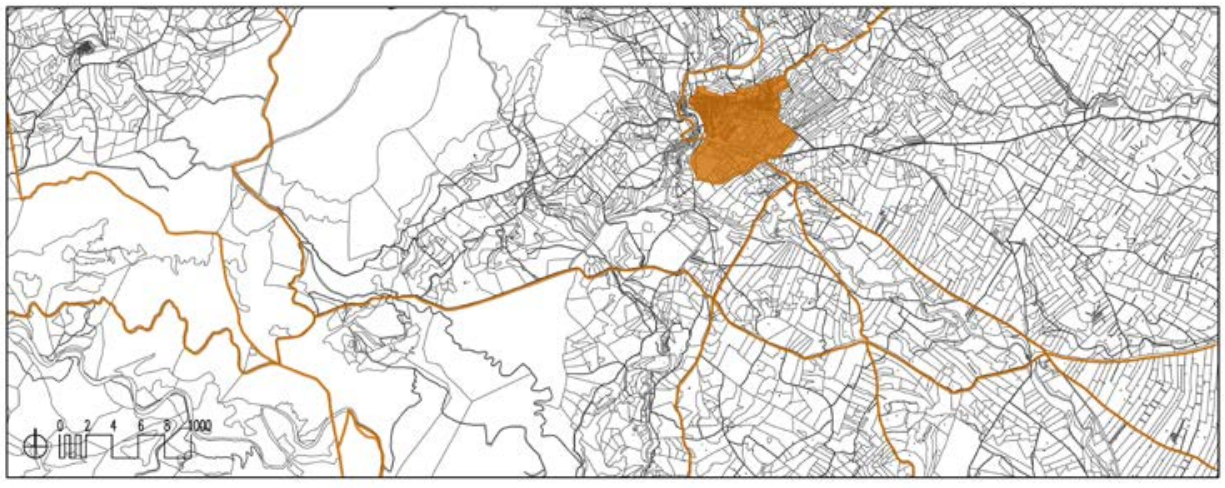


Infraestructuras + Parcelario - Zonas 5-8 - $[\mathrm{e}=1 / 75.000]$

Zona 5_Canet

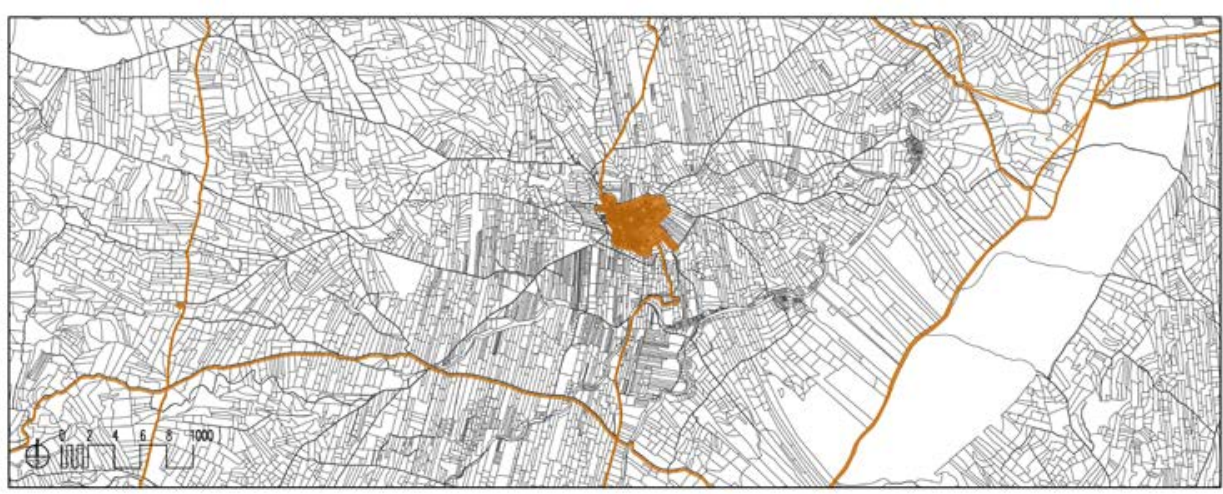

\section{Zona 6_La Jana/Carrascal}

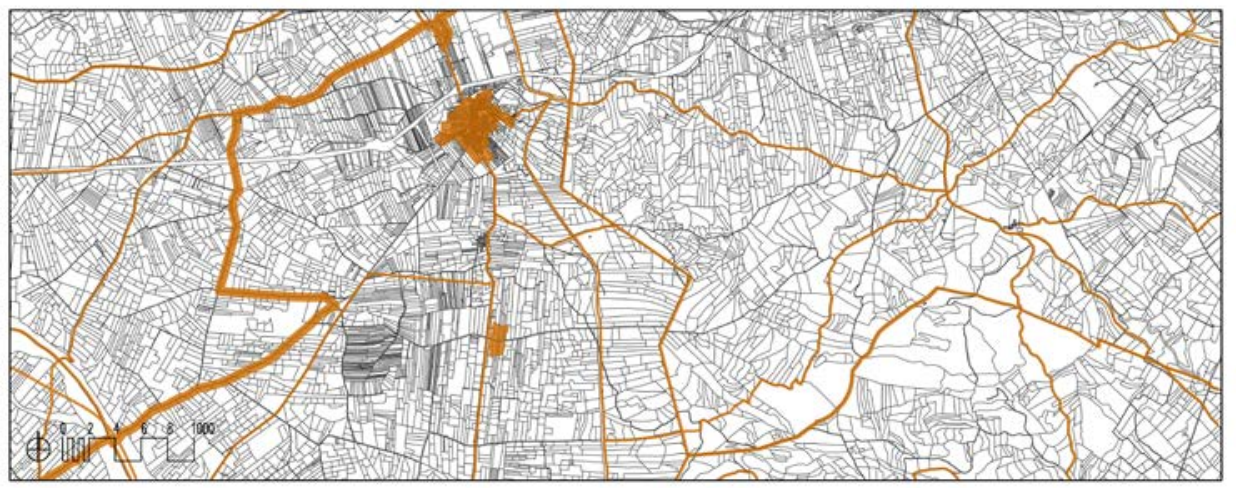

Zona 7_San Mateo

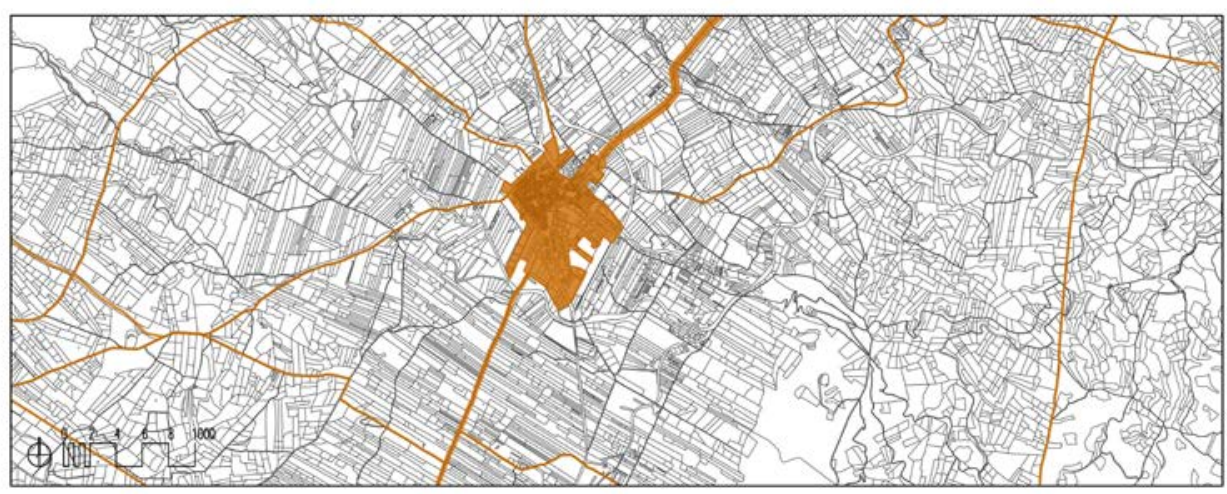

\section{Zona 8_Traiguera}

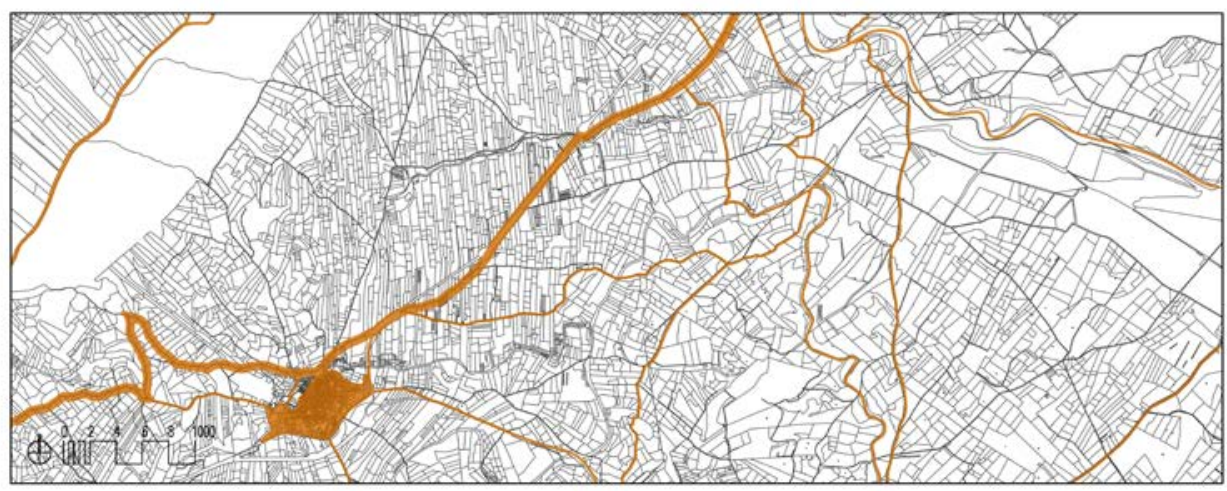




\section{Infraestructuras + Parcelario - Zonas 9-12 - $[e=1 / 75.000]$}

\section{Zona 9_Mas Stellers}

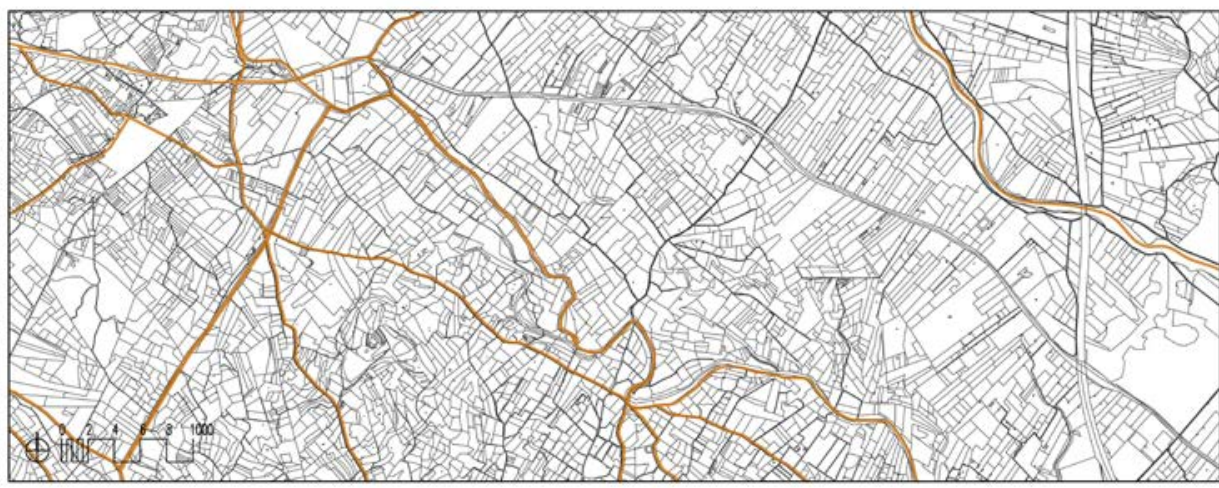

\section{Zona 10_Cervera/Calig}

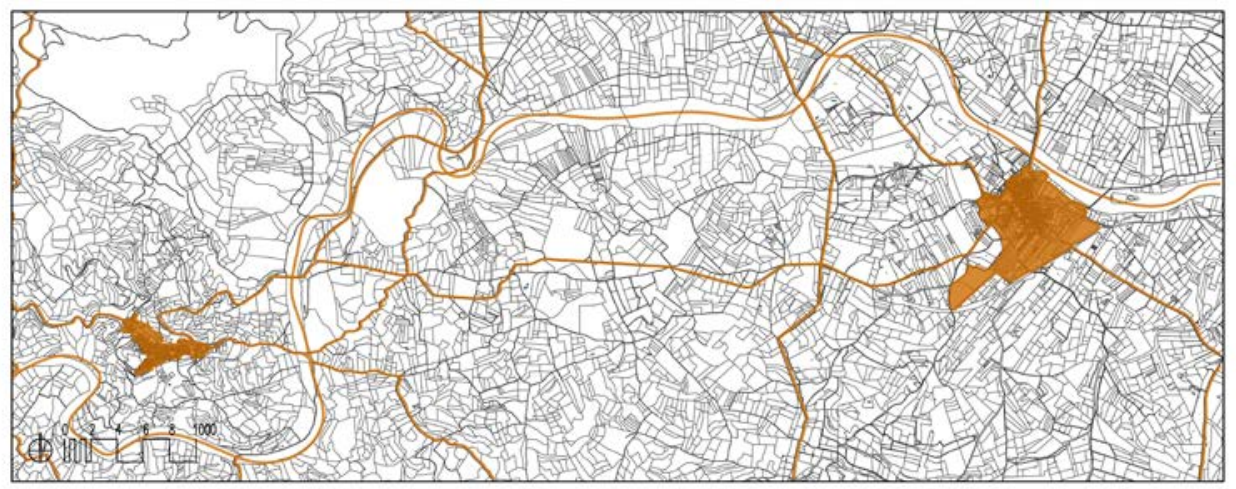

\section{Zona 11_San Joan del Pas}

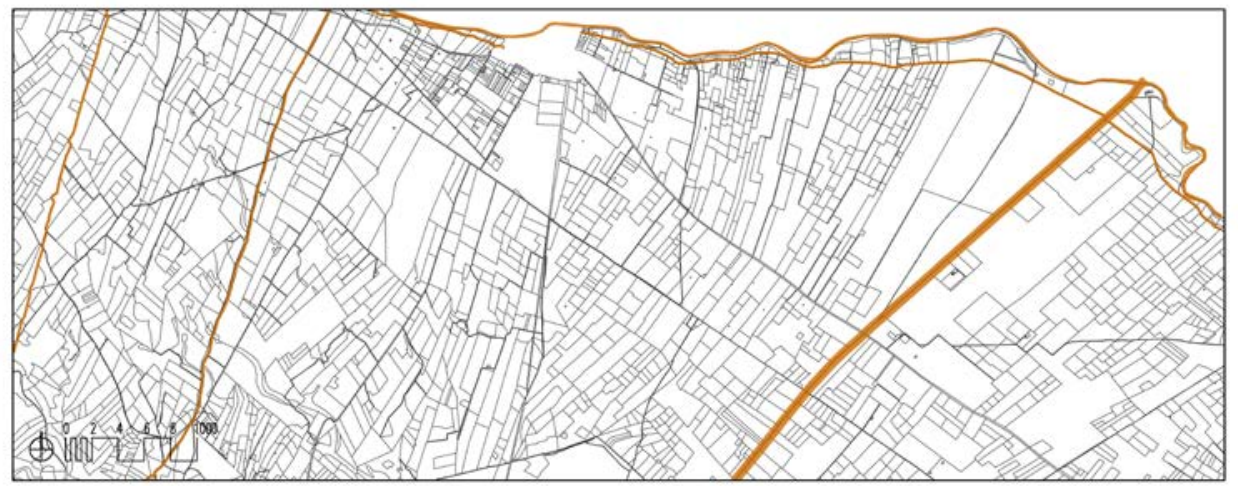

\section{Zona 12_Atalaya San Pere}

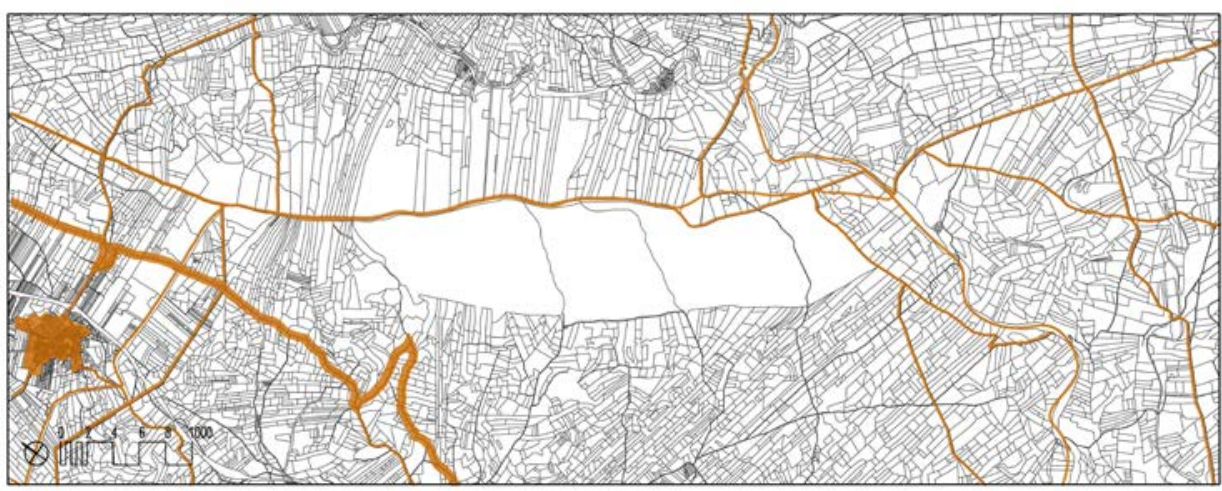


Mapa general (situación de las zonas de estudio) [e=1/200.000]

Combinaciones: Infraestructuras + Usos

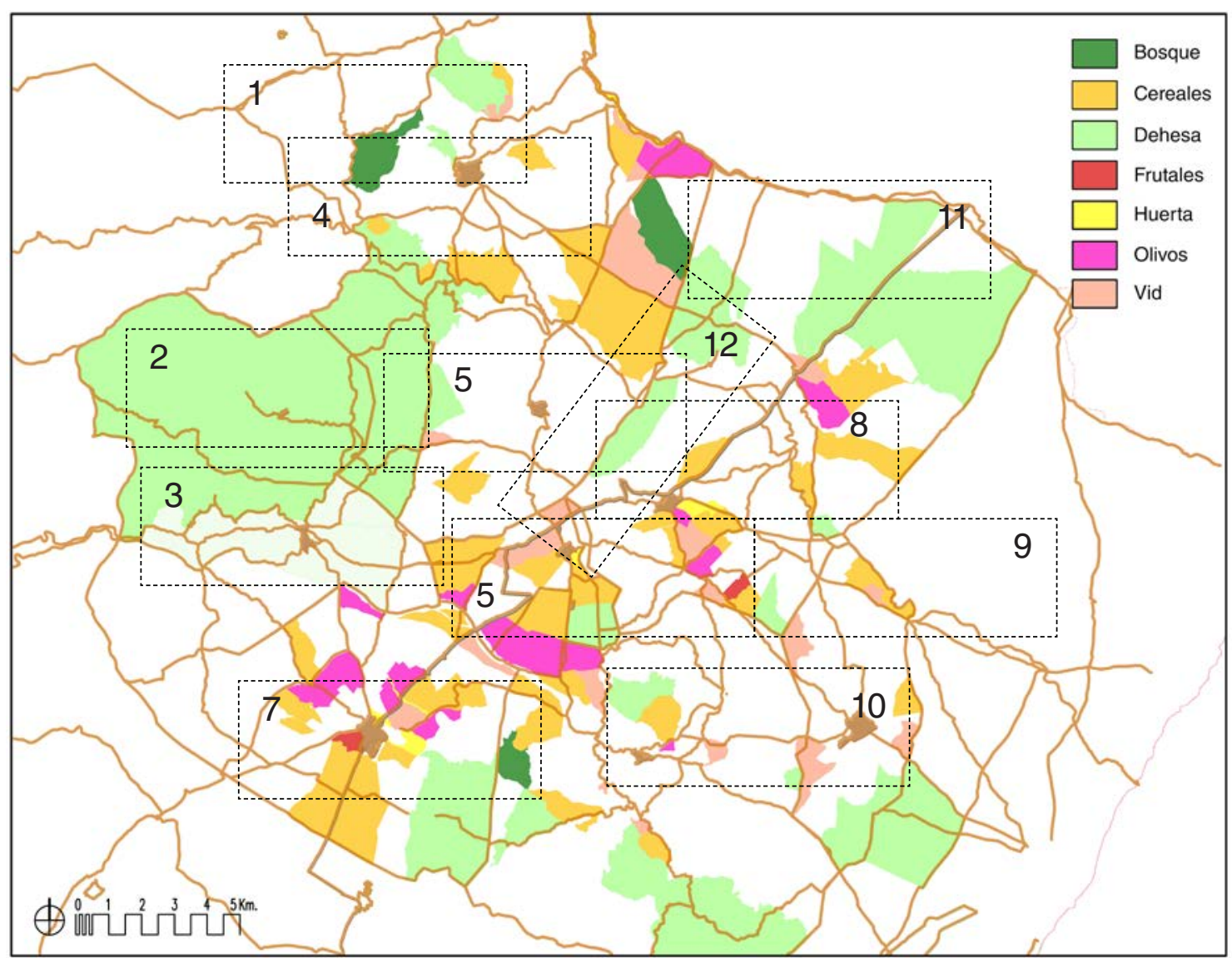

Fig. 4. 98. Plano de la Batllia a escala $1 / 200.000$ del plano de infraestructuras y uso existentes en la Edad Media. Señalización 12 zonas de estudio. 
Infraestructuras + Usos - Zonas 1-4 - [e=1/75.000]

\section{Zona1_Bel}

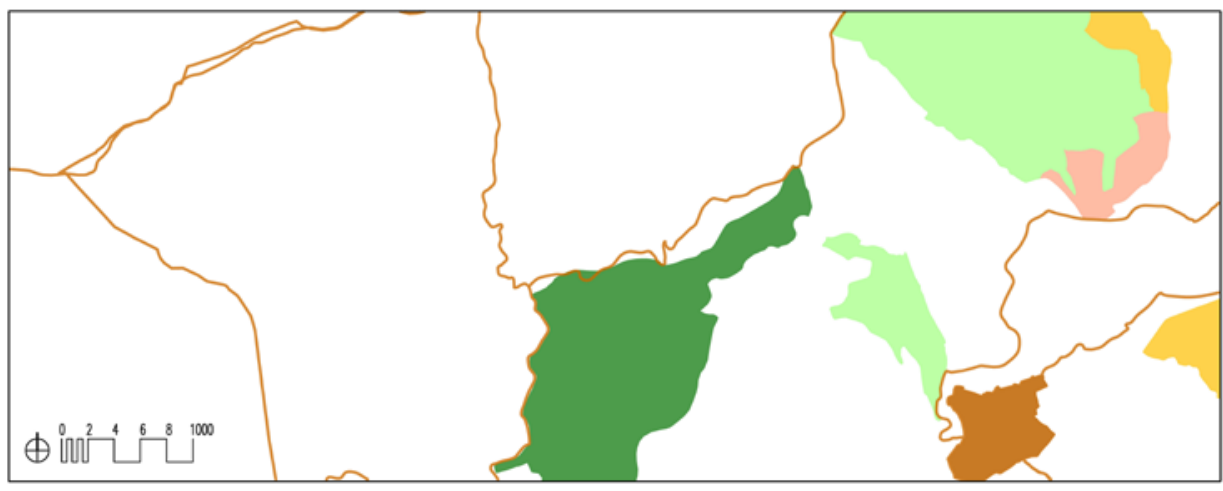

\section{Zona 2 Barcella}

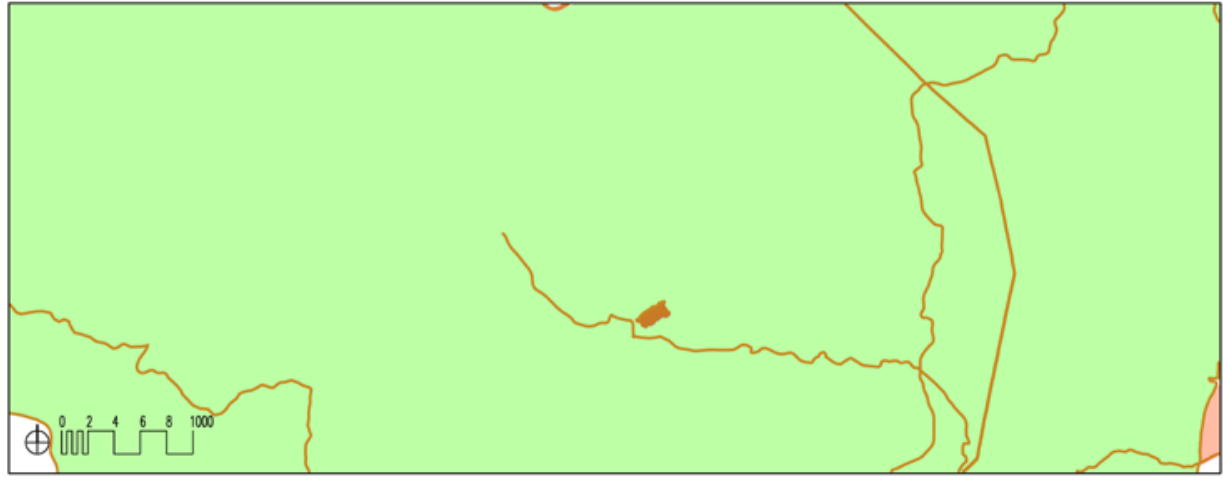

Zona 3_Molinar/Xert

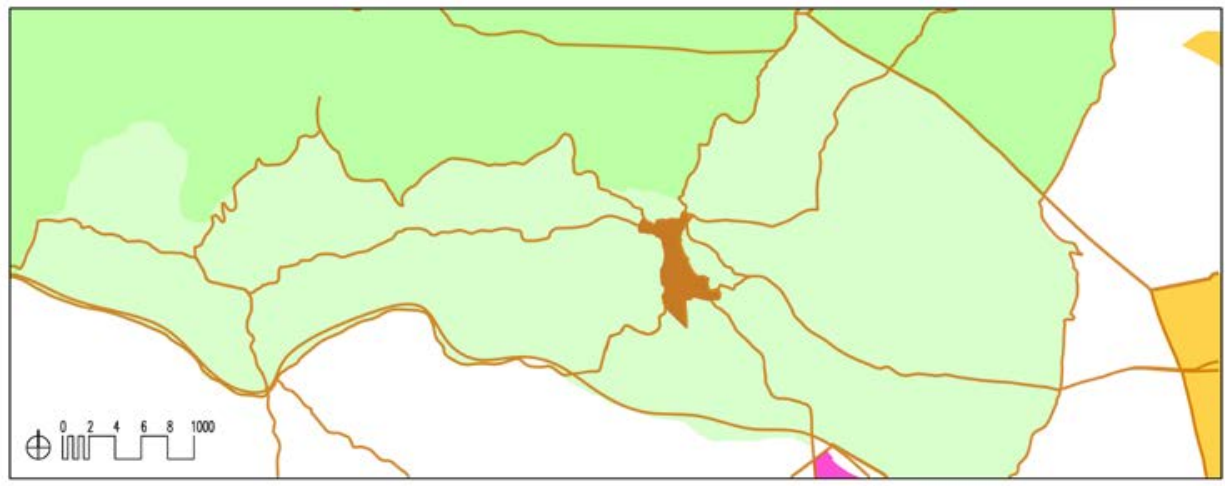

\section{Zona 4_Mas del Coll / Rosell}

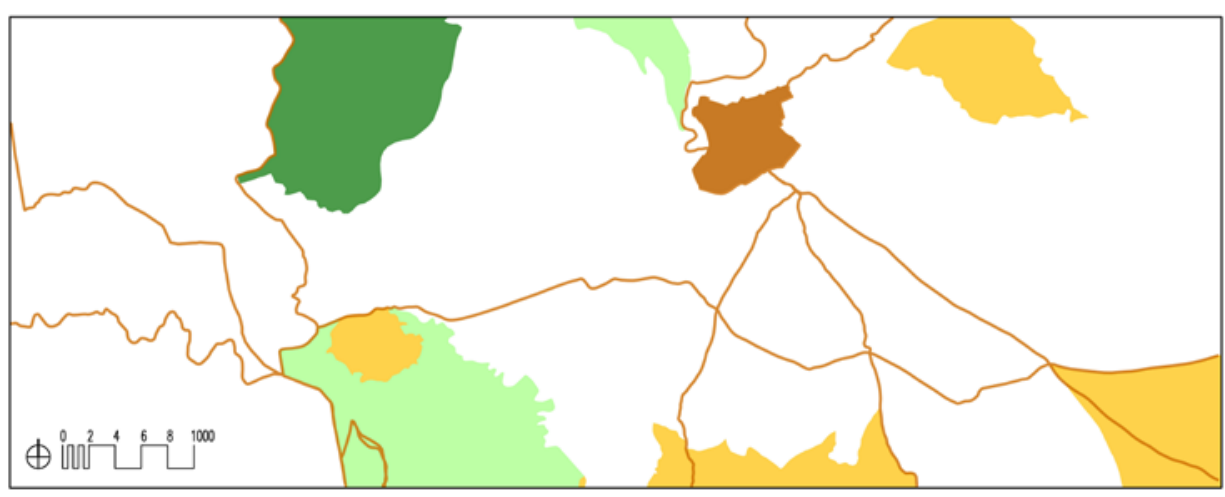


Infraestructuras + Usos - Zonas 5-8 - $[\mathrm{e}=1 / 75.000]$

Zona 5_Canet

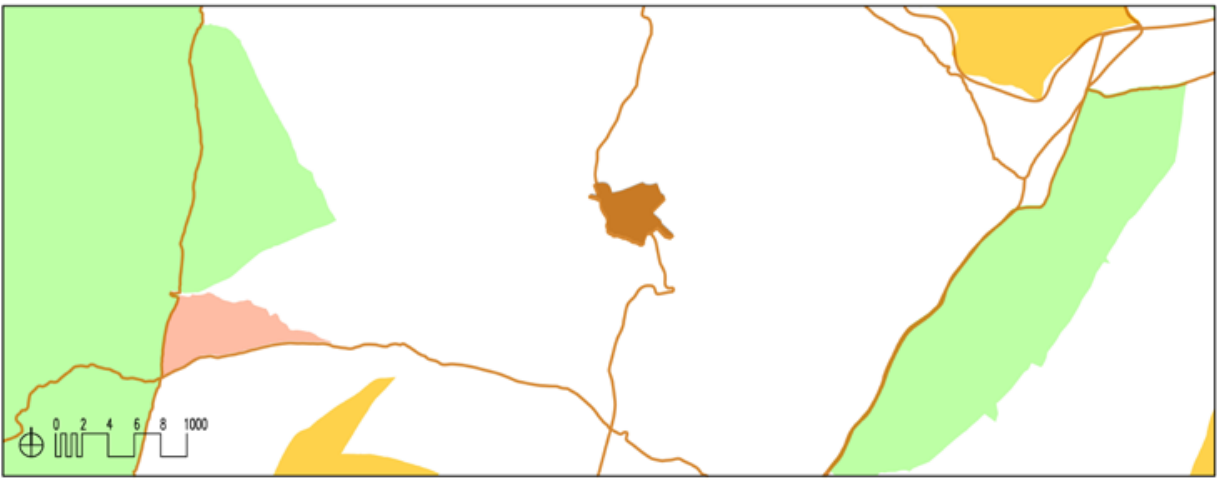

Zona 6 La Jana/Carrascal

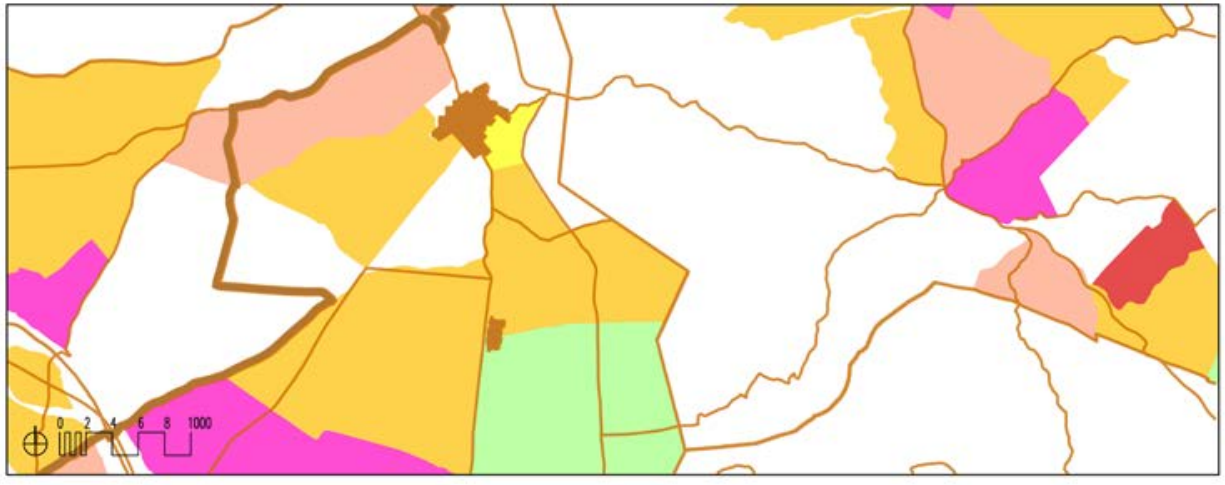

\section{Zona 7_San Mateo}

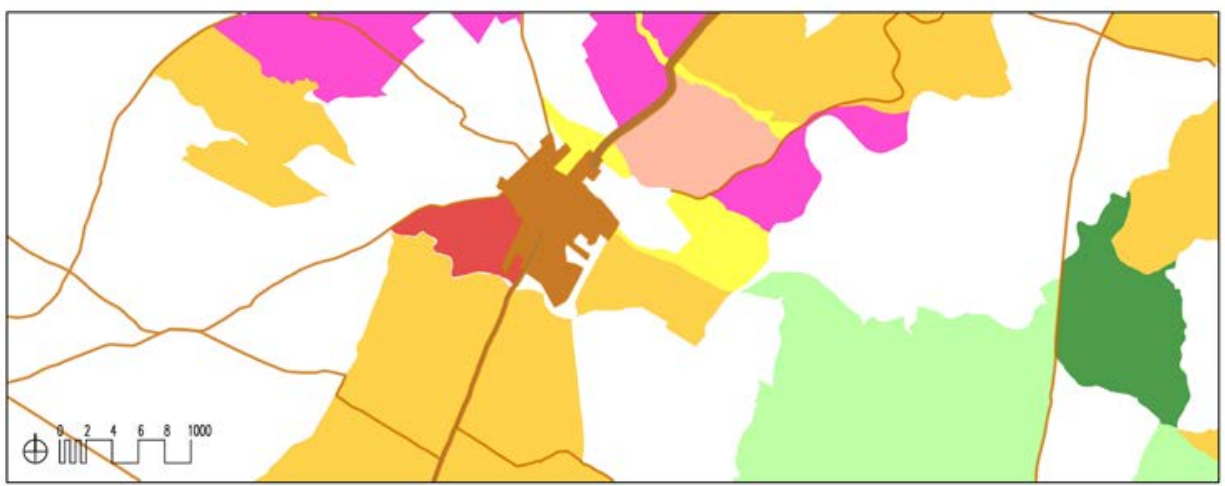

Zona 8_Traiguera

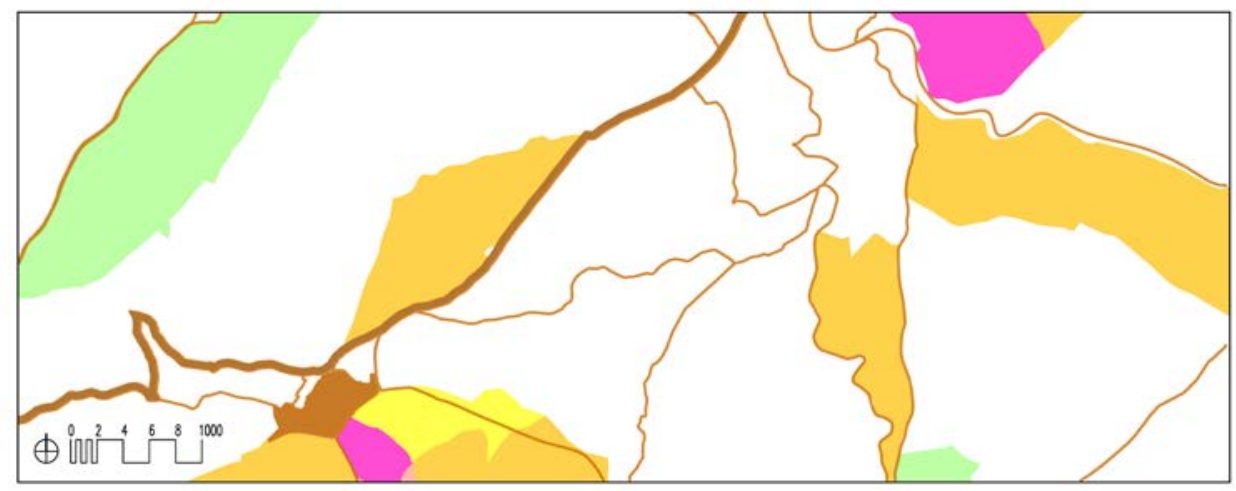


Infraestructuras + Usos - Zonas 9-12 - $[\mathrm{e}=1 / 75.000]$

\section{Zona 9_Mas Stellers}

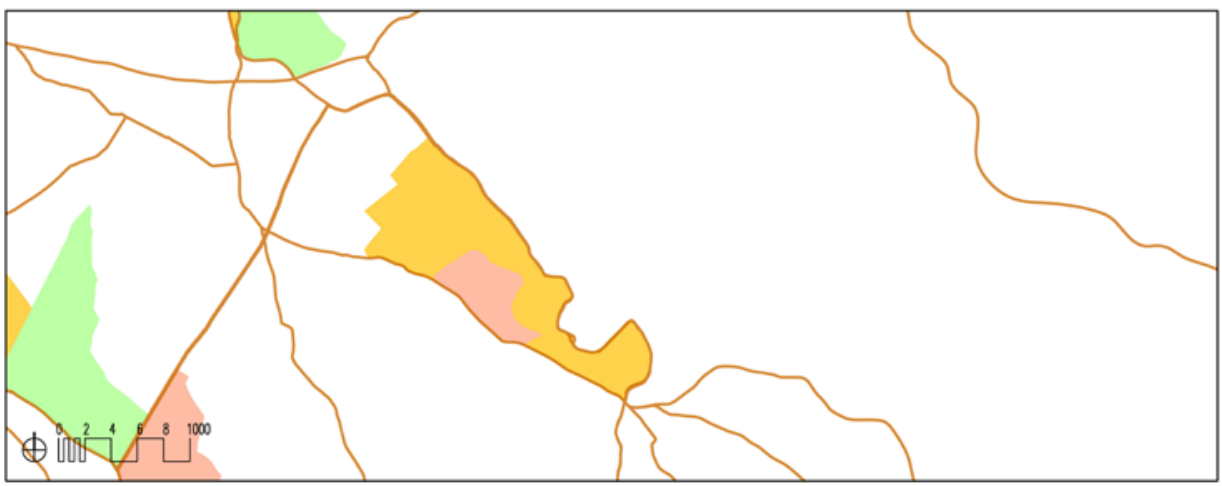

\section{Zona 10_Cervera/Calig}

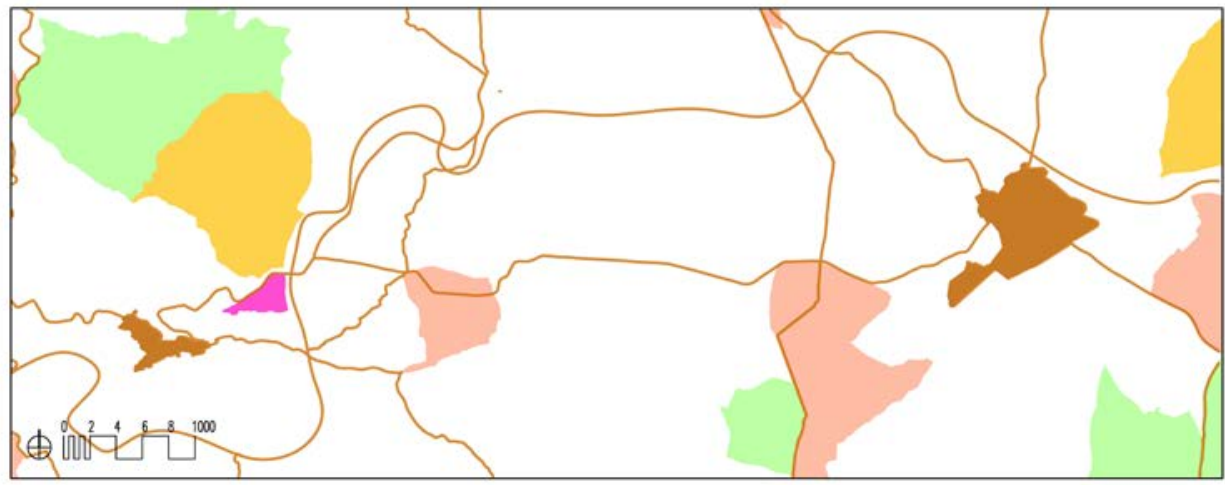

Zona 11_San Joan del Pas

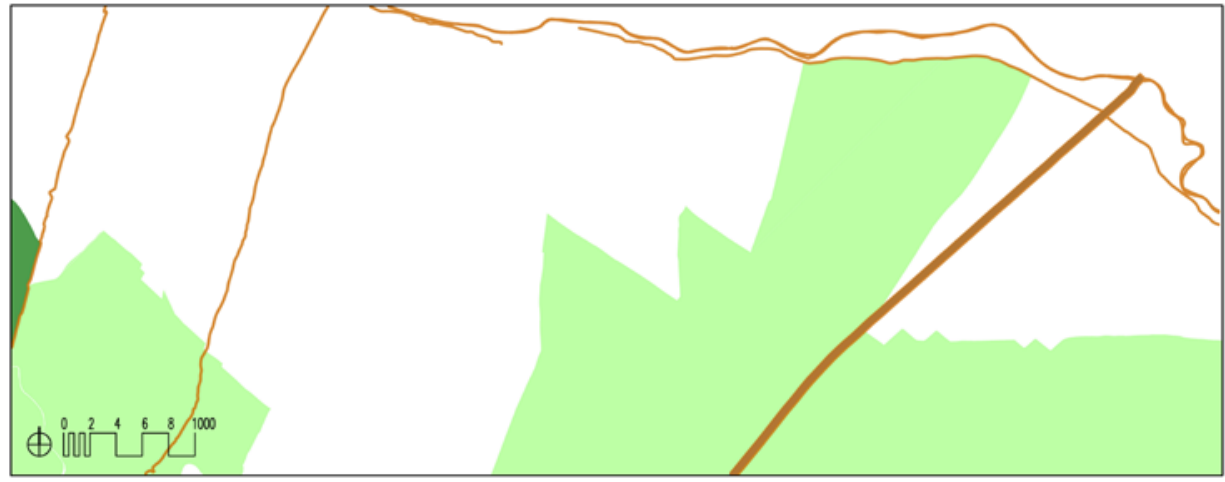

Zona 12_Atalaya San Pere

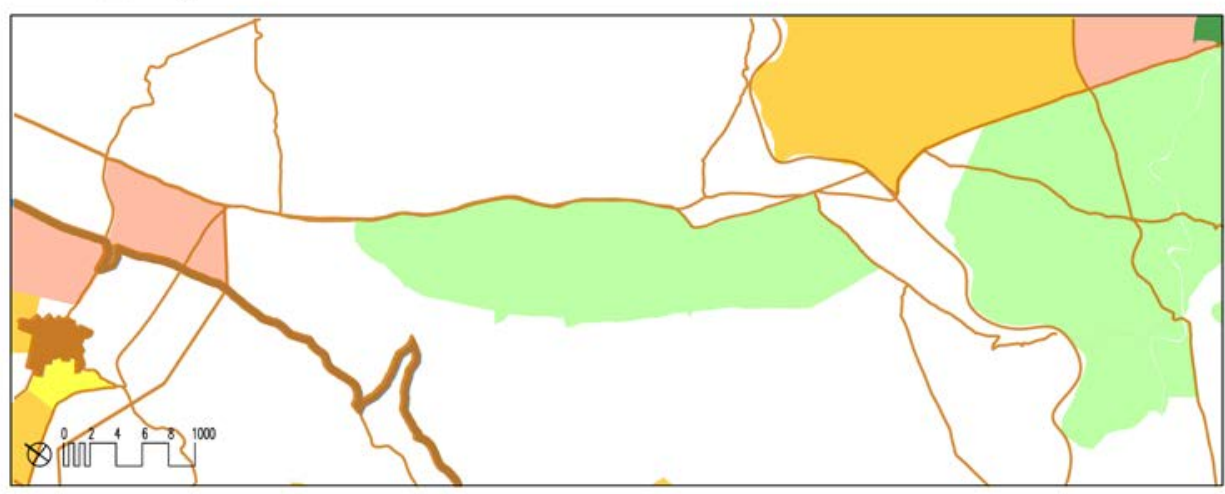


Mapa general (situación de las zonas de estudio) - $[e=1 / 200.000]$

\section{Combinaciones: Parcelario + Usos}

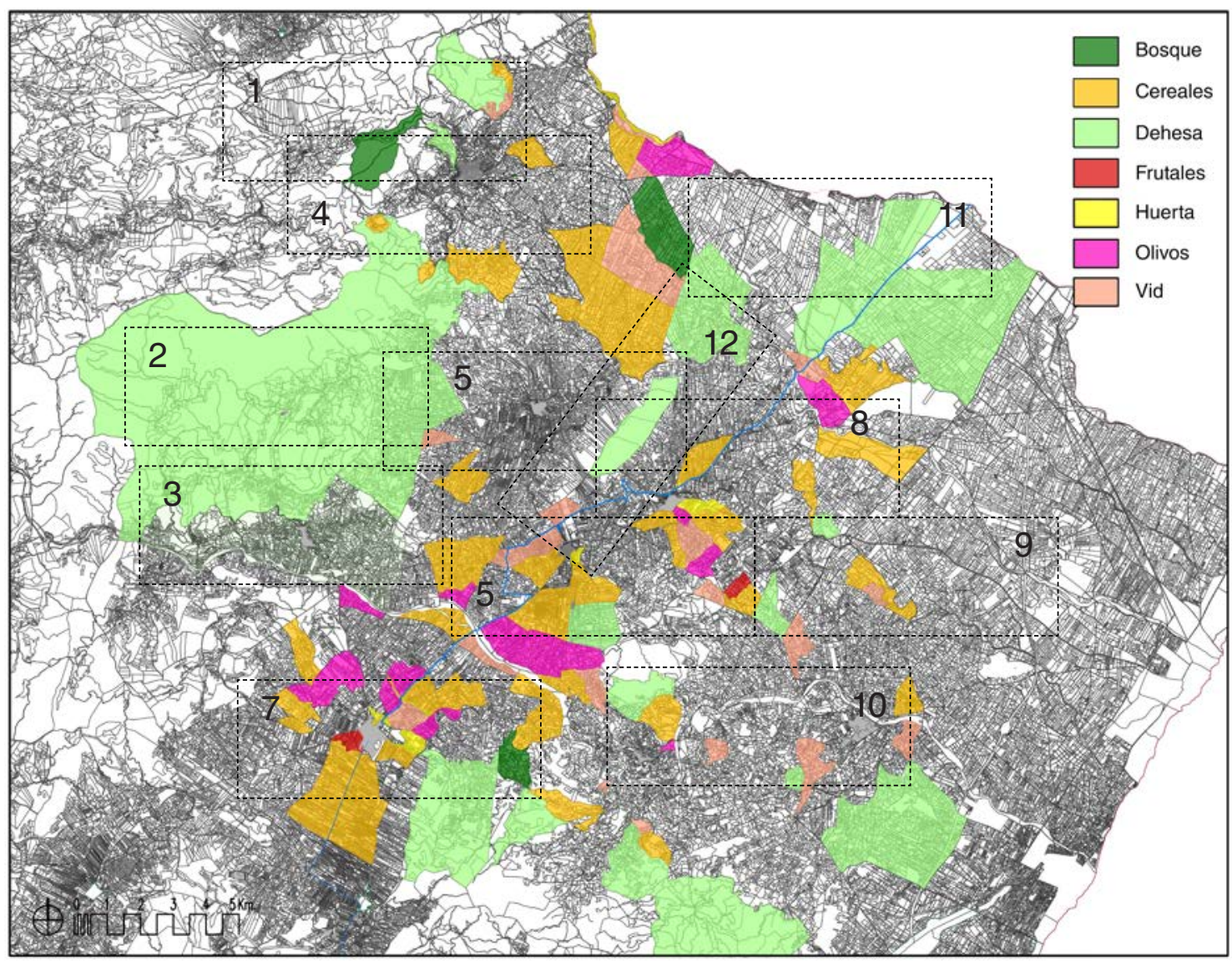

Fig. 4. 99. Plano de la Batllia a escala 1/200.000 del plano de parcelario y usos existentes en la Edad Media. Señalización 12 zonas de estudio. 


\section{Parcelario + Usos por zonas $[\mathrm{e}=1 / 75.000]$}

\section{Zona1_Bel}

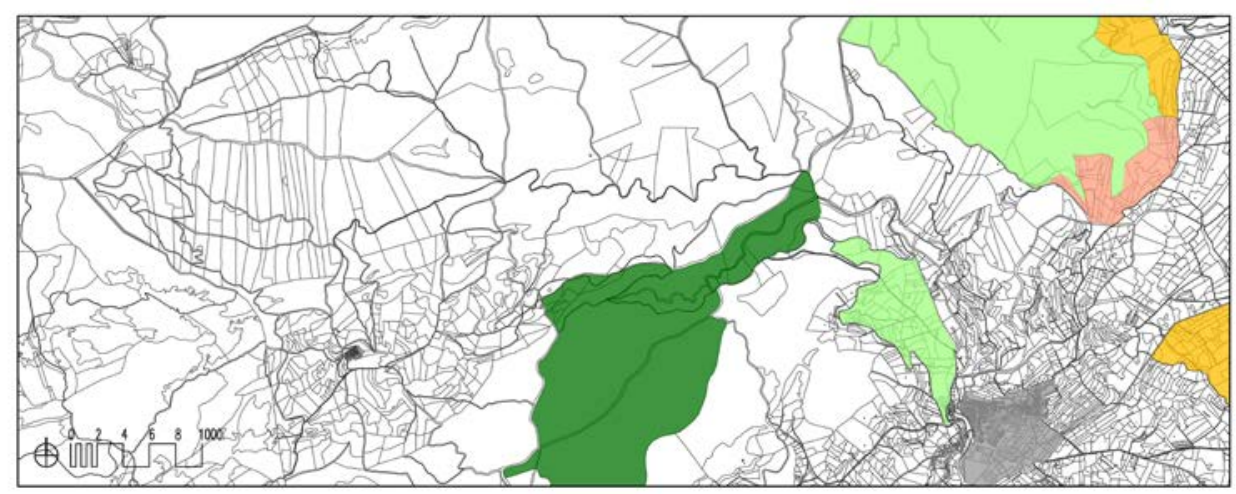

Zona 2_Barcella

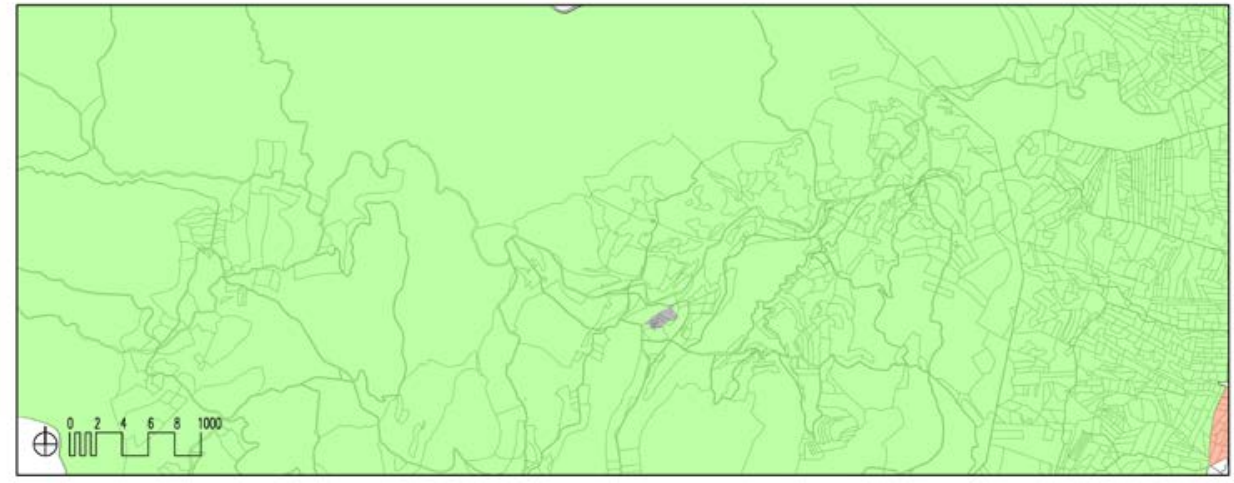

Zona 3 Molinar/Xert

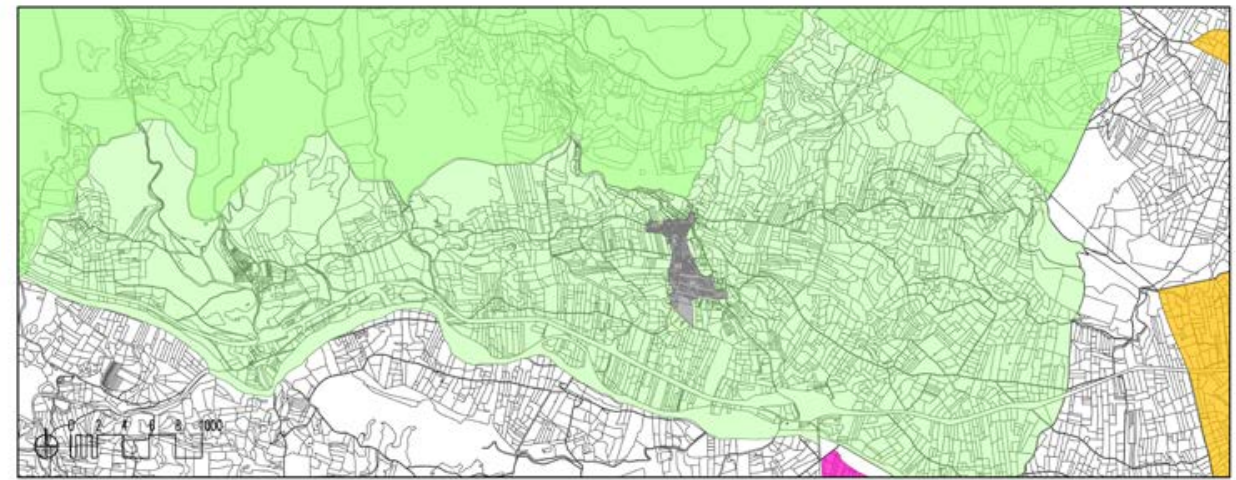

Zona 4_Mas del Coll / Rosell

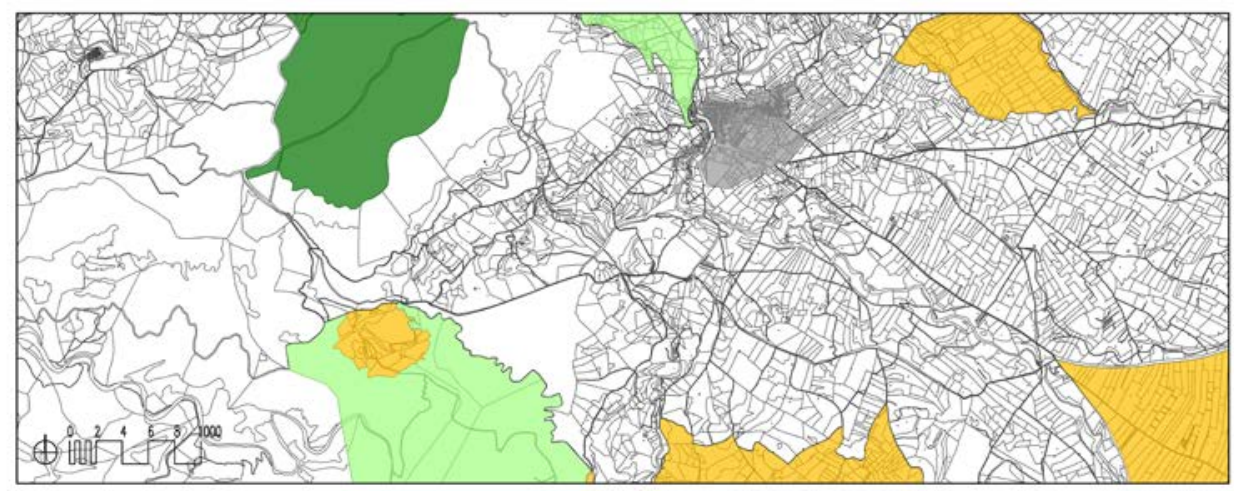




\section{Parcelario + Usos - Zonas 5-8 - $[\mathrm{e}=1 / 75.000]$}

\section{Zona 5_Canet}

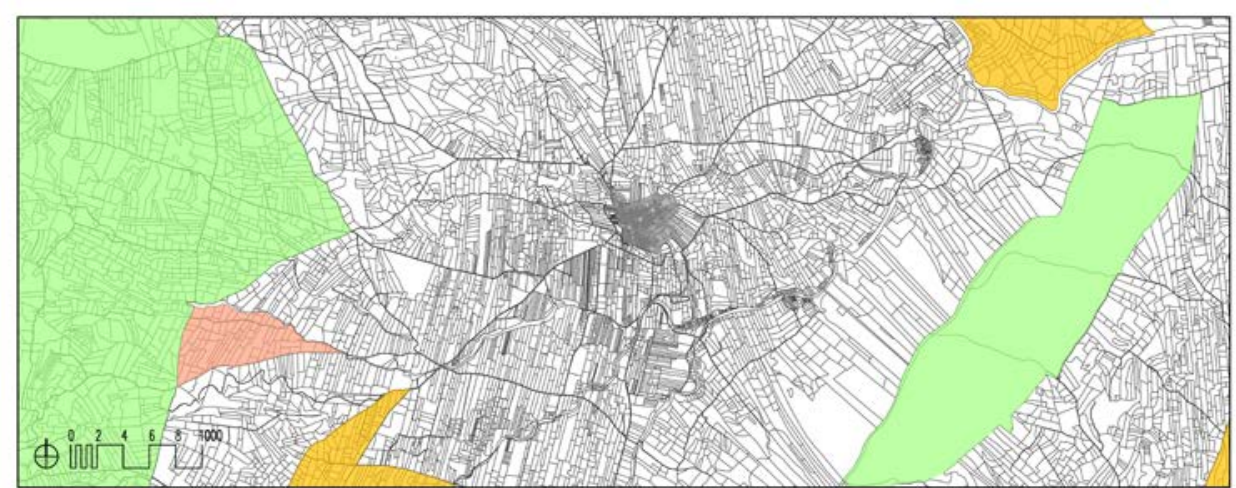

Zona 6_La Jana/Carrascal

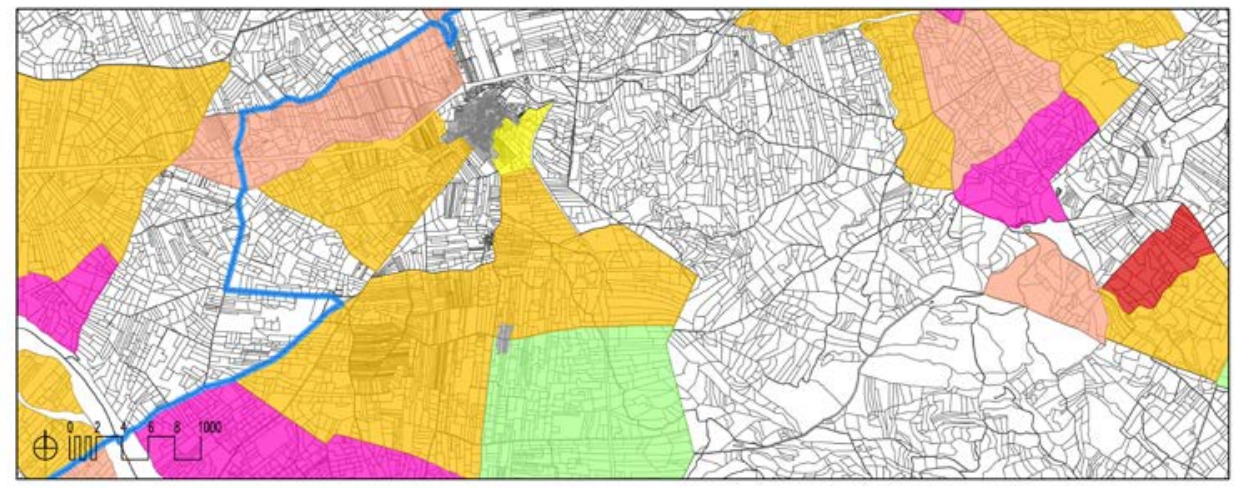

\section{Zona 7_San Mateo}

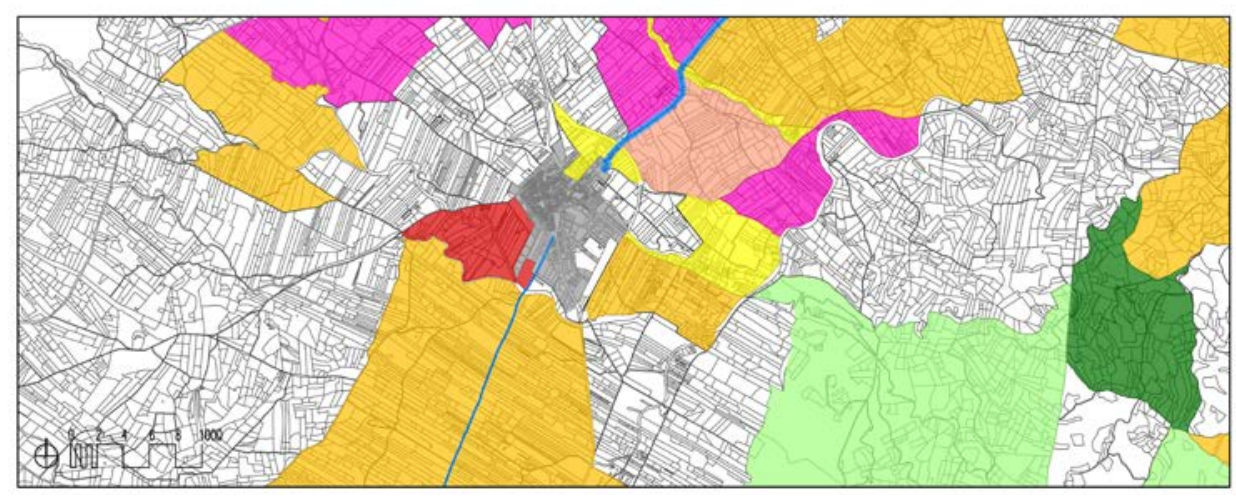

Zona 8_Traiguera

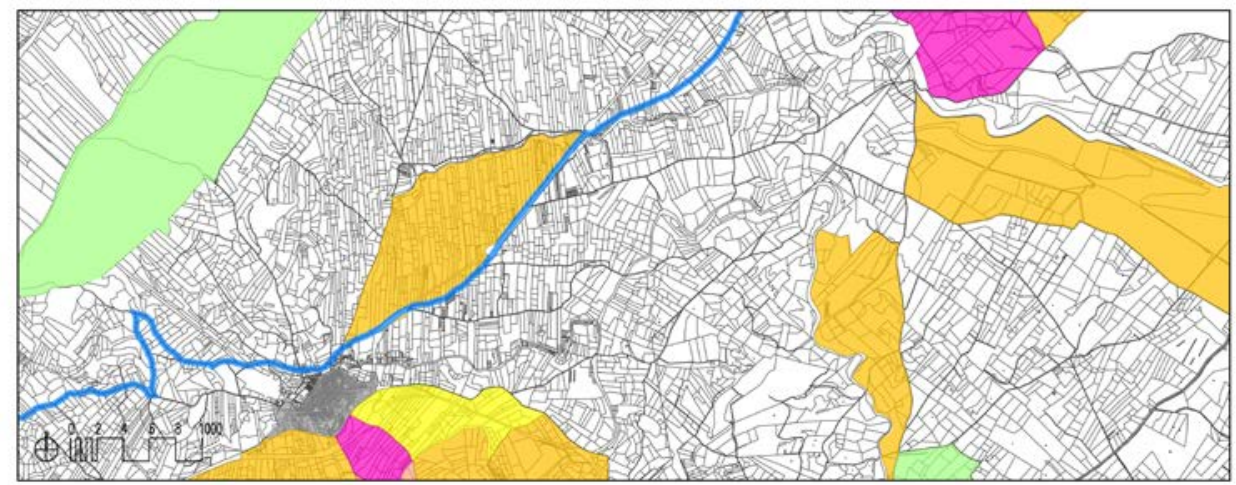




\section{Parcelario + Usos - Zonas 9-12 - $[\mathrm{e}=1 / 75.000]$}

\section{Zona 9_Virgen de la Salut / Mas Stellers}

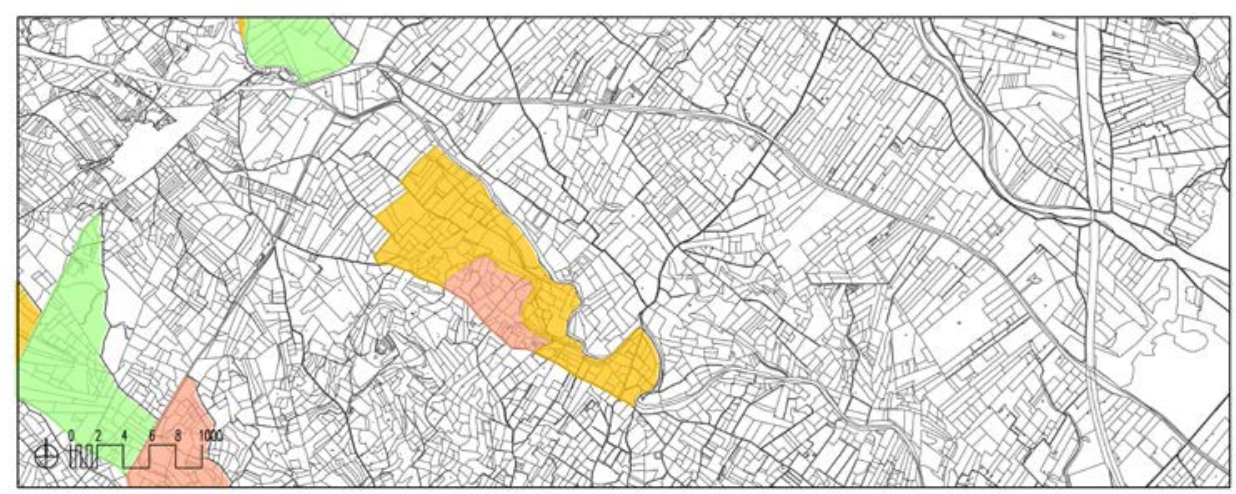

\section{Zona 10 Cervera / Calig}

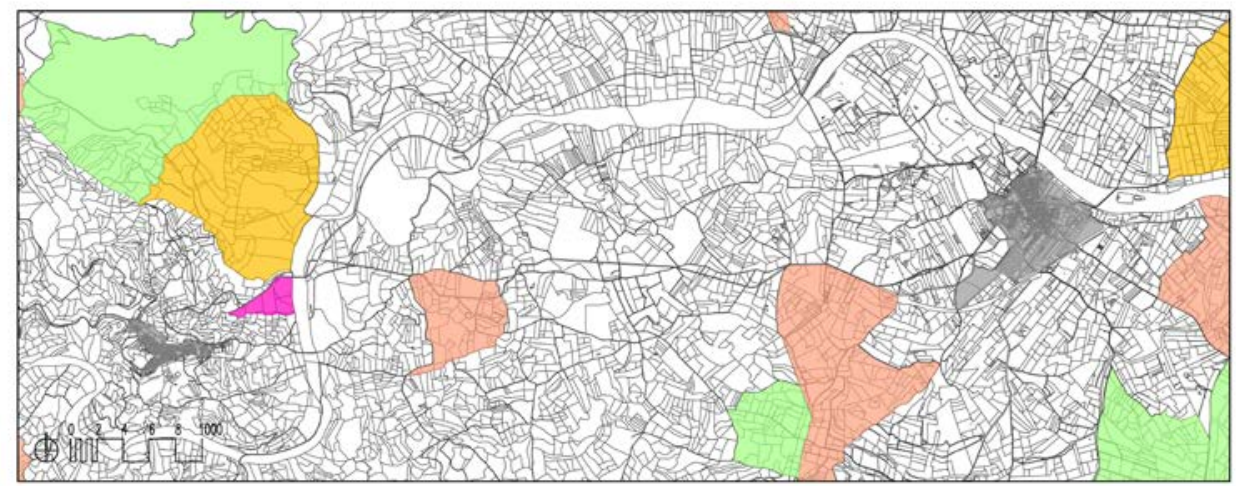

Zona 11_San Joan del Pas

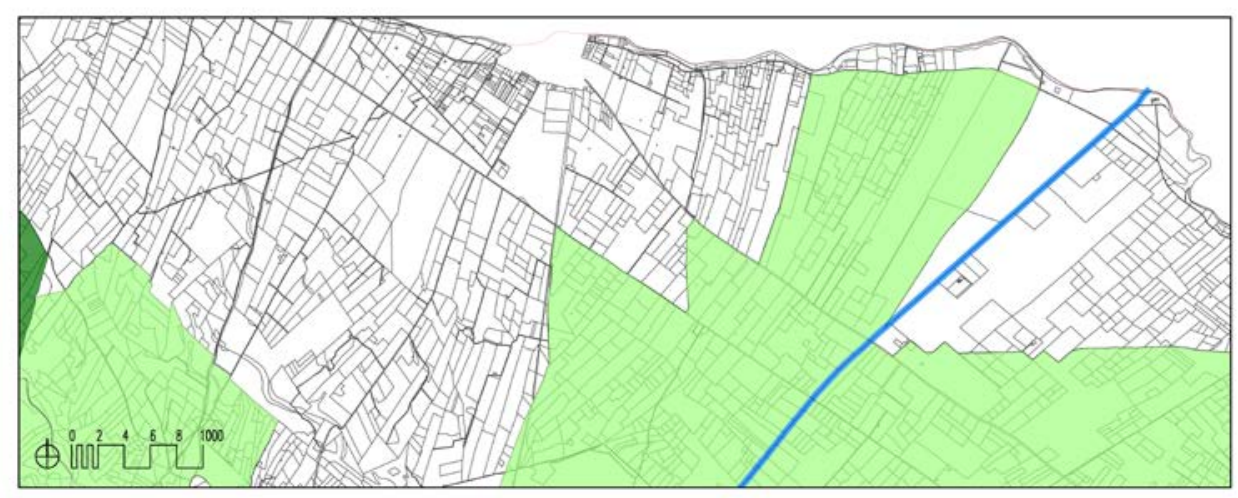

Zona 12_Atalaya San Pere

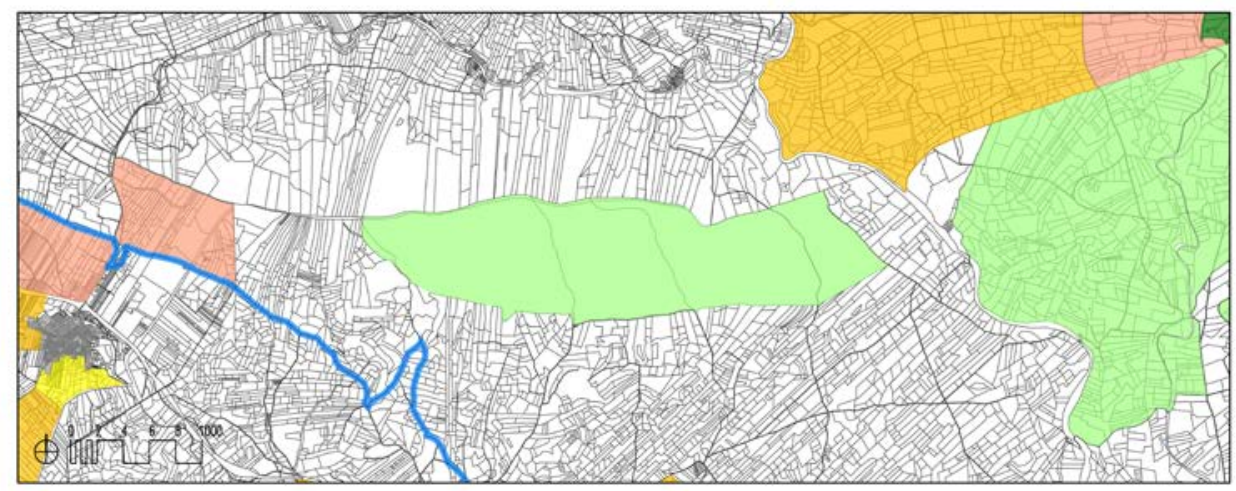



Del modo en que se agrupan las redes a lo largo del eje temporal, podemos constatar al comparar gráficamente las doce zonas de estudio con sus correspondientes redes, las siguientes relaciones:

- El relieve del territorio establece las bases de la futura transformación del mismo. El modelado del mismo que el hombre realiza con las redes de muros de contención define el nuevo relieve y por tanto pasa a ser la base de la futura transformación. Los muros construyen el propio emplazamiento. Preparan el terreno para la edificación futura y crea las condiciones de futuro acontecimientos.

- El modelado inicialmente realizado por motivos agrícolas, sienta las bases posteriores de la disposición y trazado de las futuras redes de caminos y de cursos de agua; de la forma y dimensión de la red de parcelación, de la disposición de los usos y también de la propia construcción de los edificios.

- De alguna manera, se puede decir que una red resulta idónea para la transformación del territorio, si se demuestra que puede actuar como soporte extensivo de un modelo de ocupación. Eso quiere decir que las redes, como urdimbres de un desarrollo territorial posterior, como llaves de este dominio, se han de adaptar a la situación variable que el crecimiento comporta, ya que solo un proyecto de red correctamente planteado se adapta al cambio.

- La forma de la urdimbre que hará posible la parcelación y las arquitecturas, ha de admitir su adaptación a posiciones diversas: de contorno o de centro, y paralelamente a diversos grados de uso y de densidad.

- La parcelación se basa en la red de muros y en el viario, el primero por definir el relieve y el segundo por dar acceso a las futuras parcelas - tanto de personas como del agua para el riego y desagüe-. Pero es por la parcelación que el territorio es posible. Es la forma del parcelario la que condiciona los "materiales" de que esta construido el territorio. Este tiene una estructura de base, pero se desarrolla o se manifiesta con la particular disposición de los diferentes elementos sobre el suelo, ya que tiene siempre una lectura tridimensional. Según sea la partición del suelo en el origen vendrá condicionado el uso y el desarrollo, de los usos del campo.

- La parcelación subsiste en el proceso evolutivo que transforma el espacio rural. La forma de la parcela, sirve de base a toda modificación, a todo movimiento, a toda mutación, sin tener en cuenta su magnitud o su fuerza, afectando ala estructura urbana o rural. Rígida pero flexible, resiste las rupturas, desmembramientos o cambios de forma de ocupación de suelo y de densidad de utilización, guardando siempre las grandes líneas de su morfología inicial. Esta morfología no es debida al azar y responde a un sistema geométrico riguroso en el cual las técnicas de desarrollo agrícola, la naturaleza del suelo, la orientación, son tan importantes como el relieve. Éste sistema determina el tamaño de las parcelas, sus formas, su orientación o su disposición relativa desarrollando generalmente una geometría flexible formando mosaicos.

- La unidad de base de este sistema es la parcela, célula elemental de la malla y de su trama. Esta célula posee numerosas propiedades morfológicas, de división, de unión, de mutación que le permiten evolucionar y hacer evolucionar el paisaje dentro del marco general del sistema. Esta parcelación comporta generalmente elementos implantados, construidos y/o bancales. (Gerrad Hanning architecture d'aujourd hui). 
Del mismo modo que los elementos se relacionan entre sí de tres formas distintas, las redes entre sí se pueden relacionar de esos tres mismos modos según cual sea la conectividad entre ellos:

- Conexión, si la conectividad se realiza mediante un espacio construido.

- Yuxtaposición, si la conectividad se realiza sin espacio intermedio.

- Interconexión cuando se busca la autonomía de cada tipo, a la vez que interactúan funcionalmente.

Para sintetizar de una forma gráfica estas tres formas de conexión hemos elaborado un cuadro en el que ponemos algún ejemplo significativo de ellas, por una parte la relación entre redes que no son arquitecturas y por otra redes de arquitecturas con alguna otra red diferente. Tanto en un caso como en el otro hemos elegido ejemplos de la zona de estudio y de representaciones gráficas de la Edad Media. 


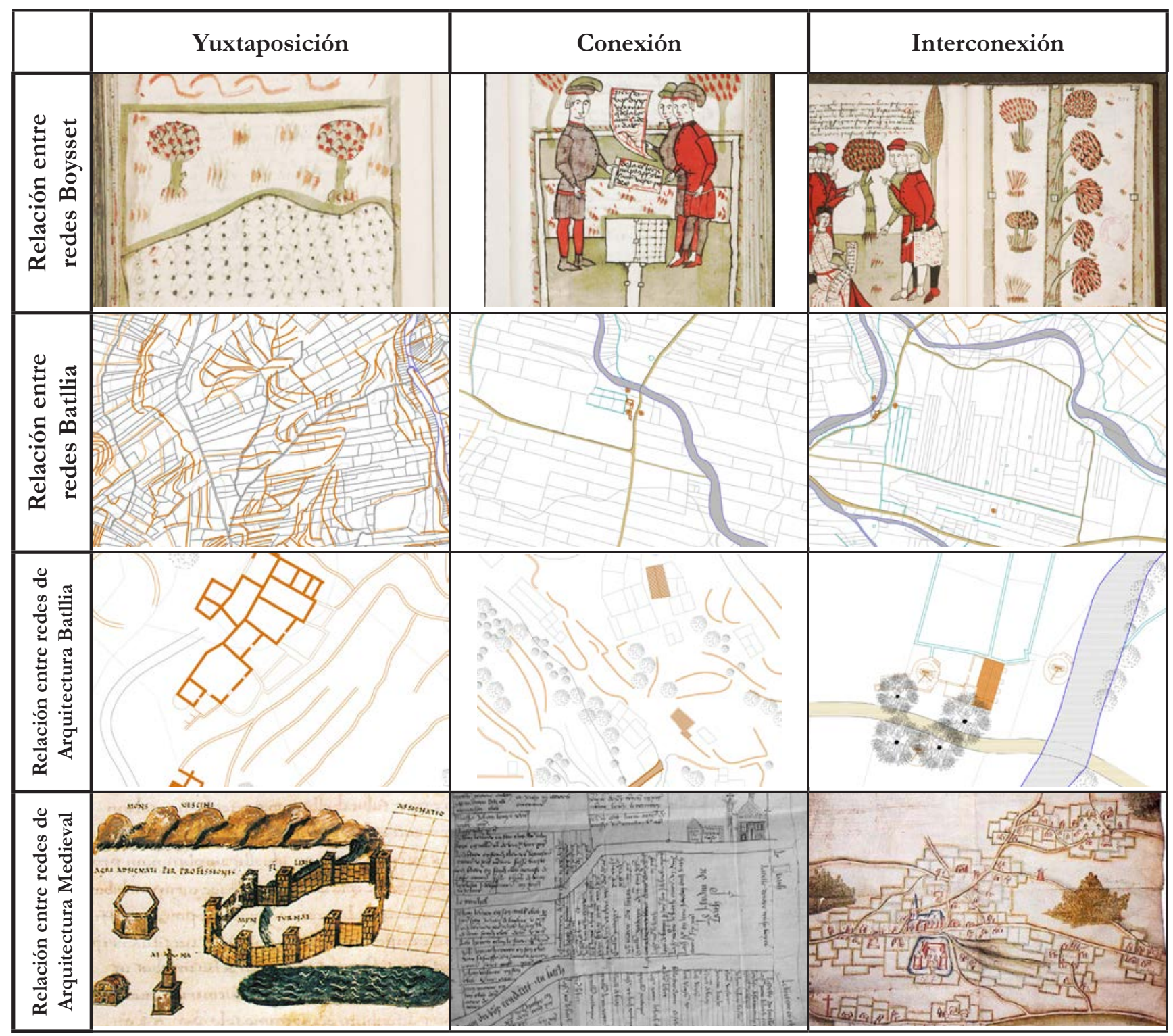

Fig. 4. 100. Cuadro relaciones entre redes: yuxtaposición, conexión e interconexión.

Relaciones entre redes de parcelas, cultivos y caminos dibujadas por Boysset: Yuxtaposición: Lámina g305.

Conexión: Lámina g231.

Interconexión: Lámina g283V284.

Relaciones entre redes de la Batllia:

Yuxtaposición: Redes de muros, parcelas e infraestructuras (caminos) en Canet.

Conexión: Redes de infraestructuras (caminos) y parcelas en Canet.

Interconexión: Redes de infraestructuras (caminos y acequias) en Canet.

Relaciones entre redes y arquitecturas en la Batllia:

Yuxtaposición: Mas de les Cardones y muros.

Conexión: Molino, puente y redes de caminos y acequias en El Molinar.

Interconexión: Cenias e infraestructuras de riego en Canet.

Relaciones entre redes y arquitecturas en grabados medievales o anteriores:

Yuxtaposición: Dibujo 89 del libro "Frontin l'oeuvre gromatique" que recoge Corpus Agrimensorum romanorum IV de lulius Frontinus.

Conexión: Dibujo de parcelación medieval normanda (1477).

Interconexión: Plano de Wismes (s. XV). 


\section{4. La in-formación del territorio antroposocial}

\section{4. 1. Los tipos}

Llegados a este punto del análisis y para poder clasificar los elementos y sistemas de elementos que comparten un conjunto de rasgos característicos y una misma estructura formal dentro del territorio detectaremos los tipos que nos permitirán ahondar en el análisis que desarrollamos.

Los tipos como concepto analítico y clasificatorio son parte importante en la metodología que estamos empleando. La clasificación que nos permite hacer el análisis tipológico nos permite conocer los elementos que conforman los sistemas y lo que es más importante conocer la estructura del territorio.

Los tipos ofrecen un particular conjunto de vínculos y posibilidades de organización significativas del territorio, más allá de las simples relaciones dimensionales y distributivas.

El territorio entendido como arquitectura supone reconocer que el proceso arquitectónico que conduce a la configuración de los tipos se realiza en el territorio de modo que se establece una relación dialéctica y no causal entre la tipología y la morfología territorial. Entre la realidad y el tipo no se establece una relación causal, de modo que la topología conduzca necesariamente a un tiponos mantendríamos en este caso dentro de una concepción funcionalista-; por el contrario han de reconocerse unas influencias biunívocas que hacen que el tipo se precise en sus relaciones con los fenómenos contenidos en el hecho territorial y que esos mismos fenómenos queden configurados de un modo determinado en el hecho territorial.

Los tipos como instrumento sintético y proyectual, nos permiten entender el territorio como memoria construida y plantear cual ha de ser nuestra actitud ante la intervención en él.

El tipo se puede entender como modelo de donde extraer copias y esquemas de comportamiento que quedan como in-formación en su propia forma. Estas formas tipológicas en ciertos períodos históricos -como en el caso que nos ocupa- acaban por asumir el carácter sintético de un proceso que precisamente se manifiesta en la propia forma, ya que como instrumento proyectual el tipo "afecta a la producción de la arquitectura misma". ${ }^{114}$

La clasificación tipológica también la podemos hacer atendiendo a los principios constructivos. Estas arquitecturas estereotómicas pasan de ser isótropas inicialmente por tener reducidas dimensiones a ser direccionales por necesitar un espacio de reunión de mayores dimensiones.

El elemento que permite hacer esta evolución es un tipo constructivo importado del Mediterráneo por las cruzadas que permite "perforar" los muros de carga.

Este tipo es el arco perpiaño que siendo un elemento constructivo sencillo, permite construir arquitecturas sólidas, sencillas y rápidas de ejecutar, adaptables a diversos usos, de fácil crecimiento o ampliación y de fácil mantenimiento; todo lo cual permitió colonizar rápidamente el territorio. En definitiva podríamos considerarlo un precedente del sistema prefabricado.

Este tipo constructivo tiene una gran importancia semántica:

"No sólo desde el punto de vista de su uso, sino del significado que éste asume como elemento de referencia de la vida asociada en la cual se solidifican una serie de juicios de valor sobre la condición histórica, sobre la relación con la tradición y sobre la esperanza en el futuro; a veces también sobre la misma concepción cosmológica propia de un grupo humano y de cierto modelo de cultura". ${ }^{115}$

114 MONEO, R. "Sobre el concepto de tipo en Arquitectura” pág. 190

115 GREGOTTI, V. “El territorio de la arquitectura” pág. 177 
La relación entre la arquitectura del arco perpiaño y el territorio de la Batllia -y comarcas limítrofesdio lugar a una dialéctica precisa. La construcción de lugares -que veremos en el siguiente capítuloque une arquitectura y naturaleza es una relación inseparable: el territorio gótico.

La tipicidad de esta solución, así como la simplicidad, hizo posible su difusión de tal manera que en algunos casos de gran valor han perdurado durante siglos como viva memoria colectiva del territorio como es el caso de las Ermitas de Reconquista.

Este tipo constructivo permite la construcción física de este territorio que en los siglos posteriores y hasta nuestros días, continuara siendo usado el tipo como forma, cargada ahora de valores emocionales. La arquitectura gótica se vincula a la cultura de la Batllia de una manera singular y por tanto ofrece la posibilidad de una aplicación unificadora sin que diminuya su originalidad.

\section{4. 2. Las permanencias}

El territorio es una construcción que se realiza en el tiempo, lo cual revela la importancia de las relaciones establecidas a lo largo del eje temporal. La atención a esas relaciones diacrónicas permite una compresión de las permanencias históricas.

El territorio como procesos de procesos, hace que en su construcción la continuidad de los hechos territoriales no quede propiamente confiada a las permanencias sino al proceso de cambio de esas mismas permanencias.

Las permanencias tiene un significado dinámico: es la relación a lo largo del eje temporal lo que permite su identificación y su valoración no como mero objeto sino como un proceso extendido en el tiempo.

El territorio se construye sobre un soporte topológico. La topología marca una determinada predisposición para un determinado uso, aquellos elementos o redes que siguen dicha predisposición son permanencias propulsoras ya que evolucionan con la topología del territorio y no se "desvían" de su proceso evolutivo. Aquellas otras que no siguen esa predisposición y que impiden la evolución natural topológica del territorio las llamaremos constreñimientos o permanencias patológicas ya que ralentizan o "congelan" el desarrollo del territorio impidiendo la predisposición natural del mismo.

Estas permanencias singulares -análogas a los monumentos de Rossi- son los que "adjetivan" el territorio y son los que la acción del hombre en dos territorios con topologías similares construya territorios distintos.

\section{Las permanencias de las redes: las cicatrices en el Territorio}

Con el paso del tiempo determinadas redes se convierten en trazados, en cicatrices que perduran en el territorio. De los tipos de redes que hemos visto, los que conectan-las infraestructuras- son las que sus trazados $\mathrm{m}$ as perduran y se convierten en permanencias propulsoras, aunque se llegue a producir un cambio en el uso del territorio. Mientras que las yuxtaposiciones son las que se convierten en permanencias patológicas ante el cambio de uso en el territorio, estas serian los muros y la parcelación. Los elementos- como los usos- no son patologías, son datos de partida. Las redes que se constituyen a partir de esos usos son las que podemos considerar propulsoras o patológicas.

En ocasiones una permanencia propulsora puede pasara a ser patológica. Los muros del entorno de un núcleo urbano inicialmente pueden ser propulsores para pasar a ser patológicas.

El cambio de uso en el territorio, junto con una construcción no estereotómica es la que produce el cambio de una permanencia propulsora a una patológica. 


\section{Como dice Fernández Galiano "las redes (él dice las infraestructuras) son el registro de nuestro} pasado y la horma de nuestro futuro". ${ }^{116}$

Las redes establecen las bases de la futura transformación del territorio, siempre que puedan actuar como soporte extensivo de un modelo de ocupación. Una red correctamente planteada se adapta a los cambios futuros y permite el desarrollo posterior de usos y arquitecturas. Las redes territoriales se construyen de una forma determinada según el recinto tipo en el que se encuentran, y esta forma condicionara su desarrollo futuro como soporte de usos y arquitecturas.

En un primer momento la red se adapta al relieve y los usos y arquitecturas se adaptan por tanto también a él. Conforme evoluciona la sociedad y se invierte más energía en la transformación del relieve, las redes se "liberan" del relieve natural y como consecuencia los futuros usos y arquitecturas también se "separan" del relieve original con el consiguiente gasto energético. Eso es lo que ocurre cuando el trazado del viario urbano no se adapta al terreno o si una infraestructura como un acueducto por su necesidad de trazado se construye ajena al relieve natural.

Aunque pueda haber excepciones podríamos resumir estas consideraciones diciendo:

Las redes de infraestructura son propulsoras y permanecen por: ${ }^{17}$

1. Las redes funcionan para construir el propio emplazamiento. Preparan el terreno para la edificación futura y crea las condiciones de futuro acontecimientos.

2. Las redes de infraestructuras son flexibles y anticipatorias. Trabajan con el tiempo y están abiertas al cambio. Al especificar aquello que debe ser fijo y aquello que puede estar sujeto al cambio. Funcionan mediante la gestión y el desarrollo, modificándose lentamente para ajustarse a condiciones cambiantes. No progresan hacia un estado predeterminado, sino que evolucionan siempre en el seno de un campo abierto de solicitaciones.

3. El trabajo con las redes de infraestructuras reconoce la naturaleza colectiva del territorio y permite la participación de múltiples actores. Las infraestructuras marcan las pautas para el futuro del territorio, sin establecer reglas o códigos (de arriba a bajo), sino fijando puntos de servicio, acceso y estructura (de abajo hacia arriba).

4. El uso continuado de infraestructuras supone el continuo mantenimiento de las mismas gracias a su permanente rehabilitación y por tanto el mantenimiento de su con-formación. Buen ejemplo de ello es el acueducto de Morella, mientras fue usado hasta hace pocos años para que discurriera por él la tubería del agua de abastecimiento a la ciudad, se mantuvo correctamente, cuando ya no se usa para conducir la tubería corre peligro de perderse. El uso de los puentes como el de Todolella garantizo su permanencia,; la construcción de un nuevo puente para proteger el primitivo pude poner en peligro su futuro.

De forma análoga a las redes de infraestructuras, podemos decir que las redes de muros y de parcelación son patológicas por los siguientes motivos:

1. Las redes de muros y parcelación no son flexibles y ante los posibles cambios de uso se adaptan con dificultad. Parten de un estado predeterminado del que evolucionan con dificultad.

2. Los muros y parcelas no son de carácter público, por lo que la actuación sobre ellos esta sujeta al deseo y consentimiento del propietario de la red.

3. Estas redes están creadas para un determinado uso y en un momento dado, son un fin en sí mismas

116 FERNÁNDEZ-GALIANO, L.A. ”Arquitectura y vida: el arte en mutación” pág. 26

117 GARCÍA-GERMÁN, J. y otros “De lo mecánico a lo termodinámico” pág. 179 


\section{Las permanencias de las arquitecturas: los monumentos}

Del mismo modo que existen permanencias en las redes, también ocurre con las arquitecturas. Estas permanencias singulares y que son catalizadoras del crecimiento y evolución del territorio, las llamaremos monumentos de forma análoga a como lo hace Rossi en la ciudad.

En determinados procesos en el Territorio existen una serie de factores que propician la aparición de estos monumentos:

1. El origen colectivo o social de determinados elementos en el desarrollo de determinados procesos en el Territorio, les imprimen un mayor dinamismo y vitalidad.

2. El momento de su génesis en que el hecho territorial queda resuelto en una arquitectura precisa. Determinadas arquitecturas en el proceso lógico de su construcción quedan investidas de la categoría de verdaderos acontecimientos de la vida social; en estos casos la arquitectura resulta al mismo tiempo signo de ese acontecimiento.

3. Es el signo último de una realidad más compleja formada por el hombre y la cultura. Pertenece a la historia de la sociedad.

En definitiva la arquitectura interviene de un modo privilegiado en la conformación y transmisión de los sistemas de valores que subyacen en la cultura, cristalizando en determinados monumentos. Esta virtualidad de la arquitectura queda ligada al respeto de su propia autonomía y vinculada a las cuestiones de composición y estilo.

Tal como se define en el discurso rossiano, el monumento es aquella arquitectura que de un modo más pleno realiza el tipo. Por ello podemos definir el monumento, en su dimensión formal, como aquel elemento de la construcción del Territorio que permite la acentuación y precisión del tipo. Para esta acentuación tipológica el estilo resulta imprescindible.

La época de nuestro estudio es un momento de decisiva importancia histórica y política que coincide con una arquitectura -la gótica de reconquista- racional y definida en sus formas. Por ello la arquitectura interviene de un modo privilegiado en la conformación y transmisión de los sistemas de valores que subyacen en esa cultura.

El gótico de reconquista como innovación arquitectónica propició realizar acentuaciones particulares que tras un largo proceso en el tiempo cristalizaron en determinados tipos.

Estos monumentos, al igual que ocurre en la ciudad, son los elementos catalizadores que como permanencias propician el desarrollo y crecimiento del Territorio. Así tenemos: puentes, acueductos, iglesia arcos perpiaños, hornos, almudines, lonjas... 


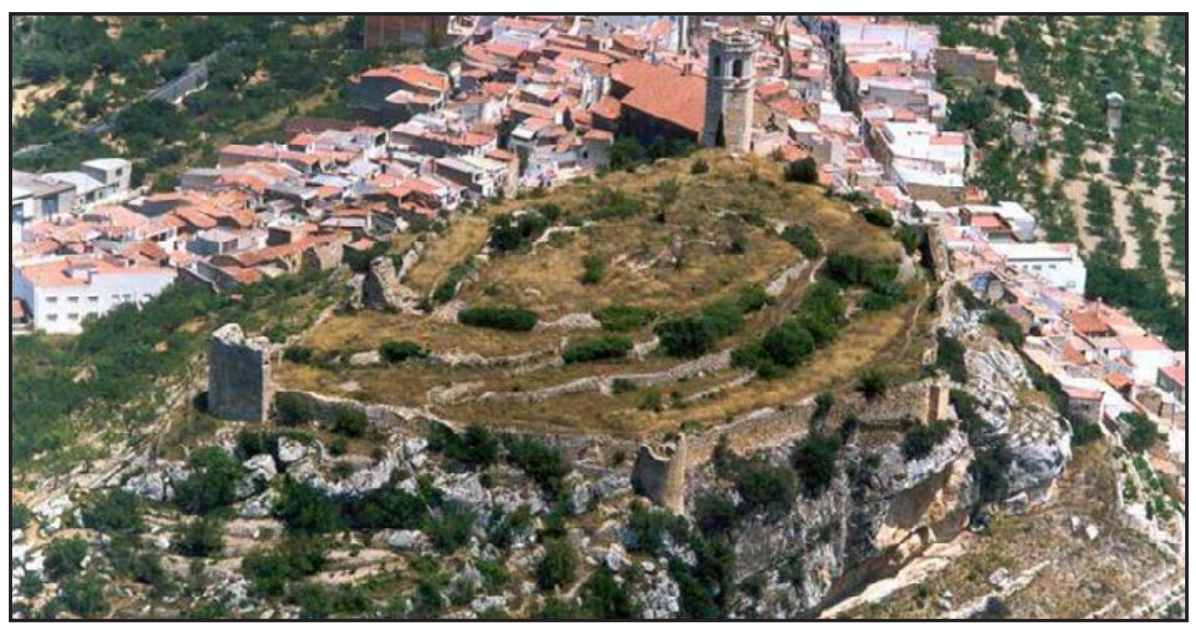

Fig. 4. 101. Vista aérea del castillo de Cervera. Ejemplo de lugar/castillo.

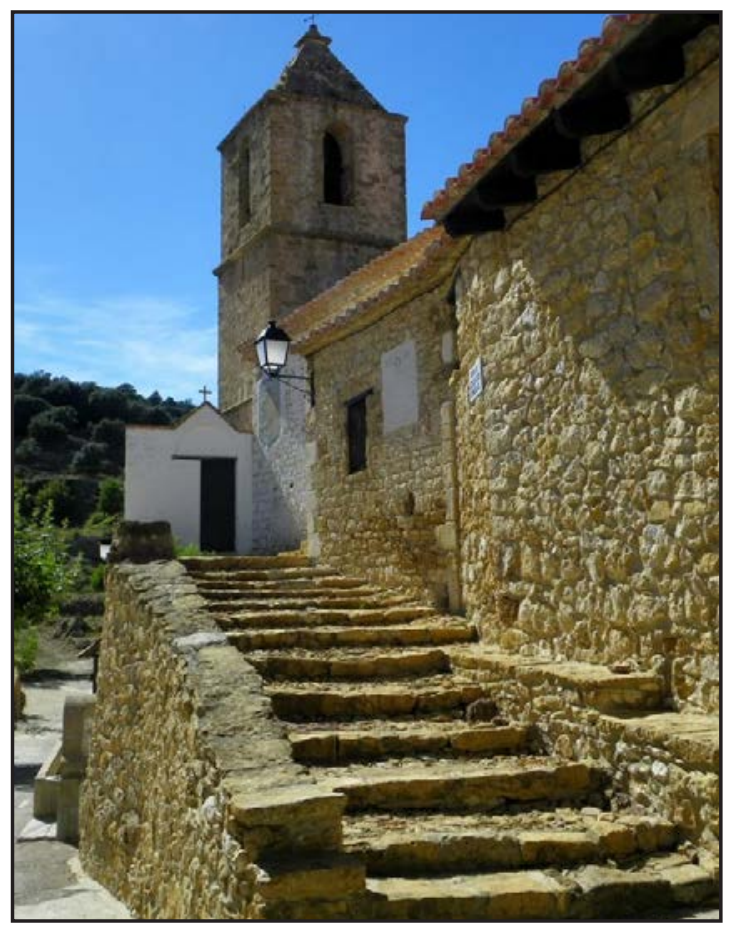

Fig. 4. 102. Iglesia de Bel.

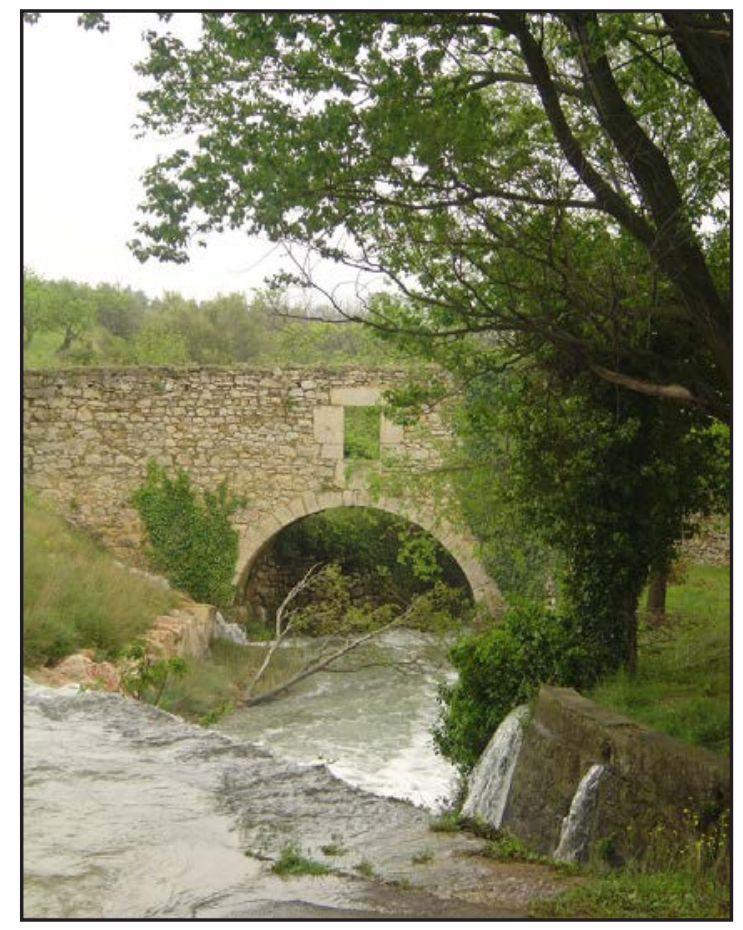

Fig. 4. 103. Vista puente de El Molinar.

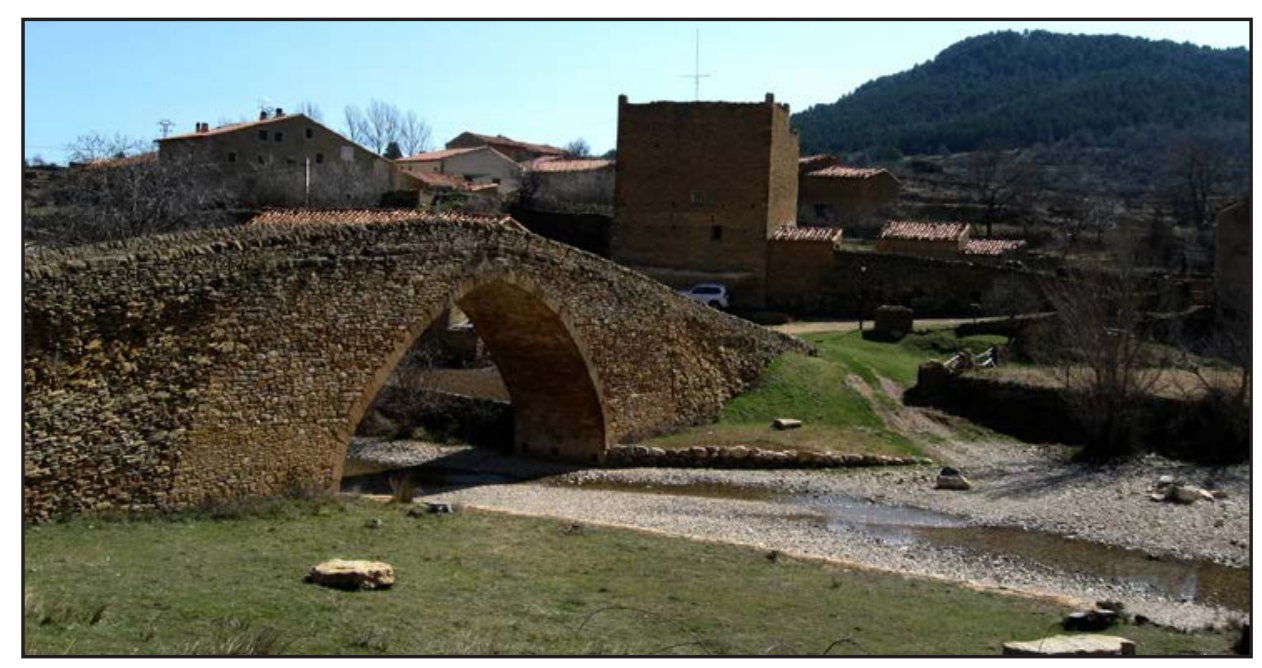

Fig. 4. 104. Puente de la Pobleta de San Miguel. 


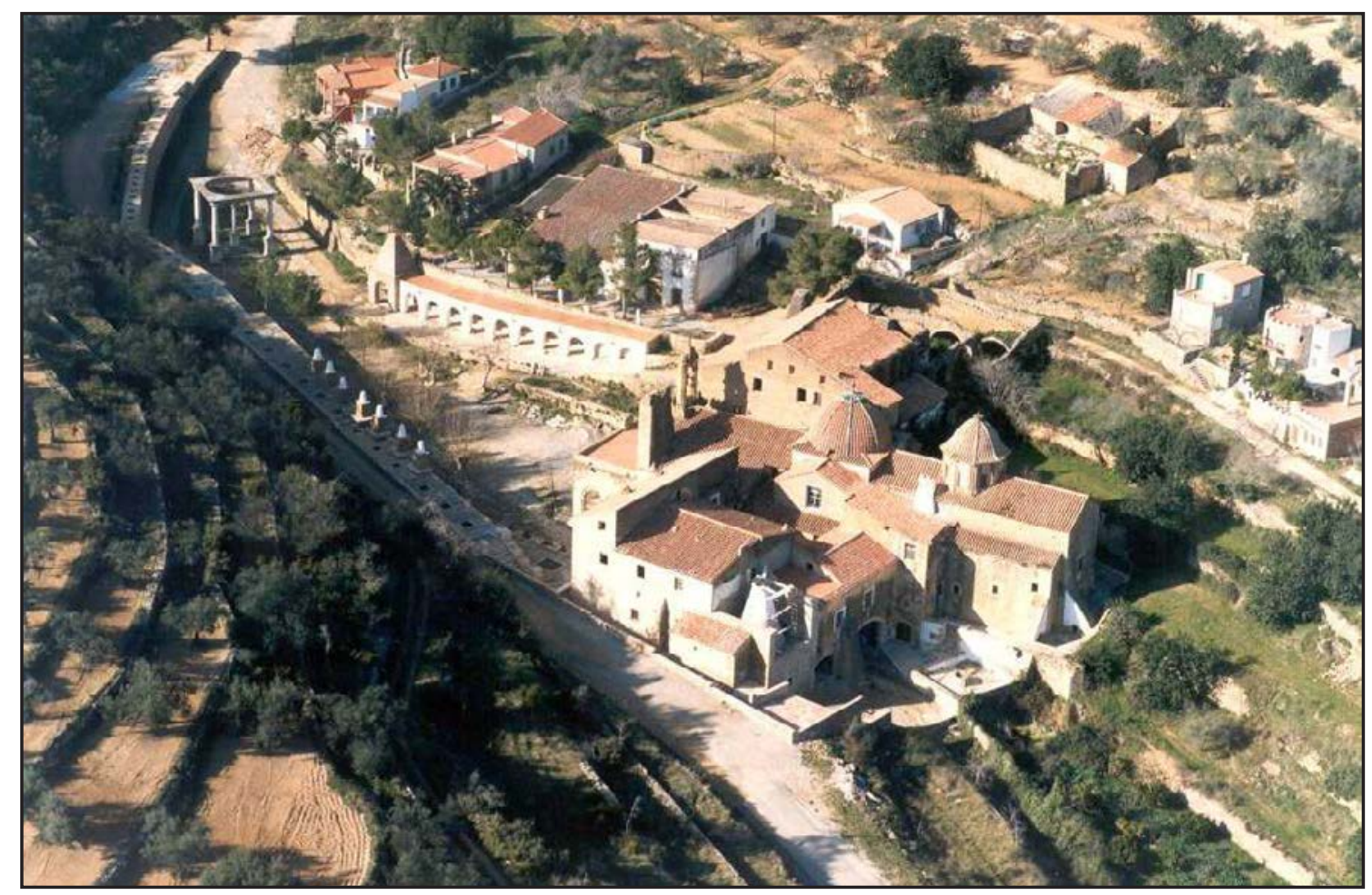

Fig. 4. 105. Vista aérea del ermitorio de la Fuente de la Salud de Traiguera.

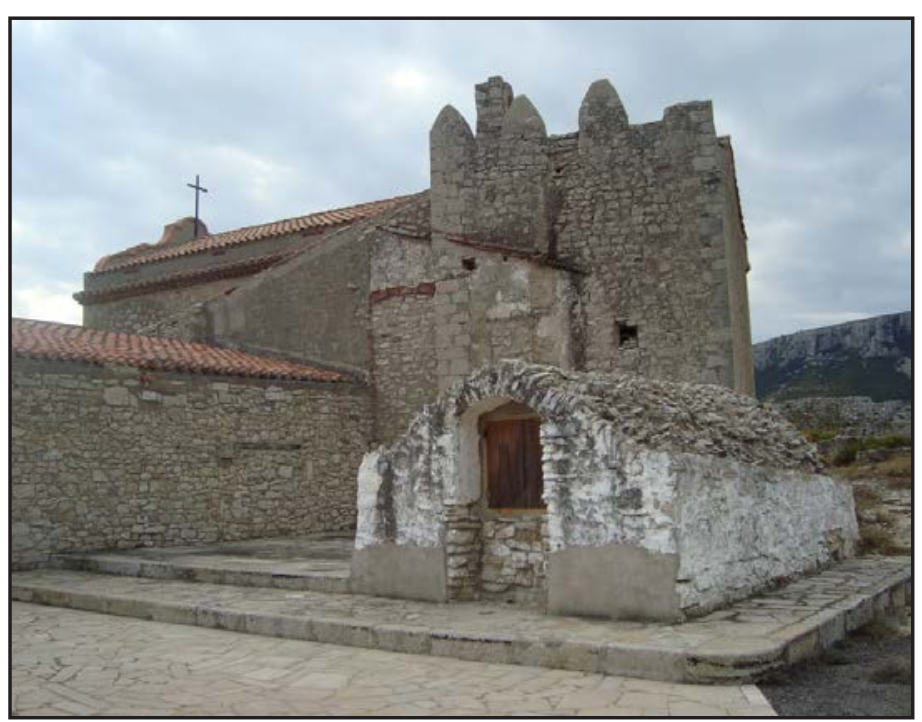

Fig. 4. 106. Torre de la Barcella, ermita de Sant Marc y aljibe.

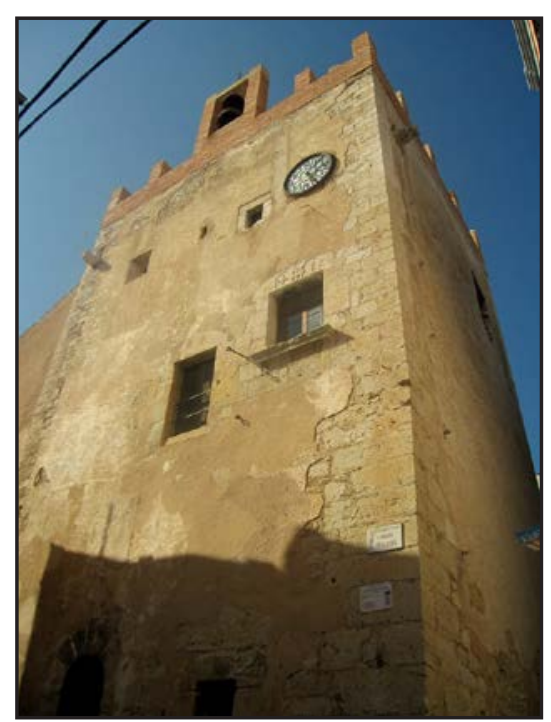

Fig. 4. 107. Torre de Calig. 


\section{5. La percepción de los elementos del territorio antroposocial}

\section{5. 1. Los elementos que estructuran la percepción y caracterizan el Territorio}

El espacio euclidiano no está estructurado en sí, sino que es completamente uniforme y de este modo se extiende en todas direcciones hacia el infinito. En el espacio en el que vive el hombre: la casa, la ciudad y el territorio, no son válidas estas reglas. Este espacio que diversos autores desde la publicación de "El Ser y el Tiempo" por Heidegger denominan espacio vivencial, no es un objeto desligado del sujeto.

Heidegger puso claramente de relieve la cuestión de la espacialidad de la existencia humana. La espacialidad es una definición esencial de la existencia humana. El hombre esta determinado en su vida siempre y necesariamente por su actitud frente a un espacio que le rodea. Para el despliegue de la vida, el espacio es tan imprescindible como el tiempo.

El hombre no se encuentra en el espacio, como por ejemplo, un objeto en una caja; ni tampoco se relaciona con el espacio como si existiese primero como sujeto sin espacio que posteriormente entrase en relación con este, sino que la vida consiste originariamente en esta relación con el espacio y no puede ser desligada de él ni de modo ideal.

Esto significa al mismo tiempo que el espacio no está simplemente ahí, independiente del hombre. Solo hay espacio en la medida en que el hombre es un ser espacial, es decir, que crea espacio, que lo "despliega" a su alrededor.

Se trata de la relación que existe entre el hombre y su espacio, y por ello, de la estructura de la misma existencia humana en cuanto esta se encuentra determinada por su relación con el espacio. En este sentido hablamos de la especialidad de la existencia humana.

Peter Sloterdijk, en su trilogía "Esferas" determina como se materializa esa espacialidad: a través de esferas. Desde la burbuja inicial que representa la placenta antes del nacimiento,la posterior burbuja del hombre una vez nace, las esferas que va creando en la convivencia con otros humanos que van "creciendo" hasta convertirse en globos de mayor tamaño y por último la formación de la espuma como suma de distintas esferas de distintos tamaños.

Basándose en la filosofía de Heidegger, Norberg-Shulz nos dice que el interés del hombre por el espacio tiene raíces existenciales: deriva de una necesidad de adquirir relaciones vitales en el ambiente que le rodea para aportar sentido y orden a un mundo de acontecimientos y acciones. Para poder llevar a cabo sus intenciones, el hombre debe "comprender" las relaciones espaciales y unificarlas en un "concepto espacial". El espacio arquitectónico por consiguiente puede ser definido como una "concretización" del espacio existencial del hombre.

El espacio existencial es un sistema relativamente estable de esquemas perceptivos o "imágenes" del ambiente circundante que consisten en el establecimiento de centros, flujos y áreas. Para orientarse el hombre necesita captar estos esquemas y sus relaciones, necesita crear un mapa cognoscitivo.

Estos esquemas se "concretizan" en el espacio arquitectónico, el centro con las arquitecturas, los flujos con las conexiones y las áreas con las formas y texturas que determinan el modelado, cultivo y parcelación del territorio.

En función de la esferología de Sloterdijk, hablaríamos no tanto de centros como de esferas concretizadas en arquitecturas que es un concepto más amplio que el de simple centro y que conlleva en el mismo la posibilidad de crecimiento por aumento del radio de la esfera; los flujos de conexiones serian entre las esferas y serán las que permitirán en la evolución del territorio bien por aumentar el radio de las esferas por absorción del entorno dentro de su membrana, bien por el establecimiento de relaciones entre esferas que conformarán espumas. Las áreas debemos de entenderlas como las formas y texturas, bien las previas que el territorio conforma antes de la absorción por la esfera a la que suministra la energía, bien las que conforman el conjunto de esferas al relacionarse entre sí. 


\section{Esferas y arquitecturas}

El espacio del hombre está subjetivamente centrado. Desde el más remoto principio, el centro representa para el hombre lo conocido, en contraste con lo desconocido y algo temible mundo circundante. "Es el punto donde toma posición, como ser pensante en el espacio, el punto donde mora y vive en el espacio". ${ }^{118}$ Los centros son metas o focos donde nos reunimos y experimentamos los acontecimientos más significativos de nuestra existencia, pero también son puntos de partida desde los cuales nos orientamos y nos apoderamos del ambiente circundante.

En la clasificación tipológica que hemos hecho de las arquitecturas, las hemos diferenciado en función de las nueve dimensiones que según Sloterdijk tiene la antroposfera y de como ellas se concretizan en diferentes esferas arquitectónicas. Estas esferas se definen por su centro, por su espacio interior o endosfera y por la membrana que hace de límite con el exterior o exosfera.

Cuando el hombre deja su morada penetra en el vasto espacio exterior, tiende que aprender a orientarse en él, es decir a alcanzar su objetivo y encontrar de nuevo el camino a casa. No hay dificultad mientras el hombre se encuentra en la proximidad de su domicilio, en una región conocida. Allí conoce los caminos. Los ha conocido poco a poco, a partir de su casa y sabe moverse por ellos. Por el contrario si se aleja y llega a parajes desconocidos tiene que orientarse por la posición del sol, gracias a el se orienta en el terreno, los puntos cardinales generales: norte y sur, este y oeste.

En la Edad Media todavía se mantiene el origen mítico de la orientación. En la "Filosofía de las formas simbólicas", al tratar del espacio "mítico" Cassirer señala la diferencia cualitativa de los puntos cardinales. A su vez hace observar que de este esquema espacial no solo puede desarrollarse el conocido número de cuatro, sino que con igual motivo el de cinco si se incluye el punto de intersección de los cuatro brazos de la cruz; o incluso más a menudo, el número de siete, a saber, si a la división de las cuatro direcciones cardinales horizontales se unen las de arriba y de abajo.

Preciosas referencias para este número de cinco o siete encontramos en Frobenius, que describe la espacial importancia del centro definido como la montaña del mundo o como pilar celeste. Ambos representan el eje vertical, que no solo determina el centro de la división horizontal sino que a la vez, asciende en sentido vertical a lo divino. La Iglesia de Sant Jaume de Coratxar, orientada según los cuatro puntos cardinales, el eje vertical con el campanario en la cabecera y el gráfico de la dirección hacia el interior de la tierra a los pies de la misma... es un caso paradigmático.

El hombre necesita no solo conocer la burbuja en la que vive y la esfera en la que ella se encuentra sino "amueblar" su territorio -el espacio exógeno a su burbuja- con hitos que como el sol, sean puntos externos a él, fijos y muy visibles que le permitan en todo momento orientarse y poder volver a su morada a su centro.

\section{Áreas}

Las áreas de territorio que no se mantienen vírgenes, que han sido modeladas, cultivadas o parceladas son reconocibles por tener unas características físicas determinadas: textura, forma, tipo constructivo, uso, actividad... Tales propiedades conducen a la formación de una "acumulación característica". ${ }^{119}$

Estas áreas junto con las naturales como los bosques, praderas, etc son reforzadas por unos contornos bien definidos. El contorno y la textura son propiedades básicas junto con los principios ya citados de la Gestalt de cierre y semejanza.

Las áreas surgen alrededor de los centros, forman el primer cinturón alrededor de ellos. El contorno de las áreas pasa a ser un límite "difuso" del propio centro. En ocasiones el centro tiene mucha "presencia" y casi no se percibe el área, pero en otras el centro no la tiene y parece que sólo exista el área, pero siempre en su origen esta existe. Estos contornos difusos pero con texturas que se van conformando poco a poco, acabaran siendo fagocitados por las esferas que han propiciado su existencia y a las que proporcionan la energía necesaria para su desarrollo y evolución.

118 BOLLNOW, O.F. “Hombre y espacio” pág. 61

119 CASSIRER, E. "Filosofía de las formas simbólicas” pág. 99 


\section{Flujos y conexiones}

Los flujos que se establecen entre los distintos esferas con las áreas y entre éstas se canalizan a través de conexiones. Éstas en la Edad Media eran físicas, bien caminos que permiten el desplazamiento de las personas o los objetos, bien visuales o acústicas entre ellos.

Según la densidad de las conexiones se puede llegar a reforzar la percepción de las áreas y el peso específico de las esferas en el conjunto del territorio.

Además de las conexiones físicas se pueden producir también conexiones mentales que relacionan las esferas y las áreas por motivos culturales. La cultura y las tradiciones establecen relaciones entre los distintos elementos del territorio.

Los flujos entre una esfera y las áreas limítrofes a su membrana, es la que permite cuando estas conexiones alcanzan una cierta densidad que la esfera fagocite esas áreas, que la membrana se amplíe y la incorpore a la esfera inicial. Este proceso es continuo, de forma que sí existe suficiente energía que absorber en el entorno de la esfera, ésta ira creciendo como dice Sloterdihjk con el efecto de una "bola de nieve".

En otras ocasiones no crecerá el volumen de las esferas, sino que las conexiones permitirán la creación de estructuras conformadas por distintas esferas entre sí, que conformaran una estructura superior o globo.

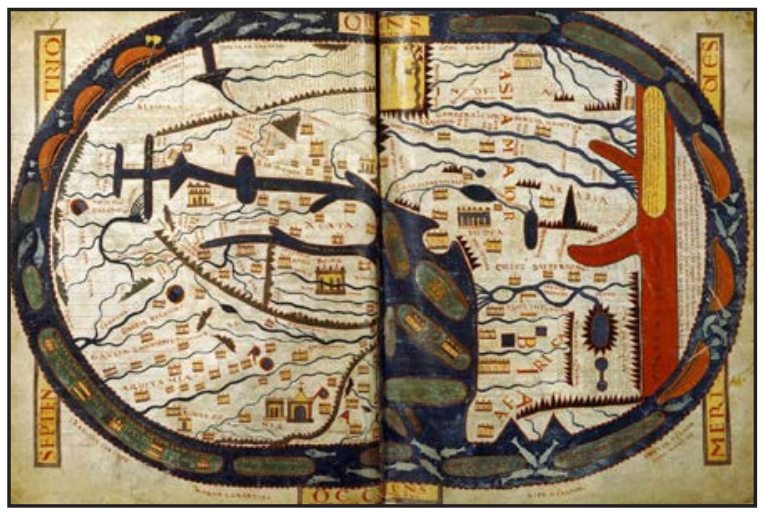

Fig. 4. 108. Código Beato de Saint Sever (1060).

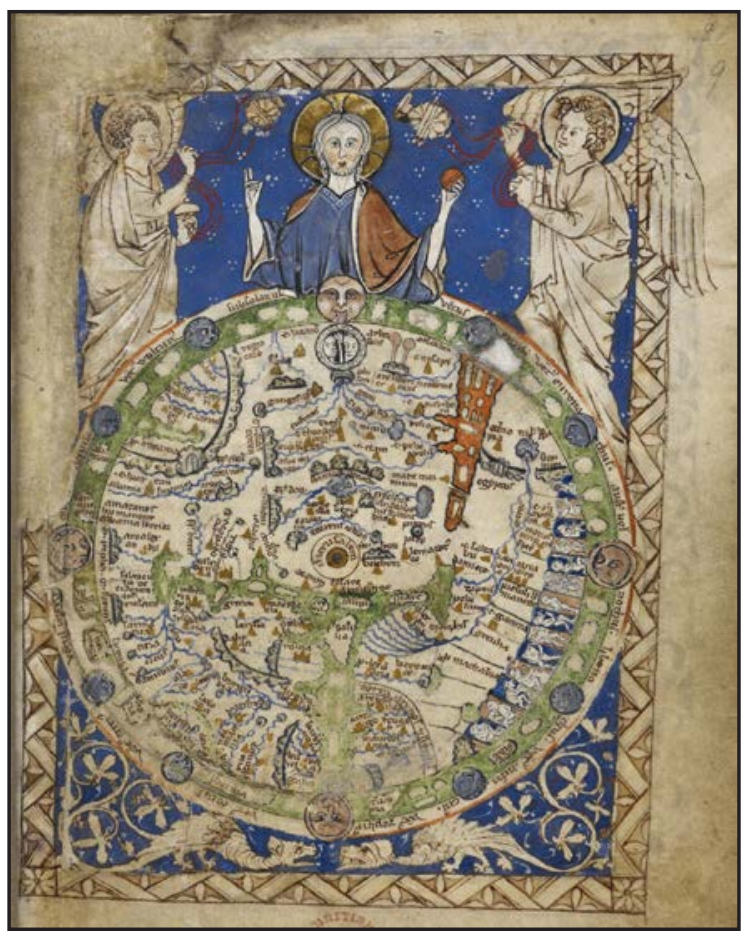

Fig. 4. 110. Mapa del mundo (s. XIII-XV).

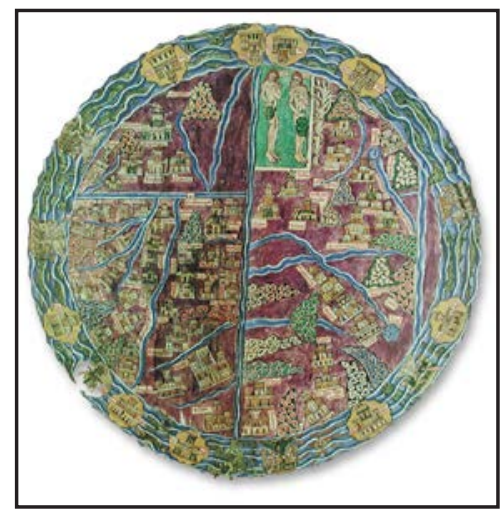

Fig. 4. 109. Código Beato de San Andrés.

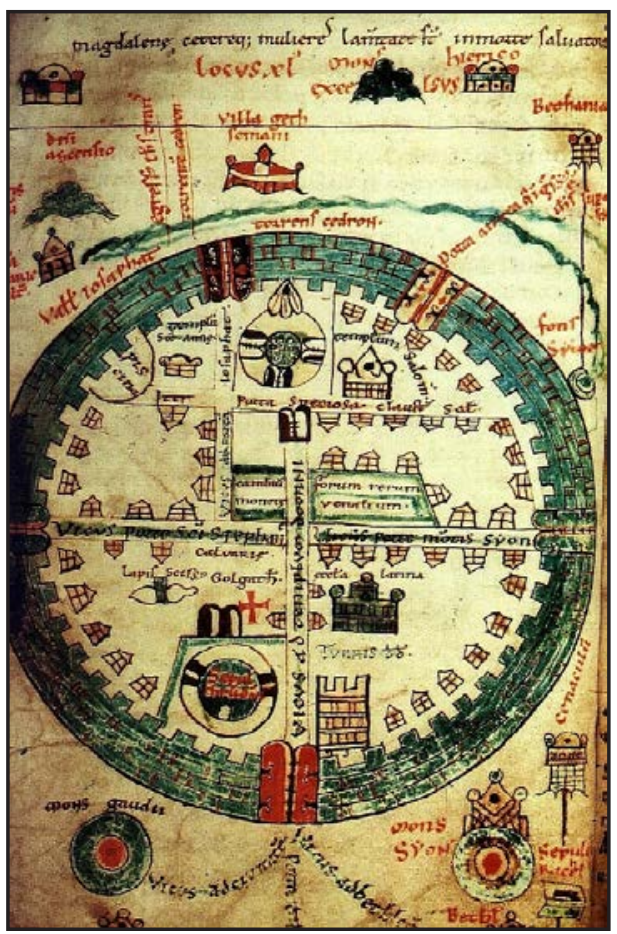

Fig. 4. 111. Plano de Jerusalén (1150).

Distintas muestras de la forma de representar el territorio (mediante esferas). 
CAPÍTULO 5. LA COMPOSICIÓN DE LA ESTRUCTURA DEL TERRITORIO DE LA BATLLIA EN LA EDAD MEDIA 



\section{1. Introducción}

Como ya hemos descrito la metodología se estructura en dos fases: la primera plenamente analítica y la segunda de síntesis y conclusión. En la fase analítica se relacionan tres operaciones complementarias: observación, clasificación y comparación. Se trata de un método de análisis del territorio a partir de su forma, en el que le desarrollo gráfico es fundamental.

En los dos capítulos anteriores hemos llevado a cabo las operaciones de análisis del soporte-relieve o ecosistema y del territorio antroposocial; observando y clasificando los elementos y sistemas de ambos. Posteriormente y de forma independiente los hemos analizado primero sincrónicamente obteniendo las volumetrías, tipologías y redes y luego diacrónuicamente obteniendo las topologías, aptitudes y los elementos o redes catalizadores o constreñidores del Territorio.

En este capítulo procederemos a la síntesis, estableceremos las relaciones sintagmáticas entre los elementos y sistemas de las dos. Analizaremos tanto las relaciones simples para definir y mostrar los sitios como complejas para hacerlo con los lugares y posteriormente detectar entre ellos los "genuis loci" que materializan la memoria del territorio.

Del mismo modo que ocurría en la fase analítica, en la síntesis las relaciones no se dan de un modo absoluto y separado, no se trata de operaciones independientes y sucesivas, sino de un proceso de vaivén entre las operaciones de observación de la realidad y de la construcción del modelo; de modo que la síntesis se convierte cada vez, en verificación o rectificación del modelo.

Posteriormente procederemos a constatar las relaciones entre los lugares que nos definen los tejidos y ciudades para poder definir partes completas del territorio que nos permitirá en la última fase llegar a demostrar la existencia de tipologías antropogeográficas en el territorio.

"Realizada la síntesis, el objetivo de nuestro estudio como el de cualquier actividad estructuralista, tanto si es reflexiva o poética, consiste en reconstruir el objeto de tal modo que en su reconstrucción aparezcan las reglas de funcionamiento.”. ${ }^{20}$

Hemos analizado por un lado el soporte o cañamazo del territorio y hemos visto que se trata de un volumen topológico, que como cualquier topología tiene una predisposición en su modo de crecimiento y evolución. Y por otra parte hemos analizado la acción del hombre sobre él, como ha ido tejiendo sobre este cañamazo inicial durante el proceso de habitar el territorio y hemos visto que se trata de una construcción estereotómica.

El cañamazo es una estructura "resistente" que "soporta" los procesos humanos que le permiten al hombre habitar el territorio. Esta estructura está formada por una malla y por una serie de planos que definen el volumen topológico. La malla es la que "une y conecta" el volumen, mientras que los planos que esta malla define podemos considerarlos, no tanto como "vacíos" que hace Robert Le Ricolais, sino como planos "libres" que están dispuestos para acoger las actuaciones del hombre, a servir de soporte al tejido que sobre el cañamazo se va a realizar.

Es decir el territorio lo podemos considerar como dos estructuras superpuestas, a las que en este capítulo vamos a descubrir cuáles son sus formas de relación entre ellas.

De la primera estructura o cañamazo, tenemos que destacar tres hechos:

1. Contiene una malla lineal que es la que la conecta y le da soporte, es el "esqueleto" del territorio.

2. Existen una serie de planos "libres" definidos por la malla, que son el campo en el que el hombre al habitar el territorio los construye.

3. Su carácter topológico, hace que tenga una determinada predisposición en cuanto a su crecimiento y evolución.

120 BARTHES,R. “Ensayos críticos” pág. 161 
De la segunda estructura o tejido antropomorfo, debemos destacar:

1. Es la materialización estereotómica de los procesos -modelar, conectar, parcelar, usar y convivir- que definen la forma de habitar el territorio mediante muros, infraestructuras, parcelaciones, cultivos y arquitecturas.

2. Las arquitecturas como esferas, se pueden clasificar en tipos distintos en función de la forma en que se materializan las dimensiones de la antroposfera -el espacio donde conviven los hombres- en instituciones.

3. Los elementos forman redes de muros, infraestructuras, parcelaciones, cultivos y arquitecturas, que se agrupan de acuerdo con cuatro modelos básicos: agrupación compacta, en cadena, concéntrica y en malla.

4. Las redes se relacionan y forman simbiosis entre sí en función de las tres formas en las que estas pueden conectarse: yuxtaposición, conexión e interconexión.

Llegados a este punto, la pregunta es la siguiente ¿cómo estos tipos de arquitecturas y redes antropomorfos se sitúan en el cañamazo inicial? ¿Qué relaciones hay entre ellos? ¿Cómo estas relaciones evolucionan con el tiempo? Las respuestas a estas preguntas son las que nos dirán como es la estructura del Territorio.

Para realizar este análisis comparativo vamos a superponer los dos levantamientos gráficos que tenemos de ambas estructuras a la misma escala y en las doce zonas de estudio. 


\section{2. Las relaciones sintagmáticas simples: El sitio}

Las relaciones sintagmáticas simples entre las dos organizaciones, la del ecosistema y la antroposocial configuran el sitio. Este caracteriza la arquitectura que en el se ubica, pero al mismo tiempo el propio enclave es configurado por las construcciones existentes.

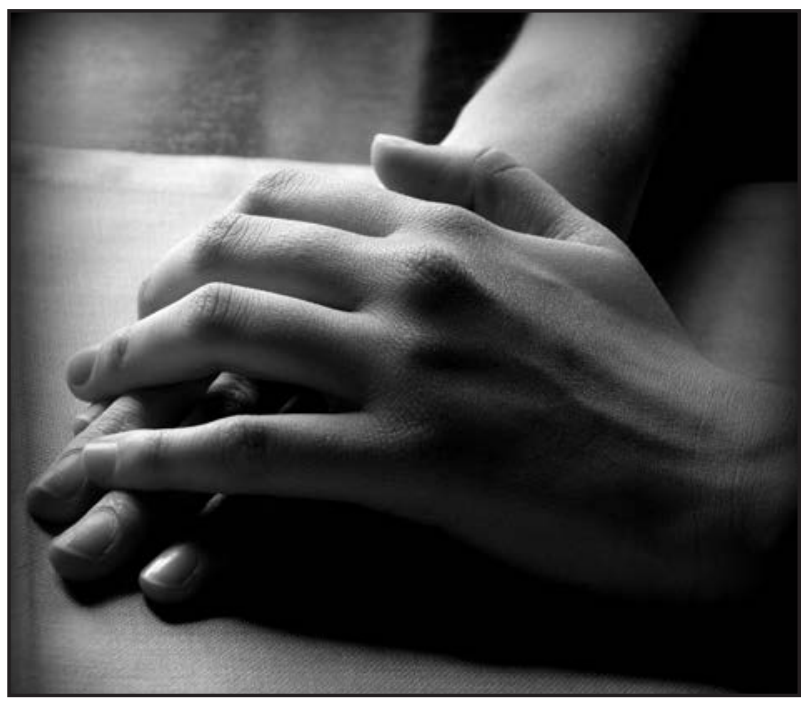

Fig. 5. 1. Manos apoyadas una sobre otra.
Según el diccionario sitio es: "espacio que es ocupado o puede serlo por algo. Paraje o terreno determinado que es a propósito para alguna cosa". Por tanto lo que caracteriza el sitio es su bondad como parte del ecosistema, para que en él se desarrollen los procesos antroposociales que configuran el territorio y por ende se materialicen, con lo que ello comporta. El sitio es el suelo "virgen" que está dispuesto a recibir una construcción, los elementos antroposociales en principio se apoyan y simplemente "contactan" con el soporte. Para comprobarlo y analizarlo superpondremos los dos levantamientos gráficos de ambas estructuras a la misma escala y en las doce zonas de estudio.

Usaremos los planos del soporte o cañamazo que hemos obtenido como simplificación formada por una malla de planos triangulares de distintas pendientes y lo superpondremos con los planos a la misma escala -1:75.000- de los distintos tipos de redes en las doce zonas de estudio. Posteriormente de cada una de estas superposiciones seleccionaremos dos sectores a los que nos "acercaremos" para ver con más detalle que tipo de relaciones existen entre ellas. Todas estas imágenes son representaciones de sitios. Las arquitecturas están simplemente apoyadas sobre el territorio.

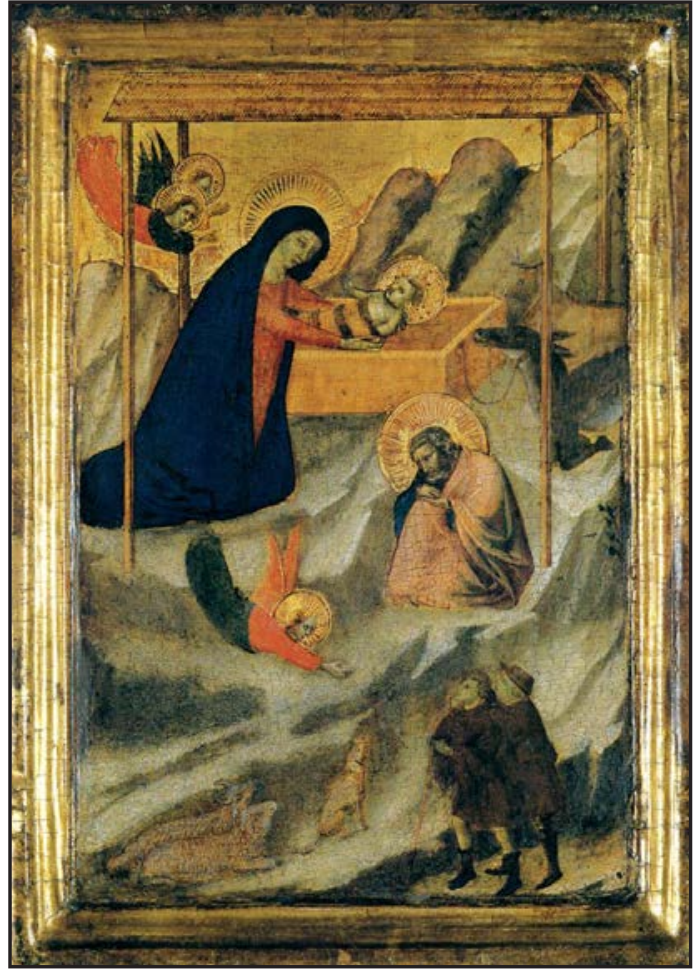

Fig. 5. 2. Cuadro de la Natividad de Bernardo Daddi (1340).

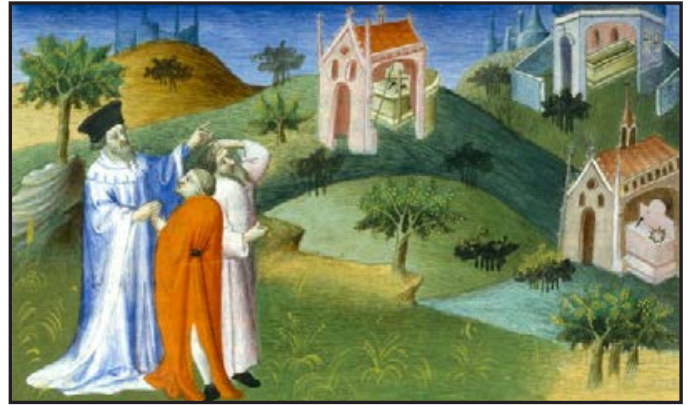

Fig. 5. 3. Peregrinos en Constantinopla del Libro de las Maravillas (1410-12).

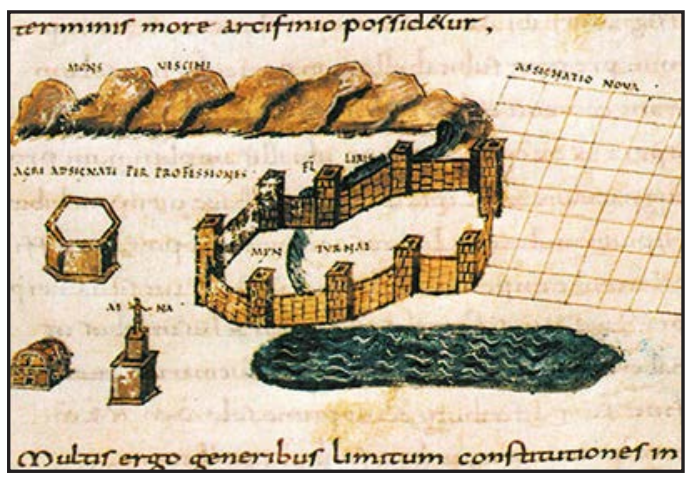

Fig. 5. 4. Dibujo 89 del libro "Frontin l'oeuvre gromatique" que recoge Corpus Agrimensorum romanorum IV de lulius Frontinus. 



\section{Mapa general (situación de las zonas de estudio) - $[e=1 / 200.000]$}

\section{Combinaciones: Simplificación por inclinaciones + Muros}

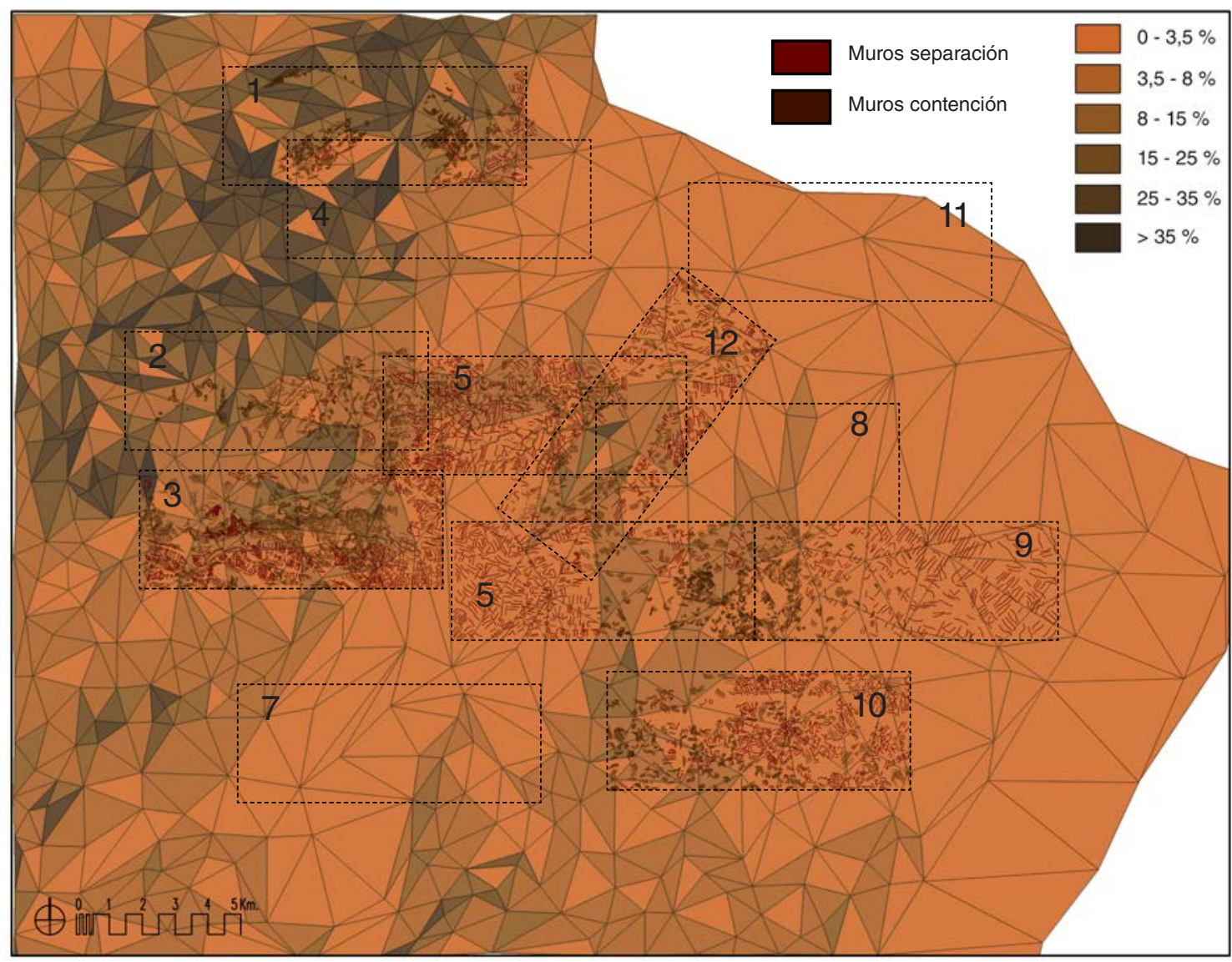

Fig. 5. 5. Plano de la Batllia a escala 1/200.000 del de la simplificación del topográfico superpuesto al de los muros. Señalización 12 zonas de estudio.

La comparación la haremos en las doce zonas de estudio (en el caso de los muros en las 8 zonas de estudio) a la escala $1 / 75.000$ y posteriormente de cada una de estas zonas seleccionamos dos sectores a lo que nos aproximamos y los analizamos a escala $1 / 37.500$

Las redes de muros se sitúan en los "vacíos" triangulares de la malla. Si tienen mucha pendiente se disponen concéntricamente respecto al vértice que conforman las aristas de la malla y perpendiculares a la máxima pendiente; si tiene poca pendiente se disponen paralelos o perpendiculares a uno de los lados de los planos triangulares del cañamazo de forma que sean perpendiculares a la máxima pendiente de ese plano. 
Simplificación por inclinaciones + Muros - Zonas 1 y 2 - [e=1/75.000]

Detalles ampliados $-[e=1 / 37.500]$

Zona 1_Bel
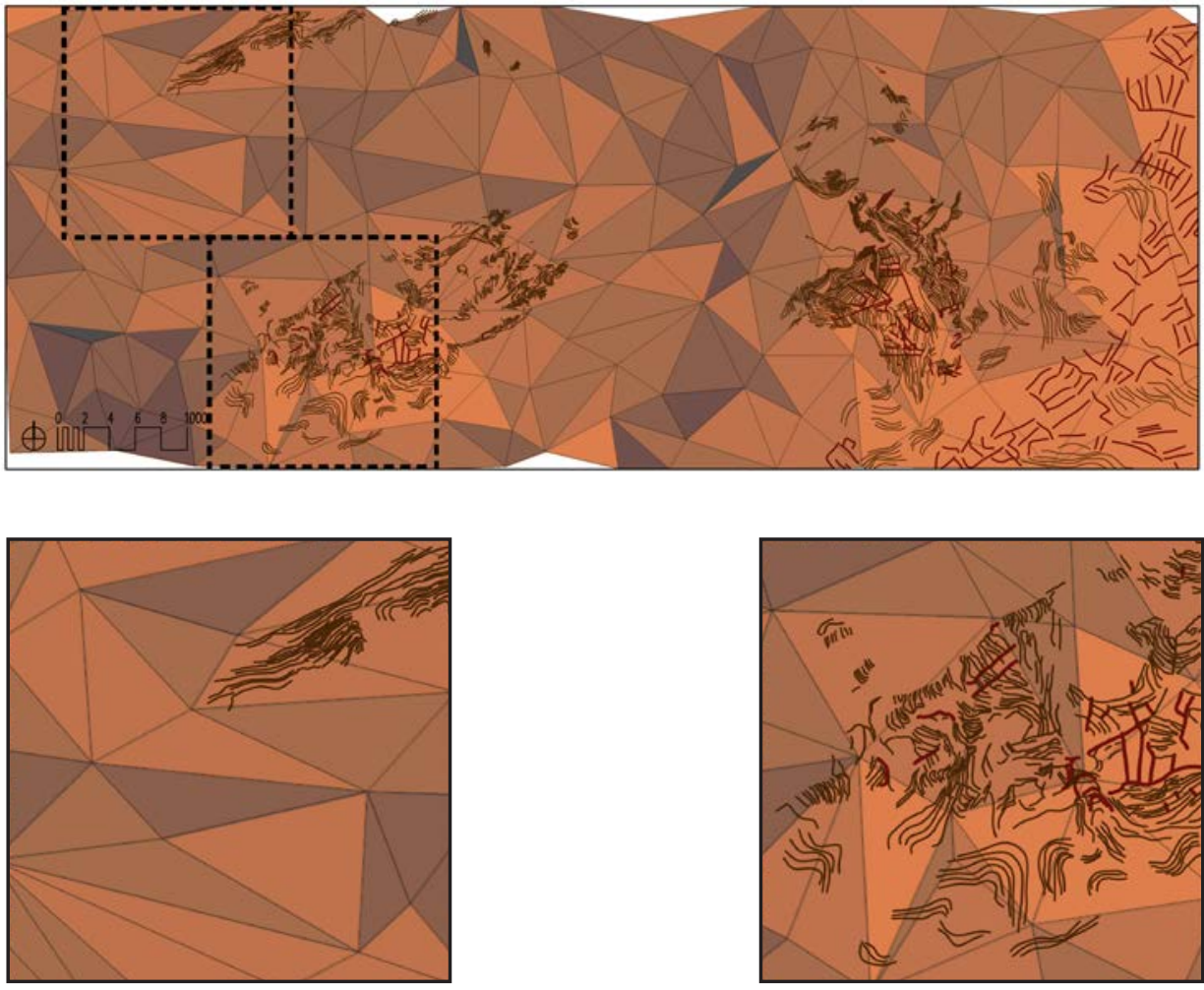

\section{Zona 2_Barcella}
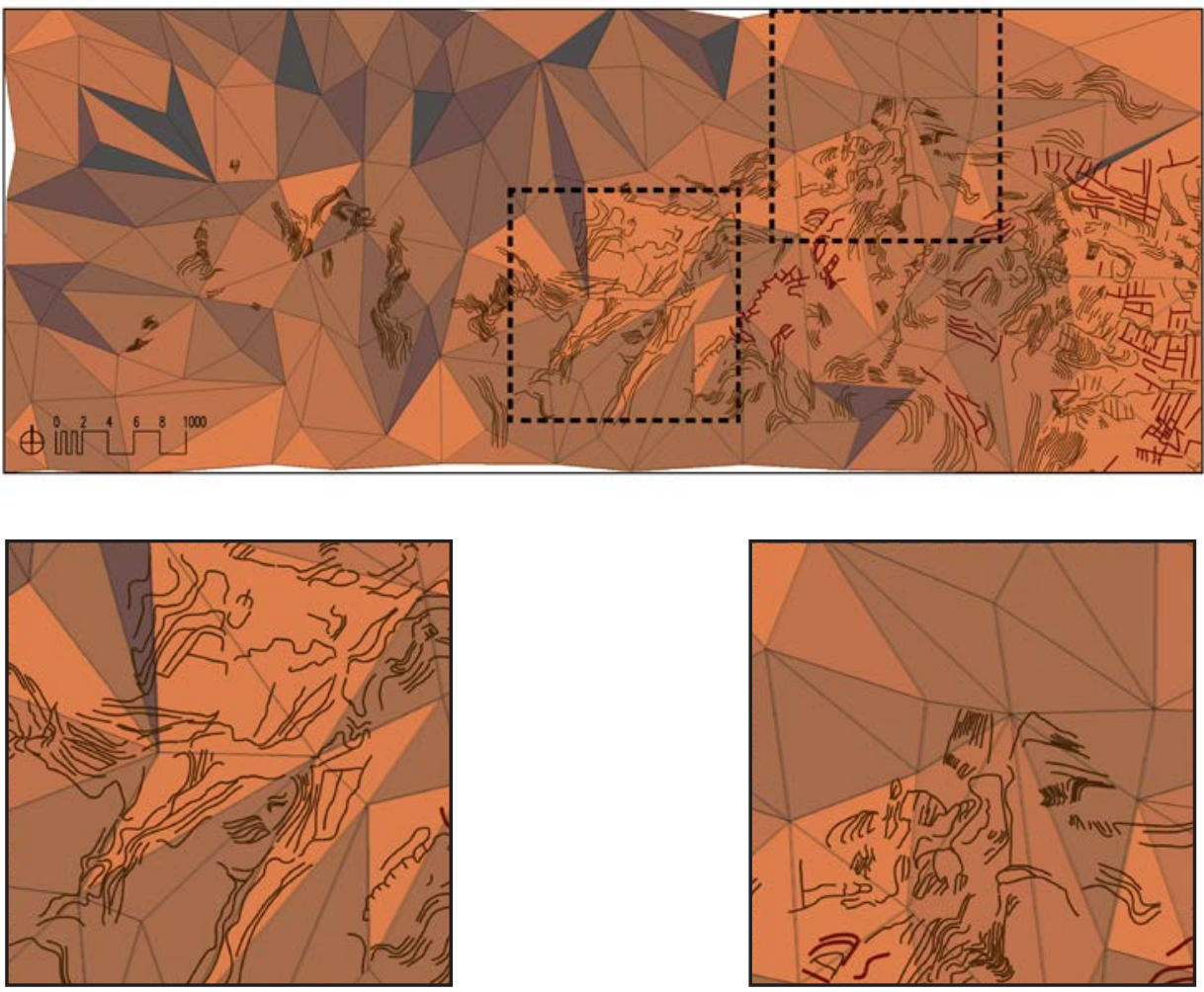
Simplificación por inclinaciones + Muros - Zonas 3 y 5 - $[e=1 / 75.000]$

Detalles ampliados $-[e=1 / 37.500]$

Zona 3_Molinar/Xert
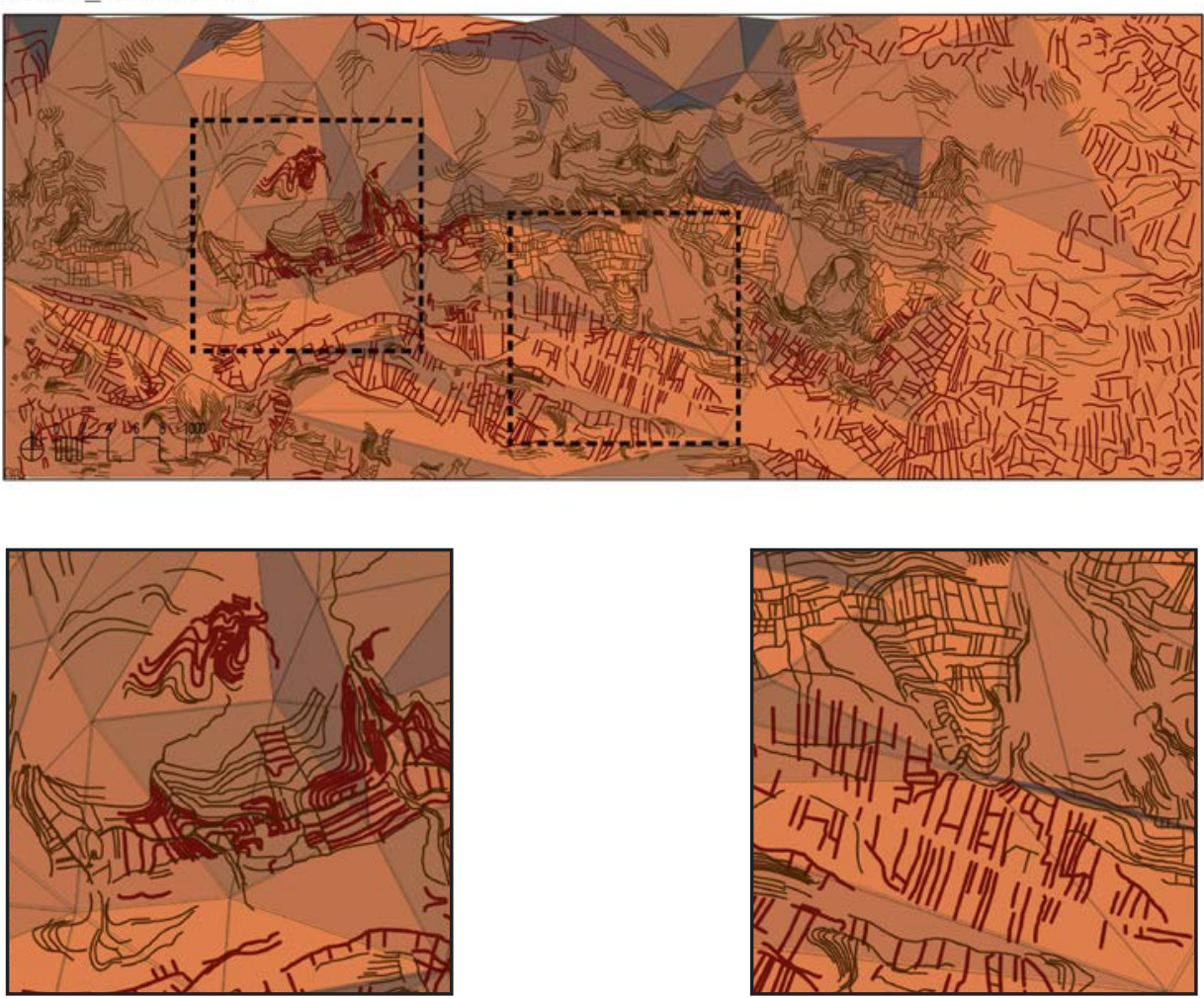

\section{Zona 5_Canet}
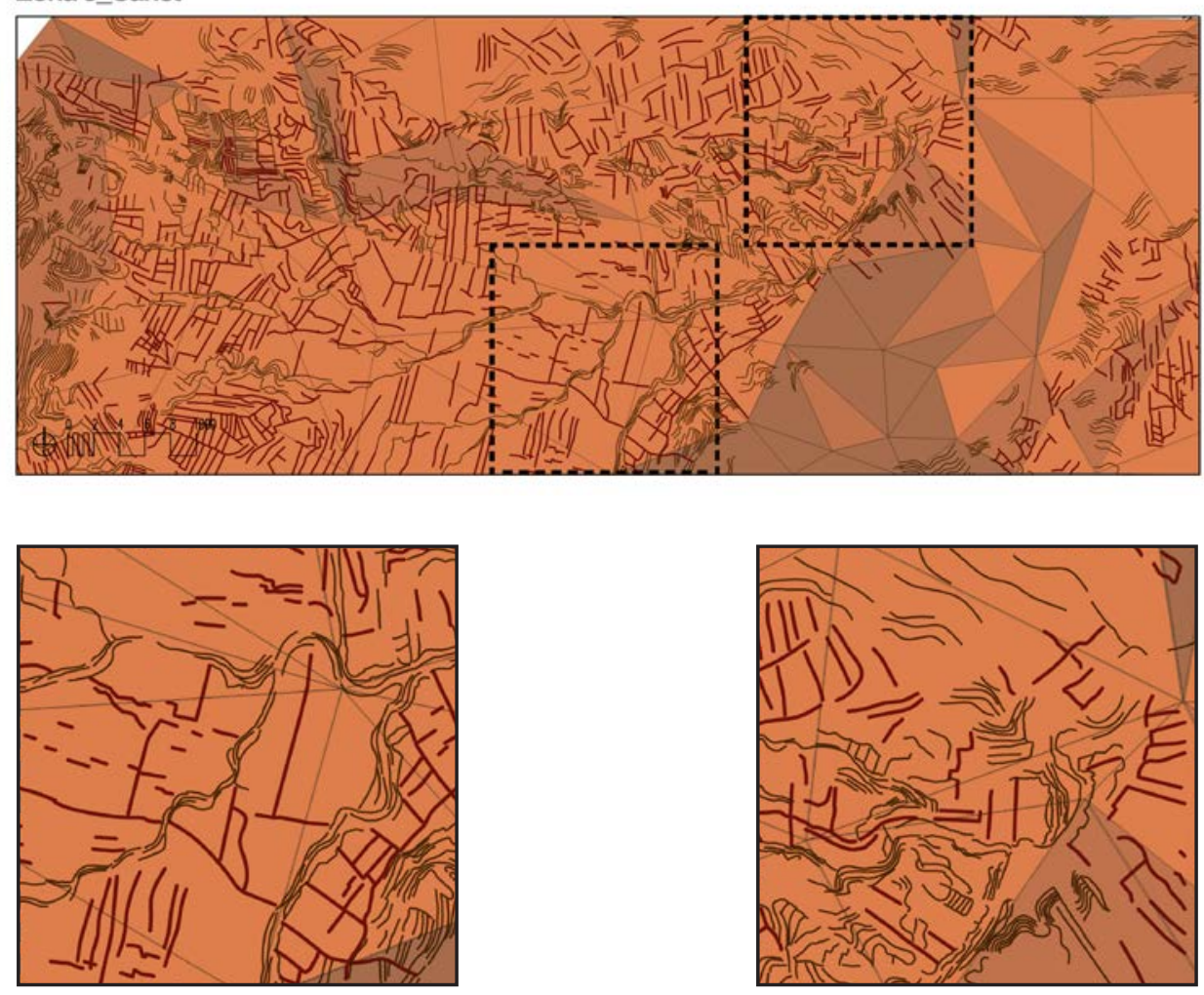
Simplificación por inclinaciones + Muros - Zonas 6 y 9 - $[e=1 / 75.000]$

Detalles ampliados $-[e=1 / 37.500]$

Zona 6_La Jana/Carrascal
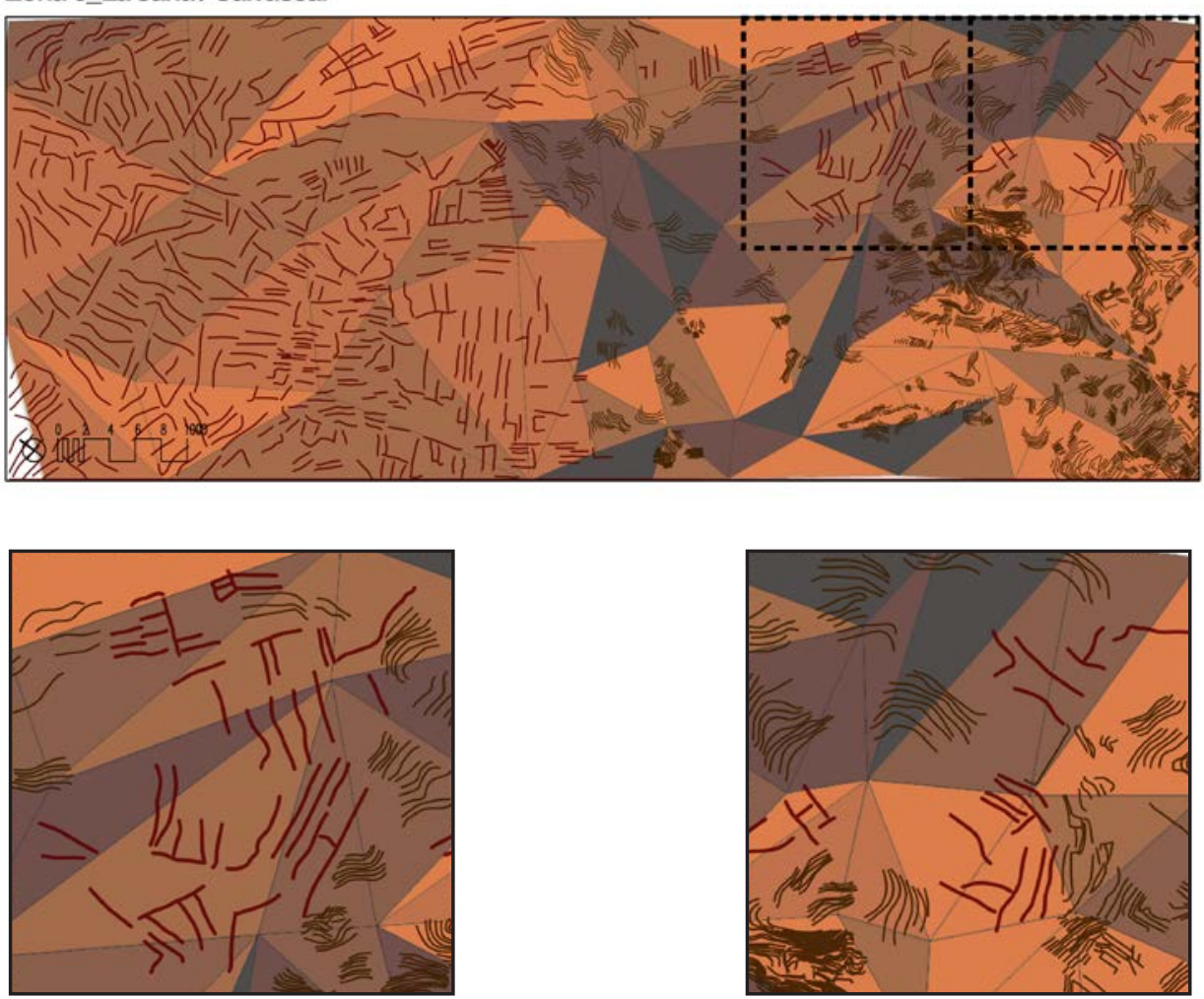

\section{Zona 9_Mas Stellers}
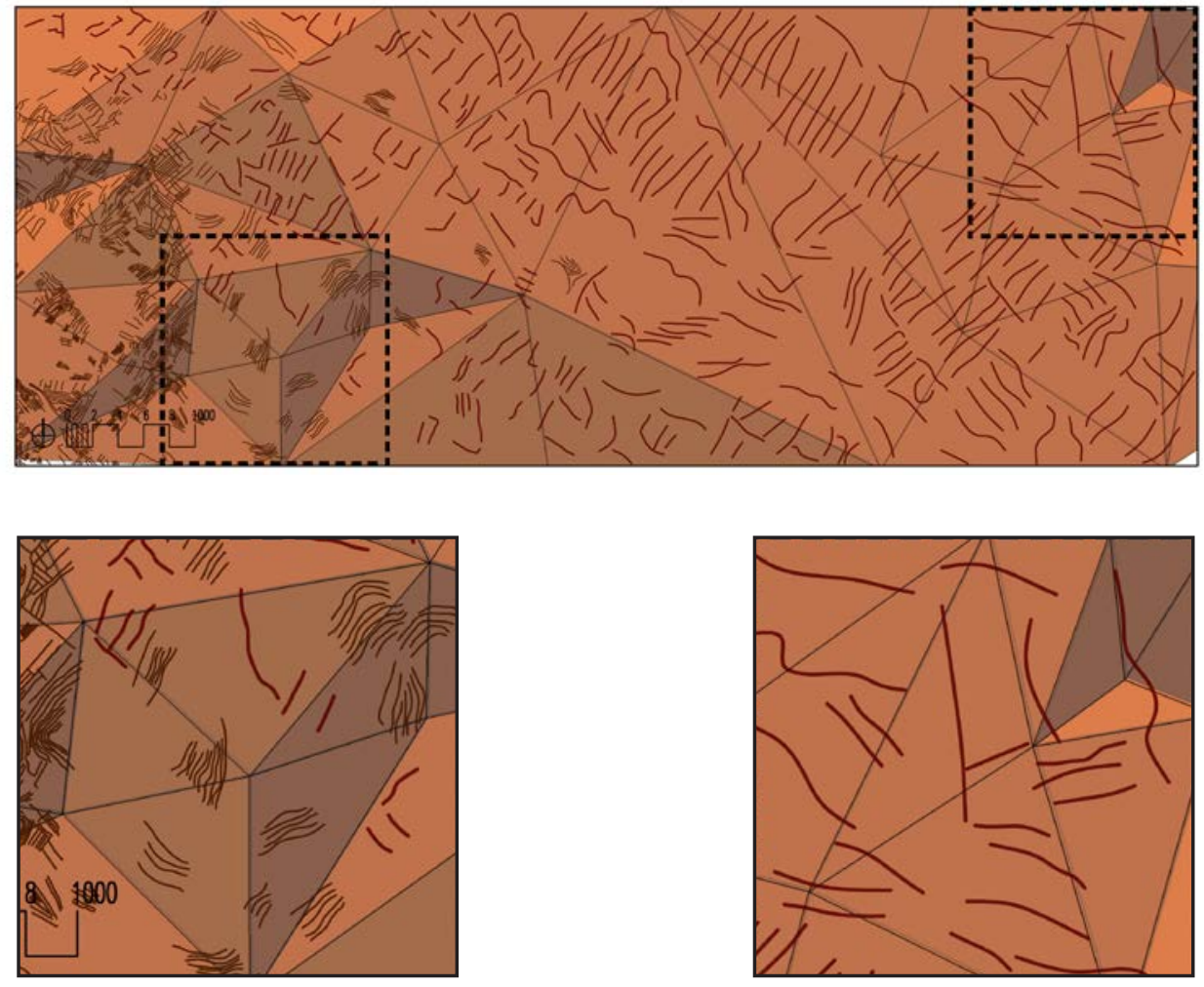
Simplificación por inclinaciones + Muros - Zonas 10 y $12-[e=1 / 75.000]$

Detalles ampliados $-[e=1 / 37.500]$
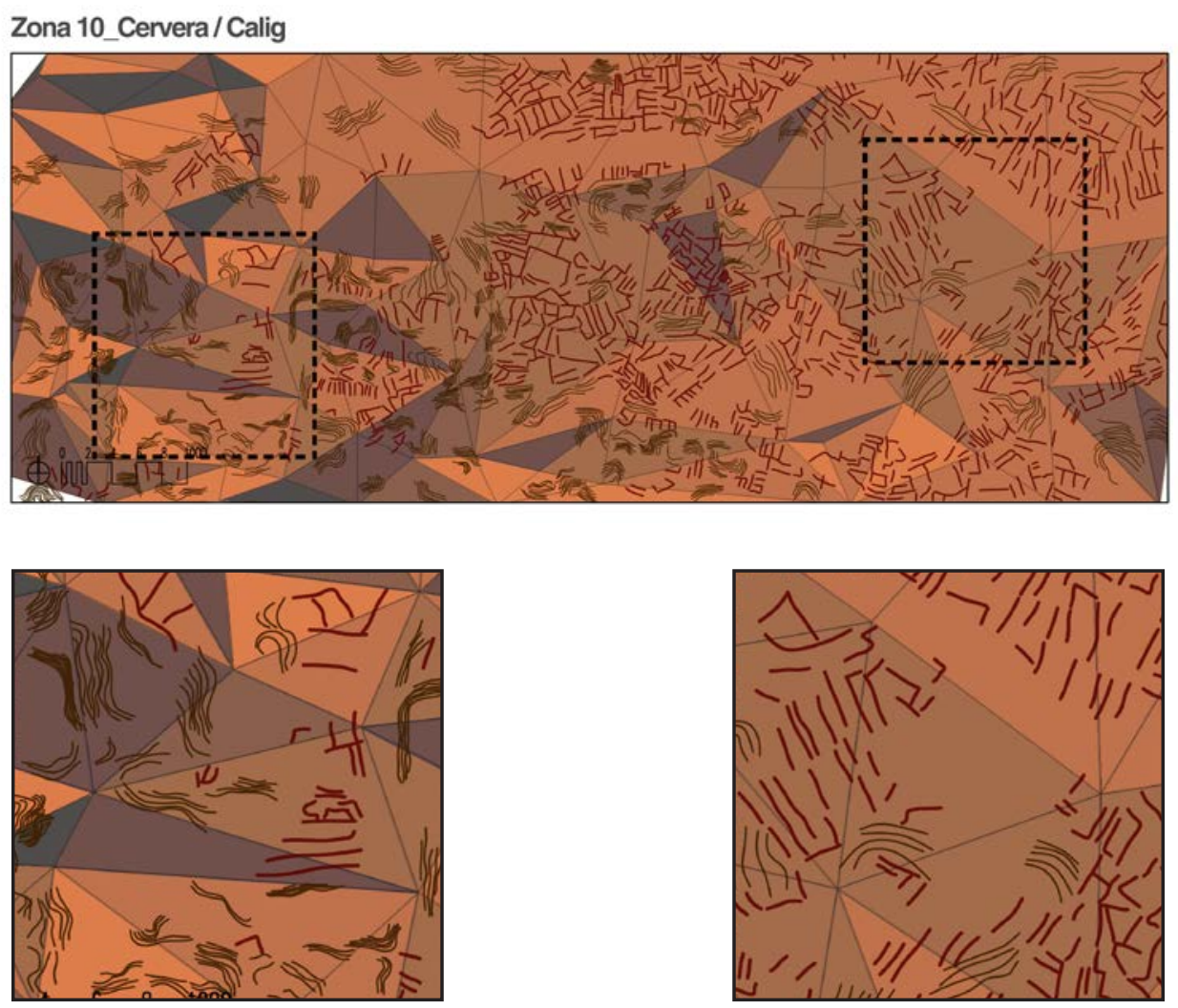

Zona 12_Atalaya San Pere
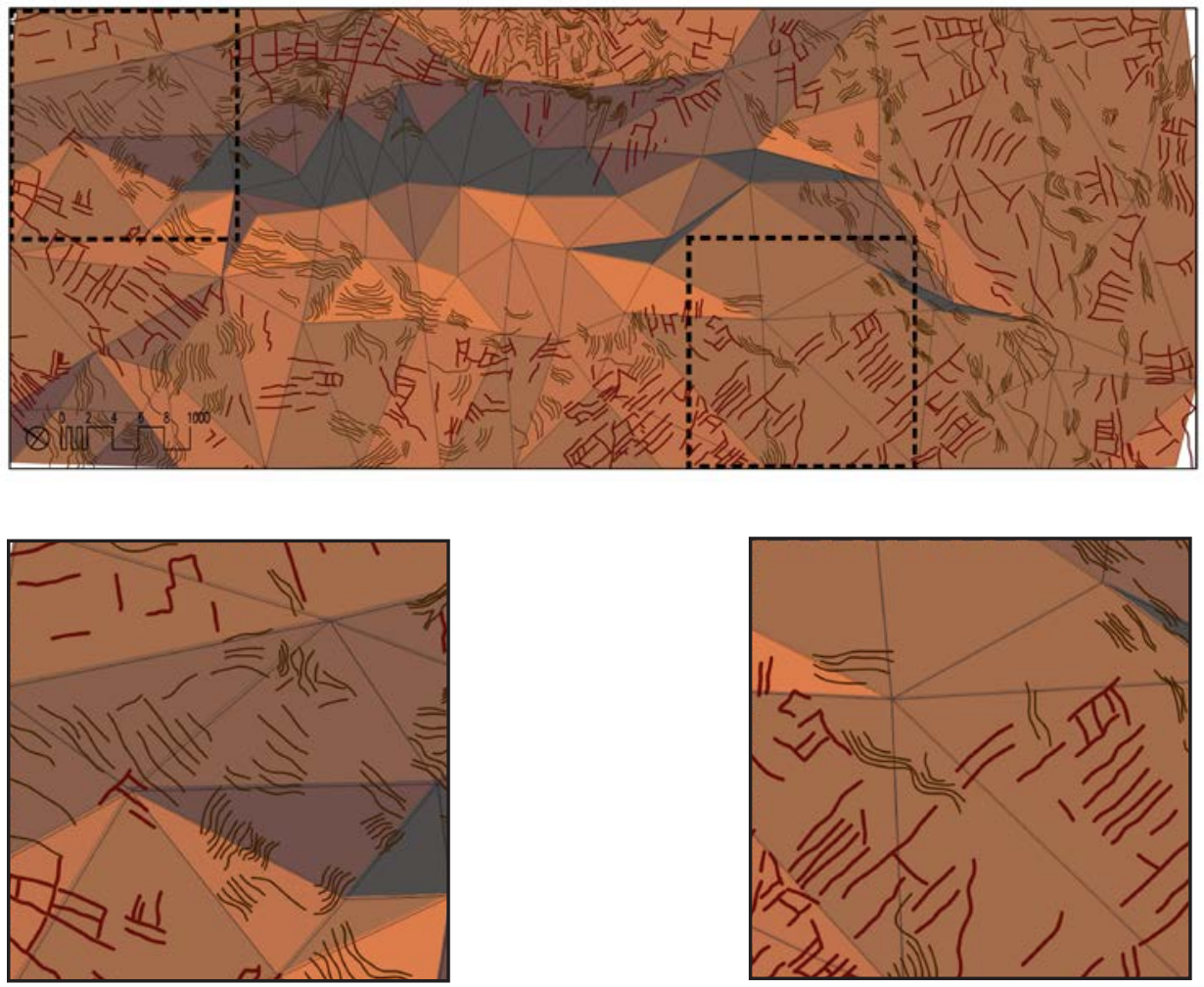
Mapa general (situación de las zonas de estudio) - $[\mathrm{e}=1 / 200.000]$

\section{Combinaciones: Simplificación por inclinaciones + Infraestructuras}

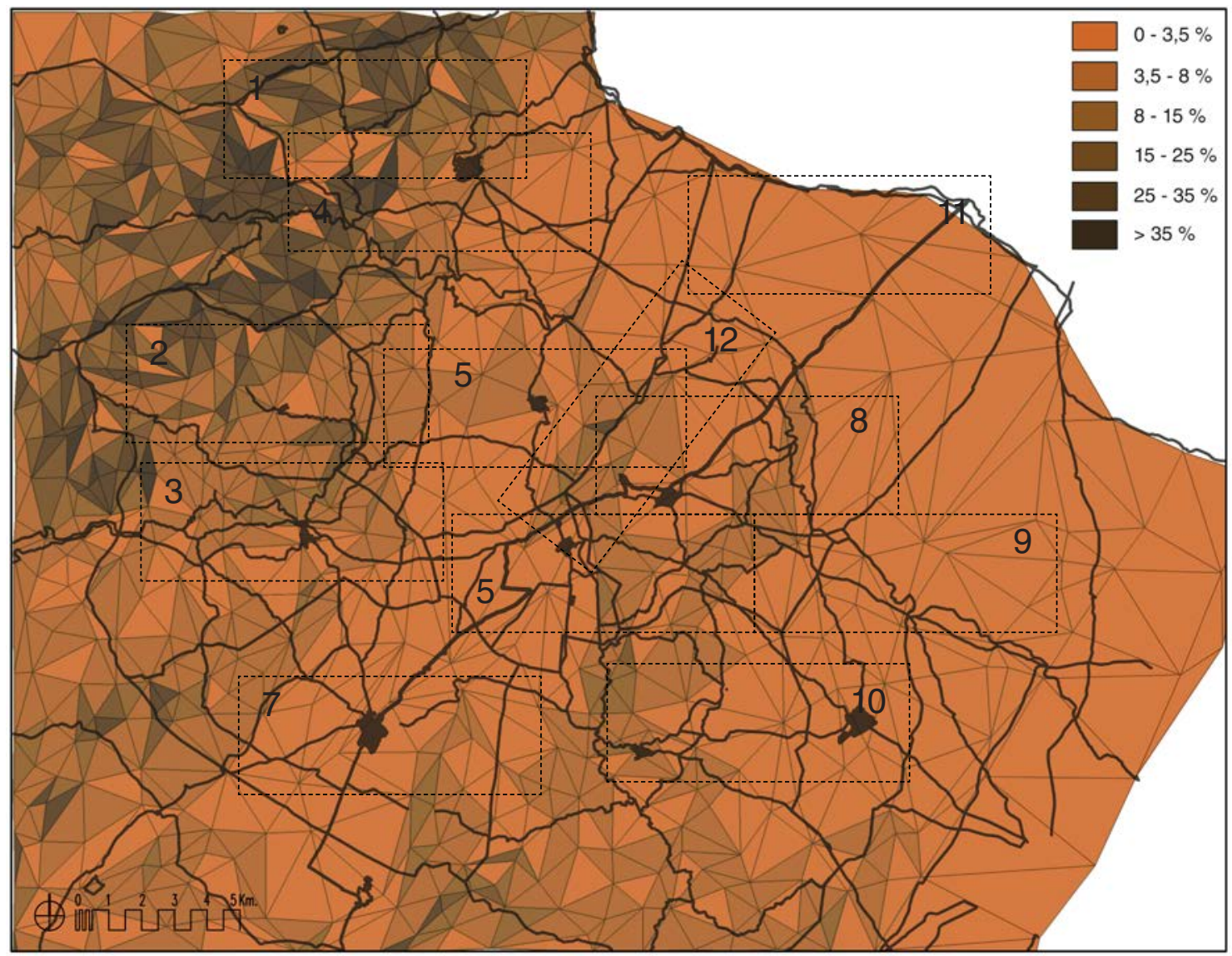

Fig. 5. 6. Plano de la Batllia a escala 1/200.000 del de la simplificación del topográfico superpuesto al de las infraestructuras. Señalización 12 zonas de estudio.

La comparación la haremos en las doce zonas de estudio (en el caso de los muros en las 8 zonas de estudio) a la escala $1 / 75.000$ y posteriormente de cada una de estas zonas seleccionamos dos sectores a lo que nos aproximamos y los analizamos a escala $1 / 37.500$

Las redes de infraestructuras se sitúan sobre la malla del cañamazo, sobre la malla que establece las conexiones del espacio topológico. No podría ser menos, al fin y al cabo las infraestructuras son las que nos establecen las conexiones del territorio. Las redes principales se corresponden con las líneas de la estructura del cañamazo de máxima importancia: la limahoya, la limatesa y la línea de cambio de máxima pendiente.

Las infraestructuras de segundo orden (menor importancia) se trazan perpendiculares o paralelas al lado del triángulo de la malla del cañamazo siguiendo la línea de máxima pendiente. 
Simplificación por inclinaciones + Infraestructuras - Zonas 1 y $2-[e=1 / 75.000]$

Detalles ampliados $-[e=1 / 37.500]$

Zona1_Bel
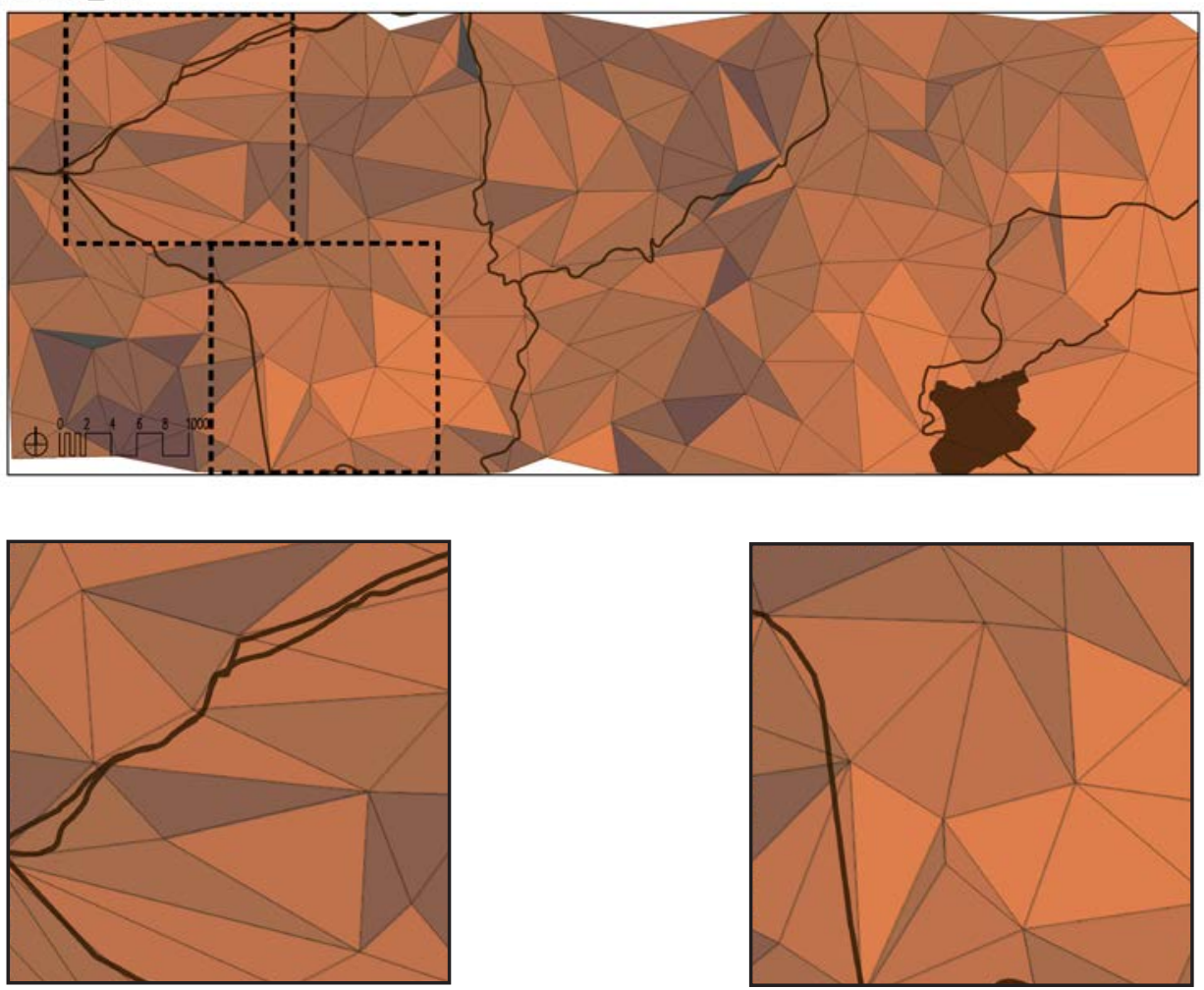

\section{Zona 2_Barcella}
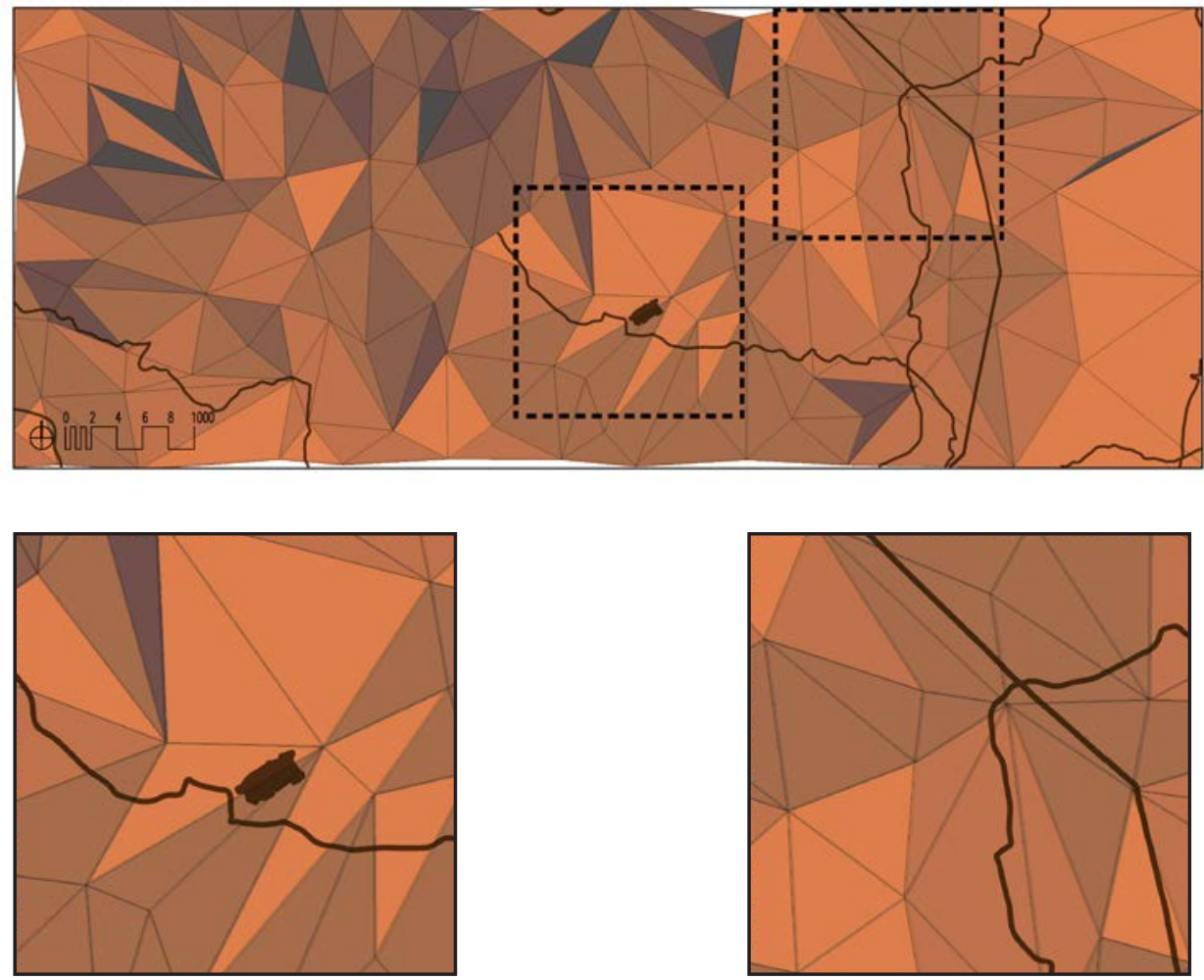
Simplificación por inclinaciones + Infraestructuras - Zonas 3 y $4-[e=1 / 75.000]$

Detalles ampliados $-[e=1 / 37.500]$

Zona 3_Molinar/Xert
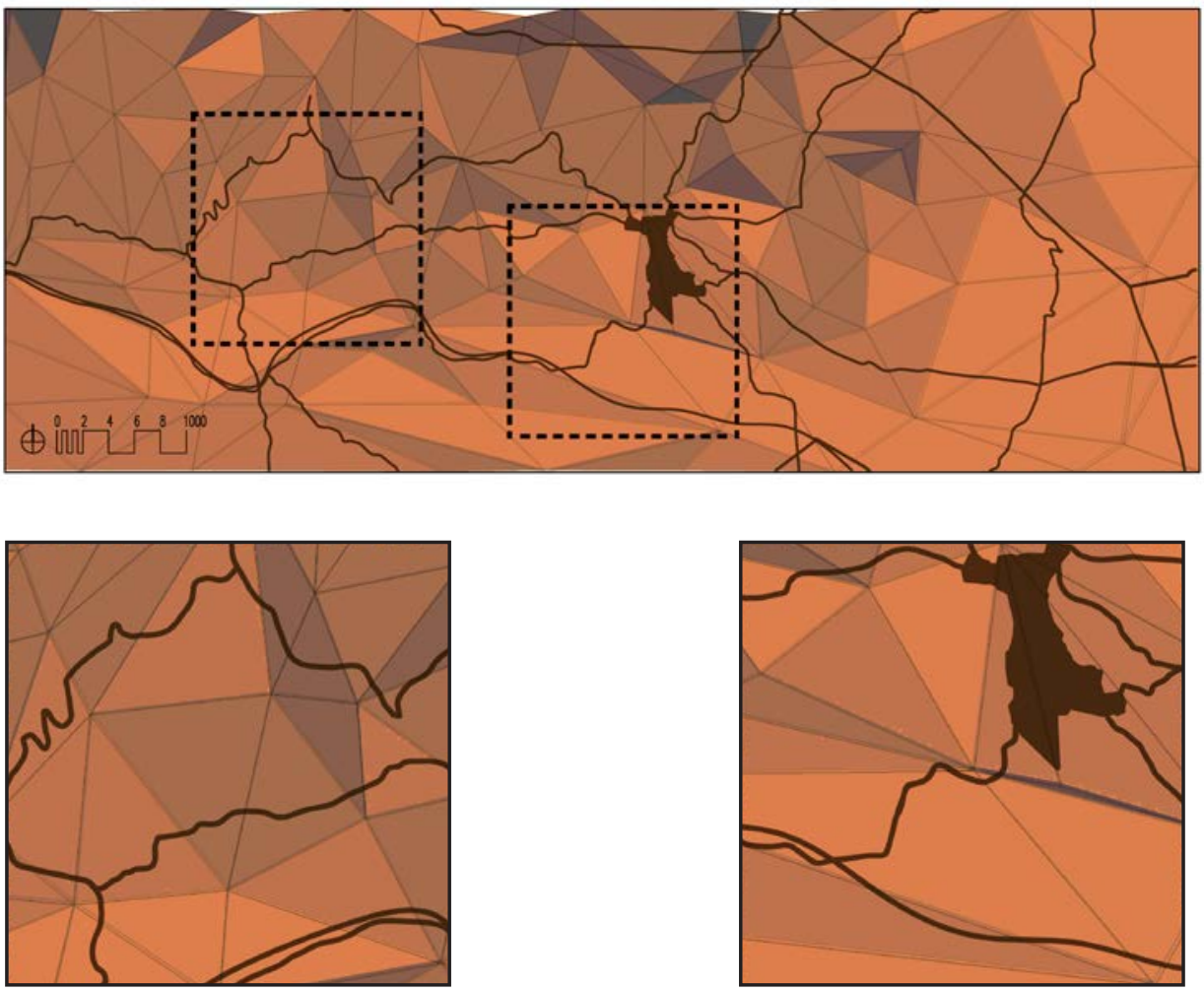

\section{Zona 4_Mas del Coll / Rosell}
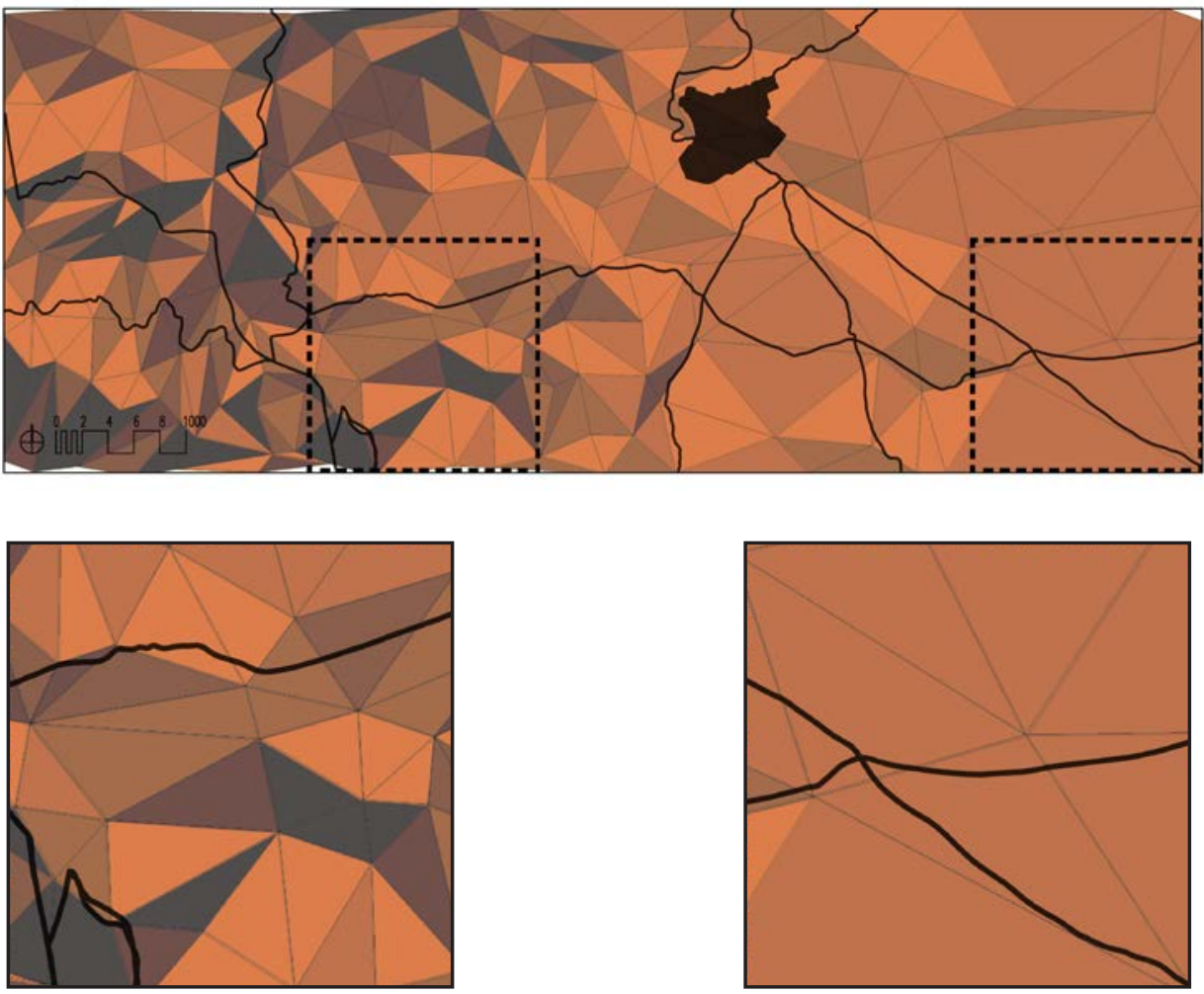
Simplificación por inclinaciones + Infraestructuras - Zonas 5 y $6-[e=1 / 75.000]$

Detalles ampliados - $[e=1 / 37.500]$
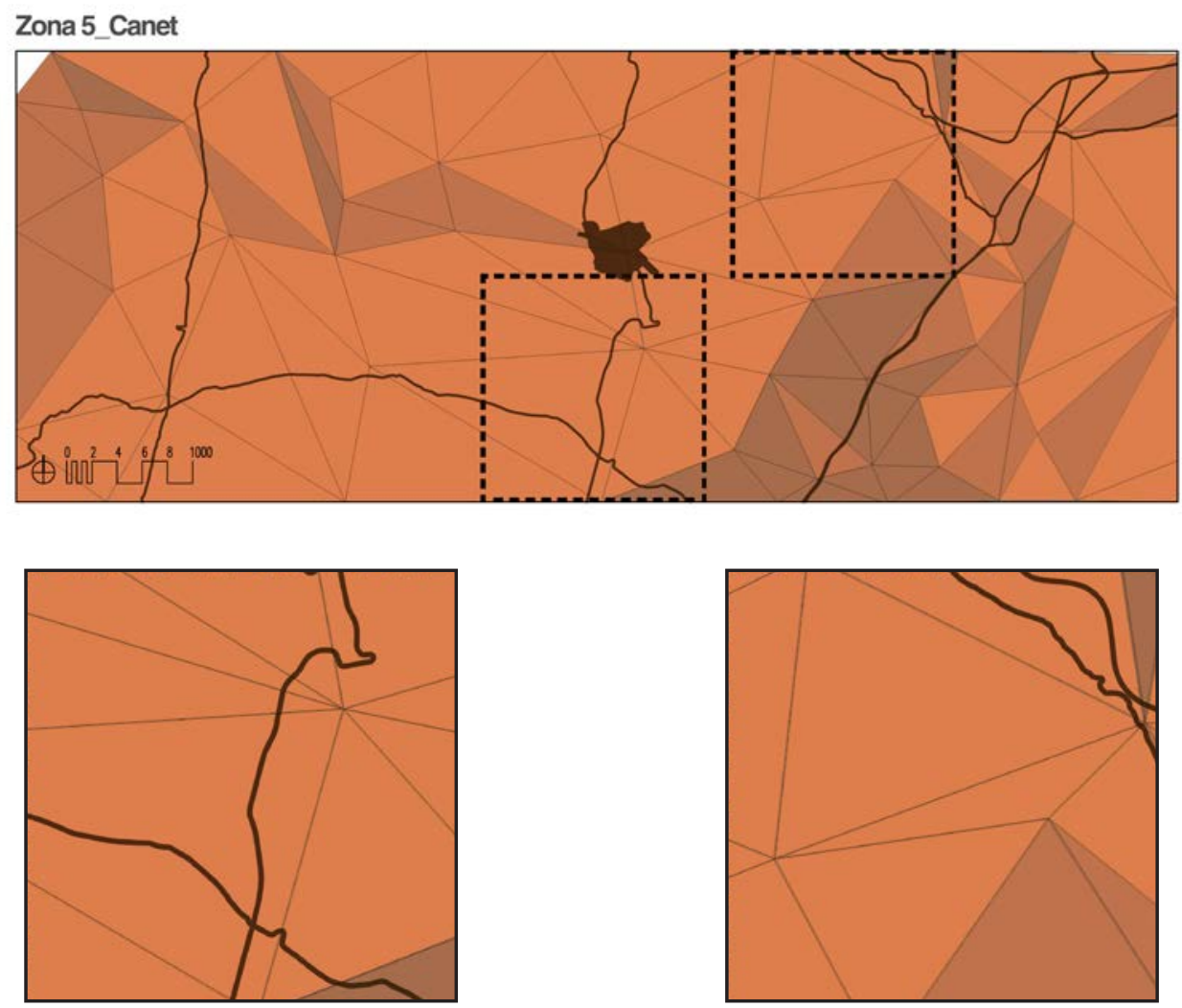

\section{Zona 6_La Jana / Carrascal}
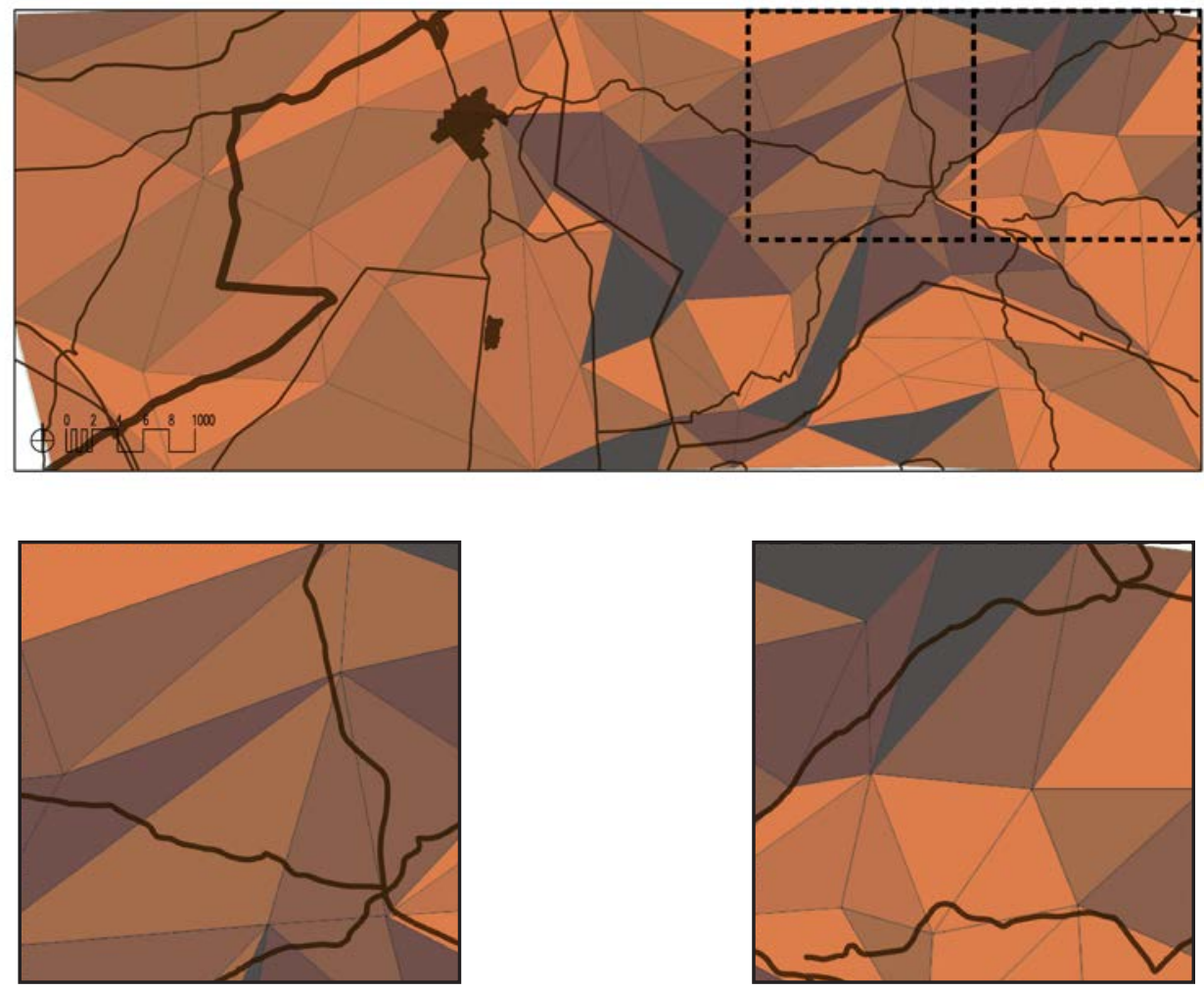
Simplificación por inclinaciones + Infraestructuras - Zonas 7 y $8-[e=1 / 75.000]$

Detalles ampliados $-[e=1 / 37.500]$

Zona 7_San Mateo
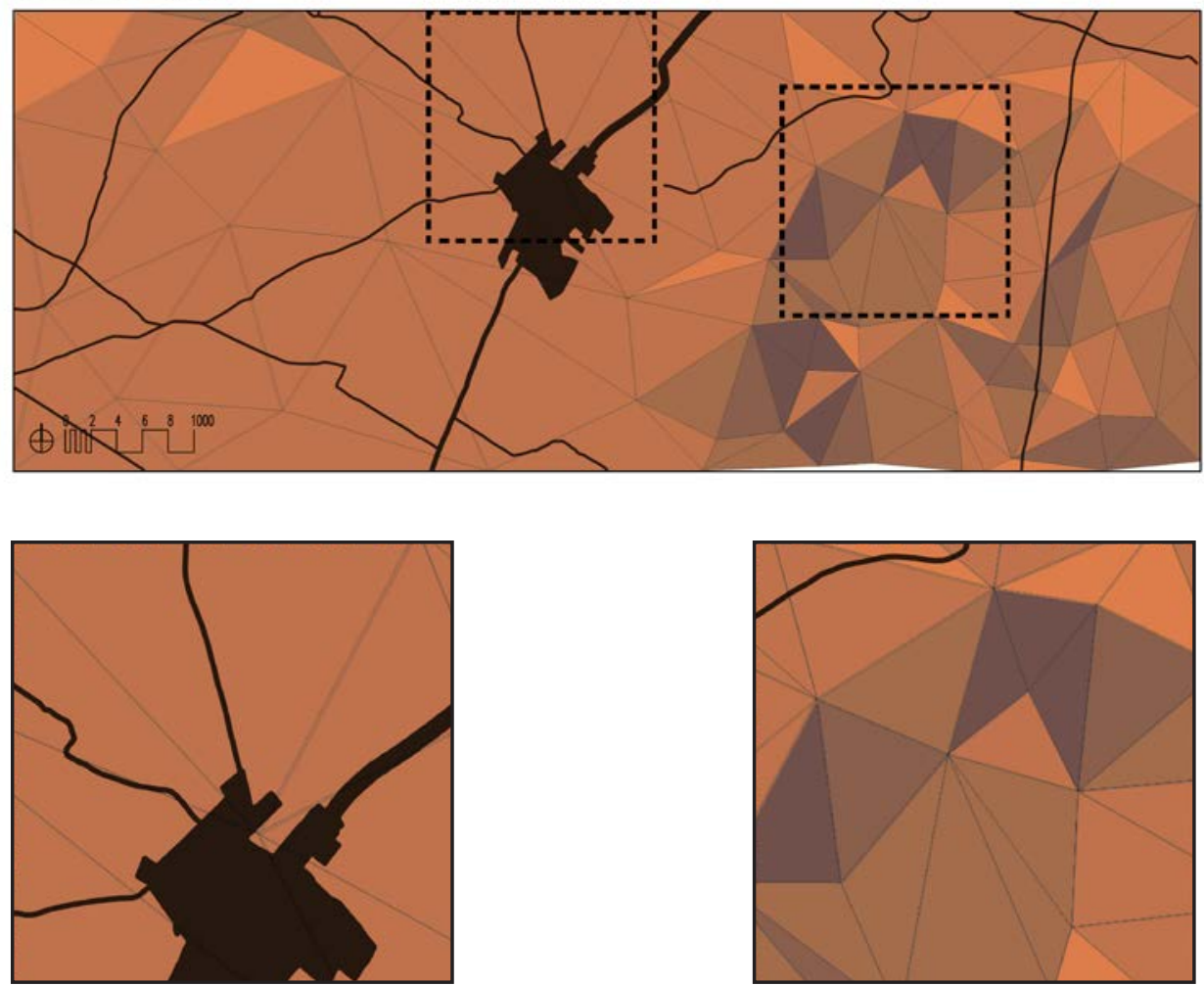

Zona 8_Traiguera
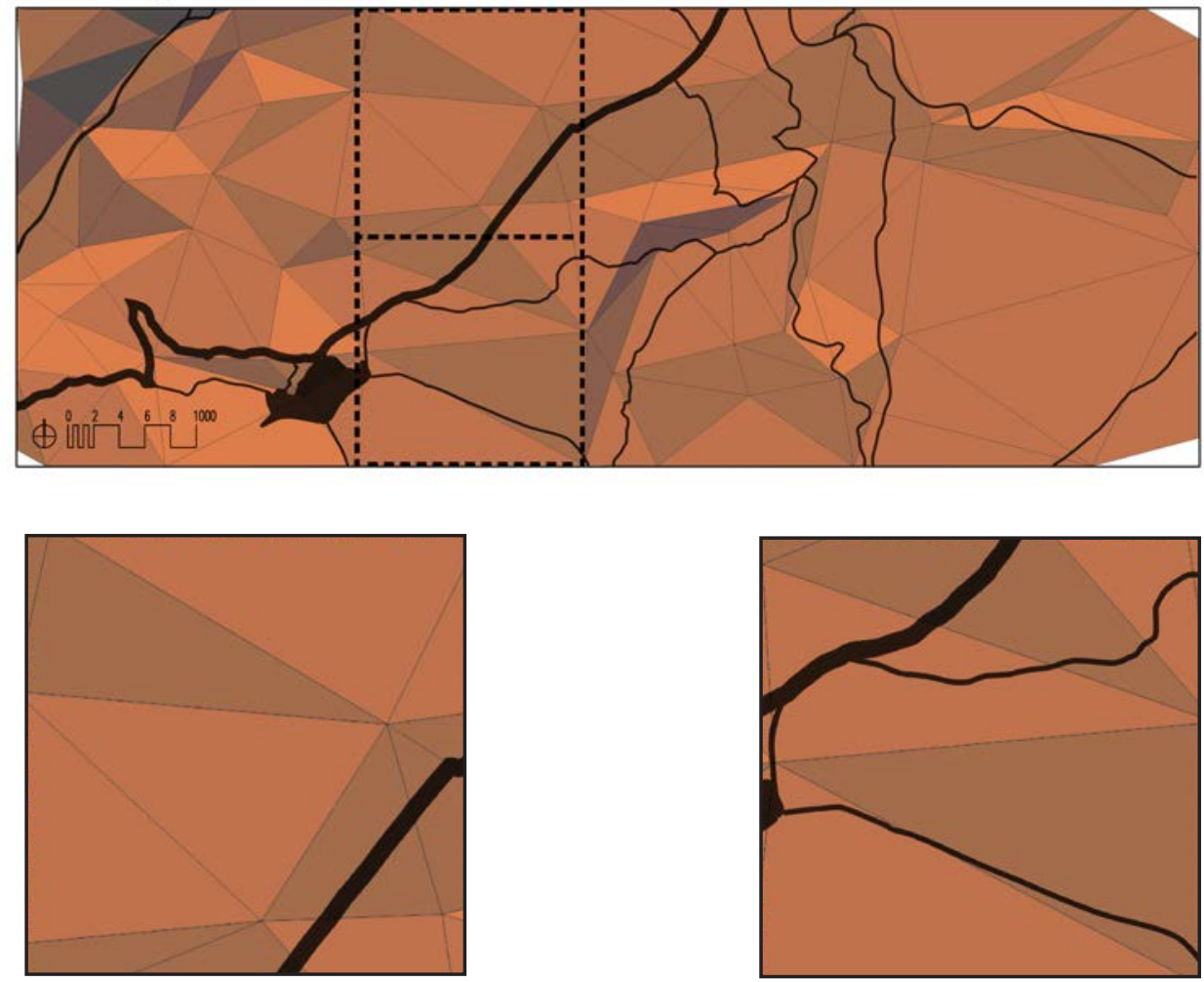
Simplificación por inclinaciones + Infraestructuras - Zonas 9 y $10-[e=1 / 75.000]$

Detalles ampliados $-[e=1 / 37.500]$

Zona 9_Mas Stellers
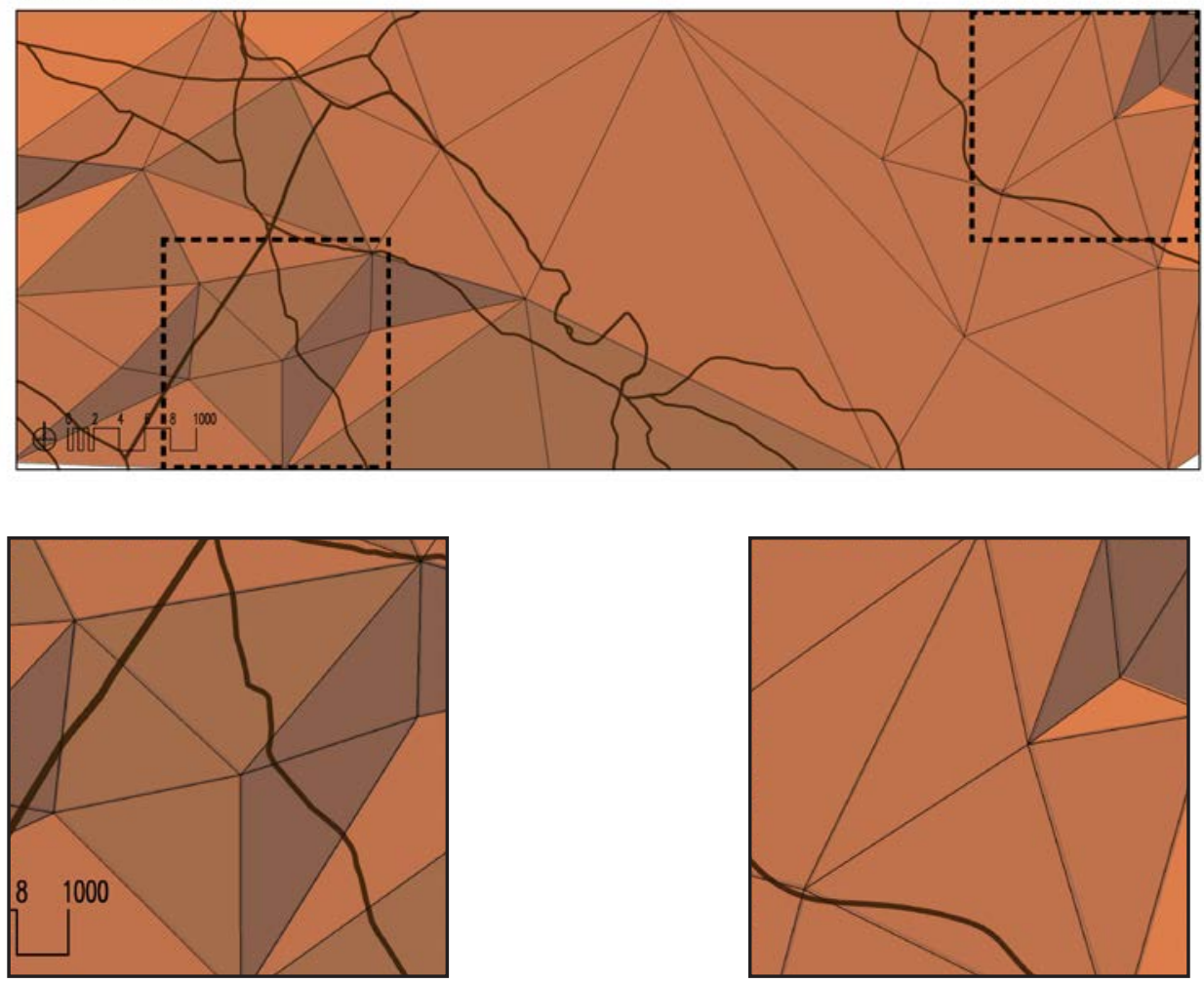

\section{Zona 10 Cervera / Calig}
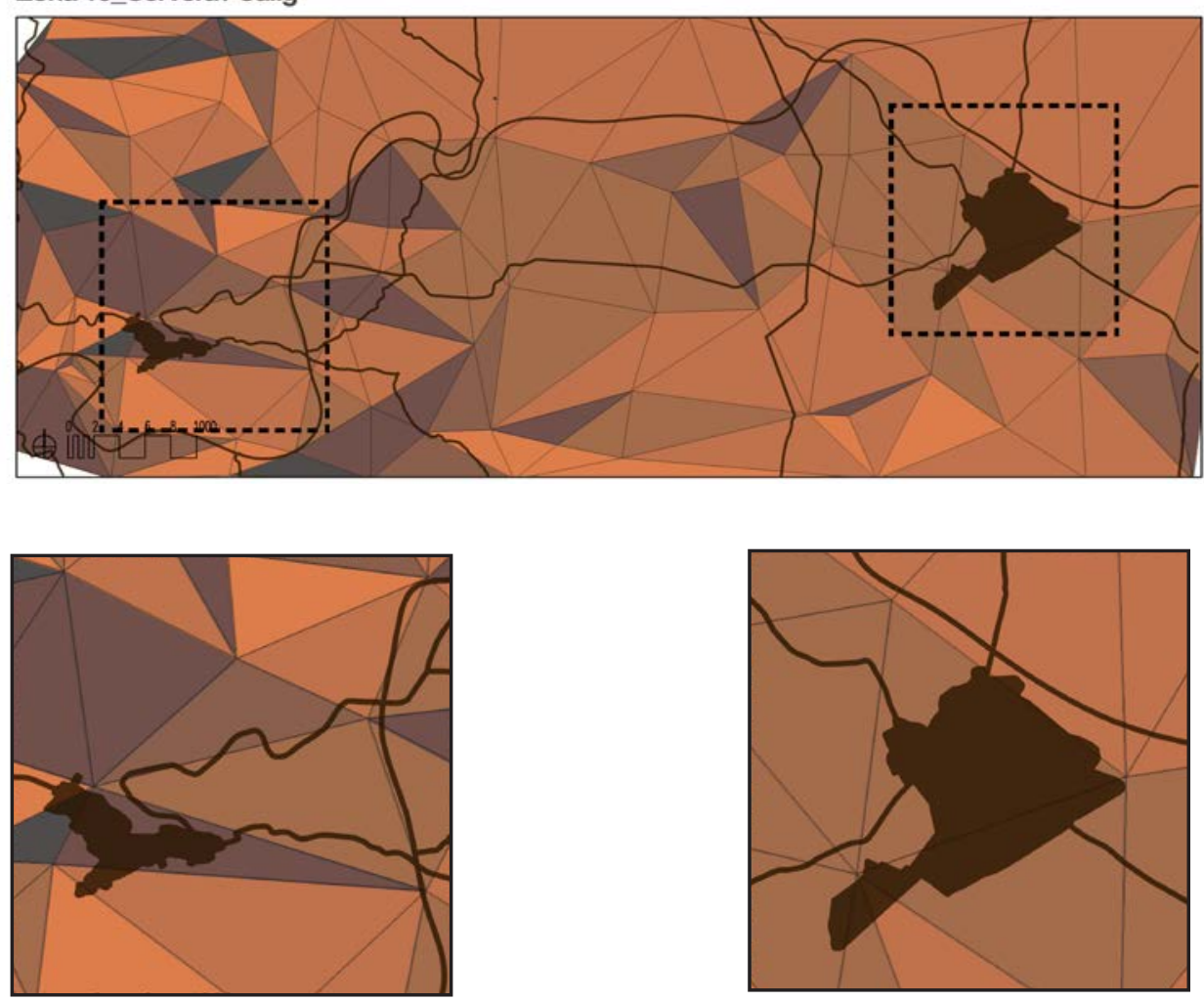
Simplificación por inclinaciones + Infraestructuras - Zonas 11 y 12 - [e=1/75.000]

Detalles ampliados $-[e=1 / 37.500]$

Zona 11_San Joan del Pas
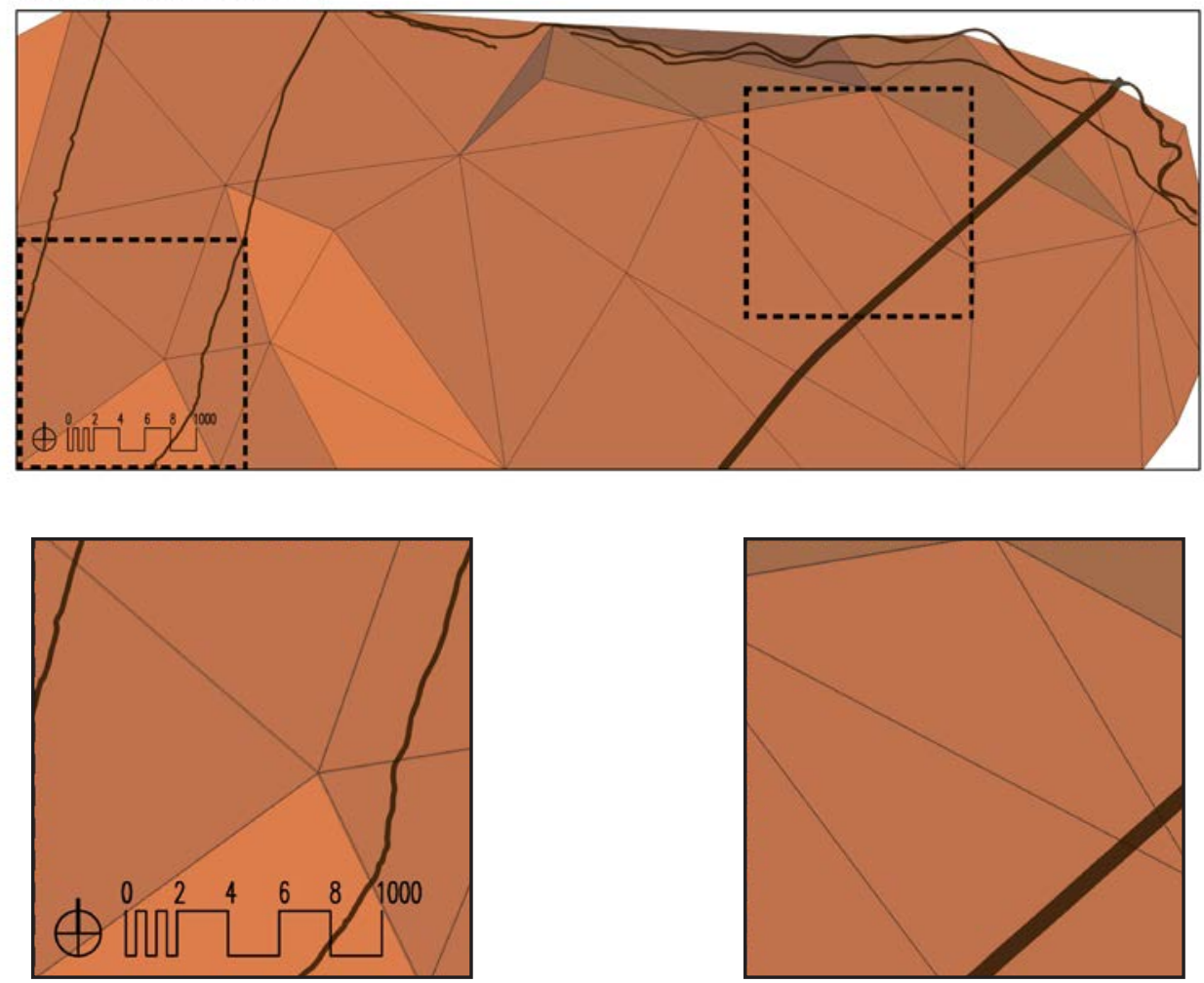

Zona 12_Atalaya San Pere
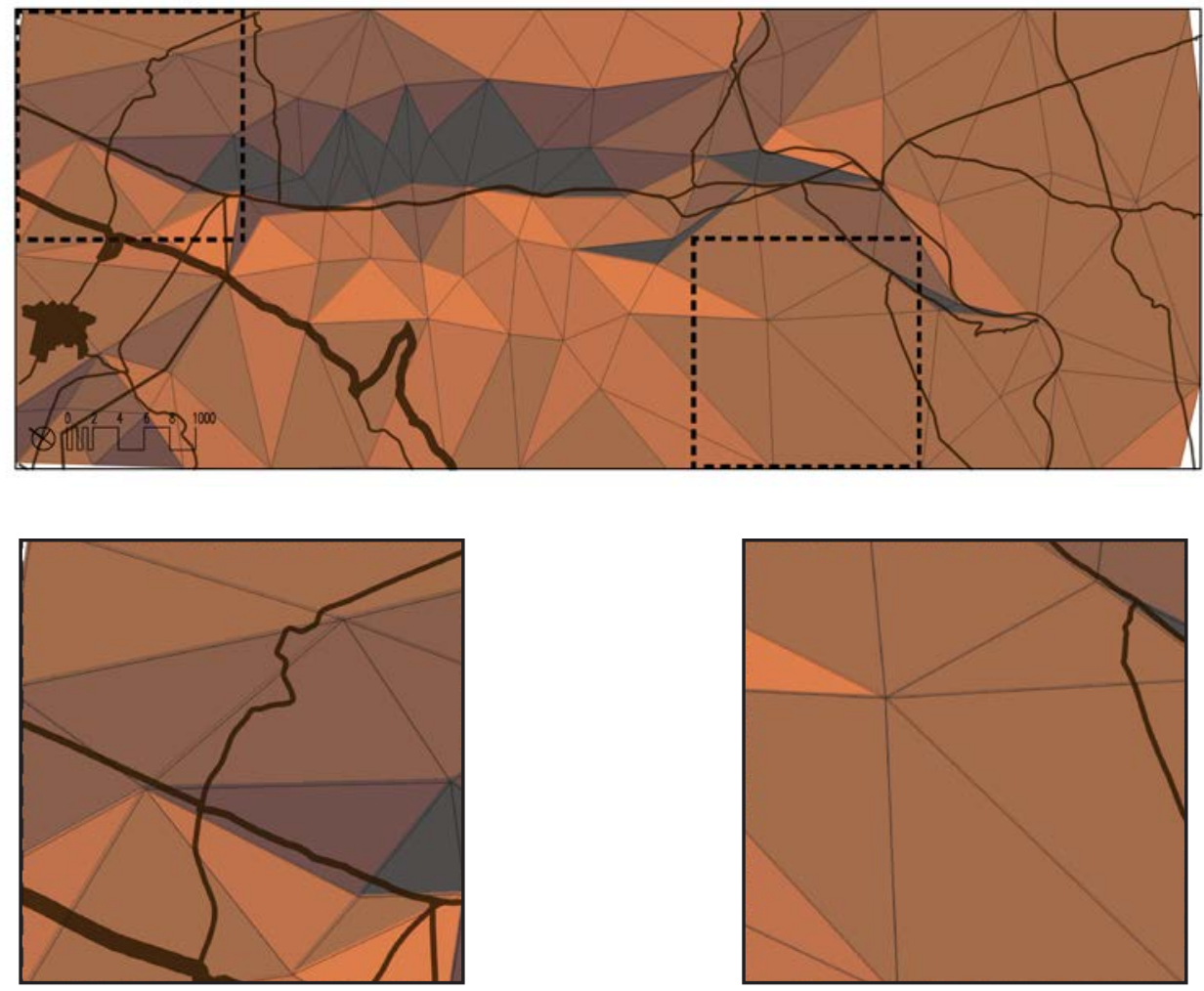
Mapa general (situación de las zonas de estudio) - $[\mathrm{e}=1 / 200.000]$

\section{Combinaciones: Simplificación por inclinaciones + Parcelario}

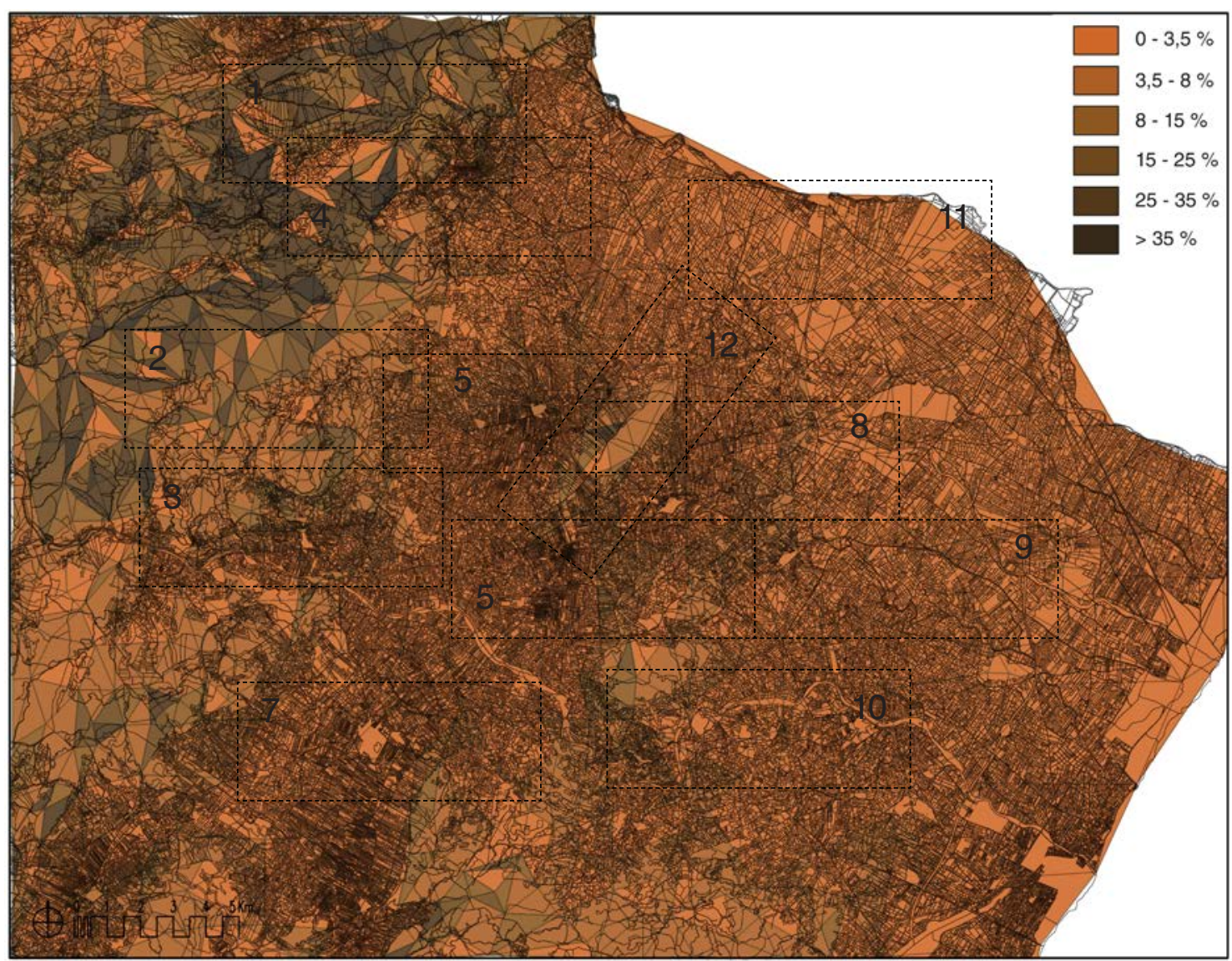

Fig. 5. 7. Plano de la Batllia a escala $1 / 200.000$ del de la simplificación del topográfico superpuesto al del parcelario. Señalización 12 zonas de estudio.

La comparación la haremos en las doce zonas de estudio (en el caso de los muros en las 8 zonas de estudio) a la escala $1 / 75.000$ y posteriormente de cada una de estas zonas seleccionamos dos sectores a lo que nos aproximamos y los analizamos a escala $1 / 37.500$

Las parcelaciones se sitúan en los "vacíos" triangulares de la malla. Si tienen mucha pendiente se disponen concéntricamente respecto al vértice que conforman las aristas de la malla y perpendiculares a la máxima pendiente; si tiene poca pendiente se disponen paralelos o perpendiculares a uno de los lados de los planos triangulares del cañamazo de forma que sean perpendiculares a la máxima pendiente de ese plano. 
Simplificación por inclinaciones + Parcelario - Zonas 1 y $2-[e=1 / 75.000]$

Detalles ampliados $-[e=1 / 37.500]$

Zona 1_Bel
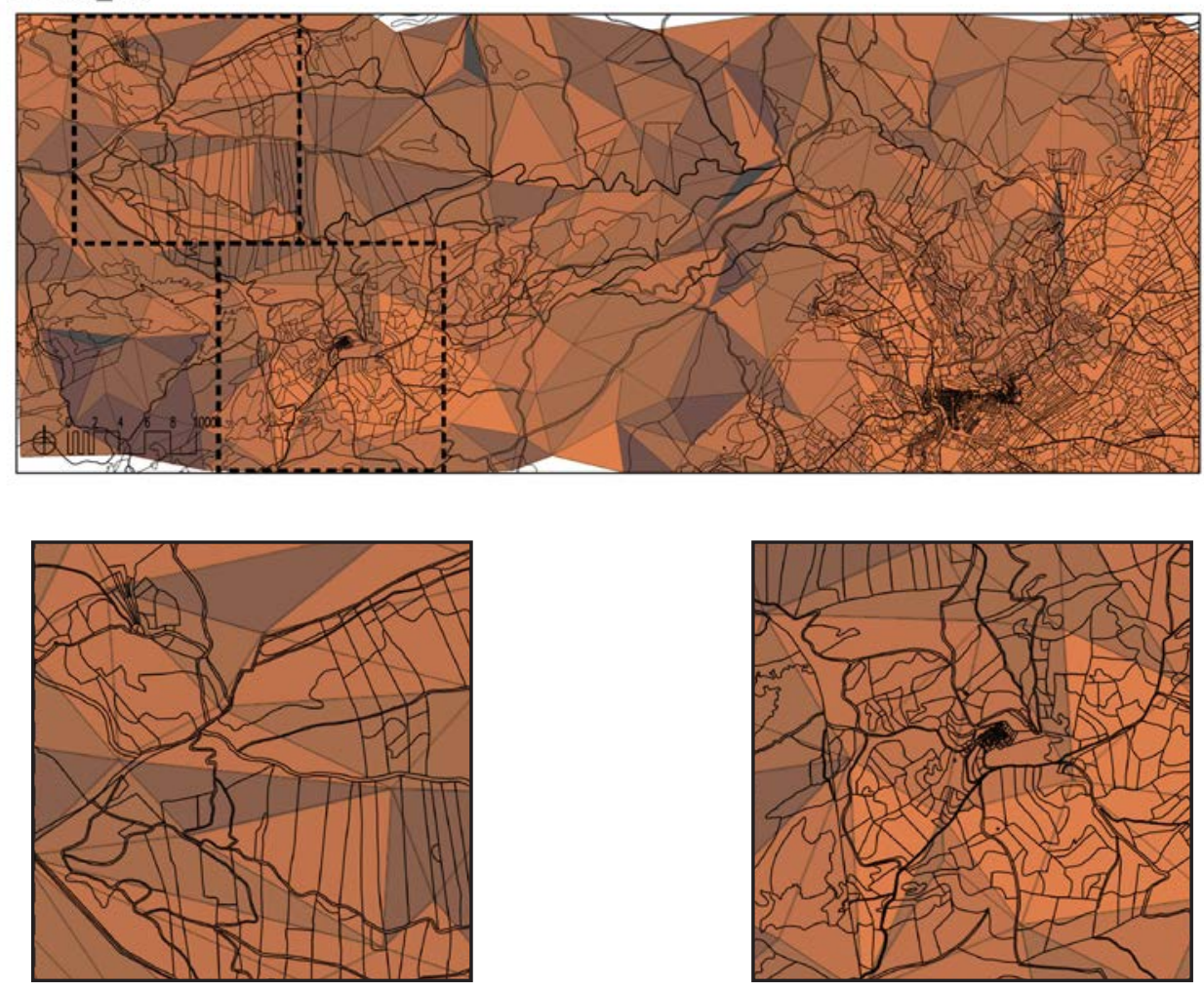

\section{Zona 2_Barcella}
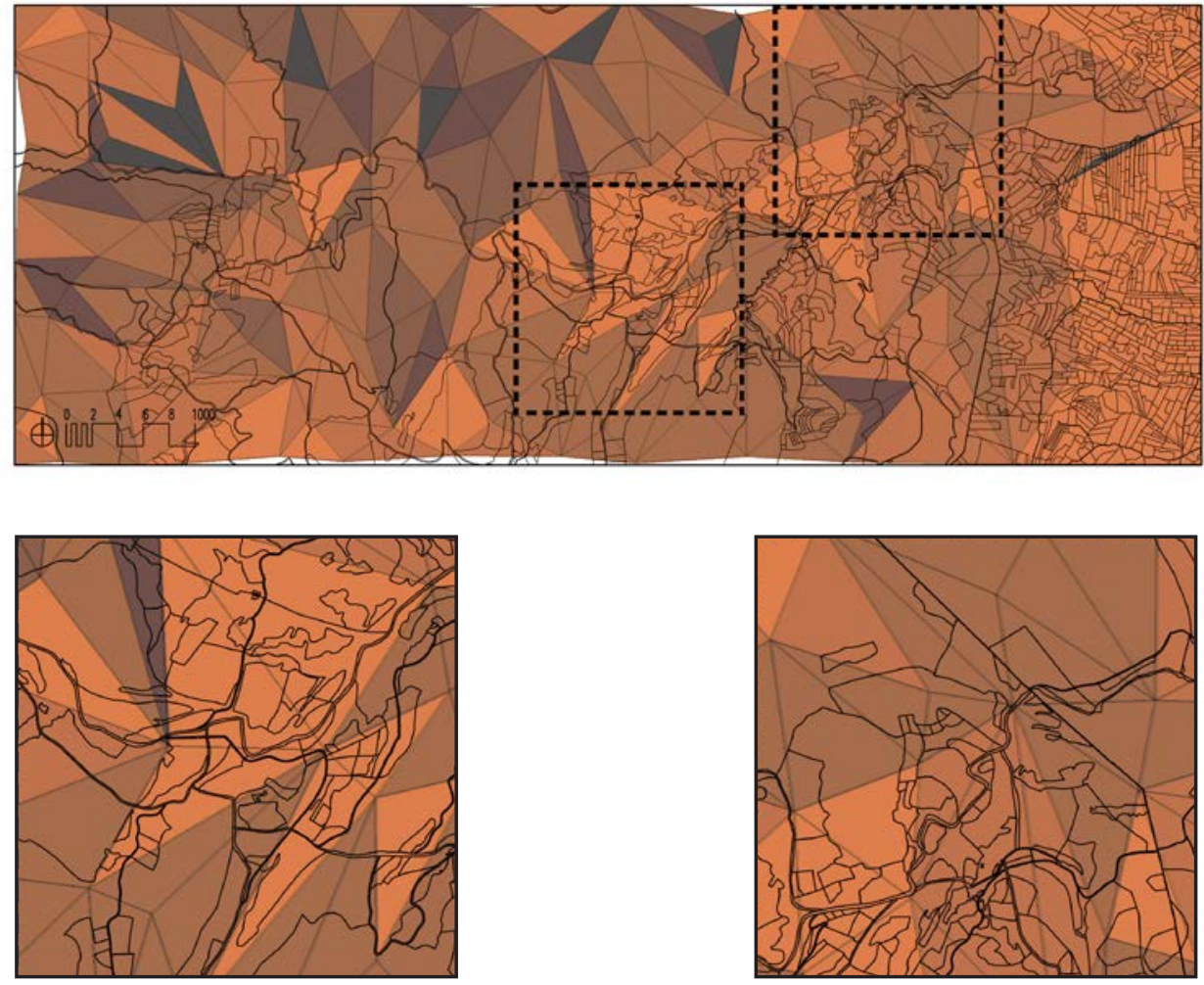
Simplificación por inclinaciones + Parcelario - Zonas 3 y $4-[e=1 / 75.000]$

Detalles ampliados $-[e=1 / 37.500]$

Zona 3_Molinar/Xert
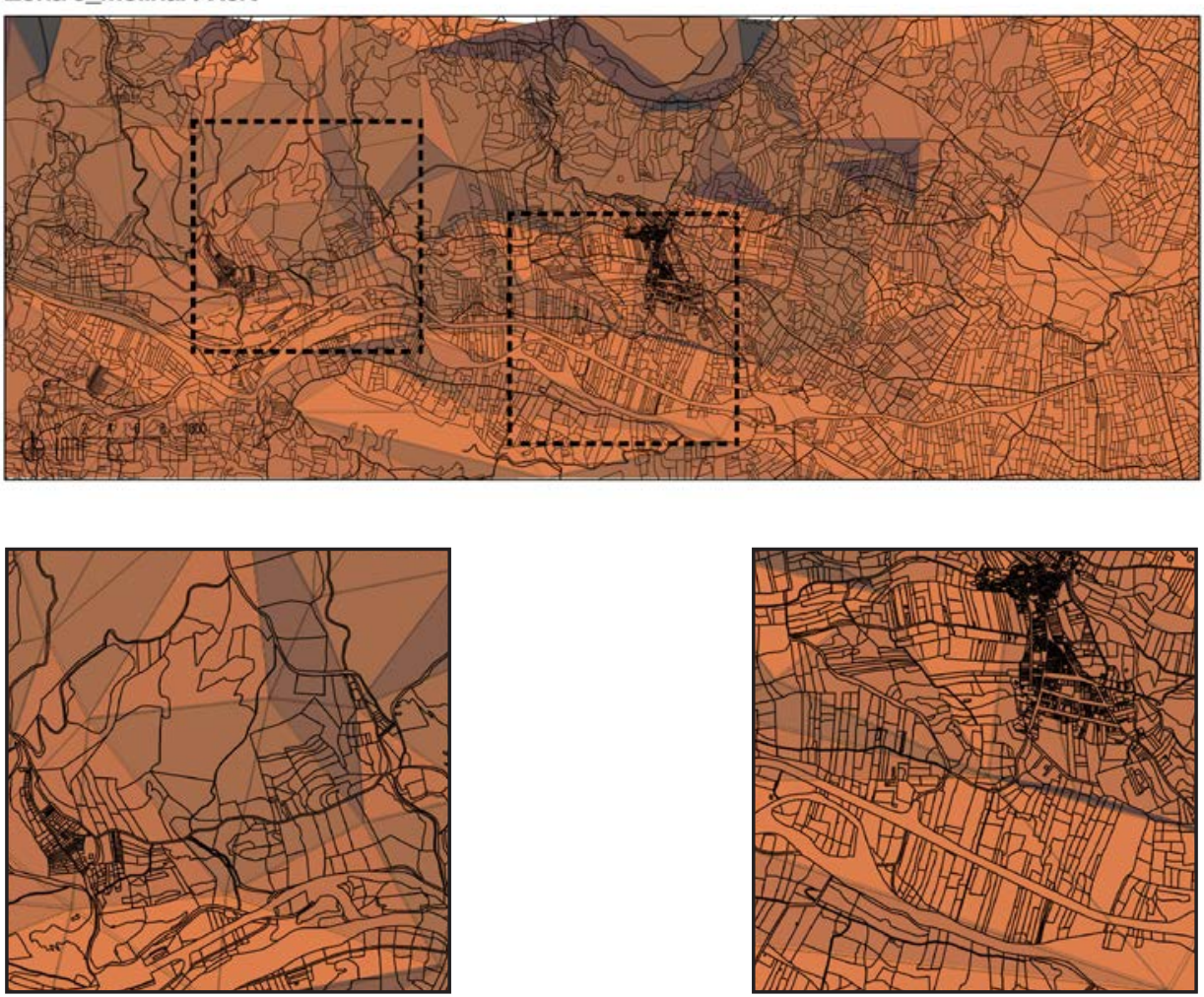

Zona 4_Mas del Coll / Rosell
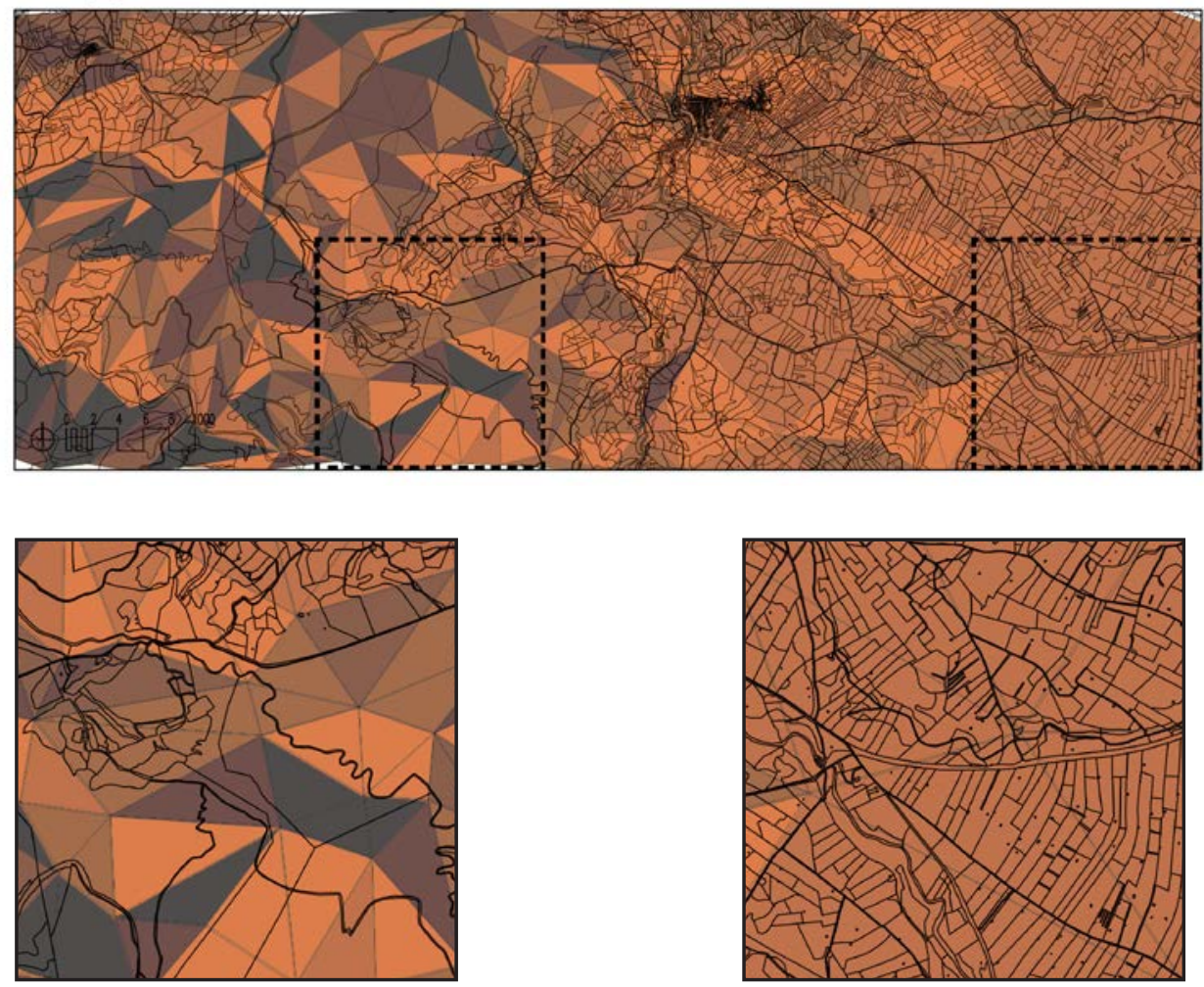
Simplificación por inclinaciones + Parcelario - Zonas 5 y $6-[e=1 / 75.000]$

Detalles ampliados $-[e=1 / 37.500]$

Zona 5 Canet
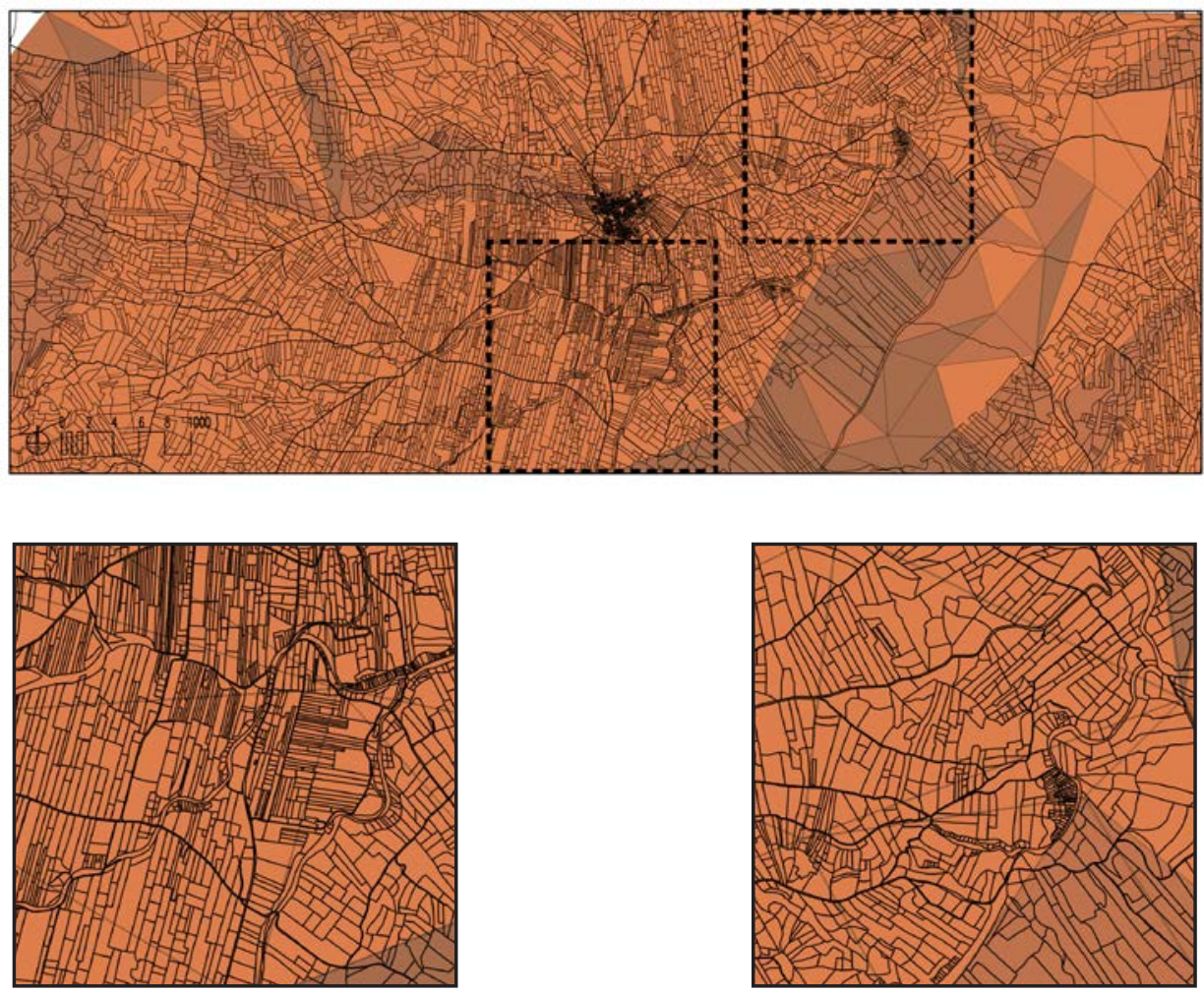

Zona 6_La Jana/Carrascal
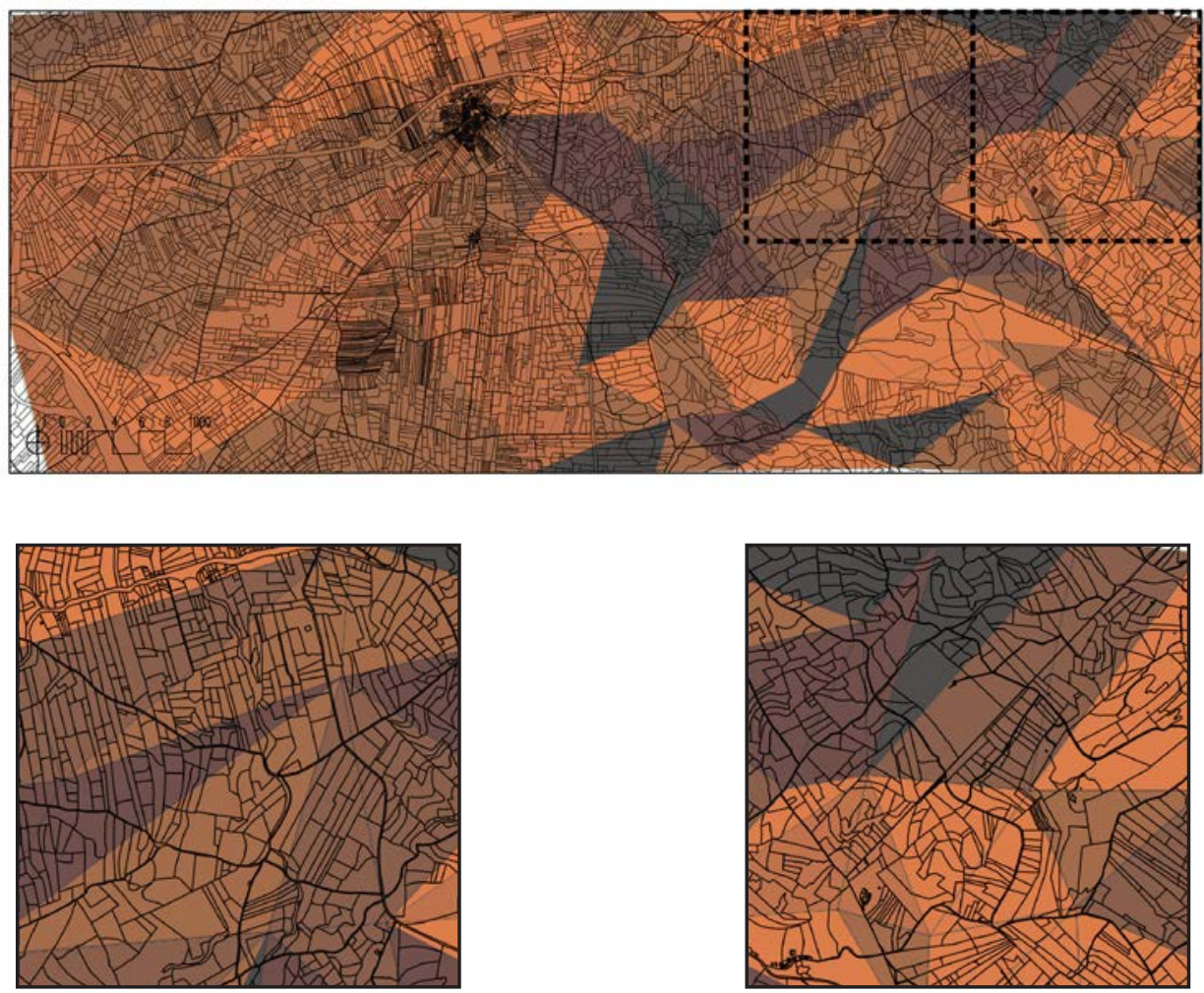
Simplificación por inclinaciones + Parcelario - Zonas 7 y $8-[e=1 / 75.000]$

Detalles ampliados $-[e=1 / 37.500]$

Zona 7_San Mateo
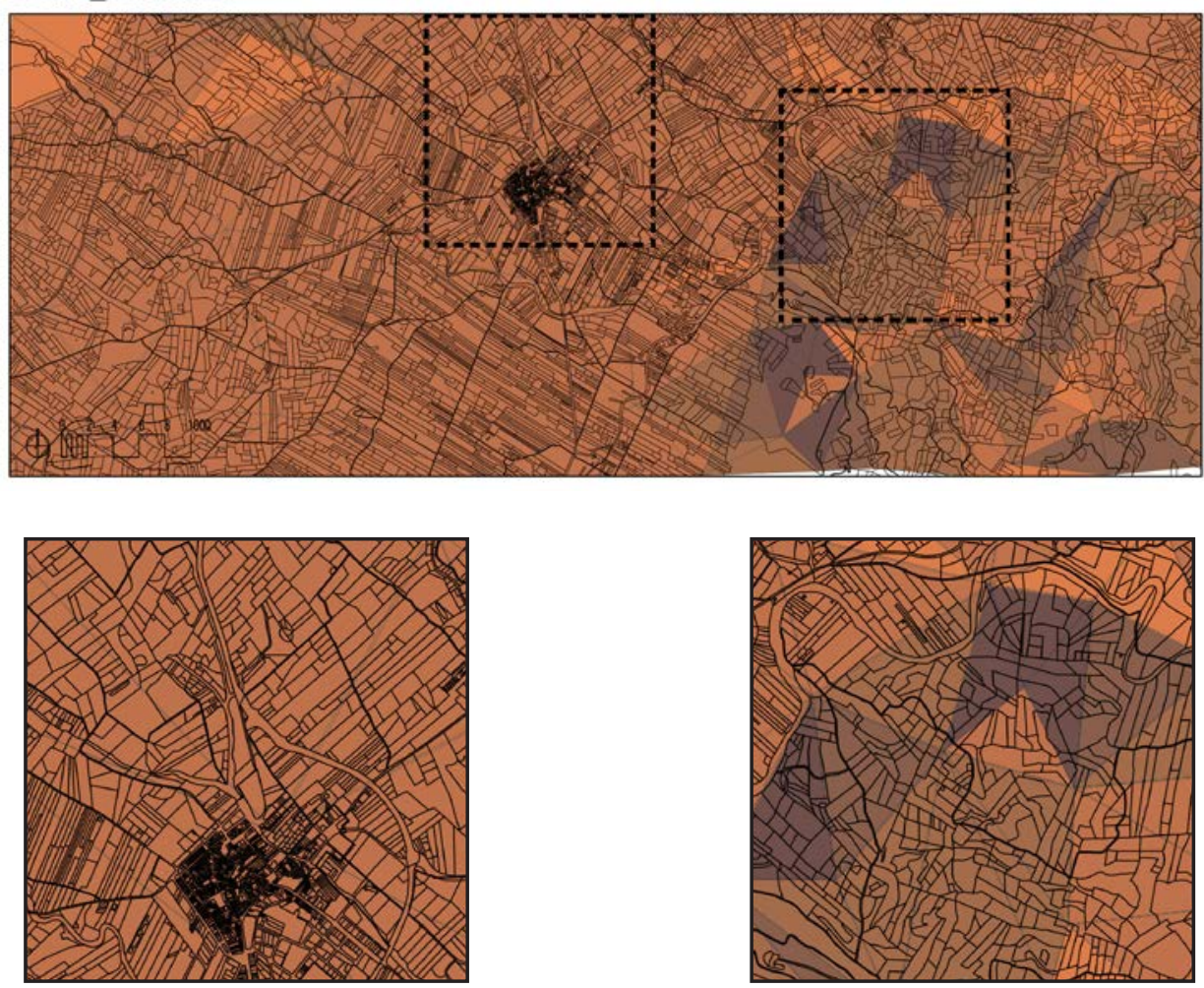

Zona 8_Traiguera
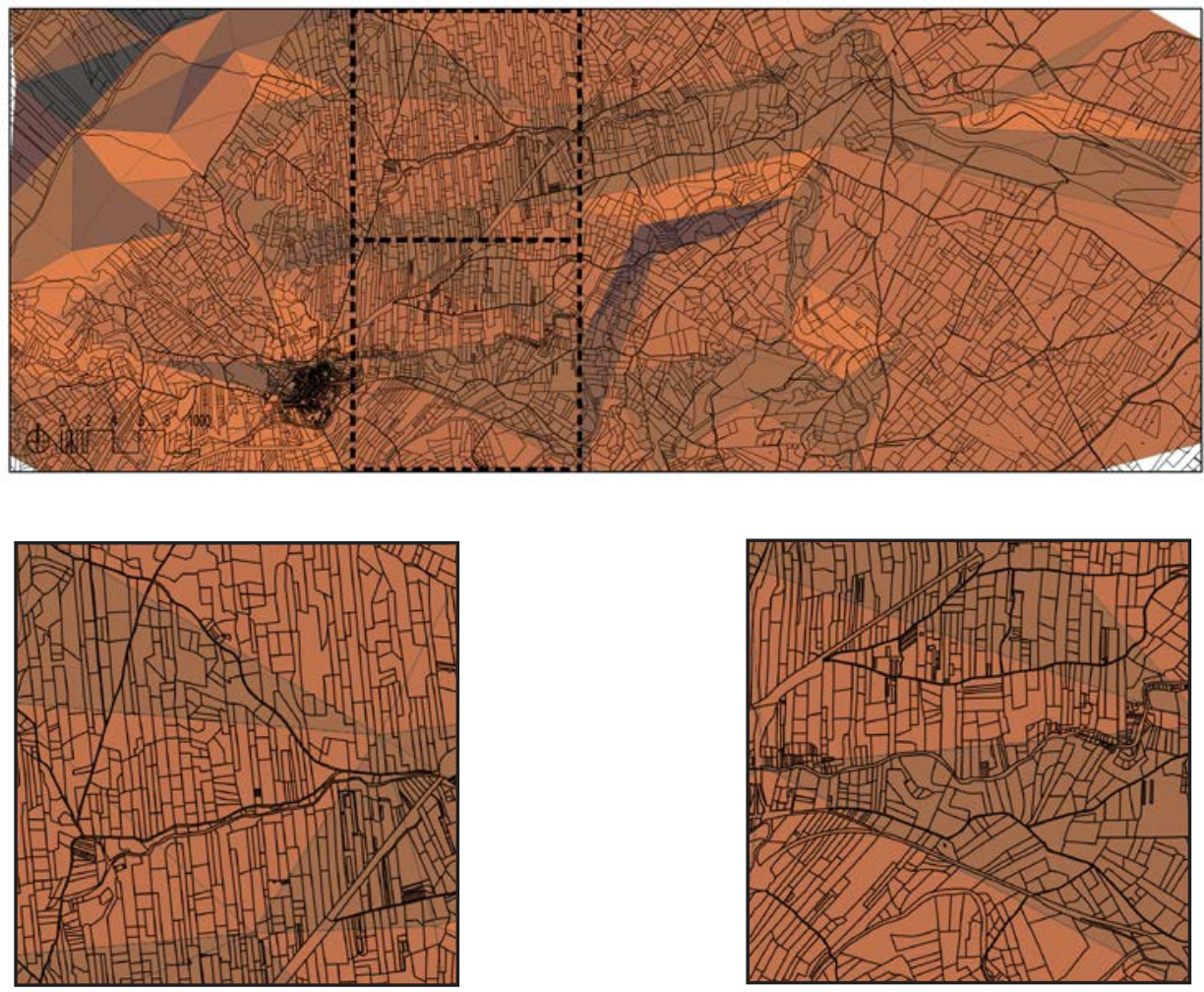
Simplificación por inclinaciones + Parcelario - Zonas 9 y $10-[e=1 / 75.000]$

Detalles ampliados $-[e=1 / 37.500]$

Zona 9_Mas Stellers
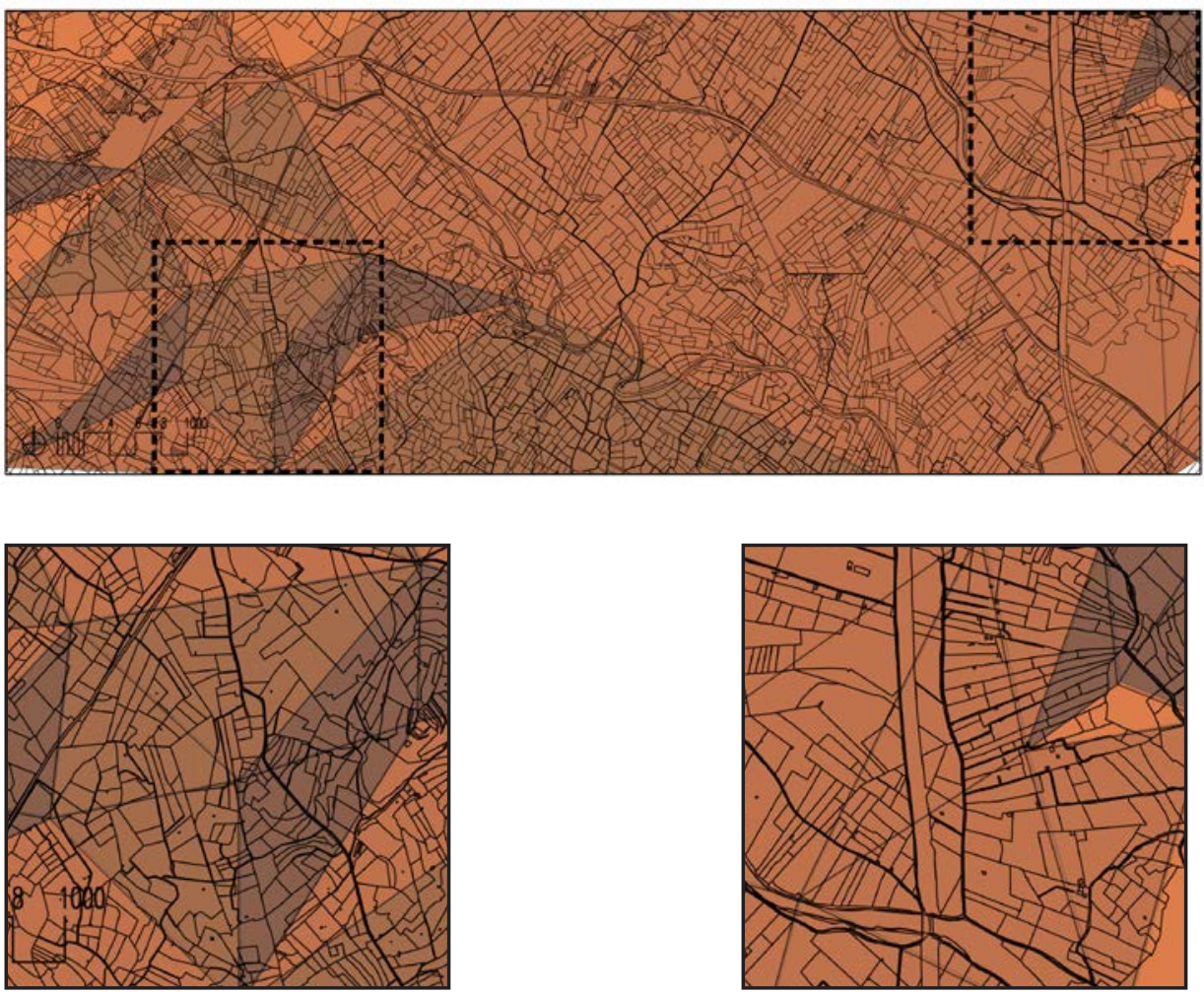

Zona 10_Cervera/Calig
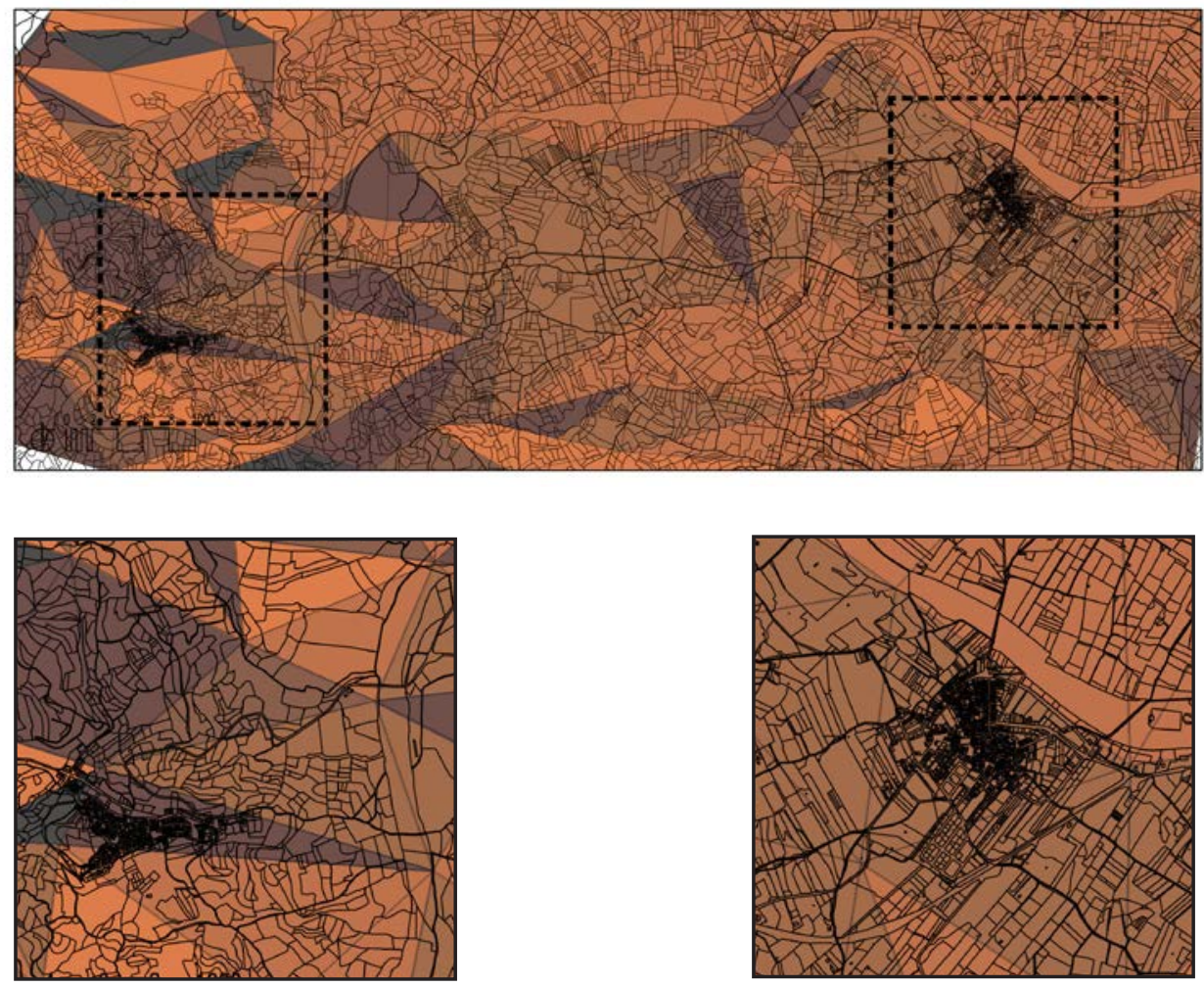
Simplificación por inclinaciones + Parcelario - Zonas 11 y 12 - $[\mathrm{e}=1 / 75.000]$

Detalles ampliados $-[e=1 / 37.500]$

Zona 11_San Joan del Pas
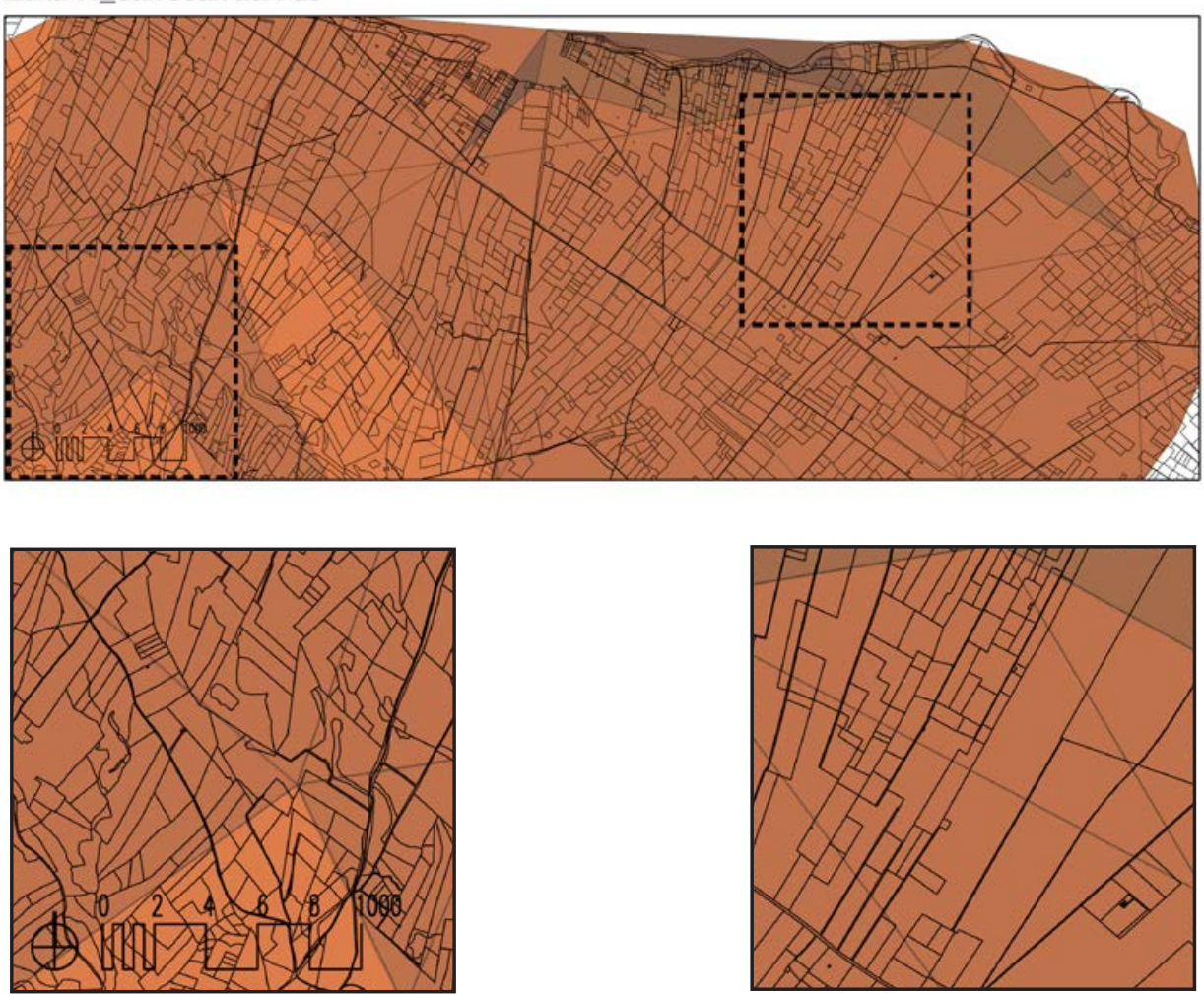

Zona 12_Atalaya San Pere
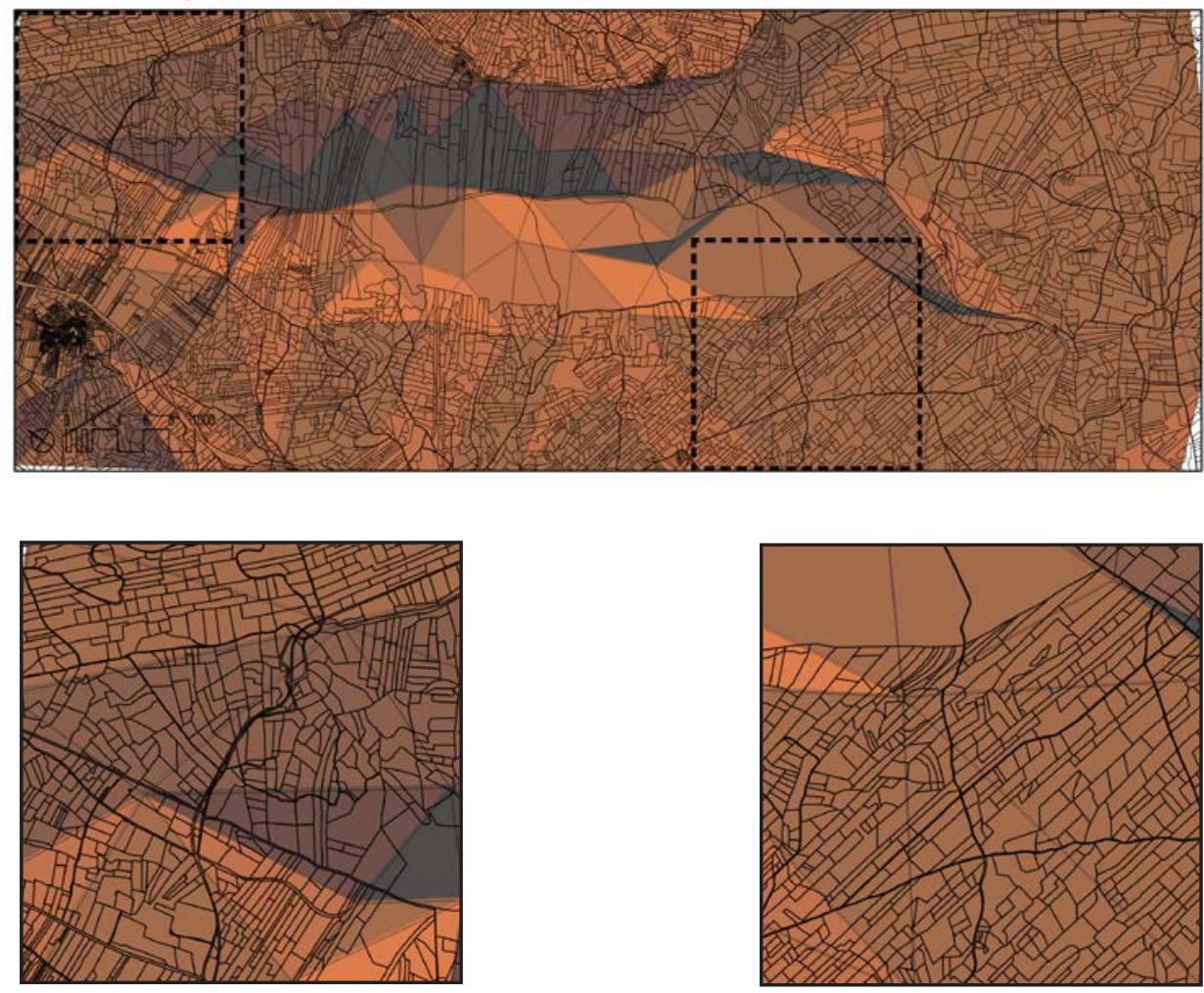
Mapa general (situación de las zonas de estudio) - $[\mathrm{e}=1 / 200.000]$

\section{Combinaciones: Simplificación por inclinaciones + Usos}

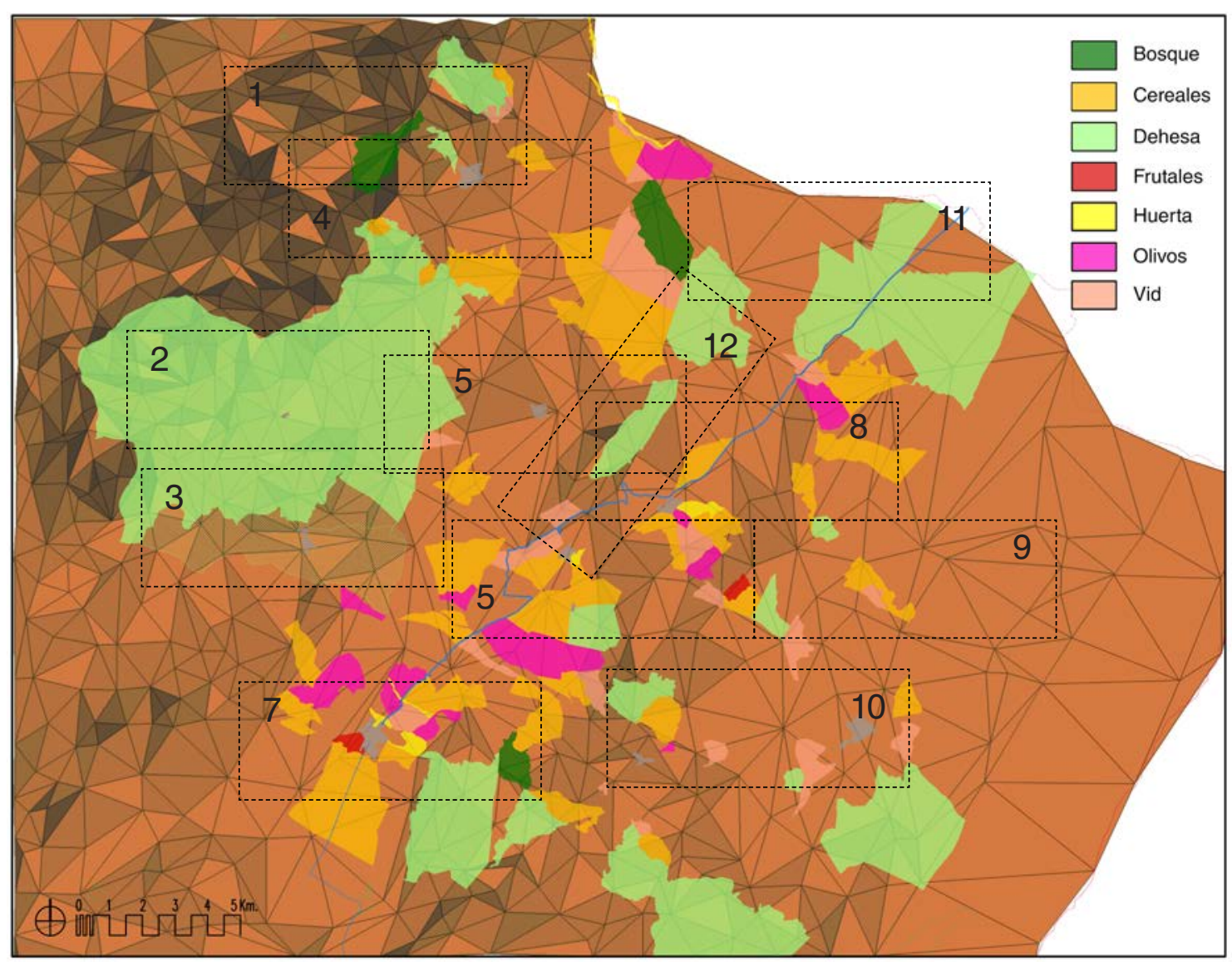

Fig. 5. 8. Plano de la Batllia a escala $1 / 200.000$ del de la simplificación del topográfico superpuesto al de los usos. Señalización 12 zonas de estudio.

La comparación la haremos en las doce zonas de estudio (en el caso de los muros en las 8 zonas de estudio) a la escala $1 / 75.000$ y posteriormente de cada una de estas zonas seleccionamos dos sectores a lo que nos aproximamos y los analizamos a escala $1 / 37.500$

Los usos se sitúan en los "vacíos" triangulares de la malla en función de la pendiente y de las condiciones de soleamiento. Tienen un mayor aprovechamiento agrícola los planos de menor pendiente, menor altura y mejor soleamiento, mientras que el uso ganadero se "reserva" para los de mayor pendiente, mayor altura y peor orientación 
Simplificación por inclinaciones + Usos simplificados - Zonas 1-4 - $[\mathrm{e}=1 / 75.000]$

Zona 1_Bel

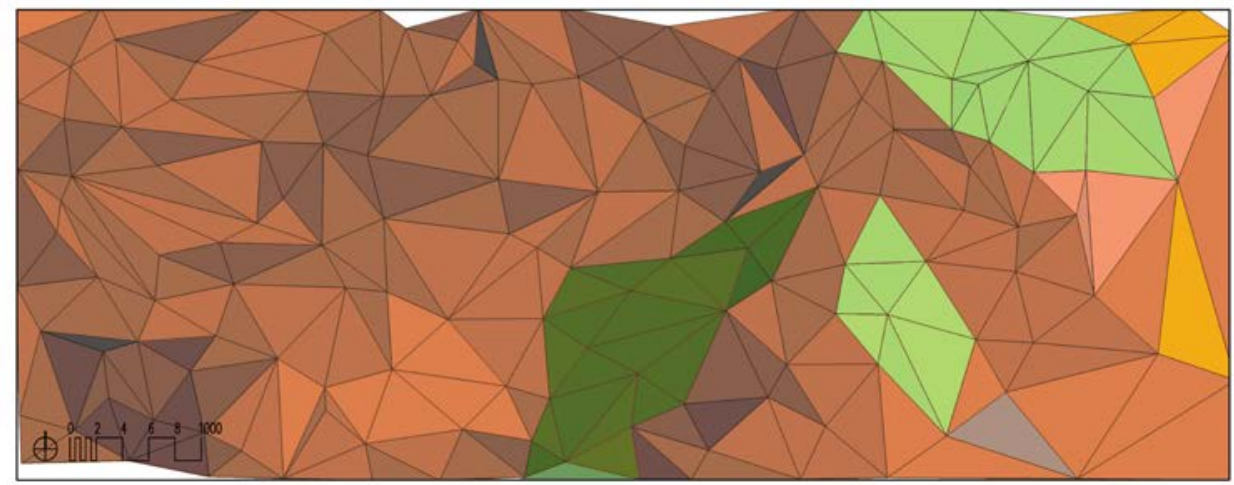

Zona 2_Barcella

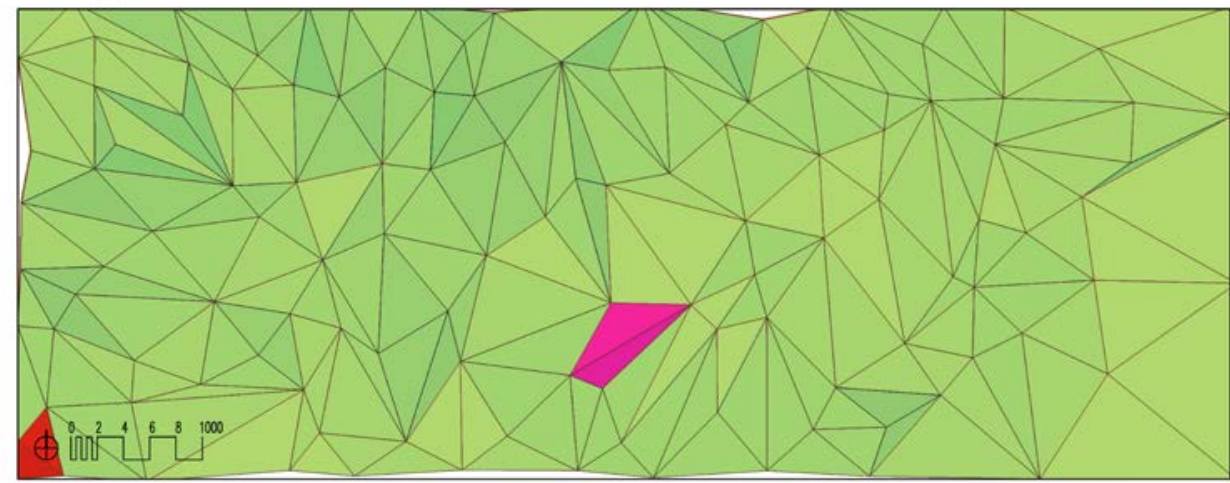

\section{Zona 3 Molinar / Xert}

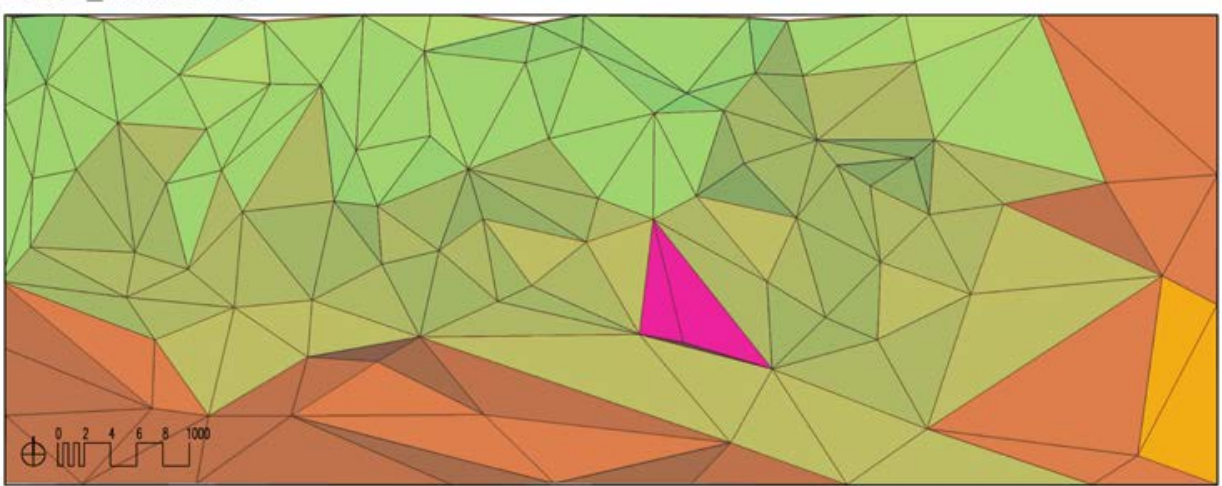

Zona 4 Mas del Coll / Rosell

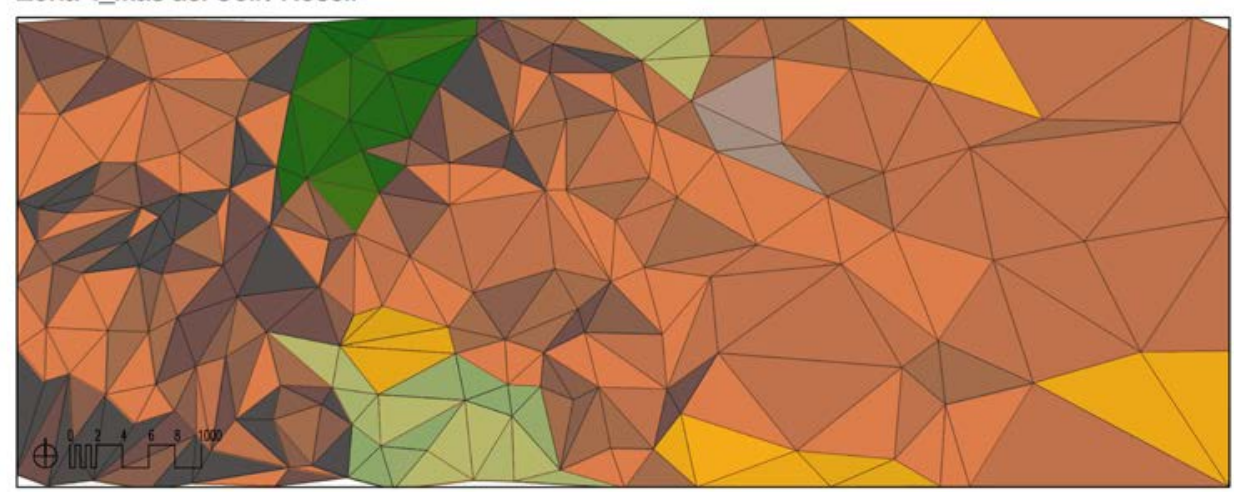


Simplificación por inclinaciones + Usos simplificados - Zonas 5-8 $-[e=1 / 75.000]$

Zona 5_Canet

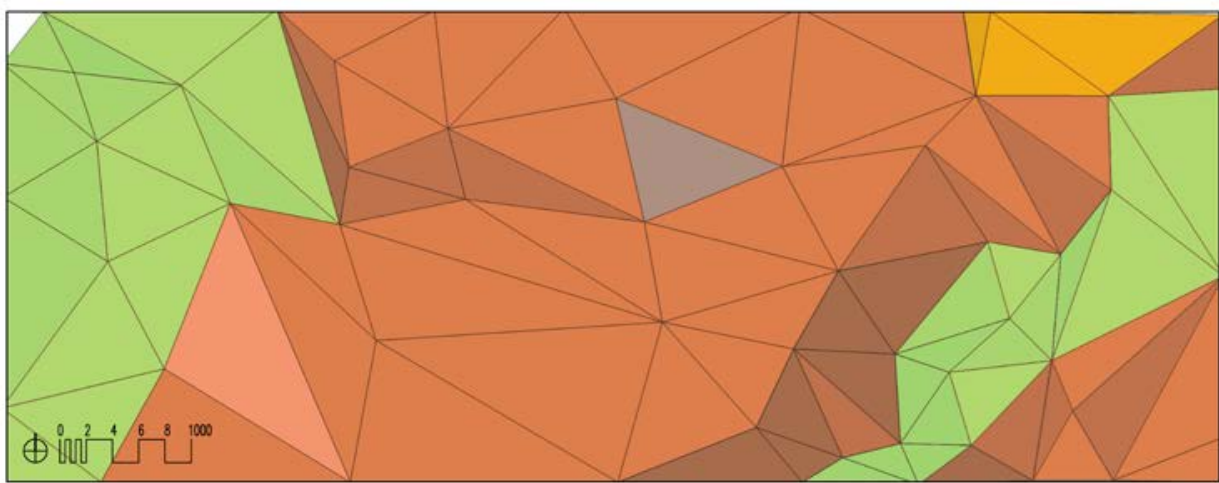

\section{Zona 6 La Jana/Carrascal}

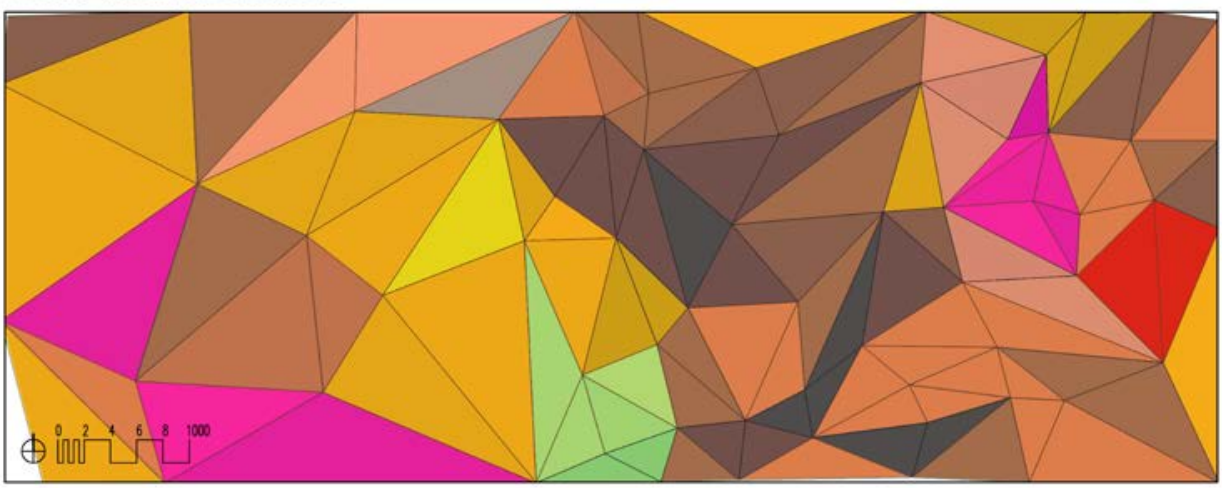

\section{Zona 7 San Mateo}

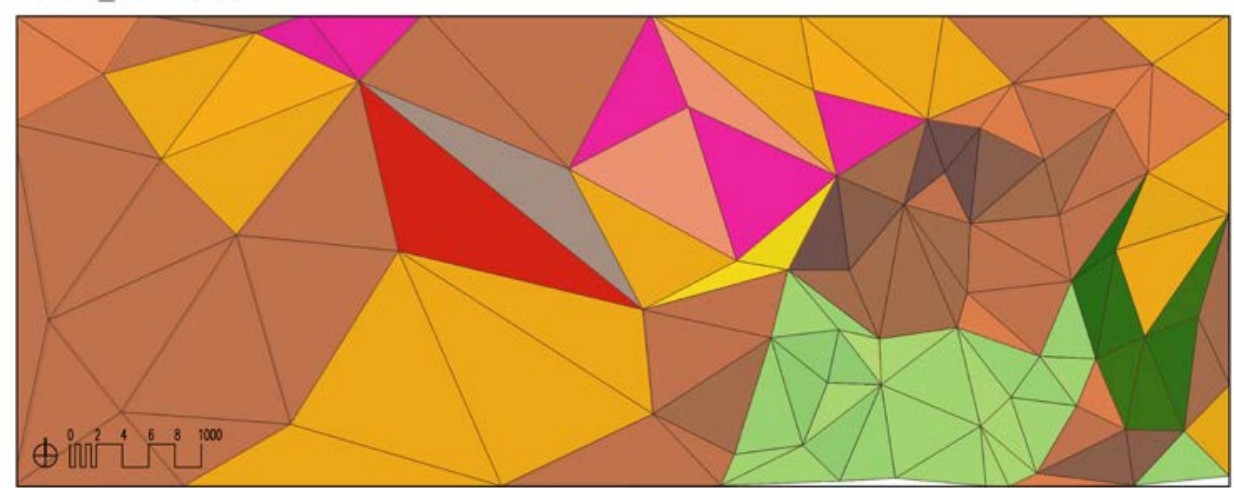

\section{Zona 8_Traiguera}

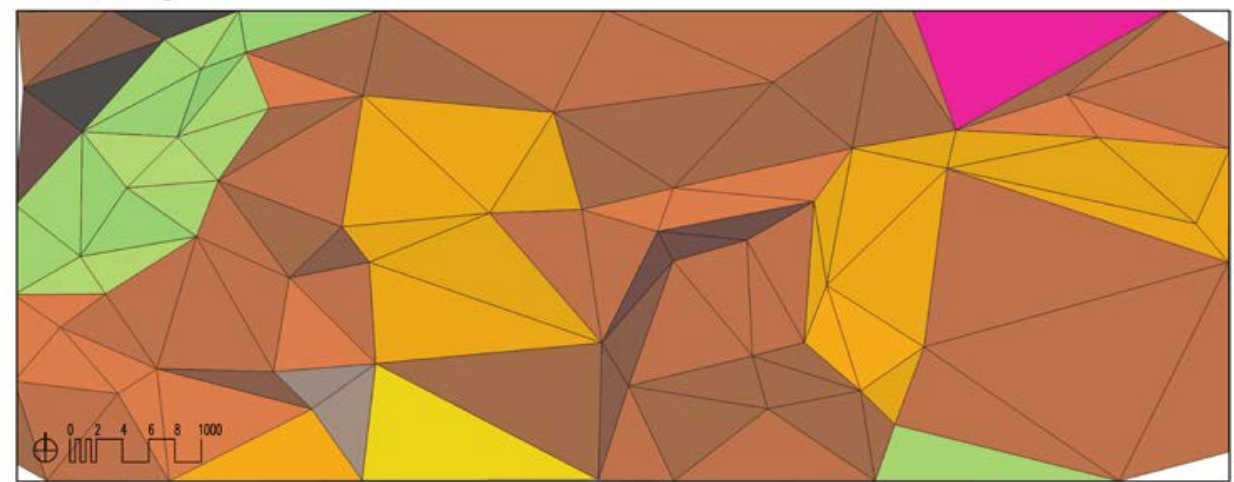


Simplificación por inclinaciones + Usos simplificados - Zonas 9-12 - $[\mathrm{e}=1 / 75.000]$

\section{Zona 9_Mas Stellers}

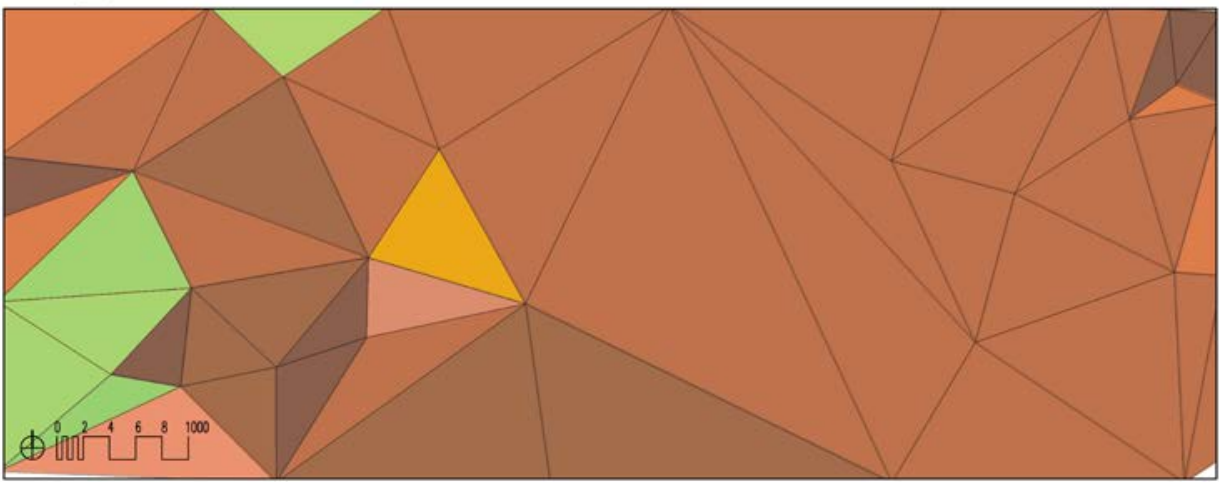

\section{Zona 10_Cervera/Calig}

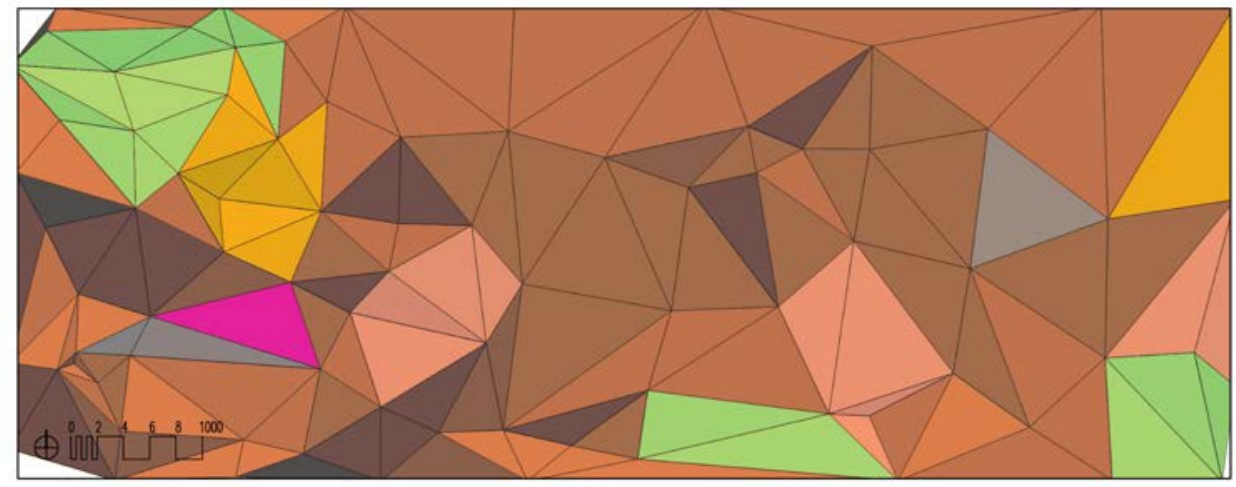

\section{Zona 11_San Joan del Pas}

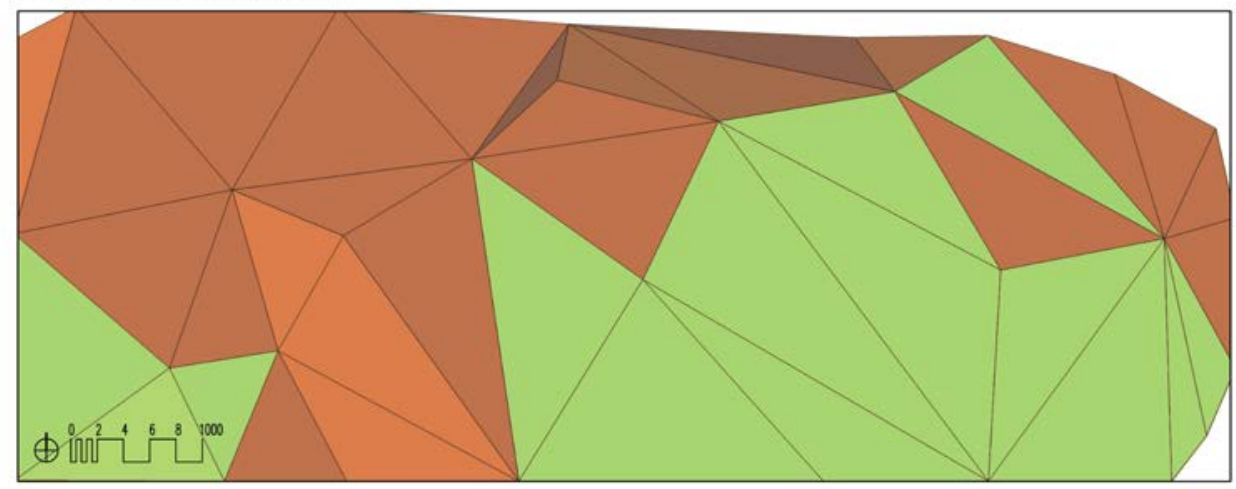

Zona 12_Atalaya San Pere

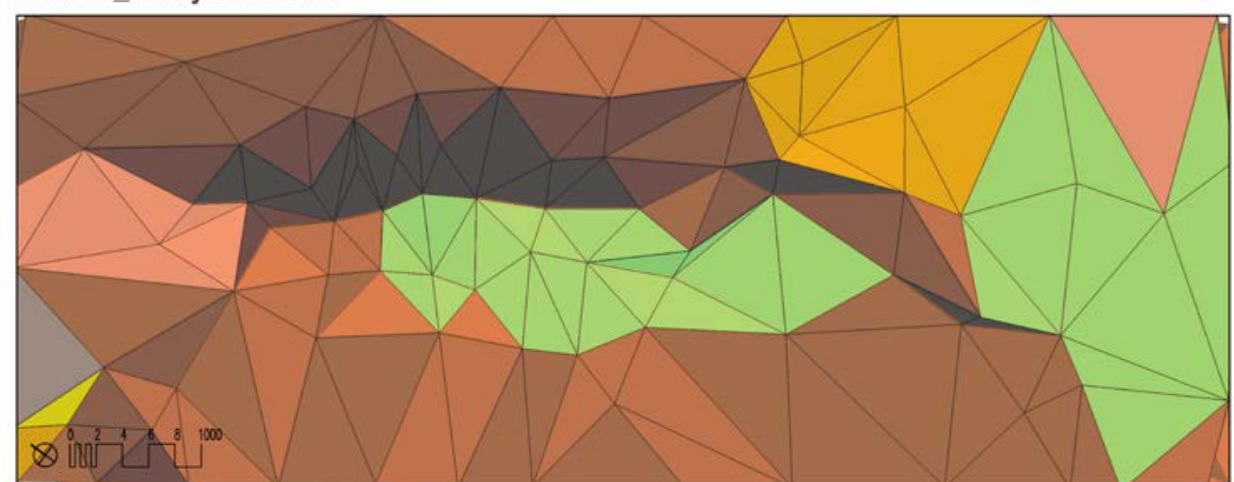



De la comparación podemos obtener las siguientes conclusiones:

- Existe una mayor diversidad de arquitecturas y redes de muros, infraestructuras, parcelación, cultivos y arquitecturas en las zonas del soporte aptas para el uso agrícola.

- Las redes de infraestructuras se sitúan sobre la malla del cañamazo, sobre la malla que establece las conexiones del espacio topológico. No podría ser menos, al fin y al cabo las infraestructuras son las que nos establecen las conexiones del territorio. Las redes principales se corresponden con las líneas de la estructura del cañamazo de máxima importancia: la limahoya, la limatesa y la línea de cambio de máxima pendiente.

- Las redes de muros se sitúan en los "vacíos" triangulares de la malla. Si tienen mucha pendiente se disponen concéntricamente respecto al vértice que conforman las aristas de la malla y perpendiculares a la máxima pendiente; si tiene poca pendiente se disponen paralelos o perpendiculares a uno de los lados de los planos triangulares del cañamazo de forma que sean perpendiculares a la máxima pendiente de ese plano.

- Las infraestructuras de segundo orden (menor importancia) se trazan perpendiculares o paralelas al lado del triángulo de la malla del cañamazo siguiendo la línea de máxima pendiente.

- Las parcelaciones se sitúan en los "vacíos" triangulares de la malla. Si tienen mucha pendiente se disponen concéntricamente respecto al vértice que conforman las aristas de la malla y perpendiculares a la máxima pendiente; si tiene poca pendiente se disponen paralelos o perpendiculares a uno de los lados de los planos triangulares del cañamazo de forma que sean perpendiculares a la máxima pendiente de ese plano.

- Los usos se sitúan en los "vacíos" triangulares de la malla en función de la pendiente y de las condiciones de soleamiento. Tienen un mayor aprovechamiento agrícola los planos de menor pendiente, menor altura y mejor soleamiento, mientras que el uso ganadero se "reserva" para los de mayor pendiente, mayor altura y peor orientación.

- Las arquitecturas se sitúan siguiendo las redes de infraestructuras, de forma que las de mayor relevancia se sitúan en las redes de mayor relevancia y por tanto en las aristas del cañamazo.

- Por tanto podemos observar una relación directa entre la topología del territorio-el cañamazoy las actuaciones antropomorfas. El tejido que el hombre va tejiendo sobre el cañamazo lógicamente tiene que seguir las pautas que este le marca, y no solo eso, sino como veremos este gran collage que es el territorio, la coherencia y unidad se la da en gran parte la estructura que subyace del cañamazo.

Del análisis de esta superposición y por tanto de los "sitios", vemos que en principio la especie humana al igual que otras especies ocupa su ecosistema siguiendo los principios que señala Margalef de las trayectorias verticales propiciadas por la gravedad y la búsqueda de la luz -la energía solar-.

Tanto las redes como las arquitecturas -como desarrollaremos en el siguiente capítulo- siguen estos dos principios de forma similar a las construcciones de otras especies animales. El modelado, cultivo y parcelación se hace en los planos triangulares de un mejor soleamiento y su conformación sigue la disposición marcada por la circulación del agua por gravedad.

Las arquitecturas como esferas en un principio no tienen ataduras respecto al suelo ni respecto a las esferas vecinas, son volúmenes que "flotan" sobre el soporte. Su imagen la podemos asimilar al concepto de Arca, como arquitectura autónoma absoluta y libre del contexto. 


\section{3. Las relaciones sintagmáticas complejas: El lugar}

En algunas ocasiones determinados sitios con el paso del tiempo se convierten en lugares, se "funden" al emplazamiento y las arquitecturas que se construyen en él, echan raíces y constituyen algo nuevo, algo más que una simple adición de un enclave y una arquitectura. Esta unión engendra una realidad diferente y adquiere una nueva identidad que perdura con el tiempo.

Las arquitecturas son la materialización de las instituciones del hombre del ser-con que habla Heidegger, pues bien, en los enclaves en los que se construyen las arquitecturas, el soporte se ha de modelar, para que las arquitecturas se "reúnan" también con los enclaves -con la tierra y bajo el cielo que dice Heidegger-. Cuando ello ocurre "surge" el lugar.

Pongamos un ejemplo: un claro en el bosque. Es una "arquitectura" en cuanto que es una "construcción" estereotómica que reúne a los hombres en el hueco que se vacía; a la vez es un lugar en cuanto que reúne a los hombres y al vacío con el enclave. Los lugares necesitan un centro y un límite, son experimentados como interiores en relación con el exterior que les rodea.

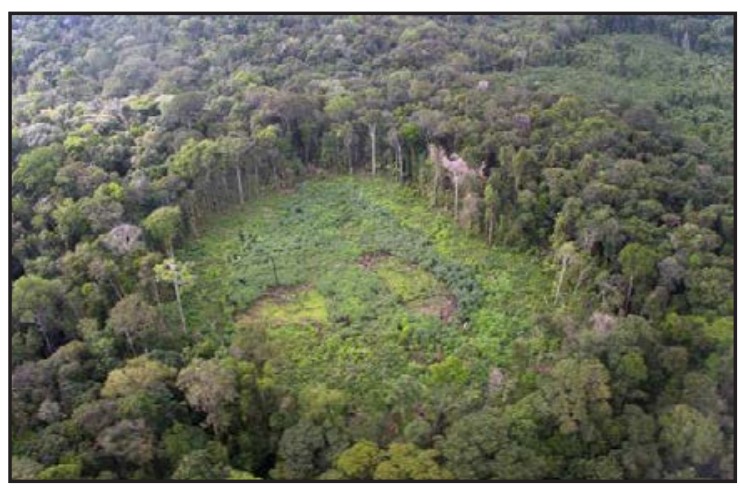

Fig. 5. 9. Vista aérea de un lugar: un claro en el bosque en la selva.

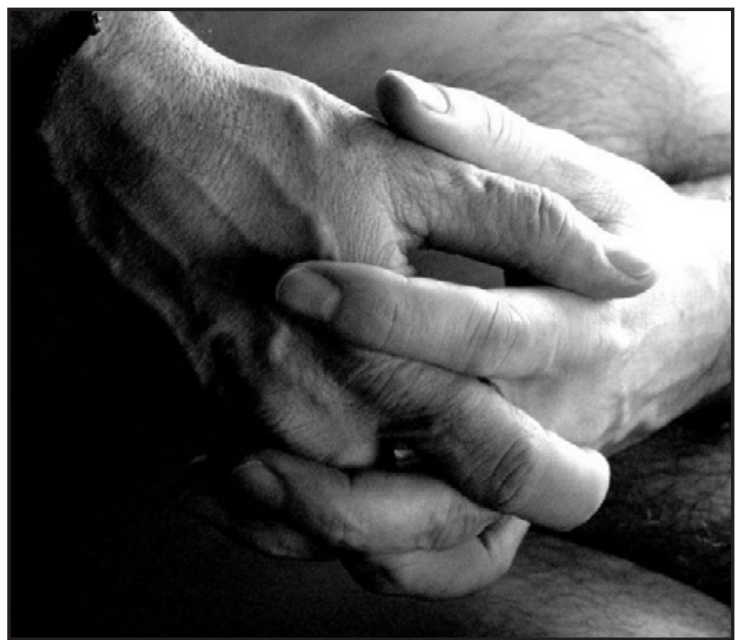

Fig. 5. 11. Dos manos entrelazadas como representación del lugar.

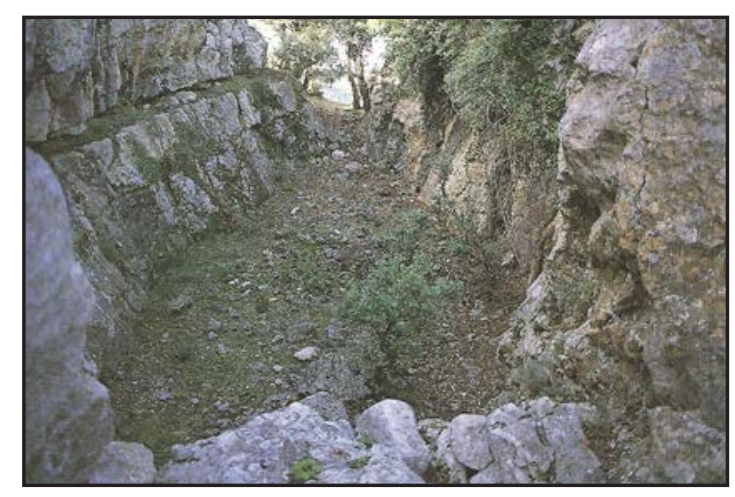

Fig. 5. 10. Vista de un lugar: la cova del cagots (leprosos) en Morella.

Lo que nosotros denominamos lugar, es lo que otros autores denominan de la siguiente forma: Aldo Rossi, lo denomina "locus" y lo define como: "relación singular y sin embargo universal que existe entre cierta situación local y las construcciones que están en aquel lugar" Samoná, lo denomina "Presencia construida" y lo define como: "Algo que forma parte del espacio en el que el hombre está inmerso, cuya configuración formal es percibible como una unidad de relaciones entre las partes que la componen y lo vinculan con el espacio de alrededor. Ese espacio tiene una estratificación histórica."

Y por último Rogers, lo denomina "Preexistencias ambientales", y lo define como: "El ambiente es el lugar donde confluyen esas preexistencias, las cuales no son simplemente de carácter natural-paisajístico, sino cultural e históricos".

En la lengua castellana fundir significa unirse y proviene del latín fundere; fundo es el conjunto formado por el suelo de un terreno con todo lo que contiene y cuanto produce natural o artificialmente y proviene del latín fundum; fundar significa empezar a edificar una ciudad, establecimiento, etc y proviene del latín fundare y por último fundamento es el fondo o trama de los tejidos, en el caso de los tapices es el cañamazo. 
Así pues si las arquitecturas y redes las hemos considerado como formas materiales estereotómicas "ensambladas", también podemos considerarlos "ensamblados" con el territorio y ello lo hacen fundiéndose con él. No simplemente se apoyan. Cuando esto ocurre se generan los lugares sobre un fondo o trama (fundamento) que permite que ello se produzca. Las arquitecturas se funden con el soporte ayudándose de las redes que hacen de hilvanes que lo "cosen" al mismo.

Las arquitecturas se funden con el territorio por medio del lugar al construir o cultivarlo. Habitar supone convertir en un lugar el sitio en que se está; al habitar construimos el lugar, lo construimos en la mayoría de los casos físicamente, pero lo construimos, siempre y fundamentalmente, en la medida en que lo convertimos en lugar. El suelo sobre el que se asientan las construcciones es su primer material, sin él las arquitecturas no existen, la tienda de un nómada no se convierte en arquitectura hasta que no establece contacto con un determinado suelo, que inmediatamente cambia su condición para constituir un lugar.

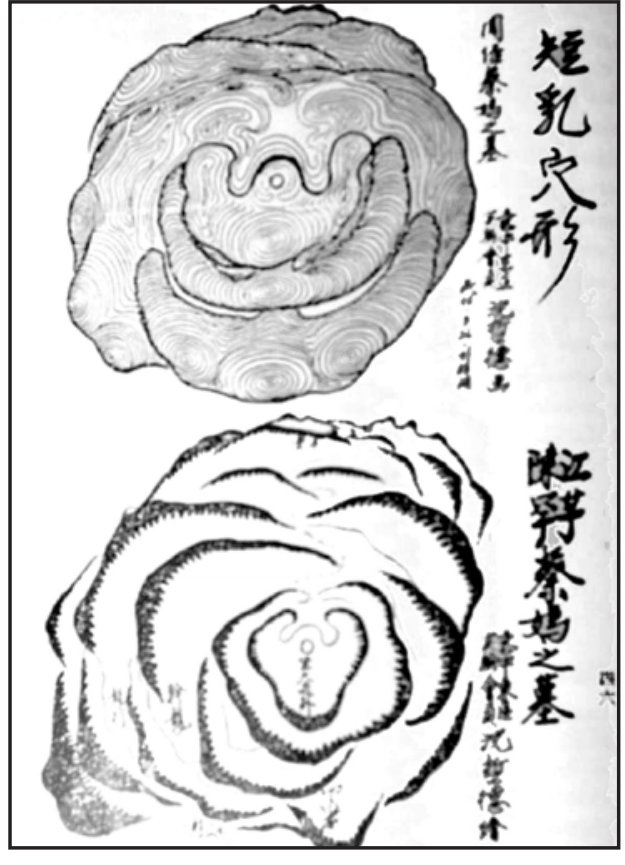

Fig. 5. 12. Puntos Feng shui.

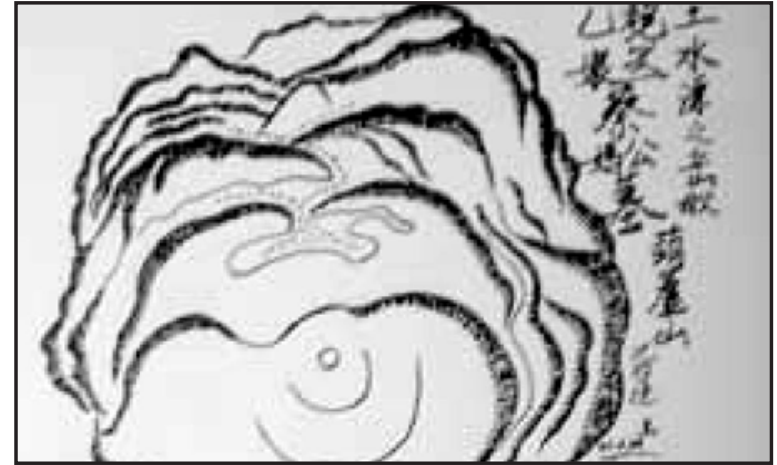

Fig. 5. 13. Representación de la relación entre la caverna, el sexo femenino y el punto Xue del Feng shui.

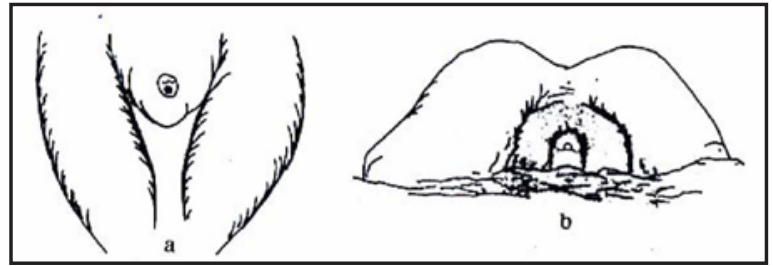

Fig. 5. 14. Diagramas del Leishu.

Ocupar un lugar significa tomar posesión de él, los ritos fundacionales explican este acto al marcar un límite que es un claro gesto de posesión. La colonización, como la de Jaume I, se sustancia en la posesión de la tierra, en su transformación, en su dominio.
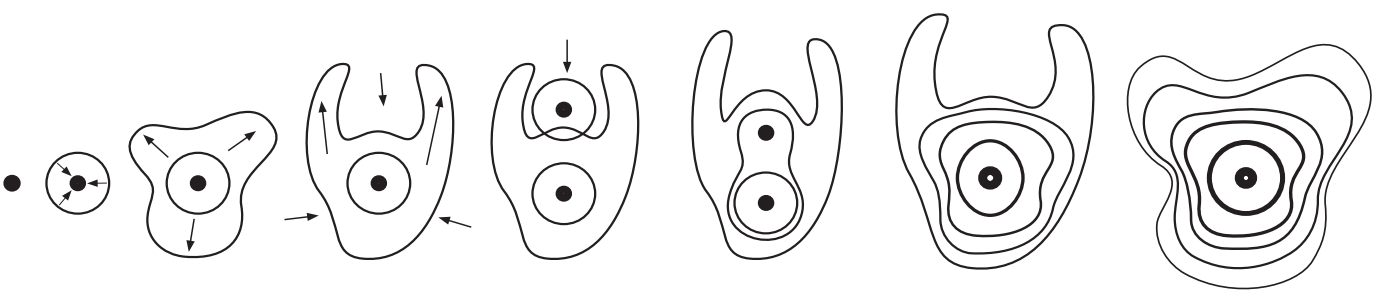

Fig. 5. 15. Esquema del paso de la arquitectura al lugar.

¿Por qué se funden los sitios hasta convertirse en lugares? Porque determinadas sitios quedan surcados por una red de relaciones que lo estructuran y conforman:

"El concepto de lugar queda identificado con ese conjunto de relaciones, es decir, con la estructura arquitectónica presente en un espacio determinado. En la medida en que estas relaciones son reconocibles y actúan dialécticamente con las construcciones presentes y futuras, la consideración del espacio como una realidad neutra y absoluta pierde todo sentido". ${ }^{121}$

121 LUQUE VALDIVIA, J. “La ciudad de la arquitectura. Una relectura de Aldo Rossi” pág. 271 
Las arquitecturas son esferas y el hombre en su afán de crear endosferas cada vez mayores que le permitan tener un mayor aporte de energía para el mantenimiento y evolución de la arquitectura. Las arquitecturas actúan como fuerzas centrípetas que atraen hacia sí lo que ocurre fuera de la membrana de la esfera. Como resultado las esferas crecen y se amplían cuando el entorno ha sido modelado, adaptado a las necesidades de la arquitectura, configurando una esfera mayor que llamaremos lugar. El radio de la esfera aumenta y la membrana se desplaza adaptándose a las condiciones topológicas, deja de ser una esfera regular, "redonda" y pasa a ser más una "placenta" que se acomoda a su entorno. El lugar es el compromiso territorial de una esfera.

El crecimiento de las esferas, es decir, la formación de lugares pude producirse bien por la ampliación del territorio que se encuentra alrededor de una esfera/arquitectura, bien por la adición de dos o más esferas/arquitecturas o porque una esfera fagocita a una contigua. En ocasiones determinadas esferas/arquitecturas no crecen y la esfera/lugar tiene la misma dimensión y se "limita" a adaptarse al territorio.

Para detectar los lugares partiremos de la relación de arquitecturas que tenemos, las situaremos gráficamente en los planos que hemos dibujado y las relacionaremos con el entorno próximo a ellas que ha sido construido -redes de muros, infraestructuras, parcelación y cultivos- delimitando así el límite del lugar. Para ello ampliamos la escala de estudio ya que el radio de la esfera aumenta.

Se trata de una delimitación compleja, sin contar con otros instrumentos como los arqueológicos, ya que los lugares como tales han evolucionado con el tiempo y por tanto sus límites actuales no tienen por qué coincidir con los de la Edad Media.

Podemos considerar que cada arquitectura define un lugar de mayor o menor importancia. Ello es así en la Edad Media por dos motivos, el primero que todas las arquitecturas responden a la materialización de las instituciones humanas, de reunión entre los hombres y segunda que esta materialización se hace de forma estereotómica y siguiendo la predisposición topológica del soporte. Con estas dos premisas toda arquitectura "genera" un lugar de mayor o menor relevancia, pero un lugar al fin y al cabo.

La construcción del lugar no es un proceso simple o unívoco, los elementos estrictamente constructivos se unen a otros culturales. Tan importante como la configuración material que al final tiene el enclave por la ubicación de una arquitectura concreta, lo es el modo en que esa nueva realidad es asumida por los hombres que en ella habitan.

El lugar supone por tanto no solo una configuración en un momento dado, sino una construcción prolongada en el tiempo con distintos ritmos, con mayor o menor intensidad, pero siempre vivo. Una vez constituido-construido- el lugar adquiere respecto a las futuras construcciones un papel eminentemente activo.

La clasificación de los lugares la haremos atendiendo al modo en el que se produce el crecimiento de las esferas de las arquitecturas que los originan. La esfera/lugar tendrá como centro la arquitectura, mientras que el límite de la esfera podemos considerarlo como una cáscara esférica que la envuelve con un limite interno claramente definido y uno exterior difuso. Así tendremos:

1. Esferas/lugares originados por la ampliación de la esfera/arquitectura:

- Las masías se sitúan preferentemente en las laderas, en las zonas de transición, por razones vinculadas a la defensa, control y dominio del territorio, así como para aprovechar al máximo los terrenos más fértiles. En las zonas de montaña el esfuerzo para ocupar un lugar es mucho mayor y casi siempre va ligado al uso ganadero de estos terrenos. Las zonas llanas estaban ocupadas por muchas menos masías, las existentes eran antiguas alquerías árabes, son emplazamientos más difíciles de defender y además la proximidad de núcleos habitados no los hacia imprescindibles, la explotación del suelo agrícola lo llevaban a cabo campesinos que residían en los núcleos urbanos. 
La lectura de los distintos planos que hemos dibujado nos revela la presencia de unos ejes que rigen la construcción del territorio en sus distintas escalas. Estas directrices no arbitrarias, justificadas por el modelado del relieve con la red de muros, el desagüe de las aguas de escorrentía y la correcta orientación heliotérmica, influyen también en la disposición y configuración de los lugares-masías.

En las laderas y en las zonas montañosas, las masías se colocan paralelas o perpendiculares a las curvas de nivel, según la orientación del relieve, haciendo coincidir una o dos de sus fachadas con los uros de los bancales. La orientación de las masías, casi siempre cerrados al norte y abiertos al sur, al este o al oeste, esta condicionada por la pendiente y la orientación de la topología, que en algunos casos obliga a exponer a las masías a los fríos vientos del norte.

Analizada la planta y la sección, vemos como las masías, se colocan dentro de la red de muros de los bancales que les rodean siguiendo las mismas pautas de adaptación al terreno natural de bancales, cuyos muros de contención se convierten en los muros de la masía. En sección la adaptación a la pendiente del relieve genera unos desniveles entre los distintos espacios (interiores y exteriores) de la masía, cuyas fachadas en muchos casos están totalmente enterradas.

En las zonas llanas, la menor influencia del relieve permite la orientación sur de las masías, que asumen formas más cuadriculadas, vinculadas a la geometría del núcleo cocina y a las direcciones de construcción del territorio. Se sitúan en puntos ligeramente elevados para dominar su entorno.

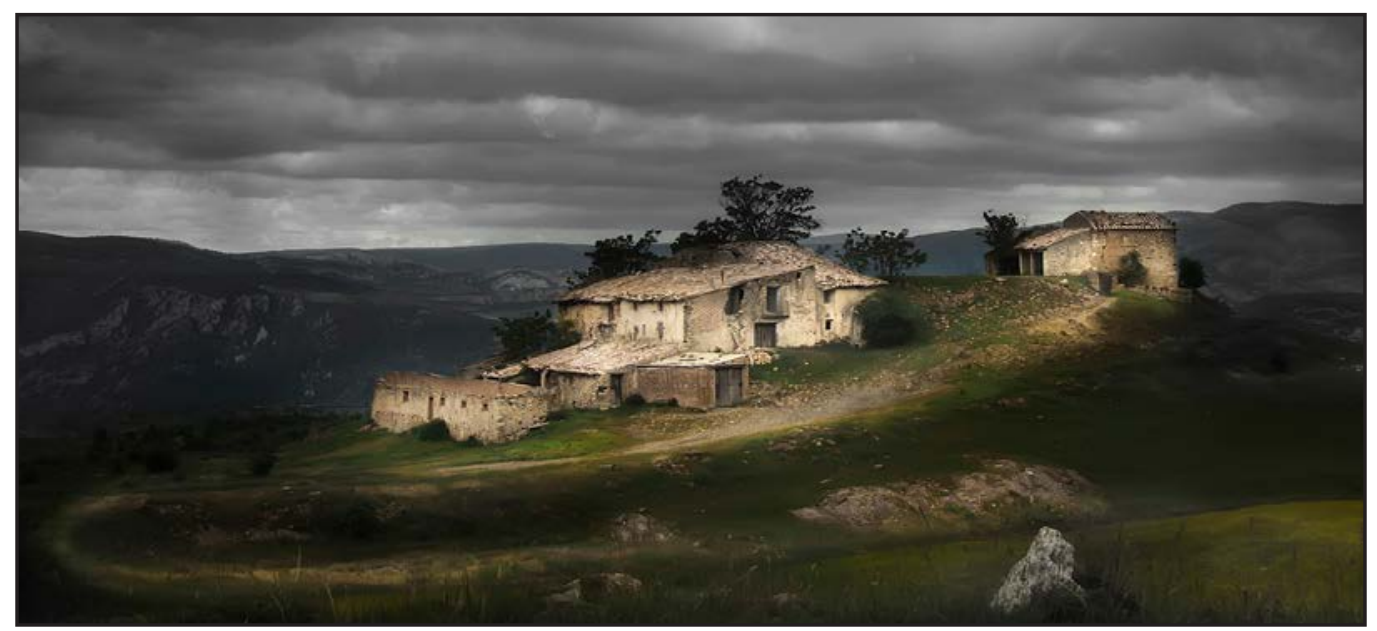

Fig. 5. 16. Vista de una masía del maestrazgo, ejemplo de lugar/masía.

El bloque central de la masía, ya hemos visto que es el espacio central de la cocina con el fuego, el porche de acceso y las habitaciones alrededor de la cocina. A partir del núcleo base, el crecimiento en horizontal de la masía asume formas de desarrollo distintas en función de la morfología del relieve y los elementos de la construcción del territorio.

Los elementos de servicio -corrales, pozos, aljibe, era, granero...- se disponen sobre el terreno asumiendo las directrices de la topología y del sistema de los muros de los bancales. Estos, son los que hacen de transición entre la geometría del núcleo base de la masía y la del lugar. La masía crece por adiciones sucesivas; la dependencia y fuerte relación que establece con el terreno sobre el que se sitúa contribuyen a crear una notable variedad formal, aunque podemos detectar unas tendencias generales de crecimiento y de relación entre el núcleo de la masía, la topología y las redes de muros, bancales y caminos. 


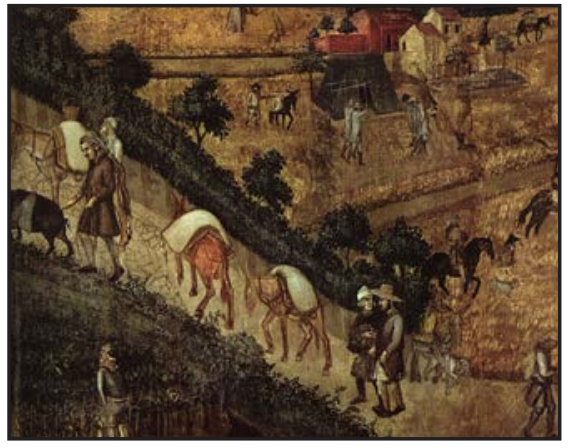

Fig. 5. 17. Detalle del cuadro de A. Lorenzetti "Los efectos del buen gobierno" Siena, entre 1338 y 1340. Ejemplo de lugar/masía.
Si el núcleo base se dispone paralelo a las curvas de nivel, la tendencia es a crecer según el eje paralelo a las mismas, mientras que una implantación perpendicular, en la mayoría de los casos da lugar a una planta en L, formada por el núcleo habitado y uno o más cuerpos perpendiculares a este, que generalmente se prolongan hacia el territorio apoyándose en los muros de los bancales y delimitando los espacios exteriores de uso de la masía y de sus accesos. Si el terreno es llano la edificación crece de forma radial alrededor del espacio cocina, mientras que el resto de dependencias se disponen alrededor de ella.

El crecimiento en altura se hace desde un primer momento en las masías adosadas a un muro, de forma que sobre las dependencias de planta baja se construye el espacio del granero con acceso independiente y directo a la era situada en el bancal superior al que se encuentra el núcleo inicial de la construcción

El centro del lugar es la arquitectura-masía. El primer límite es el que contiene las arquitecturas anejas a la propia masía: era, corrales, granero, balsa, pozo y acceso; este espacio más relacionado con el núcleo central se desarrolla normalmente a dos niveles, el inferior con el espacio y camino de acceso principal y el superior de "espaldas" al edificio donde se encuentra la era y las dependencias anejas.. El segundo límite lo forma el anillo de tierras de cultivo que se van paulatinamente desdibujando hasta llegar al suelo "virgen"; los campos de cultivo con bancales más o menos orgánicos en función de la topografía del terreno se ordenan a partir del núcleo masía y siguiendo la red de caminos de acceso.

El lugar es uniforme y homogéneo con carácter radial con centro en la masía-arquitectura si el relieve es llano y por el contrario en los terrenos con pendiente su disposición y crecimiento se hace hacia el suelo de menor pendiente, por lo que no es uniforme en todo el entorno de la masía.

- Los molinos se sitúan próximos a los cursos de agua, necesitan de su participación y de su energía potencial, pero además deben recuperar el agua para el uso de nuevos molinos o para el regadío aguas abajo.

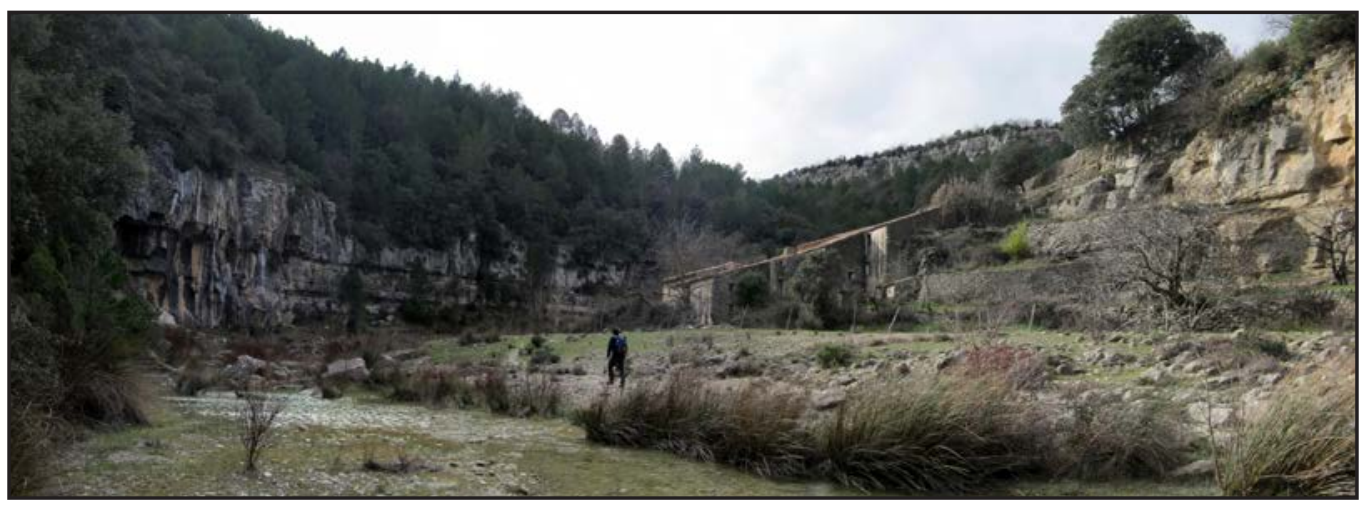

Fig. 5. 18. Foto del Molí Rico en el río Cervol. Ejemplo de lugar/molino.

$\mathrm{Al}$ igual que las masías se hacen uso de las redes de muros para adosarse a los mismos y construir los molinos, pero a diferencia de estos la diferencia de cota que se busca para ubicar los molinos es mayor que en la masías; en muchas ocasiones la altura desde la que el agua cae hasta la muela es superior a las dos plantas de altura por lo que el edificio se "apoya" en muros de mayor altura. Por este motivo el crecimiento natural de la edificación es en altura más que en planta. 


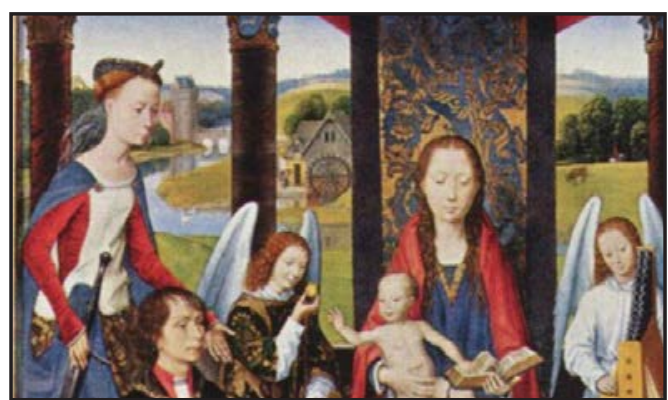

Fig. 5. 19. Detalle del tríptico de la Virgen y el Niño de Hans Memling (1465). Véase el lugar molino al fondo. Ejemplo de lugar/molino.
Esto hace que su disposición no sea uniforme. En la parte posterior se encuentran todas las construcciones necesarias para la captación y almacenamiento del agua-así como el cubo para la caída del agua- mientras que en la parte delantera se encuentran los acceso, dependencias anexas al propio molino y en ocasiones el suelo de huerta que se nutre con las aguas usadas una vez hecha la molienda.

El centro es el edificio del molino. El primer límite es el que contiene la toma de agua y desagües, la balsa, el cubo-si lo hay- situados en la parte posterior y los accesos en la parte delantera. Dado que no requiere mucho espacio los accesos el lugar se encuentra con respecto a este primer límite "descentrado". El segundo límite es el anillo que conforman las tierras de regadío-si las hay- que normalmente están en la parte delantera del molino. El propio río forma parte de ambos límites.

- Las ermitas son el centro del espacio simbólico de manifestación de lo sagrado. Van asociadas al agua o a la montaña. En el primer caso se encuentran junto a un manantial o fuente y por tanto en sitios angostos y protegidos; el lugar en el que surge o brota el manantial tiene una consideración preeminente en el lugar y adquiere dimensiones de matriz, de gran fuente primordial, por ello la advocación de estas ermitas a la figura femenina de la Virgen.

Son lugares recogidos y con ámbitos no muy extensos que se hallan normalmente adosados al relieve-se relacionan con la imagen de la caverna-, por lo que su disposición no es simétrica sino que se hallan de espaldas a la montaña y en muchas ocasiones como ocurre con los molinos o las masías hacen uso de la red de muros de modelado del territorio.

En este caso el centro lo constituye la ermita/manantial y prácticamente solo existe un límite próximo-dado las características topológicas del emplazamiento- en el que se encuentran las construcciones anejas y el acceso. El límite es la propia topografía, aunque en ocasiones se acaba materializando con un muro de cierre.

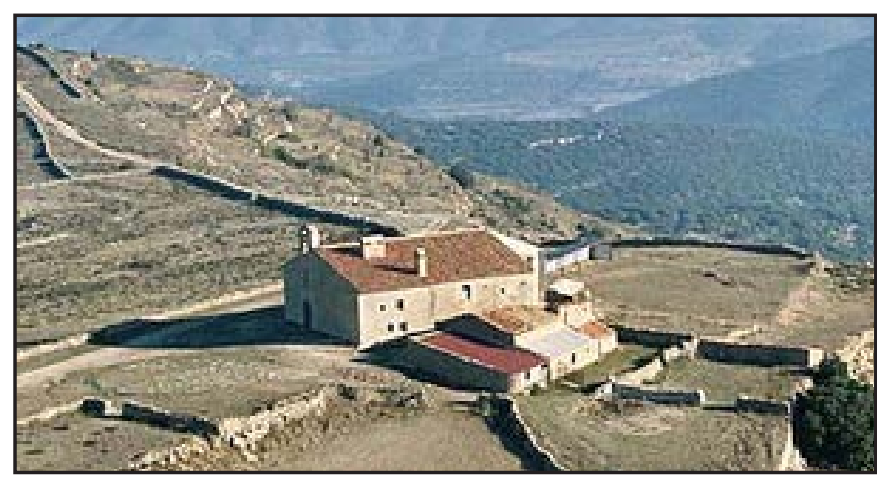

Fig. 5. 20. Vista aérea de Sant Pere de Castellfort. Ejemplo de lugar/ermita.

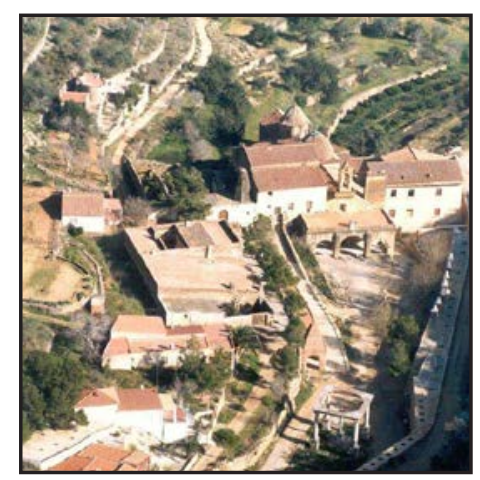

Fig. 5. 21. Vista aérea del ermitorio de la Virgen de la Salud. Ejemplo de lugar/ ermita.

En el segundo caso -el de la montaña- la ermita simboliza el centro como punto de intersección de los dos ejes vertical y horizontal a partir del cual se organiza el territorio. La montaña es el lugar donde moran los inmortales y las divinidades; a partir de el se despliegan las cuatro direcciones que ordenan el territorio..

En este caso son lugares abiertos que dominan una gran extensión de territorio y visibles desde la distancia. Es difícil fijar los límites del lugar en este caso ya que podemos considerar que alcanza hasta donde lo hace la vista. 


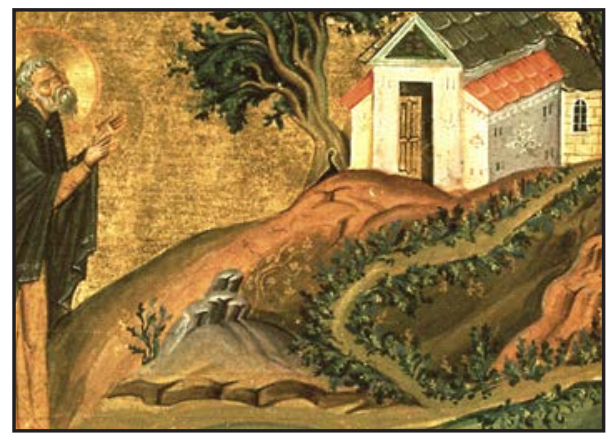

Fig. 5. 22. Detalle del cuadro de San Isidoro de Pelusio (985). Ejemplo muy primitivo de ermita/lugar.
En estos lugares, el centro es la ermita, el primer límite es en ocasiones difuso y lo constituyen las construcciones anexas y la explanada de acceso, el segundo límite es de una gran amplitud y podemos considerarlo de carácter visual.

En ambos casos estos lugares y sus centros son potenciados por los caminos de peregrinación que van hacia ellos a la ida y parten desde ellos a la vuelta. Estas peregrinaciones los convierten a estos lugares en centros "emocionales" del territorio en el que se encuentran.

- Las parroquias surgen junto con los cementerios, como diría Peter Sloterdijk forman una díada en una esfera. Esta es la diferencia con respecto a las ermitas, tiene un centro bipolar con todo lo que ello significa y se convierten en el centro de un espacio tanto terrenal como extraterrenal y en el lugar en el que se produce la unión entre los humanos y sus antepasados. Una vez más Sant Jaume de Coratxar es un ejemplo a estudiar. El cementerio cercado se halla contiguo a la ermita, en la zona norte y ambos en lo alto de un promontorio. La población se halla en los pies de la ladera. En el caso de Bel, el cementerio también es contiguo y se sitúan ambos en un extremo de la población, de alguna manera se separan la ciudad de los vivos y de los muertos pero conviviendo en contigüidad.

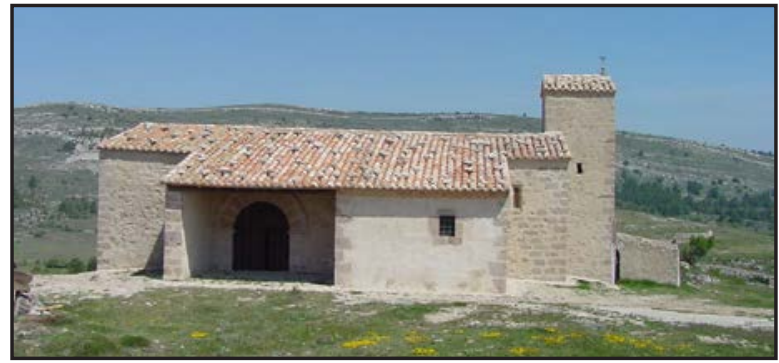

Fig. 5. 23. Vista fachada principal ermita Sant Jaume de Coratxar.

El límite más próximo es precisamente el núcleo urbano por parte de la parroquia y la valla del cementerio por otra. El limite más amplio de la esfera parroquia/ cementerio es un ejemplo de como pueden crecer según Sloterdijk. Las esferas crecen en función de su capacidad de incorporar fuerzas exteriores estresantes en su interior; utilizan la muerte como "hormona de crecimiento para elevarse de formas microesféricas a macroesféricas"122 que permite que coexistan los vivos y los muertos; a través de la religión se santifica el espacio interior. El límite exterior es el término municipal que se halla delimitado por medio de una serie de mojones sacralizados, los peirones. ${ }^{123}$

- Las arquitecturas defensivas, como ya hemos visto son aquellas en las que la configuración del límite tiene más importancia que del propio centro y ello a todos los niveles desde la torre aislada, al recinto de la plaza de armas y hasta las murallas del propio castillo. Funcionan como pieles de una cebolla, de forma que cada una de ellas envuelve y protege a la anterior. Esas necesidades de tener un límite claro y definido hacen que los emplazamientos elegidos sean singulares y de una topología singular. Sitios escarpados y de difícil acceso, capaces de dominar visualmente mucho territorio y a la vez difíciles de acceder y dominar físicamente. Estas arquitecturas, en el caso de las torres defensivas, generan lugares más allá del límite defensivo con el que cuentan otro muy desdibujado que contiene el entorno próximo, que varía en función del enclave que "protegen" -puede ser un puente, un cruce de caminos, el acceso a un valle...- y de si está asociado a una masía o no. Este último límite es más difuso, se trata de un límite visual y de relación con otras torres defensivas.

122 SLOTERDIJK, P. “Esferas II” pág. 149

123 El lugar-parroquia lo conforman no sólo la iglesia sino también la casa del párroco y el granero. Ver apéndice documental no 40 pág. 632 


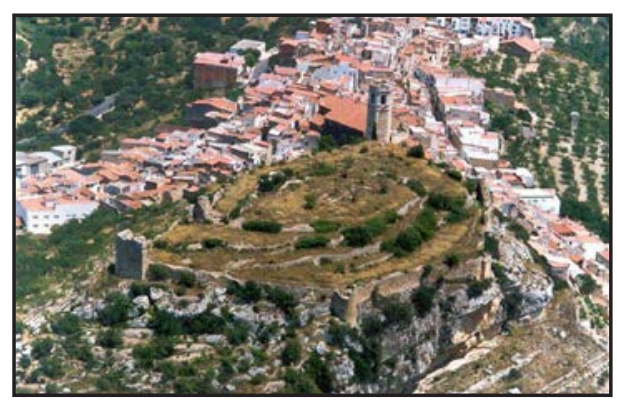

Fig. 5. 24. Vista aérea del castillo de Cervera. Ejemplo de lugar/castillo.
En el caso de los castillos, El centro es la torre celoquia. El primer límite es la muralla que contiene las edificaciones que conforman la plaza de armas. El segundo límite suele ser un segundo recinto amurallado o primera defensa. Más allá de este último límite defensivo cuentan con otro mucho más desdibujado que se corresponde con el ámbito visual desde el que se puede ver la fortaleza. Es el territorio que puede ser "defendido" desde ella.

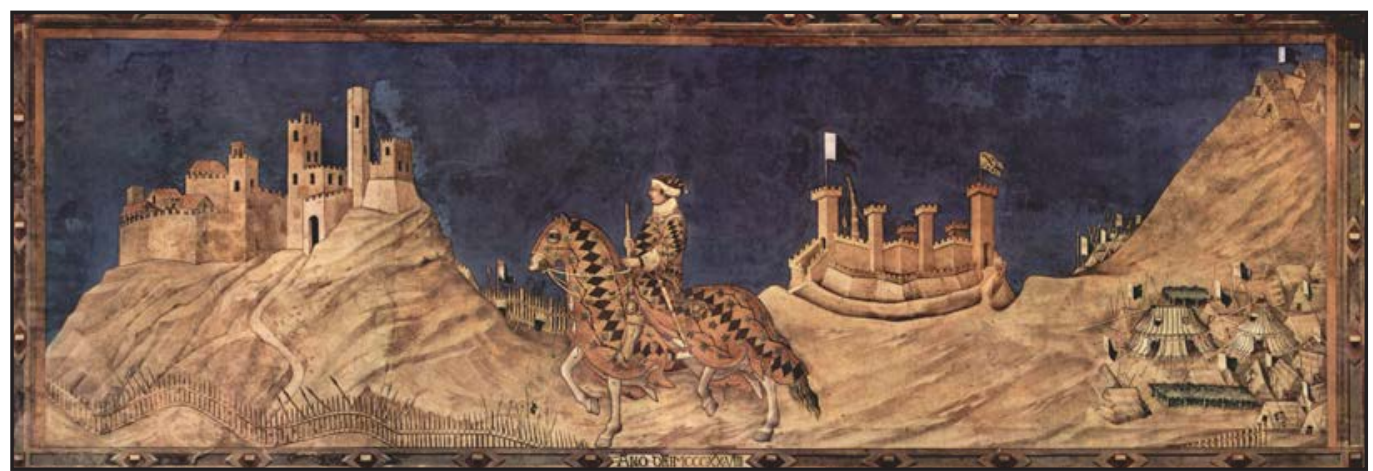

Fig. 5. 25. Pintura de Guidoriccio da Fogliano (1328) de Simone Martini.

- El monasterio es la esfera/arquitectura que más se amplía. El "embrión" que da lugar al monasterio es el pequeño espacio en el que el ermitaño o anacoreta vive entregado a la oración y la penitencia. Esta célula inicial dará lugar a los monasterios o cenobios ${ }^{124}$, cuando estos deciden vivir en comunidad.

La arquitectura del monasterio tiene como centro el claustro alrededor del cual se disponen la iglesia, la cocina, refectorio, dormitorios y el resto de dependencias, todos ellos dentro de un recinto vallado en el que también hay una zona de huerta y dependencias anejas. Por lo tanto está claramente definido y delimitado.

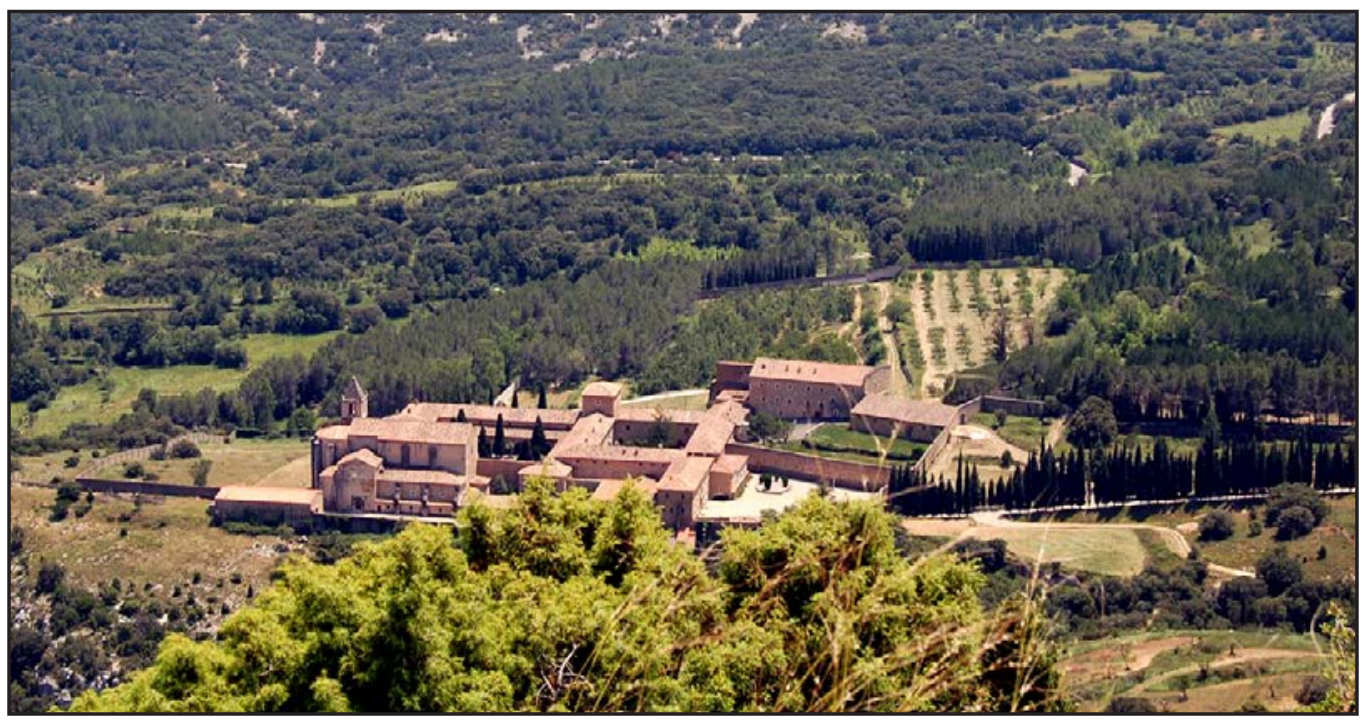

Fig. 5. 26. Vista aérea del monasterio de Benifassar. Ejemplo de lugar/monasterio.

124 En biología se denomina cenobio al grupo de células que, tras dividirse, nos se separan y permanecen dentro de una vaina o sustancia mucilaginosa. 
Los monasterios se sitúan en emplazamientos singulares, con agua y tierras fértiles a su alrededor. Normalmente son valles, por lo que el segundo limite que suele ser amplio, está delimitado por las propias condiciones topográficas del emplazamiento, es decir, el segundo límite es el límite geomorfológico del valle en el que se asienta.

La esfera/lugar del monasterio engloba las nueve dimensiones. En ella se concretizan el quirotopo, fonotopo, uterotopo, termotopo, erotopo, ergotopo, alethotopo, thanatotopo o theotopo y nomotopo.

El alcance de la membrana exterior de la esfera puede llegar a ser tan extenso como el de un importante núcleo de población. Un claro ejemplo de ello es el del Monasterio de la Pobla de Benifassar limítrofe a la Batllia de Cervera.

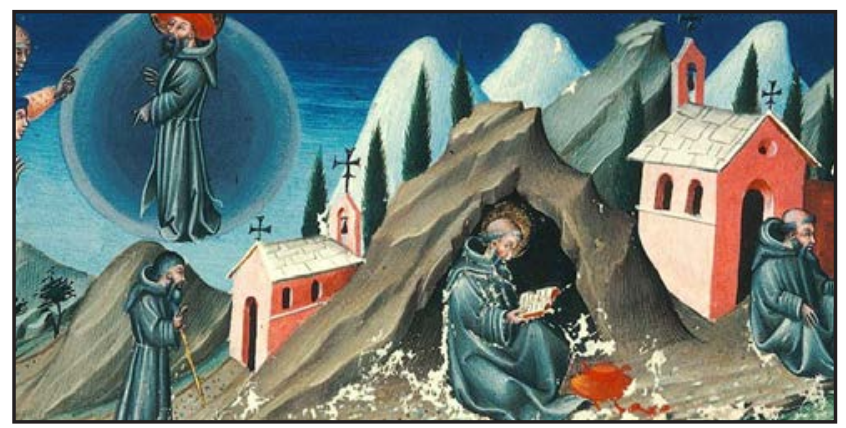

Fig. 5. 27. Ilustración de un monasterio anacoreta en la Divina Comedia de Dante. Lugar/monasterio.

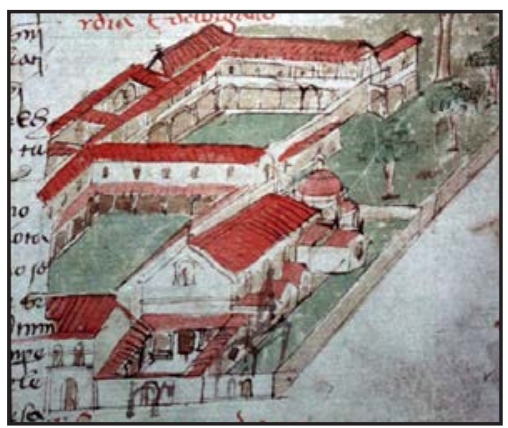

Fig. 5. 28. Dibujo de Santa María de los Ángeles del Códice Rustici (1425-50). Lugar/ monasterio.

2. Esferas/lugares surgidos por la adición de dos o más esferas/arquitecturas:

- Las agrupaciones de viviendas traen consigo la aparición de unos lugares especiales que serán el germen de la futura ciudad. Cuando una serie de viviendas se agrupan en cadena, configuran un frente de que en ocasiones se mantiene como tal sin evolucionar más allá. Sin embargo cuando ese frente de casas tiene una réplica enfrente de él, se configura un espacio intermedio: la calle que se convierte en un lugar con unas características especiales. Es el espacio de relación y reunión de todos los habitantes de las distintas casas y si en él se ubican otras arquitecturas como una iglesia y/o un horno tenemos el germen de un pequeño núcleo urbano que se completará cuando se construya en la calle una casa comunal.

Ejemplo de este tipo es el de Bel y el de otros que han perdurado hasta nuestros días congelados casi en las mismas condiciones en las que se encontraban en la Edad Media, como es el caso de Las Albaredas en Portell de Morella. Se trata de unos espacios longitudinales que coinciden con el trazado de una infraestructura viaria, son por tanto lugares de paso.

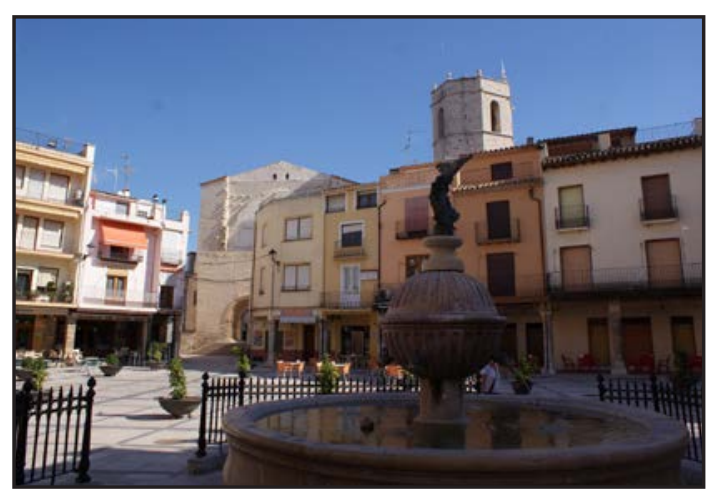

Fig. 5. 29. Vista de la plaza de San Mateo.

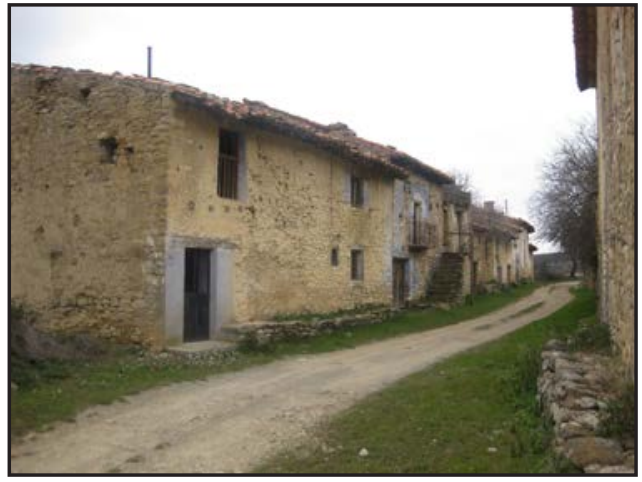

Fig. 5. 30. Vista de la calle de Las Albaredas en Els Ports.

El otro lugar singular es el de la plaza. Se produce cuando el frente de casas no tiene simplemente una replica especular, sino que alrededor de un espacio que queda libre se ordenan tres o cuatro frentes de casas, configurándose un espacio triangular o cuadrangular. Se opta por una solución u otra en función de las condiciones previas de las redes de muros 
e infraestructuras sobre las que el lugar/plaza se configura. Una bifurcación de caminos o una topografía accidentada con muros de contención generan una plaza triangular, mientras que en una topografía llana o un cruce de caminos genera una plaza rectangular.

El lugar plaza en muchas ocasiones alberga las funciones de mercado para lo que es habitual que todos los frentes de las casas o parte de ellos se resuelvan con porches para albergar esas funciones a resguardo de las inclemencias del tiempo. Ejemplo de plazas rectangulares tenemos la de Sant Mateu o la de Xert y de plazas triangulares como en Cervera del Maestre. En el lugar de la plaza, o junto a ella, se construye la casa comunal ya que en planta baja se sitúa la lonja y es el edificio publico más representativo de la ciudad.

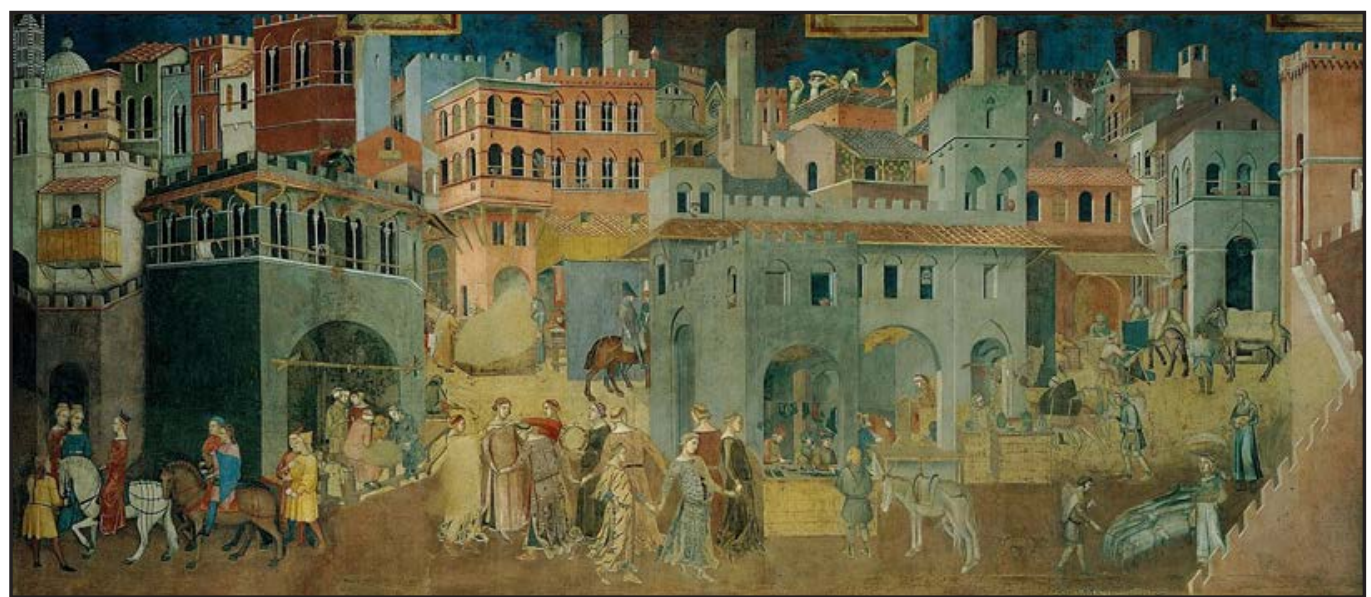

Fig. 5. 31. Detalle del cuadro de A. Lorenzetti “Los efectos del buen gobierno" Siena, entre 1338 y 1340. Ejemplo de lugar/plaza.

- Los puentes, favorecen que a un lado y otro de la orilla se dispongan arquitecturas como torres, masías, abrevaderos para el ganado o incluso ermitas. El conjunto y adición de todas ellas generan un lugar, cuyo centro es el propio puente. El primer límite son las construcciones y territorio situado a ambos lados del río y que el puente conecta directamente, mientras que el segundo límite alcanzaría hasta los territorios que esta arquitectura permite conectar aunque estén situados a una importante distancia.

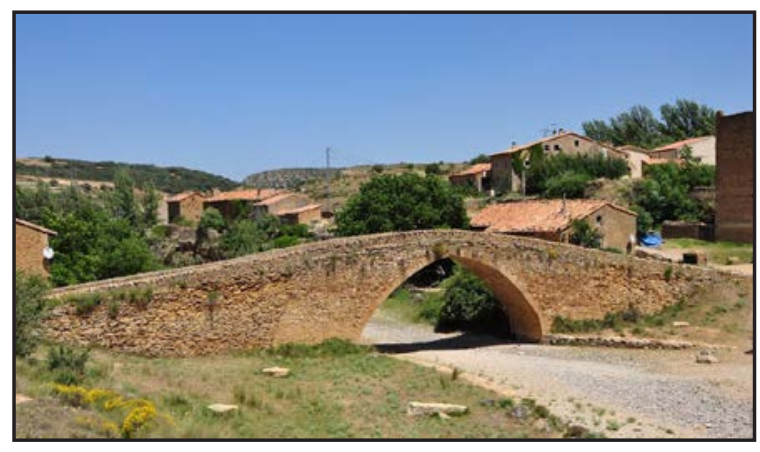

Fig. 5. 32. Foto del puente de la Pobleta de San Miguel en Els Ports.

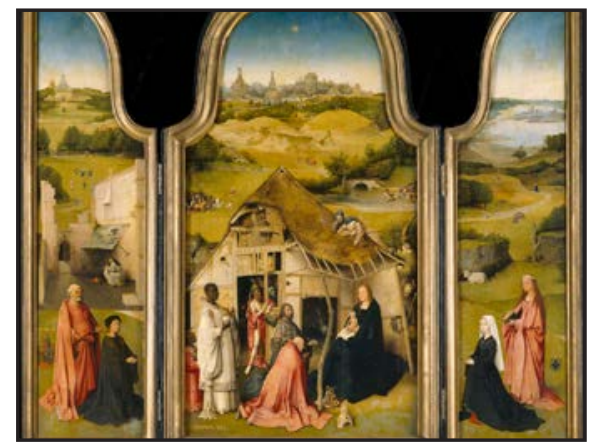

Fig. 5. 33. Fragmento del cuadro de La Adoración de El Bosco (1485). Al fondo se halla representado el lugar/puente.

- Los abrevaderos, son el lugar fruto de la conexión de una fuente o manantial y una zona de pastos o red de camino ganadero. Cuando concurren estas dos circunstancias se crea un lugar singular en al que se van agregando otros elementos como un recinto de descanso para el ganado, casetas de pastor para el cobijo de los mismos, balsas de almacenamiento de agua, etc. 



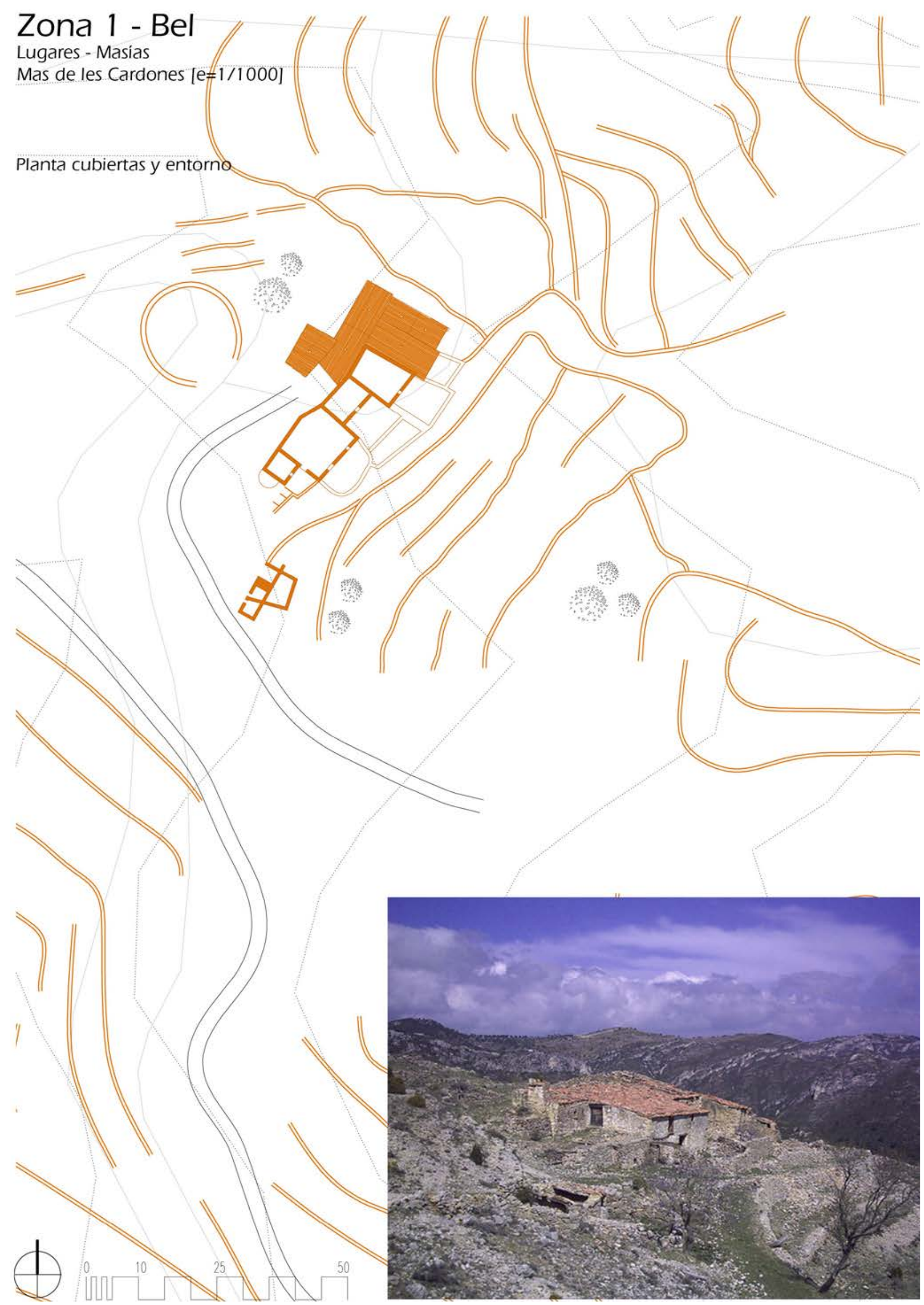




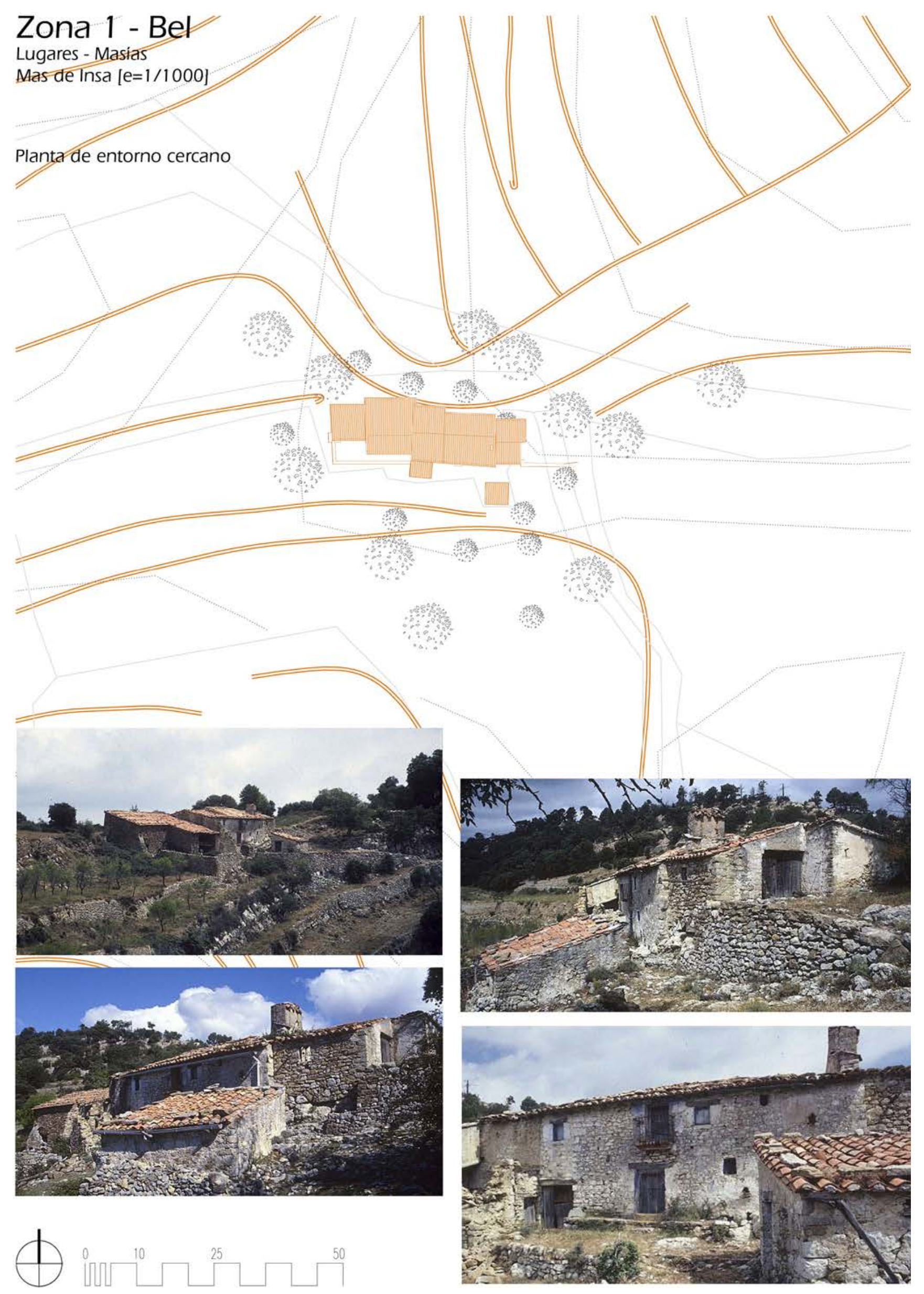




\section{Zona $3-$ Molinar / Xert}

\section{Lugares-Masias}

Mas del Regall $[\mathrm{e}=1 / 1000]$

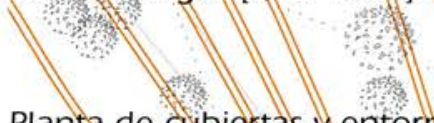

Planta de cuibiertas y entorno
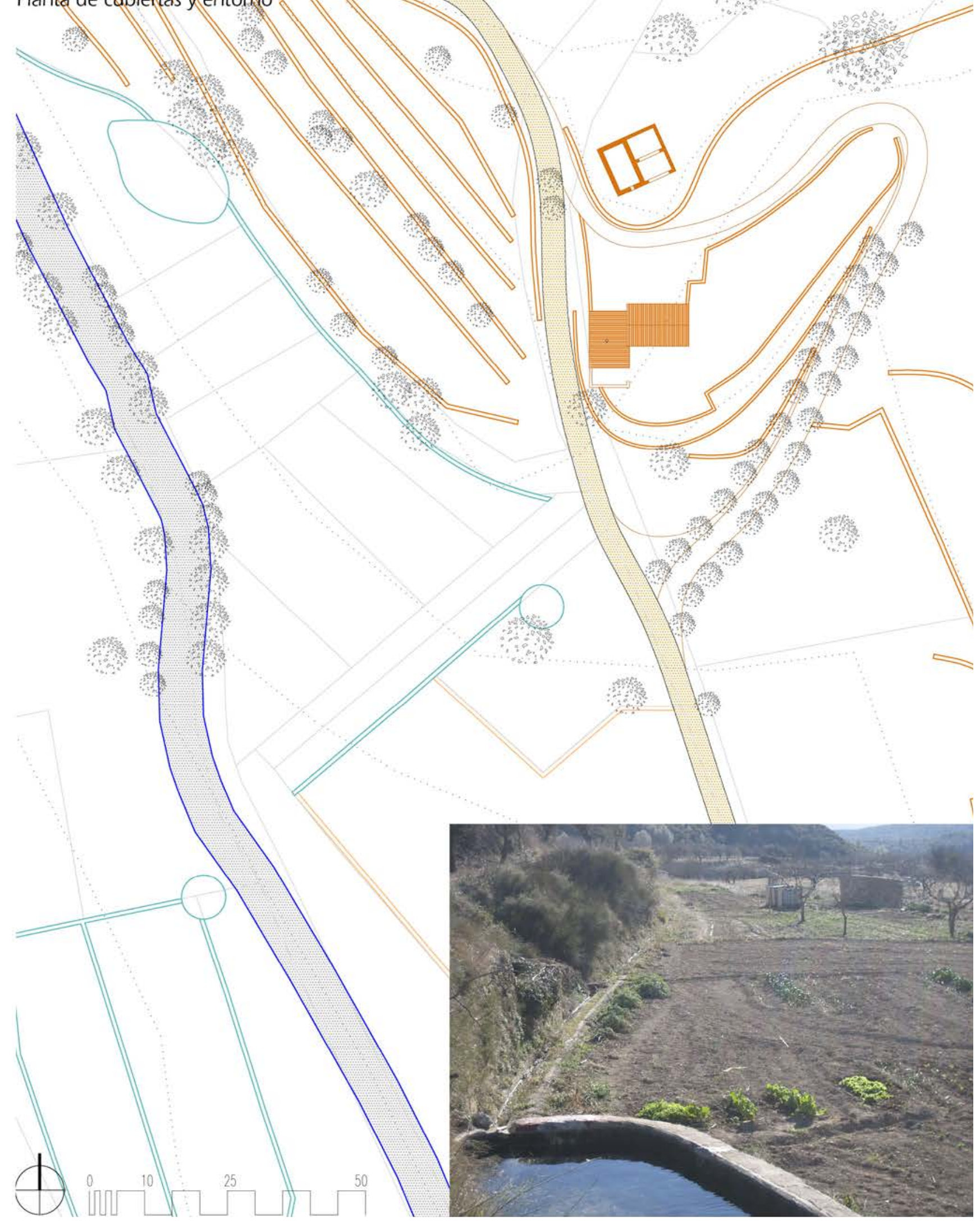


\section{Zona 4 - Mas del Coll / Rosell} Lugares - Masias

Mas de Macià $[\mathrm{e}=1 / 1000]$

Planta cubiertas y entorno

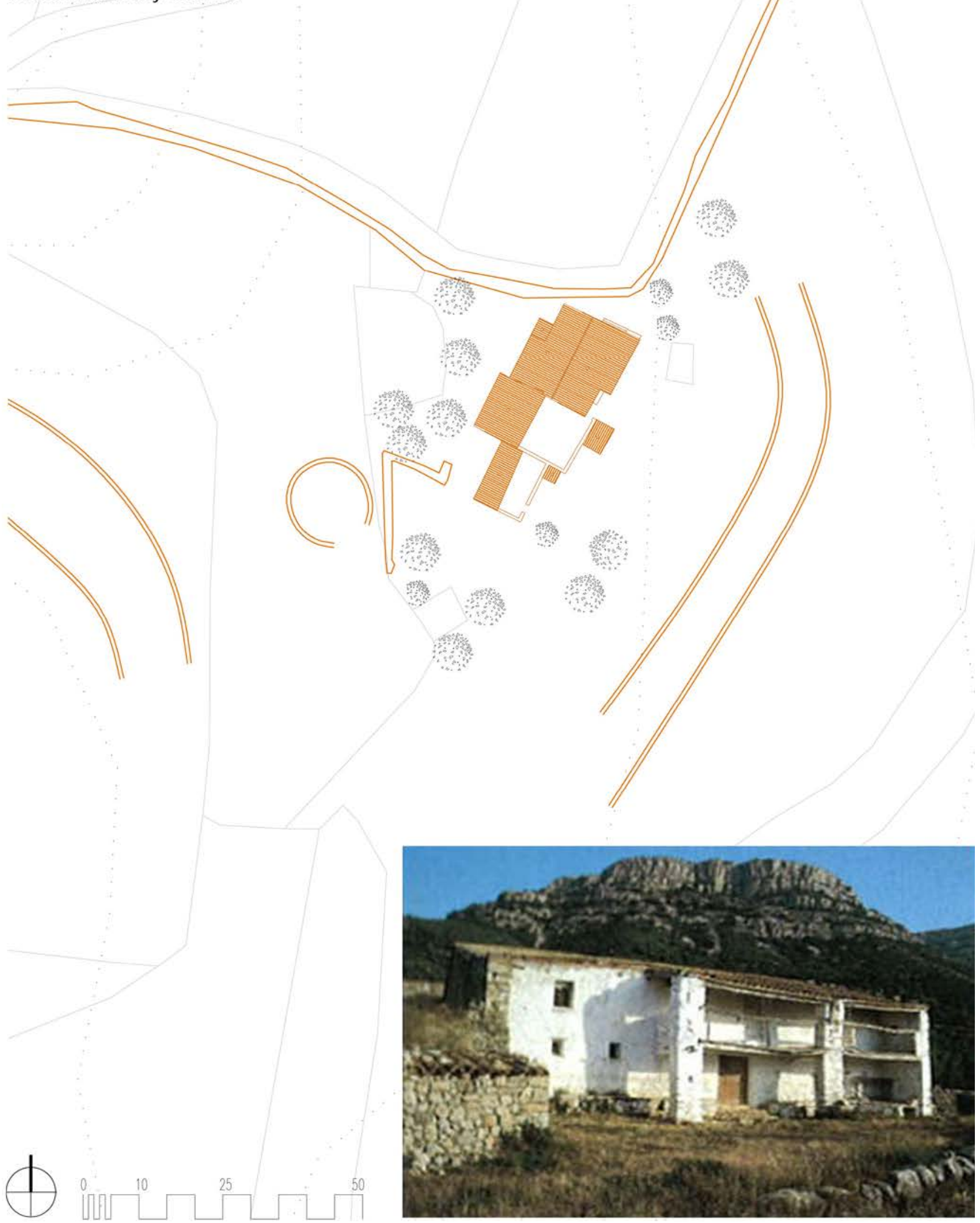



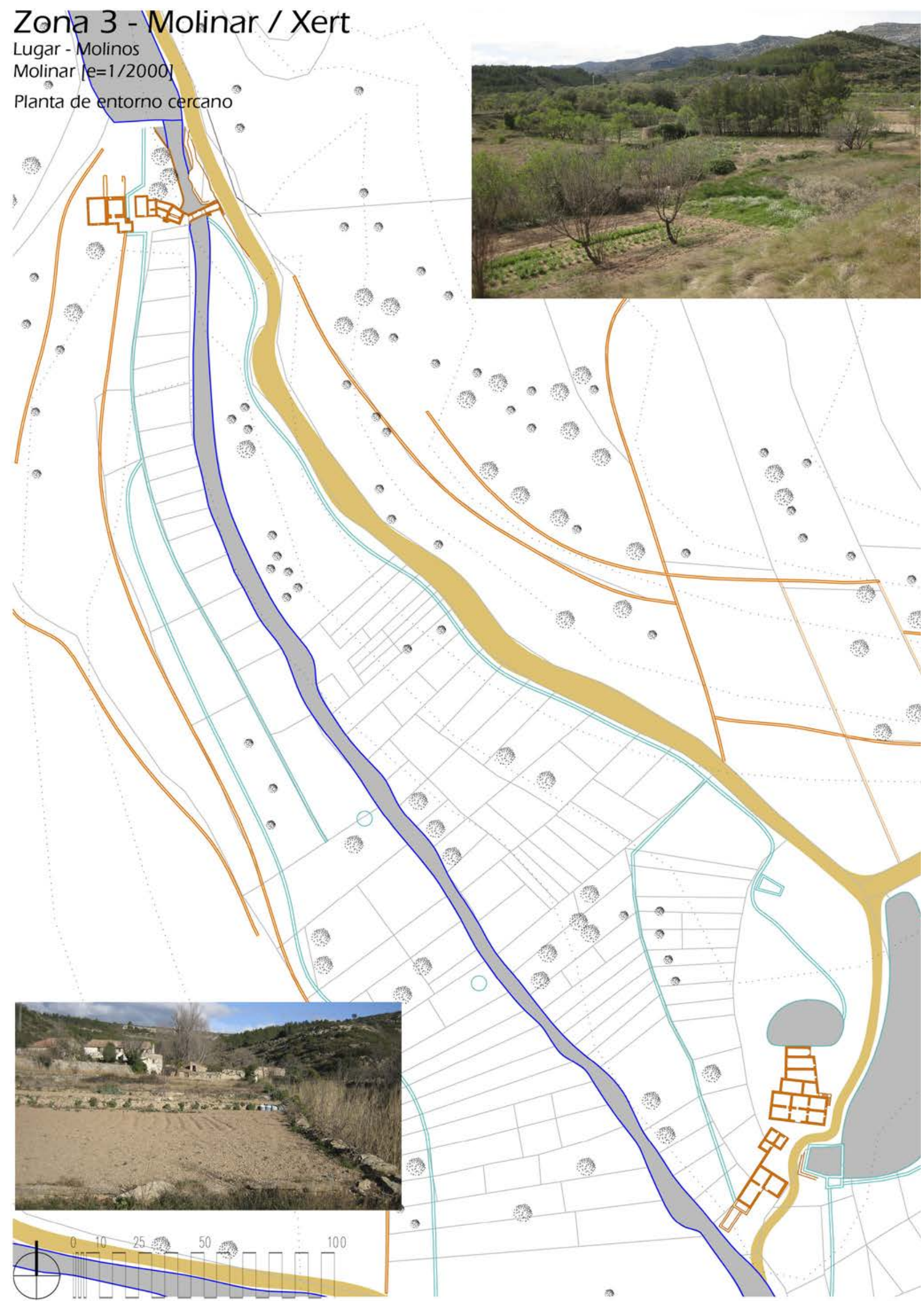

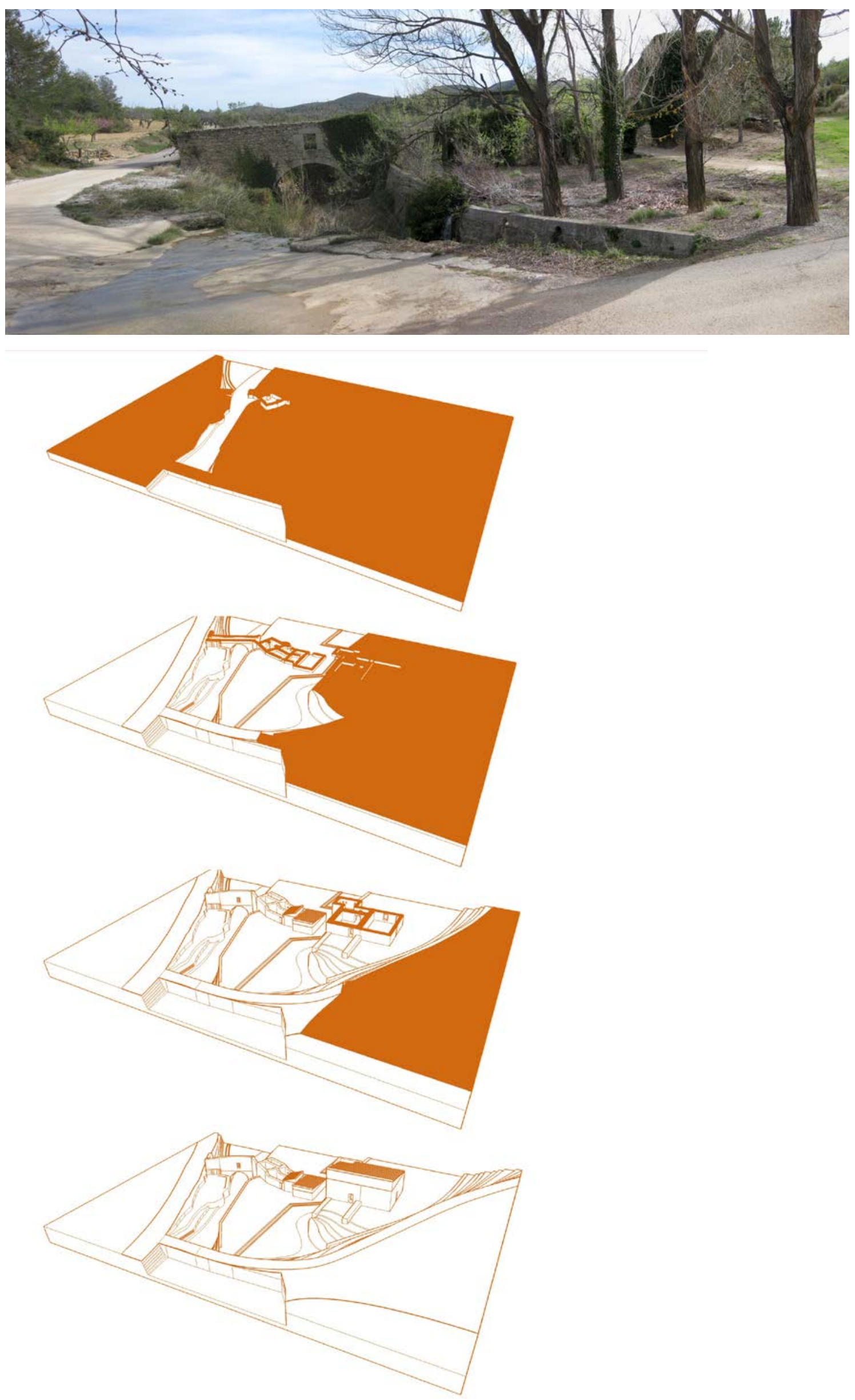

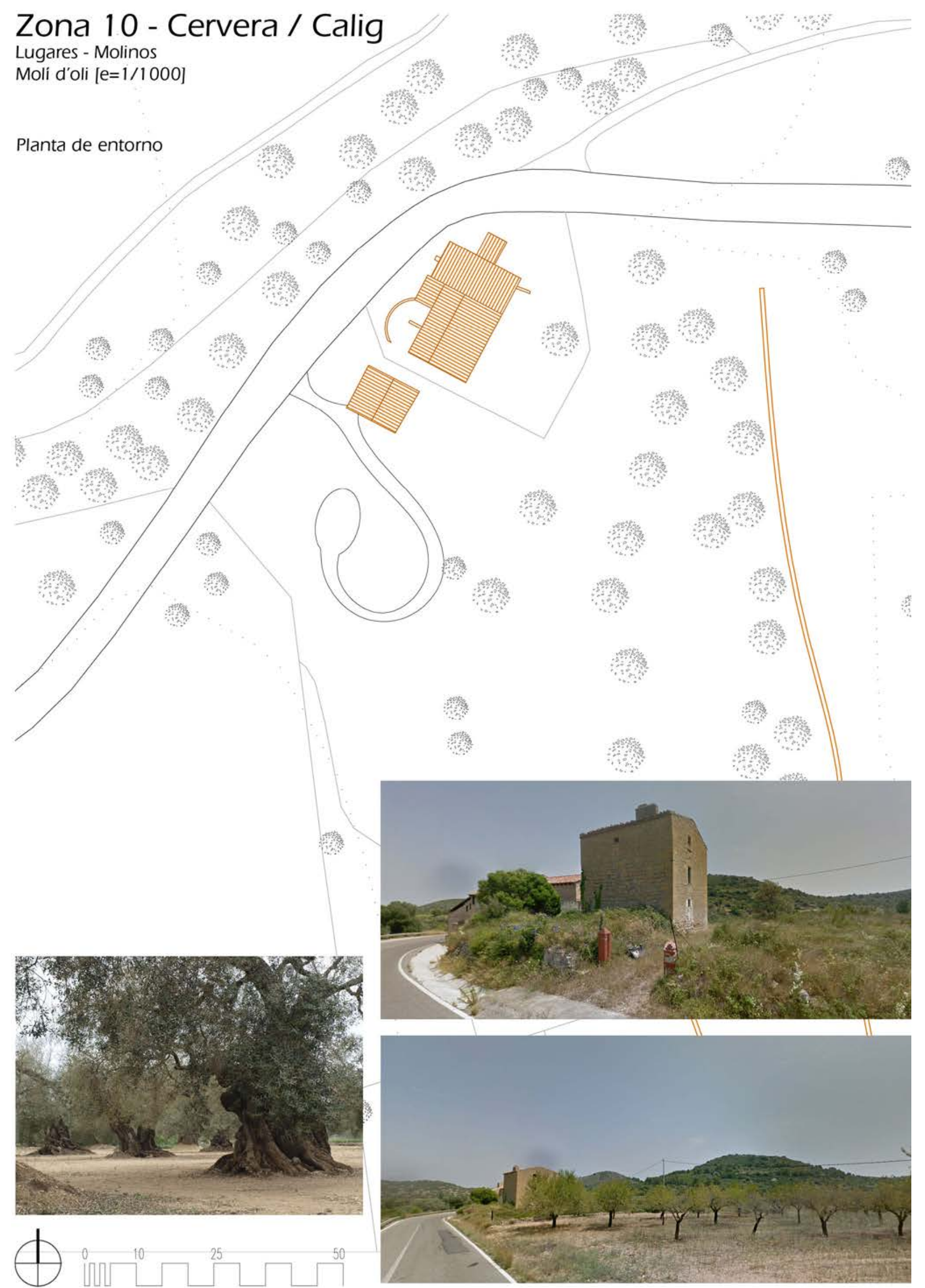


\section{Otras zonas de interés} Lugares - Molinos

Molinos de Ares $[e=1 / 1000]$

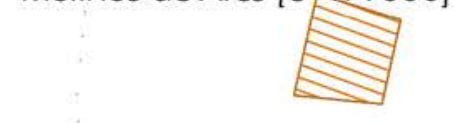

Planta entorno cercano

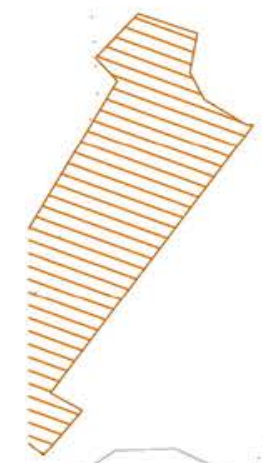

$\$$
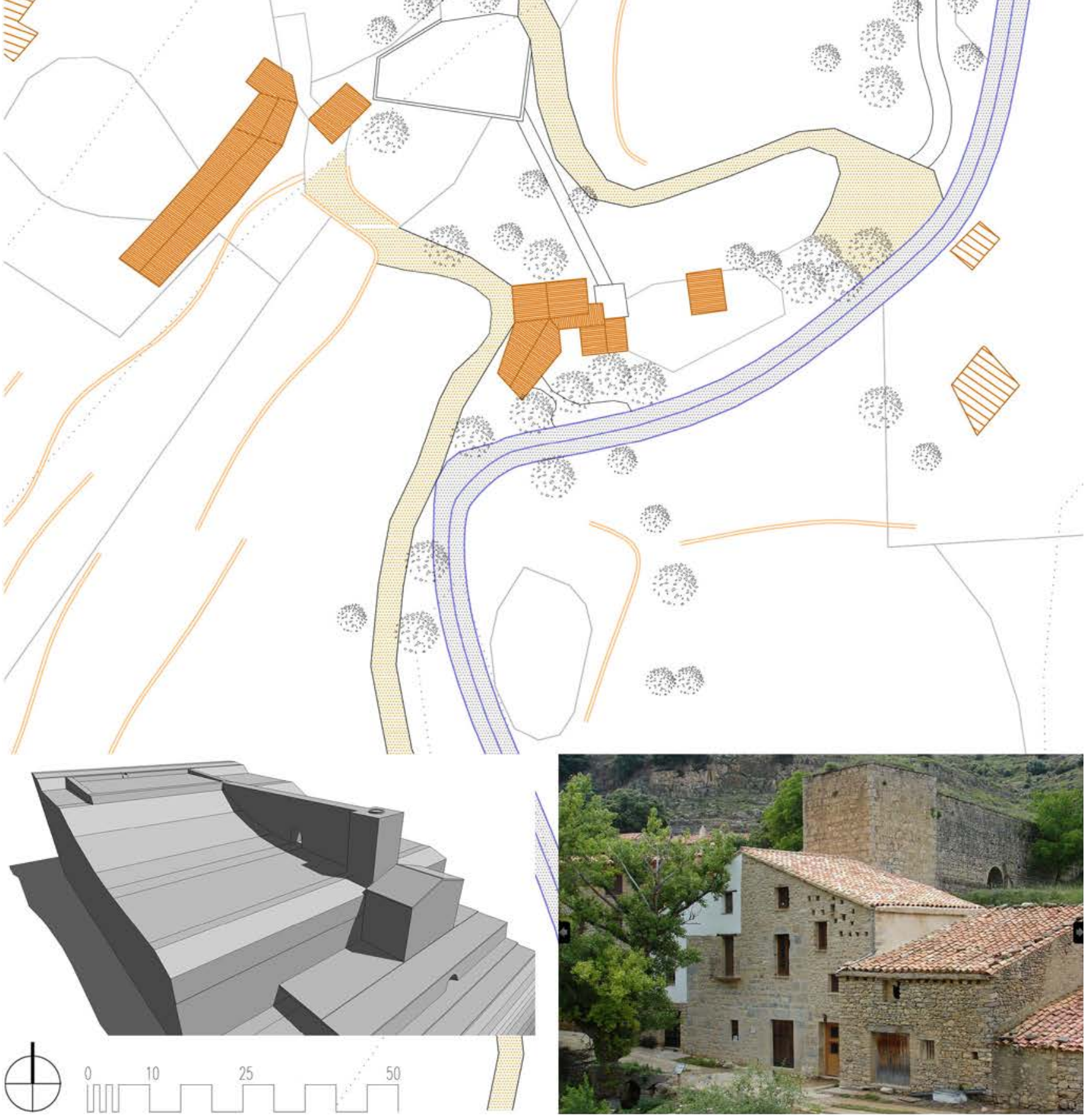


\section{Zona 2 - Barcella}

Lugares - Iglesias / ermitas

Ermita San Marc de la Barcella $[\mathrm{e}=1 / 1000]$
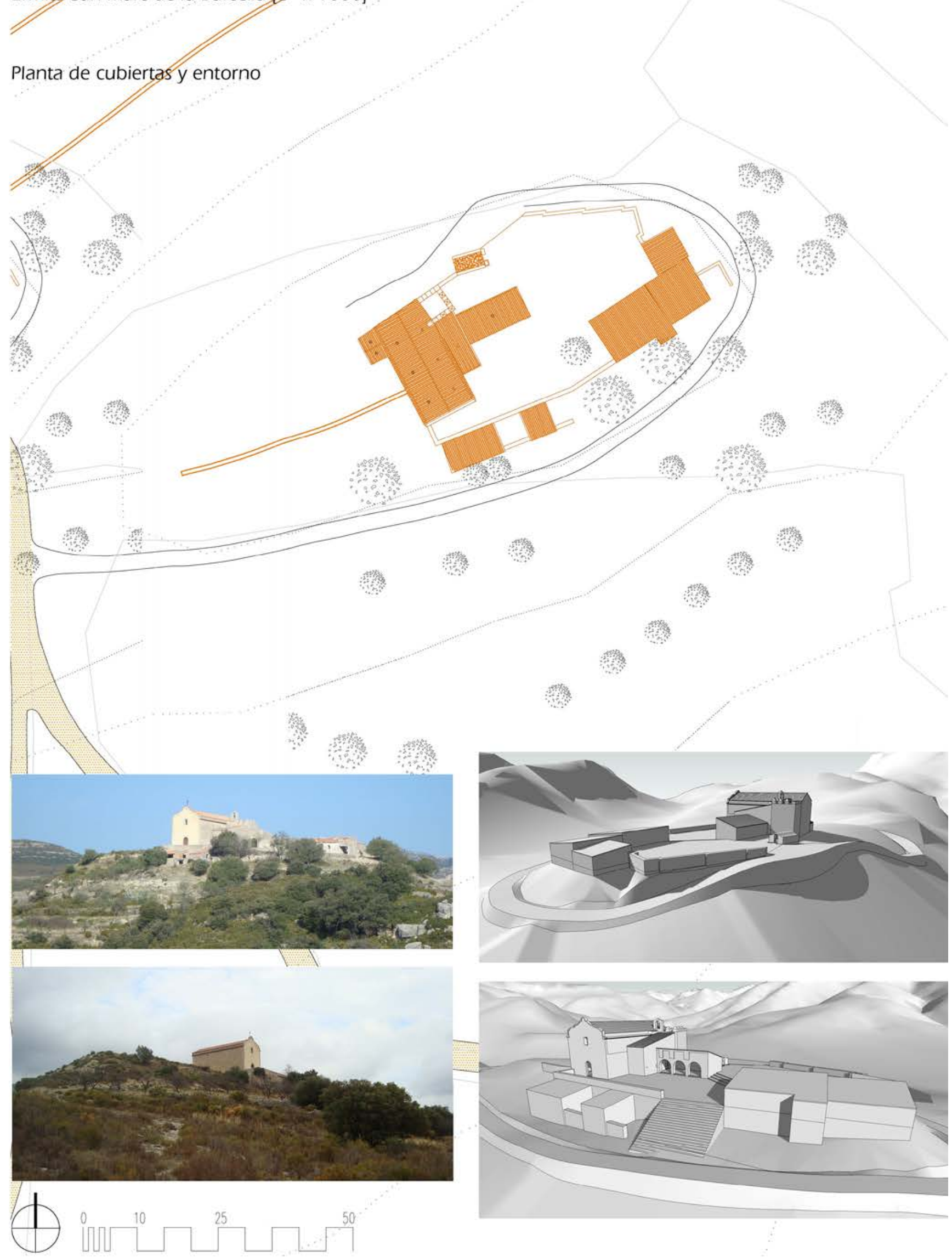

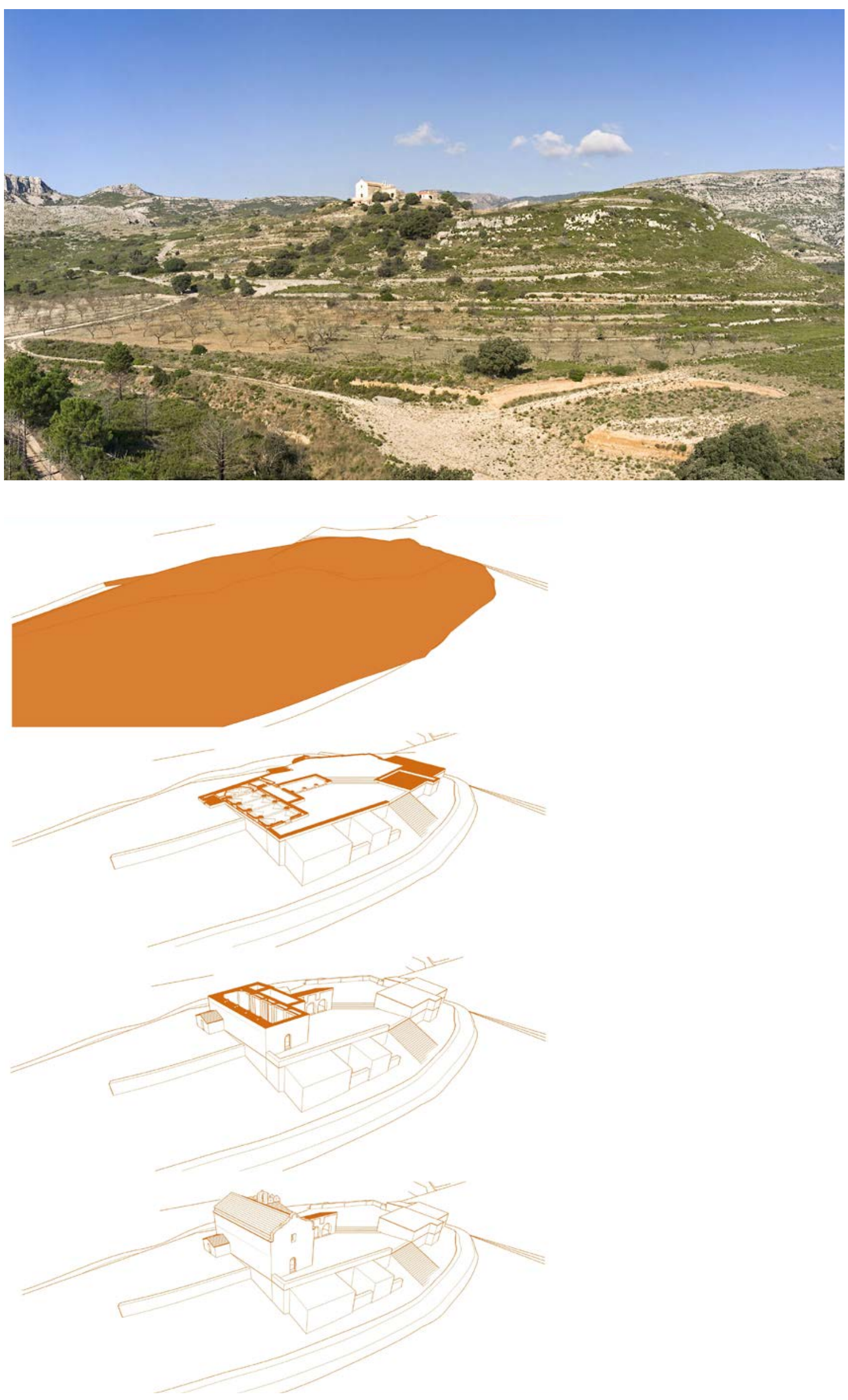


\section{Zona 3/-Molinar / Xert} Lugares - Iglesias / ermitas Iglesia de Xert $[\mathrm{e}=1 / 1000]$ $\Rightarrow \quad$ on

Planta de cubiertas y entorno
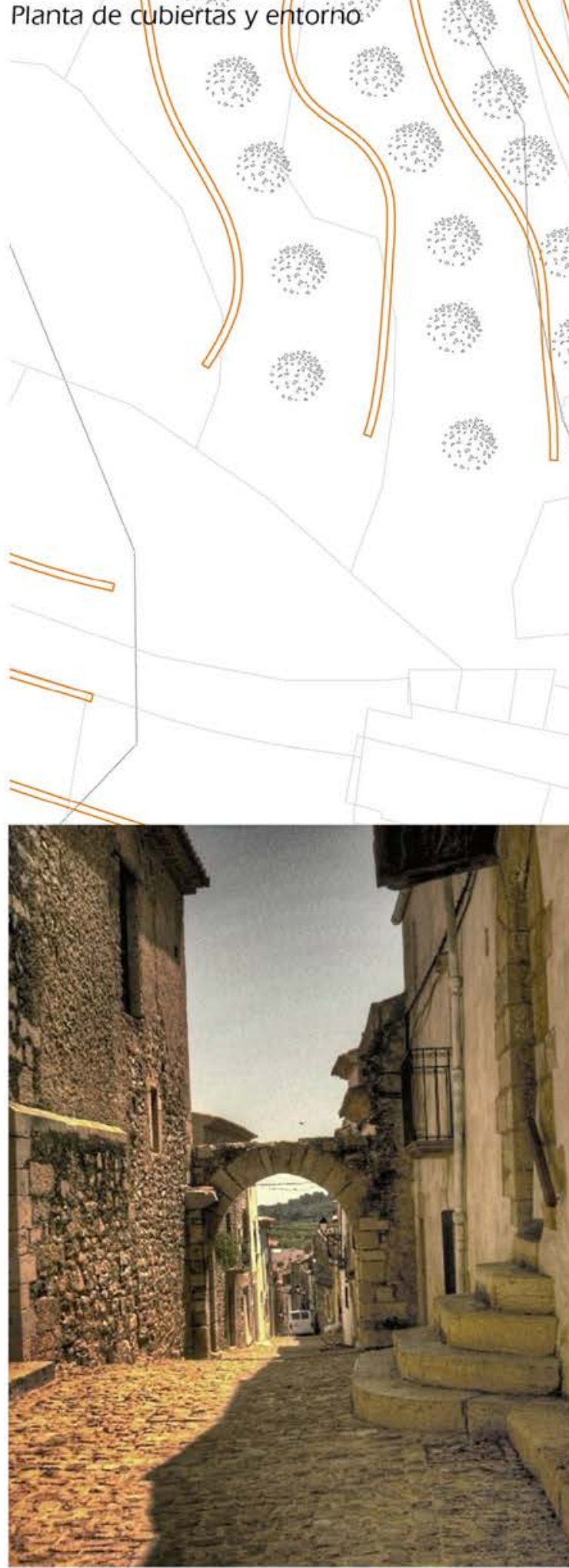

Ð
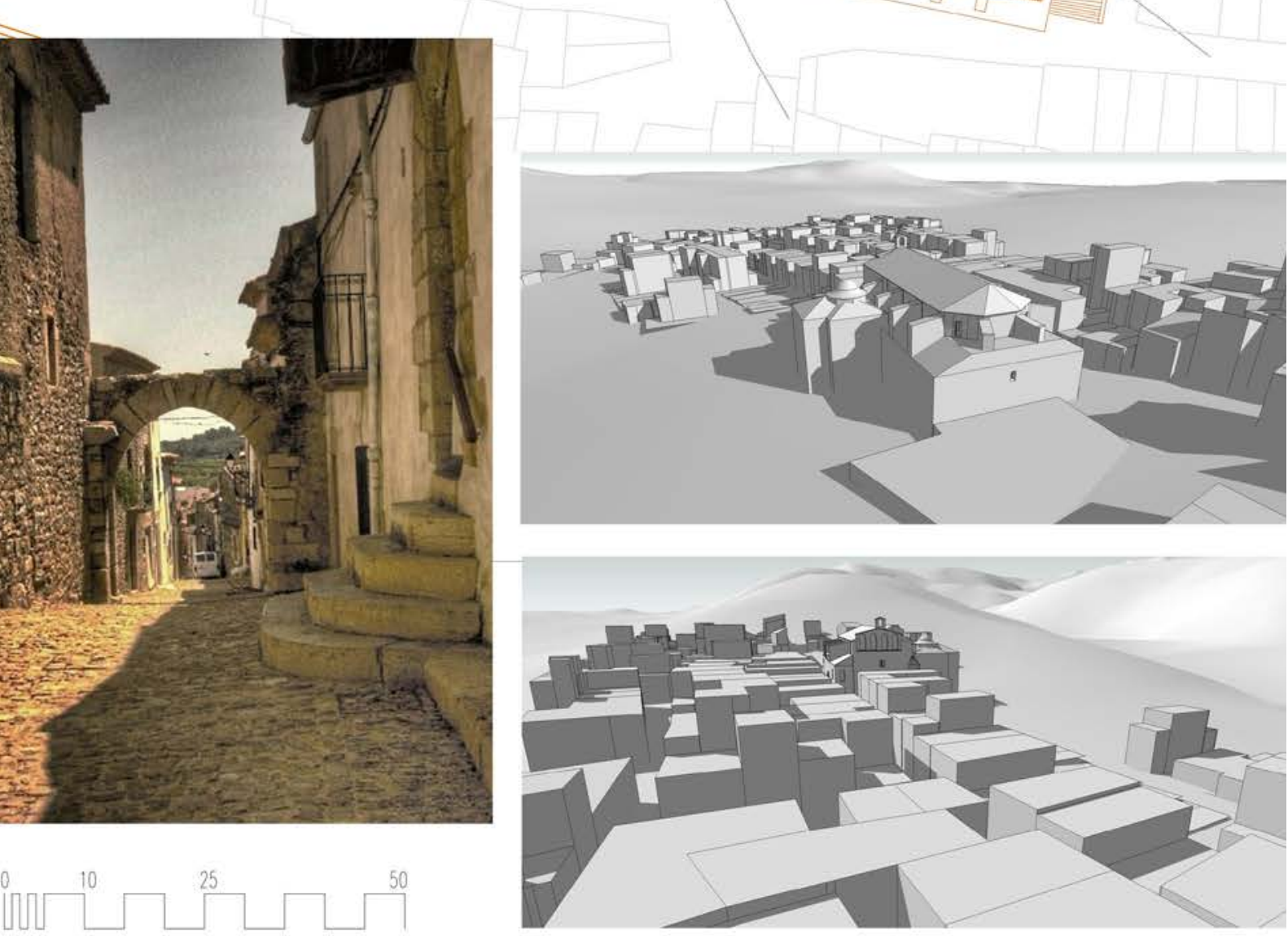


\section{Zona 5 - Canet} Lugares - Iglesias / ermitas

Conjunto de Santa Isabel $[\mathrm{e}=1 / 1000]$

Planta cubiertas y entorno
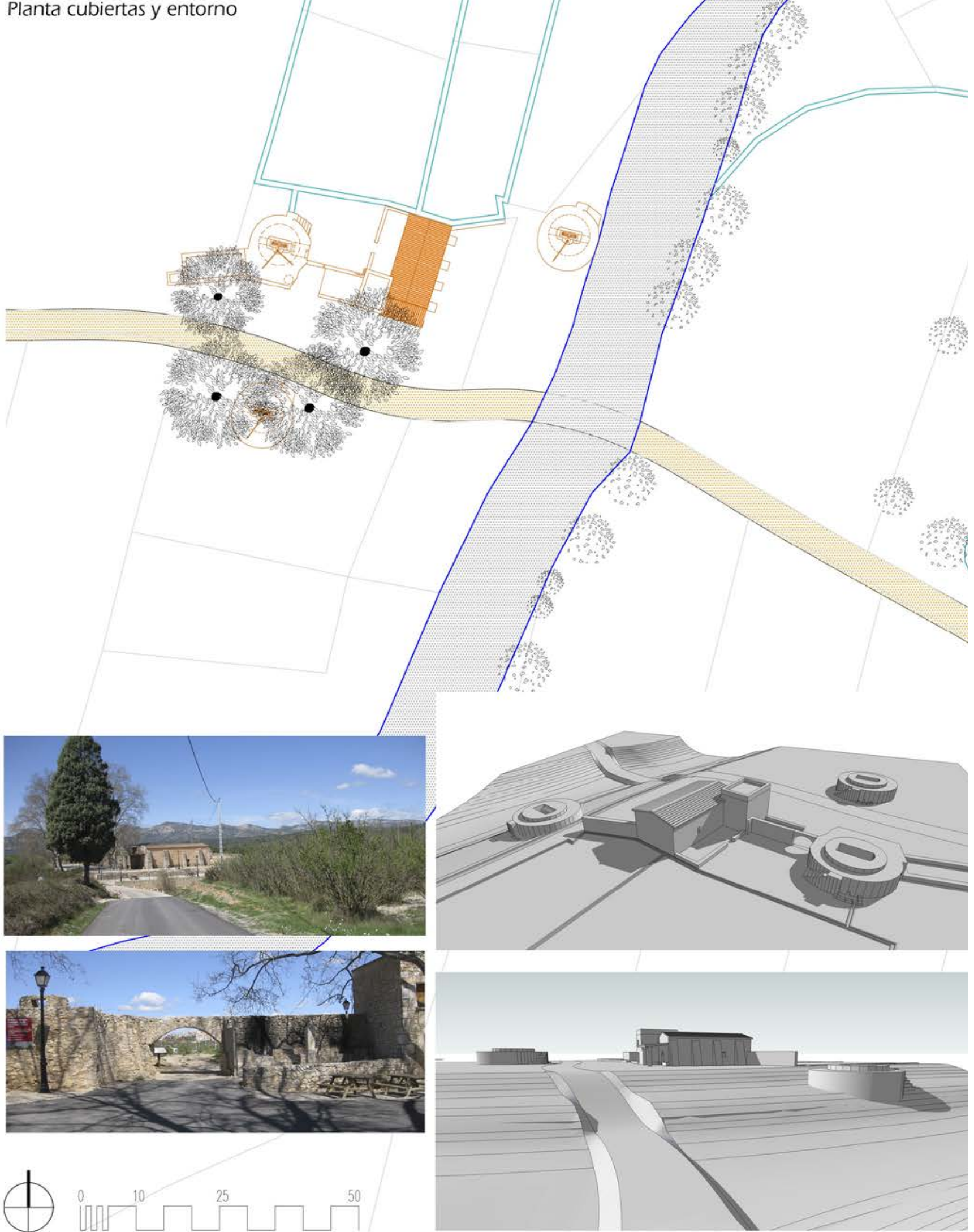

(1)

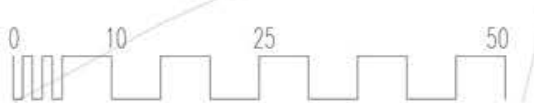



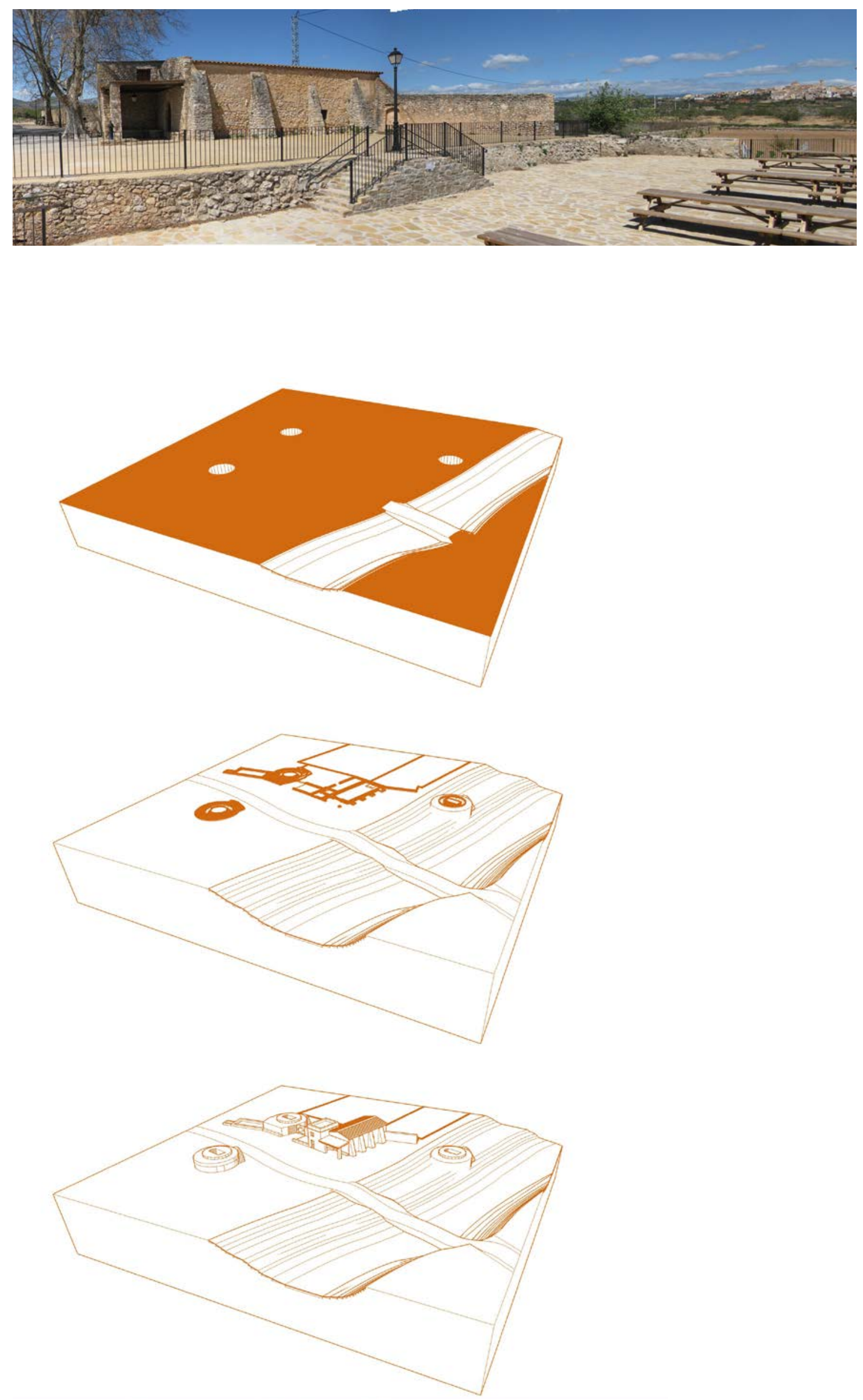


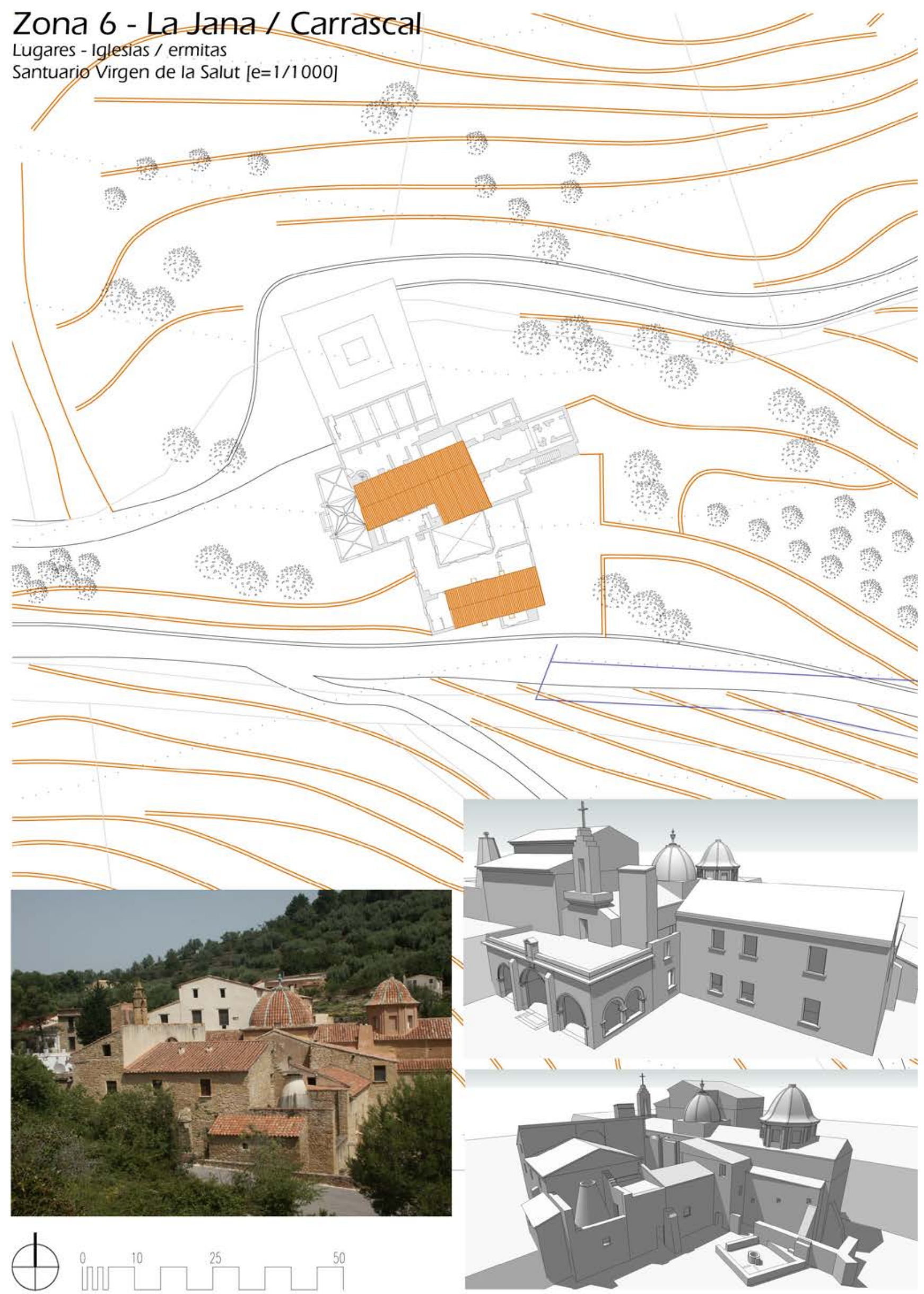



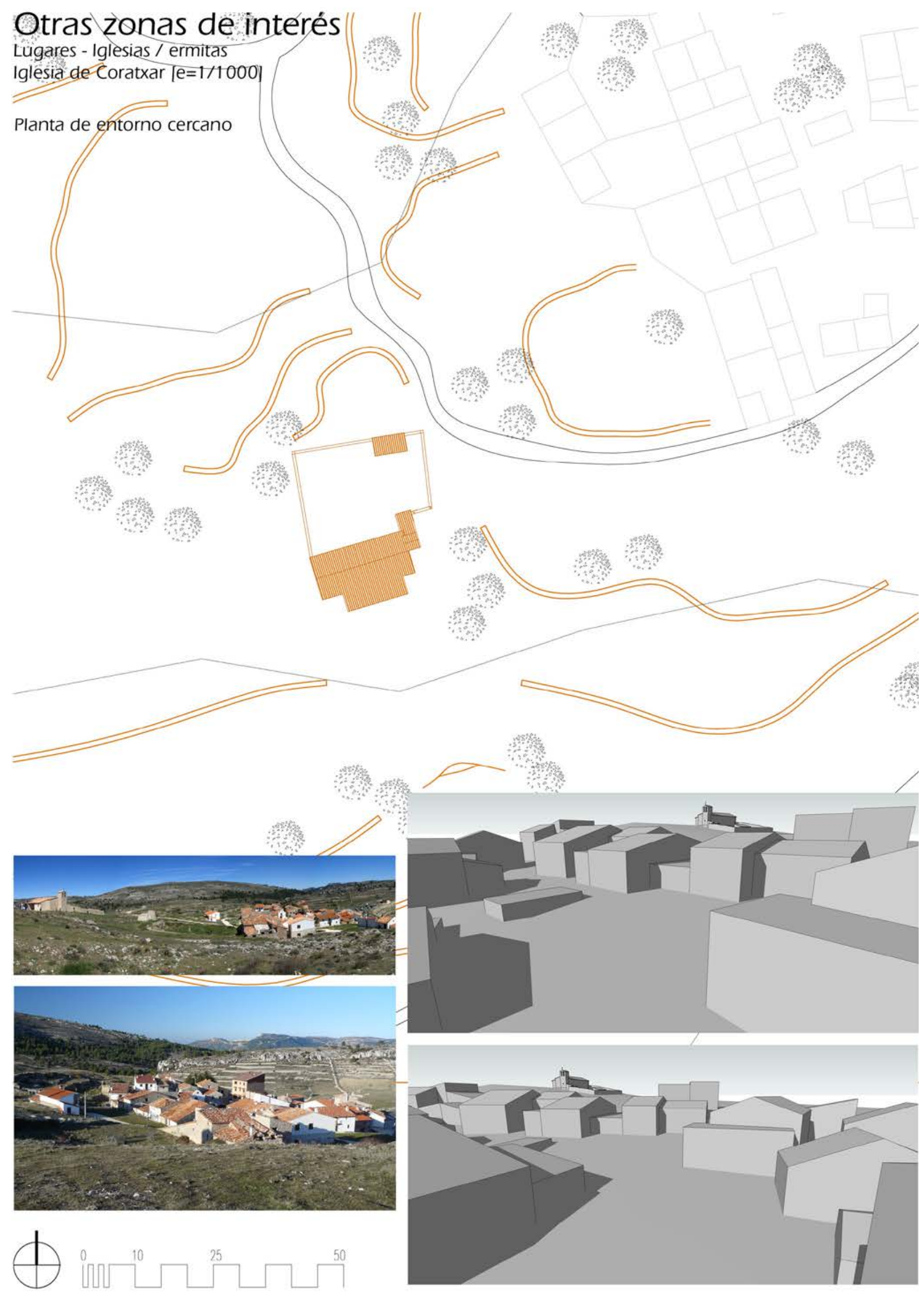


\section{Zona 1 - Bel}

Lugares - Calle

Calle principal de Bel $[e=1 / 500]$

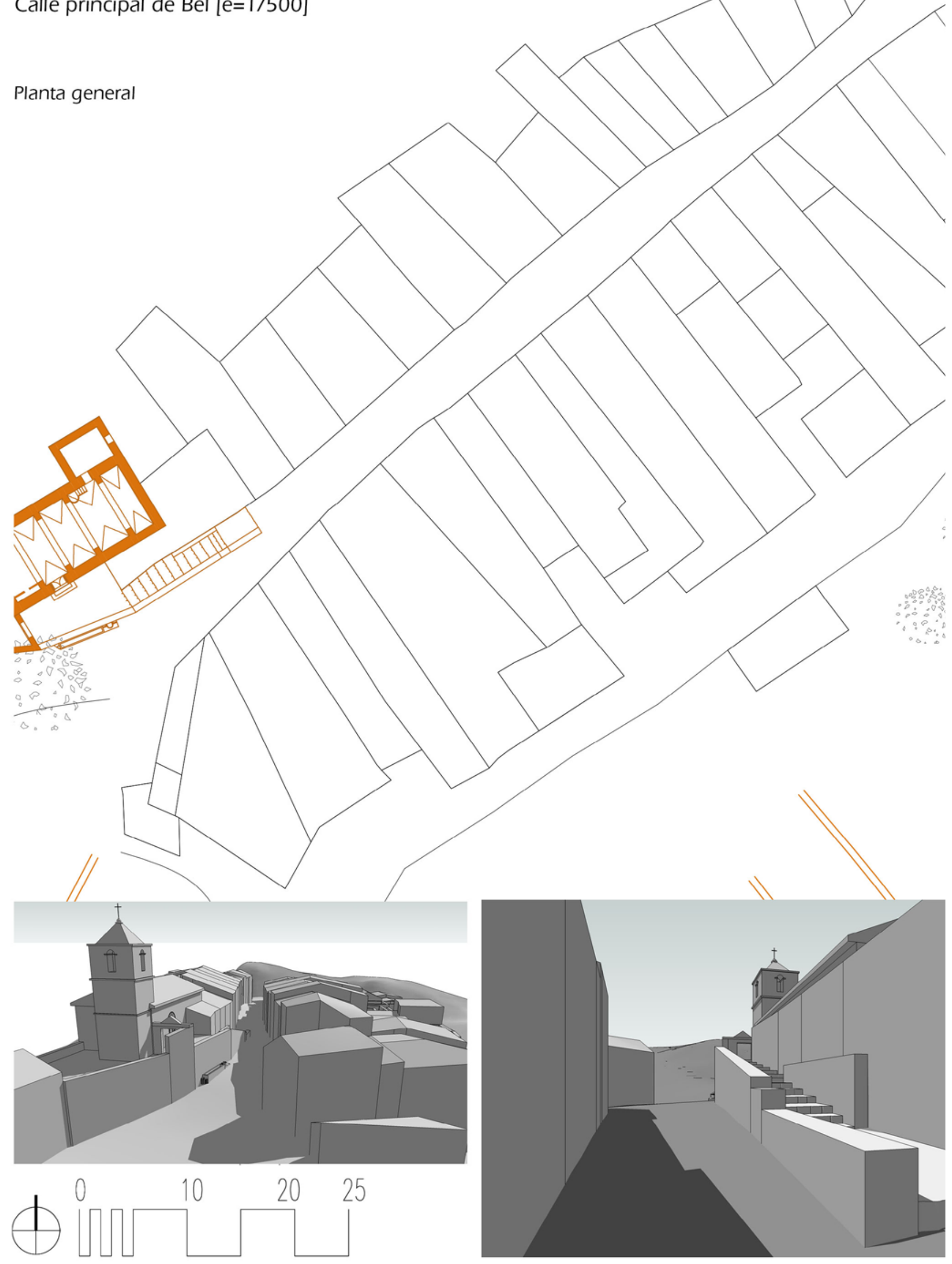




\section{Zona 7 - Sán Máteo} Lugares - Plazas

Plaza de San Mateo $[e=1 / 500]$
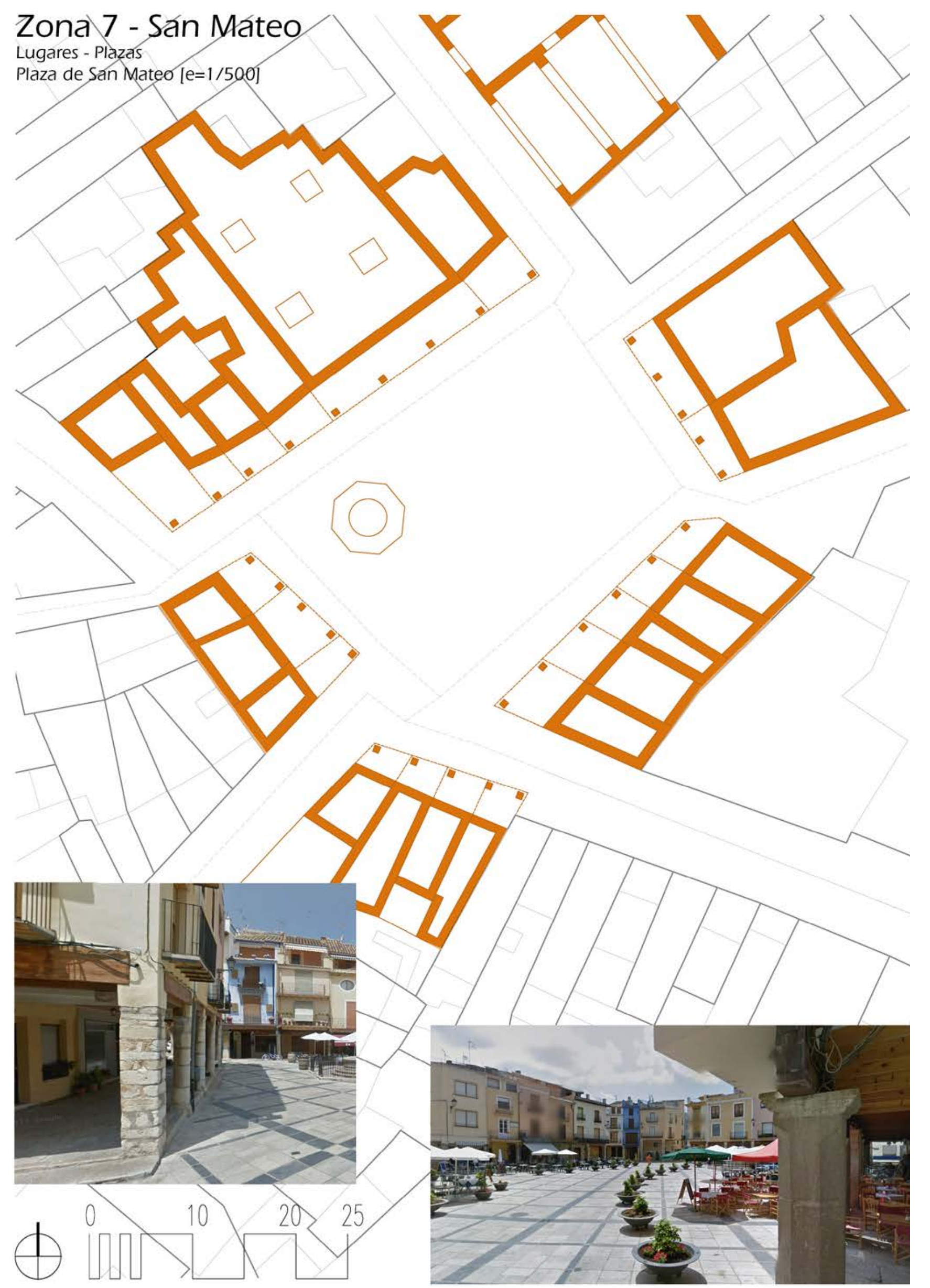


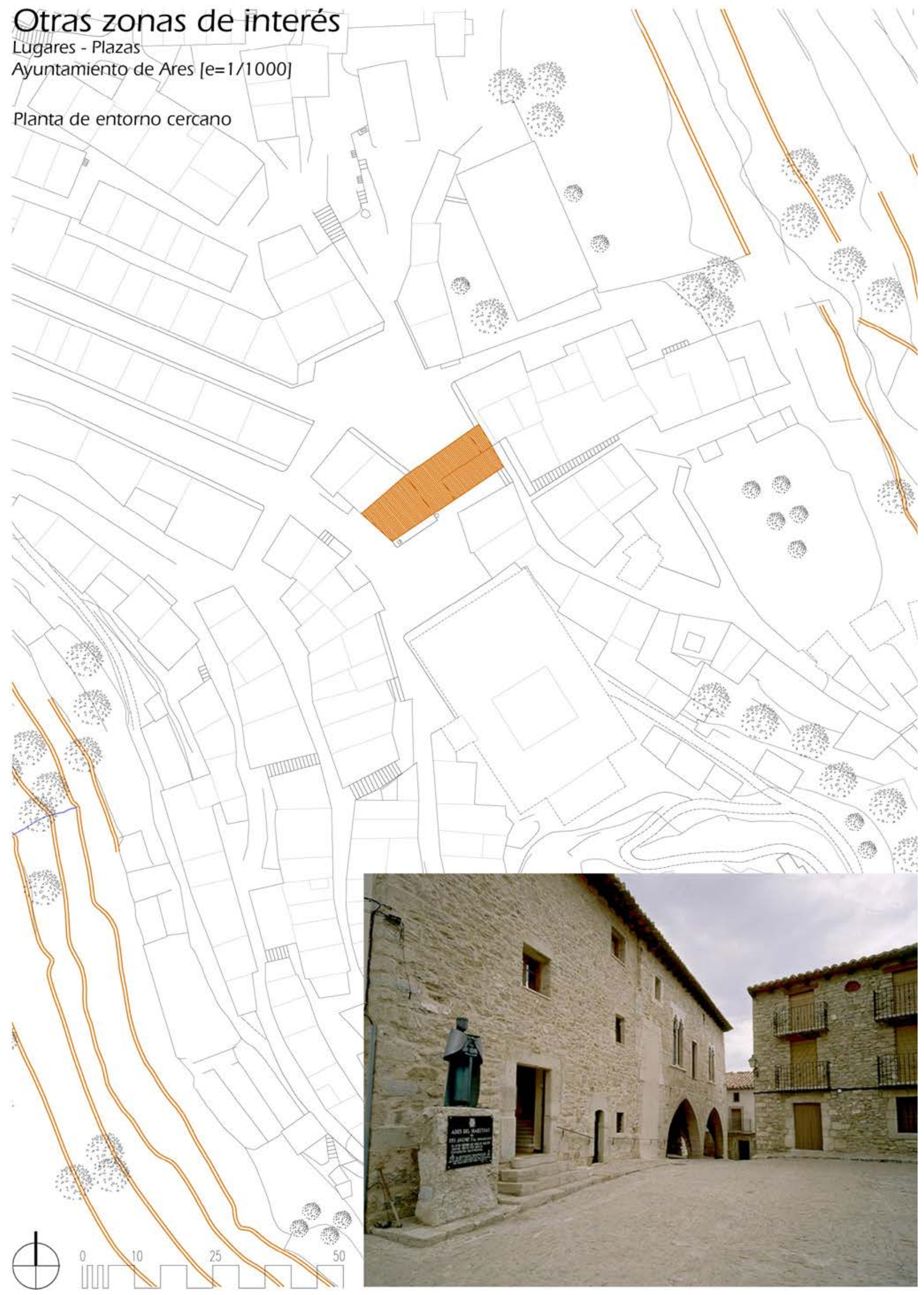




\section{Zona 10 - Cervera / Calig}

Lugares - Castillos

Castillo de Cervera $[e=1 / 2000]$
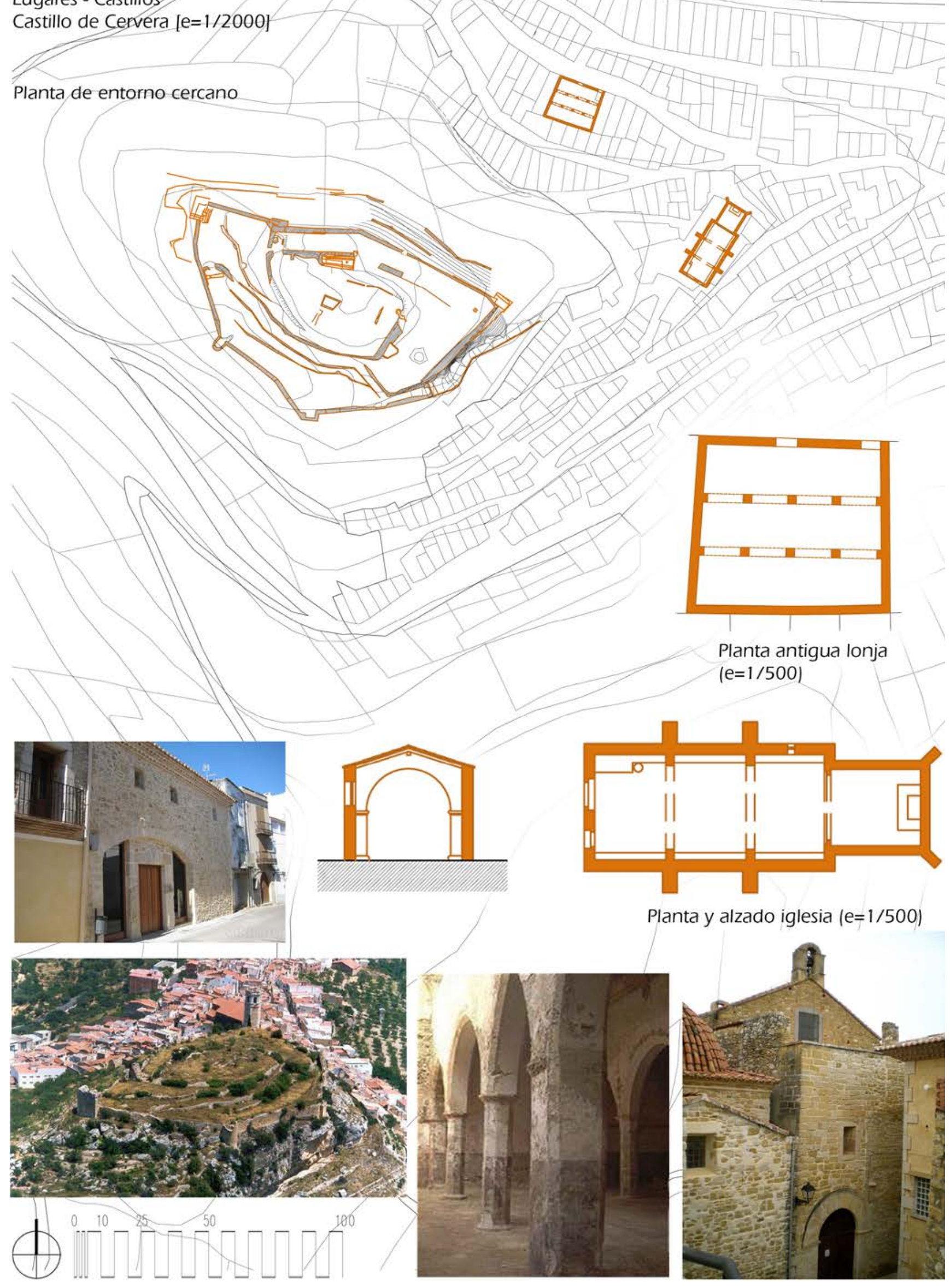

Planta antigua Ionja

$(\mathrm{e}=1 / 500)$ 


\section{Zona 3 - Molinar / Xert}

Lugares - Torres

Torre Solsides $[\mathrm{e}=1 / 1000]$

Planta edificio y entorno

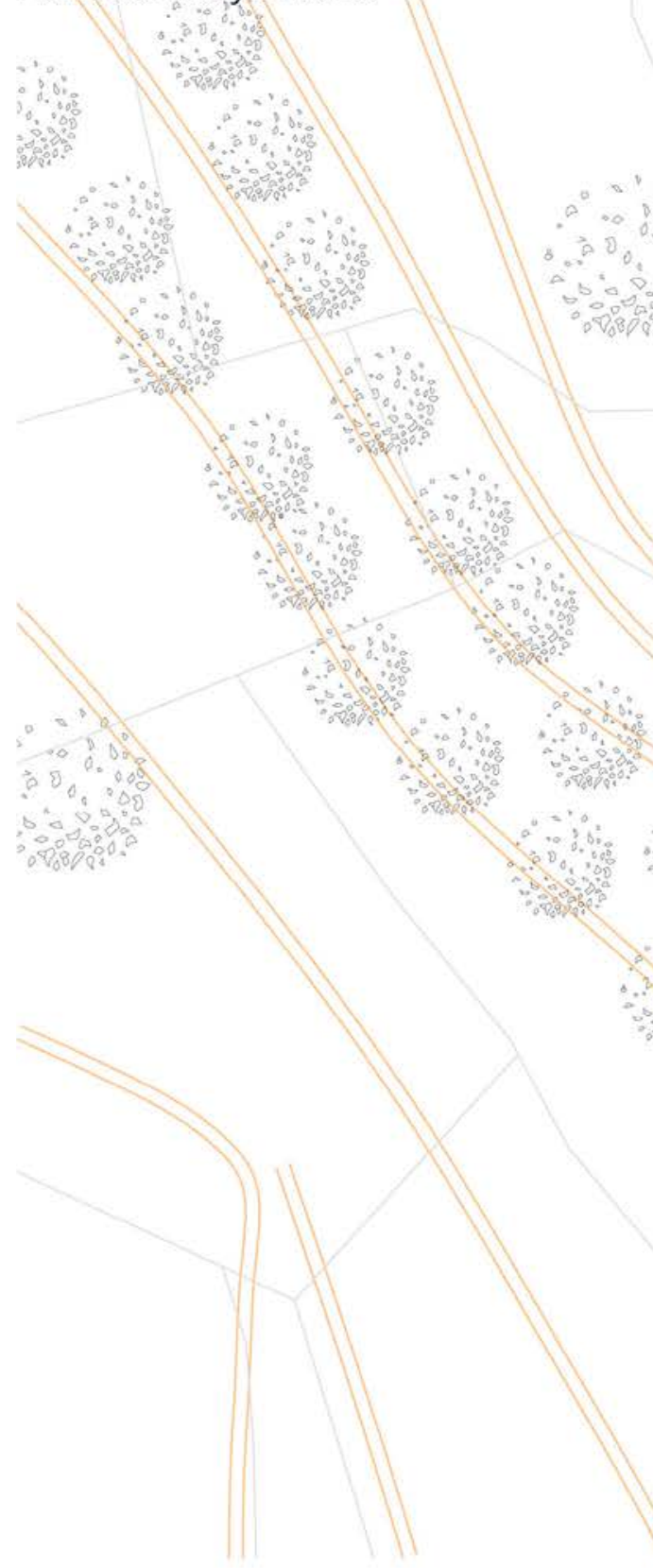

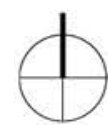
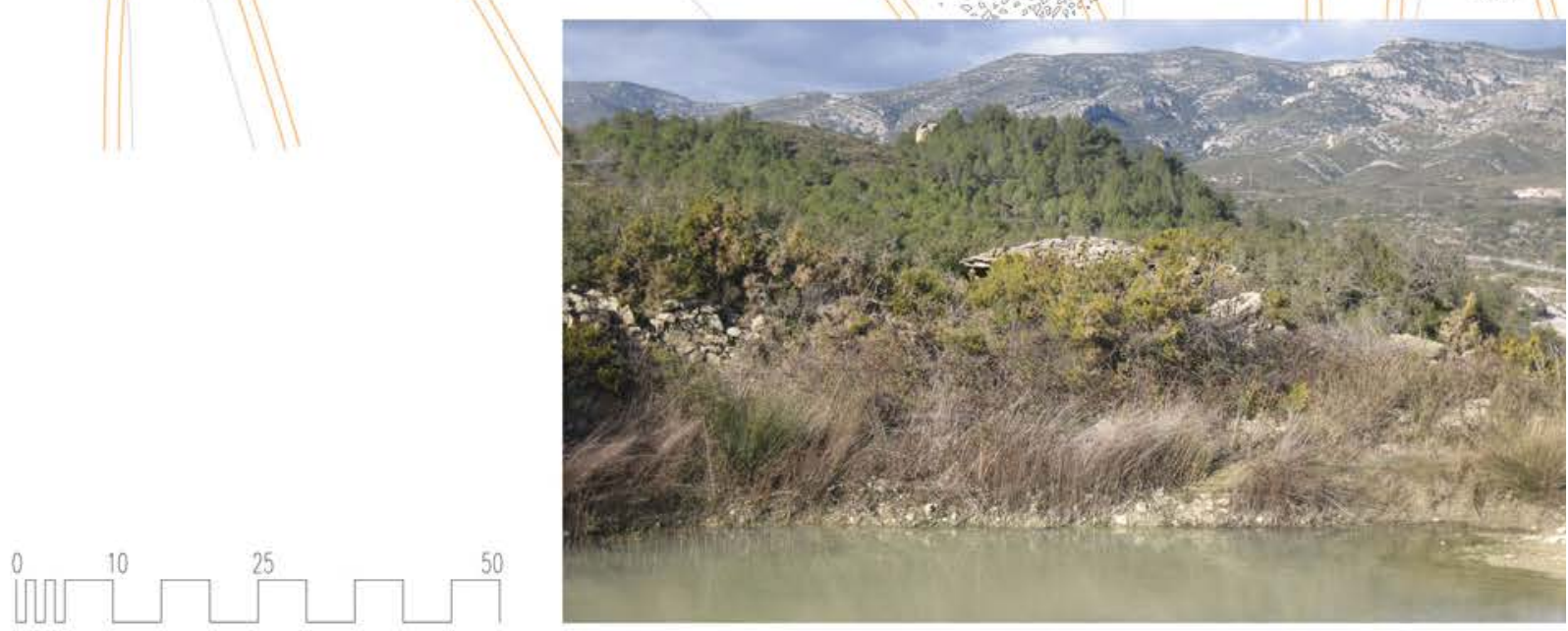


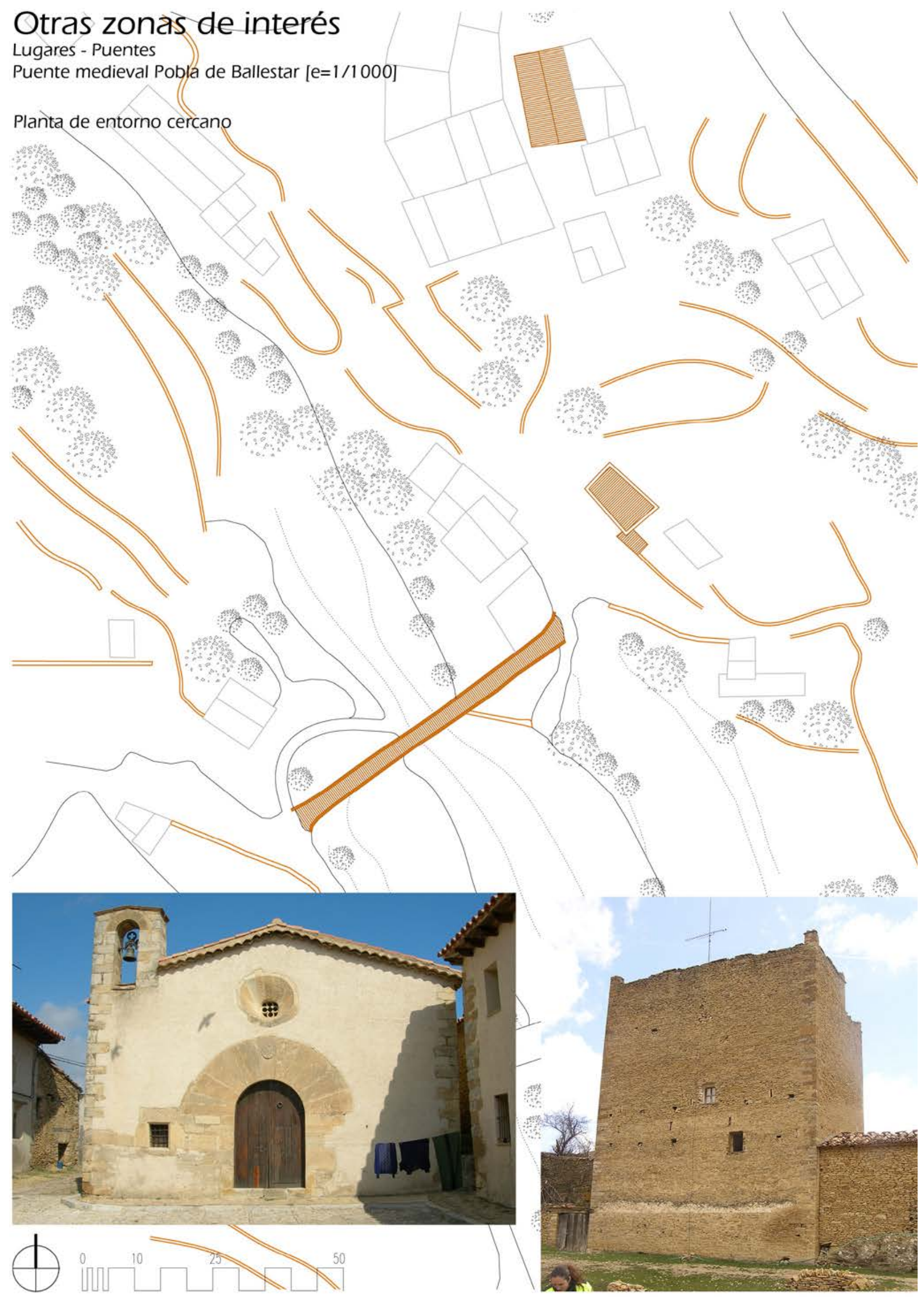



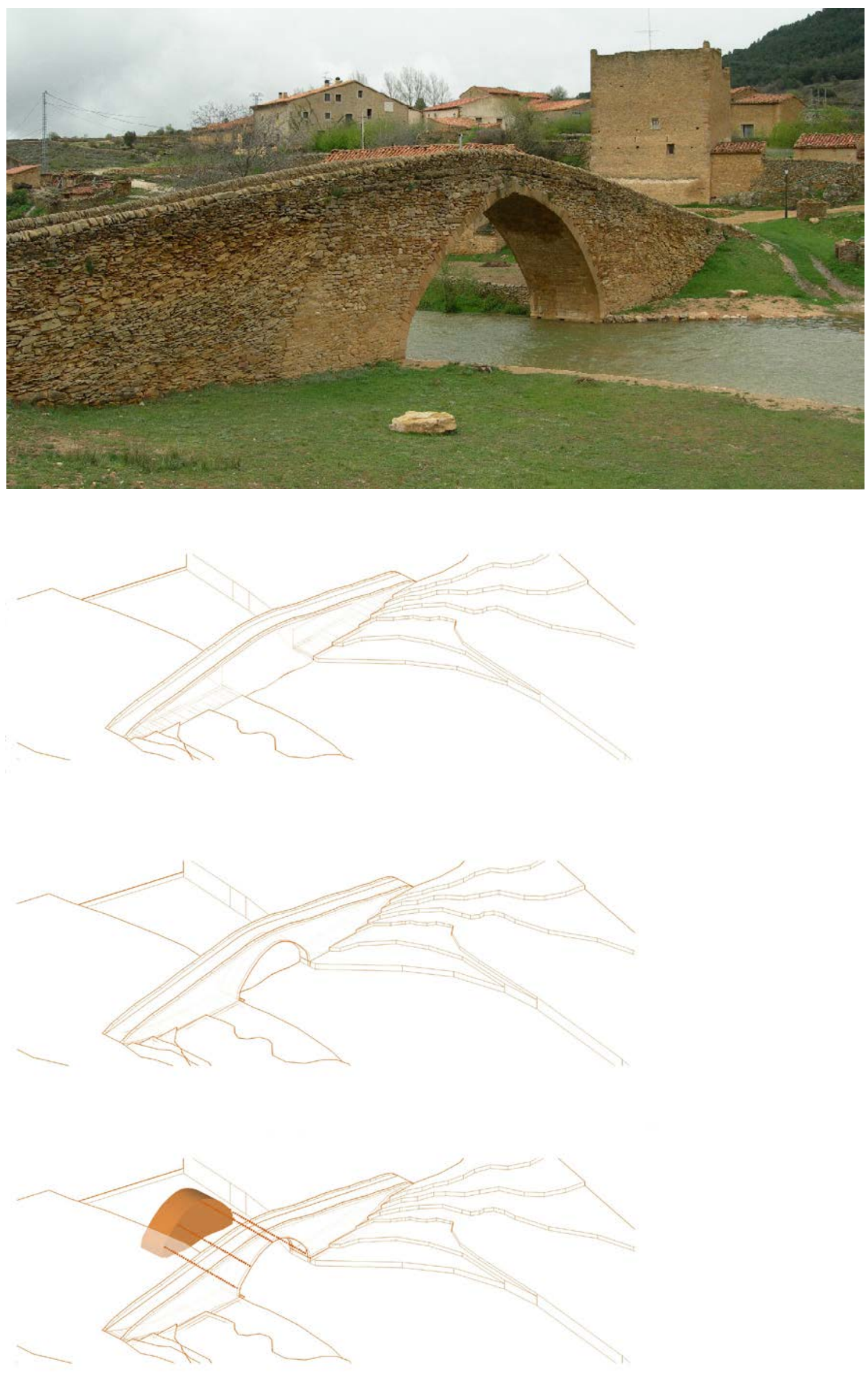


\section{Zona 7 - San Mateo}

\section{Lugares - Palacios}

Palacio de San Mateo $[\mathrm{e}=1 / 1000 \gamma$

Planta de entorno

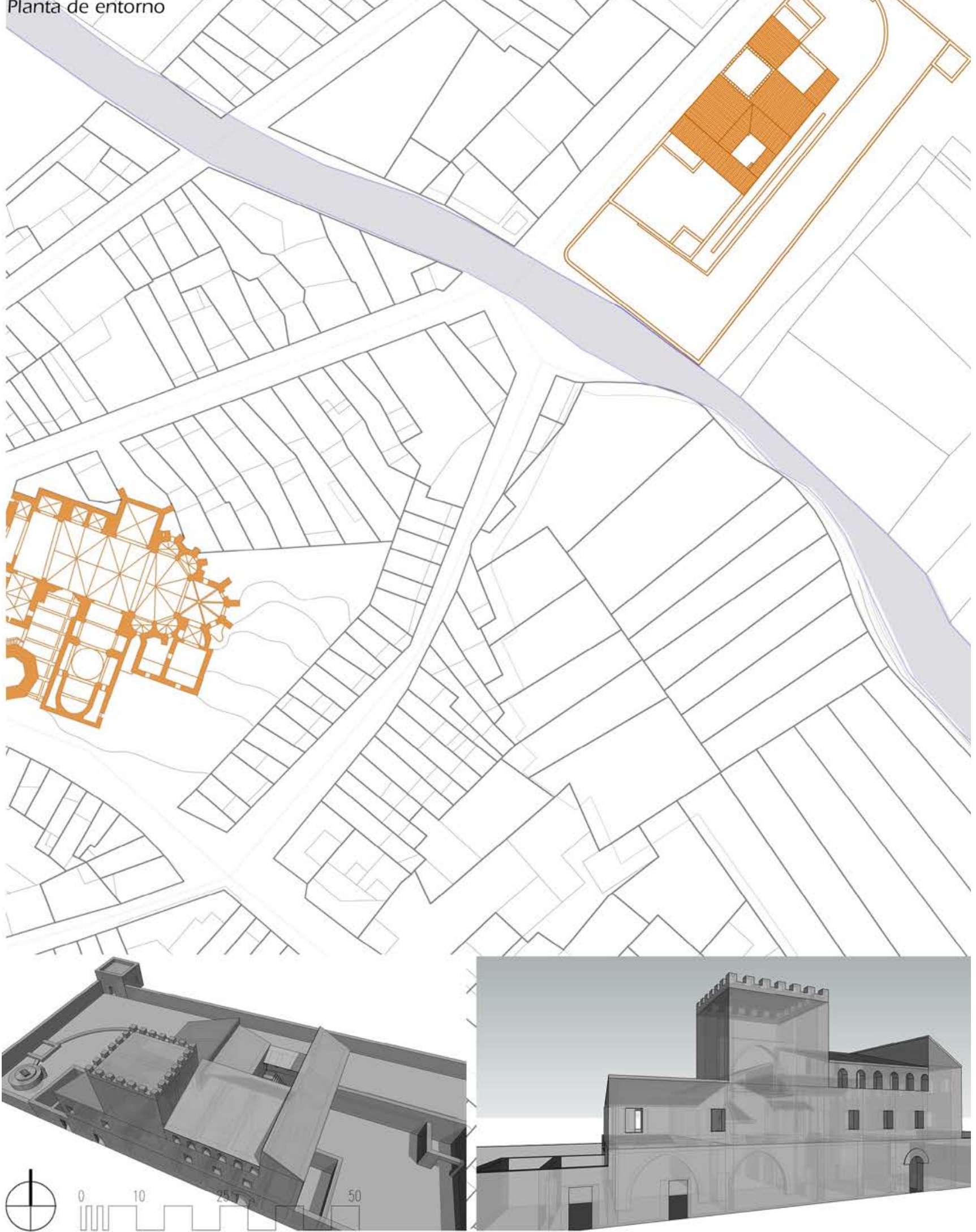




\section{Zona 5 - Canet}

Lugares - Abrevaderos

Font de la Roca $[e=1 / 1000]$

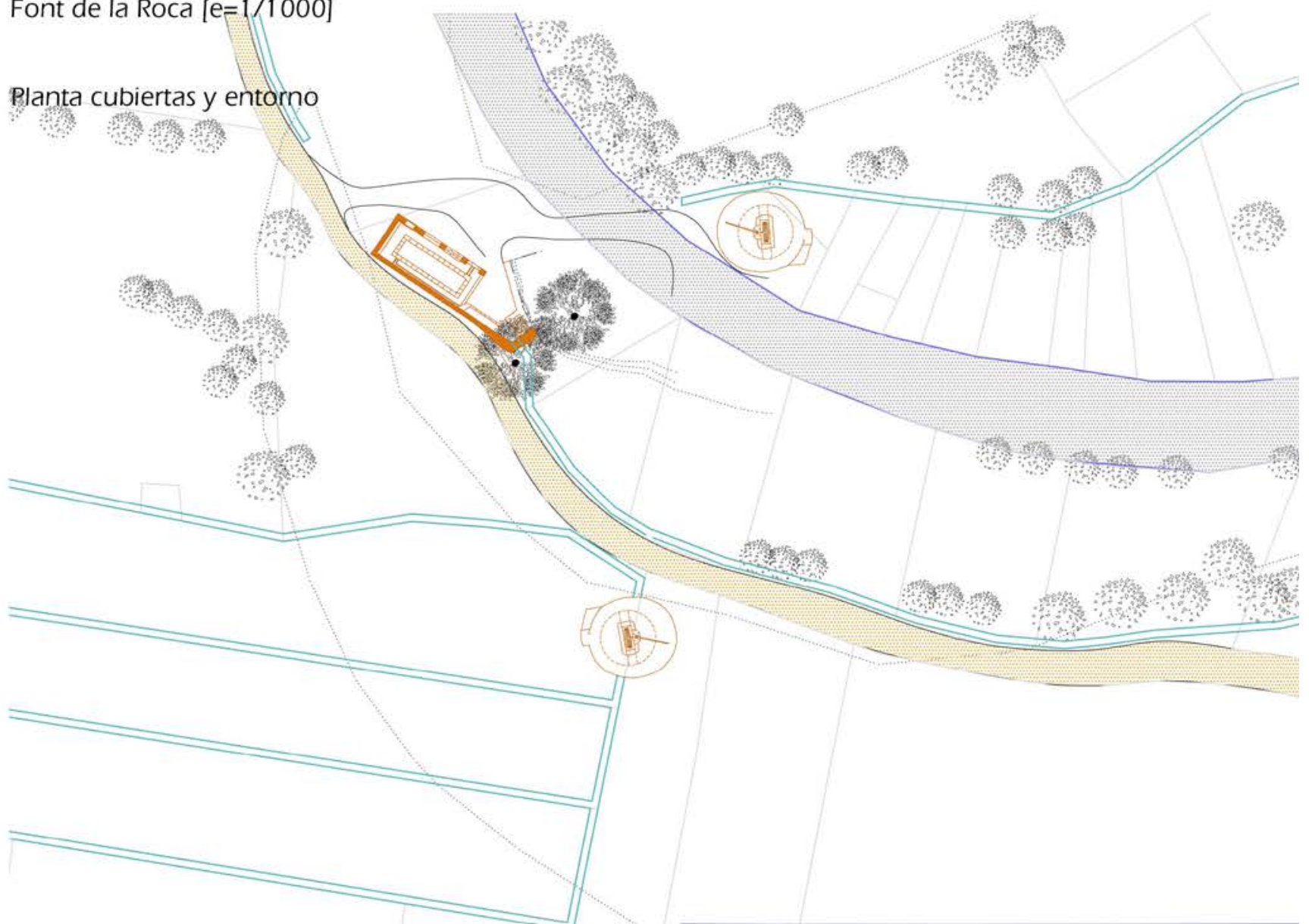

管
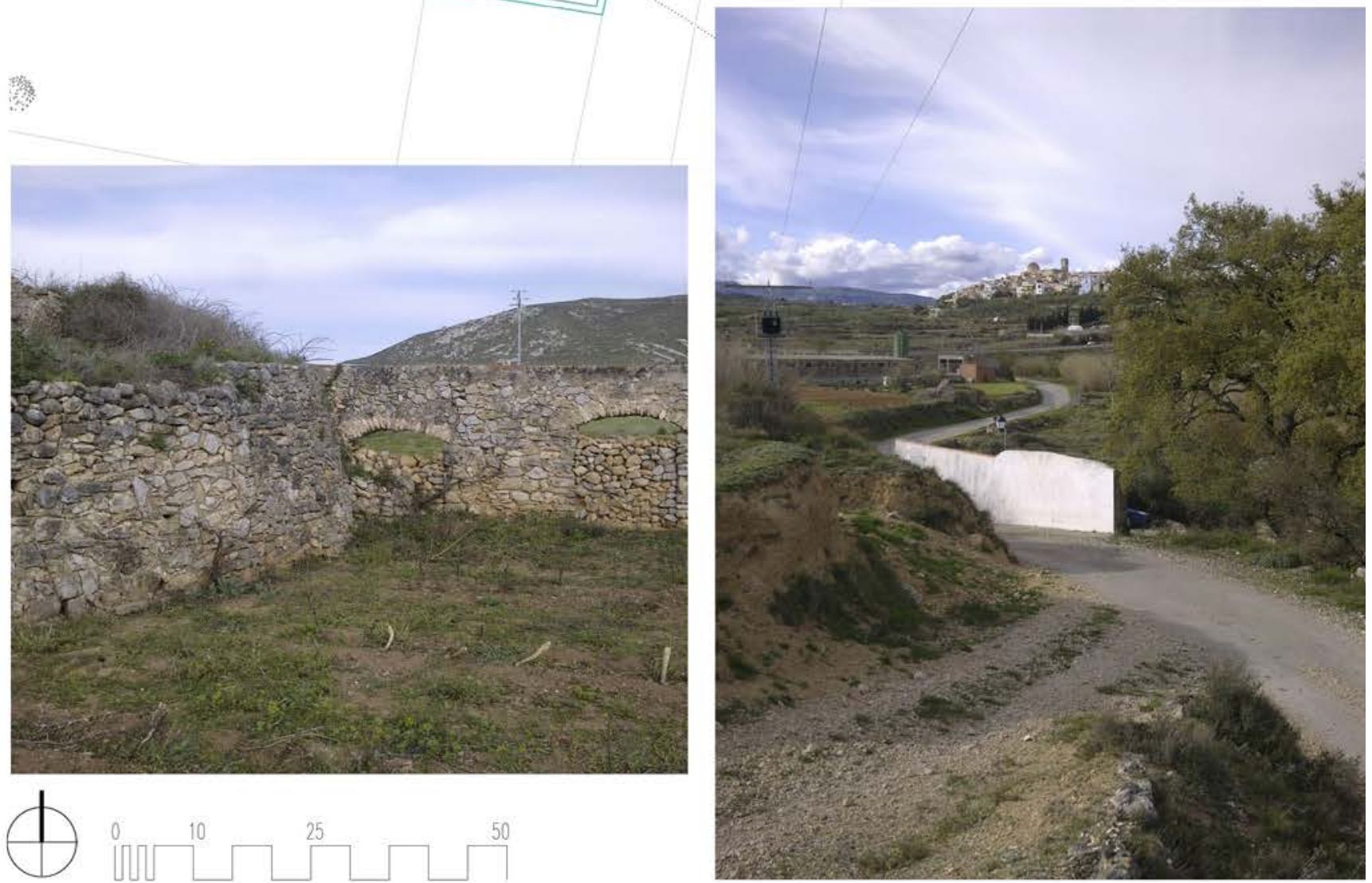


\section{Zona 7 - San Mateo} Lugares - Abrevaderos

Abrevadero San Mateo [e=1/4000]

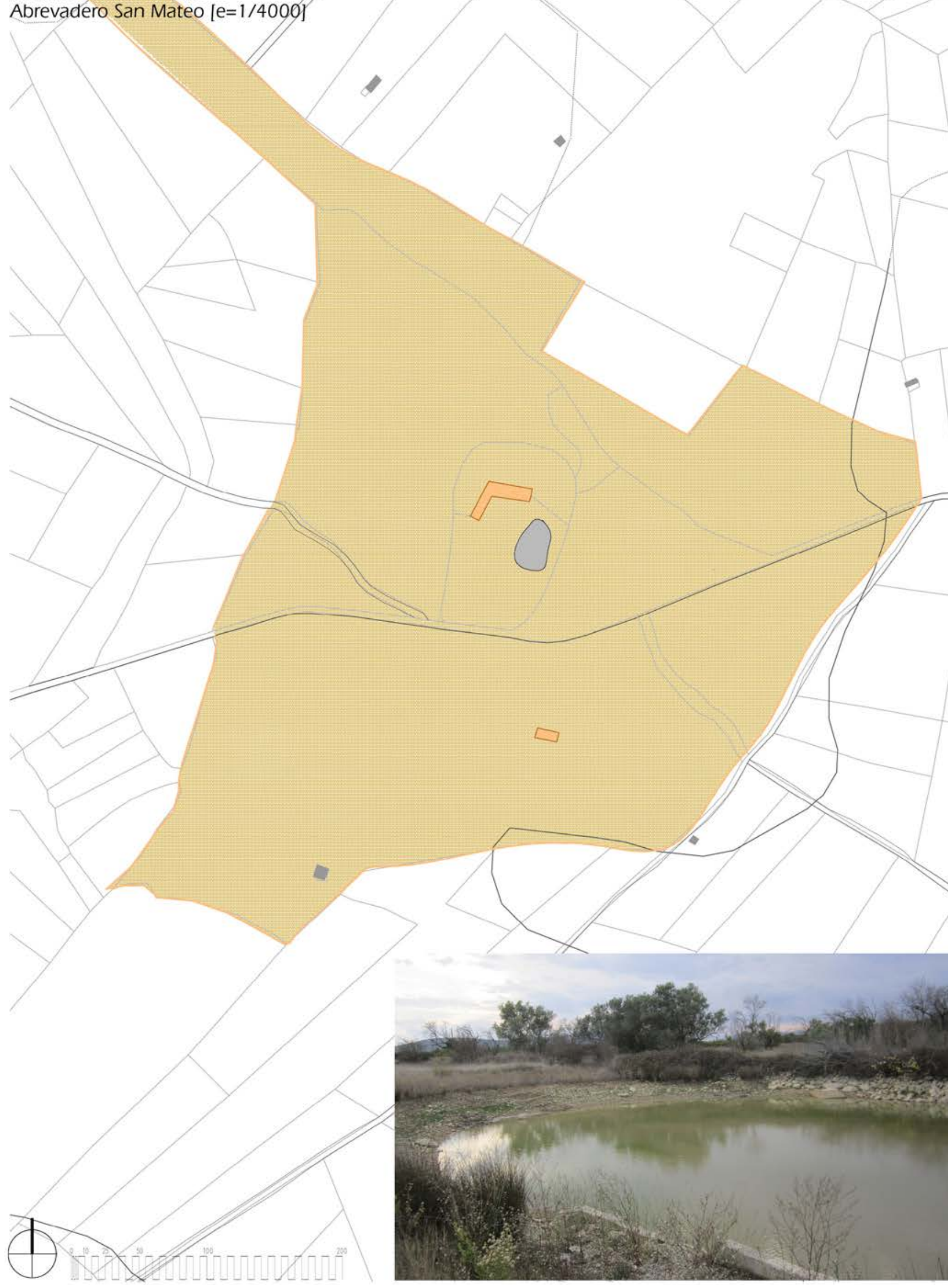




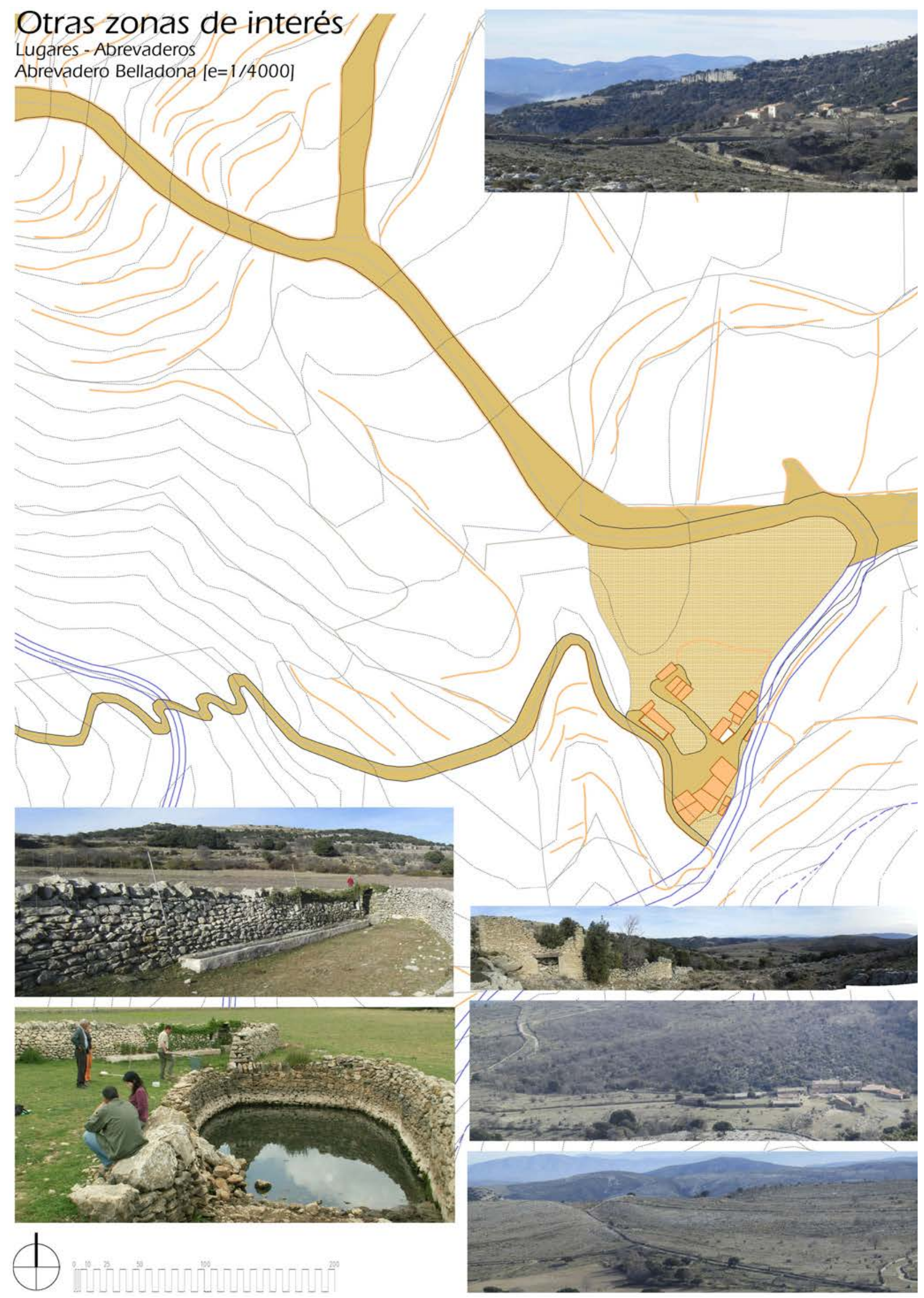


La construcción del lugar no es un proceso simple o unívoco, los elementos estrictamente constructivos se unen a otros culturales. Tan importante es la configuración material de las arquitecturas, como el modo en que estas realidades son asumidas por los habitantes de la región.

El genuis representa esa permanencia en el lugar y sus elementos a lo largo de la historia, que podemos referirla a la tradición del lugar, como tradición en continua formación que incorpora esa consideración cambiante de su carácter singular, según las circunstancias que lo determinan.

La "costumbre" que el lugar tiende a imponer es el "genuis loci", es lo que permite distinguir con sentido una morfología geométricamente ordenada y a la vez adaptada al lugar, de una yuxtaposición de tejidos derivada de una lenta sedimentación en el tiempo. El "genuis loci" le da un carácter irrepetible y singular a los hechos territoriales.

El hombre primitivo experimentaba su entorno como una revelación de genii determinadas, y consideraba que era necesario llegar a un entendimiento con el Genius del lugar donde transcurría su vida. Tenía una visión religiosa organizada del territorio con arreglo a su sistema de creencias.

"Porque he aquí, por ejemplo, que una inscripción romana diviniza el mismo nombre que tiene uno de los montes más altos o perceptibles del territorio, que otra nos da cuenta de que en cierta angostura fluvial se dio culto a unas ninfas salutíferas, que una tercera nos habla de divinidades con carácter más enigmático o con nombres difíciles de interpretar. Así pues, el paisaje ha estado animado, poblado podríamos decir, por númenes de los que las generaciones actuales no conservan memoria. Pero he aquí que si de ellos no lo hay, si existe de otros que se creía a la par que existían, como lo demuestran ciertos nombres y leyendas vinculadas a un riachuelo, un grupo de rocas o una parte del bosque". ${ }^{125}$

Rossi se centra en la relación entre la memoria colectiva y el espacio:

"Cuando un grupo se inserta en una parte del espacio, lo transforma a su imagen, pero al mismo tiempo se pliega y adapta a los hechos materiales que se le resisten. El se encierra en el cuadro que ha construido: La imagen del ambiente externo, y de las relaciones estables que le ligan con él, pasa al primer plano de la idea que el grupo se hace de sí mismo". ${ }^{126}$

Por ello, en el proceso a través del cual los grupos sociales adquieren su individualidad, la imagen del espacio ocupado adquiere un papel destacado. El reconocimiento del lugar supone un reconocimiento de la propia identidad social.

El territorio aparece así como el locus de la memoria colectiva. Esta relación entre el locus y sus habitantes llega a ser la imagen preeminente, la arquitectura, el paisaje; y como los hechos vuelven a entrar en la memoria nuevos hechos crecen en el territorio. En este sentido completamente positivo las grandes ideas recorren la historia del territorio y la conforman.

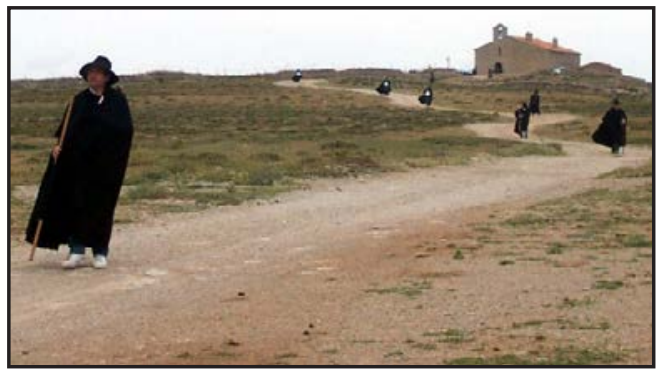

Fig. 5. 34. Foto actual de la romería desde Portell a Sant Pere de Castellfot.
Esta memoria supone la existencia de unas imágenes formales -arquitecturas- que constituyen un acervo común, que se mantienen y perfilan a lo largo del tiempo y proporcionan un marco de referencia imprescindible para las percepciones y recuerdos personales.

De los distintos "genuis loci" que hemos detectado, merece la pena destacar el de las Ermitas. Han perdurado hasta nuestros días y las peregrinaciones periódicas que aún se realizan permiten mantener la memoria colectiva del territorio.

125 CARO BAROJA, J “Arte visoria” pág. 32

126 HALBWACHS, M. ’La mémorie collective” pág. 132 


\section{4. La estructura de la estructura: los tejidos}

Los lugares -si analizamos el territorio por capas sucesivas siguiendo un proceso iterativo cada vez más complejo- podemos considerarlos elementos que se relacionan entre sí y forman sistemas.

\section{La relación entre los lugares}

Del mismo modo que ocurre con las redes, los lugares se relacionan entre sí de tres formas distintas según cual sea la conectividad entre ellos:

- Conexión, si la conectividad se realiza mediante un espacio construido.

- Yuxtaposición, si la conectividad se realiza sin espacio intermedio.

- Interconexión cuando se busca la autonomía de cada tipo, a la vez que interactúan funcionalmente.
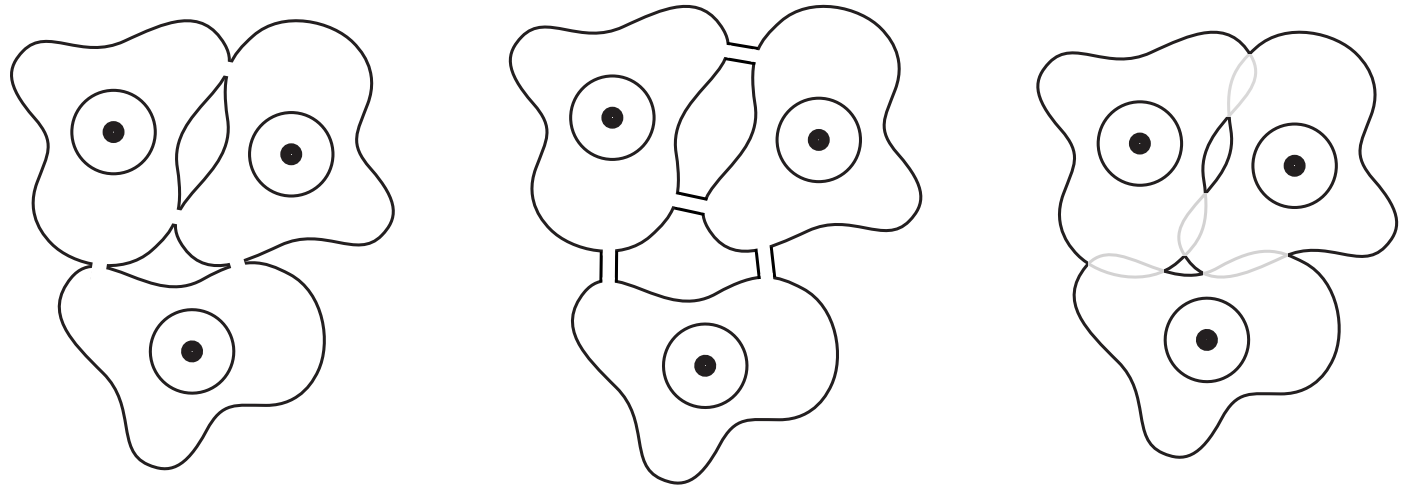

Fig. 5. 35. Esquemas de relaciones entre lugares mediante yuxtaposición, conexión o imágenes de agrupaciones interconexión.

\section{La agrupación de los lugares}

De forma análoga a la del análisis de los elementos antroposociales, podemos considerar que los lugares se pueden agrupar de acuerdo con cuatro modelos básicos de agrupación, cuatro tipos de disposición, de organización topológica de la forma, modelos de crecimiento y de generación espacial. Las formas de agrupación de los sistemas son:

- Agrupación compacta, en la que no se dejan espacios intersticiales, por ejemplo las masías.

- Agrupación en cadena, son secuencias de elementos conectados linealmente, sería el caso de los molinos a lo largo de un río o una acequia, el de las masías a lo largo de un camino o el de los abrevaderos a lo largo de un azagador.

- Agrupación concéntrica o cerrada, es aquella en la que los elementos se concentran en torno a un centro o espacio común, seria el caso del castillo y torres situadas en su en torno.

- Agrupación en malla este, caso en el que los elementos se conectan a partir de una malla de dos o más direcciones, seria el caso de los lugares de las ermitas que "sacralizan” el territorio. 


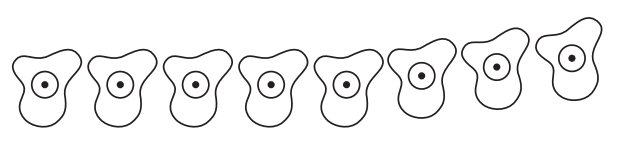

Fig. 5. 36. Esquema agrupación en cadena de lugares.

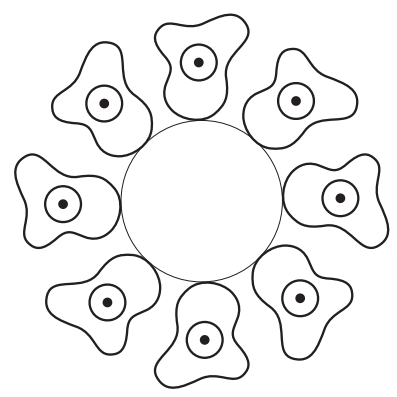

Fig. 5. 38. Esquema agrupación radial de lugares.

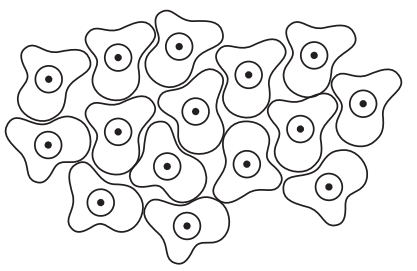

Fig. 5. 37. Esquema agrupación compacta de lugares.

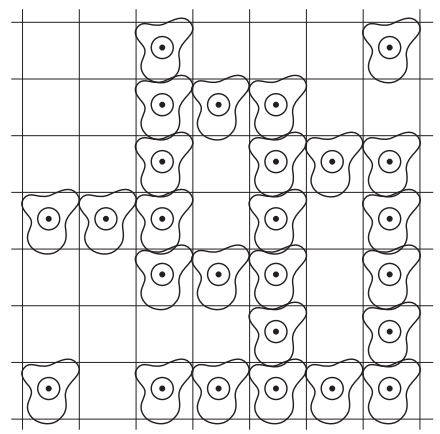

Fig. 5. 39. Esquema agrupación en malla de lugares.

Estas relaciones crean unos sistemas de lugares que denominaremos tejidos que se "tejen" sobre el cañamazo del soporte inicial. Podemos clasificarlos en los siguientes tipos:

- Tejido agrícola de secano asociado a masías, es el que constituyen la mayor parte de los distintos lugares-masías de este Territorio. Las propiedades son continuas, la unidad de propiedad es la que da la unidad a la textura. Puede ser lineal cuando se disponen a lo largo de un camino, que a su vez se pueden subdividir en peine, espina o racimo; concéntrico cuando se disponen alrededor de un centro como una ciudad o un castillo; en malla cuando se disponen formando una red en varias direcciones y se apoyan en una malla de infraestructuras y compacta cuando se trata de un conjunto de varias masías adosadas -sería el germen de un núcleo urbano-.

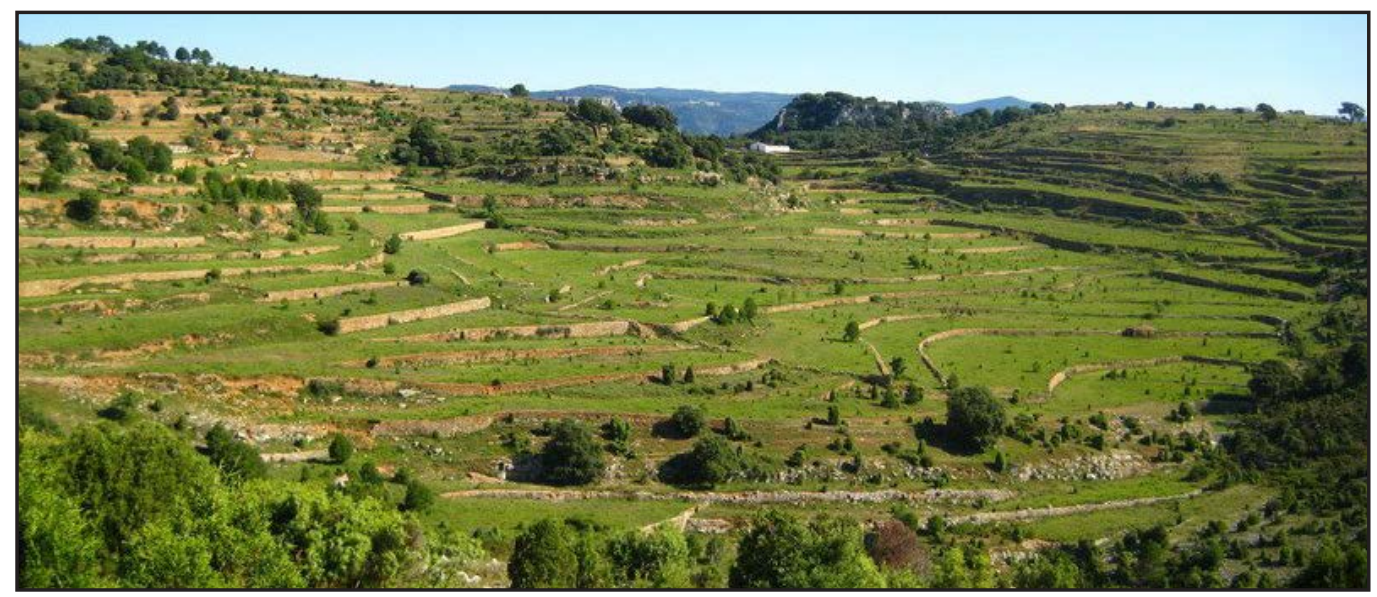

Fig. 5. 40. Foto tejido agrícola de secano asociado masías en Bel.

La geometría de estos tejidos es función de la topología del soporte. En el caso de un terreno con pendientes importantes tienen formas de arabescos irregulares y orgánicos, ocupa solo una parte reducida, por lo que se lee como "vacíos cultivados" en el interior de un territorio de bosques y pastos. Ejemplos de este tejido se encuentran en: zonas de montaña de Bel, Rosell, Xert, Sant Mateu y Cervera; en el valle de La Barcella; en las laderas de Xert y Rosell. 
En el caso de un terreno con pendientes menos pronunciadas tiene formas regulares de

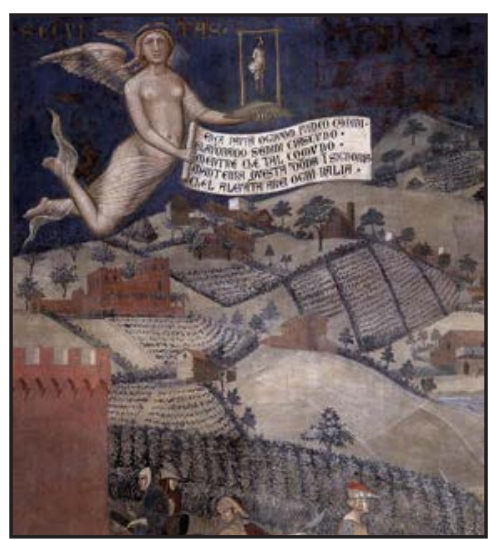

Fig. 5. 41. Foto tejido agrícola de secano asociado masías del cuadro de A. Lorenzetti "Los efectos del buen gobierno" Siena, entre 1338 y 1340. mosaico junto con otras más orgánicas de arabescos en las zonas de más pendiente; ocupa gran parte del territorio de la masía, dejando algunos "vacíos" de bosques o pastos. Ejemplos de este tejido se encuentran en: zonas de las laderas de Xert y Rosell y el altiplanoondulado de Sant Mateu, Canet, Traiguera, Calig y Cervera.

En el caso de un terreno sensiblemente llano tiene forma de alfombras regulares y rectangulares; ocupa la totalidad del territorio sin dejar "vacíos", exceptuando las zonas junto a las pocas irregularidades del terreno como barrancos o ríos. Ejemplos de este tejido se encuentran en: zonas de llano de Sant Mateu, Canet, La Jana y Carrascal.

- Tejido agrícola de secano asociado a un núcleo urbano. Es el tejido situado en sus alrededores, los agricultores residen en la ciudad y se desplazan todos los días a trabajar al campo; sus propiedades no son continuas, de forma que en este tejido se entremezclan varios propietarios, siendo la unidad del tipo de cultivo la que da la unidad a la textura del territorio. La disposición normalmente es concéntrica -o radial-alrededor del núcleo urbano o en malla si la topología del territorio lo exige. Raramente es lineal exclusivamente, aunque bien es cierto que en la disposición radial en ocasiones existe una dirección principal, como es en el caso del territorio de ladera, en el que el camino de en medio destaca sobre los otros.

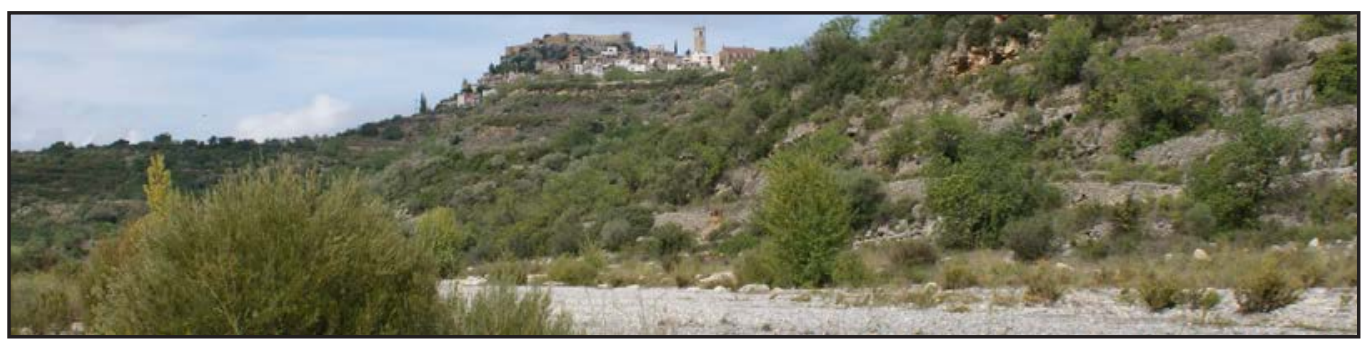

Fig. 5. 42. Foto tejido agrícola asociado al núcleo urbano en Cervera.

La geometría de estos tejidos es función de la topología del soporte. En el caso de un terreno con pendientes importantes tienen formas de arabescos irregulares y orgánicos, ocupa solo la zona más próxima al núcleo urbano, por lo que se lee como un suelo modelado en torno al núcleo urbano. Este suelo será el que con el tiempo guiará el crecimiento del núcleo urbano. Ejemplos de este tejido se encuentran en: zonas de montaña como Bel o de valle como La Barcella.

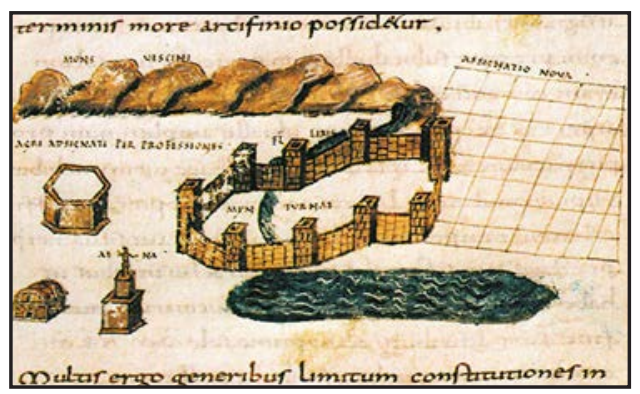

Fig. 5. 43. Dibujo tejido agrícola de secano asociado al núcleo urbano en dibujo del Corpus Agrimensorum (Figura 89).
En el caso de un terreno con pendientes menos pronunciadas tiene formas regulares de mosaico, su extensión es mucho mayor y apenas deja "vacíos"; destinando más superficie en estos núcleos urbanos a este tejido que al de las masías. Ejemplos de este tejido se encuentran en: zonas de las laderas de Xert y Rosell y el altiplano-ondulado de Sant Mateu, Canet, Traiguera, Calig y Cervera.

En el caso de un terreno sensiblemente llano tiene forma de alfombras regulares $y$ rectangulares, su extensión es mucho mayor y 
no deja "vacíos"; destinando casi la totalidad de la superficie en estos núcleos urbanos a este tejido en detrimento del de las masías. Ejemplos de este tejido se encuentran en: zonas de llano de Sant Mateu, Canet, La Jana y Carrascal.

- Tejido agrícola de regadío asociado a una pequeña parte de los lugares-masías de este Territorio. Solo se dan en algunos pocos emplazamientos y además no se da de forma exclusiva sino asociado a lugares-masía de secano. Es siempre en este territorio de carácter lineal -peine o espina- y asociado a un barranco, río o acequia. Estos tejidos tiene geometría de piezas de un puzzle de un grano más fino dentro del conjunto de un mosaico más amplio. Este tejido se da junto a los barrancos o ríos, en las zonas de ladera como Xert o Rosell y en las zonas de altiplano como Cervera, Sant Mateu o Traiguera.

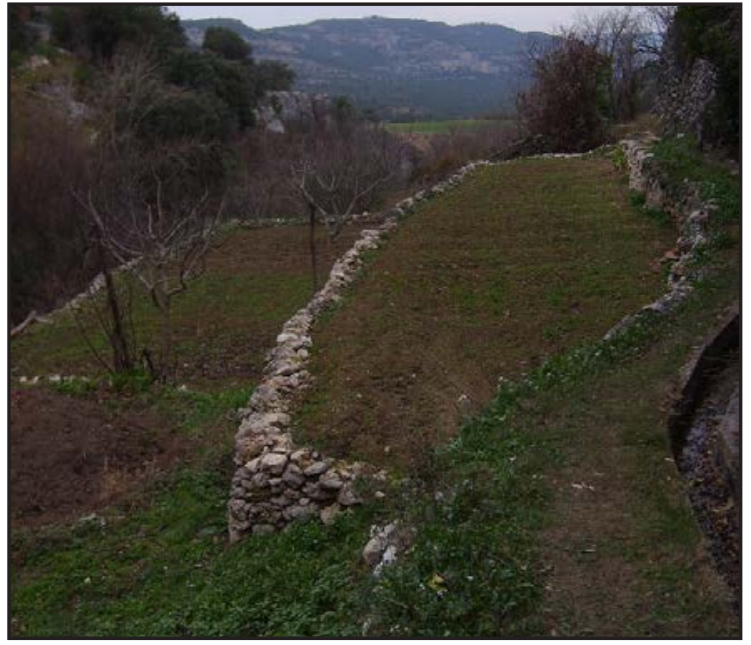

Fig. 5. 44. Foto tejido agrícola de regadío asociado al núcleo urbano.

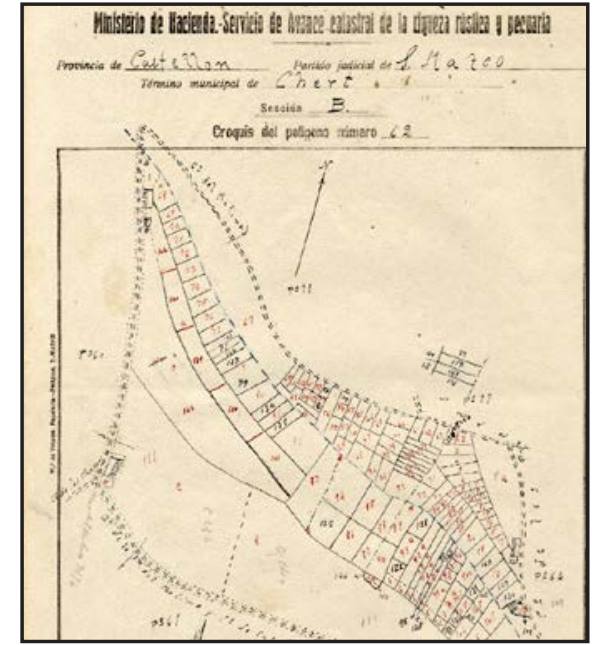

Fig. 5. 45. Croquis de tejido agrícola de regadío asociado a masías o molinos.

- Tejido agrícola de regadío asociado a una ciudad. Es el tejido situado en los alrededores de un núcleo urbano, los agricultores residen en la ciudad y se desplazan todos los días a trabajar al campo; sus propiedades no son continuas, de forma que en este tejido se entremezclan varios propietarios, siendo la unidad del tipo de cultivo la que da la unidad a la textura del territorio.

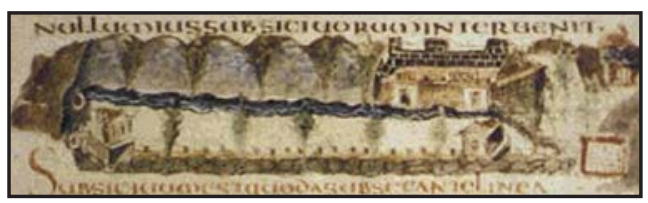

Fig. 5. 46. Dibujo tejido agrícola de regadío asociado a núcleo urbano en dibujo del Corpus Agrimensorum (Figura $6)$.

que da una lectura con una textura de Sant Mateu, Canet, Carrascal y la Jana.

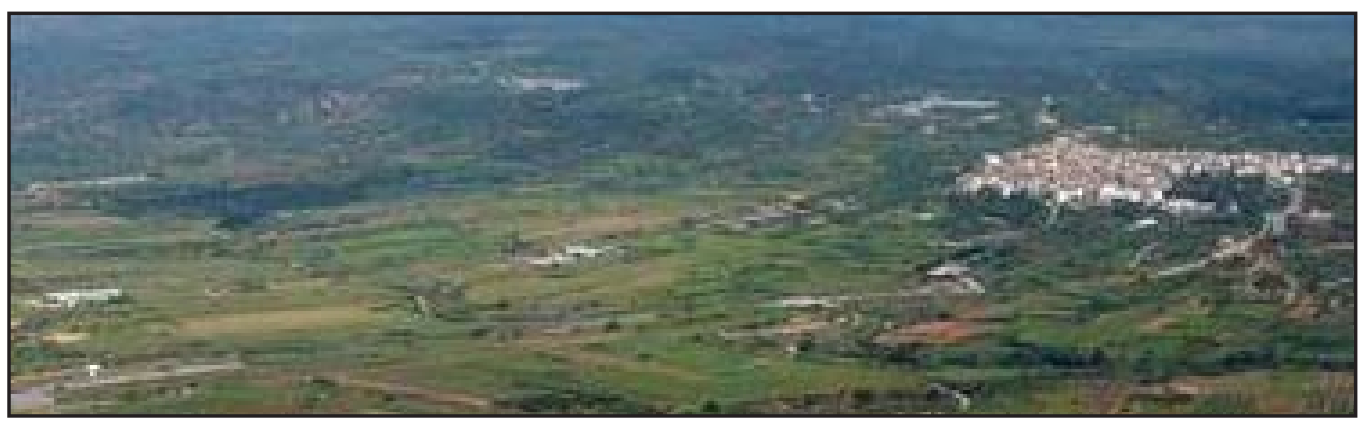

Fig. 5. 47. Tejido agrícola de regadío asociado a una ciudad, vista del llano de Canet.

Solo se de en los territorios llanos, la disposición es siempre de carácter lineal -peine o espina- y asociado a un barranco, río, acequia o manantial. Tiene la geometría de una alfombra plana hecha de formas rectangulares mucho más pequeñas $\mathrm{y}$ estrechas que las del territorio llano de secano, no más fina. Este tejido se da en el entorno de . 
- Tejido "preindustrial” formado por los molinos. Su disposición es siempre lineal a lo largo del cauce de un río, barranco o de una acequia. Los distintos lugares que forman el tejido en ocasiones están separados dificultando la lectura del tejido como tal. La forma que tienen es la de un rosario "unido" por un curso de agua.

Este tejido se da en las orillas de los ríos Cenia y Cervol; así como en los barrancos de las laderas de Xert.

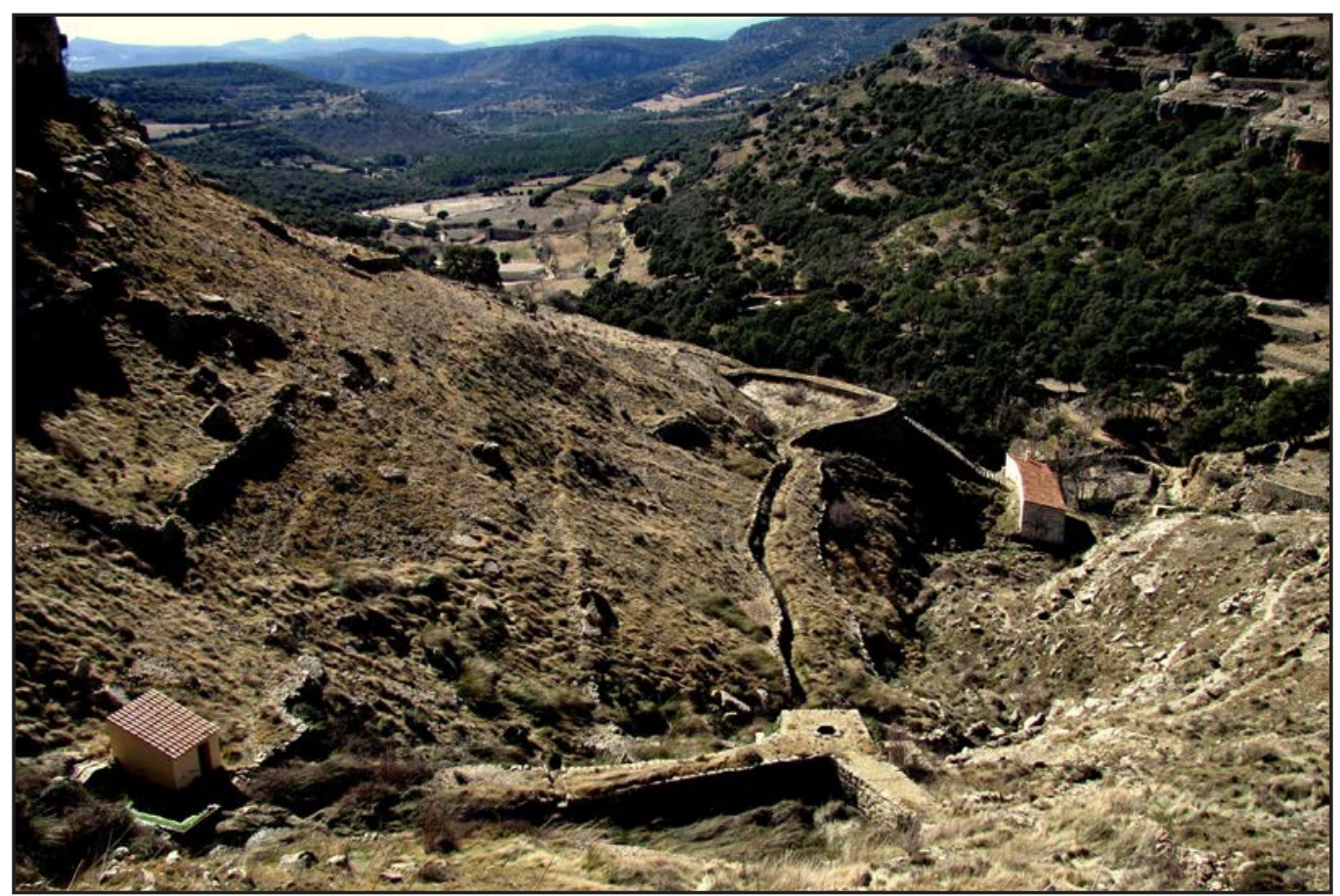

Fig. 5. 48. Vista de tejido preindustrial. Molinos en Ares del Maestre.

- Tejido ganadero formado por: los azagadores, la sucesión de abrevaderos-descansaderos a lo largo de los mismos, zonas de control y "peaje" y las zonas de pastos a las que conducen. Es por tanto de carácter lineal ya que el recorrido que realiza un rebaño así lo es, aunque podríamos considerarlo en malla ya que todas las vías pecuarias conforman una malla que se extiende por todo el Territorio.

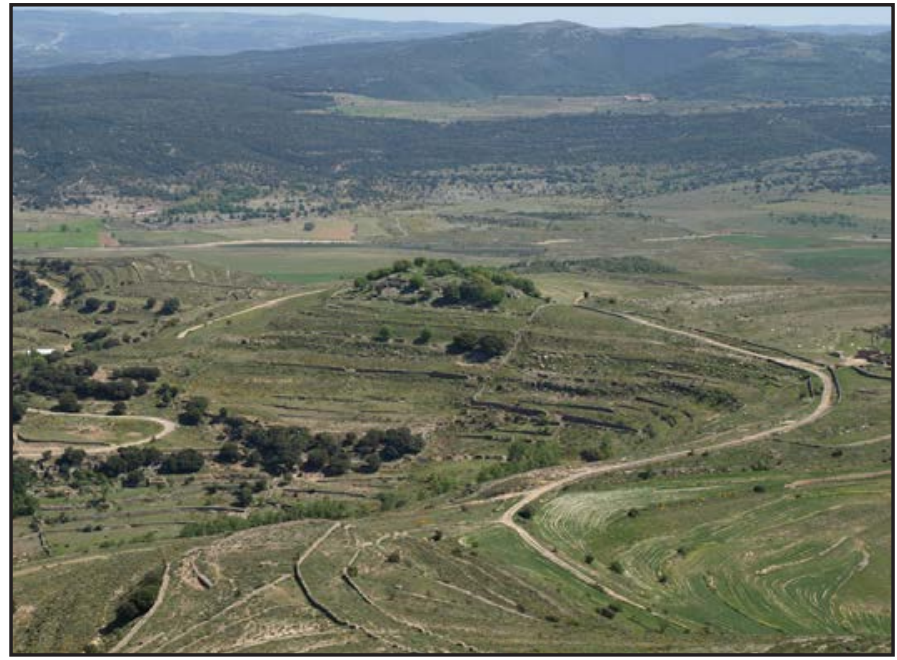

Fig. 5. 49. Foto aérea de la masía de la Belladona en Ares. Tejido ganadero.
Este tejido se da en las zonas de montaña de Bel, Xert, Sant Mateu y Cervera; en el valle de la Barcella; en el altiplano-ondulado de Cervera y en la zona llana de Traiguera entre los rios Cenia y Cervol. El resto de zonas de llano, altiplano o ladera los azagadores solo son de paso, por lo que este tejido tiene mucha menor repercusión.

Podríamos hablar de un segundo tejido ganadero de mucha menor importancia que es el formado por los bovalares que dispuestos por todo el territorio de la Batllia suministran los pastos a los animales que no realizan la trashumancia como bueyes y caballos tan necesarios para ayudar en las labores agrícolas. 
- Tejido defensivo formado por los elementos defensivos que protegen el Territorio. La Batllia inicialmente era un tejido defensivo concéntrico alrededor del castillo de Cervera y con una serie de alquerías -torres que pasaron a ser masias- torres que controlaban todo el territorio y se comunicaban visualmente; entre estas estaban las torres de les Solsides, del molinar, masía del Rey, mas del Coll, torre de Calig, etc. Esta disposición se complementaba con una lineal que protegía las infraestructuras.

Este tejido en el caso de la Batllia se adapto a otro también concéntrico pero con centro en el Palau de Montesa en Sant Mateu, quedando el castillo de Cervera como un subcentro del nuevo centro defensivo situado en Sant Mateu. Esta nueva disposición supuso también la consideración de todos los núcleos urbanos como elementos de ese nuevo tejido defensivo, por lo que todos ellos acometieron obras de construcción de recintos amurallados de mayor o menor relevancia. El tejido de elementos torre se mantuvo y adapto a esta nueva situación. Se trata de un tejido único que abarca a todo el territorio de la Batllia en su conjunto.

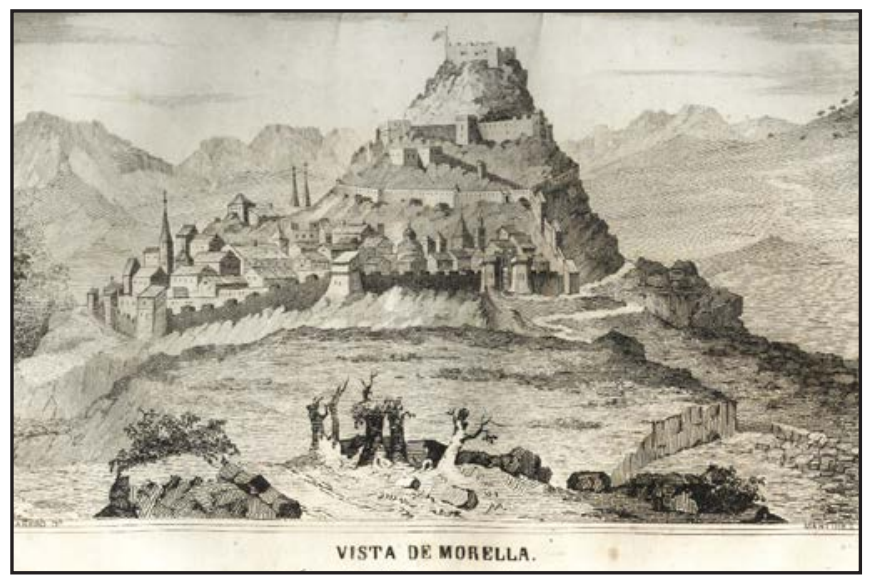

Fig. 5. 50. Tejido defensivo: Murallas y castillo de Morella.

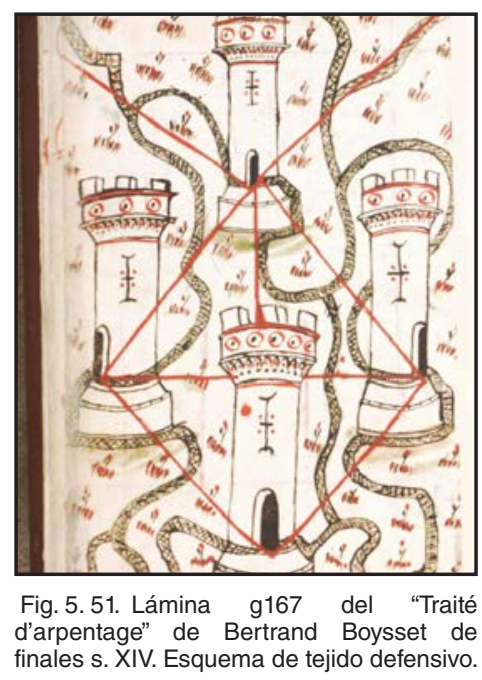

- Tejido religioso es el resultado de la superposición del formado por la división parroquial de la diócesis de Tortosa-se establece una parroquia en cada territorio en el que existe una carta puebla-, y el de los primitivos elementos míticos del territorio como manantiales, atalayas, etc que son sacralizados con la construcción de una ermita. Todos estos elementos conforman una red o malla con conexiones tanto por caminos como visuales.

Este tejido se ve complementado con la construcción de conventos en algunas de las ciudades-en este caso solo en San Mateo-, con la existencia de los cementerios junto a las parroquias y con la disposición de una serie de elementos que imprimen carácter y sacralizan el territorio como son las cruces de término.

Se trata de un tejido único que abarca a toda el territorio de la diócesis por tanto de la Batllia. Su disposición en malla, se distorsiona en parte por la existencia de un foco local- que no acaba de convertirlo en un tejido concéntrico-. Se trata de la iglesia arciprestal de san Mateo que es el foco más importante de este tejido a nivel de la Batllia.

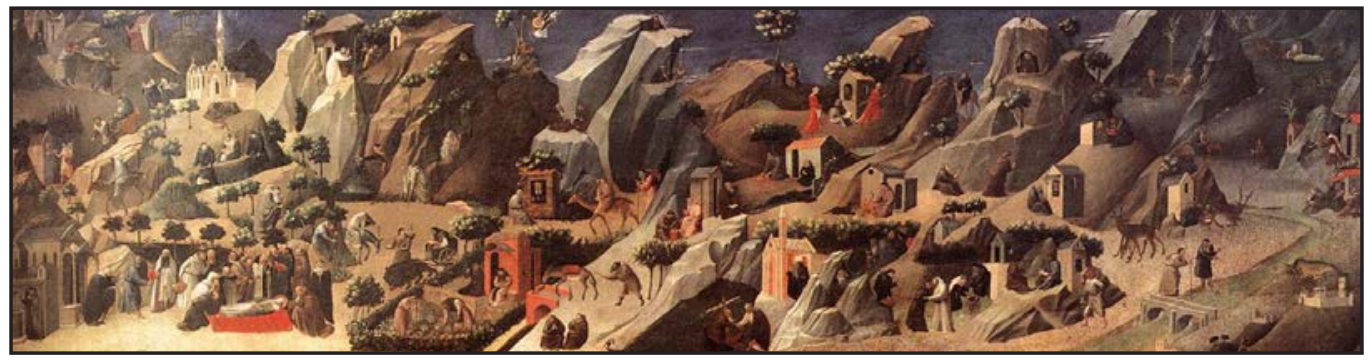

Fig. 5. 52. Pintura de Gherardo Starnina de finales del s. XIV. Tejido religiosos formado por ermitas. 
- Tejido urbano que está constituido por la disposición compacta de diversos lugares/calle y lugares/plaza. El núcleo urbano inicialmente es una simple agrupación "desordenada" como es el caso de Sant Marc de la Barcella o el Carrascal en esta Batllia; o los casos de Sarañana en els Ports y de Coratxar en la Tinença. Posteriormente se puede agrupar a lo largo de una calle, como en el caso de Bel en la Tinença o Las Albaredas y La Llacua en els Ports. Cuando el núcleo urbano adquiere una cierta relevancia, se disponen varias calles y aparecen las plazas como centros de relación social y comercial.

Si el análisis no lo hubiéramos hecho a la escala de la Batllia, sino a una escala mayor, hubiéramos detectado otros tejidos cuyo campo de acción es más amplio. Así hubiéramos "visto" que existe el tejido que conformaban en la Edad Media las Ordenes Militares, del que la Batllia es un elemento; hubiéramos "visto" el tejido de los monasterios del que el Monasterio de Benifassar y su territorio es un elemento y así mismo el tejido de los territorios bajo dominio real directo del que Morella y su comarca forman parte.

Por tanto en nuestro análisis no podemos olvidar que si ampliamos la escala del estudio "surgen" nuevos tejidos que no son perceptibles a la escala en la que estamos trabajando.

Continuando con el análisis a la escala de la Batllia hemos visto nueve tejidos que "tejen" los lugares entre sí y con las redes de infraestructuras, muros, parcelas y usos. Estos nueve tejidos podemos reducirlos a seis: agrícola, ganadero, "preindustrial", religioso, defensivo y urbano.

Del mismo modo que en otros niveles hemos hablado de redes o de arquitecturas que se convierten en permanencias algunas de ellas patológicas y otras propulsoras o catalizadoras, en el análisis al nivel de los lugares que realizamos ahora, podemos igualmente considerarlo y podemos hablar de tejidos propulsores como sería el caso del de los molinos junto al río que desde su uso medieval para la molienda del grano han propiciado su evolución a finales del XIX y principios del XX como tejidos "industriales" y desde hace unos años estos se han reconvertido en tejidos "turísticos o lúdicos". Así como de tejidos patológicos o constreñimientos como es el caso del de los abrevaderos y las vías pecuarias que pese al desuso de los mismos continúan condicionando la evolución del territorio.

Las imágenes del cuadro anterior corresponden a imágenes de tejidos según la forma de agrupación de los lugares que los originan:

Tejidos en imágenes medievales:

Compacta: Tejido agrícola masías. Detalle del cuadro de A. Lorenzetti "Los efectos del buen gobierno" Siena, entre 1338 y 1340.

Cadena: Tejido preindustrial, gravado de: "De Ingenis water" de Mariano Taccola (1433).

Malla: tejido agrícola secano, entorno ciudad. Dibujos 2 y 5 del libro "Frontin l'oeuvre gromatique" que recoge Corpus Agrimensorum romanorum IV de lulius Frontinus.

Radial: Tejido urbano radial: Detalle cuadro Simone Martini (1430).

Fotos tejidos Batllia o comarcas limítrofes:

Compacto: Tejido agrícola compacto junto al núcleo urbano de Sant Mateu.

Cadena: Tejido preindustrial en los molinos de Ares.

Malla: Tejido agrícola regadío en Villafranca.

Radial: Tejido agrícola radial en la Llecua (Morella).

Dibujos tejidos Batllia o comarcas limítrofes:

Compacto: Tejido agrícola masías en la Barcella.

Cadena: Tejido agrícola de regadío en el Molinar.

Malla: Tejido urbano de Sant Mateu.

Radial: Tejido defensivo castillo y torres de Morella.

Tejidos Kahn:

Compacto: Escuela de Arte de Filadelfia (1964-67).

Cadena: Proyecto para la ciudad de Filadelfia (1956-57)

Malla: Escuela Ahmedabad (1963).

Radial: Convento de las Dominicas (1965-68).

Tejidos algas multicelulares formando colonias:

Compacto: Ulva lactuca.

Cadena: Oscilatoria.

Malla: Diatomea.

Radial: Acetabularia mediterránea. 


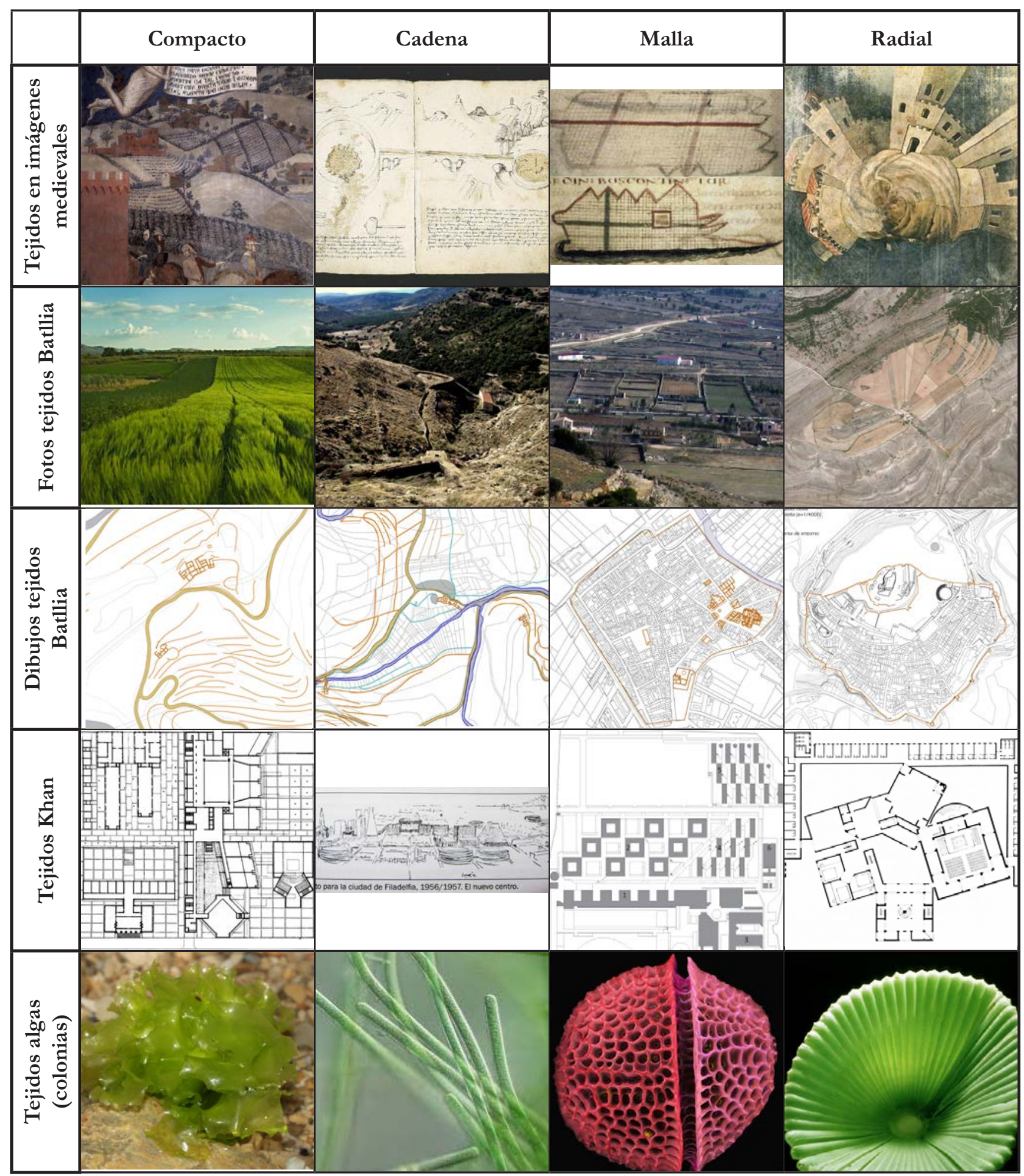

Fig. 5. 53. Cuadro de tejidos. 



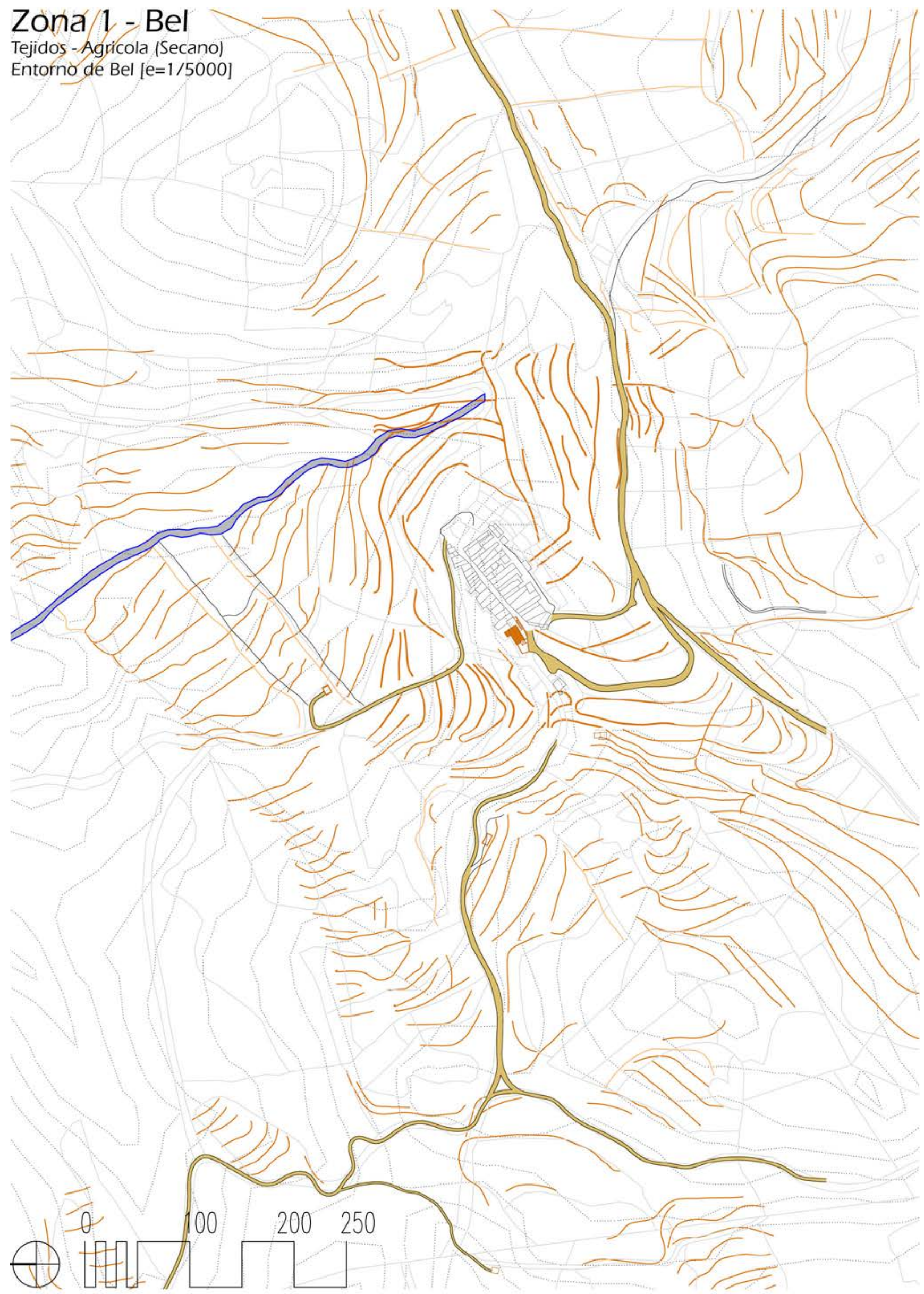




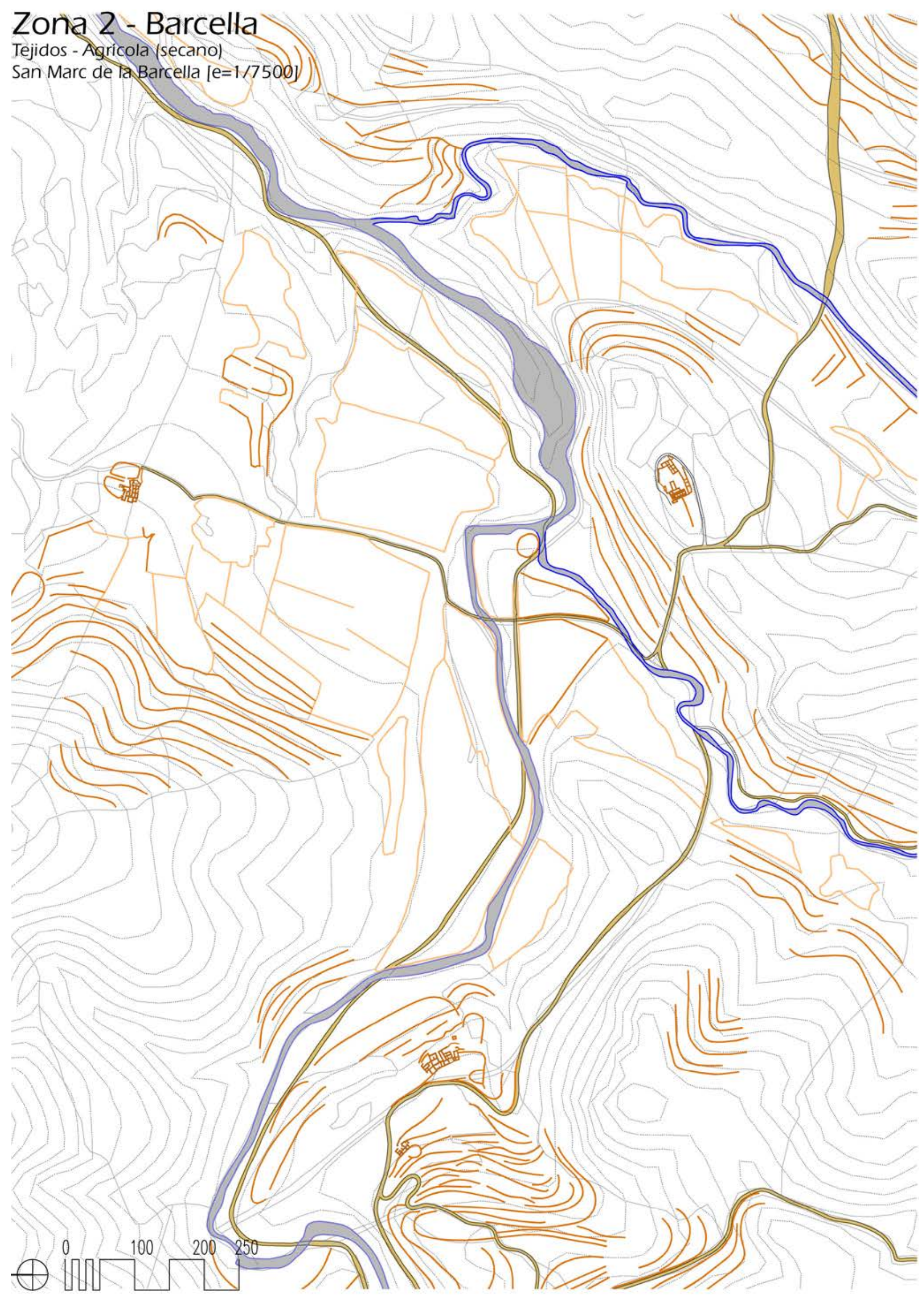




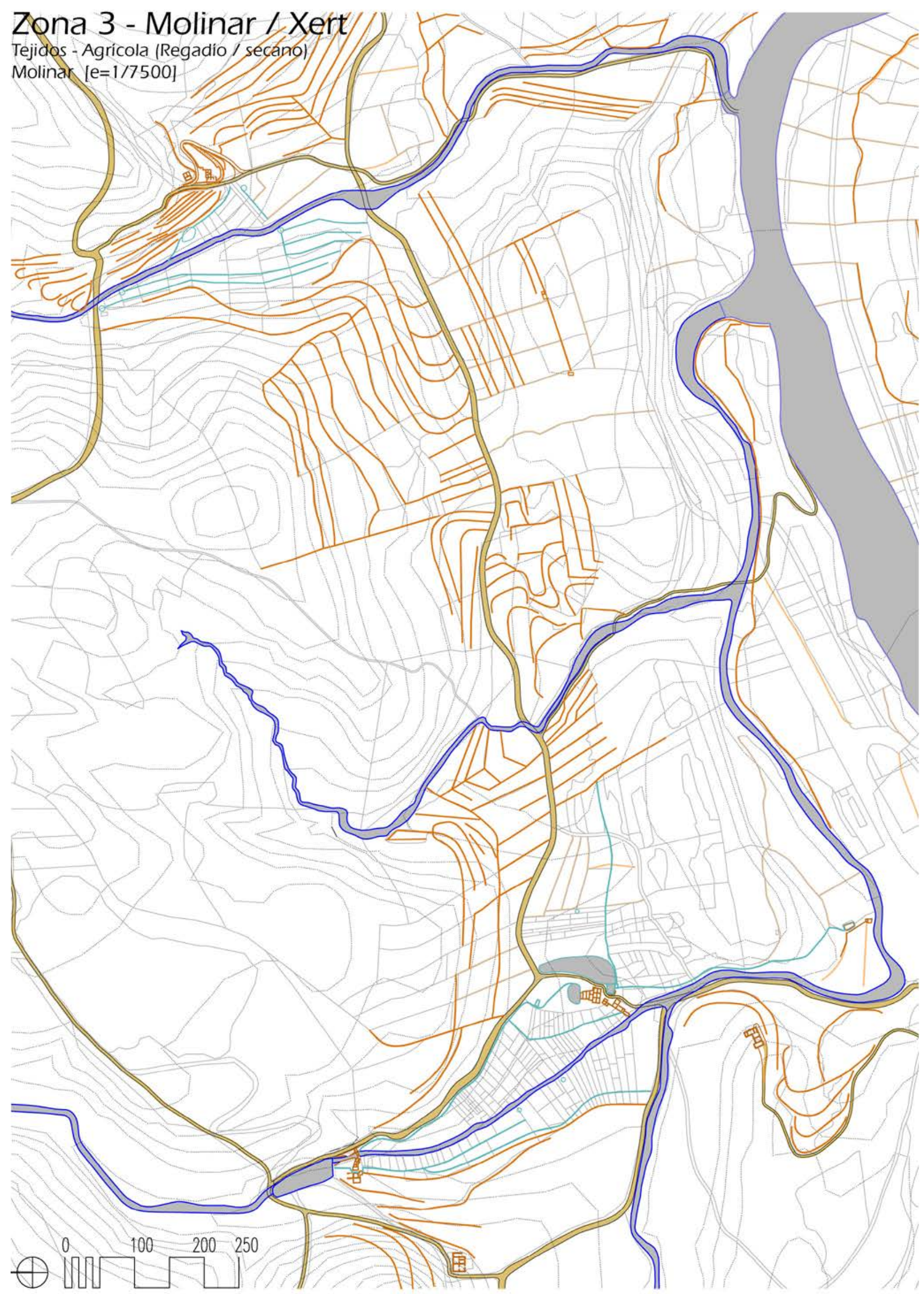




\section{Zona 5 - Canet}

Tejidos - Agrícola (Regadio / secano) canet [e=1/7500]

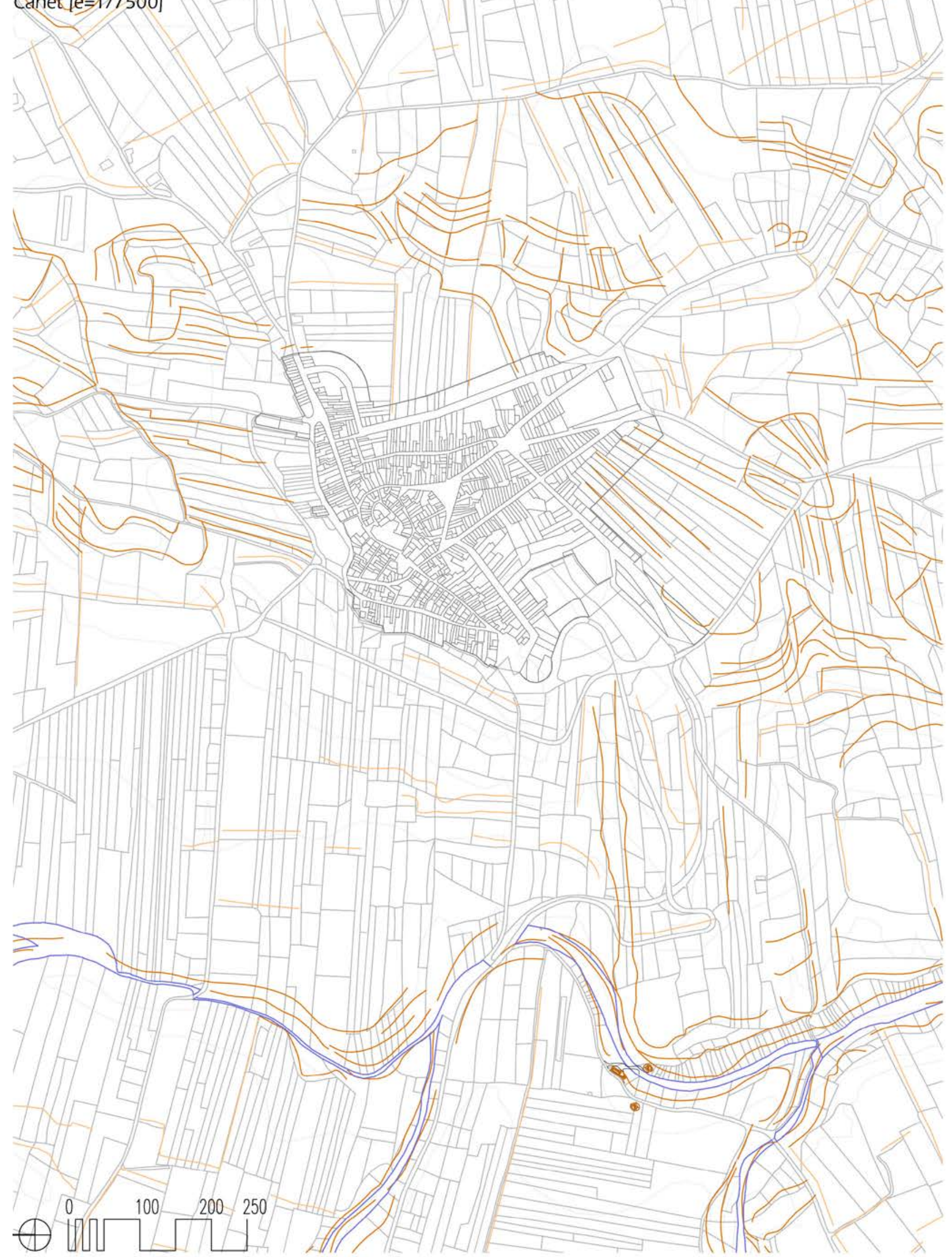




\section{Zona 5 - Canet}

Tejidos-Agricola (Regadio)

Font de Ia Roca y Santa Isabel $[\mathrm{e}=1 / 7500]$

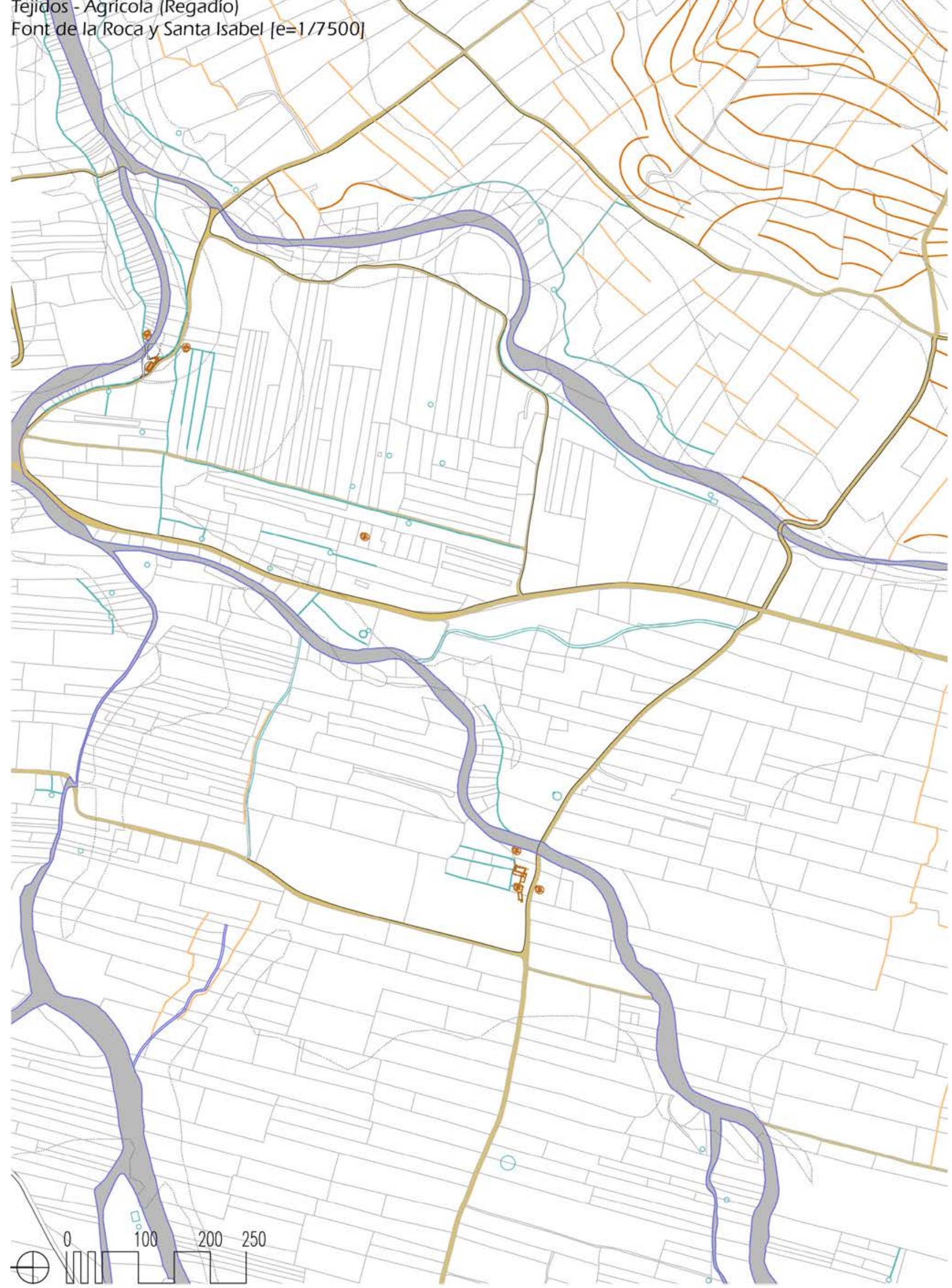




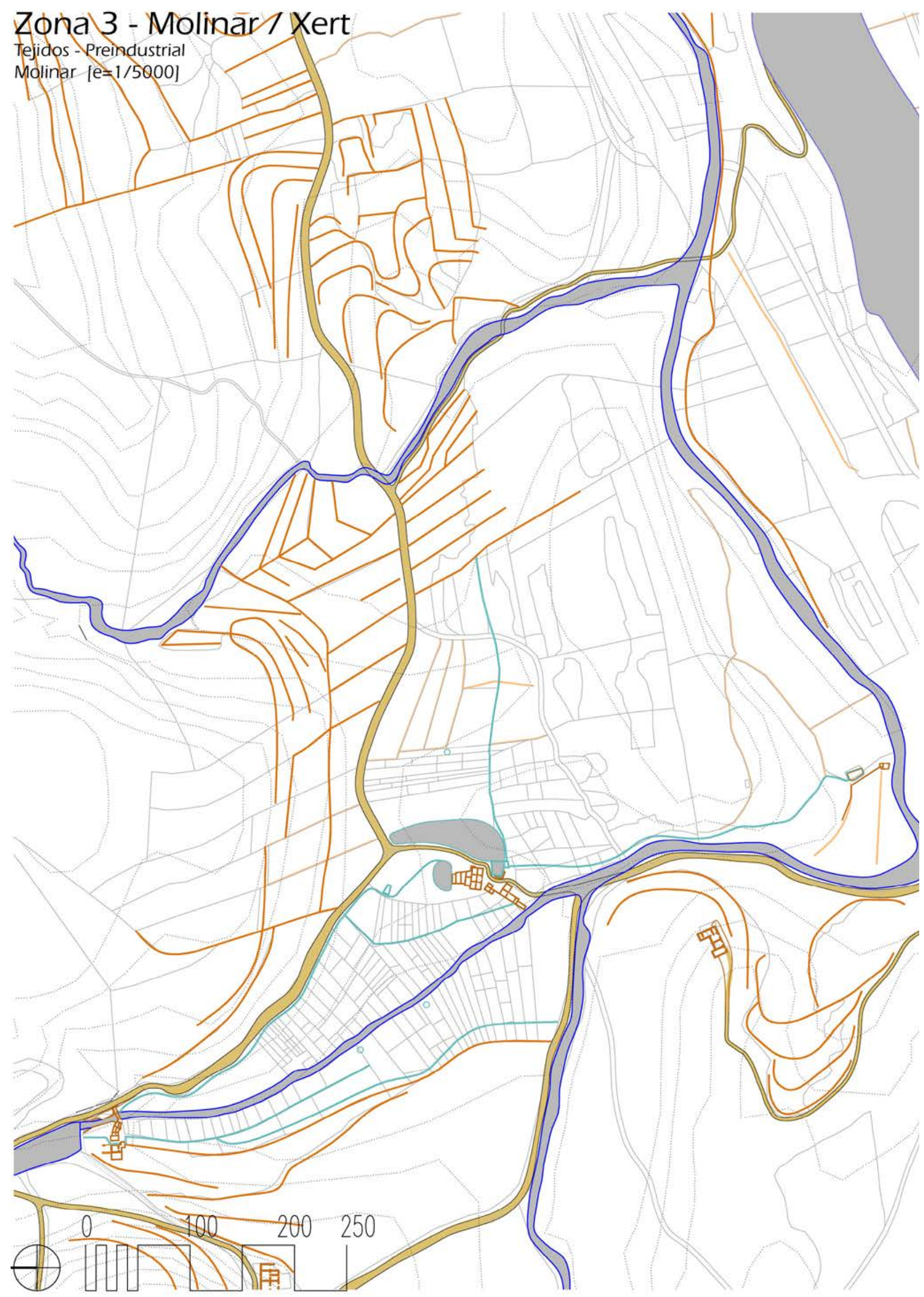




\section{Otras zonas de interés}

Tejidos - Preindustrial

Molinos de Ares $[e=1 / 4000]$
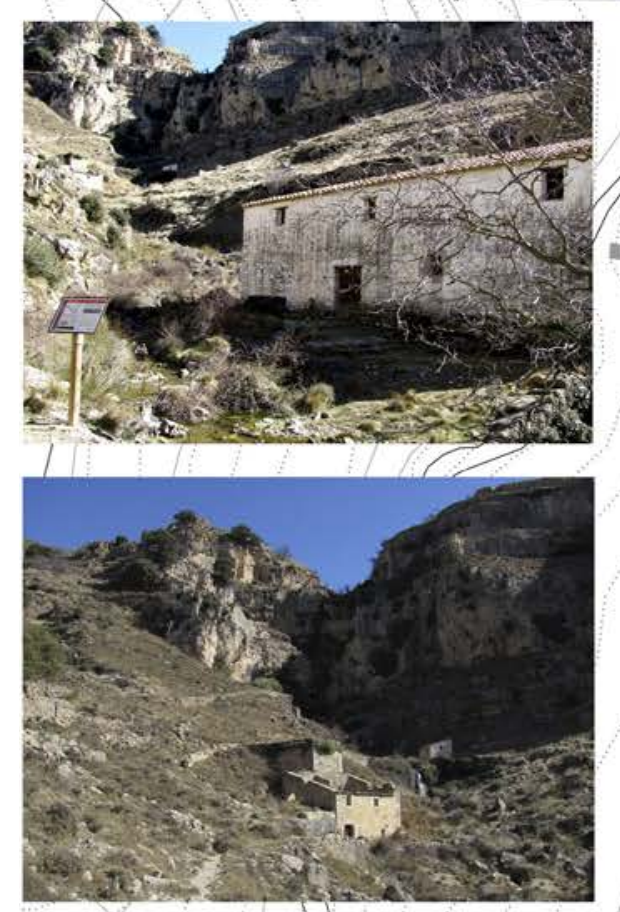

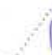




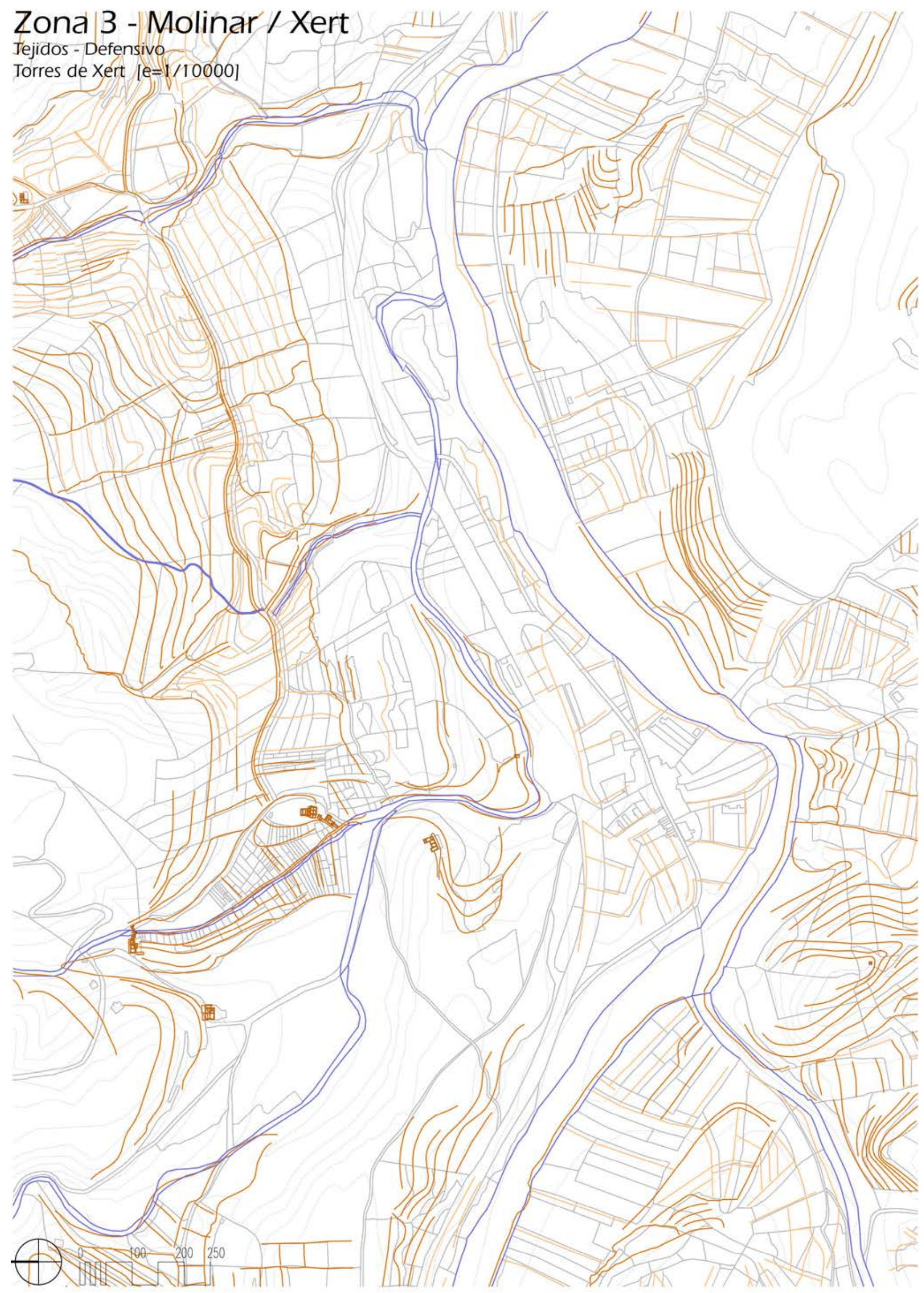




\section{Zona 8 - Traiguera}

Tejidos - Urbano / ciudad

Traiguera $[\mathrm{e}=1 / 2000]$

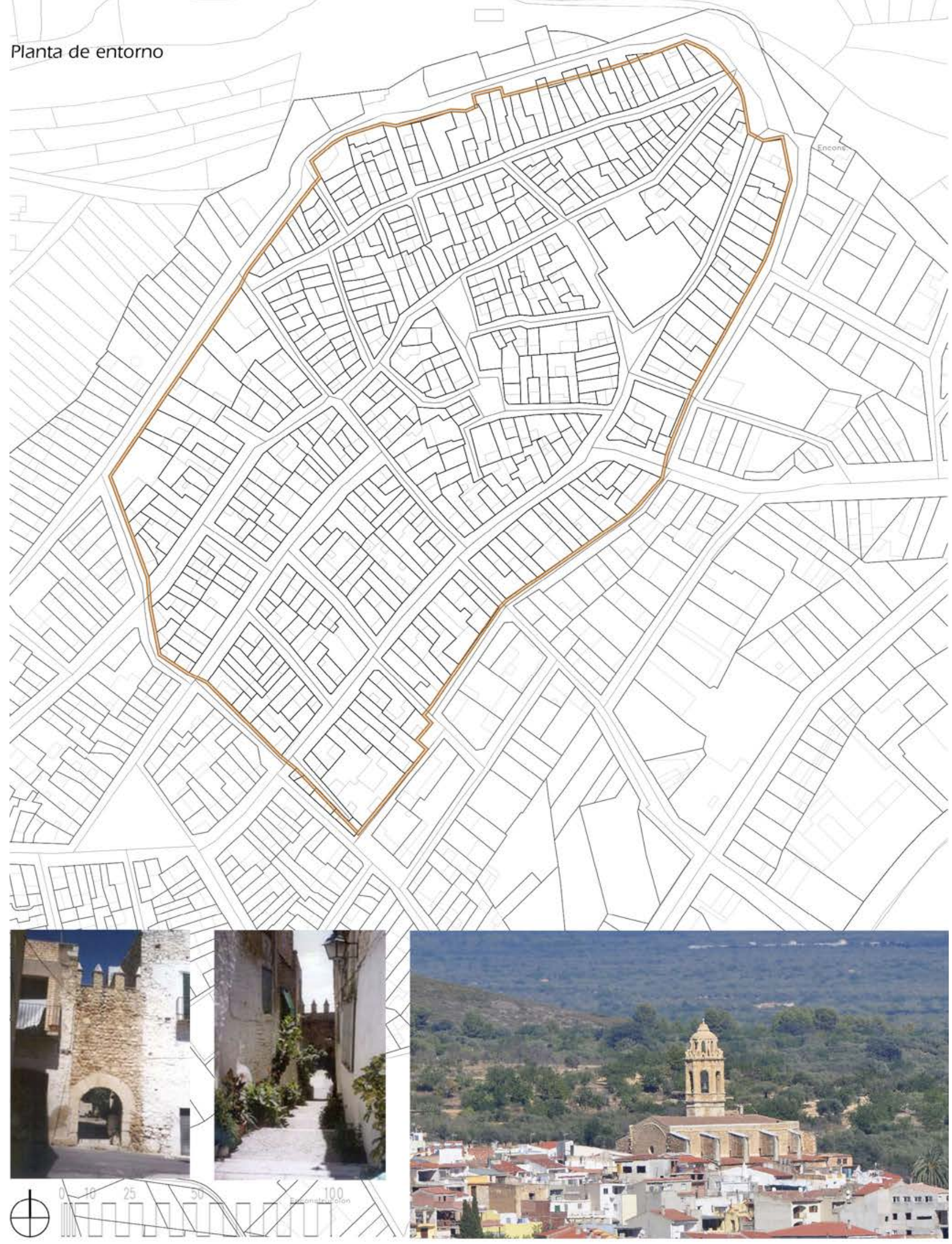




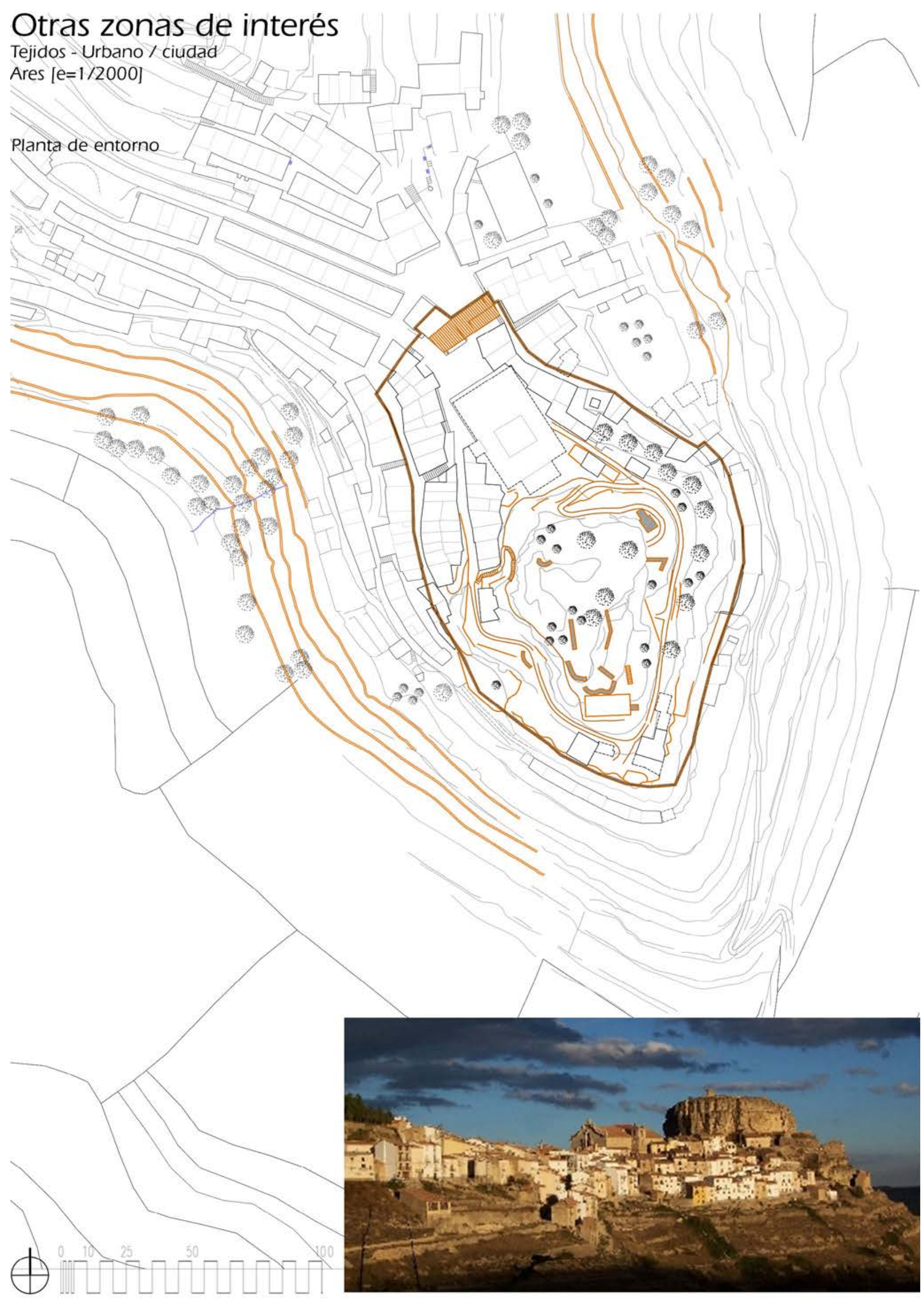




\section{Otras zonas de interés} Tejidos - Urbano //ciudad

Las Albaredas (Portelli' [e=1/1000]
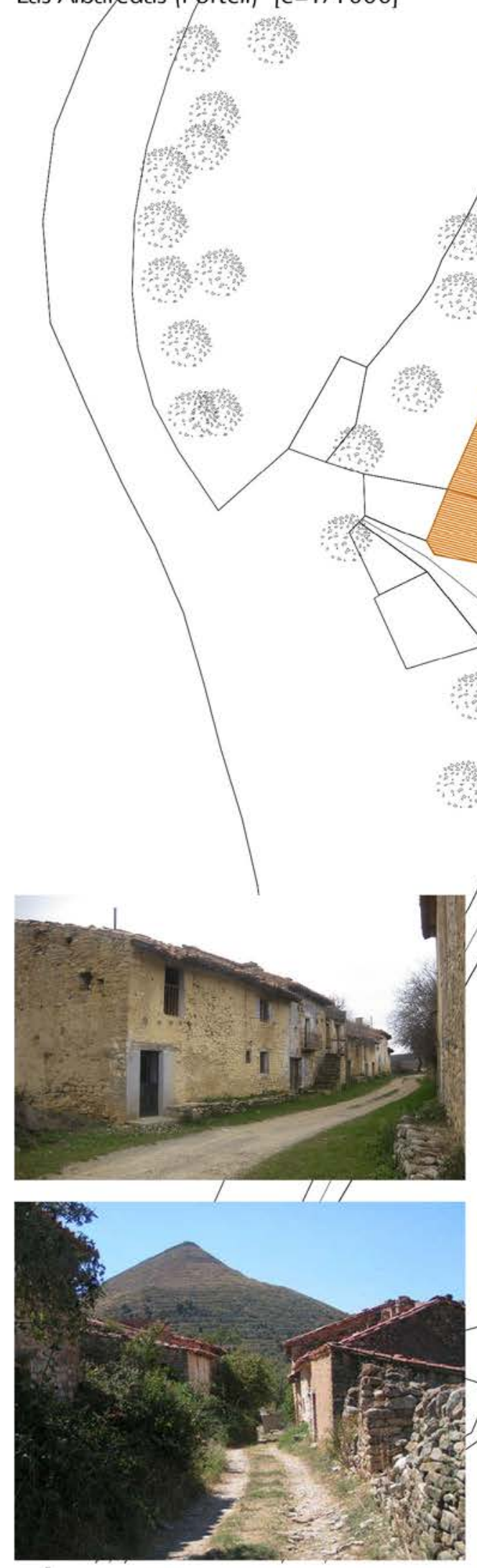

$\emptyset$
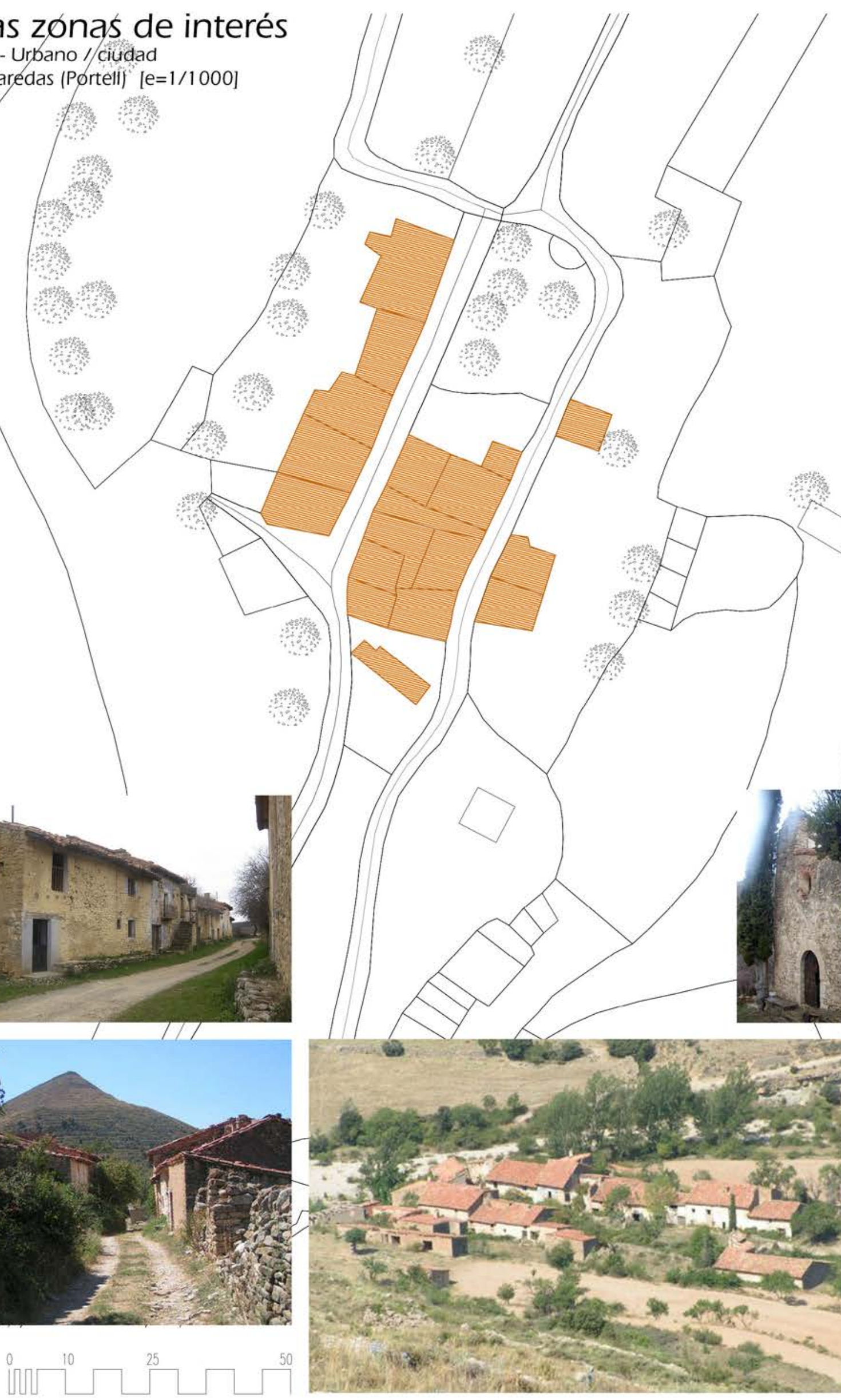

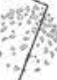
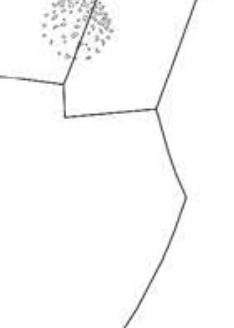



\section{Simbiosis entre los tejidos}

Del mismo modo que ocurre con las redes los tejidos se relacionan entre sí de tres formas distintas según cual sea la conectividad entre ellos:

- Conexión, si la conectividad se realiza mediante un espacio construido.

- Yuxtaposición, si la conectividad se realiza sin espacio intermedio.

- Interconexión cuando se busca la autonomía de cada tipo, a la vez que interactúan funcionalmente.

Podríamos resumir que las distintas relaciones entre los tejidos se producen de una de estas formas:

- Los tejidos agrícolas están conectados con los urbanos y ganaderos y están interconectados con el defensivo, sacro y "preindustriales".

- El tejido "preindustrial" está conectado con el urbano; interconectado con el agrícola y está yuxtapuesto al defensivo, sacro y ganadero.

- El tejido ganadero está conectado al agrícola; interconectado con el urbano y defensivo y está yuxtapuesto al "preindustrial" y sacro.

- El tejido defensivo está interconectado con el agrícola, ganadero y urbano y está yuxtapuesto al sacro y "preindustriales".

- El tejido sacro está interconectado con el agrícola y el urbano y está yuxtapuesto al ganadero, "preindustrial y defensivo.

- El tejido urbano está conectado al agrícola y "preindustrial" y está interconectado con el ganadero, defensivo y sacro.

Estos tejidos forman una estructura que se "funde" con el propio soporte o cañamazo que se superpone a la inicial del territorio "virgen".

Esta nueva estructura antropizada es una estructura con texturas, táctil, no es una estructura "plana" como el cañamazo inicial. Estos tejidos táctiles tiene vocación de ser percibidos, el hombre los construye no solo para habitar el territorio sino para que sean percibidos y "ordenar" el territorio.

Si superponemos la estructura del soporte, con la de los tejidos de los lugares en cada una de las zonas de estudio, podemos extraer las siguientes conclusiones:

- La estructura topológica inicial se extiende por todo el territorio uniformemente, mientras que la antropizada de los lugares y tejidos lo hace de forma discontinua. Existen zonas del territorio que se mantienen "vírgenes" y por tanto no existen dos estructuras superpuestas.

- La estructura antropizada de lugares se ubica en las zonas aptas para el uso agrícola que hemos considerado en el análisis.

- Los lugares y tejidos el hombre los "teje" sobre los "vacíos" de la estructura inicial. En los "vacíos" de mejor aptitud para su uso y poco a poco van colmatándolos, empezando por los de mayor aptitud y finalizando por los de menos.

- Los materiales que conforman los lugares y tejidos, se enhebran con otros, se tejen sobre los agujeros rellenándolos con una consideración topológica de disposición, de simplificar lo accesorio, de erosionar el detalle.

- Está disposición hace que los lugares conciban la forma como algo abierto, no cerrado, lo que les permite evolucionar lejos de una concepción estática de la forma. 
- Dado que los lugares en la Edad Media se construyen estereotómicamente y con una concepción topológica, al superponer ambas estructuras, comprobamos que en un primer momento las redes de infraestructuras que conectan los lugares y tejidos coinciden con las redes del cañamazo inicial.

- Podemos decir que el hombre juega sobre el tablero del territorio -que tiene una predisposición a que el crecimiento sea de una determinada forma por la topología- pero en otras "direcciones" hay libertad y el desarrollo del juego hace que no todas las topologías geográficas del mismo tipo evolucionen exactamente igual.

Del análisis del tejido antroposocial del territorio podemos extraer tres lecciones fundamentales:

- El lugar no se caracteriza al margen de su aplicación concreta, es decir, al margen de un tejido construido.

- El tejido del territorio a la vez no se caracteriza al margen de su marco, es decir, al margen del estudio del conjunto de la estructura del territorio.

- El estudio de una estructura territorial solo se concibe en su dimensión histórica, ya que su realidad se basa en el tiempo mediante una sucesión de reacciones y crecimientos a partir de una situación anterior.

El tejido territorial es entendido como un todo en el que los muros, infraestructuras, parcelas y arquitecturas solo constituyen elementos simples, que se agrupan en redes y que al interactuar con el soporte de la naturaleza conforman los lugares.

Superando la concepción de la tipología basada en el reconocimiento de arquetipos para sumergirse e n un análisis concreto del tejido. En el análisis de la Batllia utilizamos la noción de tipo en varios niveles de lectura del territorio:

- Las arquitecturas, muros, infraestructuras, parcelas y cultivos anclados en el suelo y con una relación precisa con el territorio.

- El agrupamiento de lugares en sistemas que revela la organización elemental del tejido.

El estudio de estos dos niveles permite apreciar las relaciones entre los tipos construidos y la forma del territorio.

La tipología, tal como nosotros la entendemos, permite una comprensión estructural del tejido. Los tipos construidos aparecen allí doblemente determinados por una cultura y una localización. Pero esta determinación no significa en absoluto un determinismo. En un punto determinado y en una época concreta son posibles varias soluciones, si bien las huellas de las ocupaciones anteriores siguen marcando la forma del territorio.

El punto decisivo estriba según Ricolais en encontrar la relación entre la estructura de la naturaleza y la estructura de la forma construida por el hombre. La respuesta parece estar en la sorprendente expresión "la estructura de la estructura", que se basa en la topología, la predisposición y sobre todo la conectividad. El territorio evoluciona y crece no hacia formas precisas sino posibles.

Llega un momento que el territorio antropizados se convierte en un gran collage, trufado de redes, lugares y tejidos que pueden plantear dos problemas decisivos:

1. La disposición de estas texturas por todo el territorio no sea uniforma, sino que existan ámbitos con una mayor densidad mientras que otros apenas tengan densidad. Esta descompensación hace que las conexiones iniciales se vean modificadas, algunas ganan importancia por conectar lugares y tejidos de gran densidad y otras la pierden e incluso desaparecen por no servir de conexión a ningún lugar. Esa modificación en los flujos entre 
unas conexiones y otras producen distorsiones en la predisposición inicial de las topologías que se ven condicionadas por esta variación de los flujos entre ellos.

2. Llega un momento que ya no es un problema de diferencia de flujo en las redes de conexiones de la topología inicial, sino que lo que se produce es la creación de una nueva red de conexión "ex novo" que ya no sigue las pautas de la topología. Esta nueva red se convierte en un nuevo cañamazo que se superpone con el primitivo de la topología inicial y lo "anula".

Estos dos problemas provocan que el territorio una vez antropizados no siga las conexiones predeterminadas por la topología inicial sino que siga las nuevas conexiones creadas por el territorio antropizados y sean ellas las que guíen a partir de ese momento el crecimiento y evolución del territorio.

Por ello Rosa Barba define el espacio urbano como aquel en el que la red que establece el dominio del territorio crea una topografía artificial, mientras que el suelo no urbanizable seria aquel en el que la red que establece el dominio sigue el relieve topográfico natural. 


\section{5. Las ciudades}

El desarrollo del territorio es la evolución por la creación de esferas cada vez mayores. Hemos visto que las esferas/arquitecturas pueden en ocasiones ampliarse hasta crear esferas/lugares y que estos forman entre sí tejidos que se extienden por el territorio siguiendo la predisposición topológica del soporte. A partir de este punto en la evolución de las esferas se da un salto cualitativo hacia una esfera de mayor complejidad: las ciudades.

"Es un hecho completamente decisivo y nunca apreciado en toda su importancia el que todas las grandes culturas sean culturas de ciudad. El ser humano es un animal constructor de ciudades. La historia universal es la historia del ser humano de ciudad. Pueblos, Estados, política,y religión, todas las artes, todas las ciencias descansan sobre un protofenómeno de la existencia humana: la ciudad. ....Hemos de colocarnos en el asombro de un ser humano primitivo que en medio del campo divisa por primera vez esa masa de piedra y madera, con sus calles rodeadas de piedras y sus plazas llenas de piedra, un habitáculo de forma extraña.". ${ }^{127}$

La esfera/ciudad se obtiene por la adición de esferas/arquitecturas, esferas/lugares y tejidos, que se agrupan entre sí creando una esfera con una gran fuerza centrípeta que atrae hacia sí toda la energía de su entorno. Como hemos visto que ocurría en los monasterios en esta esfera se engloban las nueve dimensiones; en ella se concretizan el quirotopo, fonotopo, uterotopo, termotopo, erotopo, ergotopo, alethotopo, thanatotopo o theotopo y nomotopo.

A diferencia de los monasterios, esta esfera no surge como ampliación de una arquitectura sino como adición de distintas esferas lo que le da una mayor complejidad y con el tiempo más posibilidades de evolución y crecimiento.

Las ciudades son componentes territoriales en el que se agrupan arquitecturas, lugares y tejidos. Las formas de agrupación de estos componentes pueden ser:

- Agrupación compacta, los componentes no tienen un elemnto interesticial claro y definido, por lo que no generan ni siquiera un tejido urbano. Es el caso de Sarañana en els Ports o de Coratxar en la Tinença. Son núcleos muy pequeños y no son capaces de generar crecimiento.

- Agrupación en cadena, son secuencias de componentes conectados linealmente aprovechando un tejido urbano como es la calle. Seria el caso de Bel o de las Albaredas en Portell, son también nucleos pequeños pero con la capacidad de crecimiento a partir del eje que disponen.

- Agrupación concéntrica o cerrada, es aquella en la que los componentes se concentran en torno a un centro o espacio común, seria el caso de Morella en el que la ciudad surge a partir del foco del Castillo y se desarrolla de forma concéntrica.

- Agrupación en malla, cuando el nucleo urbano adquiere una cierta relevancia se disponen varias calles y plazas como centros de relación comercial que conforman una malla de espacio urbano público. Es el caso de Sant Mateu, en el que esta configuración se ve favorecida por la existencia del mercado que le da a la plaza un status especial. 


\section{Otras zoonas de interés}

Ciudad compacta

Sarañana (Todolella) $[e=1 / 1000]$
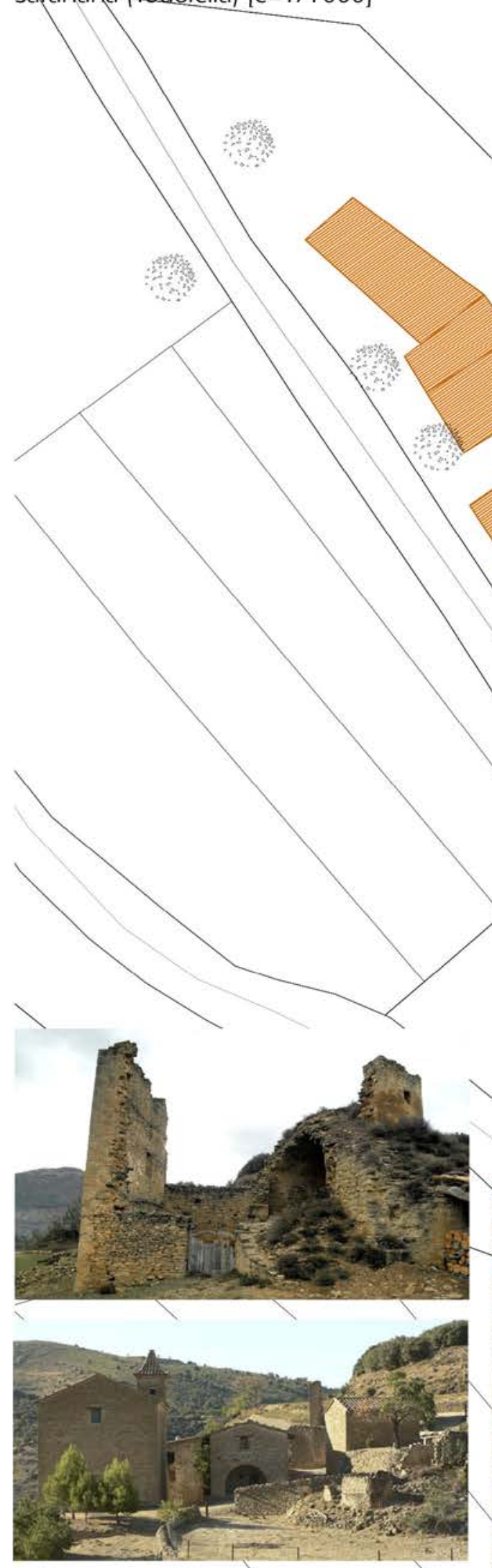

$\oplus$
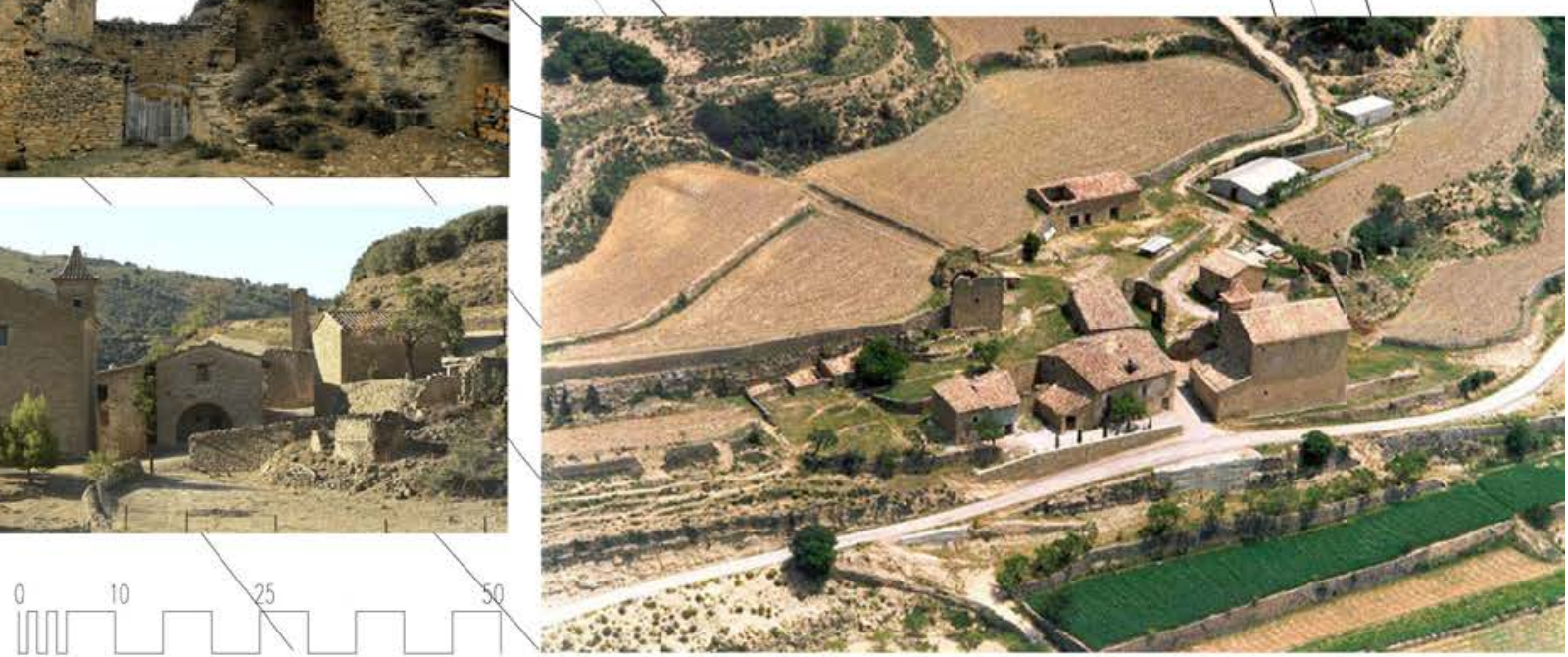


\section{Zona 1 - Bel} Ciudad en cadena Bel $[e=1 / 1000]$

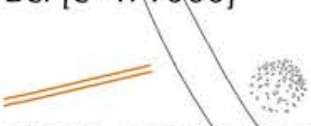

Planta de entorno cercano
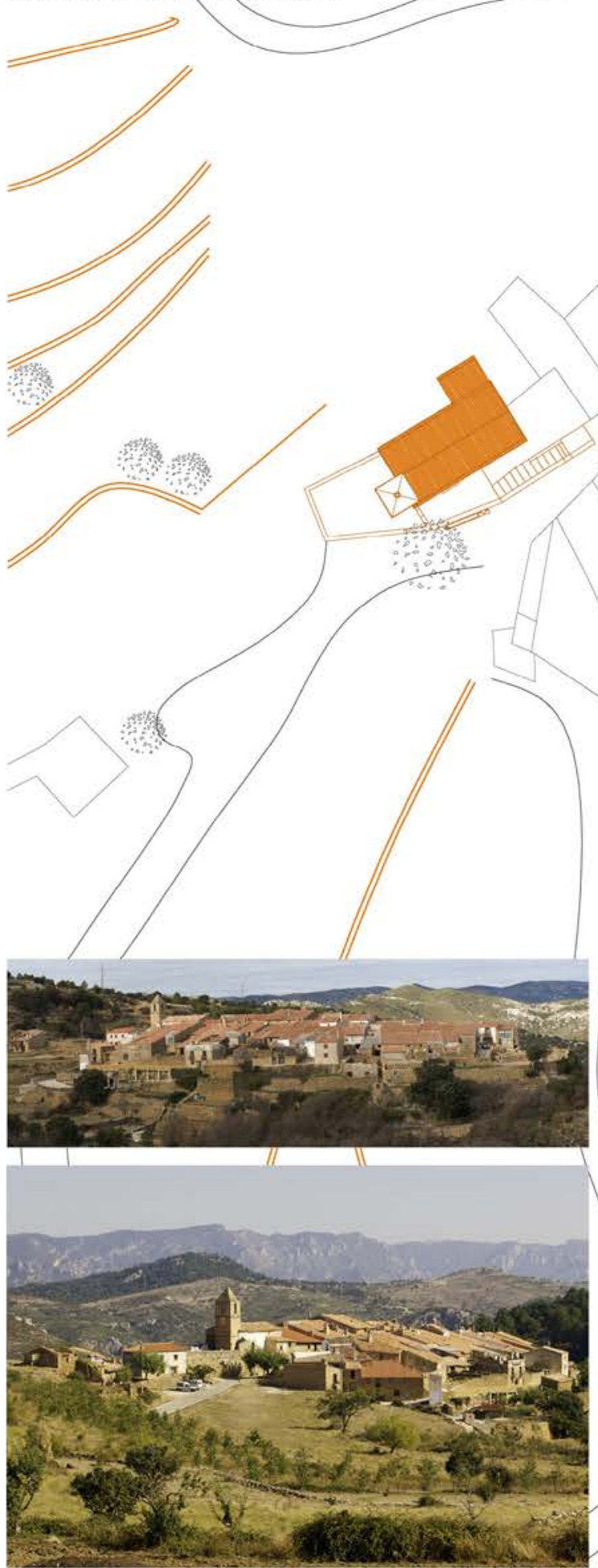

$\emptyset$

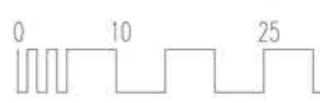

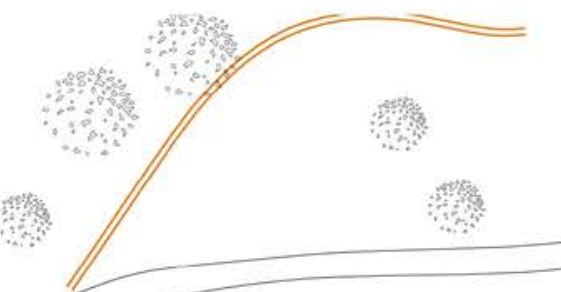
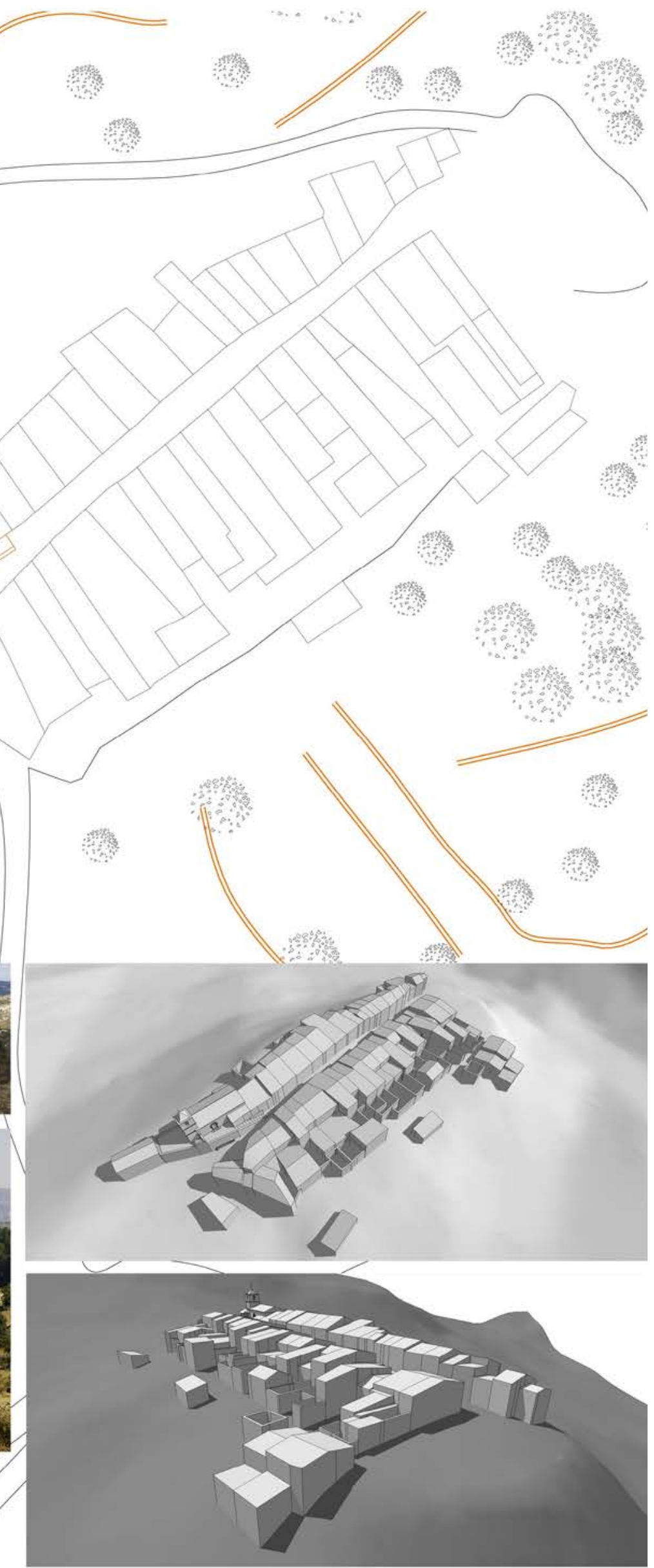


\section{Otras zonas de interés \\ Ciudad radial}

Morella $[\mathrm{e}=1 / 4000]$

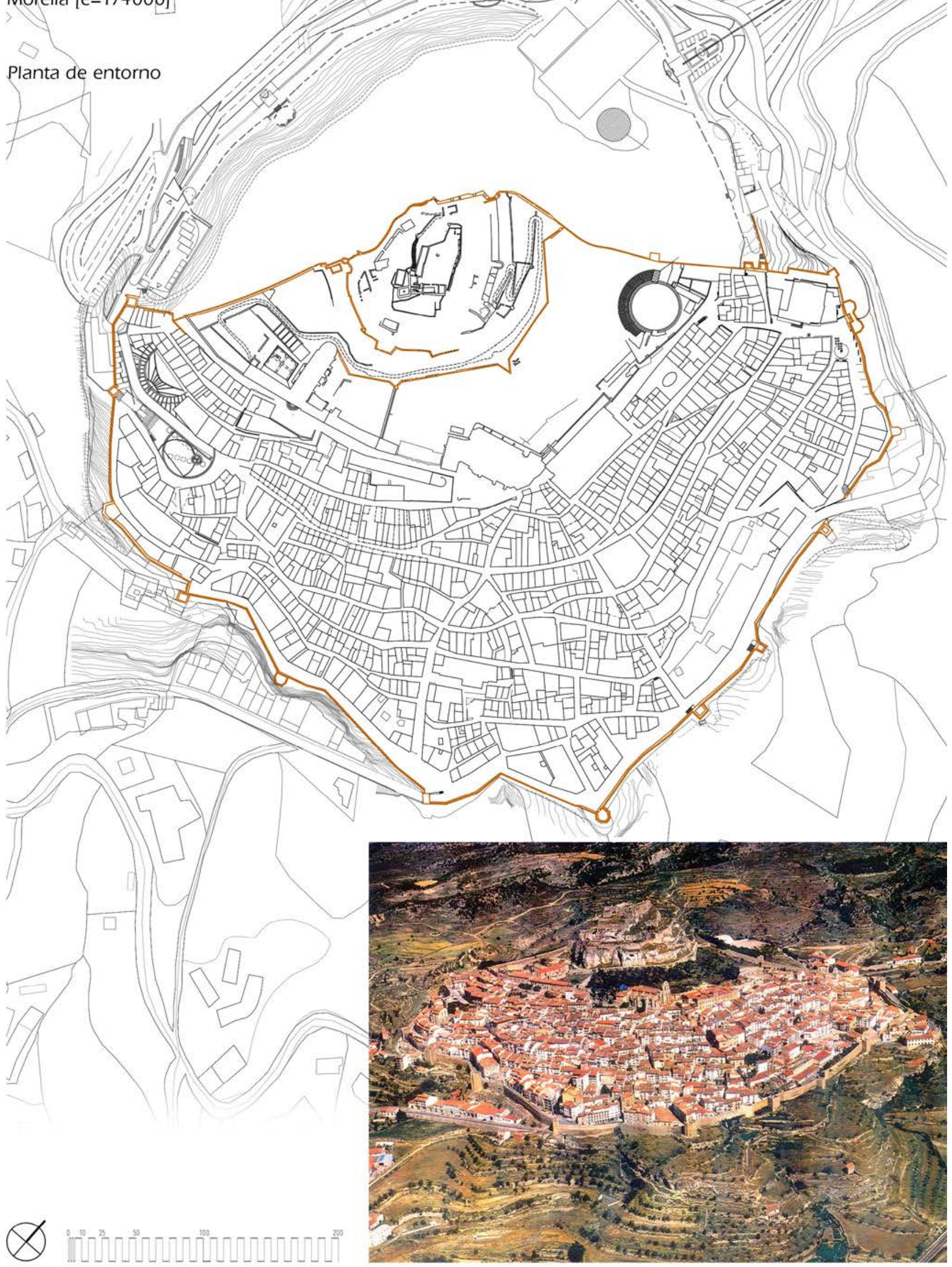




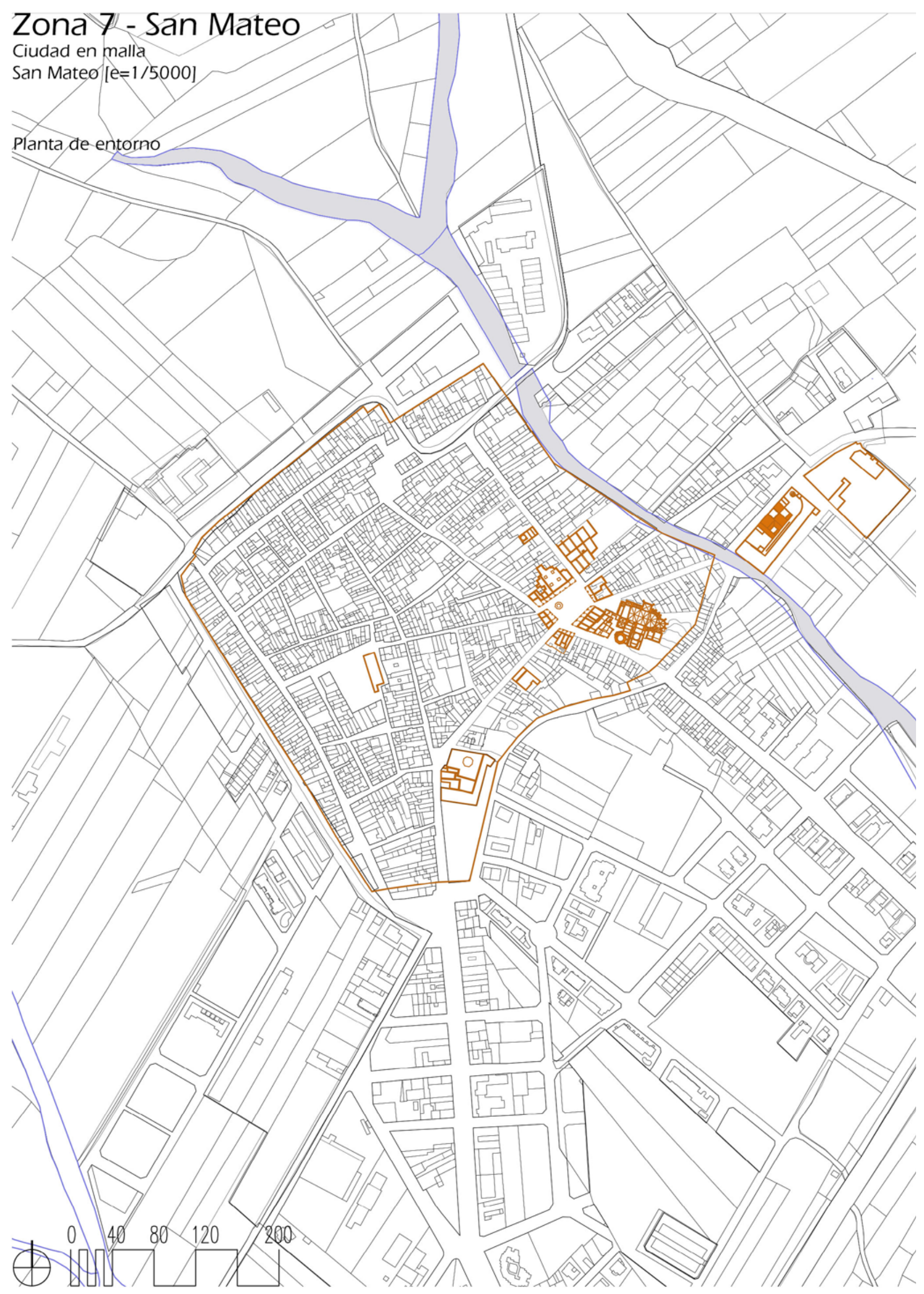




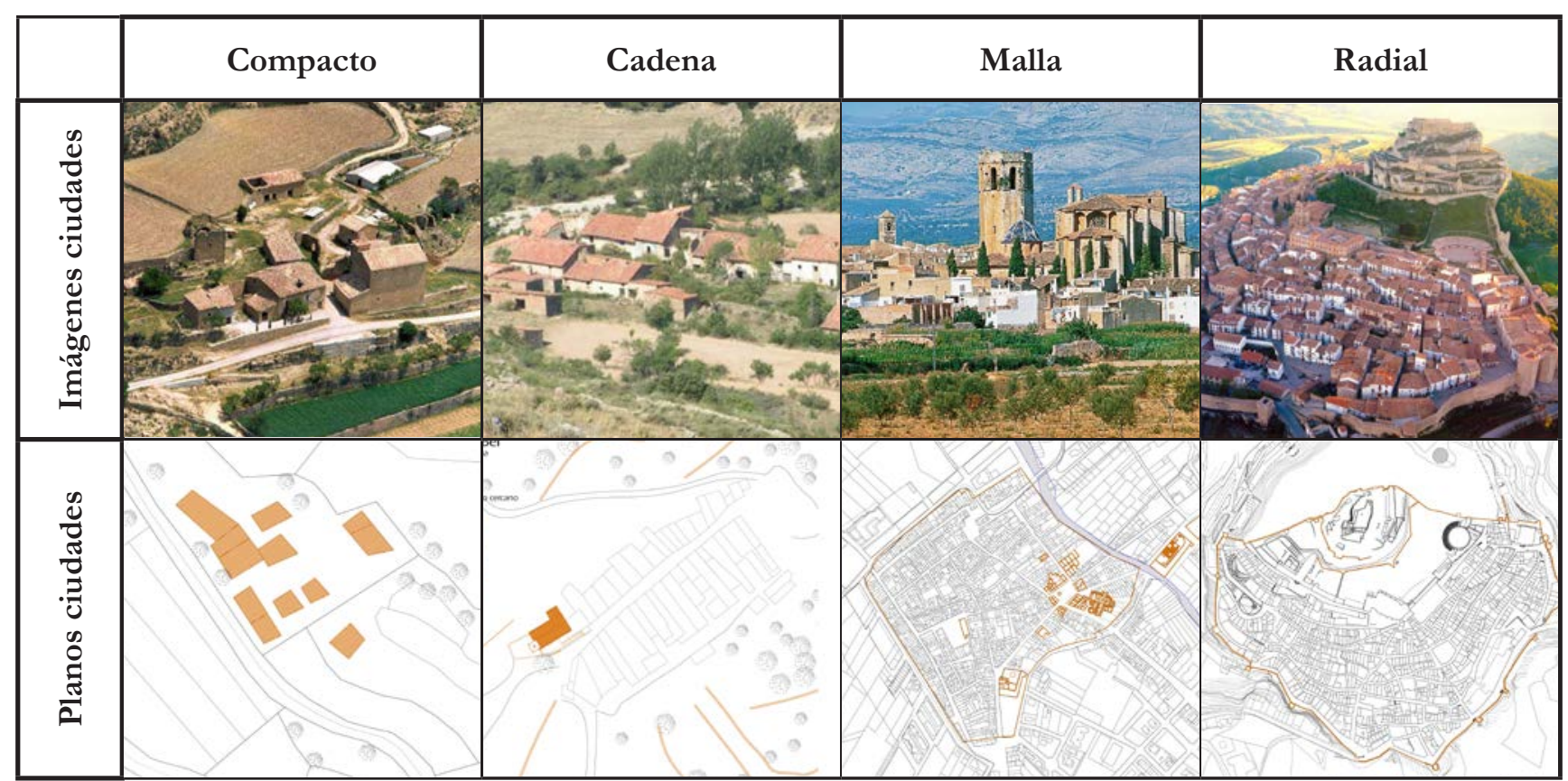

Fig. 5. 54. Cuadro de ciudades.

En las ciudades se ubican arquitecturas de una gran relevancia que les confieren unas características especiales, son las casas comunales, los hornos, las cofradías, etc. Estas instituciones hacen que la "reunión-con" que se realiza en el lugar-calle y en el lugar-plaza trascienda de forma que la "reunión-con el conjunto de la comunidad" se realice de una forma global y completa en ellas.

En la ciudad se superponen el tejido urbano con lugares pertenecientes a otros tejidos como es el caso de las iglesias y de las arquitecturas defensivas.

Por su parte el conjunto de núcleos urbanos o ciudades establecen entre sí un tejido "supraurbano" que tiene una disposición de malla pero con un centro que polariza la red hacia él. En el caso de la Batllia se trata de San Mateo.

\begin{abstract}
"La ciudad es en cierto modo, el arca que ha aterrizado: representa una embarcación de supervivencia, que ya no busca su suerte en las aguas libres, sino que se amarra obstinadamente a la superficie terrestre. Se podrían definir las ciudades como conformaciones de compromiso entre el surrealismo de la autorreferencia que flota libremente y el pragmatismo de la fijación al suelo. Por la fusión de estos dos motivos, las ciudades desarrollaron su improbabilidad triunfal; por su ensamblaje fructífero en una maquinaría de fuerza morfológica, consiguieron su poder hacedor de historia. Cobijarse en concentraciones mágicas y sacar fuerza (energía) de los templos, muros, depósitos, etc: en esta fórmula se halla el secreto esfereológico, el éxito de la forma-arquitectónica de la ciudad... La ciudad antigua tiene que concentrarse hacia dentro como un arca y hacia fuera ha de afirmarse mediante murallas triunfales para extender su influjo en la distancia desde este lugar eminente."128
\end{abstract}

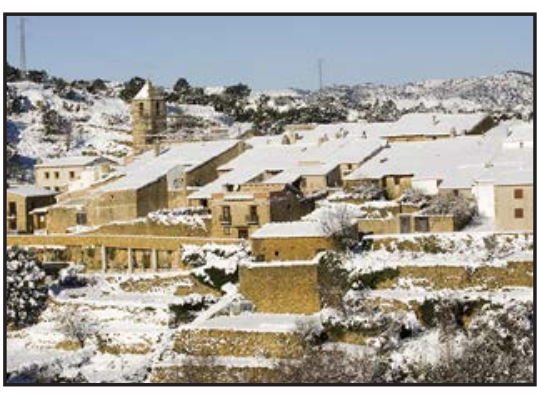

Fig. 5. 55. Foto de Bel. Tejido urbano.

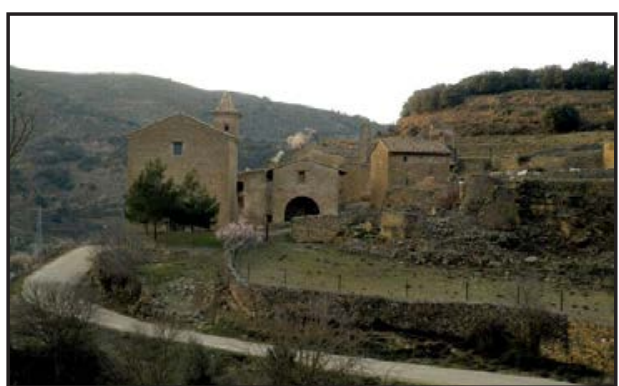

Fig. 5. 56. Imagen del núcleo de la antigua población de Sarañana.

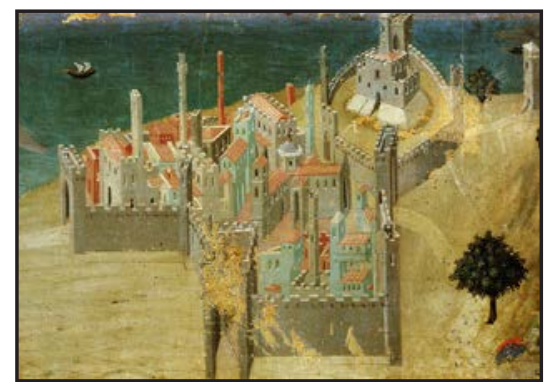

Fig. 5. 57. Cuadro de Ambrogio Lorenzetti. La ciudad en el mar (1311-20). Tejido urbano. 
La ciudad medieval por antonomasia, es la ciudad amurallada y una ciudad como Morella es ejemplo de ello. Veamos como describe Peter Sloterdijk a las ciudades amuralladas:

"Las ciudades antiguas están ahí, para encandilar miradas, elevar miradas, humillar miradas. Su desmedido afán de notoriedad declara la guerra al ojo ingenuo y le exige sumisión ante ese brillo, insolencia y permisión del espectáculo.

En la ciudad-y solo en ella- puede comprobarse lo que significa que una figura apueste sin reservas por lo contrario de permanecer oculta y se coloque en el centro de lo visible y notorio. Desde que hay ciudades, aparición significa: exposición, presentación, revelación permanente. Dicho al estilo de Heidegger: la construcción de ciudades es un modo de desocultamiento.

$\mathrm{Al}$ modo de estar ahí de la ciudad, como de una pieza, pertenece un cierto flamear, una inmediatez sublime, pero de ese rayo visual proveniente de abajo deviene una imagen enhiesta, estable, una presencia duradera, y por mucho tiempo el ojo pretende fijarse en esa masa arrogante. Nada de ese ser-ahí magnífico, triunfal, de las murallas hace suponer tendencia alguna a la desaparición. Lo que aquí aparece y persiste en la aparición es el rechazo mismo de la transitoriedad, del carácter efímero.

El dios-ciudad revela su ser en las magníficas e imponentes torres y murallas; una permanencia duradera en la visibilidad. Quien vive en una ciudad así habita una hipótesis de eternidad.

De la observación de las murallas parece entenderse que los seres humanos fueran los siervos y esclavos del dios de la ciudad. En el interior de las murallas existe una vida que solo puede entenderse en relación con esa envoltura.

Con la altura de sus edificios más eminentes, la ciudad quiere mostrar que es lo que se propone en horizontal. Con la ciudad primitiva comienza un reformateo del imaginario: política, ética, geográfica, cosmológicamente. Aquí se inicia el apogeo de las grandes formas anímicas, el experimento del alma del mundo.

La ciudad ha de ser el mundo, para una empresa de esas dimensiones el propio Dios tiene que convertirse en muralla. A partir de ahí, política, arquitectura y teología se aúnan en un proyecto común macroinmunológico. Nuestro Dios es un firme castillo.

Los gobiernos de las ciudades abandonaran la protección de la vida en lo discreto y disimulado, para buscarla de nuevo en lo más llamativo y ostentosos. No llamar la atención solo será ya para los tiempos venideros una posibilidad de la pequeña gente, una opción de los nómadas, de los marginales, para quienes vivir bien y ocultos convergen. Para los grandes hay que exponerse y llamar la atención.

Quien quiera comprender la ciudad antigua no tiene que hurgar en sus ruinas sino que ha de intentar entender a los primeros señores de las ciudades que proyectaron para ellos y concibieron la idea de que en tales promontorios ciudadanos podrían algo así como apostarse por la eternidad." ${ }^{29}$

Las esferas/ciudad se convierten por sí mismas en lugares y en el centro del territorio que dominan y les da la energía para subsistir, crecer y evolucionar. Morella es una isla -esfera- en el territorio, como una gran placenta cuyo cordón umbilical -el acueducto- la nutre. Alrededor de ella giran y son atraídos como satélites otras ciudades, lugares y arquitecturas; la fuerza centrípeta de la gravedad no les permite separarse. La ciudad se convierte en el motor de desarrollo del territorio que le rodea y que a su vez le proporciona la energía para subsistir.

Las esferas son pesadas, macizas, estereotómicas como la ciudad de Morella; están pegadas al suelo, crecen por el apilamiento o la sustracción. La gravedad y la luz son las que guían su desarrollo, ella permanece inmóvil concentrando sus arquitecturas-su vida- en el lado sur buscando el calor del sol y la gravedad hace que todo el territorio gire a su alrededor. 


\section{6. Partes completas del Territorio}

El examen de la lectura del Territorio que hemos presentado nos ha permitido identificar unas esferas/elementos y unas relaciones que por su carácter básico, su generalidad y su individualidad permiten afrontar el análisis de los distintos sistemas territoriales.

El análisis realizado hasta ahora nos muestra un territorio estructurado con esferas/arquitecturas, redes, esferas/lugares, tejidos y esferas/ciudades reconocibles y una serie de "vacíos" que serian aquellos en los que se mantienen en estado natural, que no han sido todavía antropizados. En definitiva es un territorio fragmentado y jerarquizado -un patchwork-. La recuperación de la idea de espacio como jerarquía de lugares permite también superar el estructuralismo funcional sin desvincularse a la vez de la utilidad de la idea de estructura. El método estructural intenta encontrar un sistema de relaciones desde la perspectiva de la lógica que cada situación impone al lugar concreto e incorpora la visión simultánea de la historia con la idea de tradición.

K. Frampton al referirse al lugar habla de fragmento delimitado. ¿Es posible hoy una articulación significativa de lugares y/o tejidos? O en cambio ¿existe una tendencia a la configuración de un sistema de lugares y/o tejidos disgregados? La idea del patchwork (collage) y la idea de montaje aportada por Eisenman estarán en el camino de una explicación al proponer una posibilidad distinta de orden.

Al proponer la idea de descomposición como el negativo de la composición clásica habla de un fragmento que no tenga el carácter de lo inconcluso. Propone una dialéctica que se funda en lo complejo y en la adición. Al proponer un proceso que se basa en la descomposición revela (o desmiembra) relaciones inherentes a un objeto concreto y a su estructura, que anteriormente estaban encubiertas por la sensibilidad clásica [...] Mientras que el análisis de la composición y de la transformación tiende a consolidar relaciones objetivas entre elementos, el análisis de la descomposición suspende tales relaciones [...] Se trata ahora de una naturaleza basada en el proceso, no en el ser. En la descomposición, el orden ya no es idéntico a una sustancia. Ahora reside en el modo en que los elementos son creados y conservados, es decir, en su proceso. Es una forma de elaboración autónoma [...] Se trata de una nueva naturalidad dentro de un estado no natural [...] El objeto fútil y el proceso de descomposición no son ya, respectivamente, un objeto arbitrario y un proceso anómalo, ni constituyan tampoco una mutación del clasicismo. ${ }^{130}$

La arquitectura se convierte en fragmento de un proceso abierto, excluyendo cualquier comprensión más allá de la constatación de la existencia del proceso. El orden reside en el proceso que crea sus diferencias, es el conjunto complejo de fragmentos. Esos no son partes, sino los elementos reconocibles generados por el proceso, sus huellas.

Una noción de fragmento que es simultáneamente algo completo y algo incompleto, elemento de un orden complejo que exige ser interpretado. La cuestión no es solo mostrar las huellas sino ver como estas se relacionan y evolucionan.

El fragmento deriva de la estructura compleja de la realidad y puede concebirse un orden complejo hecho de ellos y dicho orden puede asociarse al Territorio. Un orden complejo hecho de fragmentos vincula éste al lugar y al tejido.

El territorio hecho de esferas confusamente dispuestas, de fragmentos y discontinuidades ha sugerido la imagen del patchwork. Este es un método también compositivo que va más allá de la simple disposición arbitraria de elementos amontonados. La idea de patchwork está ligada a una estructura de lo complejo que no entendemos inmediatamente, que se distingue de lo amorfo precisamente en el reconocimiento de los fragmentos que lo componen. El patchwork más elemental es un conjunto de recortes y esferas cosidos en un cañamazo de tres dimensiones. Aquí es posible descubrir una visión determinada de la realidad.

Fragmento no quiere decir inconcluso, sino que el territorio no tiene una forma final determinada al ser un proceso abierto en continua conformación. El territorio es atemporal (sin principio ni

130 EISENMAN, P. “La futilidad de los objetos. La descomposición y los procesos de diferenciación” pág. 55 
fin) y complejo, es un conjunto de fragmentos, que no son partes, sino los elementos reconocibles generados por el proceso.

Estos los podemos considerar huellas que son registro de nuestro pasado y la horma de nuestro futuro, parafraseando a Fernández-Galiano, que dice: "Las infraestructuras son el registro de nuestro pasado y la horma de nuestro futuro". ${ }^{131}$

Los fragmentos son a la vez algo completo y algo incompleto, son elementos de un orden complejo que exige ser interpretado. La cuestión no esta en fijar de cuando y de donde proceden las distintas huellas, sino como se les utiliza e interrelaciona. Esta relación entre pasado y futuro, que incluye el fragmento y la idea de proceso, nos permite comprender y analizar mejor al territorio como un orden complejo hecho con ellos, que derivan de la estructura compleja de la realidad.

Por ello la lectura realizada no se detiene en el nivel de un territorio fragmentado y aparentemente desordenado, sino que trata de identificar otros elementos y relaciones de mayor complejidad. La lectura de este nuevo nivel supone identificar una estructura en que las relaciones y elementos básicos hasta ahora caracterizados aparezcan formando una unidad compleja; es decir una parte del Territorio. Ello supone considerar el estudio complejo de una realidad que tiene sucesivas capas -como una cebolla- y cada una de ellas comprende a las anteriores a la vez que no se puede entender el conjunto sin entender previamente cada una de las partes o pieles.

Para realizar el estudio complejo volvemos a hacerlo con un doble análisis ascendente y descendente. Es posible identificar dentro del territorio partes completas, configuradas estructuralmente por la tensión existente entre sus partes. En cualquier caso, la comprensión de las partes del territorio supone una operación sintética que reúne en una única noción los elementos y sistemas del soporte, las arquitecturas, lugares, tejidos y ciudades; sin embargo, el componente analítico no puede estar ausente de esta operación: la identificación de las partes del territorio supone también la división de la estructura en distintas áreas excluyentes entre sí e integradoras del territorio.

En consecuencia nos proponemos concluir nuestra indagación acerca de la lectura del territorio a través de un doble examen: en primer lugar identificaremos y caracterizaremos la relación que se establece dentro de cada parte completa entre los elementos que la componen y en segundo lugar examinaremos el papel que esas partes completas asumen en la configuración del territorio; las relaciones existentes entre ellas y entre cada una de ellas y el conjunto territorial.

Las partes de territorio aparecen así como el instrumento analítico que nos permite entender el territorio como formado por un número determinado de partes completas. Cada una de estas partes goza del carácter propio del territorio, son de algún modo territorios completos. Son esferas de una mayor dimensión.

Por tanto tenemos el territorio dividido inicialmente en partes completas que se corresponden con las topologías del relieve, posteriormente en cada uno de las partes se van "tejiendo" fragmentos que son discontinuos. Con el paso del tiempo estos fragmentos van colmatando el cañamazo a la vez que las relaciones entre los fragmentos van creando una red de conexiones independiente a la del cañamazo inicial; por lo que llega un momento que los fragmentos y sus conexiones desdibujan el cañamazo inicial y por tanto no se perciben las partes completas en las que se dividía el territorio inicialmente.

Pero vayamos a nuestro estudio, en ese momento sí que se perciben estas partes del territorio, veamos como son. Estas partes completas -macroesferas- gozan del carácter de territorio solo de un modo limitado; pues cada una de las partes mantiene necesariamente una relación con el conjunto del territorio que caracteriza al mismo tiempo a esa parte y al territorio total. Existe por tanto una relación estructural entre las partes, que es la del propio cañamazo.

La continuidad espacial no supone homogeneidad; por tanto nada obsta para que dentro del territorio

131 FERNÁNDEZ-GALIANO, L.A. ”Arquitectura y vida: el arte en mutación” pág. 26 
puedan distinguirse partes distintas, con sus propias características específicas. Lo que la proposición de la continuidad espacial afirma es el carácter estructural de esas distinciones: no existe solución de continuidad entre unas partes y otras, porque en la caracterización de cada una de ellas entra como un componente esencial su relación con el resto del territorio y con el carácter específico del cañamazo en cada parte.

Siendo conscientes de esta distinción esencial entre el territorio y sus partes constituyentes no hay inconveniente en admitir que la parte -a diferencia del territorio- sí puede llegar a responder a una sola idea base. La intervención en el territorio ha de apoyarse precisamente en esas partes completas o macroesferas.

La noción del territorio por partes proporciona así un instrumento para delimitar adecuadamente un ámbito de actuación que permita no solo el análisis sino también como luego veremos la actuación sobre él.

Un entendimiento correcto de la noción del territorio por partes y cada una de ellas con fragmentos, tiene también que ponerse de manifiesto en la atención constante al territorio completo. Cualquier fragmento de una parte así como las propias partes del territorio, establecen un dialogo enriquecedor con todo el territorio que configura tanto el fragmento, la parte y el todo.

La relación entre los fragmentos con las partes y las de estas con el territorio no es solo una relación topológica, es ante todo una relación que se apoya en la misma construcción del territorio, en la imagen del territorio tal como es conocida y querida por sus habitantes.

La forma territorial debe ser entendida como mediación entre el tipo y la topología; por ello, toda forma territorial remite simultáneamente al tipo y a la topología en la que se inscribe. Por ello la topología del soporte se corresponde con las tipologías antropogeográficas.

Los lugares en la Edad Media se conectan y agrupan siguiendo la topología por lo que la estructura es la "misma" y se identifican las topologías con las tipologías de estructuras. 


\section{7. Tipologías antropogeográficas}

Una vez definidas las partes completas de Territorio podemos establecer 6 tipologías antropogeográficas que se corresponden con cada uno de las partes distintas de territorio que se pueden establecer en función de cómo es la topología, los recintos visuales y los tejidos de la estructura del territorio.

Estas son:

\section{- Tipología de montaña}
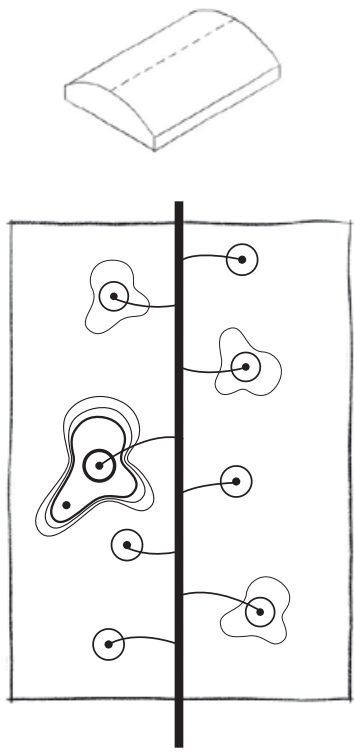

Fig. 5. 58. Tipología de montaña.
Topología

Es un soporte convexo y simétrico respecto al eje de la divisoria de aguas o línea de carena que lo recorre y lo conecta con las zonas limítrofes. Tiene estructura de espina que conforman la carena superior y el "arranque" de los barrancos que descienden hacia los valles laterales; esta estructura es complementaria de la del soporte del valle. La sección longitudinal es paralela a la divisoria de aguas y casi horizontal en muchos tramos, y cuando no es así lleva una pendiente continua y uniforme. La sección transversal es en $\mathrm{U}$ invertida con pendientes muy acusadas.

Los planos triangulares "vacíos" están dispuestos aleatoriamente, son de reducidas dimensiones, tienen mucha pendiente y son irregulares. Definen la limatesa de la divisoria de aguas.

Tiene predisposición al crecimiento lineal y discontinuo.

\section{Percepción visual}

Existencia en todo el entorno de un límite en un primer plano no muy definido y en un segundo plano el horizonte.

Direccionalidad formando parte de un recorrido de paso. La visión del espacio es muy homogénea desde todos los puntos, se tiene una visión cenital del territorio, se le "domina" en gran parte. Es un espacio "abierto".

Este es el territorio de las montañas y por tanto de los lugares que son centro y meta espiritual. Allí se ubica el "axis mundi" a partir del cual se despliegan las direcciones para que el hombre se oriente y allí por ese motivo peregrina el hombre.

\section{Estructura de los tejidos}

El tejido ganadero apropiándose (fagocitando) del camino de dominio de conquista, estructura el territorio de forma lineal y extendiéndose por todo el ámbito.

Es un territorio en gran parte "virgen" ocupado por bosques y pastos; está trufado por el tejido agrícola discontinuo de masías con formas de arabescos de carácter orgánico en las zonas más aptas para el cultivo agrícola o como apoyo al uso ganadero. En el entorno del núcleo urbano- que hace de centro del territorio- se desarrolla un tejido agrícola orgánico como si se tratará de una masía más, pero su uso es de varios propietarios que residen en él. Los tejidos ganaderos y agrícolas están interconectados, con el tejido urbano estos están conectados y los otros tejidos que coexisten en esta tipología son el religioso y el militar que se encuentran yuxtapuestos y tienen menor importancia.

La disposición de la estructura en planta es en espina, con una distribución heterogénea y asimétrica según la orientación y discontinua respecto al suelo "virgen”. La densidad es baja respecto al suelo "virgen" y disminuye conforme nos alejamos del eje principal y respecto a la superposición de los tejidos entre ellos.

Los tejidos se disponen en los planos triangulares "vacíos", de mayores dimensiones, menor pendiente y mejor orientación. 


\section{La ciudad}

En esta tipología es de reducidas dimensiones y está "separada" del eje principal como un lugar más. El centro de la ordenación no es tanto la ciudad como el propio eje.

Ejemplos

Bel y Boixar, Coratxar, Castell de Cabres, Herbeset, Ares...

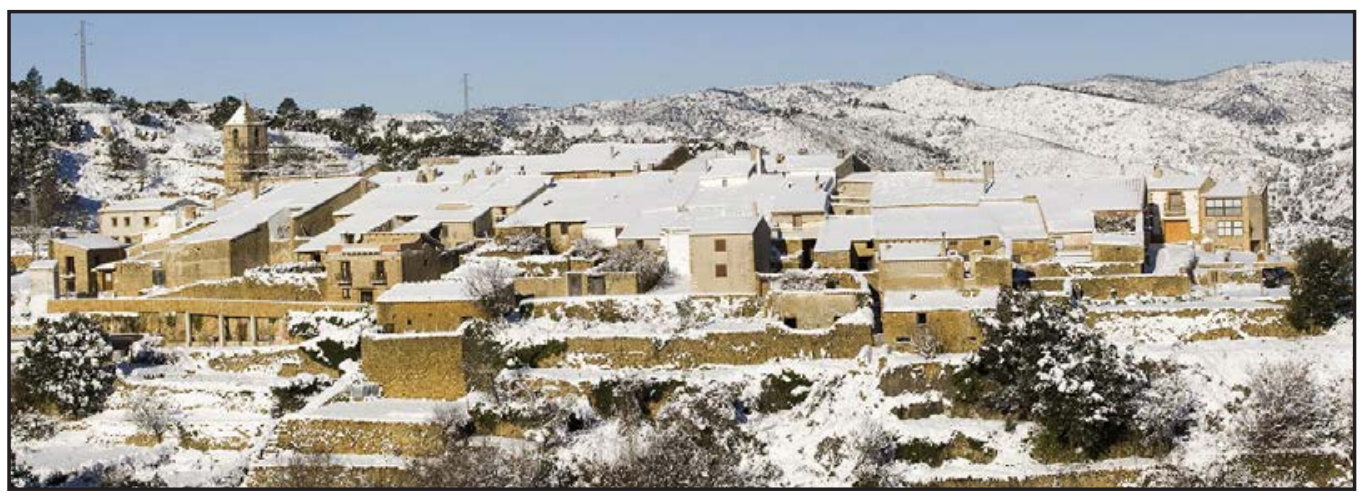

Fig. 5. 59. Foto de Bel.

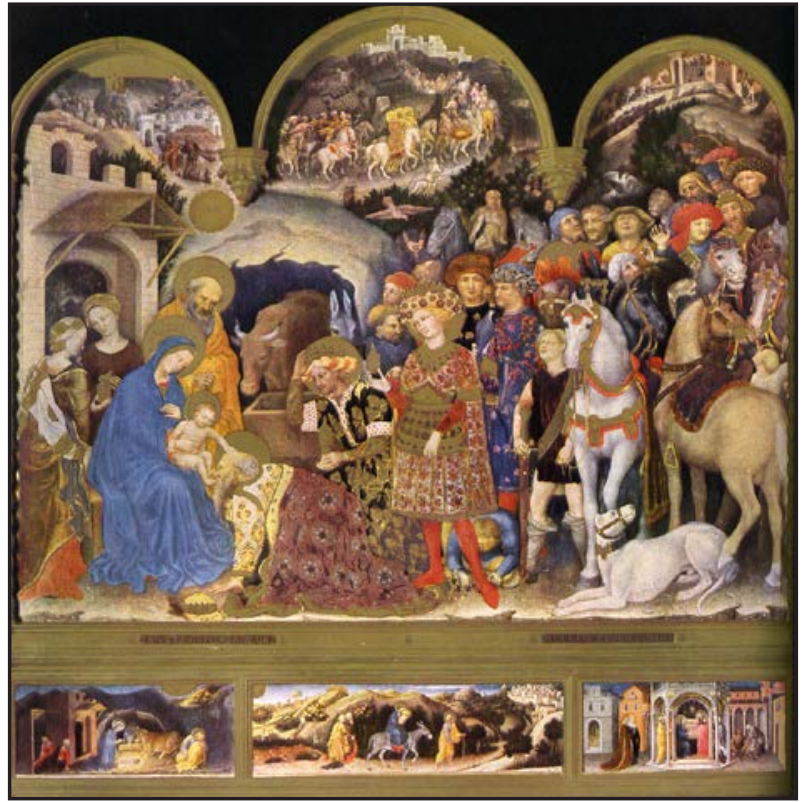

Fig. 5. 60. Imagen en la parte superior de la Adoración de los magos, de Gentille da Fabriano (1423).

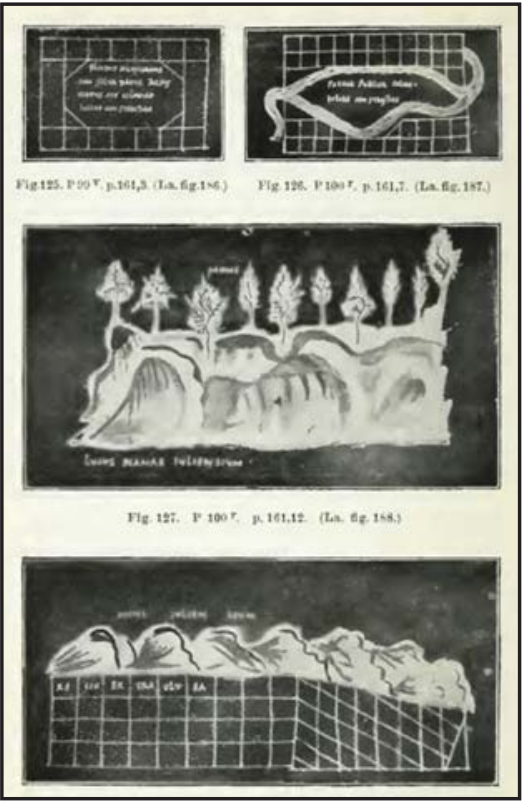

Fig. 5. 61. Dibujos 125, 126, 127 y 128 del libro "Frontin l'oeuvre gromatique" que recoge Corpus Agrimensorum romanorum IV de lulius Frontinus.

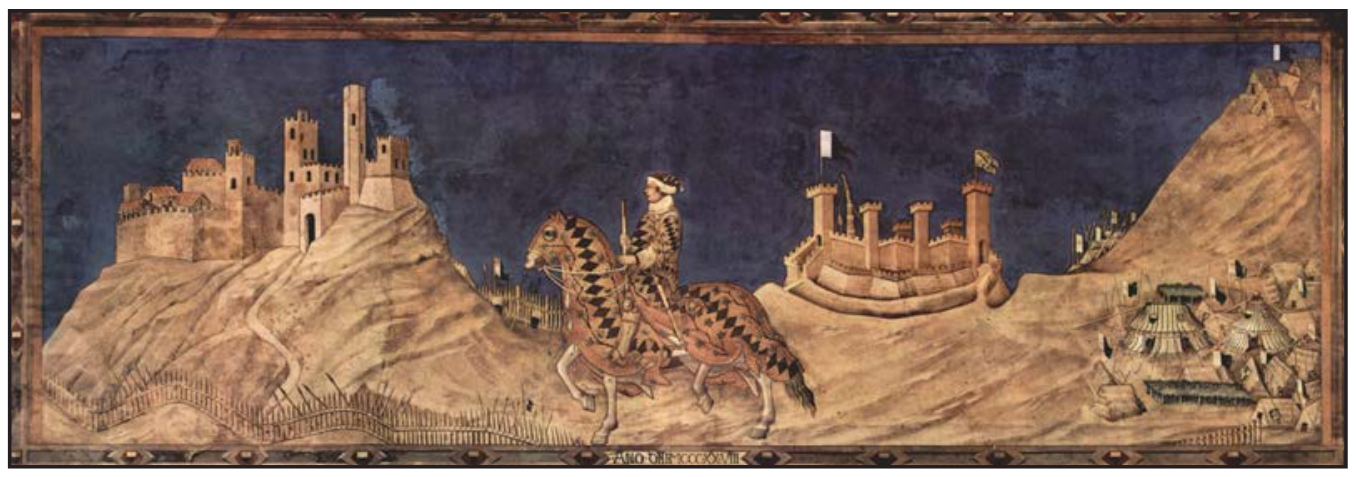

Fig. 5. 62. Pintura de Guidoriccio da Fogliano (1328) de Simone Martini. 


\section{- Tipología de valle}
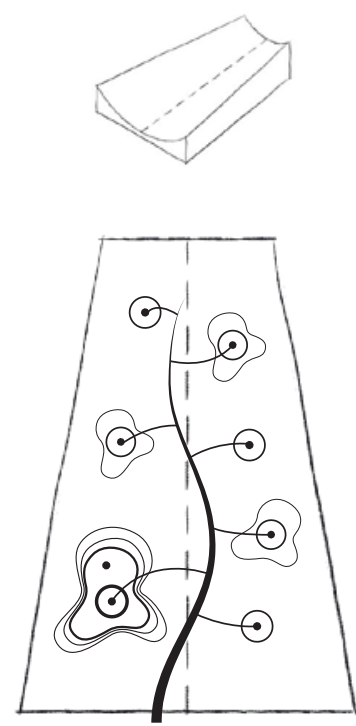

Fig. 5. 63. Tipología de valle.
Topología

Es un soporte cóncavo y simétrico respecto a la limahoya del río que recorre el valle. Tiene una estructura de racimo conformado por el río y los barrancos que confluyen con él bajando por las laderas; es complementario del territorio de montaña. La sección longitudinal paralela al curso del agua, lleva una pendiente continua aunque no uniforme. La sección horizontal es en $\mathrm{V}$ con pendientes muy acusadas. Los planos triangulares V "vacíos" están dispuestos aleatoriamente, son de reducidas dimensiones, tienen mucha pendiente y son irregulares y definen la limahoya del curso del agua.

La predisposición al crecimiento solo en la dirección de aguas abajo y de forma discontinua.

\section{Percepción visual}

Existencia en todo el entorno de un primer plano muy definido y sin percibir el horizonte. Direccionalidad muy marcada en cul de sac. La visión del espacio es diferente según desde que posición lo hagamos. Desde el interior, en el fondo del valle tenemos una visión "lineal" que nos enmarcan las cadenas montañosas; desde media ladera tenemos una visión más amplia, pudiendo alcanzar a tener una visión de conjunto de la ladera de enfrente en la que nos encontramos. Si se produce algún ensanchamiento un punto a media ladera nos permite tener una visión de conjunto de parte del valle. Conforme ascendemos tenemos una visión más amplia del conjunto.

Este es el territorio de las manantiales/caverna y por tanto de los lugares en los que se encuentra la matriz de la que manan todos los seres y fuente de la vida, por tanto centro y meta espiritual. La imagen del agua nos remite al útero materno y a lo femenino, ese carácter simbólico es el que propicia la aparición de las ermitas de carácter mariano y la peregrinación hasta ellas.

\section{Estructura de los tejidos}

El tejido agrícola de masías "orgánicas" de carácter lineal es el que estructura el territorio y se extiende por todo el ámbito. Los otros tejidos que coexisten con él, son el ganadero como zona de pastos "finales" a los que llega le red de vías pecuarias con el que está interconectado, el urbano con el que conecta y hace de centro del territorio y los tejidos defensivos y religiosos que se yuxtaponen con él. La unidad del territorio la proporcionan los bosques y pastos, los tejidos ocupan solo una pequeña parte en aquellas zonas de mejores condiciones topográficas; el núcleo urbano se ubica en un lugar preeminente que domina el territorio.

La disposición de la estructura en planta es en racimo, con una distribución heterogénea y asimétrica de los tejidos según la orientación y discontinua respecto al suelo "virgen". La densidad es baja respecto al suelo "virgen" y disminuye conforme nos alejamos del eje principal y respecto a la superposición del resto de tejidos entre ellos.

Los tejidos se disponen en los planos triangulares "vacíos" de mayores dimensiones, menor pendiente y mejor orientación.

La ciudad

En esta tipología es de reducidas dimensiones y está "separada" del eje principal como un lugar más. El centro de la ordenación no es tanto la ciudad como el propio eje. 


\section{Ejemplos}

La Barcella y Vallibona, Xiva Morella, Les Albaredes de Portell, Herbes, Pobla de Benifassar, Tirig...

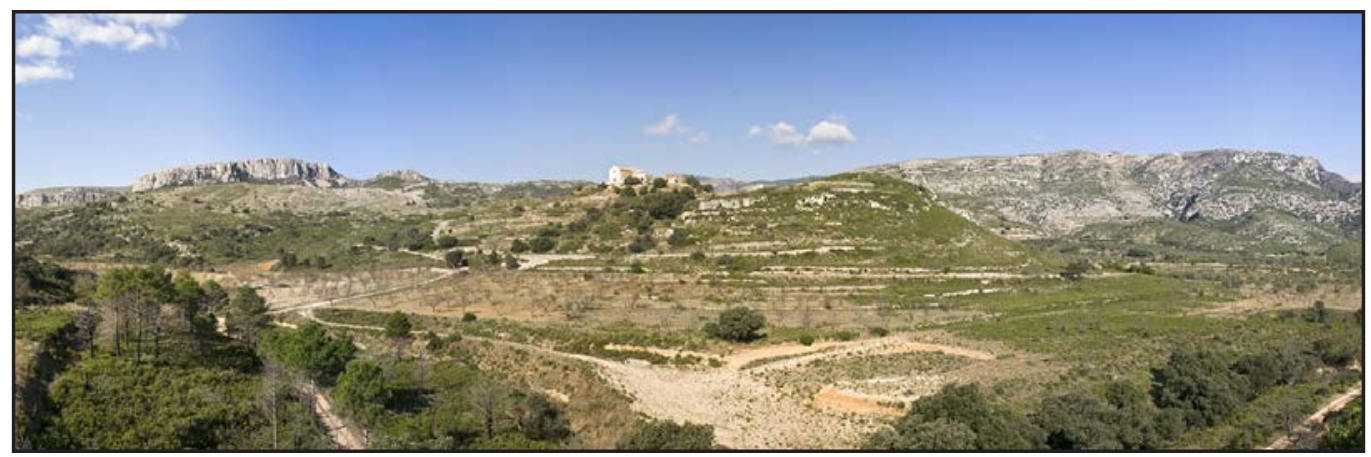

Fig. 5. 64. Foto de la Barcella y Sant Marcantonio.

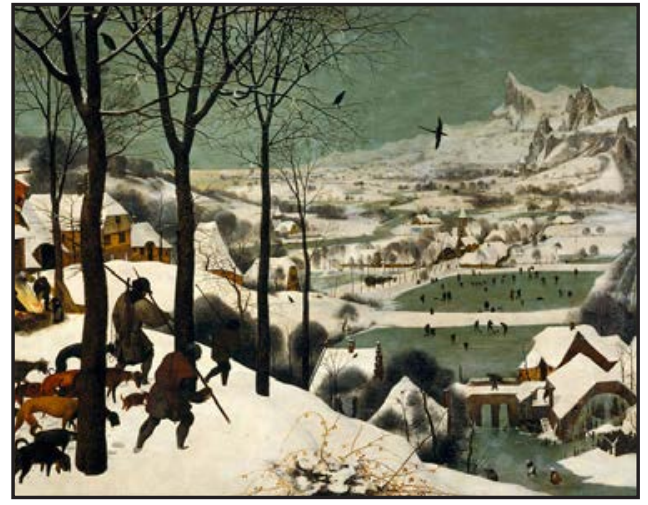

Fig. 5. 65. Cuadro de "cazadores en la nieve" de Pieter Bruegel el viejo (1565).

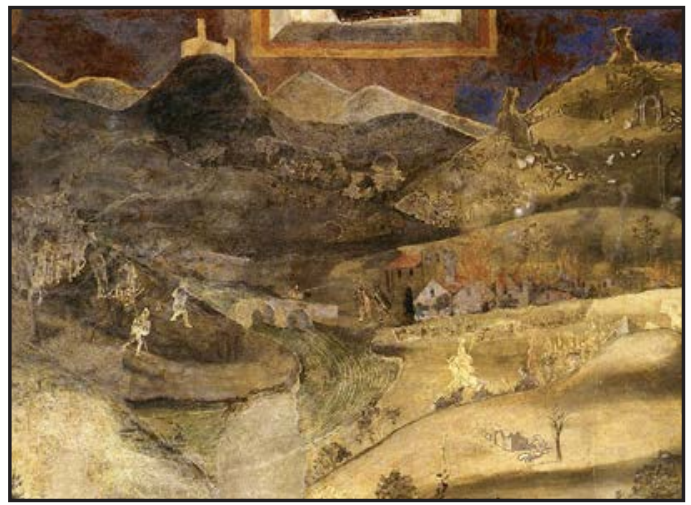

Fig. 5. 66. Detalle del cuadro de A. Lorenzetti "Los efectos del mal gobierno" Siena, entre 1338 y 1340.

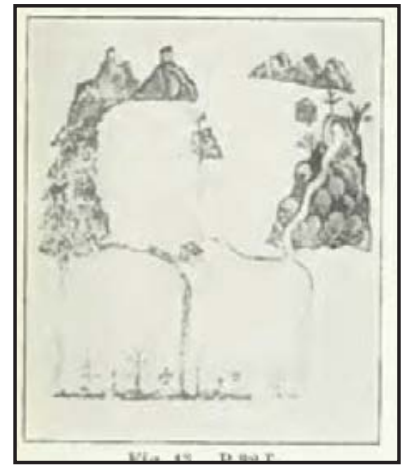

Fig. 5. 67. Detalle del cuadro de A. Lorenzetti "Los efectos del mal gobierno" Siena, entre 1338 y 1340.

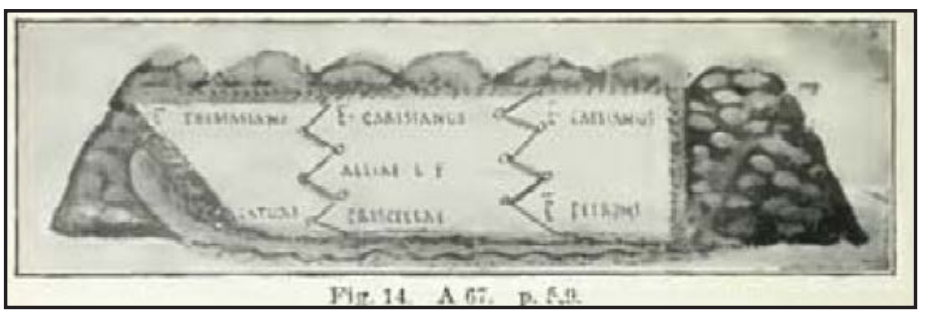

Fig. 5. 68. Dibujo 14 del libro "Frontin l'oeuvre gromatique" que recoge Corpus Agrimensorum romanorum IV de lulius Frontinus. 


\section{- Tipología de ladera}
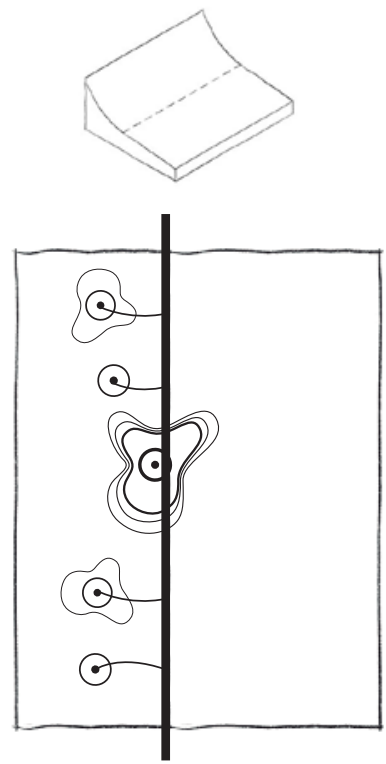

Fig. 5. 69. Tipología de ladera.
Topología

Es un espacio asimétrico conformado por los paleoconos torrenciales y el plano horizontal del suelo próximo al cauce del río. Tiene estructura de peine, que forman el río y los barrancos que vierte a él. Es complementario del territorio de montaña y de llano, es la transición entre ambos.

La sección longitudinal tiene un perfil horizontal. Las secciones transversales tienen características totalmente diferentes según se dirijan hacia la montaña-donde tiene mucha pendiente- o hacia el río en la que la pendiente se suaviza de forma apreciable. El punto de cambio de las pendientes transversales, definen la línea que hace de charnela entre el plano inclinado de la ladera de la montaña y el llano del río.

Los planos triangulares "vacíos", están dispuestos aleatoriamente. De la charnela hacia arriba son de reducidas dimensiones, tiene mucha pendiente, son irregulares y no uniformes. De la charnela hacia abajo son de dimensiones mayores, tienen poca pendiente, se regularizan y se hacen uniformes. Definen la línea de cambio de pendiente o charnela.

La predisposición al crecimiento es lineal, discontinua de la charnela hacia arriba y continua de la charnela hacia abajo.

\section{Percepción visual}

Existencia en uno de los lados de un límite muy definido y en los otros limites en planos medios u horizonte. Direccionalidad muy marcada como recorrido de paso.

La visión del espacio es diferente según desde donde la hagamos. Desde los barrancos de espaldas al nacimiento del mismo y de cara al río, tenemos una visión amplia que domina en ocasiones una gran parte del territorio, pero en la que no podemos ver a los "vecinos" de los barrancos contiguos. En dirección opuesta la visión del barranco es muy cerrada, sin apenas campo de visión.

Desde el río y mirando hacia la ladera es donde podemos obtener una visión del conjunto, donde podemos percibir a la vez todos los “entrantes" en la montaña (las "púas” del peine), a la vez que podemos tener una visión del valle por el que discurre el río. Aquí se sitúan los asentamientos defensivos y de control del territorio; con un elemento y una adecuada "triangulación" con los asentamientos de dentro de los barrancos se puede controlar el territorio.

\section{Estructura de los tejidos}

En este caso no hay un tejido predominante que estructure el territorio; es el camino de en medio el que estructura los distintos tejidos. Se encuentran los seis tejidos -agrícolas, ganaderos, "preindustriales", urbanos, religiosos y defensivos- que se relacionan entre ellos según las tres formas de relación: conexión, interconexión y yuxtaposición.

La disposición de las estructuras en planta es la de peine, con una distribución heterogénea y asimétrica de los tejidos, en función del camino de en medio. Por encima de él los tejidos agrícolas son más orgánicos, asimétricos y heterogéneos. Por debajo son más regulares y homogéneos. La densidad del camino hacia arriba es baja mientras que por debajo del camino de en medio es alta, no existiendo casi restos de suelo "virgen" y superponiéndose todos los tejidos.

En esta tipología conviven casi todos los tejidos agrícolas, los orgánicos de masías con formas de arabescos en las zonas altas de los barrancos; los de formas más regulares con 
formas de mosaicos tanto en las masías situadas en zonas más bajas como en el entorno del núcleo urbano y junto a las zonas bajas de los barrancos se desarrollan tejidos de regadío de reducidas dimensiones. Todos ellos se encuentran yuxtapuestos en el territorio y conectados con el tejido urbano y "preindustrial".

El tejido ganadero discurre paralelo o en ocasiones coincidiendo con el camino de en medio que estructura el territorio, es solo de paso por lo que tiene menor importancia que en las tipologías anteriores.

El tejido "preindustrial" se ubica de forma heterogénea en las púas del peine y conectado con el camino de en medio, se halla interconectado con el tejido agrícola de regadío con el que forma una unidad.

El tejido urbano hace de centro, ocupando uno de los encuentros de las púas con el eje del peine, su selección se realiza en función de un mejor dominio del territorio. En sus alrededores se encuentra tanto el tejido agrícola con formas de mosaico asociado a un núcleo urbano como el de regadío de pequeñas dimensiones, propiciando un lugar-ciudad en sentido extenso.

El tejido defensivo es una malla (triangular) por los problemas de visibilidad de los barrancos de la ladera. El tejido sacro es lineal a partir del camino de en medio.

Los tejidos agrícolas de regadío y preindustrial están interconectados los agrícolas entre sí están yuxtapuestos y conectados con el urbano. El defensivo esta interconectado con el urbano y el agrícola de masías; conectado con el "preindustrial" y ganadero y yuxtapuesto al resto de tejidos.

Los tejidos por encima del camino se disponen en los planos triangulares "vacíos" de mayores dimensiones, menor pendiente y mejor orientación. Por debajo del camino, se disponen en todos los planos triangulares sin excepción.

\section{La cindad}

Se sitúa en el eje-camino del cambio de pendiente. Tiene una relevante importancia al estar en un camino de paso. Conforma junto con el eje el centro sobre el que bascula la ordenación.

\section{Ejemplos}

Molinar -Xert y Rosell- Más del Coll, Catí-La Belluga, Vega río Bergantes...

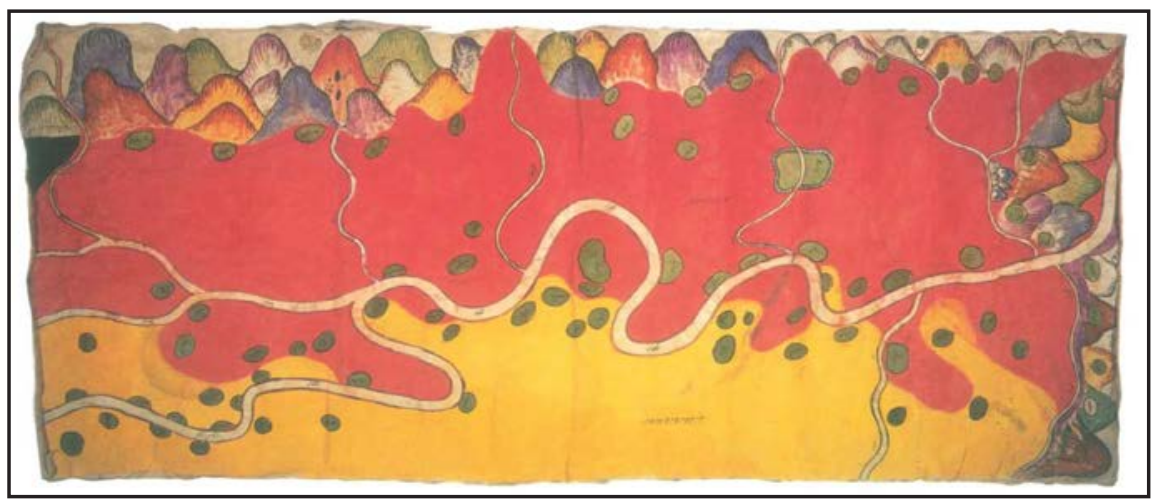

Fig. 5. 70. Plano del río Nam Mao en China.

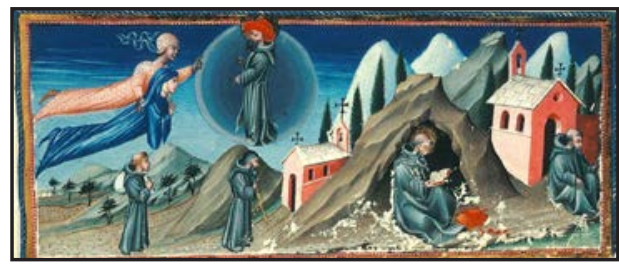

Fig. 5. 71. Pintura de ermitas anacoreta en la Divina Comedia de Dante. Lugar/monasterio.

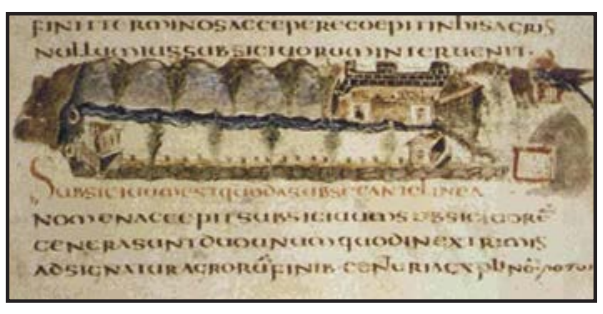

Fig. 5. 72. Dibujo 6 del libro "Frontin l'oeuvre gromatique" que recoge Corpus Agrimensorum romanorum IV de Iulius Frontinus. 


\section{- Tipología de llano}
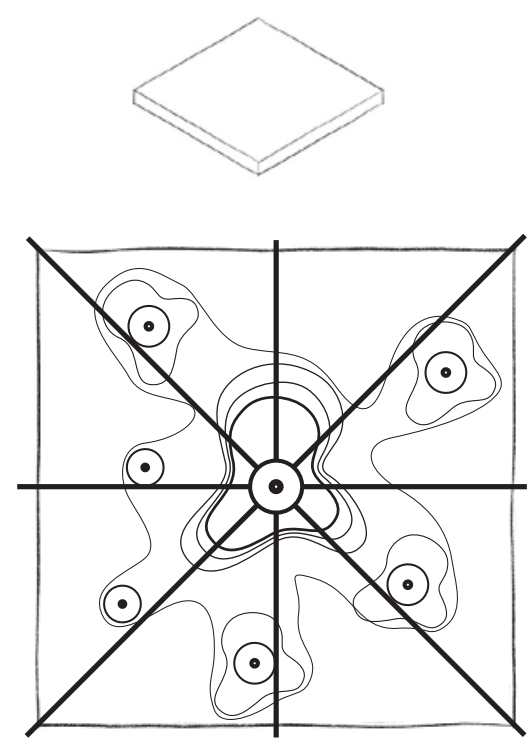

Fig. 5. 73. Tipología de llano.
Topología

Es un espacio llano e isótropo en todas las direcciones. Tiene una estructura radial con un foco central, en una posición un poso más elevado, que irradia de una forma uniforme en todas direcciones. Las secciones longitudinales y transversales son sensiblemente planas, pero una de ellas tiene una mayor pendiente que permite la escorrentía del agua. En definitiva se trata se trata de una disposición llana y central matizada por una disposición en franjas según la pendiente de la escorrentía.

Los planos triangulares "vacíos" están dispuestos según la escorrentía del agua, son de dimensiones importantes, tiene poca pendiente y regular. Las líneas definen un foco central en el soporte.

La predisposición al crecimiento es en cualquier dirección en forma de mancha de aceite desde el foco central.

\section{Percepción visual}

Existencia de un límite definido en las distancias medias y un segundo plano de horizonte. Espacio isótropo sin ninguna direccionalidad marcada.

La visión del espacio es uniforme y muy amplia en todo el territorio. Desde una pequeña elevación se puede observar y dominar una gran cantidad de terreno que solo se ve limitada por las cadenas montañosas que lo delimitan en la lejanía. En estos puntos altos se ubican los asentamientos humanos.

\section{Estructura de los tejidos}

El tejido urbano es el que situándose en el centro estructura el territorio de forma concéntrica y extendiéndose de forma isótropa por todo el ámbito.

El tejido agrícola con masías en forma de mosaico se sitúa en el límite del llano en los emplazamientos en los que la topografía comienza a tener pendiente; el llano es prácticamente ocupado por el tejido de regadío llano de forma de alfombra regular y homogénea. El territorio se ocupa casi en su totalidad, no existen bosques y los pastos son escasos.

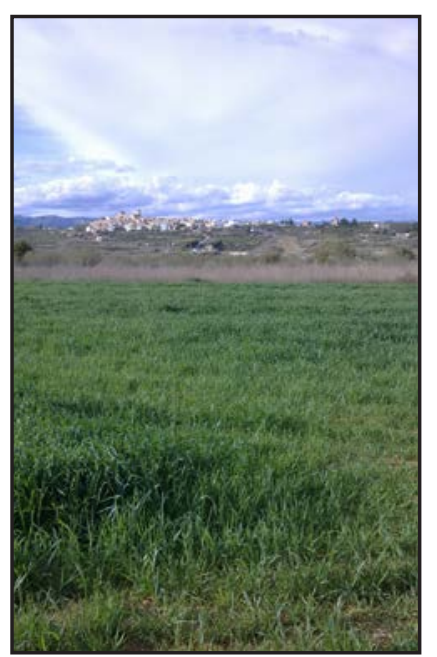

Fig. 5. 74. Foto tipología de llano en Canet.
La disposición de la estructura en planta es radial, con centro en el tejido urbano y con una distribución de los tejidos agrícolas heterogénea y concéntrica en función de la distancia al centro. La distribución es continua y la densidad es alta, ocupando la totalidad del suelo, solo existen zonas de suelo "virgen" en el perímetro del área.

Los otros tejidos coexisten de forma minoritaria y ocasional. Los tejidos "preindustriales" se sitúan en el río que normalmente es uno de los bordes del área, por lo que tiene una relación tangencial.

No existe casi la superposición de tejidos. El tejido urbano y los agrícolas asociados a él, han fagocitado todo el territorio "expulsando" al resto de tejidos al perímetro y de forma residual.

Los tejidos se disponen en todos los espacios triangulares "vacíos" independientemente de su tamaño, orientación o pendiente. 


\section{La ciudad}

Es el centro y el punto desde el que parten las conexiones con otras ciudades y partes del territorio. Son ciudades de considerable densidad e importancia relativa respecto al resto del territorio.

\section{Ejemplos}

Canet, La Jana, San Mateu, Traiguera, La Llecua, Villafranca del Cid...

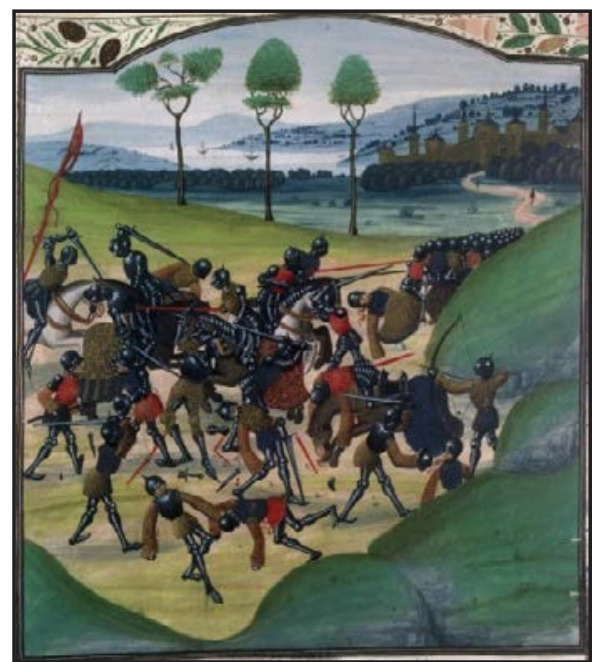

Fig. 5. 75. Pintura de la Batalla de Poitiers (1356).

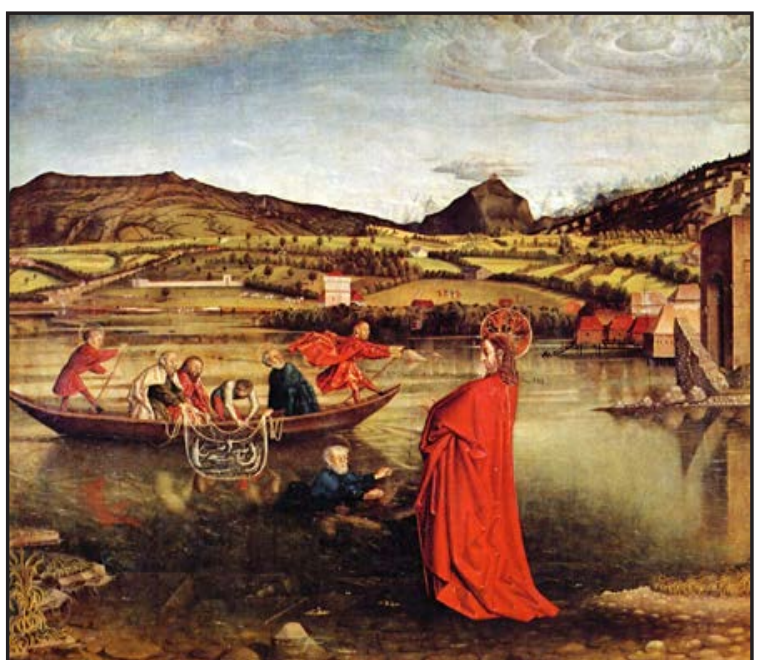

Fig. 5. 76. Pintura de Konrad Witz (1444)

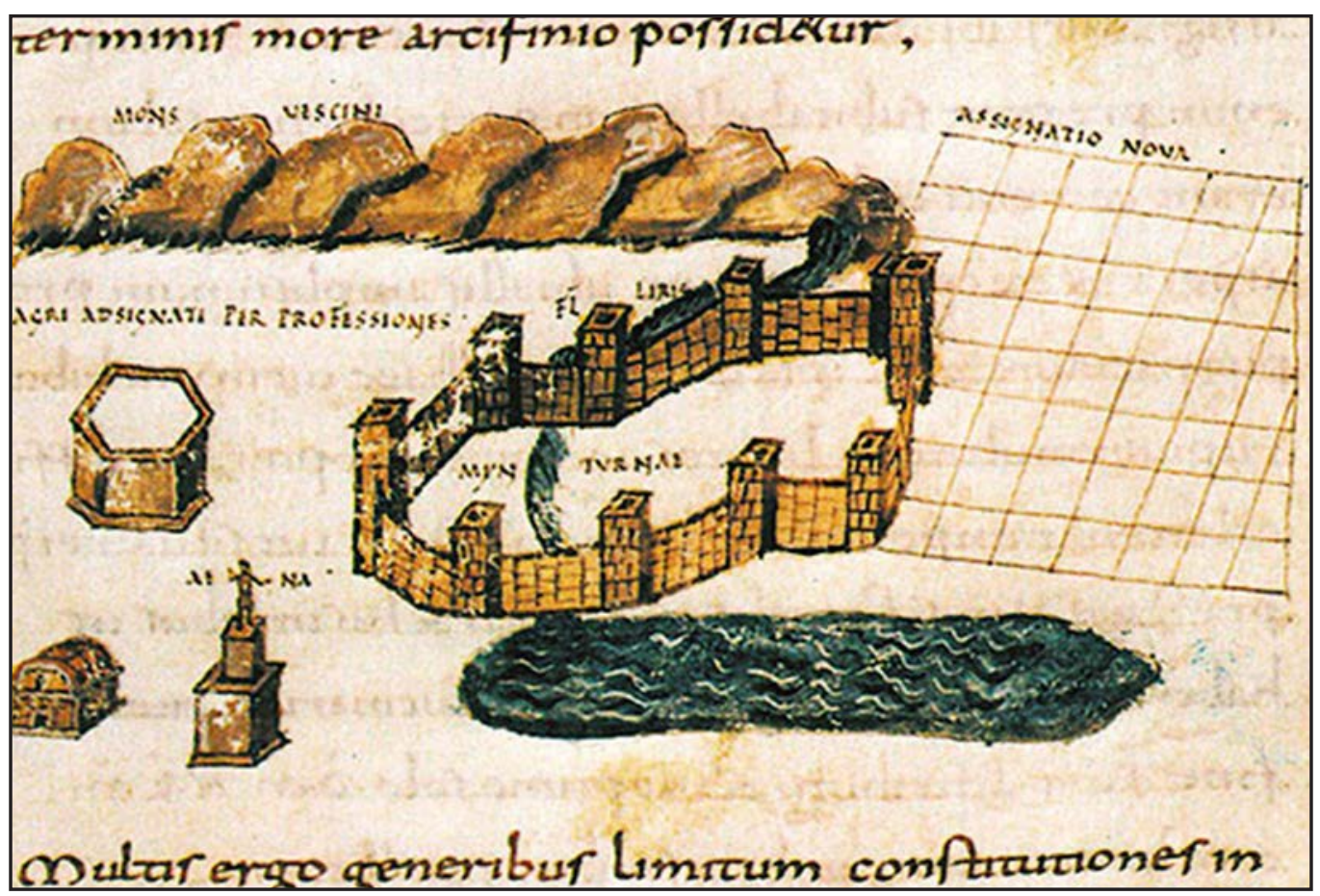

Fig. 5. 77. Dibujo 89 del libro "Frontin l'oeuvre gromatique" que recoge Corpus Agrimensorum romanorum IV de lulius Frontinus. 


\section{- Tipología de altiplano ondulado}
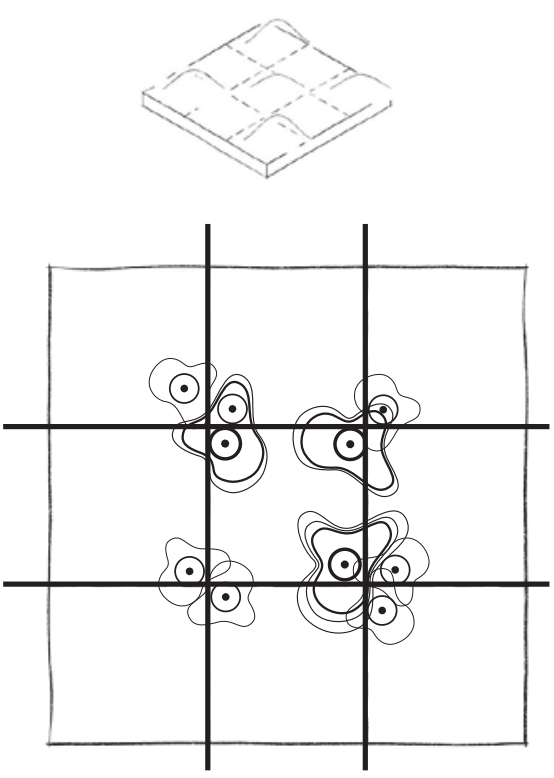

Fig. 5. 78. Tipología de altiplano ondulado.
Topología

Es una sucesión de zonas cóncavas y convexas, isótropa y sin ninguna dirección ni foco claramente determinados. Tiene una estructura en malla isótropa que discurre por las limahoyas de los volúmenes que forman el ámbito. No hay limatesas, sino una serie de puntos elevados dispersos. La malla se puede acentuaran en algún punto por coincidir alguno de los elementos de la malla con un curso de agua importante o un camino que comunique distintos territorios. Las secciones transversales y longitudinales son similares y son un continuo "sube y baja" de pendientes no muy importantes.

Los planos triangulares "vacíos" se disponen aleatoriamente, remarcando los puntos de las elevaciones cóncavas. Son de dimensiones importantes, pendientes reducidas y regulares que se reparten uniformemente.

La predisposición al crecimiento es uniforme y en todas direcciones prolongando la malla.

\section{Percepción visual}

Existencia de un límite en un segundo plano no muy definido, obstaculizado por interferencias en primeros planos que impiden la visión global del conjunto. Espacio isótropo o casi en función del valor de las interferencias que pueden darle cierta direccionalidad al espacio.

El límite del recinto es doble y ambiguo. Cuando estamos en las partes bajas el límite es próximo y no existe la visión de conjunto y cuando estamos en un punto elevado el recinto no tiene límites y la visión no es completa ya que existen muchos puntos ocultos que nos impiden siempre tener una visión de conjunto.

\section{Estructura de los tejidos}

En este caso no hay un tejido predominante que estructure el territorio. Es la malla topológica la que estructura los distintos tejidos.

Se encuentran los seis tejidos -agrícolas, ganaderos, "preindustriales", urbanos, religiosos y defensivos- que se relacionan entre ellos según las tres formas de conexión, interconexión y yuxtaposición.

El tejido agrícola es el de masías o el del entorno de los núcleos urbanos ambos con formas de mosaicos que se extienden homogéneamente por todo el ámbito del territorio. Solo la zona destinada a pastos hace que se produzcan "vacíos" en estos tejidos y que pierdan densidad

La disposición de la estructura en planta es la de una malla con una distribución heterogénea e isótropa en todas direcciones. Solo la presencia de los tejidos urbanos hace que se conviertan en focos y que se pierda en parte la isotropía.

Los tejidos que se disponen en malla-agrícolas, defensivos, religiosos y urbanos- se extienden uniformemente, los que se disponen linealmente-"preindustriales" y ganaderos- se disponen en parte de la malla, mientras que en la otra no existen.

La densidad de tejidos es elevada tanto por que casi no queda suelo "virgen" como por la superposición entre los distintos tejidos.

Los tejidos se disponen en todos los planos triangulares "vacíos" independientemente de su orientación, tamaño o pendiente. 


\section{La ciudad}

Se sitúa en uno de los cruces de la malla como el resto de lugares de este territorio. La ciudad adquiere importancia respecto al resto de lugares porque los ejes en los que esta se sitúa son las conexiones con el resto del territorio. La malla tiene más "peso específico" que la propia ciudad.

\section{Ejemplos}

Más del Stellers, Calig, Cervera...

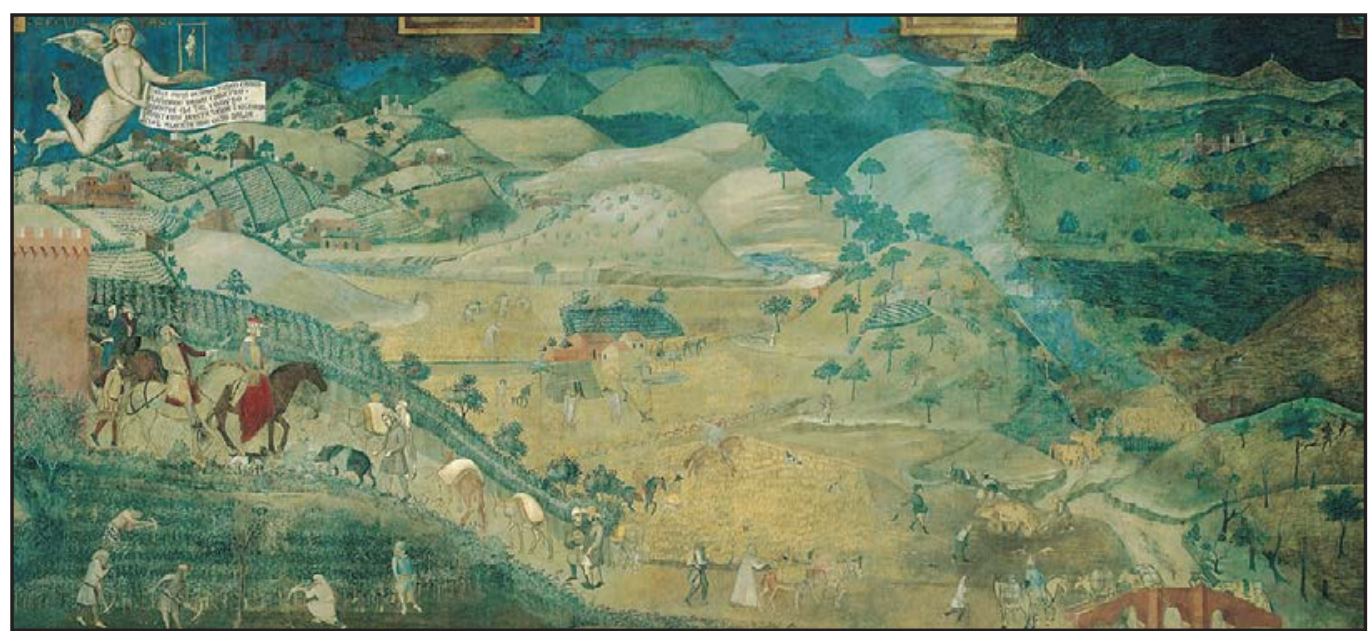

Fig. 5. 79. Pintura de A. Lorenzetti "Los efectos del buen gobierno" Siena, entre 1338 y 1340.

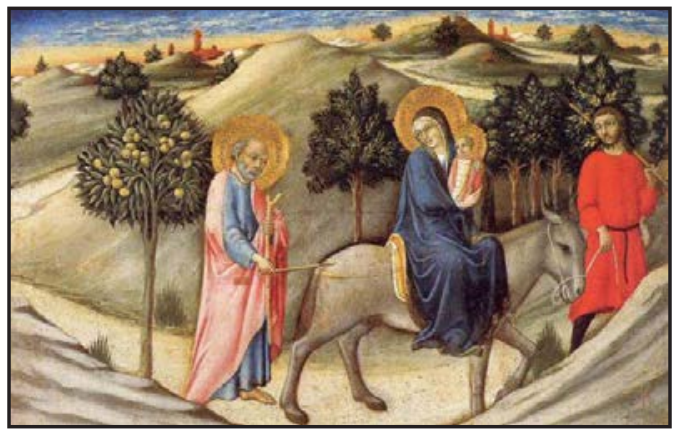

Fig. 5. 80. Pintura de la Huida a Egipto de Santo di Pietro (1445).

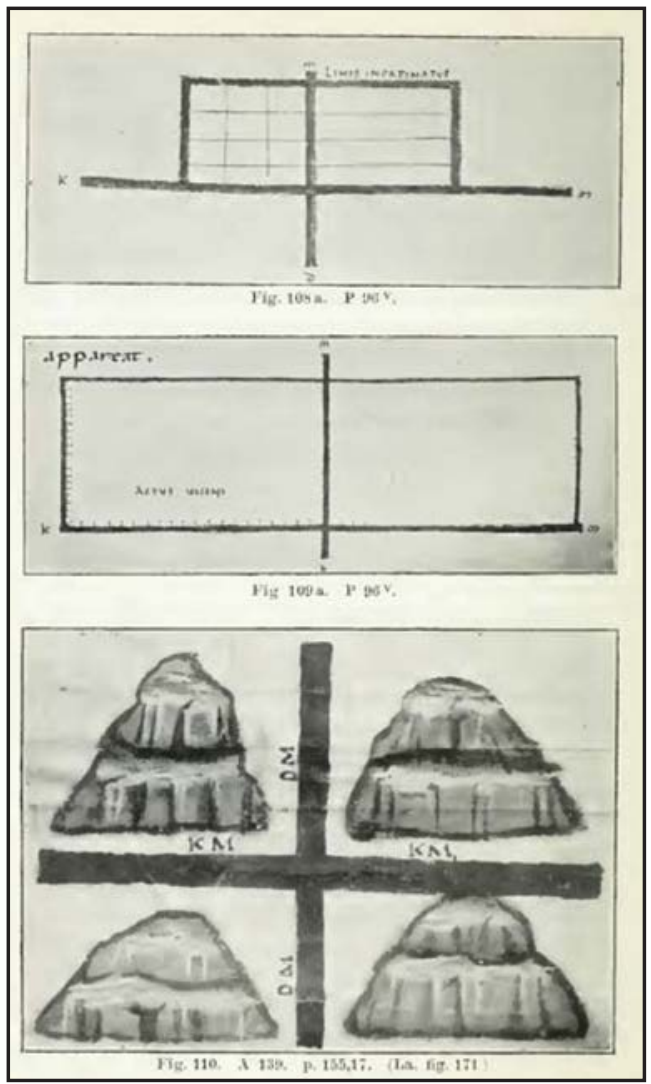

Fig. 5. 81. Dibujos 108,109 y 110 del libro "Frontin l'oeuvre gromatique" que recoge Corpus Agrimensorum romanorum IV de lulius Frontinus. 


\section{- Tipología de atalaya}
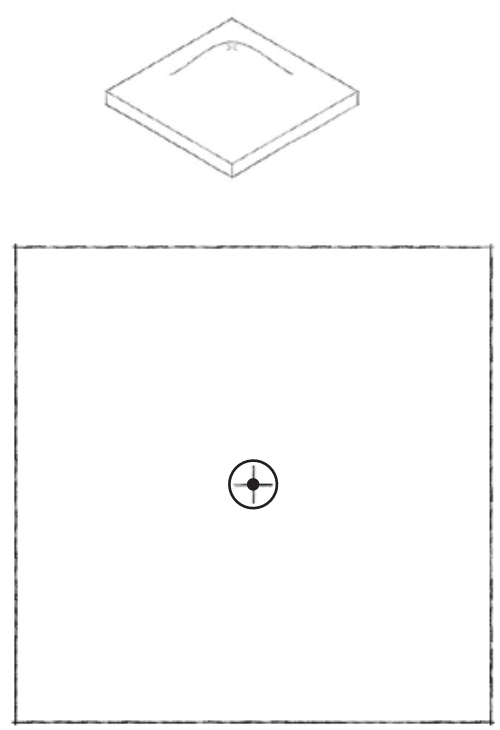

Fig. 5. 82. Tipología de atalaya
Topología

Es un elemento aislado cóncavo. No tiene ningún tipo de estructura, es solo un hito. Las secciones longitudinales y transversales son similares en forma de U invertida y de importante pendiente. Los planos triangulares "vacíos" están dispuestos concéntricamente respecto a la mayor cota, tiene mucha pendiente, son de reducida dimensión y son irregulares.

No existe predisposición al crecimiento.

\section{Percepción visual}

En estos emplazamientos la idea de lugar es la helénica, el pequeño pedazo de territorio que tiene el dominio de las distancias media o, puntualmente, de la distancia larga si es un lugar de defensa, pero donde no se puede considerar que haya un ámbito que cuente con cierta estructura visual interior compleja, que se modifica parcialmente con la evolución histórica.

Estructura de los tejidos

En este caso no hay ningún tejido, en ocasiones puede formar parte del tejido religioso o ganadero pero de forma residual. En ningún caso se da el tejido urbano.

La cindad

No hay ciudades.

Ejemplos

La Mola Garumba en Morella, la Mola de Ares o las Molas de Xert.

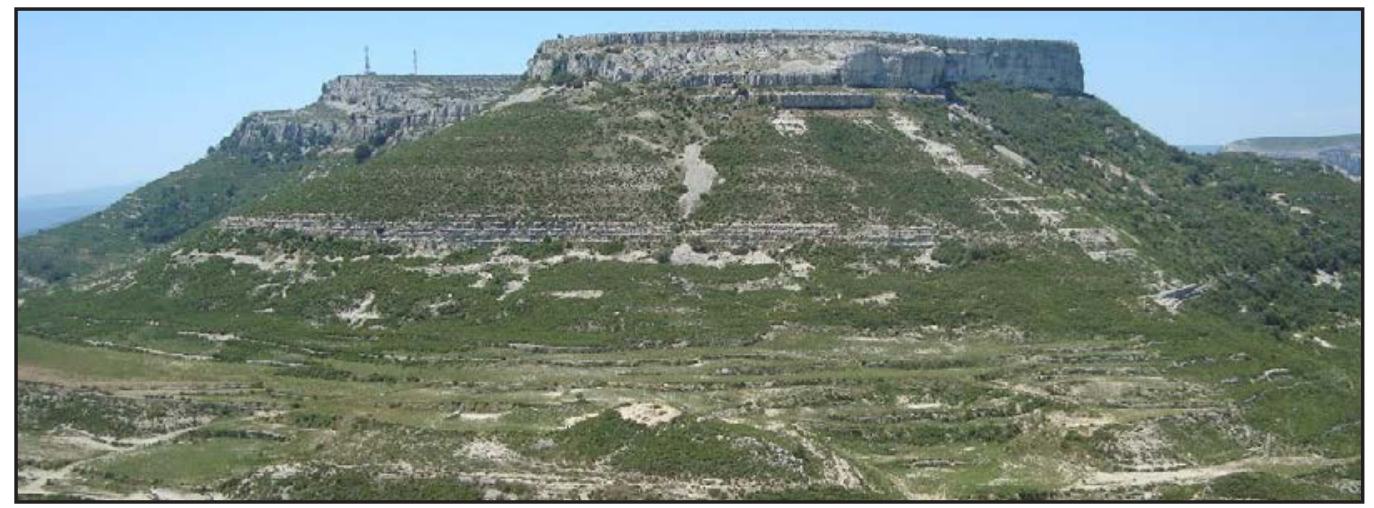

Fig. 5. 83. Foto de la mola de Xert. 


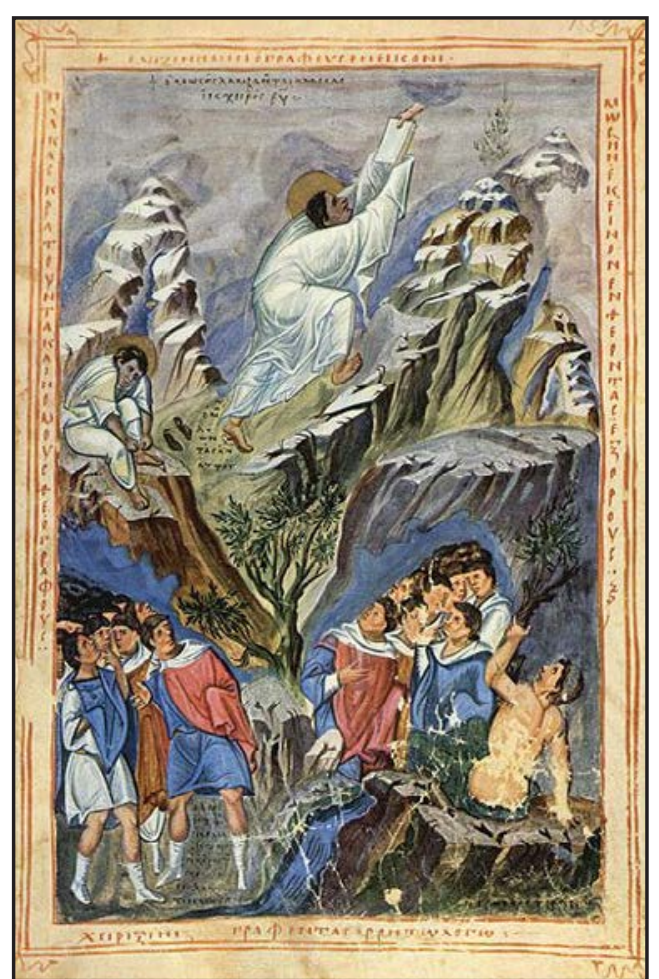

Fig. 5. 84. Pintura de los Maestros de la Biblia de Patrice Leon (s. X).

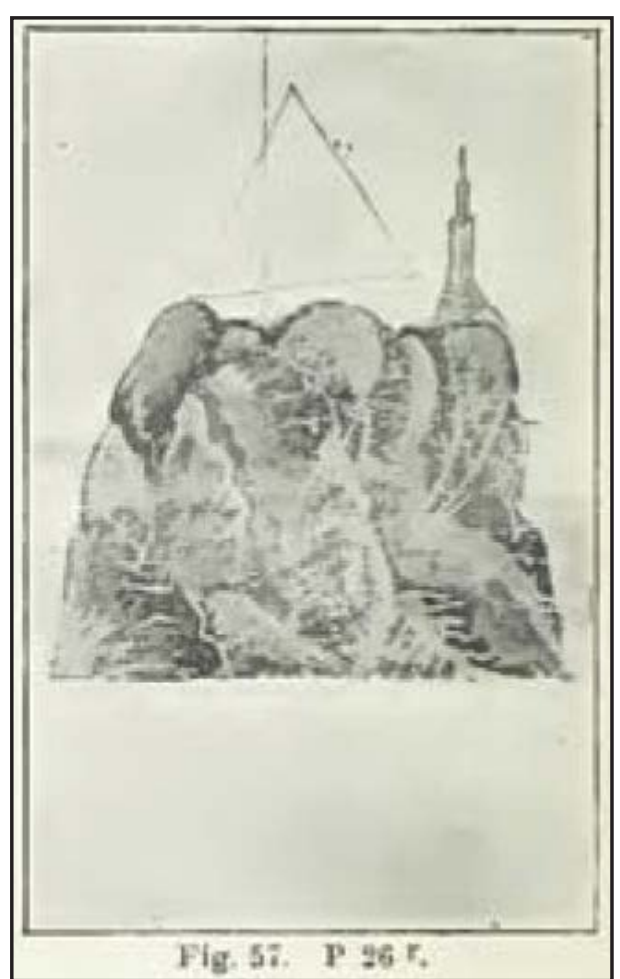

Fig. 5. 85. Dibujo 57 del libro "Frontin l'oeuvre gromatique" que recoge Corpus Agrimensorum romanorum IV de Iulius Frontinus.

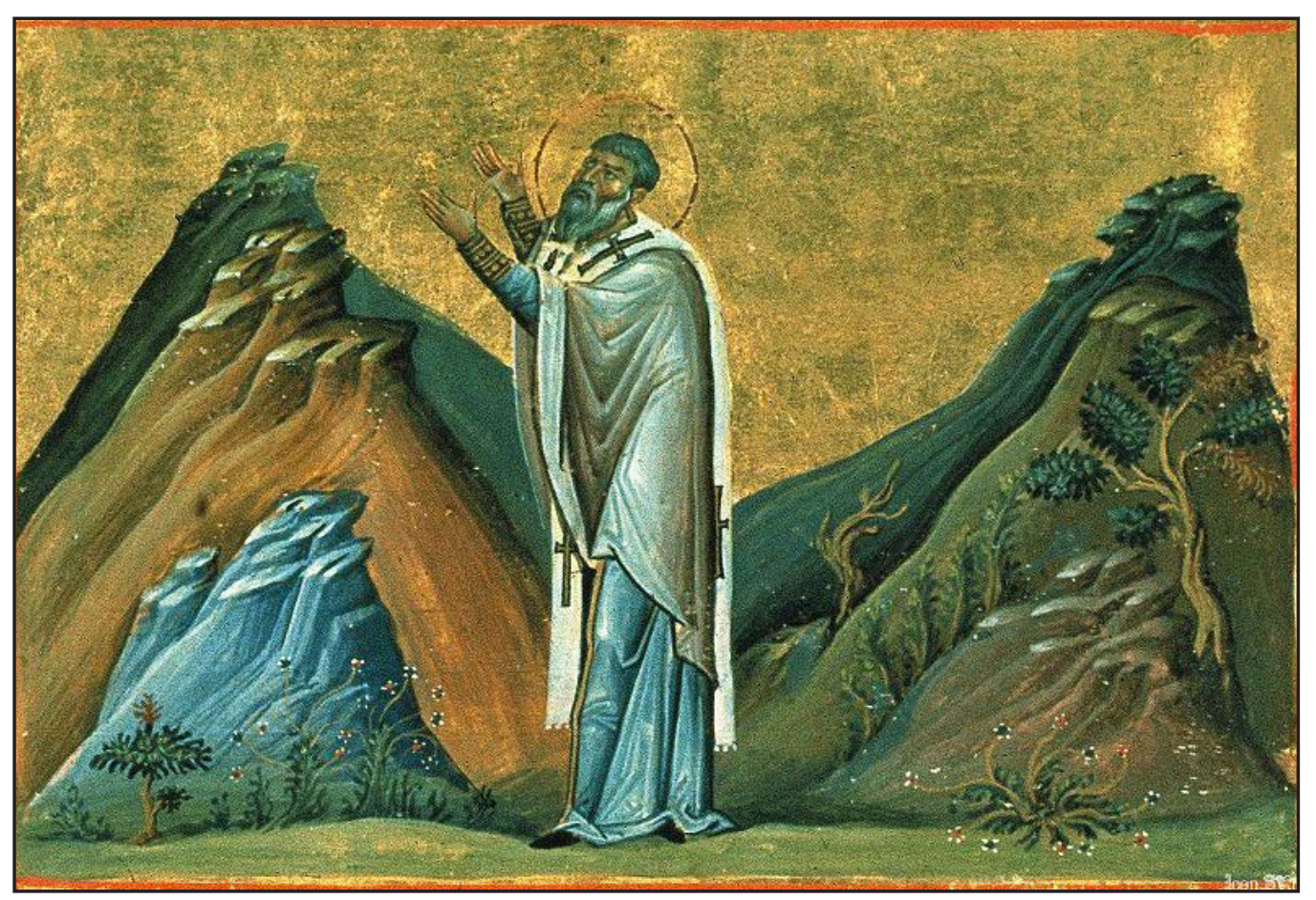

Fig. 5. 86. Miniatura de Abercio obispo de Hieropolis (s. XIII). 

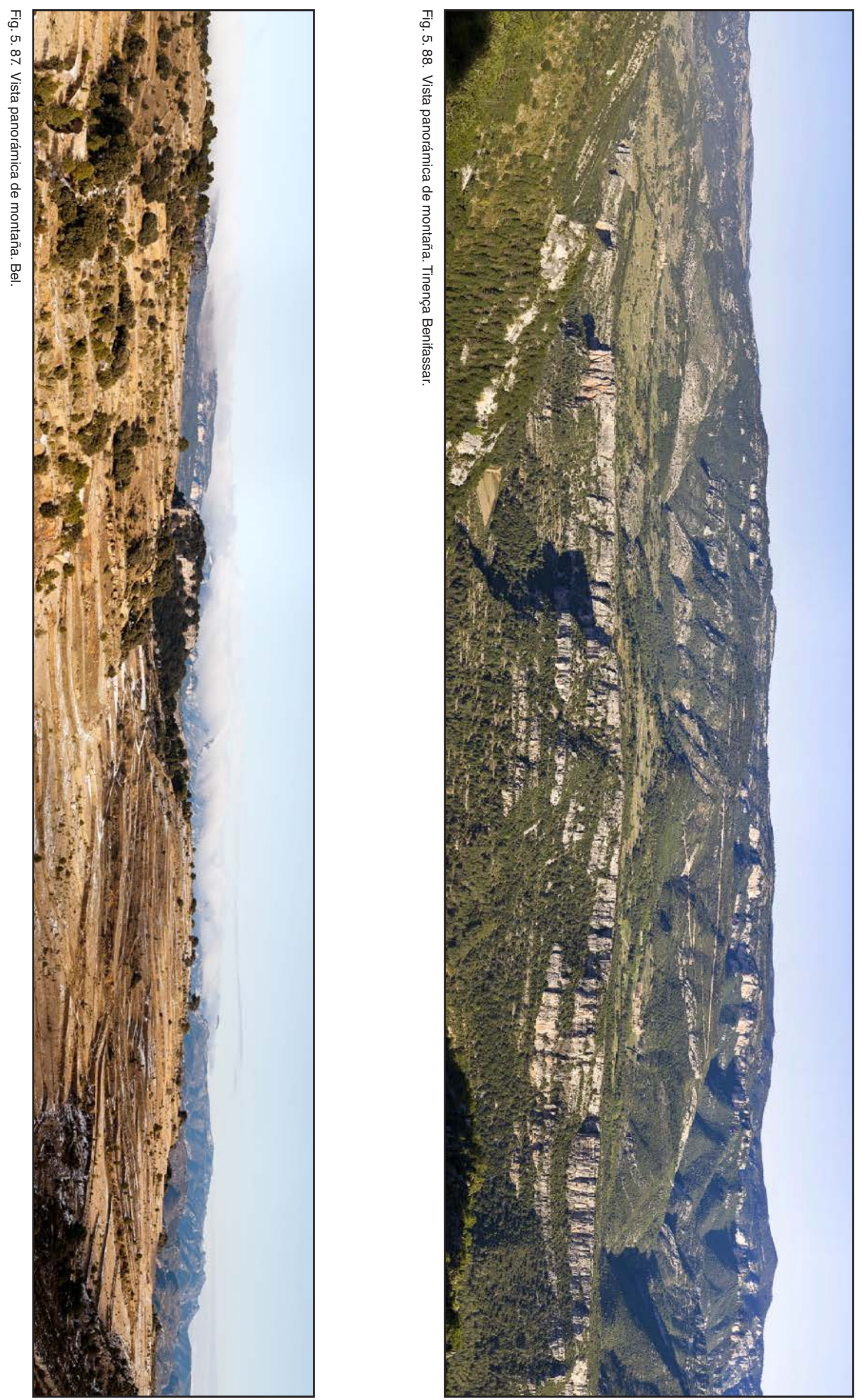

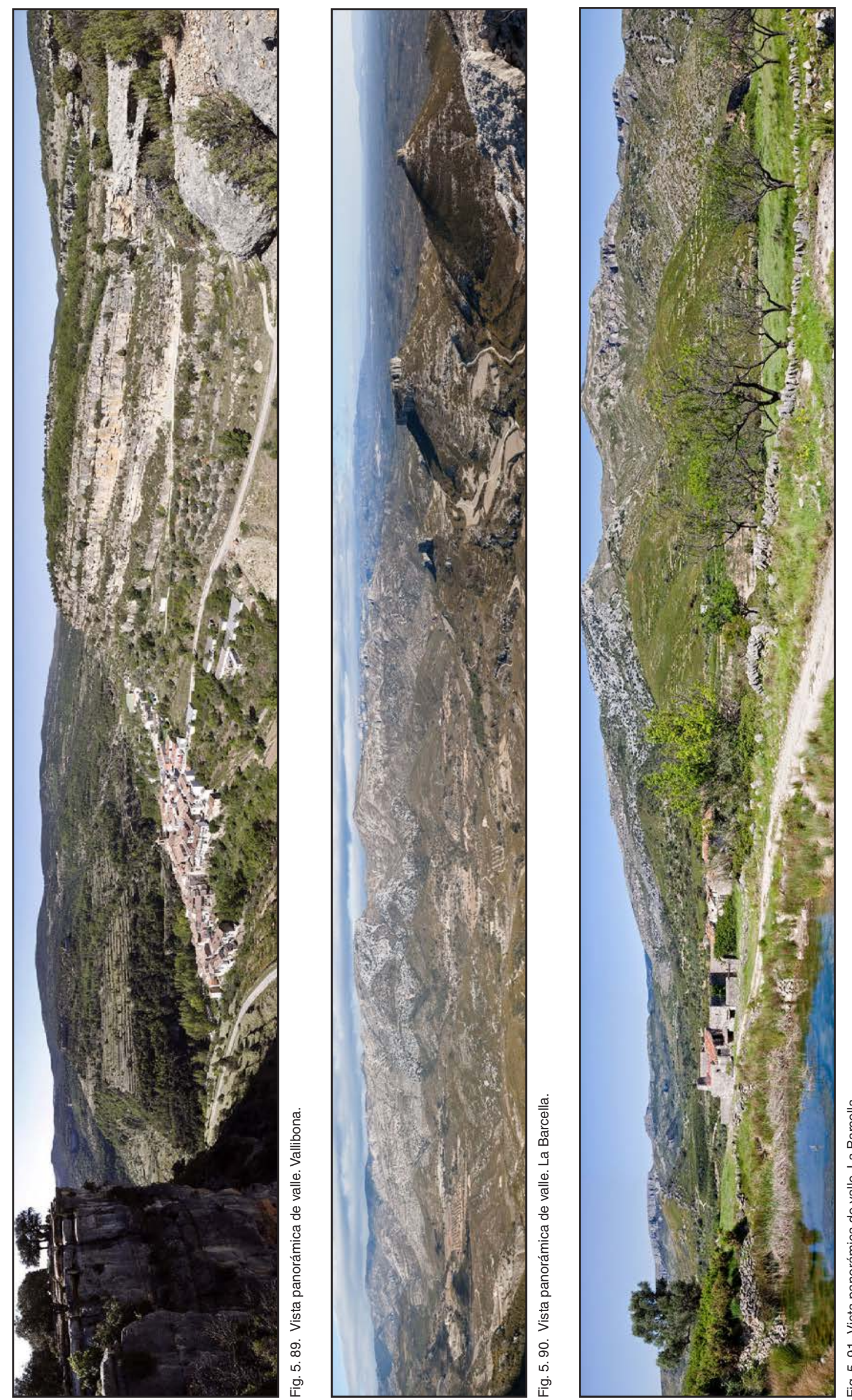

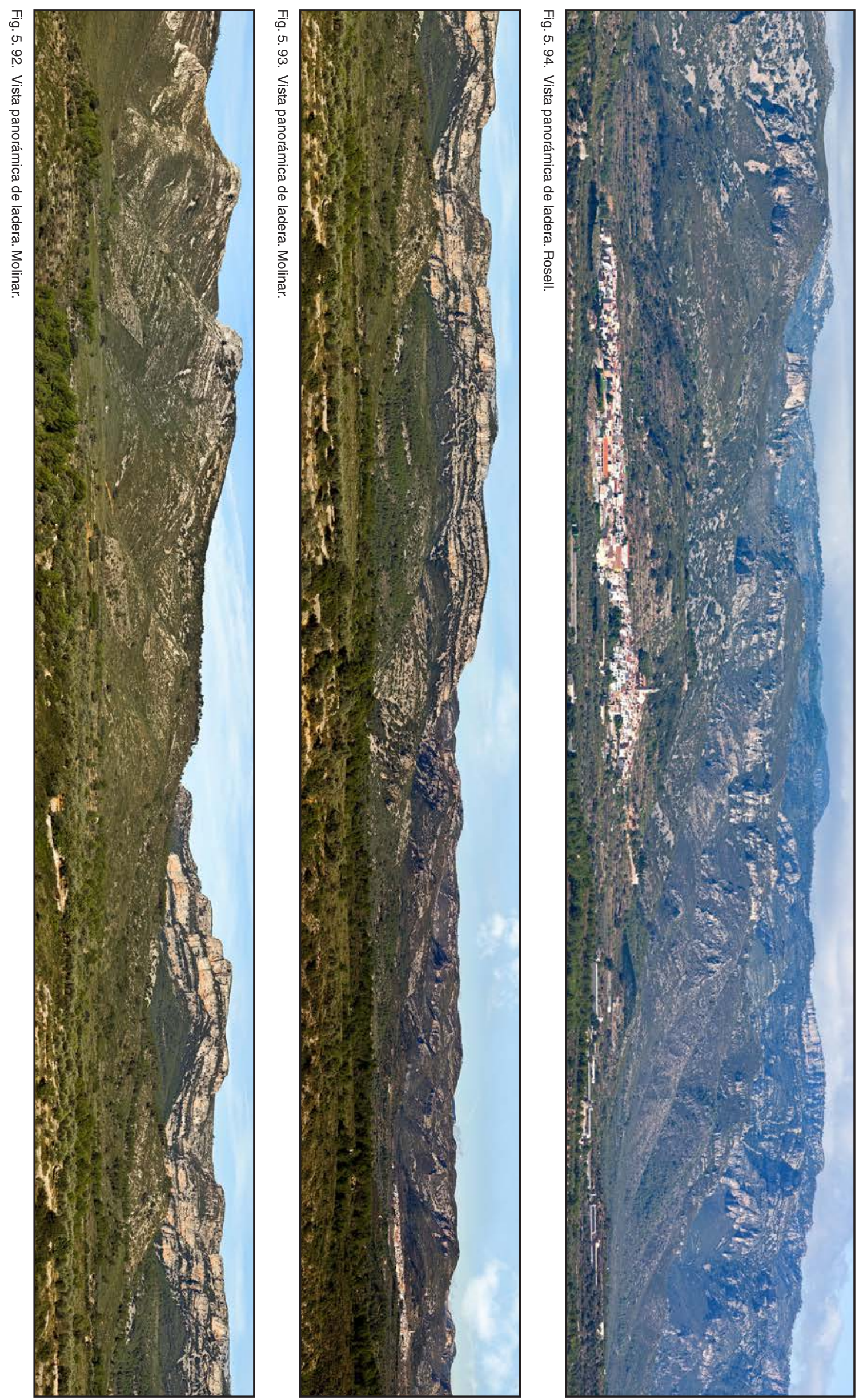

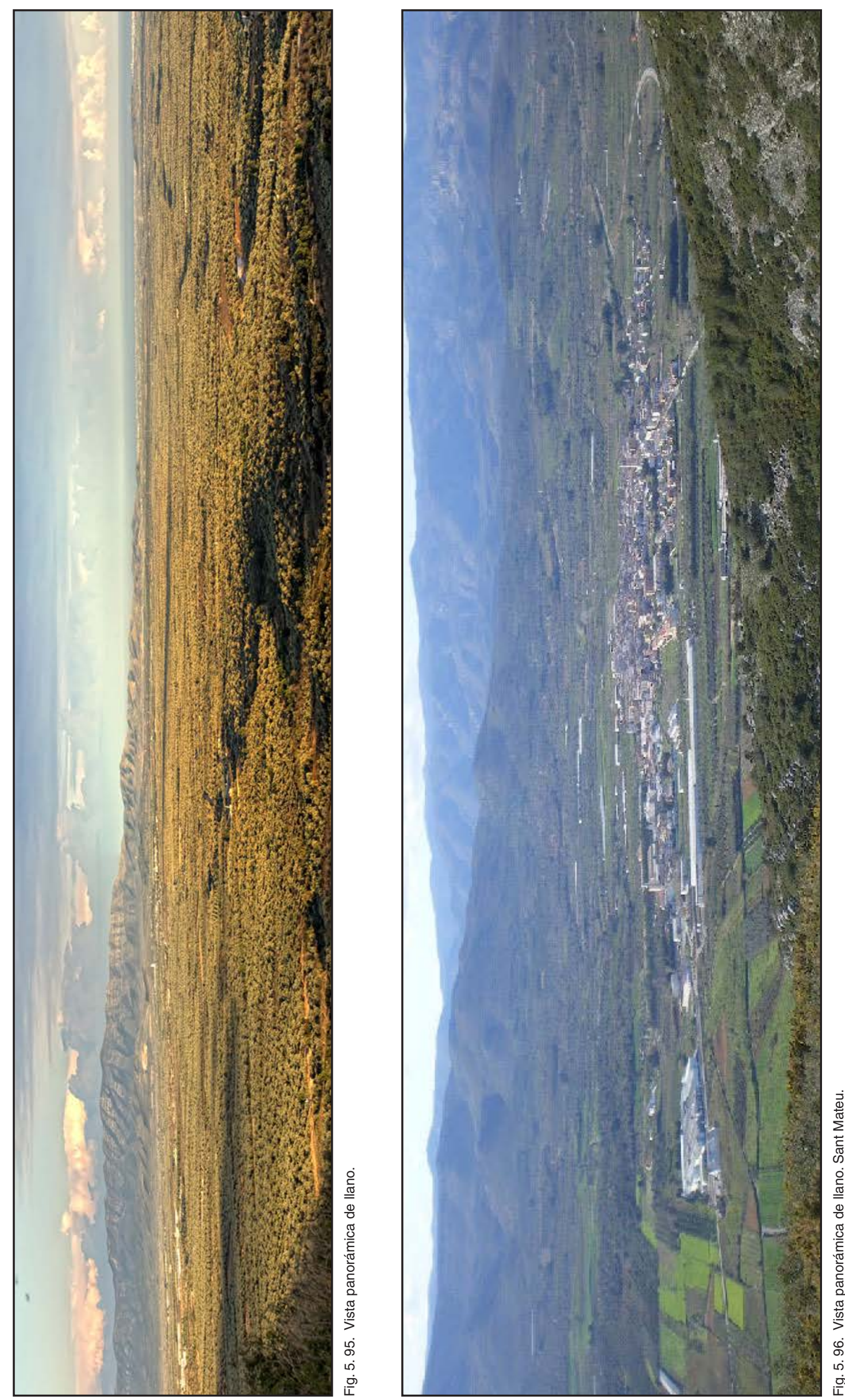


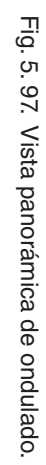

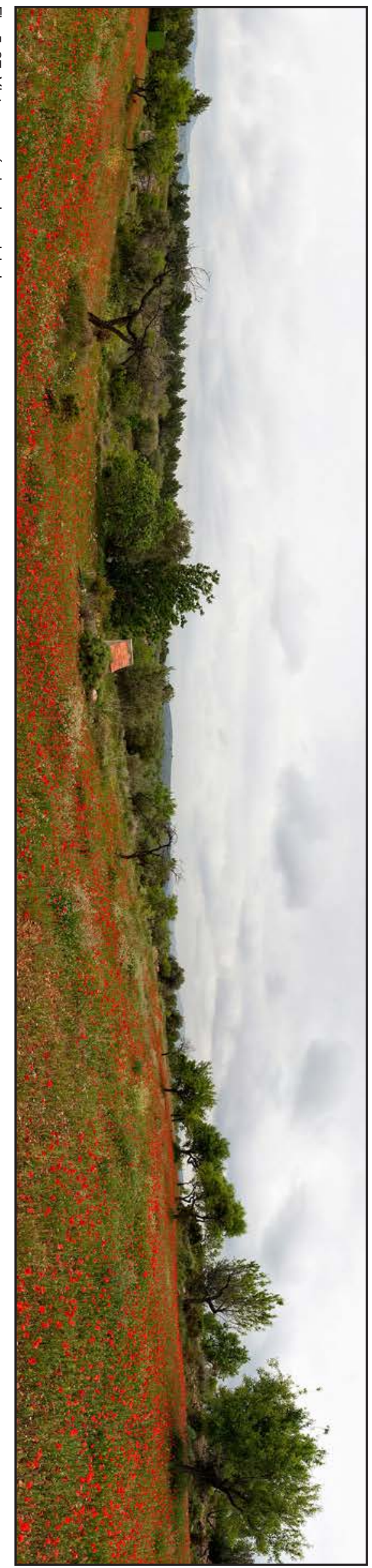

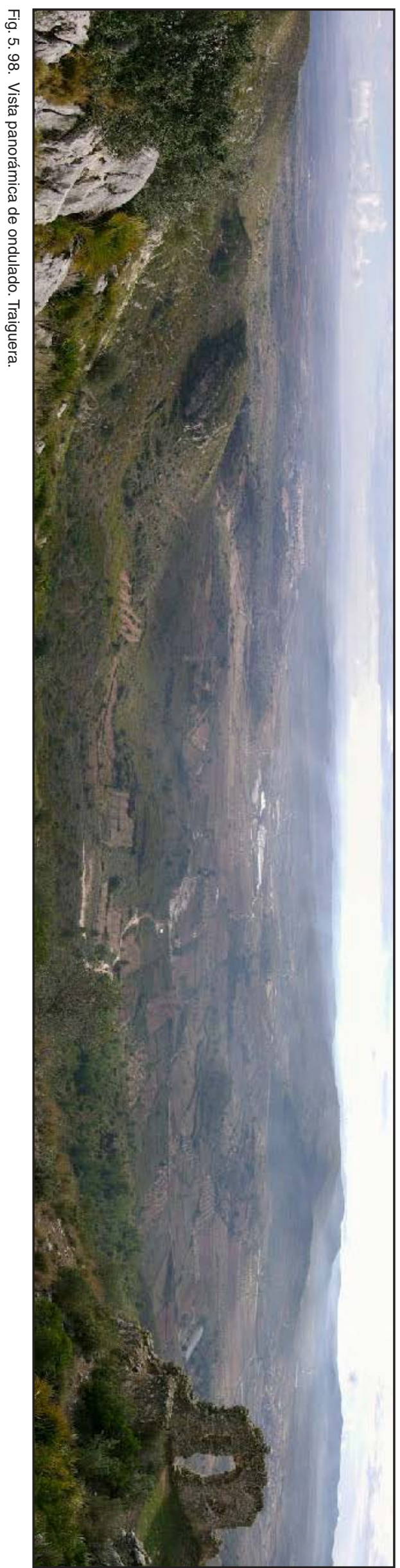




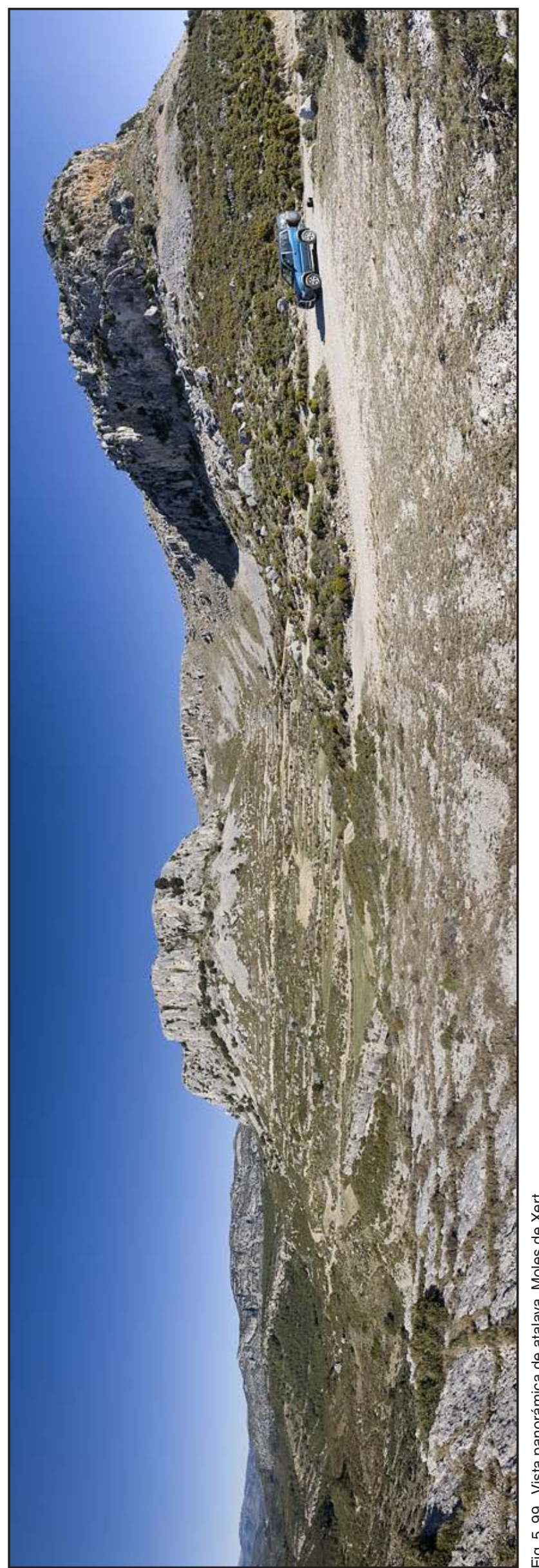




\section{8. Conclusiones: Territorio Collage}

Como si se tratara de un collage, se han superpuesto dos órdenes en el Territorio, uno abstracto, generado geométricamente a partir de las transformaciones de una malla topológica triangular que sirve de soporte y otro táctil, físico, material, que refleja las palpitaciones vitales del territorio, y que lo conforman múltiples fragmentos.

El territorio es por tanto una estructura en la que conviven, la totalidad de una trama topológica y la fragmentación de las partes, lo continuo y lo discontinuo. La superposición de los órdenes o tramas nos revela un singular collage, una superposición de estratos, cada uno de ellos con diferentes cualidades espaciales, de acuerdo con un entendimiento estratificado del territorio. Creando una única realidad, positivo y negativo, anverso y reverso del territorio como figuras y fondo. Estos órdenes están unidos por una secreta energía que los hace dependientes.

Si lo contemplamos desde un punto suficientemente distante podemos captar lo más esencial. La trama del soporte es un modelo relacionado con la idea topológica de disposición, de organización espacial de elementos. Siguiendo el símil de Robert Le Ricolais podemos considerar esta trama como una estructura resistente, como un conjunto de agujeros triangulares separados y rígidamente atados, de forma análoga a la trabazón de las fibras de un tejido.

Por tanto este soporte triangular no tiene una forma concreta sino un modo de disposición. La forma cambia el territorio no es una configuración precisa, sino posible. La trama del soporte es una estructura abierta, fluida, susceptible de ser determinada en varias direcciones.

El soporte topológico es más resistente al paso del tiempo, menos susceptible de ser alterado, es un entramado constante. Por ello antes de la intervención del hombre, el territorio tanto en la fase morfogénesis -evolución o crecimiento- como en la de morfoestasis -mantenimiento de la formas- la forma sigue la disposición topológica del soporte. Este entramado es un marco de referencia estable, mientras que en las actuaciones del hombre sobre él, vemos una expresión de lo variable, de lo móvil, de lo cambiante de la vida.

Mientras que el conceptual entramado triangular del soporte nos habla de un territorio abstracto, las actuaciones humanas en los vacíos nos refiere a un territorio tangible por la inequívoca presencia del material, de su textura, como formando un mosaico de texturas vivas.

Los materiales son la paleta del hombre, que usados según su propia naturaleza y la idea que de ellos tiene él, son el inmenso recurso con el que construye el territorio. Del mismo modo que el resto de especies animales, los materiales se ensamblan, se disponen siguiendo los dictados que imponen la gravedad y la luz. Para ello el hombre a través de la técnica, del proceso constructivo, busca el ajuste entre forma y diseño, entre idea y realidad construida.

La técnica revela la realidad profunda de las cosas. El territorio se desarrolla desde su propio sistema constructivo y la reflexión sobre el proceso de diseño va a transformarlo.. En definitiva, el modo de trabar, ensamblar, unir y ordenar los materiales y espacios estructura el territorio.

Un territorio no es primero forma y después adquiere sentido constructivo, sino que desde un sistema constructivo, desde las propias leyes que este impone, el territorio toma forma. Habitar es construir. La forma pasa a través del filtro que el sistema constructivo impone. El modo de construir determina el resultado.

La "paleta neutra" de los materiales se activa con la luz, siempre cambiante, que es la que da un color más vivo que la uniformidad predominante gris de muchos materiales usados. La "cualidad" que la luz confiere al espacio, engloba no solo los aspectos cromáticos y lumínicos de los materiales propiamente constructivos, sino también tantos otros elementos circundantes: el entorno, el agua, la vegetación, etc. Los elementos naturales se incorporan también así a ese constante flujo de energía que es la luz sobre los materiales.

El material adquiere presencia gracias a la luz, de la luz como el gran medio que hace presente la materia, de materia y luz como dos fuentes en constante intercambio de energía, reclamándose mutuamente, necesitándose mutuamente. La luz necesita de un obstáculo físico para materializarse; 
el material requiere de la presencia de la luz para hacerse visible.

Al ponerse en relación los materiales, la luz y la gravedad, se construyen los fragmentos que conforman el territorio medieval que tienen una dimensión táctil que permite la percepción de las formas y lugares, no solo visualmente, sino también por las otras percepciones sensoriales complementarias del resto de los sentidos.

Pero todos estos fragmentos no están simplemente "apoyados" sobre la trama triangular topológica del soporte inicial, sino que ellos mismo forman entre sí una nueva estructura, una nueva trama, que se superpone a la del soporte. Esta tiene también una consideración topológica por que nace a partir de la del soporte. Los fragmentos se relacionan entre sí por las leyes de proximidad, separación, entorno y continuidad, generando cuatro tipos o modelos de agrupación -compacta, secuencial, concéntrica y malla-. Se trata de modelos de disposición topológica de las partes o fragmentos que se relacionan entre sí por yuxtaposición, conexión o interconexión.

El orden jerárquico del territorio y su estructura formal, su organización flexible, permiten introducir un componente vivo, un entendimiento de la realidad como tejido de conexiones, de interrelaciones, como un juego de transformaciones que están implícitas dentro de la estructura y que interactúan de manera viva con el hombre cuando lo construye y habita.

Fragmentos y "vacíos" existen en un debate sostenido y equilibrado. Un debate en el que la victoria consiste en que cada componente emerge sin ser derrotado. Se crea un tipo de dialéctica entre lo sólido y lo vacío que permite la coexistencia de lo abiertamente planificado y lo genuinamente improvisado, la pieza colocada y el accidente, lo público y lo privado.

Tenemos dos órdenes de elementos: por un lado, los fragmentos construidos que dejan espacios intersticiales entre sí; por el otro, el soporte, el suelo ordenado con una malla triangular homogénea, como estratos que no dejan espacios residuales intermedios. Sobre esta malla se mueven los fragmentos, pero sin salirse nunca de ellos. Son "fichas" sueltas casualmente sobre un soporte tramado -tablero de juego-. Pero las fichas no se mueven con total libertad, sino que siguen unas reglas de juego -la estructura que conecta los fragmentos entre sí- y se deslizan a lo largo de una trama superpuesta a la del soporte, hay un patrón oculto que preside la aparente total libertad.

Esta superposición de dos tramas de texturas nos dice que el territorio no está meramente constituido por unos fragmentos sueltos que se posan sobre el terreno, sino que la geometría que genera los fragmentos se funden sutilmente con la naturaleza transformándola y con ella modificando el tablero de juego inicial. Cada partida que se juega, al final trae como consecuencia la modificación del tablero de juego, que servirá de base para la partida siguiente.

El territorio lo podemos imaginar como un tablero de ajedrez cambiante cuyas teselas triangulares han quedado desordenadas que nos deja confusos al intentar analizarlo. No sabemos si se trata en realidad de un damero distorsionado en el que las teselas han cambiado de posición, o si por el contrario se han superpuesto en un collage abstracto para crear una nueva realidad. Estamos ante un constante juego de transparencias y superposiciones, pues existen módulos que responden simultáneamente a ambos órdenes, entremezclándose, maclándose, creando un sutil juego espacial de llenos y vacíos, positivos y negativos. 
El territorio como collage en algunas representaciones de mapas territoriales:

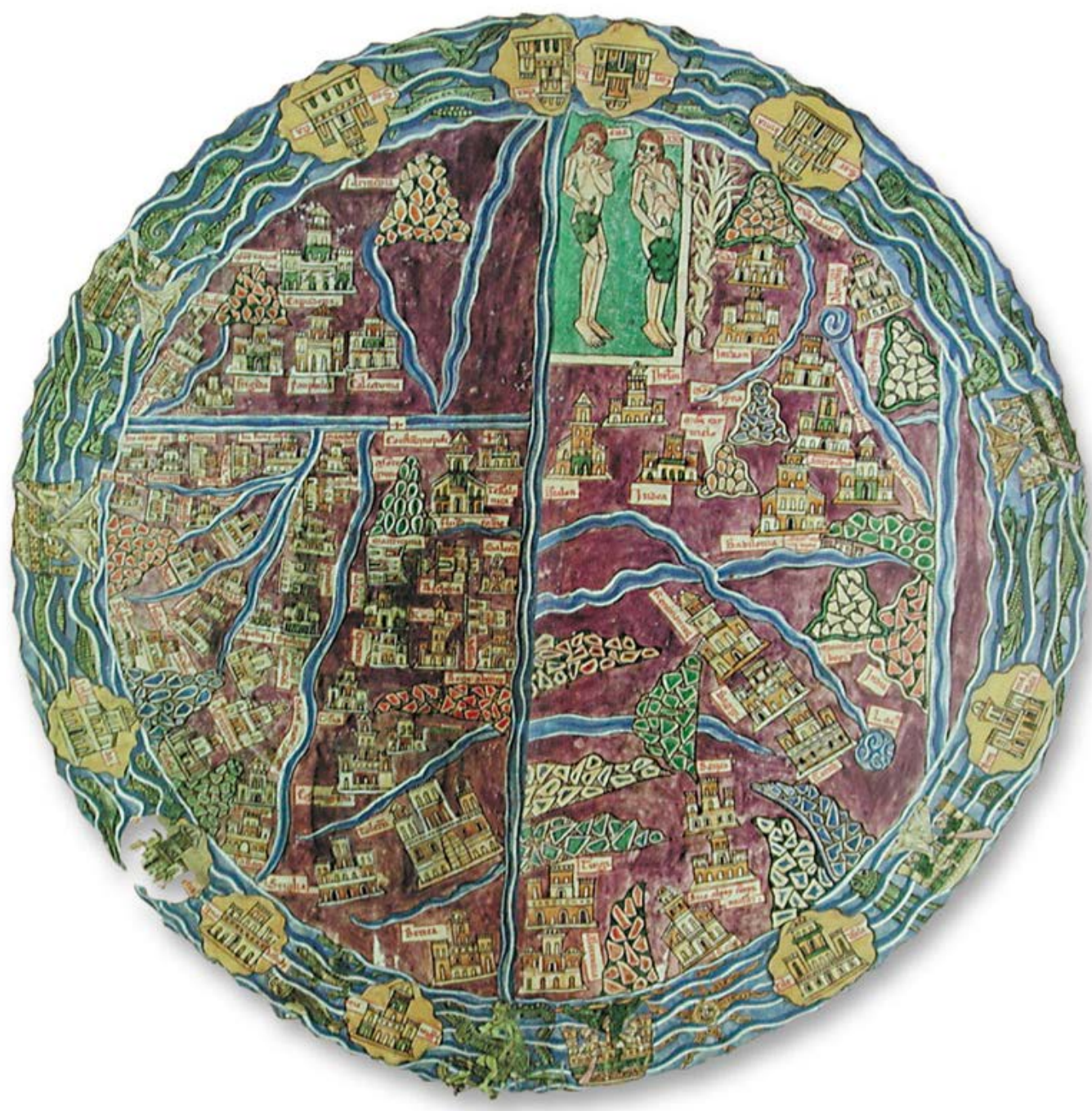

Fig. 5. 100. Plano del Beato de Liebana de San Andrés de Arroyo s. XIII.

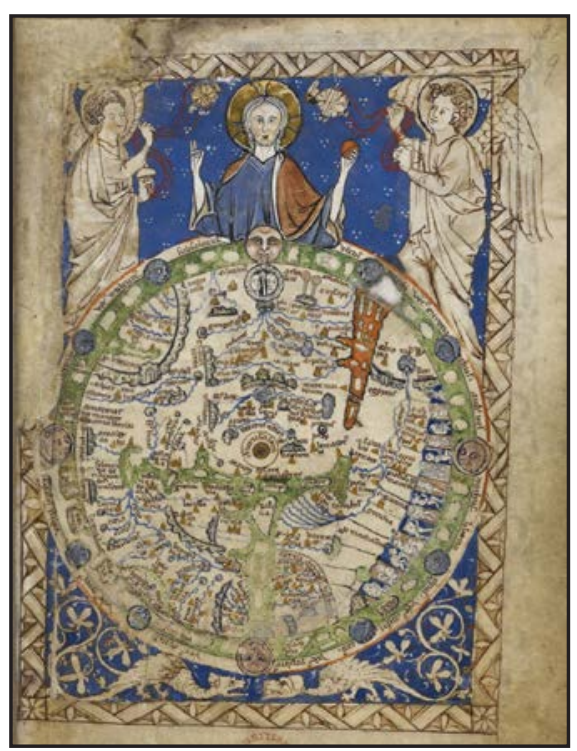

Fig. 5. 101. Mapa del mundo de un salterio en latín del s. XIV.

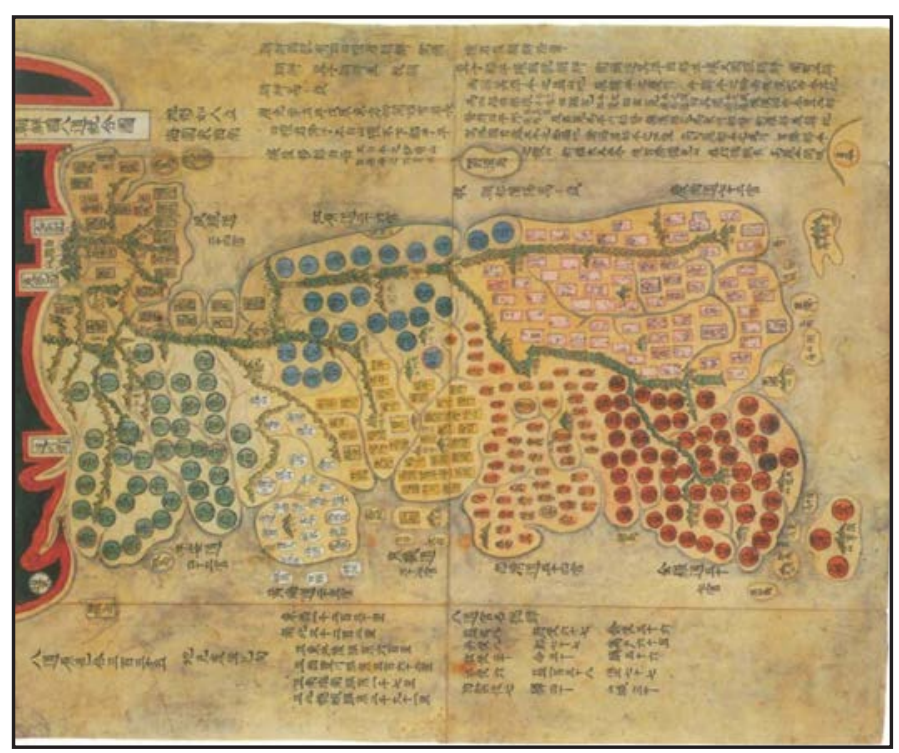

Fig. 5. 102. Mapa de ocho provincias de Choson. s. XVIII. 


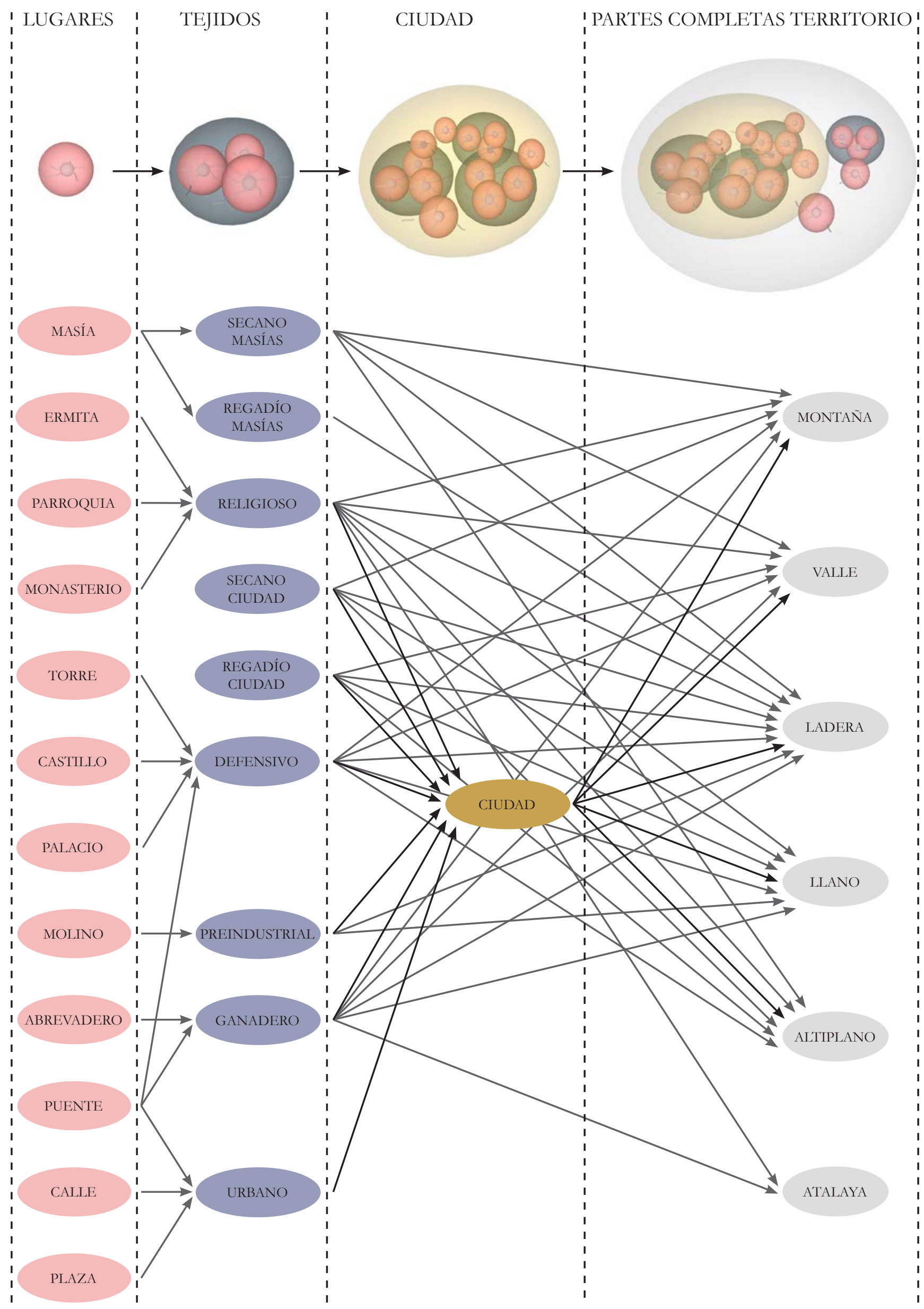






\section{1. Introducción}

Como ya hemos visto a diferencia del primer principio de la termodinámica, que postula la conservación cuantitativa de la energía, el segundo principio introduce una función de estado, la entropía, que describe la degradación cualitativa de la energía que contiene un sistema. La entropía es una variable que aumenta irreversiblemente con el paso del tiempo y manifiesta el aumento del desorden de un sistema. En este avance desde un estado ordenado a uno desordenado, un sistema pasa de un instante en el que tiene potencial para desempeñar un trabajo a otro instante en el que deja de tener potencial para desempeñarlo. De este modo la entropía introduce en los sistemas dos variables -primero, el paso del tiempo y segundo su degradación- que socavan la supuesta permanencia y estabilidad de las estructuras materiales y las conducen al territorio de las transformaciones irreversibles.

Contrariamente a la ley de la entropía, los organismos vivos demuestran que se puede avanzar hacia estados de mayor organización interna. El trabajo de Ilya Prigogine en torno a las "estructuras disipativas" demostró que en un proceso antrópico "la disipación de energía y de materia -generalmente asociada a los conceptos de pérdida y rendimiento y evolución hacia el desorden- se convierte, lejos del equilibrio, en fuente de orden". ${ }^{132}$ Frente a un sistema cerrado aislado del mundo exterior condenado a degradarse, los sistemas abiertos son creativos: intercambian materia y energía con el exterior, evolucionando hacia estados de mayor orden. Estas estructuras, consideradas "parte integrante del medio que las nutre" permiten entender que la forma no es más que un coágulo temporal de materia, energía e información en su evolución hacia otra cosa, poniendo de manifiesto que lo importante no es el coágulo (la forma), sino el control de los flujos de energía que lo atraviesan.

Los estudios de diversos autores como Sanford Kwinter o Smithson que recogen el interés por la entropía y por el tiempo y los actualizan con la teoría de las estructuras disipativas de Prigogine, pueden ser aplicados para entender la evolución del territorio en la Edad Media, la relación de la arquitectura con su entorno y su evolución en el tiempo. Nos ayudan a entender como la arquitectura y el territorio son capaces de reaccionar ante los estímulos de la materia, energía e información que recibe del lugar en el que se enclava.

Si la termodinámica ofrece unas leyes que regulan de manera abstracta la energía y la materia, mostraremos como estos conceptos se desplegaron sobre el territorio de la Edad Media y cuáles fueron los mecanismos mediante los cuales se hicieron efectivos.

Este capítulo contiene un compendio de reflexiones sobre las distintas posturas en torno a la energía en el territorio de la Edad Media. Desde distintos aspectos demostraremos como la energía se manifestaba en los procesos constructivos y de ocupación del territorio en este período.

Este compendio muestra aproximaciones muy diversas que abarcan una multiplicidad de escalas, desde la región hasta la arquitectura y los materiales que la conforman; resulta necesario realizar un doble movimiento que conecte todos estos ámbitos de trabajo:

- Un movimiento de la arquitectura hacia el soporte territorial, lugar donde se manifiesta la realidad en toda su complejidad. La arquitectura se acopla a su entorno (se funde) siendo capaz de reaccionar a los estímulos de la materia, energía e información procedentes del medio donde se enclava, que capta, almacena, transforma, organiza y dosifica recursos y que se adapta a regímenes de materia y energía cambiantes.

- Este movimiento desde la arquitectura hacia el soporte, se complementa por el del soporte hacia la arquitectura. El entorno es modificado por la arquitectura, el soporte en que cada generación habita, es el fruto de lugares y tejidos de las arquitecturas precedentes. 


\section{2. La energía como con-formación en el territorio medieval}

El territorio como artefacto exosomático es un proceso que alberga procesos. El Territorio alberga procesos pero él mismo es también un proceso y ambas circunstancias demandan la presencia de energía. La energía se instala por una doble vía: a través del consumo energético del territorio (en puridad de los usuarios del territorio) en producción agrícola, acondicionamiento térmico... y a través de la energía necesaria para organizar, modificar y reparar el entorno construido. Dicho de otro modo: a través de la energía que consumen los procesos que alberga el territorio (agricultura, ganadería,..) y a través de la energía que consume el propio territorio como proceso (como construcción). A la primera la denominamos energía de mantenimiento y a la segunda energía de construcción.

El hombre habita el Territorio, lo cultiva y lo construye; para ello lo modela, crea accesos para dominarlo, lo parcela y lo usa. Para todos estos procesos necesita consumir energía. Esta aportación de energía durante la Edad Media, la podemos corroborar en:

- La gravedad y la luz. Como en cualquier ecosistema el territorio es conformado por la luz y la gravedad. Para ejemplificarlo analizaremos los casos de: el abancalamiento de las tierras de cultivo y las arquitecturas.

- El transporte horizontal siguiendo trayectorias horizontales (no fruto de la gravedad) produce un importante consumo de energía. Lo ejemplificaremos con la trashumancia.

- El aprovechamiento de la energía cinética y potencial del agua, que representan los molinos.

- El fuego. El hombre a diferencia de los animales aprendió a dominar el fuego y con ello a usar por primera vez una fuente de energía consumible y no renovable. Su aporte energético fue fundamental para el desarrollo de la Edad Media

- La organización social. La primera máquina, tal como nos enseñó Mumford, fue la organización social. El aporte de energía que el hombre obtuvo de la organización con otros hombres realizando un trabajo colectivo, fue decisivo en los años anteriores y sobre todo durante la Edad Media.

- El mantenimiento de la estructura del territorio.

\section{2. 1. El suelo estratificado por bancales. Gradientes de energía}

El hombre en la Edad Media explota el territorio agrícolamente, los productos que obtiene le permiten alimentarse. El sistema de rentas que sustituye al de tributos hace que se busque un mayor rendimiento agrícola. Para aumentar la producción en un régimen de lluvias discontinuo y en ocasiones torrencial se tiene que adaptar la topografía del terreno y evitar la pérdida de agua por escorrentía. La escasa agua de la que se dispone es imprescindible aprovecharla para aumentar la productividad del suelo, hay que capturarla y mejorar el contenido de humedad del suelo.

El volumen de agua que impregna el suelo puede ser incrementado dando más tiempo a la infiltración y retardando la escorrentía por medio de estructuras físicas y vegetativas construidas transversalmente a la pendiente y paralelas al contorno. La construcción de bancales perpendiculares a las pendientes y en las zonas de mayor aporte de agua (las limahoyas) formando un suelo aterrazado tiene ese objetivo.

Como ejemplo para hablar del desarrollo de la forma en un proceso natural y espontáneo, Margalef habla de las termoclinas como los segmentos de los gradientes verticales de temperatura que es particularmente intenso o abrupto. Una masa de agua tiene una organización vertical formada por estratos de agua separados por las termoclinas (saltos bruscos de cambio de temperatura según va 
disminuyendo la temperatura del agua con la profundidad). Por lo que la columna de agua adquiere la forma de una serie de estratos o curvas de nivel, en lugar de tener una forma uniforme y continúa. De forma análoga y siguiendo la ley de Darcy: "el caudal que atraviesa un suelo es linealmente proporcional a la sección y al gradiente hidráulico", siendo el gradiente hidráulico el incremento de humedad entre dos puntos en relación con la distancia entre esos dos puntos; El suelo abancalado también esta estratificado coincidiendo los "saltos" o bancales con las líneas ortogonales a los máximos gradientes de humedad (los bancales permiten retener la humedad a costa de provocar saltos en la inicial continuidad de la humedad del suelo).

La disposición de los bancales se realiza en función de la orientación solar para obtener el mayor aprovechamiento de su energía y de la gravedad que permite al hombre dirigir el agua para minimizar la escorrentía y obtener el mayor grado de humedad en el suelo a cultivar. Todo el territorio se modela por tanto en base a los gradientes de humedad que permiten hacer uso de la energía que supone el agua como nutriente para la agricultura y de la exposición al sol de los cultivos. ${ }^{133}$

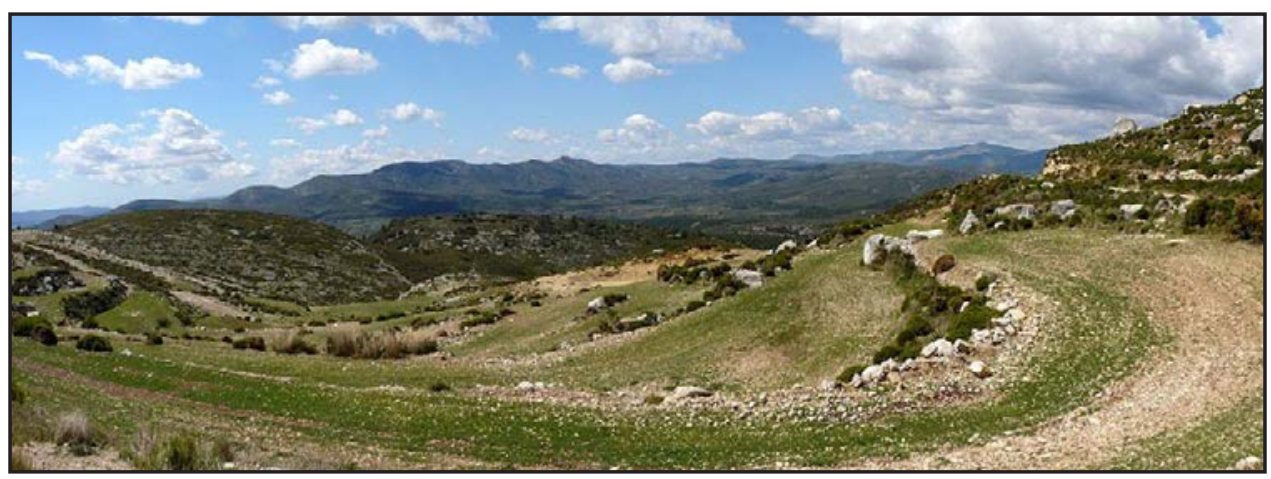

Fig. 6. 1. Foto de suelo abancalado en Els Ports.

Imágenes de suelo abancalado:

Su disposición en planta como curvas en función del gradiente de humedad del suelo, es similar a la de los gradientes de temperatura del agua en el mar (termoclinas).

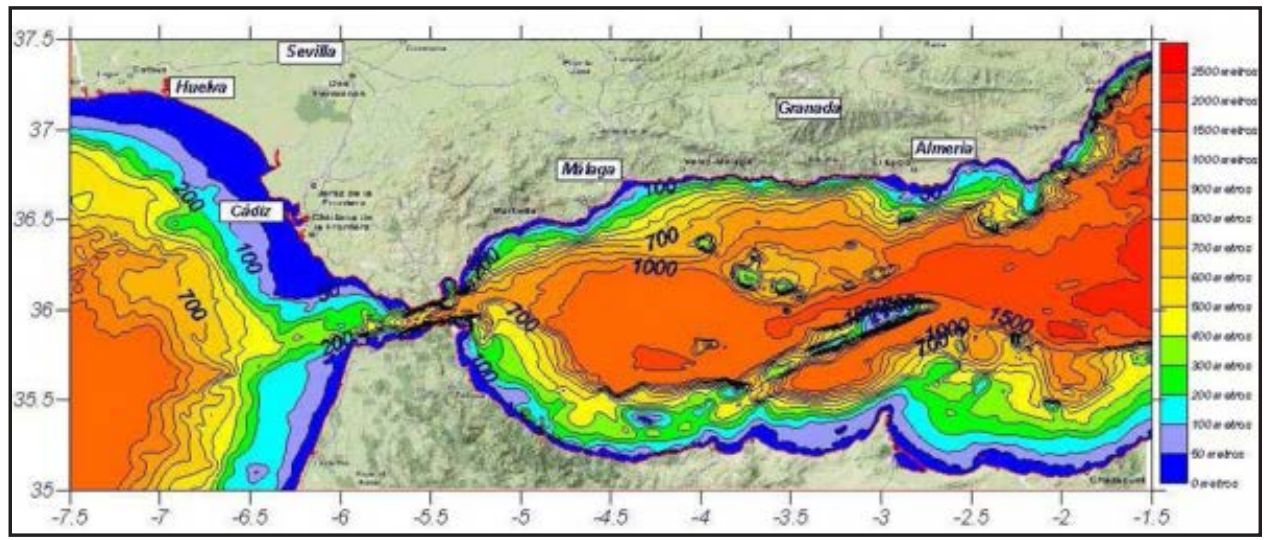

Fig. 6. 2. Representación gráfica de los gradientes de temperatura del agua del mar en el estrecho de Gibraltar.

\footnotetext{
133 Para incrementar la infiltración de agua en la Edad Media usaron dos procedimientos complementarios:

- Detención de la escorrentía por medio de barreras estructurales o físicas

- Incremento de la porosidad mediante la labranza y la preparación de tierras

Los esfuerzos iban concentrados en el incremento de la proporción de agua que podía entrar en el suelo (infiltración), minimizando la pérdida de humedad por escorrentía y evaporación y mejorando la disponibilidad de agua del suelo y la eficiencia del uso del agua mediante el mejor manejo del suelo.

El agua de lluvia que escurre de la tierra descendía rápidamente hacia los cursos de los ríos, contribuyendo a los flujos máximos y era siempre motivo de preocupación. La escorrentía no era solamente un desperdicio del agua de lluvia que podría haber contribuido a la producción agrícola y al abastecimiento de las aguas subterráneas, sino que frecuentemente causaba inundaciones o daños a los caminos y tierras agrícolas y erosionaba el suelo que es redepositado en el cauce de los ríos aguas abajo.
} 


\section{2. 2. El consumo de energía en el transporte horizontal: la trashumancia}

La trashumancia ejemplifica la importancia del consumo de energía en el transporte para el desarrollo económico de una sociedad. Gran parte de la energía usada por el hombre se destina a promover el transporte horizontal a través del territorio. Como dice Margalef: "Cada ecosistema tiende a desarrollar su ciclo interno siguiendo el eje vertical definido por la luz y la gravedad. El transporte horizontal, dependiente de energía externa, se puede considerar como una perturbación, o por lo menos, como una modificación impuesta sobre aquel esquema fundamental de trayectorias verticales" ${ }^{134}$ y continúa "En la medida en que el transporte no es simétrico, es decir, si no hay provisión para el retorno, el transporte conduce a una acumulación local y desigual de determinados elementos químicos y de materia orgánica".

La trashumancia pese a ser un transporte horizontal y por tanto consumidor de energía externa, minimiza las consecuencias que todo transporte horizontal tiene en un ecosistema, al desarrollarse con estas características:

- La trashumancia busca la luz. La luz es la que permite que haya pastos y buenas temperaturas en diferentes lugares según la época del año. Se trata de las migraciones naturales de los animales en busca de alimento, dirigidas y organizadas por la mano del hombre.

- Es un camino de ida y vuelta, a diferencia de la mayoría de los transportes horizontales en la mayoría de los ecosistemas, que acumulan restos en el lugar de llegada y producen descompensaciones entre los lugares de salida y llegada.

- El transporte lo realizan con la energía endógena de los propios animales sin necesidad de aportar energía exógena. Esta es la gran diferencia con la situación actual de los ganados estabulados, en los que el alimento es el que se traslada y no los animales.

- Es un gran elemento integrador y de transmisión cultural entre dos regiones. Los traslados continuos y periódicos permite la transmisión de conocimientos.

- El camino por sí mismo es una gran infraestructura. Son las grandes autopistas de la Edad Media, los recorridos están delimitados por muros de piedra en seco para evitar que se vaya el ganado (lo contrario de las actuales autopistas que intentan evitar que entren); estructuran el territorio con todas las comarcas limítrofes; anejos a ellos existen importantes infraestructuras como balsas, abrevaderos, casetas de pastor y otros que los convierten en un elemento integrador del territorio y que ha llegado hasta nuestros días pese a estar prácticamente en desuso.

Un territorio como el de la Batllia de Cervera en la Edad Media en el que existen grandes zonas destinadas a pastos (prácticamente todas las tierras existentes entre el río Cenia y el Cervol) y con una extensa red de azagadores y caminos ganaderos, es fruto de la importancia que el consumo de la energía en el transporte tiene para el desarrollo de un territorio y de la sociedad que lo sustenta. ${ }^{135}$

134 MARGALEF LÓPEZ, R. “La biosfera entre la termodinámica y el juego” pág. 11

135 La trashumancia fue una actividad que se empezó a desarrollar antes de la conquista y que después tuvo una importancia fundamental tanto en el desarrollo económico como en la configuración física del territorio.

Se trata del traslado anual del ganado lanar desde las tierras altas de Aragón (Cantavieja, Mosqueruela, Iglesuela, Fortanete, etc) hasta el llano próximo al mar de las tierras de la Batllia de Cervera y limítrofes. Antes de la conquista ya la orden del Hospital tenía posesiones de tierras y rebaños en Aragón, y existen noticias de que bajaba a estas tierras en invierno aunque aún no estuvieran conquistadas y fueran dominadas por los árabes a este lado del río Cenia. Ello era así porque la Orden tenía también el castillo de Ulldecona junto al río Cenia y los ganados en invierno pastaban en este territorio y en la franja entre los dos ríos Cenia y Cervol (es decir en la franja que era territorio de nadie, la franja de seguridad) Esto motivó que el rey prometiera ya a la Orden del Hospital muchos años antes de la Conquista este territorio, prueba de ello es el apéndice documental no 1 (pág. 603) del que extraemos el siguiente párrafo: 


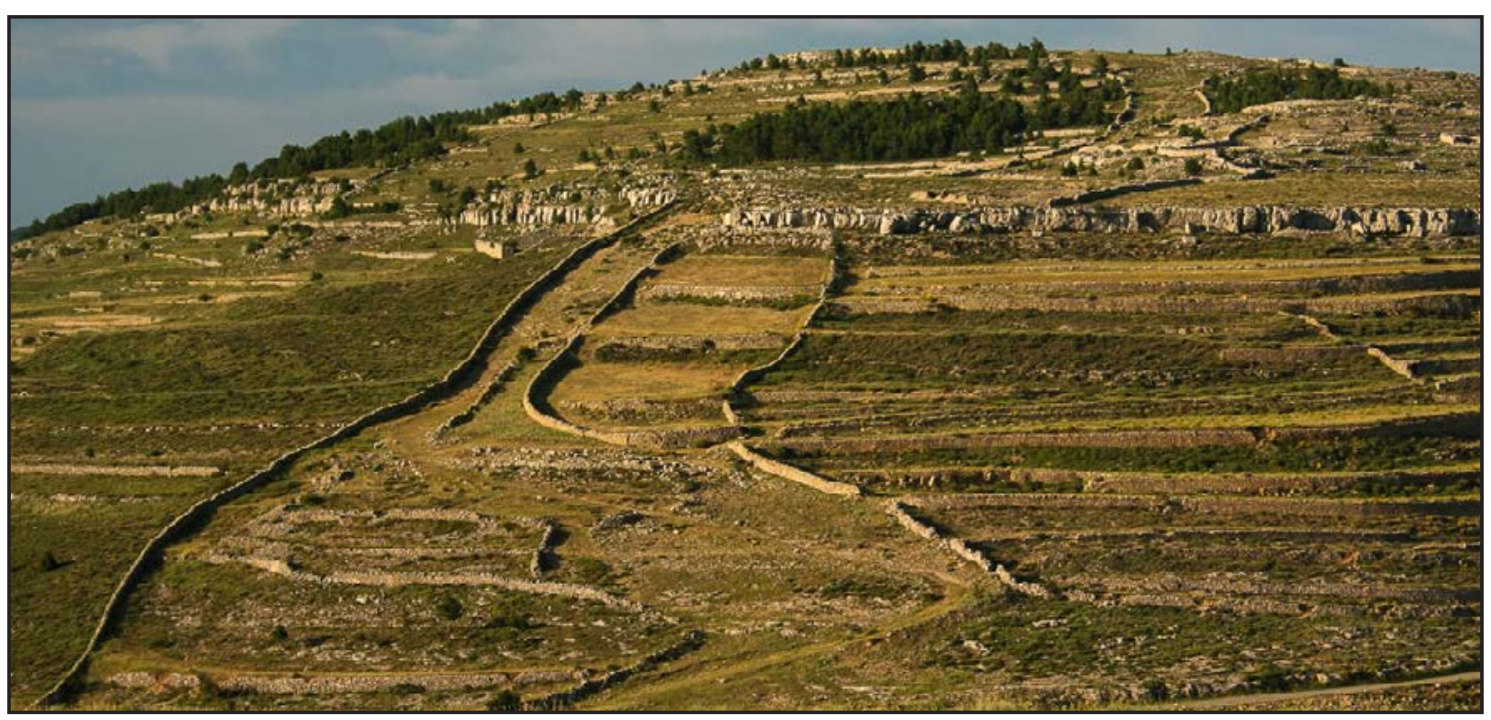

Fig. 6. 3. Foto de azagador en el Maestrat.

"Notum igitur sit omnibus, tam presentibus quam futuris, quod ego Ildefonsus, Dei gracia rex Aragonensis, comes Barchinonensis et marchio Provincie, ob remedium anime mee predecessorumque meorum, libenti animo spontaneaque voluntate, dono, laudo, concedo et presentis scripti auctoritate confirmo et auctor $\square$ zo Deo et Sancto Hospitali Iherusalem, et Fortunio Cabeza magistro universisque fratribus eiusdem domus, presentibus et futuris, ibidem Deo servientibus, locum illum qui nuncupatur Barcella, situ iuxta Cervariam, qua sarraceni inhabitant, cum omnibus ingressibus et egressibus suis, cum aquis, pratis, pascuis, montibus, silvis et nemoribus, et cum universis terminis et pertinenciis suis, cultis et incultis, ad ius et dominium ipsius loci expectantibus."

Una vez el castillo de Cervera fue posesión de la Orden del Hospital, esta actividad se amplía y consolida y hace que parte de la Batllia se dedicara a los pastos, algunas zonas en exclusividad como la zona entre ríos, y que la ganadería fuera una de las actividades más importantes y rentables de la época (ver apéndice documental no 9, pág. 610 , referente a la donación de unas de las dehesas más importantes de la comarca de Els Ports, siendo aún hoy en día de pastos de propiedad municipal). La rentabilidad de la ganadería cuyo origen era la mera subsistencia por el aporte de la carne y leche a la dieta del hombre medieval fue modificándose hasta convertirse en uno de los elementos, sino el que más, que producía rentas económicas a la Orden.

Gran parte de los ganados eran directa o indirectamente propiedad de la Orden. Los grandes propietarios tenían necesidad de recurrir a la contratación de pastores o tal como se generalizo durante la Edad Media la práctica de la aparcería en la crianza de ganados, generalmente bajo la forma del "mig guany" o partición por medias partes de los beneficios obtenidos; de este tipo de contratos, realizados con escritura pública ante notario, conocemos algunos ejemplos como el del apéndice 52 (pág. 603):

"Honorabilis Johannes Bruscha, mercator, vecinus presentis loci Villafranchae, scienter etc. Dedit, concessit et tradidit ad medium lucrum sive a mig guany Guillermo Giner, vicino ciusdem loci presenti et eius acceptanti et suis sexaginta tres borregos lanaris ad tempus unius anni de die presenti contionue computandum. Sub tamen condicionis infra expressis videlicet quod dictus honorabilis Johannes Bruscha possit ipsos vender quocumque sibi placuerit. Item quod usque vendantur quod dictus Guillermus Giner tenatur dictos borregus a salare et protegere et custodire suis sumptibus, periculo et expensis. Et quod quocienscumque vendantur dictus honorabilis Johannes Bruscha habeat et possit ex precio illorum qui vendebuntur per prius abstraere quatuor solidos e quatuor denarios qui son precium dictorum borregorum. Cuius ex ipsis LXIII, XXXXVII costiterint ad racionem sex solidorum quattor denariorum per capite et sedecim ad racione sex solidoru $7 \mathrm{~m}$ et octo denariorum. Et abstractis dictis CCCCIIII solidos III denarios uperaveerit quod illud dividatur inter nos. Et dictus Guillermo Giner acceptando dictos LXIII boregos tu dictum est per eum atendetis et complendis ombnia bona sua obligavit habita et habenda."

Esta costumbre con algunas variantes sigue perdurando, en los contratos de arriendo de masías se especifica a veces que el arrendatario no podrá poseer más ganado que el que el propietario le proporcione para ser explotado por el régimen de "mig guany". Esta gran cantidad de cabezas de ganado permitía la obtención de importantes rentas que posteriormente con el mercado de la lana con Italia produjo importantes beneficios que se añadieron a los ya tradicionales de la carne y leche. Este comercio fue el principal motivo del desarrollo económico y por tanto cultural y humano de esta comarca durante la Edad Media. Por el aumento de la demanda de lana para la exportación a Italia desde los últimos años del siglo XIII, las comarcas castellonenses conocen una progresiva aceleración del desarrollo de la ganadería ovina a partir de esas fechas. Este proceso de larga duración que se prologara hasta el siglo XVIII se inicia, pues, bajo Jaime I, en la documentación de cuyo reinado abundan las referencias al tema ganadero en tierras Castellón, con especial incidencia en lo que respecta a la comarca de Morella.

Es sin embargo, ya dentro del siglo XIV cuándo comienzan a representar las compras italianas en las regiones orientales de la península niveles de creciente importancia y paralelamente es también cuando la documentación de las comarcas castellonenses muestra no solo una mayor frecuencia de datos sobre cuestiones ganaderas sino así mismo pruebas evidentes de una acelerada intensidad de esta actividad, como se puede comprobar en el apéndice documental no 48 (pág. 643). 


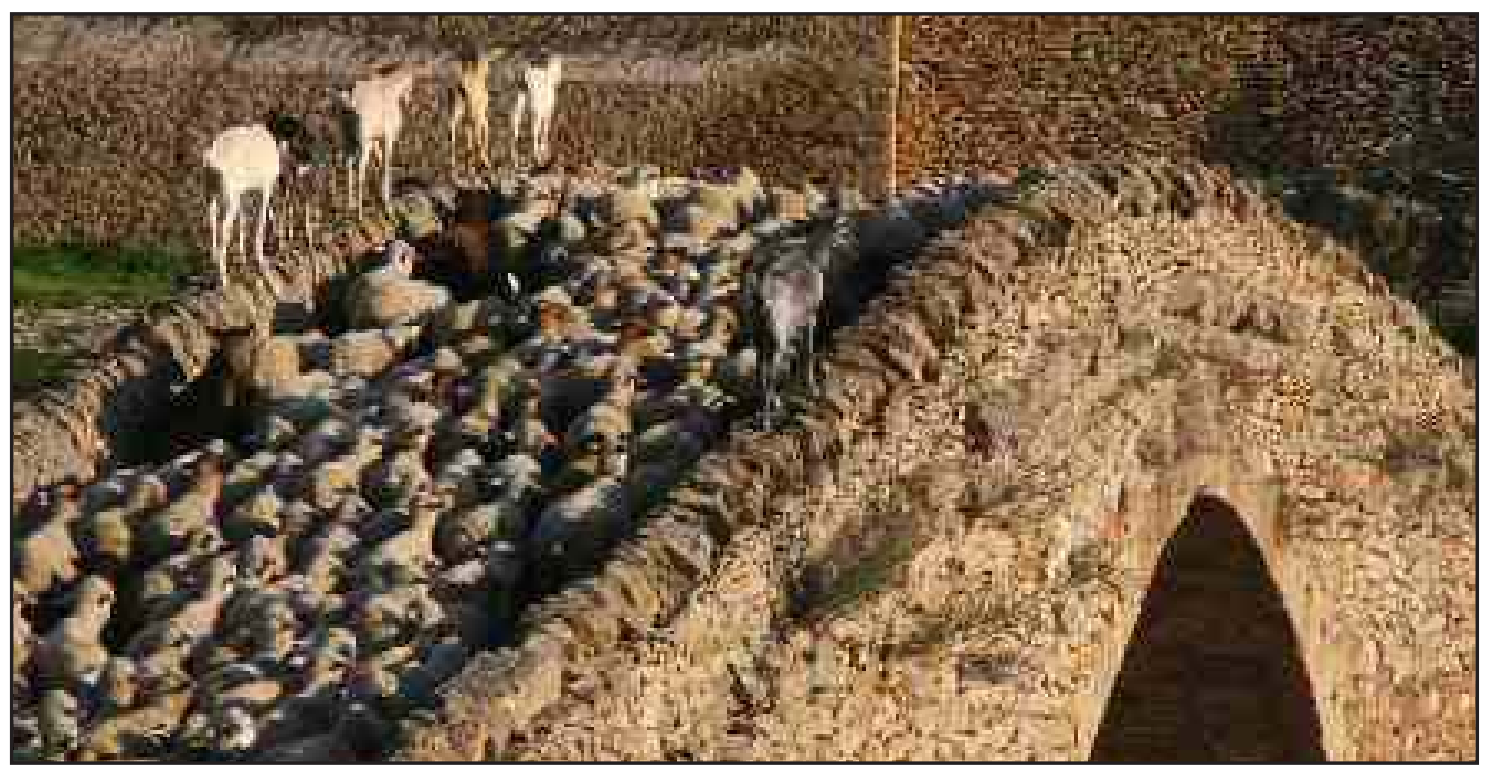

Fig. 6. 4. Un rebaño cruzando el puente de la Pobleta de San Miguel.

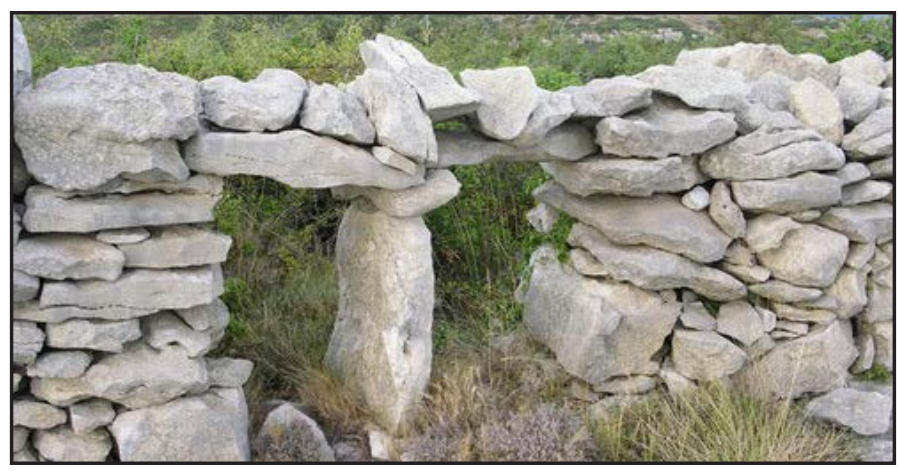

Fig. 6. 5. Foto de perforación en el muro para su recuento y control en la Belladona de Ares.

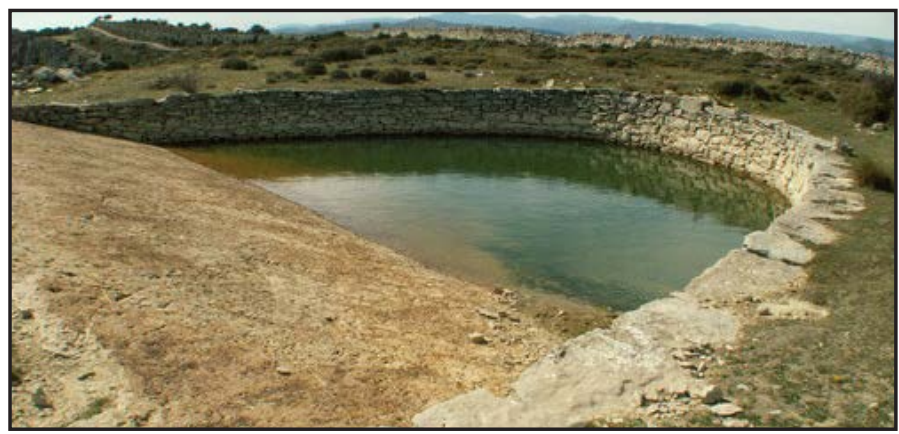

Fig. 6. 6. Balsa para abrevar en la Belladona.

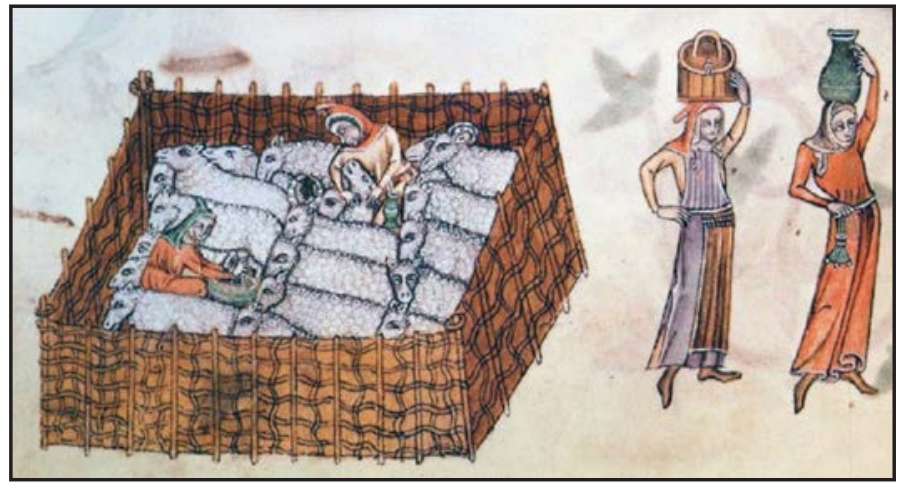

Fig. 6. 7. Dibujo de corral de ovejas del Salterio de Lutrell (1325-35).
Imágenes de trashumancia:

En el territorio perduran elementos de la construcción de las redes que permitieron durante siglos el desarrollo de la trashumancia: veredas, paredes, puentes, balsas, construcciones para el control del ganado, etc.

Prueba de ello la encontramos en las pinturas y dibujos de la época que han llegado hasta nuestros días. 


\section{2. 3. El aprovechamiento del flujo de energía del agua}

Las fuentes de energía que rigen el desarrollo y crecimiento de todos los ecosistemas son el sol y la gravedad. El humano en principio también lo era así, pero tras un lento proceso cultural inventó las máquinas y con ellas el uso de otras fuentes de energía, entre ellas aprendió a controlar la energía cinética y potencial del agua, primero para el transporte aprovechando los cauces ${ }^{136}$ y en segundo lugar por la sustitución en las primitivas máquinas de la energía que proporcionaban las caballerías por la del agua.

El uso de estas nuevas fuentes de energía, permitió aportar flujos adicionales para el desarrollo y crecimiento del territorio. Este plus de aporte energético trajo como recompensa a sus titulares en los primitivos sistemas económicos un premio en forma de acceso a la propiedad de la tierra, poder político o influencia social.

Los molinos ${ }^{137}$, son de las primeras máquinas que aprovechan la energía cinética y potencial del agua, obteniendo mayores rendimientos que con la energía humana o animal. Los molinos permiten la moldura del grano obteniendo harina, que es fundamental en una sociedad basada en las rentas; ello motivo en esta época el auge de los molinos en toda la Europa feudal.

Este motivo junto con el uso en la agricultura y la ganadería, hace que el agua sea un elemento fundamental en el desarrollo y crecimiento de un territorio. Su importancia es tal que su uso y control ha sido a lo largo de los siglos objeto de controversia y de conflicto. En el Repartiment del mismo modo que las tierras fueron objeto de reparto entre la monarquía, las órdenes religiosas, los nobles, las universidades o municipios y los propios colonos, el agua no fue objeto de ese reparto permaneciendo su uso de carácter público pero con una serie de condiciones que permitían su aprovechamiento. ${ }^{138}$

136 Ver apéndice documental no 23 y 24 pág. 620

137 Ver apéndice documental no 8 pág. 609

138 En la Batllia de Cervera se cuenta con la documentación completa de la sentencia arbitral del río Cenia de 1332 (ver apéndice documenta $n^{\circ} 41$, pág. 633) que pone fin a los litigios entre los distintos usuarios del agua del río y que establece a partir de ese momento cual será el uso que se dará el agua en las dos orillas del mismo desde el término de Rosell hasta la desembocadura en el Mediterráneo. Esta sentencia ejemplifica la importancia del agua como fuente de energía en la Edad Media

El río desde la segunda mitad del siglo XII se convirtió en frontera histórica entre Cataluña y Valencia (ojo espacio entre ríos mejor dicho, zona de seguridad) Jaime I al delimitar el reino de Valencia ya usaba el entonces llamado río de Ulldecona como frontera: En la versión de los Fueros de 1240 decía así: "Vocamus et volumus ut regnum Valenttie appelletur et sil a rivo de Ulldecona usque ad terminum de Biar..."

La Orden militar del Hospital fue la poseedora de la orilla izquierda del rió Cenia y concedío a las poblaciones de Ulldecona, La cenia y Alcanar la donación de las aguas del término y la creación de pequeños sistemas de riego: La Cenia creo una huerta al lado del río en las partes más cercanas al agua y fáciles de regar. Sin embargo, para regar el resto, precisaban de la construcción de un sistema de riego mucho más complejo, ya que el río va encajonado en este tramo y necesitaría cequias largas de más de un kilómetro (ahorro energético). Así mismo les fue concedido el derecho a levantar un molino libre de cargas allí donde quisieran. En el caso de Ulldecona la construcción de una acequia era una tarea mucho más sencilla, puesto que el río ya no circula tan encajonado y por este motivo en la conocida como "segunda carta de población" de 1274 se concedía toda el agua desde la Cenia hasta el pueblo de Ulldecona.

En cuanto a la orilla derecha, tras la conquista el primer tramo del río fue concedido al monasterio cisterciense que había fundado Jaime I: Se trataba de un territorio montañoso de difícil explotación agraria. El resto hasta el mar fue dividido en dos sectores. El primero otorgado a la Orden del Hospital con el castillo de Cervera, con los cual los hospitalarios se convirtieron en poseedores de la mayoría de las tierras relacionadas con el río. El segundo, correspondiente al termino del castillo de Peñiscola se lo reservó el rey Jaime I.

Cuando más adelante se concedieron las cartas pueblas para la creación de Vinaros y Benicarlo, fueron edificados al lado del mar y sin relación significativa con las aguas del río Cenia. Lo mismo sucedió río arriba de3ntro del gran término de Cervera. Ninguna de las poblaciones fundadas lo fue al lado del río y por lo tanto no usaron el agua para usos agrícolas a diferencia de las poblaciones de la Cenia y Ulldecona situadas en la orilla izquierda. El agua del río únicamente fue usada por diversos molinos harineros situados en la parte valenciana. La Orden del Hospital siendo poseedora de las dos orillas concedió el agua a Ulldecona y al uso ganadero.

En 1294 la situación iba a cambiar, puesto que la Orden del Temple compró Peñiscola, Vinaros y Benicarlo ql rey Jaime I. De este modo dos órdenes militares poseían tierras cercanas al r4io, los templarios junto al mar en la orilla derecha y los hospitalarios en el interior y toda la orilla izquierda. Pero el proceso abierto contra los templarios a partir de 1307 implicó el embargo de sus señoríos y Peñiscola quedo bajo la administración real hasta 1319 cuando fue fundada la Orden de Montesa. 
El hombre aprende a usar la energía del agua a cualquier hora del día y cualquier día del año almacenándola y controlando su uso. Las balsas ejemplifican la energía potencial del agua, contienen la energía futura que usará el hombre.

La energía que necesita el hombre para subsistir así como los flujos que aportan las fuentes naturales como el sol, se pueden medir y comparar como hace H.T. Odum y así saber si una sociedad tiene capacidad energética para crecer y desarrollarse.

Otros autores como Philippe Robert, compara la energía de la fuerza humana y la de un molino para así deducir la "capacidad" que tiene el grupo social que posee los molinos, en función del aporte energético que estos suministran.

En el estudio sobre los molinos en Francia: “L'Eglise et l'énergie pendant le XIe siecle Dans les pays d'entre Seine et Loire" de Philippe Robert y publicado en Les Cahiers de civilisation médiévale (pág. 105-106), compara la energía de la fuerza humana y la de un molino. La energía humana es de 0,30 $\mathrm{HP}$, siendo $1 \mathrm{HP}$ el caballo de motor métrico que corresponde a la potencia necesaria para elevar en 1 segundo un peso de $75 \mathrm{Kg}$ a una altura de 1 metro. Pues bien la energía desarrollada por un molino medieval movido por el agua considera que es de $6 \mathrm{HP}$; extrayendo de la comparación de estas cantidades el aporte energético que hacen los molinos a la sociedad medieval de la época.

Extrapolando los datos de Robert a la Batllia, el número total de molinos y almazaras que tenemos en esta época es de 29, por lo tanto la energía total producida por ellos es de:

Molinos y almazaras: 6 × $29=174 \mathrm{HP}$

El cuerpo humano no puede trabajar continuamente, necesita reposar por lo que considera que

Para su creación el Papa concedió al rey Jaime II todos los señoríos de la Orden del Temple y del Hospital situados en el reino de Valencia. De esta forma el río se convirtió en frontera entre dos órdenes militares distintas: la orden de Montesa en la orilla derecha y la Orden del Hospital en la izquierda.

Como era de esperar, pronto empezaron los conflictos entre ambas partes por diferentes motivos relacionados con el uso del agua. El aprovechamiento para los molinos, para la agricultura, para la ganadería sería motivo de enfrentamientos.

A medida que la situación se fue complicando se vio necesaria la intervención de un mediador que acabase con los conflictos y que regulase definitivamente el aprovechamiento del agua del río. Las dos partes aceptaron al obispo de Tortosa, Berenguer de Prats, como juez. La sentencia del 25 de mayo de 1332 fue el gran acuerdo medieval sobre el reparto del agua del río. La demanda del agua había crecido considerablemente, además de los cultivos y el ganado, los molinos necesitaban mucha agua y se perjudicaban unos a otros. Tanto la Orden de Montesa como la del Hospital podían otorgar el derecho a construir nuevos molinos en sus respectivos orillas. El cauce del río no siempre podía abastecer la creciente demanda de recursos hídricos.

El 25 de mayo de 1332 junto al albergue o posada del molino de la Torta, actualmente molino de Noguera, situado 1 lado del río Cenia en el término de Vinaros, el obispo de Tortosa, dictaba sentencia para evitar desavenencias y pleitos entre la orden del Hospital y la de Montesa. Estaban presentes los representantes de las partes interesadas, así como muchos testigos. La sentencia puede dividirse en veintiún puntos, destacando la división del río en cuatro tramos.

En el primero de ellos situado cerca de La Cenia, entre el molino de March de Pontons y el del Hospital, el agua se divide a medias entre las dos órdenes militares y se utilizaría para las huertas y molinos existentes en aquel momento.

El segundo, desde el molino del Hospital hasta el molino del Castell junto al actual San Rafael del Río, podía usar aguas solamente los molinos de la orilla derecha ósea los de la orden de Montesa mientras que los hospitalarios solo podían dar de beber a los animales.

En el tercero, entre San Rafael y el molino de la Torta, se establecía justamente lo contrario: Serian los de la orilla izquierda, los hospitalarios, quienes usarían el agua para el riego y los molinos yb en la orilla derecha los de Montesa podrían usar el agua para el ganado.

En el cuarto y último tramo, desde el molino de la Torta hasta el mar, como era de esperar el agua se repartía a medias entre los vecinos de Alcanar y los de Vinaros

Además de la división del río en cuatro tramos la sentencia también contemplaba la ampliación de la cequia que circulaba por el valle de Ulldecona y regulaba su uso del agua por parte de un par de molinos cerca de Ulldecona.

En conclusión la sentencia impedía innovaciones y suponía la regulación definitiva del reparto del agua del río Cenia, las dos órdenes militares por fin tenían una legislación clara a la que atenerse.

En el punto 18 de la sentencia dice que a ambos lados del río podrán beber los animales salvo en tiempos de gran sequía, como lo han hecho a ambas orillas desde tiempos inmemoriales.

"Encara dehiem e declarem que, del cap del riu tro a la mar los bestiars e bestias de cascuna de les dites parts, que abrevaren el dit riu, no carguen en alguna pena ni puixen esser carnegats ni penyorats si doncas no exien fora "arenal o glera que el riu a acostumat de tenir de la una part e de la atra, salvu en temps de gran sequera"

Como podemos observar la importancia del uso del agua para el desarrollo del territorio es fundamental. En esta sentencia se observa que el agua se reparte entre el riego, la ganadería y el uso para los molinos. 
trabaja 2/3 del tiempo que los molinos, y teniendo en cuenta que en la Batllia hay censados en 1373, 2316 fuegos, es decir familias, por lo que contamos con 2316 personas trabajando que suponen un aporte de energía de:

Personas: $0,30 \times 2316 \times 2 / 3=463,20 \mathrm{HP}$

Si la energía total es de $174+463,20=637,20 \mathrm{HP}$, los molinos suponen el 27,30 \% del total de la energía que se encuentra en manos fundamentalmente de la Orden del Hospital primero y posteriormente de Montesa. En el caso del artículo de Francia comentado la aportación de energía en Francia en esta época era del $50 \%$ mucho más elevada y que se encontraba en manos de la Iglesia. Esto nos da una idea de la importancia de las rentas obtenidas por los molinos y por tanto de la importancia de contar con su propiedad o uso; así como que conforme en Europa se fue desarrollando la sociedad cada vez tuvo más importancia la existencia de los molinos. El desarrollo económico va ligado al aumento de estas "maquinas". El desarrollo económico va ligado por tanto a una determinada forma de desarrollo del territorio y sobre todo de los cursos del los ríos. Los molinos atesoran energía y por tanto los lugares que ocupan también.

El mayor desarrollo de las zonas limítrofes a los cursos de agua, que permiten el plus de energía que aportan los molinos, condicionan el crecimiento del territorio desde la Edad Media. Todo el desarrollo industrial del siglo XIX y posteriormente del XX se produce en los mismos lugares en los que previamente estuvieron los molinos medievales. El reducido desarrollo industrial del río Cenia se realiza sobre el territorio "creado" por los molinos medievales, hace uso de la energía atesorada por ellos. Aun es más hoy en día el desarrollo turístico aprovecha esa energía atesorada iprimero en los molinos medievales y posteriormente en las industrias que en dichos lugares se instalan.

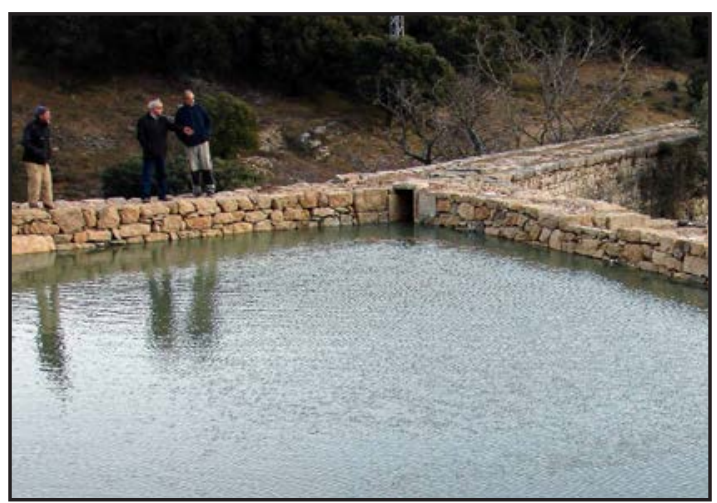

Fig. 6. 9. Foto balsa molino en Ares.

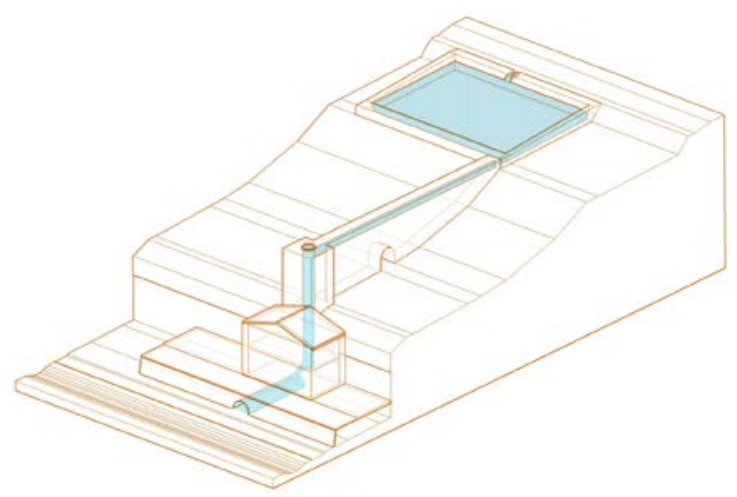

Fig. 6. 10. Dibujo del conjunto hidráulico de un molino en Ares.

El hombre aprendió a almacenar el agua y así a usar la energía potencial que atesora y regular el uso de la misma.

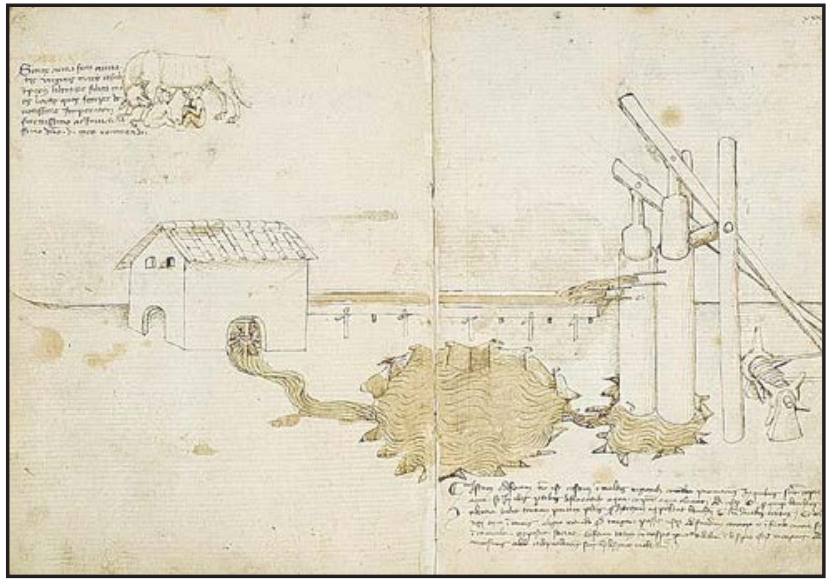

Fig. 6. 11. Dibujo de Mariano Taccola del libro: De Ingensis water (1449).

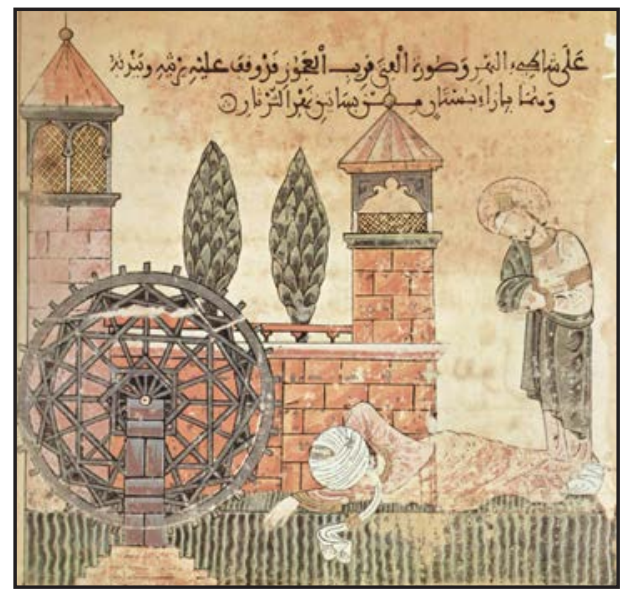

Fig. 6. 12. Dibujo de la escuela de pintura de Bayad y Riyad (s. XIII). 


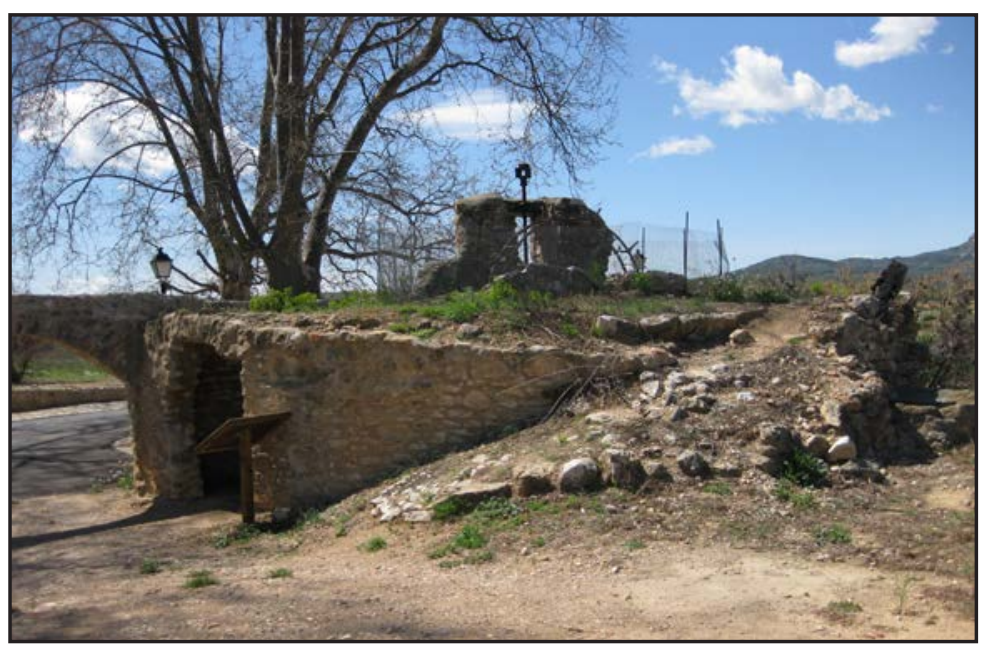

Fig. 6. 13. Foto de noria junto ermita de Santa Isabel de Canet.

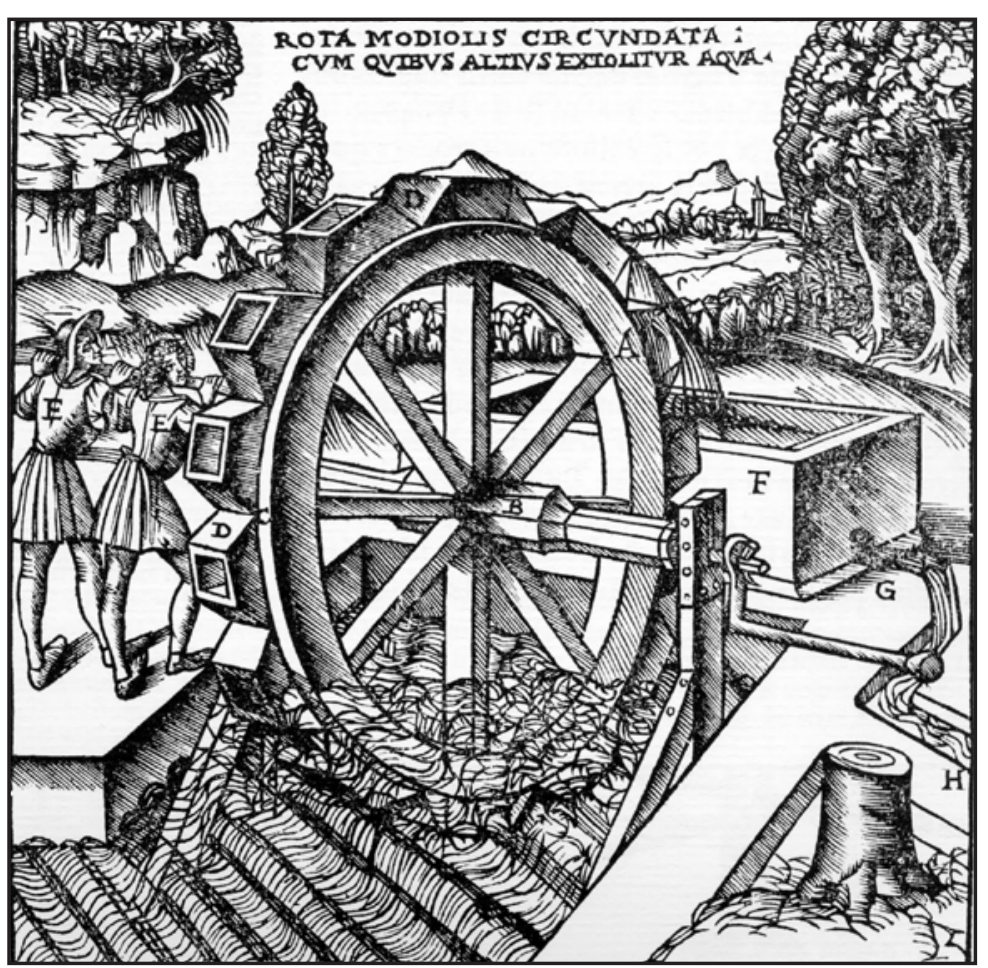

Fig. 6. 14. Dibujo de Noria manual de Los Diez Libros de la Arquitectura de Vitrubio (27-23 a.C.)
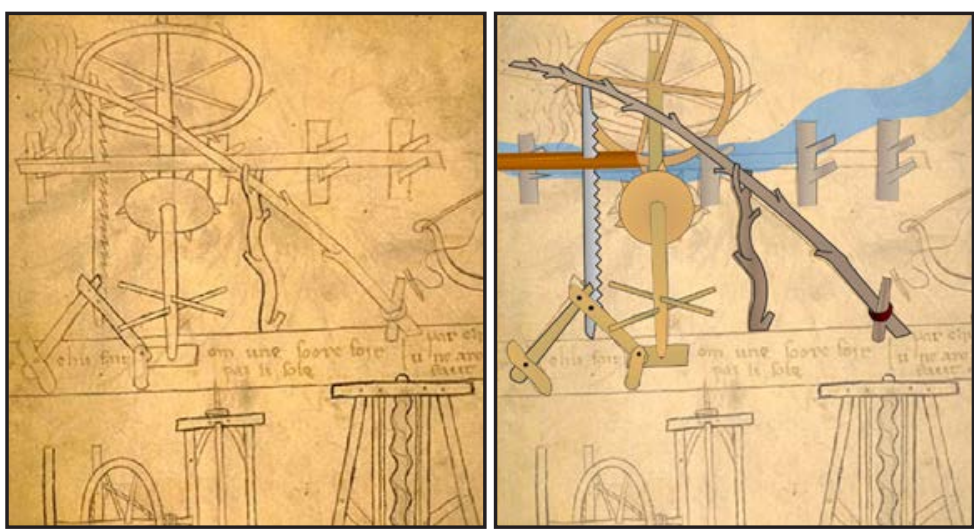

Fig. 6. 15. Sierra hidráulica. Lámina 44 de Villard de Honnecourt.
El hombre tuvo que "vencer" la gravedad para hacer uso del agua como "alimento" para el campo, las norias y las cenias fueron primitivas máquinas que lo lograron con el uso de un mínimo de energía humana o animal.

El hombre también aprendió a usar la energía cinética del agua. Este detalle de sierra hidráulica de la lámina 44 de Villard de Honnecourt así lo atestigua.

Estos dibujos provienen de una recreación de la Biblioteca de Francia, a partir de los dibujos de Villard. 


\section{2. 4. El Territorio medieval y la gravedad}

Las arquitecturas que conforman el Territorio y el mismo son estereotómicos, se rigen por los principios de la gravedad y de la búsqueda de la luz de forma análoga a como lo hacen los ecosistemas en la biosfera.

La gravedad hace que sean las trayectorias verticales las que guían el desarrollo y evolución del territorio, los desplazamientos horizontales son excepciones a los que s e intenta dar solución con el mínimo de consumo energético.

Las compresiones definen las arquitecturas, que por ello son compactas y másicas. Son volúmenes de materiales apilados que posteriormente se excavan, se les sustrae material -los canteros dirían se les roba-. Los materiales utilizados son los que trabajan bien a compresión: piedra, ladrillo, adobe... Pertenecen a la tierra, son una continuidad de ella. Este carácter estereotómico no está reñido -más bien lo contrario- con el carácter topológico del soporte sobre el que se construyen este territorio; la construcción estereotómica también lo es topológica, ya que apilar y sustraer son dos de las formas topológicas de transformación. Pensemos en los castillo de Cervera o de Morella su arquitectura es una prolongación "orgánica" del soporte en el que se encuentran, las edificaciones del Castillo y de la ciudad a sus pies son un "reordenamiento" de los volúmenes de piedra originales de la montaña. Así lo podemos ver en el apéndice documental nº 39 pág. 632:

"Jacobus, et cetera. Fideli suo iustitie Morelle vel eius locumtenenti, salutem, et cetera. Intelleximus per Petrum de Moriella, militam, alcaydum castri Morelle quod propter ruynam aquarum ceciderunt plures lapides faciunt ad opera eorum defferri. Quapropter vobis expresse mandamus quatenus preconitzare publice faciatis sub pena certa quod nullus, cuiuscumque conditionis existat, audeat vel presumat de dictis lapidibus accipere ad opus eorum defferre et a contrafacientibus penam predictam absque remedio exigatis et eso propter inobedientiam, tu faciendum fuerit, puniatis sic quod eorum pena sit aliis in exemplum. Volumus et mandamus quod in pennis castri non permitatis scindi aliquos lapides cum essetr, tu dicitur, dicto castro valde dampnosum."

La gravedad hace que inicialmente las construcciones primitivas sean isótropas, no tengan una dirección dominante y sean más "fáciles" de construir; sustraer material para obtener una forma isótropa es más sencillo. ${ }^{139}$ Así surgen las casetas de pastor, las torres...

Posteriormente al marcar una dirección y perderse la isotropía se siguen dos caminos o bien se van adosando construcciones isótropas- ver los conjuntos de casetas de pastor- o bien surgen los muros liberados de la cubierta que se perforan, se hacen permeables para intentar conseguir un espacio lo más unitario posible. Los orígenes los podemos encontrar en las basílicas cristianas sirias de los siglos II y III que van evolucionando hasta la arquitectura gótica que dará forma al territorio de nuestro estudio.

En la Edad Media, se inicia la transición hacia la estructura tectónica, hacia la transmisión de las compresiones mediante una trama y con ella de la gravedad con un sistema estructural de nudos y juntas donde la construcción es articulada. En el gótico la piedra "adopta caracteres tectónicos en una situación límite, casi milagrosa, constituyendo una estructura donde se distinguen los nervios de la plementería, como una premonición de lo que los siglos más tarde hará el movimiento moderno en su desglose de pilares y cemento". ${ }^{140}$

139 Véanse los dibujos de la pág. 498 en adelante, referentes a construcciones estereotómicas e isótropas:

Caseta de pastor: montón de piedras ordenadas de manera que permite posteriormente sustraer las interiores para que quede un vacío un molde que es el espacio habitable.

Torre: no son cuatro muros unidos por las esquinas, es un volumen que luego se excava. Por este motivo en muchas ocasiones las plantas inferiores son macizas, véase torre Forcall de Morella o el campanario de San Mateo. El espesor de los teóricos muros no es para resistir la carga de los forjados o cubierta sino que es el volumen que no se ha querido excavar Molino conducto agua: El volumen del cubo-torre es excavado por la "erosión" del agua.

Escalera de caracol: Se obtiene por vaciado o "robo" de una columna de piedra.

Ver la evolución de la direccionalidad en las construcciones estereotómicas en los dibujos de la pág. 499.

Iglesias de Reconquista: el volumen tiene direccionalidad, se perciben los muros como tales, estos se perforan y se crea un espacio direccional.

140 CAMPO BAEZA, A. "Pensar con las manos” pág. 2 
Pero no solo las arquitecturas se rigen por la gravedad, a una escala mayor también lo hace el territorio:

- La trama urbana de una ciudad como Morella sigue la disposición que le permite conducir el agua de escorrentía por las calles hacia los aljibes públicos que se sitúan estratégicamente a este objeto. La gravedad es la que "proyecta" la trama urbana de la ciudad.

- La ubicación de la acequia principal que da servicio a un sistema de riego (como en la Plan de Vila real o en la acequia real del Xúquer) condicionan el posterior desarrollo de un territorio(la ciudad de Vila real se sitúa aguas arriba de la acequia mayor). En un suelo llano sin teóricamente elementos que lo diferencien, la implantación de la acequia y su trazado por condiciones de gravedad son las que "marcan" el territorio y diferencian entre el suelo de regadío y el de secano, entresuelo productivo y suelo no productivo.

- Las tierras de cultivo abancaladas, son el resultado del modelado del territorio siguiendo las directrices que la escorrentía del agua por gravedad marcan.

- El trazado de un acueducto sigue la "huella" que el curso del agua sigue por gravedad desde el punto de captación hasta el aljibe final al que llega. En algunos tramos se excava el suelo y en otros se eleva artificialmente la cota, permitiendo "alimentar" una parte de territorio a través de ese "cordón umbilical" que le une a la madre tierra.

El agua no es transportada sino conducida ("adducere") por la cicatriz que deja en el soporte, como ocurre con el curso de un río, como se ve en el apéndice documental no 27 (pág. 622), del que transcribimos este párrafo:

"Noverint universi quod nos Jacobus Dei gratia et cetera; per nos et nostros concedimus vobis juratis et concilio ville Morelle et universis et singulis eiusdem concilii, tam presentibus quam futuris, quod possitis adducere ad villam Morelle aqua de fonte de Vinachos, et subtus illam aqua quam adducetis ad dictam villam, ut dictum est, et quam etiam in bassa que est in villa predicta et deputetis vel aliunde poteritis agregare, positis construere et facere molendinum sive molendina que sint dicti concilii, quorum redditus ponantur et expendantur in custodia et observacione dicte aque et aqueductus eiusdem, et aliarum expensarum dicti concilii."
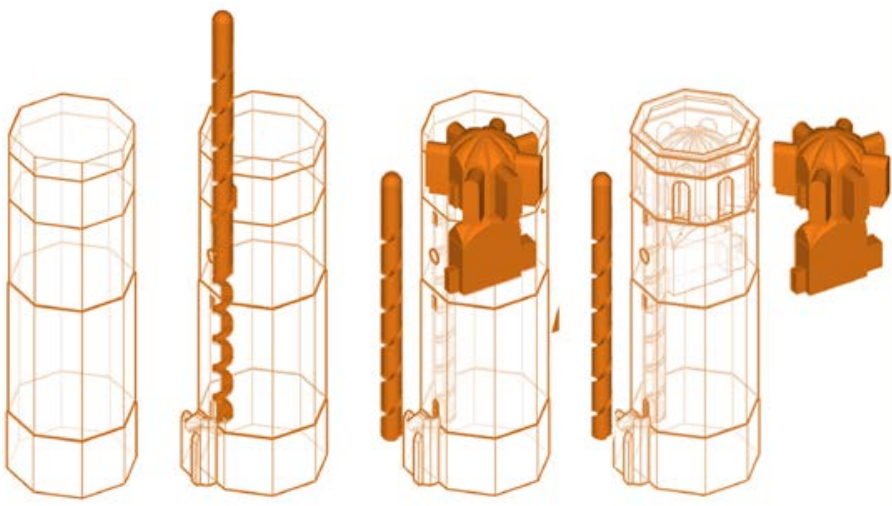

Fig. 6. 16. Desarrollo en 3D del campanario de Sant Mateu.

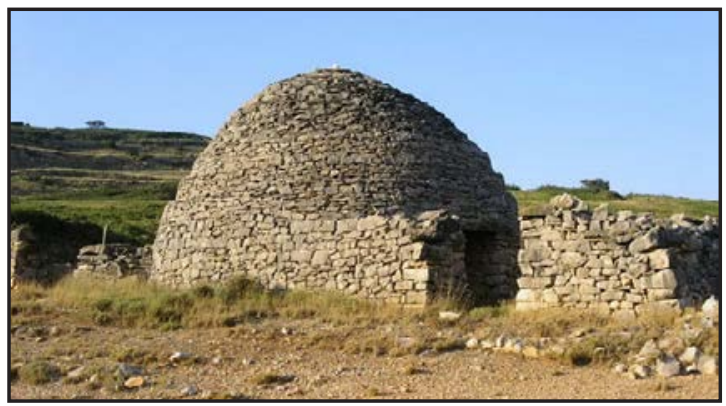

Fig. 6. 17. Foto caseta de pastor hecha en piedra en seco del Maestrat.

Ejemplos de construcción estereotómica -de "construcción de castillos de arena"- serían: la torre del campanario de Sant Mateu -torre octogonal maciza a la que se le "vacía" el espacio de la escalera de caracol y las dos salas de las plantas superiores-; caseta de pastor - montón semiesférico de mampostería que se "vacía"-. 

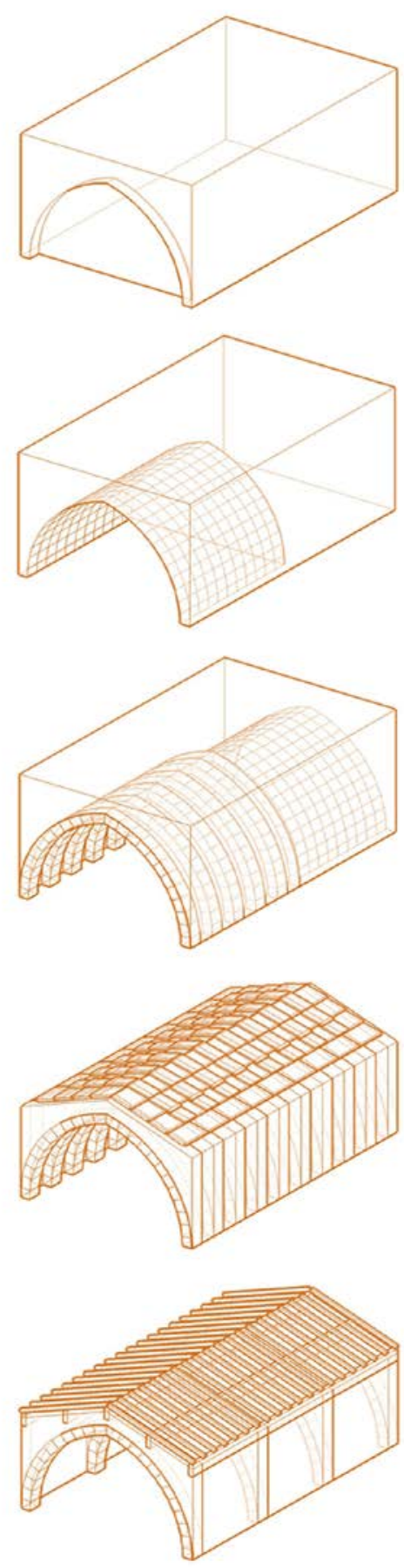

Fig. 6. 18. Secuencia de evolución de la bóveda en 3D.

Estos dibujos sintetizan la evolución desde la bóveda de sillería hasta las construcciones de arcos perpiaños. El primer paso es el de las bóvedas del templo de Rhamses en Luxor, el segundo el la iglesia de Sant Bartomeu de les Camposines (La Fatarella) del siglo XIII con arcos perpiaños cada $80 \mathrm{~cm}$ y losas de piedra entre ellos y por último la iglesia de Sant Jaume de Coratxar del siglo XIII también con arcos perpiaños ya separados unos cuatro metros y estructura leñosa entre ellos. Se evoluciona de una estructura estereotómica a una que es el origen de una tectónica.
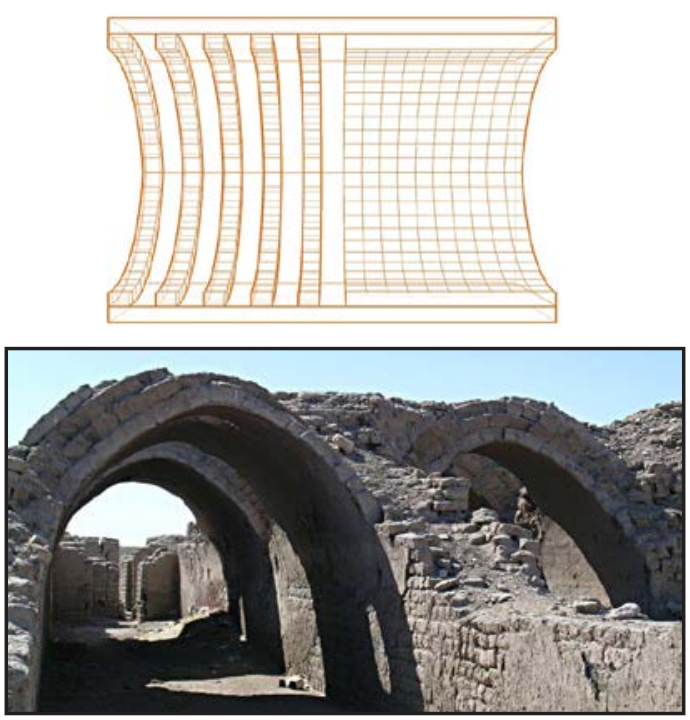

Fig. 6. 19. Bóvedas del Templo de Ramsés en Luxor.
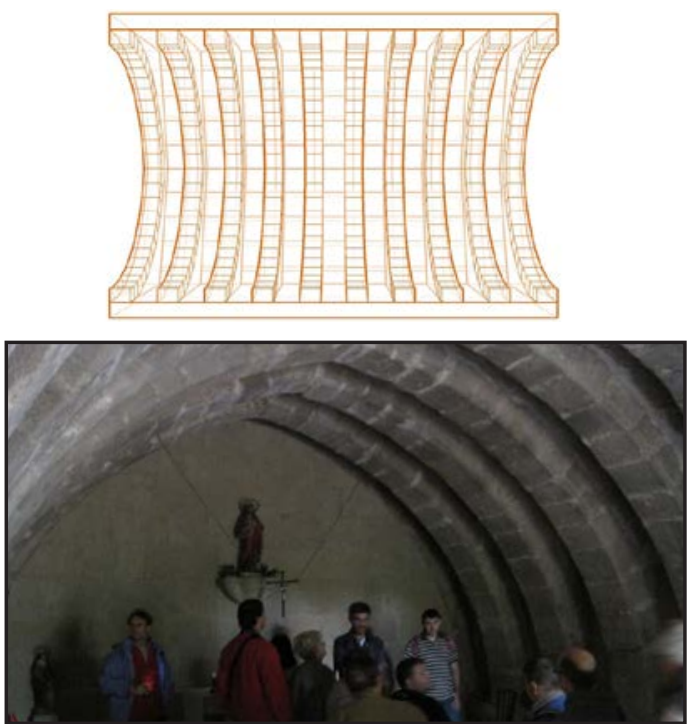

Fig. 6. 20. Arcos de la Iglesia de Sant Bartomeu.
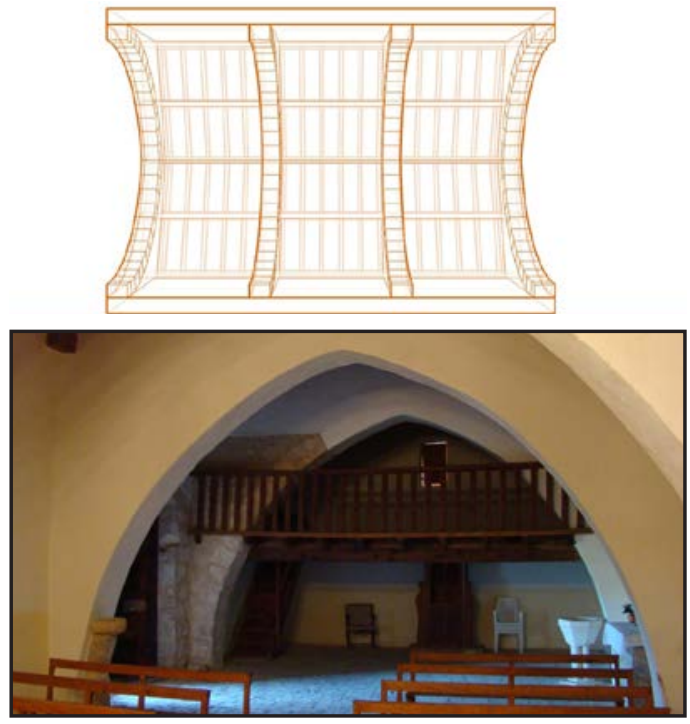

Fig. 6. 21. Interior de la Iglesia de Sant Jaume de Coratxar. 


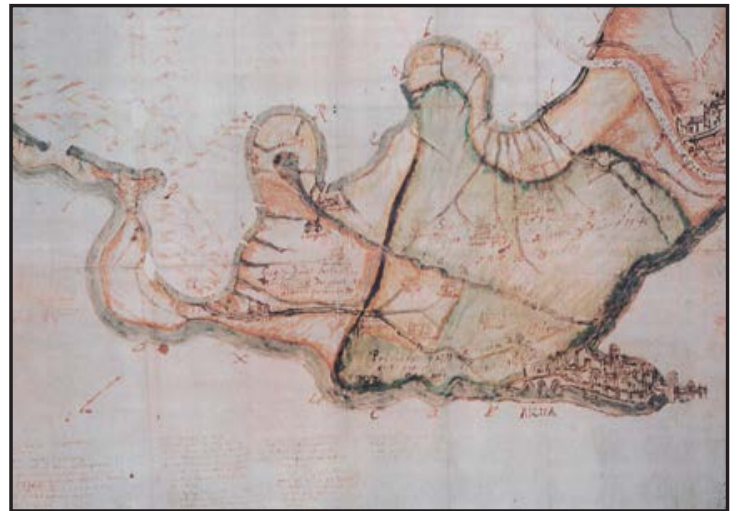

Fig. 6. 22. Fragmento de un plano de la Ribera Alta con la Acequia Real del Xuquer (1610)

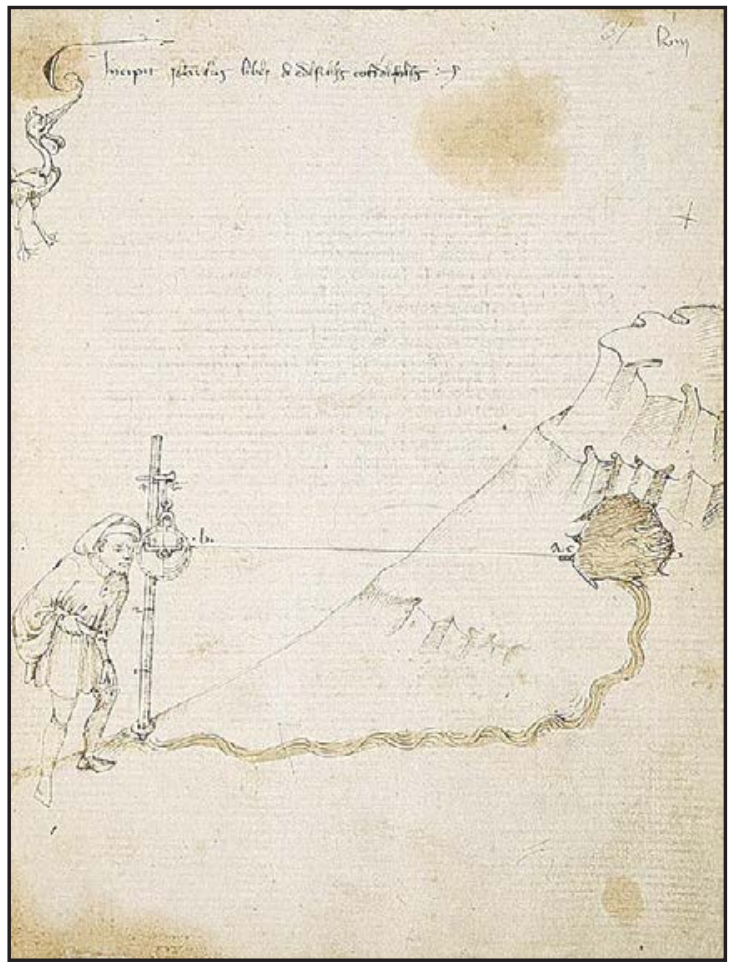

Fig. 6. 24. Dibujo de Mariano Taccola del libro: De Ingensis water (1449).

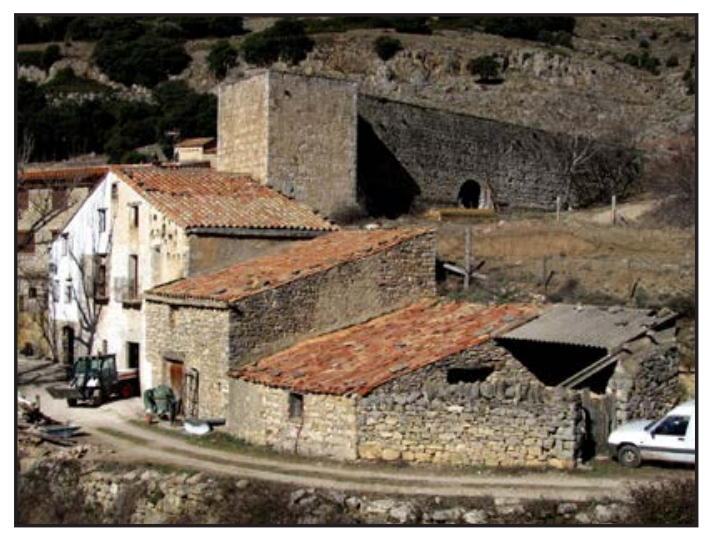

Fig. 6. 23. Foto del conjunto hidráulico de molino en Ares.

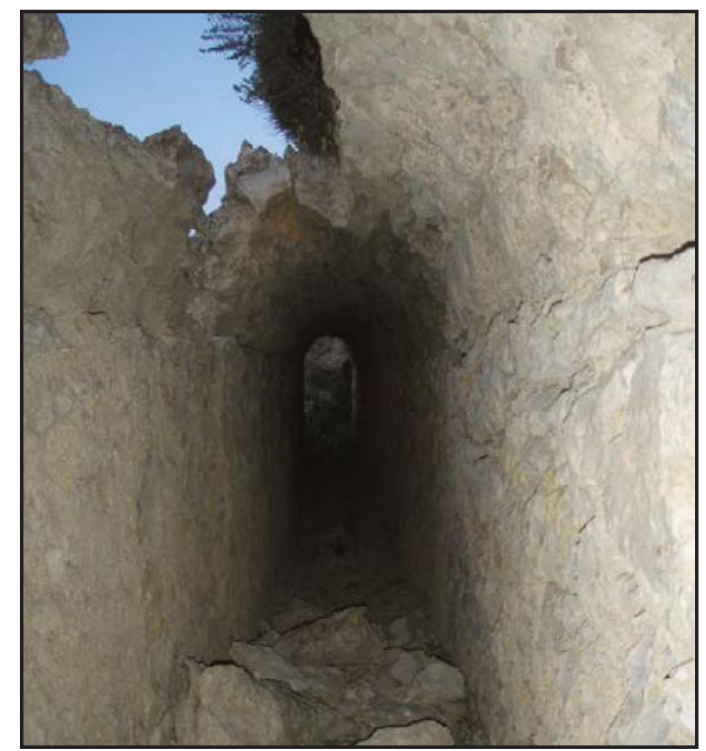

Fig. 6. 25. Foto del interior de la conducción del acueducto medieval en Morella (1315-59)

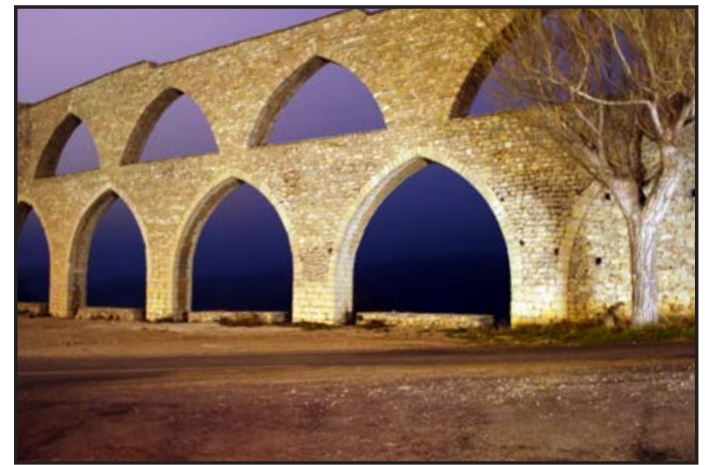

Fig. 6. 26. Foto de uno de los tramos del acueducto de Morella (1315-59). 


\section{2. 5. El fuego: el hogar y los hornos}

El calor es una energía que conforma el territorio de dos maneras, como centro de reunión y como transformador de la materia que luego se utilizara en la construcción de las arquitecturas. Ambas formas de energía permiten la construcción de instituciones humanas que se corresponde con la estructura existencia básica definida por Heidegger Ser-con. El hombre realiza las construcciones que le permiten vivir en sociedad gracias al fuego.

1. El calor del hogar reúne a las personas a su alrededor y por eso se halla el fuego presente en los ritos fundacionales tanto de la vivienda como de la ciudad. Prueba de ello es el hecho de que hoy en día la prueba irrefutable de la existencia de la vida colectiva en los estudios arqueológicos pasa por el encuentro de restos correspondientes a los primitivos hogares. Si se encuentra el fuego existía la vida en comunidad.

En los tratados de arquitectura de Vitrubio (De architectura), Alberti (De re edificatoria) y posteriormente de Semper, el fuego -el hogar- es el centro a partir del cual se produce la fundación de la vivienda o de la ciudad.

La vivienda en las más diversas culturas se diseña en torno al hogar, él es el elemento central que lo configura. Las primitivas viviendas e incluso los monasterios como el de San Gall disponen el hogar en el centro de la estancia principal, toda la construcción gira en torno a él. En las primitivas ciudades primitivas el horno es un elemento fundamental. Cumple funciones similares a las del hogar doméstico, es el centro de reunión para hablar, calentarse y alimentarse. Hoy en día en pequeñas poblaciones sigue teniendo esa función el horno.

Por todo ello no es de extrañar la importancia que del fuego en los ritos vinculados con la fundación de la ciudad o la casa. El hogar mantenía el fuego sagrado que protegía a la vivienda y a la ciudad, que les daba calor y alimento. Sin duda las costumbres que todavía hoy en día perduran en muchos municipios de esta zona de estudio, tienen su origen en esos ritos primigenios. Las hogueras de San Antonio en las que todos los vecinos se congregan en torno a una gran hoguera de forma cónica construida a partir del eje de un gran árbol cortado y dispuesto al efecto que se completa con el apilamiento de gran cantidad de ramas, formando una gran construcción estereotómica vegetal, que se vacía en la parte inferior para obtener una cueva vegetal en la que se danza mientras la hoguera se prende fuego.

El territorio se ordena en función de los hogares domésticos y urbanos que se reparten por él. El hombre necesita de la proximidad de estos lugares de reunión para vivir y los construye para habitar el territorio.

La vida alrededor del foco del hogar propicia una construcción isótropa. Este hogar central o habitáculo del fuego es el origen de la estufa o brasero. Es el fumeral de las masías o monasterios y la olla de los hornos. Es una construcción dentro de la arquitectura a la que da servicio, es un volumen calefactado dentro de otro volumen que lo envuelve. ${ }^{141}$

2. El calor de los hornos "transforma" los materiales que luego se usan en la construcción de las instituciones del hombre: masías, iglesias, molinos... El fuego con el consumo de energía exógeno permite la que los materiales naturales se transformen en cal, cerámica, vidrio o metal que luego se usaran en las arquitecturas. Este mayor coste de energía, muy superior al de las construcciones sustentadas solo por la gravedad, permite sin embargo acumular mucha más información.

El fuego permite "transformar" la materia, eso le hace ser un elemento que en los ritos se le relaciona con la vida y la creación.

Pero hay otros aspectos del fuego que merece destacarse. Y que han motivado que junto con la

141 Nótese como en inglés la palabra "Heart" significa corazón y "Hearth" chimenea. 
construcción de las instituciones conformen el territorio en la Edad Media.

El primero es que el fuego es también desorden y caos, los incendios pueden suponer la destrucción de las construcciones, son un gran peligro para las ciudades. Muchas ciudades como Morella sufrieron voraces incendios, fortuitos o provocados que destruyeron gran parte de la ciudad. Ese fuego devorador es el que motivo la existencia de ordenanzas de construcción limitando el uso de la madera y de determinadas formas constructivas como los porches o los voladizos, como se recogen en las ordenanzas de la ciudad de Morella tras el incendio que sufrió en 1356: ${ }^{142}$

"Petrus, et cetera. Fideli nostro mostaçafio ville Morelle, presenti et qui pro tempore fuerit, salutem et gratiam. Pro parte proborum hominum universitatis dicte ville fuit nobis expositum reverenter quod, licet nos cum littera nostra, pro evitando similis ignis incendio, quod non est diu casualiter accidit in dicta villa occasione perabandarum seu envanorum que erant in hospitiis dicte ville, duxissemus providendum quod amodo aliquis seu aliqui singulares ipsius ville in edificis fiendis in eorum hospitiis non auderent facere aliquas perabandas seu envana fustea, sed quod heberent operari seu edificari facere parietate seu parietes ipsorum hospitiorum, frontres ipsorum hospitiorum reddentes directe usque ad tectum superius ascendendo et in tecto superiori tectis seu cohopertis. Verumtamen aliqui singulares dicte ville, tam propter potentiam eorum quam propter favorem vestri, dicti mostaçafii sweu predecessoris vestri in ipso officio sive etiam per negigentiam, nituntur facere perabandas sive envana fustea contra formam nostre provisionis supratacte. Quocirca per eosdem probos homines fuit nobis humiliter supplicatum tu super hiis dignaremur eis de condecenti remedio providere. Nos, itaque, eorum suplicatione benigne admissa, vobis dicimus et mandamus quatenus omnia et singula envana seu perabandas factas seu cvonstructas contra formam provisionis sepedicte dirui faciatis cavendo diligenter en aliquis amodo construat sive faciat envana aliqua in suo hospitio contra provisionem prelibatam tu dicta villa a casu simili predicto valeat tutius preservari."

Este hecho condiciona el crecimiento y evolución de las ciudades y del propio territorio, supone una ralentización del desarrollo de la arquitectura tectónico realizada a partir de los entramados de madera en fachadas, forjados y cubiertas y por tanto un apoyo aun más importante si cabe por la construcción estereotómica. La tectónica en esta comarca tardo aun más si cabe que en otras zonas en implantarse. El territorio por tanto fue durante muchos más años de carácter estereotómico por el "desorden" del fuego.

Este desorden relaciona el fuego con el mal y el diablo. En los ritos del fuego de las fiestas de San Antonio el fuego se relaciona a la vez con el mal a la vez que el propio fuego purifica y libra al hombre del mal.

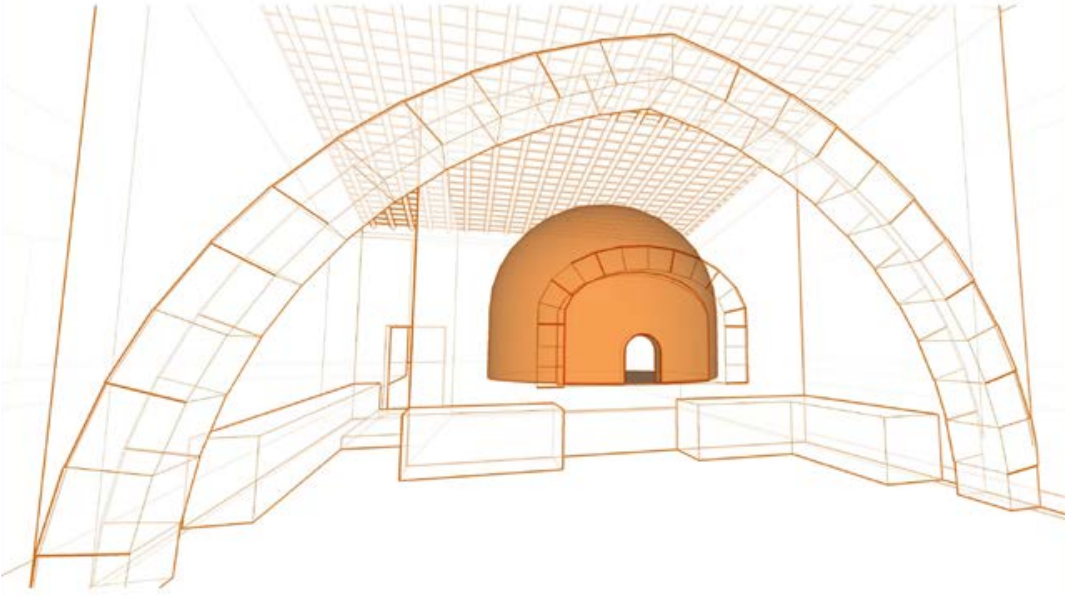

Fig. 6. 27. Dibujo en 3D del horno de Sant Mateu.
El segundo es el del fuego como vehículo que permite la transmisión de la información. Antes de la existencia de la imprenta y por tanto de la facilidad para transmitir el conocimiento con la escritura y los libros, el conocimiento y la información se transmitían verbalmente. Y en esa transmisión la reunión alrededor del

fuego era un hecho importante. Dado que la memoria es el lugar donde se deposita la información, podríamos decir que el fuego es también memoria en cuanto que junto a él y gracias a él se transmite la información.

142 Ver apéndice documental no 43 pág. 639 

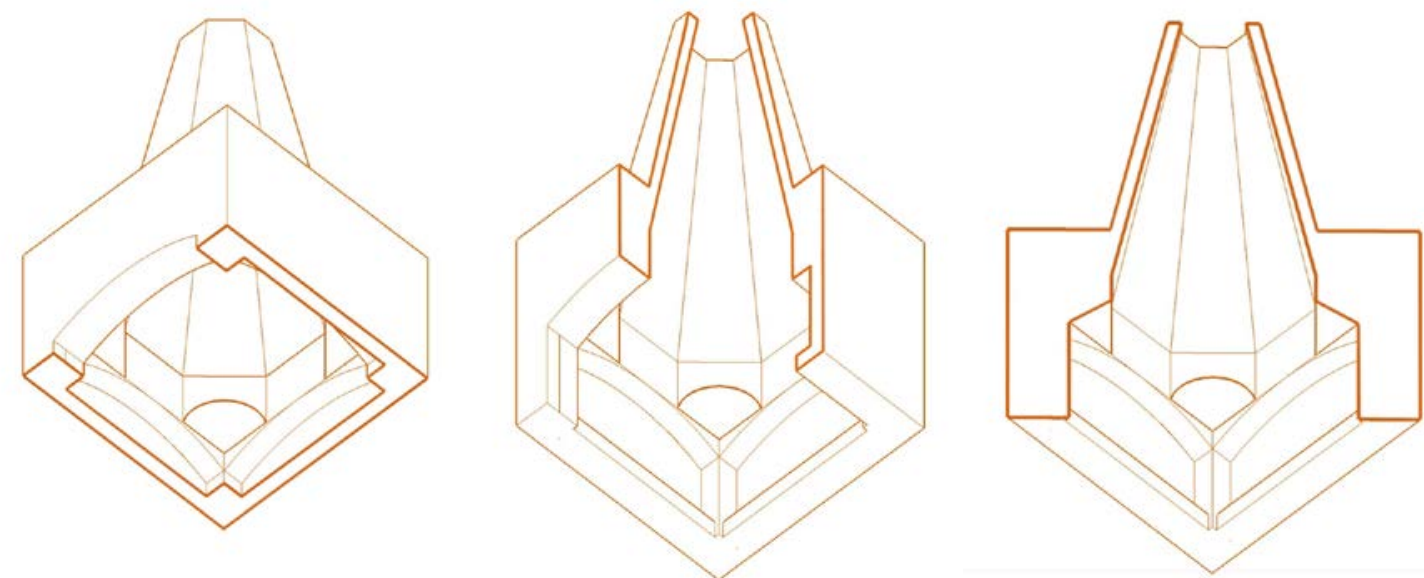

Fig. 6. 28. Dibujos en 3D del "fumeral" de la hospedería del santuario de Nuestra Señora de los Ángeles de Sant Mateu. Obsérvense la similitud del de Choisy de la Fig. 6.257.

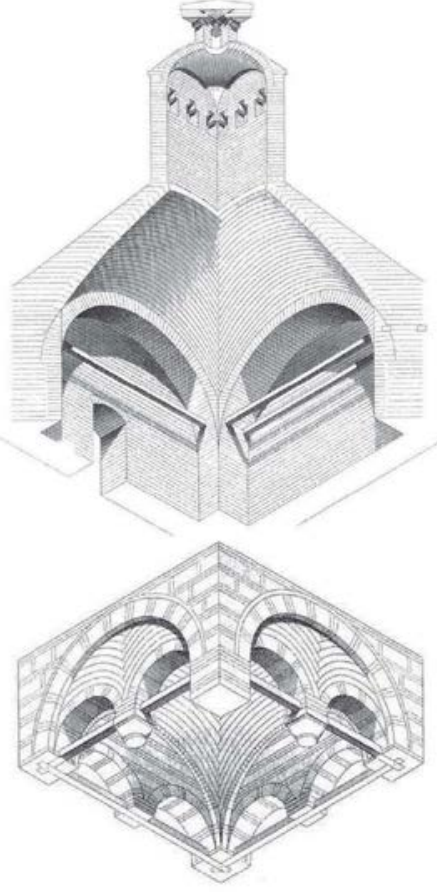

Fig. 6. 29. Grabado (XII) del libro la arquitectura de Bizancio de Albert Choisy de 1883, representando un "fumeral" en Athos.

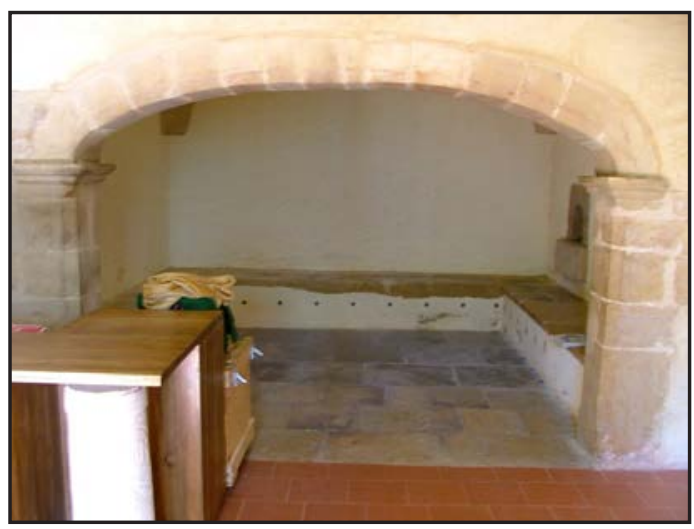

Fig. 6. 31. Foto del "fumeral" de la hospedería del santuario de Nuestra Señora de los Ángeles de Sant Mateu.

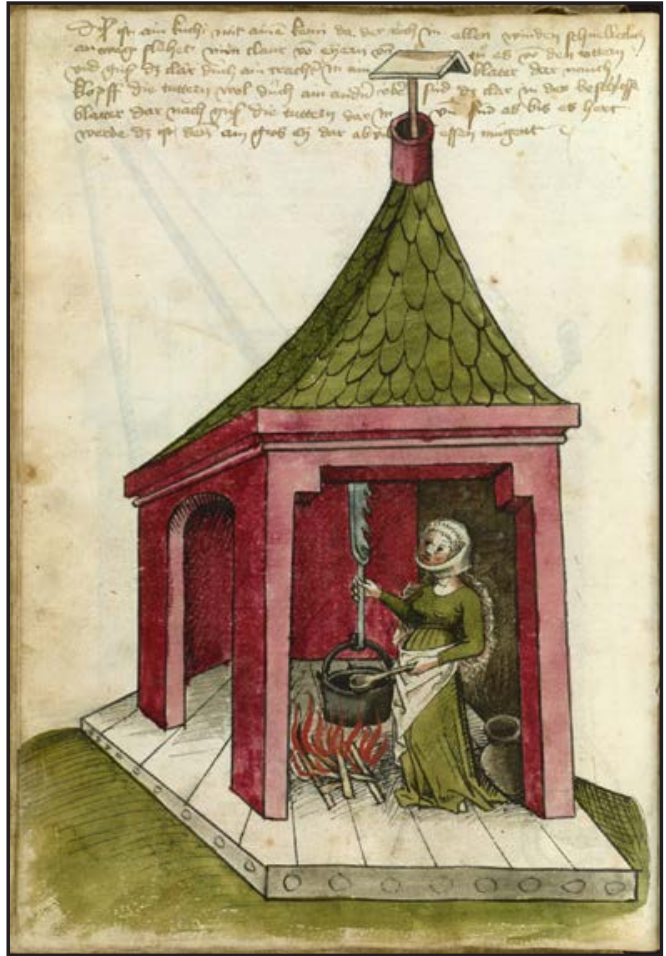

Fig. 6. 30. Fumeral en dibujo del s. XV de Ms. Thott.

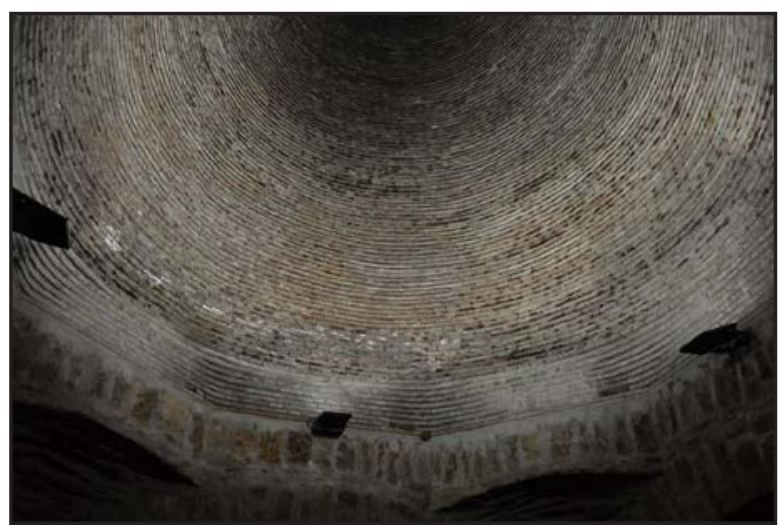

Fig. 6. 32. Foto interior del fumeral del Santuario de Nuestra Señora de la Salud de Traiguera.

Fotos del fumeral de Sant Pau de Albocasser y de la cocina de la catedral de Pamplona.

Obsérvese la similitud entre el fumeral de Nuestra Señora de Los Ángeles de Sant Mateu y el que aparece en la lámina de Athos de la arquitectura bizantina de Choisy. 

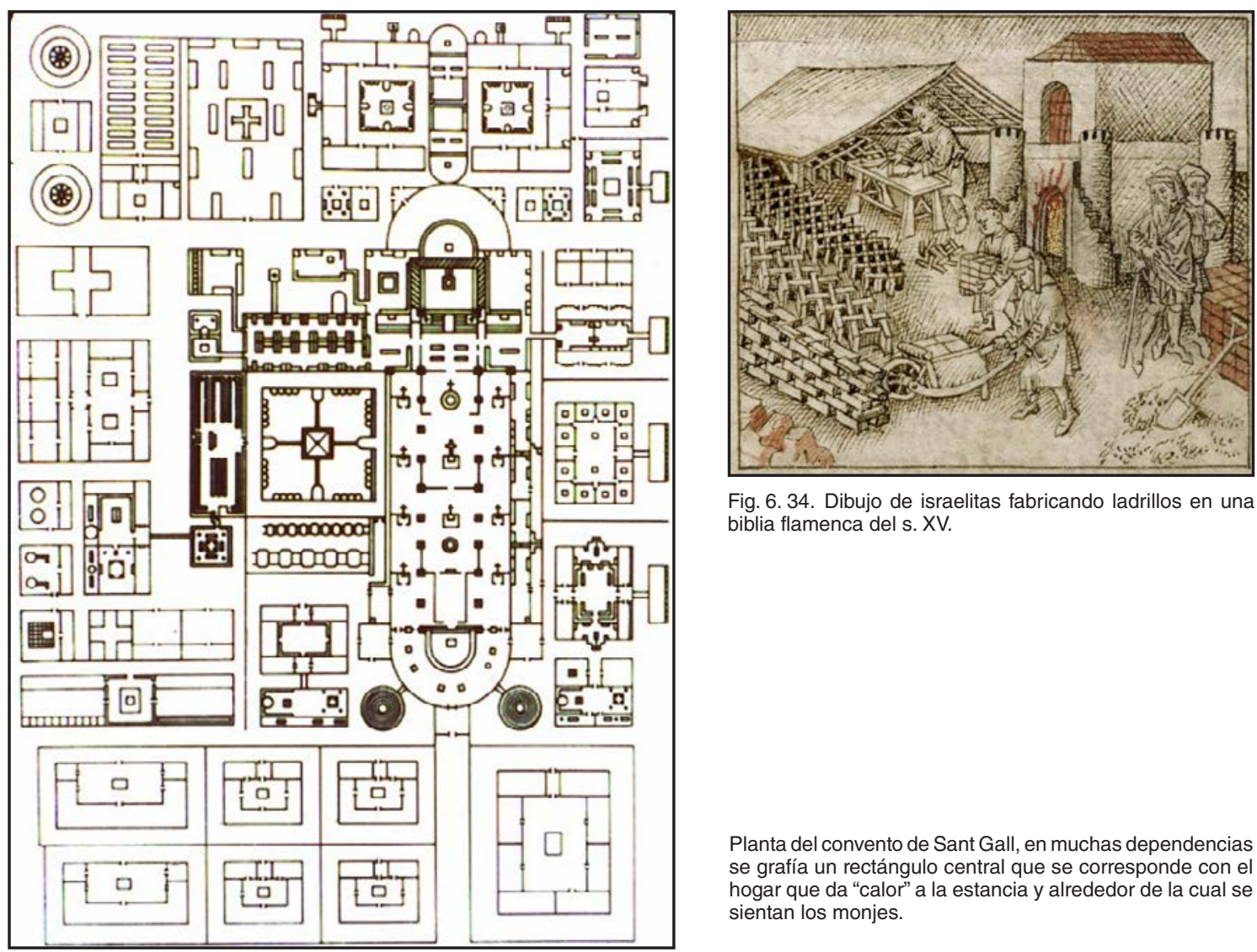

Fig. 6. 34. Dibujo de israelitas fabricando ladrillos en una biblia flamenca del s. XV.

Planta del convento de Sant Gall, en muchas dependencias se grafía un rectángulo central que se corresponde con el hogar que da "calor" a la estancia y alrededor de la cual se sientan los monjes.

Fig. 6. 33. Planta del convento de Sant Gall. El dibujo data del s. IX.

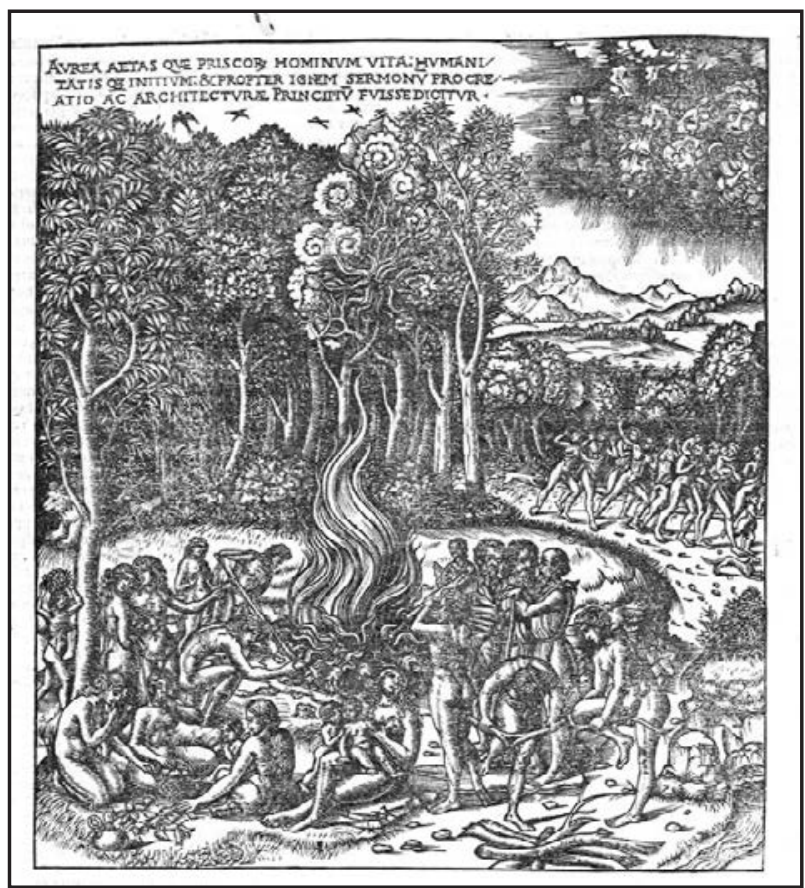

Fig. 6. 35. Fuego en el Vitruvio de Cesarino

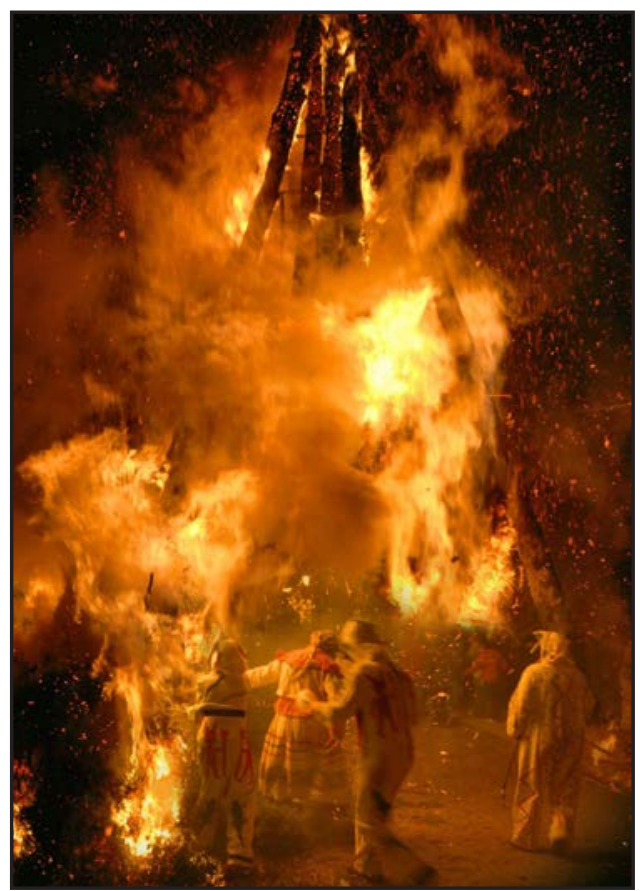

Fig. 6. 36. Foto de San Antonio en Forcall 


\section{2. 6. El Territorio medieval y la búsqueda de la luz}

La arquitectura estereotómica es aquella en la que la fuerza de la gravedad se transmite de una forma continua, en un sistema estructural continuo y donde la continuidad constructiva es completa. Es la arquitectura masiva, pétrea, pesante, la que se asienta sobre la tierra como si de ella naciera. Pero también es la arquitectura que busca la luz, que perfora sus muros para que la luz entre en ella.

La arquitectura gótica-que es estereotómica- lleva la transmisión de las cargas por compresión al límite, para permitir la entrada de luz, abre sus plementerias hasta lo más alto y las perfora para permitir que el interior del edificio se ilumine. Asciende a lo alto del edificio mediante escaleras de caracol, que perforando la piedra busca la luz de las alturas y el ascenso hacia el más allá.

¿Por qué busca la luz esta arquitectura? Podemos considerar tres motivos. El primero es la búsqueda de la energía del sol, del calor de sus rayos que son la fuente de la vida en la sociedad medieval. El segundo es la búsqueda de Dios, al considerar la luz como una realidad metafísica que lo representa. Y la tercera es la búsqueda del color, de la belleza que la luz transmite.

De las distintas formas en las que la arquitectura de este territorio busca la luz, vamos a destacar tres: las vidrieras, las escaleras de caracol y los fumerales.

\section{Las vidrieras}

La luz en la Edad Media, se entiende como metáfora de la vida transcendente, como representación de un mundo que trasciende las leyes de lo físico. Cuando la luz y el color se aúnan en los ventanales góticos se materializa la visión mística y trascendente de la luz.

La luz produce la sombra y esta es la que da forma y vida al objeto en la luz. La relación en el interior de los espacios de las luces y las sombras, permite que "la sombra inhale la luz y la iluminación la exhale" (pág. 48 los ojos de la piel). En un mundo de sombras propiciado por la arquitectura estereotómica, el color de las vidrieras de los templos más importantes de la arquitectura gótica y en una sociedad no saturada de imágenes, eran sin duda un gran espectáculo.

$\mathrm{Al}$ igual que en el resto de las especies, el hombre busca la luz, busca la energía solar, como fuente que da la vida, en las construcciones góticas el hombre no hace más que buscar esa energía a la que debe la subsistencia en el mundo hostil en el que habita.

En un primer momento la luz se obtiene cerrando las aberturas con láminas de alabastro, para posteriormente pasar a las vidrieras de colores. Las láminas de alabastro se obtenían consumiendo exclusivamente la energía endógena de la mano del artesano que la tallaba, mientras que en el segundo caso al gasto energético del artesano se le sumaba la energía exógena que se consumía en los hornos que fabricaban el vidrio y lo coloreaban. Para obtener una mayor luminosidad, una mayor aportación de energía solar que ilumine y caliente el interior del templo, es necesario hacer uso del fuego para obtener el vidrio y colorearlo. Es de los primeros ejemplos en la Edad Media en los que un mayor confort térmico o una mayor calidad arquitectónica requieren un mayor consumo de energía exógena. Como diría Louis Khan es un ejemplo de que la materia- el vidrio- es luz gastada.

Contamos para corroborarlo con documentos como el del contrato para la construcción de las vidrieras de la Iglesia Arciprestal de Morella ${ }^{143}$, del que extraemos este fragmento:

"Item, quel dit maestre sie tingut fer les dites ymages de (titllat:vidre) de diverses colors, belles e animades, així en vidre blau com en vermell, groch, violat e vert e d'altres colors que pertanyen a la obra."

\section{Las escaleras de caracol}

Es uno de los elementos recurrentes en las iglesias góticas. Además de la función de acceder a las cubiertas del edificio, marcan la dirección hacia arriba como ya vimos al hablar de las iglesias como las

143 Ver apéndice documental no 47 pág. 642 
arquitecturas que permiten en el espacio existencial orientar al hombre en el mundo y en relación con el más allá. Pero además denotan la búsqueda de la luz, ascendiendo y dando vueltas sobre sí mismo el hombre busca la luz y la encuentra de forma progresiva poco a poco hasta encontrarla plenamente en la cubierta del edificio.

La escalera de caracol la podemos considerar como el negativo de una gran broca helicoidal que ha perforado la masa de la piedra, es un claro ejemplo de estereotomia. Esa perforación de la masa, da una imagen mucho más pétrea que un simple orificio cilíndrico vertical y permite que la luz conforme se sube sea una sorpresa, no se ve desde el primer momento.

Los precedentes de las escaleras de caracol los encontramos precisamente en un monumento funerario, la columna Trajana construida en el año 112-113 por el arquitecto Apolodoro de Damasco. Es una escalera de 38 metros de altura construida con 18 bloques de mármol que fueron excavados interiormente para obtener la escalera; una única pieza de mármol se "roba" y se obtiene un tramo de escalera. Es la arquitectura estereotómica por antonomasia.

Posteriormente se construyó la escalera de caracol formada por una bóveda de cañón generada al desplazarse un arco de medio punto por una hélice- la perforación con una broca-. A este arquetipo corresponde la escalera de Saint Gilles de Gard en Languedoc del siglo XII, en este caso no es una única pieza labrada sino que ya son varias dovelas aparejadas que conforman un helicoide.

En los siglos XIII y XIV en el área mediterránea se construyen escaleras evolucionadas a partir de esta tanto en el castillo de Maniace en Siracusa como en la catedral de Barcelona, en la que se mantiene la bóveda helicoidal pero ampollándose en una pieza central del tambor que hace solidario el arranque del peldaño y de la bóveda.

Posteriormente en estas escaleras aparecerá el ojo de la escalera, propiciando una mayor entrada de luz, como en el caso del caracol de la Torre del Tesoro de la Catedral de Santiago de Compostela de Rodrigo Gil de Hontañon en el siglo XVI. A diferencia de las anteriores la bóveda helicoidal se consigue con sillares únicos por cada peldaño, similares a los caracoles de husillo.

Las soluciones puramente estereotómicas van evolucionando hacia otras tectónicas, del "robo" de un único sillar para obtener un tramo de escalera se pasa al "robo" de diversos sillares que se aparejan para obtener la bóveda helicoidal. Esa evolución conlleva como en el caso de las vidrieras el aumento de la luz y una mayor "ingravidez" de las construcciones, a costa de un mayor coste energético.

\section{Los fumerales}

Los espacios de reunión donde se hace la vida diaria en las masías, hospederias, monasterios, etc se crean alrededor del fumeral, del fuego. Este no solo proporciona el calor necesario sino también la luz. Son espacios cerrados al exterior, casi no tienen ventanas, y por tanto la luz la proporciona también el fuego.

Sin embargo sí que tiene una abertura al exterior, es la salida de humos de la chimenea, es el óculo que culmina el volumen troncocónico del fumeral. Es como en el caso del Panteón un hueco superior abierto al cielo desde el que se percibe el lugar reservado a los dioses. La arquitectura gira alrededor de este hueco central, todas las dependencias giran alrededor de la que contiene el fumeral, con el paso del tiempo el fumeral se convertirá en patio, la luz de las edificaciones la obtendrán de los patios interiores a los que se abrirán aberturas.

Pero no solo en las arquitecturas se percibe la búsqueda de la luz, también lo podemos ver en el Territorio. Los tejidos crean y evolucionan en función de la luz. Veamos algunos casos singulares:

Los tejidos agrícolas buscan la luz, la energía solar para obtener mejores cosechas. Los campos de cultivo se disponen en función de la luz solar, huyen de las umbrías y buscan las mejores orientaciones, tan importante como el agua es la energía solar que reciben.

Los tejidos urbanos buscan la luz, la ciudad de Morella es un ejemplo paradigmático. El tejido urbano de la ciudad se desarrolla en la ladera sur, buscando la luz, la energía solar que le da vida al tejido. Prueba de ello es la creación del barrio de "Sol de vila" tras la ampliación del recinto amurallado. ${ }^{144}$

144 Ver apéndice documental no 31 pág. 625 


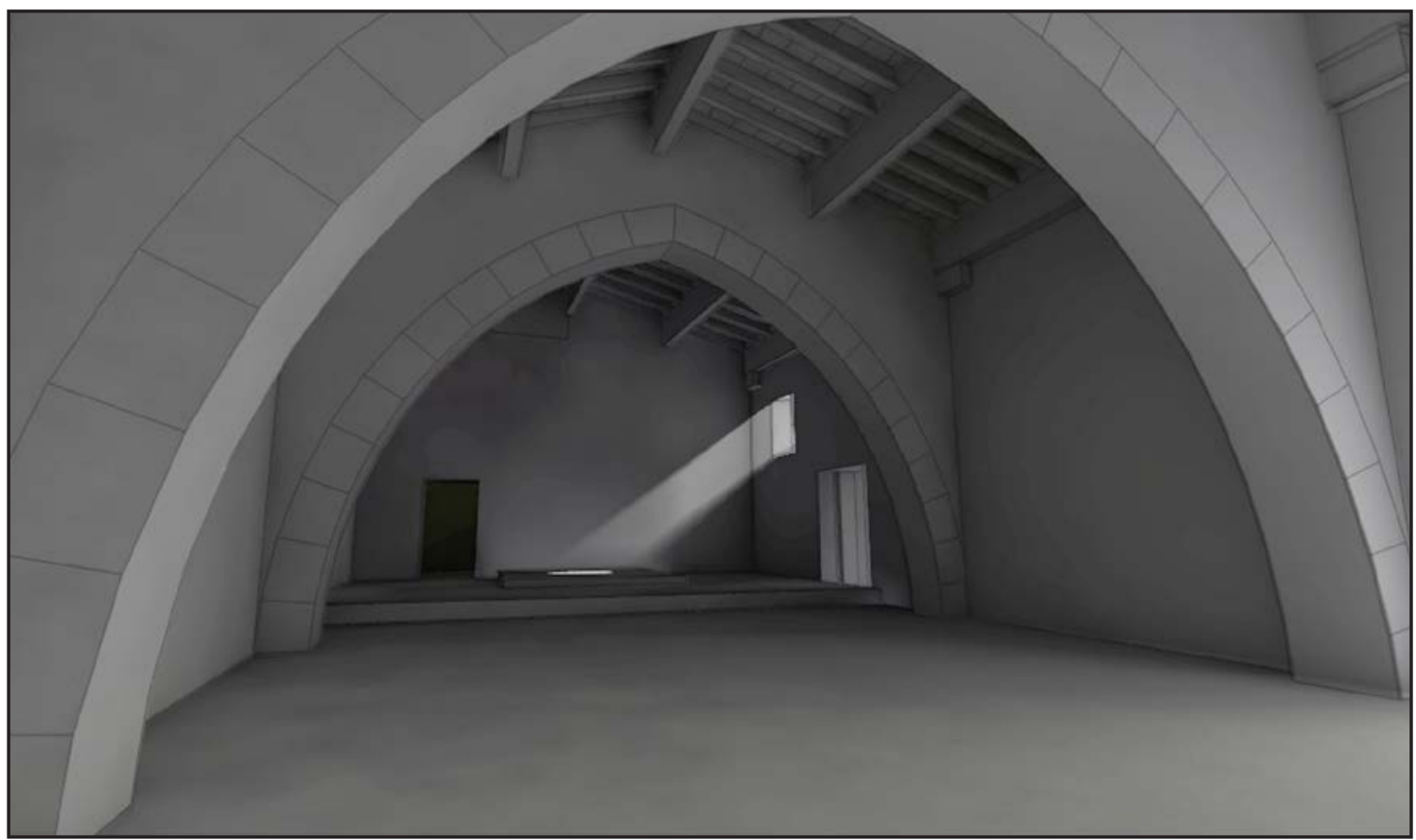

Fig. 6. 37. Vista interior en 3D de la ermita de Sant Jaume de Coratxar con la entrada del sol a las cuatro de la tarde en verano.

El gótico busca la luz, los templos gracias a la estructura cada vez más tectónica y menos estereotómica del gótico se abren a la luz. En el primer caso tenemos la Iglesia de Sant Jaume de Coratxar con la entrada de luz a las 4 de la tarde en el equinoccio de verano iluminando el altar a través de una pequeña tronera.

La foto inferior se corresponde con la entrada de luz en el ábside de la iglesia de san Francisco de Morella.

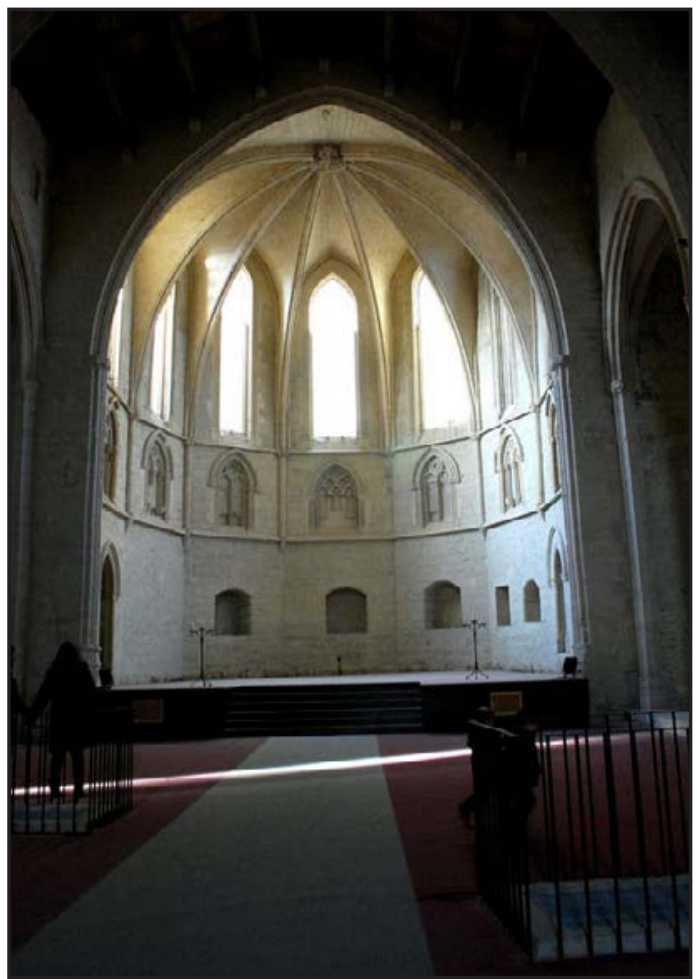

Fig. 6. 38. Foto interior del ábside de la Iglesia del Convento de Sant Francesc de Morella (s. XIII-XIV).

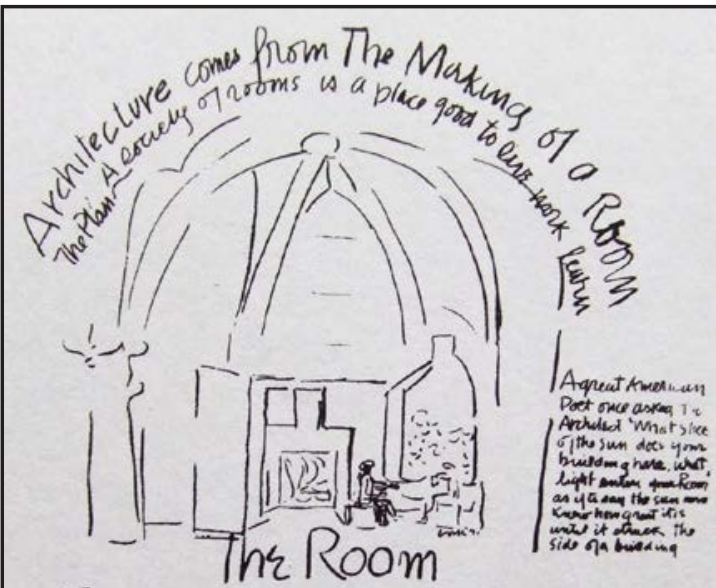

is The place of the mind. In a smace hoom one does

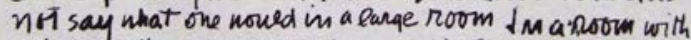
ouly one oiker peresn could be, yeveralins. The vectors Touch wet. A rcom is Mrla noom with out neatural light.

Fig. 6. 39. Dibujo de Louis Kahn de la habitación, el fuego y la luz (la chimenea y la ventana) presiden el espacio en el que el hombre habita. 


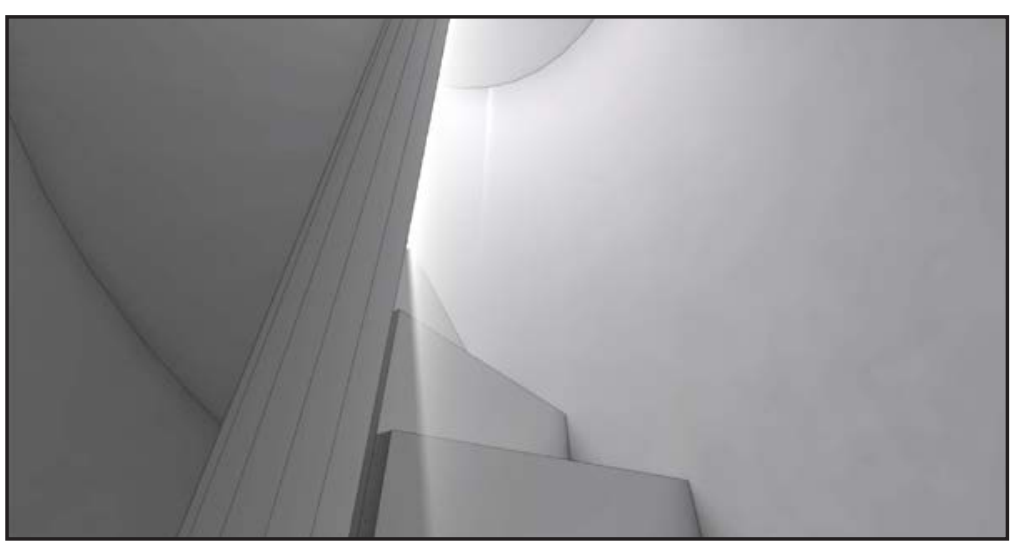

Modelo 3D de la escalera de caracol del campanario de Sant mateu. La escalera de caracol asciende dando vueltas sobre si misma buscando la luz que se encuentra en lo alto.
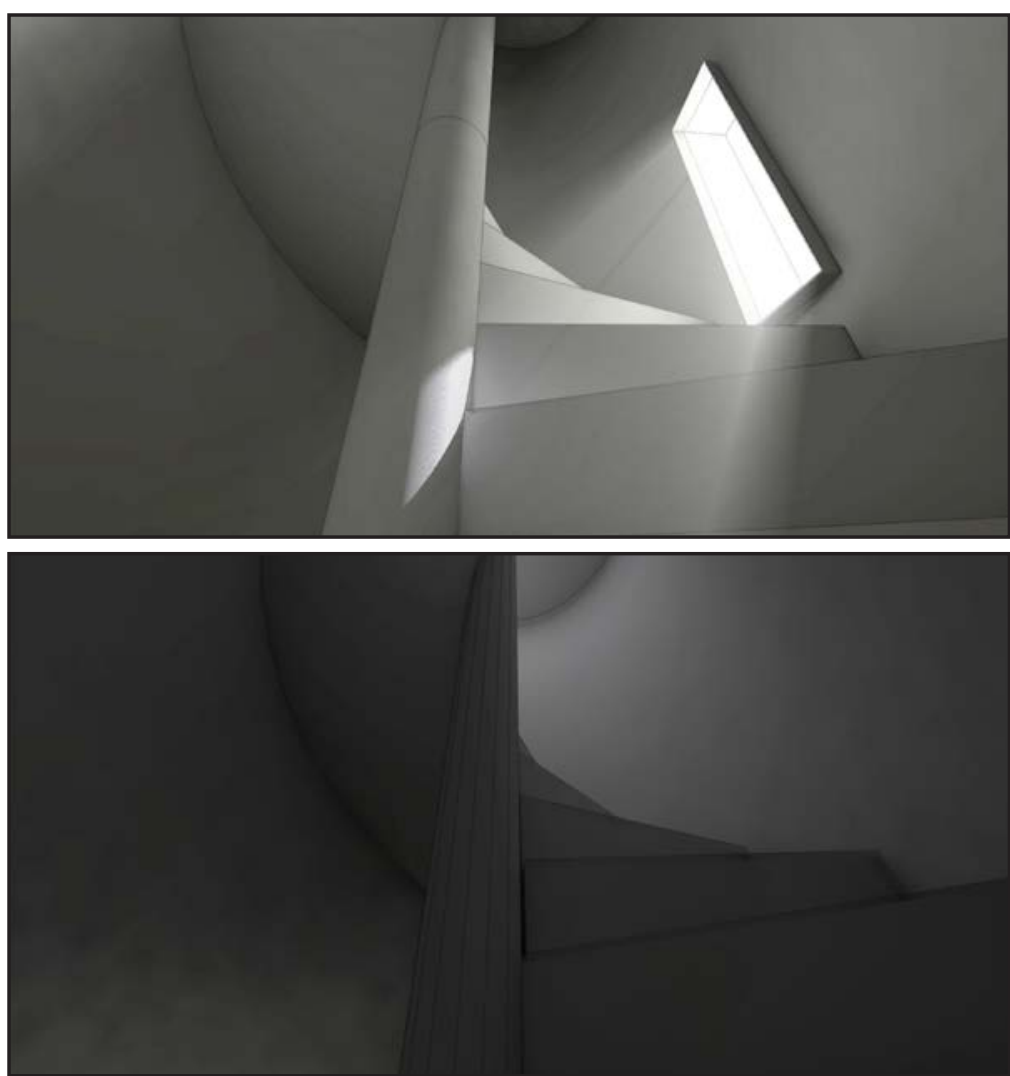

Fig. 6. 40. Vistas interiores en 3D de la presencia de la luz conforme se asciende a través de la escalera de caracol del campanario de la Iglesia arciprestal de Sant Mateu.
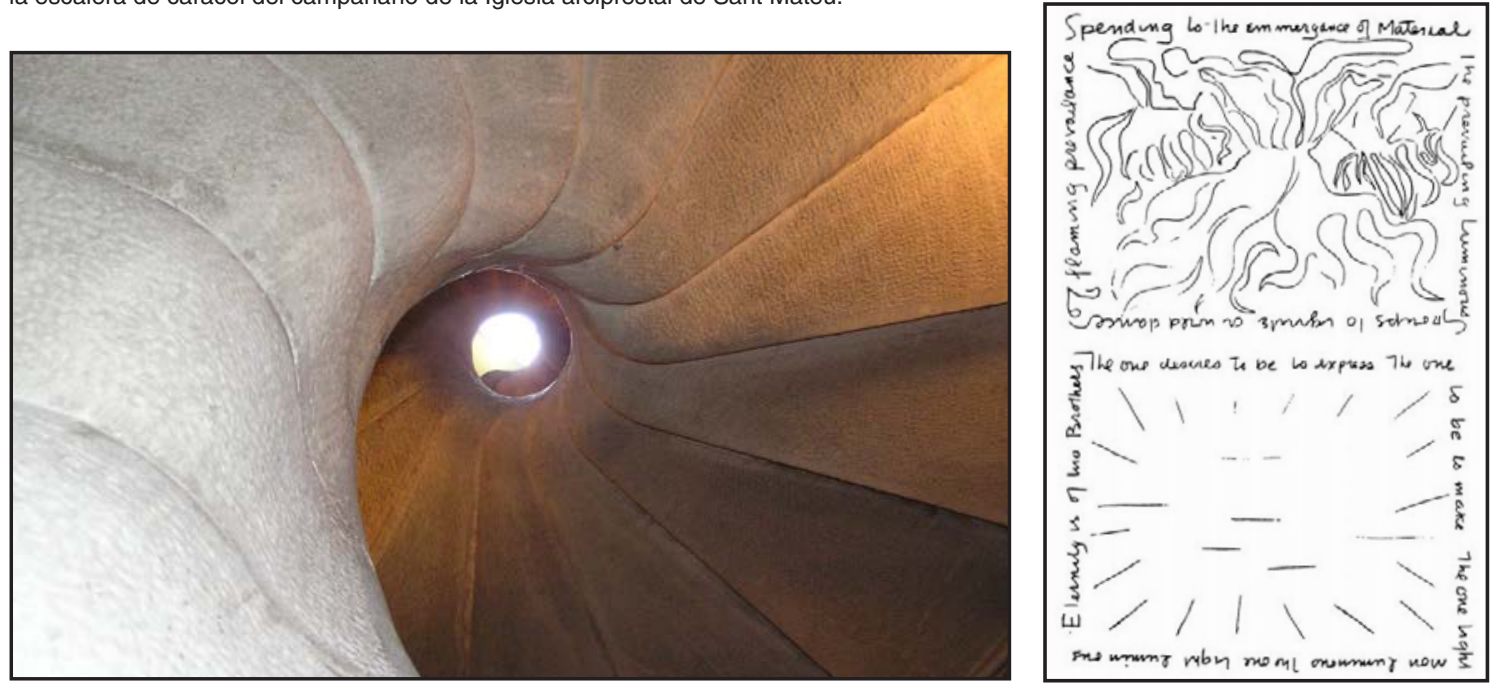

Fig. 6. 41. Foto de la entrada de luz en una escalera de caracol.

Fig. 6. 42. Dibujo "Silencio y luz" de Louis Kahn. 


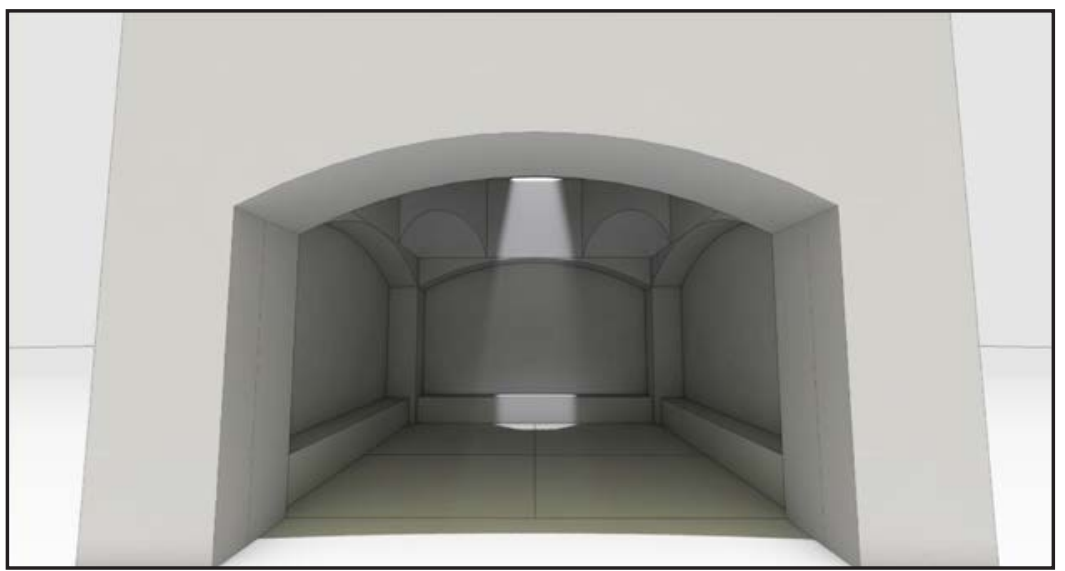

La entrada de luz a través de la chimenea del fumeral. El hombre se reúne alrededor del fuego, pero también de la luz.

Imágenes del modelo 3D del fumeral de Nuestra señora de los Angeles de Sant Mateu, foto de este fumeral y del de la cocina de la catedral de Pamplona.

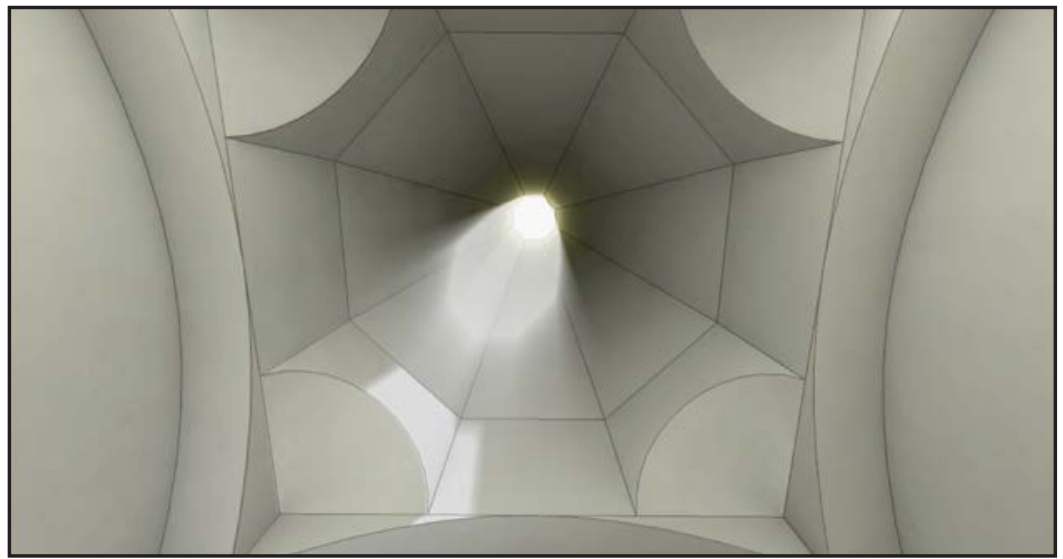

Fig. 6. 43. Vistas interiores en 3D de la entrada de luz en el fumeral de la hospedería del santuario de Nuestra Señora de los Ángeles de Sant Mateu.

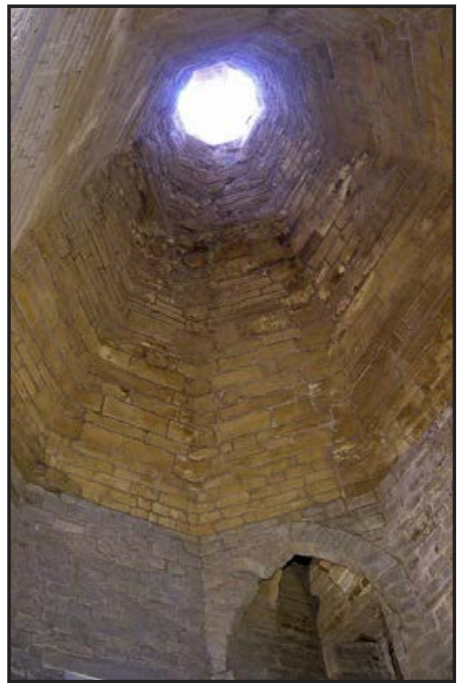

Fig. 6. 44. Foto interior del "fumeral" de la cocina de la catedral de Pamplona.

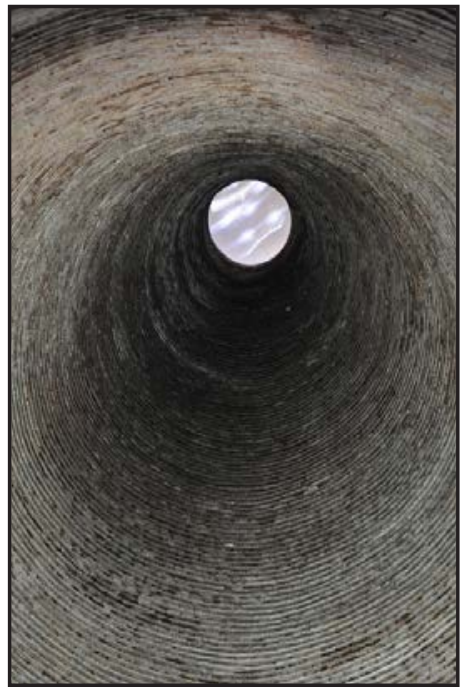

Fig. 6. 45. Foto interior del "fumeral" de la hospedería santuario Virgen de la Salud de Traiguera.

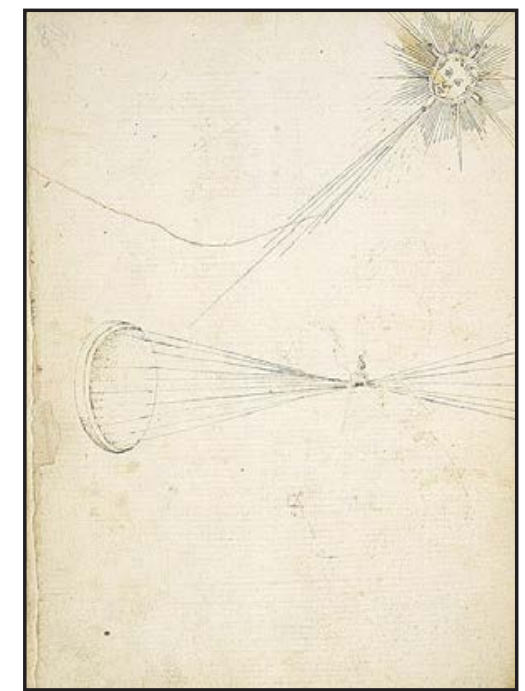

Fig. 6. 46. Dibujo de Mariano Taccola del libro: De Ingensis water (1449). 


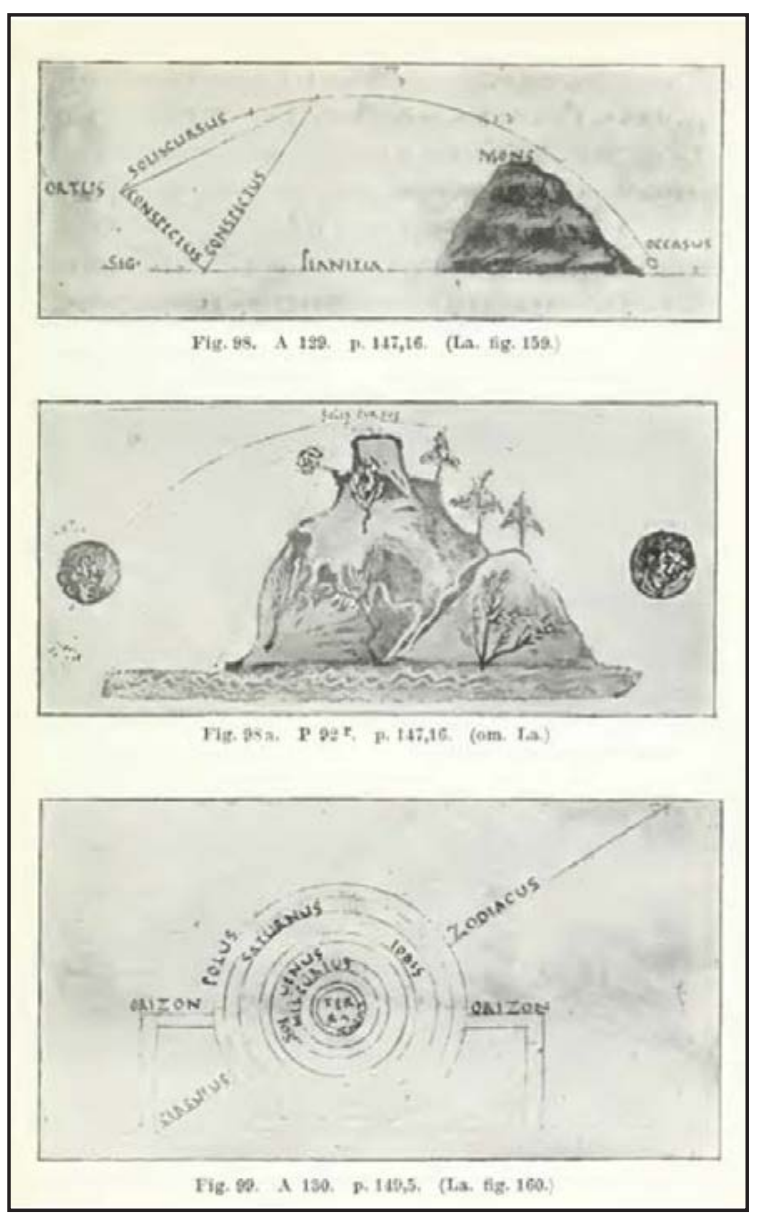

Fig. 6. 47. Dibujos 98 , 98a y 99 del libro "Frontin l'oeuvre gromatique" que recoge Corpus Agrimensorum romanorum IV de lulius Frontinus.

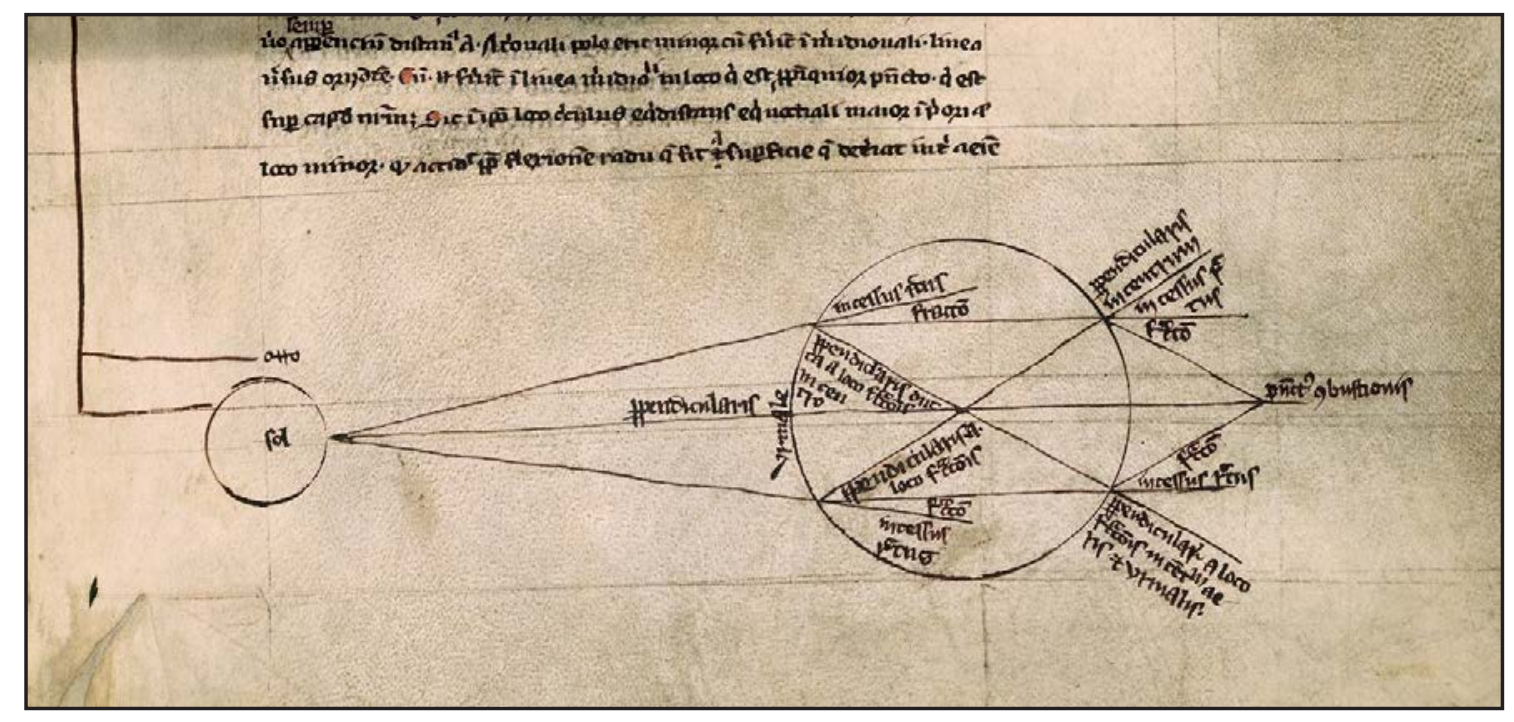

Fig. 6. 48. Grabado del libro de Roger Bacon: "De multiplicatone specierum" (s. XIII). 


\section{2. 7. El mantenimiento del Territorio}

Las estructuras autoorganizativas necesitan energía no solo para conformarse sino también para mantenerse. El territorio medieval no puede ser menos y por ello necesita de un suministro continuo de materia y de energía que le permite reparar los daños del tiempo y del azar, reconstruir su forma, regenerar su conformación originaria o adaptarla a las nuevas necesidades.

Ello lo podemos comprobar distintos documentos de la época que hablan no solo de la construcción de las grandes obras o infraestructuras territoriales sino también de la necesidad de su reparación y mantenimiento.

En 1251 Jaume I regula la forma en la que se ha de proceder a la limpieza, conservación y reparación de las acequias y azudes del término de Valencia: ${ }^{145}$

"Et per quod partitores omnes aquarum faciant et rehedificent ipsi cequiarii secundum modum statutum et forman pristinam, et quod pontes, per quos non transierint aliqui, nisi habentes hereditatum, faciant rehedificari ab heredibus hereditatum ad quas hitur ad pontes ipsos, et quod rupturas cequiarum rehedificent cequiarum, secundum modum et formam et statutum pristinum."

En el mismo año también lo hace respecto a la participación de todos los valencianos en la construcción y mantenimiento de sus respectivas obras públicas: ${ }^{146}$

"Si vero in superiori novo pariete vellet cooperire vel aliter hedificare, possit hoc facere, dummodo solvate primitus medietatem expense et operis a principio fundamenti facte usque ad locum quo edificaverit, cooperuit vel hedificatus fuerit, omni excusacione remota, omnes nobiles et milites, clerici et religiosi, cives et quecumque alia persona, quantecumque dignitatis sit, ad construccionem et reparacionem murorum et vallis, construcciones, reparacionem et mundacionem et ad instrucciones et mundaciones viarum publicarum et pontium et civitatis custodiam et mundacionem cequiarum et bra $\square$ allorum et ad prestandum cequiaticum de suo conferre teneantur, cum non sint predicta inter sordida munera numerata."

Existen otros muchos documentos que hacen referencia al mantenimiento de las grandes obras defensivas del territorio como castillos y murallas. Este es el caso de las murallas de Morella que el Rey ordena sean construidas y mantenidas no solo por los habitantes de la ciudad sino también de sus aldeas y de la comarca vecina de Benifassar: ${ }^{147}$

"Petrus, Dei gratia, et cetera. Fideli nostro iustitie ville Morelle qui nunch est et qui pro tempore fueit vel eius locumtenenti, salutem et gratiam. Pro parte universitatis et proborum hominum dicte ville fuit nobis expositum conquerendo quod abbas de Benifaçano et aliqui alii domiciliati infra terminos dicte ville contradicunt malitiose et indebite contribuere in opere murorum et vallorum dicte ville. Quamvis ipsi necessitatis tempore se recolligere, defendere et tueri habeant in eadem, unde cum de foro, privilegio etusu Regni Valentie nemo, cuiusvis conditionis et dignitatis fuerit, a premisorum contributione debeat nec valeat excussari. Ea propter vobis dicimus et mandamus quatenus predictum abbatem et eius homines ac alios quoscumque infra terminum generalem dicte ville populatos iuris et fori remediis at contribuendum in opere antedicto districte et fortiter compellatis si et prout eiusdem seu eorum bona repereritis iuste et moderate taxatos fuisse et prout etiam hactenus in predictis ac similibus est fieri usitatum. Quibuscumque superse dimentis, provisionibus et litteris in contrarium sub quorumcumque expressione verborum factis et fiendis obsistentibus ullo modo.”

145 Ver apéndice documental nº 18 pág. 617

146 Ver apéndice documental n 19 pág. 617

147 Ver apéndice documental no 46 pág. 642 


\section{3. La energía como in-formación en el territorio medieval: la materia luz gastada}

Las formas se conforman con energía pero una vez construidas la almacenan y es usada como información. Las formas son almacenes en los que se deposita la información, que pasa a estar a disposición del territorio de forma que en futuras actuaciones la experiencia ya adquirida haga la construcción más eficaz y con menor coste energético.

En el Territorio la información se almacena en la forma de cuatro maneras:

- Por la disposición de la forma.

- Por la proporción de la forma.

- Por el código de los elementos de la forma

- Por la huella que deja la forma.

- Por el tacto de la forma.

\section{3. 1. La disposición de la forma y su trazado}

Las construcciones estereotómicas se basan en la compresión y tienden siempre hacia formas de organización de sus elementos en que esta se transmita. Cada elemento está sometido a un conjunto de acciones mecánicas entre las que destaca la acción vertical de la gravedad debida al peso de los elementos y a las sobrecargas de su uso. Si un elemento se mantienen en equilibrio por la acción de la gravedad es por la existencia de una fuerza equilibrante de otro elemento constructivo. Y así elemento a elemento hasta llegar a la reacción que el terreno ejerce sobre el cimiento de la construcción. Este proceso se llama descenso de cargas.

Mientras el desplazamiento de las cargas sea vertical, simplemente con apilar los elementos será suficiente, sin embargo si se tiene que producir el desplazamiento horizontal de las cargas por la cubrición de un espacio vacío, la solución se complica, porque sus piezas deben apoyarse en elementos que en planta están alejados unos de otros.

La primera solución a este problema consiste en la transmisión de cargas por la sucesión de contrapesos que forman "falsos" arcos y bóvedas, como en el caso de las casetas de pastor. Esta forma evoluciona hasta la construcción del arco y la bóveda en la que se consigue desplazar los esfuerzos horizontales de las cargas con elementos que trabajan directamente a compresión. Esta última forma más evolucionada introduce la aparición de esfuerzos horizontales en los estribos y para contrarrestarlos es necesario prever los contrafuertes.

La transmisión por compresión de los esfuerzos, es debida a la disposición de las dovelas y de su forma. La talla de las dovelas es el secreto de la adecuada transmisión de las compresiones pieza a pieza. La forma geométrica de la cantería es inseparables de su función estructural. Las dovelas de un arco o de una bóveda solo serán estables y su comportamiento mecánico correcto si su geometría también es correcta.

La construcción es totalmente consecuente con la geometría y el oficio de construir en piedra es básicamente un arte basado en las trazas geométricas. Pero estas trazas, hasta la aparición de los tratados de construcción solo se podían encontrar en las propias formas construidas. A falta de libros u otros documentos que recogieran la información de cual debía de ser la traza y disposición de los elementos constructivos para la correcta transmisión de las compresiones, era la propia forma la que la atesoraba.

La colocación de la mampostería en un muro de bancal, el trazado en planta de los mismos y la 
disposición de la sección del muro, son consecuencia de la memoria que se deposita en los propios muros y que como una "biblioteca" de soluciones constructivas perdura en el territorio (ver imágenes pág. 238).

Algunos contratos de obras como el de la Iglesia de Olocau en els Ports ${ }^{148}$ tienen un gran valor por que son auténticos pliegos de condiciones de la forma en la que se deben de disponer los elementos para la correcta construcción de un edificio, transcribimos aquí la parte correspondiente a la ejecución de la cubierta:

"Et la cuberta de la esg $\square$ sia que sie feyta de fusta, en aquesta manera:

Que age en cada arcada V lomeres de meliz ben planegades, e que agen I palm $\mathrm{d} \square$ alna de gros a tots cayres.

Et los cabirons de la cuberta, que sien de bon meliz, e que sien serradizs e ben planegats, e que agen mig peu $\mathrm{d} \square$ alt e Ia palmada de gros.

Et en la cuberta de la esg $\square$ sia, que agen dels dits cabirons aytants com obs n.i age, en ax $\square$ que age de cabir $\square$ a cabir $\square$ I palm $\mathrm{d} \square$ alna.

Et que age de cabir $\square$ a cabir $\square$ sobre les lumeres botgers, aytantes com obs n.i age, a conexen $\square$ a dels bons $\mathrm{h} \square$ mens.

Et la cuberta de la dita esg $\square$ sia, que sie feyta de bona fulya de meliz ben planegada; e que age parafuls de Ia taula a altra, en les suintures dei $\square$ s les taules; e que sien clavades ab bones caxes de ferre, a conexen $\square$ a dels bons homens; e que la cuberta que plech fora la paret a totes parts I palm.

Et la cuberta, des $\square$ s la fulya, que sie feyta de bones canals de meliz serradi $\square$ es.

Et que sien clavades ab bons claus de ferre, a conexen $\square$ a dels bons $h \square$ mens del dit loch.

Et entre IIes canals I list $\square$ damunt, que sien clavats ab bones caxes de ferre, a conexen $\square$ a del dit conseyl.

Et que pas la cuberta de les canals e els listons, a totes parts de les parets, I palm."

La disposición de la forma de las parcelaciones también atesora una valiosa información. Los manuscritos del siglo XIV del agrimensor francés Bertrand Boysset, "La siensa de destrar" y "La siensa d'armentar", son muestra de ello.

Este segundo manuscrito se centra en la demarcación o amojonamiento de los terrenos, en función de la forma del terreno que se puede encontrar el agrimensor al que dedica ochenta y cuatro de los noventa y un capítulos. La delimitación de los linderos de un terreno sirve para afirmar la propiedad del mismo, por lo que la acción constituye un acto jurídico de gran importancia.

Los límites se definen in situ, se "formalizan" sobre el propio territorio y es este trazado el que define los límites de propiedad. La forma del trazado y el modo en la que esta se materializa engrosan la información que almacena el territorio.

La disposición de las redes de infraestructura condicionan el desarrollo del territorio. La forma en la que se ha ejecutado una infraestructura sirve de guía e información para el desarrollo de posteriores infraestructuras, este sería el caso de la construcción de la acequia de Nules que es "guiada" por la disposición de la de Vila-real. ${ }^{149}$

148 Ver apéndice documental nº 35 pág. 627

149 Ver apéndice documental no 28 pág. 622 


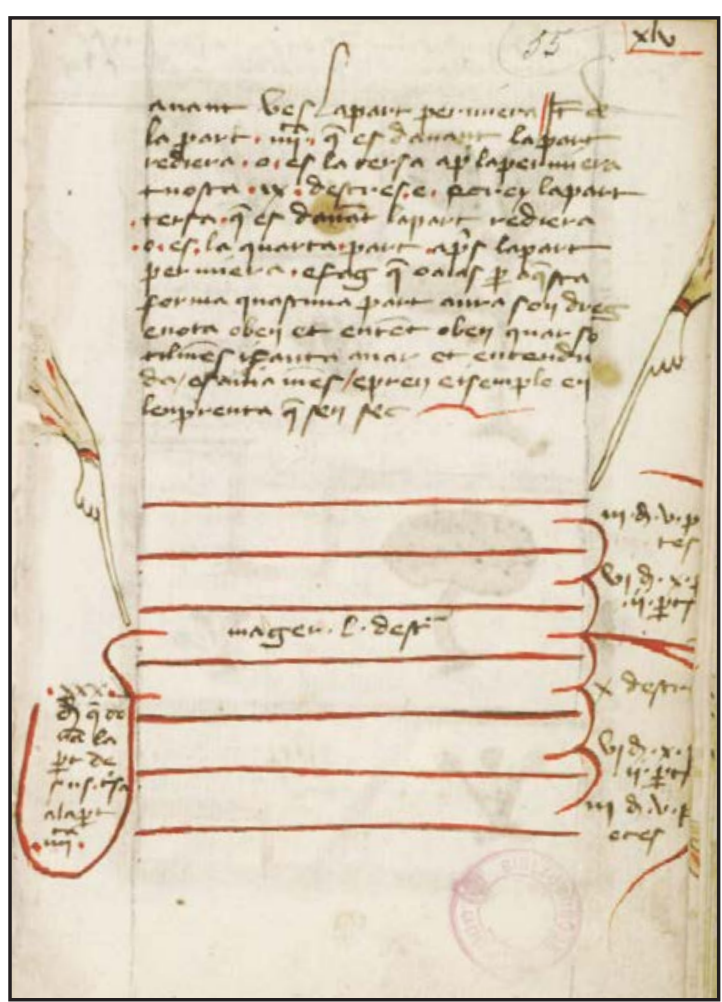

Fig. 6. 49. Lámina g055 del "Traité d'arpentage" de Bertrand Boysset de finales s. XIV.

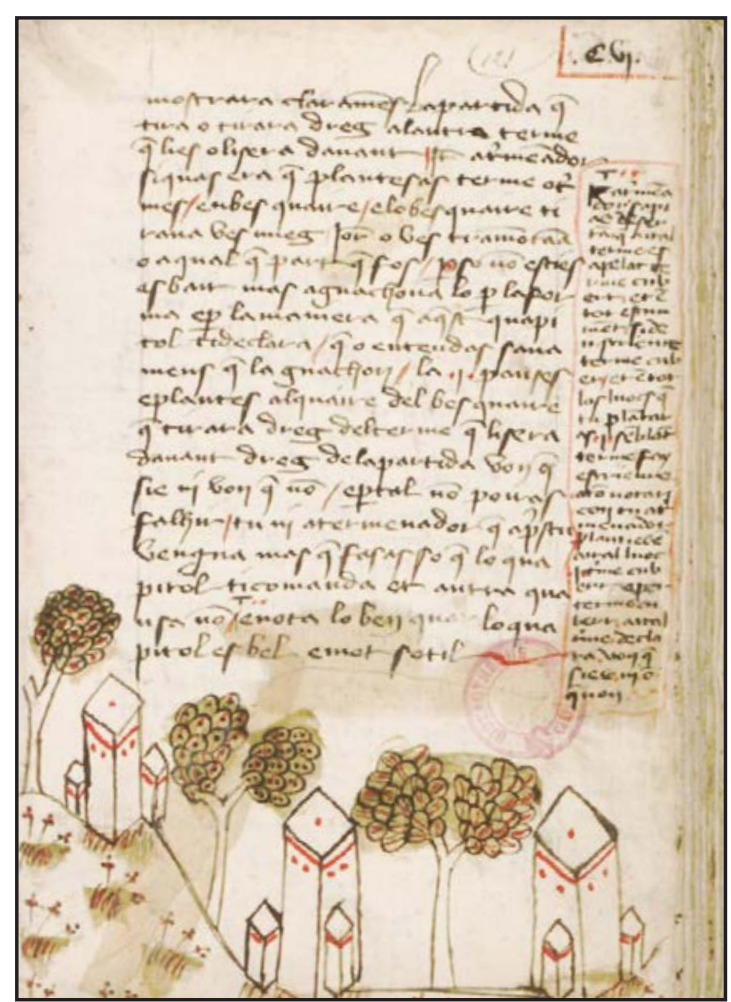

Fig. 6. 50. Lámina g121 del "Traité d'arpentage" de Bertrand Boysset de finales s. XIV.

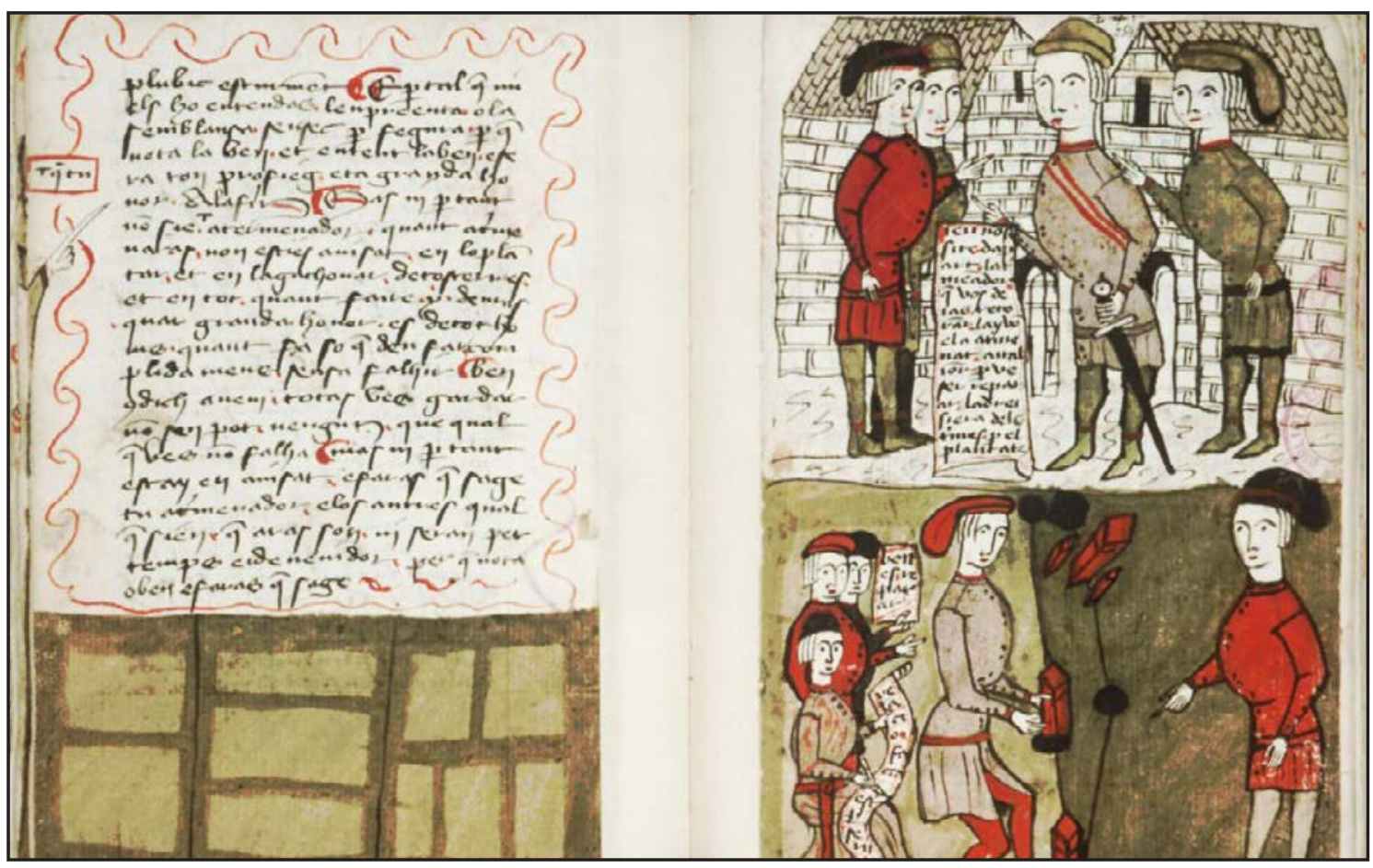

Fig. 6. 51. Lámina g253V254 del "Traité d'arpentage” de Bertrand Boysset de finales s. XIV.

En estas láminas se pude observar como se debe hacer la delimitación de los terrenos de una propiedad y cuales son aquellos elementos que "ayudan" a su delimitación y que son "signos inequívocos de ésta. No solo los agrimensores formalizaban la delimitación de los campos, sino que resuelven los problemas de tasación y medición de terrenos en las herencias o en los conflictos civiles en base a la campos, sino que resuelven los problemas de tasación y medición de te 

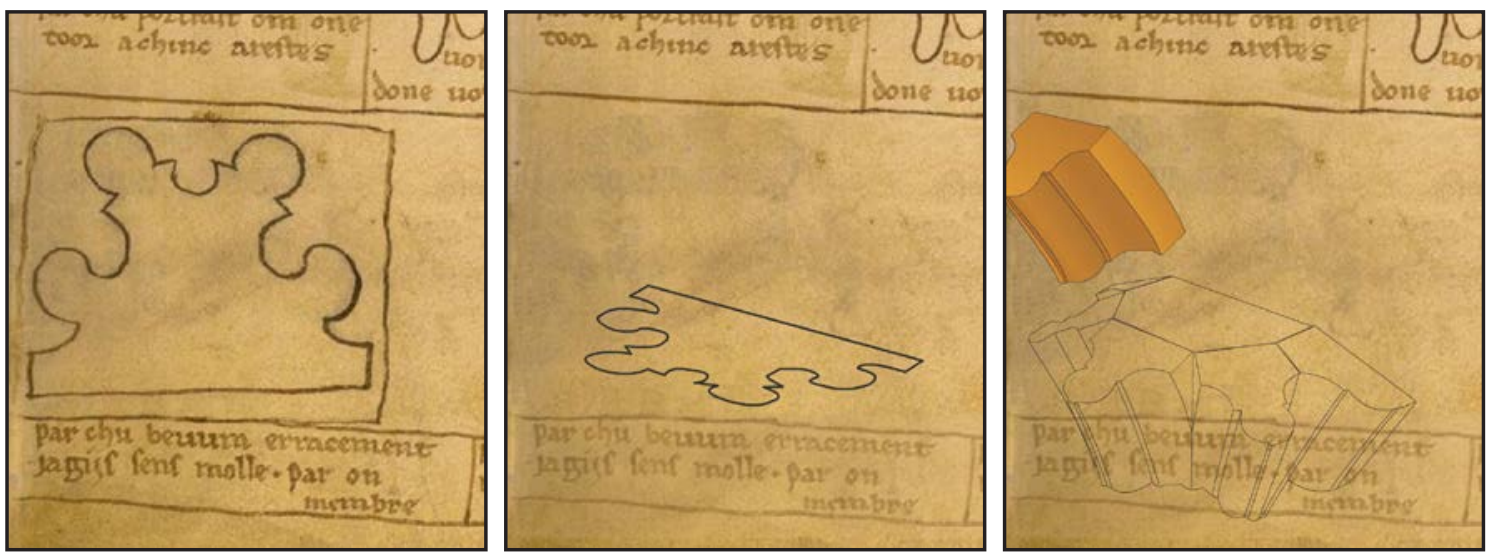

Fig. 6. 52. Detalles lámina 41 del Cuaderno de Villard de Honnecourt: Plantilla de dibujo del arranque de un dovelaje abocelado.
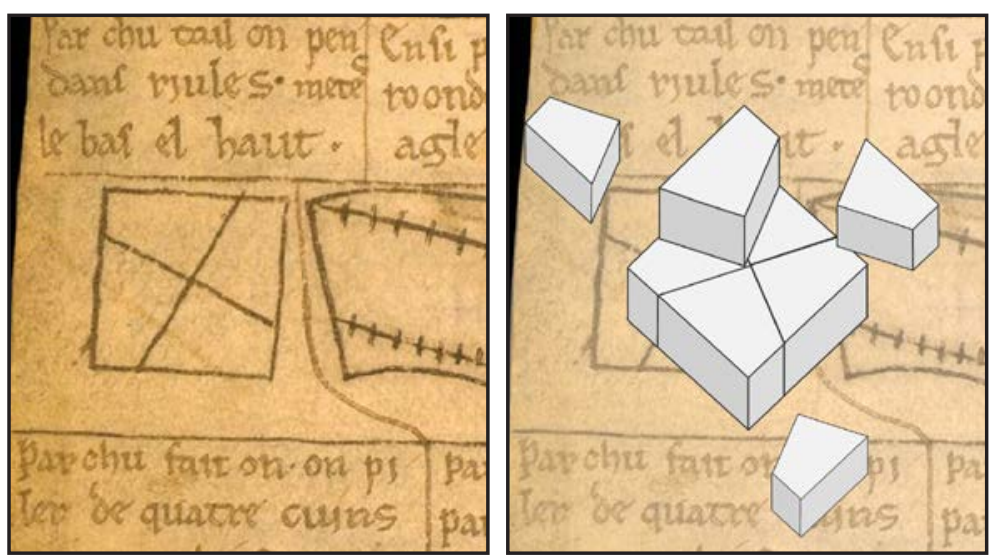

Fig. 6. 53. Detalles lámina 40 del Cuaderno de Villard de Honnecourt: Forma de hacer un pilar cuadrado con cuatro elementos ensamblados.
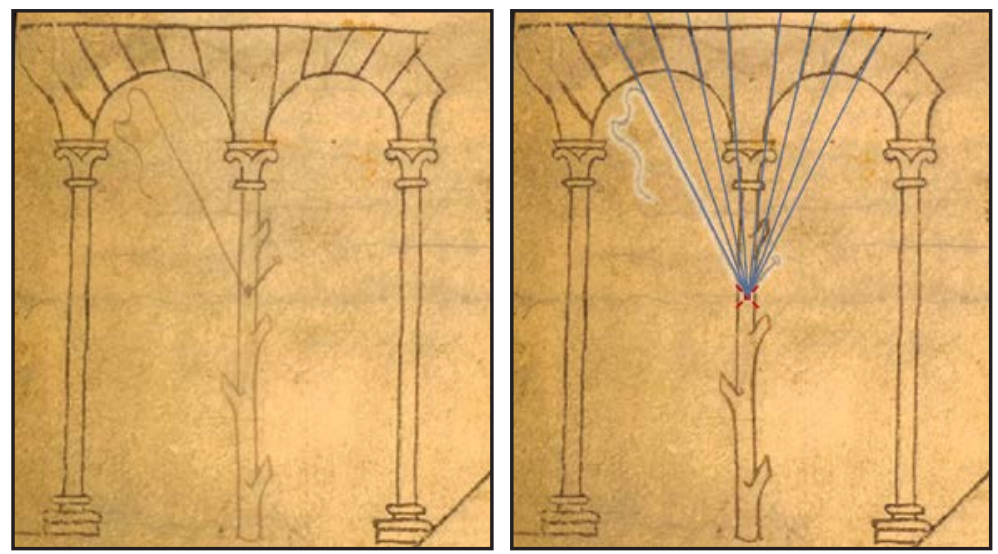

Fig. 6. 54. Detalles lámina 40 del Cuaderno de Villard de Honnecourt: Froma de trazar un dovelaje suspendido.
Estas tres series de dibujos como exponente de las formas en Villard, provienen de una recreación de la Biblioteca de Francia, en la que a partir de los dibujos de Villard, realizan la hipótesis de cómo el cantero medieval "disponía" las formas en sus obras. 


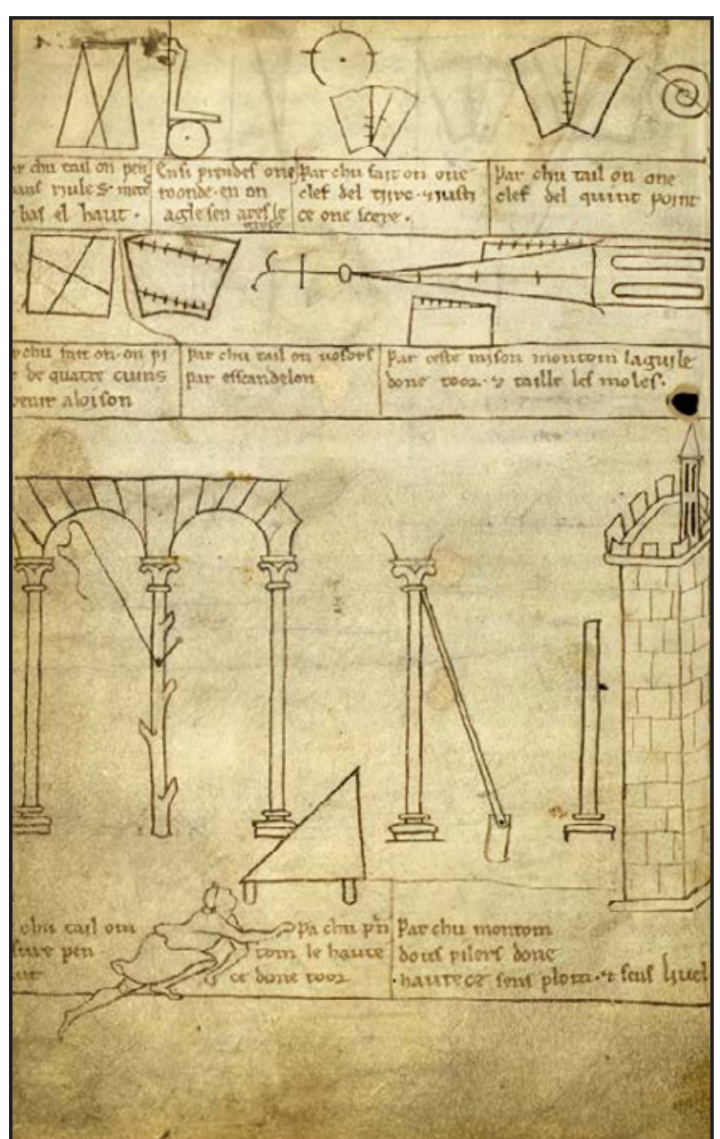

Fig. 6. 55. Lámina 40 del Cuaderno de Villard de Honnecourt "Procedimientos y diseños para la construcción".

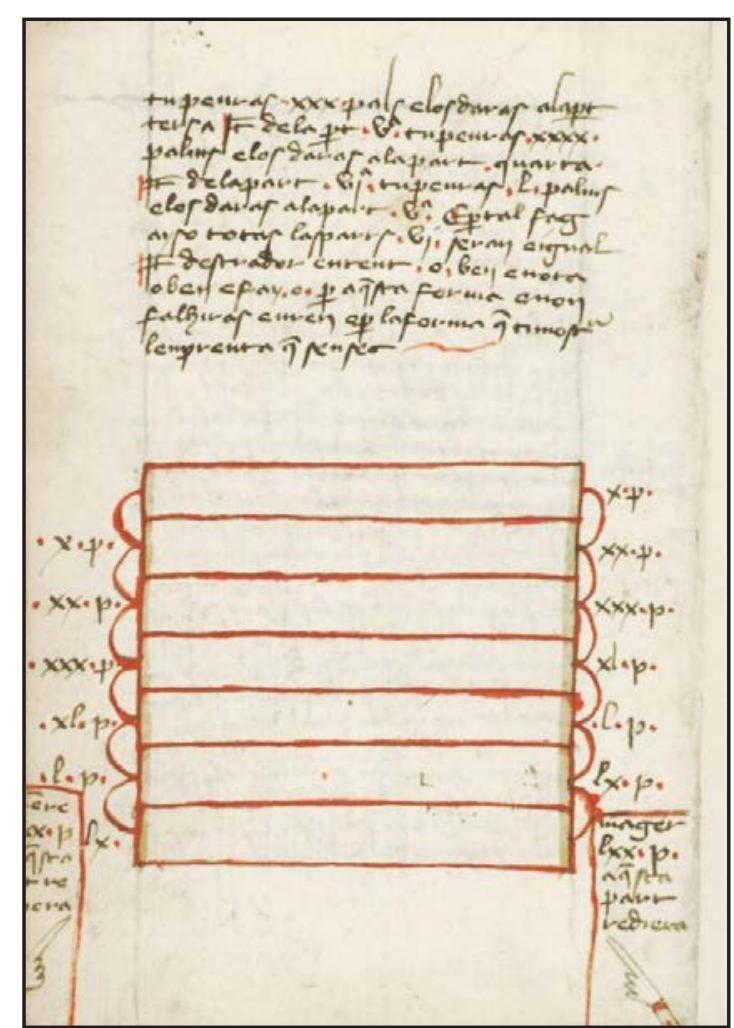

Fig. 6. 57. Lámina g053 del "Traité d'arpentage" de Bertrand Boysset de finales s. XIV. Esquema para hacer una parcelación en siete partes. Transcripción: Légende: 10 palms, 20 palms, 30 palms, 40 palms, 50 palms, 60 palms, Menre 70 palms aquesta part rediera. Mager 71 palms aquesta part rediera.

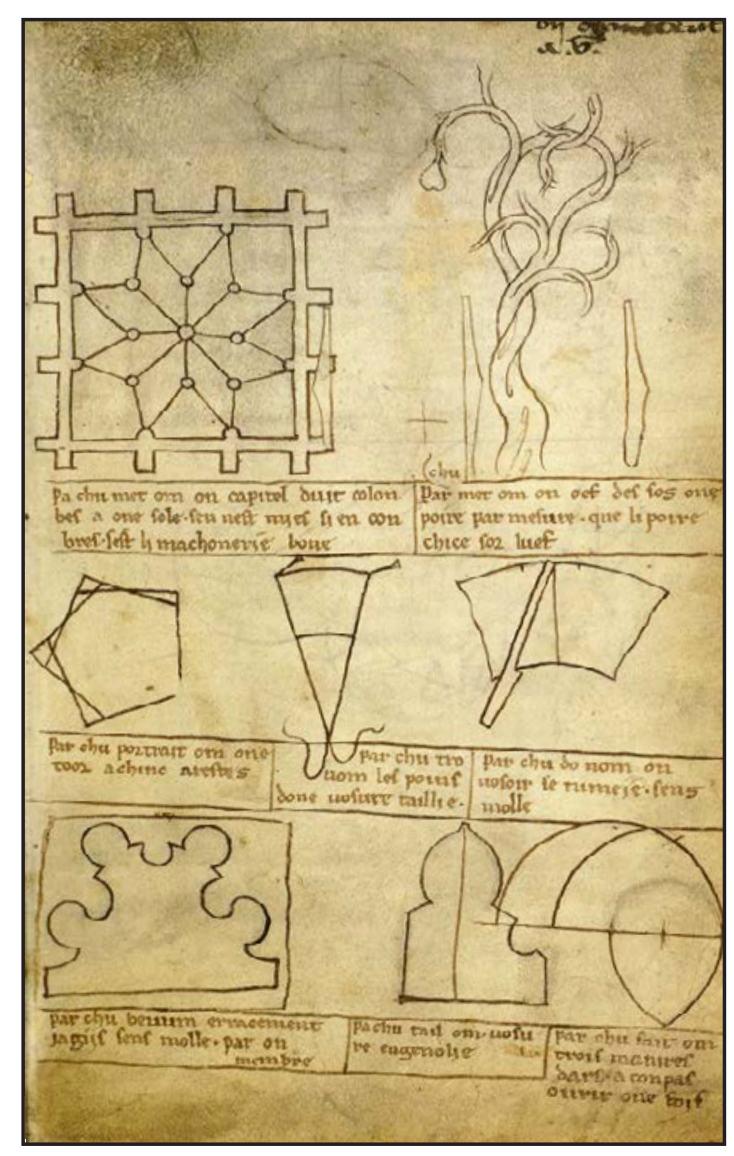

Fig. 6. 56. Lámina 41 del Cuaderno de Villard de Honnecourt: "Procedimientos y diseños para la construcción". 


\section{3. 2. La proporción de la forma}

Los estudios sobre el estado plástico de Jacques Heymann nos permiten calcular las estructuras de fábrica que trabajan a compresión desde un nuevo punto de vista, muy alejado del cálculo elástico que pretende encontrar el equilibrio "real o verdadero"; esta nueva visión se "conforma" con encontrar uno de los múltiples estados de equilibrio posibles. "Si puede hallarse un estado cualquiera de equilibrio, es decir, en el que un conjunto de esfuerzos internos estén en equilibrio con las cargas externas, y además, para el que cada sección interna de la estructura satisfaga un cierto criterio de resistencia, entonces dicha estructura es segura (...) Si se encuentra un modo en el que la estructura se comporta satisfactoriamente, con toda seguridad la estructura por sí misma puede encontrarlo también". ${ }^{150}$

El equilibrio y la característica esencial de la fábrica trabajando a compresión, nos conduce a una afirmación geométrica: el elemento estructural debe de tener tal forma que dos elementos estén siempre comprimidos bajo la acción de la gravedad. La forma de la estructura es lo que ha de examinarse, tanto los elementos individuales como la estructura completa deben de tener ciertas dimensiones para que así los empujes puedan actuar dentro de la fábrica.

Como dice Heymann: "si se puede hallar una posición cualquiera para la línea de empujes dentro de la fábrica, la estructura es estables y el colapso no se puede producir nunca bajo la carga dada". ${ }^{151}$

Por tanto no importa que sufra variaciones en respuesta a movimientos o asientos, solo se agrietará al deformarse pero no colapsará. La estabilidad queda asegurada por su forma, pero no por el material que la compone.

Los antiguos ya descubrieron de forma empírica la relación existente entre forma y estabilidad. La estructura tiene que tener las proporciones correctas, este es el método medieval. Las reglas de proporción son las que emplearon los constructores de la antigüedad clásica para proyectar sus estructuras. Las reglas de la proporción permiten construir una estructura de fábrica que se mantendrá en pie. Estas reglas son esencialmente numéricas y conducen a una geometría de la estructura que es independiente de la escala.

En el contrato ya citado de la Iglesia de Olocau ${ }^{152}$, se puede comprobar como a la hora de describir la puerta se hace referencia a que tendrá las proporciones de la de la Iglesia de San Miguel de Morella:

"Et de la part del fossar derrera, ens $\square$ s entro a la cuberta, que age la paret $V$ palms de gros, e enmig de la paret, $\mathrm{a} \square$ on los bons homens veuran per $\mathrm{b} \square$, que.y age I portal, feyt en ax $\square \mathrm{d} \square$ aquela mesura de aquel portal de la esg $\square$ sia de sent Miquel de Morella, e encara I palm o dos pus ample, si.ls bons homens del dit loch conexeran que obs y sie."

Una vez establecida la unidad de medida en una obra medieval, todas las dimensiones concretas para cada una de las partes del edificio se obtenían por simples reglas de proporción. Un edificio satisfactorio se podía construir a cualquier tamaño. De ahí la importancia de los modelos, de la forma, para probar la estabilidad de la estructura real antes de construirla. La forma contiene la información de la seguridad de la estructura. "El problema del proyecto de las fábricas es esencialmente de carácter geométrico. El cálculo de tensiones es secundario, y es la forma de la estructura la que rige la estabilidad". ${ }^{153}$

150 HEYMAN, J. “El esqueleto de piedra” pág. 14

151 HEYMAN, J. “El esqueleto de piedra” pág. 276

152 Ver apéndice documental no 35 pág. 627

153 HEYMAN, J. “El esqueleto de piedra” pág. 161 


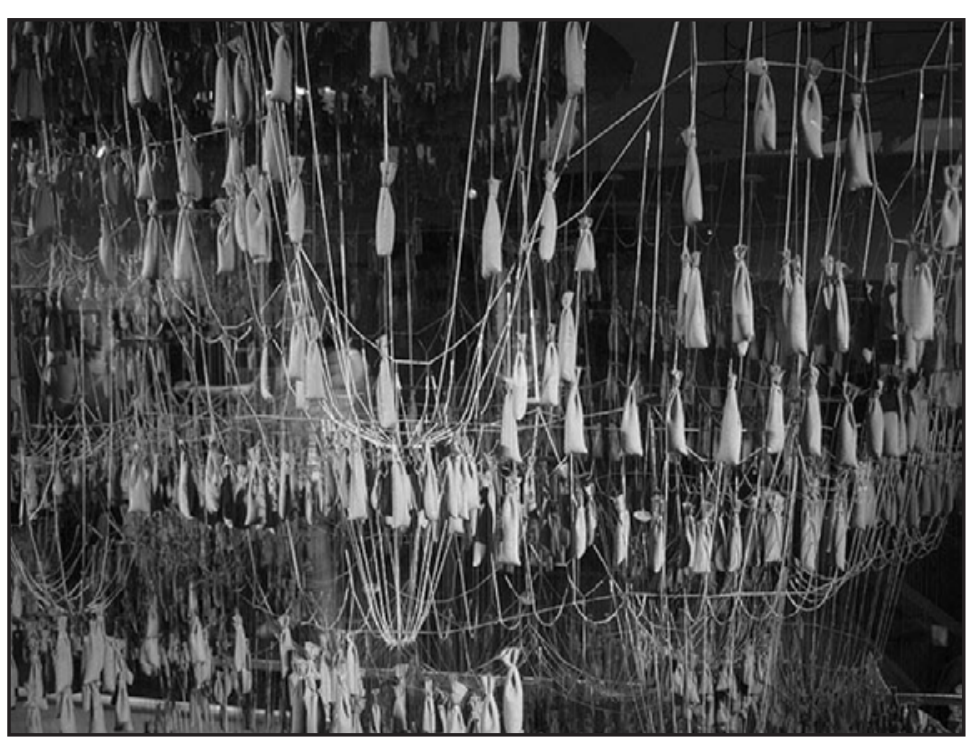

Fig. 6. 58. Foto de la maqueta realizada por Gaudí para el cálculo de las cargas de la Sagrada Familia.

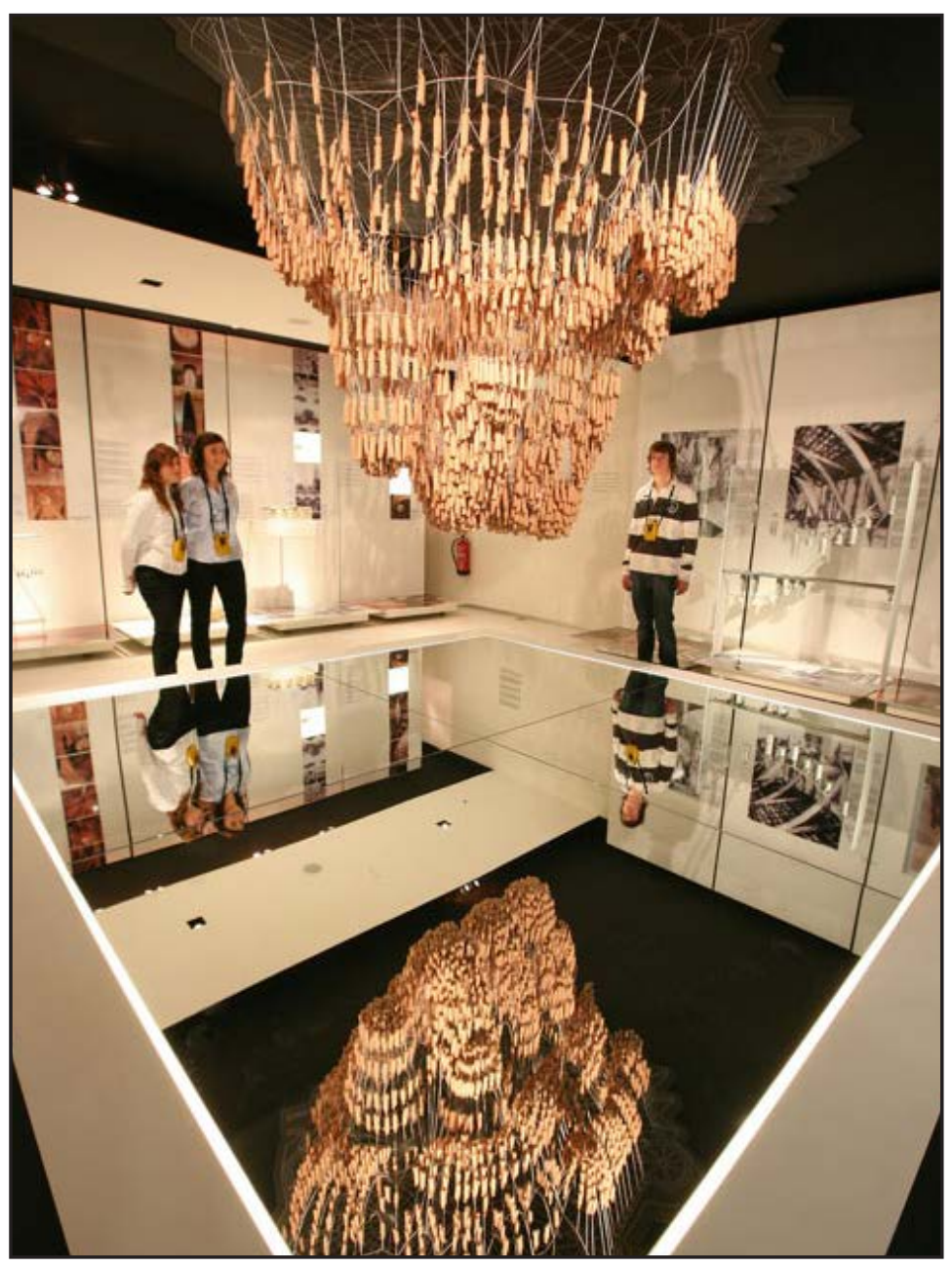

Fig. 6. 60. Foto maqueta funicular de cargas.

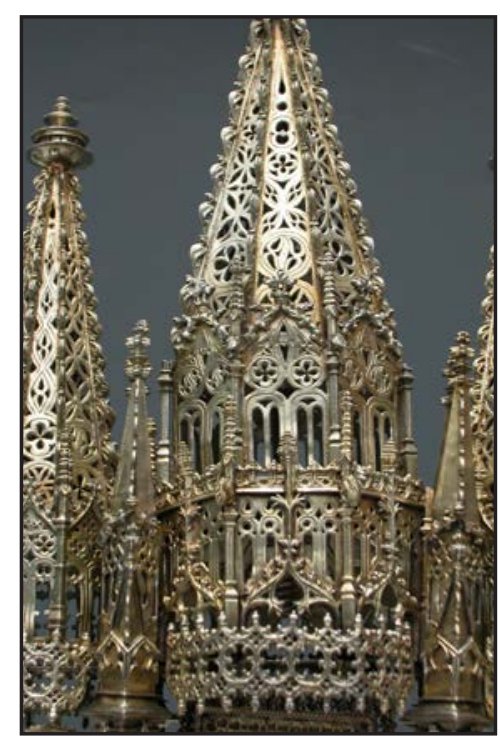

Fig. 6. 59. Foto detalle del relicario de los navegantes. Catedral de Palma de Mallorca (s. XVI)

Gaudí, como otros muchos arquitectos a lo largo de la historia, experimenta previamente con modelos antes de la construcción de los edificios para conocer cuál va a ser su comportamiento estructural.

La relación entre la orfebrería y la arquitectura en la Edad Media es muy importante, véase el artículo: "La arquitectura gótica del Maestrazgo en tiempos del Papa Luna" de Arturo Zaragoza.

Los orfebres realizaban auténticas maquetas de edificios, modelos a escala del original 
En el capítulo primero del libro noveno de Vitruvio se dice: "Si un espacio o campo cuadrado de lados iguales se hubiere de duplicar, quedando también de lados iguales, por quanto esto no se poded hallar por números, se conseguirá por líneas". ${ }^{154}$

En el siguiente capítulo trata de la escuadra o cartabón que inventó Pitágoras. "Si toman tres reglas, una larga tres pies, otra cuatro, y la tercera cinco, adaptándolas de modo que se toquen unas a otras por sus extremidades en forma de triángulo, se tendrá una escuadra perfecta”.

El descubrimiento de este principio de proporcionalidad de la escuadra en sus diversas aplicaciones ha sido una de las invenciones más ingeniosas de la humanidad.

En los Cuadernos de Villard encontramos dibujos que permiten con la ayuda de instrumentos como cuerdas la resolución de problemas geométricos, como la construcción de un claustro proporcionando el área del mismo y el espacio exterior; o la utilización de la escuadra a modo de cuadrado circunscrito para calcular la superficie del círculo.

En el manuscrito de Boysset "La siensa de destrar" dedicado a la agrimensura describe los instrumentos necesarios para la medición y dibujo de la forma geométrica de las parcelas. Entre los instrumentos que describe están: las "destres" o reglas de madera de 16 palmos, las cuerdas de diez o doce destres de longitud, la plomada, el compás de dos brazos y las escuadras largas o cortas de lados desiguales y de diferentes medidas.

Boysset se sirve de métodos simples que descomponen las formas complejas en formas simples: cuadrados, rectángulos o triángulos. A la vez que le permite obtener por proporción otras superficies de distintas tamaños.

Estos medios técnicos son los que permiten desde la antigüedad (véase el caso del Corpus Agrimensorum Romanorum) el dividir y parcelar un campo de grandes dimensiones a partir de la proporción de a forma. Las grandes parcelaciones medievales, como las de los regadíos creados a partir de la acequia mayor de Vila-real o la acequia real del Júcar se pueden materializar gracias a los instrumentos que mediante la proporción permiten parcelar el territorio.

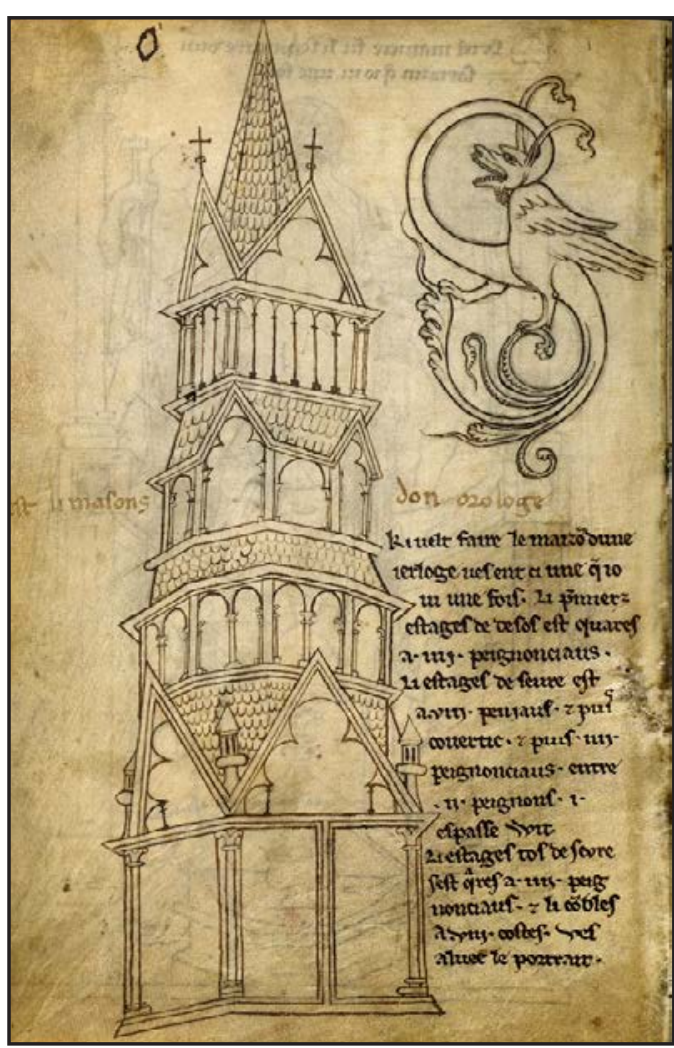

Fig. 6. 61. Lámina 12 del Cuaderno de Villard de Honnecourt.

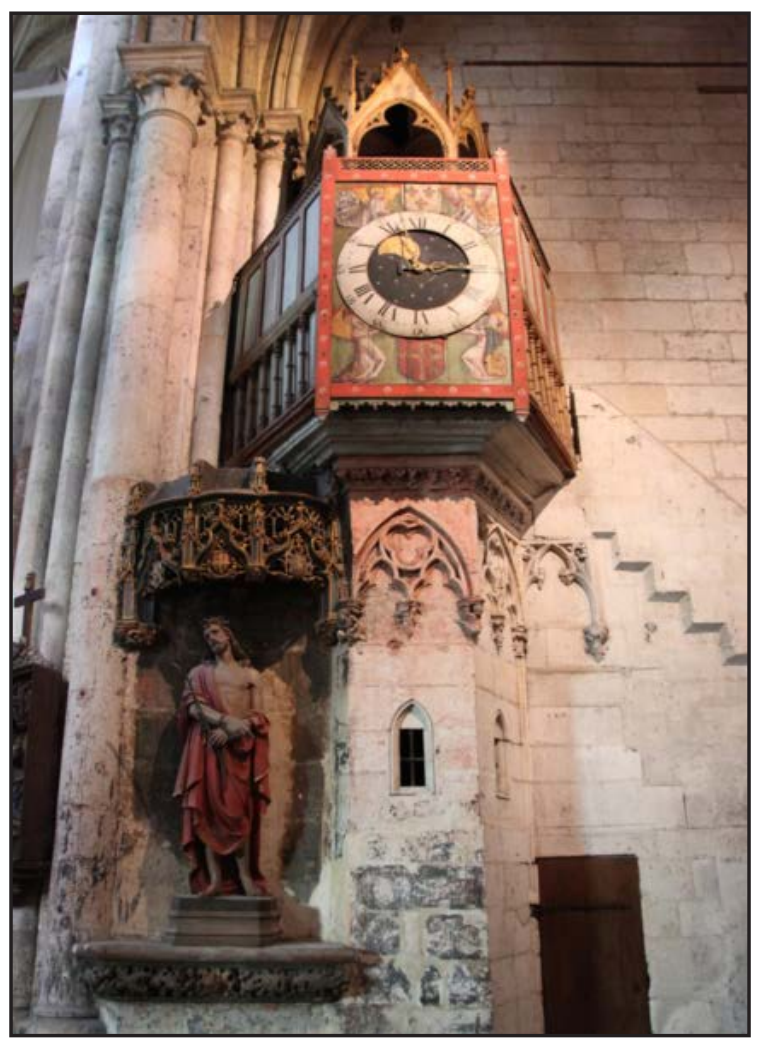

Fig. 6. 62. Modelo a escala de torre para reloj. 


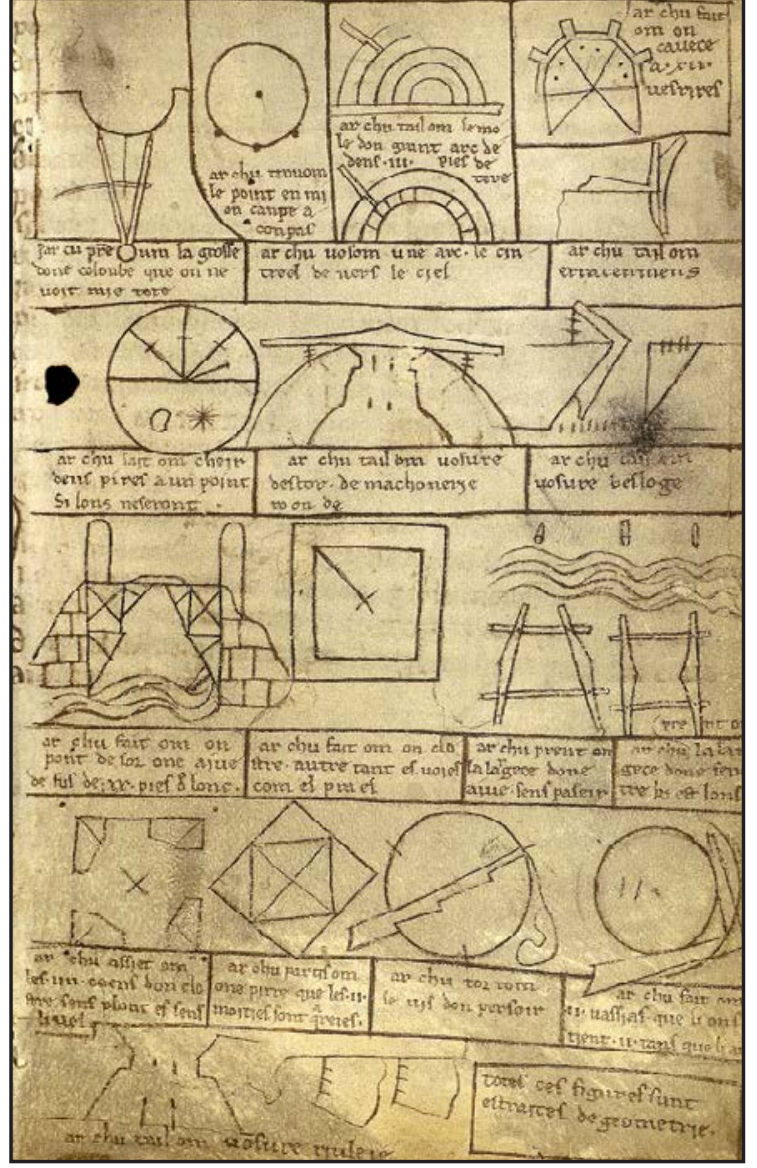

Fig. 6. 63. Lámina 39 del Cuaderno de Villard de Honnecourt, en la que aparecen distintos instrumentos utilizados en la construcción y que en ocasiones sirven como objetos a escala de las futuras construcciones.

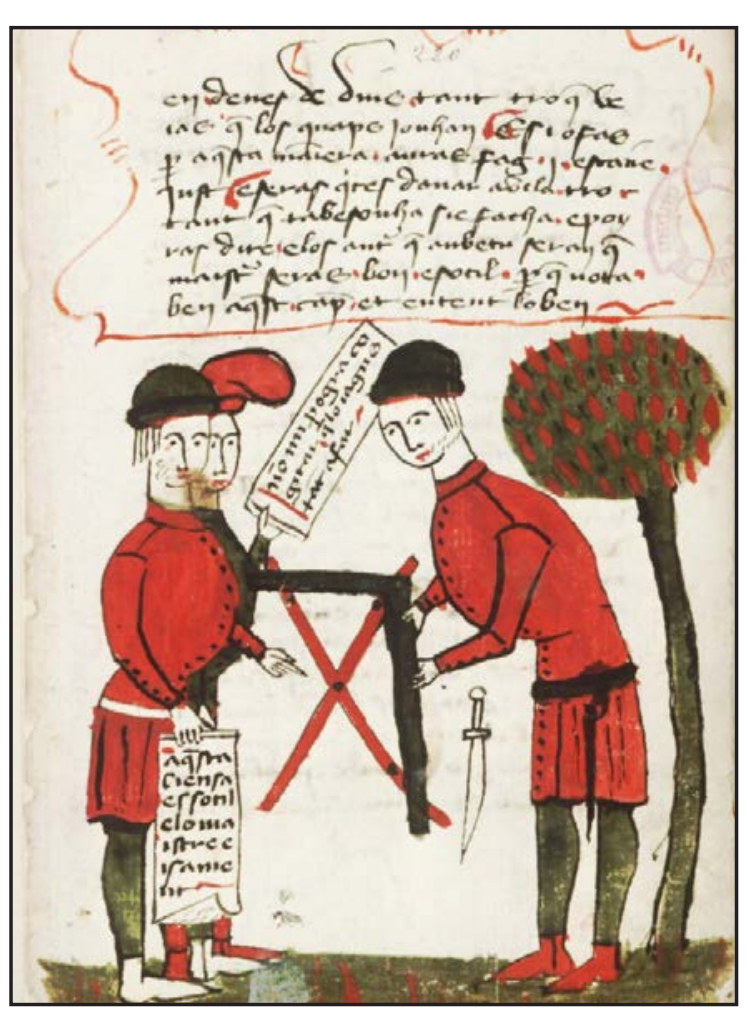

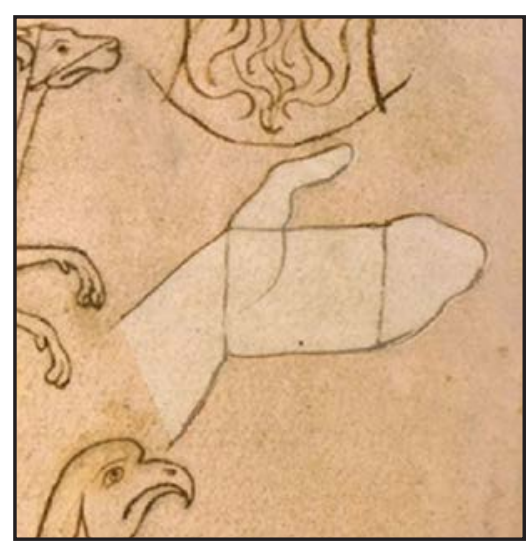

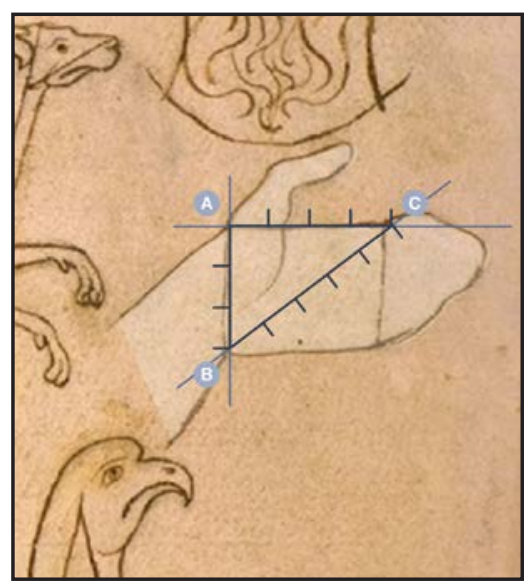

Fig. 6. 64. Detalles lámina 36 del Cuaderno de Villard de Honnecourt: La mano encierra en sí misma la "clave" para la proporción de las formas.

Estos dibujos provienen de una recreación de la Biblioteca de Francia, a partir de los dibujos de Villard

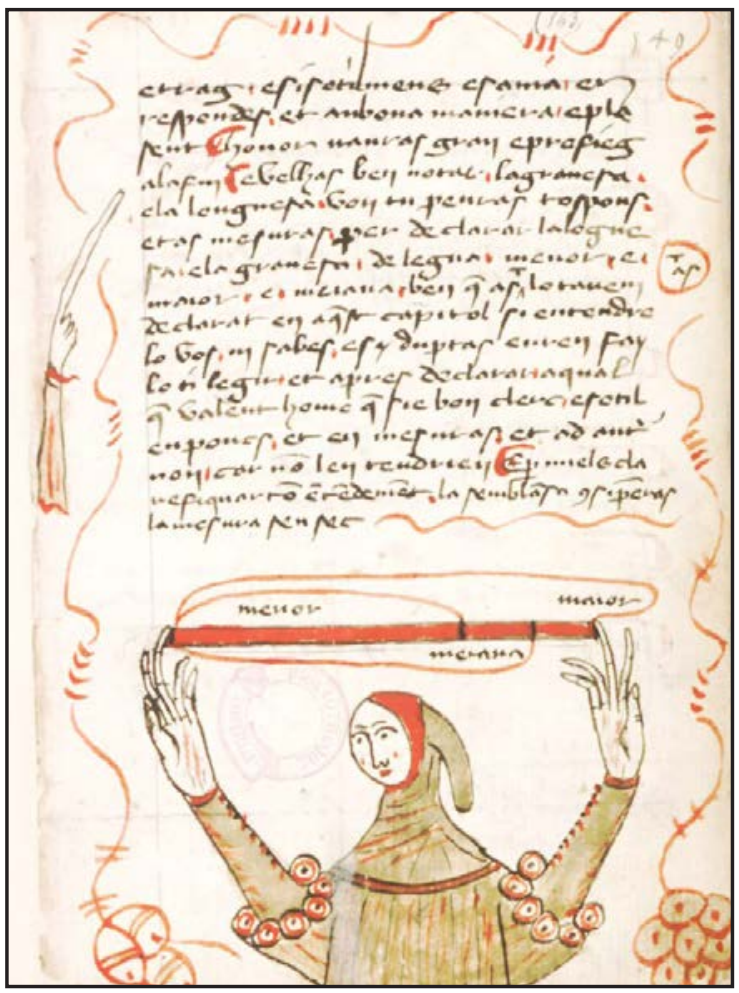

Fig. 6. 65. Láminas g220 y g163 del "Traité d'arpentage" de Bertrand Boysset de finales s. XIV. Escuadra y regla de Boysset. La escuadra es uno de los instrumentos fundamentales en la medición y trazado del territorio. Permite por una parte obtener líneas ortogonales y por otra proporcionar superficies. Un hombre tiene una regla en las manos: Légende: menor, major, mejana. 


\section{3. 3. El código de la forma: el tipo}

El tipo arquitectónico esta investido de una doble dimensión, se trata de una parte de un concepto analítico y clasificatorio-tal como hemos visto hasta ahora- y por otra parte es un concepto sintético y proyectual. El tipo según Rafael Moneo, "puede ser definido como aquel concepto que describe un grupo de objetos caracterizados por tener la misma estructura formal (...) Sin embargo la arquitecturael mundo de los objetos creados por la arquitectura-no está simplemente descrito mediante los tipos, el concepto de tipo afecta a la producción de la arquitectura misma". ${ }^{155}$

La lengua es lo que convierte un sonido determinado en un fonema, lo que hace que ese sonido no sea considerado un simple ruido es el reconocimiento como parte de un sistema, no existen razones lógicas y necesarias- exteriores a la lengua- que hagan que un sonido sea considerado un ruido o un fonema; su caracterización como fonema depende de la lengua de que se trate. De la misma forma que existen diferencias entre lengua y habla, entre el código y el mensaje, existen diferencias entre el elemento constante en la arquitectura -el tipo- y el variable -la forma concreta de un determinado estilo-.

Las estructuras formales invariables que actúan como puntos fijos, como códigos, son depositarios de la información necesaria para poder usar un "lenguaje", la arquitectura con la que se construye el territorio. Los tipos son los códigos, con los que se crean los mensajes, que son las formas concretas en las que se construye el territorio (la morfología es un estilo dado). Si los distintos tipos arquitectónicos (o territoriales) se identifican por las relaciones que se establecen entre ellos dentro del sistema, la identificación del tipo como esencia de la arquitectura, se encuentra en las características que le hacen pertenecer al sistema.

El reconocimiento de una construcción como arquitectura no depende de sus propiedades intrínsecas, sino de su pertenencia, al sistema constituido por la propia arquitectura. El territorio como sistema estructural confiere a los elementos que lo componen su carácter arquitectónico, pero al mismo tiempo el sistema -el territorio- queda conformado por las distintas arquitecturas.

La memoria recoge las formas de la arquitectura del pasado y las sitúa en el proceso de construcción de la arquitectura; en un proceso dialéctico la memoria actúa sobre las nuevas formas pero al mismo tiempo queda conformado por esas mismas formas. El recurso a la memoria permite, sin embargo, asumir la arquitectura desde su propio proceso constructivo autónomo, sin limitarse a los valores y significados correspondientes a su época, ni deformar los valores originarios con los actuales mediante una compleja amalgama que une confusamente significados culturales correspondientes a dos momentos históricos distintos.

Referencias a los tipos de la Edad Media las podemos encontrar en distintos documentos medievales, como es el caso de la mención de las viviendas de tipología de porche ${ }^{156}$ o de las Iglesias de Reconquista como en el caso del contrato de la Iglesia de Olocau ya citado. ${ }^{157}$ Pero nos gustaría destacar la clara referencia a este tipo de Iglesias en la solicitud que hacen los vecinos de Coratxar para que les construyan una Iglesia: ${ }^{158}$

“...et vestri construatis vel construi ffaciatis nobis in villa de Coratxa ecclesiam usque ad X annos habentem parietes de argamassa et duos arcus / lapideos de tusca vel de alia bona petra habentem inter se distanciam competentem, et hostium lapideum rotundum et aperimentum detabulis le / vigatis et bene posisitis el planis inferius, superius vere delantibus bene coctis et bonis qui importunitatem pluviarum ab ecclesia valeat/ evitare."

155 MONEO, R. "Sobre el concepto de tipo en Arquitectura” pág. 190

156 Ver apéndice documental nº 45 pág. 641

157 Ver apéndice documental nº 35 pág. 627

158 Ver apéndice documental nº 14 pág. 613 
Las tipologías no solo las podemos encontrar en las arquitecturas, en el territorio en la forma en la que este se parcela o en la forma en la que se disponen el propio territorio. Los tipos antropogeográficos descritos sirven de modelo para la implantación en el territorio.

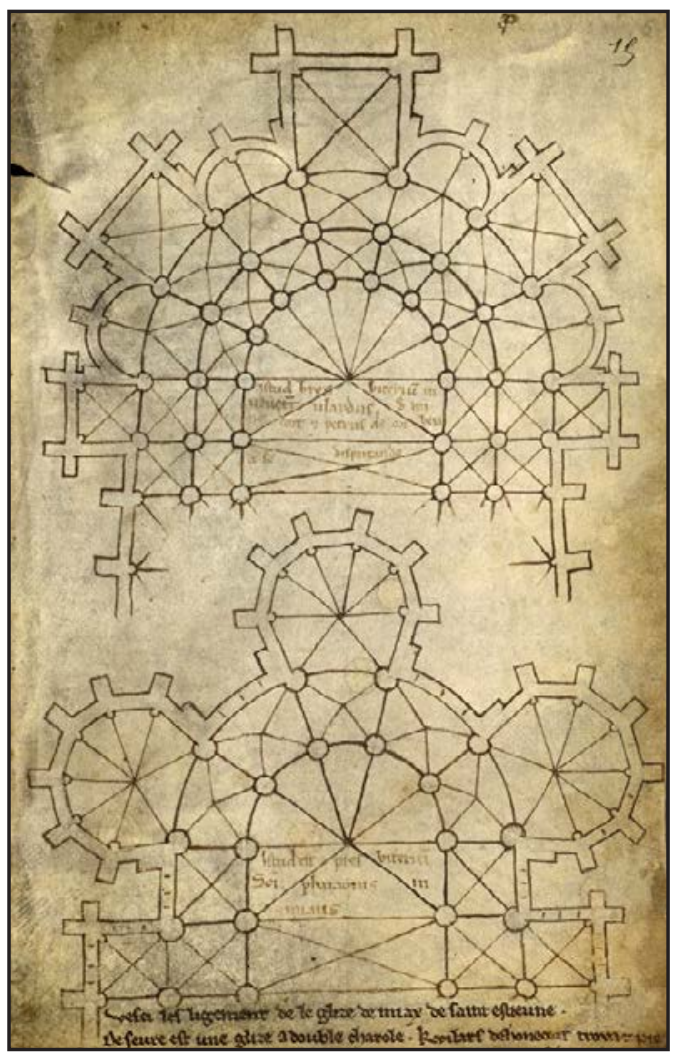

Fig. 6. 66. Lámina 29 del Cuaderno de Villard de Honnecourt Tipos de planta de las cabeceras de las Iglesias de Cambrai y Meaux.

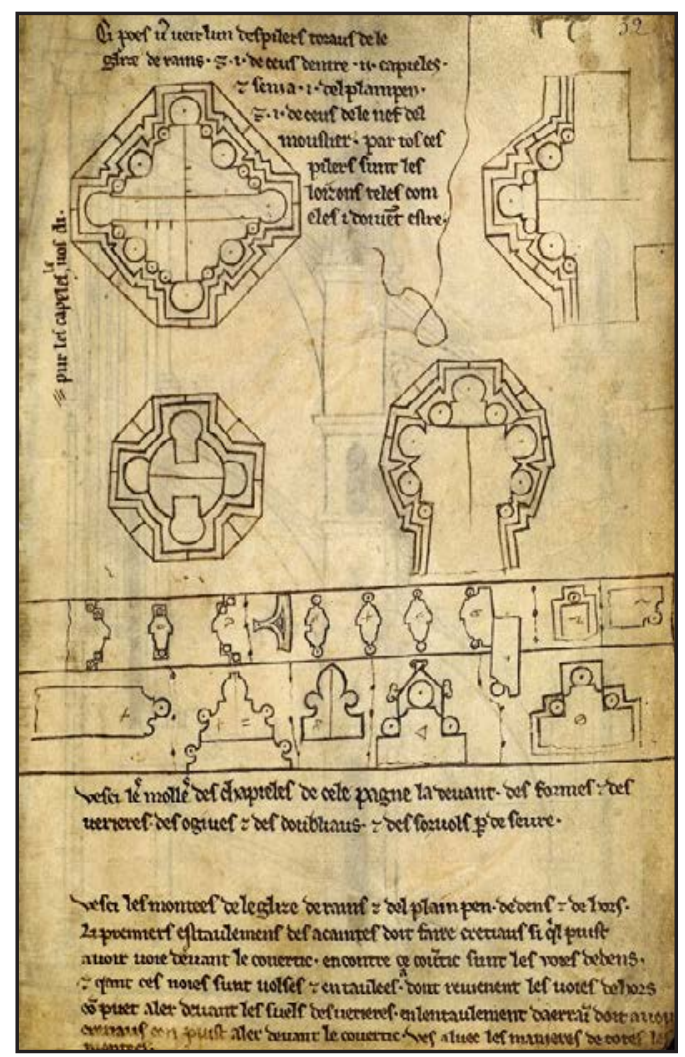

Fig. 6. 67. Lámina 63 del Cuaderno de Villard de Honnecourt: Detalles de la construcción de los pilares y del corte de piedras en la catedral de Reims. Villard dibuja las tipologías de plantillas de las ojivas, de los perpiaños y de los formeros.

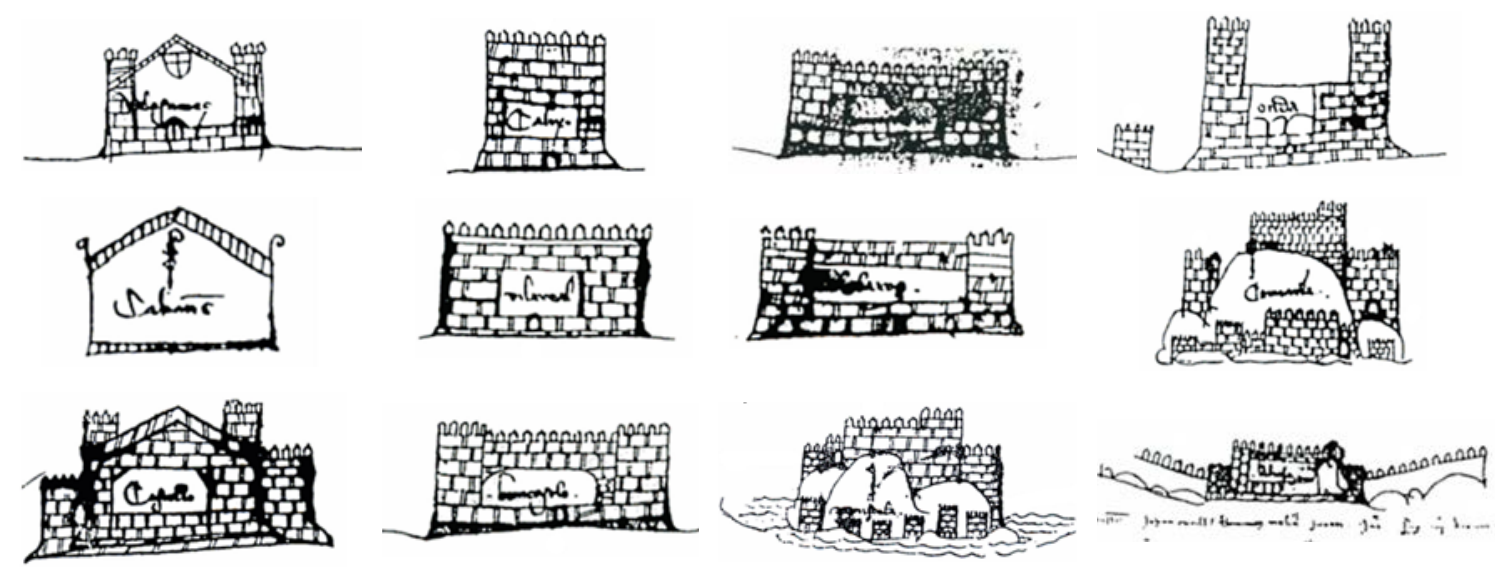

Fig. 6. 68. Dibujos de ciudades que se encuentran en el libro "Visita canónica de la Diócesis de Tortosa por su Obispo Francisco Paholac" (1314). 


\section{3. 4. La forma como huella: el suelo estratificado por bancales, la parcelación}

El territorio es una membrana en la que se graba la información, es memoria. Se sitúa en el cambio de gradiente de dos sistemas el soporte del ecosistema y el antroposocial de la cultura humana, y se depositan como un sedimento como una holografía.

Como nos dice Luis Antonio Fernández Galiano "las huellas del pasado son la horma de nuestro futuro". ${ }^{159}$

La información depositada en las huellas la recuperamos como horma del futuro. Esto es una constatación a su vez del principio de San Marcos, como dice Margalef: "cuando dos sistemas interactúan (ecosistema y la cultura del hombre), la información aumenta relativamente más en el que ya era más complicado, que parece alimentarse del más simple y puede asimilarlo". ${ }^{160}$ Las huellas impresas en el Territorio lo subdividen sucesivamente en bloques que van teniendo un comportamiento unificado y distinto uno de otro, en función de la información que cada uno de ellos tiene. La información depositada en las huellas, es aprovechada como horma del futuro de diversas maneras:

- Las infraestructuras, caminos y redes de agua, aprovechan la topografía "artificial" creada por los bancales situando y construyendo los caminos y acequias sobre los bancales y apoyándose en los muros que los conforman.

- Las parcelaciones se apoyan sobre el suelo modificado por los bancales. Los límites entre propiedades casi siempre se apoyan en los muros de los bancales.

- Las arquitecturas parten de la realidad previa del territorio abancalado. Las masías se construyen adosándose a un muro de bancal sobre un suelo horizontal y aprovechando el muro de piedra del mismo como uno de los cierres de la propia edificación. No solo se "ahorra" un muro, sino que la edificación se protege del entorno adosándose al muro.

- Los pequeños núcleos urbanos crecen a partir de la realidad topográfica de los bancales de su entorno. Los muros de los bancales y las superficies de los bancales son los elementos que definen el crecimiento del futuro núcleo urbano.

En la documentación consultada contamos con un claro ejemplo de la importancia de la huella. Tras el incendio de Morella del año 1356, se ordenaron diversas medidas para evitar futuros incendios. Entre ellas figuraba la ampliación de la anchura de las calles para impedir que este se propagara, sin embargo al final tras la petición de los vecinos se consintió que no variara para así poder aprovechar las cimentaciones y restos de los antiguos edificios: ${ }^{161}$

"Petrus, et cetera. Mostassafo et officialibus Morelle. Vos seu aliqui vestrum quibusdam vicinis Morelle, quorum hedificia pridem, dum ignos validus in dicta villa occasionaliter invaluit, ipsius ignis incendio cremata fuerunt, prohibitis dicta eorum hedificia operari seu operari et reparari facere seu reedificari de novo pretendo quod ex eo quare carrerie sive vie dicte ville, in quibus dicta hedificia operari et reparari debent, non sunt latidunis deecem et octo palmorum iuxta privilegium et forum Regni Valentie, debent fundamenta vetera dictorum hedificorum dirrui et alia de novo duobus palmis retrorsum operari et construi, ex quibus dictis vicinis hedificare et reparare predicta hedificia voplentibus accrescerentu7r labores et sumptus varii et alia plua dampna eis sequerentur. Quare supplicatum fuit nobis tu super hiis clementer providere ac remedium congruum adhibere dignaremur (...)Dicta supplicationes benigne admissa, attento quod aflicto non est danda aflictio calamitatique dictorum singularium, qui a casu tam fortuitu et inopinato quamplurimum oppressi fuerunt, misserendum existit et eorum indempnitati providendum; attento etiam quod jamdicti singulares non intendunt hedificia hedificare de novo

159 FERNÁNDEZ-GALIANO, L.A. “Arquitectura y vida: el arte en mutación” pág. 36

160 MARGALEF LÓPEZ, R. “La biosfera entre la termodinámica y el juego” pág. 28

161 Ver apéndice documental no 45 pág. 641 
sed vetera hedificia rehedificare seu reparare; attento quod circa reparationem dicte ville tamquam notabilis sicut circa reparationem aliarum villarum et locurom Regni nostri, potissime isto tempore quo guerra ardua inter nos et Regne Caselle viget, intendere et operam seu locum dare debeamus (....), tu dicta villa citius reparari valeat concesserimus singularibus, quorum hedificia concremata fuerunt, quod illa possint operari et reparari seu rehedificari facere super fundamebntis antiquis et alia de novo fundamenta nec illa retro per duos palmos facere seu operari minime teneantur(....) “

El hombre no para de borrar y reescribir sobre el territorio. El concepto arqueológico de estratificación no es la metáfora más apropiada para describir este fenómeno de acumulación. El territorio como ha dicho André Corboz es más un palimpsesto, refiriéndose a esos manuscritos, que todavía conserva huellas de otra escritura anterior en la misma superficie, pero borrada expresamente para dar lugar a la que ahora existe. ${ }^{162}$

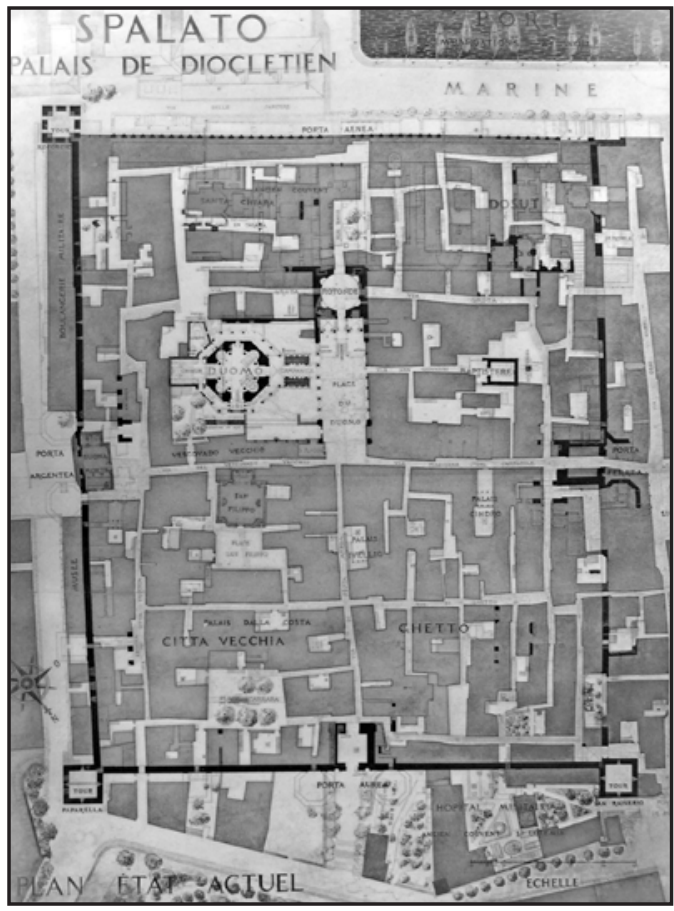

Fig. 6. 69. Plano de la ciudad de Split de Ernest Hebrard (1875-1933).

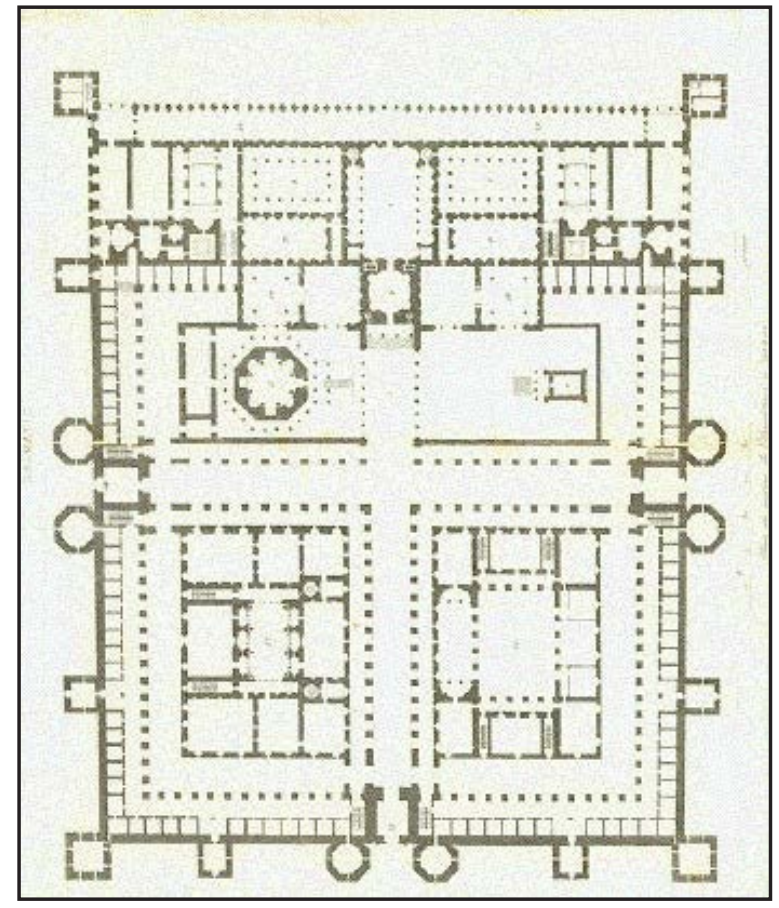

Fig. 6. 70. Plano del Palacio de Diocleciano en Split.

Un claro ejemplo de la huella que deja la forma en el Territorio es el palacio de Diocleciano en Spalato que sirvió como "base" para la construcción de la ciudad sobre la huella que él dejo.

162 Margalef para hablarnos del aumento de información y el desarrollo de la forma nos habla de las termoclinas en una masa de agua. La termoclina es un segmento del gradiente vertical de temperatura que es particularmente intenso o abrupto. Una masa de agua tiene una organización vertical formada por estratos de agua separados por las termoclinas (saltos bruscos de cambio de temperatura según va disminuyendo la temperatura del agua con la profundidad). Por lo que la columna de agua adquiere la forma de una serie de estratos o curvas de nivel, en lugar de tener una forma uniforme y continúa.

De forma análoga y siguiendo la ley de Darcy: "el caudal que atraviesa un suelo es linealmente proporcional a la sección y al gradiente hidráulico", siendo el gradiente hidráulico el incremento de humedad entre dos puntos en relación con la distancia entre esos dos puntos; El suelo abancalado también esta estratificado coincidiendo los "saltos" o bancales con las líneas ortogonales a los máximos gradientes de humedad (los bancales permiten retener la humedad a costa de provocar saltos en la inicial continuidad de la humedad del suelo).

Las discontinuidades que crean estos estratos provocan fronteras entre ellos. Estos funcionan a modo de membranas que permiten el intercambio selectivo de información, en ellas se acumula gran parte de la misma, se puede almacenar y recuperar con facilidad; los abancalamientos se pueden considerar sedimentos construidos por el hombre. El intercambio de información aparece asociado a los gradientes de organización y se propaga por ondas ortogonales a sus respectivos gradientes de temperatura-las termoclimas- o de humedad-los bancales-.

La forma en la que se deposita esta información es la memoria. La memoria toma la forma de ondas estacionarias que permiten reconstruir escenarios en el espacio y en el tiempo, como s se tratara de una holografía. 


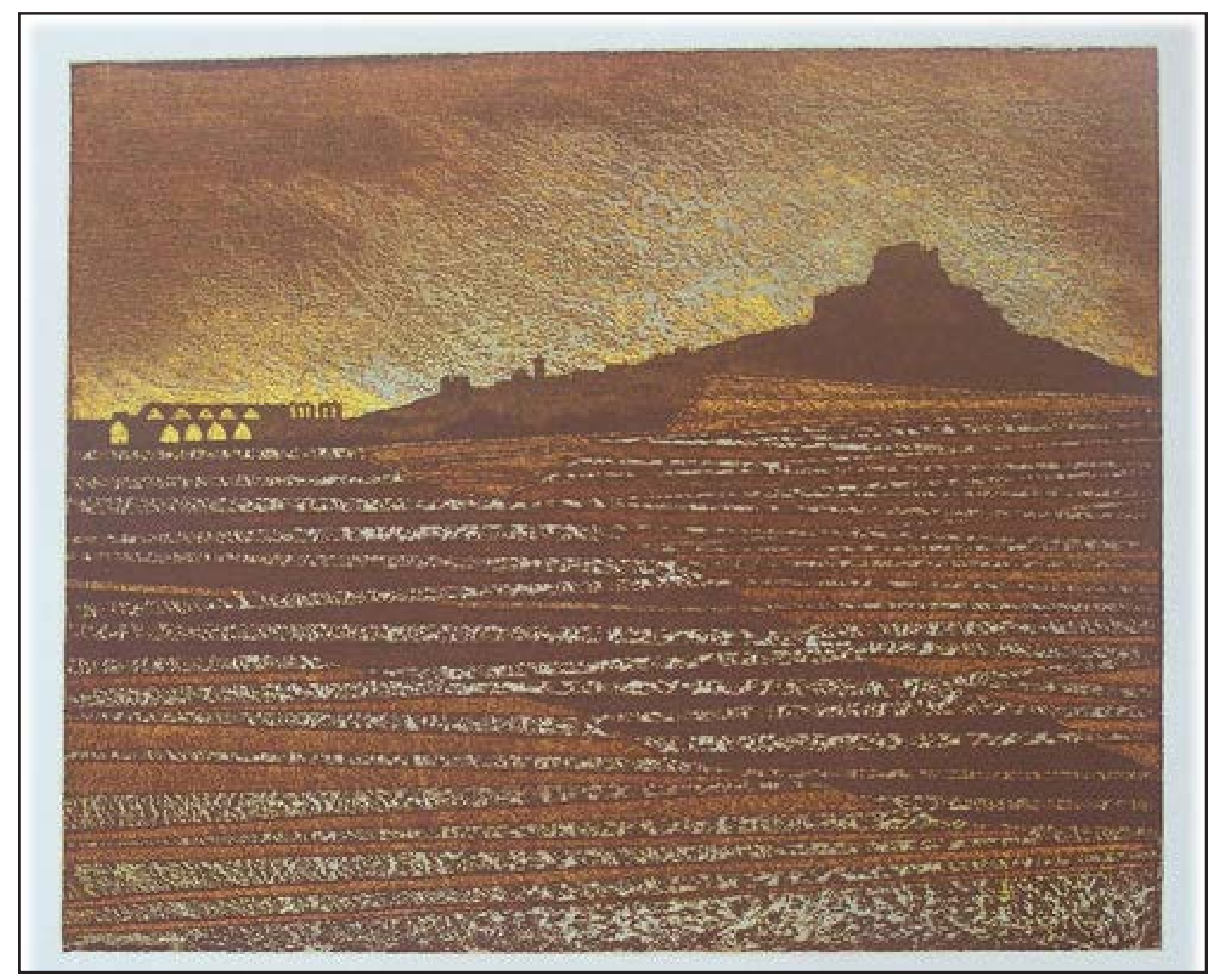

Fig. 6. 71. Cartel del Sexeni de Morella.

Este grabado de la pintora Carmen Dolz ejemplifica la imagen del territorio como membrana en el que se graba la huella de la información. Los muros de los bancales dejan huella en el territorio y en el soporte en el que la artista hace el grabado. 


\section{3. 5. El tacto de la forma}

Nuestro contacto con el mundo tiene lugar a través de la piel mediante las partes especializadas de nuestra membrana envolvente. Todos los sentidos, incluida la vista, son extensiones del sentido del tacto. En el libro "Cuerpo, memoria y arquitectura" Kent Bloomer y Charles Moore señalan la primacía de la esfera háptica: "La imagen corporal se define básicamente a partir de las experiencias hápticas y de orientación que tienen lugar en las etapas más tempranas de nuestras vidas. Solo más adelante se desarrollan las imágenes visuales cuyo significado depende de las primeras experiencias que adquirimos hapticamente". Por ello los niños se llevan todos los objetos a la boca para reconocerlos y los invidentes reconocen los objetos mediante el tacto, son los "ojos" con los que perciben el mundo.

En la Edad Media todo el mundo vital era producto de las manos, y la esfera cotidiana del trabajo y de la vida significaba una transmisión infinita de las destrezas manuales y de sus productos a otras personas; un mundo que constituye el encuentro y la unión continúas de las manos de generaciones sucesivas. Los artesanos mantenían un dialogo entre unas prácticas continuas y el pensamiento; este dialogo evolucionaba hasta convertirse en hábitos. El artesano adquiría la habilidad de su trabajo no a través de la enseñanza verbal, sino por la "transferencia directa de la destreza desde los músculos del maestro a los del aprendiz a través de un acto de percepción sensorial y de mimesis corporal. La mano capta la cualidad física y la materialidad del pensamiento y la convierte en una imagen concreta". ${ }^{163}$

En las habilidades aprendidas, la compleja secuencia de movimientos y relaciones temporales y espaciales en la ejecución de una tarea esta interiorizada e incorporada inconscientemente en lugar de entenderse y recordarse intelectualmente. Cuando una persona aprende a montar en bicicleta, si después de estar muchos años sin montar en una vuelve a hacerlo, inmediatamente y de forma inconsciente recuerda como hacerlo. Las manos saben y recuerdan.

La práctica cualificada de un cantero implica la imaginación con la mano; todo trabajo proyecta determinada intencionalidad y una visión imaginada del trabajo acabado en las manos. El cantero necesita incorporar las herramientas a sus manos, interioriza la naturaleza del material y finalmente lo convierte en un sillar. Su trabajo implica la colaboración con la piedra. En lugar de amparar una idea o una forma preconcebidas, necesita escuchar a la piedra. Se la escucha con las manos, con ellas se le "siente" y se le conduce. La piedra le dice cuales son sus caras y como hay que trabajarla y colocarla para obtener el resultado final deseado e imaginado. Este mensaje que le transmite la piedra se deposita en las formas que elabora como memoria que se transmite a nuevos canteros.

El tacto hoy en día nos permite en ocasiones reconocer la autenticidad de un billete, por ello en la Edad Media la autenticidad, la firma era táctil. La huella dejada en el lacre de un anillo, la "firma" de los canteros en los sillares o la de las marcas de los orfebres en las piezas realizadas con un punzón. Era tal la importancia de estas pruebas "táctiles" que el uso de los punzones para marcar las piezas de orfebrería que salían de un taller eran una concesión real. ${ }^{164}$

\footnotetext{
"Noverint universi quod Nos Iacobs, etc. Ad humilem suplicationem nunciorum pro Juratos et probos homines ville nostre Morella ad nostram presentiam destinatorum asserentium quod in dicta villa sunt argentarii qui morantur et operantur ibidem bene et le galitger de eorum officio sive ministerio argenterie. Proptera cum presenti privilegio volumus et concedimus dictis Juratis et probis hominibus dicte ville presentibus et quiper tempore fuerint pro decetero per in perpetuum possint habere et tenere in dicta villa marcum sive signum ad marcandum sive consignandum vasa et alia opera argentea que per argentarios dicte ville fient et operabuntur ibidem de cosimili argenteo quod operatur et quod operatuir et quod marcatur in Civitate quod quidfem marcum sive signum teneant Jurati dicte ville qui per tempore fuerent seu ille vel illi (fol. 90v.) quibus dicti Jurati ipsum marcum sive signum
}

163 PALLASMAA, J. "La mano que piensa. Sabiduría existencial y corporal en la arquitectura” pág. 12

164 Ver apéndice documental no 38 pág. 631 
pro marcandis sive consignadis dictis vasis etaliis operetibus argentis duxerint commendandum. Qui teatur satis dare in posse biuli nostri Morella qui per tempore fuerit pro bene et legaliter se habeat in marcando vel consignando vasa et alia opera superdicta. Et sic mandamus pro presens privilegium nostrum procuratoribus, baiulis, justiciis et alilis officialibus et subditis nostris presentibus et futuris quotenus concessionem nostram hanc firmam habeant perpetuo et observat et teneri et observari faciant inviolabiliter et non contraveniant en aliquem contravenire permitant alicuius ratione. In cuius rei testimonium presens privilegium nostrum sigillo nostro appendito inferius sigillari."

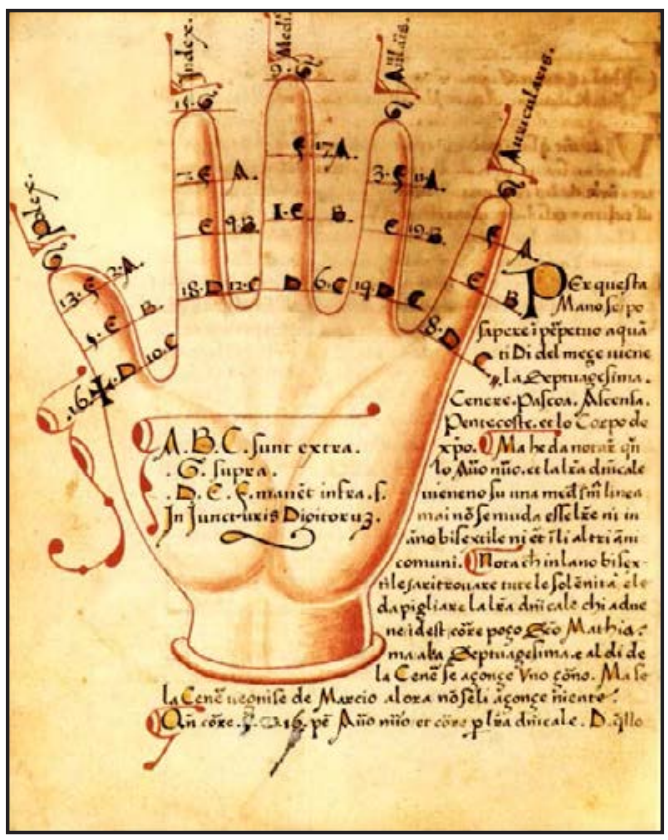

Fig. 6. 72. Fragmento manuscrito de la Biblioteca Nacional francesa. NAL 1090, fol. 82v s. XV.

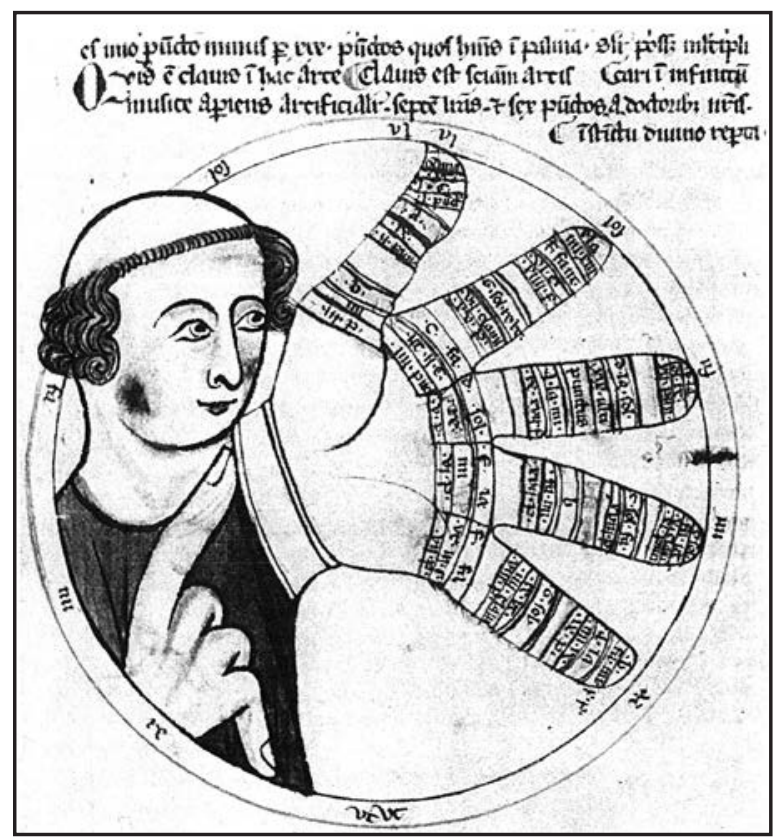

Fig. 6. 73. La mano de Guido, autor desconocido. Manuscrito de 1274 que se encuentra en la Biblioteca Ambrosiana. MS D.75 inf. Fol. $6 r$.
Las manos conocimientos
y su lenguaje
eran
utilizados
por
los distintos
oficios
para la transmisión
de los

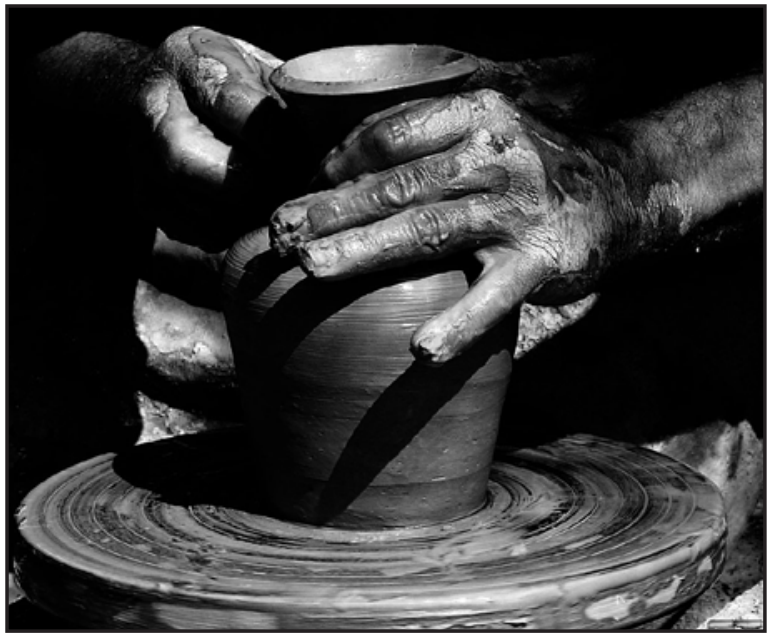

Fig. 6. 74. Fotografía de manos de un alfarero.

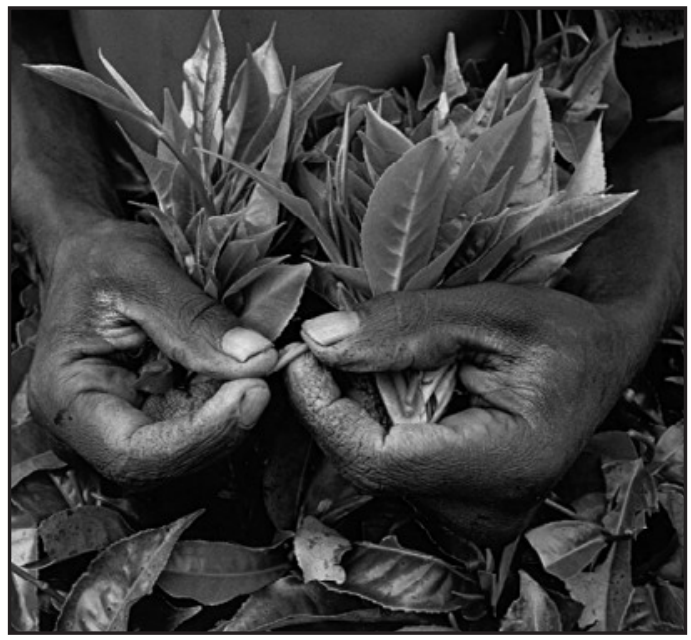

Fig. 6. 75. FotografíademanosdeagricultordeSebastiaoSalgado. 


\section{4. Conclusiones: Territorio sistema termodinámico abierto}

Como dice Luis Antonio Fernández-Galiano, el territorio "se presta admirablemente al estudio en términos termodinámicos". ${ }^{165}$ La estructura material del tablero en el que se juega la partida está sometido a un proceso de degradación y conformación simultánea, mientras que la información de las reglas de juego con las que se juega cada nueva partida están depositadas en las estructuras materiales del propio tablero.

"La relación entre forma, materia y energía; la capacidad de la materia de acumular energía como información y la necesidad de la materia de recibir energía para mantener su con-formación". ${ }^{166}$ son las bases sobre las que en el territorio como tablero de juego, el hombre va jugando partidas una tras otra. El hombre en el proceso del "juego" precisa energía para mantener la forma del territorio, a la vez que hace uso de la energía almacenada en el mismo como información.

En el análisis que hemos realizado del territorio se ha partido de elementos simples para llegar hasta estructuras más complejas. De las esferas/arquitecturas, hemos pasado a las esferas/lugares, de estos a los tejidos, a las esferas/ciudades, partes completas del territorio y por último al territorio en su conjunto (y no hay que olvidar que este a su vez forma parte de un territorio más amplio al que pertenece). Cada una de estas esferas cada vez más complejas que componen el territorio, "son sistemas no solo abiertos, sino que viven de su apertura, que se alimentan de los flujos de materia y energía que les llegan del mundo exterior". ${ }^{167}$ La arquitectura-masía "vive y se alimenta" del lugarmasía que le rodea; este del tejido agrícola en el que se agrupan los lugares-masías; este de la parte del territorio que conforman con otros tejidos y la parte del territorio de este en su conjunto. Cada una de estas fases, separadas del medio al que pertenecen se mueren; "son parte integrante del mundo que las alimenta, constituyen una especie de encarnación, local y singular, de los flujos que no dejan de transformar". ${ }^{168}$

La famosa anécdota del arquitecto Dimócrates -recogida inicialmente por Vitruvio-, que propuso a Alejandro el Grande la construcción de una ciudad sobre el monte Athos, modelado a imagen del monarca, ha servido a generaciones de trataditas para ejemplificar los desatinos a que da lugar la ignorancia de la commoditas y la necessitas en el diseño arquitectónico y urbano. La réplica de Alejandro, recordando al arquitecto que "así como un niño, apenas nacido, no puede sustentarse sino con la leche de su nodriza ni ir gradualmente creciendo, tampoco una ciudad, sin campos y sin que a él afluyan frutos, puede crecer ni ser populosa, ni mantener a sus habitantes sin abundancia de víveres". ${ }^{69}$

Las distintas esferas, desde la de menor complejidad como una masía al de mayor complejidad como una ciudad, son sistemas termodinámicos abiertos que reciben los flujos de materia y energía que los alimentan de su entorno. Los flujos lógicamente son tanto mayores cuantos mayores sea la escala y la especialización de la esfera. Conforme aumenta la complejidad, el consumo de energía es mayor y el ámbito del entorno que se la proporciona aumenta.

Llegados a este punto, vamos a intentar sintetizar -con el riesgo que ello supone de simplificacióncuales fueron los factores fundamentales que en el territorio -tablero- de la Batllia y en el periodo histórico -estrategia de juego- del estudio determinaron la partida que se jugó.

El territorio-tablero se modifica en esta época según la predisposición topológica original del soporte y de forma estereotómica siguiendo como en todos los sistemas naturales los principios de la gravedad

165 FERNÁNDEZ-GALIANO, L.A. "El fuego y la memoria. Sobre arquitectura y energía” pág. 75

166 FERNÁNDEZ-GALIANO, L.A. "El fuego y la memoria. Sobre arquitectura y energía” pág. 76

167 PRIGOGINE, I. y STENGERS, I. “La nueva alianza. Metamorfosis de la ciencia” pág. 149

168 PRIGOGINE, I. y STENGERS, I. “La nueva alianza. Metamorfosis de la ciencia” pág. 142-3

169 VITRUBIO POLIÓN, M. "De architectura" 
y la búsqueda de la luz.

Es precisamente en la Edad Media donde empieza un cambio sustancial en la evolución del territorio con el uso de forma generalizada por el hombre de energías exógenas y con el desarrollo cultural que propició el inicio del paso de un territorio estereotómico a uno tectónico.

El tablero-territorio medieval es un sistema termodinámico abierto cuya forma es el producto simultáneo de la homeorhesis -capacidad de evolución y crecimiento- y la homeostasis -mantenimiento y rehabilitación- gracias a cuatro "estrategias de juego": El paso del pago de tributos al de rentas, el cambio del trueque al dinero, el desarrollo de la técnica y por último el establecimiento y organización de una "máquina social" como el "jornal de vila" y por otra parte de la histéresis -recuperación de energía por la información- gracias a otras dos "estrategias de juego": el pensamiento escolástico y la cristalización de las normas consuetudinarias.

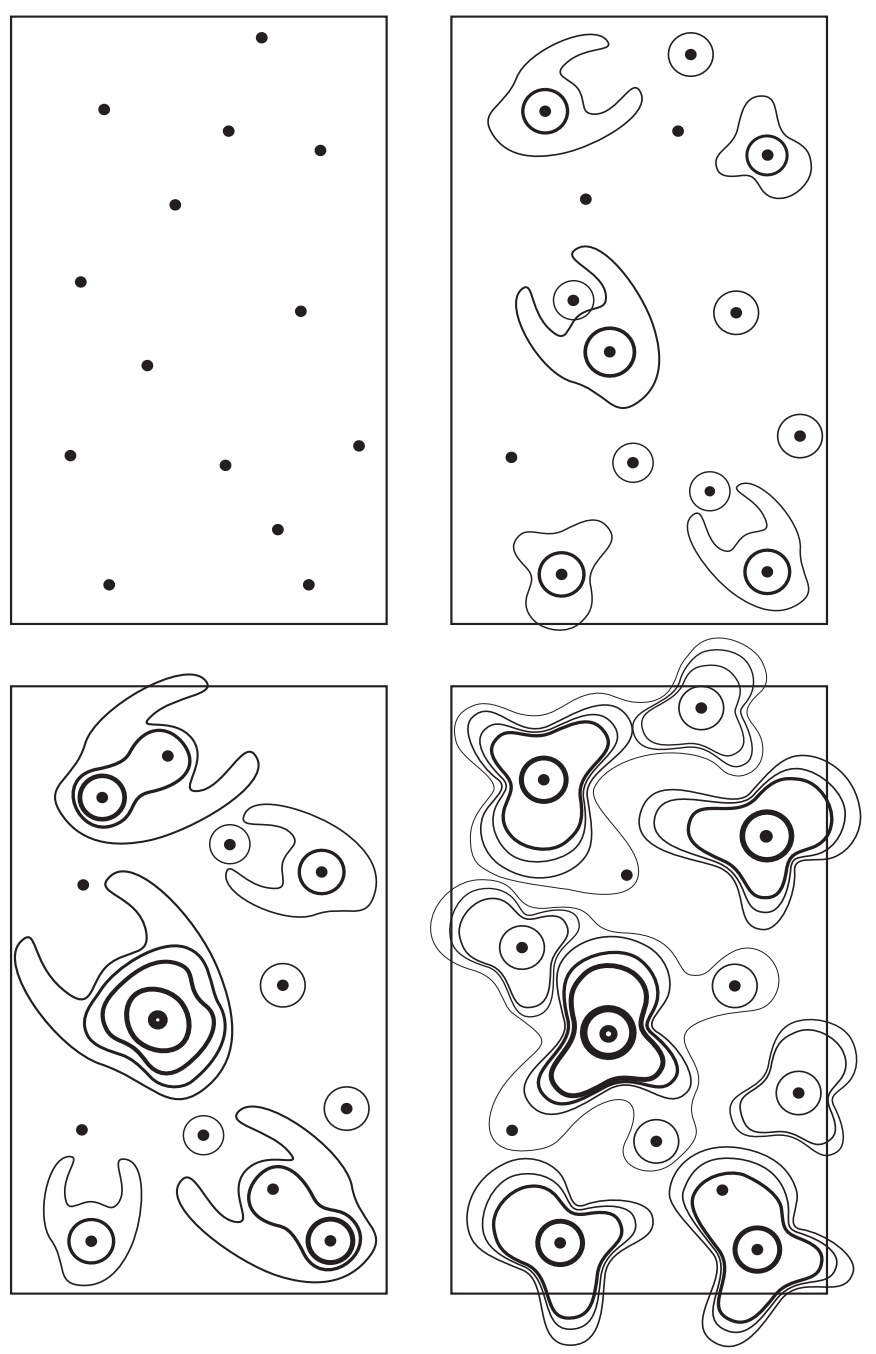

Fig. 6. 76. Esquema gráfico de cómo evoluciona un territorio a partir de las distintas arquitecturas hasta organizarse de una forma más compleja con tejidos y ciudades.

\section{Elpaso del pago de tributos al de rentas}

Los repartimientos fueron originalmente no-feudales, tanto en su carácter como en sus objetivos. El objetivo inicial fue el establecimiento de ciudadanos y campesinos libres. Ello se vio modificado (el planteamiento del monarca) por la "señoralización", la dureza de la vida de frontera y por un mercado de tierra raramente activo que no favorecía al pequeño propietario. El elemento determinante del cambio fue que los reinos fundamentaron sus sistemas militares en la posesión de la tierra. Se pagaron los servicios militares prestados con la posesión de la misma, el Rey pagó a las Órdenes Religiosas su 
apoyo en la conquista con su propiedad. Esta situación favoreció a los propietarios de grandes lotes de terreno que junto con la atomización progresiva de las propiedades de los colonos que poco a poco se fue fragmentando bien por la herencia o bien por la venta, dibujo un territorio con grandes desequilibrios entre propietarios. ${ }^{170}$

La necesidad del pago de las rentas obligó al cambio del tipo de cultivo. Se favorecieron los cultivos, sobre todo el grano, la vid y la aceituna, que son susceptibles de generar rentas por su venta como tales por no ser perecederos (las rentas se pagaban con productos agrícolas), pero sobre todo por ser transformables en harina, vino y aceite y poder entonces ser todavía mejor "moneda" de cambio y ser transportados a otros lugares generando un incipiente mercado de exportación. La ganadería adquirió en este territorio una importancia relevante por ser susceptible de generar importantes rentas, favorecido por la exportación de la lana hacia Italia. ${ }^{171}$

La exigencia del pago de las rentas y el ejercicio de la autoridad feudal fueron capaces de modificar la producción previa a la conquista, ello junto con la progresiva atomización de la tierra hicieron cambiar el territorio posterior a la conquista que previamente era un espacio productivo, segmentado y aglutinado en torno a las alquerías.

Los excedentes agrícolas fomentaron la creación de una demanda urbana para comercializar la producción agraria y estimular las funciones artesanales y terciarias de las ciudades. En el caso de Valencia desde la conquista de mediados del siglo XIII en adelante los señores feudales coexistieron con una fuerte burguesía comercial urbana vinculados por un sistema agrario y ganadero altamente dinámico y comercializado. ${ }^{172} 173$

\section{Elpaso del trueque al dinero}

En esta época nació el capitalismo y se sustituyó la economía de trueque existente hasta el momento, gracias al aumento de los excedentes agrícolas y ganaderos que propiciaron su comercialización y con ello el surgimiento de una economía de dinero con una estructura de crédito internacional y un aumento de la riqueza: oro, cheques, letras de cambio... ${ }^{174} \mathrm{El}$ comercio de la lana desde estas comarcas con Italia permitió el crecimiento de una sólida economía que catalizó el desarrollo de este territorio.

El dinero además se concentra en las ciudades mientras que en el resto del territorio perdura en gran parte el trueque. Ello es una de las causas fundamentales del mayor desarrollo de estas respecto a su territorio circundante.

En el sistema complejo del hombre el dinero, que se entrega retroactivamente como respuesta por el trabajo realizado, supone una corriente de realimentación más fluida que el reciclado geoquímica de los ecosistemas naturales.

De forma análoga a un ecosistema Odum plantea que el principio de selección por bucle de retroalimentación positiva por el cual un receptor de energía potencial recompensa a su fuente devolviéndole los materiales necesarios -los animales realimentan a las plantas a través de bucles de recompensa con los abonos necesarios para su alimentación-. Así el flujo de dinero de una población entra en un bucle que va a otra población de forma que ambas se retroalimentan. El comercio de la

170 Ver apéndices documentales no 4, 5 y 6, referentes a las cartas puebla otorgadas por la Orden del Hospital, pág. 605

171 Ver apéndice documental no 48 pág. 643

172 Ver apéndices documentales no 10 y 20, referentes a las licencias concedidas por el Rey para la celebración de mercados semanales y feria anual en Sant Mateu, pág. 610 y pág. 618

173 Como dice Thomas F. Glick en su libro "Paisajes de conquista" la transición al feudalismo en Valencia se caracteriza por el paso de una sociedad tributaria cuyo sistema de gobierno se basa en los impuestos pagados a un fisco público, a una sociedad feudal donde se pagan rentas a señores privados. La renta reemplazó al impuesto, el equilibrio económico se modificó y las relaciones feudales se hicieron más importantes que las anteriores surgiendo un feudalismo económicamente dinámico que permitió un importante desarrollo de este territorio.

174 Ver apéndice documental no 13, referente a la “Taula de Canvis” del año 1247, pág. 612 
lana con las ciudades italianas, hizo que se produjera un bucle de retroalimentación entre las ciudades que favoreció su desarrollo, a la vez que las diferencias con respecto al entorno de su territorio. ${ }^{175}$ El uso del dinero propicia la financiación de las grandes obras públicas que tendrán una importancia decisiva en el desarrollo del territorio. Esta financiación -como ocurre hoy en día- puede ser previa a la realización de la obra o bien toda o parte de ella recuperar con el uso posterior de la misma, se decir mediante peajes a los futuros usuarios.

Entre la documentación consultada se encuentran documentos que hacen mención a la financiación previa, como es el caso de la obtención de dinero por parte de Jaume I para la construcción de la acequia de Vila-real en 1274: ${ }^{176}$

"Pernos et nostros vendimus vobis Petrus de Juneda, vicino Burriane, et Bernardus Simonis et vestris, aproximo venturo festo Sancti Johanis Baptiste usque ad 11 annos primos venturos et continue completos, omnes redditus exitus et proventos nostros Burriane tam maris quam terre, excepto justiciatum ville Burriane, precio videlicet septem mille solido regalium Valencie, quos pro nobis et loco nostro tradcre debetis incontinenti frati Petrus Peyronety, helemosinario nostro, ad opus operis cequie nostre Ville Regalis, planicie Burriane. Ita cum quod omnes predictos redditus exitus et proventus nostros Burriane percipiatis per manum Petrus Eiximini de Spelluncha, baiuli nostri eiusdem loci, quolibet anno e ipsos habeatis est anch (sich) ad faciendum inde vestras omnimodas voluntates; promitentes vobis quot in predictis redditibus exitibus et proventibus nostris, quos vobis vendimus, non tangemus nec inde aliquit percipiemus nech tangi s[i]ve percipi faciemus per totum dictum tempus nec revocabimus anch vendicionem quam de ipsis vobis facimus pro maiori precio vel minori. Immo si dicti redditibus, exitus, et proventos nostris plus valen vel valebunt infra dictas duos annos precio supra dicto totum illut vobis damus de gratia speciali."

Otros documentos hacen mención a la financiación "a posterior" como son los casos de los peajes de puentes ${ }^{177}$, como es el caso del puente de Vila-real en 1311:

"Ad instanciam et humilem suplicacione universitatis Ville Regalis, volentes quod pons qui iam inceptum est fieri in rivo de Millars veniant ad effectum, et ut dictus locus suscipiat incrementum, volumus et concedimus de speciali gratia dicte universitati, in auxilio operis dicti pontis, quod quilibet qui transitum faciet per dictam villam, sive per villam de Borriana equitando, solvat unum denarium, et quislibet pedester solvat obolum, et bestia de albarda obolum, semel in die, sic quod peccuniam inde proveniens ex predictis mitatur et convertatur in opere dicti pontis, bene et legaliter, et quod presens gratia duret ab hac presenti die que scribitur presens carta, usque ad tres annos proxime venturos et continue subsequentes, de quibus omnibus teneatur computare dicta universitas cum baiulo nostro regni Valencie generali."

175 "La tierra de pastores sobre la cual deseo llamar la atención, se extiende en España, sobre la costa del Mar mediterráneo, entre dos ciudades que tuvieron gran resonancia en el mundo romano: Tarragona y Sagunto. Desde los ásperos montes de Aragón esta tierra pastoral declina hacia el mar a través de colinas boscosas y pálidos olivos; pueden verse igualmente, entremezclados, las viñas, los campos de grano, los prados y los matorrales.

Durante los siglos XIII y XIV esta comarca lejana de los centros de arte, apartada de las grandes rutas, perdida en un ángulo del Mediterráneo, parecería -a primera vista- que nada, o bien poco, haya podido tener que ver con nosotros (los florentinos). Estamos separados por una gran distancia, tanto por los caminos del mar como por los de tierra. Lo mismo sucede por tanto transcurrir de los siglos. (...) y, sin embargo, no fue así.

(...) Florencia había encontrado, casi por un instintivo reclamo de la historia, los mismos caminos que Roma. Sagunto se había hundido desde hacia siglos; pero en lugar de Sagunto surgía esta ciudad de pastores (San Mateo), donde los florentinos acudían a buscar lana que embalaban y embarcaban sobre galeras a vela hacia Porto Pisano y Talamone. La lana española, la de Garbo, esta es la de occidente (Magreb en árabe) se llamaba directamente la lana de Sanmattee por el nombre de la ciudad de Sant Mateu, donde estaba el más importante mercado de ganado. La Gabela de los puertos florentinos y los libros de los mercaderes distinguían también otras variedades de la lana de Sant Mateu: la lana Cerbiera, esto es, la lana de Cervera del Maestre y la lana Salsadella, esto es, la proveniente de Salsadella, pueblecito situado en el camino que desciende de Sant Mateu hacia la llanura (Castellón de la Plana).

Ninguna región de Italia tenia un pastoreo lo suficientemente desarrollado como para poder alimentar una industria tan potente y compleja como era la de Florencia. Por eso los florentinos estaban obligados a recorrer y buscar por otros montes y otros mares la materia prima con sus artesanías y mercancías".

Texto de Ezio Levi "I Fiorentini nel Maestrazgo al tramontyo del Medio Evo" que aparece en el artículo de Arturo Zargoza "La arquitectura gótica del maestrazgo en tiempos del Papa Luna".

176 Ver apéndices documentales no 29 y 32, pág. 624 y pág. 625

177 Ver apéndices documentales no 21 y 37, pág. 619 y pág. 631 
O sobre el pago del mantenimiento de las acequias por parte de los agricultores en funcion del uso que haga cada uno de ellos de las mismas, como es el de este documento de 1291:178

"Jacobo de Valle, baiulo Ville Regalis ve! eius et cetera. Mandamus vobis etc. Quatenus de cequiatgio quod recipicis ratione cequie que noviter constructa fuit per populatores Ville Regalis habientes hereditates subta dictam cequiam videlicet a barrancho Rivum de Julia; usque rivum Seccum tenentis ipsam cequiam codirectam et erbagitam a predicto barrancho Rivum Julia; usque ad predictum rivum Siccum et terminum de Nulles quantum proceditur ¡; equia supradictam secumdum quod G. De Turribus tune procurator domini regis super populationem predicte Ville Regalis istud concessit cum carta publica ut continetur in ea 1... J dominus rex fraternos ter aliud super eo voluerit ordinare".

Y en otros casos se produce la financiación del mantenimiento de las grandes infraestructuras con el pago en especies, como un impuesto que deben de pagar los mercaderes para sufragar este tripo de obras, como es el documento de $1258::^{179}$

"Noverint universi quod nos, Jacobus, Dei gratia rex Aragonum, Maioricarum et Valencie, comes Barchinone et Urgelli et dominus Montispesulani; per nos et nostros damus et concedimus vobis, fidelibus nostris toti concilio Turolii et vestris, imperpetuum, terciam partem caloniarum ipsius ville, quam iudez et alcaldis olim solebant recipere et habere, et palatas, que de quibuslibet rebus dantur et dare consueverunt in mercato singulis diebus iovis, ita tamen quod vos et vestri illud totum integre ponatis et mitatis in refeccione et reparacione murorum, ante muralium, carrarie et pontium iamdicte ville et terminorum eius."

\section{El desarrollo de la técnica: las máquinas}

Las máquinas tuvieron un gran auge en la Edad Media, se desarrollaron a partir de un complejo de agentes no orgánicos para convertir la energía, para realizar un trabajo, para incrementar las capacidades mecánicas del hombre y tener un mayor rendimiento económico.. En el fondo del desarrollo de los instrumentos y de las máquinas esta el intento de modificar el medio ambiente de tal manera que refuerce y sostenga al organismo humano.

En un primer momento aprovecharon la energía del hombre o de los animales, como en el caso de los molinos de aceite, en el que su capacidad de producción se encontraba supeditada al número de caballerías de que se dispusiera: "Et teneatis ibidem sufficiencia torculariorum seu molendinorum com bestiis ad hec necesssariis". 180

Posteriormente se usó la energía del agua en los molinos, por ello junto con toda gran infraestructura de agua-acueducto, acequias, etc. se prevé la construcción de varios molinos. ${ }^{181}$

Detrás del desarrollo de la máquina se extendía el prolongado desarrollo de la técnica misma, a medida que aumentaban las necesidades del hombre y aumentaba su habilidad y conocimientos. El uso de las energías exógenas no "tradicionales" -gravedad y solar- es durante estos años cuando tiene el espaldarazo definitivo. La energía del agua, viento y fuego se incorpora definitivamente con una gran relevancia al desarrollo del hombre a partir de estos años.

Ello ocurre gracias al proceso de sincretismo que describe Mumford que se produce en Europa occidental a partir del siglo X, en el que las culturas precedentes están en periodo de disolución, lo que permite extraer de las mismas los elementos fundamentales que al estar "libres" pueden desplazarse hacia el desarrollo de una nueva cultura.

178 Ver apéndice documental nº 34 pág. 626

179 Ver apéndice documental nº 22 pág. 619

180 Ver apéndice documental nº 33 pág. 626

181 Ver apéndice documental nº 27 pág. 622 
De entre todas las máquinas que el hombre inventa en este periodo una resulta fundamental. Se trata del reloj que permitirá al hombre desde ese momento organizar su tiempo. Surge del monasterio, de la rutina de su actividad diaria y a finales del siglo XIII se traslada a las ciudades; la regulación formal de la sucesión del tiempo, el hábito del orden y la rutina metódica cambia el destino del hombre, ya que permite la sincronización de sus acciones y la organización de la sociedad: ${ }^{182}$

"Sobre haver persona qui toque el reloig, por tiempo de hun anyo, visto seyr cosa a todos convenible, por saber de dia e de noche quantas horas son concordadas o passadas, fue providido quel dito acto remetan et remetieran a los regidores, presentes e advenideros, de la dita ciudat, que hi providiessen por forma e manera quel capitol de los clerigos, fidalgos, judios e moros satisfaziessen e ayudassen al Ioguero del toquant del dito reloig, et pagando el dito capitol, fidalgos, judios e moros qualquiere cosas qui sera providida por los ditos regidores presentes o ad $\neg$ venideros, o por la mayor partida de aquellos. Los ditos estantes en el dito conceio profirieron se haver por firme e ensemble por ellos e la dita ciudat. Fiat Iarge, testes ut supra."

La máquina del reloj asegura el flujo regular de la energía en los trabajos y hacían posible la producción regular y productos estandarizados y por tanto una mayor "calidad" de la energía que se aporta a la conformación del territorio.

Esta máquina complementó al resto, y permitió superar la principal debilidad del régimen eotécnico, que no estaba en la ineficacia ni menos aun en la carencia de energía, sino en su irregularidad. El depender de fuertes vientos continuos y de una corriente regular de agua limitaba la expansión y la universalización de esa economía. ${ }^{183}$

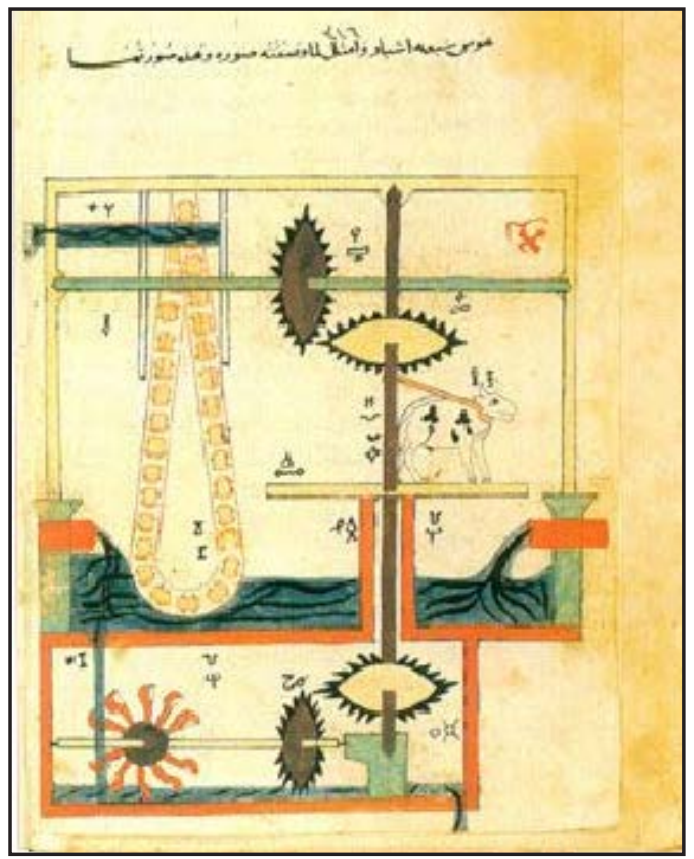

Fig. 6. 77. Dibujo de un autómata de Al- Jazari del año 1205.

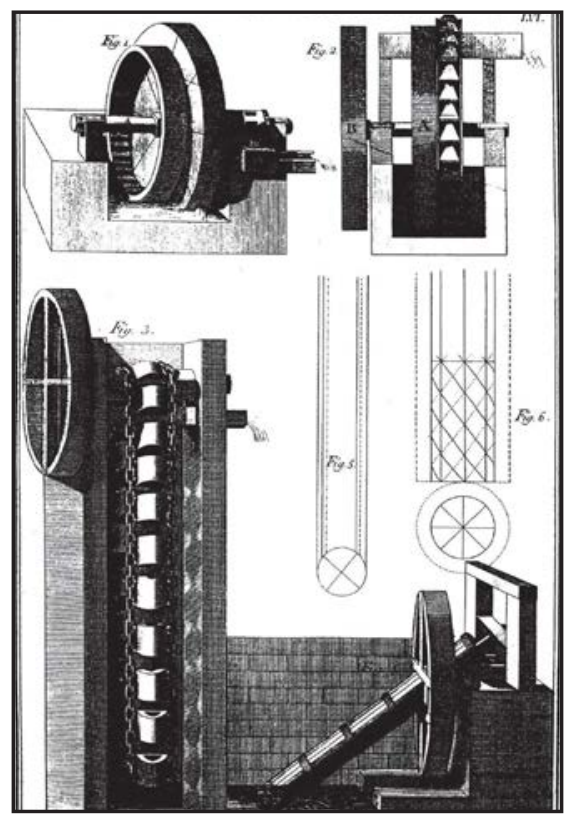

Fig. 6. 78. Dibujo de máquinas de Los Diez Libros de la Arquitectura de Vitrubio (27-23 a.C.) de la edición de Ortiz (1787).

182 Ver apéndices documentales no 49, 51 y 53, pág. 645 y pág. 645

183 Debemos a L. Mumford, el entender el papel dominante desempeñado por la técnica en la civilización moderna y la importancia de la preparación ideológica y social para que fructifique. Los avances técnicos resultan fruto de una cultura que esta dispuesta a utilizarlos y aprovecharse de ellos de forma extensa.

Según el la máquina ha invadido nuestra civilización en tres olas sucesivas. La primera ola, que entro en movimiento hacia el siglo X, acumuló e impulsó energía al tiempo que otras fuerzas de la civilización se debilitaban y dispersaban; este temprano triunfo de la máquina fue un esfuerzo para conseguir orden y potencia con medios puramente externos. Mumford la denomina eotécnica y las principales fuentes de energía son el agua y la madera. La segunda ola vino en el siglo XVIII con el perfeccionamiento de la minería y el trabajo del hierro, la denomina paleotécnica siendo la principal fuente de energía el carbón y la tercera surgió a principios del siglo XX con la invención de la electricidad y de las aleaciones, la denomina neotécnica y la fuente de energía la constituyen los combustibles fósiles derivados del petróleo, que Mumford no llegó a conocer. Hoy en día estaríamos ya en una cuarta fase. 


\section{La máquina social: el "jornal de vila"}

La primera máquina que se utilizó fue la máquina social, siendo la esclavitud el ejemplo paradigmático. La fuerza de varios hombres organizada y regulada obtiene importantes resultados, un gran aporte de energía que permite conformar el territorio.

En la época de la conquista, la esclavitud existía y su fuerza de trabajo fue utilizada de forma sistemática. No obstante nos interesa destacar la existencia de una fuerza organizada socialmente de gran importancia y que ha perdurado durante siglos.

Antes de la conquista en la época árabe los habitantes del territorio de un "husun" que vivían de forma tribal en las alquerías y que tributaba una serie de impuestos, tenían una obligación singular: la "zafra", que consistía en que de forma regular tenían que dedicar su tiempo y esfuerzo en suministra al castillo leña y agua, este trabajo lo hacían sin ninguna compensación a cambio. Era una obligación social para colaborar en dotar al castillo de suficientes medios para que posteriormente les sirviera como refugio y defensa.

Tras la conquista apareció una figura similar el "jornal de vila". Consistía en el trabajo que de forma gratuita debían realizar todos los habitantes de un municipio para obras de carácter colectivo como pueda ser la conducción de un acueducto, la construcción de murallas, la construcción de algún edificio público, etc.

El “jornal de vila”, que hasta hace pocos años aún perduraba, era una forma de aportación de energía muy importante por dos motivos:

El primero por ser un gran aporte energético sin coste para la colectividad (la monarquía o la Orden) que permitía afrontar una serie de obras de gran envergadura que con los medios que se disponía hubiera sido imposible realizarlos: ${ }^{184}$

"Si vero in superiori novo pariete vellet cooperire vel aliter hedificare, possit hoc facere, dummodo solvate primitus medietatem expense et operis a principio fundamenti facte usque ad locum quo edificaverit, cooperuit vel hedificatus fuerit, omni excusacione remota, omnes nobiles et milites, clerici et religiosi, cives et quecumque alia persona, quantecumque dignitatis sit, ad construccionem et reparacionem murorum et vallis, construcciones, reparacionem et mundacionem et ad instrucciones et mundaciones viarum publicarum et pontium et civitatis custodiam et mundacionem cequiarum et bra $\square$ allorum et ad prestandum cequiaticum de suo conferre teneantur, cum non sint predicta inter sordida munera numerata".

Segundo -y tan importante como la primera- es que era una fuerza, una energía que se dirigía en una dirección impidiendo con ello que se dirigiera en otra. Cuando los vecinos de todas las aldeas de Morella tenían la obligación de dedicar jornales de vila a la construcción de las murallas o del castillo de la ciudad de Morella, además de conseguir la realización de estas obras su esfuerzo dirigido hacia este hecho impedía que se pudiera dedicar a la construcción de las murallas de sus respectivos municipios. Era tan importante la aportación de energía que se realizaba como el lucro cesante de energía que se produce por no poder dedicar ese esfuerzo a otros cometidos: ${ }^{185}$

"Ea propter vobis dicimus et mandamus quatenus predictum abbatem et eius homines ac alios quoscumque infra terminum generalem dicte ville populatos iuris et fori remediis at contribuendum in opere antedicto districte et fortiter compellatis si et prout eiusdem seu eorum bona repereritis iuste et moderate taxatos fuisse et prout etiam hactenus in predictis ac similibus est fieri usitatum. Quibuscumque superse dimentis, provisionibus et litteris in contrarium sub quorumcumque expressione verborum factis et fiendis obsistentibus ullo modo."

El "jornal de vila" no solo construyó el territorio sino que además lo hizo en una determinada dirección, al consumir las energías en unas obras y por tanto no tenerla para dedicarlas a otras. ${ }^{186}$

184 Ver apéndice documental nº 19 pág. 617

185 Ver apéndice documental nº 46 pág. 642

186 "Mucho antes de que los pueblos del mundo occidental se volvieran hacia la máquina, el mecanismo como elemento en la vida social había aparecido ya. Antes de que los inventores crearan ingenios que ocupaban el lugar de los hombres, 


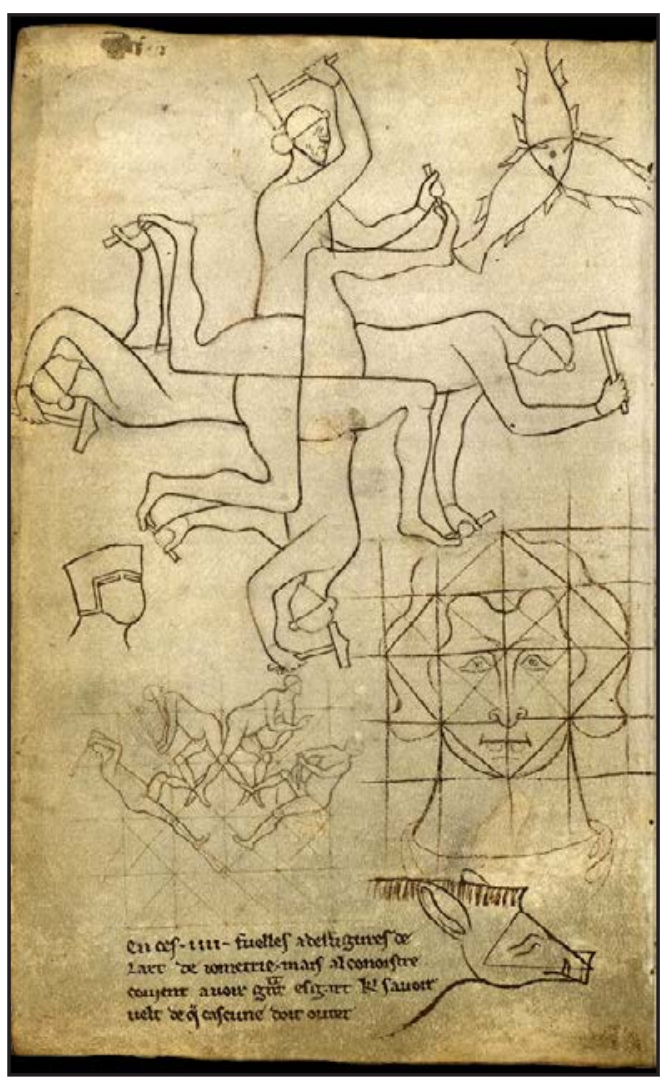

Fig. 6. 79. Lámina 38 del Cuaderno de Villard de Honnecourt (s. XIII).

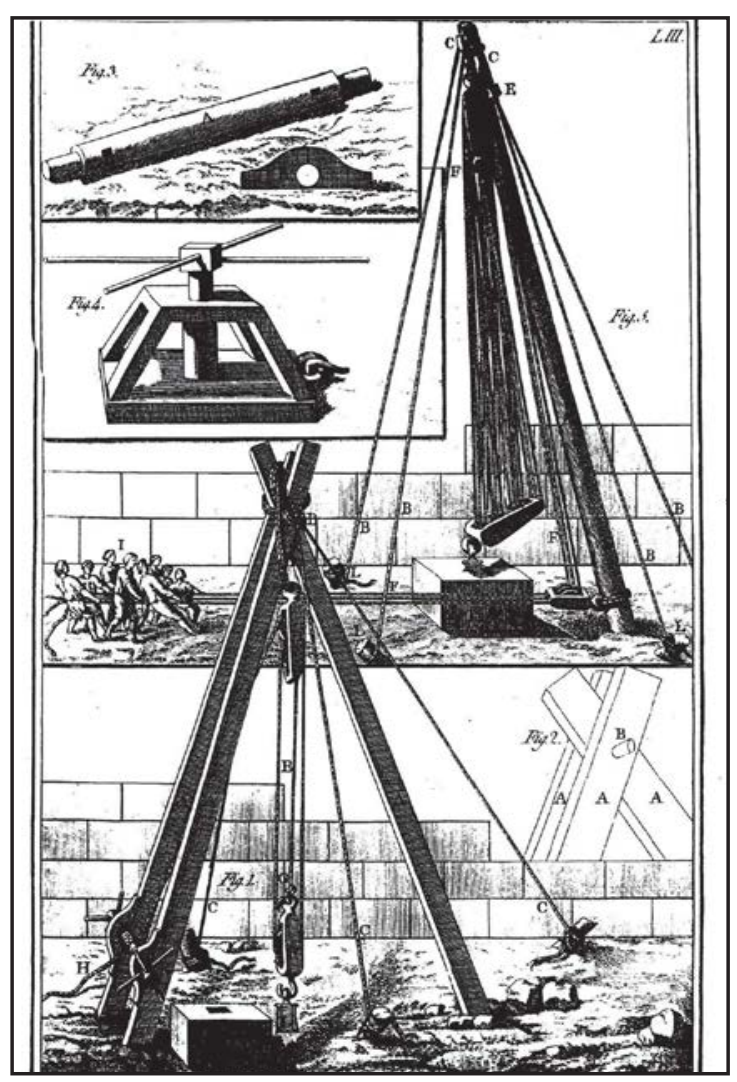

Fig. 6. 80. Dibujo de máquinas de Los Diez Libros de la Arquitectura de Vitrubio (27-23 a.C.) de la edición de Ortiz (1787).

\section{Pensamiento escolástico}

Como hemos visto, en la Edad Media, el territorio se conforma, rehabilita y transforma por la memoria depositada como información en la forma-la disposición, la proporción, los códigos, la huella y los hábitos-, pues bien ello fue posible por el cambio de mentalidad escolástica que trata de reconciliar la razón y la fe.

Esta "abertura de miras" que surge en los alrededores de París y con el crecimiento del estudio y de los conocimientos científicos a la luz de la razón, facilitan y propician que ese tipo de información que en un principio recoge las propias formas, luego posteriormente se complemente y acreciente con la llegada de la imprenta y el depósito de todo ese saber e información en los libros tanto de texto como gráficos.

Podríamos decir que existe una conexión entre el pensamiento escolástico y el territorio medieval del mismo modo que Panofsky habla de la relación entre la arquitectura gótica y el pensamiento escolástico.

Es un territorio que se "clarifica" con respecto al territorio mítico precedente. Se estructura con formas simples con una determinada disposición y proporción que permiten su comprensión y desarrollo. Como hemos visto se organiza por un sistema de partes perfectamente estructurado, como los tratados que se organizan a partir del siglo XIII conforme a un plan conjunmto, secundum ordinem disciplenae. Todo ello muestra que el territorio medieval al igual que los escolásticos hacían palpable el orden y la lógica.

los líderes de éstos habían ejercitado y sometido a control multitudes de seres humanos; habían descubierto como reducir los hombres a máquinas. Los esclavos y los campesinos que arrastraban las piedras para las pirámides, tirando al ritmo del restallido del látigo, los esclavos que remaban en las galeras romanas, encadenado cada hombre a su asiento e incapaz de realizar más movimiento que el mecánico limitado, el orden y la marcha y el sistema de ataque de la falange macedónica; todos ellos fueron fenómenos de máquina. Cualquier cosa que limite las acciones y los movimientos de los seres humanos a sus elementos puramente mecánicos pertenece a la fisiología, sino a la mecánica, de la edad de la máquina”. Mumford (56). 
Esta nueva mentalidad escolástica permitió obtener un mayor provecho a la información de la que se disponía en el Territorio y depositarla para las generaciones futuras como memoria "ordenada". Todo ello propició un consumo de energía más eficiente. ${ }^{187}$

En la documentación consultada encontramos distintas pruebas de esta nueva mentalidad, en diversos ámbitos de la vida medieval, ejemplos de ello serían:

- El control en el comercio mediante el sistema de pesas y medidas: ${ }^{188}$

"Quod marcha habeat et contineat in se octo uncias. Et uncia contineat in se viginti quatuor denarios, de denariis qui sint XVI solidorum de marcha.

Arrova et quarterium vini contineat XXX $\square$ libras.

Quintallus sit ad IIIIor. arrovis.

De arrova XXX libras, libra carnicerie habeat III libras, unamquamque librarum XII unciarum.

Kafficium habeat sex fanecas rasas. Fanecha habeat VIII $\square$ almutas rasas, et in medio et moris faneche sit virga ferrea et almuti oris; et os faneche et almuti sit ex omnibus partibus equales et similie."

- La definición pormenorizada en los contratos de obra como se pueden observar en el de la Iglesia de Olocau ${ }^{189}$ o en el de las vidrieras de la Iglesia arciprestal de Morella: ${ }^{190}$

"Item, que en los buyts dels archets,ço es en los pus alts age un cap pintat de la dita obra de la ymage de Jesu Christ, e en los altres buyts age a fer obra comú e de vidres compases.

Item, en los altres arxets aprés sie lo sinyal del dit en Miquel barreda, ço és lo camp vermell del escudet e la torre blava.

Item, que en el pany de en migsie lo crucificii, e de la huna part la ymage de Sancta Maria e lo Johan de la part altra.

Item, que en los segons panys de ça e dellà sie de la huna part Sant Pere e de la part altra Sent Paul, e en mig la Maria e son fill esús.

Item, que los terços panys, ço és mig sie la Trinitat e a la hun costat Santa Caterina e en "altre costat Sent Yvo, advocat dels pobres.

Idem, que en los IIII panys sie ficat en mig Sent Miquel ab la vibra e a la hun costat Sent Frencencesch et sent Anthoni de Padua de l'altre costat."

- El uso del dinero que conlleva una "contabilidad" pormenorizada, como podemos ver en los libros de los comerciantes de la lana: ${ }^{191}$

"48 sache di lana compramo da Giaome Ferriere di Morella, pesarono 241 ro(ve), 9 lib(re)(f.126)

83 ro(ve) di lana di Morella comprai de Michele Spigholo da Morella, 1(ibre)

$\mathrm{b}$ (archinonese) 70, s(oldi) 11 (f.138v)

166 ro. Di lana di Morella comprai da Ramondo Feriere del Forcaglio, Ib. 139, s.14 (f.140)

187 Tal como dice Erwin Panofsky en “Arquitectura gótica y pensamiento escolástico” en el periodo entre 1130-40 y 1270 se puede observar una conexión entre el arte gótico y la escolástica. Esta conexión más que un simple paralelismo es una autentica relación de causa a efecto. Esta relación de causa efecto se instaura más por difusión que por contacto directo.

"Se establece de hecho a través de la difusión de lo que puede denominarse, a falta de una expresión mejor, un hábito mental- entendido este utilizando cliché en el sentido escolástico más preciso:" principio que regula el acto". Tales hábitos mentales existen en todo tipo de civilizaciones. Así, por ejemplo, no hay escritos modernos sobre la historia que no estén impregnados de la idea de evolución y sin tener un conocimiento profundo de la bioquímica y del psicoanálisis, hablamos todos los días con la mayor suficiencia de insuficiencia vitamínica, de alergias, de fijaciones a la madre y de complejos de inferioridad" (pág. 31).

188 Ver apéndice documental nº 16 pág. 615

189 Ver apéndice documental no 35 pág. 627

190 Ver apéndice documental nº 47 pág. 642

191 Ver apéndice documental no 48 pág. 643 
417 ro. Di lana receveti da Giaome Moratone di Morella cioe e Portelli, Vila francha e Chastelforte del termini di Morella e fecila stivare, 83 sache deono dare, di 20 ottobe, Ib. trecento trentatre, soldi 12. Chomprai per messer Francho

Chornero a soldi 16 ro. Come apare in questo (Memoriale) a carta 45 (f.141 v.)"

\section{Cristalización de las normas consuetudinarias}

El desarrollo de la organización social propicio el desarrollo paulatino, que se fue gestando generación tras generación, transmitiéndose por medio de la costumbre y la lenta decantación de conocimientos. Las costumbres sociales, en nuestra ámbito de estudio, cristalizaran en instituciones que permitieron que el territorio se comportara como un sistema termodinámico abierto, entre ellas citaremos tres: El "mustaraf" que regia la actividad tanto comercial como constructora, los tribunales de las aguas que controlaban el riego y el "ligallo" que lo hacía de la actividad ganadera.

Estas instituciones eran muy coherentes con el tipo de sistema legal propio de Valencia y en general de la Corona de Aragón. En primer lugar, la España cristiana ofrecía un clima mucho más receptivo que el del mundo islámico para el desarrollo de un área de administración basada en normas consuetudinarias -esto era debido a que la "saria" se aplicaba de modo universal y no se contemplaban márgenes específicos para jurisdicciones especializadas-. En segundo lugar, estas fueron reguladas en los Furs de Valencia, el código promulgado por Jaime I, otorgándoles una firme base legal, de modo que cuando los Furs fueron "territorializándose" la misma jurisdicción se reprodujo, automáticamente, en docenas de centros urbanos. En tercer lugar, en la medida en que ganaron fuerza las tradiciones de jurisprudencia del derecho romano, con sus rigurosas prácticas curiales y procedimientos demostrativos, se beneficios el sistema legal en conjunto, al garantizar una amplia libertad a los eficientes y económicos (en coste y tiempo) procedimientos sumariales de las jurisdicciones especiales consuetudinarias. ${ }^{192}$

192 El Mustarab era un importante oficial en las villas y ciudades de la Corona de Aragón, especialmente en el Reino de Valencia; y se difundió, junto a un puñado de ordenanzas y regulaciones relativas a oficios específicos, reglamentados en provecho de una labor estandarizada y eficiente garantizada por monopolios locales y una amalgama de prácticas consuetudinarias seculares. Su origen lo encontramos en dos magistraturas griegas -agrónomos y astrónomos- que los musulmanes tomaron de las ciudades conquistadas al imperio bizantino y que los cristianos ibéricos útil mantener adaptándola en el siglo XIII con los nombres de almotacén en Castilla y mostassaf en Valencia y Cataluña.

Siguiendo la norma legal romana que consideraba las aguas como un bien público, els Furs de Valencia reiteraron la naturaleza pública de las aguas fluyentes. Pese a los primeros intentos de "señoralizar" los sistemas de riego, el control local largamente contrastados en la previa sociedad tribal musulmana, hizo que los señores que trataron de monopolizar el agua, advirtieron pronto la disfunción que habían introducido en el sistema ya consolidado y corrigieron sus errores. Cuando no lo hicieron los sistemas dejaron de funcionar. Los señores aprendieron a mantener como mantener para su propio beneficio, la autonomía de las comunidades de regantes, junto con sus normas de igualdad y equidad en la distribución del agua: los poderosos obtuvieron más beneficios dejando la institución de la cooperación del riego, haciendo cumplir sus normas del juego y dejando el control en sus manos (ver apéndice documental no 36 pág. 629). Aún hoy en día perdura el Tribunal de las Aguas de Valencia como exponente de este tipo de jurisdicción.

El "ligallo" era un tribunal que atendía los problemas surgidos por la actividad de la trashumancia. El primero que se concedió fue el de Morella en 1271 (ver apéndice documental no 44 pág. 640), mientras que en la Batllia lo fueron en La Jana- que comprendía los términos de Canet, Calig, Rosell, La Jana y La Barcella_ en 1358 y el de Cervera del que se tiene constancia desde 1384. El ligallo era un tribunal concedido a petición de los lugares afectados por el Maestre de Montesa. Cada año los jurados del baile local designaban un "Prohom." de dicho lugar que tenía que actuar como justicia del ligallo. El tribunal atendía las cuestiones relacionadas con los posibles conflictos entre ganaderos o entre estos y los municipios por los que se realizaba la trashumancia y pastaban los animales. Esta institución se abolió con la real orden de 16 de febrero de 1835. 

CAPÍTULO 7. EL DESARROLLO DE LA ESTRUCTURA DEL TERRITORIO DE LA BATLLIA EN LA EDAD MEDIA 



\section{1. Introducción. Complementariedad}

Una vez analizado el Territorio en la Edad Media como un sistema físico complejo, integrado por un sistema disipativo que genera y transforma energía y por un sistema autoorganizativo que recupera la energía disipada como información; vamos a profundizar en el tema y establecer una tesis de como se producen los cambios del territorio, de como se produce el crecimiento y desarrollo del sistema por la diferenciación interna y por la asimilación de elementos externos, y de como ésta llega a una fase de maduración y estabilización estructural del sistema o morfoestasis, gracias a su capacidad de autoorganización, para posteriormente llegar a su esclerosis y envejecimiento.

Propondremos un particular modelo de proceso evolutivo del territorio que nos permita tomar distancia conceptual respecto de las clásicas teorías con que se cuenta hasta el presente. Ello deviene así, no sólo en un modelo, sino en una teoría que difiere en algunos puntos centrales con las existentes hasta la fecha.

Si ello puede erigirse en el punto dominante de la propuesta, la misma no consiste tan solo en aportar una teoría sobre la evolución del territorio. El objetivo es hacer expresos los principios generales del territorio, esos principios que se cumplen en todo componente del mismo; y como parte de ellos, redefinir el concepto de territorio.

En primer lugar debemos detenernos en el concepto físico de complementariedad, ya que este presta servicio a la hora de evaluar la definición de Territorio, o mejor dicho la indefinición intrínseca del fenómeno territorial. El rol que se le debe asignar al concepto de complementariedad, es una muestra de la creciente importancia que puede tener incorporar conceptos de física para recrear conceptos y generar una nueva visión del Territorio. ${ }^{193}$

Los aludidos principios generales no son un descubrimiento, tan solo se pretende "soplar" algo de aire fresco, operar algunos cambios conceptuales y rescatar de las penumbras de lo "tácito", los principios mencionados. Ello puede contribuir a tenerlos más presentes, expresos, y conceptualmente más claros. Puede ayudar también, a relacionarlos mejor, y por qué no, a recrearlos desde un punto de vista distinto de los conocidos.

\subsection{Estructura y función}

La estructura bien observada permite conocer, indirectamente, datos sobre la función, sea cual sea el componente del territorio medieval que se observa. Sin embargo, para conocer datos directos sobre la función de uno de ellos, hay que verlos funcionar, del mismo modo que se observa la estructura, para tratar de conocer la misma.

Cuando un componente se destruye, y con ello pierde tanto su estructura como su función, no causa sorpresa, ni lleva a plantearse extrañas consideraciones sobre la naturaleza de su ruina. En cambio, si tan sólo dejan de funcionar, pero conservan su estructura, surgen algunos profundos interrogantes sobre la naturaleza y definición del fenómeno territorial. Tal es el caso en el que la estructura tiende

193 El principio de complementariedad nos dice que dos propiedades son complementarias cuando ambas son necesarias para proporcionar una descripción completa del sistema u objeto al que pertenecen.

La idea nació en la década de los 20 del siglo pasado, y su ejemplo clásico desde entonces ha sido la posición y el momento de una partícula. Al ser dos variables complementarias, no se las puede medir con igual precisión más allá de cierto límite fundamental, que viene dado por el principio de incertidumbre. Y en cierto modo, la complementariedad es considerada por muchos, como una simple consecuencia del principio de incertidumbre. Sin embargo, existen pruebas de que ésta no es la única razón por la que aquella se impone. Se trata en realidad, de un carácter más general y profundo que la mera ley de incertidumbre. La complementariedad es bajo esta óptica, un rasgo esencial de la realidad que se impone más allá de dicho principio.

Si dibujamos las trayectorias de dos átomos sobre un plano, las curvas se "interfieren" cuando se cortan. Al introducir un grado más de libertad - la tercera dimensión-, aparecen las correlaciones. Estas se simbolizan levantando una de las líneas a un plano que esté por encima del primero. Las curvas dejan de cortarse, y desaparece el patrón de interferencia. Para prescindir de las correlaciones se debe ignorar la tercera dimensión, proyectando las líneas sobre un solo plano común. Esto hace que parezca que las líneas se cortan, aunque en realidad discurren una sobre otra. 
a conservarse más allá del cese de la función.

Los componentes "fantasma", o sus restos, son todo lo que queda de lo que alguna vez fueron activos, estuvieron en uso. Si la estructura puede persistir sin la función, ¿podrá la función persistir sin su estructura?; o en otras palabras, así como puede existir la estructura sin actividad ¿podría existir actividad territorial sin estructura? Indudablemente que no, la función está indisolublemente unida a la estructura. Y la razón de esta unión indisoluble, es que se trata de propiedades complementarias. La estructura y la función, son variables interdependientes. ${ }^{194}$

La naturaleza del territorio medieval, es a la vez morfológica y funcional, y lo que se observa es el patrón de correlaciones entre ambas propiedades. Dichas propiedades podrían, teóricamente, presentarse cada una por separado. Pero en tal caso, la ausencia de las mencionadas correlaciones, implica la ausencia de su razón de ser tal y como la conocemos.

Más allá de cuáles sean sus causas, lo que hace la ruina, es disociar la estructura de la función, evitar las correlaciones entre ellas. Y como dichas correlaciones son las que sustentan la identidad efectiva del territorio, éste la pierde al cesar las mismas. Si se conserva la estructura, quizá sea posible, bajo las condiciones adecuadas, restablecer las correlaciones que permiten integrar la estructura con la función inicial u otra nueva.

De todas formas, la complementariedad entre dos variables impone que, no se las puede conocer a la vez con igual precisión. Cuanto más se sabe de una, menos información se tiene de la otra En física, el más socorrido ejemplo viene dado por la posición y el momento de una partícula, ya que cuanto con más precisión se conoce la posición, menos precisa es la información que se dispone sobre su momento. Ello se debe a que la posición y el momento, son propiedades complementarias.

En el territorio se pueden buscar muchos ejemplos, pero uno que puede resultar elocuente, es el del tejido preindustrial asociado a uno agrícola de regadío. En muchas ocasiones el uso de los molinos está asociado al uso agrícola de regadío para aprovechar al máximo la energía potencial del agua a lo largo de las distintas estaciones y de las distintas condiciones climatológicas que pueden llegar a producirse. El tejido esta diseñado para optimizar uno u otro uso según las necesidades, en los periodos de mayor uso del molino los cultivos está supeditado a éste, mientras que en otras épocas los cultivos no tienen esa cortapisa. Pero todo ello en función del emplazamiento en el que se encuentren y del caudal del curso de agua que aprovechen.

El cambio de uso de estos tejidos, hacen las veces del momento-época del año y condiciones climatológicas- para una partícula y la morfología del tejido -más agrícola o más industrial- hace las veces de la posición. Y del mismo modo que la posición y el momento no se pueden conocer a la misma vez con la misma exactitud, la estructura y la función tampoco se pueden determinar a la vez con igual precisión.

La consecuencia de esto es, curiosamente, lo que lleva a responder el interrogante central ¿qué es el territorio medieval? Si bien es claro que es el resultado de la integración entre cierta y particular estructura, con ciertas y particulares funciones, ello no basta para definir el fenómeno. Y no basta, porque las propiedades estructurales y funcionales, son complementarias e interdependientes, es decir, se encuentran relacionadas.

Que la función hace a los componentes territoriales, es indudable al apreciar que un tejido agrícola de regadío tiene una forma lineal a lo largo del curso de la acequia, pero no se puede pretender que la

$194 \mathrm{La}$ interdependencia es un fenómeno que se presenta cuando un componente individual del sistema es influenciado por el comportamiento de los otros componentes. Los científicos llaman a este fenómeno acoplamiento. Dos partes del sistema se dicen que están fuertemente acopladas si ellas tienen una gran influencia una con la otra. Las partes están flojamente acopladas si la influencia está presente, pero no de manera extrema. Las partes están desacopladas cuando no existe ninguna influencia entre ellas. Frecuentemente el nivel de acoplamiento en un sistema afecta el monto de tiempo requerido para propagar un cambio de una parte a otra del sistema. En una organización, el acoplamiento afecta la velocidad de transmisión de la información y la efectividad de los esfuerzos impulsores del cambio.. 
forma de un acueducto -como el de Morella- solo esté motivada por su función. ${ }^{195}$

\section{1. 2. Determinismo y azar}

La indefinición objetiva de un fenómeno como el territorial, sugiere que, tanto la estructura como la función pueden encontrarse sometidas a cierta casualidad objetiva. En otras palabras, la estructura y la función presentan un rasgo de indeterminismo, propio del azar. La casualidad objetiva, indica que los cambios que observamos, ocurren por la intervención del azar. Por lo tanto, todo lo que podamos saber sobre un sistema activo, es sólo probable, una aproximación al conocimiento del mismo.

Por otra parte el territorio medieval presenta una rara condición de no localidad. Esto se aprecia al observar que, ciertos procesos generales se expresan en más de un nivel de su organización. Sin que medie intercambio de información entre los diferentes niveles de organización, lo que ocurre en uno, afecta "no localmente" a otro, sin que se establezcan relaciones entre ellos.

Algunas de las propiedades fundamentales que describen el fenómeno biológico, se ajustan a la perfección para describir el fenómeno territorial. Cuando se estudia la estructura y la función, que definen a un componente territorial -arquitectura, red, lugar, tejido, ciudad o parte completa-, o cuando se estudian las relaciones de ellos entre sí y con el territorio en su conjunto, la descripción biológica resulta confiable.

La evolución del territorio tiene una orientación y sentido definidos, no sigue un patrón guiado exclusivamente por el azar. Su evidente direccionalidad, revela un profundo determinismo. La casualidad no opera en la selección, sino que se trata de un proceso con claras relaciones causales. Se trata de un proceso definido, causal y determinístico. Y sin embargo, ambos procesos son inseparables a la hora de considerar la evolución tanto biológica como territorial. De modo que, a cierto nivel, el proceso evolutivo responde a patrones "casuales", y en otros, a patrones "causales".

El determinismo y el azar, siguen sin poder sacarse ventaja absoluta. Es probable que el azar y el determinismo, coexistan para describir la realidad, de igual modo que la estructura y la función son variables complementarias, y no procede privilegiar una sobre otra.

La implantación de una acequia en un territorio, determina su transformación como es el caso de la plana de Vila-real. Pero en otros casos como el del río Cenia una sentencia "salomónica" -puro azarproduce que según en qué tramo del río y en qué rivera se produzca un desarrollo territorial u otro. No hay por qué elegir entre el determinismo y el azar, y aún más, es sumamente interesante la exploración de la frontera entre ambos. El conocimiento del territorio medieval, se ve afectado directamente por este marco de conocimientos.

\section{1. 3. Materia y energía}

La estructura del territorio medieval, es el resultado de cierta transformación de la materia, lo que genera su morfología. Si bien hace falta energía para producir y mantener el territorio, con la energía sola no se genera estructura. Lo fundamental para generar estructura, es la materia. Con ella, se construye y genera estructura.

Las funciones son, en cambio, el resultado de la transformación de la energía. Y si bien se requiere de estructuras morfológicas que sustenten estas funciones, es claro que ellas por sí mismas no funcionan.

195 La complementariedad entre estructura y función estaría a nuestro entender presente en el concepto de "formatividad" que emplea Rafael Moneo en su discurso de ingreso en la Academia de Bellas Artes de San Fernando: "Sobre el concepto de arbitrariedad en Arquitectura". Según él este concepto aspira a dar razón de la forma desde su "hacerse", buscando así la coincidencia entre el resultado, entre el objeto físico y tangible al que se ha llegado y los principios lógicos y formales que estuvieron presentes en su origen. Tanto la invención de los lenguajes, tratando de racionalizar la construcción y uso, como la explicación de la arquitectura que se apoya en formas previas indiscriminadas, quedan englobadas en este amplio concepto que pretendería explicar la arquitectura -y nosotros añadiríamos el territorio- desde su propia interioridad, desde la descripción del proceso que la vio nacer (pág. 55 discurso). 
Lo fundamental al generar una función, es la transformación energética que ella implica, ya que sin ella no hay función.

La materia puede transformarse y generar diversas estructuras, así como la energía puede transformarse en otras formas de energía. Pero es importante recordar que, la materia puede transformarse en energía, del mismo modo que la energía puede transformarse en materia. Luego, si cuando la estructura de un componente territorial pierde la energía que le suministraba el entorno al que esta asociado y "muere" por insuficiencia, se conserva la morfología inerte, ¿se conserva también la energía?

La energía se conserva por una parte en el propio componente territorial como información, pero también se mantienen la energía potencial, a la espera que el nuevo componente o uno nuevo que allí se asiente haga uso de ella. ${ }^{196}$

Cuando se rehabilita para el uso hostelero un conjunto como el del Santuario de la Virgen de la Salut de Traiguera, se está recuperando la energía potencial que en él permanecía latente.

1

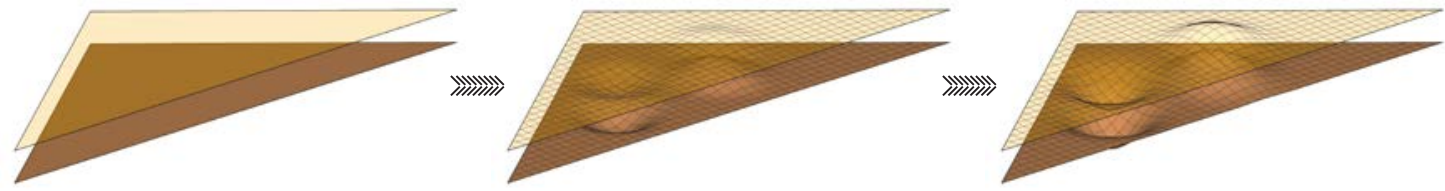

2
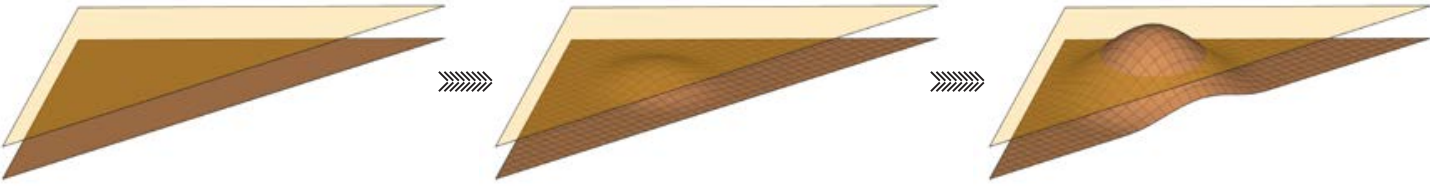

3
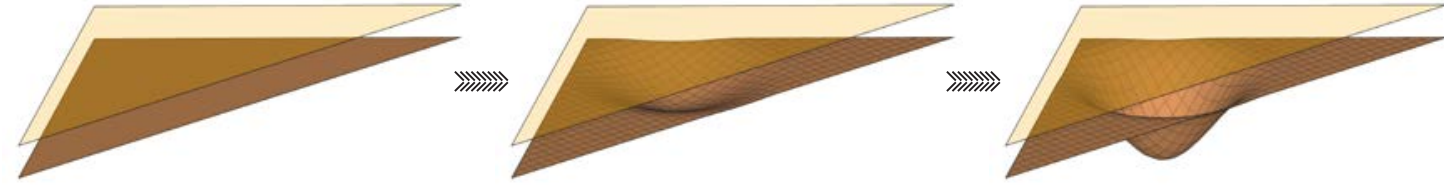

4
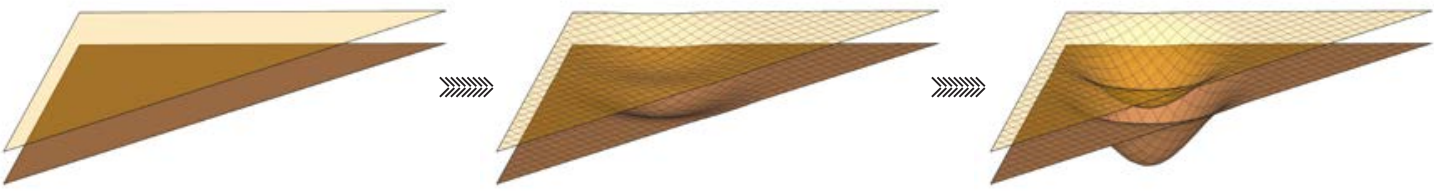

Fig. 7. 1. Si en vez de referir la actividad territorial al tiempo cronológico, se analiza la actividad territorial en relación a sí misma, la visión de estas cuestiones cambia radicalmente. Se podría grafiar la estructura y la función como dos planos superpuestos triangulares de nuestro soporte, de modo que las modificaciones funcionales se observen como un alabeo del plano inferior. Aumentos de la actividad dibujarán elevaciones, al paso que las reducciones de la actividad generarán depresiones. Las elevaciones harían irrupción en el plano superior, ondulándolo, o destruyéndolo, mientras que las depresiones semejarán hoyos en los que el plano inferior se despega del superior, succionándolo sin destruirlo, o dejándolo absolutamente indemne.

1. Los incrementos lentos y eficientes del consumo energético en el desarrollo de las funciones contribuyen a generar cambios morfológicos, por lo que en el gráfico se verán como suaves ondulaciones de ambos planos. Un aporte de energía lento y eficiente, como el de los regadíos, produce una transformación del territorio.

2. Si se trata de incrementos agudos e ineficientes se apreciará como una elevación abrupta y empinada del plano inferior que rompe la estructura del plano superior. Un aporte de energía agudo e ineficiente, como el incendio de la ciudad de Morella, provoca la "rotura" de la estructura.

3 . El caso del colapso energético extrínseco, no permite la destrucción estructural, por lo que en el gráfico se verá como una depresión del plano inferior, que se despega del superior sin alterarlo en lo más mínimo. El colapso extrínseco de una sequía prolongada provoca que la estructura del regadío se mantenga igual sin alterarla.

4. Pero cuando el colapso es intrínseco, aunque la estructura tampoco se destruye, se modifica, simplificándose, por lo que en el gráfico se apreciará como un hoyo del plano inferior, que succiona al plano superior aunque sin llegar a romperlo. El colapso intrínseco de la falta de mantenimiento de un regadío provoca el lento y paulatino deterioro en su estructura.

196 En el mundo de la biología, la posibilidad de retornar a la vida una célula congelada, son una clara muestra de que esa energía existe, y deja de ser potencial cuando el organismo retorna a la vida. El regreso de las condiciones adecuadas para poder continuar con las transformaciones energéticas, posibilita la utilización de la energía hasta entonces potencial, generando funciones biológicas. 


\section{2. Morfoestasis}

La estructura del territorio medieval se puede asimilar a la superposición de distintos tapices que se van tejiendo a lo largo del tiempo uno sobre otro, a partir del cañamazo inicial del soporte territorial. Cada "nuevo" tapiz está constituido por una serie de "esferas" entrelazadas: arquitecturas, lugares, tejidos, ciudades y partes completas del territorio, que conforman una unidad en el mismo tiempo y lugar.

Las características estructurales de cada uno de estos componentes o capas se definen por su estructura y su función, lo cual no implica que se los pueda definir, habida cuenta de que se trata de propiedades complementarias e interdependientes.

Cada una de estas esferas es, en esencia, un sistema que administra la información y la energía en función de sí mismo, como una unidad. Esto le permite relacionarse con el medio y con otras esferas, lo que es una de las más importantes funciones que debe afrontar. Estas son las condiciones mínimas que se deben cumplir. Si no hay información, no hay "cómo" relacionarse, ni "quién" se relacione; y si no hay energía, no hay "con qué" hacerlo.

Con la información y la energía se puede generar estructura, y desarrollar las funciones territoriales propias de cada uno de las esferas. Nada más por debajo del nivel esfera/arquitectura, reúne tales propiedades. ${ }^{197}$

Del estudio y análisis de la estructura del territorio y del funcionamiento del mismo, hemos podido comprobar la existencia de cuatro principios generales: identidad, relación, evolución y organización que se dan en cada uno de sus componentes -arquitecturas, lugares, tejidos, ciudades y partes completas de territorio- y que nos permitirán elaborar un modelo de morfoestasis del mismo.

\section{2. 1. Identidad}

La idea, bien desarrollada por R. Margalef, se extiende desde el campo de la física al de la vida en todos sus niveles, abarcando desde la ecología a la organización infracelular. Básicamente, todo ser vivo -o componente territorial- resulta del acoplamiento de dos sistemas, uno disipativo o energético, y otro autoorganizativo o informativo. De ellos devienen luego, la estructura y la actividad.

Pero se debe insistir en que, la estructura le confiere al componente territorial una identidad morfológica, la que en realidad no basta para definirlo como tal, si la estructura en cuestión no realiza ninguna función. Cierta identidad "a secas", nos permite reconocer que se trata de una estructura diferente del medio que la rodea, pero no se podrá decir que se trate de un componente territorial, ya que no desarrolla ninguna función. La identidad "efectiva" requiere, en cambio, que ocurran funciones, las que se resumen de una u otra manera, al intercambio de información y energía con el medio y otras esferas/componentes. ${ }^{198}$

La energía que administran los componentes territoriales en la Edad Media al desarrollar sus funciones es renovable. Por una parte aprovechan la energía del agua, viento y madera de los bosques y por otra la del hombre y animales -previa transformación metabólica de la energía de los alimentos-. Todas ellas podemos considerar que vienen en primera instancia de la energía del sol y de la gravedad como ocurre en todos los ecosistemas de la naturaleza.

197 Este nivel inferior seria asimilable al término "coronema" que Javier García-Bellido define en su tesis doctoral: "Coranomía: Los universales de la urbanística, estudios sobre las estructuras generativas en las ciencias del territorio", como "primera escala o ámbito espacial universal, celda básica y más simple de las relaciones espacio-medio-hábitat".

198 Un ejemplo de ello sería la ciudad de Split (Fig. 6. 69. en la página 524) y el Palacio de Diocleciano (Fig. 6. 70. en la página 524); una misma estructura según cual sea su función es un componente territorial distinto (ciudad) o arquitectura/ palacio. 
La información que administran los componentes corresponde por una parte al soporte físico -topología, climatología y actividades de los seres vivos- y por otra a la estructura antroposocial -actividades humanas y costumbres sociales-.

Lo que destaca a la identidad como un principio general para todos los componentes territoriales, es que independientemente de cuáles sean las características morfológicas y funcionales, todos ellos administran la información y la energía que poseen cada uno para desarrollar sus actividades, en función de sí mismos.

Las características locales de la información y la energía, revisten interés para cada uno en particular, pero no para todos en general. Lo que generaliza el principio de identidad, es que todos administrarán esa información y esa energía -sea cual sea-, en provecho de sí mismos.

La variabilidad morfológica de los componentes territoriales -esfera/arquitectura, esfera/lugar, tejidos, esfera/ciudad y esfera/parte completa de territorio- es la manifestación material de cómo se administran la energía y la información.

Todos los componentes, cada uno a su nivel, gracias a la complementariedad existente entre la estructura y la función y a la forma en la que se administra la energía y la información, les permiten tener un centro y un límite claramente definidos.

Ello es lo que nos ha permitido a lo largo de este trabajo identificar 9 tipos de arquitectura, 14 tipos de lugares, 9 tipos de tejidos, 4 tipos de ciudades y 6 tipos de partes completas de territorio.

\section{2. 2. Relación}

El principio de relación impone que, todo componente territorial se relaciona con otros de su propio nivel o de niveles superiores y con el medio, lo que implica un intercambio de materia, energía e información entre ellos. El carácter de este principio, es complementario del principio de identidad, al que se encuentra directamente vinculado.

Las funciones que contribuyen a definir la identidad de un componente territorial o esfera, implican el intercambio de materia, energía e información con el medio, o sea, su relación con el mismo. Del mismo modo, la relación con el medio, que implica las funciones a que se hace referencia, son las que hacen efectiva la identidad del mismo.

Tal es la vinculación entre los principios de identidad y relación, que ambos contribuyen mutuamente a definirse. No hay identidad efectiva sin relación, del mismo modo que no hay relación sin identidad. Es obvio que, si no hay "quién" se relacione (identidad), no hay relación posible; y si quién debe relacionarse no lo hace, no es posible que exista una identidad efectiva.

Cuando se dice que los componentes territoriales se definen por su estructura y su función, no se debe olvidar que la razón que subyace a tal definición, es la administración de la energía y la información. Si se tiene en cuenta que la estructura no es condición suficiente-aunque sí necesaria-para definir la identidad de un componente territorial, resulta claro que sus estructuras son consecuencia del manejo de la información y energía que estos llevan a cabo. La morfología que observamos, es la manifestación material de la administración de la energía y la información.

Las relaciones de los componentes territoriales o esferas entre sí y con su medio, influyen directamente sobre el desarrollo de los mismos. Dependen de factores intrínsecos, de factores extrínsecos y de la predisposición topológica del tapiz sobre el que se encuentran. Son factores intrínsecos la existencia de fuerzas centrípetas que favorecen la atracción y cohesión y la permeabilidad de los límites que permiten la transferencia de información y energía. Son factores extrínsecos la existencia de una red de infraestructuras que permita la transmisión de flujos y el control de las interferencias exógenas que puedan perturbar las relaciones.

Ejemplo de fuerzas centrípetas serían los hornos que ejercen como elementos catalizadores, normalmente se ubican en las ciudades y "fortalecen" el centro de un determinado territorio. Cuando 
se sitúan fuera de una ciudad pueden llegar a tener tal fuerza centrípeta en el territorio de su alrededor que pueden llegar con el tiempo-junto con otras fuerzas que se suman a ello-a ser el germen de una nueva ciudad. Este sería el caso del mas dels Stellers en la Edad Media, que con el tiempo paso a ser el núcleo urbano de Sant Jordi.

Ejemplo de permeabilidad lo es el tejido preindustrial conformado por los lugares molinos; sus límites tienen tal permeabilidad que por una parte es fácil añadir un nuevo lugar/molino al tejido a partir del eje del curso fluvial principal, pero además la red de infraestructuras de las acequias y desagües del tejido es susceptible de ser utilizada como red de riego agrícola. Son infraestructuras permeables a tener diversos usos compatibles entre sí.

Factores extrínsecos son por ejemplo la construcción de una acequia de riego que cambia el uso de gran parte del territorio. Este sería el caso de la construcción de la acequia mayor en Vila real que "divide" el territorio originalmente con las mismas condiciones en dos diferentes: aguas abajo de la acequia es suelo agrícola de regadío y aguas arriba de secano -una vez más la gravedad rige la evolución del territorio-. Caso similar sería el de la acequia del margen izquierdo del río Cenia que convierte las tierras de Ulldecona en la Edad Media en suelo agrícola de regadío, mientras que al no existir ninguna acequia en el margen derecho, las tierras de la Batllia de Cervera no serían de regadío. La topología establece la predisposición a la relación de cada componente con su nivel superior de un determinado modo. Así las arquitecturas se relacionan con los lugares; los lugares con los tejidos; las arquitecturas, lugares y tejidos con las ciudades; las arquitecturas, lugares, tejidos y ciudades con las partes completas de territorio. La relación con el medio, juega un rol importante en la determinación del desarrollo del territorio.

Finalmente, los dos principios hasta aquí enunciados podrían resumirse así: Todos los componentes territoriales tienen una identidad, y la hacen efectiva por medio de su relación con el medio, ésta reviste el carácter de un principio general, pues todos ellos cumplen con él. Las condiciones locales del medio, no influyen en la existencia de la relación, ya que sean cuales sean esas condiciones, los componentes, inevitablemente, van a interactuar con el medio y entre ellos.

Sin embargo, este principio general tiene consecuencias locales. Y la consecuencia local más importante, es la adaptación morfológica de los componentes territoriales. Esta es la manifestación material del intercambio de materia, energía e información. No puede existir adaptación de los componentes a las nuevas situaciones sobrevenidas sino existe relación entre él y el medio, aunque puede haber relación sin lograr adaptarse.

La relación de una esfera con su entorno, puede o no, devenir en adaptación. La adaptación implica la relación, pero ésta no implica que deba existir aquella, ya que la relación es una condición necesaria pero no suficiente, para que exista adaptación.

Como se dijo, la relación es un principio general que no depende de las condiciones locales del medio, todos los componentes se relacionan con el medio. La adaptación, en cambio, depende de las condiciones locales del medio, y no todos ellos logran adaptarse en el curso de su relación con el entorno; por ello, la adaptación es claramente, una consecuencia local de un fenómeno de orden general, como el principio de relación.

Obviamente, un fenómeno local no puede encuadrarse, como un principio de alcance general para todos los entes. Esto no denosta la jerarquía del proceso de adaptación, tan importante para los componentes territoriales, sino que lo acota a las condiciones locales que lo definen, mientras que el principio de relación, surge claramente como una condición general para todos ellos. 


\section{2. 3. Evolución}

Todos los componentes territoriales, además de tener una identidad y hacerla efectiva a través de su relación con el medio, evolucionan. Pero la cuestión no es sencilla, y pasa por definir las ideas primordiales de las bases sobre las que se asienta lo que llamamos evolución:

1. La diversidad de los componentes territoriales se basa en la variabilidad tipológica y en la selección de aquellos más aptos para desarrollar las funciones de la antroposfera.

2. La diversidad tiene un doble origen. La evolución del embrión-tipo o esfera/arquitectura que da respuesta a las instituciones humanas desde sus orígenes y la importación de un tipo exógeno a la cultura receptora.

Los pilares de la evolución son la variabilidad, la adaptación, la selección y la universalidad del proceso. La idea central de la evolución, descarta de plano la suposición Lamarckiana de que "las jirafas estiraron su cuello porque debieron comer de las copas de grandes árboles, y así tras varias generaciones fijaron el carácter para su especie". ${ }^{199}$ La teoría de la evolución supone, en cambio, que en algún momento los precursores de las jirafas sufrieron un cambio en su acervo genético que, sumado a otros cambios generó el fenotipo que se les conoce, con su majestuoso cuello largo. El ambiente en el que se debieron desenvolver, privilegió a aquellos especímenes que, por poseer dicha característica, pudieron adaptarse mejor a su ambiente. La presión de la selección forzó así, la supervivencia de los más aptos para adaptarse a su peculiar ambiente. Los más aptos podrían dejar descendencia, fijando el carácter para su especie, y los menos aptos dejarían cada vez menos, hasta que sus genes desaparezcan con ellos.

Razonamientos similares los podemos trasladar al territorio. Cuando en los años 60 del siglo XX se produce una importante presión urbanística sobre el área urbana de Castellón por la masiva emigración atraída por el desarrollo de la industria cerámica, el crecimiento se produce sobre el tejido agrícola de regadío medieval, procedente de una centuriación romana, llano, con accesos, agua, desagües, energía eléctrica y por tanto "adaptado" a un crecimiento rápido, discontinuo y económico que supuso el desarrollo de la urbanización marginal. El área urbana de Castellón creció de un determinado modo -como ocurre con el cuello de las jirafas- por que se privilegió un tejido agrícola medieval previamente sobre otros tejidos que no fueron capaces de dar respuesta a las necesidades que el crecimiento urbano demandaba.

Siguiendo con este ejemplo del mismo modo que algunos viejos saurios originaron a las aves, o cómo algunos reptiles originaron a los mamíferos, en el caso que hemos citado un tejido agrícola puede originar un tejido urbano.

La evolución produce finalmente componentes con mayor capacidad de adaptación. Esta es una de las consecuencias locales de aquella, pero no es su única ni más importante consecuencia. La adaptación es un proceso particular de cada componente con su medio, y sólo se limita a ese restringido marco de referencia. No se trata de un proceso universal y general, sino netamente local, de cada componente y el medio en el que se desenvuelve.

La evolución, en cambio, es un proceso de carácter universal. Esto significa que no es un proceso particular, de cada componente y su medio. La evolución es un proceso que ocurre a todos los componentes "en general", pero no a cada uno en particular. Para comprender esta sentencia, es imprescindible saber a qué nos referimos cuando mencionamos a los componentes "en general". ¿Cómo puede un proceso, ocurrir a todos los componentes en general, pero no ocurrirle a cada uno de ellos en particular? ¿Cuál es el significado de "en general”? ¿Qué cosas son generales para todos ellos?

La respuesta se encuentra sólo con repasar las características generales de los componentes, lo que

199 LAMARCK, J.B. “Filosofía zoológica” Ed. Mateu. Barcelona 1971 pág. 98 
nos lleva a los ya enunciados principios generales de identidad y el principio de relación. Como ya se dijo, todos ellos tienen una identidad y la hacen efectiva por medio de su relación con el medio. Esto les permite evolucionar, que es el tercer principio general que describimos. Cualquier componente territorial cumple con estos tres principios, de identidad, relación y evolución.

Pero dentro de ellos, el principio de identidad es el que especifica las propiedades que definen a los componentes. La estructura y la función se asimilan a la administración de la información y la energía, lo que explica que la identidad se haga efectiva a través de la relación en provecho del propio sistema. Esas son las características comunes a todos ellos, cualquiera sea su procedencia, época, origen o nivel de organización. Y es en términos de esas características que se debe analizar el proceso evolutivo, ya que ellas son las únicas de valor universal y general sin excepción para todos.

La evolución tendría que definirse entonces, como la tendencia hacia una creciente eficiencia en la administración de la información y la energía.

En la Edad Media el territorio evoluciona de una forma evidente, porque respecto a épocas pretéritas consigue ser mucho más eficiente en la administración de la energía y la información, y para ello podemos poner tres ejemplos:

- La eficiencia en la administración de la energía se produce por la implantación sistemática de arquitecturas capaces de aprovechar la energía exógena del agua, viento y madera, con la construcción de molinos, hornos, etc. que producen un rendimiento mucho mayor que el aportado por la energía humana o animal.

- En la producción agrícola y ganadera se generan excedentes que permiten evolucionar por bucle de retroalimentación que permiten y con ello obtener una mayor rentabilidad de la energía consumida.

- Se extienden las ciudades como forma de organización en todos los territorios, favoreciendo con ello una mayor eficiencia en el trabajo social o colectivo y sobre todo una mayor eficiencia en la administración de la información. Es en las ciudades donde gran parte de la información es "depositada" y donde es transmitida consiguiéndose con ello una mayor eficiencia.

Pero además en ésta época y en esta zona del Mediterráneo concurre otra circunstancia especial que favorece la evolución del mismo. Se trata de la importación de un tipo constructivo foráneo -el arco perpiaño- que permite un gran número de adaptaciones de las arquitecturas existentes hasta el momento y con ello una rápida evolución del territorio en su conjunto.

Las aportaciones exógenas, suponen un súbito aporte de información y energía, además de la capacidad de administrarlo con más eficiencia. Este seria el caso de la importación del gótico desde oriente medio a la comarca de la Batllia, con el gran cambio que ello supuso.

El origen de la transformación arquitectónica suscitada en estas comarcas y sus limítrofes a partir del siglo XIII se debe en gran parte a la influencia que ejerce la arquitectura persa, materializada de forma indirecta por la influencia bizantina en la evolución del románico al gótico y de forma directa por la importación con los cruzados -de las órdenes militares- de esta arquitectura.

En la arquitectura persa podemos encontrar el germen de la arquitectura gótica. La importación de la información que se produce por las Cruzadas, permite que un nuevo tipo arquitectónico a partir de los arcos perpiaños "arraigue" en estas comarcas y sea fundamental en el desarrollo de este territorio. La importación de un sistema constructivo más eficiente por su rapidez, economía y sencillez y que además permite "perforar" los muros de carga y crear espacios direccionales -donde antes solo había espacios centrales-, posibilitó que todos los componentes territoriales se adaptaran de una nueva forma y ello permitió la posterior evolución de muchos de ellos.

Si se pretende que una teoría explique los mecanismos para generar diversidad a partir de un remoto pasado común, lo primero que se debe hacer, es preguntarse "qué" cosas son comunes a todos los entes territoriales, desde la primera arquitectura que se originó, hasta el último de ellos: una parte completa de territorio. 
Y la respuesta es, todos administraron la energía y la información en función de sí mismos. La mayor capacidad de adaptación que tienen los componentes territoriales al evolucionar, es la consecuencia de ser más eficientes para administrar la energía y la información.

Un claro ejemplo es la evolución de la arquitectura/torre hacia la masía/torre; la necesidad de que la arquitectura y su lugar administren por sí mismas la energía e información necesarias para mantener su identidad, propician que la torre en determinados lugares se adapte como masía/torre, simbiosis que permite mantener la identidad, relacionarse y por tanto evolucionar. Pocas son las torres aisladas que han perdurado, mientras que las masías/torre gracias a su adaptación han perdurado en gran medida.

Cuando se dice que la evolución produce componentes cada vez mejor dotados para adaptarse a su ambiente, la razón que explica el punto, es que la evolución implica producir componentes cada vez más eficientes.

Es importante que el proceso evolutivo se defina de esta manera, y no como la mera tendencia a producir componentes con mayor capacidad de adaptación. De lo contrario, es fácil caer en yerros de interpretación. Así, algunos perfectamente adaptados a su ambiente, pueden erróneamente, considerarse como más evolucionados que otros que se encuentren pasando por serias dificultades adaptativas.

Tal situación encierra por lo menos, dos potenciales errores. Uno es que, uno puede hallarse cómodamente adaptado a su ambiente, simplemente porque el mismo no ha presentado alteraciones importantes. Y otro es que, aun cuando el ambiente cambie y él se adapte, se debe considerar también el acerbo de información y energía con que se cuenta.

Que un tejido "preindustrial" de la Edad Media -constituido por la relación entre los lugares-molinos a lo largo de un curso fluvial- se convierta en un tejido industrial en el siglo XIX, no implica en sí, que sea más evolucionado que otro. Lo único que esto implica, es que se ha adaptado correctamente al ambiente en el que le toca vivir.

Sin embargo, muchos "murieron" sin poder adaptarse al cambio y la cuestión pasa a ser dominio de las causas por las que algunos tuvieron una mayor capacidad de adaptación. La pregunta es: ¿Por qué algunos pudieron hacerlo? Y la respuesta es: porque administraron con más eficiencia la información y la energía.

El tejido que se adaptó no sólo fue porque debió, sino también porque pudo hacerlo -por ejemplo por su mejor relación con las redes de transporte-. El que pudo lograrlo, representa un grado evolutivo mayor que el de los que no pudieron tener éxito. Pero el grado de evolución, no es la consecuencia de haberse transformado en un tejido industrial, sino la causa que les permitió hacerlo.

Pero aun así, queda por saber la razón por la que algunos componentes se tornan más eficientes que otros. Y la respuesta está en la variabilidad. Aquellas variaciones tipológicas que posibiliten un incremento de la eficiencia, contribuirán a generar modelos que serán más utilizados.

Si se piensa con detenimiento en el asunto, se verá que nos permite entender la razón por la que, aún después de haber originado el tejido industrial, algunos lugares-molinos siguieron "dando batalla" en muchos cursos fluviales. La razón es que, tanto unos como otros se encontraron perfectamente adaptados a su ambiente. En ello, nadie lleva ventaja más allá de su marco adaptativo.

Si estas cosas se comprenden en su esencia, cuando en nuestros días aparece un nuevo tejido turístico en estos lugares-molino, no se puede decir que se está en presencia del proceso de evolución. Es claro que lo que ha ocurrido, es un proceso de adaptación. El tejido podrá ser "nuevo", pero pertenece a un nivel de organización territorial que hace ya mucho que existía, y es expresión de un bajo grado de evolución, también ya existente. Lo único que ha ocurrido, es que ha aparecido una nueva variante adaptativa, de un tipo de tejido ya largamente conocido. Evolutivamente, con ella no ha aparecido nada nuevo.

El proceso evolutivo no genera directamente arquitecturas, redes, lugares, tejidos, partes completas o ciudades, sino que produce las condiciones generales para que la existencia de tales componentes territoriales sea posible. 


\section{2. 4. Organización}

La organización de los componentes territoriales es otro principio general y es la consecuencia de la evolución. Pero esto no debe mal interpretarse. La evolución puede producir componentes más eficientes, sin que ello requiera obligatoriamente de un incremento del nivel de organización. La evolución no tiene la obligación de generar nuevos niveles de organización, pero la aparición de un nuevo nivel de organización es consecuencia de la evolución.

La organización general de los componentes encierra una interesante particularidad, la que puede expresarse como sigue: El territorio no desecha las formas más primitivas, sino que se sirve de ellas para producir las formas más complejas.

Que no se desecha lo primitivo por el sólo hecho de que surge una variante más evolucionada, se aprecia en el caso de las primitivas núcleos urbanos que siguen existiendo con las grandes ciudades de forma similar a como continúan existiendo las formas unicelulares aisladas, en un mundo de seres pluricelulares en ocasiones muy evolucionados.

Pero esto no debe llevar a falsas interpretaciones, la organización no es la evolución, sino la consecuencia de aquélla. La organización de los componentes territoriales, es una consecuencia de su grado evolutivo. Arquitecturas con un bajo grado de evolución, pueden requerir sólo de lugares reducidos que le bastarán para que el componente en cuestión pueda adaptarse a su territorio. Pero aquellas que posean un mayor grado de evolución, pueden requerir de una organización más compleja, y es probable que lo hagan bajo la forma de tejidos o de ciudades.

Al evolucionar, los componentes incrementan su acerbo de información y energía, así como la eficiencia con que lo administran. Ello genera cambios morfológicos y funcionales que pueden incrementar la complejidad en su organización. El tejido más simple, puede hacer muchas más cosas que las que podrían hacer sus lugares por separado. ${ }^{200}$

Los componentes aislados, persisten porque se encuentran perfectamente adaptados a su ambiente. Son tan eficientes como necesitan serlo, ser más evolucionados no implica ningún tipo de superioridad e independencia de las formas más simples. Después de todo, las formas más complejas, están constituidas por las inferiores, y dependen de ellas en más de un sentido.

Dada la profunda relación causal que entrelaza la evolución con la organización, es de esperar que en la organización se encuentren las huellas de la evolución. Así, no sorprende que en cada nivel de organización, se puedan reconocer los pasos de la evolución hasta ese nivel.

Es obvio que el proceso evolutivo es único y general para todos ellos, ya que se refiere a aquellas condiciones compartidas por todos, sea cual sea su nivel de organización, de modo tal, que el proceso evolutivo puede observarse en cualquier nivel de organización.

No hay ciudades que carezcan de tejidos, o tejidos que no tengan lugares. La arquitectura, es un componente territorial -el más simple nivel de organización posible-. Pero si una ciudad que es el más complejo y, por lo tanto posee tejidos, es seguro que tiene arquitecturas, ya que los tejidos se constituyen con lugares y estos con arquitecturas.

La formación de ciudades, implica la asociación de tejidos y, obviamente, la presencia de los lugares que los constituyen. Y así se puede seguir hasta conformar el Territorio entero. No se podrá transgredir el patrón de organización. Y ello se debe a que el mismo, es una consecuencia directa, aunque no obligatoria de la evolución -se puede evolucionar sin aumentar obligatoriamente, el nivel de organización-.

En cada nivel de organización, la eficiencia es mayor, y el acerbo de información y energía que se administra también es mayor. Y ello se debe a que la organización es la consecuencia de la evolución. En la medida que se incrementa el grado de evolución, los componentes pueden pasar a un nivel de organización superior, sin que por ello se confunda evolución con organización.

200 Varios lugares-molino aislados gestionan la información y la energía con menor eficiencia que un tejido de molinos que coordina el uso de la información y energía entre ellos. 
La evolución es la tendencia a incrementar la eficiencia en la administración de la información y la energía -y a administrar más información y energía-. Mientras que la organización se define como la manifestación material de los cambios morfológicos y funcionales de los componentes territoriales al incrementar información, energía y la eficiencia en su gestión, permitiendo que la evolución se haga efectiva. Un territorio puede ser muy eficiente, pero si no se organiza en función de poder manifestar esa eficiencia, o pone de manifiesto su mayor capacidad de adaptación -aunque no genere un nivel superior de organización-, no hace efectivo su mayor grado evolutivo. En cualquier caso, no se debe perder de vista que una de las piezas más importantes de esta "maquinaria" para generar diversidad, es la variabilidad. Las variaciones pueden o no, comportar un aumento de la eficiencia. Sólo si lo hacen, generan evolución. Ello podrá significar para el componente, un incremento de su capacidad de adaptación, sin requerir de cambios en su nivel de organización. $\mathrm{O}$ bien puede implicar, además de una mayor capacidad de adaptación, profundos cambios en su nivel de organización.

Y como corolario, se puede decir que, los componentes territoriales tienen una identidad, la que hacen efectiva por medio de su relación con el medio, y ello les permite evolucionar. El proceso evolutivo los lleva, finalmente, a organizarse, haciendo efectiva la evolución. Cualquier ente territorial que encontremos verificará estos cuatro principios, de identidad, relación, evolución y organización. La diversidad que conocemos en el territorio, empieza y termina en estos cuatros principios generales. Sin el cumplimiento de los dos primeros principios, no hay desarrollo, y si no se cumplen los últimos dos, su diversidad se reduce, autolimitado el proceso territorial.

Las variaciones que perjudiquen la eficiencia con que un territorio administra la energía y la información de que dispone, le restan capacidad de adaptación, y están destinadas a perecer. Lejos de generar evolución y favorecer la diversidad, la disminuyen. Son las constricciones

Pero las variaciones que incrementan la eficiencia del territorio, aumentan su capacidad de adaptación, lo que constituye la esencia del proceso evolutivo, favoreciendo la diversidad, son las catalizadoras. Y como ya se dijo, algunos cambios producen mayor capacidad de adaptación, pero el mismo puede hacerse efectivo sin necesidad de recurrir a un incremento de la organización; aunque en ocasiones, la mayor capacidad de adaptación sólo puede hacerse efectiva por medio de un incremento en el nivel de organización.

En todo caso, sólo son evolutivos aquellos cambios que aumentan la eficiencia del componente territorial para manejar su energía y su información. Y sólo algunos de esos cambios, requerirán un incremento del nivel de organización. Pero todos ellos, desde el más simple al más complejo que se conozca, se organizan. ${ }^{201}$

Para Javier García-Bellido en su tesis "Coronomía. Los universales de a Urbanística, estudios sobre las estructuras generativas en las ciencias del Territorio", la organización se crea por la aparición de "nódulos de condensación" de cada vez mayor grado de complejidad que son complementados por un emergente grado de orden "en vertical" que el denomina "centros emergentes de orden global de complejidad". 202

201 Un sistema territorial posee cierta información, y cuenta para administrarla, con cierta organización. Esto es de vital importancia, ya que la organización viene a significar algo así como el sistema informático de hardware y software que permite la correcta administración de la información. Nadie que utilice alguno de estos sistemas desconoce que, según sean las necesidades del operador, se requiere de diferentes sistemas para analizar la información. La calidad y cantidad de la información, requieren para su adecuado tratamiento, de diferentes sistemas. Un pequeño equipo de uso doméstico, no puede administrar la información que maneja uno destinado a administrar el flujo satelital de comunicaciones internacionales. La cuestión en los componentes territoriales, también pasa por saber "cuándo" la información es mucha para el sistema, o sea ¿cuándo es necesario un sistema de mayor capacidad para administrar la información, que de lo contrario se torna excesiva? Lo que en los componentes territoriales se traduce en "¿cuándo se requiere de un mayor nivel de organización para administrar con eficiencia, una información que se puede tornar excesiva para el ente?"

Si la información es poca, el componente no cuenta con los suficientes "datos" para configurar su identidad, y si la información es mucha, el sistema se torna caótico y no puede mantener la identidad.

202 Las interacciones entre los elementos o partículas sueltas definen un proceso que se efectúa en todo gas caótico, sin que por el hecho de darse tales interacciones durante varios Giga-años se creen estructuras per se. Los cambios internos de la organización se producen mediante aceleradores o catalizadores que favorecen y seleccionan determinadas reacciones reestructuradoras, de tal modo que los individuos que entre sí quedan aleatoriamente mejor interconectados que con otros vecinos, acaban conformando "nódulos de condensación" o "centros de reestructuración" capaces de llegar a autoorganizarse con un orden interno propio diferenciado del de sus vecinos más alejados.

Cuando las reacciones interactivas siguen creciendo por aporte de nuevos elementos -tanto endógenamente generados 
Para otros autores como Kauffman la razón de ser de la organización la encuentra en las redes boolenas aleatorias que contribuyen a desarrollar el modelo del "atractor". El sistema se define por el número "N" de sus elementos y por el número de entradas que gobiernan su comportamiento "K". Su idea se resuelve en un modelo matemático en el que el comportamiento de cada elemento del sistema, se traduce en una simple variable binaria (sólo toma uno de dos valores posibles: Activo /Inactivo). El estado de cada variable está regulado por el de otras que operan como señales de entrada. Una es la función "O", que estipula que la variable por ella gobernada se encontrará activa siempre que lo esté al menos una de sus variables de entrada.

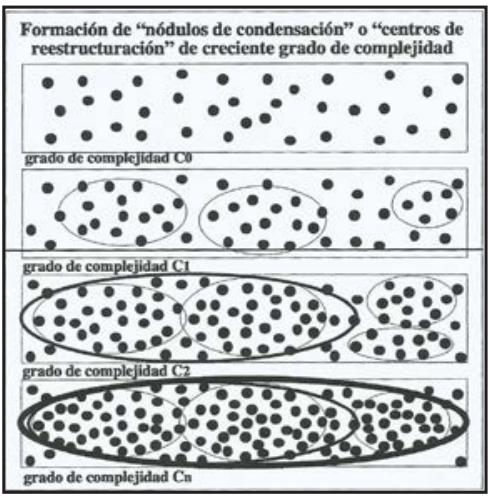

Fig. 7.2. Esquemas gráficos Javier GarcíaBellido explicativos nota al margen.

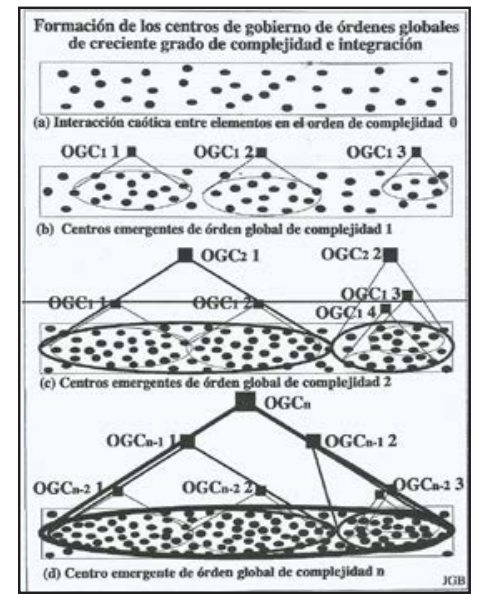

como exógenamente- se irán creando nuevas probabilidades de mayores interacciones entre los grupos o nódulos ya formados con otros individuos o grupos de condensaciones similares. El proceso es creciente (negentrópico) mientras haya un constante e ininterrumpido aporte de materia y energía externa al sistema considerado mayores probabilidades se darán cuanto mayor sea el número e intensidad de individuos y grupos que interactúan dentro del sistema abierto. Ahora bien, el que se den mayores probabilidades de contacto entre grupos locales o individuos sueltos no implica que necesariamente lleguen a dotarse de una autoorganización estructurada en su ámbito global. La aparición de un nódulo de concentración o grupo organizado es solo posible cuando las lógicas y reglas de agregación-asociación de los individuos sueltos son complementadas (no sustituidas) por una emergente grado de orden "en vertical" diferente al orden local en que ellas aisladamente se hallen, pudiendo llegar a autoconfigurar así una estructura socio-política nueva (cofradía, ciudad, pueblo, nación...).

Precisamente diremos que se ha generado un orden global con grado de complejidad 1 (OGC1) cuando emergen nuevas lógicas globalizadoras que cristalicen o reestructuren el conjunto con una nueva organización interna capaz de articular el grupo cohesionándolo y gobernándolo con una categoría colectiva de orden "vertical" superior. Es decir cuando las reglas de interacción del grupo -aún siendo homólogas y homotéticas con las anteriores y sin llegar, en ningún caso, a romper la simetría de grupo- vienen ya dictadas y gobernadas por centros de poder capaces de crear, imponer, controlar y sancionar nuevas normas y prácticas políticas de cohesión y articulación en un grado de complejidad de orden superior al inmediatamente anterior.

Esto implica que los grados de libertad de los individuos o unidades quedan parcialmente restringidos y sometidos al todo, hasta el punto en que pueden ser sacrificadas ciertas expresiones de soberanía y autogobierno de las precedentes libertades en nombre del interés colectivo del grupo, considerado ahora como una nueva unidad colectiva.

Los grupos de condensación ya reestructurados junto con los nuevos individuos sueltos pueden seguir creciendo y formando tantos grupos globales más grandes como nuevos nódulos o grupos locales de estructura global. En el estadio de orden de complejidad 2 (OGC2) interactuaran varios grupos locales de OGC1 para generar un grupo global respecto a ellos dotado de una nueva estructura de orden superior a la anterior; es decir un sintagma colectivo de complejidad 2, que viene caracterizado por la aparición de un centro de poder y gobierno con facultades de orden superior a la mera asociación de los grupos globales de complejidad 1. Y así sucesivamente, habrá orden global de complejidad n cuando los individuos interactuando en el orden de complejidad n-1 pierdan su autonomía en y por la emergencia de un centro legítimo de poder delegado con facultades para imponer reglas desde la perspectiva global de orden n sobre las individualidades locales de orden $\mathrm{n}-1$.

La clave del proceso reside en que, según aumente la complejidad de interacción, asociación-agregación de individuos/ unidades en el ámbito local, emergerán nuevos tipos de problemas y conflictos que requerirán nuevos instrumentos de gobierno y control de los mismos, apareciendo como insuficiente o incapaz de resolverlos las reglas de interacción basadas en el mero consenso interpares en el ámbito local. Entonces y solo entonces emergerá necesariamente la consciencia de la necesidad de un superior grado de complejidad de orden global, autodotándose el sistema de un centro de poder, de gobierno y control con facultades y medios necesarios y suficientes para poder resolver ese género de conflictos sólo resolubles desde un ámbito global. 
La otra función es "Y”, que estipula que la variable estará activa cuando lo estén todas las variables de entrada. ${ }^{203}$

La organización en ambos casos está vinculada directamente al tamaño y la forma de los componentes. En este contexto, se puede plantear la cuestión de ¿Cuál es el límite en el tamaño de las entes? Y si se recuerda que todos los entes dependen de la aportación de energía externa, la respuesta se convierte en un problema de geometría.

Los componentes -arquitecturas, redes, lugares, tejidos, partes o ciudades- no pueden crecer más allá del tamaño máximo que les permita administrar con eficiencia la información y la energía.

Si tales límites se exceden, en el caso de las células, estas se dividen o mueren. Cuantas más pequeñas son las células, mayor es el área por unidad de volumen, por lo que el flujo a través de la membrana puede ocurrir rápidamente, permitiendo una gran actividad metabólica. Células de gran tamaño, en cambio, serán metabólicamente inactivas, como ocurre con los huevos no fecundados. En ellos, la activación metabólica que acaece tras la fertilización, da inicio a la segmentación, permitiendo a las células hacer frente a las nuevas demandas metabólicas.

La organización biológica consiste básicamente, en la integración jerárquica de sistemas subsumidos en sistemas. El fenómeno en virtud del cual, los componentes de un sistema vivo se unen entre sí para engendrar estructuras de mayor complejidad y estabilidad, en las que aparecen propiedades nuevas e imposibles de predecir a partir de los componentes individuales, recibe el nombre de "autoensamblaje".

La célula dispone sus componentes de forma tal que ahorren máxima energía y masa a través de una tensión ininterrumpida y una compresión local -integridad tensional-. En realidad, no sólo las células se hallan sujetas a estas reglas de construcción, sino que las mismas restricciones espaciales rigen en toda la naturaleza, al margen de la escala o posición. ¿Los lugares o las ciudades no se comportan igual que las células? Después de todo, ¿que otra cosa es el desarrollo embriológico, sino una recapitulación de las etapas de autoensamblaje?, y ¿la estructura del Territorio medieval que hemos descrito no es un autoensamblaje?

Pero la organización en el Territorio está también vinculada de una forma muy estrecha a la topología. En primera instancia por que uno de los primeros eslabones de la organización son los lugares y estos están "fundidos" con la topología y en segundo lugar porque las relaciones que se establecen entre los componentes más evolucionados crean una red de flujos que inicialmente en la Edad

203 El sistema como dice Kauffman se define por el número "N" de sus elementos, y por el número de entradas que gobiernan su comportamiento " $\mathrm{K}$ ". Conociendo los valores de $\mathrm{N}$ y $\mathrm{K}$, se pueden definir una serie de redes con las mismas características locales. Al ser finitos tanto $\mathrm{N}$ como $\mathrm{K}$, el número de estados posibles también es finito, por lo que la red está obligada a recorrer cíclicamente dichos estados, con cierta periodicidad. Y la región del espacio de parámetros que atrae las trayectorias, se denomina "atractor dinámico" de la red.

Las redes $\mathrm{N}=\mathrm{K}$-llamadas gaseosas- son máximamente desordenadas y caóticas, pues al crecer $\mathrm{N}$, la longitud del ciclo crece exponencialmente. Hay unos pocos atractores -quizá sólo uno- que reclaman para sí unos pocos estados posibles, pero sumamente largos de recorrer. Este tipo de red, es altamente sensible a las condiciones iniciales, y las más pequeñas perturbaciones, modifican drásticamente su comportamiento.

Las redes $\mathrm{K}=2$-llamadas líquidas-, exhiben una tendencia espontánea al orden. Resultan además, muy poco sensibles a las condiciones iniciales, por lo que se dice que son redes "homeostáticas". En estos sistemas de N elementos el estado de uno cualquiera de ellos depende del estado de otros dos elementos del sistema, cobrando los mismos valores de estado, ciclo tras ciclo, formando "islas o núcleos congelados" de elementos que se enclavan en ciertos valores y permanecen invariables. Las redes $\mathrm{K}=1$-llamadas sólidas- son tan ordenadas que, evolucionan rápidamente hacia la formación de bucles de retroalimentación aislados, que no interactúan entre sí. Esto les confiere pocas posibilidades de sortear las más mínimas perturbaciones, sean minimales o estructurales. Las posibilidades de adaptación a los cambios, son nulas.

En la organización territorial, mantener el sesgo crítico, la baja conectividad, y $\mathrm{K}=2$, es de vital importancia, o sea, gran cantidad de información correctamente administrada, de forma tal que genere y mantenga la organización. En la medida que el $\mathrm{N}$ crece, las posibilidades de caer en el desorden son mayores, y sólo se evita el caos aumentando la eficiencia en la administración de la energía y la información. Cuando la cantidad de información atenta contra el sesgo crítico y la baja convectividad, K tiende a aumentar y el sistema se desordena. Se puede decir que la información es "mucha" para el sistema, que perece, incapaz de administrarla.

El único "remedio", es generar un nuevo nivel de organización, que permita retomar los valores de sesgo y convectividad necesarios para que el valor de $\mathrm{K}$ sea nuevamente 2. Esto se vincula íntimamente con el tamaño y la forma de los entes, así como con el concepto de integridad tensional. 
Media se "apoyaban" en la topología inicial del soporte, pero que conforme ha ido evolucionando el territorio, se han "separado" de él y han creado una nueva topología que se superpone a la del soporte inicial. En el modelo propuesto por Javier García-Bellido los "nódulos de condensación" iniciales se encuentran todos ellos en el mismo "plano" por estar la red de flujos que conectan los distintos componentes "apoyada" en la topología del soporte inicial. Sin embargo los "nódulos de condensación" conformados por los "centros de gobierno de órdenes globales" se encuentran en un plano diferente, la red de flujos que los une conforman una nueva topología y este hecho como veremos es de una gran importancia en la organización del territorio. 


\section{3. La esclerosis y el envejecimiento del territorio}

\subsection{La pérdida de la identidad}

Los componentes del territorio medieval administran la información y la energía que poseen en función de sí mismos y los distintos tipos de componentes-arquitecturas, lugares, tejidos, ciudades y partes completas- son la manifestación material de cómo estas se administran. Cuando en el binomio estructura/función se pierde el segundo, el centro deja de actuar como tal o los límites se difuminan, los componentes pierden su identidad.

La pérdida de la identidad se puede deber a cuatro motivos:

- Cuando la estructura pierda su función y con ella su identidad, se convierte en una ruina. Sería el caso del tejido ganadero medieval, que perdido su uso, se han convertido sus elementos: pastos, abrevaderos, corrales, azagadores en "restos arqueológicos".

- Si la estructura no se queda sin función, pero se produce un cambio de uso, también se ve afectada la identidad. Cuando el Castillo de Cervera dejo de ser el centro de la Batllia para trasladarse este al Palau Mestral de Sant Mateu, continuo siendo un importante baluarte defensivo pero perdió su identidad inicial.

Cuando el valle de la Barcella dejo de tener prioritariamente un uso ganadero y paso el uso agrícola a ser tan importante como él, la identidad de este territorio se vio afectada.

- Si disminuye la energía que se aporta y que por tanto que se administra, la identidad también se ve modificada. Ello puede ser motivado por la falta de caudal de agua por una sequía prolongada en un tejido preindustrial; por la falta de mano de obra por las epidemias en los lugares/masía o en un tejido agrícola o por la incapacidad del territorio de suministrar a "su" ciudad los alimentos necesarios para su subsistencia.

- Si disminuye la información que se aporta y que por tanto administra, la identidad también se ve modificada. Ello puede ser motivado por el traslado de determinados servicios urbanos de una ciudad a otra como en el caso de Cervera que al dejar de ser el centro comarcal las actividades mercantiles y artesanales se perdieron en gran parte en detrimento del nuevo centro comarcal en Sant Mateu. O la proximidad de un núcleo urbano como el de La Jana al de Carrascal, hace que el más pequeño no administre la misma información que el mayor y acabe esclerosándose.

\section{3. 2. La interrupción de las relaciones}

Como ya hemos visto en el territorio medieval se produce el intercambio de materia, energía e información con el medio, es decir, cada uno de los componentes con todos aquellos que necesita para mantener su propia identidad. Las arquitecturas, lugares, tejidos, ciudades y partes completas deben de estar relacionados para poder efectuar dichos intercambios.

Se puede producir la pérdida de las relaciones por:

- La interrupción de los factores intrínsecos, bien por la desaparición de las fuerzas centrípetas que permiten la relación con un determinado componente territorial como sería el caso del traslado del centro de la comarca desde el castillo de Cervera al Palau Mestral de Sant Mateu que produjo la perdida de "atracción" por parte del castillo de Cervera en detrimento del Palau y con ello la modificación de la estructura del territorio de la Batllia; o bien por la "interferencia" de otra fuerza centrípeta próxima, este sería el caso de como el núcleo urbano 
del Carrascal es absorbido por las fuerzas centrípetas del núcleo urbano de La Jana, que se encuentra muy próxima.

- La interrupción de las fuerzas intrínsecas también se puede deber a la pérdida de la permeabilidad de sus límites y con ella de la facilidad de transmisión de flujos en el territorio. Ello se produce en territorios de montaña como Bel o de valle como la Barcella, en la que sus propios límites se convierten en un inconveniente para su desarrollo, al no permitir una transmisión fluida.

- La aparición de factores externos pueden ser favorables a las relaciones, pero en otras ocasiones son desfavorables. La disminución del número de habitantes por las epidemias, de las cosechas por la sequía o los cambios de uso en un territorio pueden provocar que disminuyan las relaciones-la transmisión de flujos de energía e información-y los territorios afectados se esclerosen. El abandono de Rosell o el posterior decaimiento del valle de la Barcella son motivados por este tipo de factores externos.

Otro factor importante es el de la inseguridad en el territorio. Esta provoca que las relaciones no se puedan establecer con la suficiente fluidez y hacen que el proceso de desarrollo se estanque. Prueba de ello la encontramos en el territorio de estudio que durante dos siglos antes de la conquista fue un territorio fronterizo, y por tanto con una gran inseguridad, que no permitió su desarrollo.

- Por último la perdida de las relaciones se puede deber a la propia capacidad de las redes para la transmisión de los flujos; bien por resultar insuficientes para las nuevas necesidades que va demandando el territorio, como sería el caso de las redes en los territorios de montaña como Bel o de valle como La Barcella que por las condiciones topológicas no permiten la transmisión adecuada de flujos o bien por verse modificadas por nuevos elementos como un puente que prioriza unos flujos nuevos en detrimento de los existentes previamente a su construcción o la construcción de un puerto como el de Peñíscola que modifica la realidad topológica y la red de flujos. La importancia de la transmisión de flujos hacia el puerto de Peñíscola, hizo que en parte las relaciones con el resto de comarcas vecinas a las de la Batllia se vieran modificadas, ya que se potenciaron las que se producían con la costa mediterránea. Con el paso del tiempo fue creando una nueva red de flujos que conecta sobre todo las ciudades y que es ajena a la topología inicial del soporte. Esta nueva red dejó "desconectados" partes del territorio que acabaron esclerosándose.

\section{3. 3. La ineficiencia en la administración de la energía}

La evolución del Territorio de la Batllia en la edad media en ocasiones se vio frenada por la insuficiencia energética que provoca la ineficiencia en la administración de la misma. Ejemplos de ello en el territorio de la Batllia y similares son:

- Si comparamos el caso del Monasterio de Benifassar con el de la Batllia y su núcleo principal Sant Mateu, podemos comparar como dos organizaciones similares que administran la información y la energía no solo partes completas de territorio sino una región más amplia; podemos observar como San mateo - una ciudad- al ser la integración jerárquica se sistemas subsumidos en sistemas, le permite evolucionar hacia una estructura de mayor complejidad y estabilidad de cada vez mayor eficiencia, mientras que el monasterio no es capaz de hacerlo por ser una estructura más monolítica y por tanto más ineficiente.

- El aporte discontinuo de energía como el que se da en determinados tejidos preindustriales situados en los cursos de los barrancos-como el del Molinar de Xert o el barranco de los molinos de Ares-, hace que estos no tengan la misma eficiencia que otros en cursos con más caudal continuo como el del río Cenia o el Bergantes en Els Ports, a no ser que en 
los correspondientes tejidos se dispongan de balsas de regulación que permitan tener una administración de energía más eficiente.

- Las torres aisladas en el Territorio fueron desapareciendo de la comarca en detrimento de las masías-torre que tenían una mayor eficiencia al ser autosuficientes.

- La concentración de la energía -gracias al trabajo social del "jornal de vila"- en determinadas zonas del territorio en detrimento de otras, frena el desarrollo de estas y crea desequilibrios territoriales por la insuficiente aportación de energía en determinados lugares.

\section{3. 4. Desorden y caos}

Cuando la evolución de los componentes territoriales medievales dejó de estar guiada por la eficiencia en la administración de la información y la energía, la manifestación material de los cambios morfológicos y materiales se tradujo en desorden y caos.

La falta eficiencia puede ser debida al mal funcionamiento de los "centros de gobierno" de los que habla Javier García-Bellido en su tesis (ver nota al pie 202 en la página 552).; este puede ser debido a:

- Cuando no emergen nuevas lógicas globalizadoras que cristalizan o reestructuran el conjunto con una nueva organización interna -centro- capaz de articular el grupo cohesionándolo y gobernándolo con una categoría colectiva de orden "vertical" superior. Sería el caso de las cofradías que, existentes en diversos núcleos urbanos de la Batllia, nunca llegaron a conformar un tejido y por ello han ido poco a poco desapareciendo.

- Los centros que se crean, no son capaces de reunirse en grupos globales de orden superior. El resultado es que los "módulos de condensación" son tan ordenados que evolucionan rápidamente hacia la formación de bucles de retroalimentación aislados, que no interactúan entre sí. Esto les confiere pocas posibilidades de sortear las más mínimas perturbaciones. Las posibilidades de adaptación a los cambios son nulas. Este sería el caso del monasterio como centro que gobierna un territorio.

- Cuando dos centros existentes "compiten" organizando un grupo, se producen interferencias que conducen al desorden y ello obliga a buscar bien un nuevo centro superior a los dos en "disputa" bien uno de ellos acaba fagocitando al otro. Este sería el caso de los tejidos preindustrial y agrícola situado en los alrededores del río Cenia, que dado que cada una de las orillas tenía un "centro" que organizaba su funcionamiento, obligó a un estamento superior -en este caso la diócesis de Tortosa- a dirimir el acuerdo entre ellos (ver la sentencia del río Cenia ya citada con anterioridad).

- Los puentes y los acueductos son las primeras arquitecturas tectónicas que al separase del soporte, crean conexiones de redes de transmisión de flujos que no siguen la topología inicial del territorio, provocando desconexiones en partes del territorio que inicialmente lo estaban, que pueden crear el caos en ellos sino se ponen los medios para nuevamente conectarlos a la nueva red de flujos. 


\section{4. Conclusiones: Territorio entre la termodinámica y el juego}

El territorio es un gran tapiz de tapices superpuestos a lo largo del tiempo. Sobre el cañamazo inicial del soporte topológico conformado por una malla de planos triangulares "vacíos" cuyas aristas definen la malla primigenia, el hombre a los largo de los siglos ha ido tejiendo sobre él.

Se construyen primero esferas/arquitecturas que se funden con el soporte formando las esferas/ lugares que se conectan entre ellas y con el cañamazo mediante redes. Estas primeras esferas se van ampliando y van surgiendo esferas/tejidos, esferas/ciudades y esferas/partes completas de territorio; que así mismo se conectan entre sí y con el cañamazo por las redes de muros, infraestructuras, parcelas y cultivos.

Todo ello se encuentra fundido con el soporte, las esferas y las redes son cicatrices del soporte, su construcción estereotómica los une al territorio, la gravedad que les ha condicionado desde el inicio hace que se esculpan en él, los flujos de nutrientes que transmiten la energía externa que les permite vivir lo hacen por redes que como cordones umbilicales los unen al territorio y que como las raíces los atan aún más al soporte.

Poco a poco los vacíos del cañamazo inicial se van colmatando, las esferas van aumentando en número y creciendo en tamaño, pero sus membranas siguen siendo cáscaras gruesas, pesadas que los amontonan en el suelo. Las redes que los unen aumentan también en número y tamaño pero siguen adosadas al suelo como raíces que proporcionan el alimento a las esferas. Como en el olivo son raíces superficiales y no muy extensas pero que son capaces de nutrir durante cientos de años.

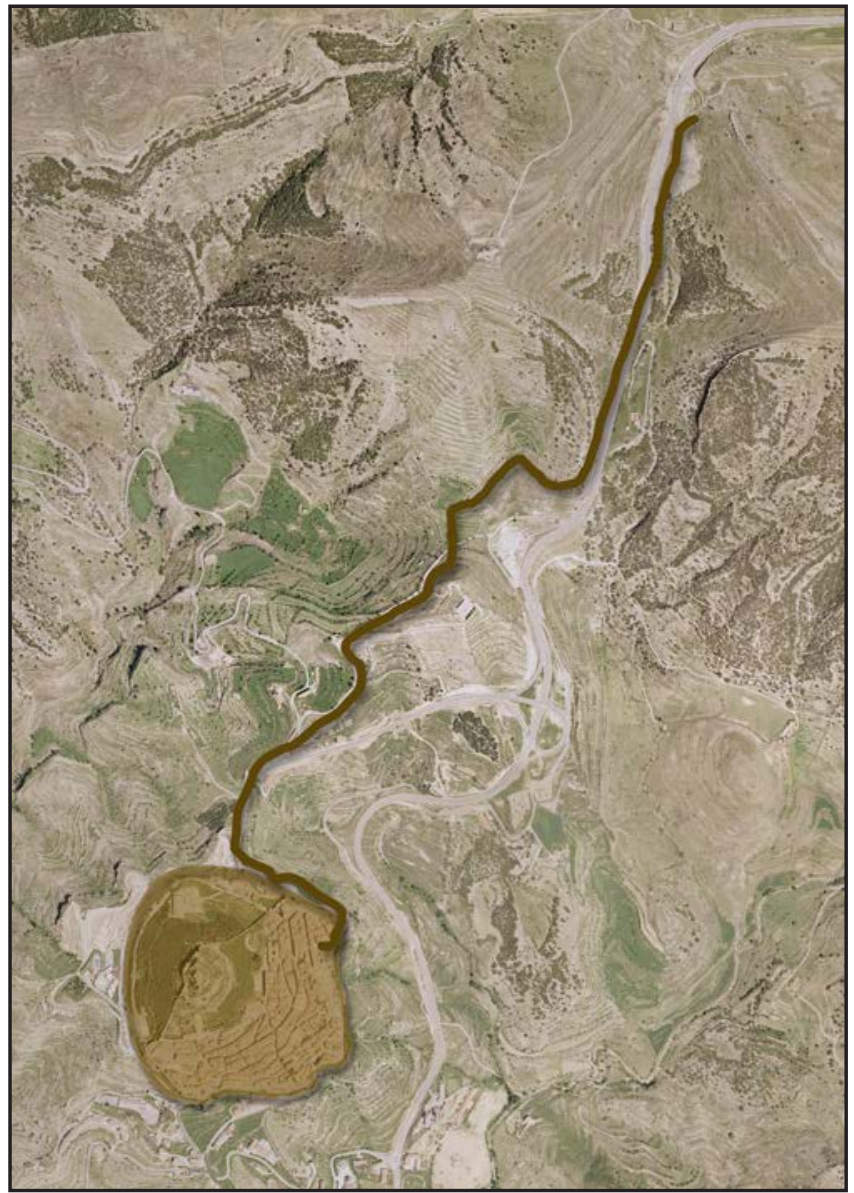

Fig. 7. 3. Morella y el acueducto: imagen de una placenta y el cordón umbilical.
Las esferas y las redes siguen la predisposición de la topología del cañamazo inicial y como en las estructuras de Robert Le Ricolais, los "vacíos" son lo importante, en ellos el territorio va transformándose, va humanizándose. El perímetro de los triángulos no se modifica y sobre el discurren gran parte de las infraestructuras que conectan los triángulos entre sí.

El interior de las esferas es denso, en él se agrupan las redes y arquitecturas. El exterior es menos denso y solo entrará a formar parte de alguna esfera cuando alcance un mínimo de densidad. Cuando aumentan de volumen las esferas necesitan un mayor aporte de energía externo que provoca la densificación del entorno y la posterior absorción de él por algún componente o el surgimiento de una esfera de nivel superior que administre la energía necesaria para su desarrollo y funcionamiento. Por ello las esferas tienen en su interior a otras de escala menor: la esfera/parte completa de territorio a todas las demás; la esfera/ ciudad a los tejidos, lugares $y$ arquitecturas; la esfera/tejido a los lugares y arquitecturas; la esfera/lugar a las arquitecturas y la esfera/arquitectura es la célula elemental. Las esferas se ordenan, de forma que siempre hay una esfera central. 
Las redes se van modificando con la creación de nuevas esferas y sus necesidades de conexión Estas nuevas redes van poco a poco modificando el cañamazo inicial de conexiones que coincidía con el de la topología virgen.

Los tapices con el paso del tiempo se superponen, convirtiéndose en un tapiz de tapices, en un palimpsesto. El último tapiz tejido toma como soporte, no solo el cañamazo inicial sino también el nuevo cañamazo creado por los tapices precedentes. Se van superponiendo esferas sobre esferas, redes sobre redes, pero mientras la construcción es estereotómica siguen anclados en la base del soporte inicial.

Los tapices se tejen con la aportación de energía externa, pero éste consumo se ve paliado por la información que contienen los tapices anteriores. La necesidad de eficiencia energética hace que los nuevos tapices se tejan con la memoria depositada en los viejos y ello hace que los tapices nuevos y viejos se ensamblen y mezclen.

El territorio es el tablero sobre el que cada generación humana juega la partida de la vida, en la que se combinan acontecimientos e información sobre el espacio y el tiempo.

La estrategia de la historia hasta la Edad Media -del juego- queda configurada dentro de una inexorabilidad que puede hallar una expresión adecuada en las leyes de la termodinámica. El territorio se comporta como un sistema termodinámico abierto, al guiarse como en el resto de ecosistemas naturales por la gravedad y la luz.

Las reglas con las que se juega la partida hasta la Edad Media son similares a las de cualquier otro ecosistema: identidad, relación, evolución y organización.

Por todo ello, parafraseando a Ramón Margalef, la historia es un juego en el que cada generación participa. Hasta la Edad Media el tablero es el territorio, la estrategia queda confinada dentro de las leyes de la termodinámica y las reglas básicas son las mismas cuatro con las que se rige cualquier otro ecosistema animal. 

Con el paso del tiempo -a partir de la Edad Media- la construcción pasa a ser tectónica, lucha contra la gravedad y se separa aunque sea con grandes esfuerzos del suelo. Las cáscaras de las esferas se adelgazan, en parte se perforan buscando la luz, en ellas entra aire nuevo y consiguen elevarse del suelo. Las redes de infraestructuras se separan del suelo, incluso llegan a dejar de funcionar por gravedad. De ser raíces en el suelo, pasan a ser lianas que discurren ajenas al suelo.

Los nuevos tapices se tejen siguiendo las pautas de los anteriores y se superponen a ellos, pero ya no se funden con ellos. La eficiencia energética disminuye, ya que el aporte de energía exógena aumenta y ésta no es paliada por la gran información depositada en el viejo tapiz ni por el aumento de la capacidad tecnológica del hombre. Los nuevos tapices dejan de estar fundidos con los anteriores para en un primer momento apoyarse y acabar flotando sobre ellos.

La percepción háptica de la Edad Media pasa poco a poco a ser una percepción visual. El desarrollo de la imprenta y de las técnicas del dibujo y pintura favoreció el paulatino uso del sentido de la vista en detrimento del resto de los sentidos De la perspectiva simbólica y utilitaria en la edad media sobre el territorio, se pasó a una mirada cultural. El territorio a partir del Renacimiento se va convirtiendo gradualmente en una construcción mental.

Se estableció poco a poco, una relación subjetiva entre el hombre y el territorio en el que vive, que se producía través de la mirada. A esta "construcción cultural" la llamamos paisaje $\mathrm{e}^{204}$. Esta mirada "filtrada" por la cultura, hace que el paisaje sea una elaboración mental, un "constructo".

El territorio desde entonces no se ha observado de una manera objetiva, se ha interpretado de forma subjetiva, reservada y poética-o si se quiere estética- convirtiéndolo en paisaje. Dejo de ser un soporte físico para convertirse en una serie de ideas, sensación es y sentimientos que elaboramos a partir de él y sus elementos constituyentes. ${ }^{205}$

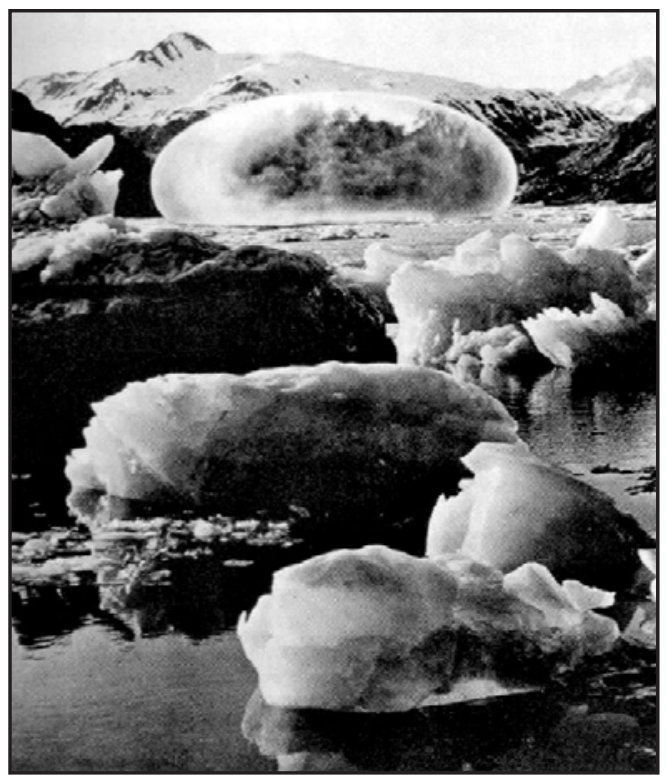

Fig. 0. 1. Montaje de Navarro Baldeweg.
Este proceso dura siglos, hasta que en los últimos decenios se ha dado un salto cualitativo importante la construcción ha dejado de ser tectónica para pasar a ser escenográfica. Las cáscaras de las esferas han adelgazado hasta convertirse en pompas de jabón, que ya liberadas del peso flotan ajenas al soporte del territorio, ello unido a la gran cantidad de esferas existentes crean una nube de espuma. Los cordones umbilicales que nutren las esferas ya no son ni raíces, ni lianas, sino finos hilos con gran capacidad de transmisión de flujos, que como en el caso de los globos de los niños son la única conexión con el suelo, si el hilo se rompe la esfera se perdería en el aire.

Las redes no solo adelgazan, sino que en ocasiones desaparecen y no existen físicamente sino solo virtualmente. Las nuevas conexiones de internet, telefonía, transmisión de datos, etc, hacen que nos sea necesario el contacto físico directo entre las

204 Esta concepción tan clara y concisa se la debemos a Javier Maderuelo en la obra ya citada con anterioridad.

205 Desde la introducción de esta tesis no había vuelto a aparecer el término paisaje, ello ha sido así voluntariamente. El término paisaje nos obliga a percibir el territorio a través de una lente que distorsiona la realidad y no nos permite reconocer y analizar la estructura interna del mismo. Ello no quiere decir que no seamos conscientes, como dice Morín, que la propia percepción cultural sea un elemento más que influye en cómo evolucione la estructura del territorio, pero para poder leer o entenderlo en su esqueleto "fundamental" hemos considerado necesario prescindir de la mirada subjetiva del paisaje. 
esferas entre ellas o mediante redes, pueden estar aisladas físicamente.

El proceso de la construcción de esferas cada vez más complejas que contienen a las anteriores para obtener una mayor eficiencia en la administración de la información y la energía se ha subvertido. Un territorio viejo se reconoce porque sus burbujas son mayores que las de los territorios jóvenes, porque las celdas jóvenes que revientan mueren en cierto modo dentro de sus vecinas, a quienes legan su volumen. Mientras más joven y húmedo es un territorio, más pequeñas redondas, móviles y autónomas son las burbujas aglomeradas en ella; mientras más seco y viejo, por el contrario, más burbujas autónomas han perecido, más grandes se hacen las celdas supervivientes, con más fuerza actúan unas sobre otras, más se hacen valer las leyes de Plateau de la geometría de vecindad en la deformación recíproca de las burbujas agrandadas.

En las espumas no existe una celda como punto central y la idea de una capital sería contraproducente per se. Se pierde la topología, se separan del soporte, "flotan" por el espacio y se crea una nueva red de conexiones ajena al soporte del territorio.

El territorio ha pasado de ser un tapiz tejido sobre un soporte topológico -fundido con él- como el de Robert Le Ricolais a ser una espuma como la descrita por Peter Sloterdijk que flota sobre el soporte natural y a la que le unen conexiones cada vez más ligeras y débiles.

La metáfora de la espuma ofrece la ventaja de captar en una imagen la estructura topológica de las producciones de espacio vital creativo-auto-aseguradoras. No solo recuerda la estrecha vecindad entre unidades frágiles, sino también la clausura necesaria de cada célula de espuma en sí misma, aunque solo puedan existir como usuarios de instalaciones de separación. Así, la representación de la espuma evoca tanto la co-fragilidad como el co-aislamiento de las unidades apiladas en asociaciones compactas. El concepto de sistemas coinsistentes pone de relieve la simultaneidad de vecindad y separación.

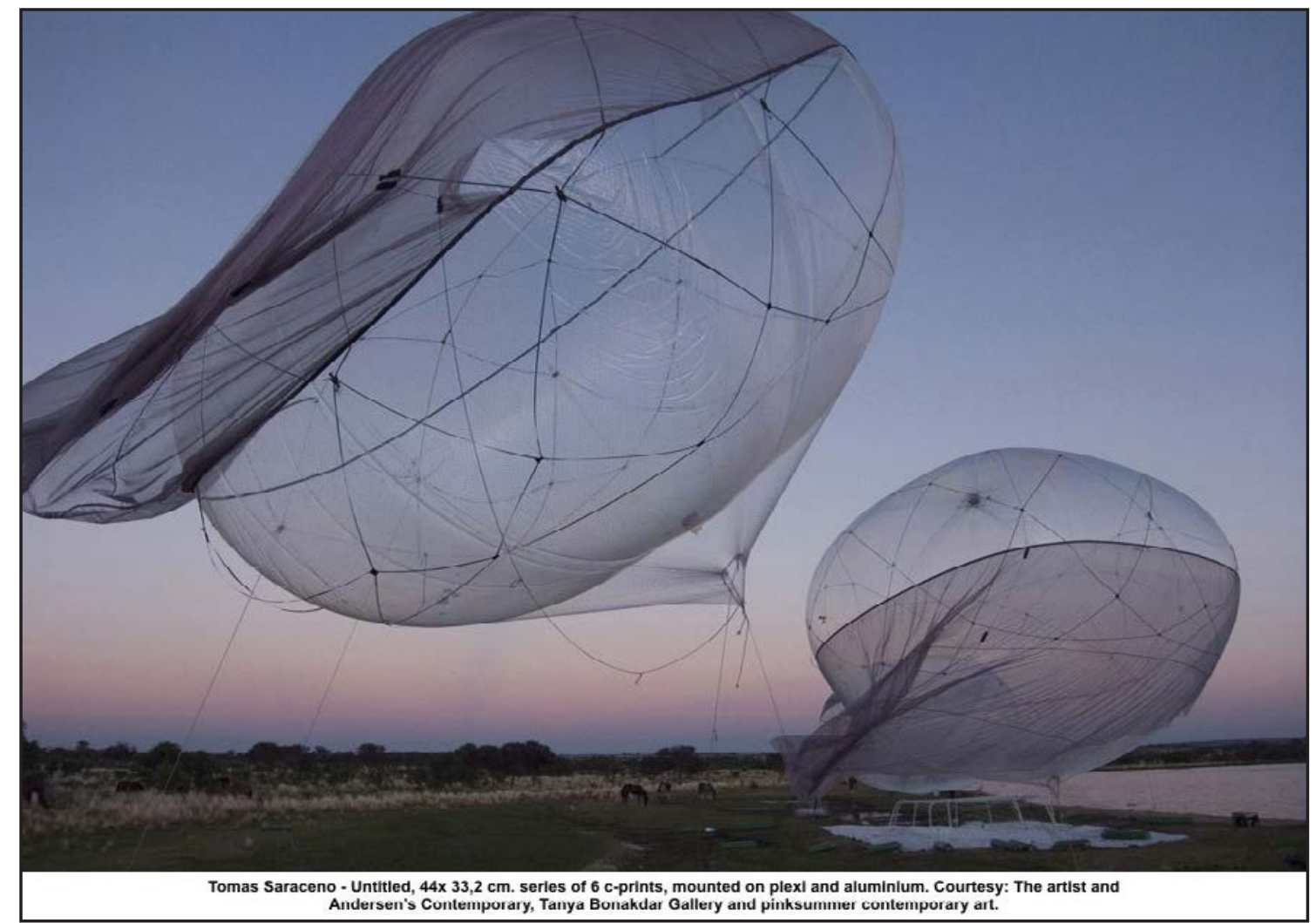

Fig. 0. 2. Montaje de Tomás Sarraceno. 


\section{La restauración del territorio}

Hemos analizado la estructura de un Territorio en la Edad Media y comprobado que se comporta como un sistema termodinámico abierto. Transcurridos seis siglos, dado que la construcción del territorio es un continuo "tapizado" que generación tras generación se va realizando sobre el tapiz anterior- es aventurado pretender restaurarlo sin estudiar previamente este largo periodo en el que el tapiz se ha visto modificado.

Sin embargo, dado que este Territorio y sus limítrofes hasta hace apenas 50 años han mantenido las condiciones iniciales de uso con sus lógicas variantes de funcionamiento y la topología de la estructura del territorio ha continuado siguiendo en gran medida la predisposición de la topología del soporte inicia.

Vamos a intentar hacer una propuesta para la recuperación de su capacidad de autoorganizarse o morfoestasis de este Territorio, siendo conscientes que para hacerlo con un mayor criterio deberíamos de analizarlo también a los largo de estos seis últimos siglos -como hemos hecho con el territorio en la Edad Media-, para corroborar que la estructura embriológica medieval se ha mantenido vigente y que subyace debajo de los sucesivos tapices que se han ido tejiendo sobre ella.

\section{1. La recuperación de la identidad}

Los distintos componentes que conforman la estructura del territorio: arquitecturas, lugares, tejidos, ciudades y partes completas de territorio, deben cada uno de ellos a su nivel mantener su estructura para poder llevar a cabo la gestión de la información, materia y energía que tienen encomendadas para el funcionamiento de ellos mismos y para el de la estructura de los componentes de nivel superior a los que sirven. Para ello:

- Los componentes deben de tener una función, si han perdido la suya original y se han convertido en una "ruina" deben de dotarse de una nueva y así volver a "reunir" al hombre respondiendo a alguna de las nueve dimensiones o "topoi" que configuran la antroposfera definida por Peter Sloterdijk.

- Los componentes deben de volver a administrar la energía por sí mismos, se deben de evitar los componentes hipertrofiados que dependan de otros que sean incapaces de suministrarles la energía suficiente a sus necesidades y acabaran muriendo. El territorio debe estar constituido por componentes con la escala adecuada a sus necesidades.

- Los componentes deben de volver a administrar la información por sí mismos, y para ello ésta no debe de ser virtual. Debemos de poder compaginar el mundo "virtual" en el que estamos inmersos, con un mundo táctil que nos permita "reunirnos" físicamente con la sociedad y con nuestro entorno.

\section{2. La existencia de relaciones}

Para recomponer el territorio se debe de favorecer el intercambio de materia, energía e información entre sus distintos componentes. La relación es función del uso del territorio. Cuando se mantiene el uso en el tiempo el mantenimiento de la relación es más sencillo, en el momento en el que este se cambia es necesario volver a encontrar cauces para que los flujos de relaciones se mantengan. Si el territorio no tiene ningún uso, las relaciones desaparecen y se puede llegar a producir el colapso del territorio. Es necesario tener un uso y a partir de él se pueden volver a establecer las relaciones necesarias entre los componentes territoriales y la esfera en la que se encuentran. Para ello: 
- Hay que favorecer las fuerzas centrípetas que reúnen el territorio alrededor de centros fuertes y con carácter, para densificarlo alrededor de estos centros-arquitecturas, lugares o ciudadesy definir límites claros que generen espacios definidos.

- Los límites que definen los distintos componentes -arquitecturas, lugares y ciudades- deben estar claramente definidos pero deben de ser permeables a la transmisión de los flujos. No pueden existir "islas" incomunicadas en el territorio.

- Se deben de controlar las interferencias exógenas que producen perturbaciones en las relaciones para evitar que afecten a la estructura del territorio en su conjunto. Toda red de transmisión de flujos es susceptible de verse interrumpida o condicionada por factores externos que la pueden llegar a hacer inútil o insuficiente. Hay que potenciar las relaciones directas, personales y físicas, ya que cada vez tienen más auge las relaciones virtuales a través de las nuevas redes sociales.

- Las redes de infraestructuras que transmiten los flujos han de tener la capacidad suficiente para que funcionen con la suficiente fluidez, para ello deben de adaptarse a la topología del soporte y deben de tener la escala adecuada a la escala de la estructura a la que sirven. Las partes de territorio que han quedado "desconectadas" por ser ajenas a las nuevas redes que han surgido para la conexión de las ciudades, deben de ser nuevamente conectadas mediante un proceso de "zurcido" sobre el tapiz existente.

\section{3. La eficiencia en la administración de la energía y la información}

Para que el territorio evolucione y se pueda restaurar es necesario que se mantenga una tendencia hacia la creciente eficiencia en la administración de la información y la energía. El territorio debe autoorganizarse mediante un proceso de homeostasis y de histéresis, es decir, debe de ser sostenible. ${ }^{206}$

206 La primera vez que a nivel mundial se manifiesta la preocupación por la problemática ambiental global fue con el informe del Club de Roma: "Los límites del crecimiento". Posteriormente durante la conferencia de las Naciones Unidas sobre el Medio Ambiente Humano que se celebró en Estocolmo en 1972 surge la Declaración de Estocolmo, en la que se estableció que la protección y mejoramiento del medio ambiente es una cuestión fundamental.

Posteriormente en agosto de 1987 la Comisión Mundial sobre el Medio Ambiente y el Desarrollo, aprobó el informe titulado: "Nuestro futuro común", conocido como "Informe Brundtland" por ser este el nombre de su presidenta.

Desde esta fecha gran parte de la normativa internacional, nacional o autonómica referente a la Ordenación del Territorio y el Paisaje, tienen como objetivo el conseguir directa o indirectamente un territorio sostenible. Ejemplo de ello pueden ser:

- Convenio Europeo del Paisaje de Florencia del año 2000.

- Ley Ordenación Territorio y Paisaje Comunidad Valenciana 4/2004.

- Ley del suelo no urbanizable de la Comunidad Valenciana 10/2004.

- Ley Urbanística Valenciana 16/2005.

- $\quad$ La Ley del suelo 8/2007.

- Ley 42/2007 del Patrimonio Natural y la Biodiversidad.

- Real Decreto 2/2.008 sobre el texto refundido de la Ley del suelo.

- Ley de Ordenación del Territorio, Urbanismo y Paisaje de la Comunidad Valenciana, 2014.

No hay una normativa de carácter territorial que se precie, que no mencione la sostenibilidad y se convierta en su objetivo prioritario. Por ello creemos conveniente analizar el Informe Brundtland y ver cuáles son sus conclusiones.

Se trata de un informe muy extenso, que tuvo una gestación con mucha anticipación y en un largo periodo de tiempo que obtuvo al final importantes resultados. La propuesta final se resume en 22 principios, derechos y deberes relativos a la protección del medio ambiente y el desarrollo duradero.

El informe pretende consolidar y ampliar los principios jurídicos pertinentes que guíen la conducta de los Estados en la transición hacia un desarrollo duradero. Su intención es servir de base para la prescripción las nuevas normas para la conducta estatal e interestatal necesarias para mantener la vida en el planeta que todos compartimos, entre ellas las normas de notificación, consulta y evaluación previas a la puesta en marcha de las actividades que tengan repercusión en el medio ambiente. 
Para conseguir la eficiencia, la energía no debe de ser insuficiente, pero tampoco debe de ser despilfarrada. Hay que hacer un uso responsable de los recursos energéticos. Para ello:

- Hay que reducir la energía destinada al transporte hay que ir hacia un territorio concentrado en nódulos densos, que disminuya el número de desplazamientos.

- Para reducir la energía de climatización hay que ir hacia un territorio atmosférico -siguiendo la denominación de Bruno Latour- que "procura un uso responsable de los recursos para el control térmico al tiempo que recobra el placer táctil de las fluctuaciones térmicas, la humedad ambiente o el movimiento del aire". ${ }^{207}$

- Hay que recuperar la energía depositada como memoria en el territorio. Por una parte hay que rescatar las estructuras físicas existentes: componentes del territorio, redes de infraestructuras y el modelado territorial, como "valioso capital temodinámico". ${ }^{208}$

- Hay que recobrar los conocimientos y técnicas constructivas tradicionales que se han ido destilando y perfeccionando durante siglos y que tiene un menor coste energético que las nuevas tecnologías.

- Por último hay que importar nuevos componentes que puedan dar respuesta a los nuevos

El informe trata los problemas con una visión realista, tratando de compatibilizar la protección del medio ambiente con el desarrollo, tanto en los países del primer mundo como en aquellos que están subdesarrollados y cuya primera prioridad es subsistir.

El objetivo del informe es ir hacia el desarrollo duradero y justo de la humanidad, en el que se esfuercen todos los países conjuntamente en función de sus posibilidades y de sus situaciones particulares.

Este desarrollo se analiza en función de varios parámetros: la población y los recursos humanos, la seguridad alimentaria, las especies y los ecosistemas, la energía, la industria, el crecimiento urbano, la administración de los océanos, el espacio y la Antártida, la paz y seguridad de los pueblos y las instituciones y leyes.

De todos estos aspectos me gustaría resaltar el de la energía por ser el hilo conductor de nuestro análisis del territorio. En el informe Brundtland por primera vez se pone de manifiesto la interconexión entre el medio ambiente y el desarrollo, que hasta entonces se consideraban sectores independientes.

La energía la considera indispensable para la supervivencia de la humanidad. Proporciona los servicios esenciales para la vida humana, siendo necesaria su conservación y la eficacia en su utilización. No se puede desperdiciar puesto que en gran parte es un bien finito hasta que no se consiga depender solo de energías renovables..

El crecimiento supone un aumento del suministro de energía, que debe ir acompañado de las medidas necesarias para asegurar la mayor eficacia en el uso y la conservación de la misma que permitan reducir al mínimo el despilfarro energético de recursos primarios no renovables.

Es inevitable consumir energía y en estos momentos gran parte de ella no es renovable, por lo que el primer objetivo es conseguir un consumo lo más eficiente posible, lo cual significa consumir la menor cantidad y aquella que se consuma lo haga con el máximo rendimiento.

El uso de la energía tiene sus consecuencias ambientales, por ello al elegir una estrategia de energía se escoge inevitablemente una estrategia ambiental.

Las conclusiones a las que llega el informe en cuanto al consumo eficiente de energía son:

- La solución energética de perfil bajo es la mejor vía hacia un futuro duradero.

- Organizar programas de fuentes duraderas de energía renovable, permite la transición hacia una era de energía más segura y duradera.

- La energía no es tanto un producto aislado como una combinación de productos y servicios.

El territorio ofrece enormes posibilidades para el consumo eficiente de energía. Por un lado las arquitecturas, lugares y ciudades pueden establecer pautas de uso y consumo que ahorren importantes cantidades de energía; por otra el transporte horizontal puede organizarse para que resulte más eficiente.

En definitiva el territorio considerado como sistema autoorganizativo -propuesta de la tesis- es un territorio sostenible tal y como lo define el informe Brundtland.

207 FERNÁNDEZ-GALIANO, L.A. “Arquitectura y vida: el arte en mutación” pág. 36

208 FERNÁNDEZ-GALIANO, L.A. “Arquitectura y vida: el arte en mutación” pág. 16 
usos que reclama el territorio y que hayan podido ser contrastados en otros territorios de características similares. Sería el caso de la importación del tipo de construcción de arcos perpiaños que se produjo en la Batllia de Cervera en la Edad Media.

El óptimo rendimiento de los recursos con los que cuenta el territorio para hacer frente a los usos que sustenta en la actualidad o unos nuevos que puedan darse, nos permitirá que el Territorio evolucione hacia formas de organización que sean más sostenibles.

\section{4. Modelo de organización}

Debemos de recuperar la organización de la estructura del territorio y evitar el desorden y el caos. Para ello:

- La nueva estructura debe de ser la manifestación material de los cambios morfológicos y materiales que permiten administrar con mayor eficiencia la información y la energía.

Hay que asumir que las infraestructuras tienen un papel clave, construyen un cañamazo artificial que se convierte en una "horma de nuestro futuro". 209

Por ello la evolución del territorio se basará por una parte en el aprovechamiento y mejora de esta red si está en uso, y en el caso de que no lo esté por ser una vieja red de infraestructuras guiada por la topología, hay que recuperarla haciendo un ejercicio de zurcido y de conexión con las nuevas redes.

Las vías de comunicación medievales se adaptaban a la topografía y escogían siempre los puntos de paso más fáciles siguiendo la topología del territorio. Con la evolución de las técnicas de ingeniería -tectónicas-, los trazados de las vías de comunicación empezaron a liberarse de las limitaciones de la topografía y se definieron recorridos más rectos a fin de acortar las distancias. En este contexto, las carreteras pasaron de ser simples enlaces entre pueblos a convertirse en auténticos instrumentos de ordenación del territorio, tanto por propiciar futuras áreas de crecimiento como por su papel en la modificación e interrupción del paisaje.

- Hay que evitar las distorsiones en la geometría ambiental y ser conscientes de las distorsiones espacio-temporales.

Hay que organizar el territorio en dos estructuras "superpuestas" y complementarias. La primera física que sigue la topología del soporte y la segunda virtual que no se apoya en el soporte y que es complementaria a la anterior.

Para dotar de una estructura a nuestro actual territorio debemos de contar con esta nueva pareja de estructuras complementarias, una física y otra virtual. Ello supone que ambas se superponen y que para entender como es cada una de estas estructuras debemos de analizarlas cada una en su plano para evitar interferencias. 


\section{La vida sobria delTerritorio frente a su imagen embalsamada: criterios de intervención}

El territorio es algo más que un paisaje, con un valor cultural que es percibido de una forma casi exclusivamente visual.

El cuerpo humano no solo es un rostro o un bello cuerpo. Detrás de esa piel y de esa imagen que envuelven el cuerpo humano hay una estructura formada por células, redes que transmiten flujos, tejidos, órganos, etc. Es impensable hoy en día que se pretenda "restaurar" un cuerpo humano sin actuar sobre sus componentes internos y para ello previamente se ha tenido que diseccionar y estudiar para saber cuáles son, cómo se forman, cómo crecen, cómo se agrupan, cómo se relacionan, etc.

Como el sistema territorial el cuerpo humano no sólo tiene una estructura que debemos de conocer sino que el cuerpo funciona gracias a un intercambio de energía entre los componentes internos de su estructura y el exterior en el que vive. Por tanto para saber del funcionamiento del cuerpo humano no solo debemos de saber de anatomía o de fisiología, sino también de metabolismo, porque el cuánta, cómo y qué energía se consumen son fundamentales para poder actuar sobre él.

Para actuar sobre el territorio lo primero es diseccionarlo para conocerlo, para saber cuáles son sus elementos más simples, sus agrupaciones, las relaciones entre ellos. Saber cómo surgen, cómo crecen, cómo se mantienen y cómo desaparecen. El territorio no es sólo una epidermis, es una estructura formada por un soporte sobre el que se ha ido tejiendo un tapiz de arquitecturas, redes, lugares, tejidos, ciudades y partes completas de territorio.

En el desarrollo de esta tesis hemos visto cómo en la Edad Media esta estructura -que en gran parte perdura hasta hoy en día en esta comarca- tejía un tapiz sobre el soporte haciendo uso del cañamazo de la topología natural. Esta era de carácter táctil y ha ido evolucionando hasta nuestros días hacia una de carácter visual que nos va alejando de la realidad del territorio para dejarlo en una mera escenografía. La "dictadura del ojo" ${ }^{210}$ nos presenta una realidad virtual en la que nuestra sociedad actualmente vive.

El territorio también ha sucumbido al espectáculo, no es más que una sucesión de imágenes, bellas o desagradables, luminosas u oscuras, enfocadas o desenfocadas, claras o borrosas, aéreas o a pie de suelo, móviles o inmóviles, lejanas o próximas, familiares o desconocidas, alegres o tristes, etc. No es más que el fondo en el que se desarrolla nuestra vida totalmente ajena a esa imagen a ese gigantesco "salvapantallas" en el que se ha convertido nuestro territorio.

Frente a esta imagen plana y embalsamada del territorio que nos ofrece la actual sociedad virtual en la que vivimos, debemos reivindicar recuperar la estructura tridimensional táctil y sobria del territorio que hemos heredado. Primero porque si queremos restaurarlo debemos de asumir que no sólo es una imagen -del mismo modo que la medicina para restaurar el cuerpo humano tuvo que admitir que era algo más que una piel- y segundo porque la estructura del territorio si funciona correctamente es autoorganizativa y tiene un consumo energético eficiente, es decir, es sostenible; mientras que un territorio embalsamado mantenerlo tiene un alto consumo energético. No podemos permitirnos el lujo de convertir el territorio en un museo de paisajes.

210 Expresión utilizada por Luis Antonio Fernández Galiano. 
Decálogo de criterios de intervención

1. El Territorio es una estructura, sus componentes son: arquitecturas, redes, lugares, tejidos, ciudades y partes completas de territorio. La actuación en cada uno de ellos está condicionada e influye en los demás. El territorio hay que estudiarlo y plantear las actuaciones en conjunto y no de forma fraccionada.

2. Cada uno de los componentes territoriales deben de tener un centro, un límite claro y mantener su identidad. Las arquitecturas deben de "reunir", los lugares deben de ser la "fusión" de la arquitectura con el soporte, los tejidos deben de ser patentes, las ciudades deben de ser compactas y las partes completas deben de ser nítidas.

3. Los componentes deben de estar relacionados entre ellos, deben de ser centrípetos, los límites deben de ser permeables y las redes de infraestructuras deben de tener la capacidad suficiente para que los flujos se muevan con fluidez.

4. El territorio debe de ser sostenible al tener una estructura autoorganizativa que sea eficiente por:

- Aportar la mínima energía externa de mantenimiento, siguiendo siempre que sea posible las pautas que marcan la gravedad y la luz.

- Aportar la mínima energía externa al transporte horizontal, para ello es imprescindible respetar la topología del soporte y propiciar un territorio de nódulos densos.

- Recuperar la energía interna almacenada como memoria propiciando el mantenimiento y la reparación de las arquitecturas, redes, ciudades; la recuperación y estudio de las técnicas constructivas tradicionales y la formación de oficios y técnicos que intervengan en la restauración del territorio.

5. El territorio se organiza como una superposición de "tapices" que se van tejiendo a lo largo del tiempo uno sobre otro, partiendo del cañamazo inicial del soporte natural y continuando con los que conforman las nuevas redes de infraestructuras. Para actuar en el territorio hay que conocer este cañamazo inicial y los posteriores que a lo largo del tiempo se hayan podido crear.

6. Las nuevas redes de flujos digitales no se apoyan en el soporte creando una red superpuesta a la de las infraestructuras físicas. Ambas redes son complementarias en el desarrollo del territorio.

7. El territorio tiene una composición fragmentaria de gran patch work con una coherencia interna que se debe de mantener en todas las actuaciones que en él se realicen.

8. El territorio debe de tener un uso que propicie la identidad y relación de los distintos componentes y que permita su evolución hacia otros más eficientes para ese nuevo uso, a la vez que permitirán la recuperación de la energía almacenada en los componentes actuales. Se debe de ser precavido en los cambios de uso, tal como se dice en la Carta de Cracovia: "el turismo cultural, aceptando sus aspectos positivos en la economía local, debe de ser considerado como un riesgo".

9. Los criterios visuales no pueden ser prioritarios, el territorio hay que mantenerlo vivo no embalsamado. La construcción cultural que llamamos paisaje, establece una relación subjetiva entre el hombre y el medio en el que vive a través de la mirada, que no puede impedirnos actuar en la estructura del territorio. La restauración del territorio no se puede limitar a una actuación de "cirugía estética".

10. La evolución hacia un territorio sostenible nos obliga a ser sobrios y renunciar a lo superfluo; ser humildes y no rehuir la mímesis para recuperar la energía almacenada; ser austeros y seguir tapizando con los pies -el cañamazo- en el suelo, ser inteligentes y usar de forma complementaria las redes físicas y virtuales. 
BIBLIOGRAFÍA 



\section{Bibliografía general básica}

BARBA, R. "L’abstracció del Territori” Tesis doctoral. Barcelona 1987

BOLLNOW O.F. "Hombre y espacio" Ed. Labor. Barcelona 1969

D'ARCY THOMPSON “Sobre el crecimiento y la forma” Ed. Akal. Barcelona 2003

FERNANDEZ-GALIANO, L.A. "El fuego y la memoria. Sobre arquitectura y energía" Ed. Alianza forma. Madrid 1991

FRAMPTON K. "Estudios sobre cultura tectónica" Ed. Akal. Madrid 1999

GEORGESCU-ROEGEN, N. "La ley de la entropía y el proceso económico". Ed. Fundación Argentaria. Madrid 1996

GREGOTTI, V. "El territorio de la arquitectura” Ed. Gustavo Gili. Barcelona 1972

HEIDEGGER, M. "Ser y tiempo". Ed. Fondo de Cultura Económica. México 2008

JUAREZ CHICOTE, A. "El universo imaginario de Louis Kahn”. Ed. Fundación Caja de Arquitectos. Colección Arquithesis n 20. Madrid 2006

LOVELOCK, J.E. "Gaia, una nueva visión de la vida sobre la Tierra" Ed. Orbis S.A. Barcelona 1985 LUQUE VALDIVIA, J. "La ciudad de la arquitectura. Una relectura de Aldo Rossi”. Ed.Oikos-tau. Barcelona 1996

LYNCH, K. "La imagen de la ciudad". Gustavo Gili. Barcelona 1985

MARGALEF LÓPEZ, R. "La biosfera entre la termodinámica y el juego". Editorial Omega, Barcelona 1980

MORIN, E. "El Método 1: la naturaleza de la naturaleza” Ed. Cátedra. Madrid 1981

MUMFORD, L. “Técnica y civilización” Ed. Alianza. Madrid 1971

NORBERG-SHULZ, C “Existencia, espacio y arquitectura” Ed. Blume. Barcelona 1980

ODUM, H.T. “Ambiente, energía y sociedad” Ed. Blume. Barcelona 1980

PALLASMAA, J. "La mano que piensa. Sabiduría existencial y corporal en la arquitectura" Ed. Gustavo Gili. Barcelona 2012

PRIGOGINE, I y STENGERS, I. "La nueva alianza. Metamorfosis de la ciencia”. Ed. Alianza. Madrid 1983

ROSSI, A. "La Arquitectura de la ciudad" Gustavo Gili. Barcelona 1976

SLOTERDIJK, P. "Esferas I” Ed. Siruela. Madrid 2009

SLOTERDIJK, P. “Esferas II" Ed. Siruela. Madrid 2004

SLOTERDIJK, P. “Esferas III” Ed. Siruela. Madrid 2006 


\section{Bibliografía general complementaria}

AAVV “Arte e historia en la Edad Media" Ed. Akal. Madrid 2009

ABALOS, I. "Naturaleza y artificio" Ed. Gustavo Gili. Barcelona 2009

ALBERTI, L.B. "De re aedificatoria" (traducción de Francisco Lozano) Madrid 1582

ALEXANDER, C. "La estructura del medio ambiente" Ed. Tusquets. Barcelona 1971

AGUILAR I PIERA, A. "La construcció de l'espai rural al Baix Empordá” Tesis. Barcelona 1993

AGUILÓ M. "El paisaje construido: una aproximación a la idea de lugar" Madrid 1999

ARÉVALO, F. "La representación de la ciudad en el Renacimiento. Levantamiento urbano y territorial" Ed. Caja de Arquitectos. Madrid 2003

ARNHEIM, R. "Hacia una psicología del arte. Arte y Entropía” Ed. Alianza. Madrid 1980

BACHELARD, G. "Psicoanálisis del fuego" Ed. Alianza. Madrid 1966

BACHELARD, G. "La poética del espacio" Ed Fondo de Cultura Económica. México 1965

BANHAM, R. "La arquitectura del entorno bien climatizado" Ed. Infinito. Buenos Aires 1975

BARRAGAN, J. "Sobre la termodinámica de los sistemas físicos biológicos" Ed científica 3/2004

BARTHES, R. "Ensayos críticos" Ed. Seix Barral. Barcelona 1983

BENEVOLO, L. "Diseño de la ciudad. El arte y la ciudad antigua" Gustavo Gili. Barcelona 1981

BLOCH, M "La historia rural francesa" Ed. Crítica. Barcelona 1978

BOYSSET, B. "Manuscrit 327 de l'Inguimbertine dit: Traité d'Arpentage" traducido por M. Motte. Ed. Presses Universitaires de la Méditerranée. Montpellier 2011

CAMPO BAEZA, A. "Pensar con las manos" Ed. Nobuko. Madrid 2007

CAPEL, H "Filosofía y ciencia en la Geografía contemporánea” Ed. Barcanova. Barcelona 1983

CARO BAROJA, J "Paisajes y ciudades" Ed. Taurus. Madrid 1984

CARO BAROJA, J “Arte visoria” Ed. Tusquets. Barcelona 1990

CASSIRER, E. "Filosofía de las formas simbólicas" Ed. Fondo de Cultura Económica. México 1976

CASTRO VILALBA, A. "Historia de la construcción medieval. Aportaciones" UPC. Barcelona 1996

CLAVAL, P. "Evolución de la Geografía Humana" Ed. Oikos-Tau. Barcelona 1973

CLAVAL, P. "La geografía cultural” Ed. Eudeba. 1999

CORTELLARO, S. "La construcción del territorio de Eivissa” Ed. COAIB. Mallorca 2003

CORBOZ, A. "El territorio como palimpsesto" (en "Lo urbano en 20 autores contemporáneos" coord. por A. Martin Ramos) 2004

CULLEN G. "Paisaje urbano" Ed. Blume. Barcelona 1974

DARWIN, C. "El origen de las especies por medio de la selección natural" Bruguera. Barcelona 1967

DE LAS RIVAS, J.L. "El espacio como lugar, sobre la naturaleza de la forma urbana" Ed Universidad Valladolid. Valladolid 1992

EISENMAN, P. "La futilidad de los objetos. La descomposición y los procesos de diferenciación" Revista Arquitectura no 246. Madrid 1984

EIZAGUIRRE X. "Las componentes formales del territorio rural" Tesis doctoral. Barcelona 1990

EIZAGUIRRE X "Hipótesis de entendimiento territorial: sus elementos formales" Estudios Territoriales no 18 CEOTMA. Madrid 1985

FARCY, H. "L'espace rural" Ed. Que sais je? PUF. Paris 1974

FERNÁNDEZ-GALIANO, L.A. "Arquitectura y vida: el arte en mutación” Real Academia de Bellas Artes de San Fernando. Madrid 2012

FRAMPTON K. "Historia crítica de la arquitectura moderna” Ed. Gustavo Gili. Barcelona 1981

FRAMPTON K. "Reflexiones sobre la autonomía de la arquitectura: una crítica de la producción contemporánea" Criterios no 31. La Habana 1994

FRAMPTON K. "Hacia un regionalismo crítico: seis puntos para una arquitectura de resistencia" Perspecta: The Yale Architectural Journal no 20. 1983

FRAMPTON K. "Llamada al orden. En defensa de la tectónica" Architectural Design 60. 1990

FRAMPTON K. "Louis Kahn y la French Connection" Arquitecturas BIS nº42. 1982

GARCÍA-BELLIDO, J. "Coranomía, los universales de la urbanística” Tesis doctoral. Madrid 1999

GARCÍA-GERMAN, J. y otros. "De lo mecánico a lo termodinámico” Ed. Gustavo Gili. Barcelona 2010 
GEDDES, P. “Ciudades en evolución”. Ed. KRK. Oviedo 2009

GOMBRICH, E.H. "El sentido del orden. Estudio sobre la psicologia de las artes decorativas" Ed. Gustavo Gili. Barcelona 1980

GONZÁLEZ-VARAS, I. "Conservación de bienes culturales. Teoría, historia, principios y normas" Editorial Cátedra. Madrid 1999

GEORGE, P. “Geografía rural” Ed. Ariel. Barcelona 1980

GOULD S.J. "La montaña de almejas de Leonardo. Ensayos de historia natural” Ed. Crítica S.L. Barcelona 1999

GREGOTTI, V. “Territory and architecture” Architectural Design no 59 pág. 28

HALBWACHS, M. "La mémorie collective" ED. Press Universitaries de France. París 1968

HEYMAN, J. "El esqueleto de piedra” Ed. CEHOPU. Madrid 1999

HIGUCHI, T. "The visual and spatial structure of landscape” Ed. Cambbridge Mass. 1983

KAUFFMAN, S.A. “Anticaos y adaptación” Investigación y Ciencia n o 184. 1992

KAUFFMAN, S.A. "Investigaciones: complejidad, autoorganización y nuevas leyes para una biología general”. Ed. Tusquets. Barcelona 2003

LAMARCK, J.B. "Filosofía zoológica” Ed. Mateu. Barcelona 1971

LATOUR, B. "La vida en el laboratorio: la construcción de los hechos científicos” Ed. Alianza. Madrid 1995

LATOUR, B. "Esperando a Gaia. Componer el mundo común mediante las artes y la política” 2011

LAURIE, M. "Introducción a la arquitectura del paisaje” Ed. Gustavo Gili. Barcelona 1983

LE CORBUSIER. "Hacia una Arquitectura” Colección Poseidón. Ed. Apóstrofe. 1998

LEFEBVRE, H. "De lo rural a lo urbano” Ed. Península. Barcelona 1975

LE RICOLAIS, R. “1935-1969. Études et recherches” Zodiac no 22. 1973

LE RICOLAIS, R. “Louis Kahn” Architecture d'aujourd'hui n’ 128. 1966

LE RICOLAIS, R. "Matiers" Libro no publicado reproducido parcialmente en VIA n 2. 1973

LE RICOLAIS, R. "Introduction to the notion of form” Ed. A. Hill. Nueva York 1968

LE RICOLAIS, R. "Visiones y Paradojas” Ed. Colegio Oficial Arquitectos Madrid. Madrid 1997

LLEDÓ, E. “El marco de la belleza y el desierto de la arquitectura” Ed. Biblioteca Nueva S.L. Madrid 2009

LYNCH, K. "Planificación del sitio” Gustavo Gili. Barcelona 1980

LYNCH, K. “¿De qué tiempo es este lugar?” Para una nueva definición del ambiente. Gustavo Gili. Barcelona 1985

MAC HARG Ian L. "Proyectar con la naturaleza” Gustavo Gili. Barcelona 2000

MADERUELO, J. “El paisaje, génesis de un concepto” Ed. Abada Madrid. 2006

MARGALEF, R. "La ecología entre la vida real y la física teórica”. Investigación y Ciencia no 225. 1995

MARTI ARIS, C. "Las variaciones de la identidad: ensayos sobre el tipo en arquitectura" Ed. Del Serbal. 1993

MARTINEZ DE PISON, E. “Arquitecturas, cordilleras” Revista ERIA pág. 173-193 1993

MONEO, R. "Sobre el concepto de tipo en Arquitectura”. Departamento publicaciones ETSA UPM. Madrid 1991

MONEO, R. "Sobre el concepto de arbitrariedad en Arquitectura" Real Academia de Bellas Artes de San Fernando. Madrid 2005

MUÑOZ, F. "Arqueología del espacio urbano. Un discurso hacia la arquitectura de la metrópoli" Teorías de la Arquitectura memorial. Ignasi de Solá-Morales. Universitat Politecnica de Catalunya. Barcelona 2003

MUÑOZ, F. “Urbanalización: paisajes comunes, lugares globales” Gustavo Gili. Barcelona 2008 NORBERG-SHULZ, C “Genios Loci: arquitectura del ambiente del paisaje” Electa. Milán 1986 NORBERG-SHULZ, C “Kahn, Heidegger. El lenguaje de la arquitectura”. Revista Arquitectura n” 223. Madrid 1980

PALLASMAA, J. "Los ojos de la piel” Ed. Gustavo Gili. Barcelona 2006

PANERAI, P. "Elementos de análisis urbano". Ed. Instituto de estudios de Administración local. Madrid 1983 
PANOFSKY, E. “Arquitectura gótica y pensamiento escolástico” Ed. La Piqueta. Madrid 1986 PANOFSKY, E. "Vida y arte de Alberto Durero" Ed. Alianza. Madrid 1989

PAVÓN MALDONADO, B. “Tratado de arquitectura hispano-musulmana” Tomos I, II y III Ed. CSIC. Madrid 1990

PARICIO, I "La construcción de la arquitectura” Tomos I, II y III Ed. Institut Tecnología de la construcción de Catalunya. Barcelona 1994

PINON, P. "Paysages" Centro George Pompidou. París 1981

PLA, J. "El pages i el seu mon” Ed. Destino. Barcelona 1978

PLA, J. "El meu pais" Obra completa, 7 Ed. 62. Barcelona 1968

PORTELA, C. "Estudio de los elementos determinantes del medio rural, tratamiento técnico y revisión jurídica: el caso gallego" DGATU. Madrid 1984

PRIGOGINE, I “'Tan solo una ilusión? Una exploración del caos al orden” Ed. Tusquets. Barcelona 1997

PRO RUIZ, J. “Estado, geometría y propiedad: los orígenes del catastro en España 1715-1941” Ed. Centro de gestión catastral y cooperación tributaria. Madrid 1992

ROGER, A. "Breve tratado del paisaje" Ed. Biblioteca Nueva. Madrid 2007

ROSSI, A. "Para una arquitectura de tendencia. Escritos 1956-1972”. Ed. Gustavo Gili. Barcelona 1977

ROWE, C. "Ciudad-collage" Gustavo Gili. Barcelona 1981

SAMONÀ. G. "An Assessment of the future of the city as a problem of its relationship with Architecture" Architectural Design no 59 pág. 16

SAMONÀ. G. "Architectural traditionalism and internationalism” Architectural Design no 59 pág. 57 SEMERANI, L. "Why not?” Architectural Design n 59 Introduction pág. 4

SOLÁ-MORALES, M. "La identitat del territori” Quaderns d'Arquitectura i Urbanismo extra 1. Barcelona 1981

SOLÁ-MORALES, M. "Reconeiximent territorial i ordenació del territori” Quaderns d'Arquitectura i Urbanismo extra 1. Barcelona 1981

SOLÁ-MORALES, M. “Sobre metodología urbanística” Ed. ETSA Barcelona. 1969

VAN DE VEN C. "El espacio en arquitectura” Ed. Cátedra. Madrid 1981

VIDAL DE LA BLACHE, P. "Principes de Geographie humaine” Ed. Armand Colin. París 1955

VILLARD DE HONNECOURT. “Cuaderno” (s. XIII) Ed. Akal (a partir manuscrito conservado en la Biblioteca Nacional de Paris) Madrid 1991

VIOLLET LE DUC, E. "Le massif du Mont Blanc; étude sur sa constitution géodésique et géologique, sur ses transformations, et sur l'état ancien et moderne de ses glaciers" Ed. Baudry. París 1876 VITRUBIO POLIÓN, M. "De architectura” (traducción de Joseph Ortiz y Sanz) Madrid 1787 WAISMAN M. "La estructura histórica del entorno” Ed. Nueva Visión. Buenos Aires 1977

WURMAN, R. "What will be has always been: The words of Louis Kahn” Ed. Rizzoli. Nueva York 1986

ZEVI, B "Hacia una arquitectura orgánica” Cambridge University Press. 1945

ZEVI, B. "Saber ver la arquitectura” Buenos Aires 1963

ZUMTHOR, P. “La medida del mundo: representación del espacio en la Edad Media” Ed. Cátedra. 1994 


\section{Bibliografía específica básica}

BAZZANA, A. CRESSIER, P. GUICHARD P "Les chateaux ruraux d'al Andalus Histoire et archeologie des Husun du sudest de l'Espagne” Ed. Casa de Velásquez. Madrid 1988

CARDONA GAVALDA, J.V. "Historia geológica del Maestrazgo" Revista Centro Estudios del Maestrazgo no 43-44 1993

DIAZ MANTECA, E. "Libro de poblaciones y privilegios de la Orden de Santa Maria de Montesa (1.234-1.426)" Ed. Diputación de Castellón. 1987

FERRERES I NOS, J. “Territori, població i econom,ia de la Batllia de Cervera a l'edat mitjana” Ed. CEM. Benicarló 2009

GARCIA EDO, V. "La Orden de Montesa en tiempos de sus dos primeros Maestres (1317-1327)" Tesis doctoral. Valencia 1990

GARCIA-GUIJARRO RAMOS, L. "Datos para el estudio de la renta feudal maestral de la orden de Montesa en el siglo XV" Ed. Alfons el Magnanim. Valencia 1978

GARCIA-GUIJARRO RAMOS, L. "Los orígenes de la Orden de Montesa" Ed. Casa de Velásquez. Madrid 1989

GLICK, T. "Paisajes de conquista. Cambio cultural y geográfico en la España medieval" Ed. Universitat de Valencia. 2007

GUICHARD, P. "Al-Andalus frente a la conquista cristiana. Los musulmanes de Valencia (siglos XIXIII). Ed. Universitat de Valencia. Valencia 2001

GUINOT RODRIGUEZ, E. "Feudalismo en expansión en el norte valenciano. Antecedentes y desarrollo del señorío de la Orden de Montesa. Siglos XIII y XIV” Ed. Diputación de Castellón. 1986 GUINOT RODRIGUEZ, E. "Cartes de poblament medievals valencianes" ED. Generalitat Valenciana. 1991

MATEU BELLÉS, JUAN F. "El norte del País Valenciano: geomorfología litoral y prelitoral” Ed. Universitat de Valencia. 1982

MIRA, E. y ZARAGOZÁ, A. "Una arquitectura gótica mediterránea” Ed. Conselleria Cultura. Valencia 2003

ZARAGOZÁ CATALÁN, A. "Arquitectura gótica valenciana: siglos XIII-XV" Ed. Conselleria de Cultura. Valencia 2000 


\section{Bibliografía específica complementaria}

AAVV "L'home i la pedra” Ed. Universitat de Valencia. Valencia 2001

AAVV "Construcció de pedra seca" Col.loqui Internacional de construcció de pedra seca 2000 Ed. UPC. Barcelona 2005

ALANYA I ROIG, J. "Urbanisme i vida a la Morella medieval”. Ed. Associació ‘Amics De Morella i Comarca. Morella 2000

AYZA ROCA, A. "Peñíscola-San Mateo-Morella, zona de invernada de pastores del sureste de Francia en el siglo XIV” Peñíscola 54. abril 1982

BARBERÁ, B Y ALVARO, F. "Molins fariners d'aigua” Ed. CEM. 2001

BAZZANA, A. GUICHARD P. "Investigaciones arqueológicas en hábitats medievales en la provincia de Castellón de la Plana” Cuadernos de Prehistoria y Arqueología Castellonense, 3. 1976

BAZZANA, A. GUICHARD P. "Habitats et sites defensifs d'epoque medievales:elements d'une recherche dans la region valencienne" Estudis Castellonecs. 11982

BOVER FALCÓ, O. "El agua del río Cenia: la sentencia arbitral de 1332" Centro de Estudios del Maestrazgo no 76. 2006

CATALAN FONT, C. "Bel: su entorno socio-político duante el siglo XIII" Centro de Estudios del Maestrazgo no 19. 1987

DIAZ MANTECA, E. "Confirmación de la carta puebla de San Mateo" BSCC LIX. 1983

DIAZ MANTECA, E. "Notas para el estudio de los antecedentes históricos de Montesa" Estudis Castellonecs, 2. 1984-1985

DIAZ MANTECA, E. "Documentos pontificios de la Orden de Montesa (s. XIV-XV) conservados en el Archivo Histórico Nacional” Estudis Castellonecs, 4. 1987-1988

FERRERES ALEU, I. “Historia de la Villa de Sant Mateu” Ed. Diputación Castellón. 2006

FERRERES I NOS, J. “Aproximación a la Historia de Sant Jordi del Maestrat” ED. CEM Quaderns, 4. 1985

FERRERES I NOS, J. "Document de partició i amollonament entre Morella i Cervera de la Frontera" BCEM, 14. 1986

FERRERES I NOS, J. “Reinvindicació dels drets d'aigua per la vila de Calig, l’any 1373” BCEM, 15. 1986

FERRERES I NOS, J. “La carta de població del mas dels Estellers” I Congres d'historia del Maestrat. Vinaros 1987

FERRERES I NOS, J. “La franquesa de Cervera del Maestrat de 1362 i altres dades d'interés” BCEM, 21. 1988

FERRERES I NOS, J. "Estudis de les capitulacions dels moros de Cervera” BCEM, 22. 1988

FERRERES I NOS, J. "Patrimoni toponimic i juridic de Xert" Ed. CEM. Benicarló 1999

FERRERES I NOS, J. "Naiximent d'una vila, del mas dels Estellers a Sant Jordi” Ed. CEM. Benicarló 2005

FORCADA MARTÍ, V. "Inventario de los Castillos de la provincia de Castellón” Penyagolosa, 10, 11, 12, 13 i $14.1973-1977$

FUGUET SANS, J. "L'arquitectura dels templers a Catalunya” Ed. Dalmau. Barcelona 1995

GARCÍA EDO, V. "Benedicto XIII y el Maestre de la Orden de Montesa, frey don Romeo de Corbera” BSCC, LVI. 1980

GARCÍA EDO, V. “Concesiones y privilegios medievales de Traiguera” Estudis Castellonecs, 1. 1981 GARCÍA EDO, V. "Murallas del Maestrazgo en los siglos XIII y XIV” Congres Historia del Maestrat. Vinaros 1987

GARCÍA EDO, V. “Órdenes militares, dominios episcopales y señoríos laicos” Historia de Castellón, vol. I. 1992

GARCÍA EGEA, M.T. "La visita pastoral a la diócesis de Tortosa del obispo Paholac en 1314” ED.

Diputación de Castellón. 1993

GARCÍA GARCÍA, F. “Censos de La Jana a Montesa (1331)” Saitabi XXX. 1980 
GARCÍA LISÓN, M. "Aportaciones a la historia de la arquitectura y el urbanismo medieval en la zona castellonense del obispado de Tortosa: los dibujos de ciudades del Obispo Paholac (1314)" Centro de Estudios del Maestrazgo no 57-58. 1997

GARCÍA LISÓN, M. Y ZARAGOZÁ CATALÁN, A. "Arquitectura rural primitiva en secá” Ed. Alfons el Magnanim. Valencia. 2000

GÓMEZ SAN JUAN, J.A. “Urbanismo medieval de San Mateu” Ed. CEM. Benicarló 1988

GÓMEZ SAN JUAN, J.A. “La Torre Hospitalaria y el Palacio Montesino de San Mateu” BSCC LXX. 1994

GRANDE GRANDE, F. “El nacimiento de la Casa Comunal” 1998

GRAU MONSERRAT, M. "Jueus al Maestrat de Montesa (Segle XIV). Aportaciones documentales" BCEM, 10. 1985

GRAU MONSERRAT, M. "Musulmans als Ports de Morella (s. XIV)" Sharq Al-Andalus no7. 1990

GRAU MONSERRAT, M. "La judería de Morella (siglos XIII-XIV) Revista Sefard no 1-2. 1962-64

GRAU MONSERRAT, M. "Los monumentos góticos civiles:Els Ports de Morella” Ed. Generalitat Valenciana. Valencia 1986

GUINOT RODRÍGUEZ, E. "El problema de la renta feudal y los fueros. Un análisis de las cartas pueblas del siglo XIII en el norte de Castellón” Saitabi XXXIII. 1983

GUINOT RODRÍGUEZ, E. "La fundación de la Orden Militar de Santa María de Montesa" Saitabi, 35. 1985

GUINOT RODRÍGUEZ, E. "La ramaderia del Maestrat medieval: entre l'expansió i la crisi” Estudis Castellonecs, 5. 1992-1993

GUINOT RODRÍGUEZ, E. "Sobre el poblament i el pas del mon musulmá al cristia en el Maestrat castellonec del segle XIII” BCEM 47-48. 1994

GUINOT RODRÍGUEZ, E. "El riu de la Senia: sistema de reg i molins medievales" en el libro: "Molins hidraulics valencians" Ed. Alfons el Magnanim. Valencia 2000

MANUEL DEL RÍO, J. “Un viaje trashumante: Cervera, Mosqueruela una cañada centenaria” Ed. CEM Cuaderno $\mathrm{n}^{\circ}$ 8. 2004

MESEGUER I FOLCH, V. "Manantiales y fuentes antiguas del Maestrazgo (I)" BCEM, 2. 1983

MESEGUER I FOLCH, V. "Manantiales y fuentes antiguas del Maestrazgo (II)" BCEM, 7. 1984

MESEGUER I FOLCH, V. "Reminiscencias de una cultura pastoril en Xert y la Barcella" Jornadas sobre Historia en el Maestrazgo. CEM. 1988

MESEGUER I FOLCH, V. y JUAN B. SIMÓ CASTILLO "El patrimonio etnológico de Canet lo Roig” CEM. 1997

MESEGUER I FOLCH, V. "El Molinar i la Barcella: dos enclaves medievales en el término municipal de Xert” BCEM, 51-52. 1995

MESEGUER I FOLCH, V. "Xert i la Barcella” Ed. Cooperativa agrícola. Sant Marc de Xert 2002

MILIAN BOIX, M "Inventario monumental dertusense. Diócesis de Tortosa" Ed. Diputación de Castellón. 2014

MIRALLES TORLÁ, J. “La vía Augusta como fuente para el conocimiento del mundo romano” Ed. CEM. 2003

MIRALLES I SALES, J. “Transllat autentich de la carta del molí de la Jana” Centro de Estudios del Maestrazgo no 28. 1989

MUNCHARAZ POU, M. “Azagadores y sistemas de pastoreo” BCEP, 4. 1985

MUNCHARAZ POU, M. "Los caminos ganaderos del Maestrazgo. Significado actual de las vías pecuarias" BCEM, 9. 1985

PHILIPPE, R.'L'Eglise et l'enregie pendant le Xie siecle dans le pays d'entre Seine et Loire" Cahiers Civilitation mediévale $\mathrm{n}^{\circ}$ 105-106. 1984

PLIEGO DE ANDRÉS, E. "La influencia persa en el origen de la arquitectura gótica: Dieulafoy y su tesis" Actas IV congreso historia construcción. 2005

PUJADES I BATALLER, R. "Espais viscuts i espais imaginats: les representaciobns del mon de la baixa Edat Mitjana" Revista Studium Medievale no3. 2010

RABASSA I VAQUER, C. "El comercio de la lana” en Historia de Castellón vol. I. 1992 
RODRÍGUEZ CULEBRAS, R. "Para el estudio de la arquitectura religiosa medieval castellonense" Revista Universidad Complutense. Vol. XXII no 85. Madrid 1973

RUBIO VELA, A. "Un documento de 1311 sobre la ganadería en las comarcas septentrionales del País Valenciano" Peñíscola, 51. 1981

SABATÉ I CURULL, F. "El andalusío de la Catalunya medieval. Percepció de l'espai i divisió territorial al llarg de l'Edat Mitjana” Ed. Fundació Salvador Vives Casajuana. Barcelona 1997

SÁNCHEZ ADELL, J. "El mapa político medieval en el norte de Castellón” Penyagolosa, 14. 1977 SÁNCHEZ ADELL, J. "Datos para la historia de la trashumancia ganadera castellonense en la Baja Edad Media" I Congres Historia del Pais Valencia tII. 1981

SÁNCHEZ ADELL, J. "Aportaciones a la historia de la ganadería medieval castellonense. La sentencia de Villahermosa entre Castellón y las aldeas de Teruel, sobre pastos en 1390" Estudis Castellonecs, 3. 1986

SÁNCHEZ ADELL, J. “Almazaras medievales en tierras de Castellón” BSCC, LXVIII. 1992

SÁNCHEZ ADELL, J. "La ganadería medieval castellonense” Historia de Castellón vol. I. 1992

SÁNCHEZ ADELL, J. "Aportaciones a la historia de la ganadería medieval en las comarcas del norte castellonense (ports de Andalus, Benifassa y Maestrazgo de Montesa)" BSCC LXXI. 1995

SÁNCHEZ ADELL, J. "Algunos aspectos de la práctica ganadera medieval en tierras castellonenses" Estudis Castellonecs no 5. 1992-1993

SÁNCHEZ ALMELA, E. "Nuevas aportaciones a la historia medieval de la villa de San Mateo" BCEM, 5. 1984

SÁNCHEZ ALMELA, E. "El Llibre de Privilegis de la villa de Sant Mateu (1157-1512)" ED. Caixa estalvis. Castellón 1986

SÁNCHEZ GOZALBO, A. "El punzón de San Mateo y sus orfebres” BSCC, LXVI. 1990

SARTHOU CARRERES, C. "El arte cristiano retrospectivo en la provincia de Castellón" 1920

SELMA CASTELL, S. "La integración de los molinos en un sistema hidráulico: la alquería de Artana" I Coloquio de Historia y Medio Físico. Almería T.II 1989

SELMA CASTELL, S. "El molí hidraulic de andalu i l'organització de l'espai rural andalusí. Dos exemples d'estudi arqueologic espacial a la Serra Espadá" Melanges de la Casa de Velásquez, Madrid XXVII-1 1991

SELMA CASTELL, S. "L’ordenació del Andalusí. Uns exemples del nord valencia" BAAC, 12. 1992 SELMA CASTELL, S. "Els molins d'aigua medievals a Sharq al-Andalus. Aproximació a través de la documentacio escrita dels segles X-XIII. Ajuntament d'Onda 1993

SELMA CASTELL, S. "La construcción del espacio urbano y la distribución de las utilidades domésticas en las morerías valencianas de Onda y Segorbe” Instituto Estudios Turolenses. 1996

SIMO CASTILLO, J.B. "El Maestrazgo Histórico” CEM. 1982

SIMO CASTILLO, J.B "Los templarios en el Maestrazgo" BCEM, 3. 1983

SIMO CASTILLO, J.B "Romeo de Corbera, destacado Maestre de la Orden de Montesa" BCEM, 4. 1983

SIMÓ CASTILLO, J.B. "Artefactes arcaics elevadors d'aigua per al reg" Centro de Estudios del Maestrazgo $n^{\circ} 62.1999$

SIMÓ CASTILLO, J.B. "La construcció de bancals i la intel.ligencia adulta" Centro de Estudios del Maestrazgo no 43-44. 1992

SIMO VALLES, P. “La Jana. Territorio y patrimonio histórico cultural” Ed. CEM. 2005

SOLER ESTRELA, A y otros. "Geometría y construcción en la iglesia arciprestal de Sant Mateu: las trazas de los sistemas abovedados” Actas VII Congreso Construcción. 2011

SORLI MOLINER, J. “Assagadors antics de Cervera del Maestrat” Ed. CEM. 1998

SORLI MOLINER, C. "El regadiu al nord de Castelló: les senies de Cervera". Centro de Estudios del Maestrazgo n ${ }^{\circ} 79.2008$

VICENT CAVALLER, J. “Inventari de Castells montesins” BSCC LVII. 1981

ZARAGOZÁ CATALÁN, A. "La arquitectura gótica del Maestrazgo en tiempos del Papa Luna" 1980

ZARAgozÁ CATALÁN, A. "El Palacio Maestral de la Orden de Montesa en Sant Mateu" San Mateu 1981 
ZARAGOZÁ CATALÁN, A. "Noticia sobre actuaciones de emergencia en el castillo de Cervera del Maestre" Ed. CEM. 1986

ZARAGOZÁ CATALÁN, A. "El seminario de Benassal. Rescatar la arquitectura popular" Cuadernos TC, 27. 1995

ZARAGOZÁ CATALÁN, A. "Naves de arcos diafragmas y techumbre de madera en la arquitectura civil valenciana" Actas primer Congreso Nacional Historia de la Construcción. Madrid 1996

ZARAGOZÁ CATALÁN, A. "El viaje de Luis Trasoyeres a la Arquitectura Gótica del Maestrazgo" Ed. CEM

ZARAGOZÁ CATALÁN, A. "El arte del corte de piedras en la arquitectura valenciana del cuatrocientos: Francesc Baldomar y el inicio de la estereotomía moderna"

ZARAGOZÁ CATALÁN, A. "El arte de corte de piedras en la arquitectura valenciana del cuatrocientos: un estado de la cuestion". Ed. Real Academia de bellas Artes de San Carlos. Valencia 2008 


\section{Bibliografía gráfica}

CORPUS AGRIMENSORUM ROMANORUM. Traducido por Carl Thulin.

https://archive.org/details/corpusagrimensor01 thuluoft

CORPUS AGRIMENSORUM ROMANORUM IV. IULIUS FRONTINUS. Texto traducido por Comisión Comunidades europeas. Luxemburgo 1998.

http://ista.univ-fcomte.fr/index.php/ed-src/gromatiques/car/416-car-iv_2

PORTET, P. “Bertrand Boysset, la vie et les oeuvres techniques d'un arpenteur médiéval (1355-1416) Ed. Le Manuscrit. París 2004. Anexos gráficos en: http://lamop.univ-paris1.fr/sites/arpenteur/

TABULA PEUTINGERIANA. Sorin Olteanu's LTDM Project.

http://soltdm.com/sources/mss/tp/tp_0.htm

TABULA PEUTINGERIANA. Biblioteca Augustana.

http://www.hs-augsburg.de/ harsch/Chronologia/Lspost03/Tabula/tab_intr.html

TACCOLA, M. "De Ingeneis" Facsimile del libro editado en 1433. Stuttgart 1984.

http:/ / ebooks.library.cornell.edu/cgi/t/text/text-idx? $=$ kmoddl;cc $=$ kmoddl;view $=$ toc;subview $=$ sh ort;idno $=\mathrm{kmod} 037$

TACCOLA, M. "De Machinis" Facsimile de libro editado en Siena en 1449. Bayerischen Staatsbibliothek München 1971

http://dmd.mpiwg-berlin.mpg.de/author/author/dmd/database/resultpage?-table=ded\&format $=$ resultpage\&theauthor $=$ Mariano $\% 20($ Taccola $) \&$ theyear $=$

VILLARD DE HONNECOURT ET LES CATHÉDRALES. Biblioteca Nacional de Francia http://classes.bnf.fr/villard/

VILLARD DE HONNECOURT. Wikisource la bibliothèque libre.

http://fr.wikisource.org/wiki/Carnet_(Villard_de_Honnecourt) 


\section{ANEXO I. BIBLIOGRAFÍA UTILIZADA PARA LA LOCALIZACIÓN DE LOS COMPONENTES DEL TERRITORIO EN LA EDAD MEDIA}

\section{Bibliografía utilizada para la localización de los elementos:}

(1) BARBERÁ, B Y ALVARO, F. “Molins fariners d'aigua” Ed. CEM, 2.001

(2) BAZZANA, A. CRESSIER, P. GUICHARD, P. "Les chateaux ruraux d'al Andalus Histoire et archeologie des Husun du sudest de l'Espagne" Casa de Velásquez, Madrid 1.988

(3) DIAZ MANTECA, E. "Libro de poblaciones y privilegios de la Orden de Santa Maria de Montesa (1.234-1.426)” Ed. Diputación de Castellón, 1.987

(4) FERRERES ALEU, I. "Historia de la Villa de Sant Matheu" Ed. Diputación Castellón, 2.006

(5) FERRERES I NOS, J. "Aproximación a la Historia de Sant Jordi del Maestrat " ED. CEM Quaderns, 4, 1.985

(6) FERRERES I NOS, J. “ Reinvindicació dels drets d'aigua per la vila de Calig,l'any 1.373” BCEM, $15,1.986$

(7) FERRERES I NOS, J. "La carta de població del Más dels Estellers" I Congres d'historia del Naestrat, Vinaros 1.987

(8) FERRERES I NOS, J. "La franquesa de Cervera del Maestrat de 1.362 i altres dades d'interés" BCEM, 21, 1.988

(9) FERRERES I NOS, J. "Patrimoni toponimic i juridic de Xert" Ed. CEM, Benicarló 1.999

(10) FERRERES I NOS, J. "Naiximent d'una vila, del más dels Estellers a Sant Jordi” Ed. CEM, Benicarló 2.005

(11) FERRERES I NOS, J. “Territori, població i econom,ia de la Batllia de Cervera a l'edat mitjana " Ed. CEM, Benicarló 2.009

(12) FORCADA MARTÍ, V. "Inventario de los Castillos de la provincia de Castellón" Penaygolosa, 10,11,12,13 i 14 1.973-1.977

(13) GARCÍA EDO, V. “Concesiones y privilegios medievales de Traiguera” Estudis Castellonecs, 1 1.981

(14) GARCÍA EDO, V. "Murallas del Maestrazgo en los siglos XIII y XIV" Congres Historia del Maestrat. Vinaros 1.987

(15) GARCÍA EGEA, M.T. “La visita pastoral a la diócesis de Tortosa del obispo Paholac en 1.314”

ED. Diputación de Castellón, 1.993

(16) GARCÍA GARCÍA, F. "Censos de La Jana a Montesa (1.331)" Saitabi XXX 1.980

(17) GOMEZ SAN JUAN, J. A. "Urbanismo medieval de San Mateu” Ed. CEM, Benicarló 1.988

(18) GOMEZ SAN JUAN, J. A. "La Torre Hospitalaria y el Palacio Montesino de San Mateu" BSCC LXX, 1.994

(19) GUINOT RODRIGUEZ, E. "Feudalismo en expansión en el norte valencxiano. Antecedentes y desarrollo del señorio de la Orden de Montesa. Siglos XIII y XIV" Ed. Diputación de Castellón, 1.986

(20) GUINOT RODRIGUEZ, E. "El riu de la Senia: sistema de reg i molins medievales" en el libro: "Molins hidraulics valencians" Ed. Alfons el Magnanim Valencia, 2.000

(21) MANUEL DEL RÍO, J. "Un viaje transhumante:Cervera, Mosqueruela una cañada centenaria" Ed. CEM Cuaderno no 8, 2.004

(22) MESEGUER I FOLCH, V. "Manantiales y fuentes antiguas del Maestrazgo (I)” BCEM, 2, 1.983

(23) MESEGUER I FOLCH, V. "Manantiales y fuentes antiguas del Maestrazgo (II)" BCEM, 7, 1.984

(24) MESEGUER I FOLCH, V. y JUAN B. SIMÓ CASTILLO "El patrimonio etnológico de Canet lo Roig” CEM, 1.997 
(25) MESEGUER I FOLCH, V. "El Molinar i la Barcella: dos enclaves medievales en el término municipal de Xert" BCEM, 51-52, 1.995

(26) MESEGUER I FOLCH, V. "Xert i la Barcella" Ed. Cooperativa agrícola Sant Marc de Xert, 2.002

(27) MIRALLES TORLÁ, J. "La via Augusta como fuente para el conocimiento del mundo romano" Ed. CEM, 2.003

(28) SANCHEZ ADELL, J. “Almazaras medievales en tierras de Castellón” BSCC, LXVIII, 1.992

(29) SANCHEZ ADELL, J. "Aportaciones a la historia de la ganaderia medieval en laas comarcas del norte castellonense (ports de ndalus, Beniofassa y Maestrazgo de Montesa)" BSCC LXXI, 1.995

(30) SANCHEZ ALMELA, E. "Nuevas aportaciones a la historia medieval de la villa de San Mateo" BCEM, 5, 1.984

(31) SANCHEZ ALMELA, E. "El Llibre de Privilegis de la villa de Sant Mateu (1.157-1.512)" ED. Caixa estalvis Castelló, 1.986

(32) SELMA CASTELL, S. "Els molins d'aigua medievals a Sharq al-Andalus. Aproximació a través de la documentacio escrita dels segles X-XIII Ajuntament d'Onda, 1.993

(33) SIMO VALLES, P. "La Jana.Territorio y patrimonio histórico cultural” Ed. CEM, 2.005

(34) SORLI MOLINER, J. “Assagadors antics de Cervera del Maestrat” Ed. CEM, 1.998

(35) VICENT CAVALLER, J. "Inventari de Castells montesins" BSCC LVII, 1.981

(36) ZARAGOZÁ CATALÁN, A. "La arquitectura gótica del Maestrazgo en tiempos del Papa Luna", 1.980

(37) ZARAgOZÁ CATALÁN, A. "El Palacio Maestral de la Orden de Montesa en Sant Mateu” San Mateu 1.981

(38) ZARAGOZÁ CATALÁN, A. "Naves de arcos diafragmás y techumbre de madera en la arquitectura civil valenciana" Actas primer Congreso Nacional Historia de la Construcción. Madrid 1.996

(39) ZARAgOZÁ CATALÁN, A. "El viaje de Luis Trasoyeres a la Arquitectura Gótica del Maestrazgo" Ed. CEM

(40) ZARAGOZÁ CATALÁN, A. "Arquitectura gótica valenciana: siglos XIII-XV Ed. Conselleria de Cultura. Valencia 2.000 


\title{
ANEXO II. COMPONENTES DEL TERRITORIO EXISTENTES EN LA ÉPOCA DE ESTUDIO
}

\author{
CERVERA (Total de elementos 39, localizada su ubicación 23)
}

Alber. Lugar y vieja partida documentada desde 1.321, situada junto a la dehesa de Exaudi. (11) Alcamer o Camer. Dehesa de origen sarraceno situada junto a la másia de la Xirosa. Documentada en el siglo XIII (Donación de la explotación a la Vila de Sant Mateu por el Castellá d'Amposta Ramón d'Ampuries) y en 1.325 (Ratificación donación por el Mestre de Montesa Arnau Soler). (11) y (34)

Almaçul. Dehesa de origen sarraceno, situada al sudoeste del término junto a la másia Pallaresa; además de pastos se cultivaba cereales y algarrobas. Documentada en 1.309 (Donación de la explotación a la Vila de Calig por el Castellá d'Amposta) y en 1.388 por litigios entre el pueblo de Cervera y Calig. (11) y (19)

Ardolich. Partida situada al oeste del término junto al barranco d'en Donat; zona montañosa y con pequeños terrenos de cultivo de cereales. Actualmente existe una partida con la denominación de Ardolls en esa ubicación. (11)

Ayuntamiento. (8), (19) y (39)

Barranc davall Cervera. Partida situada junto al molí la vila y la Rambla; dedicada al cultivo de cereales, higueras y almendros. Actualmente se denomina Molí. (11)

Benimader. Partida de bosques de origen sarraceno, situada al sudeste en el camino de Calig. (11)

Boveral. Dehesa con pastos para toros y vacas, con suelo pedregoso y situada al este del término junto al antiguo Más Stellers (actual Sant Jordi). (11)

Blanca. Dehesa, datada desde 1.325(Arrendamiento del Comendador de Cervera a tres vecinos de Sant Mateu). (19) y (34)

Cami la Jana. Partida cerca de la Jana, zona llana y dedicada al cultivo de cereales y viñas. Actualmente existe una partida con esta denominación en esa ubicación. (11)

Canter. Dehesa que contaba también con suelo para el cultivo de cereales. Situada en la partida del "Pou de les Canals" en la confluencia del camino de Cervera a Pabols; contaba con molinos harineros en la ribera del barranco del Boverot. (11)

Cominyer. Dehesa de origen sarraceno situada al noroeste junto al término de Sant Mateu y es atravesada por el barranco del Boverot. Documentada en el siglo XIII (Donación de la explotación a la vila de Sant Mateu por el Castellá d'Amposta Ramón d'Ampuries); en 1.325 (Ratificación donación por el Mestre de Montesa Arnau Soler); en 1.388 litigio entre los pueblos de Sant Mateu y Cervera. En su interior se encontraba una partida de bosque denominada Bostal. Actualmente existe una partida con la denominación de Comuñe en esa ubicación. (11), (19), (29) y (34)

Castillo de Cervera. Castillo de origen árabe anterior a la conquista, cabeza de un extenso territorio. Documentado en las cartas pueblas como ya existente. (2), (12), (19), (21), (25), (26) y (35)

Castillo de la Garotxa. Castillo musulmán anterior a la conquista situado en la confluencia de los términos de Cervera, Peñiscola y Santa Magdalena. (2)

Font del Carrascal o de la Roca. Partida situada en el camino de Cervera al Carrascal y dedicada al cultivo de cereales y viña. Actualmente existe una partida con la denominación de Font de la Roca en esa ubicación. (11)

Figueral. Partida de terreno llano situada al norte junto al camino de La Jana, dedicada al cultivo de las higueras. Actualmente existe una partida con la denominación de Asgarral en esa ubicación. (11)

Exaudi o Eixauli. Partida de origen sarraceno con una extensa dehesa, situada junta a la másia del mismo nombre al sur del término en la confluencia de los términos de Peñiscola y Santa Magdalena, junto al antiguo castillo de la Garrotxa. Datada en 1.309 (Arrendamiento de la Orden del Hospital a favor de la vila de Calig); 1.324 (Ratificada la concesión por el Mestre de Montesa Arnau Soler). Actualmente existe una partida con la denominación de Monte Eixaudi en esa ubicación. (11), (19), (21) y (29)

Foia del Bou. Partida situada al sur junto al Más d'en Veguer. Actualmente existe una partida con esta denominación en esa ubicación. (11) 
Horno 1258. (8)

Hospital actual ermita de San Sebastian. (3), (8), (11), (15), (38) y (40)

Iglesia Parroquial de la Asunción. (3), (8), (11), (15), (36), (38) y (40)

Más de les Roques. Pequeña partida situada al lado del Tossal de les Bassoles en el camino de La Jana (11)

Llacunes. Pequeña partida de suelo inundable situada al norte junto a la Rambla en la parte de La Jana; se cultivaban cereales y viñas. (11)

Más Blau. Antigua másia situado al sur cerca de la población y junto a la rambla; tenia corrales, balsa y otros edificios. (11)

Más de 1'Aller. Másia situada al este del termino cerca del pueblo de la rambla y del molí d'oli.; cultivaba ajos, de ahí su denominación. (11)

Más d'en Costa. Másia situada al oeste de la población en el camino de Cervera a Salsadella; se dedicaba al cultivo de cereales y tenia ganado. Actualmente existe una partida con esta denominación en esa ubicación. (11)

Más d'en Losco. Másia situada al norte junto al camino de La Jana; dedicada a la ganaderaza. (11)

Más dels Paüls. Másia situada al sudeste junto al camino de Benicarló; dedicada al cultivo de cereales.

(11)

Más dels Roques o de la Roca. Másia situada al norte junto a La Jana, junto a la montaña denominada "Serra de la Costa d'en Garraf" (11)

Más d'en Pere Xerta. Másia situada al oeste y cerca del pueblo al otro lado de la rambla; pertenecía a una de las primeras familias ganaderas de Cervera. Actualmente existe una partida con la denominación de Más d'en Pere en esa ubicación. (11)

Más d'en Veguer. Másia situada al sudoeste en medio de las montañas en dirección a Alcalá al lado de la "Foia del Bou"; se dedicaba a la ganadería y al cultivo de terrapa y viñas. Actualmente existe una partida con la denominación de Más de Vegue en esa ubicación. (11)

Molí d'oli de la Vila Molino de aceite situado al norte junto a la rambla en la confluencia con el barranco de la Mola; en sus tierras se cultivaban olivos y viñas. Documentado desde el siglo XIII (Donación de la Orden del Hospital) y en 1.320 (Inventario de la Orden de Montesa). (11), (19) y (28)

Pedralta. Se trata de dos partidas destinadas a pastos situadas una al oeste junto San Mateo y la otra al este junto Calig. Actualmente existe una partida con esta denominación en la ubicación próxima a Calig. (11)

Rent o La Rent. Extensa partida situada al nordeste entre la Rambla y la Perdiguera junto al viejo camino de Traiguera por la Fuente de la Salud; se dedicaba a pastos y cultivo de algarroba y Terapa. Actualmente existe una partida con la denominación de Ren en esa ubicación. (11)

Senada. Pequeña partida de huerta situada junto al molí d'oli de la Vila. (11)

Solana. Partida al este del pueblo, orientada al sur entre el Más Blau y la rambla. (11)

Somada. Partida situada al este en el camino de Calig junto a su termino y la rambla; tierras dedicadas al cultivo de viñas y algarrobas. Actualmente existe una partida con la denominación de Somades en esa ubicación. (11)

Torreta o Torre. Partida situada al sur junto al camino de Peñiscola vadeada la rambla, dedicada al cultivo de viñas y algarrobas. Documentada en el siglo XIII (Reparto en quince partes de la finca inicial). Actualmente existe una partida con la denominación de Torra en esa ubicación. (11)

Xirosa. Antigua alquería sarracena situada junto a la rambla al noroeste del término; dedicada al cultivo de olivos, cereales y pastos. Actualmente existe una partida con la denominación de Chirrosa en esa ubicación. (2) y (11)

\section{CANET (Total de elementos 38, localizada su ubicación 17)}

Ayuntamiento. (8), (19) y (39)

Boveral. Partida dedicada a los pastos de toros y vacas. Situado al oeste junto a la dehesa del Turmell junto a la Barcella. Documentado en el siglo XIV (Concesión de la orden de Montesa a la vila de Canet). Actualmente sigue existiendo esta partida con esta denominación. (11) 
Camp de na Porreta. Parcela situada dentro de la partida de Cova d'en Stalo. Situada entre el río Cervol y el barranco de la Barcella. (11)

Camps d'en Bergull. Parcela situada dentro de la partida de Cova d'en Stalo, próximo al camino viejo de Canet a Rosell (camino de los Bandoleros). (11)

Camp d'en Dauder. Propiedad situada dentro de la posesión feudal de Montesa del Más d'en Dauder, situado al oeste del término junto al tossal y moles de Xert. (11)

Clot d'en Montull. Partida situada al oeste del termino limitando con el más de la Barcella. Estaba dedicado en su mayoría a los pastos, bosques y algún campo de cultivo de cereales. Podría corresponder a parte de la actual partida de Pous. (11)

Coma. Propiedad situada dentro de la posesión feudal de Montesa del Más d'en Dauder, era un terreno llano y hondo, a su lado se encontraba el "Tossal de la Borrassa". Se dedicaba al cultivo de cereales, y viña. (11)

Cova d'en Doniu. Partida con diversas posesiones feudales de la orden de Montesa. Estaba situada al oeste del término. (11)

Cova d'Estaló. Partida correspondiente a una antigua posesión feudal de la orden de Montesa que estaba muy repartida entre los vecinos de Canet. Estaba situada al nordeste en dirección a Rosell y junto al río Cervol; eran terrenos llanos y dedicados al cultivo de cereales. Había una cueva con un "estaló" (columna), que es la que le da el nombre. (11)

Ermita de Santa Isabel. Situada al sur de la población, en medio de la llanura y rodeada de norias y huertas; esta formada por el conjunto de ermita, casa de ermitaño y dependencias anejas. (15) y (24) Espona del riu Sènia. Parcelas situadas dentro de la partida de la "Plana Della Cervol", junto al río Sènia. (11)

Fontanella del Spital. Partida situada cerca del Molí de l'Hospital al río Sènia, donde había una fuente. Se cultivaban cereales y viñas. (11) y (22)

Gatellar. Partida dedicada a la huerta junto al molino de Andreu Monserrat junto al río Cervol. El nombre proviene de la existencia de "gatells" que es un tipo de arbusto de ribera o lugares húmedos. (11)

Horno. Concesión de los primeros años tras la concesión de la carta puebla. (11)

Iglesia parroquial de San Miguel Arcángel. (3), (8), (11), (15), (24), (36), (38) y (40)

La Font de la Roca. Pequeña partida situada al oeste del pueblo en una zona baja, donde estaba la fuente que llevaba agua a un molino y a los lavaderos. Se dedicaba al cultivo de huerta, aprovechando el agua que a partir de la fuente se transportaba a los lavaderos y molino y posteriormente mediante una red de acequias se dedicaba al riego de las huertas. (11) y (22)

La Plana. Partida de terreno llano dedicado al cultivo de cereales y viña, situada al este y próximo al pueblo. Actualmente sigue existiendo esta partida con la denominación de Pla Martín y Pla Figueras. (11)

Más de la Cova. Extensa partida situada al este del término al lado del río Cervol, en dirección al Molí Castell (hoy San Rafael), parte de la misma estaba dentro del término de Traiguera. Era una posesión feudal de la Orden de Montesa. Actualmente sigue existiendo esta partida con la denominación de Cova Alta. (11)

Más d'en Dauder. Másia muy antigua, situada al oeste del término, en la partida del Boveral junto a Xert. Se trata de una másia de carácter feudal y propiedad de la Orden de Montesa. Se dedicaba a pastos y cultivos diversos. Esta másia debe corresponder por la descripción a la actual Más Encruella. (11)

Más de Plajove o d'en Bayarri. Másia situada al sur cerca de la serra de "Mont Major". Actualmente sigue existiendo una partida con la denominación de Plajove y la másia situada allí se denomina Más d'en Sans. (11)

Más Vell. Másias de grandes dimensiones situada al oeste junto al termino de Vallibona y la Barcella, en el río Cervol, seguramente es del siglo XIII. (11)

Molí d'oli. Molino documentado en 1.281 (concesión de la Orden del Hospital a na Dolceta viuda d'en Guillem Cogoma) (11), (24) y (28)

Molí del Gatellar. Molino de harina situado en el río Cervol, documentado en el año 1.345 (resumen concesiones que comparten la Orden de Montesa y el obispado de Tortosa). (11), (24) y (32) 
Molí d'en Guerau. Molino de harina situado en el río Cervol, documentado en el año 1.345 (resumen concesiones que comparten la Orden de Montesa y el obispado de Tortosa). Debe corresponder al Molí de la Roca de la sentencia del 1332. (11), (24) y (32)

Molí de la Font de la Roca. Molino situado en la pequeña partida situada al oeste del pueblo en una zona baja, donde estaba la fuente que llevaba agua a un molino y a los lavaderos. Se dedicaba al cultivo de huerta, aprovechando el agua que a partir de la fuente se transportaba a los lavaderos y molino y posteriormente mediante una red de acequias se dedicaba al riego de las huertas. (11), (24) y (32)

Molí d'en Company, Molí del Pas de la Senia, Molí de la Ribarroja, Molí d'en Roig y Molí de Canet. Situados los primeros en el río Cervol y el último en el Senia, no existen pruebas documentales de que funcionaran antes del siglo XV. (11), (24) y (32)

Pla del Fonollar o Fenollar. Propiedad situada dentro del Clot d'en Montull. Situada cerca del barranco de la Barcella. Era un terreno llano de cultivo de cereales y donde era habitual la presencia de "fonillo", planta que da nombre a la partida. (11)

Plana Della Cervol. Partida de terreno llano situada al nordeste entre el río Cervol y el río de la Senia, dedicada al cultivo de cereales y olivo. Actualmente sigue existiendo la partida con la denominación de Planes. (11)

Ponç dels Roques. Propiedad situada dentro del Clot d'en Montull, al oeste del término. (11)

Pozos: Pou Másia Planjové, pou cami dels racons.Fuentes: La Fontanella, Font de la Roca, Font de la Vila (o de la canal), Font del Vilagros. Norias: Senia de Marimon,Senia de l'hort del Cami Nou,Senia de la Font de la Roca (o de Toni Queleta). (22) y (24)

Spinal o Espinal. Partida situada junto al barranco de l'Spinal. (11)

Spital. Partida junto al Molí de l'Hospital en el río de la Senia y a la partida de la Fontanella del Spital. (1), (11) y (32)

Vilar d'en Eicerich. Partida dedicada al cultivo de olivo situada próxima al Más d'en Bayarri (o Planjové) al sur del pueblo hacia la "Serra de Mont Major". En esta partida había una posesión de la Orden de Montesa dedicada a la viña. (11)

\section{LA JANA (Total de elementos 25, localizada su ubicación 13)}

Abelló. Partida dedicada al cultivo de cereales y viña. (11), (16) y (33)

Cami del Carrascal. Partida dedicada al cultivo de viña, situada junto al camino de la antigua población de Carrascal, hoy camino de Cervera. (11), (16) y (33)

Catxol Partida dedicada al cultivo de cereales. (11), (16) y (33)

Coma. Partida dedicada al cultivo de cereales y viña. Actualmente existe la partida de Les Comes. (11), (16) y (33)

Cometa. Partida dedicada al cultivo de cereales. Partida dedicada al cultivo de cereales y viña. Actualmente existe la partida de Les Comes. (11), (16) y (33)

Cometa de les Eres. Partida destinada a cereales y huerta junto a la población Partida dedicada al cultivo de cereales y viña. Actualmente existe la partida de Les Comes (11), (16) y (33)

Ebaguets. Partida destinada a huerta junto a la población (11), (16) y (33)

Els Castellets. Antiguo poblado ibérico situado al este junto termino Traiguera. (33)

Empelts. Partida dedicada al cultivo del olivar. (11), (16) y (33)

Eres. Partida dedicada al cultivo de cereales. (11), (16) y (33)

Font. Partida destinada a huerta junto a la población (11) y (33)

Fontanelles. Partida dedicada al cultivo de viña. Actualmente existe esta partida con esta denominación. (11), (16) y (33)

Fuentes y pozos: varias. (22) y (23)

Horts. Partida destinada a huerta junto a la población (11), (16) y (33)

Más del Batlle. Másia situada al oeste del término junto a Xert. Dedicada a cultivo de cereales, olivos y viña; propiedad de la orden tal como su nombre indica. Actualmente existe esta partida con esta denominación. (33)

Molí d'oli de La Jana y del Carrascal. Establecido el 8 de junio 1.283. (11)

Norias: "La Nofra", y otras. (22) 
Plana de Canet. Partida dedicada al cultivo de cereales. Por la descripción debe ser la actual partida de les Bases de Xert. (11) y (33)

Plana de Traiguera. Partida dedicada al cultivo de cereales y viña. Actualmente existe esta partida con la denominación de Plans. (11), (16) y (33)

Quartxol. Partida dedicada al cultivo de cereales y viña. (33)

Serreta. Partida dedicada al cultivo de cereales. (11), (16) y (33)

Solá. Partida dedicada al cultivo de viña junto a la serra de Montmajor. (11), (16) y (33)

Toçal. Partida dedicada al cultivo de cereales y parte a huerta. Actualmente existe esta partida con esta denominación. (11), (16) y (33)

Toçal de n'Abellá. Dehesa situada al este de la población en el limite con Traiguera. Actualmente existe esta partida con esta denominación (11), (16) y (33)

Vía Augusta. Atraviesa el término de norte a sur. (27)

Vila. Partida destinada a huerta junto a la población (11), (16) y (33)

\section{EL CARRASCAL (Total de elementos 11, localizada su ubicación 7)}

E1 Vilarroig. Antiguo poblado ibérico situado al este junto lagunas. Actualmente existe esta partida con la denominación de Vilarroigs. (33)

Horno del Carrascal. (11) y (40)

Llacuneta del Pou del Más. Partida dedicada al cultivo de cereales. Actualmente existe esta partida con esta denominación. (11) y (33)

Les Carrasques. Antigua villa romana, situada junto a la vía augusta. (33)

Mitja del Carrascal. Partida dedicada al cultivo de cereales y viña. (33)

Molí d'oli de La Jana y del Carrascal. Establecido el 8 de junio 1.283. (11) y (28)

Parroquia de San José es unos años posterior a la época del estudio.

Pou del Carrascal. Partida dedicada al cultivo de cereales y viña. (11) y (33)

Prat. Partida dedicada a pastos. Por la descripción debe ser la actual partida de Bidofes. (33)

Vía Augusta. Atraviesa el término de norte a sur. (27)

Vilar Gros. Partida dedicada al cultivo de cereales y olivar. Actualmente existe esta partida con la denominación de Vilarroigs. (11) y (33)

\section{CALIG (Total de elementos 25, localizada su ubicación 14)}

Ali. Pequeña población sarracena, situada al este de la vila seguramente en los actuales "Murrons". Documentada en la carta puebla de 1.234. (11)

Ayuntamiento y torre fortificada. (6), (8), (19) y (39)

Bassa o Pou de la Bassa. Partida al sur del Bovalar, limitando con Benicarló. Por la configuración del terreno se almacenaba agua para el uso del ganado, además se cultivaba cereales y viña. (6) y (11)

Benigutfur. Pequeña población sarracena cercana a Ali y Calig, documentada en la carta puebla de estas poblaciones. (11)

Beniterey. Pequeña población sarracena cercana a Ali y Calig, situado al este de Benigutfur, documentada en la carta puebla de estas poblaciones. (11)

Bovalar. Partida compartida con el término de Benicarló, ocupando la zona montañosa de la Tossa. Se dedicaba al pasto de vacas y toros. Documentada su concesión en 1.326. Actualmente siguen existiendo las partidas con la denominación de Bovalar y de La Tossa. (11) y (29)

Codines. Partida situada junta a la de Surrac. Dedicada al cultivo de cereales, viña, oliveras y algarrobos. Actualmente existe esta partida con esta denominación. (11)

Iglesia Parroquial de San Lorenzo (3), (8), (11), (15), (24), (36), (38) y (40)

Llacunes. Partida situada al este, junto al término de Benicarló, al otro lado de la rambla. Su nombre indica que se acumulaba el agua en época de lluvias. Se cultivaban cereales. Actualmente existe esta partida con esta denominación. (6) y (11)

Más d'en Bernet o Vernet. Partida situada al norte de la vila en el camino del Más dels Stellers; se cultivaba viña y algarrobas. Actualmente existe esta partida con esta denominación. (11) 
Molí d'oli. (19) y (28)

Oleya. Pequeña población sarracena situada al norte del término de Calig, tal como se documenta en la carta puebla de Calig. (11)

Pàndols. Partida situada al este junto a Benicarló. Se cultivaba viña y cereales. Actualmente existe esta partida con esta denominación. (11)

Pedra Alta. Partida situada al oeste del término lindando con Cervera junto al antiguo camino de Cervera a Benicarló. Terreno abancalado destinado al cultivo de viña y algarrobas. Actualmente existe una partida con la denominación de Les Pedraltes en esa ubicación. (11)

Perdigona. Partida situada al norte junto al Más dels Stellers y al más d’en Bernet. Se dedicaba a pastos y bosque para la caza, de ahí su nombre dada la abundancia de perdices. (11)

Pou Bonet. Partida situada al oeste, junto a Cervera. Se cultivaba viña y cereales. (11)

Pou d'en Soler. Partida situada al noreste encima de la sierra de les Costes. Ocupa un suelo llano y fértil dedicado a la viña, algarrobas y olivos. Existía un pozo y abrevadero para el ganado. (6) y (11)

Povaig. Partida que se encuentra en el límite de los términos de Calig, Cervera, Benicarló y Peñiscola; es un terreno montañoso y con agua que se dedicaba a pastos. Actualmente existe una partida con la denominación de Las Polas-bajas en es ubicación. (6) y (11)

Ribarroja o Ribaroges. Partida al norte de la partida de Codines, cerca del río seco de Surrac. Se cultivaba cereal y algarrobas. (11)

Solanes. Partida al oeste junto al camino de Cervera a Benicarló; tiene pendiente en dirección al mar, cara al sol y protegido del aire del norte. Se cultivaban cereales y viña. Actualmente existe esta partida con esta denominación. (11)

Somada. Partida situada al norte junto a Cervera; es extensa y llana y dedicada al cultivo de cereales, viña y legumbres. Actualmente existe esta partida con esta denominación. (11)

Surrac. Partida situada junto al barranco de este nombre (también Oliva). La denominación es sarracena y se encuentra al este del termino cultivándose cereales, viña, olivos y algarrobos. Actualmente existe esta partida con esta denominación. (11)

Tossa d'en Morató. Toponímico correspondiente a la actual Tossa, era uno de los límites del Boveral de Benicarló en 1.326. Actualmente existe una partida con la denominación de Las Tosas en esa ubicación (11)

Tossal d'Orat. Pequeña montaña situada entre Calig y Benicarló; cerca de él se sitúa el pozo y la Bassa de Ali. (11)

Vilar de Na Maciana. Situado cerca del Tossal d'en Morató en el limite con Benicarló se encontraba este Vilar de oliveras. (11)

\section{XERT (Total de elementos 40, localizada su ubicación 23)}

Abelló. Pequeña partida de huertas; dedicadas al cultivo de verduras, legumbres y forraje para ganados; regados por una fuente. Posteriormente se tiene noticias de la "Font de l'Abelló". (11)

Abreurador del Molinar. Pequeña parcela, cerrada y con agua para abrevar los ganados del Molinar y alrededores. Situado en el curso medio del barranco del Molinar, al sudoeste de la vila. Actualmente sigue existiendo esta partida con esta denominación. (11) y (21)

Ayuntamiento. (8), (19) y (39)

Bovalar Turmell. Amplio territorio de dehesas que ocupa casi el 30\% del territorio del actual Xert, documentado desde el año 1316 situado en los alrededores del la montaña del Turmell, limitado por los términos de Morella y Vallibona y por el este el azagador de los Bandidos y por el sur la rambla de Cervera. Tenia derecho de pastos todos los ganaderos de la Batllia de Cervera desde sus orígenes de la Orden del Hospital y posteriormente continua con la de Montesa. Documentada en las cartas pueblas de Xert, la Barcella, Morella y Cervera axial como en los "llibres de Privilegis" de Xert y de Sant Mateu. Actualmente esta partida esta subdividida en varias de menor dimensión. (11) y (19)

Castevells o Castellvi. Partida próxima a la vila, junto a la "redona" de la Creveta. (11)

Closa. Pequeña parcela situada junto a la vila y cerrada por una valla o "closa". Dedicada al cultivo de huerta. (11)

Clot d'en Simó. Partida dedicada al cultivo de olivos y situada al sudeste del término. (11) 
Clot d'Oliver.Partida situada al nordestejuntoaltérmino deCanetyla dehesa de "Marranxons"(dedicada para los ganados de cerdos). Estaba dedicada al cultivo de cereales y oliveras. (11)

Coll d'en Bertran. Partida que formaba parte de la dehesa o "redona" de la Creveta, en la parte baja de la vila en dirección a la rambla. Se dedicaba al cultivo de cereales, viñas, oliveras e higueras. Tal como aparece documentada en el "establiment" 47, estaba regulado el acceso temporal de ganado. (11)

Coll d'en Gil. Partida situada próxima a la anterior en la "redona" de la Creveta y estaba dedicada al cultivo de secano. (11)

Coma. Partida situada junto a la "redona" de Marranxons que era una dehesa dedicada al pastoreo de cerdos. (11)

Cometa. Pequeña partida situada junto a la "redona" de Marranxons y dedicada a cultivo de cereales, viñas y frutales, en los que podían temporalmente entrar a pastar los cerdos. (11)

Creveta o Creueta. Partida de gran extensión a la que le daba nombre la cruz de término situada a la salida de la vila. Situada al sudoeste de la vila junto a ella, se dedicaba al cultivo de cereales, frutales y viña. Documentada en el Llibre dels Establiments de Xert. (11)

Curolla. Partida próxima a la Font de l'Abelló, a la que le da nombre una formación montañosa con la cima de forma llana. En la cima se encuentran los restos de un antiguo poblado ibérico Documentada en el Llibre dels Establiments de Xert. (11), (25) y (26)

Font de la vila. Fuente situada junto a la vila en la que se encontraban tanto el molino de harina como el de aceite. En esta fuente desde la época de los sarracenos acudían los vecinos acoger el agua para su consumo doméstico, abrevaba el ganado y con los sobrantes se regaban pequeñas huertas situadas aguas abajo en el barranquet de la font. (11) y (19)

Forques. Era un promontorio situado entre el coll d'en Bertran y la Plana al este de la vila. Era el lugar en que las autoridades colgaban a los condenados. (11)

Horno. (8)

Iglesia Parroquial de la Asunción. (3), (11), (15), (36), (38) y (40)

Magraner. Partida situada dentro de la "redona" de la Creveta cerca de la vila y dedicada a diversos cultivos, documentado en el establiment 124 de Xert en el que se regula la entrada del ganado a este espacio boscoso. (11)

Marranxons. Partida o "rodona" situada al este de la vila en dirección a Canet, donde podían entrar a pastar los cerdos todo el año menos agosto, septiembre y octubre; documentado en el establiment 25 de Xert en el que se regula la entrada del ganado a este espacio boscoso. (11).

Más d'en Roig. (9)

Más del Rei. (9)

Más del Regall. (9), (25) y (26)

Más del Molinar. (9), (25) y (26)

Másos d'en Ferreres (9)

Mola Murá. Situada al este del término. Restos arqueológicos de un poblado del bronce final. (25) y (26)

Mola Llarga. Situada al este del término. Restos arqueológicos de un poblado del bronce final. Actualmente sigue existiendo esta partida con esta denominación. (25) y (26)

Moles. Partida muy montañosa situada al este del termino en su limite con el termino de Canet. Dedicado al uso forestal y como dehesa. (11)

Molinar. Lugar situado en el barranco del Molinar al sudoeste del término en la parte baja del Boveral del Turmell que consta de fuente, molino, abrevadero y másia. Durante la Edad Media tuvo una gran importancia como cruce de caminos. Actualmente sigue existiendo esta partida con esta denominación. (11), (19), (25) y (26)

Molí d'oli. Situado en el núcleo urbano junto a la font de la vila. (9), (19) y (28)

Molino harinero. Situado en el núcleo urbano junto a la font de la vila. (1), (9) y (19) Molinos harineros en el Molinar. Existían tres. (1), (9), (25) y (26)

Plana o Planetes. Partida extensa al este del término cerca de la rambla junto al término de San Mateo. Era un terreno llano dedicado al cultivo de cereales, oliveras y viñas documentado en el establiment 47 de Xert en el que se regula la entrada del ganado a este espacio boscoso. (11) 
Poblado ibérico de la Curolla. (9) y (25)

Rambla. Extensa partida situada junto a la rambla que le da nombre y que divide el termino de Xert en dos partes de oeste a este; es el límite inferior de la dehesa del Turmell. Se cultivaba olivos, cereales y pastos. (11)

Torre de les Solsides. Torre situada cerca del Molinar al oeste de Anroig y al otro lado de la rambla. Se trata de una torre defensiva de planta cuadrada. (25) y (26)

Vilar. En este caso no se trata de una partida dedicada al cultivo de olivos sino que se trata de un bosque de la Barcella, documentado en el establiment 28 de Xert en el que se regula la entrada del ganado a este espacio boscoso. (11)

Vinyes. Partida o "redona" de las viñas, estaba situada al nordeste del termino estaba dedicada al cultivo de viñas y estaba cercada para regular el acceso del ganado, tal como esta documentado en el establiment 16,20,85 y 124 de Xert en el que se regula la entrada del ganado a esta "redona". (11)

\section{LA BARCELLA (Total de elementos 24, localizada su ubicación 7)}

Barcella o Barçella. Antigua población sarracena dedicada fundamentalmente a la ganadería. Situada al norte del termino en una zona muy abrupta con grandes dehesas, bosques y barrancos. Tiene desde el primer momento de la conquista, carta de población, por tanto con un término independiente del de la vila de Xert. En él se encuentra la ermita de Sant Marc o de Sant Pere. Documentada en las cartas pueblas de Xert, la Barcella y Morella, así como en el Llibre del Establiments de Xert. Es citada ya en 1.192 antes de la conquista cristiana. Actualmente sigue existiendo esta partida con esta denominación. (11), (19), (25) y (26)

Bovalar Turmell. Amplio territorio de dehesas que ocupa casi el 30\% del territorio del actual Xert, documentado desde el año 1316 situado en los alrededores del la montaña del Turmell, limitado por los términos de Morella y Vallibona y por el este el azagador de los Bandidos y por el sur la rambla de Cervera. Tenía derecho de pastos todos los ganaderos de la Batllia de Cervera desde sus orígenes de la Orden del Hospital y posteriormente continúa con la de Montesa. Documentada en las cartas pueblas de Xert, la Barcella, Morella y Cervera axial como en los "llibres de Privilegis" de Xert y de Sant Mateu. Actualmente esta partida esta subdividida en varias de menor dimensión. (11) y (19)

Coma Negra. Situada en el término de la Barcella, entre el Vall de la Tea, el barranc de la Font del Teix y el término de Vallibona y se dedicaba al cultivo de cereales. (11) Ermita de Sant Marc. (3), (8), (11), (15), (25), (26), (36), (38) y (40)

Fontanella. Partida situada junto a una pequeña fuente situada junto a un barranco que nace detrás de las Muelas, y va hacia el barranco de la Barcella. Lugar dedicado a la ganadería. Actualmente sigue existiendo en este lugar un barranco con esta denominación. (11)

Freixar o Teixar. Bosque de fresnos de la Barcella, documentado en el establiment 28 de Xert en el que se regula la entrada del ganado a este espacio boscoso. (11)

Horno. (8)

Lledó. Bosque de "lledoners" de la Barcella, documentado en el establiment 28 de Xert en el que se regula la entrada del ganado a este espacio boscoso. (11)

Más d'en Segura. (9)

Más d'en Capafons. (9)

Más d'en Tiboba o Tizona. (9)

Más d'en Dauder. (9)

Más d'en Costa (9)

Mola Murá. Situada al este del término. Restos arqueológicos de un poblado del bronce final. (4)

Mola Llarga. Situada al este del término. Restos arqueológicos de un poblado del bronce final. Actualmente sigue existiendo esta partida con esta denominación. (25) y (26)

Moles. Partida muy montañosa situada al este del termino en su limite con el termino de Canet. Dedicado al uso forestal y como dehesa. (11)

Molino harinero. (1), (9) y (19)

Monintiu o Monant. Bosque de la Barcella, documentado en el establiment 28 de Xert en el que se regula la entrada del ganado a este espacio boscoso. (11) 
Roureda. Bosque de robles de la Barcella, documentado en el establiment 28 de Xert en el que se regula la entrada del ganado a este espacio boscoso. (11)

Saltadora. Dehesa situada al nordeste que recibe el nombre de un salto de agua que es el desagüe natural de la sierra de Tormással. (11)

Talaiola. Dehesa situada junto a la montaña de 948 metros de altura situada en el encuentro de los términos de la Barcella, Vallibona y Canet. Actualmente sigue existiendo esta partida con esta denominación. (11)

Tormással. Dehesa situada al norte del término formada por una mása montañosa de 800 metros de altura. Actualmente sigue existiendo esta partida con esta denominación. (11)

Vall de la Tea. Bosque de encinas de la Barcella, documentado en el establiment 28 de Xert en el que se regula la entrada del ganado a este espacio boscoso. (11)

Vall de l'Os. Bosque de la Barcella, documentado en el establiment 28 de Xert en el que se regula la entrada del ganado a este espacio boscoso, su nombre indica la existencia en el mismo de osos. (11)

\section{ROSSELL (Total de elementos 34, localizada su ubicación 20)}

Ayuntamiento. (8), (19) y (39)

Ballesteres. Partida situada al noroeste de la vila en el camino hacia el Ballestar. En esta partida había corrales de ganado, ya que este lugar era la salida hacia las dehesas y bovalares del término. Actualmente sigue existiendo esta partida con esta denominación. (11)

Bonamina. Partida situada al este junto a un arroyo que desagua en el barranco de la Sotarranya. Es un terreno llano y se extiende entre el camino de la Senia y el azagador de los Bandoleros. Se cultivaban cereales y es de las primeras partidas repartidas tras la conquista. Actualmente sigue existiendo esta partida con esta denominación. (11)

Bosc dels vint llops. Bosque situado al noroeste del término junto a la partida de la Coma Negra; eran abundantes los lobos de ahí su denominación. (11)

Carrascal. Bosque de carrascas situado al nordeste y estaba atravesado por un azagador que conducía al ganado a las dehesas de la parte norte. Actualmente sigue existiendo esta partida con la denominación de Carrascalet. (11)

Cervol. Partida situada al sur del término junto al río de su nombre. Actualmente sigue existiendo esta partida con esta denominación. (11)

Coma Negra. Partida situada junto al barranco de la Coma Negra que desemboca al río Cervol, esta situada al oeste de la vila; recibe este nombre de su aspecto "oscuro" por la frondosa vegetación de encinas y pinos que la poblaban inicialmente; la parte baja con menos arbolado se usaba como dehesa. Actualmente sigue existiendo esta partida con esta denominación. (11)

Coves de n'Arques. Partida situada junto al río Cervol y la másia de Capafons al sur del término. En esta partida había una serie de cuevas y corrales que se dedicaban para guardar el ganado. Actualmente sigue existiendo esta partida con esta denominación. (11)

Cogulla, Cugulla o Cogulles. Partida situada al noreste cerca de la vila. Es una de las partidas más antiguas, de origen sarraceno, ya que hasta el siglo XVI se cobraba una parte de los frutos, lo cual indica que no se había "transformado" su pago en dinero. (11)

Ferreginals o Freginals. Pequeñas parcelas situadas alrededor de la vila, en su parte este junto al camino Davall la Vila. En ellos se cultivaba forraje para los animales domésticos. En él se encontraban también las eras y algunos corrales de ganado. (11) Font de na Almenara. Partida situada al norte de la vila, es de origen sarraceno y se dedicaba al cultivo de huertas que se situaban en los márgenes del barranco de Requena o de Rossell. (11)

Forat d'en Ros. Partida ubicada al norte de la vila cerca de la ermita de San Marc y del barranco de les Cogullas. (11)

Horno. (8)

Hortals. Partida de huertos situada al noreste del término al lado del río de la Senia. Actualmente sigue existiendo esta partida con la denominación de Els Horts. (11)

Iglesia Parroquial de la Asunción. (3), (11), (15), (36), (38) y (40) 
Más d'en Capafons. Másia situada en la partida de Cervol al sudeste del término, a su lado estaba la másia d'en Salom. (11)

Más d'en Coll. Másia situada al sudoeste del término junto al Ligallo Real que atraviesa el término en dirección al molino del Hospital y da nombre a un barranco que desemboca en el río Cervol. Actualmente sigue existiendo esta partida con esta denominación. (11)

Más d'en Roca. Másia situada al sudeste del término dentro de la partida del Cervol; podría ser el actual más de la Viuda, ya que se encontraba al lado del camino de Rosell a Cervol y cerca del río. (11) Más d'en Salom. Másia de grandes dimensiones con varios edificios y cultivos de cereales, olivos y ganado; estaba situado seguramente en la actual partida de Salom. Podría ser el actual más de Querol. (11)

Más d'en Savit. Másia situada cerca de la másia d'en Salom, en la partida de su nombre. Podría ser el actual más de Sargantano. (11)

Molí de Cervol. Molino de harina desaparecido hace muchos siglos y situado en el río Cervol. Según la documentación existió por lo menos en el periodo entre 1345 y 1471. (1), (11) y (20)

Molí de Malany. Molino harinero de origen sarraceno situado en el río de la Senia. Documentado en la sentencia arbitral del obispo de Tortosa de 1332 y posteriores reseñas documentales (1), (11) y (20)

Molí de Vinatea. Molino harinero de origen sarraceno situado en el río de la Senia. Documentado en la sentencia arbitral del obispo de Tortosa de 1332 y posteriores reseñas documentales (1), (11) y (20)

Molí d'en Guiot o la Tosca. (o Marc de Pontons) Molino harinero de origen sarraceno situado en el río de la Senia. Documentado en la sentencia arbitral del obispo de Tortosa de 1332 y posteriores reseñas documentales. A su alrededor tenia huertos y campos de olivos que explotaba. (1), (11) y (20) Molí del Hospital. Molino harinero del río Senia, situado entre el de Guiot y el de Taix; estaba situado junto a la partida de las Planas de Rosell. Documentado en la sentencia arbitral del obispo de Tortosa de 1332 y posteriores reseñas documentales. A su alrededor tenia huertos y campos de olivos que explotaba. Actualmente sigue existiendo esta partida con esta denominación. (1), (11) y (20)

Molí d'en Taix o d'en Lloch (o de Canet). Molino harinero situado en el río Senia al lado del término de Canet. Documentado en la sentencia arbitral del obispo de Tortosa de 1332 y posteriores reseñas documentales. A su alrededor tenia huertos y campos de olivos que explotaba. (1), (11) y (20) Planes. Partida situada al este del término junto al de Canet, de terreno llano estaba dedicada al cultivo de cereales, viña y olivos. Actualmente sigue existiendo esta partida con la denominación de Planes dels Carros. (11)

Planes del Borró. Partida situada al nordeste junto al río Senia al lado de las Planas del Hospital; es un terreno llano dedicado al cultivo de cereales y viñas, por que el nombre proviene del aspecto que tenia el trigo espigado y la viña florida en primavera. No podían entrar el ganado a pastar. Actualmente sigue existiendo esta partida con la denominación de Planes. (11)

Pla d'en Teixidor. Pequeña partida dedicada al cultivo de forrajes para el ganado, situada al este de la vila; formaba parte de la partida de Ferreginals. (11)

Roca del Roure. Promontorio rocoso con un viejo roble, situado al sur del término cerca del río Cervol; era un punto de referencia de la delimitación de la másia d'en Salom. (11)

Tossal d'en Martí. Promontorio que servia de referencia para delimitar la partida de la Font de n'Almenara, por tanto se situaba al norte del término. (11)

Tossal del Perelló. Promontorio situado al sur del término cerca del río Cervol; era un punto de referencia de la delimitación de la másia d'en Salom. Actualmente sigue existiendo esta partida con la denominación de Els Tossals. (11)

Vilars de la Senia o Carrascals. Partida situada al este de la vila en dirección al río Senia, atravesado por el camino de dicha población; por la parte este limitaba con la partida de Bonamina. Se cultivaba olivos, cereales y viña. Actualmente sigue existiendo esta partida con la denominación de Carrascalet. (11)

Vilaret del más d'en Salom. Parcela destinada al cultivo de olivos del más d'en Salom. Estaba limitado por el camino de la másia a la vila, y el camino que iba a Canet y el río Cervol. Actualmente sigue existiendo la partida de Salom. (11) 


\section{SANT MATEU (Total de elementos 40, localizada su ubicación 30)}

Ayuntamiento. (3), (4), (14), (17), (19), (30), (31), (35), (36), (37), (39) y (40)

Boverot. Partida situada próxima a vila, junto al río Beniforquell, aguas abajo de la partida Torre dona. Se cultivaban cereales y olivos, además de dedicar parte a pastos para el ganado. (11)

Camer. Dehesa de grandes dimensiones situada junto al término de Cervera. (11) y (19)

Coll d'el aljub. Partida situada al norte en dirección a Xert. Actualmente sigue existiendo la partida con la denominación de Aljup. (11)

Coma dels Molins. Partida situada en el curso bajo del río Beniforquell, donde recibe las aguas de los barrancos de la Coma, Piques y Bassot. Era un terreno plano y húmedo donde se encontraban los molinos de harina posiblemente desde la época sarracena. Actualmente sigue existiendo esta partida con la denominación de Molins. (11) y (19)

Cominyer. Dehesa de grandes dimensiones situada junto al término de Cervera. (11) y (19)

Convento de San Francisco. (3), (4), (14), (17), (19), (30), (31), (35), (36), (39) y (40)

Els Térreas. Se cultivaban cereales. (11)

Ermita de Sant Cristofol. (4), (11), (15), (17), (30) y (31)

Ermita de Santa Ubaldesa. (4) y (11)

Hornos. Existían tres en la vila (3), (4), (8), (14) y (36)

Iglesia Parroquial de Santa María. (4), (11), (15), (17), (30), (31), (36), (38),(39) y (40)

Iglesia de Sant Pere. (4), (11), (15), (17), (30), (31), (36), (38),(39) y (40)

La Coma. Partida situada al norte de la vila. Se dedicaba al cultivo de los olivos. Actualmente sigue existiendo esta partida con esta denominación (11)

Les Fontanelles. Partida situada en la parte alta del término en dirección a Morella. Nace allí el río Beniforquell o Sant Mateu. Actualmente sigue existiendo esta partida con esta denominación. (11)

Les Quarterades. Partida situada aguas debajo de la de Boverot junto a la vila; el nombre proviene que la partida estaba dividida en quadres. Se cultivaban cereales. Por su descripción debe ser la actual partida de "Bajo Vila". (11)

L'Espartera. Partida situada al lado de les Quarterades y dedicada al cultivo del esparto por ser un lugar muy húmedo al estar junto al río. (11)

La Font del Senyor. Partida situada aguas abajo de la vila siguiendo el curso del río Beniforquell, cerca de la vila y dedicada al cultivo de huerta. Debe ser la actual partida de la Font de Siso. (11)

La Font de Morella. Partida situada junto a Les Fontanelles, aguas abajo siguiendo el curso del río, al oeste de la vila y dedicada al cultivo del olivo; junto a la fuente había una zona regada dedicada a la huerta.. Actualmente sigue existiendo esta partida con esta denominación. (11)

Lo Camp. Partida situada junto al convento de predicadores. Actualmente sigue existiendo la partida con la denominación de Santo Domingo. (11)

Les Forques. Partida situada alejada de la vila al noreste del termino en la carretera de la Jana. (11)

Más d'Anglada. Másia situada alejada de la vila. (11)

Más de Simó. Másia situada alejada de la vila. (11)

Más de Vaquer. Másia situada alejada de la vila. (11)

Más Torre Palomar. Enclave estratégico en el que posteriormente se construyó la actual másia.

Molí olí del Pla dels Homs. Molino de aceite cerca de la vila extramuros. (11), (19) y (28)

Molí oli del Portal de l'Espital o de la Vedilla. Molino de aceite situado extramuros junto al portal que le da nombre. (11) y (28)

Molí de la Peguera. Molino harinero. (1), (4), (19) y (32)

Molins situados en la partida de la coma dels Molins. (1), (4), (19) y (32)

Palau Montesa. (3), (4), (14), (17), (18), (19), (30), (31), (35), (36), (37), (39) y (40)

Paxols. Partida situada al este del término junto al camino de la Jana a Salsadella. Actualmente sigue existiendo esta partida con esta denominación. (11)

Pla de Sant Mateu. Extenso territorio situado en dirección a Salsadella, prácticamente llano dedicado a la agricultura y que se divide en diversas partidas. Actualmente en este lugar se encuentran las partidas de: Roquetes, Pontarrón, Parat y Llacunes. (11) y (19) 
Pla dels Oms o Molinars. Partida situada junto a la vila donde se encontraba uno de los molinos de aceite; era una zona húmeda y dedicada al cultivo de huerta. Debe ser por su descripción la actual partida de la Closa. (11)

Piques. Partida situada al norte de la vila junto al barranco de les Piques y dedicado al cultivo del olivo. Actualmente sigue existiendo esta partida con esta denominación. (11)

Povet. Partida situada a continuación de la Font de Morella siguiendo el curso del río, en ella se encuentra el barranco del Povet. Actualmente sigue existiendo esta partida con esta denominación. (11)

Quatremitjana. Partida de una cuadra de tamaño medio. Actualmente sigue existiendo esta partida con esta denominación. (11)

Rambla. Partida situada al norte y alejada de la vila junto a la de les Forques y la rambla en la carretera de la Jana. Se cultivaban cereales, viña y olivos. Actualmente sigue existiendo esta partida con esta denominación. (11)

Raval del Palau de Montesa. Partida situada junto al Palau, extramuros de la vila en dirección a la Jana y dedicada al cultivo de huerta. (11) y (19)

Santa Bárbara. Partida situada cerca de la vila en la parte baja del término junto a la partida de Molins. Se cultivaban cereales, viña y olivos. Actualmente sigue existiendo esta partida con esta denominación. (11)

Torredona. Partida situada al norte cerca de la vila y en el curso del río Beniforquell cuando recibe las aguas del barranco de Bonanza. Actualmente sigue existiendo esta partida con esta denominación. (11)

TRAIGUERA Y MAS DELS STELLERS (Total de elementos 48, localizada su ubicación 31)

Ayuntamiento. (7), (11), (13), (19) y (36)

Albagues. Partida situada al sureste de la vil aproxima a ella a continuación del Freginal. Actualmente existe una partida con esta denominación en esa ubicación. (11)

Barbeguera o Barbiguera. Extensa partida situada junto al barranco del mismo nombre al noreste de la vila y entre el río Cervol y el Senia. Es una zona llana y dedicada al cultivo de cereales y olivos.

Era una zona de boverals y tierras francas que no controlaba Montesa. (11) y (19)

Barranc de Cervol. Partida situada en el barranco que le da nombre y dedicada a los pastos de ganado. (11)

Barranc de la Mustera o Mostera. Partida situada al sudoeste junto al término de la Jana, al lado del barranco de la Roureda. Se cultivaban cereales y viña. (11)

Barranc dels Dellans. Partida al sur cerca de la vila, dedicada al cultivo de algarrobas y cereales. (11) Barranc de Surrac. Partida situada en el barranco que le da nombre y dedicada a los pastos de ganado. Actualmente existe una partida con esta denominación en esa ubicación. (11) y (19)

Bostal. Partida dedicada al pastoreo de ganado. Actualmente existe una partida con la denominación de Bustal junto al barranco de Barbiguera. (11)

Boveral. Se encontraba en la sierra de San Pere y como todos los bovalares se dedicaba a pastos para bueyes y vacas. Actualmente esta partida se denomina Pou Sort.

Boverals del Más dels Stellers. Partida dedicada al pastoreo de ganado. Actualmente existe una partida con la denominación de Bouvalars en esa ubicación. (11)

Cami de Sant Mateu. Partida situada al sur junto a la vila en el camino que iba a Sant Mateu junto al portal de Valencia. Era una zona plana dedicada al cultivo de cereales, higueras y forraje para los animales; es la actual partida de "Cap de la vila". (11)

Cami Estret. Partida situada junto a un camino estrecho entre márgenes de piedra que comenzaba en el portal de la pescadería y atravesaba los "ferreginals" en dirección a la partida de les Albagues. Se dedicaba al cultivo de huerta. (11)

Carrascal de la Font de la Salut. Bosque próximo al ermitorio de la Virgen de la Salud. (11) 
Censalets. Partida del Más dels Stellers, junto al barranco de Surrac; se llama así por que diversas posesiones de la partida estaban sometidas al pago de censales a la Orden de Montesa. Actualmente existe una partida con la denominación de Sensalets en esa ubicación. (11)

La Closa. Pequeña partida junto a la muralla y barbacana de la vila. Era un terreno cerrado por una pared de piedra, en él se encontraban las eras del "comú" y la balsa d'en Ferrus. (11)

Clot de na Iniesta. Partida situada en la Serra d'en Menor junto a la partida de "Clot del Más dels Stellers" en el camino de la Virgen de la Salud al noreste de la vila. Era una partida de grandes dimensiones en las que se cultivaba cereales, olivos, viña, higueras y algarrobos. Es una de las partidas más antiguas, ya que se encuentra documentada desde 1.261. (11) y (19)

Clot d'en Neri. Partida situada al este, cerca de les Planes del Regne y els Hostalets, junto al camino viejo de Tortosa. Actualmente existe una partida con esta denominación en esa ubicación. (11)

Clot d'en Polo o Codompolos. Partida situada al norte cerca de la vila al lado de la actual carretera de San Rafael. Actualmente existe una partida con la denominación de Clot de Polo en esa ubicación. (11)

Ermita de Sant Pere. Ermita situada en el Mont Major. La autorización eclesiástica es de 1.369. (13) Ermita Mare de Deu de la Font de la Salut. (7), (11), (13) y (15)

Ferreginals. Partida situada junto a la vila en la parte baja. Se dedicaban al cultivo de forraje para los animales domésticos. Actualmente existe una partida con esta denominación en esa ubicación. (11)

Figueral d'en Prima o dels Buichs. Partida de higueras de la familia Prima. Actualmente existe una partida con esta denominación junto al barranco de la Virgen al sur del Más dels Stellers. (11)

Foia o Foies. Partida pequeña situada dentro del Más de na Cabanes. Era un terreno llano y hondo. (11)

Font de la Salut o Vergemaria. Partida que inicialmente formaba parte de la del Clot de na Inseta, y que se popularizo a partir del descubrimiento de la imagen de la Virgen a finales del siglo XIV. Actualmente se denomina "Mare de Deu" y se cultivaban cereales y algarrobas. Actualmente existe una partida con la denominación de La Virgen en esa ubicación. (11) y (19)

Font de na Rotlana. Partida situada junto a una fuente que existía cerca del camino Real que iba de Traiguera a Tortosa, junto al barranco de la Font en la zona de Caminous.

Horno en la vila. (8)

Horno en el Más dels Stellers. (7) y (8)

Hostalets. Partida de terreno llano situada entre el Cervol y el Senia, junto a les Planes del Regne. Actualmente existe una partida con esta denominación en esa ubicación. (11)

Más dels Stellers. Másia y partida más grande del término de Traiguera, que posteriormente se convirtió en el municipio de Sant Jordi. Estaba situada al este del término de Traiguera en dirección a Vinaros. La totalidad de posesiones del Más dels Stellers son monopolios de la vila (molino de aceite, horno). La mayor parte de las propiedades de esta partida eran posesiones francas. (7), (11) y (19)

Más de na Bota. Másia situada al este en el más dels Stellers. Actualmente existe una partida con la denominación de La Bota al noreste del más dels Stellers. (11)

Más de na Cabanes. Partida de grandes dimensiones situada al este entre los barrancos de Cervol y la Barbiguera. Parte de la partida paso a formar parte del futuro municipio de Sant Jordi. Se dedicaba al cultivo de olivos. Actualmente existe una partida con esta denominación en esa ubicación, parte en el Más dels Stellers. (11)

Más d'en Serra o Más Roig. Actualmente existe una partida con esta denominación entre el actual término de Traiguera y de Sant Rafael. (11)

Molí d'oli en la vila. (8) y (28)

Molí d'oli en el Más dels Stellers. (7), (8) y (28)

Molí del Castell. Actual San Rafael del río. Molino harinero de origen sarraceno situado en el río de la Senia. Documentado en la sentencia arbitral del obispo de Tortosa de 1332 y posteriores reseñas documentales. (1), (11) y (20)

Molí de la Tosca o de Noguera. Molino harinero de origen sarraceno situado en el río de la Senia. Documentado en la sentencia arbitral del obispo de Tortosa de 1332 y posteriores reseñas documentales. (1), (11) y (20) 
Molí de les Canals. Molino harinero de origen sarraceno situado en el río de la Senia. Documentado en la sentencia arbitral del obispo de Tortosa de 1332 y posteriores reseñas documentales. (1), (11) y (20)

Molí del Pas, situado junto al puente en el río Servol. (11)

Mont Major. Es el toponímico que corresponde a la actual Serra de Sant Pere o Serra Sola. Se dedicaba a los pastos de ganado. (11)

Pla d'en Bort. Partida situada al sur de la vila a la izquierda del camino que va al ermitorio de la Virgen de la Font de la Salud. Se dedicaba al cultivo de cereales y algarrobas. Actualmente existe una partida con esta denominación en esa ubicación. (11)

Planes del Regne. Partida de terreno llano situada entre el Cervol y el Senia. Actualmente existe una partida con esta denominación en esa ubicación. (11) y (19)

Puente del Pas sobre el río Servol. (27)

Segre. Partida situada en el actual Sant Jordi en la zona de Surrac, junto a la partida de "Els Clots" y cerca del barranco. (11)

Serra. Extensa partida situada al sudeste del término; corresponde a la Serra d'en Menor en la parte de la Font de la Salut. Estaba dentro de la partida de "Clot de na Inseta". Se dedicaba al cultivo de olivos y algarrobos. Actualmente existe una partida con la denominación de Serres y otra de Serretes en esa ubicación. (11)

Serra d'en Menor. Partida situada en la Serra d'en Menor en la parte del camino que va de Traiguera al Más dels Stellers. Se dedicaba al cultivo de algarrobos y pastos de ganado. Actualmente existe una partida con la denominación de Serres y otra de Serretes en esa ubicación. (11)

Sortanella. Partida de reducidas dimensiones cuya propiedad se adquiría por sorteo. Actualmente existe una partida con la denominación de Sorts al sur de la Vila. (11)

Tossalet. Partida dedicada al pastoreo de ganado. (11)

Vall de la Jana. Partida situada al sudoeste en el camino de La Jana por la parte de "els Esboïcs" y la "Maniga". Se cultivaban cereales y viña. (11) 


\section{ANEXO III. APÉNDICE DOCUMENTAL}

\section{Índice de documentos}

1. 1192, octubre. Lleida. Alfons II de Aragón otorga a la Orden del Hospital el lugar de la Barcella, situado en el Reino de Valencia, cuando sea conquistado a los musulmanes.

2. 1208, septiembre 9. Huesca. Pere II de Aragón otorga a la orden del Hospital franquicia del pago de lezda y otros impuestos. Al mismo tiempo promete que le dará el castillo de Cervera o el de Cullera, cuando se puedan conquistar a los musulmanes. 603

3. 1217, octubre 13. Vilafranca del Penedés. Jaume I autoriza a los hombres de Lleida i al resto de villas reales de Cataluña a poder dejar dinero en préstamo y a cobrar las deudas en la forma que estimen más oportuna. 605

4. 1235 , octubre 8 . Carta puebla del término general de Cervera otorgada por la Orden del

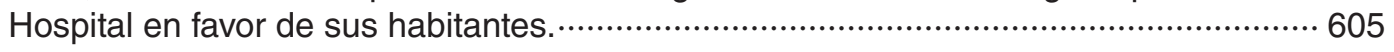

5. 1237, abril 17. La Orden del Hospital otorga la carta puebla de Carrascal. ………............6 607

6. 1237, junio 17. La Orden del Hospital otorga la carta puebla de Sant Mateu. ....................67 607

7. 1238, julio. Blasco de Alagón dona el lugar de Bel, situado en el término de Morella, a

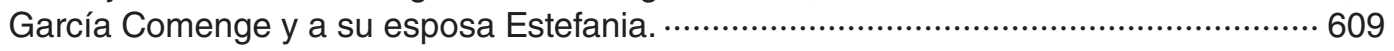

8. 1239, mayo 31. El Maestre de la Orden del Hospital dona a Miquel Moliner y P. Riquer dos molinos situados en el río de Ulldecona: el nombrado como molino de Tosca y otro cerca de este.

609

9. 1242, enero 10. Barcelona. La reina Violant dona al consell municipal de Morella las dehesas de La Vallivana y Salvasoria. ……………......................................... 610

10.1244, marzo 6. Perpinya. Jaume I otorga licencia a la Orden del Hospital, para poder establecer un mercado semanal en la villa de Sant Mateu.

11. 1244, mayo 22. Xàtiva. Jaume I confirma la delimitación de los términos generales de Morella y Cervera.

12.1247, mayo 8. Valencia. Jaume I establece la nueva moneda para los reinos de Valencia y Mallorca. 611

13.1247, mayo 8. Valencia. Jaume I dicta una serie de normas relativas a la "taula de canvis" de la nueva moneda de los reinos de Valencia y Mallorca.

14.1247, septiembre 15. Benifassar. El abad de Benifassar atiende la solicitud de los vecinos de Coratxar para la construcción de una nueva Iglesia.

15.1248, julio 29. Valencia. Jaume I otorga a la villa de Sagunto el régimen municipal de la ciudad de Valencia, regula el sistema judicial de la población, reparte las aguas del río Palancia y los del Valle de Sego, y ordena que el camino real pase por la villa y termino por los lugares establecidos en este privilegio.

16.1249, noviembre 16. Jaume I regula los pesos i medidas de la ciudad y Reino de Valencia. 615

17. 1250, marzo 21. Carta puebla del castillo y villa de Cervera, otorgada por la Orden del Hospital en favor de sus habitantes.

18.1251, enero 19. Morella. Jaume I regula la forma de limpieza, conservación y reparación de las acequias y los azudes del termino de Valencia.

19.1251, junio 19. Zaragoza. Jaume I regula las servidumbres de les paredes medianeras de las cases de la ciudad y reino de Valencia, la participación de todos los valencianos en la construcción de sus respectivas obras públicas, y regula el pago de "sequiatge" o riego. 
20.1255, julio 12. Lleida. Jaume I da licencia a la Orden del Hospital para poder celebrar una feria anual de quince días de duración en la villa de Sant Mateu. 618

21. 1257, diciembre 2. Barcelona. Jaume I da licencia al Consell municipal de Zaragoza, para poder cobrar peaje durante los próximos tres años, por el paso de cualquier animal forastero de carga por el nuevo puente de la ciudad. 619

22.1258, junio 17. Cocentaina. Jaume I otorga al consejo municipal de Teruel la tercera parte de les "calònies" y también les da las "palades" que se acostumbran dar por las mercancías en el mercado del jueves, para reparación de muros, torres, carreteras y puentes....... 619

23.1268, enero 30. Alzira. Jaume I da licencia a los habitantes del Reino de Valencia, para poder transportar madera a la ciudad de Valencia, incluso por los ríos Guadalaviar i Xuquer, sin tener que pagar ciertos impuestos.

24.1270, diciembre 22. Alzira. Jaume I ordena que cada uno de los azudes del riu Xúquer, desde el azud de la Acequia Real hacia abajo, se coloquen pasos de unas ciertas medidas para que puedan pasar las barcas.

25.1271, marzo 16. Valencia. Jaume I instituye el Tribunal del Lligallo de Morella. 621

26.1271, julio. Medición de unas tierras de Russafa, Carpesa i Moncada, motivado por una demanda que hacia la Orden del Temple al rey Jaume I .......................................6. 621

27. 1273, mayo 4. Lleida. Jaume I da licencia al Consell municipal de Morella para poder canalizar el agua de la fuente de Vinachos, y para poder construir unos molinos. ........ 622

28.1273, agosto 20. Valencia. Jaume I da a Guillem Ramon de Montcada, señor de Nules, toda el agua sobrante de la acequia de Vila-real que está en proceso de construcción. También se establece el impuesto de "sequiatge" (riego) y se crea el del "sequier" (regador). .... 622

29.1274, mayo 12. Lyon. Jaume I vende las rentas de Borriana para obtener dinero para la construcción de la acequia de Vila-real. ............................................................6 624

30.1274, octubre 8. Sant Mateu. La Orden del Hospital confirma la carta puebla de Sant Mateu............................................................................................. 624

31. 1276, enero 15. Valencia. Jaume I dona el suelo a los habitantes de Morella para poder hacer una plaza, y confirma las vías públicas. Se trata de la zona de ampliación del barrio del "Sol de vila"...................................................................................... 625

32.1276, enero 15. Valencia. Jaume I aprueba los gastos hechos en la acequia de Vila-real y las cuentas que le ha presentado el comendador de la Orden del Temple en Borriana. 625

33.1283, julio 8. Sant Mateu. Concesión Moli del Oli de la Jana y el Carrascal. 626

34.1291, marzo. Nota al "Baitle" de Vila-real para señalar que se costee el mantenimiento de la acequia con los pagos que realizan los usuarios. 626

35.1296, noviembre 19. Olocau. Compromiso y contrato firmado entre el Consell municipal de Olocau y Meliá Malres, maestro de obras, mediante el cual el municipio le cede durante veinte años la mitad de les primicias, a cambio de la construcción de la Iglesia de la población, les características de las cuales se especifican con detalle. 627

36.1307. Vila-real. Los jurados de Vila-real nombran "els sequiers" (regantes) de la villa y dictan el reglamento del oficio. . 629

37. 1311, mayo 6. Morella. A instancias de los vecinos de Vila-real, el rey Jaume II establece un imposto de peaje con el cual es contribuya a sufragar la obra del puente sobre el río Mijares.

38.1320, agosto 8. Tirasone. Jaime II concede el uso del punzón para marcar las piezas de orfebrería salidas de los obradores de la villa de Morella. .. 631

39.1322, marzo 26. Prohibición del Justicia de Morella para que se utilice la piedra que se ha desprendido del castillo para la construcción de las casas particulares. 632 
40.1322, abril 25. Tortosa. El rey Jaume II de Aragón ordena al batlle general del reino de València que se traslade a Vall d'Uixó y elija un lugar adecuado para la construcción de una iglesia cristiana, una casa para el parroco y un depósito para almacenar los frutos de las "delmas". 632

41. 1332, mayo 25. Molino de la Torta. Sentencia arbitral dictada por el Obispo de Tortosa sobre el uso de las aguas del río Cenia en sus dos orillas por las Ordenes del Hospital y de Montesa..... 633

42.1347, marzo 20. Valencia. Sentencia dictada por el infante Pedro, conde de Ribagorza, por la cual regula la partición de les aguas del río Mijares, entre les villas de Castelló de la Plana, Vila-real, Almassora i Borriana.

43.1358, febrero 20. Valencia. Prohibición de construir casas con porches y con fachadas de montantes de madera ("barandats") después del grave incendio que sufrió Morella en 1356 . 639

44.1358, marzo 12. Les Coves. Concesión privilegio del tribunal del Ligallo para los lugares de Calig, Canet, Rosell, La Jana y la Barcella. 640

45.1358, octubre 12. Barcelona. Pedro III acepta la petición de los vecinos de Morella para reconstruir sus casas después del incendio de 1356 sin ampliar la calle de 16 palmos a 18 como inicialmente se había ordenado.

46.1364, febrero 10. Gurrea. Pere el Ceremonioso obliga tanto al abad de Benifassar como a las aldeas de Morella a contribuir a la construcción de las murallas de Morella. 642

47. 1385, mayo 23. Morella. Contrato para la ejecución de la vidriera mayor de la Iglesia Arciprestal de Morella, hecho entre el sabio en derecho Miquel Barreda y el maestro vidriero Pere Ponç. 642

48.1398, Tirasone. Baremo incompleto, de lana de Morella, sus aldeas y comarca, concentrada en Sant Mateu y expedido por Tuccio Gennanio, con la indicación del peso, costo, procedencia, destino y margen comercial calculado. ..............................................6.6. 643

49.1416, octubre 11, Teruel. Disposición sobre el toque de campanas. ............................ 645

50.1418, Xátiva. Roturación de tierras y desecación marjal 645

51. 1428, abril 5. Teruel. Provisión acerca de la elección y pago de una persona que toque las horas del reloj. 645

52.1440, septiembre 24. Villafranca. Contrato de mantenimiento de ganado a "mig guany".645

53.1483, junio 16. Teruel. Capítulos concordados entre Sebastián de Canyamache y los regadores de Teruel acerca del reloj de la ciudad. 646 

1. 1192, octubre. Lleida. Alfons II de Aragón otorga a la Orden del Hospital el lugar de la Barcella, situado en el Reino de Valencia, cuando sea conquistado a los musulmanes.

Archivo Histórico Nacional. Madrid. Ordenes Militares. Pergaminos. Carpeta 479, nº 11.

Transcripción con variantes formales efectuada a partir de la edición de: Ana Isabel Sanchez Casaban. Alfonso II rey de Aragón, conde de Barcelona y marques de Provenza. Documentos (1162-1196). Institución Fernando el Católico. Zaragoza 1995, documento 574.

Publicada en el Archivo Virtual Universidad Jaume I de Castellón.

Notum igitur sit omnibus, tam presentibus quam futuris, quod ego Ildefonsus, Dei gracia rex Aragonensis, comes Barchinonensis et marchio Provincie, ob remedium anime mee predecessorumque meorum, libenti animo spontaneaque voluntate, dono, laudo, concedo et presentis scripti auctoritate confirmo et auctor $\square$ zo Deo et Sancto Hospitali Iherusalem, et Fortunio Cabeza magistro universisque fratribus eiusdem domus, presentibus et futuris, ibidem Deo servientibus, locum illum qui nuncupatur Barcella, situ iuxta Cervariam, qua sarraceni inhabitant, cum omnibus ingressibus et egressibus suis, cum aquis, pratis, pascuis, montibus, silvis et nemoribus, et cum universis terminis et pertinenciis suis, cultis et incultis, ad ius et dominium ipsius loci expectantibus.

Hoc modo videlicet ut predicti fratres locum ipsum quandocumque voluerint, sicut melius potuerint, populent ibique castrum, edificent et construant, atque villam.

Et hec omnia cum omnibus hominibus et feminabus et ceteris ad illa pertinentibus perpetuo iure hereditario habeant, teneant atque possideant libere, quiete atque potenter, sine alicuius hominis contradictione et contrarietate, ad propriam hereditatem ipsi et successores illorum prefato Hospitali Domino servientes, salva mea meorumque omnium successorum fidelitate per secula cuncta.

Datum apud Ilerdam, mensse octobris, per manum lohannis Berachensis, domini regis notarii, anno Domini millesimo C XC II.

Signum + Ildefonsus, regis Aragonensis, comitis Barchinonensis, et marchio Provincie.

Signum + infantis Petri, filii eius, qui predicta donacione laudo et signo proprio confirmo.

Sig+num Guillelmi de Granata. Sig+num Enneco de Aveo. Sig+num Petri de Maza. Sig+num Eximini de Rada. Sig+ num Petri, maiorisdomus. Sig+num Otonis de Insula. Sig+num Pelegrin de Castellazolo. + Berengarius, Terrachonensis archiepiscopus.

Signum + Iohannis Berachensis, qui hanc cartam scripssit mense et anno prefixo.

2. 1208, septiembre 9. Huesca. Pere II de Aragón otorga a la orden del Hospital franquicia del pago de lezda y otros impuestos. Al mismo tiempo promete que le dará el castillo de Cervera o el de Cullera, cuando se puedan conquistar a los musulmanes.

Archivo Municipal de Sant Mateu. Llibre I de Privilegis, ff. 37v-39r. Còpia simple de comienzos del segle XV.

Transcrito el 12-VII-2006 a partir del manuscrito de referencia.

Publicada en el Archivo Virtual Universidad Jaume I de Castellón.

In Christi nomine.

Sit notum cunctis quod nos, Petrus, Dei gratia rex Aragonum et comes Barchinone, attendentes karitatis et misericordie studia et hospitalitatis opera ac sancte religionis fervorem, quibus sancta domus Hospitalis Jherosolomitani et fratres Deo servientes in ea pollere cercuntur in cismarinis et transmirinis partibus et florere; considerantes etiam quanta sollicitudine defensioni et propagacioni fidei christiane invigilent iugitur et intendant, et pie ad memoriam sepius reducentes dilectionem et bonam ac in Domino laudabilem voluntatem, quam predecessores nostri erga predictam domum et fratres hactenus habuerunt, idcirco corde bono et animo volenti, ob remedium etiam anime nostre et parentum nostrorum, per nos et omnes successores nostros, ad preces domine Sancie illustrissime regine Aragonum matris nostre, et nobilissime sororis Hospitalis eiusdem, et obtentu dilecti nostri fratris Eximini de Lavata, venerabilis magistri Yspaniarum et magni, damus, concedimus et laudamus in perpetuum, domino Deo et eidem domui Hospitalis et prenominato magistro et fratribus presentibus et futuris, quod ab hac hora in antea ab hominibus Hospitalis christianis, scilicet judeis et mauris, quos alicubi in toto regno Aragonum et Cathalonie tota habere noscuntur vel in futurum, ex largicione et concessione nostra aut successorum nostrorum, aut collacione fidelium aut empcione aut comutatione, aut aliis justis modis ibidem acquirere poterunt et habere, nullam questiam vel peytam, nullam toltam vel forciam, nullam hostem vel cavalcatam, vel appellitum, vel eorum redempcionem aliquam, nullumque malum servicium vel demandam, nullumque bovaticum vel monetaticum, vel 
eorum solucionem ullam, nullumque erbaticum, nullumque censum vel usaticum, nullamque lezdam vel portaticum, vel consuetudinem novam et veterem constitutam vel constituendam, nullamque aliam exaccionem regalem ac vicinalem vel aliquam aliam que dici vel nominari possit, queramus aut demandemus unquam aut demandari sinamus in aliquo loco terre nostre ullo modo.

Facientes cum hoc presenti scripto perpetuo duraturo, fratres Hospitalis predicti et eorum homines et feminas cuiuscunque dignitatis vel legis aut condicionis sint ubique per totam terram nostram, cum omnibus rebus et mercibus suis propriis, franchos, liberos, ingenuos et inmunes ac quitios, ac penitus alienos a supradictis omnibus et singulis per secula cuncta.

Ita quod neque nos neque nostri, neque aliquis homo noster vel alienus, supradictos fratres Hospitalis vel eorum homines ubicumque sunt vel erunt, in tota terra nostra aliquid de predictis audeat demandare unquam vel ad aliorum aliquid dandum vel solvendum, vel faciendum vel aliquid aliud quod cogitari possit distringere vel forciare presumat aliquo modo, aliqua ratione vel aliqua occasione vel causa. Predictis autem fratribus Hospitalis et eorum hominibus, presentibus et futuris, ubique sint vel erunt, hanc franchitatem et libertatem perpetuam, concessionem et donacionem, damus, facimus et indulgemus quamvis hoc diu est datum et concessum, sit eis a predecessoribus nostris per idonea instrumenta, et nominatim et specialiter omnibus illis hominibus et feminis majoribus et minoribus, et eorum posteris quos idem Hospitale et fratres habent nunc vel habituri sunt in Gerunda et in Sancto Cededonio eorumque terminis universis. Quosquidem homines de Gerunda et de Sancto Celedonio et aliorum locorum ad ipsum Hospitale pertinentes, nos quibusdam necessitatibus inducti nimium et compulsi agravavimus aliquando exaccionibus indebitis et demandis, a quibus vero omnibus et aliis universis, cum hac carta perpetuo duratura eos omnes et eorum successores, cum aliis universis et singulis hominibus eiusdem Hospitalis christianis scilicet et judeis et mauris, cum omnibus rebus et mercibus et hereditatibus suis, liberos facimus et inmunes, et quitios, nunc et semper et penitus alienos. Quia vero ea omnia que a predecessoribus nostris et nobis ipsis juste et secundum Deum facta sunt et concessa domui Hospitalis et fratribus eiusdem, debent semper inviolata manere. Idcirco omnia privilegia et qualibet alia instrumenta omnesque donaciones, concessiones, et franchitates eidem domui Hospitalis et prenominato fratri Eximino de Lavata, honorando Ispaniarum magistro et fratribus eiusdem, presentibus et futuris, laudamus, concedimus et presentis scripti patrocinio communimus. Decernentes ea robur perpetuum obtinere, sicut melius et utilius et sanius dici potest ad comunem utilitatem sepedicti Hospitalis et fratruum. Et confirmantes atque laudantes predicto Hospitali et fratribus, omnes res et possessiones suas quas nunch alicubi habent in tota terra nostra, vel in antea dante Domino poterunt adipisci, sicut eas juste alicubi possident et quiete, et in eorum privilegiis et instrumentis inde factis a predecessoribus nostris et nobis ipsis plenius continetur. Preterea volumus, statuimus et mandamus, ut fratres et sorores Hospitalis Jherosolomitani, crucis in signum defferentes, si aliquem in causam traxerint vel ab aliquo tracti fuerint, aut eos super aliquo facto vel causa placitari contigerit, non donent nec dare teneantur unquam in aliquo loco totius donacionis nostre aliquam justiciam vel caloniam vel expensas ullo modo illi vel illis sub quorum examine litigaverint. Mandamus igitur firmiter et districte omnibus baiulis, vicariis, merinis, çalmedinis, justiciis, judicibus, alcaydis, juratis, senioribus, repositariis, majoribus domus et aliis universsis et singulis tocius terre nostre, presentibus et futuris, ut hanc cartam et omnia que in ea scripta sunt teneant et illibata conservent et faciant ubique ab omnibus firmiter observari, si de ipsis et de gracia nostra confidunt. Quicumque autem contra hec scripta in aliquo venire presumpserit, iram Dei omnipotentis et omnium sanctorum eius incurrant et extorres a corpore et sanguine Christi, cum Juda proditore et Datan et Abiron intereant et eant, nisi resiperverint ad tartara non redituri, et ne aliqua pena eis desit hii indignacionem nostram perpetuam cum corpore et avere se noverint sine aliquo remedio recurssuros. Datum Osce, quinto idus septembris Era millesima ducentesima quadragesima sexta, per manum Ferrarii, notarii nostri.Signum + Petri, Dei gratia regis Aragonum ac comitis Barchinone.

Testes huius rei sunt, dompnus Guillermus episcopus oscensis. Dompnus Guillermus episcopus tirasonensis. Comes Sancius, Eximinus Cornelii, Garcias Romei, Michael de Losia, Eximinus de Lusia, Lop Ferrench de Luna, Adam de Ascuno, Arnaldus de Alascuno, Gomeç de Luna, Assallitus de Gudayll, Raymundus de Podio, Petrus Eximini de Oriryha, Alvarus Gatarretes maiordomus, Petrus Guitarretes, Didacus Ferrandi.

Et ego Ferrarius, notarius domini regis, hoc scribi feci mandato ipsius loco, die et anno prefixis. 
3. 1217, octubre 13. Vilafranca del Penedés. Jaume I autoriza a los hombres de Lleida i al resto de villas reales de Cataluña a poder dejar dinero en préstamo y a cobrar las deudas en la forma que estimen más oportuna.

Archivo Municipal de Lleida. Reg. 1372, f. 123.

A. Huici. Colección diplomática de Jaime I el Conquistador (1916-26), documento 4. Transcripción con variantes formales efectuada a partir de ésta edición.

Publicada en el Archivo Virtual Universidad Jaume I de Castellón.

Sit notum cunctis, presentibus atque futuris, quod nos Jacobus, Dei gratia rex Aragonum, Maioricarum et Valencie, comes Barchinone et Urgelli et dominus Montispesulani; cupientes utilitati subiectorum salubriter providere, attendentes etiam quod reffert reipublicae, ut in necessitatibus suis possint homines mutuo pecuniam invenire, sicut usus in iure civili est antiquissimo tempore approbatus, auctoritate venerabilis S. Dei gratia comitis Provincie, procuratoris nostri regni, magni patrui nostri, consilio etiam G. vicecomitis Cardone, G. de Cervaria, G. de Montecatano, Petri Aunisii, consiliariorum nostrorum; assistentibus etiam nobis in sollempni curia a nobis super his et quibusdam aliis capitulis mandata, G. R. vicecomite Bearnensi, A. vicecomite Castriboni, H. de Mataplana, R. Gaucerandi, B. de Portella, G. de Cervilione, F. de Sancto Martino, G. de Claromonte, R. Alaman, G. de Mediona, Poncio G. de Torrecella, R. de Palacio, G. R. senescalcho, et multis magnatibus Catalonie et hominibus civitatum et villarum, comunicato consilio et habito diligenti tractatu, occurrentes maliciis quorundam, qui suo sensu et voluntate abutentes, intendunt pervertere ea que, temporibus gloriosissimi R. comitis Barchinone proavi nostri, et illustrissimi domini Adefonsi avi nostri, et serenissimi domini Petri patris nostri inclite recordacionis, regum Aragonum, sunt ab omnibus per totam terram nostre iurisdiccionis subditam inviolabiliter observata, hac presenti scriptura perpetuo valitura, concedimus et laudamus vobis dilectis, charis nostris et fidelibus civibus et populo et toti universitati civitatis Ilerde et omnium aliarum civitatum et villarum, que sunt de dominicatura et regalia nostra, ut auctoritate nostra liceat vobis, universis et singulis, dare pecuniam mutuo, sicut hactenus antecessores vestri fecerunt temporibus antecessorum nostrorum et vos fecistis.

Liceat etiam vobis et successoribus vestris, universis et sngulis, defendere pignora vesta mobilia et inmobilia, habita et habenda, contra omnes personas donec de pecunia vobis debita, fuerit creditoribus vestris, secundum tenorem instrumentorum vestrorum, plenarie satisfactum.

Si quis vero miles, vel alterius condicionis, spreto presente privilegio, vos vel aliquem vestrum in pignoribus vel debitis, contra tenorem instrumentorum vestrorum, vel per aliquam potestatem vel per aliquem iudicem vos infestare presumpserit, aut per se vel per amicos suos, seu per aliam quamlibet personam, aliquod impedimentum inferre vel etiam acceptare, liceat vobis, nulla facta fatiga, ipsum viriliter coercere.

Et quia certum est quod in pacibus et treuguis antiquis a comite, proavo nostro, regibus, avo, et patre nostro, institutis et iuratis, pignora omnium civitatum et villarum, ut dictum est superius, continentur; idcirco ea omnia sub nostra proteccione et custodia recipientes, mandamus atque districte precipimus vicariis et baiulis nostris, et aliis locum nostrum tenentibus, presentibus et venturis, quod, non expectata iussione nostra, in eos qui contra dictum privilegium vobis aut alicui vestrum in pignoribus et debitis vestris, habitis et habendis, contra tenorem instrumentorum vestrorum aliquid atemptare presumpserint, tanquam violatores pacis et treugue et lese maiestatis reos insurgant et quodcumque dampnum eis datum fuerit, non requiratur pro pace fracta.

Illo vero debitores, milites sive alii, qui contra vos vel aliquem vestrum propter debita vel pignora, aliquam sentenciam sive interdictum per se vel per aliquam personam fecerunt aut studuerint promulgari, rei auctore cum omnibus suis a pace et treugua eiectis, nisi infra mensem, postquam a vicario nostro amoniti fuerint, fecerint sentenciam aut interdictum perpetuo relaxari, bona eorum mobilia et inmobilia sint deinte exposita cuilibet ocupanti.

Datum apud Villam Francham de Penitensi, in sollempni curia, III idus octobris anno Dominice Incarnationis M. CC. septimo decimo.

\section{1235, octubre 8. Carta puebla del término general de Cervera otorgada por la Orden del Hospital en favor de sus habitantes.}

Archivo Histórico Nacional. Madrid. Ordenes Militares. Pergaminos. Carpeta 512, no 6P. Copia autorizada de 1260.

Transcrita el 7-VII-2006 a partir del manuscrito de referencia.

Publicada en el Archivo Virtual Universidad Jaume I de Castellón. 
Hoc est translatum a quadam instrumento diviso per alphabetum de verbo ad verbum fideliter sumptum, cuius series sic haberet:

Sepe accidit quod de factis hominum questio nascitur, nisi lingua bonorum testium robur adhibeat aut scriptura.

Idcirco, ad honorem Patris et Filii et Spiritus Sancti, notum sit cunctis tam presentibus quam futuris, quod nos frater Hugo de Fulalcherio, Dei gratia magister sancte domus Hospitalis in regno Aragonum et Catalonie et castellanus Emposte, assensu et voluntate fratris Dominici de Antiniana comendatoris Cervarie, et fratris Guillermi Hugonis comendatoris Emposte, et fratris Raymundi de Ciri comendatoris Orpese, et fratris Poncii de Beldisnar comendatoris domus Hospitalis Maioricharum, et fratris Egidii prioris Emposte, et aliorum fratrum nostrorum, per nos et omnes successores nostros, cum publico instrumento imperpetuum inter vivos valituro, damus in donacione perpetua vobis, Bernardo Michaeli de Tevi $\square$ a, et Bernardo de Pegueroles, et Arnaldo de Podio Alto, de Falceto, et Arnaldo Catalano civi Dertuse, et omnibus populatoribus quos ibi miseritis, et in posterum ibi fuerint, totum terminum integrum de Cervaria ad populandum, cum omnibus planis, paschuis, lignis, erbis, montibus, nemoribus, lignis et lignaminam, et boscos, ad omnes vestros usus proprios, tam domorum quam aliarum rerum.

Predictum terminum totum integrum habeatis vos et successores vestri, et omnes populatores et habitatores quos ibi miseritis et ibi fuerint post vos, cum omnibus ingressibus et egressibus, et cum omnibus suis pertinenciis, preter dominicaturas quas ad nostrum opus ibi retinemus, et donacionem quam fecimus Petro de Balaguario et aliis, cum cartis usque in hunc presentem diem, et unus quisque vestrum et omnes populatores quos ibi miseritis et ibi fuerint, habeant suam pareliatam ad omnes suas proprias voluntates faciendas.

Ita quod possitis ipsas vendere vel impignorare aut dare cuicumque volueritis, sine omni fatiga, preter militibus et sanctis, salva fidelitate nostra et successorum nostrorum et dominio nostro.

Retinemus autem nobis decimam et primiciam panis et vini.

Item, retinemus nobis tantum decimam de oleo, de agnis et capritis, et de lino et canamo; et de aliis ortalicis nichil nobis teneamini dare.

Retinemus etiam omnes furnos et molendina et fabricas, ita videlicet quod cochemus vobis viginti et quinque panes pro uno.

Item, detis nobis pro multura sextam decimam partem.

Item, detis nobis pro locea unam fanecham tritici et aliam ordei, ad mensuram Ylerde, pro unaquaque pareliata, et nos teneamus vobis fabricas paratas cum nostro carbone infra terminos de Cervaria, per ydonea loca, et faciemus vobis exolam, et barrinam, et rastellum, et exadam, cum vestro ferro, sine aliquo loguerio.

Item, retinemus nobis medietatem de omnibus invencionibus quas aliquo modo feceritis.

Item, retinemus nobis quintam de omni lucro quod feceritis in terra serracenorum.

Item, retinemus nobis quod quociens dominus rex fecerit regualem exercitum, ut eatis nobiscum in dicto exercitu cum vestra missione.

Item, retinemus ibi quod omnes venatores qui ibi fuerint, ut dent nobis annuatim tria paria cunillorum cum pellibus, et possint venare de festo sancto Michaelis usque ad Carniprivium Quadragesime.

Item, retinemus ibi quod venatores qui interficient porchos et cervos, yrchos silvestros, et heuros, ut dent nobis vel baiulo nostro unum carterium ultimum de utraque bestia.

Item, retinemus nobis mensuras et pensum ad consuetudinem Ylerde.

Item, retinemus nobis firmamenta et justicias ab bonos mores et consuetudines civitatis Ylerde.

Item, volumus et concedimus quod possitis vos de sentencia et judicio super vos lato appellare civitate Ylerde.

Sub predictis condicionibus damus vobis predictis predictum terminum, ut ipsum inter populatores dividatis, et sitis vos et successores vestri et populatores quos ibi miseritis nobis et successoribus nostris boni et fideles, sicut boni vassalli debent esse dominis suis.

Et volumus et concedimus quod utraque pareliata sit de viginti et quatuor kafisiis ad mensuram Ylerde. Quod est actum VIII $\square$ ydus octobris anno Domini M $\square$ CC $\square$ XXX $\square$ quinto.

Sig+num Hugonis de Fulalcherio, Dei gratia magistri sancte domus Hospitalis in regno Aragonum et Catalonie, et castellani Emposte. Sig+num fratris Dominici de Antiniana comendatoris Cervarie. Sig+num fratris Guillermi Hugonis comendatoris Emposte. Sig+num fratris Raymundi de Ciri comendatoris Orpese. Sig+num fratris Poncii de Beldisuar comendatoris domus Hospitalis Maioricarum. Sig+num fratris Egidii prioris Emposte; qui hoc firmamus et concedimus et testes firmare rogamus.

Sig+num Bernardi Gizberti. Sig+num Bartholomei Anguirarii. Sig+num Raymundi Castellani. 
Sig+num Petri de Olivela, testium.

Sig+num Bernardi de Linerola, capellani altaris sancti Bartolomei, qui hoc scripsit cum literis supra positis in XVI $\square$ linea, que notatur "et cervos", die et anno quo supra.

Sig+num Berengarii de Pulcro Monte, notarii Dertuse, pro teste. Sig + num Petri Egidii, pro teste.

Sig+num Petri de Tamarito, notarii Dertuse, qui hoc translataum scribi iussit, et cum originali comprobavit nullo addito vel dimisso.

Sig+num Sebastiani de Manso, qui hoc translatavit, translaturus mandato Petri de Tamarito, notarii publici Dertuse, VII $\square$ idus aprilis anno Domini M $\square$ CC $\square$ LX $\square$, cum literis supprapositis in IX $\square$ linea, ubi dicitur "Item detis nobis pro multura sextamdecimam partem", et in XII $\square$ ubi dicitur "ibi", et in XIIII $\square$ ubi dicitur "et judicio", die et anno prenotatis.

\section{1237, abril 17. La Orden del Hospital otorga la carta puebla de Carrascal.}

Transcripción realizada por Manuel Ferrandis Irles.

Publicada en BSCC año 1968. Tomo XLIV, pág. 234.

Notum sit cunctis quod nos frater Hugo de Fullalquer Dei gracia castellanus Emposte, humilis consilio et voluntate fratum nostyrorum scilicet fratis Raymundi de Ceci preceptoris Cervarie et fratis Guigno, et fratis Martini Aneguiz damus et concedimus vobis Petro de Capellano et Bernardo Guasch el Balgueiro de Abela et Arnaldo de Castrobono et vestris om, nes pariter totasm illam herededtatem eum heremis et populatis quam preceptoris Cervarie in loco dominato Carrascalium sicut dividit ab oriente in alia populaciones dictum Carrascalium, ab occidente in termino de Xchert, a meridie in rivo sicco et in heriditate sarracenorum a tercio, in termino de Caneto de jana. Sicut ab istis quator affrontacionibus que aliis populatoribus de termino Cervarie faciunt totam dictam hereditatem a celo usque in abisum vobis et vestris et omni posteritati vestre damus in perpetum melius et sanius intelligi potest at vestrum vestrorum que bonum intellectum et comodum. Salvis tamem directis nostris et domui Hospitalis. Si vero dictum hereditatem vendere et impignotare vel alienare volueritis possitis farece expceptis sanctis et militibus et eorum uxoribus. Et nos prenominati populatores promettimus vobis fratri Hugonis de Fullalqueiro et aliorum fractrum Hospitali quod ibi laborabimus et cultivabimus et casis faciemus et ibi habitatimus cum omnibus rebus nostris. Actunm est hoc XV kalendas Madii anno Domini millesimo ducentesimo tricesimo et nono. Sig+num fratris Raymundi de Teris preceptores Cervarie. Sig+num fratris Hugonis de Fullalquer Dei gracia castellanus Emposte humilis. Sig+num fratris Raymundi de Teris Preceptores Cervarie. Sig+num fratris Guigno. Sig+num fratris Martini Eneguiz. Sig+num Guilleremi Ruffa. Sig+num Bernardi de Orta. Testes huius rei.

Petrus Sabdelis qui hoc scripsit mandato fratris Arnaldi prioris Cervarie die et anno quo supra.

\section{1237, junio 17. La Orden del Hospital otorga la carta puebla de Sant Mateu.}

Archivo Histórico Nacional. Madrid. Ordenes Militares. Pergaminos. Carpeta 512, n ${ }^{\circ}$ P. Copia autorizada de 1309.

Transcrito el 3-VII-2006 a partir del manuscrito de referencia.

Publicada en el Archivo Virtual Universidad Jaume I de Castellón.

Hoc est translatum sumptum fideliter, undecimo kalendas julii anno Domini $\mathrm{M} \square \mathrm{CCC} \square$ nono, a quodam publico instrumento tenor cuius talis est:

In christi nomine.

Sit notum cunctis, quod nos frater Hugo de Fulalcherio, Dei gratia magister sancte domus Hospitalis in regno Aragonum et Catalonie, et castellanus Emposte, assensu et voluntate fratris Arnaldi de Spalarges, militis, et Bernardi de Valle Forti comendatoris de Burriana, et fratris Martini Sanxis comendatoris de Maioricha, et fratris Bernardi de Salanova comendatoris Valle Mollis, et fratris Arnaldi de Bellovicino comendatoris de Cervaria, et fratris Mathei capellani nostri, per nos et omnes successores nostros, cum hoc publico instrumento perpetuo valituro, damus imperpetuum vobis, Guillermo Colom, et Guillermo Fornerio, et Petro Clavigero et vestris, et omnibus aliis populatoribus quos ibi miseritis ad populandum, totum illum locum qui nuncupatur Sanctus Matheus, qui est in termino de Cervaria, cum omnibus planis, montanis, pascuis, lignis, hermis, nemoribus, garrigis, et aquis, ad omnes vestros usus, tam domos et fortitudinem quam alia, sicut vobis videbitur expedire ibi faciendum.

Predictum autem locum damus vobis et aliis populatoribus, quos ibi miseritis et qui ibi steterint. Damus imperpetuum, cum omnibus antedictis et aliis pertinenciis suis, et cum ingressibus et egressibus suis, preter dominicaturas quas ibi nobis retinemus. Tali videlicet modo quod quilibet vestrum, et omnium aliorum populatorum quos ibi miseritis, habeatis ibi pro vestra hereditate terram 
sufficientem ad viginti quatuor kaficia Ylerde de frumento, ad omnes vestras voluntates inde faciendas. Itaquod ipsa omnia possitis vendere vel impignorare seu alienare, quoquo modo volueritis cuicumque magis vobis placuerit, sine omni faticha, quam in nobis vel in nostris successoribus inde facere non teneamini, preter militibus et domibus sui locis et hominibus religiosis, salvo iure et fidelitate nostra et successorum nostrorum.

Retinemus etiam inde nobis et nostris successoribus, quod teneamini nobis dare fideliter decimam et primiciam panis et vini tantum, et decimam de oleo, et de agnis, capritis, lino et canabo. De aliis vero ortaliciis nichil dare teneamini.

Item, retinemus nobis furnos, molendina et fabricas, ita videlicet quod teneamur cochere vobis viginti quinque panes pro uno tamen pane.

Et teneamini vos nobis dare sextamdecimam partem cuiuscumque mesure fuerit pro multura.

Et pro locide cuiuslibet hereditatis, teneamini nobis dare unam fanecham frumenti, et alteram ordei, annuatim, ad mesuram Ylerde.

Et nos et nostri successores teneamur ipsas fabricas tenere semper paratas vobis cum nostro carbone, in termino supradicti loci, in ydoneo loco, et facere fieri vobis exolas, barrinas, et rastella et exadas, cum vestro tamen ferro, sine omni alio logerio.

Item, retinemus nobis medietatem omnium invencionum que valeant ultra decem solidos, sed a decem solidos infra nichil nobis dare teneamini de ipsis invencionibus.

Item, retinemus nobis quintam, in omni lucro quod super sarracenos feceritis.

Et teneamini nos sequi, cum vestra missione, quandocumque cum domino rege in regali exercitu nos oporteat ire, et non aliter.

De venacionibus autem, quas ibi feceritis, nichil nobis dare teneamini, nisi tantum illi qui venatores fueritis, et de illo labore vixeritis vobis ballistarii de monte, vel paratores, qui teneantur nobis dare unum quarterium de omnibus bestiis feris, et de [ciro]gallis tria paria in quolibet anno. Et isti tales venatores possint cassare a festo Sancti Michaelis usque ad Carnisprivias Quadragesime tantum.

Item, retinemus nobis mensuras et pensum ad consuetudinem Yllerde.

Volumus etiam et concedimus vobis quod super judiciis et sentenciis vobis latis, possitis vos apellari cuicumque volueritis de illis qui infra terminos de Cervaria permanserint.

Justicias vero et firmamenta directi nobis retinemus, ad bonos mores et consuetudines civitatis Illerde. Damus etiam vobis supradicta omnia et concedimus tali videlicet modo, quod vos et omnes alii populatores quos ibi miseritis, et qui ibi de cetero permanserint aliquo modo, sitis nobis et successoribus nostris legali et fideles, sicut boni vasalli debent esse suis dominis. Et nos et successores nostri erimus inde semper vobis et vestris successoribus auctores et defensores, et faciemus omnia predicta vobis et populatoribus quos ibi miseritis, et vestris et eorum successoribus imperpetuum tenere, et habere in pace contra omnes homines.

Actum est hoc, quintodecimo kalendas julii anno Domini M $\square \mathrm{CC} \square \mathrm{XXX} \square$ septimo.

Sig+num mei, fratris Hugonis de Fulalcherio, Dei gratia magister domus Hospitalis in regno Aragonum et Catalonie, et castellani Emposte.

Sig+num Arnaldi de Spalarges, militis. Sig+num Bernardi de Valleforti comendatoris de Borriana. Sig+num fratris Martini Sanxis comendatoris de Maioricha. Sig+num fratris Bernardi de Salanova comendatoris de Valle Mollis. Sig+num fratris Arnaldi de Bellovicino comentatoris de Cervaria. Sig+num fratris capellani nostri, qui omnes hoc firmamus et laudamus, et firmari a testibus rogamus. Sig+num Petri de Bordello. Sig+num Berengarii de Gruno. Sig+num Raymundi Deude, testium.

Sig+num Petri Bonelli, qui hoc scripsit mandato magistri Guillermi Terrachone, notarii, cum suprascripto in linea XI, ubi dicitur $\square$ quinque $\square$, die et anno prefixis.

Sig+num Raymundi Moragues, tenentis locum justicie ville Sancti Mathei, qui huic translato auctoritatem suam prestitit et decretum.

Sig+num Berengarii Moragues, notarii publici ville Sancti Mathei et curie eiusdem, qui mandato dicti Raimundi Moragues, tenentis locum justicie dicti loci Sancti mathei auctoritatem suam manu mea propria scripsi.

Sig+num Bernardi Paschasis, notarii ville Sancti Mathei, testis. Sig+num Guillermi Mercerii, notarii publici ville Sancti Mathei, testis.

Sig+num Petri Galini, notarii publici ville Sancti Mathei, qui hunc transumptum de originali suo, de verbo ad verbum bene et veraciter translatavi, et cum eo comprobavi, et clausi et subsignavi die et anno in prima linea contentis, et cum raso et emendato in II $\square$ linea, ubi scribitur "et", et cum suppraponito in XXII $\square$ linea, ubi scribitur "mei", et cum raso et rescripto in eadem linea, in loco ubi scribitur "magistri", et cum raso et emendato in ultima linea, ubi scribitur "Terrachone". 
7. 1238, julio. Blasco de Alagón dona el lugar de Bel, situado en el término de Morella, a García Comenge y a su esposa Estefania.

Archivo Histórico Nacional. Madrid. Clero. Pergaminos. Carpeta 420, nº 5. Original.

García Edo, Vicent: “Nuevas aportaciones documentales sobre don Blasco de Alagón”. Boletín de la Sociedad Castellonense de Cultura, 1989, pp. 296-297.

Publicada en el Archivo Virtual Universidad Jaume I de Castellón.

Notum sit cunctis, tam presentibus quam futuris, quod ego Blaschus de Alagone, per me et omnes successores nostros, cum presenti scriptura perpetuo valitura, bono corde et obtima voluntate, dono et confirmo et in presenti trado vobis, Garcias de Comenge et uxori vestre Stephanie, propter multa et grata servitia que mihi fecistis et cotidie faciatis, illam pignam de Biel, cum omnibus suis terminis dicte pinne pertinentibus, cum aquis et rivis et erbis, pascuis et lignis et venationibus, et furnis et molendinis, et molenaris, et cum omnibus hominibus et feminis ibi habitaturis, et cum omnibus melioramentis que vos et ipsi ibi feceritis, ita plenarie et integre, sine diminutione aliqua, et sine nostro nostrorumque retentu, sicut melius et utilius dici vel intelligi et excogitari potest ad salvamentum et profectum vestrum vestrorumque, sicut superius continetur.

Et dicta pinna de Biel habet affrontaciones, de prima parte serra que dicitur de Benifazan, de secunda parte sicut cludent en la sierra de Totis Vallibus, et exit al villar de Rosel, et de tercia et quarta parte termino de Ballibona, pena pena sicut torna a Benifazan.

Sicut iste predicte affrontaciones includunt et dividunt dictam pinnam per circuitum, sic dono vobis illam cum introitibus et exitibus et pertinenciis suis, francam, liberam et quitiam, sine interdicto et contrario aliquo, et mala voce viventis persone.

Ita quod habeatis et possideatis et teneatis et expletetis dictum locum, omni tempore iure hereditario, ad dandum, vendendum, impignorandum, comutandum, alienandum, et quoquo modo alio vestras proprias voluntates faciendum, et que nobis vel nostris non teneamini aliquod debitum servicium inde facere, set illam pinnam habeatis ita integre, cum omnibus supradictis superius continetur.

Salva tamen in omnibus nostri nostrorumque fidelitate.

Et ut presens donacio firmior et stabilior habeatur, et ne a nobis vel nostris possit cassari et in posterum revocari, vobis inde cartam istam facimus, sigilli nostri dependentis munimine roboratam.

Actum est hoc in mense julii Era M $\square$. CC $\square$. LXX $\square$. VI $\square$.

Johannes Regis scriptor et sunt testes huius donationis, domini B. dopno de Alagone, scripsit et mandato eius sigillum apposuit et hoc sig + num fecit.

[1 $\square$. col.] Michaelis de Lison, alcayde de Moriella, et dopno Alegre, justicia de Moriella. [2 $\square$. col.] Johannes dona Rama, et Petrus Gasco.

\section{1239, mayo 31. El Maestre de la Orden del Hospital dona a Miquel Moliner y P. Riquer dos molinos situados en el río de Ulldecona: el nombrado como molino de Tosca y otro cerca de este.}

Archivo Histórico Nacional. Madrid. Órdenes Militares. Montesa. Pergaminos. Carpeta 512, no 13. Original.

Transcripción efectuada el 21 de enero de 2008, a partir de una reproducción del manuscrito de referencia, que nos ha estado facilitada por el señor Santiago Roig, de Vinaros.

Publicada en el Archivo Virtual Universidad Jaume I de Castellón.

Notum sit cunctis quod nos frater Ugo de Fulalquer, Dei gratia castellanus Emposte humilis, consilio et voluntate fratrum nostrorum, scilicet fratris Raymundi de Ciri, preceptoris Cervarie, et fratris Guadoelmi et fratris Guigo, et fratris Arnaldi de Talarn, priori Cervarie, damus et concedimus vobis Michaeli Molinarii, et vobis P. Riquer, et vestris quibus volueritis, duo casalia molendinorum.

Primum, scilicet, molendinum de Toscha in rivo Uldeconem in termino Cervarie damus in hunc modum: quod de omnibus lucris quod Deus ibidem dederit, nobis et nostris vel cui voluerimus recepta molineria ab utrisque partibus, scilicet, VIIII mensura, donetis medietatem fideliter sine omni nostra aliqua missione.

Damus siquidem molendinum inferiorem propinquus supradicti in hunc modum: quod de omnibus lucris quod Deus ibi dederit, donetis nobis tercium bene fideliter sine omni aliqua missione, que ibi non faciamus.

Preterea dicta molendina damus sub tali conditione quod teneatis ea parata suorum necessariorum, sic quod propter vestram culpam nec vestrorum nullomodo unquam cessent, ad nostrum et vestrum 
profectum iugitur operari.

Ad hoc damus dicta molendina vobis et vestris ad vendendum, impignorandum vel alienandum, salvo iure nostro in omnibus, ad vestras voluntates perpetue faciendas, tali modo quod si velletis eam vendere vel impignorare, nobis et nostris fratribus per spacium XXX dierum faciatis scire primitus, et si vellemus ea retinere per quantum in eis dederint, possumus facere. Sin autem faciatis ad vestras vestrorumque voluntates exceptis sanctis et militibus et eorum uxoribus.

Et non eligatis inde alium dominum nec patronem nisi nos et nostros successores perpetue.

Et nos et nostri successores erimus inde vobis et vestris legales guirentes ac defenssores contra omnes personas propter potestatem terre vel principem suo loco.

Et ego prenominato Michaeli Molinarii promito vobis fratri H. de Fulalquer et omnibus fratribus Ospitali, et iuro per Deum et per sancta Euvangelia Domini esse bene fideliter de omnibus directis vestris, sic Deus me adiuvet et Sancta Dei IIIIor Evangelia coram me positis et tactis cum meis propriis manibus, quod nisi [fruo] nec teneamini nobis de dicto donativo in aliquo respondere.

Actum est hoc II kalendas iunii anno Domini M CC XXX et VIIII.

Sig+num fratri H. de Fulalquer, Dei gratia castellanus Emposte humilis. Sig+num fratris R. de Ciri, preceptoris Cervarie. Sig+num fratris Guadoelmi. Sig+num fratris Guigo. Sig+num A., priori Cervarie. Sig+num A. Catala. Sig+num P. de Capellano. Sig+num G. Esteler, testes.

Petrus, subdiachonus, qui hoc scripsit mandato frater A., priori Cervarie, cum literis suprapositis in VII linea ubi dicitur bene, die et anno quo supra. +

$\mathrm{ABC} A B C \mathrm{ABC} A B C$

\section{1242, enero 10. Barcelona. La reina Violant dona al consell municipal de Morella las dehesas de La Vallivana y Salvasoria.}

Archivo Municipal de Cinctorres. Llibre de privilegis i documents variats. Copia simple del siglo XV. Publicada en el Archivo Virtual Universidad Jaume I de Castellón.

Manifestum sit omnibus, quod nos Yoles Dei gratia regina Aragonum, Maioricarum et Valentie, comitisa Barchinone et Urgelli et domina Montispesulani, damus, concedimus et laudamus vobis, populatoribus de Morella et de termino ipsius, presentibus et futuris, pro vedato seu devesa, totum illum montem qui vocantur Vallivana et Salvasoria, sicut afrontatur ex prima parte cum termino de Catin et ex secunda cum termino de Aras, et ex tertia parte cum serra de Vallibona, et de quarta parte sicut aque labuntur circa dictum terminum.

Predictum itaque montem, cum suis introitibus et exitibus, ingresibus et regresibus, aquis, pascuis, venationibus et pertinentibus universis, damus et concedimus vobis, dictis populatoribus, liberum et franchum, ad vestras vestrorumque proprias voluntates.

Mandamus igitur firmiter et stricte, quod nullus homo preter vos, dictos populatores, audeat vel presumat incidere ligna, cremare, venare vel pascere in dicta devesa vel termino eius, sicut in predictis affrontationibus continetur.

Datum Barchinone IV idus januarii anno Domini M $\square$ CC $\square$ XXXXI $\square$.

Huius rei testes sunt, dominus Arnaldus Corella, dominus Joannes Petri de Tara $\square$ ona, dominus Fortunuis Gata, dominus Santius de Fraga.

Et ego magistro Guido, qui mandato domina Regina hoc scribi fecit, loco, die et anno prefixis.

\section{1244, marzo 6. Perpinya. Jaume I otorga licencia a la Orden del Hospital, para poder establecer un mercado semanal en la villa de Sant Mateu.}

Archivo Municipal de Sant Mateu. Llibre I de Privilegis, f. 80v. Copia simple de comenaments del siglo XV.

Transcrito el 17-VII-2006 a partir del manuscrito de referencia.

Publicada en el Archivo Virtual Universidad Jaume I de Castellón.

Noverint universi, quod nos Jacobus Dei gratia rex Aragonum, Maioricarum et Valencie, comes Barchinone et Urgelli et dominus Montispesulani, ad preces fratris Hugonis de Folio Alquer castellani Emposte, per nos et nostros damus et concedimus pauperibus Hospitale Sancti Johannis Jherosolomitani et omnibus fratribus eiusdem presentibus et futuris, inperpetuum, mercatum in loco qui dicitur Sanctus Matheus de Cervaria. Ita quod singulis septimanis habeant et teneant mercatum ibidem per unum diem, in qua vellet circunstantes non teneant mercatum.

Quem mercatum habeat dictum hospitalem franchum et liberum, cum toto iure suo, ad omnes 
voluntates libere faciendas, sine omni impedimento et contradictio.

Recipientes ita quod omnes homines et feminas ad dictum mercatum venientes, cum omnibus rebus suis, eundo, stando et redeundo salve et secure. Et nullus audeat eis malum facere vel bonis eorum, et qui faceret iuxta nostre voluntatis arbitrium punietur.

Datum Perpeniani, pridie nonas marcii anno Domini millesimo CC $\square \mathrm{XL} \square$ tercio.

Signum + Jacobi, Dei gracia regis Aragonum, Maioricarum et Valencie, comitis Barchinone et Urgelli, domini Montispesulani.

Testes sunt: B. de Sanctaugenia, Galcerandus de Pinos, Galcerandus de Cartella, P. Maza, Petrus Berengarii comes Impuriis.

Signum Guillamoni Scribe, qui mandato domini regis hec scripsit loco die et anno prefixis.

\section{1244, mayo 22. Xàtiva. Jaume I confirma la delimitación de los términos generales de Morella y Cervera.}

Archivo Històrico Nacional. Madrid. Códice 1126B, procedente del monastiro de Benifassàr. Siglo XVI.

Transcrito en 1999 a partir del manuscrito de referència.

Publicada en el Archivo Virtual Universidad Jaume I de Castellón.

Noverint universi, quod nos Jacobus, Dei gratia rex Aragonum, Maioricarum et Valencie, comes Barchinone et Urgelli et dominus Montispesulani, per nos et nostros laudamus, concedimus et confirmamus in perpetuum divisionem illam quam mandato nostro fecerunt Luppus Otxova, alcaydus de Morella, Bartholomeus de Molendinis, Ioannis de Na Rama, I. Franch, et B. de Quadres, super terminis videlicet qui sunt inter Morelam et Cervariam.

Confirmantes et concedentes in perpetuum, quod castrum et villa de Cervaria habeant perpetuo illos terminos, sicut diviserunt et terminaverunt eos homines supradicti.

Datum in exercitu Xative, XI kalendas iunii, anno Domini millesimo $\mathrm{CC}^{\circ}$. XL $\mathrm{XL}^{\circ}$ quarto.

Signum + Iacobi, Dei gracia regis Aragonum, Maioricarum et Valencie, comitis Barchinone et Urgeli et domini Montispesulani.

Testes sunt: Petrus, infans Portugalie; Petrus d'Alcala, Eximinus Petri, Eximinus de Focibus, R. de Peralta.

Signum + Guillamoni scribe, qui mandato domini regis pro Guillelmo de Bello Loco, notario suo, hec scribi fecit die et anno prefixis.

\section{1247, mayo 8. Valencia. Jaume I establece la nueva moneda para los reinos de Valencia y Mallorca.}

Archivo del Reino de Mallorca, Llibre de Privilegis i Franqueses confeccionado en 1334 por Romeu dez Poal, ff. 15r-16v.

Transcrito el 7-VI-2006 a partir del manuscrito de referencia.

Publicada en el Archivo Virtual Universidad Jaume I de Castellón.

Noverint universi quod nos Jacobus, Dei gratia rex Aragonum, Maioricarum et Valentie, comes Barchinone et Urgelli et dominus Montispesulani; ad honorem illius per quem reges regnant et principes locuntur justiciam, devictis iam per nos divino auxilio in finibus Ispanie, barbaricis nacionibus cupientes civitates, et regna Valencie, et Maioricarum, que dudum a perfidis captivata paganis dignata est divina clementia nostro ministerio restituere cultui christiano, in statum debitum iuxta christianorum morem in melius reformare, ut abiectis vetustatibus et moribus perfidorum quodam nove generationis augmento usus christiane religionis longos ponat ubique funiculos, et sua possit tentoria dilatare, subditorum utilitatibus deliberato consilio providentes, monetam cudi fecimus sub signo salutifere crucis supra florem et nomen regni Valencie, posite nostre etiam imaginis, et nominis insigniis figuratam, ut sit christianis, omnibus judeis et sarracenis in supradictis civitatibus, et regnis comorantibus, necnon et aliis omnibus undecumque ibidem confluentibus una et comunis forma monete, qua sola in suis comerciis empcionibus, et vendicionibus, et quibuscumque aliis pactionibus et contractibus absque trepidatione utantur.

Et ut ad usum predicte monete cum omni $\square$ ecuritate concurrant, statuimus quod presens moneta civitatis, et tocius regni Valencie, et civitatis, et tocius regni Maioricarum semper sit ad legem trium denariorum exeunte argento ad undecim denarios, et obolum, et denariis predicte legis exeuntibus ad pondus decem et octo solidorum pro marcha; et quod oboli ipsorum denariorum semper sint ad 
legem predictam trium denariorum, exeunte argento ad undecim denarios, et obolum, ad pondus viginti solidorum pro marcha.

Quam monetam volumus et statuimus quod semper apelletur et vocetur "reals de $\mathrm{Val} \square$ ncia", in cuius una parte sit caput regium coronatum, et in reliqua parte sit arbor ad modum floris, in cuius sumitate, extensa usque ad superiorem circulum, ponatur crux contigua ipsi arbori infra extremum circulum.

Statuimus itaque per nos et nostros, quod in tota vita nostra, et post per decem annos, continuos et completos predicta moneta realium Valentie sit sub eisdem lege, scilicet pondere, figura, nomine, litteratura, valore, signo et magnitudine, et currat, duret, et eius usus sit singularis et publicus in civitate et regno Valentie, et in civitate et regno Maioricarum, et in insulis Minorice, et Evi $\square$ e, et in aliis circum adjacentibus eidem regno subditis.

Et alia moneta cuprea vel argentea, vel alia moneta in qua sit cuprum vel argentum mixtum de quacumque lege sit vel valore, non recipiatur in predictis locis preter istam monetam que superius nominatur que a nobis, vel ab aliquo alio non destruatur, mutetur, minuatur, augeatur nec anulletur aliqua necessitate racione vel causa vel aliquo iure arte vel ingenio, sed in diminutione sive deffectu ipsius monete, ipsam eandem monetam cudere, et fabricare possimus, in predictis lege pondere et figura nomine literatura, valore et signo, rotunditate et magnitudine.

Nullus itaque christianus, et judeus, aut sarracenus, qui in predictis regnis vel eorum pertinentiis emerit, vendiderit, impignoraverit, vel alio aliquo modo alienaverit aliquas res mobiles et inmobiles, ac semoventes non emat, vendat impignoret vel aliter alienet, recipiat, donet vel solvat nisi predictam monetam, set eam donet habeat, et recipiat ad omnem usum suum.

Et qui alia moneta cuiuscumque legis valoris vel ponderis ex nunc usus fuerit in prefatis civitatibus, et regnis tanquam transgressor regie ordinacionis, et lese maiestatis reus confiscatis omnibus bonis suis ultimum suplicium paciatur.

Sub eadem pena firmiter statuentes quod aliquis notarius vel scriptor in predictis civitatibus, et regnis ex nunc non audeat conficere instrumenta nisi solummodo ad modum ad nomen predicte monete realium Valencie, exceptis censualibus rebus in quibus possint ponere aurum, vel argentum censuale. Et ut predicta omnia et singula per nos, et nostros semper in tota vita nostra, et post per decem annos continuos et completos valeant et in aliquo non violentur set observentur, corporaliter juramus per Deum et eius sancta quatuor euvangelia nos habere ratum et firmum, quicquid superius continetur, et in omnibus inviolabiliter faciemus quamdiu vixerimus, observari, et ad hoc successores nostros usque ad prefinitum tempus sicut superius scriptum est obligamus.

Datum Valentie, VIII $\square$ idus madii, anno Domini millesimo ducentesimo quadragesimo septimo.

Signum + Jacobi, Dei gratia regis Aragonum, Maioricarum et Valentie, comitis Barchinone et Urgelli et domini Montispesulani.

Testes sunt: Carrocius, R. de Timor, G. de Montecatano, G. de Angularia, Jacobus de Cervaria.

Signum + Guillermi, domini regis scribe et notarii, qui mandato ipsi hec scribi fecit loco die et anno prefixis.

\section{1247, mayo 8. Valencia. Jaume I dicta una serie de normas relativas a la "taula de canvis" de la nueva moneda de los reinos de Valencia y Mallorca.}

Archivo del Reino de Mallorca, Llibre de Privilegis i Franqueses confeccionado en 1334 por Romeu dez Poal, ff. 16v-18r.

[Huici-Cabanes, 1976, n $\square$ 459]. Revisada la transcripción el 7-VI-2006 a partir del manuscrito de referencia. Los fragmentos que figuran entre paréntesis no es encuentran en la copia mallorquina del documento, pero si en la valenciana, y los hemos incluido a partir del texto valenciano contenido en el Llibre de Privilegis de Valencia (1515), o Aureum Opus, documento 22 de Jaume I.

Publicada en el Archivo Virtual Universidad Jaume I de Castellón.

Noverint universi quod nos Jacobus Dei gratia, rex Aragonum, Maioricarum et Valencie, comes Barchinone et Urgelli et dominus Montispesulani; quia in nova moneta nova est constitucio facienda, statuimus quod tabula presentis monete realium Valentie duret in civitate, et toto regno Valencie, et in civitate, et toto regno Maioricarum per quadraginta dies continue completos in unoquoque locorum computandos, a die qua a nobis et nostris substitutis publicabitur ipsa moneta.

Statuimus itaque volumus, et mandando sancimus quod infra tempus predictorum quadraginta dierum, aliquis palam vel occulte modo aliquo causa necessitate, vel aliqua alia ratione, non extrahat, vel extrahi fatiat a predictis regnis vel eorum pertinentiis, jaccensis, malguyrensis, barchinonensis, platam aurum vel argentum, nec aliquam aliam monetam, vel bozonaylam, set tota predicta moneta et quelibet bozonayla deferatur ad magistrum ipsius monete, vel ad campsores, sive tenentes tabulas 
nostras monete, cum realibus Valencie, justo et taxato precio inferius distrahenda.

Et quamdiu tabula nostra per dictos quadraginta dies duraverint in unaquaque civitatum illarum et locorum, dentur et recipiantur sexdecim melgurienses, pro duodecim realibus Valentie, et unus denarius plate ponderis detur et recipiatur pro tribus denariis malgurienses, et quindecim denarii jaccensis dentur et recipiantur pro duodecim realibus, et quindecim turonensis dentur et recipiantur pro duodecim realibus, [et octodecim barchinonensis dentur et recipiantur pro duodecim realibus], et unus morabatinus alfonsinus detur et accipiatur pro sex solidis realium, et una macemotina jucifia, detur et accipiatur pro quatuor solidis regalium, et macemotina contrafacta, detur et accipiatur pro tribus solidis, et sex denariis realium, [et duo genovini sive duo reales Marsilie dentur pro uno denario realium Valencie, et unus genovinus grossus de argento detur pro tribus realibus, et marcha argenti detur pro XXXVIII solidis realium].

Transactis autem predictis XL diebus, statuimus quod si aliquis christianus, judeus, vel sarracenus habitator in predictis civitatibus, et regnis, necnon et omnes alii confluentes ibidem qui debent vel debuerint cum cartis vel sine cartis jaccenses, melgurienses, barchinonenses vel quamlibet aliam monetam, in qua sit cuprum, non solvat nisi denarios realium Valentie, et pro jaccensibus, melguriensibus, turonensibus, et barchinonensibus, quos debuerint, solvant denarios realium [Valencie], secundum quod denarii reales cum predictis monetis in tabulis cansorum ad cambium valuerint.

Et qui tenetur solvere pro rebus censualibus denarios, jaccenses, vel melguyrenses, censuales solvant, tot denarios realium Valencie, quot jaccenses vel melgurienses fuerin contenti in instrumentis emphiteoticis.

Et qui tenetur jaccenses vel melgurienses, solvere pro loguerio domorum, furnorum, molendinorum, vel operatorium, vel pro loguerio quorumbet aliorum, solvant tot denarios reales, quot denarios melguyrenses vel jaccenses tenebatur solvere pro logueriis.

Et hoc idem intelligatur de venditione ad tempus facta de fructibus, sive expletis terre, vel arborum vel aliorum reddituum.

Et quia de mandato et constitutione nostra spetiali melgurienses cum jaccensibus erant et currebant comunes in omnibus usibus hominum, et solutionibus, licet contineatur in instrumentis quod fiat solutio jaccensibus, constituimus quod fiat solutio realium Valentie, secundum quod melgurienses cum realibus valuerint in tabulis cansorum ad cambium illa die qua fiet solutio debiti, et sic non teneatur aliquis deducere reales cum jaccensibus, nisi solum modo cum malguriensibus, cum de mandato nostro solutiones melguriensibus fiebant in regno Valentie, pro jaccensibus, et erat in electione debitoris solvere melgurienses vel jaccenses, quos tunc magis vellet, et numerus, et quantitas sive pondus ex eo non augmentabatur danti nec recipienti.

Et transactis etiam predictis quadraginta diebus tabule qui debet aurum, vel argentum pro censualibus, vel alia qualibet de causa vel contractu, solvat illud, vel creditor, dominus census recipiat pro auro, vel argento denarios realium, secundum quod valuerint in tabulis camsorum ad cambium, si recipiens maluerit denarios realium quam aurum vel argentum.

[Contractus autem matrimoniales et censuales possint fieri ad quantitatem auri vel argenti].

Quicumque autem contra predicta vel eorum aliqua fecerit, confiscatis omnibus bonis suis corporalem penam patiatur, quamcumque sibi decreverimus influgenda.

Datum Valencie VIII $\square$ idus madii anno Domini millesimo ducentesimo quadragesimo septimo.

Signum + Jacobi, Dei gratia rex Aragonum, Maioricarum et Valentie, comes Barchinone et Urgelli et domini Montispesulani.

Testes sunt: Carrocius, Jacobus de Cervaria, G. de Montechatano, G. de Angularia, R. de Timor. Signum Guillermi, scribe et notarii domini regis, qui mandato ipsius hec scribi fecit loco die et anno prefixis.

\section{1247, septiembre 15. Benifassar. El abad de Benifassar atiende la solicitud de los vecinos de Coratxar para la construcción de una nueva Iglesia.}

Transcripción realizada por Vicent Domènec.

In Di nomine. Sit notum cunctis. Quod nos universitas hominum de Coratxa per nos et omnes nostros cum hoc presenti publico instrumento / commandamus et in presenti tradimus et concedimus vobis dompno Berenguer, abbati et conventui Scarpii presenti et futuro primicias omnium rerum / in villa de Coratxa et in omnibus terminise eius tam de seminibus quam de animalibus percipi possunt vel solent vel debent usque ad XX annos ab / hoc scilicet primo venturo festo beate Marie semper virginis mensis Septembris continue completos et ultra tundum videlicet quandum concilium et universitas 
de / Morella vel aliqui pro ipsis tenebat et possidebat ac percipient primicias in villa de Morella et in terminis eius talividelict pacto quod vos / et vestri construatis vel construi ffaciatis nobis in villa de Coratxa ecclesiam usque ad $\mathrm{X}$ annos habentem parietes de argamassa et duos arcus / lapideos de tusca vel de alia bona petra habentem inter se distanciam competentem, et hostium lapideum rotundum et aperimentum detabulis le / vigatis et bene posisitis el planis inferius, superius vere delantibus bene coctis et bonis qui importunitatem pluviarum ab ecclesia valeat/ evitare. Utensilia ero eccle sie tam in libris quam in vestimentis et calice ac aparatua altaris, sin ita sufficientia et apta, quod officium / divinum in missis sive in aliis horis honeste et devote ibidem valat celebrari. Sud ito inquam pacto predictas primicias tradimus / vobis quod omnia hace superiur memorata usque ad X annos bene et sufficienter extotto compleatis. Si autem contingeret aliquo casu quod ecclesi / Dertuser sis haberet vel perciperet primicias de Morella ante spatium XX annorum superius memoratum, quod nos et nostri faciamus vos et / vestris habere tnere et possidere predictas primicias quandum vi cini et universitas de Morella vel aliquid loco ipsorum possederint et perceperint / primicias de Morella. Ita quod si semper eis fratia facta fuerit ab ecclesia Dertusensis, quod semper predictas primicias habeant et percipiant / vos similiter in pace habeatis semper et percipiatis = Ita quod nullus super hoc unquam nostrum vel sucessorum nostrorum vel alius pro nobis loco contra / vos vel vesros moveret posset aliquam questionem vel aliquid a vobis repente vel causam intrare $=$ Et nos frater Berengarius, dictus abbas Scarpii per nos / et totum conventum nostrum predicta et singula complere promitimus secundum quod superius est expressum. Et ut securiores inde sitis nos omnes proceres / et omnis universitas de Coratxa damus vobis fidan cias salvetatisvidelict guilelmus de Vindodi et Guilelmus de Pena Rubea qui vonis dicto plere ut superius scriptum est.. Bona fide et sine omni malo ingenio./ Et nos ictus frater Berengarius, abbas monasterii Scarpii, per nos et per totum conventum nostrum, damus vobis fidancias salvetatis. Videlicet Matheus de Paner et Dominicus Sancius, qui obiomnibud proceribus de Coratza et omni eiusdem universitat eiusdem loci. Haec omnia superius nominata nobiscum et sine nobis faciant / attendere et complere bona fide et sine dolo ac sine omni contradicto. Quod actum est XVII kalendas octobris, anno Domini $\mathrm{M}^{\circ} \mathrm{CC}^{\circ} \mathrm{XL}^{\circ} \mathrm{VII}^{\circ}$.

Sig(signo) num fratris Berengarii abbatis. Sig(signo) nun fratris Johannis de Taurynano prioris. Sig (signo) num fatris G. Subprioris. Sig(signo) num fratris Raymundis Peregrini, celleratii maioris. Sig(signo) num/fratris Johanis Martini, cellerarii medii, monachorum Scarpii qui hoc laudamus firmamus et concedimus per nose et per totum conventum nostrum presentem atque futurum. Testes atque fidevissores/firmarique rogamus Sig(signo) num Mathei de Pnaer. Sig(signo) num Dominici Sancii fidevissorum exp parte domini Abbas et conventus Scarpii qui hoc superius scriptum concedimus et firmamus. Sig (signo) num/Guilelmi de Vinbodi Sig (signo) num Guillemi de Pena Rubea fidevissorum ex parte procerum de Coratzano qui hoc laudamus firmamus et concedimus per nos et per omnes proceres de Coratzano / testes firmarique rogamus. Sig (signo) num Petri Pelicerii Sig (signo) num Johanis de Pena Rubea. Sig(signo) num Pascualii filii den Lozar Sig(signo) num Salvatoris de Pena. Testium. / Sif(signo) num fratris G. Subprioris qui hoc scripsit et per alfabetum divisit.

\section{1248, julio 29. Valencia. Jaume I otorga a la villa de Sagunto el régimen municipal de la ciudad de Valencia, regula el sistema judicial de la población, reparte las aguas del río Palancia y los del Valle de Sego, y ordena que el camino real pase por la villa y termino por los lugares establecidos en este privilegio.}

Transcripción con variantes efectuada el 4-2-2010 a partir de la edición del texto efectuada por A. Huici “Colección Diplomática de Jaime I de Aragón”, documento 338.

Publicada en el Archivo Virtual Universidad Jaume I de Castellón.

Nos Iacobus, Dei gratia rex Aragonum, Maioricarum et Valencie, comes Barchinone et Urgelli, et dominus Montispesulani, statuimus extendendas et alicubi in toto regno Valencie aliquas consuetudines valere nolumus preter istas.

[1] Per nos igitur et nostros concedimus vobis, universis et singulis habitatoribus castri et ville et arravale et tocius termini de Murvedre, presentibus et futuris, in perpetuum, quod salvis vobis et vestris in perpetuum specialibus cartis hereditatum vestrarum in omnibus aliis capitulis, habeatis consuetudines Valencie et secundum eas omnes causas civiles et criminales et cuiuscunque condicionis fuerint terminentur. Et franchitates et quelibet alia in consuetudinibus Valencie contenta, posita, statuta et statuenda, vos et vestri perpetuo in omnibus et per omnia habeatis.

[2] Concedimus etiam vobis et vestris, in perpetuum, quod ad opus et usum curie ville habeatis unam domum in Muroveteri, ubi cause pertractentur; quam domus habeatis francham et liberam, cum introitibus, exitibus, affrontacionibus, et suis pertinenciis universis, a celo in abissum; et in dicta domo 
curia sedeat, audiat, determinet et diffiniat omnes causas criminales et civiles et querimonias que inter aliquos vertentur in villa et toto termino de Murvedre, et in dicta domo, ex quacunque causa civili vel criminali seu qualibet racione vel occasione semper capti detineantur in carcere, et ad castrum vel alibi non ducantur nec capti detineantur nisi in carcere ipsius domus, nec presumat aliquis habere privatum carcerem vel locum ad repponendum ibi aliquos captos, racione querimonie alicuius seu maleficii vel contractus, nisi in dicto loco curie.

[3] Concedimus etiam vobis et vestris in eternum, quod quicunque castrum de Muroveteri tenuerit vel quicunque cum dicto castellano in dicto castro vel aliter cum eo fuerit, non possit reddere ius sibi vel familie sue, vel illis qui cum eo fuerint, si de aliquo habitatore Muriveteris vel etiam extraneo conqueratur; sed recipiat inde ius a curia Muriveteris qui pro tempore fuerit.

[4] Concedimus etiam quod dictus castellanus vel aliquis qui cum eo sit, neminem possit capere vel captum detinere pro crimine vel contractu, licet ipsemet vel sui de illo, quem vellet capere, conquerantur. Sed si forsan ille de quo conquereretur aliquis, esset talis vel tantus quod sine auxilio castellani capi non posset, vel captus detineri, vel probi homines in hoc essent negligentes vel remissi, vel ad hoc impedimentum prestarent, volumus quod in hiis casibus castellanus qui ibi fuerit possit iuvare curiam, et loco curie ipsum capere, et captum si necesse fuerit in villa detinere.

[5] Concedimus etiam vobis quod milites aliqui non possint habere domos in villa de Muroveteri, nisi hereditatem ibi habuerint ex donacione nostra vel licencia speciali.

[6] Concedimus etiam vobis et vestris successoribus in perpetuum, quod totam illam aquam que transit per rivum de Segorp et per cequiam de Torres Torres, habeatis et expletetis ad usus et utilitates vestras quolibet mense, continue de die et nocte, per primos quindecim dies. Ita quod nullus in predictis XV diebus et noctibus audeat vobis predictis populatoribus Muriveteris impedimentum aliquod facere, quin dictam totam aquam libere et ab integro habeatis et percipiatis ad rigandum, ad bibendum, ad molendum et ad omnes alias necessitates et utilitates vestras et usus. Et si quis in predictis quindecim diebus vel noctibus vobis in tota dicta aqua vel in parte ipsius aliquod impedimentum faceret, sciat se soluturum penam mille solidorum regalium Valencie.

[7] Item, concedimus quod curia mutetur ibi anuatim festo Nativitatis Domini.

[8] Concedentes insuper quod caminum semper transeat per villam Muriveteris, et per portam mediam ipsius ville, et inter olivam et sequam, et transeat per medium ravallum, et claudatur locus ille per quem viam consuevit ire tempore sarracenorum, sub domibus Petri de $\mathrm{Na}$ Miquela.

[9] Volumus etiam et mandamus quod aqua vallis de Segon et aqua que transibit per Murumveterem dividatis, et inde regetur secundum quod tempore sarracenorum fuerat consuetum. Hoc tamen fiat libere et sine aliquo tributo.

Datum Valencie quarto kalendas augusti anno Domini millessimo ducentessimo quadragessimo octavo.

Sig+num Iacobi, Dei gratia regis Aragonum, Maioricarum et Valencie, comitis Barchinone et Urgelli et domini Montispesulani.

Testes sunt: G. de Montecathano, G. de Aquilon, Carrocius, G. de Pinos, G. de Grayena. Sig+num Guillelmi Scribe, qui mandato domini regis hoc scribi fecit, die et anno prefixis.

16. 1249, noviembre 16. Jaume I regula los pesos i medidas de la ciudad y Reino de Valencia. Archivo de la Corona de Aragón. Barcelona. Cancelleria Reial. Códice 9 de la Casa Real, ff. 10v-11r. Copia simple de comienzos del siglo XIV.

[Aureum Opus, 1515, documento 30 de Jaume I], [Huici-Cabanes, 1976, n $\square$ 511], [García Edo, 1988, pp. 128-9].

Publicada en el Archivo Virtual Universidad Jaume I de Castellón.

Noverint universi, quod nos Jacobus Dei gratia rex Aragonum, Maioricarum et Valencie, comes Barchinone et Urgelli et dominis Montispesulani; cum secundum consuetudines a nobis datas civitati et regno Valencie, et civitate et omnibus villis, castris, et quibuslibet aliis locis eiusdem regni, unum et similis pondus esse debeat et mensura; statuimus per nos et per nostros imperpetuum decernimus: Quod marcha habeat et contineat in se octo uncias. Et uncia contineat in se viginti quatuor denarios, de denariis qui sint XVI solidorum de marcha.

Arrova et quarterium vini contineat XXX $\square$ libras.

Quintallus sit ad IIIIor. arrovis.

De arrova XXX libras, libra carnicerie habeat III libras, unamquamque librarum XII unciarum.

Kafficium habeat sex fanecas rasas. Fanecha habeat VIII $\square$ almutas rasas, et in medio et moris faneche sit virga ferrea et almuti oris; et os faneche et almuti sit ex omnibus partibus equales et similie. 
Annona, itaque, quod triticum, avena, ordeum, pacinium multum, et omnia alia sementa que debent mensurari, mensurentur; de ferro ad ferrum, sal, castane, avellane, furfur, cal $\square$ et consimilia, mensurentur cum fenecha currenti.

Alnee sint IIIIor. palmorum, et eorum capita sint ferrea. Et omnes panni, lenci et lane, et quilibet alii, recipiantur et dentur cum tali alnea, et ultra alneam dentur duo digiti.

Saumata sive carga vini sit XV quarteriorum, et si duxerit portadores sit XIII quarteriorum.

Si igitur omne avere de levante et ponente, et aliunde, et victualia, lana, vinum, vindemia, oleum, casca, seda, linum, stuppa, canabum, ficcus, panses, farina, et omne aliud avere grossum et minutum, quod ponderari debeat, ponderetur, liberetur, tradatur, recipiatur, ad pondus predictus.

Et nunquam predicta marcha, uncia, libra, arrova, quarterium, quintallus, libra carniceria, cafficium, fanecha, almutus, saumata, sive carga vini et alne mutentur, minvantur vel augeantur, sed predicta semper sint, sicut superius continetur, in civitate et toto regno Valencie, salvo iure nostro.

Datum Calataiubo, XVI kalendas decembris anno Domini M $\square$ CC $\square$ XL $\square$ nono.

Sig+num Jacobi, Dei gratia regis Aragonum, Maioricarum et Valencie, comitis Barchinone et Urgelli et domini Montispesulani.

Testes sunt Jacobus de Cervera, Guillermus de Granyana, Guillermus de Enten $\square$ a, Eximinus de Focibus et Eximinus Petri.

Sig+num Petri Andree, qui mandato domini regis hec scribi fecit pro Guillermo de Bello Lucho, notario suo, loco, die, et anno prefixis.

\section{1250, marzo 21. Carta puebla del castillo y villa de Cervera, otorgada por la Orden del Hospital en favor de sus habitantes. \\ Archivo Histórico Nacional. Madrid. Ordenes Militares. Pergaminos. Carpeta 514, nº 130P. Original. Transcrito el 8-VII-2006 a partir del manuscrito original. \\ Publicada en el Archivo Virtual Universidad Jaume I de Castellón.}

Notum sit cunctis, quod nos frater Petrus de Alcalano castellanus Emposte humilis, de consilio et voluntate fratris P. de Graniana comendatoris domus Valencie, et fratris P. de Asyn comendatoris Emposte, et fratris Johannis de Parisio comendatoris castri Cervarie, et fratris Bernardi capellani nostri, et fratris $\mathrm{A} \square$ nar Petri, et fratris P. Gar $\square \mathrm{e} \square$ de Molendinis, et fratris Eximen Pere $\square$, et fratris Berengarii de Rubone, et fratris Martini Enegi $\square$, et fratris Enegi prioris Emposte, et fratris A. Mascaroni, et fratris Ferrarii subpreceptoris Huildecone, et aliorum fratrum nostrorum, per nos et per omnes successores nostros, damus et concedimus inperpetuum vobis Raymundo de Belloc et Johanni Pere $\square$, et Eximino Pere $\square$, et Bernardo Ballistario, et Raymundo De $\square$ coll, et Martino Enegi $\square$, et omnibus aliis hominibus qui modo in castro et villa de Cervaria permanent vel de cetero permanebunt, et omni proieniei et posteritate vestre et eorum, totum terminum corporis castri Cervarie, quod iam possidetis et laboratis, ut ipsum populetis et laboretis, et possideatis ac explectetis.

Ita tamen quod de omnibus fructibus tam terre quam arborum, et de omni nutrimento, tam bestiarum quam volatilium, detis nobis decimam et primiciam legaliter, et de omnibus rebus aliis similiter sicut ceteri vicini vestri.

Et quod vos neque successores vestri non possitis bladum aliquod cuiuscumque seminis vel nature sit, de areis vestris levare nec abstinere, nec vindemiam de vineis vestris levare neque abstraere, sine aliquo homine vel nuncio Hospitalis, et quod partem illam que nobis in fructibus vestris contigerit, nobis intus castrum Cervarie cum vestris propriis bestiis et suptibus adducatis.

Similiter est in pacto, quod vos et successores vestri faciatis nobis et successoribus nostris semper annuatim duas jovas et duas batudas et quinque traginos, tres videlicet in tempore vindemiarum et duos in tempore messium.

Et faciatis nobis similiter hostem et cavalcatam, et omnia alia servicia sicut vicini vestri fecerint, qui sunt in termino Cervarie populati.

Furnum quidem et fabricam ville Cervarie nobis duximus penitus retinenda.

Quod est actum XII kalendas aprilis anno Domini $\mathrm{M} \square \mathrm{CC} \square \mathrm{XL} \square$ nono.

Sig+num fratris P. de Alcalano castellani Emposte. Sig+num fratris P. de Graniana comendatoris domus Valencie. Sig+num fratris P. de Asyn comendatoris Emposte. Sig+num fratris Johannis de Parisio comendatoris castri Cervarie. Sig+num fratris Bernardi capellani domini castellani. Sig+num fratris $\mathrm{A} \square$ narii Petri. Sig+num fratris P. Gar $\square \mathrm{e} \square$ de Molendinis. Sig+num fratris Eximinii Pere $\square$. Sig+num fratris Berengarii de Rubione. Sig+num fratris Martini Enegi $\square$. Sig+num fratris Enegi prioris Emposte. Sig+num fratris A. Mascaroni. Sig+num fratris F. subpreceptoris Huildecone. Nos omnes supradicta omnia et singula concedimus et firmamus, testesque firmare rogamus. 
Sig+num Bernardi de Alfo $\square$ ea. Sig+num Raymundi Dalmacii, civium dertusensium, rei huius testium. Sig+num Guillermi de Ciresola, notarii domini castellani Emposte, qui de mandato predictorum hec scripsit.

$\mathrm{ABC} A B C \mathrm{ABC}$

18. 1251, enero 19. Morella. Jaume I regula la forma de limpieza, conservación y reparación de las acequias y los azudes del termino de Valencia.

Archivo de la Corona de Aragón. Barcelona. Cancelleria. Codice 9 de la Casa Real, ff. 12v-13r. Copia simple de principios del siglo XIV.

V. García Edo. Llibre de Privilegis de Valencia. Valencia 1988, doc. 28.

Publicada en el Archivo Virtual Universidad Jaume I de Castellón.

Noverint universi, quod nos Iacobus, Dei gratia rex Aragonum, Maioricarum et Valencie, comes Barchinone et Urgelli et dominus Montispesulani, per nos et nostros concedimus et statuimus imperpetuum, quod cequiarum condiciones sive cequiarii civitatis Valencie et eius termini, semel in anno de solo ad solum ex toto et funditus purgent cequias, et ultra dictam purgacionem purgent eas de erbis semel quolibet anno, et non redeant ad aquam in cequiis quousque iurati vel eorum substituti viderint si sufficienter cequie fuerint mundate modo predicto, et semel in anno faciant brachallos mundari de solo ad solum, ab heredibus habentibus hereditates contiguas ipsi bracallis.

Et per quod partitores omnes aquarum faciant et rehedificent ipsi cequiarii secundum modum statutum et forman pristinam, et quod pontes, per quos non transierint aliqui, nisi habentes hereditatum, faciant rehedificari ab heredibus hereditatum ad quas hitur ad pontes ipsos, et quod rupturas cequiarum rehedificent cequiarum, secundum modum et formam et statutum pristinum.

Et si rupta fuerit resclosa reparent eam ipsi cequarii infra octo dies in estate, secundum formam, statutum ad modum pristinum, et non accipiant a fanechatas ortorum vel vinearum, nisi secundum quantitatem iovatarum in quibus panis seminatur, et in vendiote cequiarum que facta fuerit eis simper exprimatur quantum debeant accipere pro qualibet iovata terre ab illis, et que cequias vel cequiarum filiar $\square$ as diruent vel aliqua dimitent ire indebite, et non redierunt aquam ad matrem tempore quo debuerint, sive non fuerint eis necessaria, exigant et extorquiant penas constitutas in consuetudine, et distringant hereditarios quod mundent braccallos semel in anno et nisi infra diem cequiariis eis assignata mundaverint, cequiarii mundent eosdem bra $\square$ allos et habeant heredibus duplum mundacionis.

Et si hereditarius qui regabit vel non rigaverit vel alias proiceret aquam in viis, solvat $\mathrm{V}$ solidos et restituat dampna passo quadam fuerint transeuntibus vel quibuslibet aliis hereditari cum distringant et pignorent, ad cognicionem iuratorum et sine curia, cequiarium, si non miserit aquam sufficientem in cequiam, dum possit eam accipere et invenire in Godalaviar.

Et si non mundaverit cequiam de solo ad solum et de erbis pro ut supradicitur, et sic mundata, si non hostenderint, et eam iuratis antequam redeant aquam in marem.

Et si non fecerint mundari bra $\square$ allos, sicut dictum est.

Et si non prohibuerit quod non effundatur aqua in viis publicis.

Et si non reffecerit franctionis et partitores aquarum modo predicto.

Cequiarii in super qui cequiam extrahent de encanto vel alias cequiarum detentores, iurent et obligent bona sua antequam recipient cequias, ut faciant et compleant et compleri faciant omnia supradicta.

Datum Morelle, XIIII kalendas febroarii anno Nativitatis Domini M $\square$. CC $\square$. quinquagesimo.

Signum Iacobi Dei gratia regis Aragonum, Maioricarum et Valencie, comitis Barchinone et Urgelli, et domini Montispesulani.

Testes sunt, Petrus Cornelli, Carrocius Alaman, Guillelmus de Montecatheno, Guillelmus de Angularia, Ferrarius Garces de Roda.

Signum Guillelmi $\square$ a Rocha, qui mandato domini Regis pro Guillelmo Scribe notario suo, hec scribi fecit loco die et anno prefixis.

19. 1251, junio 19. Zaragoza. Jaume I regula las servidumbres de les paredes medianeras de las cases de la ciudad y reino de Valencia, la participación de todos los valencianos en la construcción de sus respectivas obras públicas, y regula el pago de "sequiatge" o riego.

Archivo de la Corona de Aragón. Barcelona. Cancelleria. Codice 9 de la Casa Real, ff. 15r/v. Copia simple de principios del siglo XIV.

V. García Edo. Llibre de Privilegis de Valencia. Valencia 1988, doc. 31.

Publicada en el Archivo Virtual Universidad Jaume I de Castellón. 
Noverint universi, quod nos Iacobus, Dei gratia rex Aragonum, Maioricarum et Valencie, comes Barchinone et Urgelli et dominus Montispesulani, per nos et nostros statuimus imperpetuum in civitate et toto regno Valencie, quod vicinus in pariete medio, qui vicini sui stillicidia receperit in domum sive locum suum, possit stillicidia removere, quando parietem vel hedificium fecerit vel reparaverit, et supra ipsa parietem hedificandi in quantum voluerit elevare, dummondo ad expensas suas vicinus operans vel hedificans faciat aliquam stillicidii discurrere in viam, si in via aqua exire poterit, alioquin donet locum aque stillicidii per quem sine incomodo vicini domini stillicidii exire possit.

Vicinus etiam $\mathrm{m} \square$ dium parietem possit ex toto removere et illum hedifficare, in vico vicino, et elevant quantum voluerit et relinquat lumina et fenestras aptas, si ibi antique et prescripte sint; et alius vicinus possit inmittere tignum vel cooperturam eo loco et altitudine ubi primitus erat, et non teneatur ponere in expensis circa parietem illum, nisi usque ad illum locum ubi tingum vel cooperturam inmiserit factis.

Si vero in superiori novo pariete vellet cooperire vel aliter hedificare, possit hoc facere, dummodo solvate primitus medietatem expense et operis a principio fundamenti facte usque ad locum quo edificaverit, cooperuit vel hedificatus fuerit, omni excusacione remota, omnes nobiles et milites, clerici et religiosi, cives et quecumque alia persona, quantecumque dignitatis sit, ad construccionem et reparacionem murorum et vallis, construcciones, reparacionem et mundacionem et ad instrucciones et mundaciones viarum publicarum et pontium et civitatis custodiam et mundacionem cequiarum et bra $\square$ allorum et ad prestandum cequiaticum de suo conferre teneantur, cum non sint predicta inter sordida munera numerata.

Vinee et hereditates que possunt regari donent cequiaticum, licet domini ipsarum vinearum et hereditatum aque accipere ad rigandum voluerint.

Et si quis aliqua loca possidet, que non consueverint actenus rigari, si voluerit illa loca redire ad agriculturam, posit illa rigare absque alicuius prohibitione, et donet inde cequiagium, secundum tenorum aliorum vicinorum ipsius cequie.

Datum Cesarauguste, XIII $\square$ kalendas iulii anno Domini M $\square$. CC $\square$. L $\square$. primo.

Signum Iacobi Dei gratia regis Aragonum, Maioricarum et Valencie, comitis Barchinone et Urgelli et domini Montispesulani.

Testes sunt Artallus de Luna, Eximinus de Focibus, Petrus Cornelli, Guillelmus Romei, Sancius de Antilone.

Signum Petri Andree qui mandato domini Regis pro Guillelmo de Belloloco notario suo hec scribi fecit loco et die et anno prefixis.

\section{1255, julio 12. Lleida. Jaume I da licencia a la Orden del Hospital para poder celebrar una feria anual de quince días de duración en la villa de Sant Mateu.}

Archivo Municipal de Sant Mateu. Llibre de Privilegis, ff. 150v-151r. Copia simple de comienzos del siglo XV.

Revisada la transcripción el 17-VII-2006 a partir del manuscrito de referencia.

Publicada en el Archivo Virtual Universidad Jaume I de Castellón.

Noverint universi, quod nos Jacobus Dei gratia rex Aragonum, Maioricarum et Valencie, comes Barchinone et Urgelli et dominus Montispesulani, per nos et nostros concedimus et indulgemus vobis, venerabile et dilecto ac religioso viro fratri Geraldo Amici castellano Emposte et successoribus vestris, et toto ordini Hospitalis Sancti Johannis Jherosolomitani, quod semper quolibet anno possit facere seu celebrare nundinas seu ferias in villa Sancti Mathei, que est in regno Valencie propter Cervariam, et incipiant octava die ante festum ascensionis Domini et durent continue usque ab octo dies post dictum festum.

Volentes et concedentes vobis, quod habeatis et percipiatis in dictis nundinis omnia iura que consueta sunt dari in aliis nundinis nostris.

Recipientes et constituentes omnes homines et feminas ad dictam feriam venientes, ac inde redeuntes, cum omnibus rebus et mercibus que ad dictas nundinas aduxint, vel adduci fecerint, ac inde duxerint vel reduci fecerint, sub nostra proteccione, custodia, comenda ac nostro speciali guidatico.

Ita quod non pignorentur, nec impediantur, vel modo aliquo molestentur in veniendo ad dictas nundinas, ibidem existendo, vel inde redehundo, nisi homicide vel incartati seu proditores fuerint maniffesti, nech etiam in hiis casibus dum parati fuerint conquerentibus de se facere iusticie complementum.

Mandantes firmiter justiciis, juratis, vicariis, baiulis, $\square$ almedinis, paciariis, et alcaydis, et universis aliis officialibus et subditis nostris, presentibus et futuris, quod hanc concessionem et indulgenciam nostram firmam habeant et observent, et contra ipsam non veniant nec aliquem venire permittant 
aliqua racione seu causa.

Quicumque autem contravenire attemptaverit, iram et indignationem nostram et penam quingentorum morabatinorum se noverit incursurum, dampno illato passim plenarie restitutis.

Datum Ilerde IIII idus julii anno Domini millesimo CC $\square \mathrm{L} \square$ quinto.

21. 1257, diciembre 2. Barcelona. Jaume I da licencia al Consell municipal de Zaragoza, para poder cobrar peaje durante los próximos tres años, por el paso de cualquier animal forastero de carga por el nuevo puente de la ciudad.

Archivo de la Corona de Aragón. Barcelona. Cancelleria reial. Registre 9, f. 52v.

Transcripción con variantes formales efectuada a partir de la edición de $\mathrm{M}^{\mathrm{a}}$ de los Desamparados Cabanes Pecourt: Documentos de Jaime I relacionados con Aragón. Institución Fernando el Católico. Zaragoza 2009, documento 115.

Publicada en el Archivo Virtual Universidad Jaume I de Castellón.

[Noverint universi] quod nos Iacobus, [Dei gratia rex Aragonum, Maioricarum et Valencie, comes Barchinone et Urgelli et dominus Montispesulani], per nos et nostros damus et concedimus vobis, iuratis et concilio Cesarauguste, quod hinc usque ad festum Natalis Domini et ab ipso festo usque ad tres annos primo venturos et continue completos, pro qualibet bestia extrannea que transeat onerata per pontem Cesarauguste donetur ibi unus obolus semel in die, quibuscumque et quocienscumque diebus per inde transeant onerate et undecumque et cuiuscumque sint bestie ipse, in auxilium operis ipsius pontis et ad emparandum et deffendendum ne flumen Iberis erumpat et veniat contra ravallum, quod est in capite illius pontis. Concedimus igitur vobis ac damus liberam potestatem accipiendi predictos obolos a predictis bestiis, ut superius continetur, ac faciendi pignora inde si sit necesse.

Datum Barchinone, IIII nonas decembris anno Domini M $\square$. CC $\square$. L $\square$. septimo,

Signum + Iacobi, Dei gracia regis Aragonum, Maioricarum et Valencie, comitis Barchinone et Urgelli et domini Montispesulani.

$(1 \square$ col.) Testes sunt: Berengarius de Angularia. (2 $\square$ col.) Gaucerandus de Urgio. Bernardus Raimundi de Ribellis. (3 $\square$ col.) Eximinus de Focibus. Eximinus de Urrea.

Sig+num Michaelis de Alcoario, qui mandato domini regis pro domino fratre Andrea episcopo Valencie, cancellario suo, hoc scribi fecit loco, die et anno prefixis.

22. 1258, junio 17. Cocentaina. Jaume I otorga al consejo municipal de Teruel la tercera parte de les "calònies" y también les da las "palades" que se acostumbran dar por las mercancías en el mercado del jueves, para reparación de muros, torres, carreteras y puentes.

Archivo Histórico Provincial de Teruel. Pergamino 13A. Original en mal estado de conservación.

La reseña se extrae en parte a partir del resumen del documento, que figura en el reverso del pergamino en letra de época posterior, hecho cuando aún se podía leer el texto completo.

Publicada en el Archivo Virtual Universidad Jaume I de Castellón.

Noverint universi quod nos, Jacobus, Dei gratia rex Aragonum, Maioricarum et Valencie, comes Barchinone et Urgelli et dominus Montispesulani; per nos et nostros damus et concedimus vobis, fidelibus nostris toti concilio Turolii et vestris, imperpetuum, terciam partem caloniarum ipsius ville, quam iudez et alcaldis olim solebant recipere et habere, et palatas, que de quibuslibet rebus dantur et dare consueverunt in mercato singulis diebus iovis, ita tamen quod vos et vestri illud totum integre ponatis et mitatis in refeccione et reparacione murorum, ante muralium, carrarie et pontium iamdicte ville et terminorum eius.

Datum Cocentaine $\mathrm{XV}^{\mathrm{o}}$ kalendas julii anno Domini $\mathrm{M}^{\circ} \mathrm{CC}^{\circ} \mathrm{L}^{\circ}$ octavo.

Signum + Jacobi, Dei gratia regis Aragonum, Maioricarum et Valencie, comitis Barchinone et Urgelli et domini Montispesulani.

Testes sunt: [1 ${ }^{\mathrm{a}}$ col.] [Ex. de] Focibus. [2 ${ }^{\mathrm{a}}$ col.] R. de Montecateno, Bn. Guillermi de Entença. [3 ${ }^{\mathrm{a}}$ col.] Ex. de Urrea, Ato de Focibus.

Sig+num Micha[elis] de Alcoario, qui mandato domini Regis pro domino frater Andrea, episcopo Valencie, cancellario suo, hec scribi fecit. 
23. 1268, enero 30. Alzira. Jaume I da licencia a los habitantes del Reino de Valencia, para poder transportar madera a la ciudad de Valencia, incluso por los ríos Guadalaviar i Xuquer, sin tener que pagar ciertos impuestos.

Archivo de la Corona d Aragón. Barcelona. Cancelleria. Códice 9 de la Casa Real, ff. 30v-31r. Copia simple de principios del siglo XIV.

V. García Edo. Llibre de Privilegis de Valencia. Valencia 1988, doc. 65.

Publicada en el Archivo Virtual Universidad Jaume I de Castellón.

Iacobus Dei gratia rex Aragonum, Maioricarum et Valencie, comes Barchinone et Urgelli et dominus Monstispesulani.

Dilectis fidelibus suis richis hominibus, militibus, ordinibus et universis et singulis aliis subditis nostris et fidelibus nostris regni Valencie, presentibus et futuris, ad quos presentes pervenerint, salutem et gratiam.

Noveritis nos vellem quod quilibet homines volentes aportare fustam ad civitatem Valencie, possit eam scindere minutam sive grossam, et facere scindi in quibuslibet locis regni Valencie, et apportare per rivum de Godalaviar et de Xuquer, et qualibet alia loca dicti regni, salve et franche ac libere, et sine contradictu alicuius persone, secundum quod in foro Valencie continetur.

Unde mandamus vobis firmiter et districte, quatinus visis presentibus, de cetero non faciatis dictis hominibus impedimentum aliquod vel contrarium in aportando fusta minuta vel grossa, quam aportare voluerit et apportabunt per terram vel per aquam; immo permittatis eos eam aportare franche et libere et sine aliqua ledda et pedagia, quam vel quod ab eis inde non petatis, cum leddam vel pedagium racione fuste secundum forum Valencie, nobis nec alicui non teneantur solvere ullo modo, pro ut in dicto foro continetur.

Scientes quod cum ipsi hoc ut dictum est ut possint facere secundum forum Valencie pro ut in eo foro plenius continetur; quicumque contra dictum forum in predictis eis molestiam aliquam fecerit et impedimentum, vel contrarium seu gravamen intulerit, iram et indignationem nostram incurreret.

Mandantes nichilominus firmiter et districte tenenti locum nostrum in supervintariis nostris regni Valencie, presentibus et futuris, quod dicta predicta servari faciant et teneri ut superius continetur, et dictos homines ipsam fustam aportantes vel aportari facientes, de cetero inde manuteneant et deffendant.

Datum in Algezira III $\square$ kalendas febroarii anno Domini M $\square$. CC $\square$. LX $\square$. septimo.

24. 1270, diciembre 22. Alzira. Jaume I ordena que cada uno de los azudes del riu Xúquer, desde el azud de la Acequia Real hacia abajo, se coloquen pasos de unas ciertas medidas para que puedan pasar las barcas.

Archivo del Regne de Valencia. Cancelleria Reial. Registre 613, f. 216r/v. Copia simple de la primera mitad del siglo XV.

Publicada en el Archivo Virtual Universidad Jaume I de Castellón.

Noverint universi quod nos, Jacobus, Dei gratia rex Aragonum, Maioricarum et Valencie, comesque Barchinone et Urgelli et dominus Montispesulani; per nos et nostros damus et concedimus vobis, probis hominibus et universitati ville Algezire, presentibus et futuris, quod in unoquoque illorum açutorum que sunt in rivo seu flumine Xuquari, ab açuto çequie nove Algezire quam nos fieri fecimus usque in mare, dimittatur et sit semper de çetero unus portellus in medio uniuscuiusque açuti, qui habeat viginti quinque palmos regales in amplium, per quem portellum barche vacue et onerate et alia transire possint libere et sine aliquo obstaculo et impedimento.

Et in ipsis portellis vel aliquo eorum, non sit ausus aliquis canarum facere ad piscandum, nec palos etiam ibi firmare seu ponere ad parandum retes, nec ponere etiam, seu eicere ibipetras vel trabes, aut aliquid aliud, propter quod transitus aquel vel barcharum aut aliorum que per dictum flumen ducentur possunt in ipsis portellis modo aliquo impediri, seu aliquem recipere districtum.

Concedimus etiam vobis quod barquerii seu quibuslibet alii duçentes barquas vacuar vel oneratas, predictum flumen Xucari possint ipsas sirgare per ripam ipsius fluminis, seu per extremum hereditatum ipsi flumini contiguarum, ex utraque parte eiusdem fluminis a suppradicto scilicet açuto usque in mare, franche scilicet et libere, et sine impedimento et contradiccione alicuius persone, sicut illis qui ipsas barquas sirgabunt neccessarium fuerit.

Mandantes firmiter universis tenentibus dictos açutos, ac universis officialibus et aliis subditis nostris presentibus et futuris, quod predictos portellos in dictis açutis, faciant et teneant ac teneri faciant de 
latitudine viginti et quinque palmorum regalium, sine ullo contrario et impedimento, quod ibi non fiat ab aliquo vel ab aliquibus, ut dictum est.

Et predicta omnia firma habeant et observent ac faciant perpetuo inviolabiliter observari, ut superius continetur, et non contraveniant nec aliquem contravenire permittant aliqua racione.

Quicumque autem contra dictum mandatum nostrum sive concessionem aut statutum in aliquo venire attemptaverint, iram et indignacionem nostram et penam quinquagintarum morabatinorum auri nobis vel baiulo nostro Algezire loco nostri solvendam se noveritis incursurum, dampno illato primitus et plenarie restituto.

Pro qua siquidem penam liceat vobis dicte universitati et vestris semper pignorare auctoritate vestra propria illos qui indideant in eadem et ea pignora reddere baiulo dicti loci.

Datum in Algezira XI kalendas januarii anno Domini millesimo ducentessimo septuagesimo.

\section{1271, marzo 16. Valencia. Jaume I instituye el Tribunal del Lligallo de Morella.}

"Aureum opus regalium privilegiorum civitatis et regni Valencie". Valencia 1515. Extravagants no I, f. $234 \mathrm{v}$.

Transcripción efectuada en 1999 a partir de la edición de referencia.

Publicada en el Archivo Virtual Universidad Jaume I de Castellón.

Noverint universi, quod nos Jacobus, Dei gratia rex Aragonum, Valentie et cetera; per nos et nostros concedimus vobis, consilio Morelle et universis hominibus aldearum et locorum omnium terminorum eiusdem, tam nostris scilicet quam ordinumque militum quorumlibet imperpetuum, quod possitis facere ligallum in termino Morelle.

Quodquidem ligallum celebretur bis in unoquoque anno de cetero, videlicet una vice in tercia die post unumquodque festum Pentecostes, et alia vice in unoquoque festo sancti Michaelis septembris.

Ad quod ligallum ubicumque in terminis Morelle celebrabitur, teneantur venire vel mitere pastores suos, omnes illi qui habuerint vel tenuerint ganatos suos ad pascendum in terminis antedictis, et abducere ibi ganatum "mostrench" sive amissum quod habuerit.

Et ille qui diebus predictis celebracionis dicti ligalli ad ipsum ligallum non venerit vel suos pastores non miserit, ut est dictum, teneatur persolvere et dare nobis vel baiulo nostro Morelle loco nostri decem solidos pro pena.

Statuentes etiam quod illud ganatum "mostrench" sive amissum, quod in dito ligallo invenietur, reddatur domino cuius fuerit libere et sine impedimento.

Et si aliquis vel aliquem predictum "mostrenc" quod tenuerit ad dictum ligallum non adduxerint, ut est dictum, et de hoc postea convicti fuerint vel postmodum inter ganatos suos inventum fuerit, illud ganatum "mostrench" in duplo reddant cuius fuerit, et teneantur solvere nobis vel dicto baiulo nostro loco nostri sexaginta solidos pro pena.

Et si forte aliquod ganatum "mostrench" sive amissum ad celebrationem dicti ligalli adductum fuerit, et dominus ei non fuerit inventus, cuius sit, teneatur manifeste usque ad primam tunc sequentem celebrationem ipsius ligalli; et si in ipsa sequenti celebratione ipsius ligalli dominus nondum eidem ganato invenietur, illud tale ganatum sit nostrum et accipiat ipsum baiulus noster Morelle vel locum eius tenens loco nostri.

Insuper, etiam statuimus et volumus ac concedimus vobis, quod baiulus noster Morelle, cum consilio consilii Morelle, eligat aliquam personam ydoneam singulis annis, qui predicta omnia pro ipso distringat et colligat ac faciat observari, ut superius continetur, eaque iuret quod bene et fideliter se in predictis habeant atque gerat.

Datum Valencie XVII kalendas aprilis anno Domini M $\square$ CC $\square$ LXX $\square$.

Sig+num Jacobi, Dei gratia regis Aragonum, Maioricarum et Valencie, comitis Barchinone et Urgelli et domini Montispesulani.

26. 1271, julio. Medición de unas tierras de Russafa, Carpesa i Moncada, motivado por una demanda que hacia la Orden del Temple al rey Jaume I

Archivo Histórico Nacional. Madrid. Ordenes Militares. Pergaminos particulares de Montesa, $\mathrm{n}^{\circ}$ 332P. Original.

Aguilella Miralles, Rosa - García Edo, Vicent: "Documents particulars castellonencs del segle XIII escrits en catalá". Segon Congrés Internacional de la Llengua Catalana. VIII area. 7. Historia de la Llengua". Valencia 1989, pág. 232. Revisión del texto en marzo de 2006 a partir del manuscrito de referencia. 
Publicada en el Archivo Virtual Universidad Jaume I de Castellón.

Coneguda cosa sia a tots homes, que con demanda fos feyta al seyor en Jacme, per la gr $\square$ cia de D $\square$ u rey d'Arag $\square$, de Malorcha e de Val $\square$ ncia, comte de Bar $\square$ alona e d'Urgel e seyor de Monpesler, per frare A. de Castelnou, maestre del Temple en Arag $\square$ e en Catalunya, sobre.l feyt de Russaffa, que demanava lo dit maestre compliment de $\square$ o que li fah $\square$ a de.l escambi de Russaffa; hon lo senyor Rey dix que li daria volenter $\square$ o que fah $\square$ s de dit escambi, e que fos sogriada Russaffa e Monchada e Carpesa.

Hon los dits logs $f \square$ ren sogriats de volentat del senyor Rey e del maestre del Temple, e foren trobades en Russaffa CCII jovades e XI fanecades e XXVII brasses e miga de la corda menor; e feren a la corda del fur CXCI jovada e XVII fanecades. E tot a $\square \square \square$ s regadiu.

E $\mathrm{f} \square$ ren trobades a Moncada XLIII jovades e XIII fanecades e miga.

E $\mathrm{f} \square$ ren trobades a Carpesa XXXVIIII jovades a la corda menor, e en regadiu ab la margal que.y an crext, e X jovades que $f \square$ ren d'en G. Escriv $\square$; e totes aquestes jovades deuen tornar a la corda del fur. Item, d'altra part XX jovades que.l senyor Rey don $\square$ al Temple ab lo donatiu de les cases de Va $\square$ ncia, les cals $\square$ l nos deu asignar en lo terme de $\mathrm{Val} \square$ ncia el locg convinent.

E al sogriar d'aquesta terra fon en Bernat de Murveder tan solament en Carpesa; e en Moncada e en Russaffa fo A. de T $\square$ rmens, el fil d'en Castelar, en Domingo de C $\square$ scar. E en $\square$ o de Russaffa fon en Bonfil, ab aquests damunt dits.

$\mathrm{E} a \square \square$ fon feyt en lo mes de juliol, en l'an de Nostre Senyor M.CC.LXX.I.

27. 1273, mayo 4. Lleida. Jaume I da licencia al Consell municipal de Morella para poder canalizar el agua de la fuente de Vinachos, y para poder construir unos molinos.

Archivo de la Corona de Aragón. Barcelona. Cancelleria reial. Registre 21, f. 142v. Original.

Transcripción efectuada en 1999 a partir del manuscrito de referencia.

Publicada en el Archivo Virtual Universidad Jaume I de Castellón.

Noverint universi quod nos Jacobus Dei gratia et cetera; per nos et nostros concedimus vobis juratis et concilio ville Morelle et universis et singulis eiusdem concilii, tam presentibus quam futuris, quod possitis adducere ad villam Morelle aqua de fonte de Vinachos, et subtus illam aqua quam adducetis ad dictam villam, ut dictum est, et quam etiam in bassa que est in villa predicta et deputetis vel aliunde poteritis agregare, positis construere et facere molendinum sive molendina que sint dicti concilii, quorum redditus ponantur et expendantur in custodia et observacione dicte aque et aqueductus eiusdem, et aliarum expensarum dicti concilii.

Et nullus alius preter dictum concilium, possit molendinum vel molendina facere, que veniant de dicta aque.

Ita tamen, quod vos, dictum concilium, teneamini procurare et facere nobis et nostros semper unam mazmodinam jucifiam et boni auri censualem pro unoquoque molendinorum, que subtus dictam aquam facietis singulis scilicet annis, in unoquoque festo Natale Domini postquam vestra molendina fuerint ibi facta.

Et sic habeatis et teneatis de cetero dictam aquam et molendina que ibi facietis, ut dictum est, ad usus vestros et vestrorum, libere et sine aliqua servitute.

Salvis nobis et nostris singulis mazmodinis in unoquoque molendinorum que subtus dictam aquam facietis, ut superius continetur.

Mandantes firmiter baiulis, curiis, justiciis, alcaydis et universis aliis officialibus et subditis nostris, presentibus et futuris, quod predicta omnia firma habeant et observent, et faciant observari nec aliquem contravenire permittant aliqua racione.

Datum Ilerde IIII $\square$ nonas madii anno Domini M $\square$ CC $\square$ LXX $\square$ III $\square$.

28. 1273, agosto 20. Valencia. Jaume I da a Guillem Ramon de Montcada, señor de Nules, toda el agua sobrante de la acequia de Vila-real que está en proceso de construcción. También se establece el impuesto de "sequiatge" (riego) y se crea el del "sequier" (regador).

Archivo de la Corona de Aragón. Barcelona. Cancelleria Reial. Registre 873, ff. 194v-195r. Copia autorizada de la primera mitad del siglo XIV.

Felip Sempere, Vicent y García Edo, Vicent. Privilegios y concesiones del termino general del castillo de Nules en época foral (1251-1709). 2003, pp. 93-94.

Publicada en el Archivo Virtual Universidad Jaume I de Castellón. 
Noverint universi, quod nos Jacobus, Dei gratia rex Aragonum, Maioricarum et Valencie, comes Barchinone et Urgelli et dominus Montispesulani; per nos et nostros damus et concedimus vobis, nobili et dilecto Guillermo Raymundi de Moncada, domino de Nules, et vestris successoribus imperpetuum, totam illam aquam que de cequia illa quam noviter extraximus de rivo de Millars ad opus populacionis nostre Burriane, que vocatur Villa Regalibus, superabit hominibus eiusdem populationis, et quam ipsi homines dicte populacionis necessaria non habuerint ad rigandum.

Ita, videlicet quod ipsius aquam que eis superabit et ipsi necessariam non habuerint ad rigandum, habeatis vos et vestri homines de Nules ad rigandum terminum castri de Nules, quantumcumque scilicet inde rigare poterunt cum eadem. Ita quod ad unaquaque jovata terre, que de dicta aqua rigabitur in termino de Nules, teneamini dare et detis nobis et nostris duos solidos et medium regalium Valencie, in unoquoque anno, quolibet festo sancti Michaelis septembris, vos seu homines vestri de Nules, qui de dicta cequia sive aqua rigabunt.

Volentes et statuentes ac concedentes vobis, quod homines dicte populacionis Ville Regalis statim cum rigaverint id quod rigare habuerint de dicta aqua, qualibet die seu nocte, tornent aquam ad matrem, scilicet ad cequiam maiorem dicte populacionis, et claudant presam dicte cequie; de qua aquam accipient ad rigandum, quod si non fecerint, donent sexaginta solidos regalium nobis, pro pena, quandocumque scilicet et quocienscumque aquam illam, cum qua rigaverint, non tornabunt ad matrem et presam.

De qua ipsam aquam accipient permiserint ad claudendum, nos autem et nostri, teneamur facere vobis cequiam maiorem in termino de Nules, per quam dicta aqua discurrat et discurrere possit ad rigandum terminum de Nules predictum, nostris propriis missionibus et expensis, et ipsam cequiam maiorem tenere condirectam in termino de Nules, et mundare singulis annis nostris propriis missionibus et expensis.

Vobis tamen seu hominibus vestris, solventibus nobis cequiaticum antedictum, ut superius continetur, et homines vestri teneantur mundare bra $\square$ allos sive filas, qui seu que de dicta cequia emanabunt.

Volumus etiam et constituimus, quod in dicta cequia populacionis nostre, quam nos facere debemus, sunt duo cequiarii qui custodiant aquam dicte cequie, ne aliquis eam devastet vel in vanum eiciat vel exsolvat de matre sive de cequia maiori; unus scilicet pro nobis, et alius pro vobis.

Sed cequiarius vester non habeat in termino dicte populacionis aliquem districtum nos quod possit videre et custodire, ne aliquis ipsam quam devastet.

Cequiarius vero dicte cequie nostre, vel baiulus dicte populacionis nostre, possint compellere et pignorare homines vestros intus in villa de Nules et extra, singulis annis, persolvendo cequiatico antedicto; et nos vel nostri non teneamur dare aliquid salarium cequiario vestro dicte cequie, nec vos nostro.

Et sic per nos et nostros promittimus attendere et complere predicta, ut superius continetur, et in aliquo non contravenire.

Ad hec ego, Guillermus Raymundi de Moncada predictus, recipiens a vobis dicto domino Rege donacionem et concessionem aque predicte, sub modis et condicionibus supradictis, et concedens ac laudans omnia et singula supradicta, promito vobis domino Regi, quod ego seu homines de Nules que de dicta aqua rigabunt, dabunt vobis et vestris singulis annis, duos solidos et medium racione cequiatici, pro unaquaque scilicet jovata terre, quam de dicta aqua rigabunt, pro quo cequiatico, cequiarius seu baiulus vester iamdicte populacionis, possint homines qui de dicta aqua rigabunt, compellere et pignorare ut superius continetur.

Et promitto etiam per me et meos, predicta omnia et singula attendere et complere, et in aliquo non contravenire nec permitere aliquo de hominibus de Nules contrafacere ullo modo.

Actum est hoc in Valencia, XIII kalendas septembris, anno Domini M $\square$. CC $\square$. LXX $\square$. tercio. Sig+num Jacobi, Dei gratia regis Aragonum, Maioricarum et Valencie, comitis Barchinone et Urgelli et domini Montispesulani.

Sig+num Guillermi Raymundi de Moncada predicti, qui hoc concedo et firmo.

Testes sunt: Petrus Ferrandi, Bernardus Guillermi de Enten $\square$ a, Petrus Martini de Luna, Carrocius dominus Rebolleti, Ferrarius de Li $\square$ ana.

Sig+num Simonis de Sancto Felicio, qui mandato domini Regis et Guillermi Raymundi de Moncada predictorum, hec scribi fecit et clausit, loco, die et anno prefixis. 


\section{1274, mayo 12. Lyon. Jaume I vende las rentas de Borriana para obtener dinero para la} construcción de la acequia de Vila-real.

Archivo de la Corona de Aragón, Reg, 19 fol. 128v.

Transcripción de Inmaculada C. Román Millán en el libro: "El regadío de Vila real durante los siglos XIII-XV” ED. Ajuntament de Vila-real. Año 2000.

Pernos et nostros vendimus vobis Petrus de Juneda, vicino Burriane, et Bernardus Simonis et vestris, aproximo venturo festo Sancti Johanis Baptiste usque ad 11 annos primos venturos et continue completos, omnes redditus exitus et proventos nostros Burriane tam maris quam terre, excepto justiciatum ville Burriane, precio videlicet septem mille solido regalium Valencie, quos pro nobis et loco nostro tradcre debetis incontinenti frati Petrus Peyronety, helemosinario nostro, ad opus operis cequie nostre Ville Regalis, planicie Burriane. Ita cum quod omnes predictos redditus exitus et proventus nostros Burriane percipiatis per manum Petrus Eiximini de Spelluncha, baiuli nostri eiusdem loci, quolibet anno e ipsos habeatis est anch (sich) ad faciendum inde vestras omnimodas voluntates; promitentes vobis quot in predictis redditibus exitibus et proventibus nostris, quos vobis vendimus, non tangemus nec inde aliquit percipiemus nech tangi s[i]ve percipi faciemus per totum dictum tempus nec revocabimus anch vendicionem quam de ipsis vobis facimus pro maiori precio vel minori. Immo si dicti redditibus, exitus, et proventos nostris plus valen vel valebunt infra dictas duos annos precio supra dicto totum illut vobis damus de gratia speciali. Mandantes firmiter dicto Petra Eiximini, baiulo nostro Burriane, quod vobis et qui ve! quibus volueritis loco vestri respondat quolibet anno de omnibus et singulis redditibus exitibus et proventibus nostris antedictis a predicto festo Sancti Johanis Batiste in[...] annos continue venturos et completos ut est dictum et [...] aliqui ali. Data dicti anno quo supra.

\section{1274, octubre 8. Sant Mateu. La Orden del Hospital confirma la carta puebla de Sant} Mateu.

Transcripción de la biblioteca virtual valenciana.

Anno Domini millesimo ducentesimo septuagesimo quarto, octavo kalendas octobris. Cum reverendus dominus frater Berengarius de Almenara, castellanus Emposte, esset // apud Sanctum Matheum presentialiter constitutus, comparuerunt coram ipso Dominicus Narbones, Petrus Galia, jurati, A. Mercer, Bernardus Tallaferre, Bernardus de Angularia, G de For // nellis, A Forner, P. Columbi, F. Seguarra, A. Balaguer, Bernardus Roy, Roger Focentes, vaquerius, Bernardus Guitart, et alii probi homines dicti loci requirentes cum instantia // et humiliter suplicantes ut cum ipsi essent populati in quibusdam casibus ad consuetudinen Ilerde, et in quibusdam servarent foros Valentie ac in pluribus casibus di // versos usus tenerent. Quod ipse deberet eis dare certas consuetudines et assignare usus et mores, secundum quos de cetero ipsi nec non et alii populatores presentes et futuri,// termini Cervarie regerentur. Unde dictus dominus castellanus eorum precibus inclinatus, de consensu fratrum inferius scriptorum duxit taliter providendum. In // primis, nos predictus frater Berengarius de Almenara, humilis castellanus Emposte de assensu et voluntate fratris Petri de Pulcrovicino, comendatoris Cervarie de Frontaria, / / et fratris Petri de Fonoleto, et fratris Guillermi de Sarriano, et fratris Iacobi de Gualter, capelláni nostri, confirmamus vobis universis habitatoribus ville et termini supradicti // et successoribus vestris instrumenta priora acquissitionis cum locus Sancti Mathei fuit datus ad populandum.

Volumus etiam quod tam in causis quam in iusticiis et caloniis, // ponderibus et mensuris, pannis et vini, pannorum linis et lane, et omnium aliorum, sitis iudicati et ducti ad consuetudinem Ilerdemsis, et usus scriptos et non scriptos // sicut cives et alii habitatores civitatis et termini Ilerde utuntur et reguntur ad bonum intellectum vestrum et successorum vestrorum.

Retinemus preterea in hac // concessione et confirmatione nobis et fratribus.

Hospitalis, presentibus et futuris, omnia que retenta fuerunt in alia donatione facta vobis tempore populationis // per H. de Fullalquer, condam Castellani Emposte, et in alia carta facta vobis per fratrem Bernardum de Salanova, vicecastellanum Emposte. Salvamus etiam vobis instrumentum // factum per Gui de la Guespa super mensuratico, leuda et penso, laudimio, a quibus vos estis liberi. In dicta autem conccessione non intelligimus mensurati//cum quantum ad homines termini Cervarie. Immo volumus quod dent mensuraticum ut consueverunt et laudimium ut tenentur. Retinemus et dominicaturas // nostras quas habemus in Sancto Matheo et in toto termino Cervarie, cum firma faticca, laudimio, et alia iura dominacionis sicut modo habemus et habere debemus. Item // retinemus quod iurati semper ponantur et mitantur de voluntate nostra vel comendatoris Cervarie qui pro tempore 
fuerit et proborum hominum cuiuslibet ville ter//mini Cervarie et confitemur pro hac concessione recepisse a vobis et habuisse mille solidos regalium Valencie et eos in utilitatem Hospitalis posuisse. Et ideo // renunciamus omni excepcioni non numerate pecunie et doli. Et nos predicti omnes et singuli qui hanc concessione liberaliter recipimus, promittimus omnia // predicta attenderé et complere.

Actum est hoc die et anno in prima linea contentis.

Sig [signo] num fratris Berengarius de Almenara, castellani. Sig [signo] num fratris P. / / de Pulcrovicino, comendatoris. Sig [signo] num fratris P. De Fonoleto. Sig [signo] num fratris Guillermi de Sarriano. Sig [signo] num fratris Ja. de Gualter, predictorum // qui supradicta omnia concedimus et firmamus. // Testes huius rei sunt Dominicus de Belltayll, rector ecclesie de Burriana. Guillermus de Montealbano. Berengarius Renart, rector ecclesie Sancti Mathei, //

Salvator Rubei,. Arnaldus Ermengou,. P. Cortit. //

Sig [signo notarial] num Guillermi Taraschoni, notarii publici auctoritate domini regis Aragonum per totam iurisdicionem suam qui mandato dictorum domini cas//tellani et aliorum fratrum predictorum hec scripsit et clausit die et anno in prima linea contentis.

31. 1276, enero 15. Valencia. Jaume I dona el suelo a los habitantes de Morella para poder hacer una plaza, y confirma las vías públicas. Se trata de la zona de ampliación del barrio del "Sol de vila".

Archivo de la Corona de Aragón. Cancelleria reial. Registre 20, f. 309r. Original.

Transcripción efectuada el 1999 a partir del manuscrito de referencia.

Publicada en el Archivo Virtual Universidad Jaume I de Castellón.

Per nos et nostros laudamus et concedimus et confirmamus vobis concilio seu universitati ville Morelle, et singulis habitatoribus eiusdem ville et terminorum suorum et vestris imperpetuum, campum illum situm infra cingles Morelle, quem ad usus universitatis Morelle emistis seu empturi estis a Berengario de Quadres e d'en Siurana.

Ita scilicet quod illum campum cum suis pertinenciis habeatis imperpetuum vos et vestri prout predicte cingle concludunt et in cartis inde factis continetur, ad opus platee et ad quoslibet alios usus vestros et universitatis dicte ville, libere, scilicet et sine contradiccione alicuius persone, et ad vestras etiam et vestrorum omnimodas voluntates.

Nichilominus etiam per nos et nostros laudamus, concedimus et confirmamus vobis et vestris imperpetuum, omnes et singulas plateas et vias et exitus ac intratas Morelle, usque hodie assignatas et per vos usque modo habitas et possessas et usitatas seu etiam consuetas.

Ita videlicet ut ipsas plateas et vias ac exitus et ianuas dicte ville et terminorum suorum habeatis vos et vestri successores secundum forum Valencie, sine preiudicio tamen nostri et alterius, prout ipsas et ipsos usque modo melius tenuistis et habuistis.

Mandantes firmiter baiulis et cetera.

Datum Valencie XVIII $\square$ kalendas febroarii anno Domini M $\square$ CC $\square$ LXX $\square$ quinto.

32. 1276, enero 15. Valencia. Jaume I aprueba los gastos hechos en la acequia de Vila-real y las cuentas que le ha presentado el comendador de la Orden del Temple en Borriana.

Archivo Histórico Nacional. Madrid. Ordenes Militares. Pergaminos. Carpeta 483, nº 132R. Original. Transcripción efectuada en el año 1999 a partir del manuscrito de referencia.

Publicada en el Archivo Virtual Universidad Jaume I de Castellón.

Noverint universi quod nos, Jacobus, Dei gratia rex Aragonum, Maioricarum et Valencie, comes Barchinone et Urgelli et dominus Montispesulani; per nos et nostros recognoscemus et confitemur vobis fratri P. Peyroneti, comendatori Burriane et elemosinario nostro, vos reddidisse nobis bonum et rectum ac legale computum de omnibus et singulis denariis quos vos vel aliis pro vobis recepistis, usque in presentem diem quo presens scribitur carta a nobis vel ab aliis quibuslibet personis, ad opus cequie populacionis nostre Ville Regalis, et de omnibus etiam et singulis expensas et missionibus per vos vel alium loco vestri factis in opere cequie antedicte, et de opere et administracione eiusdem cequie et populacionis predicte.

Et quia de predicto computo et de omnibus predictis denariis quos pro nobis ad opus dicte cequie, vel racione eiusdem operis recepistis, et de opere et administracione dicte cequie et populacionis predicte, nostri bene paccati sumus nostre voluntati.

Renunciamus excepcioni non recepti dicti computi et inde factum et doli. 
Et absolvimus ac clamamus quitium vos firmam per predictum, ab omnibus et singulis predictis, et a reddicione computi eorumdem.

Ita videlicet quod de predictis vel eorum aliquo, non teneamini vos vel aliis alius racione vestri vobiscum vel cum nostris iterum computare, nec ullam aliam inde nobis seu nostris reddere racionem, nec inde vobis seu ordini Templi de predictis vel eorum aliquo peticionem aliqua vel demandam, nos vel nostri unquam de cetero facere valeamus, set sitis inde penitus perpetuo absolutus, sicut melius et utilius dici, scribi, et intelligi potest, ad vestrum et vestrorum bonum et sincerum intellectum.

Datum Valencie, XVIII $\square$ kalendas febroarii anno Domini M $\square$ CC $\square$ LXX $\square$ quinto.

\section{1283, julio 8. Sant Mateu. Concesión Moli del Oli de la Jana y el Carrascal.}

Transcripción de Josep Miralles i Sales. Boletín del Centro de Estudios del Maestrazgo no 28 pág. 5.

Hoc es traslatum fideliter factum in villa Sancti Mathei die videlicet prima mensisd augusti anno a Nativitate milesimo quadrigentesimo vicesimo tercio, sumptum(ex) quodam publico instrumento pergameneo, in publica forma redacto, non viciato, non cancellato, neque in aliqua eius parte aboluto seu corrupto, cuius instrumenti tenor istis exaratur verbis:

"Sit omnibus notum quod nos, frater Guillelmus de Claramonte, Comendator Cervarie et Emposte domorum Hospitalis lerosolimitani, consilio et voluntate ffratrisPetri Scutifferi prioris Cervarie, ffratis Arnaldi de Cervarie, ffratis Guillermi Terraconi, damus et stabilimus, per nos et nostros, vobis Peturs Valés et uxoris vestre Dulcie, habitatoribus Carrescal.li, et vestris perpetuo omnia torcularia seu molendina olivarum ville de Jana et Carrascalis et termino eiusdem; ita quod nullus alius, nisi vos et successores vestri, habeat it dictas villas vel eius termino molendinum aliquid olivarum. Et quod nullus habens olivas infra termino earundem villarum audeat molere olivas in aliquo torculario seu molendino nisi in illo vei in illlis quo vos et vestris ibe habebitis. Quod si aliquis fecerit, imponimus in presenti contra illos qui alibi moluerint olivas suas penam sexaginta solidorum regalium Valencie, de quibus vos et vestri habebitis terciam partem si denunciaveretis hoc nobis vei vostris successoribus. Et recipiatis vos et vestri pro moltura seu salario vestro sextam decimam partem de olivis, que ibi contigerit vos molere, de qua moltura seu salario detis nobis et nostris successoribus quartam partem integriter, fideliter et quitiam. Et teneatis ibidem sufficiencia torculariorum seu molendinorum com bestiis ad hec necessariis.

Pro hanc autem donacionem et stabilicionem concedimus nos habuisse a vobis viginti et quinque solidorum regalium quod misimus et convertuimus in bonum et utilitatem domus et hospitalis. Iodeoque renunciamus excepsioni peccunie non recepte et doli. Promittimus itaque sub obligacione omnium bonirum domus Cervarie quod faciemus vos et vestros predicta tenere et habere et in pace posidere. Et erimus inde legales actores et deffensores contra omnes personas. Et liceat vobis et vestris predicta torcularia seu molendina, cum omnibus melioramentis factis et fiendis, vendere, impignorare seu alienare cuicumque velatis, exceptis militibus et sanctis, salvo tanem semper in omnibus jure, senioracio et fatica decem dierum tantum et laudimium, secundum forum Valencie, nobis et successoribus nostris, intelligaturtamen quod nos vei nostri successores non habemus laudimium nec factam de domibus vel locis in quibus dicta torcularia seu molendina sunt vei erint edifficata.

Atque ego Petrus Valés et uxor elus Dulcie accepimus a vobis, domino ffratre Guillelmo de Claramonte et aliis ffratribus supradictis dictam donacionem sive stabilimentum sub modis et condicionibus ante dictis.

Actum est hoc in villa Sancti Mathei VIII idus julii anno Domini milessimo ducentisimo octuagesimo tercio. Signum ffratris Guillelmi de Claramonte Comendatoris predicti; signum ffratris Petri Scutifferi; signum Arnaldi de Cervarie; signum Guillelmi Terrachoni, predictorum qui hec laudamus et firmamus. Testes huius rei sunt Guillelmus de Fornelis, Dominicus Gavaldá, Arnaldus Carreus et Petrus FF. Signum Petri Mercerii regentis scribaniam ville Sancti Mathei pro Petro Vilardells, notario eorumdem locorum pro domino rege, que hec scripsit... et clausit loco, die et anno prenotatis".

\section{1291, marzo. Nota al "Baitle" de Vila-real para señalar que se costee el mantenimiento de la acequia con los pagos que realizan los usuarios.}

Archivo de la Corona de Aragón, Reg, 85 fol. 125v.

Transcripción de Inmaculada C. Román Millán en el libro: “El regadío de Vila real durante los siglos XIII-XV” ED. Ajuntament de Vila-real. Año 2000.

Jacobo de Valle, baiulo Ville Regalis ve! eius et cetera. Mandamus vobis etc. Quatenus de cequiatgio quod recipicis ratione cequie que noviter constructa fuit per populatores Ville Regalis habientes 
hereditates subta dictam cequiam videlicet a barrancho Rivum de Julia <; usque rivum Seccum tenentis ipsam cequiam codirectam et erbagitam a predicto barrancho Rivum Julia<; usque ad predictum rivum Siccum et terminum de Nulles quantum proceditur ;;equia supradictam secumdum quod G. De Turribus tune procurator domini regis super populationem predicte Ville Regalis istud concessit cum carta publica ut continetur in ea $1 . . . \mathrm{J}$ dominus rex fraternos ter aliud super eo voluerit ordinare.

\section{1296, noviembre 19. Olocau. Compromiso y contrato firmado entre el Consell municipal de Olocau y Meliá Malres, maestro de obras, mediante el cual el municipio le cede durante veinte años la mitad de les primicias, a cambio de la construcción de la Iglesia de la población, les características de las cuales se especifican con detalle.}

Archivo Municipal de Olocau. Pergamino original.

García Edo, Vicent. "Uns documents per a la història medieval de Morella". Papers dels Ports de Morella, 2002, pp. 123-126.

[1] Sie a tots coneguda cosa, com $n \square$ s, en Domingo Ponz, just $\square$ cia d $\square$ Olocau, e en Bernat Torner, e en Guiem de Lyna, jurats del dit loch; conseyl cridat e ajustat en la esg $\square$ sia de santa Maria d $\square$ aquel metex loch, ax $\square$ com costum $\square \mathrm{s}$, de assentiment e voluntat del dit conseyl, per $n \square \mathrm{s}$ e tots los nostros, donam e liuram ab aquesta $\mathrm{p} \square$ blica carta, a v $\square \mathrm{s}$, en Meli $\square$ Malr $\square \mathrm{s}$ e als vostres, al qual o als quals v $\square \mathrm{s}$ volrets, la meytat de la prim $\square$ cia de la vila e de sos $\square \square$ rmens del dit loch, ax $\square$ com $\square$ s costum de reebre ni de donar prim $\square$ cia en lo dit loch.

$\mathrm{Ax} \square$ prometents a $\mathrm{v} \square \mathrm{s}$ e als vostres, de donar la dita meytat de la prim $\square$ cia de tots los b $\square$ ns nostres entro a XX ans, de to $\square$ aquels $\mathrm{b} \square$ ns que avem usat ni costumat de donar prim $\square$ cia entro al dia d.uy. En ax $\square$, enper $\square$, que sie ent $\square$ s que dintre.ls XX anys, que.y age XX esplets acabats.

Enper $\square$ retenim a $\square \square$ s, que a cab de $V$ ans, que.l conseyl del dit loch que.s pusque la prim $\square$ cia lo VIen an per a ses necess $\square$ ries pendre, e ax $\square \mathrm{d} \square$ aqu $\square$ a davant, entro que.ls XX ans sien passats.

En ax $\square$ que v $\square$ s, dit Meli $\square$ Malr $\square$ s, o els vostres, que.ns entegrets de pendre la dita meytat de la prim $\square$ cia oltra els XX ans, per aytants ans com lo dit conseyl la pendr $\square$.

[2] En ax $\square$, enper $\square$, donam a v $\square$ s la dita prim $\square$ cia, que fa $\square$ ats Ia esg $\square$ sia en lo dit loch, denant lo ciminteri, en aquesta manera:

Que age lo solament de la esg $\square$ sia, a dareredor del s $\square$ l de la esg $\square$ sia a enj $\square$ s VIII palms de pregon. Et age la paret de part de la riba, del s $\square$ l de la esg $\square$ sia a enj $\square$ s VII palms de gros, VIII palms de pregon.

Et de la part del cor e de la part del fossar, age la paret del s $\square 1$ de la esg $\square$ sia a enj $\square$ s VII palms de gros et VIII palms de pregon.

Et de la part del capanal, que age la paret del $₫ \square 1$ de la esg $\square$ sia a enj $\square$ s VIIII palms de gros e VIII palms de pregon.

E els cantons de les dites parets daval terra, que sien feyts de bona pedra calar caregats.

Et de part de la riba, age la paret del s $\square 1$ de la esg $\square$ sia enss $\square$ s entro en egual de la carera, VI palms de gros; e de la carera amont entro en egual de la cuberta $\mathrm{V}$ palms de gros.

Et el front del cor, que age la paret entro en gual de la cuberta $V$ palms de gros.

Et de la part del fossar derrera, ens $\square s$ entro a la cuberta, que age la paret $V$ palms de gros, e enmig de la paret, a $\square$ on los bons homens veuran per b $\square$, que.y age I portal, feyt en ax $\square \mathrm{d} \square$ aquela mesura de aquel portal de la esg $\square$ sia de sent Miquel de Morella, e encara I palm o dos pus ample, si.ls bons homens del dit loch conexeran que obs y sie.

Et de la part del campanal, que age la paret del s $\square 1$ de la esg $\square$ sia a ens $\square$ s, entro a la cuberta, en egual de la clau de $\square$ arch, VI palms de gros; e de la cuberta a ens $\square$ s, entro al $\square$ on sa fiuran los pilars de les campanes, que age la paret $\mathrm{V}$ palms de gros, e que age la paret $\mathrm{X}$ palms $\mathrm{d} \square$ alt, de la cuberta ens $\square \mathrm{s}$, entro al $\square$ on sa fiuran los pilars.

Et els cantons de les dites parets, del sol de la esg $\square$ sia a ens $\square$ s, que sien feyts de bona pedra picada als cantos e reequantons.

Et el cap de la paret, $a \square$ on se fiuran los pilars de les campanes, que sie losada de bona pedra picada. Et de sobre.l losar, que.y age III pilars que sien feyts de pedra picada, e que agen los pilars del losar entro en la clau de les voltes XII palms d $\square$ alt de tou, e els pilars cada un que agen IIII palms e mig de gros, a tots cayres, e sobre les voltes dels pilars que age Ia creu de pedra picada.

Et les voltes dels pilars, que sien losades de bona pedra picada.

El les parets de la esg $\square$ sia que sien feytes de bona pedra mamposta, ab bona argamasa, e lo morter que sie feyt per terz, en guisa que sie feyt ben gras.

Et que pugen les parets del s $\square 1$ de la esg $\square$ sia a ens $\square$ s, a totes parts, salu de la part del campanal, XL 
et IIII palms de palm d $\square$ alna, en guisa que pusquen versar a dues parts; e en la paret de part del cor, que age Ia finestra sorda, de bona pedra picada.

Et en la paret de part del campanal altra finestra sorda.

Et en la paret del fossar, que.y age IIII finestres sordes, en aqueles arquades on lo conseyl veur $\square$ per $\mathrm{b} \square$.

Et totes les finestres sordes, que agen VI palms $\mathrm{d} \square$ alt de tou e Ia palmada $\mathrm{d} \square$ ample, e que sien feytes de bona pedra blanca picada.

Et en lo cor de la esg $\square$ sia, que age IIes voltes de pedra picada blanca, per armaris, que agen IIII palms $\mathrm{d} \square$ ample e VI palms d $\square$ alt, et II palms e mig de pregon.

Et en la dita esg $\square$ sia, que agen VII archs de pedra picada blanca, e quada arch que age del s $\square 1$ de la esg $\square$ sia a ens $\square$ s X palms de peu dret e II palms e mig d $\square$ asta e I palm e mig de seti.

Et que age cada arch, del s $\square 1$ de la esg $\square$ sia entro sus en la clau de.l arch, L palms $\mathrm{d} \square$ alna de tou.

Et que age davant lo cor III graes de pedra picada, de la Iaparet a $\square$ altra.

Et tot entorn dintre la esg $\square$ sia del cor a aval, que age altres IIIes graes de pedra picada.

Et de sobre les graes, davant lo cor, que sien losades II arcades de pedra picada.

Et de sobre.l losar de pedra picada, que age II a $\square$ ats de pedra picada blancha.

Et $\square$ altar de santa Maria, que age X palms de lonch e VI palms d $\square$ ample, e V palms $\mathrm{d} \square$ alt.

E $\square$ altar de santa Agn $\square$ s, que sie de la sisa que.y bast la losa que.y bast la losa [sic] que $\square$ s sobre

$\square$ altar de santa Maria, e que age $\square$ altar IIII palms e mig d $\square$ alt.

Et el payment dels altars que sie ample, a conexen $\square$ a del capel $\square$.

Et que age $\mathrm{d} \square$ alt lo payment sobre.l losar I forch.

Et que age la dita esg $\square$ sia XXXII alnes de tou, $\mathrm{d} \square$ alna de $\mathrm{Val} \square$ ncia de lonch.

Et XIIII alnes $\mathrm{d} \square$ ample de tou.

Et el respatlle dels archs, que sie feyt de bona pedra manposta ab argamassa.

[3] Et la cuberta de la esg $\square$ sia que sie feyta de fusta, en aquesta manera:

Que age en cada arcada $V$ lomeres de meliz ben planegades, e que agen I palm $\mathrm{d} \square$ alna de gros a tots cayres.

Et los cabirons de la cuberta, que sien de bon meliz, e que sien serradizs e ben planegats, e que agen mig peu $\mathrm{d} \square$ alt e Ia palmada de gros.

Et en la cuberta de la esgl $\square$ sia, que agen dels dits cabirons aytants com obs n.i age, en ax $\square$ que age de cabir $\square$ a cabir $\square$ I palm $\mathrm{d} \square$ alna.

Et que age de cabir $\square$ a cabir $\square$ sobre les lumeres botgers, aytantes com obs n.i age, a conexen $\square$ a dels bons $\mathrm{h} \square$ mens.

Et la cuberta de la dita esg $\square$ sia, que sie feyta de bona fulya de meliz ben planegada; e que age parafuls de Ia taula a altra, en les suintures dei $\square \mathrm{s}$ les taules; e que sien clavades ab bones caxes de ferre, a conexen $\square$ a dels bons homens; e que la cuberta que plech fora la paret a totes parts I palm.

Et la cuberta, des $\square \mathrm{s}$ la fulya, que sie feyta de bones canals de meliz serradi $\square$ es.

Et que sien clavades ab bons claus de ferre, a conexen $\square$ a dels bons $h \square$ mens del dit loch.

Et entre IIes canals I list $\square$ damunt, que sien clavats ab bones caxes de ferre, a conexen $\square$ a del dit conseyl.

Et que pas la cuberta de les canals e els listons, a totes parts de les parets, I palm.

Et les lumeres del cor que isquen a totes parts fora la paret I palm.

Et les portes de la esg $\square$ sia que sien feytes de bon meliz a mig amont, e que agen IIII dits de gros, qua sien planegades dintre e de fora.

Et que sien les polegueres de les portes, al $\square$ on deuen balar, cubertes ab fulya de ferre.

Et les portes que sien ben listonades e $\mathrm{b} \square$ obrades e clavades, segons aqueles portes de la esgl $\square$ sia de sent Miquel de Morella; e en cada porta que age I anel de ferre gros.

Et que.y age forellat, e tancadura, que cost X sous.

Et que age dintre les portes barra corredi $\square$ a e balda de ferre, que sie bona per a les dites portes.

Et les voltes dels dits armaris, que agen bones portes de meli $\square$ ben planegades dins e de fora, e que sien ben clavades e listonades ab sos forellats e ab ses tancadures.

Et les parets de la esg $\square$ sia que sien reparades de bon morter prim.

Et encara que age en la arquada denant lo cor Ia lumera, en que balen les lancees, e que age I palm e mig $\mathrm{d} \square$ alt e i palm de gros.

[4] Et que sie feyta la dita obra, $\mathrm{d} \square$ esta primer vinent Pascha de Resurecci $\square$ de nostre Senyor en V ans continuament conplits.

Et $\mathrm{v} \square \mathrm{s}$, feen la dita obra be e leyalment, $\mathrm{n} \square \mathrm{s}$ e el dit conseyl, de possessi $\square$ e de senyoria nos gitam e a $\mathrm{v} \square \mathrm{s}$ e als vostres, sens nenguna mala veu e enbarg neng $\square$, en corporal possessi $\square$ e tene $\square$ en la 
meytat de la prim $\square$ cia metem e transportam, ad aver e a tenir e a poseyr salvament e en pau, en tro al dit termini, a dar, a vendre, empenyorar, alienar, a totes vostres voluntats, en per tots temps faedores, salvu a cavalers e sants.

Et $\mathrm{d} \square$ aqu $\square$ a davant $\mathrm{n} \square$ s e el dit conseyl salvarem e defendrem la dita meytat de la prim $\square$ cia, contra totes persones, sens tot engan.

Et si per ventura ara, o alguns temps $\mathrm{d} \square$ aqu $\square$ a davant, q $\square$ esti $\square$ o demanda vos ere feyta de la dita meytat de la prim $\square$ cia, per bisbe o per reys o per fils de reys, o per potestat de terra, o per altres persones poderoses, o per esg $\square$ sia o per altres persones seglars, prometem tantost en continent de parar $\mathrm{n} \square \mathrm{s}$ davant $\mathrm{v} \square \mathrm{s}$ en pleyt, e reebre el pleyt e la demanda tantost en continent en les nostres $\mathrm{pr} \square$ pies persones, e del dit consseyl, e ab les nostres pr $\square$ pries missions dur a acabament denant qualsevulle jutge eclesi $\square$ stich o seglar, entro a la sent $\square$ ncia diffinitiva, de la qual neng $\square$ no.s pusque apellar, o.l pleyt o la q $\square$ esti $\square$ o demanda sie determenada per dret.

Et demanar tot $\square$ o que a v $\square$ s de la dita meytat de la prim $\square$ cia ser $\square$ tolt ni en ven $\square$ ut per qualsevullye manera per nenguna persona vivent.

Et $a \square \square$ atendre e conplir, obligam $\mathrm{n} \square$ s e tot los $\mathrm{b} \square$ ns del dit conseyl on que sien.

[5] Et yo dit Meli $\square$ Malr $\square$ s, promet e covinch en bona fe a v $\square$ s, dit conseyl, de fer la dita obra $b \square$ e leyalment, segons que damunt $\square$ s dit, entro al dit termini.

E si per aventura yo la dita obra al dit termini no avia acabada, segons que dit $\square$ s, puscats pendre [en] la dita meytat de la prim $\square$ cia, e de vendre aquella, e de logar maestres, tants en tro que la obra sie complida, segons que des $\square \mathrm{s} \square \mathrm{s}$ cogitada.

Et $a \square \square$ atendre e conplir, oblig tots los meus $b \square$ ns on que sien.

Et que mas segurs seyats de la dita obra, do a v $\square$ s fian $\square \square$ s en P. Lopiz de Lison e P. Mi., e en Pere Ter $\square$ a, los quals e els seus conplesquen e conplir facen la dita obra entro al dit termini, e sien tenguts de totes aquestes coses damunt dites atenedores e conplidores ab $\mathrm{m} \square$ e sens $\mathrm{m} \square$.

[6] La qual fianceria $n \square$ s, dits en P. Lopiz de Lis $\square$, e P. Mi. e P. Ter $\square$ a, volenterosament fem e atorgam per $\mathrm{n} \square \mathrm{s}$ e tots los nostres, sub obligaci $\square$ de tots nostres b $\square$ ns, on que sien, ax $\square$ com damunt $\square \mathrm{s}$ escrit, sens engan.

[7] Feyt fo a $\square \square$ en Olocau, XIII kalendas de deembre en $\square$ an de M. e CC. e XCVI.

Sey+nal $\mathrm{d} \square$ en D, Ponz, just $\square$ cia damunt dit. Sey+nal d $\square$ en Bernat Torner, jurat. Sey+nal d $\square$ en G. de Lyna, jurat.

Sey+nal de Meli $\square$ Malr $\square$ s. Sey+nal d $\square$ en P. Lopiz de Lison, fian $\square$ a. Sey+nal de P. Mi., fian $\square$ a. Sey+nal $\mathrm{d} \square$ en P. Ter $\square$ a, fian $\square$ a, $n \square$ s tots ensemble, qui a $\square \square$ loam e atorgam e fermam.

Testimonis s $\square \mathrm{n} \mathrm{d} \square \mathrm{a} \square \square$ Ar. Urgel, Berenguer Batlle e G. Montlober e Miquel Vilela, e R. Aguna, $\mathrm{ve} \square$ ns $\mathrm{d} \square$ Alocau.

Sig+num Bernardi de Segarra, notario publico Morelle, qui hoc scripsit cum literis supraponitis in quatuordecima linea, ubi dicitur $\square$ de part $\square$, loco, die, anno prefixis.

\section{1307. Vila-real. Los jurados de Vila-real nombran "els sequiers" (regantes) de la villa y dictan el reglamento del oficio.}

Archivo Municipal de Vila-real. Pergamino original, sin firma.

García Edo, Vicent. Derechos históricos de los pueblos de La Plana a las aguas del río Mijares. 1994, pp. 132-134. Este documento podría estar fechado en 1307 o 1308, ya que habiéndose perdido el texto conteniendo el día y mes del otorgamiento del documento, este podría haberse hecho entre enero y marzo de 1307 y siguiendo el sistema de datación de documentos en aquel tiempo, por el sistema de l"Anno Domini", tendríamos que sumar un año al que figura escrito en el documento. Publicada en el Archivo Virtual Universidad Jaume I de Castellón.

Coneguda cosa s $\square$ e a totz com nos, en Borra $\square$ Colomer, en G. Ocell $\square$, en R. Guasch, e en Bernat Gal $\square$, juratz de Vila-real; en Bernat $\square$ afont, en Berenguer de Cardona, en G. Juneda, en Jacme Amill, en P. Escuder, n’Arnau de Soler, en Bartholomeu Peyr $\square$, en Bertran de Calaceyt, en G. Esco $\square$, en P. Giner, en R. de Conques, en G. Tremunt, en R. de Guardiola, en R. Comes, en Bernat Verdet e en Bernat de Calvera, ve $\square$ ns e habitadors del dit loch de Vila-real; consell cridat per p $\square$ blich corredor e ajustat en la pla $\square$ a de Vila-real, en loch acustumat de consell ajustar, per nos e tota la universsitat e consell del dit loch de Vila-real, a $b \square$, profit e utilitat de tot lo dit consell e universsitat, affermam e reebem en cequiers de la c $\square$ quia e c $\square$ quies majors de Vila-real, de aquell bra $\square$ al [...] la heretat d'en Bernat d'en Ocell, e regue les terres e ortz qui s $\square$ n sobre la c $\square$ quia maior, vos, en Johan de Berbegal e en G. Senthilarii, ve $\square$ ns e habitadors del dit loch de Vila-real, de aquest dia de huy tro en cinch ayns primers esdevenidors e cont $\square$ nuament complit e comtatz. 
En $a x \square$ que la dita $\mathrm{c} \square$ quia e cequiers maiors $\mathrm{b} \square$ e convinentment escuretz cascun an, dins lo dit temps, XV dies dins lo mes de febrer, de sol a sol, de ora en ora, de la gola de la dita c $\square$ quia entro aytant quant aquella c $\square$ quia e c $\square$ quies iu [...] ana tenen de longuea.

E que escuretz de sol a sol, de ora en ora, lo dit bra $\square$ al, de aquell loch on l'aygua se reeb tro a una fita qui $\square$ s dins la heretat del dit en Bernat d'en Ocell, e en totz aquells lochs on lo dit bra $\square$ al, frontera de ortz o de jovades no aur $\square$, tantes vegades dins lo dit temps quantes menester si $[r \square$......... emper $\square$ sie tengut de escurar sa frontera del dit bra $\square$ al, exceptat tro en la dita fita, que escure[tz] vos di[tz] cequiers, segons que dit $\square \mathrm{s}$.

$\mathrm{E}$ aerbetz les dites $\mathrm{c} \square$ quies e bra $\square \mathrm{al} \mathrm{b} \square$ e convinentment dins lo dit temps, en cascun an tantes vegades quantes necessari e menester sir $\square$.

E visitetz abdosos ensemps, o la un tan solament [les dites c $\square$ quies] e bra $\square$ al, cont $\square$ nuament e cada dia, ab exada [e a]b caba $\square$.

E si alcun portell o trench en la dita $[\mathrm{c} \square$ quia] per qualque ra $\square$ se far $\square$, que aquell cloatz e tanquetz ab vostres missions e despeses, emper $\square$ si lo dit trench o portell tancar o cloure no.s podie convinentment sens argamassa, nos prometem aquella argamassa dels $\mathrm{b} \square$ ns del dit consell de Vila-real pagar.

E giretz ayg $\square$ es del riu de Millars per les dites c $\square$ quies, e de les dites c $\square$ quies per lo dit bra $\square$ al, tantes quantes necess $\square$ ries siran al terme de Vila-real, e que basten a.rregar totes les terres, ortz e heretats del terme del dit loch de Vila-real.

E siatz tengutz de tenir en condret la $\square$ ut del dit loch de Vila-real dins lo dit temps. En la $\mathrm{f} \square$, emper $\square$, dels dits $\mathrm{V}$ ayns, lexetz la dita $\square$ ut en aquell estament en que ara la reebetz.

Et encara siatz tengutz de metre e posar en la dita $\square$ ut, per cascun an cinquanta cartres e cent estaques, e $\mathrm{m} \square \mathrm{s}$ si en la dita $\square$ ut en cascun an menester siran, a coneguda de nos e de aquells qui per temps siran juratz e proh $\square$ mens del dit consell de Vila-real.

Casc $\square$, emper $\square$, sie tengut de escurar sa frontera en totz los bra $\square$ als qui s $\square$ n dei $\square$ s les dites c $\square$ quies maiors. E aquell o aquells qui sa frontera dels dits bra $\square$ als escurar no volrran, que vos escuretz o $\mathrm{fa} \square$ atz escurar aquells. E que.n puxatz pendre e demanar la dobla de $\square$ o que costar $\square$ d'escurar casc $\square$ dels ditz bra $\square$ als.

E si les dites canals del riu Sech, $\square$ o que d[......... per diluvi d'ayg $\square$ es o per altra qualsevol rah $\square$ cauran, que vos ab vostres pr $\square$ pies missions cerquetz aquelles. E si aquelles atrobar poretz, tornetz aquelles sobre los pilars en que ara $\mathrm{s} \square \mathrm{n}$, aytals quals aquelles trobaretz sanceres o trencades, e fer en aquelles canals, tota missi $\square$ que s.i age a fer de vostres $b \square$ ns. Salvu, emper $\square$, que si les canals faran a fer de nou, o post pos[...] alcunes hi aur $\square$ menester per adobar aquelles, nos prometem aquelles comprar e obrar dels $\mathrm{b} \square$ ns dels hereters qui s $\square$ n dell $\square$ riu Sech.

E que vos abdosos, o la un de vos, departiscatz l'aygua de les dites c $\square$ quies e bra $\square$ al, a obs de regar les terres, ortz, heretatz, posessions, del terme de Vila-real, segons que $\square$ s acustumat, o segons encara que a avant per la dita universsitat e conssell de Vila-real sir $\square$ establit e ord[ena]t. E si a alc $\square$ o a alcuns les dites ayg $\square$ es a obs de regar liuraretz o atorgaretz contra la dita custum, o contra $a \square \square$ qui davant sir $\square$ ordenat o establit per lo dit consell e universsitat de Vila-real, que paguetz e siatz tengutz de pagar de ca $\square$ nia sexanta solidos de reals, lo ter $\square$ al seynor rey, lo ter $\square$ al cum $\square$ de $[$ la vi]la, e l'altre ter $\square$ a.l acusador, salvu lo nov $\square$ a la just $\square$ cia del dit loch.

Et encara que tingatz en condret aquella c $\square$ quia $[\ldots . . . . . \square$ ut de la] c $\square$ quia sobirana qui $\square$ s dins lo riu Sech.

E si vos $a \square$ no faretz $\mathrm{b} \square$ e convinentment, segons que dit $\square$ s, que dels $\mathrm{b} \square$ ns vostres e de les fermances per vos dei $\square$ s donades o puxen fer los jur[atz] qui ara $\mathrm{s} \square \mathrm{n}$ o qui per temps siran en lo dit loch de Vila-real, o aquell qui per lo dit consell a $\square \square \square$ sir $\square$ asignat. Et nos [prometem ...................] fer donar cascun an per cascun ort diner diner, e per cascuna jovada onzen diner, los quals ab vostra missi $\square$ cullatz e reebatz en cascun an, la meytat en continent que comen $\square \mathrm{a}[\mathrm{t}] \mathrm{z}$ a escurar, e l'altra meytat cascun an en cascuna festa de sent Miquel del mes de setembre. Prometens a vos fer [.......... ............. $\square$ c $\square$ quies e bra $\square$ al dins lo dit temps contra totes persones. Obligans scientment $[$ a vos e als nostres, nos e] totz los $\mathrm{b} \square$ ns nostres e del dit conssell e universsitat de Vila-real, mobles e no mobles, on que sien $a \square$ tz e per aver.

A aquestes coses nos, ditz en Johan de Berbegal e en G. Senthila[ri ................... ju ]ratz e proh $\square$ mens [.......... les dites c $\square$ quies e bra $\square$ al, segons que des $\square \mathrm{s} \square$ s contengut. Prometens nos abdosos ensemps e cascun per $\mathrm{s} \square$, attendre e complir $\mathrm{b} \square$ e lealment totes les coses des $\square$ s contengudes, segons que mills e pus largament des $\square \mathrm{s} \square \mathrm{s}$ espressat. Obliga[ns] scientment a aques[tes ...............] universsitat del [dit loch de Vi]la-real, nos e totz los $b \square$ ns nostres, mobles e no mobles, on que sien ha $\square$ tz o per avers. Renuncians sobre aquestes coses, a benefici de departida demanda, nova e vella custum, e a tot altre dret contra $a \square \square$ vinent. 
E a maior fermetat yo, en Johan de Berbegal, [do a vos e a tot lo conssell ferman $\square$ es, $\square$ o] $\square$ s a saber, en Folch Miquel e en Pere Pineda, ve $\square$ ns de Vila-real, qui ab $\mathrm{m} \square$ e sens $\mathrm{m} \square$, totes les dites coses des $\square$ s espressades sien tengutz atendre e complir.

E yo dit G. de Senthilari, do a vos e a tot lo conssell ferman $\square$ a, $\square$ o $\square$ s a saber, en P. de Senthilari, […. .......... $]$ qui $\mathrm{ab} \mathrm{m} \square[$ e sens $\mathrm{m} \square$..............] totes les dites coses attendre e complir.

Les quals fermances los ditz Folch Miquel, P. Pineda, e P. Senthilari [atorgaren], e totz lurs b $\square$ ns, on que fossen, $a x \square$ mobles com seents, $[\ldots . . . . . .$.$] als ditz juratz, proh \square$ mens e conssell de Vila-real obligaren.

Feyt $[\ldots . . . . . . . . . . . . . . . . .$. anno Domini $] \mathrm{M} \square$ CCC $\square$ septimo.

Sey+nal d'en Borra $\square$ Colomer. Sey+nal d'en G. Ocell $\square$. Sey+nal d'en [R.] Guasch. Sey+nal d'en Bernat Gal $\square$, juratz.

Sey+nal [d'en Bernat $\square$ afont. Sey+nal d'en Berenguer de Cardona. Sey+nal d'en G. Juneda. Sey+nal d'en Jacme Amill. Sey+nal d'en P. Escuder. Sey+nal d'en Arnau de Soler. Sey+nal d'en Bertholomeu] Peyr $\square$. Sey+nal d'en Bertran de Calaceyt. Sey+nal d'en G. Escol $\square$ [......... perduda la resta del text]

37. 1311, mayo 6. Morella. A instancias de los vecinos de Vila-real, el rey Jaume II establece un imposto de peaje con el cual es contribuya a sufragar la obra del puente sobre el río Mijares. Archivo de la Corona de Aragón. Barcelona. Cancelleria Reial. registre 207, ff. 233v-234r. Original. Transcripción efectuada en 1999 a partir del manuscrito de referencia.

Publicada en el Archivo Virtual Universidad Jaume I de Castellón.

Nos Iacobus et cetera.

Ad instanciam et humilem suplicacione universitatis Ville Regalis, volentes quod pons qui iam inceptum est fieri in rivo de Millars veniant ad effectum, et ut dictus locus suscipiat incrementum, volumus et concedimus de speciali gratia dicte universitati, in auxilio operis dicti pontis, quod quilibet qui transitum faciet per dictam villam, sive per villam de Borriana equitando, solvat unum denarium, et quislibet pedester solvat obolum, et bestia de albarda obolum, semel in die, sic quod peccuniam inde proveniens ex predictis mitatur et convertatur in opere dicti pontis, bene et legaliter, et quod presens gratia duret $\mathrm{ab}$ hac presenti die que scribitur presens carta, usque ad tres annos proxime venturos et continue subsequentes, de quibus omnibus teneatur computare dicta universitas cum baiulo nostro regni Valencie generali.

Mandantes per presentem cartam nostram universis officialibus et subditis nostris, quod predicta omnia firma habeant et observent, et faciant ab aliis inviolabiliter observari per dictos tres annos, ut superius continetur.

Datum Morelle, pridie nonas madii anno domini $\mathrm{M} \square$. CCC $\square$. XI $\square$.

38. 1320, agosto 8. Tirasone. Jaime II concede el uso del punzón para marcar las piezas de orfebrería salidas de los obradores de la villa de Morella.

Archivo de la Corona de Aragón. Barcelona. Cancelleria Reial. registre 218, ff. 90 r y v.

Transcripción efectuada por Manuel Milian Boix.

Publicada en el libro: "Homenaje a Mosen Milian 2" Editado por la Diputación de Castellón en el año 1.989 pag. 208.

Noverint universi quod Nos Iacobs, etc. Ad humilem suplicationem nunciorum pro Juratos et probos homines ville nostre Morella ad nostram presentiam destinatorum asserentium quod in dicta villa sunt argentarii qui morantur et operantur ibidem bene et le galitger de eorum officio sive ministerio argenterie. Proptera cum presenti privilegio volumus et concedimus dictis Juratis et probis hominibus dicte ville presentibus et quiper tempore fuerint pro decetero per in perpetuum possint habere et tenere in dicta villa marcum sive signum ad marcandum sive consignandum vasa et alia opera argentea que per argentarios dicte ville fient et operabuntur ibidem de cosimili argenteo quod operatur et quod operatuir et quod marcatur in Civitate quod quidfem marcum sive signum teneant Jurati dicte ville qui per tempore fuerent seu ille vel illi (fol. 90v.) quibus dicti Jurati ipsum marcum sive signum pro marcandis sive consignadis dictis vasis etaliis operetibus argentis duxerint commendandum. Qui teatur satis dare in posse biuli nostri Morella qui per tempore fuerit pro bene et legaliter se habeat in marcando vel consignando vasa et alia opera superdicta. Et sic mandamus pro presens privilegium nostrum procuratoribus, baiulis, justiciis et alilis officialibus et subditis nostris presentibus et futuris quotenus concessionem nostram hanc firmam habeant perpetuo et observat et teneri et observari 
faciant inviolabiliter et non contraveniant en aliquem contravenire permitant alicuius ratione. In cuius rei testimonium presens privilegium nostrum sigillo nostro appendito inferius sigillari.

Datum Tirasone, vi idus augusti anno Dimini M CCC XX.

Signum Iacobi Dei gratia regis Aragoniae. Etc.

Testes sunt (...) ferrer, oxitanus, Petri de Aros castellanus Emposte, Ihoannes Eiximenii de Urrea, Petrus Tirasonensis episcopus, Artaldus de Luna, Egidius de Roda de Podio.

Fuit clausum per Bn. De Aversone notario domini Regis.

39. 1322, marzo 26. Prohibición del Justicia de Morella para que se utilice la piedra que se ha desprendido del castillo para la construcción de las casas particulares.

Archivo de la Corona de Aragón. Barcelona. Cancelleria Reial. registre 247, ff. 42 r y v.

Transcripción efectuada por Josep Alanyà i Roig.

Publicada en el libro: Urbanisme i vida a la Morella medieval S.XIII-XV” Editado por el Ayuntamiento de Morella en el año 2.000 pag. 421.

Jacobus, et cetera. Fideli suo iustitie Morelle vel eius locumtenenti, salutem, et cetera. Intelleximus per Petrum de Moriella, militam, alcaydum castri Morelle quod propter ruynam aquarum ceciderunt plures lapides faciunt ad opera eorum defferri. Quapropter vobis expresse mandamus quatenus preconitzare publice faciatis sub pena certa quod nullus, cuiuscumque conditionis existat, audeat vel presumat de dictis lapidibus accipere ad opus eorum defferre et a contrafacientibus penam predictam absque remedio exigatis et eso propter inobedientiam, tu faciendum fuerit, puniatis sic quod eorum pena sit aliis in exemplum. Volumus et mandamus quod in pennis castri non permitatis scindi aliquos lapides cum essetr, tu dicitur, dicto castro valde dampnosum.

Datum Dertuse, VII kalendas aprilis, anno Domini M CCC XX secundo. P.. mercerii, mandato regio.

40. 1322, abril 25. Tortosa. El rey Jaume II de Aragón ordena al batlle general del reino de València que se traslade a Vall d'Uixó y elija un lugar adecuado para la construcción de una iglesia cristiana, una casa para el parroco y un depósito para almacenar los frutos de las "delmas".

Archivo de la Corona de Aragón. Barcelona. Cancelleria Reial. Registro 221, f. 199v. Original.

García Edo, Vicent. "La carta pobla de 1250 i el dret dels musulmans de la Vall d’Uixó”. 2000, pág. 105-106.

Publicada en el Archivo Virtual Universidad Jaume I de Castellón.

Jacobus et cetera.

Fideli suo Bernardo de Nuce, baiulo regni Valentie generali. Salutem et cetera.

Nostram presenciam adiens Raymundus Andree, archidiaconus dertusensis, nobis humiliter supplicavit ut cum nos de fructibus sarracenorum et aliorum degentium in valle nostra de Uxone decimam et primiciam ecclesie et personis ecclesiasticis, quibus competit tribui mandaverimus et exsolvi, ut in littera concessionis nostre lacius continetur; et in valle ipsa non sit ecclesia nec domus ubi rector ipsius valeat comorari; ut patuum congruum ad ipsa ecclesiam et domos edifficandas, et ad orreum in quo dictus archidiaconus possit recolligere redditus sibi competentes ex decima fructuum predictorum eidem assignare atque concedere dignaremur; nos vero dignum arbitrantes et debitum, ut ad laudem divini nominis ibidem construhatur ecclesia, in qua divina possint officia celebrari, et domus etiam in quibus clerici ibi degentes possint iuxta illam habitacionem habere, vobis dicimus et mandamus quatenus accedento personaliter ad vallen eandem, assignetis conveniens et idoneum patuum in quo ecclesia et domus rectoris ac orreum dicti archidiaconi hedifficari valeant, et in eis possint morari ac recolligere fructus suos.

Datum Dertuse $\mathrm{VII}^{\mathrm{o}}$ kalendas aprilis anno Domini $\mathrm{M}^{\circ} \mathrm{CCC}^{\circ} \mathrm{XX}^{\circ}$ secundo.

Dominico de Biscarra, mandato regio, fecit pro vicecancellario. 


\section{1332, mayo 25. Molino de la Torta. Sentencia arbitral dictada por el Obispo de Tortosa sobre el uso de las aguas del río Cenia en sus dos orillas por las Ordenes del Hospital y de Montesa.}

Archivo del Ayuntamiento de Ulldecona en el "Llibre de privilegis d'Ulldecona" fechada en 1483. Transcripción efectuada por Oscar Bover Falcó.

Publicada en la revista de Estudios del Maestrazgo no 76 del año 2006, en el artículo: "El agua del río de la Cenia: la sentencia arbitral de 1332" pág. 20.

Sentència arbitral donada per lo bisbe de Tortosa entre los órdens del Spital e de Muntesa sobre la qüestió de la aygua e dels molins del riu de la Cénia, la qual sentència és stada comprovada ab lo original en lo qual és insert lo compromés de la dita sentència.

On nós, en Berenguer, per la gràcia de Déu bisbe damunt dit, àrbitre e arbitrador e amigable conposador, hoÿdes e rebudes per nós totes les rahons e instruccions e scriptures públiques e no públiques per les parts a nós ofertes e per nós lestes e enteses e ab gran diligència vistes, regonegudes e examinades no tant solament una vegada más moltes, hoÿdes encara e enteses moltes vegades les verbals rahons e instruccions les quals les dites parts davant nostra presència dir, mostrar e proposar volgueren, haüda plenera deliberació sobre les dites coses e sobre les qüestions e demandes e nego[f. $72 v$ ]ci damunt dits sobre altres coses tocant les qüestions e negoci desús dits, havén Déu davant nostres ulls e volents posar fin deguda e perpetual a les qüestions e negoci davant dits, en per açò, per beu de pau e de concòrdia e per perdonar a treballs e despeses de les parts desús dites en aquests scrits segons lo poder a nós donat per les dites parts sentencialment difinim e pronunciam segons que $\bullet$ segueix:

Com a nós ne sia stada feta plenera fe del dret de la possessió o quaix del ús e ampriu de la dita aygua emperaçò sobre les demandes de la dita possesió o quaix cascuna de les dites parts de la demanda de l'altra absolvem a cascuna de les parts sobre la dita possessió o quaix perpetual callança posam. E axí matex sobre les injúries e dampnages per la una part e per l'altra e lurs síndichs e procuradors demanades e demanats aquelles parts e cascuna per sí e lurs procuradors sentencialment absolvem inposam a cascuna de les dites parts o lurs procuradors sobre aquelles injúries e aquells dampnages callança perpetual salvu emperò la condempnació o satisfació fahedora per la part dels hòmens del Espital a n Domingo Cogoma, segons que•s segueix. Encara dehim e pronunciam que els hòmens de Ulldecona donen e sien tenguts de donar $a^{\bullet} n$ Domingo Cogoma en satisfació e esmena de les messions e dans que ha fetes e sofertes en fer e construir la obra del molí en la part del terme de Cervera, tres milia sous de reals dels quals li deguen haver donats e pagats mil solidos per tot lo mes de juny primer vinent e d'ací a la primera vinent festa de Sent Miquel altres mil solidos e los altres mil solidos d'ací al derrer [f. 73r] dia del mes de jener ladonchs primer següent, jatsia que a nós sia evident dupte per cartes públiques si $\bullet$ dit molí podia en aquell loch ésser construït e edificat o no, prejudici de les dites cartes. Encara dehim e pronunciam que l'aygua tota que decorre e per tots temps decorrerà per lo riu de Ulldecona o de la Cénia, de la pexe- ra dels molins que en March de Pontons ten per l'orde de Muntesa a amunt, sia partida mig per mig per a molins farinés e drapers e per abeurar bestiars e per a regar segons lo regadiu que cascuna de les parts del Orde del Spital e de Muntesa e els vasalls lurs han acostumat d'aver de la dita pexera a amunt. Retenim emperò el departiment de la dita aygua que cascuna de les dites parts en temps d'estrenyiment d'aygües cascun any que mester o hajen, se puxen entresí avenir del departiment de la dita aygua en aquella manera que a ells plaurà. En axí emperò que per lo lur departiment o avinença no volen ni entenen que sia feyt alcun prejudici al decorri- ment de la dita aygua de la dita pexera avall segons que és acostumat e•stat tro al present dia. Encara sentencialment difinim e pronunciam que la dita pexera dels molins que $\bullet$ dit en March de Pontons ten per lo dit Orde de Muntesa entró al cacau del molí d’en Castell, que•s ten per lo dit Orde de Muntesa e és de part del terme de Cervera, la part del Orde de Muntesa e aquells qui dret han o hauran en los molins que són o seran dins l'espay desús dit, puxen pendre si's volrran énte- grament tota la aygua del dit Riu de Ulldechona o de la Cénia a molre solament e obs de molins drapers, salvu que puxen regar si’s volran los [f. 73v] orts qui són entre la céquia e el riu dins l'espay desús dit, ço és, de la dita pexera dels molins d'en Pontons entró al cacau del dit molí d'en Castell, axí emperò que tota la dita aygua o aquella part que del dit riu pendran segons que desús és dit, haien a tornar con- tínuament e éntegra e sens frau al riu al dit cacau del dit molí d'en Castell. E de la part que és ves lo terme de Ulldecona dins lo dit spay de la dita pexera entro al cacau del dit molí d'en Castell e en dret d'aquell cacau, l'orde del Spital ni lurs vas- salls ni alcuna altra persona del dit terme de Ulldecona no puxen treher per null temps alguna part pocha ni gran del aygua del dit riu a regar ni a molrre, salvu que retenim que puxen abeurar lurs bestiars propris e aquells que seran erbejats e han o hauran empriu en lur terme el dit riu 
en la part que és ves Ulldecona. Encara que si los dits bestiars que abeuraran el dit riu en la part del dit terme de Ulldecona dins lo dit spay passaran part l'aygua en ves lo terme de Cervera, que per lo dit passat- ge no sien penyorats ni carnejats ni cayguts en alguna pena en aytant com l'arenal e glera de la aygua s'estén comunament sens rouina gran. Encara sentencialment difinim e pronunciam que $\bullet$ Orde del Spital e sos vassals puxen reebre si's volran en lo cacau del dit molí d'en Castell e d'aquí avall tota l'aygua del dit riu e menar e treher al terme d'Ulldecona a necessitats de molins fariners tan solament e de regar e d'abeurar bestiars lurs propris e erbetjats e que po[f. 74r]den haver enpriu en lur terme e a qualsevol altre ús sens prejudici dels molins hedificats el terme d'Ulldecona, del dit cacau del molí d'en Castell a avall segons la carta del atorga- ment de la aygua fet als dits hòmens d'Ulldecona per l'onrat frare Berenguer d'Almenara, castellà d'Emposta, ab carta pública feyta per en Guiem Taraschó, notari públich per auctoritat real XII kalendas aprilis anno Domini $\mathrm{M}^{\circ} \mathrm{CC}^{\circ} \mathrm{LXX}^{\circ}$

tercio, la qual carta volem que romanga en sa força exceptat en ço que per nós en la present sentència és sentenciat e pronunciat, e declarant entró a la vila d'Ulldecona e oltra la vila entró al cap hon comença la céquia de la Lacuna per la qual volien treher l'aygua en ves les Aventalles, e en lo dit loch sia feyt per los dits hòmens de Ulldecona per tot lo mes de juny primer vinent un molló d'argamassa, de gruxa de VI palms e de alçària de XII palms de cana de Tortosa, e d'aquí avant la dita aygua per a regar ni per a negun altre ús per negun temps no puxen passar ni amenar ni aemprar aytant com tendrà l'endret del dit molló de muntanya a muntanya. Salvu emperò que en temps de necessitat, de minva d'aygua, puxen omplir de la dita aygua la bassa que és e•l camí públich que va d'Ulldecona a Tortosa, la qual bassa és davant la vila de les Aventalles, la qual cosa puxen fer tota hora que la dita bassa sia execa en tal manera que covinentment no y poguessen abeurar ni pendre aygua. Retenim emperò que si del dit cacau del molí d'en Castell alguna partida de la aygua escaparà o decorrerà per lo riu entró al molí que és dit de la Torta, que la part del Orde de Muntesa e sos vassalls puxen abeu[f. 75v]rar en la dita aygua lurs bestiars propris e els erbatgats en lur terme franchament e sens carnatge e pena alguna. E si per aventura los dits bestiars passaran part l'aygua que $\bullet$ decorre e $\bullet$ s decorrerà per lo riu dins lo dit spay, no sien penyorats ni carnejats ni cayguts en alcuna pena si donchs no exien ultra l'arenal e la glera del riu en ves lo terme de Ulldecona. Encara pronunciam e sentencialment difinim que $\bullet$ Orde de Muntesa ni els vassalls lurs dels termes de Cervera ni de Peníscola ni de Vilanaroç ni algun d'ells no puxen pendre per null temps del cacau del molí d'en Castell entró a la pexera del molí de la Torta alguna part o parts de la aygua que decorre o deco- rrerà per lo dit riu a molre ni a negun altre ús sinó abeurar los dits bestiars segons que deús és dit. Encara difinim e pronunciam que 1 molí que ara es dit d'en Erbolí haia a pendre l'aygua del riu ab pexera en guisa que en lo riu de la pexera amunt hon ell pendrà l'aygua romanga abeurador als bestiars caminants e altres bestiars de la una part e de la altra, en lo qual abeurador los dits bestiars puxen ésser abeurats sens pena alcuna segons les declaracions dels altres abeuradors del dit riu. Encara difinim e pronunciam que $\bullet$ s hòmens de Ulldecona sien tenguts de fer a lur cost e a lur missió, de la primera vinent festa de Sent Johan del mes de juny en un any una céquia tan pregon e tan ampla que suficientment puxa reebre en per tots temps les aygües que $\bullet$ decorren e $\bullet$ decorreran de tot lo regadiu de la orta e de la foya e de la vila de Ulldecona, la qual céquia començ en la sort de na Queralta, que•s té ab lo vall e va[f. 75r]ja entró sobre la bassa del Engollidor, e de la dita bassa entró al cap de la céquia que•ls dits hòmens de Ulldecona tenen per a decòrrer l'aygua de la foya, axí que la dita céquia e el decorriment del engolidor los hòmens d’Ulldecona sien tenguts de tenir en condret suficientment e contínua per tots temps en tal guisa e en tal manera que les dites aygües que's decorreran de tot lo regadiu de les dites orta e foya e vila puxen venir a la dita céquia e decorre per aquella entró a la céquia de la foya e per la dita céquia de la foya al riu e a la mare [sic]. Entenem emperò que de la dita céquia nova lo regadiu qui és entre la dita céquia nova entró a la mare del engolidor, puxen pendre aygua a regar aquells qui han e hauran heretat e orts en aquella partida segons la tanda ordenada o els dies que•ls vendrà de regar segons los altres vehins e no en altra manera, e axí que en continent com hauran regat dejen e sien tenguts cascun de tornar l'aygua a la dita céquia nova, e axí matex ente- nem d'aquells que han acostumat de regar de la bassa del Engolidor a avall que no puxen regar sinó segons la tanda ordenada o els dies que•ls vendrà de regar segons los altres vehins e no en altra manera, ni pus heretats regar que dentró ací han acos- tumat de regar e encontinent que hajen regat dejen e sien tenguts cascun de tornar éntegrament la dita aygua a la céquia, la qual aygua tornada a la céquia per que $\bullet$ buyda la foya alcú no puxa pendre tota ni partida a regar ni a molre, ans francha- ment vaja en lo riu tro al cacau del molí de la Torta. Encara pronunciam e sentencialment difinim que tota l'aygua del riu, [f. 75v] del cacau del molí de la Torta a avall puxa pendre lo molí o molins que en Pere Galí ha dins lo terme de Ulldecona, a molre tan solament, e no a negun altre ús, e l'aygua que escaparà del dit molí que torna e deu tornar al riu, puxa pendre tota lo molí de les Canals qui és dins lo terme de Peníscola, e del cacau del dit molí de les Canals que•s el dit terme de 
Peníscola, los hòmens del Canar puxen pendre entró a la mar la meytat de tota l’aygua per a regar e per abeurar tant solament lurs bestiars propris e aquells qui seran erbatjats $\mathbf{e} l$ lur terme e a altres qui han o hauran poder de aemprar lo terme d'Ulldecona e no a negun altre ús, la qual aygua com hauran regat encontinent sens alcun frau dejen e sien tenguts de tornar al dit riu e•l cacau qui és davall lo dit molí de les Canals. E l'altra meytat de la dita aygua puxen pendre entró a la mar los hòmens del terme de Paníscola e Vinalaroç per a molre e per a regar e per abeurar lurs bes- tiars propris e aquells qui seran herbetjats e $\bullet$ ls lurs termes e per a tot altre ús que a ells plàcie. Emperò si en temps de necessitat d'aygua axí que no pogués bastar a la una part ni a l'altra los del Canar e aquells qui han los molins o hauran el terme de Vilanaroç, del cacau del molí de les Canals a avall la hon l'ayguàs partex tro a la mar, se volran avenir entresí que per dies certs la una part o l'altra prenga tota l'ay- gua, que u puxen fer sens tota pena. Encara pronunciam e jutjam que los hòmens de Paníscola e de son terme e de Vilanaroç e de son terme e els hòmens de Ulldecona e del Canar e de lurs térmens, puxen abeurar lurs bestiars propris e aquells qui seran erbetjats e•ls lurs térmens e al[f. 76r] tres bestiars que han o hau- ran poder de aemprar los dits térmens en l'aygua que decorre o decorrerà per lo dit riu del cacau del molí de la Torta entró a la mar, franchament et quítia, axí que si algun bestiar o bestiars dels desús dits propris o erbetjats o altres han o hauran a empriu de aemprar los dits térmens, passa o passaran part l'aygua del dit riu vers los térmens de Ulldecona e del Canar en l'arenal o en la glera de la aygua, e axí matex alcun bestiar o bestiars propris o erbetjats dels dits hòmens de Hulldecona e del Canar e de lurs térmens o d'altres que han o hauran aempriu e•ls dits térmens, passarà o passaran part l'aygua en ves lo terme de Peníscola e de Vilanaroç en l'arenal o en la glera, que $\bullet$ dit bestiar o bestiars no puxen ésser penyorats ni carnejats deçà ni dellà ni sien cahuts en alcuna pena per lo passatge desús dit si donchs no exien fora l'arenal e glera de cascuna part del riu aytant com l'aygua del riu pren sens gran rouina. Encara pronunciam e sentencialment difinim que tota l'aygua que's decorrerà per lo dit riu entró a la pexera que ara és o d'aquí avant serà del molí de la Torta entró al pont començant a avall o aytanta com penren volran puxen pendre l'orde de Muntesa o sos vassalls per a obs del dit molí suficientment e enca- ra si regar volran ço qui és entre la céquia e el riu, e aquella sien tenguts de tornar al cacau del dit molí de la Torta. Encara pronunciam e sentencialment difinim que $\bullet$ Orde del Espital e els hòmens de Ulldecona contínuament sien tenguts de donar sufficientment en per tots temps, de la céquia del re[f. 76v]gadiu de Ulldecona aygua al molí o molins qui solen ésser dits de na Forcadella e ara són d'en Bernardo d'Osona, lo qual molí o molins sentencialment difinim no poder ésser mudat o mudats per propri moviment del senyor o senyora del dit molí o molins qui són o seran d'aquí avant ni encara per atorgament feyt per la senyoria de Ulldecona, com no puxen ésser mudats sens prejudici evident e gran dan del molí de la Torta, la qual aygua que escaparà o decorrerà del dit molí o molins del dit Bernardo d'Osona puxen pendre lo senyor o senyors dels dits molins de la Torta en lo riu e menar énte- grament als dits molins si•s volran a molre tan solament e no a negun altre ús salu si regar volran ço és que és propri ara del dit molí de la Torta entró en la sua céquia e el riu, la qual aygua sien tenguts de tornar éntegrament e sens alcuna frau e machinaçó al cacau dels dits molí o molins de la Torta. Entenem emperò que•l Orde del Spital e els hòmens de Ulldecona, en temps de necessitat d'aygua, puxen pendre tota l'aygua de la dita céquia a regar la orta e les heretats del dit molló a ençà mentre que mester l'auran sens tota frau e machinació que no sia feyta al dit molí del dit Bernardo d'Osona ni al dit molí de la Torta. Encara entenem que en temps que los hòmens de Ulldecona tota l'aygua menaran e poran menar segons que dit és, si alcuna quantitat de la aygua decorrerà o escaparà de la céquia on lo molí del dit n'Osona deu pendre l'aygua al [f. 77r] dit molí que lo senyor del dit molí que ara és d'en Osona puxa retenir e ajustar en la bassa que ha aquella quantitat d'ay- gua pocha o gran e d'aquella molre com porà. E açò matex puxa fer lo senyor del molí de la Torta com serà escapada al dit molí. Retenim emperò e salvam e decla- ram que no contrastant ço que per nós damunt és stat sentenciat e pronunciat, les dites parts e singulars de aquelles puxen pendre e aemprar de la dita aygua a beure e a regar a mà sens céquia o reguero e a lavar draps e vexells e a obrar e abeurar bés- ties grosses e menudes e altres necessitats d'ells e de lurs companyes e de lurs alberchs. Absolvents per aquesta nostra sentència totes secrestacions o empares entró al dia de huy fetes de la aygua desús dita, donants poder a les dites parts e al dit en Guillem Erbolí que la dita aygua puxen usar de continent e d'aquí avant per tots temps segons la forma de la nostra sentència damunt dita. Encara dehim e declaram que del cap del riu entró a la mar, los bestiars e bèsties de cascuna de les dites parts que abeuraran e $\bullet$ dit riu no cayguen en alcuna pena ni puxen ésser car- nejats ni penyorats si donchs no exien fora l'arenal o glera que $\bullet$ riu a acostumat de tenir de la una part e de la altra, salu en temps de gran rouina. Totes e sengles coses per nós desús dites, pronunciades, difinides e declarades nós, dit àrbitre e arbitra- dor segons lo poder a nós donat per les dites parts, dehim, sentenciam, difinim, jut- jam, declaram e manam per beu de pau e de concòrdia $[\mathrm{f} .77 \mathrm{v}]$ e per perdonar a treballs e despeses per les dites parts 
e per cascuna d'aquelles e per lurs procuradors per tots temps éntegrament e sens alcuna frau, machinació e lesió ésser tengudes, conplides e no corrempudament observades sots les penes en los dits conpromeses contengudes, posades e expressades. Retenim emperò a nós segons la forma del pri- mer conpromés que puxan declarar e enterpretar aprés la present nostra sentència o pronunciació quant e quant e quantes que vegades request ne serem per les dites parts e per la una tant solament si algunes coses en aquesta nostra present sentèn- cia o pronunciació apparran obscures o duptoses. Retenim encara que la present nostra sentència faça dret tant solament entre els conpromeces e ratificants e fer- mants los conpromesses damunt dits e a nulla altra persona per aquesta present sentència no puxa alcun prejudici ésser feyt o engenrat.

Lata sententia hec die lune, hora vesperorum que fuit $\mathrm{VIII}^{\circ}$ kalendas junii anno Domini $\mathrm{M}^{\circ} \mathrm{CCC}^{\circ}$ $\mathrm{XXX}^{\mathrm{o}}$ secundo, iuxta hospicium molendini de la Torta qui est ultra rivum de Ulldecona o de la Cénia, presentibus dictis Raymundo Gondiçalbi et Guillermo Lorach, procuratoribus, et Dominico Cogoma nec non dictis Miquaele Minorisse et Guilermo de Ponte, procuratoribus, presentibusque venerabilibus fratre Ferrario de Bars, Ordinis Hospitalis tenente locum comendatoris Ulldecone, Poncis de Guàrdia, camerario, Francisco de Corbino, decano sedis Dertusensis, Petro de Marçano, rectoris ecclesie de Gandesia, Guillermo de Nogaria, rectore ecclesie vallis Traygarie, Raymundo de Bars, iurisperito dicte civi[f. 78r]tatis Dertusensis, Johanne Eximini de Montetornesio, et Raymundeto de Sancto Minato, ad hec vocatis pro testibus specialiter et rogatis. Ego Berengarius, Dertusensis episcopus, arbiter et arbitrator predictus subscribo.

Sig+num Guillermi Geraldi, notarii publici Dertusensi et per totam terram et dominacionem illustrissimi domini regis Aragonnum auctoritate regia qui predic- tis interfuit et de mandato dicti reverendi domini arbitri predictam sentenciam in hanc publicam formam scribi jussit cum supraposito etc.

\section{1347, marzo 20. Valencia. Sentencia dictada por el infante Pedro, conde de Ribagorza, por la cual regula la partición de les aguas del río Mijares, entre les villas de Castelló de la Plana, Vila-real, Almassora i Borriana.}

Archivo Municipal de Castellón de la Plana. Aguas. Caja 13. Libro de diferentes sentencies referentes a aguas, relativas a les villas de Castellón y Almassora, ff. 23r-26v. Copia simple en papel de la primera mitad del siglo XV.

V. García Edo. La sentencia del conde de Ribagorza para el reparto de las aguas del río Mijares. 1997. Transcripción efectuada el día 11-IV-2008 a partir de la edición citada.

Publicada en el Archivo Virtual Universidad Jaume I de Castellón.

Treslat de la sent $\square$ ncia donada per l'alt senyor infant en Pere, compte de Ribagor $\square$ a e de les montayes de Prades, sobre la partici $\square$ de l'aygua del riu de Millars.

Noverint universi, quod cum questio vel controversia verteretur, aut verti sparetur inter universitates ville Castillionis et Ville Regalis et loci de Alma $\square$ ora, ex una parte, et universitatem loci Boriane, ex altera, racione videlicet vel occasione aque rivi de Millars, racione cuius questionis seu controversie inter dictas partes materiam dicensionis erat suborta, cumque dicte partes super premissis diucius contendisset et coram diversis judicibus ad hec delegatis litigasent, et inter se convenire non posent; attamen volentes parcere partium laboribus et spensis et eligentes pocius per viam pacis questionem hanc dirimere quam eventum dubium iudici expectare; compromisserunt super premissis in inclitum dominum infantem Petrum, comitem Ripacurcie et Montanearum de Prades, tamquam in arbitrum et arbitratorem, lauda[to]rem et amicabilem compositorem ab ipsius partibus comuniter electi, videlicet Guillermus Berengarii, notarius, et Arnaldus de Torrafre, vicini ville Castillionis, sindici, procuratores et actores ad hec specialiter constituti ab universitate ville Castillionis et singularibus de eadem, cum publico instrumento facto per Miquaelem de Pegeroles, [notarium] auctoritate regia, tercio idus febroarii anno infra scripto, et Miquele Gali, juratus, et Guillermus $\square$ afont, vicini Ville Regalis, procuratores, sindici et actores ad hec una et insolidum specialiter constituti cum Jacobo Mas et Petro Tremunt ab universitate Ville Regalis, et insolidum specialiter ad hec constitutus ab universitate dicti loci de Alma $\square$ ora et Ville Regalis duodecimo kalendas marcii anno a Nativitate infrascripto. Et Bartholomeus de Tapioles, notarius, vicinus de Alma $\square$ ora, procurator, sindicus et actor una cum Johanne Malet et insolidum specialiter ad hec constitutus ab universitate dicti loci de Alma $\square$ ora et singularibus eiusdem, cum publico instrumento facto per Thomam de Vilamajor, auctoritate regia notarium publicum, tercio nonas febroarii anno infrascripto, ex parte una; et Laurencius de Munit, juratus, et Bernardus de Valporcar, vicini ville Burriane, procuratores, sindici et actores ad hec specialiter constituti ab universitate dicte ville Buriane et singularibus eiusdem, cum publico 
instrumento factum per Berengarium Solzina, auctoritate regia notarium publicum, tercio nonas febroarii anno infrascripto ex altera; super omnibus et singulis questionibus, peticionibus et demandis, quas dicte partes nominibus predictis, silicet altera pars contra alteram partem adinvicem posent facere, proponere [vel movere, verbo vel] scriptis, et omni solempnitate iuris [et fori] obmissa, vel que iam mote essent inter dictas partes ratione dicti [aque] rivi de Millars, vel moveri etiam posent seu speraretur, tam super iure possessionis quam proprietatis quam alias quoquomodo ratione dicte aque. Et super omnibus et singulis exceptionibus et defensionibus, quas pars contra partem nominibus predictis adinvicem habet et vellet ac posset facere, proponere, vel movere, et omnibus predictis et aliis quibuscumque.

Et promiserunt dicte partes nominibus iam dictis, dicto inclito domino arbitro et arbitrarori et sibi adinvicem, quare super predictis compareret coram ipso, diebus, horis, et locis quos et quas in que eis asignaret.

Promisserunt eciam quod super premissis procederent coram dicto domino arbitro et arbitratoris simpliciter et de plano, et sine omni difugio et malicia, et sine strepitu et figura iudicii, et cum scriptis vel sine scriptis et aliis iuris solepnitatibus, prout ipsi inclito domino arbitro et arbitratori videretur. Et quod quidquid dictus inclitus dominus arbiter et arbitrator super predictis diceret et pronunciaret, de iure, laudo, vel amicabili composicione, illud ratum, gratum, et firmum, perpetuo, dicte partes nominibus iamdictis haberent, tenerent et observarent, et ea facerent et complerent; et eidem pronunciacioni starent sub pena mille marchorum argenti, de quaquidem pena medietas voluerunt quod adquireretur illustrissimo domino regi Aragonum, et altera medietas pacti sententie seu pronunciationi dicti domini arbitri et arbitratoris adquirendi, sine omni appellacione et contradiccione et omni excepcione remota.

Et renunciaverunt dicte partes, nominibus predictis, quantum ad predictum, gratis et ex certa sciencia, omni appellacioni et contradiccioni, et omni cuilibet legi et foro aut consuetudini, per quas licitum est appellare a sentencia arbitrali.

Renunciarunt [etiam] quantum ad predictam, gratis et ex certa scientia, omnes adinvicem ex pacto remisserint quod a dictis sentencia seu pronunciacione dicti incliti domini et arbitratoris non possent recurere ad arbitrium boni viri, et omni [alii] iuri, foro, racioni et consuetudini obviam venientibus.

Voluerintque dicte partes, nominibus predictis, quod predictum negocium firmaretur et determinaretur per dictum inclitum dominum arbitrum et arbitratorem, a die confeccionis dicti compromissi instrumentum usque ad festum Pasche Domini, prout hec et alia in compromisso inde facto auctoritate notarii infrascripti pridie kalendas marcii anno infrascripto plenius et lacius continetur.

Quo compromisso prefato in dictum inclitum dominum infantem Petrum, arbitrum et arbitratorem suscepto coram ipso domino arbitro et arbitratori comparuerunt partes predicte, nominibus predictis, videlicet sindici, procuratores, et actores superius nominati, universitatem ville Castillionis, Ville Regalis et loci Alma $\square$ ore, en una parte; et sindici, procuratores et actores superius nominati universitatis ville Boriane, ex altera, et proposuerunt coram eo verbotenus raciones et defensiones suas.

Et post predicta, auditis ac etiam intellectis racionibus et defensionibus utriusque partis, coram ipso domino arbitro et arbitratore verbotenus propositis, habitaque plenaria deliberacione super predictis per ipsum, et consilio cum peritis, pro bono pacis et concordie, ac inter [dictas] partes amicabiliter componendo super premissis, idem dominus arbiter et arbitrator tulit suam sentenciam in hunc modum:

[On] $\mathrm{n} \square \mathrm{s}$, infant En Pere, comte de Ribagor $\square$ a e de les muntanyes de Prades, $\square$ rbitre et arbitrador e amigable composidor per la universitat de la vil $\square$ la de Castell $\square$ e los singulars d'aquella, e per la universitat de Vila-real e los singulars d'aquella, e per la universitat del loch de Alma $\square$ ora e dels singulars d'aquella, o per lurs $s \square$ ndichs e procuradors per les dites universitats $[a] a \square \square$ constituhits, de la una part; e per la universitat del loch de Boriana e/o per lurs s $\square$ ndichs [a] $a \square$ constituhits, de la altra part, comuniter elets sobre la q $\square$ esti $\square$ que era entre les dites universitats, [per rah $\square$ ] de la aygua del riu de Millars, segons que en $[\mathrm{lo}]$ comprom $\square \mathrm{s}$ daqu $\square \mathrm{n}$ en $\mathrm{n} \square \mathrm{s}$ fet pus larguament se cont $\square$.

Vist e regonegut lo dit comprom $\square$ s en $\mathrm{n} \square \mathrm{s}$ fet, e lo poder per les dites parts en aquell a $\mathrm{n} \square \mathrm{s}$ donat, elegint via de arbitrador e de amicable composador entre aquelles parts; ho $\square$ des les parts des $\square \mathrm{s}$ dites e cascuna d'aquelles una vegada e moltes, e enteses les rahons per cascuna de les parts denant $\mathrm{n} \square \mathrm{s}$ a $\square$ legades; ha $\square$ t encara col $\square$ loqui e tractament ab les dites parts sobre la avinen $\square$ a del departiment de la dita aygua; e ha $\square$ t consell e acort sobre lo dit contrast ab moltes $s \square$ vies e discretes persones entenents e spertes [en dret e] en semblants contrasts, volent lo dit contrast ax $\square$ de la possessi $\square$ lo qual era pendent entre aquelles denant los jutges [a] a $\square \square$ asignats, com encara de la proprietat sobre la quall entre aquells se sperava a moure; per aquesta nostra sent $\square$ ncia determinar e donar, e donants [a] aquell fi arbitran, [e] entre aquells amicablement component pronunciam: 
Que en temps que ser $\square$ minva d'aygua en lo dit riu, e per rah $\square$ de la dita minva, se haur $\square$ a fer entre ells partici $\square$ d'aquella aygua.

De tota la dita aygua sien feytes sexanta fil $\square$ les o parts eguals, al partidor sobir $\square$ qui $\square$ s a.l azut [o damunt lo asut] de Vila-real, les qualls fil $\square$ les e parts eguals, al partidor sobir $\square$ sobredit sien eguals partides en la forma sig $\square$ ent:

Primerament, de les dites LX fil $\square$ les o parts eguals asignam e ajutjam que haja la vil $\square$ la o universitat de Vila-real quatuordecim filas o parts.

E.n apr $\square$ s, d'aquelles sexaginta fil $\square$ les o parts eguals, asignam e ajutjam a la vil $\square$ la e universitat de Castell $\square$ quatuordecim files o parts et mediam.

Item, d'aquelles sexaginta fil $\square$ les o parts eguals, asignam e ajutgam que haia la dita [vila et] universitat d'Alma $\square$ ora duodecim filas sive parts et mediam.

E les romanents decem et novem parts o files de les dites sexanta fil $\square$ les e/o parts eguals, asignam et ajutgam a la vil $\square$ la e universitat de Boriana.

En ax $\square$ que si l'aygua [que] adonchs descorer $\square$ per lo dit riu, bastar $\square$ a les dites sexanta fil $\square$ les, que sien feytes e partides segons que des $\square$ s se cont $\square$.

En altra manera, si no bastaven a LX fil $\square$ les, que.n sien feytes sexanta parts eguals, e que aquelles sien partides segons que damunt $\square$ s declarat.

E segons lo dit compte de les dites fil $\square$ les e parts, sie feyta partici $\square$ de la dita aygua per tots temps; en cars de necessitat o minva d'aygua, o en cars que haia a venir a partici $\square$.

Enper $\square$, si l'aygua del dit riu venia a tan gran minva o fretura, que segons la partici $\square$ des $\square \mathrm{s}$ dita la part que pervendr $\square$ a la vila d'Alma $\square$ ora no bastava a una fil $\square$ la, que en aquell cars tota l'aygua del dit riu fos donada a una c $\square$ quia, e.n ax $\square$ que la $\mathrm{c} \square$ quia de Vila-real haia tota la dita aygua viginti octo hores cont $\square$ nuament, que $\mathrm{s} \square \mathrm{n}$ un dia natural et quatuor hores $\mathrm{m} \square \mathrm{s}$.

E.n apr $\square$ s la c $\square$ quia [de Castell $\square$ ] haia tota la dita aygua per viginti novem horas cont $\square$ nuament, [e] que $\square \square \mathrm{n}$ un dia natural e cinch hores.

E tantost apr $\square$ s la $\square \square$ quia d'Alma $\square$ ora haia tota l'aygua damunt dita per viginti quinque ores cont $\square$ nuament, que s $\square \mathrm{n}$ un dia natural e una hora.

E.n apr $\square$ s tantost la c $\square$ quia de Boriana haia tota la dita aygua per triginta octo hores [cont $\square$ nuament, que $\mathrm{s} \square \mathrm{n}$ un dia natural e catorze ores].

$\mathrm{E}$ ax $\square$ cascuna universitat haia en lo dit cars tota la dita aygua, segons que.s particularment declarat des $\square$ s.

Deh $\square$ m encara e arbitram, e amigablement component pronunciam, que en temps que la dita partici $\square$ se haur $\square$ a fer, qualsevulla de les dites universitats puxa notificar e requirir a les altres universitats, o als jurats de cascuna d'aquelles, si presents seran en les dites vil $\square$ les, e si no, a aquells qui presents seran o c $\square$ pia haver poran.

E si los dits jurats no.y seran, o c $\square$ pia d'aquells haver no porien, que en aquell cars haien a fer la dita notificaci $\square$ ab escriptura p $\square$ blica, en pres $\square$ ncia de quatre o $V$ proh $\square$ mens de la vil $\square$ la e [viles], que apr $\square$ s la dita notificaci $\square$ trameten al dit loch que facen [de la dita] partici $\square$ dins spay de un dia natural, comen $\square$ ador apr $\square$ s de la hora de la dita notificaci $\square$.

Lo partidor per cascuna de les dites universitats elet, o elegidor, que sia present ab ells a fer la dita partici $\square$, e si no.y eren, pasat lo dit dia e ora, aquell o aquells qui presents seran puxen fer la dita partici $\square$ segons que des $\square \mathrm{s} \square \mathrm{s}$ declarat.

Dehim encara e arbitram, e amigablement component pronunciam, que totes sent $\square$ ncies e pronunciacions, o altres juhins ordinaris o extraordinaris, judicialment o extrajudicialment feytes, sobre lo contrast de les dites ayg $\square$ es, ax $\square$ sobre la posessi $\square$ que ja sia liurada o tenguessen de fet, com sobre la proprietat en quant poguessen obviar a la nostra present pronunciaci $\square$ o sent $\square$ ncia, sien e romanguen nul $\square$ les e sens alguna effic $\square$ cia e valor, ans segons aquesta nostra sent $\square$ ncia e pronunciaci $\square$ se haia d'aqu $\square$ avant en per tots temps en los dits casses a fer la dita partici $\square$ e divisi $\square$ de la dita aygua, e totes les altres coses en la present nostra sent $\square$ ncia ordenades, les qualls coses haien a tenir e observar les dites universitats e.ls singulars d'aquella e lur sucesors, sots la pena en lo dit comprom $\square \mathrm{s}$ spresades.

En totes les dites coses e quiscuna d'aquelles contengudes en la nostra present sent $\square$ ncia o pronunciaci $\square$, manam $\square$ sser emologades, loades, confermades e aprovades en continent per los dits $\mathrm{s} \square$ ndichs denant $\mathrm{n} \square$ s presents.

En ax $\square$ matex, totes les dites coses per cascuna de les dites universitats sien emologades, loades, confermades e aprovades dins quindecim dies primer vinents, comptadors apr $\square \mathrm{s}$ lo dia de la promulgaci $\square$ de la present nostra sent $\square$ ncia, sots la pena en lo dit comprom $\square$ s spresada e contenguda. Retenim, emper $\square$, e reservam a $n \square \mathrm{s}$, de spresa voluntat de les parts, [que] si alcuns duptes ocorien 
sobre la present sent $\square$ ncia o pronunciaci $\square$ nostra, [o] algunes coses contengudes en aquella, o sobre alcun incident, emergent e dependent de aquella vel occasione predictorum, que aquell puxam determenar, declarar [e] interpretar, tota vegada que a $n \square \mathrm{s}$ ben vist ser $\square$, la quall interpretaci $\square$ o declaraci $\square$ haia aquella matexa for $\square$ a e vigor que ha la present sent $\square$ ncia nostra.

Lata fuit sentencia per dictum inclitum dominum infantem Petrum, arbitrum et arbitratorem.

Et lecta per me, notarium infrascriptum, de mandato dicti domini arbitri et arbitratoris, et de voluntate et consensu partium predictarum, que ibidem presentes erant, coram dicto domino infante, videlicet in domo fratrum predicatorum civitatis Valencie, in quadam camera eiusdem domus ubi dictus inclitus dominus arbiter et arbitrator hospitabatur, die martis qua computabatur tertio decimo kalendas aprilis anno Domini millesimo CCC $\square$ quadragesimo sexto.

Presentibus silicet me, dicto notario, et venerabilibus Jacobo de Pertusa, canonico et preposito valentino, Jacobo Pallares, legum doctore, Johanne Calvonis, iurisperito Valentie, et nobile Gilaberto de Cintillis et Johanne de la Raga, presbitero, testibus ad hec vocatis specialiter et adiunctis.

Et confestim dicte partes, nominibus iam dictis, videlicet [Guillermus Berengarii, Arnaldus Torrafrer, Michael Gali], Guillermus Safont et Bartholomeus de Tapioles, procuratores et sindici supradicti, ex una parte, et Laurencius de Muntso, procurator et sindicus iam dictus, ex altera, nominibus et auctoritatibus supradictis, laudarunt et aprobarunt, emologarunt et confirmarunt sentenciam supradictam, et omnia et singula in ea contenta, prout superius continetur, ipsaque omnia iurantes ad sancta Dei quatuor euvangelia manibus eorum corporaliter tacta, promisserunt nominibus predictis tenere, complere, et observare in perpetuum, ipsamque non revocare nec contrafacere vel venire, aliquo iure, causa, vel etiam racione, sub pena in compromisso contenta.

Presentibus silicet dicto domino arbitro et arbitratore et me notario infrascripto ac testibus ut predicitur supradictis.

Et voluerunt dicte partes quod de presenti sentencia fiant seu fieri possint tot originalia instrumenta quod partes pecierint.

Sig+num Bernardi de Fabrica, notarii publici per totam terram et dominacionem serenissimi domini regis Aragonum, et auctoritate eiusdem, qui prolacioni dicte sentencie et aliis omnibus supradictis et singulis, ut superius continetur, presens interfui et hec scribi feci [et] clausi, cum literis rasis et emendatis in linea XXIIII, ubi dicitur "super", et cum supraponitis in linea VIII ubi scribitur "ad hec", et in linea XIIII ubi legitur "vel sine scriptis", et in linea XXIX ubi dicitur "en cars", et in linea XLII, ubi invenitur "e c $\square$ pia haver poran. E si los dits jurats no.y eren".

43. 1358, febrero 20. Valencia. Prohibición de construir casas con porches y con fachadas de montantes de madera ("barandats") después del grave incendio que sufrió Morella en 1356.

Archivo de la Corona de Aragón. Barcelona. Cancelleria Reial. registre 694, ff. 58 v y 59 r.

Transcripción efectuada por Josep Alanyà i Roig.

Publicada en el libro: Urbanisme i vida a la Morella medieval S.XIII-XV' Editado por el Ayuntamiento de Morella en el año 2.000 pág. 429.

Petrus, et cetera. Fideli nostro mostaçafio ville Morelle, presenti et qui pro tempore fuerit, salutem et gratiam. Pro parte proborum hominum universitatis dicte ville fuit nobis expositum reverenter quod, licet nos cum littera nostra, pro evitando similis ignis incendio, quod non est diu casualiter accidit in dicta villa occasione perabandarum seu envanorum que erant in hospitiis dicte ville, duxissemus providendum quod amodo aliquis seu aliqui singulares ipsius ville in edificis fiendis in eorum hospitiis non auderent facere aliquas perabandas seu envana fustea, sed quod heberent operari seu edificari facere parietate seu parietes ipsorum hospitiorum, frontres ipsorum hospitiorum reddentes directe usque ad tectum superius ascendendo et in tecto superiori tectis seu cohopertis. Verumtamen aliqui singulares dicte ville, tam propter potentiam eorum quam propter favorem vestri, dicti mostaçafii sweu predecessoris vestri in ipso officio sive etiam per negigentiam, nituntur facere perabandas sive envana fustea contra formam nostre provisionis supratacte. Quocirca per eosdem probos homines fuit nobis humiliter supplicatum tu super hiis dignaremur eis de condecenti remedio providere. Nos, itaque, eorum suplicatione benigne admissa, vobis dicimus et mandamus quatenus omnia et singula envana seu perabandas factas seu cvonstructas contra formam provisionis sepedicte dirui faciatis cavendo diligenter en aliquis amodo construat sive faciat envana aliqua in suo hospitio contra provisionem prelibatam tu dicta villa a casu simili predicto valeat tutius preservari.

Datum Valenttie, XX die februarii, anno a Nativitate Domini Millesimo CCC quinquagésimo VIII. Visa Rodericus

Johannes de Figuerola, ex causa provisa per Berengarium de Codinachs et Arnaldum Johannis, legum doctores, consiliarios.

Probata. 


\section{1358, marzo 12. Les Coves. Concesión privilegio del tribunal del Ligallo para los lugares de Calig, Canet, Rosell, La Jana y la Barcella.}

Transcripción efectuada por Miquel Gual i Camarena.

Publicada en "La institució ramadera del Ligalló: Unes ordenances desconegudes del segle XIV” pág. 74-78.

En nom de Deu sia e de la sua beneyta mare la verge Maria, amen. Sapien tots, presents e esdevinadors que nos, frater Pere de Thous, per la gracia de Deu humil mestre de la casa de la cavalleria de Santa Maria de Montesa, attents ésser a nos humilment supplicats per part dels justicies, jurats et prohomens dels lochs nostres de Canet,de Rossell, de la Barcella, de la Jana e de Calig, que graciosamente deguessem attorgar e donar licéncia a les universitats damunt dites dels dists lochs e als dits jurats e promens damunt dits, que comunam,ent e cascún any en lo loch de la Jana, tots temps poguessen fer a tener ligallo de moltes e diverses bestiars que van exarrats e radius en dan de aquells de qui són, axi en los termes dels dits lochs con en altres circumvehins; com tenir lo dit ligalló sia gran profit de les dites universitats, attenents la dita supplicació ésser molt profitosa et fructuosa, cobeiant vetlar en lo profit et utilitat de la cosa pública dels dits lochs e universitats, e perço encara que els dits bestiars e besties radives e exarrades venir puxent en mans de aquells de qui son e per tal que nos paresquen nis perden a aquelles. Attenents res no menys lo dit loch nostre de la Jana ésseer sufficient e convinent a tenir e celebrar lo dit ligalló, com sia e stia quasi enmiig de tots los lochs damun dits, per ço, per tenor de la present carta nostra, donam et otorgam licència als dits justicies, jurats, promens e universitats dels damunt dits lochs de Canet, de Rossell, de la Barcella, de la Jana e de Calig, presents et esdevenidors, que puxen fer, tenir a celebrar cascún any ligalló en lo dit loch de la jana sots la manera e condicions dels capitols deius segunts:

Primerament que.l dit ligalló sia feten lo dit loch de la Jana, dáci avant, és a saber lo dilluns inmediat según de la festa de la Pascha de la Resurrecció de nostre Senyor, e en la festa de Simeni e Judes del mes de octubre, cascún any.

Item que cascún any sia elet a creat, per los jurats e consellers del dir loch de la Jana, un prohom del dit loch a justicia del dit ligalló lo qual jur en poder del batlle del dit loch o son lochtinent, que bé e lealment se hará en lo dit offici e que levará be e diliginment la pena o penes que posaders e ordenades són en los capitols deius scrits, con comeses serán.

Item que lo justicia del dit ligalló e los jurats del dit loch, tots ensemps e cuansevol de aquells en abséncia el altre o altres loch damunt nomenats, quien lo dit loch en la jana són tenguts de fer lo dit ligalló, per la manera que.ls será ben vist, los bestiars mostrenchs, exerrats e radius, aixi dels stranys com privats. Et si per aquells atrobats ní serán, que diguen als pastors e guardians dels ramats de bestiars on les dites besties mostrenques e radives serán, que aquelles dejen menar a menem al dit ligalló. Et si fer no ho volran queladonchs lo dit justicia del dit ligalló e ladonchs lo dit justicia del dit ligalló puxa a forçar e destrenyer los pastos o guardians dels dits bestiars, en los quals les dites besties mostrenques o radives serán de menar aquelles al dir ligalló per imposicció de pena de LX sous, e aquesta dita pena crèxer e multar contra aquells qui inobedients e bens lurs si e aytantes vegades con comesa será. De les quals pena o penes sobredites e eius scrites haiam nos e nostre ordre lo terç, lo comú dels dits loch lo terç e lo dit justicia del dit ligalló lo terç, per sos treballs.

Item que.ls senyors dels bestiars sien tenguts de dir a manar als lurs pastors o guardians que cascun any o cada vegada manen totes les besties mostrenques e radives que.n lo dit bestiar lur seran a cascuns les dits ligallós del dit loch. E si no.ls manaran, que paguen per pena LX sous, partidors según que damunt es dit. E si serà negat per lo dit pastor o pastors que.l dit senyior lur no.ls haja fet lo dit manament, que, en aquest cas, lo senyor sobredit en sia cregut per son sagrament.

Item que.ls dits pastors pus lo serà manat o en cas que no.ls sia manat per lur senyor, sien tenguts menar los dits bestiars radius o mostrenchs que serán en lo lur ramat o guarda per cascuna vegada al ditt ligalló, sots la dita pena de LX sous, segons que dessus és dit partidora.

Item que.ls senyors dels dits bestiars, que pastors o altres guardes no tendràn a aquells semblantment sien tenguts menar o tramettre al dit ligalló totes les besties mostrenques que en lur poder o bestiar serán. E aço sort la pena damunt dita, partida segons que dessus.

Item que ninguna guarda o pastor o alcuma altra persona, qui menará les dites besties mostrenques o radives al dit ligalló no sien osats lexar o aturar alcuna de aquelles en alcún altre loch, en abcegar aquelles al dit ligalló, sots la pena dessus dita. Axi com dit es partidora.

Item que.l dit justicia del ligalló do e pach a cascún qui bestar o besties mostrenques o radives menarán al dit ligalló, per cascuna de les dites besties dos diners per sos traballs.

Item que cascún que en lo dit ligalló atrobará e coneserà alcunes qualsevol besties sues, provant ab son 
sagrament e per altra legitima prova que sien sues, que.l dit justicia en lo dit cas la delliure o faça de lliurar aquelles. E que aquell de qui serán les duites besties do per cascuna de aquelles al dit justicia dos diners.

Item que alcú no sia osat traher del dit ligalló alcuna bestia o besties radives o mostrenques, per sues o de la sua guarda, que sien "altra persiona sens voluntat de aquell de qui serán, sots la dita pena de LX sous, aixi com dessus dit és partidora. E si pagar no lo porá que stia pres en la presò del dit loch, tro que la haja pagada.

Item que alcún hom o persona stranya que será habitador, vehin o guarda del bestiar del loch on ligalló no.s faça, no puxa traher alcuna bestia o besties radives o mostrenques o suees del ligalló del dit lloch, ni aquelles li sien liurades.

Item que tengut lo dit ligalló lo bestiar o besties mostrenques o radives que en poder del dit justicia e jurats romandràn en lo dit ligalló, a les quals no será exit senyor o guarda, aquell ditr justicia e jurats facen guardar aquelles per XV dies continuament seguens. E mentre seran guardades alcú o alcuns conexeràn dins lo dit temps alcuna de les dites besties per lur o de lur guarda que.ls sien liurades per lo dit justicia a que aquells de qui seran paguen per cascuna bestia a la guarda del dit bestiar radiu o mostrench IIII diners.

Item finit e passat lo dit temps de la dita guarda ae quansevol bestiar que sia romas del dit ligalló, per corredor públich al mes donant. E del preu que.n será haut, sia pagada la guarda de aquell, reben emperò en comte de la dita soldada del dit temps de la dita guarda los dits IIII diners, que.n haurá hauts de cascuna de les dites besties que dins aquell temps en seràn tretes.E tot lo romanent del dit preu del bestiar venut do e sia tengut donar en continent,ço és, lo terç a nos e a nostre ordre e les dues parts entre la luminaria de Sent Berthomeu e dde madoma Santa María del dit loch e comú dels dits lochs.

Item que si per ventura alcuna persiona será tenguda pagar les penes en los dits capitols tengudes o alcuna de aquelles que en aytal cas lo dit justicia del dit ligalló puga e faça pendre aquell e stiga tant pres en la presó sobredita, tro haja pagada la dita pena.

Item que si per ventutra lo dit justicia del ligalló será negligent a levar les dites penes, si comeses serán, de aquella persona que comeses les haurà e bens seus que en aquets cas l'altre justicia del dit loch puxa levar aquelles del dit justicia del ligalló. E si levar no les porà o no volrà, nos o lo nostre lochtenient les puxa levar o fer levar dels bens del sobredit justicia del ligalló.

Item que si per ventura als dits promens, consell e universitat sobredita será ben vist que a la ordibnació sobredita del dit ligalló e al dits capitols o quansevol de aquelles faça alguna cosa crexer, minvar, millorar, mudar, corregir e esnmenar que açò puxen fer consell e ferma nostra. Manants a tots universes e sengles comanadors, justicies, batles e altres officials e sotsmeses nostres, presents e esdevenidors, que contra la present carta e licència no vinguen ni contradesquen si de la nostra gracia e amor confien. En testimoni de la qual cosa manan fer la present carta per lo notari deius scritt per haver memòria de les dites cosas en l'esdeveenidor.

La qual cosa fon feta e acabada en lo lloch nostre de Les Coves, dijopuis a XII dies del mes de març de l'any de la Nativitat de nostre Senyor, mil CCCLVIII.

Se (signo) nyal de nos frare Pere de Thous, maestre damunt dit, que les dites coses loam ee affermam. Se (ssigno en blanco) nyal de mi, ferrer casladuch, notari publich per autoritat reyal per torta la terra e senyoria del senyor rey d'Aragó, qui a les dites coses fuy present e aquelles scriure fiu e cloy e subsigni, en lo loch, dia et any damunt dits.

\section{1358, octubre 12. Barcelona. Pedro III acepta la petición de los vecinos de Morella para reconstruir sus casas después del incendio de 1356 sin ampliar la calle de 16 palmos a 18 como inicialmente se había ordenado.}

Transcripción efectuada por Josep Alanyà i Roig.

Publicada en el libro: Urbanisme i vida a la Morella medieval S.XIII-XV' Editado por el Ayuntamiento de Morella en el año 2000 pág. 58.

Petrus, et cetera. Mostassafo et officialibus Morelle. Vos seu aliqui vestrum quibusdam vicinis Morelle, quorum hedificia pridem, dum ignos validus in dicta villa occasionaliter invaluit, ipsius ignis incendio cremata fuerunt, prohibitis dicta eorum hedificia operari seu operari et reparari facere seu reedificari de novo pretendo quod ex eo quare carrerie sive vie dicte ville, in quibus dicta hedificia operari et reparari debent, non sunt latidunis deecem et octo palmorum iuxta privilegium et forum Regni Valentie, debent fundamenta vetera dictorum hedificorum dirrui et alia de novo duobus palmis retrorsum operari et construi, ex quibus dictis vicinis hedificare et reparare predicta hedificia voplentibus accrescerentu $7 \mathrm{r}$ 
labores et sumptus varii et alia plua dampna eis sequerentur. Quare supplicatum fuit nobis tu super hiis clementer providere ac remedium congruum adhibere dignaremur (...) Dicta supplicationes benigne admissa, attento quod aflicto non est danda aflictio calamitatique dictorum singularium, qui a casu tam fortuitu et inopinato quamplurimum oppressi fuerunt, misserendum existit et eorum indempnitati providendum; attento etiam quod jamdicti singulares non intendunt hedificia hedificare de novo sed vetera hedificia rehedificare seu reparare; attento quod circa reparationem dicte ville tamquam notabilis sicut circa reparationem aliarum villarum et locurom Regni nostri, potissime isto tempore quo guerra ardua inter nos et Regne Caselle viget, intendere et operam seu locum dare debeamus (....), tu dicta villa citius reparari valeat concesserimus singularibus, quorum hedificia concremata fuerunt, quod illa possint operari et reparari seu rehedificari facere super fundamebntis antiquis et alia de novo fundamenta nec illa retro per duos palmos facere seu operari minime teneantur(....) Datum Barchinone, die XII mensis octobris, anno a Nativitate Cdomini M CCC L octavo.

46. 1364, febrero 10. Gurrea. Pere el Ceremonioso obliga tanto al abad de Benifassar como a las aldeas de Morella a contribuir a la construcción de las murallas de Morella.

Archivo de la Corona de Aragón. Barcelona. Cancelleria Reial. registre 1193, ff. 67 r.

Transcripción efectuada por Josep Alanyà i Roig.

Publicada en el libro: Urbanisme i vida a la Morella medieval s. XIII-XV' Editado por el Ayuntamiento de Morella en el año 2.000 pág. 419.

Petrus, Dei gratia, et cetera. Fideli nostro iustitie ville Morelle qui nunch est et qui pro tempore fueit vel eius locumtenenti, salutem et gratiam. Pro parte universitatis et proborum hominum dicte ville fuit nobis expositum conquerendo quod abbas de Benifaçano et aliqui alii domiciliati infra terminos dicte ville contradicunt malitiose et indebite contribuere in opere murorum et vallorum dicte ville. Quamvis ipsi necessitatis tempore se recolligere, defendere et tueri habeant in eadem, unde cum de foro, privilegio etusu Regni Valentie nemo, cuiusvis conditionis et dignitatis fuerit, a premisorum contributione debeat nec valeat excussari. Ea propter vobis dicimus et mandamus quatenus predictum abbatem et eius homines ac alios quoscumque infra terminum generalem dicte ville populatos iuris et fori remediis at contribuendum in opere antedicto districte et fortiter compellatis si et prout eiusdem seu eorum bona repereritis iuste et moderate taxatos fuisse et prout etiam hactenus in predictis ac similibus est fieri usitatum. Quibuscumque superse dimentis, provisionibus et litteris in contrarium sub quorumcumque expressione verborum factis et fiendis obsistentibus ullo modo.

Datum in loco de Gurrea, sub nostro sigillo secreto, decima die februarii, anno Nativitate Domini Millesimo CCC LX IIII. Johannes Egidii.

Franciscus Castilionis, mandato Domini regis ad relationem R. Nepotis, consiliari et auditoris. Probata.

47. 1385, mayo 23. Morella. Contrato para la ejecución de la vidriera mayor de la Iglesia Arciprestal de Morella, hecho entre el sabio en derecho Miquel Barreda y el maestro vidriero Pere Ponç.

Archivo Histórico eclesiástico de Morella. Protocolos del notario Guillem Esteve año 1385.

Transcripción efectuada por Josep Alanyà i Roig.

Del articulo "Els vitrals de Santa Maria de Morella (s. XIV)", publicado en la revista del Boletín de AMYC nº 17 del año 2000, en la pág. 49.

Primo, que lo dit en maestre Ponç sie tengut de fer quatre panys compasats de la finestra major que és davant l'altar de la església de Santa Maria de la vila de Morella. Ço és que hage tant hun pany com altre de larch et de ample de obra de les dites vdieres.

Item, que en los buyts dels archets,ço es en los pus alts age un cap pintat de la dita obra de la ymage de Jesu Christ, e en los altres buyts age a fer obra comú e de vidres compases.

Item, en los altres arxets aprés sie lo sinyal del dit en Miquel barreda, ço és lo camp vermell del escudet e la torre blava.

Item, que en el pany de en migsie lo crucificii, e de la huna part la ymage de Sancta Maria e lo Johan de la part altra.

Item, que en los segons panys de ça e dellà sie de la huna part Sant Pere e de la part altra Sent Paul, e en mig la Maria e son fill esús.

Item, que los terços panys, ço és mig sie la Trinitat e a la hun costat Santa Caterina e en "altre costat 
Sent Yvo, advocat dels pobres.

Idem, que en los IIII panys sie ficat en mig Sent Miquel ab la vibra e a la hun costat Sent Frencencesch et sent Anthoni de Padua de l'altre costat.Item, quel dit mestre age et sie tengut fer et posar les dites vidrieres en la dita finestra acabadament et perfeyta ab sa capa de fil de ferre estanyada e ab totes les coses quey sient necessàries ab se pròpiesmessions et despeses d'ací a la primeravinent festa de Sancta Maria del mes de setembre.

Item,. Que dit maestre age(titllat: e sie tengut) per preu de la dita obra L florins al dit maestre, ço és de presente XX florins e los altres XXX restants acabada la obra desús dita e posada en la dita finestra, los quals XX florins confessa aver auts e en contant reebuts.

Item, quel dit maestre sie tingut fer les dites ymages de (titllat:vidre) de diverses colors, belles e animades, així en vidre blau com en vermell, groch, violat e vert e d'altres colors que pertanyen a la obra. Fide e principal paguador Bernat Johan Morelle.

Actum Morelle XXIII die Medii, anno a Nativitate Domini M CCC LXXXV. Testes Raymundus cardona e Guillermo Company Morelle. Dissabte a X de noembre anno a Nativitate domini M CCC LXXXVI fon cancelada de volentat del dit en Miquel Barreda. Testes en Ramon Carcellera e N'Arnau Borell, prevere e Guillermo Vidal Morelle.

Archivo Histórico Eclesiástico de Morella (AHEM), Protocolos del notario Guillem Esteve. Año 1385.

48. 1398, Tirasone. Baremo incompleto, de lana de Morella, sus aldeas y comarca, concentrada en Sant Mateu y expedido por Tuccio Gennanio, con la indicación del peso, costo, procedencia, destino y margen comercial calculado.

Archivo Datini di Prato en Florencia, busta 938,ff. 126-159 (Memoriale) Libro di San Matteo tenne Tuccio di Gennaio.

Transcripción efectuada por Manuel Milian Boix.

Publicada en el libro: "Homenaje a Mosen Milian 2" Editado por la Diputación de Castellón en el año 1989 pág. 456-459.

48 sache di lana compramo da Giaome Ferriere di Morella, pesarono 241 ro(ve), 9 lib(re)(f.126)

83 ro(ve) di lana di Morella comprai de Michele Spigholo da Morella, 1(ibre) b(archinonese) 70, s(oldi) 11 (f.138v)

166 ro. Di lana di Morella comprai da Ramondo Feriere del Forcaglio, Ib. 139, s.14 (f.140)

417 ro. Di lana receveti da Giaome Moratone di Morella cioe e Portelli, Vila francha e Chastelforte del termini di Morella e fecila stivare, 83 sache deono dare, di 20 ottobe, Ib. trecento trentatre, soldi 12. Chomprai per messer Francho Chornero a soldi 16 ro. Come apare in questo (Memoriale) a carta 45 (f.141 v.)

190 ro.e 1/4 di lana recevetti del peto (Piero Monserrato di Catino) a la Lacoua e al maso di Zavalle e 45 1/4 a la Lacova, deono dare li. Cento sesanta, s. 4, d(enari) 9. Comprai per Antonio Contarino, di Venegia (f.142v.)

86 ro. Di lana di Benazalle ricevetti da Piero Prungiolosa di Benazalle, deono dare di 20 ott(obre) lib.70,s.19. Comprai per Antonio Contarini da Vinegia a soldi 16 de(nari) 6 rova (f.144v)

39 ro.e 29 lib. di lana di Morella ricevetti da Michel Oliere di Morella, fecila stivare in 8 sach Ib. 33,s.16,d.6. Comprai per Antonio Contarino de Vinegia.

66 ro. E mezo di lana di Morella, comprai da don(n) a Mateba di Morella e fecila stivare in 13 sache a Ib. 56, s. 10. Comprai per Antonio Contarino di Venegia (f.145 v.)

48 ro. Di lana di Morella, comprai da Michele Feriere di Morella e fecila stivare in 9 sache, deono dare Ib. 40, s. 16. Comprai per Antonio Contarino di Venegia (f.145 v.)

170 ro. Di lana di Portelli del termini di Morellas, comprai da Piero Frasxcinero di Portelli e fecila stivare in 34 sache, deono dare Ib. 136 s. Comprai per Antonio Contarino di Venegia (f. 146 v)

280 ro. Di lana di Furtanieti, compraui da Giaome Moratone di Morella e fecila stivare in 56 sache, deono dare di 20 ottobre Ib. 251. Compramo per Antonio Contarino di Venegia, a soldi 16 ro.-Ib.224 (f. 146v)

208 ro. Di lana di Vilanarozo, ricebetti da Piero Antibocha. Fecila stivare in 37 sache, deono dare di 20 ottobre Ib. 194, s.2, d.8. Comprai per Barnaba propio a soldi 19, d.8 (f.147 v).

35 ro. E 25 libre lana di Valibona, comprai de Piero di Bartolomeo Seghjara e fecila stivare in 7 sache. Comprai per Barnaba Degliangli propio (f.148 v).

30 e 1/2 ro. Di lana di Morella, ricevetti da Arnao Orpinelli, fecila stivare in 6 sache, deono dare Ib. 25, s, 18, d. 6. Comprai per Barnaba (f.149v). 
68 ro. 16 lib. da Giovanni Manzipo di Morela, fecila stivare in 13 sache. Comprai per Piero Dui a soldi 17 ro. Deono dare Ib. 58, s. 6 (f.151v).

14 ro,. Di lana di Morella, comprai da Guiglelmo Pere di Morella in 3 sache. Comprai per Lospino a soldi 17 ro. Deono dare Ib. 15, s. 18, d. 6 (f.154 v)

14 ro. Di lana comprai da Giaome Masdo di Morella sta la Lacova in tres sache, deono dare di detto Ib. 11, s. 18, per Scholaio Deglispini a soldi 17 ro. Ib. 11, s. 18 (f.154 v)

796 ro. Di lana ricevetti da Bernardo Ulzina di Coraçano coe a dal Boscare e Coraçano s. 16 ro.

79 ro. Di lana ricevetti in Coraçano da Piero Ulzina e tutto feci stivare insieme con quelle di Coraçano, costorono s. 17, queste somano in tutto ro. 875, per i nostri de Valenza... fecil stivare tutte in 166 sache. Deono dare Ib. 703, s. 19 (f.155v)

24 ro. Di lana di Bonifazan recevetti da Fra Ghaldino zeliere magiore di Bonifaza, fecila stivare in 4 sache... Deono dare Ib. 18,s. 19,d. 6 (f.155v)

40 ro. Di lana recevetti a Morella di Gelmo Peralta, fecila stivare in 8 sache.... comprai per in nostri di Valenza a s. 17 ro. Deono dare lib. 34 (f.155v)

5 ro. E mezo di lana comprai da Bernardo Zerdano di Morella in $1^{a}$ sacha... comprai per i nosgtri di Valenza. Deono dare Ib. 4. s. 13, d. 6 MCCCLXXXXVIII (f.156 r)

60 ro. Di lana recevetti al Campiglio d'Antonio Charbone per nostri s. 16, d. 8.

90 ro. Di lana recevetti al Campiglio per Piero Monserato, di Catino, costo s. 16, de. 6, rova. Di tutte 150 ro. Feci lana boregla e fecila stivare in 29 sache per nostri di Valenza. Diedio 10 sache di queste a Nicholó di Piero, Prato, montano Ib. 124 s. 10, como apare in questo a carta 22, debbe 60 r. a carta 26. Deono dare Ib. 14, s 10.

742 ro. Di lana di Morella ricevetti da Ghuilielmo Amela di Morella e fecila stivare in 148 sache, deono dare di 20 ottobre fiorini 630, s. 14. Comprai per nostri di Valenzxa a s. 17 ro., eogli a dare 10 sache di lana tutto come apare in questo a carta 58...Deono dares Ib. 630, s. 14.

430 ro. 33 lib. ricevetti a Morella da Se(r)ra, charneziere di Morella, fecila stivare in 79 sache. Deono dare di 20 ottobre Ib. 366,s. 5, d. 6. Comprai per nostri di Valenza a s. 17 rove come apare in questo a carta 40. Deono dare Ib. 366, s.5.de.6

214 ro. Di lana comprai da Ghiglelmo Bonetto di Furtanieti per nostri a s. 13, de.6.

74 ro. Di lana compraui da Giovanni chougnato di Furtanmeti, sono per tutto ro. 288, fecila stivare in 60 sache, deono dare, di 20 ottobre Ib. 194, s.8, comprari per nostri di Valenza. Ib. 194,s.8

82 rop. Di lana ricevetti a Morella da Mateo Zavalle di Morella, fecila stivare in 16 sache, deono dare di 20 ottobre Ib.70,s. 14 a s. 17 ro. E soldi 20 mese al tutto come apare in questo a carta 41. Ib. 70, s. 14 25 ro. Di lana ricevetti e Fredes da Domenecho Zalomon di Bizette feceme 4 sache, deono dare Ib. 20, s. 12 , de. 6 .

10 ro. Di lana comprai da Piero Martini d'Alzaneta, deono dare di 20 ottobre Ib. 8, s. 10, comprai per nostri, fecila stivare in 2 sache come apare in questo a carta 63, IB. 8, s. 10,(somma) Ib. 1413 s. 15 (f.156 v) Sache 358, (f.157r)

84 ro. E 13 lib. di lana di Morella ricevetti da Michel Pichere di Morella, fecila stivare in 16 sache... comprai per Ambrogio di Meo, di Firenze, a s. 17 ro..,Ib. 71, s. 14, d. 4 (f.157 v.)

15 ro. Di lana di Morella ricevetti di Giovanni Rivera di Morella, in sache 3..., comprai per Ambrogio di Meo per s.17 ro., Ib. 12, s. 15. (f.158 v)

22 ro. Di lana di Vallibiona comprai da Domenicho Vidalta in 4 sache... comprai por Ambrogio di Meo a soldi 16, de. 6 ro.Ib. 18, s.3. (f.158 v)

455 ro. Di lana d'Aries ricevetti in Aries da piu omni, fecila stivare in 89 sache...., comprai por Ambrogio di Meo a soldi 16, de. 9 ro., Ib. 379, s.3, d.4. (f. 158 v)

276 ro. E 34 lib. di lana ricevetti d'Antonio Chapangnes di Morella..., comprai per messer Francescho Cvornero, a soldi 17 ro., fecila stivare in 53 sache. Ib. 245, s.8.

69 ro. 8 lib. di lana comprai da Pasq2ualle Capangnies, fecila stivare in 13 sache a soldi 17 ro., per messer Francescho Cornero..., Ib. 58, s. 17, d.8. (f.159v.) 
49. 1416, octubre 11, Teruel. Disposición sobre el toque de campanas.

Archivo Municipal de Castellón, Libro de Cons, t.21.

Transcripción efectuada por Francisco A. Roca Traver.

Publicada en el libro: "El tono de la vida en la Valencia Medieval"; editado por la Sociedad Castellonense de Cultura en 1983. Pág. 149.

"Item lo dit honorable consell, per be, utilitat e profit dels habitadors de la dita vila e dels vehinants en aquella, ordena que un seny o campana toch les hores del dia e de la nit ab son relotge, segons se pertanay e lo dit fet comana als honrats jurats que prestament ho facent e que'l 'pesador de les farines, qualque sia, ho rege d'aqui avant per aquell salari que ab aquel pora e3sser convengut"

50. 1418, Xátiva. Roturación de tierras y desecación marjal

Archivo Regne de Valencia, Ctas. Nmtre. Racl., C. 38, fol. 228, v.

Transcripción efectuada por Francisco A. Roca Traver.

Publicada en el libro: "El tono de la vida en la Valencia Medieval"; editado por la Sociedad Castellonense de Cultura en 1983. Pág. 162.

“.... en Berthomeu Cases-noves, obrer de la vila de la ciutat de Xativa, per salari seu e d'en Pere Arboreda, obrer de la vila de la dita ciutat, per $\mathrm{V}$ jorns que d'ordinació mia baccaren en venir de la dita ciutat de Xativa a la Vila e baronia de Corbera e estar en aquella per liverar les aygues que son en les marjals de la dita baronia e de la vila de Cullera, per veure si’s porien traure en lo iu Xuquer per axugar les dites marjals per ço que's poguesen panificar."

\section{1428, abril 5. Teruel. Provisión acerca de la elección y pago de una persona que toque las} horas del reloj.

Archivo Histórico Provincial de Teruel, Libro de Actos Comunes, 1428, f. lv.

Transcripción efectuada por Juan José Morales Gómez.

Publicada en la Revista Aragón en la Edad Media no 81989 pág.. 472 dentro del artículo: “Tiempo y relojes en Teruel en el siglo XV'.

fl v.f Die predicti en publico conceio.

Sobre haver persona qui toque el reloig, por tiempo de hun anyo, visto seyr cosa a todos convenible, por saber de dia e de noche quantas horas son concordadas o passadas, fue providido quel dito acto remetan et remetieran a los regidores, presentes e advenideros, de la dita ciudat, que hi providiessen por forma e manera quel capitol de los clerigos, fidalgos, judios e moros satisfaziessen e ayudassen al Ioguero del toquant del dito reloig, et pagando el dito capitol, fidalgos, judios e moros qualquiere cosas qui sera providida por los ditos regidores presentes o ad $\neg$ venideros, o por la mayor partida de aquellos. Los ditos estantes en el dito conceio profirieron se haver por firme e ensemble por ellos e la dita ciudat. Fiat Iarge, testes ut supra.

52. 1440, septiembre 24. Villafranca. Contrato de mantenimiento de ganado a "mig guany". Transcripción efectuada por José Sánchez Adell.

Del artículo: “Algunos aspectos de la práctica ganadera medieval en tierras castellonenses" de José Sánchez Adell. Publicado en Estudis Castellonencs no $51992-93$ pág. 390.

Die sabati XXIIII septembris anni supra dieti

Honorabilis Johannes Bruscha, mercator, vecinus presentis loci Villafranchae, scienter etc. Dedit, concessit et tradidit ad medium lucrum sive a mig guany Guillermo Giner, vicino ciusdem loci presenti et eius acceptanti et suis sexaginta tres borregos lanaris ad tempus unius anni de die presenti contionue computandum. Sub tamen condicionis infra expressis videlicet quod dictus honorabilis Johannes Bruscha possit ipsos vender quocumque sibi placuerit. Item quod usque vendantur quod dictus Guillermus Giner tenatur dictos borregus a salare et protegere et custodire suis sumptibus, periculo et expensis. Et quod quocienscumque vendantur dictus honorabilis Johannes Bruscha habeat et possit ex precio illorum qui vendebuntur per prius abstraere quatuor solidos e quatuor denarios qui son precium dictorum borregorum. Cuius ex ipsis LXIII, XXXXVII costiterint ad racionem sex solidorum quattor denariorum per capite et sedecim ad racione sex solidoru $7 \mathrm{~m}$ et octo denariorum. Et abstractis dictis CCCCIIII solidos III denarios uperaveerit quod illud dividatur inter nos. Et dictus 
Guillermo Giner acceptando dictos LXIII boregos tu dictum est per eum atendetis et complendis ombnia bona sua obligavit habita et habenda.

Testes qui supra.

53. 1483, junio 16. Teruel. Capítulos concordados entre Sebastián de Canyamache y los regadores de Teruel acerca del reloj de la ciudad.

Archivo Histórico Provincial de Teruel, Libro de Actos Comunes, 1483-84, fs 41-42.

Transcripción efectuada por Juan José Morales Gómez.

Publicada en la Revista Aragón en la Edad Media no 81989 pág.. 473 dentro del artículo: “Tiempo y relojes en Teruel en el siglo XV".

Ihesus Maria.

A XVI de Junyo MCCCCLXXXIII, en la sala del consello de la ciudat de Teruel, los honrados Miguel Perez Arnal, Frances de Puigmiga, Francisco Besant y Johan d'Alda, regidores, mediant el honrado Miguel Sanchez Gamir, present, abinieron con Savastian de Canyamache, menor de dias, cerragero.

Testes: Miguel Sanchez Gamir y Miguel Rajadel.

Chapitoles del reloig entre la ciudat de Teruel e Savastian de Chanamaig, eragero, menor de dias, del reloig que ha el dito Chanamaig de fierro con sus rodas, contrapessos e todas aquellas pertanecientes al dito reloig, cepto las chuerdas pora los contrapessos e pora el canpanar, pora toquar el dito reloig el vadago de la canpa (sic), las quales chuerdas sea tovido pagar la dita ciudat e sostener aquellas migestant quel dito Savastian terna chargo del dito reloig.

ltem que el dito Savastian promete et se obliga de dar hachabado el dito reloig perfetament d'aqui hal dia de Nadal primero vinient, e si non lo fara, que la dita ciudat lo pueda fazer achebar ad espensa del dito Savastian, dandole la dita ciudat el reloig que oy tiene desbaratado francho por had aiuda del que ha de fer nuevo. 


\section{ANEXO IV. GLOSARIO}

ACOPLAMIENTO: Fenómeno que se presenta cuando un componente individual de un sistema es influenciado por el comportamiento de los otros componentes.

ANTROPOGEOGRÁFICO: Referente al resultado de la actuación del hombre sobre el soporte geográfico natural.

AUTOENSAMBLAJE: Es la organización, reparación o fabricación de un sistema o estructura por el propio sistema o estructura.

CAÑAMAZO: Tela de tejido ralo, dispuesta para bordar o tapizar en ella.

COMPLEMENTARIEDAD: Principio que nos dice que dos propiedades son complementarias cuando ambas son necesarias para proporcionar una descripción completa del sistema u objeto al que pertenecen.

CONEXIÓN: Enlace, atadura, trabazón, concatenación de una cosa con otra mediante un espacio construido.

CORONEMA: "Primera escala o ámbito espacial universal, celda básica y más simple de las relaciones espacio-medio-habitat". Se trata de un término utilizado por Javier García Bellido en su tesis doctoral: "Coranomía: los universales de la urbanística, estudios sobre las estructuras generativas en las ciencias del territorio".

DESORDEN DE UN SISTEMA: Consiste en la uniformización del sistema, así como su incapacidad de diferenciación y diversificación.

DETERMINISMO: Teoría que supone que la evolución de los fenómenos naturales esta completamente determinada por las condiciones iniciales.

ENERGÍA: Capacidad para realizar un trabajo y producir cambios en la materia.

ENERGÍA ENDOSOMÁTICA: Es la energía que pasa por las vías del metabolismo somático de los seres vivos.

ENERGÍA EXOSOMÁTICA: Es la energía que contribuye a mantener la vida y la organización de los ecosistemas, pero que no pasa o se degrada a través de las vías del metabolismo somático.

ENTALPÍA: Es una medida del orden de un sistema físico.

ENTROPÍA: Es una medida del desorden de un sistema físico.

ESCLEROSIS: Es el decaimiento y la progresiva reducción de la capacidad de fluctuación y regulación de un sistema, es el envejecimiento del mismo.

ESFERAS: Espacio animado y vivido, no neutro; un receptáculo en el que estamos inmersos. Las esferas son necesarias para vivir como el aire para respirar. La teoría de las esferas de Sloterdijk es un instrumento morfológico y mental que constituye un proceso bilateral entre observador y observado que permite fortalecer la imagen del espacio que habitamos mediante artificios simbólicos y dotarlo de una atmósfera en la que el hombre se encuentra protegido.

ESTEREOTÓMICO: Construcción realizada a través de la superposición de unidades idénticas que tienen continuidad estructural y constructiva.

FRACTAL: Es un objeto geométrico cuya estructura básica, fragmentada o irregular, se repite a diversas escalas. Los fractales representan los sistemas dinámicos, la geometría de la naturaleza, las infinitas retroalimentaciones, en síntesis, lo que no puede ser medido en términos Euclidianos. Un fractal es un modo de ver el infinito.

GRADIENTE: Medida de la variación continúa de una magnitud de un elemento en función de la distancia.

HABITAR: Construir en sentido amplio que incluye el cultivar y el compartir. Según Heidegger ser hombre significa habitar en este sentido.

HISTÉRESIS: Es la capacidad de un sistema para recuperar la energía como información, lo cual pone de manifiesto que el estado de un sistema depende de su historia previa.

HOMEORHESIS: Es la capacidad de un sistema para comportarse como una estructura flexible sin una forma cerrada, sino con una predisposición a una determinada evolución y crecimiento.

HOMEOSTASIS: Es la capacidad de mantener la estabilidad interna de un sistema compensando los cambios en su entorno mediante el intercambio regulado de materia y energía con el exterior. 
INFORMACIÓN: Es la manera en la que la energía y la materia se combinan y extienden en el espacio. En este sentido este concepto es asimilable al de forma como algo añadido a la materia y que le da propiedades particulares y concretas.

INTERCONEXIÓN: Enlace, atadura, trabazón, concatenación de una cosa con otra sin espacio construido intermedio.

MATERIA: Es todo lo que tiene masa, ocupa un lugar en el espacio y posee almacenada una cierta cantidad de energía.

MEMORIA: Lugares en los que la información se almacena y puede posteriormente recuperarse con facilidad.

MORFOESTASIS: Es la fase de maduración y estabilización estructural de un sistema, en el que una vez desarrollado mantiene su capacidad de autoorganización.

MORFOGÉNESIS: Es el crecimiento y desarrollo de un sistema por la diferenciación interna y la asimilación de elementos externos.

ORDEN DE UN SISTEMA: Consiste en la compartimentalización del sistema, su diferenciación y su potencial diversificación.

PALIMPSESTO: Manuscrito antiguo que conserva huellas de una escritura anterior borrada artificialmente.

PATCHWORK: Es sinónimo de almazuela, y es la pieza tejida uniendo fragmentos de otras telas.

RED: Conjunto de elementos organizados para determinado fin.

SISTEMAS FÍSICOS AUTOORGANIZATIVOS: Son aquellos que son capaces de recuperar la energía disipada como información, garantizando su orden y su creciente organización.

SISTEMAS FÍSICOS DISIPATIVOS: Son aquellos que generan y administran la energía, dado que parte de la energía se transforma en calor, esta no se recupera como tal para futuras transformaciones. SOSTENIBILIDAD: Es el equilibrio entre un sistema o estructura con los recursos de su entorno, de forma que es posible el funcionamiento de todas sus partes, sin necesidad de dañar o sacrificar las capacidades del mismo.

TECTÓNICO: Construcción realizada a través de elementos diferentes ensamblados para crear una unidad espacial.

TEJIDO: Cada uno de los diversos agregados de elementos de la misma naturaleza, diferenciados de un modo determinado, ordenados regularmente y que desempeñan en conjunto una misma función. TEORÍA DEL CAOS: Estudia ciertos tipos de sistemas dinámicos muy sensibles a las variaciones en las condiciones iniciales que pueden implicar grandes diferencias en el comportamiento futuro, imposibilitando la predicción a largo plazo.

TERMOCLINA: Es un segmento del gradiente vertical de temperatura que es particularmente intenso o abrupto.

TERMODINÁMICA: Es la rama de la física que estudia los valores de las variables de un sistema durante la transición entre dos estados estacionarios y describe el sistema en dicha fase. Permite conocer la energía total del sistema, así como los flujos de la misma, el grado de orden del sistema y la información disponible sobre el mismo. Tales conocimientos permiten luego, clasificar los sistemas físicos (desde el punto de vista termodinámico) como aislados, cerrados y abiertos.

La primera ley de la termodinámica dice que la energía no se crea ni se destruye, sino que se transforma, mudando de una forma a otra.

La segunda ley de la termodinámica dice que una forma de energía, el calor, no es completamente transformable en otra forma de energía, por lo que va en constante aumento en detrimento de otras formas de energía.

TIPOLOGÍA: Es la ciencia que estudia los conceptos que describen un grupo de objetos caracterizados por tener la misma estructura formal.

TOPOI: Punto común de partida de una argumentación.

TOPOLOGÍA: Es la rama de las matemáticas que estudia las propiedades de los cuerpos geométricos que permanecen inalteradas por las transformaciones continuas. La topología considera que la forma es una estructura abierta, fluida, susceptible de ser determinada en varias direcciones. No tiene predeterminada una ordenación precisa sino que tiende únicamente a una ordenación posible.

YUXTAPOSICIÓN: Poner una cosa junto a otra. 

